\title{
MÁRIO CAEIRO
}

\section{A RETÓRICA

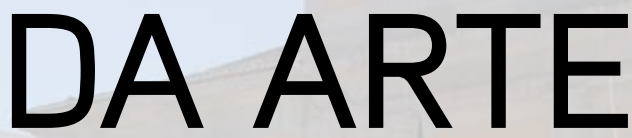

NA CIDADE

I) $9 \square 0$

\section{DISPOSITIVO, ENVOLVIMENTO E GRAÇA}

\section{O PROJECTO EXTRAMUROS COMO PROPOSTA DE INTERVENÇÃO URBANA}

\section{UNIVERSITAT POLITÈCNICA DE VALÈNCIA}





\section{MÁRIO CAEIRO}

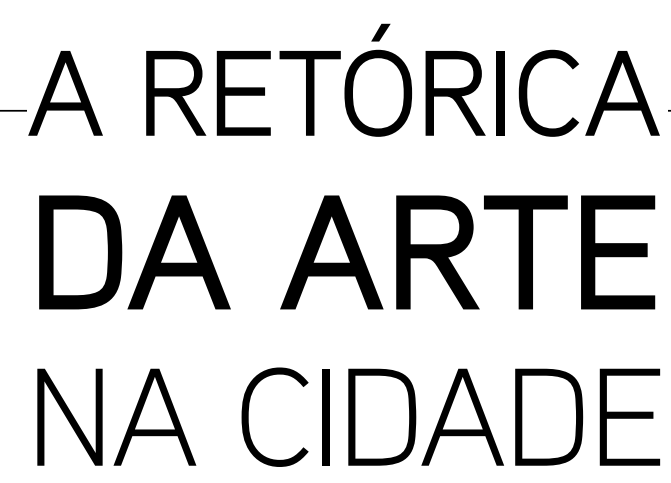

DISPOSITIVO, ENVOLVIMENTO E GRAÇA

\section{O PROJECTO EXTRAMUROS COMO PROPOSTA DE INTERVENÇÃO URBANA}





\section{RETÓRICA DEL ARTE EN LA CIUDAD}

Esta investigación es una teoría crítica del arte en la forma urbana. Propone un conjunto de términos y operaciones clave consolidados entorno al noema 'arte-público', presentando como meta-modalidad de la emancipación ciudadana basada en la estética de lo social. Concluye que la retórica, con su estructuración ethos/logos/pathos, es la racionalidad total que concretiza una concientización plástica de los valores proyectuales de la atención, del dispositivo y de la gracia. Estos son considerados fundamentales en una experiencia emancipada de la ciudad.

En la Parte I, se explicitan las consecuencias de varios movimientos críticos en las vanguardias artísticas y urbanísticas, y en el ensayo y en la crítica cultural. En el régimen del arte contemporáneo, destaco figuras y modos del viraje conceptual al Land art, sedimentando una gramática del arte en el Espacio Público. Tres binomios condensan la problemática: Museo, intervención (la intervención urbana como propuesta de otra memoria y representación del colectivo); Contexto/situación (la situación como corolario de una consciencia de lo efímero y contextual; Activismo/participación (el activismo como modalidad de la participatividad comunitaria). Se intenta revisar la jerga del arte público contemporáneo en orden a problematizar radicalmente la cultura urbana, en el marco de un urbanismo general continuamente emergente.

En el Parte II, se analiza los casos de estudio LISBOA CAPITAL DO NADA - MARVILA 2001, SINAIS, A CIDADE HABITADA, LUZBOA (todos eventos en Lisboa) y SKYWAY (en Polonia). En esta secuencia de experiencias curatoriales, las intervenciones artísticas, separadamente y en cuanto dinámica integrada, definen un conjunto de valores, actitudes e ingenuidades que desvelan una estética.

En el Parte III profundizo la aplicación del modelo retórico a la praxis curatorial, proponiendo, primero, una axiomática de la intensidad retórica del arte en la forma urbana (las tensiones Bello/Sublime y Cuerpo/Idea) y después posiciones artísticas ejemplares, encuadrando la posibilidad de una gracia de lo social en el núcleo del arte en/de la ciudad. La dinámica ethos de la atención, logos del dispositivo (en punto crítico) y pathos de la gracia social revela finalmente el proyecto extramuros como propuesta de intervención urbana. 


\section{A RETÓRICA DA ARTE NA CIDADE}

A presente investigação é uma teoria da arte crítica na forma urbana. Expõe um conjunto de termos- e operações-chave consolidados em torno do noema 'arte pública', desvelando esta como meta-modalidade da emancipação cidadã baseada na estética do social. Conclui que a retórica, através da sua estrutura tripartida ethos/logos/pathos, é a racionalidade total que concretiza uma conscientização plástica dos valores projectuais da atenção, do dispositivo e da graça. Estes são considerados fundamentais para uma experiência emancipada da cidade.

Na Parte I, explicita-se as consequências de vários movimentos críticos nas vanguardas artísticas e urbanísticas, no ensaio e na crítica cultural. No regime da arte contemporânea, destaco figuras e modos da viragem conceptual à Land Art, sedimentando uma gramática da arte face ao Espaço Público. Três binómios condensam a problemática: Museu, intervenção (a intervenção urbana como proposta de outra memória e representação do colectivo); Contexto/situação (a situação como corolário de uma consciência do efémero contextual); Activismo/participação (o activismo como modalidade de participatividade comunitária). Trata-se de rever o jargão da arte pública contemporânea no sentido de uma problematização radical da cultura urbana, no quadro de um urbanismo geral sempremergente.

Na Parte II analisa-se os casos de estudo LISBOA CAPITAL DO NADA - MARVILA 2001, SINAIS, A CIDADE HABITADA, LUZBOA (todos eventos em Lisboa) e SKYWAY (Polónia). Nesta sequência de experiências curatoriais, as intervenções artísticas, separadamente e enquanto dinâmica integrada, definem um conjunto de valores, atitudes e ingenuidades que desvelam uma estética.

Na Parte III aprofundo a aplicação do modelo retórico à prática curatorial, propondo primeiro uma axiomática da intensidade retórica da arte na forma urbana las tensões Belo/ Sublime e Corpo/Ideia) e depois posições artísticas exemplares, enquadrando a possibilidade de uma graça do social no âmago da arte na/da cidade. A dinâmica ethos da atenção, logos do dispositivo (em ponto crítico) e pathos da graça social revela finalmente o projecto extramuros como proposta de intervenção urbana. 


\section{RETÒRICA DE L'ART A LA CIUTAT}

Aquesta investigació és una teoria crítica de l'art en la forma urbana. Proposa un conjunt de termes i operacions clau consolidats voltant del noema 'art-públic', presentant com a meta-modalitat de l'emancipació ciutadana basada en l'estètica del social. Conclou que la retòrica, amb la seva estructuració ethos / logos / pathos, és la racionalitat total que concretitza una conscienciació plàstica dels valors projectuals de l'atenció, del dispositiu i de la gràcia. Aquests són considerats fonamentals en una experiència emancipada de la ciutat.

A la Part I, s'expliciten les conseqüències de diversos moviments crítics en les avantguardes artístiques i urbanístiques, i en l'assaig i en la crítica cultural. En el règim de l'art contemporani, va destacar figures i maneres del viratge conceptual al Land art, sedimentant una gramàtica de l'art en l'Espai Públic. Tres binomis condensen la problemàtica: Museu, intervenció (la intervenció urbana com a proposta d'una altra memòria i representació del col · lectiu); Context / situació (la situació com corol · lari d'una consciència de l'efímer i contextual; Activisme / participació ll'activisme com a modalitat de la participatividad comunitària). S'intenta revisar l'argot de l'art públic contemporani amb vista a problematitzar radicalment la cultura urbana, en el marc d'un urbanisme general contínuament emergent. Al Part II, s'analitza els casos d'estudi LISBOA CAPITAL DO RES - MARVILA 2001, SINAIS, A Cidade HABITADA, LUZBOA (tots esdeveniments a Lisboa) i Skyway (a Polònia). En aquesta seqüència d'experiències curatorials, les intervencions artístiques, separadament i quant dinàmica integrada, defineixen un conjunt de valors, actituds i ingenuïtats que desvetllen una estètica.

En el part III aprofundeixo l'aplicació del model retòric a la praxi curatorial, proposant, primer, una axiomàtica de la intensitat retòrica de l'art en la forma urbana lles tensions Bell / Sublim i Cos / Idea) i després posicions artístiques exemplars, enquadrant la possibilitat d'una gràcia del social en el nucli de l'art en / de la ciutat. La dinàmica ethos de l'atenció, logos del dispositiu (en punt crític) i pathos de la gràcia social revela finalment el projecte extramurs com a proposta d'intervenció urbana. 


\section{THE RHETORIC OF ART IN THE CITY}

This research is both a theory and a critique of art in the urban form. It proposes a set of key terms and operations, consolidated around the noema 'public art'. Public art is presented as a meta-modality of citizen emancipation based on social aesthetics. It concludes that rhetorics, with its tripartite structure (ethos/logos/pathos), is the total rationality where an artistic conscientization of the projectual values of attention, device and grace becomes a concrete dynamics. Those values are considered fundamental in the emergence of an emancipated experience of the city.

In Part I, I evoke the consequences of several critical movements in the artistic and urban avant gardes, in essay and cultural critique. In the contemporary art regime, I highlight personalities and modes of the conceptual turn and in land art, stabilizing a grammar of art in Public Space. Three binomic sets of issues condense the problematic: Museum, intervention lthe urban intervention as proposing another kind of memory and representation of the collective); Context/situation (the situation as corollary of a conscience of the ephemeral and the contextual); Activism/participation (activism as modality of communitarian participativity). My intention is to revisit the jargon of contemporary public art, in order to radically problematize urban culture, in the framework of an ever-emergent general urbanism.

In Part II, I make an analysis of the case studies LISBOA CAPITAL DO NADA - MARVILA 2001, SINAIS, A CIDADE HABITADA, LUZBOA (all events which happened in Lisbon) and SKYWAY (in Poland). In this sequence of curatorial experiences, the artistic interventions, separately and as an integrated dynamics, define a set of values, attitudes and ingenuities which reveal an aesthetics.

In Part III I underscore the application of the rhetorical model to curatorial praxis, proposing, first, an axiomatics of rhetorical intensity of art in the urban form lthe tensions Beautiful/Sublime and Body/ldea) e then exemplary artistic positions, framing the possibility of a social grace in the core of art in/of the city. This rhetorical dynamics - ethos of the engaged attention, logos of the device in a critical point, and pathos of social grace - finally reveals the extramuros project as a particular urban intervention proposition. 


\section{PREÂMBULO. HISTÓRIA E LUGARES DE UM PERCURSO PESSOAL}

Da anamnese da vivência ao entendimento e uma dinâmica..............................................11

Objectivos e sentido da investigação - o tema da arte pública extramuros....................................13

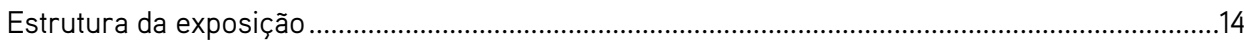

Extramuros: conceito e metáfora, élan vital e retórica da arte na cidade ........................................16

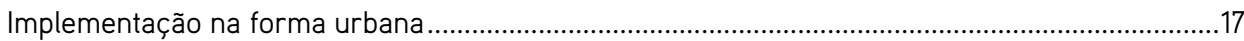

Atenção, dispositivo, graça: uma dinâmica complexa no espaço público ..........................................18

Do Nada à Luz: a dialéctica temática de um argumentário .............................................................19

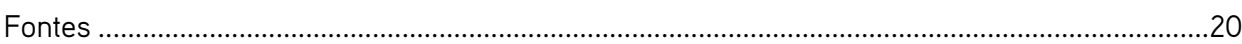

\section{ARTE PÚBLICA CONTEMPORÂNEA: ÉTICA, POLÍTICA E ESTÉTICA NA FORMA URBANA}

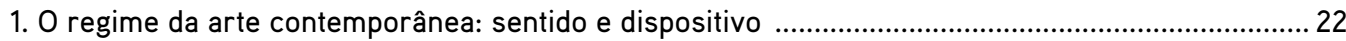

1.1 A arte na sociedade da comunicação: regime e perspectivas críticas.......................................22

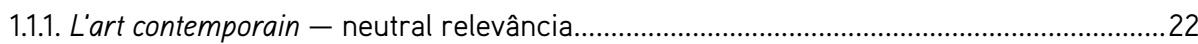

1.1.1.1 Estetização da vida quotidiana, urbanidade, performatividade................................ 24

1.1.1.2 O regime da arte contemporânea - rede, comunicação, produção, discurso.......33

1.1.1.3 Actualizações pós-modernas: lugares, relações, resistências cidadãs ..................35

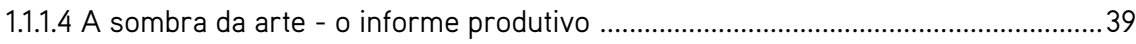

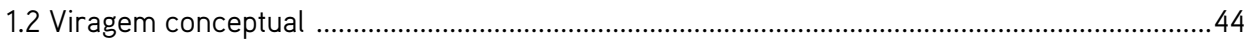

1.2.1 Figuras e modos: do motor de arranque Duchamp ao Movimento DADA,

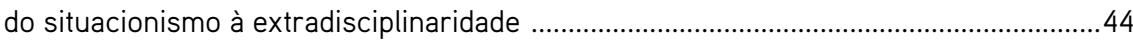

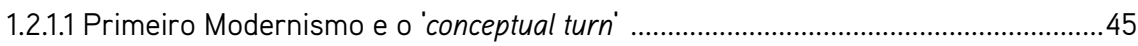

1.2.1.2 Pós-Guerra: provocação ou consequência, a deriva situacionista ........................... 47

1.2.1.3 Dobras barrocas - do fractal ao possível ............................................................... 51

1.2.1.4 Fluxus, Kaprow, neo-concretistas brasileiros, minimal - o conceptualismo

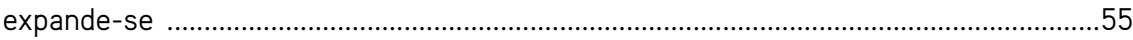

1.2.1.5 Aproximação ao activismo, indiscisciplinas extradisciplinares ...............................59

1.3 Natureza (e o Homem) e a arte contemporânea: a tradição da Land Art ...................................66

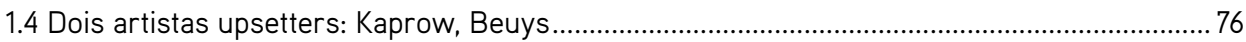

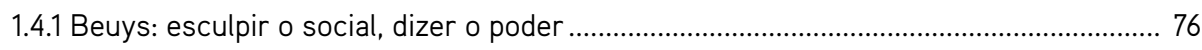

1.4.2 Kaprow: o quotidano como poder criativo ........................................................................... 79

2. 0 campo semântico da arte pública contemporânea: termos ……................................................ 87

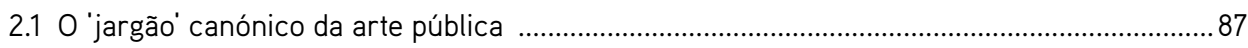

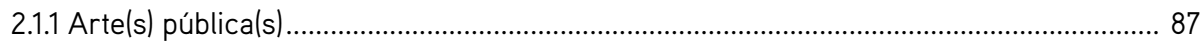

2.1.1.1 Actualizar o belo: símbolo e festa............................................................................... 88

2.1.1.2 Artes públicas - anos 80 e 90, movimentações de interesse público .................. 91

2.1.1.3 Da cultura como evento, da cidade como imagem, à procura do público .............92 
2.1.2 Obras eloquentes: uma gramática .95

2.1.2.1 Do monumental ao social, uma síntese tipológica ..................................................95

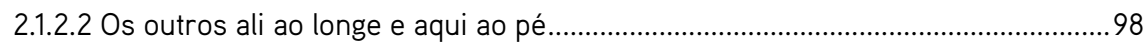

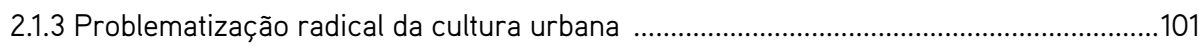

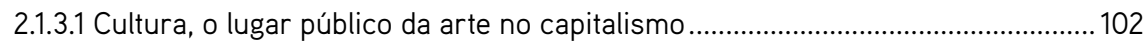

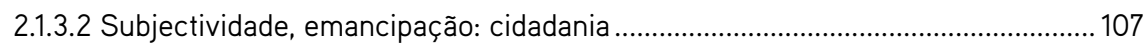

2.1.3.3 Outra política cultural para a indústria - o desígnio do design.............................110

2.1.3.4 Cinismo e progresso. Para um ambiente propício à democracia ...........................111

2.1.3.5 Cinética mobilizadora, dar lugar à materialização da cultura ................................... 119

2.1.4 Futuros urbanos na cidade pós-industrial ....................................................................... 123

2.1.4.1 Cidade e urbanismo, cultura e arte: a atenção à cidade....................................... 123

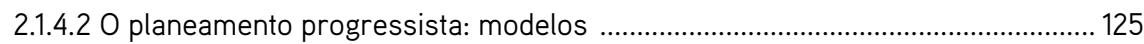

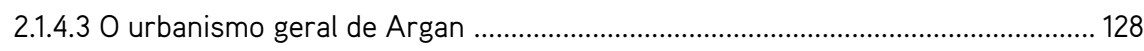

2.1.4.4 Ambientes responsivos - da totalidade operativa (do design) .............................. 130

2.2. Espaço Público vs. esfera pública: uma dynamis na esfera do urbanismo ........................... 136

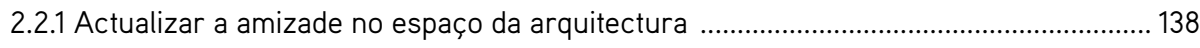

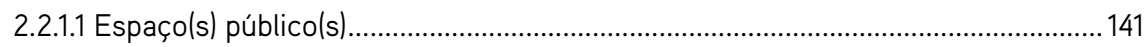

2.2.1.2 Entre o público e o privado, o espaço público como display ................................ 144

2.2.2 Museu, intervenção - rever o valor, a memória e a representação colectivos ...............147

2.2.2.1 Ritual da arte: o museu e o objecto ..........................................................................147

2.2.2.2 Resgatar, activar, propor outra memória ............................................................... 151

2.2.3 Contexto/situação - equacionar o lugar, a temporalidade e os limites do objecto ..... 157

2.2.3.1 Da arte contextual à arte da rua, a situação como encontro urbano .................. 158

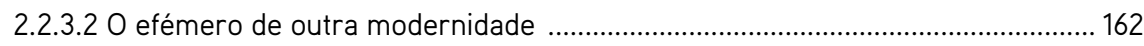

2.2.4 Activismo/participação - promover a imaginação social partilhada............................... 165

2.2.4.1 Activar a comunidade experimentalmente - do activismo lúdico às batalhas

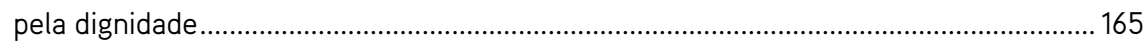

2.2.4.2 Transcendência obscurecida, comunismo ............................................................169

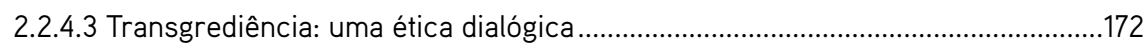

2.2.4.4 Estética (relacional) num tempo de urgência: o discurso da provocação à produção, o colectivismo depois do modernismo ........................................................... 175

2.2.4.5 O estranho, o hóspede e a máquina - da mediação à externalidade .................. 180

\section{DO NADA À LUZ: UMA PRAXIS CURATORIAL}

3. Lisboa, atitude extramuros: metáfora operativa e princípios projectuais

4. A arte como provocar do espaço público: Lisboa Capital do Nada - Marvila 2001...........................199

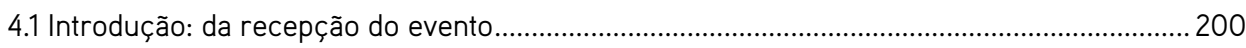

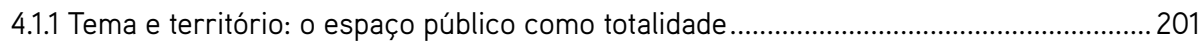

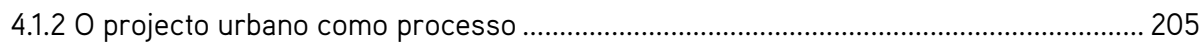

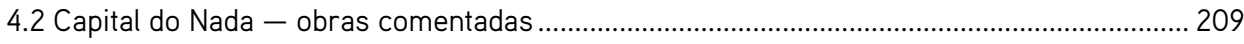


4.2.1 Projectos Estruturantes. Expressão mediática, contacto humano,

gesto ecológico,memória urbana ........................................................................................... 210

4.2.2 O caso Maçãs de Carvalho - imponderável comunicação .............................................. 212

4.3 As componentes 'Arte' e 'Fotografia' - obras comentadas..........................................................217

5. 0 design como acção de cidadania: Sinais, a Cidade Habitada ........................................................ 223

5.1 Introdução: um projecto de sinalética participada para Marvila ..................................................223

5.1.1 Tema: um sistema de sinalética específico para a freguesia de Marvila .........................223

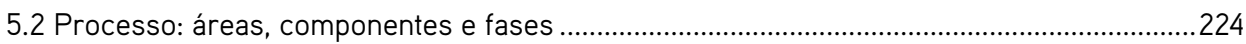

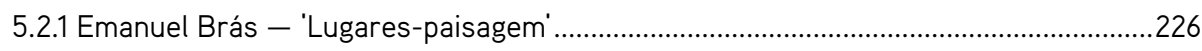

6. A arte da luz como celebração da cidade: Luzboa 2003 - 2006 .......................................................231

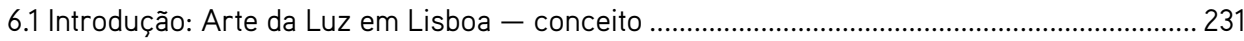

6.1.1 Do Conceito ao Evento. Luzboa '04 - tema-contexto da primeira Edição........................233

6.2 Luzboa 2004, uma constelação de eventos - obras comentada .............................................237

6.2.1 Luzes exteriores: os elementos iluminados.....................................................................238

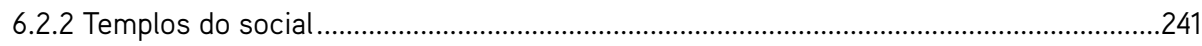

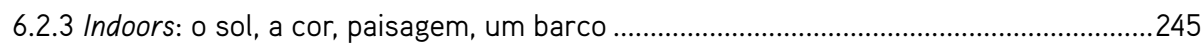

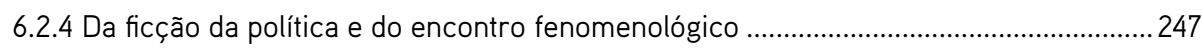

6.3 Luzboa 2006, um percurso de Luz na cidade - obras comentadas ...................................... 251

6.3.1 Implantação, percurso, programação: intervenção, intervenções......................................252

6.3.2 O habitar do espaço público - palavras, desenhos, tendas ............................................254

6.3.3 Imagens e corpos: flores interactivas, a lua à mão, rostos cerrados,

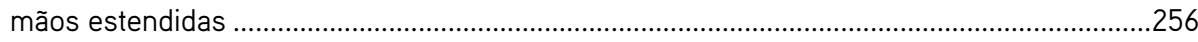

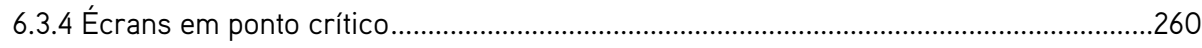

6.3.5 Indoor/outdoor: intervenções de câmara, o mar ao largo.................................................261

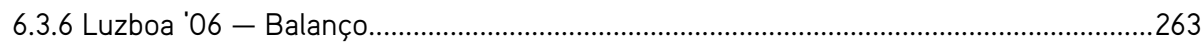

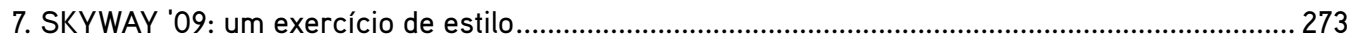

7.1 A aplicação do modelo Luzboa noutra cidade .........................................................................2. 273

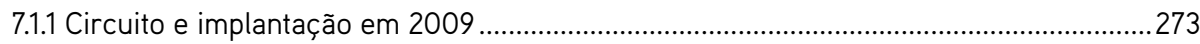

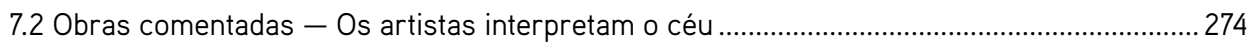

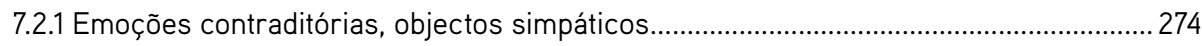

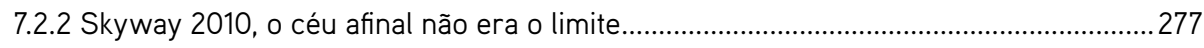

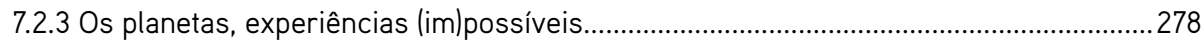

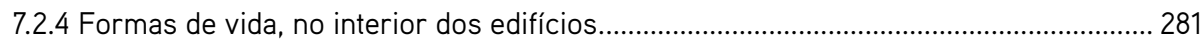

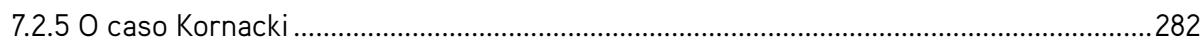

\section{O MODELO RETÓRICO APLICADO A UMA DINÂMICA CURATORIAL}

8. Axiomática da intensidade retórica na forma urbana .................................................................. 287

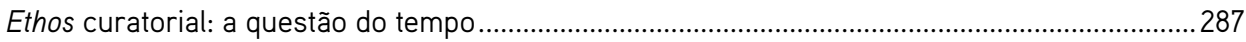

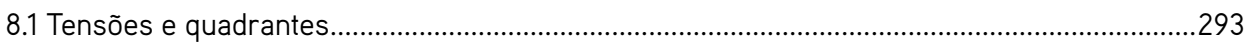

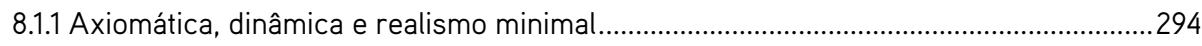

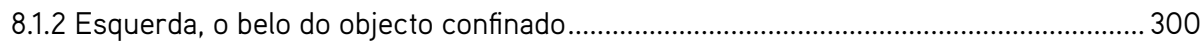


8.1.3 Direita: Land Art e esfera social, o contexto ecológico ....................................................302

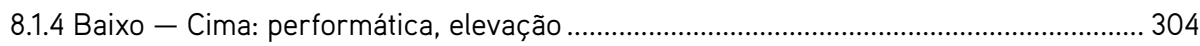

8.1.5 Vector vertical, Cima-direita: texto e demos - o sentido vs. o significado ...................... 310

8.1.6 Quadrante oblíquo, cima/direita: anónima totalidade inteligida ........................................ 315

8.2 Ethos da atenção, logos do dispositivo, pathos da graça:

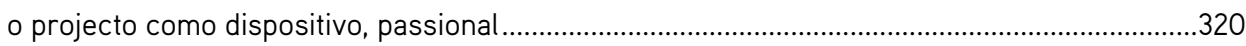

8.1.2.1 A atenção: $O$ objecto de arte no coração da retórica da atenção............................322

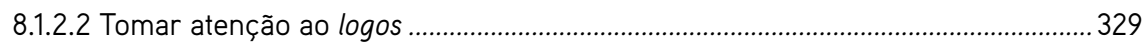

8.1.2.3 Logos projectual. Do dispositivo em ponto crítico - ponto crítico .........................334

8.1.2.4 A redistribuição do sensível: apatia vs. empatia, outra política ............................ 341

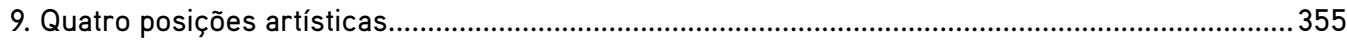

9.1 Miguel Chevalier - a beleza efémera no fluxo da imagem urbana..........................................355

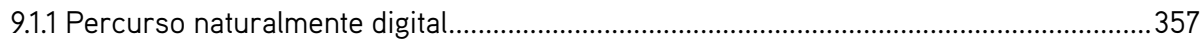

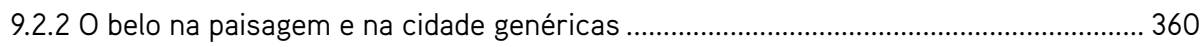

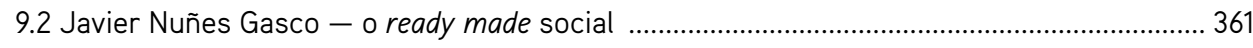

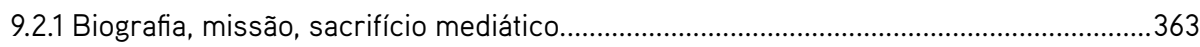

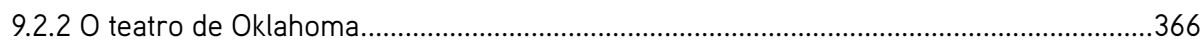

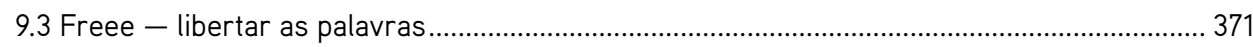

9.3.1 As Functions: a arte pública como valor económico, estético e social .............................373

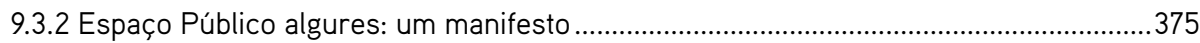

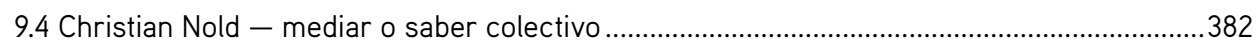

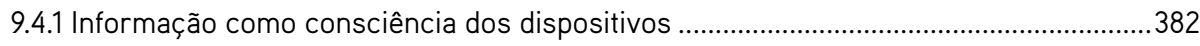

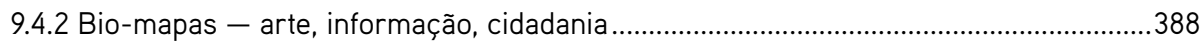

\section{CONCLUSÃO}

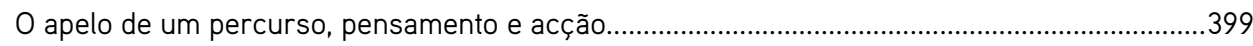

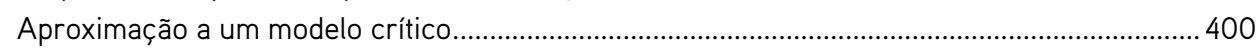

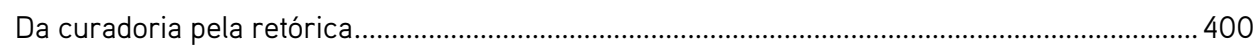

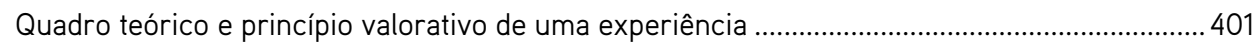

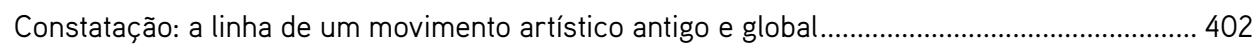

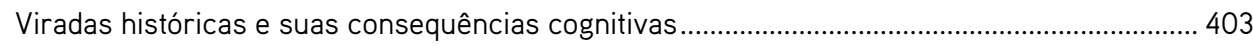

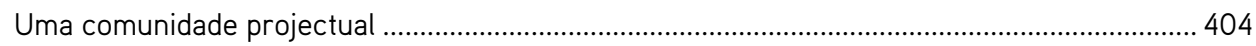

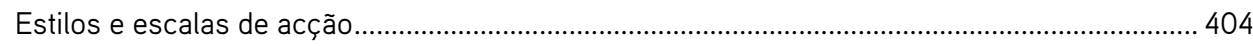

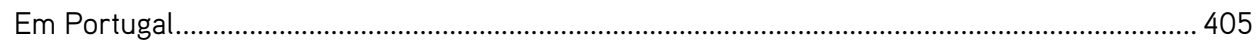

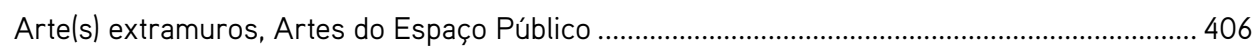

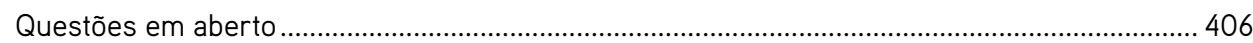

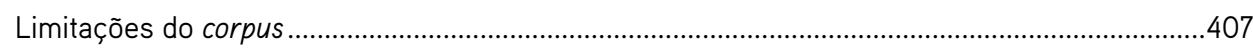

Economia conceptual de uma retórica...................................................................................... 408

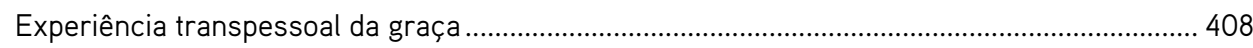

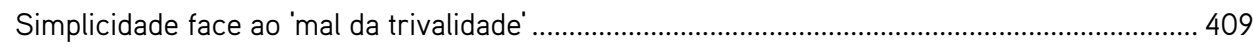

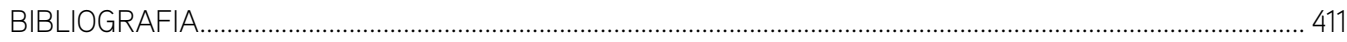




\title{
DA ANAMNESE DA VIVÊNCIA AO ENTENDIMENTO E UMA DINÂMICA
}

\begin{abstract}
A hesitação da minha geração posso eu compreender, já não é de resto nenhuma hesitação, é o esquecimento de um sonho sonhado há mil noites e mil vezes esquecido; quem se quererá zangar connosco devido ao milésimo esquecimento?

Franz Kafka
\end{abstract}

A anamnese da presente investigação reflecte sobre a origem e o futuro da arte face à cidade contemporânea. Este labor da memória, que Kafka um dia condensou na metáfora da investigação', assenta na apropriação retro e prospectiva da produção cultural e artística no campo da arte pública. Parto do princípio de que é possível ter desta uma ideia operatória, partindo dos campos da história, da crítica e da filosofia da arte, alargando-os a perspectivas críticas relativamente da relação entre arte e social (formuladas na filosofia, no ensaio e na retórica) e finalmente integrando memórias pessoais (a experiência dos eventos que realizei durante dez anos, fundamentalmente em Portugal, que conduziu à posição teórica de que a investigação dá nota). No projecto de arte pública, a atenção à multidimensionalidade dos mecanismos sociais, aplicada ao projecto artístico como dispositivo, é constituição quotidiana de possíveis experienciáveis com enorme poder expressivo (poética) e persuasivo (retórica). Laboro assim na comunicação de um inconsciente cultural que reconheci apenas quando, já durante a investigação, vislumbrei uma visão esquemática e de conjunto.

A presente Tese é sobre a energia de abertura e entendimento que a arte crítica contemporânea inscreve na vida urbana enquanto totalidade, sob a figura emancipatória da cognição ${ }^{2}$ da contingência social. A investigação aborda a forma como a imaginação artística problematiza os seus próprios limites e ao mesmo tempo a sua morfologia face ao socius. Trata-se de relevar a emergência contemporânea de um tipo de dinâmica projectual que nunca deixou de constituir, sob diversas figuras de modernidade ou da vanguarda, a arte que atenta à totalidade da cidade. Proponho-me partilhar a minha experiência como curador de eventos de arte pública contemporânea, mostrando como a atitude subjacente aos principais eventos que coordenei integra uma genealogia de intervenções artísticas que fazem da arte um espaço-tempo pertinente para dar visibilidade a um imperativo ético que se define a partir da comunidade. O trabalho é acerca dos mecanismos retóricos inerentes ao tecer colectivo do urbano de que a arte é epifania (Argan).

A interrogação fundamental reflecte várias ansiedades: será que a abordagem retórica da

1 As Investigações de um Cão (Forschungen eines Hundes), 1922.

2 Cognição aqui como acto ou processo de conhecer, que envolve atenção, percepção, memória, raciocínio, juízo, imaginação, pensamento e linguagem. Recordo que o termo tem origem nos escritos de Platão e Aristóteles. 
arte - por oposição às exclusivamente filosóficas ou estéticas - nos permite tornar a imaginação, a criatividade e a própria techne mais instrumentais num entendimento dos possíveis (e do seu próprio sentido)? É possível atribuir à arte crítica na cidade, hoje um movimento tão disperso quanto global (Scholette), a responsabilidade de problematizar a transparência do funcionamento da polis, isto é, da cidade como dispositivo? Será que a única arte verdadeiramente legítima é a pública? No âmbito da curadoria e programação cultural, pode a ética retórica contribuir para uma performática da cidadania no tempo actual?

Na cidade contemporânea, refém da crise de crescimento do modelo capitalista, a investigação releva uma atitude perante a pulsão artística que, num sentido antropológico e humanista (ainda) moderno, radicaliza ou revisita o que as vanguardas artísticas agendaram, mas agora num quadro mais fluído. Isto é, numa altura em que alguns dos desafios específicos da teoria crítica deixam de ser reconhecíveis, continua a ser pertinente pensar e experimentar a ligação entre arte e vida - arte e social -, agora tendo em conta a intuição de ferramentas conceptuais e poéticas contemporâneas, tal como cinicamente (Sloterdijk) intuídas na arte como processo e durée (Fiedler, Bergson) do contacto social. A investigação sugere que em certos momentos da história colectiva, da biografia dos agentes culturais, ou da vida de uma cidade, há situações que reinscrevem, no território contingente da sua performance quotidiana, possibilidades novas relacionadas com uma desejada superação de determinadas condições sociais. É um desassossego criativo através do qual certas obras rejeitam a filosofia para abraçar a retórica, num desejo de tornar o processo de emancipação através da pulsão artística mais partilhado e transparente, afastando os espectros da divisão cultural caracteristicamente burguesa e capitalista (Hewitt and Jordan). É uma retórica que continua a reabrir o debate acerca da função da arte na cidade.

Cruzando vários aparelhos teóricos e tradições intelectuais e propriamente artísticas, sustenho que a retórica é o campo do conhecimento adequado para pensar esta articulação efectiva entre arte e social na cidade; procedo por intuições e analogias em torno do campo semântico da arte pública para exprimir tensões produtivas de uma arte cujo princípio criativo é definido na aplicação experimental - decisões discretas num continuum criativo - da metáfora operativa extramuros.

As experiências que destaco afirmam a identidade provisória de uma década de produção cultural. É uma ética projectual específica que considera a arte um dispositivo crítico (do quotidiano) e um lugar de celebração espiritual (da communitas). Nessa identidade, um conjunto de acções manifestaram um estilo (Balzac), mais do que uma estética; vejo assim a minha própria produção curatorial, interdependente da criação e reflexão dos artistas com quem trabalhei colaborativamente. Foram eles que alimentaram a teoria, até ao momento em que pude estabelecer os princípios de um modelo. Nesse modelo - axiomática em que situo valores de projecto (o campo semântico da arte pública) - determino tensões produtivas (Miles) e depois criadores exemplares na apropriação retórica da mesma. Na sua superficialidade - what you see is what you get -, arredada de muita da produção no campo da arte contemporânea que se auto-propõe crítica mas redunda em pura metafísica, esta meta-operatividade retórica tem o condão de estabelecer premissas efectivas para debates alargados e comuns sobre a ética, a lógica e a estética do projecto artístico na cidade. 


\section{Objectivos e sentido da investigação - o tema da arte pública extramuros}

Sometimes it is necessary to uncover those earlier moments, not to establish some false pedigree, but to reconnect with and even celebrate what was previously overlooked.

Mark Wallis

A investigação aspira à comunicação da minha prática da curadoria em arte pública. Expõe uma metodologia de intervenção urbana que procura entender a intensidade retórica da arte na forma urbana. Revisita uma hipotética genealogia crítica de projectos artísticos que, perante diferentes contextos, espaços e oportunidades, colocaram aos participantes e intervenientes a responsabilidade de evoluírem de forma autónoma, na conscientização do seu ser-no-mundo (Heidegger), para além da vivência trivial. Todos esses projectos partilham traços fundamentais comuns, desde logo porque reformulam a concepção separada (Debord) da arte no quotidiano contemporâneo, por via da simplicidade, discrição e evidência dos seus mecanismos constituintes, e em prol da sua dimensão comunicacional. Como na arte pública crítica (Wodiczko), tal resulta na produção de saber partilhado sobre/na cidade.

Quanto ao ethos artístico, interessa-me como contribui para o destino colectivo, à força de acções exemplares e experimentais que são formulações críticas que se tornam património colectivo, para além dos lugares comuns a que é confinada pela organização social le sua indústria cultural) que não a reconhece. Parto do princípio de que o projecto na cidade é o dispositivo por excelência para nos apropriarmos desta forma produtiva do quotidiano. Ou seja, perante o socius definido pelo design (Flusser), e sendo este a cultura de ponta na globalização hegemónica, proponho a experiência do carácter interessado da retórica aplicada à forma urbana, na medida que esta me ajuda a compreender o sentido dos interstícios que a arte crítica humildemente orgulhosa (Gross) cria. Atenção (um cuidar), disposição (um expor) e graça (um sentir) aparecem então como os tropos de um território proposicional sempremergente que continuamente redesenha o horizonte do social, indistrinçãvel da emergência de uma consciência especificamente pública (Grout) da arte na cidade, bem como da produção artística enquanto possibilidade emancipatória (Lefèbvre), assumindo um desígnio poiético (ao nível discursivo). To cut a long story short, empreendo um elogio da arte pública enquanto meta-modalidade (parafraseio Wagner) adequada à pulsão artística que integre preocupações retóricas na sua aproximação à redenção da pulsão social.

No revisitar dos textos e produção de artistas como Duchamp, Smithson, Morris, Beuys ou Kaprow, renovo o sentido da arte pública como a arte que, mais do que representar, cria públicos. É isso que distingue essa arte da que, sob a designação burocrática de 'arte pública', se limita a laborar no seio das indústrias do consumo e da comunicação (Cauquelin), seja sob a forma da cultura événementielle, seja sob a forma da tradição turd on the plaza, cúmplices da negação generalizada da potencialidade da arte para a transformação política. Ao avaliar experiências inovadoras de monumentalização, activismo, colaboração comunitária ou celebração (festa), procuro contribuir para uma arte do espaço público; é essa 
disponibilidade para uma consciência colectiva da materialidade actual da esfera pública fugaz e muitas vezes contraditória, senão inoperativa (Nancy) - que abre caminho para um entendimento alargado do que possa dialecticamente ser relevante e/ou irrelevante para a contemporaneidade (Agamben). Constatar e abordar materialmente a dimensão retórica da arte na cidade passa por analisar a forma urbana; na órbita do urbanismo - sobretudo crítico ou radical -, decorrem de motivações, contextos, oportunidades concretas, sendo para mim determinantes aquelas que instauram ou criam um sentimento de graça social.

Em termos sintéticos, procuro surpreender os termos e a dinâmica específicos de uma arte que, progressivamente, determino a partir dos lugares da atenção (ethos), do dispositivo (logos) e da graça (pathos). Depois, penso esta arte a partir da sua implantação graciosa (Kleist) no território, como que querendo captar o seu carácter de evento-acontecimento (Buci-Glucksmann), cujo interesse é o de que expõe a intensidade retórica das suas proposições de uma forma tão dinâmica quanto retoricamente equilibrada lao nível do peso de ethos, pathos e logos na sua economia/. Nestes termos, trata-se de afirmar que alguma arte, e a um certo nível apenas alguma arte, ou alguns momentos de arte, criam verdadeiramente cidade.

\section{Estrutura da exposição}

Na história da arte, as ideias de quotidiano, participação ou comunidade, na sua articulação com a dimensão artística e estética, produziram acções que, sobretudo desde os anos 60, impuseram, progressivamente, uma vasta gramática projectual. Esta é pensável a partir da problemática da liberdade e da emancipação. Nesta suspeição inicial, busco confirmar, sempre que possível, a acuidade de certos conceitos históricos - afirmados em paradigmas de conhecimento diversos (Romantismo Alemão, Vanguarda Modernista) - e a possibilidade de certos trabalhos, formalmente díspares, serem frutos de uma mesma pulsão que seria a da liberdade da necessidade (Schiller), resultando numa performática da (curadoria em) arte pública.

A dada altura, a recorrência de termos-chave de campo profissional para campo profissional, de época para época, de artista para artista, revelou um campo semântico que se estabilizou e ao qual acabei por ir contrapondo, quase sempre com interesse, a denominação extramuros. Grosso modo, havia encontrado o termo-chave da referida pulsão retórica da arte crítica na cidade, talvez um ponto onde esta é recorrentemente chamada a recentrar-se, para legitimar a sua apropriação instrumental do próprio termo.

Laborei no quadro de uma crítica da 'arte pública'. Não satisfeito com a sua instrumentalização decorativa e/ou institucional, recuei até à operação para lhe contrapor um ethos e um logos retóricos, enquanto princípio vital (Bergson) de ordem argumentativa, persuasiva, exemplar - numa palavra, comunicacional. Ou seja, há uma arte diferente das outras, porque cria vida urbana, e operacionaliza, em consciência e no discurso, uma função social urbana. Essa será a arte pública como arte do futuro (Wagner), uma arte do entendimento comunista (ainda Wagner). Proponho concretizar uma aproximação a essa arte através de um percurso simbólico 'Do Nada à Luz'. Em torno de metáforas operativas - o extramuros genérico e os específicos Lisboa 
Capital do Nada ou Luzboa - articulo a acção e a boa vida artistotélicas com um senso táctico modelo cínico (Sloterdijk) e formal (Flusser) de revitalização política da sociedade.

Vários pensadores balizam o essencial desta posição. A visão da arte como pulsão, conhecimento específico e cognição em Konrad Fiedler e a disponibilidade para a construção utópica - retórico-projectual - em Richard Wagner constituem uma feliz 'origem' e 'futuro' de um saber complexo - o saber artístico -, que já em Schiller e Novalis havia sido abordado (ver Anexos). Este saber é convocado para a criação de cidade (e já não apenas do cidadão educado, iluminista primeiro, pequeno burguês mais tarde) na senda da sociologia experimental de Henri Lefèbvre, informada/determinada pelo contacto com as experiências das primeiras vanguardas e o Situacionismo.

Acompanho a emergência dos conceitos críticos que, especialmente na Modernidade e na Pós-Modernidade, têm servido para os criadores informarem/legitimarem as suas actividades. De Benjamin a Foucault, de Simmel a Sennet, de Arendt a Rancière - as suas distribuição do sensível e emancipação do espectador têm tido um impacto tremendo -, de Nancy a Miles ou hoje Agamben e Sloterdijk, discorro possibilidades para o discurso de/na arte, articulando essencialmente o paradigma do texto (Barthes, Bakhtin) e uma consciência eminentemente (neo-)marxista (Debord, Deleuze e Guattari) do quotidiano. A viagem brota da articulação entre posições teóricas e teórico-práticas (de Brecht a Duchamp, de Beuys a autores em actividade nos campos da Arte Conceptual, da Land Art, da Crítica Institucional e de outros movimentos afirmados desde os anos 80), com base numa reflexão sobre como arte e forma urbana se co- e reproduzem mutuamente. Na prática, trata-se de reflectir sobre a criticidade da arte na/face à cidade, perspectivando os traços críticos nos eventos do meu corpus através da irreverência critica que as esferas mais dinâmicas da retórica ou da curadoria permitem (do estudo da paixão em Daniel E. Gross à non-representational theory de Nigel Thrift, exponenciados pelas propostas de nomenclatura crítica em Lacy, Jacobs, Ardenne, Kester, Bishop, Doherty, Lind ou Holmes). Tal permite-me distrinçar reflexões políticas fundamentais das meramente terminológicas, características da moda (Wagner).

Se é a partir da cartografia afirmada desde os anos 60/70 que penso - Beuys e a escultura social, Kaprow e um bluring of art and life ou Krzysztof Wodiczko e a arte pública crítica -, dedico igual atenção à produção teórico-prática iniciada na década de 90 , de que sublinho a produção teórica ininterrupta de Malcolm Miles. No meio do repensar e questionar, por tantos autores, dos próprios campos semânticos, dos chavões e dos soundbytes, senão dos próprios princípios da racionalidade (desde Deleuze, Lacan, Foucault, Habermas), acabei por aceitar a forma como este autor, inicialmente focado no noema 'arte pública' lhe vai problematizando o interesse. Ainda assim, não abdico do termo ${ }^{3}$ porque me permite reconhecer uma genealogia, uma origem e ao mesmo tempo, sem me restringir à dimensão histórica de cada termo, explicitar a minha prospectiva de forma metaoperativa e experimental.

3 Apesar de assumir que, neste preciso momento, a arte pública não é de todo termo aceite nem pelos que sei que a advogam, nem pelos que dela não esperam grande coisa. A minha manutenção do termo prende-se com uma provocação histórica e mística, na medida em que busca um novo sentido para o que é, afinal, apenas a composição de duas palavras, em muitas esferas do discurso esvaziadas de poder. 
Portanto, esta investigação procura relevar aquelas acções e projectos que, mais do que desenrolarem-se na esfera ou no espaço público, mais do que laborarem no seio de programas de intervenção ou animação urbana, são pensados a partir da energia crítica que os move no sentido de uma intervenção urbana genuinamente extramuros. No fundo, não escapo à tautologia: esta arte é genuinamente pública porque é extramuros e genuinamente extramuros apenas e só porque é pública - o quiasmo implica um entendimento concreto das características projectuais (atitude, Sena da Silva), que a aplicação da tripartição retórica permite integrar (ou não) no espírito extramuros.

Na minha abordagem helicoidal (Justo) da história da arte, procuro situar-me no quadro de uma pragmática poiética e performática de schemas e figuras, predando conceitos e experiências à medida da intuição projectual que se apaixona pelas complexidades labirínticas do social. Isto conduz-me ao elogio de uma dimensão ética do conhecimento - dimensão que Lefèbvre deixa explícita na sua observação marxista de que a lei primeira do mundo moderno, experiência do hegemónico (Gramsci) é o desenvolvimento desequilibrado. Noutros termos, não é sustentável ser-se intelectual e não realizar uma autocrítica responsável desse estatuto, aplicando-a tanto quanto possível, ou desejável, na praxis cultural, entendida como violência (Bourdieu) necessária.

Ora para captarmos a dinâmica deste mundo violentamente injusto podemos recorrer à dialéctica. Nesta, os conceitos estão permanentemente sob escrutínio, tanto conceitos estabelecidos como novos conceitos que o investigador esteja a propor. Sem dialéctica não há retórica; e quando a arte pública tem de assumir o jogo intuitivo da nomeação (new genre public art, community based art, art contextuel, relational aesthetic...), é isso o que permite a manutenção de uma potencialidade dialéctica para a arte no mercado das ideias. Aí reside uma questão de géneros e modalidades (sempre provisoriamente) críticos desde que sobre eles possamos falar.

\section{Extramuros: conceito e metáfora, élan e retórica da arte na cidade}

A investigação reflecte sobre os dispositivos apropriados para uma arte cujo impulso vital a impele para 'fora de si', na direcção de um sentimento do social. Face aos limites impostos pelo meio urbano, estes dispositivos assumem perante a cidade uma função interventiva (espaço) e interpelativa (discurso), promovendo activamente uma forma de posteridade (Duchamp) relativamente imediata (em tempo real). Neste anseio vital de superação dos limites do quotidiano trivial através da arte, aspecto determinante nas carências oitocentistas e novecentistas (Schiller, Novalis, Schopenhauer, Feuerbach, Wagner), desenrola-se esta arte do público (Knight) como plataforma de encontros transdisciplinares (Basarescu) que se alimentam historicamente do movimento conceptual (na senda situacionista) e da deriva ambiental (e feminista) da land art. Renovar os limites da arte é então renovar a própria cidade, tanto como ideia (conceitos) como espaço-tempo vivido. Aqui, são mais uma vez as premissas de um urbanismo geral (Argan) e de uma ecologia profunda (Capra, Guattari), sob o signo do cinismo (Sloterdijk), a prefigurar a força desta acção para a 
lebenswelt urbana, que sob a forma da denúncia, da revolução, da festa ou da revelação se encontra consigo própria.

Neste sentido, é deliberadamente que o 'extramuros' do título autoriza a interpretação enquanto adjectivo e advérbio. No primeiro caso, remete para a ideia de que existirá uma estética extramuros que o tempo vem consolidando como modalidade específica; no segundo, de que se trata de uma atitude - uma maneira de fazer - que aborda expande o projecto até este integrar a vida a ser vivida. Supõe-se portanto, no processo de afirmação desta arte, que algo como uma mística dialógica do social (Buber) emerge, constituindo uma fonte inesgotável de esperança (Harvey). Esta, sendo sempre um trabalho sobre o possível, é porém verdadeira ou convincente nuns projectos mais que em outros. Precise-se que aquela abertura favorece formas de imprevisibilidade, de imponderabilidade, que tanto podem passar por integrar elementos díspares numa harmonia periclitante como apontar para um infinito especial ou temporal de que a obra é não apenas testemunho gasoso (Jimenez) mas também causa.

Tal problematização tem porém de ser devolvida ao real como universo de tensões discretas e identificáveis perante as quais somos convidados a tomar partido. A Tese dá portanto consistência teórica a uma tipologia da acção cultural no espaço urbano. Ela evidencia princípios e legitimidade de uma modalidade da arte na cidade, cuja retórica, espécie de coração de um urbanismo crítico, corresponde a uma dinâmica de participação, transparência dos dispositivos e evidência informativa e pedagógica.

\section{Implementação na forma urbana}

A proposição de uma retórica da arte extramuros pode ser abordada em função de dois principais eixos paradigmáticos. Estes correspondem a quatro modalidades-paradigma da produção artística. Este esforço de sistematização clarifica quatro interpretações da função da obra de arte na cidade. Ao longo de um primeiro eixo que determino horizontal, temos uma tradição confinada que se consubstancia numa funcionalidade decorativa do objecto de arte no espaço urbano - o seu modelo será o do Belo, e parece encontrar a sua justificação mais remota num desejo de inserir no tecido urbano momentos de contemplação de uma beleza conforme à instituição burguesa do museu; no seu oposto, uma tradição arquitectónico-paisagista, cujo modelo é o da intervenção urbana participativa-colaborativa, sob o signo da arquitectura-jardinagem (Grout) e da ecologia social (Guattari); no eixo vertical, em baixo, uma tradição performativa Dada, cujos promotores apostam na ironia, no choque, na surpresa para interferirem no fluxo sob o modelo da interrupção mais ou menos traumática, intimamente relacionada com a experiência do corpo do artista; e finalmente, no extremo deste eixo, uma tradição textual, gráfica e meta-discursiva, que assenta na articulação de conceitos - filosóficos, políticos; esta última determina-se a partir de um projecto iluminista de partilha da informação no território do debate e da comunicação. Note-se como a crucial tradição dada-surrealista, que assenta no modelo do ready-made a sua metodologia de provocação - é a linhagem estética e produtiva que, na história da arte contemporânea, inscreve e intensifica este eixo vertical, ligando a performance física (o corpo) à performática 
discursiva (a palavra). No meu corpus, estas direcções correspondem ao trabalho de quatro criadores contemporâneos - Miguel Chevalier, Christian Nold, Javier Núñes Gasco e FREEE.

Todo este trabalho esquemático é já genuinamente retórico, ao explicitar a dinâmica comunicacional das obras. Revela a possibilidade de cada obra poder ser interpretada enquanto economia (Bataille) específica (Perniola). No território da convivência e da comunicação humana, exprime a intenção de aproximar o artista da consciência do seu fazer e o público da consciência da sua fruição. No cerne desta dimensão, o dispositivo equivale ao logos da arte pública contemporânea, o contrário da idiotia (de novo Perniola). No âmbito do projecto - trabalho, produção, fazer, cognição, no real social de que o criador faz parte - dicotomias como museu/intervenção, contexto/situação ou activismo/participação cobrem grande parte de uma problemática da arte pública contemporânea, e de uma forma que nos permite entender alguns movimentos extramuros. Esta estratégia permite recuperar abordagens lúcidas das formas como a arte se apresenta ao seu público (white cube vs. situação; monumento vs. instalação; a questão da expansão do campo em Krauss) ou das formas como ela é recebida (da teatralidade de Fried ao comunitário de Kester), num quadro complexo em que, paradoxalmente, é possível, graças à retórica, definir conceitos operativos.

\section{Atenção, dispositivo, graça: uma dinâmica complexa no espaço público}

Da minha posição sincrética, identifico a constância de alguns termos que reduzo a uma economia retórica nuclear. Refiro-me à atenção lacção que condiciona um impulso de envolvimento e de empatia mais ou menos radical); à graça (no sentido de uma emoção redentora que brota da experiência intensa e consciente do corpo social); e finalmente ao dispositivo (num sentido de apparatus, inspirado nas investigações de Foucault ou Agamben e que se consuma de forma instrumental no conceito-experiência do projecto).

Por vocação histórica, a arte tem sido definida por uma actividade em que, de forma concentrada, explícita, consciente, o Homem se supera no sentido do próprio fazer artístico. Com Duchamp e a arte conceptual, toda a genealogia autocrítica e auto-reflexiva adquire uma expressão e uma visibilidade ontológica e um carácter epistemológico le por vezes cognitivol que torna a arte necessariamente mais colectiva e objecto de uma consciência social cuja densidade é a da informação. A relação entre arte e texto é aqui historicamente uma conquista relativamente recente (Beech). Exponenciada pela multiplicidade de canais de informação e comunicação disponíveis, consciente de uma dimensão material-temporal-temporal (desde o minimalismo), a arte veio ao terreiro da cidade questionar-se, valorizar-se e, nesse movimento, fazer de todos uma problemática que até aí lhe havia sido de alguma forma exclusiva. Essa a premissa para uma análise da função social da arte, uma premissa que a investigação procura contextualizar historicamente. Não pude por isso deixar de explorar categorias filosóficas tais como utopia ou sublime, especialmente como produto ou referência de acções mais ou menos radicais de aproximação entre arte e esfera do social. Nos dispositivos extramuros que abordo, é desejavelmente nestes termos, de uma democratização utópica da experiência artística, na espécie de sublime social que é a graça 
secular do socius que se trata. Talvez seja isso que procuro na resenha histórica mostrar como as formas estagnadas da indústria cultural (o objecto de arte no Museu é o seu ícone) podem ser substituídas ou complementadas por processos sociais construtivos de que a obra de arte participativa, comunitária ou relacional são modelos nossos contemporâneos.

Cultura e comunicação, traços civilizacionais exponencialmente desenvolvidos na contemporaneidade, são dois dos campos que a arte extramuros deliberadamente integra, reconhecendo o seu peso na definição do nosso mundo. São dois termos que permearam a minha própria abordagem da arte do espaço público, sendo que esta é uma membrana (Capra) em constante adaptação a todas as carências de uma publicidade, visibilidade e sentido da criação que supere a separação que nos inferniza o quotidiano. Daqui à antevisão de uma dimensão espiritual que, depois, na economia da nossa retórica, o termo comunismo (Wagner) autoriza a extrapolar no sentido da festa do social (graça). Face ao quotidiano da abstracção - reificado, disciplinado, mistificado, mercantilizado, alienado... - a arte extramuros terá um sentido emancipatório e redentório concretos.

Por aqui passa a questão de uma expansão transdisciplinar da própria 'arte política'; mas no termo extramuros é como se concentrássemos a dimensão política da arte numa metáfora cuja origem territorializada é em si um comentário potencialmente crítico à própria ideia estagnada ou reificada da polis. Uma das conclusões da reflexão crítica assente nesta premissa é portanto a de que só uma arte tão complexa e contraditória (Venturi) como a cidade the pode fazer (à cidade) justiça, nela se integrando de uma forma mutuamente esclarecedora. Trata-se, tautologicamente, de 'salvar a arte através da cidade' e de 'salvar a cidade através da arte'. É que algumas obras inscrevem a publicidade do espaço de uma forma total, desafiando todos os aparelhos teóricos e filosóficos, no presente imediato de encontros vitais. O Espaço Público é mais do que o espaço público infra- e superestrutural das cidades, e naturalmente outra coisa que o domínio público (burguês e capitalista). Ou melhor ainda, se a cidade é arte, o Espaço Público crítico é o seu punctum.

\section{Do Nada à Luz: a dialéctica temática de um argumentário}

A investigação é um exercício de argumentação baseado nos diferentes dados recolhidos (na teoria dos pensadores, na evidência da documentação, na paixão da memória). Identificadas as questões mais evidentes, relaciono-os com conceitos fundamentais (de épocas mais remotas). A selecção de tais conceitos decorreu da sua importância mais ou menos explícita no âmbito dos projectos, eventos e obras que tencionei expor e serviu concomitantemente de grelha de selecção de textos chamados a cotejar as suas ideias com o real do corpus. O resultado é um exercício retórico de articulação entre conceitos e experiências, formulados em época diversas. A Tese procura portanto articular uma experiência pessoal com a teorização de um modelo de emancipação através do conhecimento. $O$ seu objectivo é o de constituir uma síntese cognitiva pragmática. É um saber dialógico, contextual, situacional, poético, cuja pragmática exige a integração do encontro, da partilha do efémero, enquadrados por uma dialéctica de emergência meta-operativa. 
Durante dez anos, toda uma vontade de intervenção cultural se orientou em função de dois pólos que parecem hoje condensar as afeições projectuais, dois pólos de vitalidade que estabelecem uma dialéctica: um pólo positivo, utópico, idealista, absoluto, redentor que a metáfora da Luz parece conter, e um pólo negativo, niilista, performativo, que a metáfora do Nada parece sugerir ${ }^{4}$. Sugiro que ambos correspondem a polaridades tão dinâmicas quanto profundas do agir na polis - sendo ambos necessários, na sua interrelação produtiva, para que o pulsar extramuros se transforme em manifestação da criticidade da vida na cidade. Estes dois pólos - cachos de possibilidades poiéticas - não excluem outras metáforas e hipóteses de argumentação e discurso - Alma, Dor, Sinais, Skyway... Mas o que é essencial é que a intensidades das intervenções que coordenei debaixo de ambas as bandeiras levou-me a considerá-los estruturantes. O Nada e a Luz são, nestes termos, os valores activos de uma ética projectual - talvez específica da realidade portuguesa de que me sinto imanência.

Seja como for, a minha experiência projectual conduziu-me a uma série de operações discursivas básicas, que determinaram, na esfera das actividades artísticas realizadas, múltiplas leituras das duas principais metáforas operativas a que acima fiz referência - o Nada e a Luz. Em torno da Alma - Retratos da Alma (1995) -, da Dor - Um Cálice de Dor (1999) -, do Nada - Lisboa Capital do Nada (2001-02) -, dos Sinais - Sinais - a Cidade Habitada (2003) - e da Luz - Luzboa (2004-2006) -, esta metodologia programática ver-se-ia testada internacionalmente no Festival Skyway $(2009,2010)$. Cronologicamente, a Alma e a Dor conduziram ao Nada: dois eventos realizados em espaços interiores expandiram a sua metodologia para o espaço da cidade; os Sinais constituíram uma pausa reflexiva antes da Luz - o primeiro procurou restringir-se a uma ideia de design participativo, no concreto de uma encomenda, o segundo abraçou o conceito de evento urbano a partir de uma ampla acção comunicacional, na esfera do marketing urbano. ${ }^{5}$ Já a modalidade Festival de Luz assume no evento Skyway uma identidade compósita que de alguma maneira procede à síntese ética- e conscientemente cínica do conjunto de experiências anteriores; o facto de este acontecimento se ter desenrolado no quadro de uma consultoria para a candidatura da cidade polaca de Torun a capital europeia da cultura em 2016 sugere um reconhecimento internacional das premissas projectuais de que a Tese enuncia a dinâmica.

\section{Fontes}

Quanto às fontes, recorri à reflexão crítica editada em livro e na internet - artigos, ensaios, teses de mestrado e doutoramento, catálogos. Na hibridez das suas formas, algumas outras fontes foram importantes para recuperar aspectos explícita e simultaneamente teóricos, políticos e propriamente artísticos (conversas, memórias). Relativamente aos eventos propriamente ditos, não posso deixar de ressalvar que há em muitos casos a tendência para a memória do catálogo substituir-se à experiência da obra, uma vez que um número considerável de acontecimentos não podem ser experienciados pessoalmente.

4 Até certo ponto, é o par nietzscheano Apolo/Dionísios revisto à luz das experiências da contemporaneidade.

5 No intervalo, a proposta dos projectos-memória (2007) surge como modelo de reflexão a partir do documentário e, de uma forma genérica, não cabe na economia da presente investigação a não ser pontualmente. 


\title{
ARTE PÚBLICA CONTEMPORÂNEA: ÉTICA, POLITTICA E ESTÉTICA NA FORMA URBANA
}

\author{
First, find where you belong... \\ Then dig in \\ Gary Snyder
}

Esta Problemática estabiliza as ideias necessárias e suficientes para o desenho da argumentação. Recupero temas/movimentos essenciais na transição da arte moderna para a arte contemporânea e, com o concurso dos estudos urbanos, reflicto acerca da condição pós-moderna que enquadra a minha retórica da arte pública. Num carrossel de conceitos operativos (o jargão da arte pública), evito a tecnicidade, por forma a operacionalizar a concreção fundamental arte-cidade, no quadro de uma movimentação global (Scholette) de aproximação entre arte e vida urbana. Busco assim o sentido actual de uma arte pública crítica, conceito que Krzystof Wodicskco avança nos anos 90, como hipótese de uma transformação crítica da cultura a partir de dentro'. Um autor que faz uma intervenção teórica de fundo dedicada à arte pública (inspirada por Arendt, Marcuse, Freire, Rancière) é Malcolm Miles $^{2}$, cuja extensa obra aborda múltiplos ângulos da forma urbana, e a multidimensionalidade $^{3}$ do espaço público no quotidiano. Miles filosofa o urbano numa perspectiva ensaística transdisciplinar, no quadro de um urbanismo geral. O modelo discursivo de Miles - menos dialéctico que filosófico, mais conversacional que estritamente argumentativo, como num metadiálogo ${ }^{4}$ remotamente socrático - constitui o enquadramento ideal para a minha própria edificação de uma genealogia crítica, que ganhou 'foros de cidadania' quando entendeu como o contributo da retórica (de Aristóteles a Gross, passando por Perelman) poderia enriquecer os debates da teoria crítica.

1 Vidal,Carlos, «Peter Bürger - O Futuro da Vanguarda», in Democracia e Livre Iniciativa - Política, Arte e Estética, Fenda, Lisboa, 1996, p. 41

2 Tive a oportunidade de editar em Portugal a sua obra Para Além do Espaço Público em 2001. Cf. Miles, Malcolm; Para Além do Espaço Público / Beyond the Public Realm, Extra]muros[, Lisboa, 2001. Desde então, é presença regular em eventos que tenho promovido.

3 Cf interdimensionalidade. Pedro Andrade.

4 Cf. Bateson, Gregory; Metadiálogos, Gradiva. O conceito do antropólogo tem uma leitura terapêutica no âmbito do construccionismo social. Jürgen Hargens e Uwe Grau, encaram o metadiálogo como uma plataforma comunicacional entre therapists as experts in interviewing (questioning, asking, and reflecting) and clients as experts for their domains (their lives). Thus, the authors see it as crucial to Express basic respect to the people who come to consult them in a cooperative way in order to enlarge the options of all the people taking part in the interview. Hargens, Jürgen; Grau, Uwe; «Meta-dialogue», in Contemporary Family Therapy, Vol. 16, N. 6, pp. 451-462. 


\section{O REGIME DA ARTE CONTEMPORÂNEA: SENTIDO E DISPOSITIVO}

The art of tomorrow will be a collective treasure or it will not be ART at all.

Victor Vasarely

\subsection{A arte na sociedade da comunicação: regime e perspectivas críticas}

Na criação contemporânea entendida como sistema, a arte é mais um discurso (Cauquelin). $\mathrm{Na}$ abordagem estrutural da transição da arte moderna para a contemporânea, a obra de arte, o artista, as redes de produção e circulação, a recepção, são perspectivados numa nova relação, complexa e instável, com a esfera pública e a vida social. Algumas práticas, entretanto, transformaram-se, desde os anos 80-90, num sub-regime crítico da arte actual, a que regular ou pontualmente artistas, mediadores e investigadores dedicam atenção, quando entendem necessário reflectir sobre os valores de projecto em causa na sua actividade. Presto aqui atenção ao jargão para-técnico desse sub-regime crítico da arte contemporânea, na sua relação com o tema da cidade, e que tanto foi surgindo (primeiro) em diversas vanguardas históricas como (hoje) nas expressões mais vernaculares da arte pública crítica.

\subsubsection{L'art contemporain - neutral relevância}

O conceito de arte contemporânea é uma expressão que se afirma nos anos 80 , arredando para o esquecimento expressões como 'vanguarda' (avant-garde), art vivant ou art actuel 5 . Interrogo-me sobre as razões para o sucesso do termo. Será que esta contemporaneidade da arte, em detrimento das ideias de vida ou actualidade significa uma negação das articulações entre arte e social que as vanguardas do século XX arriscaram? Nessa eventual sublimação acrítica dar-se-á uma negação do poder da arte $(G r o y s)^{6}$ ? Millet, face à cultura que a enquadra, a arte contemporânea transporta muitas vezes o valor da transformação, e na sua vocação constitutiva interpela cognitivamente o social urbano, especialmente nalguma arte assumidamente pública. No campo da arte contemporânea, aquela pulsão de mudança, por definição crítico-emancipatória, é historicamente constrangida, por um lado, pela hegemonia do aceitável (conservadorismo) e por outro pela ditadura do novo (moda); pelo que às formas mais vitais sobra cortar, mais ou menos enfaticamente, com o sistema:

Breaking out of the museum means becoming popular, alive, and present outside the closed circle of the established

5 Millet, Catherine; Art Contemporain - Histoire et Géographie, Paris, 2006.

6 Segundo Millet, algumas ideias-chave definem o campo da arte contemporânea: sentido de experimentação tecnológica e conceptual, praxis de superação das formas tradicionais, enfoque na processualidade do projecto, estendendo-o à colaboração interdisciplinar, consciência da complexidade e contingência dos processos de produção e recepção artísticas, desejo de inovação cutting edge... Em suma, um conjunto de traços em função dos quais o milieu vai legitimando o que está no centro - na moda -, nas margens ou até fora do seu campo de acção - abaixo do radar. Tudo isto desenrola-se no quadro de uma indústria cultural (Adorno, Horkheimer) que promove uma economia de falsas necessidades em função de uma mercantilização do sensível. Resta então saber em que medida essa mercantilização é mortal para a vitalidade do socius. 
artworld, outside the museum's walls. Therefore, it seems to me that the positive excitement about the end of the new in art is linked in the first place to this promise of bringing art into life - beyond all historical constructions and considerations, beyond the opposition of old and new?.

\section{Material, quotidiano: formas na cidade}

Situando a génese da arte contemporânea entre 60 e $69^{8}$. Millet descreve autant de formes d'art ayant recours à toutes sortes de materiaux hétéroclites. À des objets manufactures, des matières naturelles et périssables, et jusqu'au propre corps de l'artiste. Esta questão - fundamental da materialidade (e da desmaterialização, Lippard ${ }^{10}$ ), que entronca na da inscrição da problematicidade do(s) dispositivo(s) ${ }^{11}$ - encontra uma formulação feliz no título de uma exposição que é um marco na curadoria - When attitudes become form lQuando as atitudes de tornam forma) comissariada por Harald Szeemann em 1969. Esta perspectiva ancora dois temas interligados: o quotidiano da produção, recepção e valoração artísticas; a esfera das relações sociais que se estabelecem em função do acontecimento-arte e da sua legitimação em múltiplas esferas discursivas. Afinal, após desmaterializações várias, l'art est devenue contemporain en nous parlant de notre vie de tous les jours. ${ }^{12}$ Num processo de aproximação ao quotidiano ${ }^{13}$, esta sutura da arte com o real está na forma como o nouveau réaliste Raymond Hains realiza ironicamente o seu próprio (e outro) Project Modern ${ }^{14}$, modelo de apropriação criativa da cidade. Arte contemporânea e arte urbana, enquanto arte da cidade viva e actual, serão então, no limite, uma e a mesma coisa? Apenas quando a arte urbana crítica corresponde ao desenvolver de competências ao mesmo tempo tácticas (reacção aos desafios da forma na vivência urbana) e estratégicas (abertura teórica para um social em mutação acelerada). Nestes termos, a arte emergente da cidade exprime (e produz) a natureza urbana ${ }^{15}$. Millet confirma, a propósito da pop art de Robert Rauschenberg ou Jasper Johns: [...] c'est la combinaison de cette esthétique, où chacun s'exprime dans les formes qui lui sont personelles, avec des images qui au contraire appartienent à tout le monde. ${ }^{16}$

7 Groys, Boris; «On the New», in Art Power, 2008, p. 23-42. Mas há ilações mais complexas que Groys retira desta dicotomia arte (no museu) / vida(lá fora), mormente face ao desafio da autonomia.

8 Com o novo realismo (nouveau realisme), o accionismo, a op art e a arte cinética, a arte minimal e os monocromáticos, Fluxus e o happening, arte conceptual, arte povera, land art, body art, support-surface.

9 Millet, p.27.

10 Lippard, Lucy; Six Years: The Dematerialization of the Art Object from 1966 to 1972, Praeger, New York, 1973.

11 Millet, p. 29. [...] la définition de cet art contemporain est peut-être, pour partie, dans cette relation entre des ouvres qui tentent d'imposer un mode d'existence qui ne serait rigoureusement valable que pour elles et des structures sociales qui acceptent, chaque fois, d'inventer les moyens de s'y adapter.

12 Idem, p. 31.

13 Que já vinha sendo ensaiado de Balzac a Courbet, de Baudelaire a Manet, de Picasso a Duchamp, de Chaplin a Brecht, passando por Mallarmé ou Péret, torna-se definitiva com os Situacionistas. Cf. Johnstone (ed.). Stephen; The Everyday, Whitechapel, MIT Press, Cambridge, Massachusetts, 2008.

14 Sob título sintomático, Travailleurs Communistes, a pintura, entre o ready-made e o espectáculo, denota uma verve colaborativa, colectivista e anónima. Nela a cidade desvela-se já não sob a forma de paisagem ou tema exterior, mas re-velação imanente do que, não fosse o olhar artístico, seria a mera acumulação quotidiana de cartazes públicos nas paredes.

15 Num processo em que a metáfora do cartografar me parece apropriada, Mapping the Terrain foi o título do marcante projecto de Lucy Lippard em que 'nasce' a new genre public art.

16 Idem, p. 33. 


\subsubsection{Estetização da vida quotidiana, urbanidade, performatividade}

A questão da estetização da vida quotidiana é traço marcante da contemporaneidade (Millet). A cultura emergente do design industrial ${ }^{17}$ teve impacto na cultura material quotidiana, no design funcional ou decorativo da cidade actual. Quando nivelado como moda (international style), foi objecto de reacções de antagonismo e ironia (o cinema de Jaques Tati). Mas a questão da designificação $0^{18}$ do real deve ser vista não apenas na sua relação com o design que se apoia na racionalidade científica. Há ao mesmo tempo a emergência de uma visão estética expandida (Rancière, Miles), tanto transmutação plástica e poética do quotidiano como modelo crítico de design (Stiegler).

Podemos falar de estetização da vida quotidiana em pelo menos três sentidos. Primeiro, relativamente às subcultras artísticas que nas vanguardas históricas procuraram desvanecer as fronteiras entre arte e vida. ${ }^{19}$ No seio desta tendência, qualquer coisa pode ser arte, na base do happening e hoje de um aproveitamento táctico (comunicacional) do intersticialidade da cultura do consumo. Segundo, a estetização da vida quotidiana pode referir-se ao projecto de transformar a vida em obra de arte. ${ }^{20} \mathrm{Um}$ terceiro sentido refere-se à vertiginosa realidade sígnica do fluxo de imagens e significados que saturam o tecido da sociedade actual. De Lukács à Escola de Francoforte, de Benjamin a Lefèbvre, Baudrillard ou Jameson, o que está em causa é a centrality of the commercial manipulation of images through advertising the media and the displays, performances and spectacles of the urbanized fabric of daily life therefore entails a constant reworking of desires through images. ${ }^{21}$ Neste quadro de crítica da prevalência da imagem, apontando ao discurso e às figuras, podemos partir de Lyotard para apontar a number of features which make postmodern culture figural: its emphasis upon primary processes (desire) rather than secondary (the ego); upon images rather than words; upon the immersion of the espectator and investment of desire in the objects as opposed to the maintenance of distance..$^{22}$ Há aqui todo um contexto urbano da pós-modernidade a considerar, complementado pela gentrificação nas cidades ou a emergência de ambientes simulacionais (Certeau), ou por exemplo pela abordagem populista do público por parte da nova museologia; é todo um quadro que formas experimentais de pedagogia procuram incorporar em práticas emancipatórias quotidianas. A estetização da vida contemporânea, associada à designificação para o obscurecimento do seu funcionamento é uma meta-matéria comunicacional do tecido urbano (de onde a arte pública parte para as suas aventuras). Porém a arte nem sempre está consciente de que repete essa designificação noutro nível de estetização, controlando o carnavalesco no ethos do pequeno burguês.

17 Esta passou pelo labor precursor das vanguardas, de Bauhaus a Moholy-Nagy, que funda o Institute of Design em Chicago.

18 Curiosa polissemia de um termo que aqui tanto poderá remeter para o 'design' como para 'o signo'.

19 De Dada às experimentações pós-modernas da arte crítica.

20 Desde o Bloomsbury Group de Virginia Woolf à consciência, em Rorty, de que a boa vida é função de uma expansão do eu.

21 de Certeau, Michel; «The Aesthetization of Everyday Life», in The Everyday Life Reader, p. 66. Para esta questão, rever o trabalho de Marcuse em particular Baudrillard, que define a condição da pós-modernidade a partir da nossa subjugação às imagens.

22 Lash, p. 68. 
Em casos eloquentes, irrompem no entanto momentos persuasivos acerca da necessidade de repensar a função da arte no social ${ }^{23}$; a arte que assim se desmaterializa faz a proposta de uma experiência décevante sur le plan estéthique mais [...] philosophiquement d'une grande fécondité théorique. ${ }^{24}$ Ela vai à luta (da) política no tempo da estética. A expansão dos limites da arte, associada ao aumento da permeabilidade nas suas margens, tornou esse mundo, por um lado, mais forte - como que vacinado para enfrentar os agentes externos -, mas também mais fraco - num processo de desidentificação crescente (Jimenez, Clair). Interessa-me então a emergência da figura cultural do artista como voz de uma radical urbanidade ${ }^{25}$, desenhando a sua autonomia. Na imanência da sua posição ao nível do seu próprio posicionamento ético, facto que levou muitos criadores das neo-vanguardas a desenvolverem carreiras com um pé na arte e outro noutras actividades. ${ }^{26}$ É um tipo de protocolo, que passa por uma dimensão colaborativa, e que é uma operatividade integrada, ampla performatividade social. ${ }^{27}$ Os artistas que passam à acção na cidade no âmago do social, são os que não estão disponíveis para aceitar o regime do consumismo egoísta (do objecto), no seio de um espectáculo fundado sobre a passividade do espectador, para ensaiar a viabilidade de dispositivos artísticos que resistam à dispersão e à neutralização da sua função plástica na sociedade. ${ }^{28}$ Muitos artistas procuram então dominar as imagens no sentido de dominar as hierarquias de pensamento, sublinhando neste programa menos a (necessária) autonomia individual e mais a sua consequência: um pathos colectivo de informação, conhecimento e entendimento que brota do encontro transpessoal. ${ }^{29}$ São muitas vezes

23 A própria beleza do social em ponto crítico, precisamente na senda da obra de arte como materialização do desejo de criação de situações e acontecimentos em que barreiras antigas - público/artista, autor/obra, objecto/processo - caem com maior ou menos estrondo. No interior da galeria, as combine paintings de Robert Rauschenberg são exemplo da aproximação ao real quotidiano urbano por via de um olhar esteta (como em César, Arman); mas na metodologia empresarial de Andy Warhol já temos uma arte de consumo e fruição públicos, que integra nos seus métodos de apropriação e intervenção aspectos organizativos, institucionais, materiais, formais, desse mesmo quotidiano em que se dilui. Quando Jeff Koons, nos anos 80-90 se apropria do movimento pop, desvanecem-se as incidências teóricas e políticas, numa cedência ao mercado que porém não é necessariamente acrítica - Victor Vasarely, já nos anos 50 , havia sido estrela de uma op-art que recolheu a simpatia dos campos da pop, da moda e da publicidade. Vasarely, em profunda sintonia com o campo do design gráfico, falava mesmo de uma 'arte social', e desenvolveu múltiplos que se tornariam ícones populares. É com Vasarely que se dá uma ampla apropriação da arte moderna pelo grande público, sob o signo da cultura visual. O facto de Vasarely ter visto os seus designs aplicados aos sacos de compras de grandes armazéns não é, neste contexto, o menor dos detalhes.

24 Jimenez, Marc; La Querelle de l'art contemporain, Folio, Paris, p. 201. Jimenez nota que é uma arte que precisa de teoria para ser genuinamente compreendida. Nesta tensão entre conceito, sensação e sentido, a experiência da obra de arte exige e propõe ao espectador um apparatus 'crítico' complexo.

25 Não confundir com a ideia profundamente burguesa das 'boas maneiras'. Cf. Lopes, João Teixeira; «Reflexões sobre o arbitrário cultural e a violência simbólica: os novos manuais de civilidade no campo cultural», in Museus, discursos e representações, Afrontamento, Porto, 2005.

26 O exemplo de Acconci é elucidativo, com um historial de peças marcantes no quadro da performance, durante os anos 60 e 70, e hoje uma prática profissional da arquitectura e do desenho urbano experimentais.

27 Porém, outros artistas, conscientes deste tipo de possibilidade, ignoram-na. Por recearem 'perderem-se' ou à sua aura (greenberguina). Mas a disponibilidade para a mudança fundadora, é, usualmente a descoberta e domínio do protocolo artístico (Scholes). Paradoxalmente, no campo da arte contemporânea, disso depende a possibilidade de um projecto artístico se inscrever no cânone e conquistar o seu público e depois o seu mercado.

28 Rancière, Jacques; in Público, Ípsilon, 12 Novembro 2010, p. 15.

29 Destaco o desejo de transparência - de procedimentos, do processo, dos contextos de produção - e dessa dimensão informacional pode dizer-se que interpreta uma intencionalidade generosa, de partilha das condições do próprio ofício. Por outras palavras, a arte irrompe como campo arbitrário em que o social é desmistificado (Lefèbvre) e então acontece. Esta operação implica uma opacidade de outro tipo; muitos artistas não estão conscientes de que os seus dispositivos não são nem transparentes nem inóquos, e assim, novas divisões culturais se afirmam, apesar de, nunca como hoje, o artístico se prestar a um escrutínio generalizado. Por outro lado, Lefèbvre havia diagnosticado na cidade moderna a perda de dimensão simbólica, a trivialidade do discurso ou a indiferença face às situações. Neste quadro, a arte ou 
Ouvres éphémères qui exarcebent l'instant bref qu'une poignée de spectateurs partagent avec elles; ouvres «ouvertes» qui n'existent que parce que les spectateurs les ont touchées, pénétrées. ${ }^{30}$

Estar-lá destas acções relacionais - da performance de Vito Acconci aos monumentais embrulhos arquitectónicos de Christo, do accionismo de Beuys aos happenings de Kaprow - uma lógica de situação-momento-acontecimento, um processo criativo colectivo ${ }^{31}$, contínua construção de sucessivos públicos. $O$ acontecimento, cristalização do momento, torna legível a figura do activismo (Felshin ${ }^{32}$ ); deslinda o lugar da acção-participação depois na inclusão do espectador ${ }^{33}$ num território de negociação da tensão entre palavra a imagem ${ }^{34}$. Mas quando Hans Haacke, no registo austero de Moma Poll (Exposição Information, 19705), desenvolve um sistema de democracia directa, temos uma retórica activista e ao mesmo tempo contravisual (Vidal) que actualiza a 'velha' retórica num quadro de consciência da sociedade como dispositivo comunicacional:

Ancient theories of memory regularly describe it as a technique of coordinating a sequence of words with a structure of visible places and images, as if the mind were a wax tablet inscribed with images and words, os a temple or a museum filled with statues, paintings, and inscriptions. Contemporary culture has made the interplay of Word and image even more volatile, intricate, and pervasive. ${ }^{36}$

Na sociedade da comunicação, a arte vê-se 'obrigada' a lidar com esse enfoque na instrumentalidade partilhada do dispositivo artístico sobre o qual assenta a relevância (Agamben $^{37}$ ). Este tipo de obras trazem consigo uma dimensão não apenas de informação ${ }^{38}$ mas de especulação crítica sobre a própria arte enquanto dispositivo. A deriva contestatária em Haacke é exemplo maior, como no minimalismo e na land art surgem momentos relacionais com teor cognitivo. Para Joseph Kosuth, l'art conceptuel relaie la philosophie ${ }^{39}$ o que deve ser lido à luz de Duchamp, quando afirmou que a obra é função da sua posteridade 10 Acto Criativo, 1957) e hoje do termo 'Arte Contextual' (Ardenne).

consegue fazer sentido ou aliena. Cf. Lefèbvre, Henri; A Linguagem e a Sociedade, Ulisseia, Lisboa, 1966.

30 Millet, p. 54.

31 Algo que tema ver com o sentido que, em escala diferente, encontramos nos movimentos revolucionários ou nos períodos de transição; na festa; mas também num iluminado momento quotidiano, em que o lento esforço quotidiano, com a sua contrapartida, a pesada trivialidade quotidiana, subitamente se revela ao ser pensante. (Lefèbvre, Henri; $A$ Linguagem e a Sociedade, Ulisseia, Lisboa, 1966. p. 202).

32 «But is this art?», in V.a. Aa..; Modos de hacer - Arte Crítica, esfera pública, acción directa, Ed. Universidad de Salamanca, Salamanca, 2001.

33 Cf. Jauss, Iser ou Barthes, e sobretudo Umberto Eco em A Obra Aberta, 1962.

34 CF. Mitchell, W. J. T.; «Word and Image», in Critical terms for Art History, The University of Chicago Press, Chicago, 1996, 2003, p. 51-61. Mitchell, p. 53: The domains of Word and image are like two countries that speak different languages but have a long history of mutual migration, cultural Exchange, and other form of intercourse. The Word/image relation is not a master method for siddoslving these borders of for maintaining them as eternally fixed boundaries; it is the name of a porblem and a problematics - a description of the irregular, heterogenous, and often improvised boundarie sbetween "institutions of the visible" (visual arts, visual media, practices of display and spectation) and "institutions of the verbal" (literature, discourse, practices of speech and writing, audition and reading.

35 Recordo que Information é considerada por vários historiadores como a primeira exposição de arte conceptual.

36 CF. Mitchell, W. J. T.; «Word and Image», in Critical terms for Art History, The University of Chicago Press, Chicago, 1996, 2003, p. 51-61. Mitchell, p. 54: Effective rhetoric is characteristically defined as a two-pronged strategy of verbal/visual persuasion, showing while it tells, illustrating its claims with powerful examples, making the listener see and not merely hear the orator's point.

37 Agamben, Giorgio; O que é o contemporâneo? E outros ensaios, Argos, Chapecó, 2009.

38 Felshin, p. 82.

39 Millet, p. 58. 
Numa era de máxima fragmentação narrativa e transbordando de comunicação (Jeudy), a colaboração e a participação em sede de argumentação e persuasão, inscritas pelas neo-vanguardas nos anos 60, transportaram até hoje a legitimidade desta arte para responder a uma carência de urgência democrática ${ }^{40}$, para a qual se vem desenvolvendo um logos apropriado. Nos limites desta arte (que já não tem limites), os projectos críticos representam um informe social e político (Chantal Mouffe ${ }^{41}$ ), assim como a sua gramática de valores em constante (re)construção. A arte, nestas condições, designe un nouveau rapport à l'autorité, sans illusion, déceptif sans doute, nourri du sentiment quion ne peut de toute façon plus changer la société de controle dans laquelle nous vivons $[. . .]^{42}$. Ora, em linguística, chamamos 'performativo' a um enunciado que é acção ao mesmo tempo que descreve a acção: «Je te promets que.... ${ }^{43}$. Quotidiano e mundo ${ }^{44}$ - cidade e política - tornam-se equivalentes, enquanto 'palco' das interacções sociais (Arendt) e do seu desdobramento em acção-experiência estética conduzindo, no limite, à performática, emergente ciência da acção que Lynette Hunter define como science of making through form $(s) .45$

\section{A arte a baixa altitude, arte contemporânea e projecto moderno}

Neste campo de possibilidades realistas ${ }^{46}$ - when conventional politics is seen as void of real possibilities for change $e^{47}-0$ apelo original da vanguarda, enquanto estética radical, transmuta-se em renovados mecanismos de aproximação ao contexto e à participação concretos, directos e adequados a uma agenda política entretanto despolitizada, rejeitanto os heroísmos (modernistas) em nome de verdades anacrónicas (Agamben) e cínicas (Slotjerdijk). Quando legitimados apenas no sistema da arte, estes artefactos críticos caem frequentemente numa irrelevância mais ou menos anedótica, ${ }^{48}$ sem possibilidades de atingir um público urbano em sentido lato. Portanto, é na arte crítica urbana, mais aberta aos públicos e contextos diversos, criando esses públicos, que se pode falar de transformação cultural. ${ }^{49}$ As modalidades dessa crítica do urbano podem depois incidir em aspectos diversos - infraestruturais, superestruturais, culturais, simbólicos, comunicacionais. Pensada como consciência criativa do real, a cidade reconfigura-se atomicamente, na micropolítica (Deleuze, Guattari), na heterotopia (Foucault), na multitude (Negri), nos interstícios (Miles).

40 Felshin, p. 74.

41 Core to democracy is the unknowability of the social: this is what generates pubic space. Mouffe, Chantal; «Democratic Citizenhip and the Political Community» in Mouffe, Chantal; Dimensions of radical Democracy: Pluralism, Citizenship, Community, London Verso, 1992

42 Ardenne, Paul; «L'Espace Publique est devenu une fiction», in Lieux Publics, 2008, p. 9.

43 Millet, p. 61. [...] un énoncé performatif. Non seulement on dit qu'on promet, mais c'est en le disant qu'on promet effectivement.

44 A mundialidade em Christine Buci-Glucksmann, e o lifeworld de Habermas.

45 Hunter, Lynette, in «Performatics: Making a noun out of an adjective», in Va. Aa; On Performatics, Performance Research, Vol. 13, N.2, June 2008, Routledge.

46 Para uma reflexão diacrónica sobre o realismo, desde o acontecimento-Courbet, ver Miles, Malcolm; «Critical Practice: Art, Intervention, Power», Routledge, 2004. Conferir igualmente o realismo de Deleuze/Guatarri, por O-Sullivan.

47 Miles, Malcolm, «Aesthetics in a time of Emergency», p. 1.

48 Em 1993, Pierre Pinoncelli urinando sobre uma réplica de Fountain, antes de a destruir com um martelo. In 2000, os artistas Juan Chi e Jian Jun Xi tentando urinar sobre outra. Mais recentemente, em 2006, Pinoncelli destrói nova cópia. A ironia é de que estes actos aumentam o valor icónico da obra (e portanto o valor do próprio ataque).

49 Maderuelo, Javier; Vv. Aa,; Espaço Público e Interdisciplinariedade, Centro Português de Design, Lisboa, 2000; p. 240. 
O caso de Barbara Kruger é exemplar deste novo regime de agency táctico, que preda as vanguardas para thes reconduzir o choque no seio dos media. ${ }^{50}$

As várias formas da autonomia em arte vão dar origem a parte importante do actual 'jargão' da arte pública; no seu desejo de 'rua', elas mantém com o sistema da arte uma relação oblíqua ou tangencial. A arte pública crítica será aí já outra arte que não a contemporânea, mas apenas tanto quanto essa 'divisão de águas' for produtiva; muitas obras colocam estas questões de forma ostensiva (e mesmo com visibilidade no regime da arte contemporânea): Parfois, cet interstice social, l'artiste, qui garde «mauvais esprit», le remplit d'une drôle de façon..$^{51}$ A este propósito, as práticas intersticiais da Estética Relacional (Bourriaud) ${ }^{52}$ - Tiravanija, Hirschhorn, Höller ou Cattelan -, apesar da porosidade das suas excentricidades, decorrem num âmbito restrito lo sistema da arte), o que torna improdutiva a destrinça entre provocação e filosofia, proselitismo, denúncia e retórica. Muitos gatekeepers do mundo da arte não arriscam a imponderável descida (Millet) a uma arte que chegou para reavaliar radicalmente as divisões culturais nela inscritas. Aos conformistas está vedada a retoricidade da arte, porque lhes é invisível a inscrição histórica da criação nas circunstâncias totais do seu tempo. Escapa lhes ao radar uma 'pequena (grande) arte' (Pinçon ${ }^{53}$ ) contextual, participativa, comunitária, informacional, cuja grandeza, para ser percepcionada, necessita de ser vista por outros prismas que não os que o mercado ou o campo artísitico consagram. Por outro lado, se o campo da arte se define pela valorização - tautológica - de certos princípios e figuras, há artistas e pensadores que apontam estrategicamente à sua própria irrelevância mercantil, procurando trazer à superfície a verdade urbana de outras economias (Bataille, Purves). A arte, quando do espaço público tem por por valor supremo a busca desse real social contingente; ela procura uma graça secularizada que será o seu entendimento popular e vernacular (Knight) do sublime - um sublime que o 'jargão' técnico da arte contemporânea, ainda a lidar com os paradoxos da modernidade (Compagnon), é depois incapaz de enquadrar.

Em crise (Benjamin) com o seu eros humanista, iluminista e romântico ${ }^{54}$, a arte contemporânea percorre o labirinto das verdades quotidianas (a hipermodernidade, Lipovetski) procurando preservar a sua autonomia, menos que como um tabu e mais como sustentáculo da sua realpolitik ${ }^{55}$. Isto implica debater, com todos - e sem recurso à violência - aquilo sobre que vale a pena debater. Certo é que a arte implica, ao mesmo tempo, a produção de objectos - interrogações técnicas: ${ }^{56}$

50 Millet, p. 83. Les oeuvres de Barbara Kruger, par leur contenu textuel et para la conscience sociale à laquelle elles font appel, font penser à l'art conceptuel. Mais la mise en page des textes - Kruger a été graphiste - sur des bandeaux rouges contrastant efficacement avec de grandes photographies en noir et blanc leur confere une force d'attraction qui est celle des «unes» de la presse de sensation.

51 Idem..

52 Um exemplo do gesto relacional: Pendant le vernissage de la Biennale de Venise en 2001, Cattelan, encore lui, embarque dans un avion cent cinquante invités parmi les plus chics. Destination Palerme, où ils contemplent de loin l'ouvre de l'artiste - une replique des grandes lettres blanches de Hollywood -, tout en déjeunant en plein soleil, au beau milieu de la plus grande décharge de la ville. Millet, p. 122.

53 Pinçon, Jean-Claude; L'Art apres le Grand-Art, Édtions Cécile Defaut, Paris, 2005.

54 Ainda que no Romantismo, porque pensamento da contradição e laboratório aberto de experiências (Shefer, p. 30), esta crise seja não apenas 'natural' como 'desejada' e o cadinho para as misturas heterogéneas (Novalis).

55 Perniola, Kester, Pinson, Beech ou Groys são pensadores que entendem esse projecto quase impossível; as divisões naturais que a arte hoje supõe são demasiado estáveis para permitirem que certas acções, por mais exóticas, exógenas, multívocas, críticas, mesmo extáticas, ponham em causa o campo enquanto forma de manutenção de assimetrias de um apparatus (Foucault).

56 Schefer, Olivier; «Propostas para a revisitação de um Romantismo frio» in Nada, n. 14, 2010. P. 31 lentrevista por Jorge 
Après tout, les arts visuels ne sont pas faits pour conforter la raison. [...] On se rend compte que les ouvres peuvent investir l'espace réel, de mêler à la vie, ou susciter un comportement nouveau de la part de celui qui regarde, sans pour autant cesser d'être des entités, ou, pour reprendre une expression du sculpteur Donald Judd, des «objets spécifiques». ${ }^{57}$

Isto implica tomar uma posição no rescaldo (da falência) do modernismo que rejeitou a cidade em toda a sua contingência: Controversy over the meaning of modernism can now be seen as having been central to modern debate about the meaning and value of art and culture. ${ }^{58}$ A conclusão inevitável é a de que o fundamental é a questão do espectador no dispositivo, que vem enriquecer e tornar multidimensional a do público face à obra. Foi isso que tornou Olympia de Manet (com L'Origine du Monde, de Courbet) retrospectivamente contemporânea: Este espectador é alguém que trabalha. ${ }^{59} \mathrm{E}$ a sua ferramenta é necessariamente a imaginação social-relacional (Marcuse, Mills) - não propriamente fantasia (Schiller) de afastamento face ao real, mas encontro com a sua matéria e mecanismos constitutivos: I take imagination to be a realistic faculty, and thus to be radically distinct from fantasy - albeit it is the persistent tendency of modern culture to conflate fantasy and imagination. ${ }^{60} \mathrm{E}$ então, de Manet até Alfredo Jaar,

\begin{abstract}
[...] a "contemporaneidade", enquanto poder de agir e poder de responder, seria aquilo que interrompe ou suspende o encerramento deste tempo num "fechamento epocal" laquilo que confina uma época à entropia e à repetição dos seus estereótipos. A contemporaneidade contrapõe a esse fechamento epocal a abertura do espaço lou a abertura da história) enquanto um tempo e um espaço a cada vez únicos [...] "Contemporâneo" seria uma forma de interrogar o que nós somos enquanto conjunto de acontecimentos, de formas de viver e de pensar, de sentir, de criar. Uma interrogação, como nós sabemos, é sempre uma interrupção e uma suspensão: ela puxa a atenção para o que está a ser interrogado, ela é, numa definição que não apenas é rigorosa como é bela, "convocação da atenção" lexpressão que retomo de Simone Weil); uma interrogação implica uma descontinuidade que requer e solicita a atenção mas que é uma "atenção configurada". [...] Essa mostração ou apresentação seria, não do mundo que hoje aparece naquilo que mais o caracteriza de forma ostensiva e sensacionalista no mainstream mediático, mas daquilo que nele mais permanence eclipsado, silenciado, oculto, por revelar, por reconhecer, por anunciar. ${ }^{61}$
\end{abstract}

\title{
Da ideologia à política (os objectos possíveis) no regime do consumo
}

Já nos anos 50, quando artistas como Support-surface ou Daniel Buren, engajados politicamente, instauram uma filosofia literalista relativamente aos próprios materiais que utilizam, pode dizer-se que deixam os materiais falar - exponenciando o seu entendimento da apropriação. ${ }^{62}$ Se relacionarmos esta posição com muita da arte conceptual e contex-

Leandro Rosal.

57 Millet. p. 167. L'objet participe d'une dialectique. Il est un écran qui evite que les gestes de l'artiste ne se dispersent dans la totalité du réel et ne s'y abîment (au sens premier du mot), ou ne s'y écrasent et se s'y abîment (au sens second). L'objet s'ajoute au monde (il ne se confond pas en luil comme un porte-à-faux et ce porte-à-faux fait que l'artiste marque obligatoirement, par rapport aux idées, aux sentiments, aus fantasmes, aux pulsions qu'il y investit, un écart.

58 Harrisson, Charles; «Modernism», in Critical Terms for Art History, The University of Chicago Press, Chicago, 1996, 2003, p. 195.

59 Harrisson, p. 197. A ideia é obviamente afim às de apropriação, performatividade e jogo. De acordo com Harrisson, Manet, em Olympia, sugere a identificação provisória entre o 'cliente' e o espectador: This not actually a person represented in a picture but someone whos eexperience or "repertoire" is supposed to be represented by it, as if he or she were standing in front of the scene of reality and experiencing it as the painting shows it.

60 Harrisson, p. 199. A propósito de Manet, Harrisson: The space of Manet's painting, on the other hand, is the space of Imodern) social imagination.

61 Silva, Rodrigo; «A Condição do Contemporâneo», in Matos, Sara Antónia (Coord. e Ed.); ESPAÇO, Oficinas do Convento, Montemor-o-Novo, 2009, p. 83-84.

62 Nelson, S. Robert; «Appropriation», in Critical Terms for Art History, The University of Chicago Press, Chicago, 1996, 2003, p. 160-173. Em operações afins à do mito (Barthes, Mitologias), os artistas empreendem visual constructs [que] succeed because viewers make themselves part of the communicative structures and appropiate, if only for a moment, one of 
tual - que são formas de deskilling (Roberts) - problematizamos a instrumentalidade da entrega à pura materialidade de uma general social technique dela, dela indissociável. Os ready-mades duchampianos foram essa experiência inicial, assim como as posições iconoclastas ensaiadas pelos situacionistas. No regime comunicacional da arte contemporânea, algo destes projectos vingou - Le moins que l'on puísse dire est que le souhait des premiers avant-gardistes de faire descendre les ouvres d'art de leur piedestal a été pleinement exaucéb3. Mas se muitas propostas de arte (dita) participativa, comunitária ou relacional, se limitam a oferecer aos participantes uma espécie de panaceia, ou funcionar como 'cimento social'64, nas margens da arte instituída há exemplos de uma criação que efectivamente, ao descer do pedestal, eleva a vida urbana e os seus protagonistas quotidianos, numa radical renovação da sua dignidade, talvez também porque, enquanto intervenção pós-media (Bréa), é irrelevante (Agamben) ela ser arte ou não. Hoje, a proliferação de criadores e projectos, filiando-se nos modelos de Beuys, Kaprow, Christo ou Haacke, muitas vezes colectivos, indica a solidez de uma falange política da arte pública urbana. Felizmente ${ }^{65}$ ou não, muita dessa arte é acção; por vezes legitimida nos palcos do campo politico em sentido estrito. Por outro lado, depois de rupturas radicais que se constituiram como acontecimentos históricos no campo da arte, há uma nova geração de artistas que abordam as questões da utopia com um cinismo projectual que evita as ilusões ${ }^{66}$. Eles servem-se do modernismo ou da vanguarda como meras ferramentas ${ }^{67}$, mesmo que uma leitura profunda da retórica em Platform, Stalker, Group Material, Francis Alys, Tim Collins ou Wochenklausur desvele um complexo movimento de fundo que não abdica da figura da responsabilidade colectiva.

Evidentemente, a filosofia da modernidade tem de ser re-interpretada para se manter elemento válido do projecto político dos criadores críticos ${ }^{68}$ apaixonados ou afectados pelo colectivo. Certo é, as condições efectivas do mercado ${ }^{69}$ não são propícias a muito mais que operações de sobrevivência: Comme les artistes peuvent utiliser toutes techniques et tous matériaux adaptes à ces conditions de travail, beaucoup réagissent au coup par coup, sans se donner le temps ni les moyens de parfaitement maîtriser ces techniques et ces materiaux. ${ }^{70}$ Nestes termos, a dimensão retórica da obra é crucial. A dupla injunção implantada pela

the dialogic positions so skullfully constructed for them.

63 Millet, p. 144.

64 Idem.

65 Millet teme deriva populista-vernacular da arte: Réjouissons-nous que la jonction de l'art et du réel ne soit pas parfaite. Beuys préchait pour une «notion de l'art élargi». Par «sculpture sociale», il entendait que le matériau sur lequel l'artiste devrait intervenir était celui de la vie politique et économique. Millet, p. 157. Mas talvez as noções de 'arte' e 'social' em Millet, agente do sistema, estejam longe das abertas pelas perspectivas mais radicalmente político-cognitivas da contemporaneidade (de Brea a Thrift, passando por Groys).

66 Veja-se a dramática confrontação com o que sucedeu às vanguardas russa ou italiana (rapidamente consumidas nos vórtices do Estalinismo e do Fascismo), ou o subsumir da imaginação em Marcuse numa voraz indústria cultural da pop.

67 Millet, p. 158: S'ils [os artistas das novas gerações] restent attachés à certains caracteres de l'avant garde, ce n'est plus avec l'ambition de transformer le monde, mais, on l'a vu, avec l'intention plus conciliante de contribuer, par exemple, à l'amélioration de l'environment urbain, ou de créer des conditions nouvelles de communication entre les personnes.

68 De Peter Bürger a John Roberts ou Dave Beech, este último integrado no colectivo FREEE, parece ser essa a agenda.

69 Toutefois, un risque demeure. Non pas celui de containdre le réel, mais celui d'être contraint par lui. Trop d'ouvres ne sont que le respect du cahier des charges d'une commande publique, ou encore la réponse à la sollicitation du commissaire d'expositions. Millet, p. 158.

70 Idem. 
modernidade da comunicação - que obriga a obra a ser o que é e ao mesmo tempo a mostrar-se como se mostra (display) - é confrontada com os desafios - discursivos - da legitimidade e da integração ${ }^{71}$. Rancière tem compreendido o desafio de abertura participativa que esta arte inscreve na paisagem da cultura, qual contra-dispositivo capaz de lidar com o excesso retiniano da cultura pós-moderna; entrementes, o visual textualiza-se $e^{72}$ e vice-versa, num modelo de autonomia da recepção que coloca os próprios códigos - os sinais e supersinais ${ }^{73}$ de Lefèbvre - sob observação,

The difference between traditional modernist art and contemporary art is, therefore, relatively easy to describe. In the modernist tradition, the art context was regarded as stable - it was the idealized context of the universal museum. Innovation consisted in putting a new form, a new thing, into this stable context. In our time, the context is seen as changing and unstable. So the strategy of contemporary art consists in creating a specific context that can make a certain form or thing look other, new and interesting - even if this form has already been collected. Traditional art worked on the level of form. Contemporary art works on the level of context, framework, background, or of a new theoretical interpretation. ${ }^{74}$

\section{Vanguarda(s)}

Enquadrada pela própria cultura como bem consumível, os anos 70 assistem à transição de um regime de consumo para um regime de (consumo de) comunicaçãa ${ }^{75}$. Une sorte de grande machine industrieuse, aguichante, tentaculaire, se met en place. Cela s'appelle «marché», mais très vite la simple loi de l'offre et de la demande, exciter l'évenement, le provoquer, l'aiguillonner, le fabriquer. Car la modernité se nourrit.7 Neste regime sociocultural a pulsão criadora é abraçada por uma evolução tecnocientífica inédita - o campo da criatividade imerso num complexo quadro de interdisciplinariedade -, mas ao mesmo tempo 'sequestrada' pela transformação fulminante da própria vida urbana, que retira à arte poder simbólico e de representação. Isto ao mesmo tempo que a explosão da arte moderna se vai desvelando o signo cultural de uma época que tinha tido início em meados do século $X I X, c o m$ a ascensão da pequena e média burguesia ${ }^{77}$ - a mesma burguesia (industrial) que vai definir a 'cosmovisão' consumista (Lefèbvre). O mundo da arte desta sociedade de consumo, dispositivo cultural de criação industrial de necessidades, assistirá, por outro lado, a uma multiplicação inevitável de potenciais pontos de ruptura, ao mesmo tempo que

71 Idem, p. 159. Elle [a obra de arte] devient aussi plus difficile à identifier. C'est alors qu'intervient le commentaire, aide nécessaire à cette identification.

72 Cf. Beech, Dave; Art and Text, Blackdog, 2009.

73 Cf. Lefèbvre, Henri; A Linguagem e a Sociedade, Ulisseia, Lisboa, 1966

74 E prossegue Groys, numa ponte para a moda na arte contemporânea: But the goal is the same: to create a contrast between form and historical background, to make the form look other and new.

75 Cauquelin, p. 18. Mencionando Baudrillard, Cauquelin: on consomme les signes spectaculaires en tant que produits, et les produits comme signe de la consommation des produits... bref, on consomme.

76 Cauquelin, p. 18.

77 Cauquelin, p. 19. Le mouvement [transformação do regime industrial clássico em puro consumo] prend sa naissance cependant les années 1850, avec la montée en pusissance de la moyenne et petite bourgeoisie. N'oublions pas que la fin du XIXe et toute la première moitié du xxe siècle sont occupées par le débat sur les théories économiques qui sous-tendent les mouvements sociaux, revendications au sujet de, travail, du juste salaire, du droit à l'expression, que valeur d'usage et valeur d'échange s'affrontent en des conflits réglés. Tandis que krachs financiers et spéculations boursiéres vont bon train, une classe moyenne emerge lentement et se stabilise dans ses goûts, ses comportements, ses opinions. Aliás, é neste quadro que se afirma uma definição burguesa de Espaço Público. Entretanto ela própria em crise. 
o objecto de arte se torna elemento de divisão cultural. ${ }^{78}$ É nestes termos que conceito de vanguarda será mot d'ordre de uma 'fuga para a frente' de vários núcleos de criação e crítica. Vários começares do zero significam isso mesmo, uma tensão insolúvel entre a pulsão da vanguarda (invenção moderna) e a modernidade como regime, num jogo de personagens - dandy, anarchist, aesthete, technologist, mystic ${ }^{79}$ - de que são porém obscurecidas as virtualidades emancipatórias, isto é, o aspecto cognitivo da experimentação ou do estilo.

\section{Isolamento}

Complexidade e Contradição, de Robert Venturi, em $1966^{80}$ contribuiu para reacender do interesse pela vanguarda culminando numa linha de entendimento da modernidade que vai de Duchamp e Man Ray a Tzara ou Brecht, até Warhol ${ }^{81}$. Nesse entendimento, se art, music, and literature [...] had degenerated thorough thoughtless and habitual formulas ${ }^{82}$, impõe-se um choque terapêutico, ${ }^{83}$ não poucas vezes legitimado pelo sentido humanista de uma reforma genérica (total) da sociedade. A arte é por isso afirmativa Marcuse), anacrónico momento de beleza numa cadeia de sofrimento ${ }^{84}$; mas também, noutra perspectiva, institucionalmente transgressiva - epitomizada na conflação arte-vida - novo culminar da ética modernista ${ }^{85}$, sendo que estas duas vias não são incompatíveis. ${ }^{86}$ No Dada berlinense, that goal was to protest the institutionalization of art in order to reengage it with life - but in conjunction with, not in opposition to, its embrace of "affirmative" popular culture. ${ }^{87}$ Dada enquadra a emergência do ready made de Duchamp (que Apollinaire anunciara premonitoriamente). ${ }^{88}$ Acontece que para que os mediadores-intermediários da cadeia de consumo da obra de arte moderna

78 Cf. Baudrillard, Pour une critique de l'économie politique du signe, Gallimard, 1972. [...] adéquation de chacun en tant que consommateurs au système de l'échange général qui est aussi échange social accompli.

79 Krauss, Rosalyn; 1986, p. 157.

80 Gibson, Ann; «Avant-Garde» in Critical Terms for Art History, The University of Chicago Press, Chicago, 1996, 2003, p. 204.

81 A outra linha integraria Manet, Picasso, Proust, Kandinsky, Mondrian, Pollock ou Stella, todos personagens de uma perspectiva habermasiana da função da cultura (face à natureza). Gibson, Ann; «Avant-Garde» in Critical Terms for Art History, The University of Chicago Press, Chicago, 1996, 2003, p. 204.

82 Gibson, p. 205. Gibson acompanha aqui Adorno e o seu elogio, por exemplo, de Kafka.

83 Gibson, p. 206. [...] when aestheticism gave way to a historical avant-garde lthose instrumental in contesting the deadening effects of art's institutionalization), including Italian futurism and German expressionism [...] cubist collage, and specially movements of the 1920s, including dadaism, the Russion avant-garde after the October Revolution, and particularly surrealism.

84 Idem, p. 207.

85 Harrisson, p. 188: Alike in all the arts, modernism is at some point grounded in the intentional rejection of classical precedent and classical style.

86 O modernismo necessita de laborar na anacroconismo para realizar as suas provocatórias continuidades: To conceive the need for a modern art is to experience one's inherited resources of expression as if they were the forms of an ancient language, such that one's would-be spontaneous utterances are required to conform to established patterns of rhetoric. Loosely conceived meaning a commitment to the modern, "modernism" thus serves to declare an interest in the revision or renewal of a language and a curriculum. Harisson, p. 188-189.

87 Gibson, p. 207-208

88 Cauquelin, p. 30. I/ será peut-être réservé à un artiste aussi préocupé d'énergie que Marcel Duchamp de réconcilier Art et le Peuple: [...] «Un art qui se donnerait pour but de dégager de la nature non des géneralisations intelectuelles, mais des formes et des couleurs collectives dont la perception n'est pas encore devenue une notion est três concevable et il semble qu'un peintre comme Marcel Duchamp soit en train de le réaliser.» [...] à réaliser «en avant» du conservatisme bourgeois. [...] Pris ainsi comme phare d'un progrès social, l'art d'avant garde se teinte de politique. Les critiques qui théorisent ces mouvements mènent un combat idéologique, dont le ton est souvent celui du manifeste. 
sejam eficazes (sistema da arte como sistema de divisão cultural), é necessário isolar esse artista-produtor, torná-lo inconsciente da potencialidade da abrangência da sua produção. $\mathrm{O}$ artista moderno - vanguardista mas num quadro reduzido e optimizado mercantilmente - vai aceitar esse destino como preço para a sua autonomia, condenada a ser a epidérmica manifestação das contradições que a haviam gerado ${ }^{89}$. Isso não impede porém uma continuidade da vanguarda no pós-modernismo crítico, pois do complexo e rico momento vanguardista vão brotar a number of related shards, each of which retains one or more avant- garde features - political, stylistic, theoretical, rhetorical, obnoxious, and so forth. ${ }^{90}$

Ainda quanto à relação entre vanguarda e recepção (a criação do público, pela obras ${ }^{91}$ ), a verdade é que aquele, ao longo de quase todo o Séc. XX, se désintéresse des avant-gardes et continue à se fixer sur les valeurs de l'art, moderne, certes, mais représentées pour lui par les Impressionistes. ${ }^{92}$ Sob a capa da pedagogia (divulgação) ou da história (canonização), as principais instituições (os museus, a universidade) passam ao lado das revoluções contemporâneas, incapazes de tecer um discurso coerente sobre os valores radicais emergentes. Groys complementa: The art of the avant-garde consciously withdrew itself from the judgement of the public. Now it is not the observer who judges the artwork, but the artwork that judges and often condemns its public. ${ }^{93}$ Este elitismo é porém relativo e, ao final, democrático, equally open to anyone insofar as it excludes everyone to the same degree. [...] De resto To demand that art be practiced in the name of existing social diferences is actually to demand the affirmation of the existing structure of society in the guise of social critique. ${ }^{94}$ Boris Groys propõe por isso um entendimento produtivo e performativo dos paradoxos da vanguarda, sobretudo enquanto consciência dos limites do próprio sistema, so that we can see modern and contemporary art for what it is, namely, a site of revelation of the paradox governing the balance of power. ${ }^{95}$

\subsubsection{O regime da arte contemporânea - rede, comunicação, produção, discurso}

Um marxismo devidamente actualizado vem introduzir uma ideia do social como mega-dispositivo, em que tudo é produção, de uma forma ou de outra. ${ }^{96}$ Nesta condição urbana

89 Gibson, p. 214: But, as Paul Mann has noted, even to talk about the death of the avant-garde is to recuperate it, and recuperation is (also) the spectacle of the internalization of the margins of cultural discourse that appears to be peculiar to the late capitalist culture that produced the avant-garde in the first place.

90 Herwitz, Daniel; Making Theory / Constructing Art: On the Authority of the Avant-Garde, University of Chicago Press, Chicago, 1993.

91 Cf. Vv. Aa.; La relation du public dans les arts de la rue, L'Entretemps, Vic de la Gardiole, 2006. A obra reflecte sobre as possibilidades dos termos público, espectador, pessoas ou população, na sequência do encontro com a arte. Pierre Sauvageot sintetiza: «J'ai beaucoup aimé ton dernier public», voilà donc le plus beau compliment à faire à un artiste. (p. 72). Gambetta di-lo de outra forma: «ll ne suffit pas de décréter des citoyens, il faut en faire» (p. 99).

92 Dário Gamboni, L'iconoclasme contemporain, le goût vulgaire et le «non-public», in Sociologie de l'art, op. cit. S'agit-il alors d'un «non-public», comme l'entendent certains sociologues de l'art?

93 Groys, pp. 111-112. It did not address the public as it was but instead spoke to a new humanity as it should-or at least could - be. The art of the avant-garde presupposed a diferent, new humanity for its reception [...] The avant-garde thus introduced a rupture in society not reducible to any previosuly existing social differences. The new, artificial difference is the true artwork of the avant-garde.

94 Idem, p. 113.

95 Idem, p. 4.

96 Smith, p. 363. 
produtiva, Being is social, and consciousness a consequence of the social production of self97. De acordo com sucessivos movimentos num campo transversal às artes e às letras (Foucault, Kristeva, Derrida, Butler, Flusser) a produtividade da arte (a poiesis), é a busca (sísifica?) de novos contextos, públicos e exigências para o discurso ${ }^{98}$. Smith sugere aqui um modelo meta-crítico, mais do que de encontro romântico, para a acção artística, recuando ao realismo conceptual de Courbet ${ }^{99}$ em que há ao mesmo tempo, uma cena concreta e a imagem de uma condição geral. ${ }^{100}$ Nesta actualização, produção já não se trata tanto de uma mimesis mas da explicitação da verdade acerca das relações sociais de produção. ${ }^{101} \mathrm{O}$ realismo de Courbet aponta assim para ao mesmo ethos crítico dos Construtivistas ${ }^{102}$, décadas mais tarde.

Within critical art history, one-sided conceptions of production have been rapidly replaced. The "ideal" realist artwork, one which pictured production as tangible, fundamental truth, has evaporated, a victim of the recognition that the master narratives, even those of universal liberation, were always going to be repressive. [...] But artwork which acknowledges its reflexivity as part of its nature, while it goes about working on the tasks at hand-questions of being, for example, of identity, of sexuality, of survival - continues to be productive. ${ }^{103}$

Em todo o caso, os produtores do real, na arte contemporânea como sistema, são os especialistas de contactos e programas de financiamento, de marketing e investimento, estrategicamente posicionados na cadeia de valor por via do seu estatuto social e da velocidade que imprimem à circulação de ideias ${ }^{104}$. No campo da arte como nas várias esferas do socius, com este predomínio da velocidade sobre os factos, dá-se, para todos os efeitos, o avanço do signo sobre aquilo de que é signo ${ }^{105}$ : Quand nous voyons une ouvre dite d' "art contemporain», nous voyons en fait l'art contemporain dans son ensemble. Il se mete en vue lui-même dans son processus de production. Il s'expose comme totalité, et totalité bouclée. ${ }^{106}$ Só que

Ce que nous appelons «le public», c'est-à-dire des citoyens ordinaires, sont conviés au spectacle, auquel ils ne peuvent que souscrire. Leur jugement esthétique mis entre parenthèses, il s'agit d'art et d'art contemporain, indépendamment

97 Idem.

98 Ainda que, no processo de mistificação capitalista do quotidano, a arte, que por princípio é a transformação de materais na comunicação e consumo de imagens, sentimentos e ideias imateriais (Idem, p. 364), possa não ter reamente poder para produzir um discurso.

99 The Stonebreakers e The Studio.

100 Smith, p. 366.

101 Idem.

102 Idem, p. 374: a group of Russian artists sought to fuse the processes of transformation and presentation. The difference is that representation, in the sense of picturing, is dispensed with. Artistic practice becomes a matter of material production which is at the same time social construction. The Productivist Group, whose active members included Tatlin, Rodchenko, Punin, and Gan, saw themselves as revolutionary creators of a new society

103 Idem, p. 379.

104 Cauquelin, p. 49

105 Idem.

106 Cauquelin, p. 55. Il devient nécessaire alors - c'est un effet du bouclage et de la saturation - de renouveler de quelquer manière cette masse qui tourne à l'identique, de proceder à une individuation, autrement dit, de multiplier des nouvelles entrées. Ce será a course au changement, à la recherche de nouvelles appellations, de nouveaux artistes, de nouveaux «mouvements». Version contemporaine de l'ancien système d'avant-garde qui caracterisait l'art moderne. [...] A la différence des avant-gardes de l'art moderne qui se montaient à l'encontre du marche officiel pour préserver l'autonomie de l'art, on a affaire avec l'art contemporain à une absorption de l'autonomie par la communication. Claro que o artista que consegue entrar na rede - ou reentrar, legitimado pelas suas descobertas no mundo exterior - é levado a procurar cumprir as regras, sob pena de ser excluído, o que impõe formas de renovação, mais ou menos desejadas. A principal: C'est-à-dire de se renouveler et de s'individuer en permanence, sous peine de disparaître dans le mouvement perpétuel de nomination qui maintient le réseau à flots. Mais cette exigence de renouvellement et d'individuation contredit constamment à une autre exigence: celle de la répétition, de la redondance. Por outras palavras, 0 artista é ao mesmo tempo 'obrigado' a repetir-se para que o seu produto seja reconhecido... E a procurar constantemente 'golpes publicitários' (Koons, Cattelan), mudanças de papel (Buren, Aconcci), situações de impacto mediático (Christo, Kapoor). 
de ce qu'ils peuvent eux-mêmes en penser. [...] C'est le réseau qui affiche son propre message: voici le monde de l'art contemporain. Ainsi le public consommé-t-il du réseau, tandis que le réseau se consomme lui-même.107

Eis a situação fundamental que a arte pública crítica coloca em causa, apontada ao enfraquecimento da dinâmica social neste regime: explorando espaços intersticiais de resistência colectiva. ${ }^{108}$ Em diversas dimensões, o trabalho crítico é assim sempre pioneiro, seja nas neovanguardas nos anos 70 (Art \& Language, Matta-Clark, Ukeles, Ehrenberg ${ }^{109}$ ), nos anos 80 (Political Art Documentation, Group Material) ou nos anos 90 (Guerilla Girls, Stalker, uma miríade multiforme de práticas relacionais nos interstícios da esfera pública pós-industrial) no enfrentar do carácter rarefeito ${ }^{110}$ da arte contemporânea, radicalmente alienada. ${ }^{11}$ Ora, quando têm origem em agentes do campo da arte, desassossegados por uma ansiedade democrática, surge uma modalidade da arte crítica e excêntrica - extramuros - no sentido de social, comunicacional, colaborativa, que contribui com uma graça específica para superar aquela condição da arte contemporânea profundamente separada: The binding value of art can thus be sought only in noncommercial - if not directly anticommercial and simultaneously collaborative - practice.12

\subsubsection{Actualizações pós-modernas: lugares, relações, resistências cidadãs}

Quando, nesta retórica, designer c'est aussi montrer ${ }^{113}$ - o carácter explícito que o dispositivo expositivo assume na arte contemporânea mais democrática - a questão da linguagem surge como pedra-de-toque na deriva contextual (Ardenne), sua 'tradução' na actual forma urbana. Cauquelin chama-lhe o trabalho sobre os lugares ${ }^{114}$ que, começando pela reflexão sobre a sua própria linguagem, levará continuamente a ensaios de refundação experimental do espaço público e da vida política - l'ouvre peut se comporter comme un «lieu», une simple enveloppe sans caractère particulier ${ }^{175}$ - vai desfragmentando os ensinamentos do minimalismo extrapolando a liberdade do conceptual e adoptando a universalidade da land art lo tópico sempre em eterno retorno do cosmos), sob figuras de temporalidade, como a da co-enunciação. Serão assim contemporâneas, num sentido político e cito tópicos soltos de

107 Cauquelin, p. 58.

108 Moulène, p. 18.

109 Cf. O seu A Date With Fate at the Date, 1971, merece comentário alargado.

110 Semedo, Alice; «Introdução», in Semedo, Alice; Lopes; João Teixeira (Coord.) Museus, discursos e representações, Afrontamento, Porto, 2005, p. 16. Este texto parte da teorização do discurso em Pierre Bourdieu para reflectir sobre a relação entre os conceitos de representação e discurso e o de museu, realizando uma síntese das problemáticas do habitus e da violência simbólica.

111 Cauquelin, p. 60. Autrement dit, l'art (les ouvres) ont-elles encore quelques réalités en elles mêmes, venues de leurs qualités propres et pouvant être jugées comme telles - une sorte d'autonomie - ou bien sont-elles tributaires de l'image que la communication peut faire circuler? De la cette hésitation, cette ambiguité: l'art est-il toujours ce qu'il était «avant», lié à ses critères esthétiques, ou bien cede-t-il la place à une réalité qui r'a plus rien à voir avec le goût, le beau, le génie, l'unique, ou la charge critique?

112 Groys, Boris; «A Genealogy of Participatory Art», in The Art of Participation, San Francisco Museum of Modern Art, 2008.

113 Cauquelin, p. 101.

114 Lieux investis, numa metafóra não isenta de ressonâncias vanguardistas (militares): Travailler ce lieu devient un imperatif pour un mouvement qui fait porter l'identification d'une ouvre comme ouvre d'art non sur son contenu mais sur son affirmation comme telle. Cauquelin, p 103.

115 Cauquelin, p. 103 
um texto de Rodrigo Silva ${ }^{116}$, experiências que transportem a inquietude, a intranquilidade, o diferendo com o tempo - tudo aspectos da origem da pulsão artística - para um plano de comunicação que é o da expectativa do espectador:

\begin{abstract}
Pode haver uma conivência ou uma cumplicidade entre-nós, tecida por aquilo que nos é comum, ou pelo que nos interessa (inter-esse), por um "entre-dois", ou por um "entre-muitos". Mas esse comum não é exactamente um depósito comum: aquilo que aí, nessas ocasiões e nesses lugares, é comum será sobretudo uma perplexidade, uma espécie de espanto, um assombro do qual nasce uma procura, ou uma busca, uma demanda, que é feita em comum - aquilo que gostaria de designar aqui como a expectativa do espectador. Por vezes, esse assombro pode tomar a forma de uma indignação, ou de uma cólera, para a qual é exigida uma formulação e uma enunciação.17
\end{abstract}

Nos territórios gasosos desta mistura (Novalis), pós-modernidade e crítica tornam-se basicamente equivalentes. A sua inovação é uma retórica de equilíbrio dinâmico entre um ethos da dissolução da identidade la paixão da atenção radical pelo outro, superando a reificação da autonomia), um logos do dispositivo tornado transparente (a desmaterialização da arte nos percursos conceptual, performativo, land, conduzindo à arte como técnica social geral, Roberts) e finalmente um pathos da graça do social (espécie de belo infinito ou de sublime redentor, que redime a condição urbana em alegorias de impacto cognitivo e experiencial).

Confirmando esta minha intuição, Cauquelin guarda para as derradeiras páginas do seu estudo as suas notas sobre a tendência relacional na arte contemporânea -

[...] une activité qui prenda au sérieux la recherche conceptuelle et questionne les conditions de possibilite de l'ouvre, et une activité surtout relationelle qui prend pour support une tradition picturale ancienne dans ce qu'elle a de plus banal, s'instaure une autre attitude face aux techniques de communication: I'utilisation des machines à communiquer elles-mêmes comme matière première d'une activité artistique. ${ }^{118}$

A esta arte - sociológica (Cauquelin), pós-média (Brea) - não falta um acento dadaísta ${ }^{119}$, assim como a verticalidade do ideal performativo-romântico-conceptual (romantismo), agora integrado numa ideia de vida urbana, sistémica, complexa e quântica na emergência (da performance à bioarte). Portanto, um princípio a move, a inovação: Mais le véritable interêt dês débats futurs dépendra certainement de la volonté dont témoigneront les différents acteurs du monde de l'art occidental pour refuser que la création artistique se réduise à n'être que l'écho fidèle de ce que la société atend d'elle. ${ }^{120}$

Daí que, ao nível de cada decisão em projecto, será possível, graças a uma grelha retórica, distinguir entre a arte que reproduz o social da que o produz? Como distinguir discursos $e$ práticas institucionais ou artísticas que contribuem para reproduzir uma certa ordem ${ }^{121}$, das que contestam o senso comum (Gramsci) na consciência pragmática de que artistic and cultural

116 Silva, Rodrigo; «Cadernos Par, Pensar a Representação», n. 3, Instituto Politécnico de Leiria - ESAD.cr, Caldas da Rainha, 2008.

117 Idem, p. 128.

118 Idem.

119 Idem, p. 115

120 Jimenez, p. 37. Enquanto aprofundamento radical desta ideia, basta lembar-nos de um caso anedótico - no sentido mais profundo da palavra: é o de Pierre Pinoncelli, artista que em 1993 destrói uma réplica de Fountain; indiferentes ao facto de a obra destruída ter sido uma réplica de fabrico recente, o pintor foi condenado a pagar cerca de 300000 francos pelos danos.

121 Mouffe, Chantal; «Every Form of Art Has a Political Dimension», Chantal Mouffe interviewed by Rosalyn Deutsche, Branden W. Josep, and Thomas Keenan, in Grey Room 02, MIT. Winter 2001, pp.99. 
practices are absolutely central as one of the levels where identifications and forms of identity are constituted ${ }^{122}$ ?

\section{Arte, política (,) relacional}

Em suma, L'art contemporain s'implique dans la vie quotidienne, s'insère dans l'environment, contribue à la transformation de l'espace public. II suppose l'adoption d'attitudes, de «postures» artistiques où les concepts, les mots, les discours tiennent une place importante, surtout lorsqu'il y a peu ou rien à voir, à sentir ou à toucher. ${ }^{123} \mathrm{E}$ precisamente porque já não se confina à representação, fréquemment, l'art contemporain [...] en appele à sa capacité de juger, d'appécier, de contempler, de méditer ou de... s'ennuyer de la part du public ${ }^{124}$. No fundo, é o nascimento do socius através da arte, em toda a sua diversidade: C'est donc ce nouveau lien social qu'il convient d'établir en créant un réseau de relations intersubjectives et participatives entre l'artiste et le public à l'opposé du tourisme culturel superficiel et consumériste. ${ }^{125}$ Certas obras - as que Estética Relacional (Gonzalez-Torres, Orozco, Hirschhorn) ou a Arte Contextual (Buren, Christo, Stalker) elencam - tendem para esta intersubjectividade, de forma exemplar. Mas apenas uma posição construída quotidianamente a partir da retórica pode expor a validade, os mecanismos ou os 'rabos de palha' de cada projecto ou percurso, porque é a única forma para problematizar publicamente o património da estética,

\footnotetext{
[...] só há democracia cultural no contexto de uma democracia avançada quando o artista deixar de ser subalternizado como "homem de corte" (que apenas decora comitivas de Estado), e passar a ser aquele que constrói HOJE o património do futuro (separando o património, tal como ainda é entendido, de um passado "aurático", lidando nós inteligentemente com, ou mesmo superando, aquilo que Walter Benjamin dizia ser uma equação que fazia equivaler um "acto de cultura" a um "acto de barbárie", sucedendo isto quando se enquista a "cultura" num patrimonialismo aurático, caro à direita que da arte não tem outra noção - pois não conhece outra dimensão de cultura que não seja a equivalência entre vida e representação, desprezando a cultura como "vida", aqui e agora!).126
}

Voltando à de rivalidade (Vidal) entre arte e natureza, Carlos Vidal esclarece quatro vias-chave: as das relações entre arte e política, entre arte e sociedade, entre artista e sociedade e entre artista e política. ${ }^{127}$ Vidal encara esta quádrupla questão como essencialmente uma única - daí a dimensão pleonástica do termo arte política - mas o cerne do seu argumento é que urge pensar aquelas questões parcelares, a partir de uma crítica dos processos destrutivos de expropriação do trabalho - o trabalho alienado torna a espécie humana estranha ao homem (Marx) - e das máquinas de linguagem associados. Convocando Badiou para junto de Baudrillard, Vidal recorda-nos que a política cria o pensamento e não o contrário [.... ${ }^{128}$ Certas obras, desde que intervenções (Mouffe) deliberadas ou abertas a uma certa contingência processual do socius, têm o condão de evocar a complexidade simultânea das dimensões artística, arquitectural e da economia política; perante um trabalho como o de Haacke Der Bevölkerung/The People para o Reichtag, em 1999, At issue seems to be a

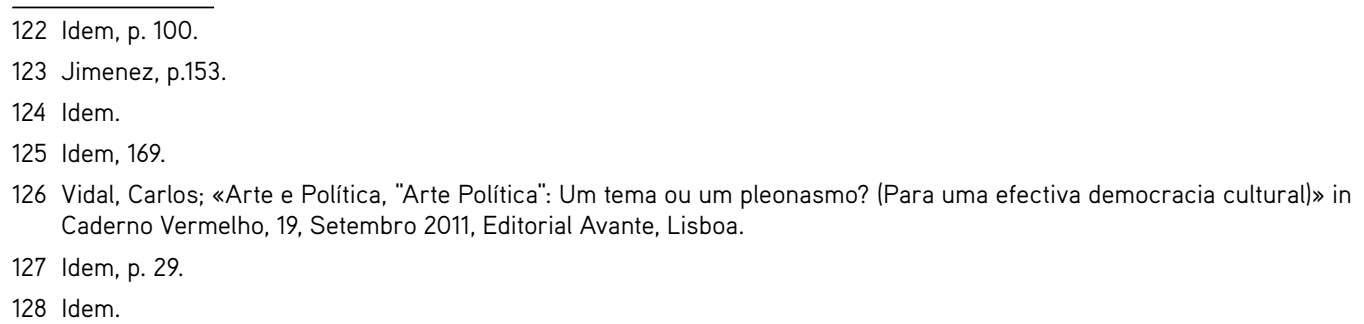


redefinition of the homogeneity that you have discussed as necessary for a democratic state, a redefinition of the political us/them or friend/enemy distinction. ${ }^{129}$ É então uma redistribuição quotidana da categoria do Povo que as obras de arte pública crítica empreendem. ${ }^{130}$ Para Arendt: Humans don't become political until they are accepted, recognized, and legitimized as citizens. ${ }^{131}$ Só que devemos estar conscientes de que é na intersticialidade da tensão liberalismo (cidadania) e emancipação (democracia) que a polis o é: [...] where I see the importance of the idea of "humanity" is in its capacity to interrupt the idea of "the demos" and bring to the fore the fact that a demos is always predicated on the exclusion of certain people. ${ }^{132} \mathrm{~A}$ arte é portanto crítica quando em ponto crítico na gestão do que nos seus dispositivos de inclusivão exclusiva do público: It's a question of constantly making people aware of the gap between the people and the population, ${ }^{133}$ ideal e pragmaticamente no quadro de uma democracia cosmopolita. ${ }^{134}$

Face à forma como os artistas reagem aos desafios do socius emancipatório, sigo a tipologia de Carlos Vidal em Malevich (ou Ângelo de Sousa), teríamos assim o artista que entende a arte como autónoma, participando na sociedade pelo seu empenhamento cívico, intervindo na sociedade pessoal ou colectivamente, mas não artisticamente; num segundo tempo (Vidal), em Alys, Sierra ou Wodiczko, não há obra de arte sem um olhar para a sociedade e seus problemas, pois a política está inscrita no medium utilizado [...] é parte do mundo politico e social envolvente; terceiramente (em Courbet ou Redol), temos os realistas, em que a partilha dos problemas (do operariado, do campesinato) reflecte vidas, experiências e dramas colectivos, sob a figura do comprometimento; por fim, o artista não aborda directamente temas "políticos" (num sentido estrito), mas antes eventos (ou temas) que têm e, em permanência, conduzem a uma força de crítica social (Gericault) com consequências políticas. Se os segundos já introduzem a arte do dispositivo face às disciplinas (tanto artísticas como quotidianas), por via tanto de objectos como sistemas que se integram no sistema dos objectos capitalistas, enquanto acções de design, será que entre a segunda, terceira e quarta tipologias há um território híbrido que seria um realismo mágico do dispositivivo social? A community art, ou formas radicalmente retóricas e/ou persuasivas de arte pública crítica e/ou dita relacional, vão ao encontro dessa hipótese na forma urbana. ${ }^{135}$

129 Joseph; W. Branden; in idem, p. 101, questiona Mouffe. Can this be considered as example of a new type of political identification or a re-identifying of the political imaginary that you're been proposing?

130 Mouffe, in idem, p. 101. If Haacke's piece is seen as a way of questioning the manner in which "the german people" is currently defined, it is a very interesting intervention. In terms of political philosophy, it points to the need to redefine "the people."

131 Idem, p. 106. [...] The depoliticizing move is to eject people from citizenship back into humanity, which is what Arendt wants to fight against.

132 Idem, p. 107.

133 Idem, p. 108. Daí que 'populaçèo' seja um conceito demasiado sociológico para se tornar politico (Branden W. Joseph) e que, com Mouffe, tenhamos de distinguir entre 'direitos humanos' e 'direitos de cidadania'.

134 Idem, pp. 110-112: I don't think the idea of cosmopolitan citizenship really makes sense. I think it is a liberal illusion that you can have citizenship without belonging to a demos. Aliás, Mouffe aponta a Europa como uma experimentação a seguir: After all, the Greek pois was not a nation-state. Today, with the formation of the European Union, for instance, there is clearly a possibility of developing a form of citizenship that would not correspond to the nation-state, but which would nevertheless correspond to demos.

135 Vidal, Carlos; «Arte e Política, "Arte Política": Um tema ou um pleonasmo? (Para uma efectiva democracia cultural)» in Caderno Vermelho, 19, Setembro 2011, Editorial Avante, Lisboa, 33. 


\subsubsection{A sombra da arte - o informe produtivo}

O regime da arte contemporânea pós-moderna equivale a uma formação contida da arte, não espelhando uma abordagem crítica de todas as possibilidades da objectificação artística. Isso não significa que seja desejável diluir completamente a arte na vida, colocando-a numa relação de concorrência com os instrumentos de comunicação de massa, com a informação e com a moda retirando à arte a capacidade de gerar sentido. ${ }^{136}$ Ora a máxima amplitude e intensidade desta problemática dá-se na virtualidade da arte pública, em que a arte lida com um plano político inscrito nas formas e nos espaços sociais, mantendo para si um espaço discursivo próprio, uma indescernibilidade necessária para a expectativa do espectador (Silva) e ao mesmo tempo a ansiedade específica da experiência colectiva. $O$ informe da arte ${ }^{137}$ será então uma reserva de infinito relacional; no regime comunicacional, só pode surgir pelo contraste com as lógicas necessariamente confinadas das instituições artísticas de comunicação dos mass media, da indústria cultural, da democracia representativa? ${ }^{138}$

Enquanto alteridade, o artístico enriquece, de obscuras hipóteses (Rancière) o fenómeno da comunicação de massas. Os gestores da periclitante relação entre arte e comunicação devem ser capazes de manobrar o objecto de arte - do ponto de vista da criação, da mediação, da investigação - por forma a lhe ir revelando diferentes facetas às diferentes luzes que the incidem, nisso porém preservando a sua relação intrínseca com a sombra de um indice original - a pulsão artística (Fiedler, Silva). Por tudo isto, a metáfora da sombra ${ }^{139}$ resiste inclusive quer às pretensões filistinas, quer ao défice teórico que na contemporaneidade conduz à idiotia. ${ }^{140}$

Se a sombra da arte abranda os fluxos dos sentidos reificados,

[...] II ne s'agirait plus d'attendre le miracle, mais de favoriser ces moments avec ce qu'ils comportent d'inconnu. [...] L'éxperience est un échange qui n'a aucune suite révendiquée et qui n'instaure aucun après; il n'y a pas aparemment de consequence, et malgré tout, cela pourrait être au commencement du politique. [...] lci, l'action est sur les bordures, en contact avec le tissue e non au centre. ${ }^{147}$

O trabalho de Gabriel Orozco é um exemplo desta sombra da arte (urbana):

Les dérives du marcheur ne sont donc pas là pour nous faire rever, pour produire du rêve - en tout cas telle n'est pas leur préoccupation essentielle - mais pour oeuvrer là où le rêve lui-même trouve matière à cristalliser sons sens comme son obscurité, sa vérité comme son mystère: dans le déplacement. Et le regardeur - piéton, analyste - invente un système de circulation dans un univers de menus artefacts, d'objets partiels que Freud designe comme le rebut, le refus de l'observation. C'est bien ce qui se refuse à la vision orthodoxe, formatée, de la ville, le laissé pour compte de son décor, qui atteint Orozco comme un punctum. [...]142

136 Perniola, Mário; A Sombra da Arte, Assírio e Alvim, Lisboa, pp. 7-8.

137 Caeiro, Mário; «Forma/informe: notas soltas. Sobre a tangibilidade formal da actividade artística e o informe produtivo», in Arq./a, N. 62, Out. 2008, Lisboa.

138 Perniola.

139 Um texto acerca desta sombra da arte é Acasto (1987) de Iris Murdoch, um 'diálogo platónico' que mostra como a experiência da arte gera espaço discursivo, sem nunca deixar de manter algo de irredutível a essa reflexão no espaço da polis.

140 Perniola, p. 20: [...] o grau zero da teoria, hoje alcançado, faz desaparecer também esse problema [o desmoronamento das certezas acerca do objecto de arte, agora que críticos e instituições são incapazes de definir parâmetros de qualidade ou legitimidade], porque retira qualquer aura não só à obra e ao seu autor, como também ao crítico e à instituição.

141 Grout, Catherine; Pour une réalité publique de l'art, Paris, pp. 114-127.

142 Davila, Thierry; Marcher, Créer - Déplacements, flaneries, derives dans l'art da la fin du XXe siècle, Regard, Paris, 2002, p. 61. 
Se nele a atenção ao detalhe é cuidar da verdade, within the biopolitics of neoliberalism, there remains a case for arguing that a politics resistant to totalizing projects must not only articulate difference and alterity but must also bare witness to the incommunicable. ${ }^{143} \dot{E}$ este o interesse do 'informe' para a praxis artística:

O informe seja um termo que podemos aplicar ao que para nós não tem limite, é desprovido de configuração reconhecível, é ou parece caótico, se desconhece, também deliberadamente [...] Inquestionável é que muita da produção artística contemporânea coloca a questão do informe como modelo de superação artística dos limites da própria arte, enquanto acção e actividade socializada. ${ }^{144}$

Quanto ao relacionar deste informe da urbanidade da arte com a dialéctica da sua aparição:

Hoje, a visão da arte passa por interpretar os objectos artísticos não nas suas evidências ingénuas (Perniola), mas na sua dimensão formal, enquanto produção de um informe tornado tangível. [...] Daí que qualquer movimento artístico seja ele próprio uma forma construindo a tangibilidade do seu tempo. Por via de acções participativas, contextuais, de denúncia moral, de comunicação de realidades, da estetização dos lugares, alguma arte urbana pode entender-se como uma arte transicional e de superação dos paradigmas culturais e científicos, no cadinho de um informe político. [...] Esta é a mensagem do informe em Boltanski lem Maison Manquante - monumento à vazio da ausência de uma casal ou na ideia de contra-monumento de Jochen Gerz, exemplos do transcendente encriptado na experiência quotidiana. Outros informes: o híbrido, o experimental, o efémero, o múltiplo, o imaterial ${ }^{145}$, o gasoso [sic, Marc Jimenez ${ }^{146}$ ] propõem uma arte finalmente liberta das formas do Belo e empenhada num desígnio de re-configuração do real. Trata-se de uma actividade que vai cartografando as formas, e em que toda uma gama de formulações do informe ganha corpo e, por vezes, expressão de uma produção revolucionária ou mobilizadora. Mais ou menos crítica ou radical, experimental ou acessória, alguma arte pública dá forma ao futuro e às nossa informes ilusões de mudança. ${ }^{147}$

\section{Belo privado, sublime público, da matéria do design à forma das pessoas}

A linguagem estercorária (Clair), a tendência anything goes, o n'importe quoi que os anos 90 trazem ao sistema da arte são um sinal de um fascismo dissimulado no cerne do que pareceria ser uma consumada palpitação da democracia, a livre-circulação das pessoas, dos bens e das ideias? ${ }^{148}$ Perniola chama a certas obras precisamente 0 simples protocolo da agonia $^{149}$, querendo com isso dizer que são inautênticas na sua indecisibilidade, enjeitando a possibilidade de uma urbanidade imponderável de traços graciosos. Seja como for, a arte contemporânea propõe uma zona descentrada tanto em relação à imaginação como em relação à vida vivida, ainda que relacionada com ambas. ${ }^{150} \mathrm{O}$ desafio que as obras mais importantes impõem é um processo de desmistificação através de um «desmascaramento do desmascaramento». ${ }^{151}$ Aí, Perniola (ou Kester ou Groys) receiam que as transgressões das

[...] Tous se passe comme si le détail recueillait la vérité criante des rues.

143 Curtis, Neil; «Art and the Immemorial», in Space and Culture, 7 (3), 2004, pp. 302-312.

144 Caeiro, Mário; «Forma/informe: notas soltas. Sobre a tangibilidade formal da actividade artística e o informe produtivo», in Arq./a, N. 62, Out. 2008, Lisboa.

145 Cf. a reflexão marxista de John Roberts em The Intangibilities of Form, Verso, Londres/Nova lorque, 2007.

146 Marc Jimenez, La querelle de l'art contemporain, Gallimard, Paris, 2005.

147 Caeiro, idem. É prospectiva. E oferece uma alternativa polimorfa aos produtos de uma indústria cultural de consumo imediato, onde um outro informe não tem um papel produtivo mas simplesmente desmobilizador, atemorizador ou simplesmente de figurante no processo de conhecimento.

148 Nesta arte sem publicidade da sua artisticidade surgem porém percursos pessoais que convidam à reflexão do público, como em determinadas peças de Santiago Sierra ou Félix Gonzalez-Torres.

149 Perniola, p. 69.

150 Idem, p. 70. O comentário é a propósito do filme Blue, de Derek Jarman.

151 Perniola citando Vattimo de /l soggetto e la maschera. Nietzsche e il problema della liberazione, Bompiani, Milano, 1974. 
fronteiras da arte não são obrigatoriamente uma evolução progressista, mas sim a subjugação do artista e da sua competência cidadã, crítica e criativa, aos imperativos dos regimes vigentes, nomeadamente o que por detrás do da comunicação como choque é o obscuro modelo económico burguês e ocidental. Em síntese, e quanto à irrelevância de tais obras, d'après Agamben:

To perceive, in the darkness of the present, this light that strives to reach us but cannot - this is what it means to be contemporary [...] to be contemporary is a question of courage, because it means being able not only to firmly fix your gaze on the darkness of the epoch, but also to perceive in this darkness a light that, while directed toward us, infinitely distances itself from us. ${ }^{152}$ [...] A produção cultural e artística surge então portanto acção mais ou menos relevante na medida em que relativiza os valores do seu tempo e nesse tempo inscreve uma ansiedade única e particular, apontada ao vazio. Em concreto, e seguindo a lógica de Agamben, o artista tem de desconfiar do reconhecimento para se manter não relevante, mas precisamente irrelevante. Só assim persiste uma voz do futuro e do que vem. Somos portanto criadores contemporâneos na exacta medida em que soubermos ser ao mesmo tempo, e de acordo com diferentes contextos e situações, relevantes e irrelevantes. É a atenção à emergência desta consciência específica do anacronismo que nos permite traçar de forma dinâmica um percurso na arte e nos define a posição, sempre relativa, perante o nosso tempo. ${ }^{153}$

Na sua aproximação entre objecto e discurso, na sociedade designificada, Flusser avança no sentido de uma nova operatividade do materialismo: ${ }^{154}$ Todo artefacto é produzido por meio da ação de dar forma à matéria seguindo uma intenção. [...] a manufactura corresponde ao sentido estrito do termo in-formação (literalmente, o processo de dar forma a algo). No sentido amplo, fabricar é informar. [...] Ao concretizar uma possibilidade de uso, o artefacto se faz modelo e informação. ${ }^{155}$ Logo, informar é o mesmo que fabricar, os objectos transportan - in-formam uma semântica. Numa lógica eminentemente fiedleriana, há que rejeitar uma separação dicotómica entre representação e referente, entre signo e coisa em si, entre teoria e prática das estruturas da linguagem. ${ }^{156}$ Depois, há que entender o indivíduo como nódulo (Cardoso) numa ampla rede de relações e possibilidades, de que se apropria pela sua capacidade de entender (e porventura superar pela sua 'arte') os códigos e as convenções. Dependente de uma relação de escritura (Rancière) com o próprio legado da memória colectiva tal mecanicidade (Novalis) é estruturante para a noção emancipada do quotidiano. Por detrás das peças e instalações mais desarmantes, da sua sombra, está a forma do seu trabalhar aos olhos da nossa consciência. Actualizando Platão na era digital, Flusser constata: $O$ despropósito consiste não apenas no abuso do conceito "imaterial" (em lugar de "energético") como também na compreensão do termo "informar". 157 "Numa crucial definição do objecto de arte como in-formação de tensões ideológicas, conclui que a forma é o como da matéria, $e$ a matéria é o quê da forma. ${ }^{158}$ Logo, as inovações da arte contemporânea que prefigurem uma noção da arte como coisa pública informam-nos acerca da matéria relacional do socius. E se hoje pensamos mais formalmente (Flusser), a arte contemporânea (mormente desde a deriva conceptual e suas sombras sócio-lógicas) deu um contributo decisivo para tal: as

152 de la Durantaye, Leland; Giorgio Agamben: A Critical Introduction, Stanford University Press, Stanford, 2009, p. 53.

153 Caeiro, Mário; «Objet Perdu. Ao encontro do infinito da arte», in Objet Perdu, Lisboa, Plataforma Revólver, Lisboa, 2010.

154 Flusser, Vilém; O Mundo Codificado, COSAC NAIFY, São Paulo, 2007.

155 Cardoso, Rafael; «Introdução», in Flusser, p. 13.

156 Idem, p. 14.

157 Idem, p. 25.

158 Idem, p. 27. 
formas não são descobertas nem invenções, não são ideias platónicas nem ficções; são recipientes construídos especialmente para os fenómenos ("modelos").159 Daí a importância de atentar ao modo como as formas aparecem - ao seu dispositivo de aparição na vida pública, ao materialismo da sua inscrição no socius. Ora, daqui Flusser parte para outra consequência:

[...] existem de fato dois modos distintos de ver e de pensar: o material e o formal. [...] A material resulta em representações (por exemplo, as pinturas de animais nas paredes das cavernas). A formal, por sua vez, produz modelos (por exemplo, os projectos de canais de irrigação na stábuas mesopotânicas). A maneira material de ver enfatiza aquilo que aparece na forma: a maneira formal realça a forma daquilo que aparece..$^{160}$

É por isso que Cézanne surge como figura-charneira na história da arte, porque conseguiu impor a uma mesma matéria duas ou três formas simultaneamente. ${ }^{161}$ Até aos dias de hoje, veio então instalar-se uma questão crucial, outra forma de pensar a criticidade (meta-) produtiva de uma obra de arte - trata-se de passarmos a considerar as formas não mais como descobertas (aletheiai), nem como fiç̧ões, mas como modelos. É neste pano de fundo da arte como emergência conceptual e conscientizadora que passo a reflectir sobre em que medida certos modos e figuras da arte se constituem, retrospectivamente, modelos da ars extramuros. 


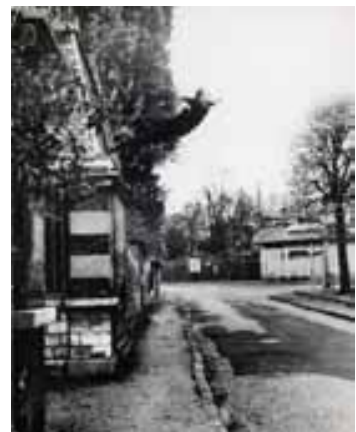

Saut dans le Vide, Yves Klein, 1960. (C) Harry Shunk

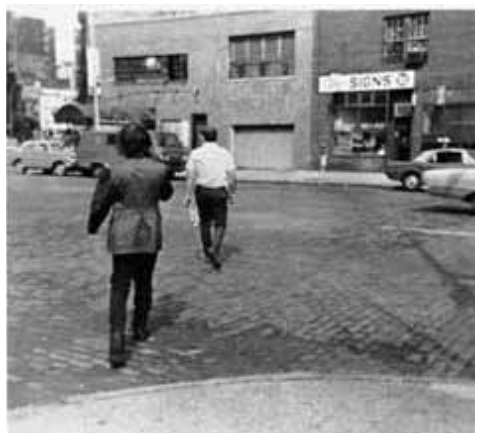

Following Piece, Vito Acconci, 1969. (c) Vito Acconci

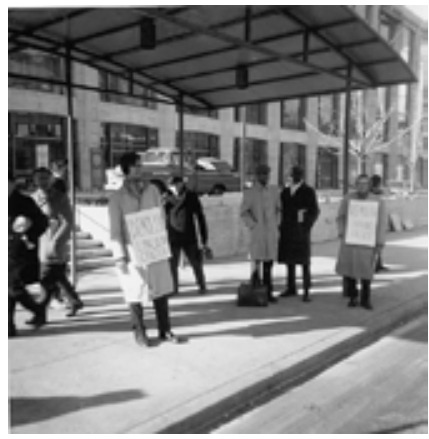

Jack Smith and Henry Flynt manifestam-se diante do MOMA, 1963. (c) Tony Conrad

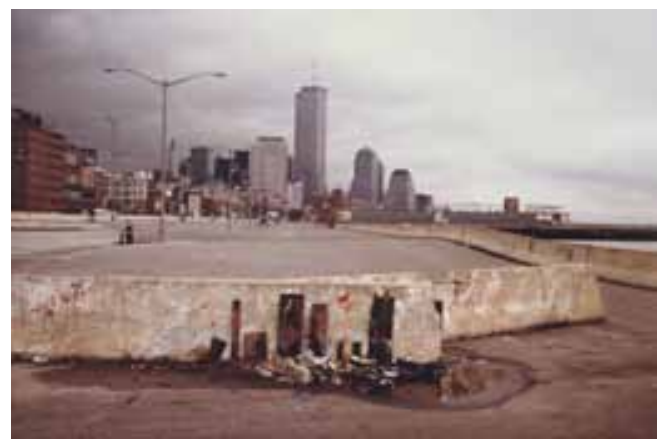

Isla en la Isla (Island within an Island), Gabriel Orozco, 1993.

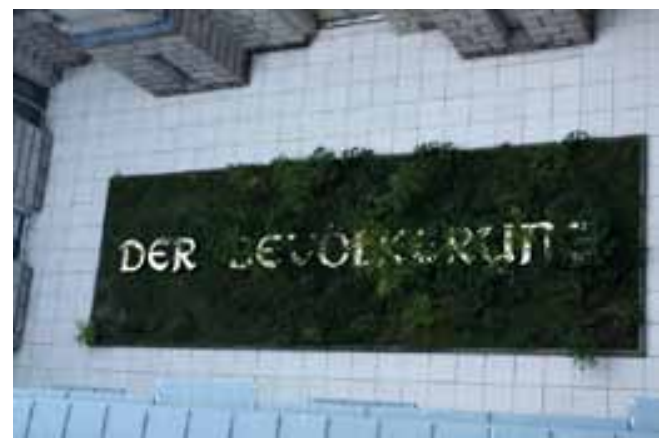

Bevölkerung, Hans Haacke, 1999.

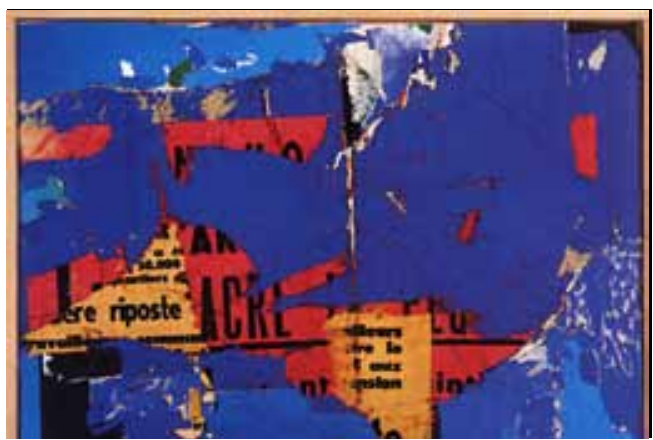

Travailleurs Communistes, Raymond Hains, c. 1962,

Musee d'Art Contemporani de Barcelona. () Raymond Hains

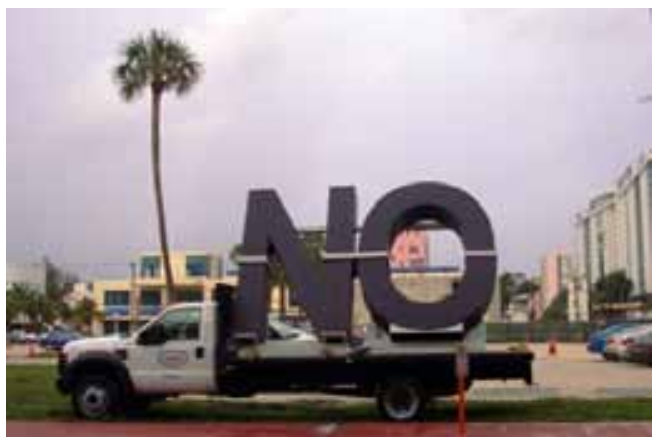

NO, GLOBAL TOUR, Santiago Sierra, 2010

Fotografia cortesia Galerie Ulf Saupe, Berlim.

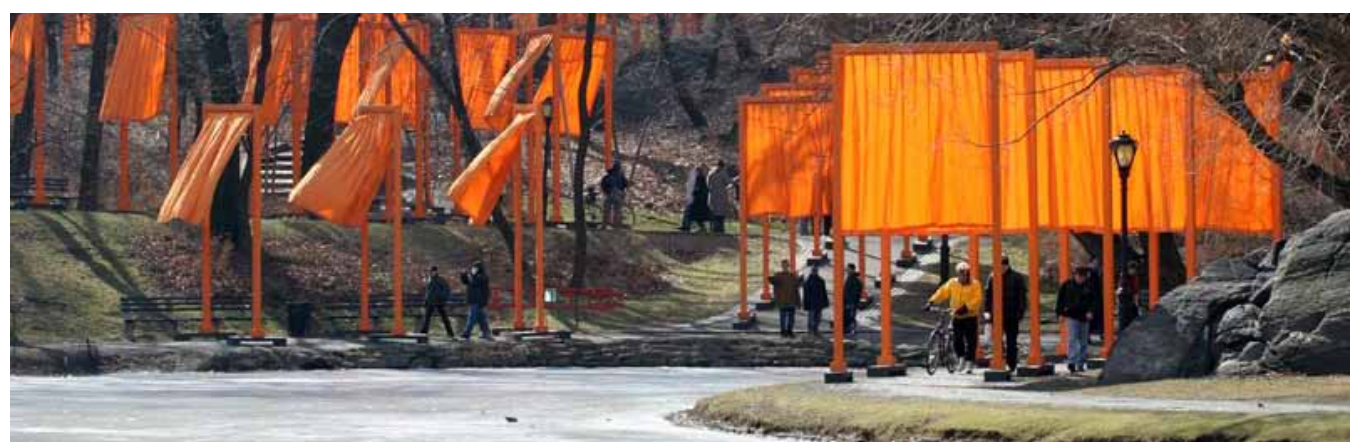

The Gates, Christo\&Jean-Claude, 2005. 


\title{
1.2 Viragem conceptual
}

\subsubsection{Figuras e modos: do motor de arranque Duchamp ao Movimento DADA, do situacionismo à extradisciplinaridade}

\author{
The museums and collections are stuffed, the floors are sagging, \\ but the real space exists. \\ Michael Heizer
}

Na transição do regime da arte moderna para o da contemporânea (Cauquelin), o «motor de arranque» fundamental é Marcel Duchamp (1887-1968). Duchamp contribui para estabelecer a arte como simplement une sphère d'activités parmi d'autres, sans qu'il soit précisé comme contenu particulier. ${ }^{162}$ Assim, o papel do artista é intercambiável com o de produtor (Benjamin), com a arte a desvelar-se sistema de signos entre outros sistemas de signos, o que abre margem para um amplo linguistic turn: la réalité qui est dévoilée est construite par le langage qui en est le moteur déterminant. ${ }^{163}$ Paradigmática, cognitiva, pragmática e sobretudo cínica, esta revolução duchampiana é central para o movimento do objecto para o processo na arte pública contemporânea ao estabelecer o primado do dispositivo. Com Duchamp, o display - o dispositivo(-lexpositivo - entra em produtiva relação com o inconsciente e o acaso, ${ }^{164}$ na contingência de cada momento, o artista duchampiano torna-se agente de uma intuição criativa que é disponibilidade para o gaze. O não-pintor é a imagem negativa desta figura, no ready-made que é porém menos negação do pictórico, que o abrir de territórios dispositivos próprios de uma radical consciência quer do indizível (sombra, informe), quer da materialidade do que é dito. $\mathrm{O}$ artista passa a estar mais ciente do coeficiente de arte $\mathrm{e}^{165}$ que outorga a um facto material, em nome de uma recepção que passa a fazer a obra (posteridade $\left.^{166}\right)$, assim se suspendendo a reificação da vanguarda pela crítica e história de arte.

Sendo o dispositivo crítico de base linguística, ${ }^{167}$ compreende-se a importância dos títulos em Duchamp, que não são, como nos surrealistas, meramente poéticos, mas propriamente uma poiética que convoca o espectador: Or les mots sont des signes impalpables, peu pesants, que la châne de communication peut faire circuler dans la pesanteur. Ils servent à la fois de lieu et de temps aux objects qu'ils titrent, et se subtituent à la matière: le titre est une couleur. ${ }^{168} \mathrm{Em}$ Duchamp os jogos de linguagem (Wittgenstein) revelam o sistema da língua e o seu uso, em afinidade com a ironia romântica (Santos). Esta faceta de transformateur (Cauquelin) discursivo opera a transição da arte moderna para as modalidades arte conceptual, minimalismo,

162 Cauquelin, p. 65.

163 Idem, p. 66.

164 A questão do encontro (Santos), que é ainda um traço da revolução surrealista, e que o conceito mais 'contemporâneo' da serendipidade permite captar - o contingente e sobretudo o momento, como ocasião - le hasard en conserve.

165 Cf. Duchamp, Marcel; O Acto Criativo, Águaforte, Lisboa, 1987.

166 Idem.

167 Cauquelin, p. 74: Dernier effet dans l'ordre axiomatique: l'importance du langage.

168 Idem. 
pop art, instalação e o próprio happening; Duchamp inaugura uma inédita intencionalidade da mensagem como problema material, na transparência da sua mecânica (Novalis); do autor como sujeito livre e voluntário (Barthes, Foucault); da linguagem como base do pensamento (pragmatismo); e, finalmente, de uma superação da vanguarda no sentido das pós-vanguardas relacionais, contextuais, participativas, em suma, retóricas. Com Duchamp, le domaine de l'art n'est plus celui du retrait et de la mésentente, du conflit avec la société, mais d'une mise au clair, circonstanciée, des mécanismes qui l'animent ${ }^{169}$ nos termos de uma general social technique.170 É com Duchamp e os gestos coevos de anti-arte (DADA) que, por volta de 1916, chegamos a uma arte que de forma consistente se apresenta como arte, ao mesmo tempo que se questiona acerca do que é - ou para que possa servir - a arte (Tony Godfrey), enquanto protocolo. [...] De forma geral, até ao ready made a arte era produto das disciplinas artísticas [...] Este facto, como sabemos, foi essencial para que se reformulasse todo o sistema protocolar em que se apoiava quer a produção quer a fruição artística. ${ }^{171} \mathrm{~A}$ prova de que Duchamp vai ser decisivo para as neo-vanguardas está no facto de que estas vieram validar a sua proposta. ${ }^{172}$

\subsubsection{Primeiro Modernismo e o 'conceptual turn'}

No advento do Modernismo encontramos exercícios de auto-consciência do dispositivo artístico que são modelos remotos da arte conceptual. ${ }^{173} \mathrm{Com}$ os primeiros ready-mades - realizados entre 1913 (roda de bicicleta aplicada a cadeira) e 1917 (Fountain), a singeleza circunstancial (economia nos dados de uma situação) e ao mesmo tempo todas as consequências da racionalidade conceptual em arte transportam a actividade artística para uma conscientização da totalidade quotidiana. Numa evolução indissociável de uma crise generalizada das formas de autoridade, a obra de arte traz consigo os termos de um debate, que decorre, desde Marx, num território socio-económico que começa a ter consciência de como os objectos nunca são apenas objectos na nossa sociedade; eles são sobrecarregados de significados e significância ${ }^{174}$. 0 discurso sobre arte não poderá doravante esquecer o problema da fetichização do objecto e o do seu valor (material e imaterial), e sobretudo das formas como esse valor acontece, no corpo político. Ora a crítica que na esfera artística primeiro aborda a problemática do iminentemente social é o movimento DADA (com o qual Duchamp chega a estar ligado).

Em cinco anos - de 1016 a 21 - DADA torna-se n'o acontecimento da Modernidade para

169 Cauquelin, p. 77.

170 Roberts, John; The Intangibilities of Form, Verso, London, New York, 2007.

171 Marchand, Bruno; «EXPERIMENTAR - Investigar, desconstruir e afirmar. A imagem no espaço contemporâneo», in Matos, Sara Antónia (Coord. e Ed.); ESPAÇO, Oficinas do Convento, Montemor-o-Novo, 2009, p. 63.

172 Bethan Huws, «The ready made...», Word vitrine, 1999 concentra estas múltiplas questões numa simples e quotidiana vitrina de letras.

173 Poemas como Un Coup de dés de Mallarmé (1897), ou a pintura A Bar at the Folies-Bergère (1882), ou o Cubismo de Picasso em Still Life with Chair Caning (1912). Ou mesmo Nude descending a Staircase (No. 2) (1912), de Duchamp, que é rejeitado para uma exposição por ostentar semelhanças com o trabalho dos Futuristas mas sobretudo porque a pintura had 'too much of a literal title, in the bad sense - in a caricatural way'. Moreover the painting had its title actually written on the lower part of the canvas. Godfrey, Tony; Conceptual Art, Phaidon, New York, 1998.

174 Godfrey, p. 32. 
Henri Lefèbvre, - to the degree that modernity has a meaning, it is this: it carries within itself, form the beginning, radical negation - dada, this event which took place in a Zurich café"175. DADA confirma a intuição nietzscheana acerca da radical negatividade que a modernidade transporta no seu ethos, uma negatividade produtiva que DADA elabora como vitalidade; esta constitui-se anti-arte para problematizar a instituição da arte (seus limites) e nisso reelabora uma praxis de plasticidade social. DADA torna a arte um processo participativo, circunstancial, imprevisível nas suas consequências, ganhando contornos de uma plataforma imponderável de acontecimentos colectivos, ${ }^{176}$ formas inéditas de co-enunciação artística, do recurso ao ultrage (os insultos de Benjamin Peret a padres) ou à intencionalidade de fundir vários media, na exploração do dispositivo-exposição como espectáculo. Sublinho, nesta diversidade, a promoção de uma relação crítica palavra-imagem: at the heart of $D A D A$ was an implicit critique of language as supposedly transparent. .77 $^{177}$ uanto à intervenção lato senso na esfera pública, esta arte acompanha os tempos: atentados bombistas aleatórios e assassinato político de figuras da autoridade pelos anarquistas mais violentos ${ }^{178}$. A arte interrompe a norma ${ }^{179}$, desvelando uma matriz performática, de choque e excesso significante que é no fundo revolta contra a negação burguesa do corpo físic ${ }^{180}$ e se encontra imbrincada com formas mais polidas de intervenção, como nos modelos construtivistas, na orla da pedagogia social, de Rodchenko (na União Soviética) a Theo van Doesburg (na Europa Central). Nesta linhagem surgem traços pedagógicos (Lorca e sua La Barraca ${ }^{181}$ ), numa altura em que já John Heartfield e George Grosz tinham anunciado, em Berlim (1919), que a designação 'arte' destruía a igualdade entre os homens.

Note-se aqui a importância da questão da organização e montagem das exposições: 0 design expositivo. Quando em 1919, Marx Ernst e Johannes Baargeld são convidados para apresentar o seu trabalho numa exposição colectiva no Köln Kunstverein, vêem o seu trabatho relegado, pelo director, para uma ala separada. A sua rápida reacção foi a de apresentar não apenas as suas obras, mas também obras de pintores amadores, crianças, e objectos quotidianos como guarda-chuvas e esculturas africanas. Nascia a consciência da exposição como objecto de confronto e acção, colocando o desafio do design de exposições ${ }^{182}$ Clari-

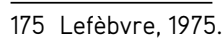

176 Caso, por exemplo, de The Cacodykic Eye (1921), que Picabia 'assina' sobre um conjunto de dezenas de autógrafos de pessoas que durante algum tempo o tinham visitado no ateliê.

177 Godfrey, Tony; Conceptual Art, Phaidon, New York, 1998, p. 44. Isto passou pela completa reformulação do uso da tipografia, com impacto extraordinário em toda a cultura visual contemporânea.

178 Uma modalidade não-retórica (porque violenta) da intervenção política que manifestamente fascinou as mentes mais envolvidas com as possibilidades da vanguarda - Kafka é um exemplo interessante, conhecendo-se o seu envolvimento com os círculos anarquistas de Praga e a forma como submete as suas personagens, precisamente ao contrário do anarquista e do activista - ou do bombista - à violência máxima de um quotidano brutalmente alienante.

179 Godfrey, Tony; Conceptual Art, Phaidon, New York, 1998, p. 41. Como quando um anarquista dança na rua com o corpo de um freira assassinada: This was carnival at its most grotesque and extreme: all the decorum and taste that maintains polite society was overturned. It was such a carnival, when the world is stood on its head, that the Dadaists wanted to initiate.

180 Idem, p. 41.

181 Uma mistura de teatro de saltimbancos, pedagogia social, animação cultural, que moveria pequenas multidões (não apenas em Espanha), convocadas para o duende do social. Lorca fala num «segundo teatro» ao serviço da moral da Terra, baseada na exaltação do instinto da guerra aberta contra as interdições caducas. [...] In Belamich, André; Lorca, Arcádia, Maia, S/D, p. 91.

182 Ernst e Baargeld voltam a inovar na crítica do dispositivo expositivo, quando em 1920 alugam uma estufa cujo acesso apenas era possível somente pelas casas-de-banho dos homens, convidando depois os mais audaciosos a destruir tudo o que quisessem. Alexander Dorner concebia por sua vez o Museu como fábrica energética - Kraftwerk -, oscilando entre 
ficada a decisão projectual de problematizar, na forma exposição, a própria violência simbólica (Bourdieu) da sua inscrição na vida urbana, a arte (instalação) torna-se experiência total imersiva, já não um fenómeno de mera fruição contemplativa no quadro da hegemonia burguesa (epitomizada no museu como reduto do belo). Delfim Sardo recorda-nos que é desta altura que data uma decisiva aproximação entre arte e arquitectura, cidade e projecto:

Da arte é esperado um novo vínculo à realidade que só o espaço da cidade, do edificado pode fornecer. Nesse sentido, o construtivismo russo representa um momento de viragem, no qual a arte caminha em direcção à arquitectura, fazendo desta o seu alter ego - ou mesmo mais, a linguagem que as artes falam. Acrescente-se que esta viragem no sentido do real trouxe consigo a adopção de uma cultura de projecto que era inerente à prática arquitectónica, mas que não fazia parte do universo das artes visuais. ${ }^{183}$

Concluindo, o valor do conceptual não está exclusivamente no repudiar ou dessensibilizar da experiência estética ${ }^{184}$, em nome de uma ingénua relação arte-vida que a concatenação arte-cidade transportaria, mas em grande medida numa rejeição do gosto burguês - negation of bourgeois taste for the sake of the bohemian, or the negation of content in favor of form, or the negation of representation in favor of experience, or the negation of art in favor of life. (After all, even the old avant-garde slogan of "art into life" sought much more than a simple renunciation of the former as a mythic counterpoint to the latter..$^{185}$

\subsubsection{Pós-Guerra: provocação ou consequência, derivas situacionistas}

No pós-Guerra, a criação encontra little appetite for a radical art that questioned or mocked traditional assumptions, especially in Europe. Rather, there was an audience eager for what were believed to be the healing and civilizing powers of the visual arts, particularly the long accepted genres of painting and sculpture. 186 'Este é o tempo do 'belo', integrado numa hegemonia do consumo. Nas belas-artes que transitam para o espaço urbano, a época assiste a uma explosão de investimento na decoração da cidade, com arte modernista cujo cânone é a escultura abstracta em diálogo formalista com a arquitectura (Maderuelo), que por sua vez é objecto de vários projectos de requalificação em toda a Europa. Neste quadro de estabilização e crescimento do regime das galerias, centros de arte, museus, crítica especializada, a arte conceptual desenvolve-se então a custo da sua legibilidade no exterior do campo. ${ }^{187}$

Em nome da urgência, surgem por esta altura actualizações das provocações dadaístas: nos anos 40, as primeiras manifestações dos Letristas (Isou, Jorn) - ser letrista é querer fazer poesia de tudo (Guy Marester) - conduzem às colagens metagráficas e à edição de

objecto e processo, ponte entre artistas e várias disciplinas. Obrist, Hans Ulrich; «Preface: Participation lasts forever», in Miessen, Markus; Basar, Shumon (eds.); Did someone say participate? - An Atlas of Spatial Practice, MIT Press, 2006.

183 Sardo, Delfim; «Dos amores correspondidos entre arte e arquitectura», in Matos, Sara Antónia (Coord. e Ed.); ESPAÇO, Oficinas do Convento, Montemor-o-Novo, 2009, p. 170.

184 Stimson, Blake; «l am the social: Blake Stimson on the line of Edward Krasinski - Critical Essay», ArtForum 2003. Artforum FindArticles.com. $02 \mathrm{Nov}, 2011$ : An art that gives nothing more of itself than its own guilty self-abnegation as art has little more appeal than one that measures up only to its bricks or concepts.

185 Idem.

186 Godfrey, Tony. Idem, p. 55.

187 E enquanto crítica da instituição 'arte' e da ética de outros artistas (caso célebre da interrupção pelos Letristas, Debord incluído, de uma conferência de Chaplin em 1952). 
Potlatch. Alguns traços do movimento são a intenção de sabotar o status quo do circuito cultural - a revista tinha distribuição gratuita - ou as autorias anónimas e/ou colectivas, que de forma lúdica e no seio de um futuro encarado como móvel (Letaillieur), visaram una forma de control sectorial de la creación, en una comunicación universal de las palabras abiertas. ${ }^{188}$ Em 1950, e num registo já teatral-performativo, Michel Mourre, vestido de frei dominicano e acompanhado de dois outros Letristas, invade a catedral de Notre Dame e lê em público um sermão denunciando os crimes da Igreja Católica; em breve, John Cage, influenciado pelo Budismo Zen, realiza, noutro registo, os primeiros happenings, marcados por uma posição quietista de aceitação. Em 1960, já as Anthropometries de Yves Klein, escandalosas performances de sucesso mundano, tinham tornado explícita a posição complexa do artista face à relação mística entre corpo e espiritualidade. Logo depois, a Art Informel (pintura 'ao vivo') de George Mathieu coloca problemas de indecisibilidade semelhantes, prefigurando Gutai ou o Cage do Black Mountain College; os Accionistas Vienenses (Günter Brus, Hermann Nitsch) incorporam o público em sessões violentamente eroticizadas da arte como espectáculo (dimensão ritualística levada ao extremo estercorário). Isto não invalida o impacto de uma linha soft: Les Levine (Canadian-Kosher restaurant, 1969) propõe projectos que se desenrolam fora dos limites da arte (parques ou restaurantes), no mundo real, mas que 'traduzidos' para a forma documentário ou a apresentação em galeria se transformam em obras de arte. A Universidade Livre (Free International University em Düsseldorf) de Beuys ou os Healings de Lygia Clark (1970), ou os projectos de reflorestação de Alan Sonfist, de reivindicação de Newton e Helen Mayer Harrisson, ou ainda os earthworks de Walter de Maia e Robert Smithson são nestes termos ainda mais emblemáticos, a par dos projectos activistas de longa duração, como Crossroads Community, 1974-80, de Bonnie Ora Sherk. Outro modelo de provocação é o interpretado pelo já referido grupo Gutai no Japão, que convoca a natureza para a obra de arte, de uma forma tão linear e literal - o vento, a chuva, galinhas - quanto apolítica/micropolítica; ${ }^{189}$ destas actividades, como das de Arman e Daniel Spoerri (Nouveau Réalisme), envolvidos em trabalho com lixo e outros desperdícios, dir-se-á constituem o movimento Neo-Dada, que das pinturas brancas de Rauschenberg aos alvos de Donald Judd, empreende o que Pierre Restany denominava uma 'sociologia do mundo.'190 Em Fluxus ou Kaprow (conforme notou ao tempo o próprio Duchamp), existe não tanto a transformação de objectos quotidianos em arte (Neo-Dada), mas a introdução processual de objectos e factos quotidianos no mundo da arte. Aliás este traço de provocação neo-conceptual interessa tanto mais quanto constitua um modelo de acção colectiva.

Ora Godfrey concebe o movimento situacionista ${ }^{191}$ neste enfiamento da arte conceptual.

188 Letaillieur, Francçois; «Letrismos Situacionistas»1946-1968, in Carta, Primavera-Verano 2011, Madrid, Centro de Arte Reina Sofia, p. 63. [...] la construcción de la situación, compuesta de todas las actividades humanas, proponía una revolución global, un rechazo de los fundamentos ideológicos del desorden presente.

189 Godfrey, p. 69. Neste tipo de obra, naturalmente, como no trabalho de Yves Klein ou Piero Manzoni, é muito difícil deduzir-se até que ponto se trata de desmistificar, ou re-mitificar o circuito artístico.

190 De Arman, pode dizer-se, empreende uma arqueologia ou uma sociologia do quotidiano, mas não a enriquece com qualquer tentativas de mudança; os seus 'restos' não têm o carácter de inscrições retóricas num debate público e permanecem irónica resistência no interior do espaço galerístico e museológico.

Numa apaixonada aventura (Restany). Sublinhe-se o pathos deste envolvimento, que rejeita quer a ideia de transcrição acrítica do real, quer a sujeição abstratizante à dimensão conceptual, desenhando um campo de criticidade da obra face à comunicação e à 'cidade'.

191 O grupo forma-se em 57, após um encontro entre membros da Internacional Letrista (dissidentes dos Ultra-Letristas) 
Urbanismo unitário, flânerie, psicogeografia, arquitectura experimental, são os materiais para uma 'arte do território', ${ }^{192}$ em que o próprio futuro urbano se torna jogo estético. ${ }^{193}$ Esta deriva urbanística e social da arte conceptual - It was the radiation of art into pure existence, into social life, into urbanism, into action and into thinking which was regarded as the important thing"194 - é ao mesmo tempo, participação experimental na própria crítica da arte, e do espaço público. No projecto New Babylon (1957), Constant, manifestamente influenciado por Lefèbvre, leva então os visitantes da exposição a circular livremente por entre maquetas de cidades imaginárias. E Chtcheglov, juntamente com o amigo Henry de Béarn, chega a congeminar fazer explodir a Torre Eiffel com dinamite, alegadamente para impedir que os seus reflexos continuassem a incomodar-lhe o sono.

Ao fim e ao cabo Psychogeography consisted in experimenting with the affective variants of the urban environment, an immediate aesthetic experience (this is obviously a paradox in terms of the Western philosophical tradition, which associates aesthetic possibility with distance and contemplation). [...]195 Por vezes, estas ideias irrompem com radicalidade, como na decapitação da Pequena Sereia em Copenhagen, alegadamente por membros da Segunda Internacional Situacionista, num protesto contra o sentimentalismo institucionalizado. A atitude iconoclasta, no limite extra-retórica, incide aqui sobre a modalidade 'monumento', materializando a critica do consensual. ${ }^{196}$ Neste situacionismo arquitectónico, em que o tema da mutação do urbano dá origem ao 'slogan' Dériville (Constant), a criticidade encontra sérios problemas para ser aceite pelo status quo (contexto que thes anula a dimensão radical e experimental, lúdica e inventiva). Esta interpretação psicogeográfica da cidade é hoje reinterpretada por criadores como Orozco, Alys ou Stalker, cujas expedições em espaços liminares da cidade sugerem uma identidade de flâneurs pós-heróicos, pós-modernos, pós-crítico-políticos (Holert). Surgem ainda outras flâneries de base tecnológica e verve activista, procurando produzir espaços sociais por via de telefones móveis ou instrumentos de navegação GPS, os materiais nobres do controlo e da segurança. ${ }^{197} \mathrm{E}$ por vezes, o flâneur dá lugar ao activista quando o logos do projecto substitui a resistência individual pelo processo construtivo comunitário.

Confirma-se a minha intuição de que o logos artístico (de Aristóteles a Fiedler) é uma ferramenta determinante na participação de cada um no corpo sem órgãos que é a cons-

e o movimento para a Bauhaus Imaginista. O cerne da cisão é a oposição entre uma linha funcionalista, representada por Max Bill, e a corrente de Asger Jorn, interessado menos na pedagogia que numa educação experimental, com muito relevo dado à auto-descoberta. Juntar-se-ão a Jorn Constant, Guy Debord e Giuseppe Pinot-Gallizio.

192 Cf. Ivan Chtcheglov, cujo Formulário para um Novo Urbanismo (1953) seria inspiração para Letristas e depois Situacionistas). Cito: We are bored in the city, there is no longer any Temple of the Sun. Between the legs of the women walking by, the dadaists imagined a monkey wrench and the surrealists a crystal cup. That's lost. We know how to read every promise in faces - the latest stage of morphology. The poetry of the billboards lasted twenty years. We are bored in the city, we really have to strain to still discover mysteries on the sidewalk billboards, the latest state of humor and poetry [...]. Cf. http://www. bopsecrets.org/SI/Chtcheglov.htm

193 Henri Lefebvre: [...] a New Babylon - a provocative name, since in the Protestant tradition Babylon is a figure of evil. New Babylon was to be the figure of good that took the name of the cursed city and transformed itself into the city of the future. Essa cidade do futuro será habitada pelo homo ludens, d'apés Huizinga e naturalmente, lá atrás, Schiller; motivada pela realidade do nomadismo cigano, persiste como modelo social alternativo. Entrevista conduzida e traduzida por Kristin Ross. Publicada em Outubro de 1979, Inverno de 1997. Fonte: http://en.wikipedia.org/wiki/New_Babylon_(Constant_Nieuwenhuys)

194 Godfrey, p. 70.

195 Kaufman, Vincent, «Theory of the derive, Debord», in Everyday, p. 96.

196 Ross, Kristin,; Everyday, p. 45.

197 Cf. Christian Nold, na Terceira Parte. 
ciência $e$ a vida colectivas, enquanto conjunto de opções discretas, projectuais, a práctica da arte (da arquitectura, do design) functions as a kind of blockage in the smooth running of larger institutional, and indeed global, coding machines. ${ }^{198}$ São as máquinas desejantes da arte que criam momentos de diferença no tecido alienado do quotidiano sujeito à hegemonia tecnológica-tecnocientífica:

For Guattari (following Pierre Levy) this is particularly important in terms of 'trying to break down the ontological iron curtain between being and things' [...] For Guattari it is in fact not so much a question of overcoming alienation but rather of reordering ourselves and our relationship to the world, a question of reconfiguration. ${ }^{199}$

A resingularização (Guattari), para utilizar a mesma terminologia dos lugares aristotélicos, é uma forma de a capacidade individual remapear o mundo ${ }^{200}$; tem a ver com a capacidade da arte crítica (em particular quando em ponto crítico) realizar conexões transversais.

We will call art that which produces an aesthetic effect, although this will be contingent and strategic. The same object 'plugged' into another kind of subject-machine may produce another kind of effect altogether lor not produce any effect at all). Likewise, a different (non-art) object plugged into a certain kind of subject-machine may produce what we would recognise as an aesthetic effect. As such, and to the extent that it produces such an effect, it would become, for that time, 'art'. Art here is less a label for an object than a name for a specific kind of coupling. This is not necessarily to override other factors - the specific location and context of the object, or indeed the specific socio-economic and cultural background of the participant, but it is to place both of these within a larger machinic economy of the art work. ${ }^{201}$

Ecoa aqui a transdisciplinariedade e o seu logos de totalidade; face à multiplicidade, a atenção tem de focar-se nos pontos de conexão entre tudo:202 An art practice is then a specifically open system in this sense, one that changes its nature as the number of its dimensions increase (as it crosses into other milieus). In this place art is less the name for an object or a discipline as such but again a name for a function of deterritorialisation. ${ }^{203}$ Nesta arte como 0 sistema aberto, This is a programme for an expanded notion of art practice and for living our lives as an art practice. ${ }^{204}$ Pragmaticamente: Art practice as a form of cartography then, the creative mapping of our connections and potentialities, a mapping that pays attention to regions of intensity (the distribution of affects) and to trajectories of future becomings, as well as to those already delineated continents of representation and signification. ${ }^{205}$

Na atenção à forma urbana,

[...] The important thing is to understand life, each living individuality, not as a form, or of a development of form, but as a complex relation between differential velocities, between deceleration and acceleration of particles. A composition of speeds and slownesses on a plane of immanence. [...] Indeed, it is the selection of augmentative affects that is the very precondition of such concept creation. Affects then are not to do with signification or 'meaning' as such. Indeed, they occur on a different, asignifying register. In fact this is what differentiates art from language, although language

198 Idem, p. 25.

199 Idem, p. 26.

200 Idem, p. 27.

201 O'Sullivan, p. 23.

202 Na verdade, We are quite close to the Buddhist or the Taoist here: no essences, indeed no theology (no representation), but a 'fundamental' insubstantiality, impermanence and interpenetration of all phenomena. O'Sullivan, p. 31.

203 Idem, p. 32.

204 Idem.

205 Em Mille Plateaux, Deleuze e Guattari distinguem entre as actividades cognitivas de 'mapear' e 'traçar', "mapping" and "tracing," positing the former as "entirely oriented toward an experimentation in contact with the real" while understanding the latter as a merely repetitive, rote mimicry. Mapping, they explain, "has to do with performance," while tracing "always involves an alleged 'competence'". In Hegglund, Jon; «Ulysses and the rhetoric of cartography» Twentieth Century Literature. FindArticles.com. 02 Nov, 2011. 
can and does have an affective register (for example, we have an affective relationship with writing - as Deleuze often reminds us, not least in his book on Kafka, writing always involves becomings). [...] In fact an affect is something else entirely, precisely an event, or 'happening'. [...] Knowledge then is important, but this knowledge is not the accretion of signifying sedimentations, but, as we have seen, the formation of adequate ideas which themselves arise from affects. This is to experientially 'understand' the conditions and causes of specific encounters, and then to utilise such knowledge in organising one's life.206

Em suma, é no acontecer da arte da cidade, enquanto cocktail de conceptualismo e comunicação total, que Indeed conceptual art might have more in common with what Deleuze and Guattari call philosophy [...] Installation art on the other hand might be a paradigmatic case of art as access point to 'other worlds' ${ }^{207}$ Ressoam aqui ideias de Lefèbvre: Art then might make use of the components of cliché in order to resist cliché. ${ }^{208}$

\subsubsection{Dobras barrocas - do fractal ao possível}

Reflicto sobre a cidade situacionista a partir da questão d'o possível e do virtual ${ }^{209}$. O virtual é metáfora que dá consistência ontológica ao processo (palavra-chave na arte contemporânea); quanto ao possível é um acumular de existências, espécie de 'exterior'. ${ }^{210}$ Nesta investigação, defino os lugares do debate menos com base no fractal e mais no possível211, uma vez que, a cidade, enquanto texto que acumula discursos - strata - se torna, como acontece com os situacionistas (mais que nos primeiros neovanguardistas da Land Art), um lugar de investigação particularmente apropriado para pensarmos os anacronismos mais necessários a um presente sustentável. E se a imagem da actualização fractal é fundamental numa ideia de modulações possíveis da vontade de transformação que a arte transporta, ${ }^{212}$ apenas se concretiza, formalmente, numa esfera de possíveis a que as imagens conjugadas do contexto, da situação, da participação e do activismo vão dar vida. ${ }^{213}$ Os conceitos filosóficos da mónada $a^{214}$ e da dobra ${ }^{215}$ definem aqui os caminhos para entender

206 O'Sullivan, p. 43. From a deconstructive perspective it might be argued that 'affects' are only 'meaningful' 'within' language.

207 Idem.

208 Idem, p. 67.

209 Cf. O'Sullivan, pp. 98-120. Para O'Sullivan, Smithson, juntamente com Donald Judd ou Robert Morris, levam ao extremo o corte com a representação, não sem manter aspectos de uma fantasia (a imaginação) que o autor define psicadélica. É a arte como imagem do pensamento, para além da representação, resultado menos da relação entre real e possibilidade do que entre o actual e o virtual. É uma nuance-chave: The virtual on the other hand names a field of difference that is not, and cannot be, subsumed by the concept. The virtual 'designates a pure multiplicity' which as such 'radically excludes the identical as a prior condition' (DR 211-12). The virtual then names a real place but one which has yet to be actualised. Whereas the real and the possible instigate a philosophy of transcendence, the virtual and the actual affirm immanence. We might rephrase this and say that whereas the possible names a logic of Being (ontology of stasis), the virtual affirms a logic of becoming (ontology of process).

210 O'Sullivan, p. 102.

211 Ecoando Miles quando diz que não está disponível para adbdicar do socialismo.

212 Particularmente patente nos novos monumentos do minimalismo, de Smithson a Serra.

213 Smithson, Robert; «A sedimentation of the Mind: Earth Projects»: When a thing is seen through the consciousness of temporality, it is changed into something that is nothin. In O'Sullivan, p. 107. Repare-se que, na arte comunitária-activista, se trata desta tensão entre o nada da pura temporalidade abstracta e os possíveis da intervenção urbana, que vão aportar a imaginação e sua durée específica ao quotidiano.

214 Gabriel Tarde, no final do séc. XIX, desenvolveu o conceito afirmando que as mónadas são abertas e criam o socius, abrindo espaço ao perspectivismo, Deleuze, na segunda metade do séc. XX, vai articular o conceito com o dos fractais da Teoria do Caos, sem abdicar das definições de Leibniz: as mónadas terão então dois andares, como uma casa barroca - o de cima fechado e o de baixo aberto (a tudo, em total transversalidade).

215 Fundamental mecanismo da subjectividade. 
a cidade situacionista como uma expansão barroca (O'Sullivan), em termos da virtualidade participativa da condição urbana. ${ }^{216}$ Nesta posição há uma viragem profundamente retóri$\mathrm{ca}-a$ turn from the linguistic turn of much art theory towards the actual matter of art and to the latter's expressive character ${ }^{217}$ - que me parece abrir uma série de possibilidades ao possivel: On this level then we have the Baroque conception of matter: a world of material fabric, composed of smaller and smaller parts and of relationships of capture between these parts. We might call this a general texturology of the world. ${ }^{218}$ Aceito a ideia do possível da dobra para entender os encontros com a arte pública crítica na cidade como momentos que desdobram as dimensões da experiência urbana:

\begin{abstract}
[...] the whole point is always to try out whether that situation, that event, that hole in the ground, that wrapping of a building, those pebbles placed on the ground, that cut made on the body, that illustrated diary of a schizophrenic, those trompe l'oeil sculptures, and all the rest - whether they too say something to us. The powers of sensing and phrasing are being probed on the limits of what is possible, and thus the domain of the perceptible-sensing and the speakable-speaking is being extended. ${ }^{219}$
\end{abstract}

É neste quadro que a revolução do ready-made foi um contributo para a consciência da dobra ao nível de um realismo urbano: The invention of the readymade seems to me the invention of reality, in other words the radical discovery that reality in contrast with the view of the world image is the only important thing. ${ }^{220} \mathrm{O}$ ready-made veio para ser determinante em toda uma axiomática potencial da arte na textura da vida contemporânea. Quando ars combinatória do social, a arte contemporânea actualiza a própria utopia como virtualidade situada. Noutros termos, a utopia - um mito comunista, ${ }^{221}$ torna-se pretexto para a invenção de histórias ${ }^{222}$, narrativa mitopoética. Citando Richter, O'Sullivan menciona a questão dos inícios - já não de quaisquer partidas estéticas. Isto é, haverá uma arte que é 'utópica' no sentido específico de que convoca um público ainda não, em afirmação potencialmente total do 'nós' de um novo barroco, cósmico e social:

This perspective or projected unity, although not altogether disappearing is however changing. It is no longer the unity of a singular monad but rather the paradoxical unity of a kind of divergent series, or trajectory, which in the arts Deleuze names 'performance'. Although this is not a new term in terms of art history, what we have with Deleuze's use of it is a specifically philosophical description of the 'new' expanded practices of the 1960s and onwards. A description of that art which includes its audience, and the wider world, in its being as art (which is incomplete without this participation). [...] We are moving from the autonomy of the Baroque house and of the art object to something more open, something more complex. The Baroque house has been opened out, at least in part, and this will have a profound effect on the kinds of subjectivities that these new kinds of monads express. [...] We might move here from the utopian paintings of Richter to the earlier utopian urban 'plans' of the Situationists: the 'city models' of Constant, or the larger city paintings of Asger Jorn (both of whom specifically made the move from easel painting to urban planning).223

É um novo socius, corpo social de nova e ampla teatralidade (Fried) da cidade: This extensive

216 O'Sullivan, p. 122. We might also characterise this new Baroque as the introduction of a logic of participation into art practice.

217 Idem.

218 Idem, p. 123.

219 Lyotard, p.190.

220 (RIC 124). [...] (produced by itself). And sometime or other it will again be a question of denying the value of this reality in order to produce pictures of a better world (as before).

221 O'Sullivan, p. 147.

222 Idem.: In fact, this future orientated practice might involve the utilisation of past myths, albeit in new and novel combinations /such myths will be precisely bastardised). Indeed, and as Raymond Williams once pointed out, residual cultures, residual myths, might hold a certain amount of potential resistance to those of the dominant culture, although it will be crucial to demarcate those that have been 'incorporated' (we might say those that have become major) from those that remain potentially resistant lor resolutely minor.

223 Idem. 
unity of the arts forms a universal theatre that includes air and earth, and even fire and water. In it sculptures play the role of real characters, and the city a decor in which spectators are themselves painted images or figurines. The sum of the arts becomes the Socius, the public social space inhabited by baroque dancers. ${ }^{224} \mathrm{Um}$ novo urbanismo, performativo: The architecture of tomorrow will be a means of modifying present conceptions of time and space. It will be a means of knowledge and a means of action. The architectural complex will be modifiable. Its aspect will change totally or partially in accordance with the will of its inhabitants. ${ }^{225}$ Portanto, a cidade é ela própria uma espécie de dobra, monumental (infinita) plataforma para novas dobras. Prolongando em sede de projecto urbano ou de arte pública contemporânea as flâneries de Baudelaire, nas acções situacionistas não estão ausentes traços de 'religiosidade': Everyone will live in his own personal 'cathedral' so to speak. ${ }^{226}$

\section{Debord: a negação de uma sociedade transbordante de imagens}

Com Debord, para quem a necessária desorientação é uma forma de modificar as relações humanas existentes, ${ }^{227}$ as experimentações vanguardistas são micro-tecnologias de reorganização e resingularização. ${ }^{228}$ No texto 'Separation Perfected', logo no título, Debord enuncia a relação entre o dispositivo cidade e uma situação generalizada de alienação (separação) que a situação - juntamente com o momento lefebvreano - torna operativo no sentido da criação de massa (socialmente) crítica. Na análise de Debord, temos a questão de o espectáculo ser antónimo de vida, da vitalidade necessária ao corpo social: The spectacle in general, as the concrete inversion of life, is the autonomous movement of the non-living. (§1). Estando em causa problematizar a linguagem oficial da separação generalizada (§3), há que contrapor uma mediação de imagens (§4). Por outro lado, tal como Lefèbvre, Debord sublinha que a separação é vivida mais do que simplesmente compreendida: Separation is itself part of the unity of the world, of the global praxis split up into reality and image. (§7). E por isso: Considered in its own terms, the spectacle is affirmation of appearance and affirmation of all human life, namely social life, as mere appearance. But the critique which reaches the truth of the spectacle exposes it as the visible negation of life, as a negation of life which has become visible. (§10) Logo, na perspectiva de Debord, o espectáculo não será superado apenas porque é objecto de uma crítica ela própria separada: When analyzing the spectacle one speaks, to some extent, the language of the spectacular itself in the sense that one moves through the methodological terrain of the very society which expresses itself in the spectacle. (§11) Mas uma hipótese interessante na abordagem do irreal social é tomá-lo como dispositivo abstracto que é; isso revela-lhe uma disponibilidade para ser apreendido pelo seu carácter tautológico (§13), traço que partilha com a própria linguagem.

224 Deleuze, F p. 123.

225 Chtcheglov 1989, p. 24.

226 Idem, p. 25. There will be rooms more conducive to dreams than any drug, and houses where one cannot help but love. Others will be irresistibly alluring to travellers [...] The principal activity of the inhabitants will be the Continuous Dérive. The changing of landscapes from one hour to the next will result in complete disorientation.

227 O'Sullivan, p. 140. Cf. Guattari, Félix; Chaosmosis: An Ethico-Aesthetic Paradigm, Indiana University Press, 1995.

228 O'Sullivan, p. 150. This is the raison d'etre of much contemporary art practice: the production of idiosyncratic archives and inventories, the construction of alternative narratives and mythologies by traitor prophets. 
De resto, e numa crítica da filosofia em nome da retórica: The spectacle does not realize philosophy, it philosophies reality. The concrete life of everyone has been degraded into a speculative universe (\$19). O espectáculo (o mundo da arte que rejeita a contemporaneidade), is the technical realization of the exile of human powers into a beyond, it is separation perfected within the interior of man. (§20) Isto é, a alienação estética (re)nega o acto místico, donde que toda a arte crítica - como o ensaio, como o aforismo romântico - é sempre um exercício de libertação da mais remota das disciplinas ${ }^{229}$, em particular as que estabelecem a divisão perene entre o que é artístico e o que não o é. Ora a arte crítica interrompe o fluxo do espectáculo e da(s) sua(s) disciplina(s). Ela representa uma demora: Debord worked to delay this suppression [da rua], because the derive consisted, if not in re-creating streets, at least in occupying them for as long as possible. ${ }^{230}$ Logo, se The spectacle reunites the separate, but reunites it as separate. (§29), é na transdisciplinariedade crítica que a vitalidade do socius pode começar a redesenhar-se (Flusser), mais não fosse pela clareza com que enuncia a noção de um espectador político, imerso mas ao mesmo tempo consciente da potencialidade da sua capacidade para contemplar criticamente. É um ethos que se traduz numa desconfiança básica das imagens, como a arte conceptual e depois os seus desenvolvimentos mais variados não deixariam de sublinhar. Mas se The spectacle is capital to such a degree of accumulation that it becomes an image (§34), terá razão Perniola quando assevera, que Debord se subsumiu ao extremismo político e ao moralismo anti-estético iconoclasta. ${ }^{231}$ Será isso que separa a contravisualidade debordiana dos situacionistas mais próximos da arquitectura e portanto do modelo de intervenção activista-vitalista da land art.

\section{Manifesto para uma praxis artística futura}

O'Sullivan termina a sua reflexão sobre Deleuze e Guattari com um Manifesto que procura a intertextualidade com Wagner. Nela, a dimensão operática e neo-barroca, em Fluxus, Kaprow e Beuys evidencia a visão helicoidal (Miranda Justo) que tenho vindo a exercitar a partir da arte do futuro de Wagner.

Fiction: manifesto for future art practice

1. Activate immanence. Turn away from transcendent modes and points of organisation, especially religion and art, but also fashion, the mass media and other telematic standardisations. Celebrate the 'isness' of all things. Practice is the utilisation of that which already is (what else is there?) but in the production of new and specifically different combinations. Always affirm the eternal return.

2. Harness affect. Practice is the foregrounding of the world's intensive and affective properties. The practice will involve the production of novel constellations of affects, away from opinion, away from habit, away from the clichés of so-called culture (the affective assemblages offered to us on a daily basis). (2) The practice will operate as a rupture in our overly anxious, paranoid and stratified habits of being (the practice will affirm new kinds of joy,

229 Debord avança aqui o seu letal diagnóstico da divisão do sensível, tributário da ética kafkiana: If the spectacle, taken in the limited sense of "mass media" which are its most glaring superficial manifestation, sems to invade society as mere equipment, this equipment is in no way neutral but is the very means suited to its total self-movement. (§24)

230 Kaufmann, in Johnstone, p. 102. E neste aspecto o Situacionismo está longe de ser um movimento homogéneo: Similarly, Debord's theses on urbanism and regional planning can be read as the exact opposite of the psycogeographic experience of the Lettrists and Situationists. Psychogeography was a conquest, or reconquest, of the reality of space. And the spectacle is what removed reality from space (as from life in generall.

It is a matter of subjectivity or subjectivization, that is, of singularity, of differentiation, to which is opposed the generalized interchangeability brought about by the economic management of space.

231 Perniola, p. 92. 
and new kinds of becoming). This is an aesthetics. We affirm the necessity of style in this harnessing of affect.

3. Build probe-heads. The practice is an experimental device aimed at dismantling the strata that binds us and constitutes us as 'human' (our habitual states of being and responding). [...]

4. Actualise the virtual. [...] We are involved in mirror-travel and in the production of crystal objects.

5. Always stuttering, always stammering. Our practice is a collective enunciation, even when there is only one (we are always the group). Our practice is always linked to the larger political milieu (no oedipalisations and no nuclear families). Our practice is a future fragment projected backwards in time. [...]

6. Always folding. The inside as a fold of the outside (we refuse interi- ority and so-called 'essence'). We hold that our practice is the production of new folds, new worlds arising from these folds, and new myths appropriate to these future worlds (we will use past forms and yesterday's codes, but they will be made unrecognisable in their turn). ${ }^{232}$

\subsubsection{Fluxus, Kaprow, neo-concretistas brasileiros, minimal - o conceptualismo expande-se}

Os anos 60 trazem consigo uma dinâmica libertária inédita: ideologically transparent freeing of suppressed energies and potentials in each individual233. Este vai ser o cadinho da concepção de happening; do jogo schilleriano contra a mundividência capitalista (da negação do objecto à valorização de actividades 'inúteis'), o criador estetiza a vida, sob o regime da arte mas nas suas margens; na senda situacionista, Kaprow assume a divergência com a arte apenas retoricamente politizada, preferindo-lhe uma criatividade genérica da vida urbana.

We have to conclude that, despite the claims made [...] by Maciunas (he compared Fluxus to Russian revolutionary art and identified himself, with typical inconsistency, as anarchist, communist, socialist and apolitical), few Fluxus events had more revolutionary potential than a stamp-collecting convention. ${ }^{234}$

Podemos contestar que Fluxus não deixa de ter um elemento de festa, carnaval, lapso temporal de libertação. A existir 'inconsistência' operática ${ }^{235}$ das performances de Maciunas/ Fluxus podemos relativizá-la, sobretudo no quadro do que possa ser um projecto meta-discursivo na era da comunicação; neste aspecto, as formas mais ritualísticas de Milan Knizak, em que o corpo humano - metonímia do corpo social - estabelece com o espaço configurações de uma simbologia rarefeita, ${ }^{236}$ são de uma ordem mais intensamente fenomenológica, como entretanto ia acontecendo também na arte conceptual brasileira, explicitamente politizada. Helio Oiticica - com Parangolé lum termo calão que se refere a uma agitação súbita entre transeuntes) - desenha situações em que o corpo de pessoas é vestido por uma espécie de trajes minimais em que surgem textos escritos, sendo muito evidente o carácter de informação acerca de quem 'veste' as obras; como nalguns trabalhos de Lygia Clark, é difícil definir o estatuto da obra: performativo, teatral, informativo, metafórico. ${ }^{237}$

232 O'Sullivan, pp. 156-157.

233 Idem. Termos com que Larsen descreve o ethos do activismo marxista e neo-marxista nos anos 60 e 70.

234 Kaprow, p. 104. When, in 1963, Fluxus held a demonstration in Amsterdam the provos, a group of anarchists who believed - like the Situationists - that art should be subsumed into political activism, disrupted the event. The provos no doubt saw it as mere dilettantism, whereas what they did-providing free bycicles throughout Amsterdam or, more nihilistically, smoke bombing the wedding of Princess Beatrix - was considered to be a genuinely social version of Dadastic ideas.

235 Gomes, Júlio do Carmo; in Beuys, Joseph; Cada Homem Um Artista, 7 nós, Lisboa, 2010, p. 33. Note-se a intertextualidade wagneriana.

236 Instant Cathedrals (1971), que seria curioso comparar com as nossas contemporâneas Minute Scuptures de Wurm.

237 Cf. Bishop, Claire; Installation Art. 
Nos Art\&Language impõe-se já uma outra tendência conceptual, na coincidência teoria-objecto de arte. Henry Flynt já a havia sublinhado no início dos anos sessenta: Since concepts are closely bound with language, concept art is a kind of art which the material is language $^{238}$. Podemos extrapolar que a arte conceptual é uma conquista histórica da própria racionalidade artística, no quadro da perspectiva neo-aristotélica, elaborada pelo filósofo Richard Wollheim, de que a existência de arte fora de uma sociedade da linguagem é algo de inimagináve ${ }^{239}$. Isto confirma a minha intuição: a arte inscreve tensões binárias (Lefèbvre) específicas $^{240}$, apenas apropriável discursiva/verbal/conceptual/politicamente, porque as formas em si, enquanto materialidade tanto exigem como provocam ou iludem o comentário (cujo aparelho, por outro lado, não estático e se revela por vezes manifestamente inadequado). É nesta ponte entre arte e discurso que uma vida unidimensional (Marcuse) é o alvo por excelência da arte crítica urbana. Porque o contrário da unidimensionalidade existencial no sistema capitalista é o questionar radical dos seus princípios alienantes, o que apenas é possível no discurso e num discurso que seja simultaneamente um dispositivo (autoconsciência retórica, técnica, poética, dos seus mecanismos) e fala de uma verdade, o valor realmente operacional que permite a construção de significados mais profundos. $\mathrm{E} a$ obra de arte é assim, antes de tudo o mais, uma ideia-máquina ${ }^{241}$; e aproximação entre conceptualismo e romantismo que enquadra os processos cognitivos e a intuição criadora ${ }^{242}$, um élan vital (Bergson), um elemento místico ou energético (Beuys); ela integra, na forma do impulso, da emoção operacional, os esquemas mais luminosos da retórica, como acontece na obra de Robert Erwin em Varese, para o colecionador Panza di Biumo, momento de um acto artístico de dessublimação do seu próprio contexto; a obra é basicamente uma janela aberta para essa meta-public sphere ${ }^{243}$ que é a natureza. 0 trabalho de Richard Long ${ }^{244}$ pode ser revisitado nesta perspectiva - positioning the possibility of being in nature, not just seeing it, but being in it, he is also making a political statement. We can escape from alienation and false consciousness: by a willful act we can be wholly in the world - reconnected. ${ }^{245}$

O movimento da Minimal Art revela-se outro momento charneira na arte contemporânea que se aproxima do devir urbano. Introduz uma economia das formas, mas também das ideias, na gramática da arte urbana, podendo ser contraposto dialecticamente, num mesmo eixo vertical, quer às formas mais discursivas do conceptualismo (Kosuth, Burgin), quer à tradição performativa do happening e da acção (Fluxus, Kaprow, Christo, Oiticica). De algu-

238 Idem, p. 102.

239 Idem., p. 140.

240 No meu trabalho, o nada vs. a luz, por exemplo.

241 Idem, p. 152.

242 Um 'activo' que inclui para além da flânerie, inclui o acaso, a serendipidade, a ssociação livre de ideias, a poesia.

243 Collins, Goto, p. 42. Caberia aqui reflectir sobre inúmeros constructos conceptual-minimalistas, de Judd a Flavin, de Walter de Maria (no seu maximalismo, Lighting Field é uma obra tão importante para o minimalismo como a land art) a Robert Morris (com um percurso demasiado complexo para aqui caber num breve comentário). A este último voltarei pontualmente porém, a propósito de diferenças fundamentais face às ideias de Kaprow.

244 Cf. A Line Made of Wakling, 1967.

245 In Godfrey, p. 130. This political level of interpretation is significant. In 1988 Dan Graham was to say, of the changing mood of the 1960's, that 'minimal was closer to disillusioned existentialist intellectual, say from Antonioni to Beckett, which is a disillusioned left position. As it veered to Conceptual - Conceptual would be moral, utopian puritanical and personal. Personal in the sense of the personal ethos; it would be closer to the New Left - a very moral puritan kind of vision.' What makes Long's work so much more than Fluxus whimsy is this potential moral/political meaning. There is also a complete absence of pathos and sentimentality. 
ma maneira, o minimalismo é uma espécie de grau zero, não tanto das formas gestaltiano, mas do próprio ethos relacional.

\section{Usando as palavras escritas}

Whenever we see words presented visually in public, we are seeing political or ideological struggle. ${ }^{246}$ Nas costas de uma $t$-shirt (Félix Gonzalez-Torres, Untitled, 1994 - 'Nobody owns me'), uma das formas mais triviais de comunicação, produzida no quadro de uma encomenda de uma marca comercial, é um comentário crítico à condição da cidadania de consumo. Gonzalez-Torres actualiza o legado situacionista na durée da ocasião. Mas também recupera a arte do texto dos primeiros conceptualistas activistas, como Burgin. Para os editores de Art and Text (2009), este tipo de reflexão sobre o texto face à arte (e vice versa), acompanha a emergência das teorias estruturalista e pós-estruturalista. Ela integra o que Beech denomina um linguistic turn que acompanha the dissolution of the art object, the primacy of the concept, the play of appropriation and readymade, and the acceptance of the new media e portanto can be seen to perform a much more profound transformation in art practices than a simply formal tool that connects so many artists of our time. ${ }^{247}$ Este linguistic turn trouxe consigo um rhetorical turn - em particular para a arte pública. Neste quadro, a deriva conceptual é uma vaga de fundo na direcção da comunicação. ${ }^{248}$ Mas se nos anos 60 o texto em arte era abordado essencialmente pela sua potencialidade de disembodiment, ${ }^{249}$ nos anos 90 ancora-se na dimensão do contexto.

A explosão do texto em arte, que vem complementar a descoberta do espectador no minimalismo, chega quando there was virtually nothing else to use, ${ }^{250}$ alguns percursos individuais são esclarecedores desta emergência da importância do texto-como-conceito na arte contemporânea; já sem grande pompa ou impacto (Beech), o texto é hoje matéria nobre do logos artístico: Cornelia Parker (Words that define Gravity, 1992, realiza as letras do nome da peça em chumbo e atira-as de um penhasco); Martin Creed coloca a frase (EVERYTHING IS GOING TO BE ALRIGHT, 1999, na fachada neoclássica da antiga sede do Exército de Salvação, acompanhada da edição de um CD com canções pop); Jeremy Deller imprime posters, autocolantes e $t$-shirts impressos com letras de canções, invertendo através da reescrita dos slogans o sentido moralizador de campanhas de saúde pública contra o álcool e as drogas. Com Jenny Holzer a linguagem tipo-gráfica da arte 'conquista' definitivamente o espaço público. It is not language per se but language rammed up against visual appearences,

246 In Godfrey, p. 346. Gonzales-Torres recorda-nos o essencial em Saussure. Para Miller e Lupton, Saussure destruiu a assumpção corrente de que a linguagem existe para representar ideias: For Saussure, the most troublesome feature of the linguistic sign was it arbitrariness: there is no resemblance between a sound such as 'horse' and the concept of 'domesticated quadruped'. [...] Only a social agreement appears to hold the two sides together. Miller, Abbott; Lupton, Ellen; «A Natural History of Typography», in Looking Closer: Critical Writings on Graphic Design, Allworth Press, New York, 1994.

247 «Foreword», Art and Text, Blackdog, London, 2009.

248 Em «Think Again», Charles Harrisson, dos Art\&Language, a questão do texto vai iluminar um equívocod e que priemiararte conceptual sofre: [...] ar argument for Conceptual art that represented it both as postmodernist and as hyperabstract was clearly doomed to incoherence from the start. «Think Again», in Art and Text, Blackdog, London, 2009.

249 Culminando um longo percurso iconoclástico em que se destacam as experiências de Schwitters, Marinetti, Gris, Apollinaire, Magritte ou Duchamp.

250 Harrisson, p. 23. 
including its own, that ultimately characterizes Conceptual art. ${ }^{251} \mathrm{E}$ assim, quando Rosemarie Trockel 'publica' a frase 'Ich habe Angst' (Eu tenho medo) na ábside de uma igreja em Colónia em 1993, encenando uma atmosfera específica para a leitura daquela frase, é toda uma imponderabilidade do político que se impõe através do dispositivo cénico-textual. ${ }^{252}$ No fundo, há na interpelação pela palavra um eco das mesmas na mente do leitor, que é da ordem de uma privacidade conquistada. ${ }^{253}$ Barbara Kruger, uma das artistas que mais claramente articula esta tradição conceptual-interventiva, dava já em 1988 sinais de uma ansiedade - I don't think about conceptual art. I prefer effectively to sadly deluded romanticism. ${ }^{254}$ - que num quadro de falência das grandes narrativas, não abdica da urgência democrática. ${ }^{255}$

Ao definirem a prática conceptual como o colapso nervoso do modernismo, ${ }^{256}$ é em tudo isto que os Art \& Language pensavam. No fundo, a arte conceptual revolta-se contra o progresso na arte para se concentrar no progresso como totalidade do social. Este movimento de uma arte conceptual indissociável da abertura do discurso hermético e técnico do Modernismo à filosofia, à linguística, às ciências sociais e à cultura popular, evita o enclausuramento disciplinar em nome do interesse gereralista (Lefèbvre). Evocando as experiências de Kosuth ou On Kawara, Harrisson afirma, explicitado uma diferença entre aquilo que a Arte Conceptual trouxe ao campo da arte (libertação de constrangimentos técnicos, disciplinares, estilísticos, relacionados com a questão quer dos media, quer da autonomia) e a sua função mais radicalmente renovadora:

It is beyond this moment that the pathways diverge, as do the art-historical theorisations that follow. [...] In this account, continuing careers in Conceptual art are celebrated alongside those multifarious and often highly spectacular kinds of not-painting and not-sculpture that are popularly gathered under the label of Conceptualism. Works in both categories may include an amount of text, but generally either as the now customary component of a brand or as a kind of filigree added to an avant-garde product.

There is an alternative view. Once works in textual form had been established as potential works of art - rather than works of literature, of philosophy or whatever - what remained to be recovered from the traditions of art was the unique kinds of virtuality, opacity and intellectual repletedness that had once been associated with works in visual form, and particularly with paintings. The real problem was not how to make plausible paintings with words, or how to exploit the freedom that came with conceiving of art as an entirely open concept, but rather how to reinvest fine art with the discursive and essaysit potential that modernism had in the end had to sacrifice in its critique of the aesthetic. ${ }^{257}$

Nestes termos, a arte que continuamente renova o apelo conceptual é a proposição de um novo tipo de arte. ${ }^{258}$ É uma posição refractária por princípio lao sistema e seus mecanismos

251 Godfrey, p. 351.

252 Idem, p. 355. First one had to ask who was speaking: Trockel, God, Christ or oneself - the reader? Trockel had shrouded the windows so that the church was unusually dark and gloomy. Who was the reader? An art groupie who had wandered in from the nearby Cologne Art fair or a parishioner who had come in for peace and prayer? How an the particular reader respond to the implicit injunction to internalize this statement: to be fearful, and think on the cause for fear? The altar is the site of the word, both written and spoken: are these words then to be spoken in the somber silence?

253 Em Novembro de 2010, Alfredo Jaar, por exemplo apresenta o seguinte poema de William Carlos Williams no seu site: it is difficult / to get the news / from poems / yet men die miserably / every day / for lack / of what is found / there. O facto de assinalar a palavra 'there' a vermelho e de esta constituir o botão para aceder aos conteúdos mostra que o 'ali' da palavra é o lugar poético que é preciso atravessar para chegarmos ao sentido.

254 Idem, p. 382

255 Para Lucy Lippard, the notion of cultural democracy was selectively accepted ino the mainstream lthrough the agressive works of Jenny Holzer and Barbara Kruger [...] and Krzysztof Wodiszco's subtle projections). In Lippard, p. 267.

256 Godfrey, p. 14.

257 Harrisson, p. 25.

258 Idem. The resulting body of work stands apart both from the continuing work of Conceptual art's other veterans and from the institutionally supported avant-gardism of the past quarter century. It is not well attuned to the prevailing modes of criticism and publicity. It proposes what might be seen as a new kind of art, though one with strong links both to the traditions that 
de legitimação e circulação). ${ }^{259} \mathrm{E}$ é daqui que Beech parte para identificar três questões-chave do que chama uma ontologia da arte pós-Duchamp. Em primeiro lugar, a referida dinâmica skill-desliling-reskilling referenciada por John Roberts, ${ }^{260}$ no seio do interesse pela general social technique; em segundo lugar, o carácter contingente la questão da situação face ao contexto) do objecto de arte actual (sinal da sua abertura à visibilidade contextual e à participação), tal como proposta por Martha Busbirk; e finalmente a importância da intersubjectividade (isto é, do relacional), que tem sido advogada por, por exemplo, Nicolas Bourriaud. Ora em Roberts, passamos a ter a certeza de que the reskilling that follow from the elimination of handcraft from art is linguistic in the widest sense - conceptual, discursive, theoretical, managerial, organisational. ${ }^{261}$ De Haacke a Beuys, de Kaprow a Nold, é de uma estética da administração (Buchloch) que se trata, o logos do dispositivo (Aristóteles, Foucault). The contingency of the objects of contemporary art - including, of course, art's contingency on language - does not stop at the art object, it penetrates every aspect of art, from the encounters with it to its institutions, and from what art can do to who it wants us to be $e^{262}$. Na prática, If a work of art is successful it will invariably set its sights beyond its mere presence in space, it will be open to dialogue, discussion, and that form of inter-human negotiation that Marcel Duchamp called 'the coefficient of art'. ${ }^{263}$

\subsubsection{Aproximação ao activismo, indiscisciplinas extradisciplinares}

Nalguma bioarte, modalidade crítica potencialmente empenhada em desmontar a hegemonia tecnocientífica, temos o caso extremo da criação em que o fundamental é a importância do cuidado para com todas as formas de vida. ${ }^{264}$ Paradoxalmente, nela está implícito um humanismo radical (e experimentalmente transdisciplinar), enriquecendo a condição humana com visões críticas da oposição artificial criada pelo racionalismo clássico entre arte, ciência e filosofia. ${ }^{265}$ Aliás, é por aí que a bioarte tem sido factor de mediação entre as aplicações da ciência e o público ${ }^{266}$, caso particularmente evidente nos Critical Art Ensemble, responsáveis por patentear a relação estreita que a arte pode ter com a sociedade [...] na sua declaração de que aquilo que nos aparece sob a forma mística da ciência pura e do conhecimento objectivo da

Modernism interrupted in the nineteenth.

259 Beech, p. 31. Contemporary text art holds a strong place within our post-Conceptual understanding of what art is and what makes it interesting.

$260 \mathrm{Em}$ The Intangibilities of Form, Roberts defende que Duchamp inaugura uma viragem da manufactura e da representação para a um discurso sobre a difusão da autoria no quadro da divisão social do trabalho. Isto é, Duchamp produz uma cópia la questão da mimesis actualizada num quadro de produção em massa) mas no fundo nada produzindo, e sem copiar original, e nisso coloca o acto da nominação no cerne do acto artístico (que para Beech conduz à text-art), para além de abrir todo um campo de comentário, crítica, dialogo em torno da arte, em que a divisão entre literatura primária e secundária deixa de fazer sentido.

261 Idem. Cf. Roberts, John; The Intangibilities of Form, pp. 101-132.

262 Beech, p. 32.

263 Bourriaud, Nicolas; Relational Aesthetics, trad. Simon Pleasence, Fronza Woods, Dijon, Les Presses du Réel, 2002, p. 41.

264 Costa, Palmira Fontes da; «Da Natureza e Aspirações da Bioarte», in Ciência e Bioarte: Encruzilhadas e Desafios Éticos, Caleidoscópio, Lisboa, p. 15.

265 Idem, p. 17. [...] que não tem mais razão de ser e poderá mesmo significar a morte da nossa espécie. [...] 0 mundo actual obedece demasiado à unidimensionalidade das lógicas cruzadas da tecnociência e da economia de mercado.

266 Idem. 
natureza revela-se, no fundo, ideologia política, económica e social. ${ }^{267}$ Só que particularmente complexa é a situação gerada pelas formas de bioarte que, transgredindo os limites humanos aceites por determinada(s) comunidade(s), já não ilustram a arte acomo acervo de possíveis inscritos numa matriz universal mas a arte como realização dos possíveis per si. ${ }^{268}$ Por vezes, esta política criativa do facto consumado - como na escultura antisocial, mas na órbita da acção especificamente laboratorial - gera polémica, problematizando a neutralidade da arte moderna-contemporânea do ponto de vista de um saber exterior à arte ${ }^{269}$ senão exterior ao próprio mainstream do socius. Ou seja,a questão do coeficiente de arte è radicalmente problematizada, senão suspensa, em função de questões éticas e ontológicas vitais.

Num new sort of carnival that would embody pleasure, communication and political upheavel, ${ }^{270}$ a virtualidade do programa da eco-arte conceptual conduz ao espaço público como cena do politico. Richard Long havia-o demonstrado numa sucessão de apertos de mão a transeuntes, convidados a conhecer pessoalmente aquele artista cuja marca identificatória é uma quotidianíssima t-shirt da St. Martin's School. Mas é 68 o ano em que a política obriga a arte a pensar o seu ethos (na abordagem crítica não apenas da sociedade do espectáculo, mas especificamente de formas de distinção social como os museus; ${ }^{271}$ a liberdade de 68 é crítica dos dispositivos capitalistas que parecem querer eternizar um estado de alienação, mistificação, desinformação. É significativo que quando o Art Workers Coalition (cujos membros incluiam Carl Andre, Robert Morris e Mel Bochner) realizaram em 1970 uma das obras mais abertamente activistas da arte conceptual - And babies? A. And babies - o que está em causa é uma intervenção eminentemente interpelativa, que envolve por via do texto $e$ da imagem o espectador numa enunciação crítica da informação disponível. Hans Haacke é outro exemplo deste artista consciente do carácter do espaço museológico como ocasião simbólica para um discurso informativo:272 A museum knows nothing about economic power; it does indeed, however, know something about spiritual power. ${ }^{273}$ Este crescendo de consciência política, conduz alguns artistas a formas de intervenção inspiradas em processos revolucionários; outros tenderão a perseguir objectivos menos doutrinários; outros ainda, afastam-se do sistema da arte em nome do socius (como Gilardi). Certo é que, em 1972 contemporary art was a real apart, rather than an integral and decisive factor in the contemporary world. Art's revolutionary

267 Idem, pp. 18-19. Um dos objectivos dos membros do grupo e colaboradores é encontrar meios e modos através dos quais uma audiência de não especialistas, incluindo os próprios artistas, pode utilizar as ferramentas da biotecnologia com vista à sua apropriação em diferentes contextos culturais.

268 Cascais, Fernando; «A Bioarte na Encruzilhada da Arte, da Ciência e da Ética», in Ciência e Bioarte: Encruzilhadas e Desafios Éticos, Caleidoscópio, Lisboa, p. 75. A arte transgénica convida a repensar as noções românticas do que é 'natural' ea reconhecer o papel do homem na história evolutiva das outras espécies (e vice-versa). Idem, p. 79. É isto que leva Virilio a reagir com ênfase: Impiedosa, a arte contemporânea já não é impudica, mas tem a impudência dos profanadores e dos torcionários, a arrogância do carrasco. In idem, p. 83.

269 Idem, p. 77.

270 Gilardi, comentando entusiástico um famoso jogo de futebol entre artistas em pleno pavilhão de exposições da Third International Exhibition of Figurative Art, Amalfi, 1968.

271 No caso de Hans Haacke, como que se torna clara a hipótese de se encontrar inscrita, na genética da arte conceptual, a crítica não apenas da instituição arte, como de qualquer instituição e na verdade do próprio fenómeno da institucionlização da criatividade e da criação. Até que ponto tal crítica é uma consequência política essencialmente reactiva là situação do pós Guerra [Vietname]), seria interessante explorar.

272 Quando, em MoMA Poll (1969) desmonta publicamente as afirmações de Hermann Abs, director dos Amigos do Museu, a quem o artista denuncia não apenas o passado nazi mas sobretudo a hiprocrisia autónomo-modernista.

273 Idem, p. 247. 
or subversive character was minimized and absorbed, to the extent that it now seemed little more than another tool in the arsenal of the establishment [...] $]^{274}$ Apesar de toda a proficiência de uma geração de artistas que cada vez melhor domina as linguagens da arte - como em When attitudes become form, entre o supermercado e o wunderkammer ${ }^{275}$ - a arte (conceptual e/ou ambiental) não parece conseguir descolar-se de uma irrelevância política que já Lucy Lippard, já em 73, diagnostica, no seu livro Six Years.

Na obra Arte Y Revolucion, Brian Holmes estabelece uma deriva extradisciplinar nas formas de activismo cultural e o desejo generalizado de, quer activistas, quer artistas (simplificando), consumarem a sua pulsão de associação entre arte e social. Sem o mencionar explicitamente, Holmes confirma a minha intuição de que a liberdade no atravessamento das disciplinas - e portanto das modalidades artísticas -, que não pode ser desligada da meta-filosofia transdisciplinar, sendo até sua crítica -, é condição sine qua non para um activismo genuinamente transformativo. Though they are not the same, interdisciplinarity and indiscipline have become the two most common excuses for the neutralization of significant enquiry. ${ }^{276}$ Ora,

[...] extradisciplinary ambition is to carry out rigorous investigations on terrains as far away from art as finance, biotech, geography, urbanism, psychiatry, the electromagnetic spectrum, etc., to bring forth on those terrains the "free play of faculties" and the intersubjective experimentation that are characteristic of modern and contemporary art, but also to try to identify, inside those same domains, the spectacular or instrumental uses so often made of the surprising and subversive liberty of aesthetic play [...] $]^{277}$

Nessas investigações extradisciplinares trata-se de entender a indisciplina ${ }^{278}$ como fundamento vital da democracia:

I've atempted to rethink democracy by refusing both its official identification with the statal forms and lifestyles of rich societies and denunciation of it as a form that masks the realities of domination. [...] I've reactivated the real scandal of democracy - which is that it teveals the ultimate absence of legitimacy of any government. [...] I've thus been led to conceive democracy as the deployment of forms of action that activate anyone's equality with anyone else [... $]^{279}$

É uma posição que vai 'minando' a identificação democracia/capitalismo (sujeito/consumo). Apelando a um ethos anarquista-idealista, ela realiza-se como modelo para a desclassificação de discursos, a principal função que Rancière atribui à arte (Literatura) ${ }^{280}$ e que é no fundo a proposta de uma tensão: a tension between two contradictory requirements: one of these makes art and aesthetic perception into a specific sphere of experience, disconnected from the rules that operate in other spheres; the other feeds on interchange between the arts and spheres of experience and converts art's ways of making into collective ways of life. ${ }^{281} E$ então nos termos de uma activação política da arte da terra que podemos pensar o activismo, pro-

274 Idem, p. 251.

275 Godfrey, p. 252.

276 Holmes, Brian; «Extradisciplinary Investigatons. For a New Critique of Institutions», in Arte Y Revolucion, Brumaria.

277 Idem, p. 197.

278 Entrevista «Jacques Rancière and Indisciplinarity», Translated by Gregocy Elliot, in Art\&Research - A Journal of Ideas, Contexts and Methods, Vol. 2, N.1, Summer, 2008, p. 1. Jacques Rancière: It's not only a matter of going besides the disciplines but of breaking them. [...] My problem has always been [...] the distribution of territories.

279 Idem.

280 A contraposição Literatura/Filosofia é importante, sobretudo nesse género-pivot que é o ensaio. Pois na literatura há uma poiesis e uma materialidade das emoções que a filosofia não oferece.

281 Idem, pp. 1-2. 
blematização identificada por Rancière (mas também em Claire Bishop, Grant H. Kester ou Malcolm Miles), do ponto de vista do conceito de transversalidade (Guattari, entre outros):

The concept helps to theorize the heterogenous assemblages that link actors and resources from the art circuit to projects and experiments that don't exhaust themselves inside it, but rather, extend elsewhere. The projects that result can no longer be unambiguously defined as art; they are based instead on a circulation between disciplines, often involving the real critical reserve of marginal or counter-cultural positions [...] which can't be reduced to an allembracing institutionality. ${ }^{282}$

Godfrey sintetiza-o como terceira fase da crítica institucional. A propósito da exposição Making Things Public, comissariada por Bruno Latour ${ }^{283}$. Holmes sublinha a intenção do curador: [...] elucidating the specific encounters between complex technical objects and specific processes of decision-making. [...] For that, he says, one must proceed in the form of "proofs,", established as rigorously as possible, but at the same time necessarily "messy," like the things of the world themselves. ${ }^{284}$ Ou seja, o activismo sócio-ambiental é a lógica indisciplinada da criação face aos desafios sociais mais prementes do capitalismo.

Entretanto ${ }^{285}$ has what was once a critique of spectacle become merely spectacle? ${ }^{286}$ Victor Burgin, em 1988, afirma que a arte conceptual dos anos 60 havia sido uma vanguarda faIhada ${ }^{287}$, exactamente na medida em que a nova arte conceptual dos anos 90 se reduz a ser nothing but commodity, nothing but style. ${ }^{288}$ Esta anulação da potencialidade cognitiva da arte conceptual (em espaço público, como contributo para a consciência ecológica), esteve sempre a pairar sobre o desígnio emancipatório dos movimentos críticos, na ideia de que na arte conceptual dos anos 60 aos anos 90 do que se trata de um projecto inacabado (Foster, Newman, Perniola). House de Rachel Whiteread, em $1993^{289}$, é exemplo icónico de uma arte pública resiliente à tentação comunicacional, tal como os contramonumentos de Jochen Gerz, que conseguirão permear o sublime contemporâneo de uma discrição clássica que é todo um programa de argumentação politizada na esfera de uma re-monumentalização minimal da cidade.

Entre posições de grande vigor estético e experimentação da street art, é num contexto de prolongamento da cultura popular (do porno à pop) que vão nascendo focos de uma crítica que recupera os adágios das primeiras vanguardas e da neovanguarda dos anos 60 em novas contextos e situações em que o social ganha relevo retórico porque aceita o jogo da totalidade do habitat humano. Em artistas com sabor a provocação mas que no fundo são expressão de uma complexidade do social vivida performaticamente - Orozco, mas também Alys ou Gonzalez-Torres, a arte conceptual está no limite de uma funcionalidade micro-política que convida a uma poética: Politique dans le sens grec de polis la ville comme un lieu de sensations et de conflits d'où l'on peut extraire eles materiaux pour créer des fictions,

282 Holmes, Brian; «Extradisciplinary Investigatons. For a New Critique of Institutions», in Arte Y Revolucion, Brumaria., p. 200.

283 E em que participou Christian Nold.

284 Idem, p. 201.

285 Na sequência do sucesso mediático de artistas como Rachel Whiteread, Damien Hirst e os chamados Young British Artists.

286 Godfrey, p. 382.

287 Idem, p. 386.

288 Idem, p. 386.

289 Peça emblemática dos anos 90 e que é muito semelhante a uma obra de 1967 de Ed KJienholz, a qual por sua vez não procura de tdo o efeito de Whiteread, mas algo de muito mais equilibrado, em termos ret'roricos. 
de l'art et des mythes urbans. ${ }^{290}$ Conclui-se que If the paradigm for the Conceptual artist in the 1960s was the philosopher, that for the artist in the 1990s has been the researcher. ${ }^{291} \mathrm{Um}$ investigador que por vezes não hesita em integrar equipas complexas, ou a colaborar com outros artistas e criadores, sempre com o objectivo de enriquecer a sua capacidade colectiva de lidar com a complexidade em fluxo da forma urbana: [...] working together. The key aspect of Conceptual art today, would, thus lie not in objects or spaces, but in communality, and an emphasis on communication and on how people behave. ${ }^{292}$ Se nada disto é completamente novo, é inédita, desde os anos 90, a escala, quer em número de artistas e em disponibilidade para estes alargarem o âmbito tradicional da arte, quer da sua distribuição pelo globo (Scholette): Perhaps more than its impact on the museum it is in the impetus that Conceptual art has given to interventions outside the museum, in social space, that matters - the reformulation of public sculpture as something that interacts with life around it. ${ }^{293}$ Podemos então tecer um paralelismo entre a prática da arte conceptual na cidade e a formulação de perguntas: [...] if Duchampian ready-made functions like a full stop, arresting one's progress, breaking the flow, these little objects [no caso, uma peça de Gabriel Orozco] so cunningly placed, function like accents, pointing and enlivening the sentence. ${ }^{294} \mathrm{Na}$ cidade-texto, a micro-arte pós-conceptual-ambiental limita-se, por vezes, a sublinhar momentos de uma consciência colectiva sempre em emergência; outras vezes, torna-se parte do Projecto maior da urbanidade. Trata-se de finalmente integrar, já não apenas negativa ou positivamente, mas imanentemente, a ideologia na arte: Art should be concerned with how things and representations relate to one another in the world today (that is to say, ideology). ${ }^{295}$ Nada mais que o que Lefèbvre havia afirmado, tem vindo a ser objecto de uma reflexão e sobretudo de uma acção fundada em várias formas não apenas da teoria crítica, mas das ciências sociais em conjunto.

\section{O conceptual turn na cidade, bolsas de novas economias}

Há um inventio específico da obra de arte conceptual: Conceptual art begins with [...] negativity or doubt, but then moves beyond it by imagining, or making a proposition; ${ }^{296}$ a arte conceptual explicita um possível, sob a forma de desafios discursivos. Notará Lucy Lippard, ${ }^{297}$ a realização de arte neste regime acarreta a criação de mundos próprios no espaço urbano. Haveria radicalidade 'política' na arte sem a arte pública ser 'conceptual' na abordagem do espaço social tal como expresso na forma urbana? As definições de arte conceptual que sublinhem a dimensão política dessa desmaterialização/expanção do dispositivo artístico são as que permitem 'fazer a ponte' entre a arte como arquitectura-jardinagem (Grout) e formas que me parecem determinar todo um território de encontro com o urbano como

290 Alys, Francis; Walks/Paseos, Museo de Arte Moderno, México/Museo Regional de Guadalajara, 1997.

291 Godfrey, p. 416

292 Idem, p. 419

293 Idem, p. 420.

294 Idem, p. 415.

295 Idem, p. 255.

296 Godfrey, p. 12 . Godfrey reitera os termos de Millet.

297 Lippard, Lucy; The Lure of the Local, New York, London, The New Press, 1997. 
formalização de relações de poder, da institutional critique à arte informacional, passando por formas embrionárias, activistas, de participação cidadã. Em suma, a intuição conceptual é o principal aspecto de intensificação da experiência artística numa axiomática da arte urbana: [...] Conceptual art is concerned both with intellectual speculation and with the everyday. ${ }^{298}$ Penso que se trata, muito evidentemente, de abrir à arte um espaço vital retórico.

Em The Royal Road to the Unconscious ${ }^{299}$, de 2003, obra em que a linguagem cria, destrói e modifica a significação, num acto colectivo que é dispositivo complexo de participação multidimensional, a filosofia serve precisamente - e apenas - para irmos de encontro ao desejo do outro, para além da significação. A relação que Simon Morris estabelece com a filosofia se situe à un niveau profond mais refuse nettement tout systématique car celui-ci contredirait la dynamique même de son travail300 e é nesses termos que a arte conceptual pode ser a base da retórica como racionalidade da arte na cidade.

De acordo com Godfrey - Conceptual art is not about forms or materials, but about ideas and meaning -, a arte conceptual tem uma função de ideação e de significação, ao mesmo tempo que questiona os fundamentos da sua instituição plenamente contingente ${ }^{301}$ na consciência dos seus mecanismos de materialização (formal). Se toda a história da arte conceptual, em sentido estrito (como género), e como metodologia, acaba por ser uma importante fatia da história da experimentação e da cognição em arte, as suas implicações na deriva urbana da arte contemporânea vão levar ao problematizar de valores propriamente sociais e civilizacionais. Não é por isso de estranhar que a instituição-forma museu seja dos primeiros objectos de crítica da arte conceptual; nas acções de Jack Smith e Henry Flint em 1963, o dispositivo gráfico de crítica do museu (cartazes políticos manuscritos, idênticos aos de qualquer acção de reivindicação) é textual, explícito, com um nível directo que advém da sua integração em painéis de tipo de manifestação política, à escala do corpo humano, mas que integram a forma urbana na sua discursividade (o passeio público como resiliência ao museu) ${ }^{302} \mathrm{Em}$ harmonia com esta atitude, a arte é hoje cada vez menos concebível fora de uma social aesthetics:

The "social" interests of contemporary art are articulated along an axis of artistic strategies that in different ways are said to take place on the borderline of the art institution. Typically these strategies describe an involvement with

298 Godfrey, Tony; Conceptual Art, Phaidon, New York, 1998, p. 15.

299 Dans The Royal Road to the Unconscious, Simon Morris a photocopié et grandi au format A2 les cent trente-six pages de L'Interprétation des rêves, de Freud, puit il a travaillé avec soixante-dix étudiants qui suivent son enseignement d'histoire de l'ar à découper ces pages mot à mot, au long d'un cours de trois heures, en prononçant à haute voix chacun des mots à mesure qu'ils étaient découpés dans chaque phrase. Ces trois cent-mille-trois mille neuf cent soixante mots ont été ensuite recueillis dans l'ordre. Une vídeo a été tourné de cette performance, sur la bande son de laquelle le psychanalyste lira a haute voix l'interprétation des rêves à l'envers. Puis Simon Morris jettera les mots découpés pas la vitre baissée d'une voiture conduite par le psychanalyste de Freud à Hampstead. Une vídeo será aussi tournée de cette éjection des mots hors de l'unité structurelle du texte de Freud, éjection qui les soumettra à un moment aleatoire. Le psychanalyste aura ensuite la responsabilité de mener um photographe enrigestrer la manière dont les mots seront tombes, et ces photographies seront recueillies dans un livre. Britton, Howard; «Simon Morris: philosophiquement irresponsable», in Revue d'Esthétique, n. 44, 2003, pp. 139-140. A peça evoca outra, de John Latham em 1966, em que artista levou uma série de estudantes seus a rasgar as páginas de Art and Culture de Clement Greenberg, mastigá-las, recuperar a pasta obtida e depois destilar o líquido, para finalmente preservá-lo num frasco.

300 Idem, p. 140-141.

301 Kosuth: The 'purest' definition of conceptual art would be that it is inquiry into the foundations of the concept 'art', as it has come to mean. In Kosuth, Joseph; 'Art after Philosophy', Studio International, 1969.

302 Lash, p. 32. Ao pôr em causa a evidência material da sua arte, não está o artista a negar, mas a refundar a sua arte. Não estamos longe do acto de Duchamp, quando trouxe Fountain para o museu: he was not questioning the status of the art object, but that of the museum as site. 
corporate structures or with an activist ethos or aesthetic; with alternative economies and systems of distribution; and collaborative models and collective identities. ${ }^{303}$

Esta questão é hoje revisão das vanguardas (e das neovanguardas) históricas ${ }^{304}$, revisitação (helicoidal) do 'produtivismo' e sinónima de uma retórica crítica da relação arte-social. ${ }^{305}$ Terei, com Larsen, cuidado para não extrapolar esta genealogia; mas reconheço que em épocas passadas como agora há seres humanos movidos por energia com traços comuns à de outros seres humanos e que perante certas condições de produção artístico-cultural, reagem na consciência mais ou menos plena de que é possível enfrentar de forma crítica o status quo e desenvolver projectos urbanos colectivamente, com um sentido emancipatório: What artistic activity during the 90s have demonstrated is that the only possibility in relation to the public sphere is to act in limited pockets in social space - and thereby attempt to establish other economies. ${ }^{306}$ Larsen emprega o termo bolsas de novas economias (ecoando Bataille), esfera de um laboratório (Shefer), ou melhor ainda, de um ensaiar intranquilo (Barrento), modos fragmentários e fulgurantes da criatividade política. Na prática, penso em trabalhos em que exista a simultaneity of interests, which so to speak give up the comprehensive view of themselves. ${ }^{307}$ Ora Larsen é preciso no sublinhar da dimensão performática de obras que propõem tais economias alternativas: What I choose to call 'social aesthetics' is an artistic attitude focusing on the world of acts, and which experiments with the transgressions of various economies. ${ }^{308}$ Está em causa uma dinâmica entre actividade artística e esferas que, por tradição, pertencem exclusivamente ao tecer do social:

Social and aesthetic understanding are integrated into each other. The same thing goes for the dichotomy of institutional/non-institutional space. [...] The social aesthetic artwork involves a utilitarian or practical aspect that gives a sense of purpose and direct involvement; in the construction of the subject's interaction with culture it could be said that social aesthetics discusses a notion of the lasting phenomenon which substantiates a critical cultural analysis, a reason for one's existence. It is a way of involving the metaphorical value of artistic concepts and projects on other professional spheres, such as architecture, design, financial structures etc. [...] This often involves collective organisation and an employment of art's capacities for going against professional specialisation. ${ }^{309}$

Se depois as obras que interpretam este programa se inclinam para a crítica do museu e da galeria ou se optam pela via do activismo comunitário, privilegiando ou não o carácter de situações em determinados contextos considerados mais ou menos oportunos, essas já são questões formais (técnicas).

303 Larsen, Lars Bang; in http://www.aleksandramir.info/texts/larsen_afterall.html.

304 Idem. Now, the tradition of avantgarde art has aspired to a concrete form of cultural work in the public sphere - even if it has rarely performed that work. In connection with the present focus on artistic "productivism", different spheres are being, not necessarily transgressed, but they are being articulated simultaneously in ways which remove these articulations from a traditional artistic radicalism.

305 Idem. Volto a citar Larsen para justificar a perspectiva específica que move este meu scan da arte contemporânea actual: As with any other type of art it hardly makes sense to talk about any ultimate curatorial and artistic motivation for dealing with social sensibilities. Nor is it particularly productive to attempt a definition of ethics, aesthetics or the social from any institutional or social outside. I believe it makes more sense to establish as a starting point the intentionality of specific agents, to try to verify particular standards in a diversity of spaces.

306 Para esta questão sugiro a posição de Georges Bataille em A Parte Maldita, nomeadamente o capítulo «O Mundo Burguês». Parente a constatação da redução do homem à coisa (à mercadoria). Bataille avisa: Se o homem deve acabar por se reencontrar, é em vão que procura seguindo as vias que o fizeram afastar-se de si próprio. Ao texto encontra-se subjacente o fulgor de uma outra economia que não a hegemónica no mundo ocidental capitalista la não confundir com a experiência do comunismo reduzido à coisa nos regimes 'soviéticos'). Bataille, Georges; A Partida Maldita, Fim de Século, Lisboa, 2005.

307 Purves, Ted (ed.); What we want is free. Generosity and Exchange in Recent Art, State University of New York Press, New York, 2004. There is no ideological monomania...

308 Idem.

309 Idem. 


\subsection{Natureza (e o Homem) e a arte contemporânea: a tradição da Land Art}

O Homem não é a apenas uma figura na paisagem. Ele molda essa paisagem.

Jacob Bronowski

A conexão dos seres humanos com o meio ambiente é primária. A Natureza é uma 'vasta matriz' (Kastner), mas a combinação da nossa ambição e dos nossos dons levou-nos a querer mais do que sobreviver. ${ }^{310} \mathrm{~A}$ Land Art é modalidade de intervenção artística que programaticamente responde aos desafios da Terra, do Planeta e do Cosmos; representa, um interesse crescente pela natureza, emergência da consciência ecológica (Jimenez). Na prática, o afastamento da galeria empreendido por um pequeno número de artistas conceptuais nos anos 60 representou a desire to measure the power of the artwork isolated from the cosmopolitan commoditications of the white cube; $;^{311}$ mas também uma forma de atenção conceptual à natureza: Land Art is an imperfect hyponym for a slippery and widely interconnected brand of conceptual kinship. ${ }^{312}$

Na Land Art emerge um paradigma cultural que é uma ética de intervenção no território: the late-industrial biosphere, all the work included here has as its pivot the land and the individual's responses to and activity within it. Em Robert Smithson, cujos escritos ${ }^{313}$ revelam o minimalista que mais convictamente partiu para os grandes espaços naturais para desenvolver a sua linguagem, temos um campeão desta deriva. Spiral Jetty, de 1970, é obra icónica de toda a neo-vanguarda land, sintetizando materialmente reflexões precisas acerca das possibilidades de a arte expandir a sua gramática interventiva. Smithson propõe a rejeição do apparatus museológico, galerístico ou curatorial como lugares adequados à apresentação da arte contemporânea; um interesse por espaços que são o contrário dos idílicos jardins desenhados pelos paisagistas - regiões infernais com as quais a sociedade não sabe o que fazer; o desprezo pelas lixeiras em que se tornaram as galerias de arte, intervalos de desolação visual; o fascínio pela entropia como valor de projecto luma ideia na Física mas igualmente na história inactiva de Dan Flavin); a entrega da emoção estética ao infinito banal das superfícies e das estruturas, isto é, à indiferenciada massa de sensação orgânica (Barthes); a aceitação do erro e dos impasses como culminares do processo artístico - Problems are unnecessary because problems represent values that create the illusion of purpose. ${ }^{314}$ Esta é a posição do artista que se apercebe da radicalidade das aberturas que está a inscrever no habitus da arte. Para Smithson - mais gramático que retórico, e numa convicção heróica e individual - faz assim todo

310 Kastner, Jeffrey (Ed.); Land and Environmental Art, Phaidon Press, 2005, p. 11. We aspire to leave our mark, inscribing our observations and gestures within the landscape, attempting to translate and transgress the space within which we find ourselves. If our culture is the manifestation of this drive, then its continuing with the land is testament to both the potential and the strictures of our terrestrial condition. Subject both of science and art, the landscape functions as a mirror and a lens: in it we see the space we occupy and ourselves as we occupy it.

311 Idem, p. 12.

312 Idem.

313 Entre 1964 e 1973, Smithson escreve com enorme verve acerca dos seus contemporâneos, entre eles Dan Flavin, Donald Judd, Sol Lewitt, Robert Morris, num testemunho em primeira mão ethos das neovanguardas minimal e ambiental.

314 Smitshon, Robert; «Cultural Confinement», 1972; «Entropy And The New Monument», 1979. 
o sentido que a cidade the interesse sobretudo na sua abstracção ${ }^{315}$ - ele pensa o mundo como monumental tela, barro, superfície.

Mas outra conquista correlata da Land Art é a da intervenção artística informada pelo paradigma propriamente ambiental (no sentido do mundo como macro-contexto, sistema vivo, ecologia). Seguindo os termos de Catherine Grout, articula-se aqui ideia da Land Art a partir do mundo como 'jardim', uma terra-jardim que os artistas se sentem chamados a abordar no sentido do cuidado. É um programa artístico holístico, que à medida que o mundo se foi urbanizando a um ritmo exponencial, se tornou social por excelência, numa articulação fundamental da comunidade com o seu habitat. A Land Art é então também a articulação não apenas multidimensional mas propriamente multi-escala entre território e comunidade, sociedade e civilização. Portanto, a arte - tal como a língua, tal como a cidade - é sempre um conjunto de constrangimentos formais elementares perante os quais a pulsão individual criadora, quando temperada (temporizada) por um ethos de atenção e envolvimento, se constrói a partir da experiência total e conscientemente colectiva ${ }^{316}$ da cidade. Tal consciência, ou é eco-lógica ou não é. Isto é, ou lida com o legado ideológico, as infraestruturas e poluição ${ }^{317}$ do constructo natureza-cultura dominante na contemporaneidade, ou não será capaz de realizar as operações de reclamação e/ou restauração ${ }^{318}$ que uma ampla comunidade de disciplinas têm identificado. Hefele explicita uma Restoration Ecology que parte de questões importantes como o significado de uma natureza pós-industrial e a consciência de que as formas discursivas e espaciais da esfera pública não são separáveis de uma noção sistémica la questão das relações entre as partes de qualquer todo no quadro da teoria dos sistemas), da intervenção paradigmática (a ideia de que na transcendência dos paradigmas prevalecentes radica o motor da mudança), da ética ambiental ou do projecto de planeamento colaborativo. ${ }^{319}$ Aliás, nestes termos, a 'arte da cidade' é necessariamente informada por novas ecologias: pela ecologia social (Murray Bookchin) that calls for a grand decentralization scheme with a move to smaller cities and appropriate Technologies, 320 pelo eco-feminismo, cujo foco é the biological relationship between humanity and nature; ${ }^{321}$ e pela Ecologia Profunda (Deep Ecology), posição já completamente bio-cêntrica, an ecology that recognizes the intrinsic value of non-human nature. ${ }^{322}$ Naturalmente, se nem todos estes movimentos são pontual ou regular e programaticamente abraçados pelos artistas, é subjacente à arte crítica a cidade como sistema de relações materializada como consciência total.

315 Smithson aborda os trabalhos de Robert Morris e o seu 'vazio': This kind of nullification has re-created Kasimir Malevich's "non-objective world," where there are no more "likenesses of reality, no idealistic images, nothing but a desert!" But for many of today's artists this "desert" is a "City of the Future" made of null structures and surfaces. This "City" performs no natural function, it simply exists between mind and matter, detached from both, representing neither. In Smitshon, Robert; «Entropy And The New Monument», 1979.

316 Cardoso, in Flusser, p. 15. O fim da história parece ser o fim de nossa capacidade coletiva de lutar contra a entropia, contra a desagregação do sentido e da forma. Perante este quadro, a land art (pública, crítica) é fundamental na reformulação da percepção, muito mais do que da paisagem.

317 Hefele, p. 223.

318 Idem, pp. 223-224.

319 Cf. idem, p. 227.

320 Idem, p. 232.

321 Idem, p. 233. The eco-feminist approach is built upon a critique of the oppressive nature of an inherently masculine society.

322 Idem. The deep ecology approach is the most radical of the three ecologies; it is built upon a critique of materialism and technological progress. O seu impacto em Guattari ou Capra é conhecido. 


\section{Consciência, natureza, cultura. Operações e cuidar}

Kastner expõe um conjunto de operações básicas de inscrição dessa arte no território integração, interrupção, envolvimento, implementação, imaginação, incepção, iluminação; esta gramática fundamental, descendente do minimalismo fenomenológico, implica o território como sistema numa visão da retórica na forma urbana como uma retórica de situações, de momentos, possibilidades, de maior ou menor intensidade persuasiva. A 'arte da terra' é desde então crucial para a morfologia do urbano. ${ }^{323} \mathrm{Em}$ suma, o natural (par dialéctico da cultura, Eagleton) fornece pistas para a percepção e a conceptualização de um pathos eco-ambiental. ${ }^{224}$ É uma atenção fundamental ao que a natureza tem para dizer, que pode passar pela poetização (Kastner) do real mas que, nos casos mais activistas, assume contornos de uma cidadania complexa e interventiva, disponível para uma apropriação de quaisquer media (Brea) ou dispositivos que proporcionem um desenvolvimento sócio-económico vocacionado para os valores da igualdade, da fraternidade ou da justiça social lquestões éticas inscritas na retórica da boa vida de Aristóteles).

Por agora, delimito o crucial da problemática: os dispositivos da/na arte são ferramentas essenciais para lidar com a contradição intransponível entre cultura e natureza (Schiller e Wagner, hoje Flusser e Eagleton), uma contradição produtiva nos dispositivos mais interpelativamente críticos: The only thing we have to preserve nature with is culture; [...] The best Land and Environmental Art highlights this contradiction, probing the limits of artistic activity with the limitless tools of the artistic imagination. ${ }^{325}$ Kastner resume assim a dimensão ambiental da arte nos termos de uma síntese artística que decanta Lefèbvre (o quotidiano) ou Marcuse (a imaginação) no território da produção do urbano. ${ }^{326}$ Esta aproximação à Land Art como retórica processual prefigura, paradoxalmente, uma cultura urbana em fase de acelerada expansão. $O$ design da arte expande o seu logos aos espaços, territórios e eco-sistemas, não sem a irrupção pontual da hubris fáustica da criação humana, fascinada pelo seu poder de transformação. Acentuando o traço territorialmente extramuros deste movimento, surpreende-se-lhe uma urgência vital. ${ }^{327}$ Para esta aproximação ética específica entre arte e cidade - Here the sphere of ethics and aesthetics merge. ${ }^{328}$ - a Land Art foi em dado momento a principal forma de resistência cultural na era pós-moderna, precisamente porque alargando a liberdade discursiva do conceptual ao material comum que é a terra. É por isso a Land Art a forma escultórica por excelência (Jonathan Miles), aquela que de forma mais completa e profunda interpreta uma ansiedade que veremos

$323 \mathrm{Na}$ forma como se sucedem terminologias como site-specificity, context-specificity, place-specificity, o que importa é o carácter de imperativo ético perante um destino urbano comum.

324 É uma longa história, de que menciono aqui apenas dois curtos momentos no dealbar da modernidade. Goethe had argued that rather than subjecting nature to artificial situations in the laboratory we should indulge in a two-way dialogue. When this is done, nature will provide us with "the example worth a thousand". [...] Cézanne wrote: "The landscape becomes reflective, human and thinks itseld through me. I make it an object, let it Project itself and endure within my painting... I become the subjective consciousness of the landscape, and my painting becomes its objective consciousness. Peat, David F.; «The Dancing Strands», in Artful Ecologies, University College Falmouth, 2006, pp. 19-20.

325 Idem, p. 17.

326 A razão para a actualidade de Michael Heizer, Robert Smithson, Robert Morris, Dennis Oppenheim, Mierle Ukeles, Nancy Holt ou Walter de Maria é no fundo o impacto retórico dos seus gestos.

327 Rose, Barbara; Artforum, 1969. Já em 1969, A dissatisfaction with the current social and political system results in an unwillingness to produce commodities which gratify and perpetuate that system.

328 Idem. 
mais tarde transitar de movimento artístico em movimento artístico, sempre renovando o seu apelo vitalista a partir de uma operação de cruzamento de um qualquer tipo de fronteira (Turner), nomeadamente artificial. É evidente, aqui, a co-optação desta modalidade artística com a tradição performativa, o género da instalação e as derivas sociológica e feminista. Acerca da própria relevância da arte num mundo contemporâneo em acelerada mutação, é portanto 'lá fora' o lugar onde a arte renova o seu sentido. Ora é essa realidade do espaço - um espaço infinito, mas ao mesmo tempo próximo, com carácter de acontecimento iminente/imanente que, desde então tem oferecido à arte uma relevância política inédita.

\section{Acção-informação: o social do gesto cidadão}

A politicidade do gesto artístico passa em muitos casos por um apagamento do autoral como ego - uma de-authored lineage (Bishop) que não poucas vezes equivale a um aspecto femino-maternal do cuidar da cidade: feminists are more willing than others to accept the notion that art can be aesthetically and socially effective at the same time. ${ }^{329}$ Algures entre a lógica (técnica) conceptual e o ethos (ética) ambiental joga-se um novo programa de atenção feminina (Miles) e mesmo maternal (Irina Aristarkhova) ao real do social e urbano. 0 enfoque feminista ajudou assim a definir uma dimensão funcional-utilitária que aproximará definitivamente a arte e o design crítico e cidadão. ${ }^{330}$ É a arte feminista que impõe a dimensão de crítica social imanente que se instalará com impacto generalizado já nos anos 90, aportando vitalidade terapêutica ao tecer da cidade. Regra geral, esta Performance Art recupera a energia Dada e do happening de uma forma que é deliberadamente refractária ao modelo de desenvolvimento de sociedade capitalista. Esta genealogia (Bruce Nauman, Vito Acconci ou Chris Burden), tem em Ana Mendieta ou Adrian Piper intérpretes excepcionais de uma atenção ao quotidiano urbano e social que began to turn away from dead-end behavioural critique and nascisistic tests of physiology, toward practically effecting changes in the realms of cultural identity, community, co-operation and personal realization. ${ }^{331}$ Beuys e 7 000 oaks, ou Mierle Laderman Ukeles e Touch Sanitation, ${ }^{332}$ representam respectivamente um acto urbanístico, participado pela comunidade e comunicado à escala de uma temporalidade complexa); e uma micro-acção (paradoxalmente com uma escala monumental) delicada, cuja aparente irrelevância a torna um poderoso libelo de atenção ao outro. São 'acções-catalizadoras'. ${ }^{33}$

Há que sublinhar igualmente toda uma linha de intervenção proselitista, já não propriamente envolvida em formas de mero jogo processual, mas em rituais ou cerimónias. ${ }^{334}$ É o caso dos

329 Lippard, 1980, «The contribution of Feminism to the Art of the 1970's», Art Journal, New York, Fall/Winter 1980.

330 Tanto quanto o primeiro impulso da Land Art acarreta uma apoteose da linguagem minimalista, por via de um formalismo que, paradoxalmente, ecoa o Alto Modernismo que pareceria querer derrubar.

331 Kastner, p. 15.

332 Cf. http://www.communityarts.net/readingroom/archivefiles/2002/09/touch_sanitatio.php

333 Idem, p. 233. Em Adrian Piper each act being a 'catalytic' agent between myself and the viewer' la catalytic agent is one that causes change, but does not change itself). She did not want to make Happenings, so she behaved cooly, as if nothing untoward was going on. She wanted to preserve the impact and the uncategorized nature of the confrontation

334 É o caso de Ana Mendieta, ou de Hannah Wilke. 
lenços de Annete Messager, em que são bordadas frases ('You can trust your dog, never your wife') que colocam questões relacionadas com o estatuto da mulher na vida social (Kristeva, Irigary) de uma sociedade desequilibradamente patriarcal. Em causa está o dar visibilidade (Arendt) a quotidianos obscurecidos pelo logos urbano hegemónico: Signs that say what you want them to say and not signs that say what someone else wants you to say. ${ }^{335}$ Por isso em vários artistas encontramos um corpo-a-corpo com a cidade-sistema - as estéticas intervencionistas de Christo ou Wodisczko; There has been a tendency to interpret Land Art as not truly Conceptual, both because it created such large objects and because it is thought to have somewhat uncritical, sentimental or nostalgic philosophy. ${ }^{336}$ Os gestos que esses artistas laboram numa micro-escala performática para assim se dirigirem ao seu público sem colocar entre si e esse público, tanto quanto isso é possível, o objecto de arte. De facto, em Ukeles

[...] it was precisely the everyday (washing, cleaning, gardening, nurturing) that held the raw material for artistic investigation. Dovetailing with a generalized reawakening of environmental interest, linked to notions of caretaking conventionally associated with the feminine, the works of leading female figures in the avant-garde of the time profoundly altered the course of post-war cultural discourse and practice, changing our expectations of what a work of art could be. ${ }^{337}$

O quotidiano, nessas obras, transforma-se em momento. Malcolm Miles sublinhará o interesse político destas práticas intersticiais, precisamente através da sua relação com a Teoria dos Momentos em Lefèbvre. Falamos de práticas que expanded into the contextual spaces between previously delimited boundaries of sociology, science, history and art by conflating all of them into a messy and frequently exuberant expression of 'postmodernist' twentieth-century life. . $^{338}$ Se este interstício é o da habitabilidade no espaço público contemporâneo, há outro legado partilhado entre os neo-vanguardistas conceptuais/contextuais de 70 e os artistas críticos contemporâneos, o da 'informação'; mas se Victor Burgin, Dan Graham ou Donald Judd acreditaram que a informação era inerentemente positiva, num período posterior, desencantado com a violência quotidana dos mass media, a informação é mais difícil de se abordar produtivamente. A informação é condição sine qua non para nos tornarmos mais atentos e escaparmos à máquina de produção social da estupidez que está na base da alienação e da apatia. No entanto, often neither a single fixed belief nor a single lie is sufficient to generate stupidity. The world thrives on intrincate fictions and irrational values of symbolic capital. ${ }^{339}$ Mais, some truly spectacular forms of stupidity deploy intelligence to maintain the power of their persuasion. ${ }^{340}$ Isto é, A remarkable agility is deployed in the service of rigidity. ${ }^{341}$

A todos os níveis das decisões do urbano - dos campos de detenção em Guantanamo aos condomínios fechados na Europa e na América, dos resorts no Dubai à gestão de uma espaço de acesso restrito, estas questões tornam-se eminentemente arquitecturais (Easterling), enquanto materialização da estupidez:

A three-dimensional materialization - a cartoon - of stupidity is also a common technique of contemporary urbanism. [...] These urban protocols physically reinforce the desire for the end of politics as a clearing house of diversity

335 Nome de uma obra de Gilliam Wearing, em 1992.

336 Idem, p. 237.

337 Idem.

338 Idem.

339 Easterling, Keller; «Too smart to be right: the stunning political stucess of special stupidity», in Miessen, Basar (eds.), p. 35.

340 Idem, p. 36.

341 Idem. 
and representation. They [zonas de comércio livre, resorts de golfe e outras formações de enclave] are designed to materialize and support special stupidity. ${ }^{342}$

Nestes termos, uma idílica estância turística no Extremo Oriente ou um condomínio fechado em Óbidos, mas também, no limite, qualquer decisão urbanística pouco transparente, torna banality into a political extreme and that aspect of utopia that is prescriptive and self-reflexive into a naturalized urban paradigm. ${ }^{343}$ Easterling conclui:

In this light, tools like architecture and urbanism, which seem to be innocent of political dealings, may be particularly well suited to send in a new technology or logistical wrinkle - one that tips the power of the lockdown towards other political contigencies. ${ }^{344}$

A informação crítica torna-se factor central da ideia de intervenção urbanística, na consciência do artista not as a creator of materials but rather as a co-ordinator of existing materials. ${ }^{345}$ Esta tensão entre obra (limitada) e intervenção (acção significativa, no território, na cidade pode ser elucidada pela emergência do conceito de contexto, ${ }^{346}$ no devir da urbe, a humildade da 'não-arte' de Kaprow, relevando que o que é importante é o que o artista não toca, amplia exponencialmente a própria civilização como monumental ready-made, ${ }^{347}$ por outro lado, Beuys é tanto capaz de ser misticamente dialógico ${ }^{348}$ como pleno de wit e intuição táctica. ${ }^{349}$ Apesar de o seu enorme ego (Godfrey), e de uma performatividade demagógica o afastarem do ethos prosaico e quotidiano que a maior parte da arte conceptual-ambiental trouxe depois confirmada pela arte comunitária, Beuys é um artista que nos permite clarificar várias das pontes possíveis entre a linhagem conceptual-contextual e a linhagem da Land Art, precisa-

342 Idem, p. 37.

343 Idem, p. 40.

344 Idem, p. 41.

345 Lash, p. 33. Note-se que esta deriva leva Victor Burgin a perceber desde logo que a arte conceptual mais 'pura' é ela mesmo um último estertor do formalismo, do próprio modernismo.

346 Idem, p. 176. Num autor como Daniel Buren, já se dá uma importante reavaliação da intencionalidade do happening. abertura do espaço de diálogo com o ambiente à totalidade dos elementos em jogo, giving a momentary structure to the place and time where they manifest themselves.

347 Kaprow, Allan, On the Blurring of Art and Life, 1964, p. 94. «The Shape of the Art Environment». Em «The Education of the Un-Artist, Part I» (1971), Kaprow afirma: Sophistication of consciousness in the arts today (1969) is so great that it is hard not to assert as matters of fact that the LM mooncraft is patently superior to all contemporary sculptural efforts. É um apelo ao mais humilde (Gross) dos sensos do acontecimento-contexto: It may be proposed that the social context and surroundings of art are more potent, more meaningful, more demanding of an artist's attention than the art itself! Put differently, it's not what artists touch that counts most. It's what they don't touch.

348 Em harmonia com esta posição, Cada Homem um Artista [...] não é um discurso de ideias. É o resultado de uma "acção". 100 dias seguidos num dos mais importantes encontros internacionais de arte contemporânea lo documenta $V$ em Kassel, 1972), onde Beuys não expõe, não contesta, nem reivindica mas simplesmente dialoga.

A ruptura com a norma individualista do artista criador a solo, dessubjectivando o papel da "autoria" na obra de arte ao ampliar a prática artística à criação colectiva, pressupôs o abandono do atelier e da galeria em favor da abertura do campus [...] mas também ao cidadão em geral - ora dentro de portas (em espaços púbicos, como a escola) com colectivos de artistas e/ou de alunos, ora fora de portas, com "não-artistas" [...] Importante para esta actualização do messianismo é a dimensão terapêutica do diálogo: Beuys here effectively changes the monologue of messianic revelation into a dialogue and thus multiplies the available speaking positions: anyone who feels addressed by the appeal is here invited to adopt the messianic position. This moment of multiplication is in fact also the primary formal characteristic of the installation. Júlio do Carmo Gomes, in Beuys, Joseph; Cada Homem Um Artista, 7 nós, Lisboa, 2010.

349 No dia 20 de Julho de 64, Beuys é agredido por jovens indignados, durante a sua performance Kukei, akopee - Nein!, que abordava o tema do nazismo e do silêncio pesado que caracterizava a relação das pessoas com esse passado.

Depois do grupo "desestabilizador" ter abandonado o palco do auditório, Beuys, apesar de sangrar do nariz la foto circulou nos media, e não apenas na Alemanha), não foi ao tapete e a sua reaç̧ão à violência e ao caos momentâneo foi vencida por uma postura dramatizada (e ainda mais provocatória): com o sangue a jorrar do nariz, ergue na mão esquerda um crucifixo enquanto a mão direita se estende numa saudação nazi. [...] 
mente pela linguagem radicalmente povera. ${ }^{350}$ Em aproximação à ecologia, um projecto de Beuys responde enfaticamente a estas questões e destaca-se emblematicamente: "7 000 carvalhos - Reflorestação Urbana de Kassel", de 1982. E a operatividade a-/transdisciplinar desse projecto passa pela superação belicosa (Deleuze/Guattari) da própria questão da forma: Confrontar-se com as estruturas de poder da arte implicava irromper das fronteiras convencionais da arte - não as fronteiras de conteúdo, discursivas, mas a fronteira da forma -, e implodir com os territórios convencionados do seu poder e exercício. ${ }^{351} \mathrm{Na}$ respiração vital desta retórica, Beuys concebeu, como ninguém de forma tão decisiva, a arte fora de todos os sítios, como se a arte fosse um rizoma, essa raiz adventícia e errática que cresceria em todos os campos sociais. ${ }^{352}$ No panorama deste pragmatismo complexo, sistémico e eco-lógico, Kaprow antecipa o meu modelo axiomático:

[...] five root types found in everyday life, the nonart professions, and nature: situational models (commonplace environments, occurrences, and customs, often ready-made), operational models (how things and customs work and what they do), structural models (nature, cycles, ecologies, and the forms of things, places and human affairs), self-referring or feedback models (things or events that 'talk' about or reflect themselves), and learning models (allegories of philosophical enquiry, sensitivity-training rituals, and educational demonstrations. A number of the artworks do nor fit neatly into their assigned categories but can belong in two or three at once, depending on where we want to put the emphasis. ${ }^{353}$

350 Na primeira geração da Arte Povera, a arte conceptual acede ao comum de uma forma inédita. Mesmo quando temos de ir buscar ao interior da galeria um momento de informação radical, como acontece com a peça de David Lamellas na Bienal de Veneza de 68, cuja obra consistia numa máquina de telex que debitava as útimas notícias do Vietname.

351 Idem, p. 29.

352 Idem.

353 Idem. 


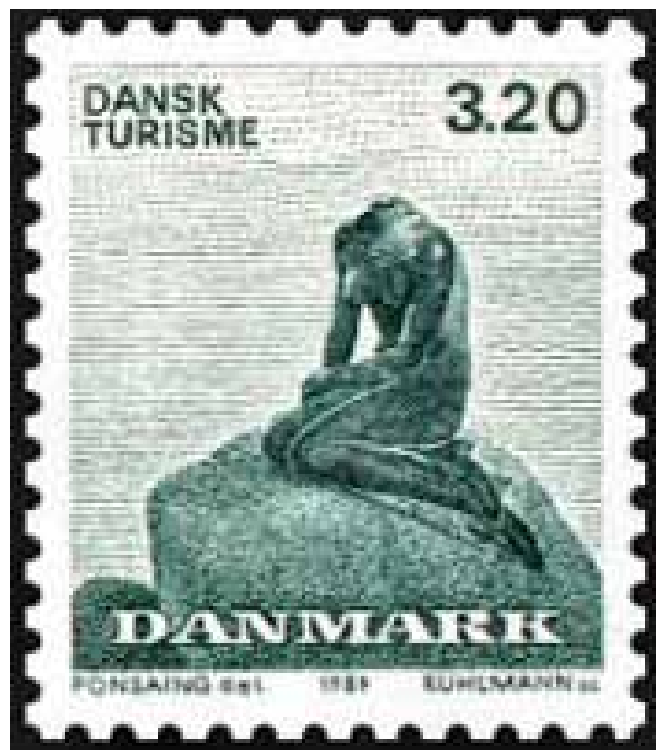

Decapitação da Pequena Sereia de Copenhaga, Jorgen Nash, Abril de 1964

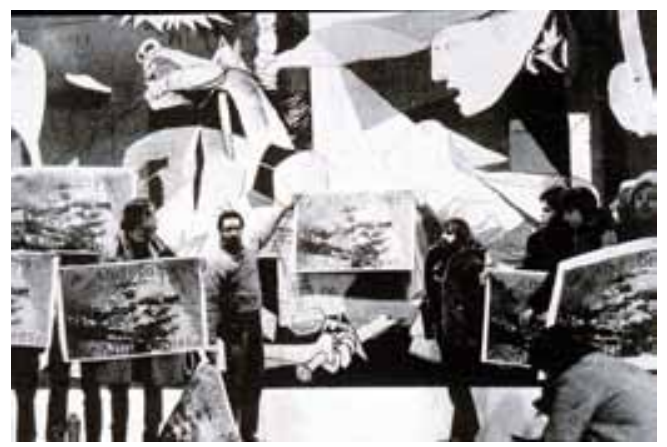

And babies, Art Workers Coalition, 1970

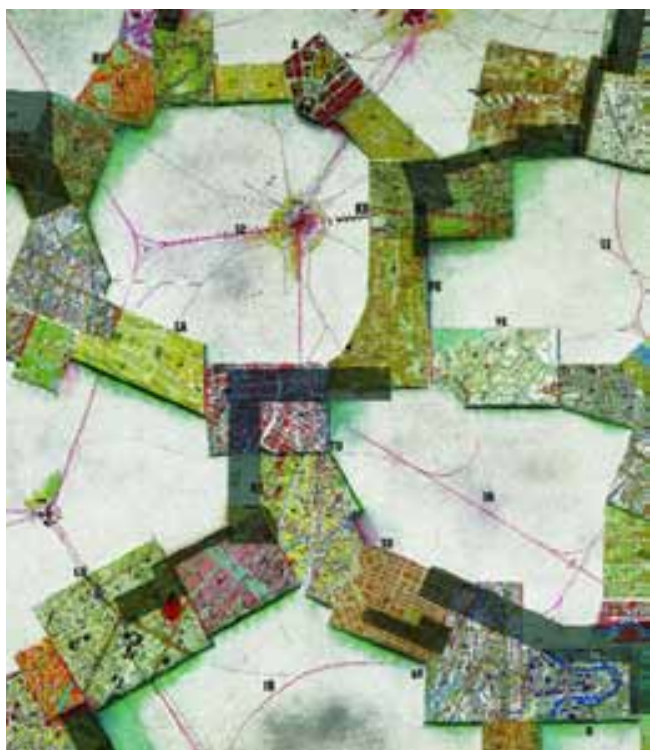

Representação simbólica de New Babylon,

Constant Nieuwenhuys, 1969.

Colagem s/ papel, 55×60. Fotografia de Victor E. Nieuwenhuys.

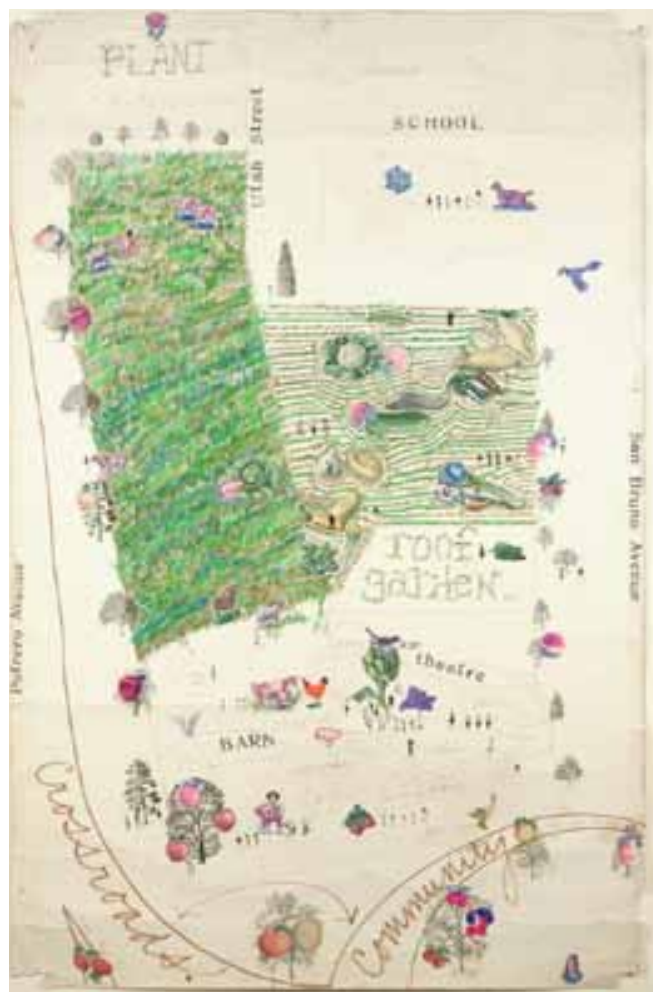

Crossroads Community, Bonnie Ora Sherk, 1974-80

Desenho original, primeira proposta para The Farm, 1974

(c) 2011 Life Frames, Inc. \& A Living Library 


\section{EVEPYTHING IS GOING TOBE ALRIGHT}

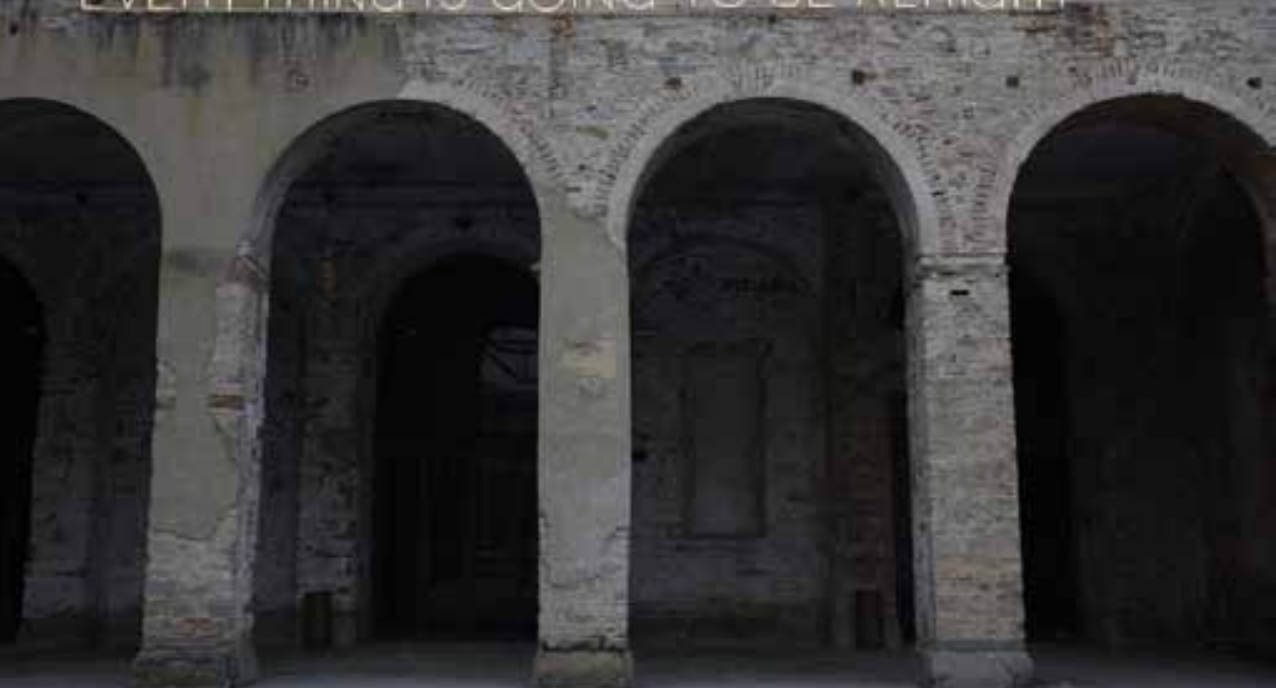

Work No. 203: EVERYTHING IS GOING TO BE ALRIGHT, Martin Creed, 1999

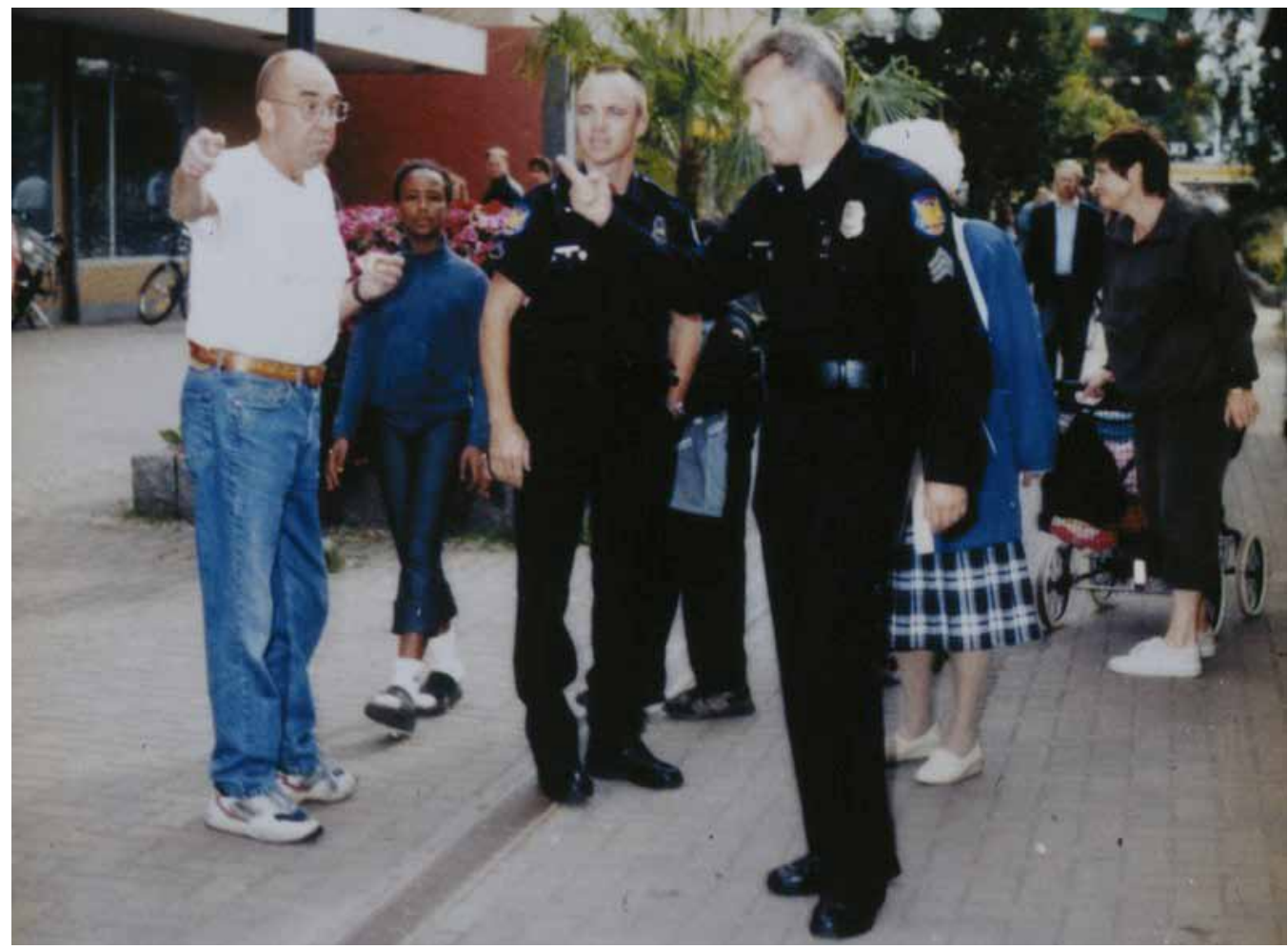

Public Safety/Two American Policemen, Jörgen Svensson, 2000 


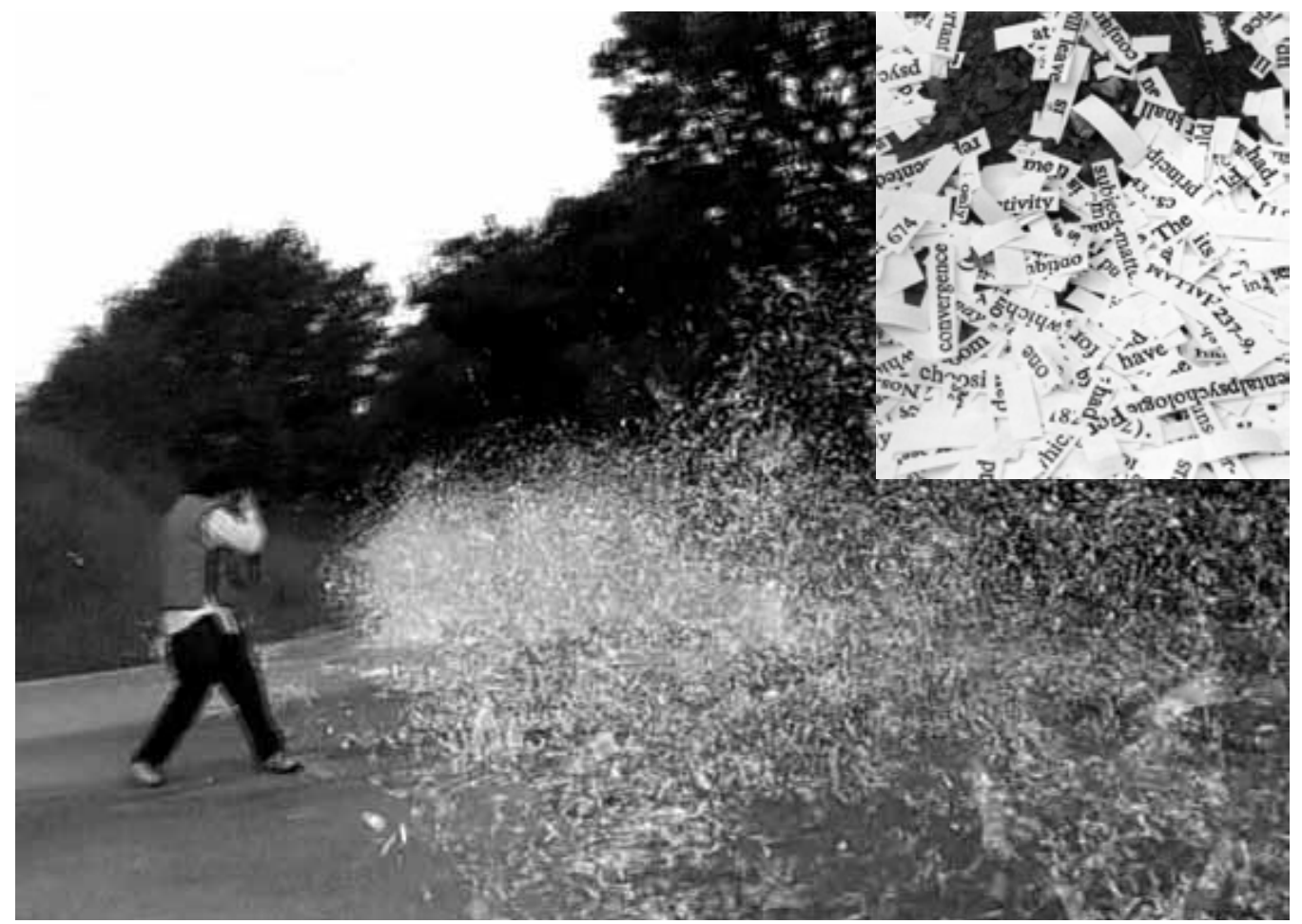

The road to the Unconscious, Simon Morris, 2003

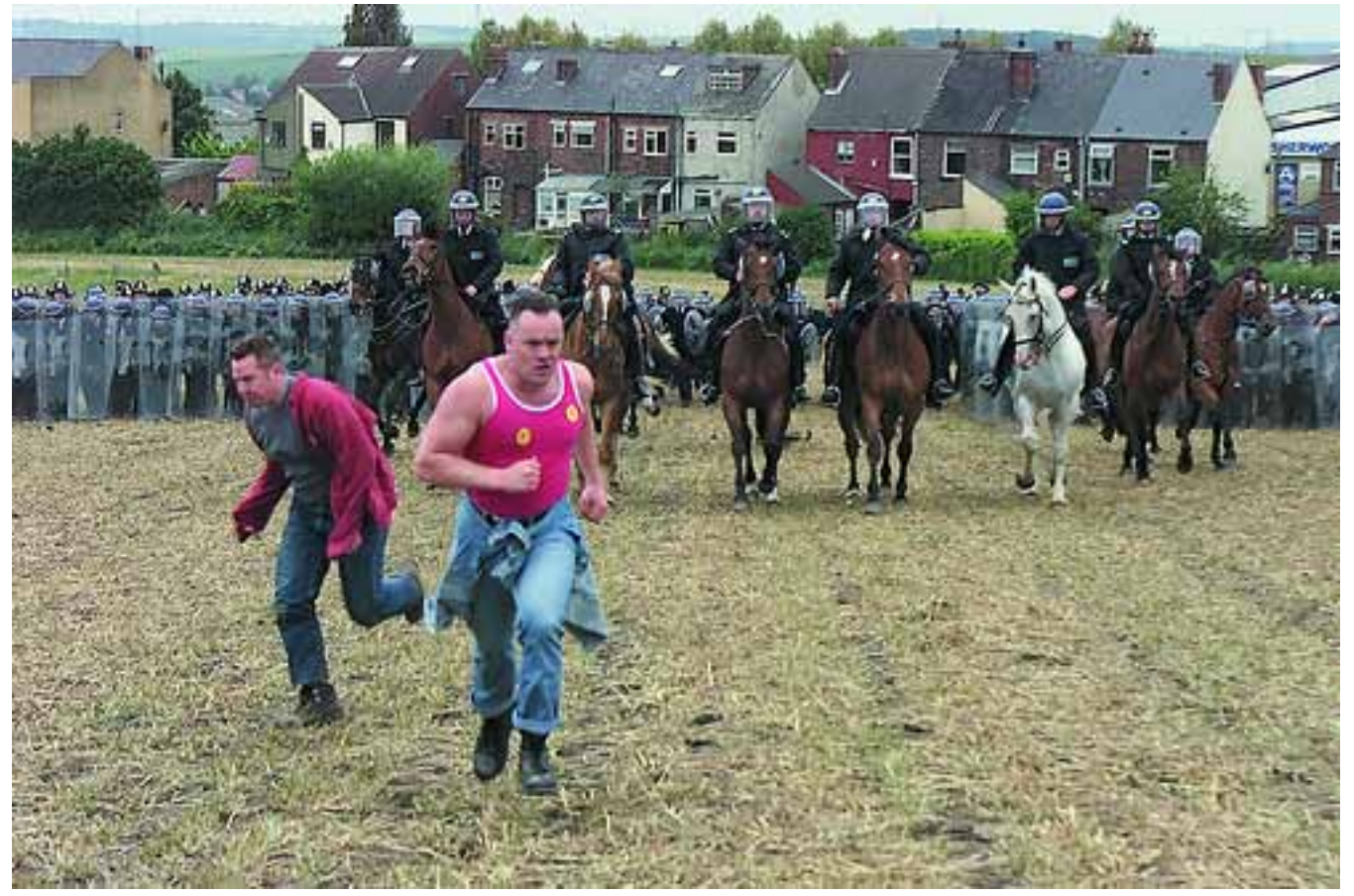

The Battle of Orgreave, Jeremy Deller, 2004 


\title{
1.4 Dois artistas upsetters: Kaprow, Beuys
}

\begin{abstract}
A picture never changed the price of eggs. But a picture can change our dreams; and pictures may in time clarify our values. The power of artists is precisely the influence they wield over the fantasies of their public.
\end{abstract}

Allan Kaprow

\subsubsection{Beuys: esculpir o social, dizer o poder}

Joseph Beuys, um expoente da perturbação teórica e prática do mundo das artes e da educação ${ }^{354}$ é um dos artistas mais interessantes para surpreendermos as possibilidades da radicalidade em arte e o seu sentido na polis. Beuys defendia que a transformação da sociedade só ocorreria se a criatividade se tornasse moeda de troca das relações humanas, ocupando o lugar do capital e do lucro, da moda ${ }^{355}$. Beuys actualiza o programa romântico wagneriano e schilleriano: [...] somente a arte, (...) a arte concebida ao mesmo tempo como autodeterminação criativa e como processo que gera a criação, é capaz de nos libertar e de nos conduzir rumo a uma sociedade alternativa". ${ }^{356}$ Mas é uma posição já consciente da revolução duchampiana. ${ }^{357}$ Esta crítica encontrará a forma do slogan na sua célebre afirmação de que o silêncio de Duchamp estava a ser sobrevalorizado. Problematizar o "período de silêncio" do autor de Nu descendent un escalier foi antes do mais recusar-se a silenciar o artista francês, um acto de diálogo que impedia a cristalização do discurso. ${ }^{358}$ Aliás, nas peças de arte pública mais emblemáticas Beuys vê-se na necessidade de estilhaçar, não o silêncio denunciado pelo "missionário da insolência", mas o prolongamento estéril, incrustado, desse eco reverberado pela arte e em coro quase geral pelos artistas. ${ }^{359} \mathrm{O}$ silêncio (traço do sublime estercorário ${ }^{360}$ ) é

354 Júlio do Carmo Gomes, in Beuys, Joseph; Cada Homem Um Artista, 7 nós, Lisboa, 2010, p. 7.

355 Idem, p. 8. Para Beuys a arte é a única força revolucionária ("A Revolução somos nós", 1972). O seu é um conceito ampliado de arte que exprime uma crítica deliberada do valor e da fantasmagoria em que a arte e o indivíduo-mercadoria se converteram na avalanche da sociedade de consumo, desconstruindo o discurso do capitalismo por meio de um novo paradigma que revitaliza a criatividade, a liberdade e a indeterminação do sujeito face aos controlos disciplinários da sociedade.

356 Idem.

357 Idem, p. 9. Embora recuse o beco sem saída do "já" ready-made: sabe que a relação da arte com a sociedade e com o seu tempo é evanescente, virtual, neutralizada. E, no entanto, esse é o lugar que Beuys recusa para a arte e, mais ainda, para a sociedade e o indivíduo.

358 Idem, p. 10

359 Idem, p. 11.

360 Clair, Jean; De Immundo - Apophatisme et apocatástase dans l'art d'aujourd'hui, Galilée, 2004, p. 4: C'est tout ce qui pousse l'homme vers la rive noir de la décomposition, de la purriture, du groullement, de la vermine. P. 29: Tout se passe comme si, de l'exposition de ces corps livres à l'horreur, un autre corps, le corps social, tirait une nécessité et, peut-être, les condition mêmes de sa cohésion. Tout se passe comme si l'unité du socius, autrefois assumée par le religieux et le politique, et parce qu'elle est devenue impossible à maintenir ni dans l'ordre du religieux ni dans l'ordre du seul politique, trouvait désormais son assise dans la manifestation publique d'une scatologie acceptée et célébrée. P. 33: Joseph Beuys, dans les années 1970, fut aussi le chaman invité par tous les musées d'Europe, célébrant d'un rituel qui usait comme matériaux de la graisse et du feutre, c'est-à-dire, là encore, des production organiques et informe, pâteuses ou filandreuses, fondantes et hirsut, la sécretion du tidu conjonctif et les cheveux. Escapa ao conservador autor francês uma dimensão revolucionária (política) de que histrionismo de Beuys é apenas o lado mais mediático. De qualquer forma, é aguda, da parte de Clair, a noção de que o fechado sistema da arte precisava de Beuys como que um escape para a sua negação da vida pública. Aliás, ao confirmar Duchamp como primus inter pares de uma deriva conceptual-estercorária de Bataille ao accionismo vienense, de Koons a Hirst, está a abdicar de pensar esta dinâmica num quadro mais amplo de provocação também intelectual à própria vitalidade do Belo. 
em Beuys um elemento terrífico ${ }^{361}$. Ao longo da sua vida pública, Beuys buscou infatigavelmente vias para efectivar a voz - algumas vezes caindo no lugar-comum, ou mesmo em contradição ${ }^{362}$ - , instaurando o diálogo e fomentando a abertura de sentido, corporizando acção e verbo em simultâneo: [...] nunca parar de falar. [...] Permanente "instalação verbal", fulcro da sua desdobragem enquanto activista, pensador e professor itinerante [...] "A linguagem é a primeira forma de escultura", Beuys dixit. ${ }^{363}$ A palavra-pharmakon de Beuys é uma acção escultórica-discursiva contra a "grande narrativa do individualismo" ${ }^{364}$.

\section{Mística, intuição, wit}

Beuys actua no sentido de recuperar para a arte um sentido do misticismo colectivo:

A retórica beusyana - se quisermos ultrapassar uma mera interpretação centrada no folclore do discurso - ao evocar o conhecimento indigena traduz a sua convicção de que o indivíduo, como nas sociedades tradicionais, tem de possuir um elo com a sociedade, pois se cai na individuação pura e dura perde-se e sai do mundo. ${ }^{365}$ [...] Em contra-ciclo aos mitos maiores postos à circulação, a que a arte não estava imune, o artista alemão sustentava no final dos anos sessenta: "Actualmente [a cultura] não tem nenhuma relação com a sociedade, e esta separação leva-nos a uma conclusão perigosa: que a cultura está estritamente ligada à lei, à produção, ao dinheiro, ao produto nacional, ao status de cada indivíduo dentro da sociedade." "366 [...] Ao mesmo tempo, estas interrogações conduzem (e conduziram-no) à questão antropológica: realizou-se ou não a profecia nietzschiana do "último homem"? Quem de facto desaparece quando tudo parece desaparecer? E que pode o individuo só no corpo social? Ou, melhor, pode haver lugar ao indivíduo sem corpo social?367

Por isso o performer de Coyote... não evoca mitos para lamber as feridas e consolar o "público", suscita antes interrogações existenciais que impelem à energia humana, criativa e dionisíaca, que reitera a vida... ${ }^{368}$ Ora onde Wagner mencionava a 'moda', Carmo Rodrigues refere uma ideia de arte como clonagem, posição estéril da adequação. ${ }^{369}$ As acções de Beuys são pelo contrário momentos de contacto com o real social, implicam uma dimensão convivial, dialógica, interactiva e participativa ${ }^{370}$. Diz Beuys: Necessitamos de relações mais profundas com as forças do indivíduo e da sociedade. Vejo que há uma necessidade inevitável de acção. ${ }^{371} \mathrm{E}$ como se o ready-made ou o inframince fossem à batalha da vida urbana, já informados pela ética ambiental: Beuys ${ }^{372}$ recupera ironicamente a banalidade do incessante objecto anónimo da indústria de consumo para instaurar o poder corrosivo e criador do artista - pondo a nu a era

361 Podendo imaginar-se aqui, com Jean-Didier Vincent, um diabólico abandono à vida material da carne, entre imitação e tagarelice: O diabo é um tagarela... Cf. Vincent, Jean-Didier; A Carne e o Diabo, Publicações Europa-América, Lisboa, 1997, p. 47.

362 Ver declarações que fez sobre o conceito de estetização da política de Walter Benjamin.

363 Gomes, p. 12.

364 Gomes, p. 32.

365 Idem, pp. 25-26.

366 Uns anos depois, Heiner Müller di-lo-ia de uma forma sintética, e cito de cor: a cultura mata a arte.

367 Idem, p. 28.

368 Idem, p. 30.

369 Idem, p. 31.

370 Historiadores e críticos como Buchloch, Stefan Germer ou Rosalind Krauss apontam porém, neste aspecto, uma certa incapacidade de Beuys entender que a formação de sentido é um processo contextual e colectivo. Esta questão parece-me porém sobrestimada - pois o que me parece acontecer em Beuys é uma convicção mística que torna as suas acções retoricamente, até certo ponto desequlibradas (no sentido do ethos); uma convicção mística porém cuja operatividade social não deixa de constituir um avanço cognitivo na transpessoalidade. E esta não se compadece com a sua versão materialista da participação democrática tout court.

371 Beuys entrevistado por Jean-Pierre Van Tieghem ("Dossier Joseph Beuys"), em Creacion, n.2, Outubro, Madrid, 1990.

372 Que é em .. co-fundador do Partido Politico «Os Verdes». 
$\mathrm{Na}$ arte crítica, qual o lugar de uma intuição táctica?

Podemos considerar este volte-face improvisado como um exemplo da prática artística baseada na intuição e da contundência com que o performer lidava com situações indefinidas e ambíguas, dando respostas, ao mesmo tempo directivas e contraditórias, agressivas e de múltiplas interpretações, às energias e às tensões criadas no desenrolar das suas "aç̧ões". 374

É em plena noção de wit que Beuys aborda a questão da violência simbólica de qualquer autoridade, desvelando estruturas de domínio e controle social. $\mathrm{O}$ acto artístico crítico vive aqui da exposição da sua própria violência, da sua periclitate constituição. ${ }^{375}$ Beuys sabe que a transformação do pensamento em actos não é directa; ainda que Plastik não possa abdicar de ser simultaneamente skhema e praxis: Não tens de fazer o que desejas, mas o que é fruto do teu pensamento. ${ }^{376} \mathrm{O}$ que Beuys sugere é uma reformulação do ego num quadro de evolução espiritual colectiva, em que não podes passar toda a etermidade dando voltas na tua cabeça, deves procurar na realidade um modelo para praticá-lo. ${ }^{377}$ Sobretudo, a arte propõe-se como fenómeno de entendimento (Wagner) - acção de produção de saber.

Então, não importa se uma pessoa imaginou ou não aquilo que você quis representar com essa obra? Não, não é obrigatório (...) Interpretar é antiartístico. A arte já é um meio de tornar visivel algo em forma de imagem. Com uma interpretação prematura arruína-se o efeito do quadro. Primeiro, é preciso vivê-lo, a primeira, a segunda, a terceira vez. E então depois pode ser que seja interessante a interpretação. ${ }^{378}$

É um diálogo muitas vezes em delicado equilíbrio retórico:

In this sense, Der Chef can be read as a parable of cultural work in a public medium. The authority of those who dare-or are so bold as-to speak publicly results from the fact that they isolate themselves from the gaze of the public, under the gaze of the public, in order to still address it in indirect speech, relayed through a medium. What is constituted in this ceremony is authority in the sense of authorship, in the sense of a public voice. ${ }^{379}$

E mesmo quando episodicamente espectacular, como em «l Like America and America Likes Me», a arte questiona a totalidade na totalidade: To be certain, art offers answers. Its strength, ho-

373 Júlio do Carmo Gomes, in Beuys, Joseph; Cada Homem Um Artista, 7 nós, Lisboa, 2010, p. 42. Na medida em que Duchamp provoca o transtorno da linguagem da arte, consubstanciando-se como o mais notável hermeneuta da subversão artística, Beuys perturba o mundo da arte e dos seus poderes (e da estabiidade desses poderes) assumindo o papel de dissidente, não só contra a linguagem da arte, mas contra a linguagem do poder, e ainda mais inusitadamente contra o exercício desses poderes, transcendendo a crítica hermenêutica da política de arte para fundar uma prática crítica da arte política.

374 Idem, p. 47.

375 Numa acção emblemática como / like America and America likes me (1974), o dispositivo acentua a oblíqua transparência de um ethos - o artista não chega a pisar solo americano. Mas aí não consegue libertar-se, como a própria civilização, dessa maladie das sociedades modernas, distanciando-se de atributos xamâmicos que deveriam resolutamente dar respostas claras e videntes, para a qualidade humana e artística que não pára de questionar o seu tempo e que caracterizou a sua vida, in Idem, p. 56. É por isso que An unconditional acceptance of Beuys' interpretive authority over his own practice has caused the discourse surrounding the oeuvre to fail to touch on a central unresolved question within it: the question of authority itself. In order to understand the significance of Beuys' work in the context of the artistic and political debates of the 1960s and 1970s, however, it is crucial to grasp the inner conflicts and unresolved contradictions that run through it, as well as the way Beuys publicly performed the role of the artist with regard to this question of authority. In Verwoert, Jan; «The Boss: On the Unresolved Question of Authority in Joseph Beuys' Oeuvre and Public Image».

376 Gomes, p. 71.

377 Gomes, pp. 71-72. Beuys: Com isso ganha-se mais experiência que revolvendo as coisas na cabeça.

378 Gomes, p. 78

379 Verwoert, Jan; «The Boss: On the Unresolved Question of Authority in Joseph Beuys' Oeuvre and Public Image», in http://www.e-flux.com/journal/view/12. Consultado em Agosto de 2011. 
wever, often lies in its unresolved problems. ${ }^{380}$ Noutros termos, [...] Beuys did not simply produce an aura of authority but that he also exhibited the material conditions of its production in all their crudity, and exposed the contradictions inherent in this process in all their obvious absurdity. E é por isso que obras em ponto crítico como Der Che ${ }^{\beta 81}$ desmantelam a própria aura do objecto artístico. Este é o sentido do termo evento nesta estética do contacto político, que no caso de Beuys pode oscilar entre o exorcismo corporizado de Der Chef e a luminosa clareza de princípios morais de 7000 carvalhos.

\subsubsection{Kaprow: o quotidano como poder criativo}

Do outro lado do Atlântico, Allan Kaprow é fundamental em quaisquer leituras críticas do minimalismo, da arte contextual ou da land art. É um autor que nunca pára de emitir textos e sound bites acerca da condição do artista na sociedade, sob o signo da persuasão retórica:

If politics on national or global scale is presumptuous for amateurs (as "serious" Sunday painting is presumptuous), art politics is not only possible but necessary. It is the new means of persuasion. And persuasion leads to a verification of artist's contact with the world. ${ }^{382}$ [...] The measure of this power lies not only in the magnitude of this influence but on its quality as well. Picasso competes with Walt Disney, who in turn competes with TV soap operas. [...] the effectiveness of any artist's vision becomes largely a matter of how that artist balances insights with responsibility to them as value. Practically, this means defending them against other values that may be more immediately compelling; it also means attending to their future. ${ }^{383}$

A reflexão de Kaprow despoleta-se com o impasse que este identifica em Pollock, momento-chave na deriva processual e relacional da arte contemporânea. O protocolo inventado por Kaprow para levar a arte a revelar a sua constitucionalidade foi o happening ${ }^{384}$, em que Kaprow estabelece uma teoria do dispositivo discretamente contestatária da emergente cultura visual americana (TV, publicidade). É um quotidiano liberado pelo momento, da consciência do cósmico através da materialidade mais crua. ${ }^{385}$

380 Verwoert. Cf. a sua reflexão sobre a acção «Kukei, akopee-Nein!», em que o que está em causa é o wit de uma reacção imediata de Beuys a uma agressão por estudantes de extrema direita, em Julho de 64

381 Verwoert: In Der Chef, Beuys stages the creation of such a public voice as an event that is as dramatic as it is absurd. He thus asserts the emergence of such a voice as an event. [...] This performance offers no answers. But it articulates the unresolved crux of a question that deeply concerns both art and politics: by virtue of what authority is it possible to embody a voice in the public and for the public?

382 Kaprow, Allan; On the Blurring of Art and Life, 1964, pp. 51-53.

383 Idem, pp. 52-53. At one time, modern art, on its way from the gallery to the museum, stopped off at a collector's home, looking out of place there because it was lived with. Now it is the reverse. Kitchen-Sink art, Pop art, Common-Object art, Assemblage, Junk-Culture, Rearrangeables, Multiples, and Environments, united in their appeal to, and often literal involvement in, the themes and space of daily existence, appear absurd and out of kilter in museums where they cannot be lived with. (Even the current Hard Edge or Retinal painting and sculture, whose forms are retardataire, reveal their precarious purity in contact with active life rather than deprived of it.)

384 Idem, p. 62: The Happenings are are the one art activity that can escape the inevitable death-by-publicity to which all other art is condemned, because, designed for a brief life, they can never be overexposed; they are dead, quite literally, every time they happen. At first unconsciously, then deliberately, they played the game of planned obsolescence, just before the mass media begin to force the condition down the throat of the standard arts (which can little afford the challenge). O happening surge por volta de 1957; em 1966 já era parte do jargão generalizado das neovanguardas.

385 Idem, p. 63: The line between the Happening and daily life should be kept as fluid and perhaps indistinct as possible.; The composition of all materials, actions, images, and their times and spaces should be undertaken in an artless and, again, again, practical a way as possible. 


\section{O Contexto e a não-arte (uma perspectiva de desmateralização da arte)}

Neste quadro da 'não-arte', Kaprow sublinha, logo em 1971: Nonart is whatever has not yet been accepted as art but has caught an artist's attention with that possibility in mind. ${ }^{386} \mathrm{E}$ esta linhagem que conduz às experiências posteriores de não-arte-social (Christian Nold, Platform, Wochenklausur). Esta é uma posição que aponta uma 'terceira via' a ideia de autonomia da arte, nem subjugada ao sistema e à moda, nem reificada como instância de uma resistência ou de um afastamento 'românticos'. A arte torna-se jogo do instante, da ocasião, da oportunidade, e It's to be done with gusto, wit, fun; it's to be play. ${ }^{387} \mathrm{Kaprow}$ ecoa démarches conceptuais e situacionistas conforme enunciadas no wit Duchampiano ${ }^{388}$. Aliás, em termos muitos semelhantes aos de Kafka: If you see things clearly, really clearly. You've got to laugh because nothing's been accomplished. ${ }^{389}$ Quanto à forma como esta questão se liga a uma cognição artística d'après Duchamp:

As an addition to the history of thought, the Readymade is a paradigm of the way humans make and unmake culture. Better than "straight" philosophy and social science, a good Readymade can "embody" the ironic limits of the traditional theory that says reality is nothing but a projection of a mind or minds. ${ }^{390}$

A verdade é que o readymade apenas funciona pelo contexto socialmente:

Duchamp, a cool subscriber to that tradition, knew, I suspect, that metaphysics, theology, science, and art were "useful fictions" (Hans Vaihinger's phrase). "The intellectual or artist merely needs a persuasive consensus to launch an idea into the world," Duchamp said in a speech in 1957. Otherwise, the fiction will be useless, only a fiction and not a reality. The Readymade is thus both exposure meter and confidence game.

Kaprow acaba por propor a própria cidade como o readymade por excelência:

According to some of my friends, the freeway of Los Angeles are great theater, modern theater, with no beginning or end, full of chance excitement and plenty of the sort of boredom we all love. I pass that observation on here. Their future as Readymade art depends on the reader. That is, I am engaging in gossip. Duchamp's generous reminder to his posterity is how fragile public relations are. ${ }^{391}$

Numa definição instrumental da arte crítica contemporânea: The models for the experimental arts of this generation have been less the preceding arts than modern society itself, particularly how and what we communicate, what happens to us in the process, and how this may connect us with natural processes beyond society. ${ }^{392}$

Sumariamente, Kaprow entende por modelos situacionais as acções como a de Beuys em 1973 (sit-ins em Kassel), de Haacke em 1970 (MoMA Poll) ou de Merce Cunningham em 1953 (convidando dezassete pessoas - a maioria não bailarinos - para, no palco, simplesmente 'fazerem gestos que fazem normalmente'). Quanto aos modelos operacionais, Kaprow dá o

386 Idem, p. 98. «The Education of the Un-Artist, Part l»

387 Idem, p. 113.

388 Idem, p. 127. Hence, his verbal-visual play, perhaps born of mixed skepticism and dandyism, confronted a romantic tradition of high, often tragic, seriousness in art making. Humor was superficial. Even humor as arch as his was overcast by the dreamwork of Surrealism and the existential struggles of Abstract Expressionism. But since Pop art (itself indepted to him), artist are quite funny and still avant-garde! The Fluxus movement, many Bodyworkers, Conceptualists, and Happeners are evidence of the permission he gave to wit. Wit, from the Duchampian perspective, is the condition and consequence of keen thought.

389 Idem.

390 Idem, p. 128.

391 Idem, p. 128-129.

392 Idem, p. 130. «The Education of the Un-Artist, Part III». 
exemplo de acções de Michael Heizer em 1971 (com um bulldozer a escavar uma cratera no deserto), dos japoneses High Red Center em 1968 (limpando, equipados a rigor, uma movimentada rua de Tokio), ou ainda de Max Bense em 1963, quando propõe sixty-two common words at random on a page, words [...] $]^{393}$ Já se dos Structural models, Kaprow dá os exemplos de obras de Michael Snow em 1971 (sistema de captação de fotografias instalado no deserto, cujo aparato técnico se relaciona com uma temporalidade cósmica) ou de Newton Harrison em 1970 (cultura de camarões), dos Self-referring Models dá os exemplos de peças de John Baldessari em 1969 (C.A.L.I.F.O.R.N.I.A.) ou ainda Robert Whitman (uma acção teatral com recurso a projecções video ${ }^{394}$; sob a designação de Learning Models, Kaprow agrupa os trabalhos de Rauschenberg em 1951 e 1953 (telas brancas em que o espectador 'projecta' o seu próprio aparelho de visão) ou 4'33 de John Cage, em 1952 e 1954, que valoriza o silêncio musical para avançar um conceito expandido da própria ideia de musicalidade ou de som. Particularmente importante para um emergente regime da atenção seria, nestes termos, uma peça de Vostell em 1962, em que este providenciava ao espectador um mapa de Paris, convidando-o a procurar postes deitados abaixo, ruínas, ruídos, gritos... Todas estas peças são retóricas na medida em que expõem o logos da obra de arte, mirror of the mirror no seio de uma teoria crítica das formas ${ }^{395}$ na iminência de atingir inédita consciência da sua estrutura e complexidade. Anos 80 e 90 afora, este pragmatismo das formas da arte leva Kaprow a concluir:

Western art actually has two avant-garde histories: one of artlike art and the other of lifelike art. They've been lumped together as parts of a succession of movements fervently committed to innovation, but they represent fundamentally contrasting philosophies of reality. [...] In other words, there is art at the service of art and art at the service of life. The maker of artlike art tends to be a specialist; the maker of lifelike art, a generalist. [...] Of the two, artlike art and lifelike art, avant-garde artlike art occupies the attention of the majority of artists and the public. It is usually seen as serious and as a part of mainstream Western art-historical tradition, in which mind is separate from body, individual is separate from people, civilization is separate from nature, an each art is separate from the the other. Avant-garde artlike art is supported, tardily but steadily, by high culture's institutions, the galleries, museums [...]. These share the same separating point of view about art and life: that art could vanquish life's problems as long as it was far enough away from life so as not to be confused by it and sucked back into its mire. These institutions need artists whose work is artlike. [...] $]^{396}$

Recupere-se aqui a posição wagneriana de uma arte total que supere as modalidades separadas sob a forma de uma arte pública contemporânea, na rejeição da arte de vanguarda em nome na sua própria ideia de povo. Nalguns casos destas misturas (Novalis) extradisciplinares (Holmes), a arte-vida limita-se a constituir um momento de experiência de um processo; noutros mais raros, uma experiência dialogal: Lifelike art's message is sent on a feedback loop: from the artist to us (including machines, animals, nature) and around again to the artist. You can "talk back" to, and thus change, an artlike artwork; but "conversation" is the very means of lifelike art, which is always changing. ${ }^{397}$ Em suma:

393 Idem, p. 135. [...] as in mathematical set theory. They could be recombined by the reader in almost endless "sets" as object values rather than verbal ones.

394 Em C.A.L.I.F.O.R.N.I.A., o artista seleccionou um mapa da California. Determinou onde as letras impressas C.A.L.I.F.O.R.N.I.A. caíam, e depois viajou para cada local, onde realizou em pedras, Madeira ou tinta cada letra, que depois voltou a fotografar. Já na peça teatral de Robert Whitman, duas mulheres actuavam em frente à projecção de um filme de si próprias. Outra mulher, toda vestida de branco, funcionava como um Segundo écran, sobre a qual eram projectadas imagens, soncronizadas com os seus movimentos, dela própria a despir-se. A da altura, ela aparecia nua, apesar de se poder ver que estava despida.

395 Idem. The very idea of form is in the last analysis too external, too remote, to allow for urgent fantasies of integration, participation, and signification brought about by an increasingly crowded and compressed planet.

396 Idem, p. 201-202. «The Real Experiment», 1983

397 Idem, p. 204. 
The key experiment was not simply the invention of new art genres by which the period [desde os anos 60] is usually known but the recognition of the secularization of the entire art situation: genre, frame, public, and purpose.

The critical move in the experiment was the shift of art away from its familiar contexts, the studios, museums, concert halls, theaters, etc., to anywhere else in the world.

Various performative modes became the effective way to deal with this shift to the actual environment. Performing was doing something, not acting in theater - moving furniture, for example, just to do it, or because you were changing apartments.

The structural model for the experiment were real (not merely implicit) processes: for example, seasonal changes; food that is grown, eaten, digested, and composted; thoughts that are transmitted, converted, and put into action.

The possible boundaries between lifelike art and the rest of life were kept intentionally blurred. Where the art was located, where life was, and when one or the other "began" and "ended" were of no importance. Such distinctions were merely provisional.

The typical art public and critic used to going to exhibitions, concerts, and plays became irrelevant. Instead, there were small groups of travelers to far-off sites, participants in organized events, thinkers on commuter trains, and artists in their art by themselves. The emerging public for this lifelike art was no longer ideal and unified but was diversified, mobile, and particular in interests, like people in the real world.

Lifelike art did not merely label life as art. It was continuous with that life, inflecting, probing, testing, and even suffering it, but always attentively. (That's the source of its humour; when you look closely at your suffering, it can be pretty funny...) $)^{398}$

The purpose of lifelike art was therapeutic: to reintegrate the piecemeal reality we take for granted. Not just intellectually, but directly, as experience - in this moment, in this house, at this kitchen sink... ${ }^{399}$

Na posição de Kaprow (e nas de George Brecht, Cage, Filiou) a arte-vida não procura qualquer consenso; apenas o social contingente, o que passa em Krapow (por influência de Cage) por procurar fora da tradição artística Ocidental os caminhos para uma redenção da vida (social). ${ }^{400} \mathrm{Em}$ suma, We bracketed life with all that we knew about high art but restricted the art we made to our imagination. Whenever we found something interesting, we conceived an artwork. We saw people crossing the street, and they became modern dance. [...] We entered into the "art" or not, as we wished. ${ }^{401}$ Isto conduziu ao beco sem saída de uma acumulação de modalidades (ainda que híbridas), todo o campo expandido da escultura (Krauss) é que um aprofundar de uma crise inerente à dificuldade de encontrar uma função satisfatória para uma arte do fluxo e do imponderável social: We couldn't bypass the framing devices, perceptual clichés, and value of traditional modern art. ${ }^{402}$ Ainda assim, a questão do conceptual, base da minha aproximação à arte como retórica, é considerada determinante: The third example (discovering high art everywhere) was the most sophisticated release from the tangible side of normal art production. It tacitly acknowledged that culture, like reality, is created in the mind and can be de-created. ${ }^{403}$ Esta é uma pequena história da evolução do dispositivo 'arte' no quadro de uma crítica do terceiro momento - It wasn't enough to discover that an elevator ride or a sandwich could be art; we had to ask where that art belonged, whom it was for, and why. [...] it was necessary to change the whole situation, not just the genre, which was the easiest part to change. 404

\footnotetext{
398 Kafka não o diria melhor...

399 Kaprow, pp. 205-206.

400 Idem, p. 207. I'm saying that non-Western cosmologies might have given us, in the late fifties and early sisties, an integrative alternative to our society of overspecialization.

401 Kaprow, p. 207.

402 Idem, p. 207.

403 Idem, p. 208.

404 Idem.
} 


\section{Arte não-arte não arte}

Na forma urbana, esta abertura terá de passar por questionar os próprios paradigmas urbanístico, de planeamento urbano, arquitectónico, social (jurídico), para além dos que subjazem à própria comunicação em/do contexto urbano. Podendo chegar a uma situação como a do artista conceptual Raico Puusemp, que concorre para o lugar de mayor de Rosendale, vencendo e depois realizando um notável trabalho autárquico em que arte e vida decididamente se misturam num regime em que o ego artístico dá lugar a formas inclusivas de governação e participação cívica. Kaprow, fascinado pelo facto, reconhece este desafio do urbano: With the task accomplished, he felt that his usefulness had ended land that the artwork was completel. He submitted his resignation as mayor. [...] Its genre was unusual, but so its frame, its public, and its purpose. [...] The genre was the village and its survival problems. ${ }^{405}$ Trata-se de uma imersão realista da arte no real social e político: In practical terms, what's the point of saying youre an artist who is making art out a vilage's troubles? 406 Nesta nota ética temos Kaprow a afastar-se do sistema da arte e de colegas como o própio Beuys: ${ }^{407}$

If you view the world as a unity, with all things connected, including yourself and your work, then being celebrated with the exaggerated attention and flattery that go with stardom almost invariably leads to self-importance, separation, and, in time, isolation. We don't yet know how to honor someone, or to be honored, without ego getting in the way. 408

Esta deriva relacional-social da arte é exemplificada por Kaprow através do exemplo de outro caso, porventura ainda mais radical, o de uma artista 'anónima'409 em cujo 'trabalho' não há ironia na associação entre este evento e a ideia de que se trata da verdadeira experiência. Tratou-se, por parte desta artista anónima, de uma atenção radical - a si, ao mundo, à experiência do mundo e às consequências dos actos criados pelo dispositivo 'artístico'. Uma ilação: I've gone this far to show how the last generation's most experimental art lexperimental because it was lifelikel often stopped short of realizing its vision because it still clung to habits associated with artlike art. ${ }^{410} \mathrm{E}$ assim, let's say art is a weaving of meaning-making activity with any or all parts of our lifes [...] This definition shifts the model for art from the special history of the field to a broad terrain embracing not only lifelike art but religious, philosophical, scientific and social/personal exploration. Hoje que a arte pública se tornou outra arte com circuito, valores, sistema (assistematicidade) e retóricas próprias a intuição de Kaprow permite que a minha própria intuição, de uma genealogia que integra o romantismo de Novalis e de Wagner numa ideia genérica de revolução quotidana (Lefèbvre, Marcuse), se confirme. Duas décadas de depois deste texto de Kaprow, a arte pública crítica confirma-se como simpósio

405 Idem, pp. 201-211.

406 Idem.

407 Que aliás, em sentido inverso, se torna artista profissional relativamente tarde e não deixará de o ser até ao fim da vida, exponenciando a sua própria imagem mediática.

408 Idem.

409 All of us are part herd animals and part lone wolf, so the two events should form a nice relationship, each illuminating the other. Since each was unmarked at the time as art of any kind, it is understandable that the artist of this work chooses to be nameless, simply to best emphasize the experiential aspect of what went on. [...] Each day of a week around 3 p.m., when the wind rose on the dunes, a woman took a walk and watched her tracks blow away behind her. Every evening she wrote an account on her walk in her journal. To begin each successive day, she read her journal story and then tried to repeat exactly what happened. [...] She described the sens of breaking the earth, of disturbing the immaculate and fragile crusts of glass particles; she wrote of her secret pleasure in making her marks in that remore realm free of others; she accepted with satisfaction the absorption of her tracks back into the earth as if they were herself. Idem, p. 212.

410 Idem. 
da totalidade, (Diane Rothenberg e Jerome Rothenberg, citados em «The real Experiment». Um exemplo recente desta experiência real da urbe é o caso da cidade de Sortland, na Noruega, que deu seguimento a uma ideia de Bjorn Elvenes, um artista local que 'mandou às malvas' a disciplina quotidiana e desenvolveu o projecto de uma cidade azul. $\mathrm{O}$ artista aproveitou a oportunidade das Festas do Milénio e distribuiu 50000 litros de tinta azul (em várias tonalidades) pela população, que de imediato transformou uma anónima cidade nos confins da Noruega num lugar único, pleno de identidade. ${ }^{411}$ Nesta totalidade, Kaprow estabelece relação entre a criação e um ethos de auto-conhecimento em graciosa entrega:

Self-knowledge is where you start on the way to becoming "the whole", whether this process takes the form of social action or personal transformation. [...] The Rosendale dissolution and the dune treks are not presented here as pinnacles of enlightenment (there probably are no such things); they are just steps along the way, and the artist's eyes may have opened up a little. ${ }^{412}$

Eis-me confirmada a ideia de que a arte contemporânea mais radical e próxima da vida é profilaxia do próprio dispositivo 'arte contemporânea' (o logos); (re)conectando-se com a imponderabilidade cósmica:

Suppose you telephone your own answering device and leave a message that you called - you might learn something about yourself. / Suppose you offer to sweep a friend's house, and then spread the gathered dust through your own place - you might learn something about friendship. I Suppose you watch a clear sky and wait for a cloud to form you might learn something about nature. Suppose you wait longer, for the sky to clear - you might learn something else about yourself.413

Esta é uma arte-linguagem-da-vida-a-ser-vivida:

Unless the identity (and thus the meaning) of what the artist does oscillates between ordinary, recognizable activity and the "resonance" of that activity in the larger human context, the activity itself reduces to concentional behavior. Or if it is framed as art by a gallery, it reduces to conventional art. Thus toothbrushing, as we normally do it, offers no roads back to the real world either. But ordinary life performed as art/not art can charge the everyday with metaphoric power. 414

Diviso aqui uma continuidade genealógica entre géneros que na arte contemporânea, e na sua essência, procuraram não propriamente expandir a área de intervenção da arte (para o urbano em geral), mas sobretudo uma recorrência de um mesmo princípio vital, sempre que os artistas optam por problematizar os seus dispositivos correntes e partem para aventura quotidana da reinvenção da instrumentalidade da criatividade. E daí a hipótese de concluirmos, com Kaprow, a propósito de Cage e do seu misticismo oriental: [...] experimental, or any other experimental art of our time, can be an introduction to right living; and after that introduction art can be bypassed for the main course. ${ }^{415}$ Nos anos 90, «Meaning of Life» (1990), é escrito já a partir de uma perspectiva genuinamente não-artística (uma impossibilidade?): The experimental artist today is the un-artist. Not the antiartist but the artist emptied of art. ${ }^{416} E$ uma posição que me interessa particularmente na abordagem do trabalho dos arquitectos-jardineiros (Grout) contemporâneos.

411 Masboungi, Ariella; «A luz e a cidade: a experiência francesa», in Luzboa - A arte da Luz em Lisboa», p. 103.

412 Kaprow, p. 217. Aliás: Self-knowledge is necessary and often painful work. But it is not new work, or the work of lifelike art alone. It has been at the core of artlike art as well. [...] But we heard little of these vestiges of the sheer role of art after World War II. Writings and daily work about art during the sixties and the seventies tended to become impersonal and quasi-intellectual, borrowing heavily from Neo-Marxism, cultural structuralism, and semiotics. The practice of art seemed professionalistic, while on the popular, newsky level it seemed all about careerism. The suprapersonal implications of art making, however, were never absent from private conversations; they just dropped out of public discourse.

413 Idem.

414 Idem, p. 222.

415 Idem.

416 Idem, p. 229. 


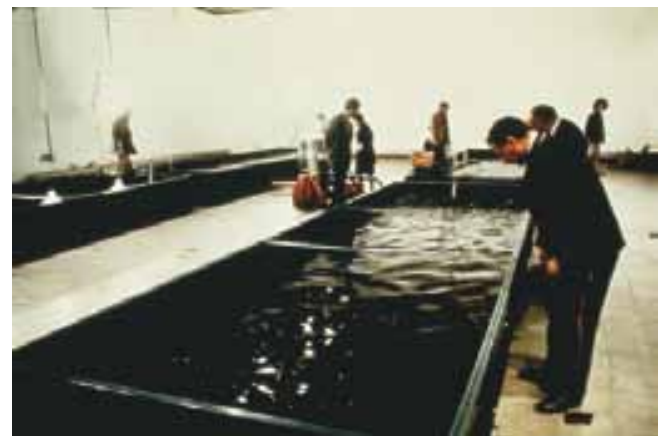

Brine Shrimp, Helen Mayer Harrison e Newton Harrison, 1971. Foto Ronald Feldman Fine Arts, New York, e artistas.

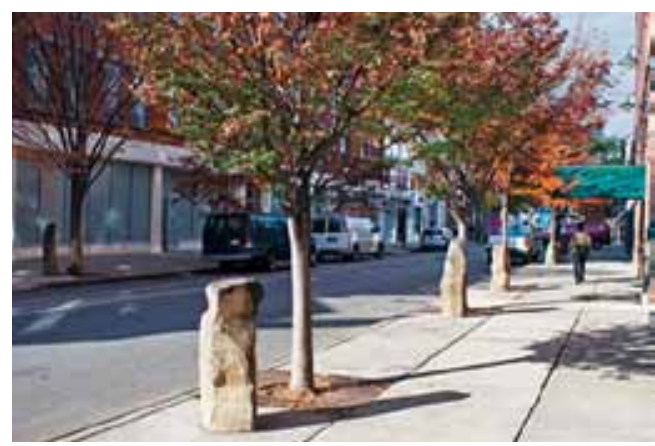

7000 Oaks, Joseph Beuys, 1982

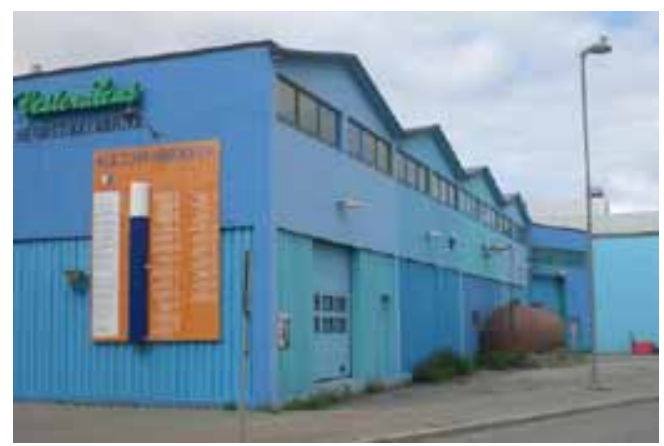

Sortland, Bjorn Elvenes, 1998

Foto: Kari Frøyland

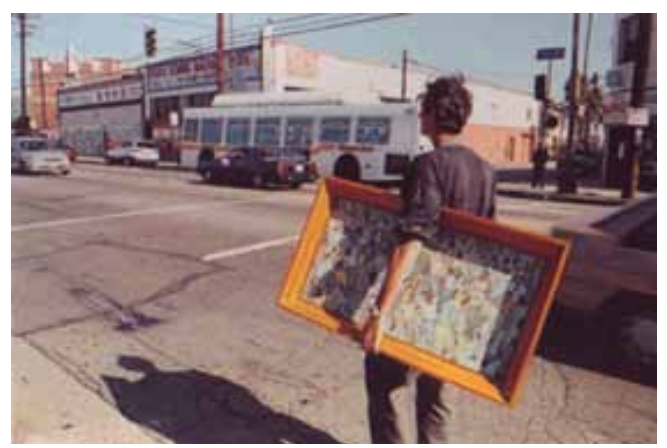

Walking a painting, Francis Alys, 2002

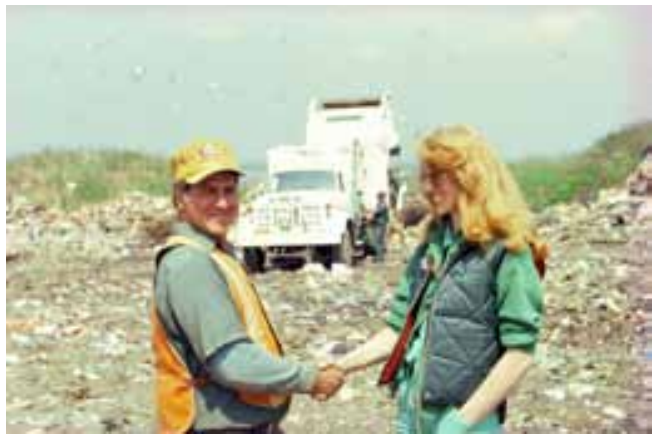

Touch Sanitation, Mierle Laderman Ukeles, 1977-80.

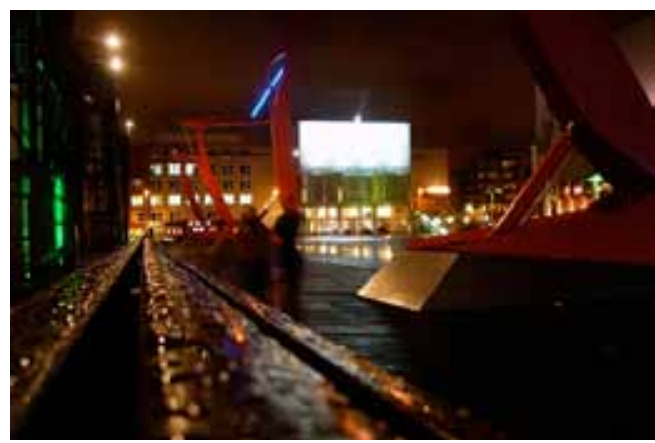

Schouwburgplein, West 8, 1991

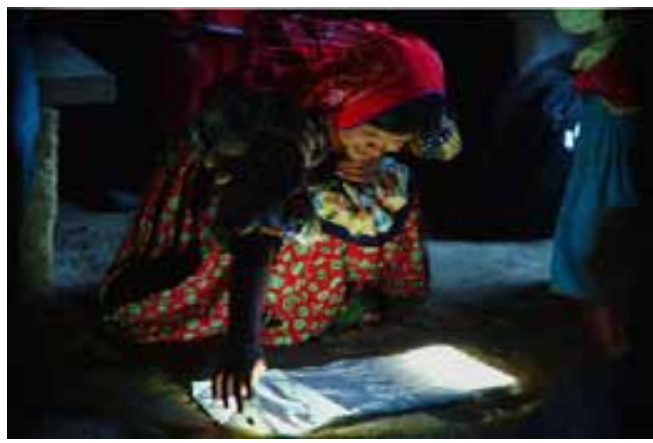

Portable Light, KVA Architects, 2002 Foto: KVA MATx

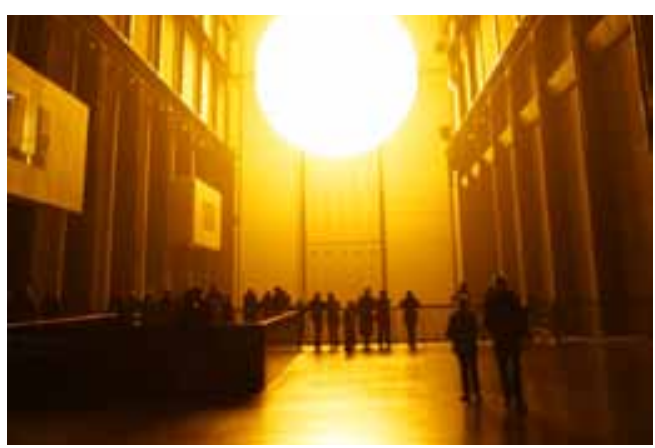

The Weather Project, Olafur Eliasson, 2003

Foto: Thomas Pintaric 


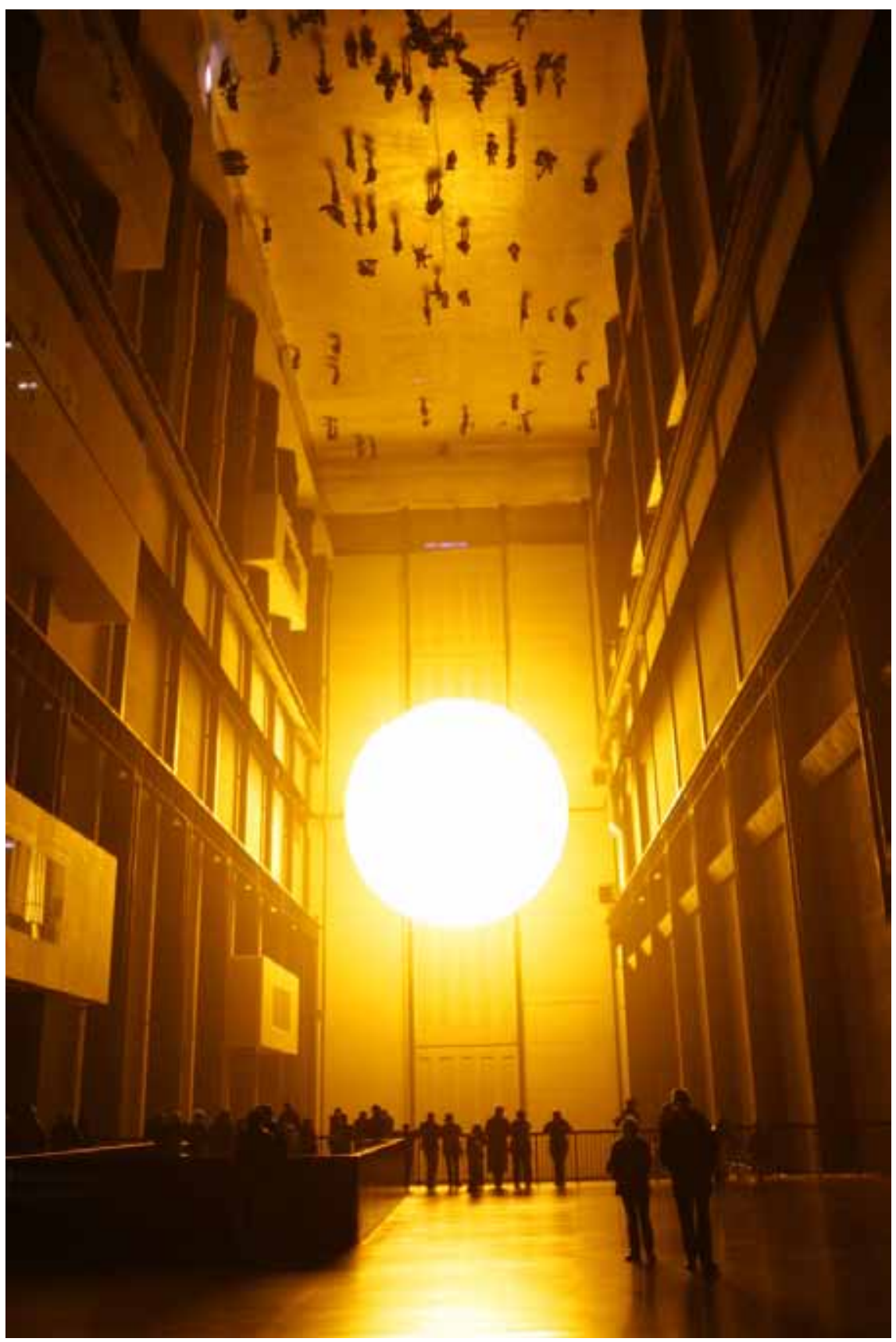

The Weather Project, Olafur Eliasson, 2003

Foto: Thomas Pintaric 


\section{O CAMPO SEMÂNTICO DA ARTE PÚBLICA CONTEMPORÂNEA: TERMOS}

Public art has had a mixed reception by artists, critics, curators and the public for whom it was intended. It has been claimed as an attempt to bring art to a mass public, but also as a misuse of public funds, or the imposition of institutional taste on spaces used by diverse publics. For artists, public art offered opportunities and constraints. But the opportunities have also been seen in different ways, as possibilities for social engagement precluded by galleries and museums, or more cynically as an extension of the market for sculpture.

Malcolm Miles

\subsection{O 'jargão’ canónico da arte pública}

The term Public Art in the strict sense refers to art practices that abandon the art world's institutional halls in favor of a broader public, not least by aspiring to relevance for political and social groups. ${ }^{1}$ Nesta definição operativa, a indecisibilidade do termo 'arte pública' é vista de forma positiva, na perspectiva de que se trata de um campo sempre em expansão da arte contemporânea.

\subsubsection{Arte(s) pública(s)}

É crítica a arte que reage à codificação no seio da hegemonia burguesa, no sentido de contínua procura de um novo léxico de expressão. Afirmando-se desde os anos 60 até obter visibilidade global (Scholette), esta arte reage retoricamente a múltiplos aspectos daquela hegemonia; hoje, por exemplo, resiste à burocracia dos programas per cent for art característicos dos fenómenos de requalificação urbana, à violência simbólica que o sistema da arte contemporânea expande para os espaços públicos urbanos ou à pressão alienante do marketing experiencial. O que importa é que esta arte desenvolve publicamente uma realidade dialógico-discursiva - this discoursive matrix forms a complex inter-institutional framework which artists increasingly find themselves working within. ${ }^{2}$ É um vasto campo relacional e potencialmente democrático:

I believe we have also arrived at a point in the history of this kind of practice where we can legitimately ask what the potential might be for the transfer of resources to locally-based community and cultural interests. Such a shift in the control of resources would constitute a counterpoint to the often nomadic nature of public art practice and its administration, towards creating the conditions for more enduring creative investment between artists and those communities who live and remain in place. ${ }^{3}$

1 Marchart, Oliver; «Public Art», in Sculpture Projects Münster, 2007.

2 Murphy, Ailbhe; «Public Art: an expanded field», in http://www.publicart.ie/main/critical-contexts/writing/archive/writing/view//82eb3blafb/?tx_pawritings_uid=15 (consultado 2 de Agosto de 2011).

3 Idem. 
Outro desafio da arte pública é ainda mais fundamental, porque exercício crítico colectivo d'os possíveis do social:

[...] public art and memorials can be an opening in society's value structures, just as much as a closure. Official histories and constructions of community can be re-examined as well as simply marked and endorsed. Instead of marking simple affirmations, a new type of contemporary memorial is being created. These kinds of memorial make gaps for new readings and meanings to emerge in the spaces they make. They create discussion, embody contradiction. Art and culture have historically been used to endorse the values and beliefs of the dominant ideology, but contemporary socially-engaged art is now also proving a fifth column within the structures it inhabits, which sees it playing its own effective part in shaping new and more inclusive social agendas for the future. ${ }^{4}$

Na recepção produtiva que a arte pública promove, está uma questão básica: Para quem? Desta noção em aberto de público, outra pergunta decorre:

[...] public art is rendered meaningless, or at least has a questionable existence, without an audience for which it is the object. Whether a project purports to be a question, a conversation, a warning, a happening, a lament, a celebration, a shout, a mirror, it needs an audience to complete what it has set in motion. The heart of public art is relational. But what is a public? ${ }^{5}$

E quem somos nós? Que ideia de comunidade (Nancy) nos importa?

\subsubsection{Actualizar o belo: símbolo e festa}

Em La actualidade de lo belo (1977/1991), Gadamer sistematiza o seu pensamento a partir de três termos-chave - símbolo, jogo e festa - ao encontro de um argumentário que legitima o entendimento da arte pública como actualização do legado grego clássico. Em termos sintéticos, o artista do século XIX no está en una comunidad, sino que se crea su própria comunidad. ${ }^{6}$ Ora se com Aristóteles nos lembramos da definição de 'arte' como saber e capacidade de produzir, a idade moderna traz a ideia da obra como objecto intencional (discursivo portanto) de um esforço regulado, livre, emancipado (Gadamer), finalmente disponível para continuar os programas aristotélico - a Poesia é mais filosófica que a própria história ${ }^{7}$ - e schileriano - a bela moralidade do idealismo alemão actualizada como crítica do mecanicismo sem alma do Estado Moderno (Gadamer ${ }^{8}$ ). O artista recupera aqui um reconhecimento público; actualizando o belo: la función ontológica de lo bello consiste en cerrar al abismo abierto entre lo ideal y lo real?. Mas como actualizar o belo na esfera pública, acompanhando as consequências do choque sublime das vanguardas? A plataforma comunicacional da arte pública vernacular é um modelo fundamental. Gadamer recorda-nos a este propósito a proximidade entre poética e retórica, dando a esta última, aliás, primazia: Esta es la forma universal de la comunicación humana, e incluso hoy sigue determinando nuestra vida social mucho más profundamente que la ciencia. ${ }^{10}$ Mais do que comparar arte pública e retórica, leio a arte pública não apenas retoricamente, mas como retórica. Isso permite que a redistribuição

4 Tipton, Gemma; «Public Art: memory and tradition», in http://www.publicart.ie/main/critical-contexts/writing/archive/ writing/view//7c299b0cb9/?tx_pawritings_uid=17 (consultado 2.8.2011).

5 Lyons, Alice; «For whom?», in http://www.alicelyons.ie/for_whom.html. (consultado 2.8.2011).

6 Gadamer, Hans-Georg, La actualidad de lo bello, Paidós, Barcelona-Buenos Aires-México, 1991, p. 36. Daqui vem a ideia do artista como entidade messiânica que se sente tomado por um imperativo de reconciliação, impregnado de ideias utópicas.

7 Poética, 1451 b 5.

8 Gadamer, p. 49.

9 Idem, p. 52.

10 Idem, p. 56. 
do sensível seja um imperativo pedagógico - el sentido de cada indivíduo para lo belo tiene que ser cultivado hasta que pueda llegar a distinguir lo más bello de lo menos bello ${ }^{11}$-, o mesmo é dizer, a crítica é a experiência em si do belo. E portanto, a arte pública - arte crítica da cidade, na órbita de uma crítica do espaço e da esfera públicos, é o belo contemporâneo. Ou ainda, a arte é onde filosofia e estética se encontram ${ }^{12}$ - é isso a arte conceptual - e de forma tanto mais criativa (imaginativa) e produtiva (emancipatória) quanto esse encontro for orquestrado pela retórica, espécie de racionalidade e técnica (Flusser, Roberts) dos símbolos, das imagens e das coisas. É uma genuína entrega ao logos retórico que nos ajuda a superar o sentido burguês do gosto estético aplicado, impedindo a reificação do belo. ${ }^{13}$

Em torno da questão fundamental da relação entre a arte (o artificial) e a terra, Félix Duque ${ }^{14}$, conflatindo arte pública e land art, propõe a superação de alguma ingenuidade acerca da arte (pública) enquanto prática espacial; o espanhol segue Gadamer numa busca do sentido especificamente humano da liberdade: Eso es el arte: crear algo de ejamplar sin producirlo meramente por reglas. Definição que aplicada ao corpus da arte pública me permite, entender a cogenialidade do receptor ${ }^{15}$ no âmbito de uma vida urbana que se oferece como tema e palco ao jogo. Tal pulsão lúdica e de liberdade (Schiller) enquadra e enriquece a minha ideia de dispositivo vital: El automovimiento es el carácter fundamental de lo viviente en general [...] movimiento en cuanto movimiento, que indica, por así decirlo, un fenómeno de exceso, de la autorrepresentación del ser viviente. ${ }^{16} \mathrm{~A}$ arte pública é portanto o jogo vital e excessivo do tecer da cidade, tanto mais que, jogar é jogar-com, participatio. ${ }^{17}$ Diz Gadamer, perante a afirmação das neovanguardas como modelos de encurtamento da distância entre obra e fruidores da mesma, que ese impulso por transformar el distanciamento del espectador en su implicación como co-jugador puede encontrar-se en todas las formas del arte experimental moderno. ${ }^{18}$ Isso faz de cada evento de arte pública, na sua efemeridade, na sua contingência, na sua identidade hermenêutica ${ }^{19}$, na sua mesmidade ${ }^{20}$, um factor de vida-entendimento, no encontro luminoso ${ }^{21} \mathrm{com}$ o dispositivo simbólico. Através da experiência simbólica ${ }^{22}$, o individual se representa como un fragmento de Ser [...] conformação. ${ }^{23} \mathrm{Na}$ arte pública que é cognição cidadã, isto é exponenciado: la obra

11 Idem, p. 58.

12 Cf. Rancière, em The Politics of Aesthetics.

13 Idem, p. 61. La función del arte decorativo es desempeñar ese papel secundário. Por conseguiente, serán bellas e nada más que bellas las cosas de la naturaleza en las que no se pone mingún sentido humno, o las cosas configuradas por el hombre que conscientemente se sustraigan a tida imposición de sentido y solo representen un juego de formas y colores.

14 Duque, Félix; Arte Público e Espacio Politico, Akal, Barcelona, 2001.

15 Idem, p. 64. Duque aprofunda a co-enunciação em Rodrigo Silva.

16 Idem, p. 68. El juego es, en definitiva, autorrepresentación del movimento de juego.

17 Idem, p. 69.

18 Idem, p. 70.

19 Idem, p. 77. Mencionei atrás a metáfora da edição do real, próxima da da leitura do mundo em Gadamer.

20 Idem, p. 71.

21 Idem, p. 73.

22 Idem, p 83. Gadamer evoca Goethe e Schiller, que notam no símbolo a remissão para o indeterminado. É por isso que a destruição de uma obra de arte tem qualquer coisa de sacrílego, assim como a sua reificação algo de bárbaro - en la obra de arte hay algo más que un significado experimentable de modo indeterminado como sentido.

23 Idem, p. 87. 
de arte significa un crecimiento en el ser, ${ }^{24}$ surgindo de un carácter estrutural del arte verdaderamente global y creador de comunidad. ${ }^{25}$ Tal criação é impulso comunicativo que el arte exige de nosostros y en el que todos nos unimos ${ }^{26}$-, e quando é redenção, no palco público da cidade, pode ser uma experiência da graça. Gadamer evoca o tema da festa em condições especiais de participação neste logos-dispositivo artístico: Propriamente, todos deberián - éste es el desafio del artista criador - abrirse al lenguage de la obra de arte, apropriárselo como suyo [...] se trate de un logro colectivo, del logro de una comunidad potencial. ${ }^{27} \mathrm{E}$ então, si el arte tiene de verdad algo que ver con la fiesta, entonces tiene que sobrepasar los limites de esta determinación que he descrito y, com ello, los limites impuestos por los privilégios culturales; e, igualmente, tiene que permanecer immune a las estructuras comerciales de nuestra vida social ${ }^{28}$ - isto é, tem de inscrever a festa do povo num programa de autonomia simultaneamente absoluta e relativa, em contínua e instável constituição revolucionária. Si hay algo asociado siempre a la experiencia de la fiesta, es que rechaza todo el aislamento de unos hacia otros. ${ }^{29} \mathrm{E}$ se o trabalho nos separa e divide, ${ }^{30}$ e a solidão nos pesa, a arte vai consistir em saber celebrar ${ }^{31}$ a consciência crítica de um nada que une: ¿En qué consiste propriamente ese arte? [...] en una comunidad que no puede precisarse del todo, en un congregarse y reunirse por algo de lo qual nadie puede decir el porquê. ${ }^{32}$

Tomada como actividade intencional, ${ }^{33}$ a arte pública é em particular a festa do diálogo - o encontro (silencioso) com a conversação - e a comunicação graciosa da contínua renovação da potencialidade dessa festa: la fiesta está siempre y en todo momento ahi. ${ }^{34}$ Donde que há um aprender a demorarmo-nos ${ }^{35}$ no logos e na poética de um certa economia do dispositivo: Una cosa es bella si no se puede añadir ni quitar nada. ${ }^{36} \mathrm{~A}$ arte pública é então um jogo de símbolos que abrandam, suspendem ou problematizam o tempo trivial - isto si nosotros mismos somos realmente activos para escucharlo del exterior. ${ }^{37} \mathrm{E}$ aí, é tanto mais pública a arte, quanto persuasiva, desde logo pela sua singeleza de processos. Na verdade, é por aqui que a metáfora da cidade, como obra de arte, palimpsesto urbano, combate a apatia: la transmisión no implica dejar lo antiguo intacto, limitándose a conservalo, sino aprender a concebirlo e decirlo de nuevo. ${ }^{38}$

24 Idem, p. 91. Esto es que la distingue de todas las realizaciones productivas humanas en la artesania y en la técnica [...].

25 Idem, p. 96.

26 Idem, p. 98.

27 Idem, p. 99. Ressoa Aristóteles. Apenas possível no re-conhecimento - não o voltar a ver uma coisa mas propriamente, ideação, num quadro de uma comunidade que aprende a construir-se em comunicação.

28 Idem, p. 118

29 Idem, p. 99. La fiesta es comunidad, es la presentación de la comunidad misma en su forma más completa.

30 Idem, p. 100. Gadamer nota que, neste aspecto, as culturas antigas nos superam.

31 Idem.

32 Idem. Gadamer nota: lo próprio de la solemnidad de la fiesta es el silencio - a imagem sonora da graça do social.

33 Idem, p. 101. Celebramos al congregarnos por algo y esto se hace especialmente claro en el caso de la experiencia artística. No se trata solo de estar uno junto a otro como tal, sino de la intención que une a todos y les impide desintegrarse en diálogos sueltos o dispersarse en vivencias individuales.

34 Idem, p. 102.

35 Idem, p. 110.

36 Aristóteles, Etica a Nicomaco, 8 5, 1106 b 9, in Gadamer, p. 106. Ecos ainda de Wagner/Beethoven neste contacto com a totalidade do socius: Piénsese en la música.

37 Idem, p. 109.

38 Idem, p. 116. Ciertamente que un peligro enorme para la civilización humana acecha en la passividad que ha producido el uso, demasiado cómodo, de los múltiples canales de la cultura, especialmente en lo que se refiere a los médios de comunicación de masas. 


\subsubsection{Artes públicas - anos 80 e 90, movimentações de interesse público}

Deste quadro de resistência filosófica e estética ao regime da comunicação (Cauquelin), passo à análise de três tipologias de publicitação da arte. É uma questão ingrata desde que a 'arte pública' se tornou 'palavra feia' no campo da arte (Cartiere e Willis), perdida entre o mercado comercial a as instituições públicas (Gadamer), entre o kitsch (Gadamer, Duque) e a alienação estética, tornando-se sinónimo de compromisso, diluição e dependência. ${ }^{39}$ Mas impõe-se a tarefa, dada a desconexão entre o riquíssimo trabalho que tem sido produzido e a escassa produção de análises críticas $^{40}$, mesmo num quadro de proliferação de práticas efémeras e transdisciplinares em contextos arquitectónicos e urbanísticos ${ }^{41}$. Afinal, Pairing art with civic process can seem to some a deceptively simple matter..$^{42}$ Mas talvez seja esse 0 imperativo de uma arte menor (Deleuze/Guattari, Pinçon) que, sob o foco da acção (Philips) micropolítica (Guattari, Negri), é o suporte performático para ancorar as outras derivas da arte pública que quero relevar. De Marchant ou Mouffe, é a questão do conflito que está em jogo - e curiosamente, o jogo que está em conflito - o que mostra em que medida arte pública e retórica (o conflito discursivo, em sede de persuasão e argumentação) são indissociáveis. Logo, só uma politicização $0^{43}$ dos conceitos de arte pública e de esfera pública (Marchant), desde que traduzidos em formas contingentes, dialógicas, negociais, agonistas, colaborativas no quotidano urbano, ajudam a deslindar a hipótese da arte (como) política. ${ }^{44}$

Os termos art in public interest ${ }^{45}$ e new genre public art ${ }^{46}$ propondo um envolvimento directo da criação na agenda social, culminam um amplo movimento que, desde os anos 80 , valoriza o engajamento directo, activista e muitas vezes comunitário, da arte com a cidade. A tese é a de que é possível retirar o público da apatia face aos problemas sociais, expandindo a participação numa sociedade democrática de acordo com diferentes visões experimentais da mesma. Nos anos 80 , o reavivar da arte conceptual através do conceito de projecto ${ }^{47}$, focado nos conflitos que caracterizam a sociedade, havia dado origem à Project $\operatorname{art.} .^{48} \mathrm{Na}$ década de noventa, há desenvolvimentos desta tendência múltiplice: art as service ou community based art (Kester) são novas terminologias numa sociedade de ser-

39 Cartiere, Cameron; Willis, Shelly; «Introduction», in The Practice of Public Art, Routledge, New York, 2008, p. 1.

40 Idem, p. 2.

41 Over forty years since public art was coined as a term, it has yet to be clearly defined in any art history text. This is partially due to the relationship between public art, architecture, and urban design. Idem, p. 8.

42 Lacy, Suzanne; «Time in Place. New Henre Public Art a Decade Later», in The Practice of Public Art, Routledge, New York, 2008, p. 23.

43 Cf. Smith, Neil; Low; Setha; «Introduction: The Imperative of Public Space», pp. 1-15.

44 A presente investigação não marca essa hipótese a traço grosso; sendo que assumir a retórica no lugar da politica é talvez fechar a arte ao palco do social de que ela, paradoxalmente, pode ser máxima epifania.

45 Cf. Raven, Arlene (ed.); Art in the Public Interest, Da capo, 1993. A obra é uma abordagem, através de vários estudos de caso (de Tim Collins a Richard Serra), da interacção entre arte, consciência social e politicas públicas.

46 Cf. Lacy, Suzanne (ed.), Mapping the Terrain, New Genre Public Art, Bay, 1994.

47 Babias, Marius; «Project Art » in Sculpture Projects Münster, 2007, p. 422.

48 Idem. Mesmo quando claramente recuperada pelo sistema da arte - Oda Prodeji, Group Material, por exemplo - 0 carácter político destes produtores culturais não se desvanece completamente e adquire um estatuto meta-artístico. [...] which is often processually developed by groups made up of artists and non-artists in parallel roles, media and genres, arose in the knowledge that the fine arts should be freed from their bourgeois function of enhancing prestige, and should act instead as a vehicle of societal practice. 
viços em que a proficiência do campo da arte se vira para os seus próprios mecanismos de mediação (muitas vezes acabando por ampliar o poder hegemónico das ideologias que definem a divisão cultural, como nalguma 'parachute art'). A partir de meados da década, a tendência da arte comunitária (community based) afirma-se assim de forma algo ingénua ou descoordenada como nos projectos pioneiros de Mary Jane Jacobs em que a participação radica na problemática conceptualização das identidades como sendo "definitivas/ formadas"; apenas depois se torna mais científica, recorrendo a conceitos como o de comunidades imaginadas. Chegados à new genre public art, o trabalho pluridisciplinar estimula comunidades mais ao menos provisórias ou informais, exigindo porém uma teorização de base que passa por exemplo por sublinhar as diferenças estratégicas. De resto, Lacy e este movimento colocam sempre mais perguntas do que respostas acerca dos tópicos e forças em conflito num projecto de colaboração.

Na ideia de arte pública, o espaço urbano define-se então na capacidade de se propor como máquina de fazer cidade - conscientização da cidade - a arte pública é portanto, ao mesmo tempo, a emergência e o próprio sismógrafo de um acontecer existencial da vida urbana. Umas vezes, experimentamos essa noção de polis ${ }^{49}$ como sendo de um todo comunal, de uma forma ritualizada e festiva; outras vezes exigimos ao espaço que seja nosso confidente íntimo, ressoando a nossa solidão e outras, ainda que nos represente através de símbolos. Ora, se o Espaço Público é portanto o espaço da construção de alternativas à alienação - sensíveis, experimentáveis, inteligíveis - a arte pública - plataforma de esperança (Harvey) - é um desafio social estratégico, nomeadamente ao nível do território. Ou seja, a arte pública é tanto mais pedagógica quanto mais o seu sentido crítico for pertença colectiva, também ao nível da capacidade específica de interpretarmos a forma urbana e sobre ela termos capacidade de agirmos.

\subsubsection{Da cultura como evento, da cidade como imagem, à procura do público}

A perspectiva da arte pública como evento acentua a questão da experiência, e portanto da recepção. Pressupõe, no quadro da sociedade pós-industrial, o conceito de evento cultural, seja da ordem do micro-acontecimento (por pequenas estruturas) ou dos mega-acontecimentos (por poderosas marcas e instituições) ${ }^{50}$. Há nesta cultura événementielle um aspecto kitsch (Duque), que nem sempre é filtrado pelo populismo (Knight). Por outro lado, há o valor da celebração do efémero à medida e ao gosto das expectativas de diversos grupos de interesse face ao espaço cidade..$^{51}$ Um exemplo desta cultura de massas na arte são as grandes exposições-acontecimento; algumas, como a de Olafur Eliasson (The Weather Project, na Tate, 2003-2004), fortemente apoiados financeira e mediaticamente. E funcionam como 'mega-serviços' de experiências únicas (design de experiência), são

49 [...] Esta possibilidade é da maior importância política se entendermos (como os gregos entenderam) a polis como o domínio politico-público em que os homens alcançam a sua plena humanidade, a sua plena realidade enquanto homens, porque nele não só são (como na privacidade da esfera doméstica) como aparecem

50 Isto conduz a duas situações perversas: uma sensação de que a maior parte da produção cultural é irrelevante los seus números são irrisórios em comparação com os feitos mais espectaculares); depois um efeito de cópia que multiplica os melhores (e os menos bons) exemplos desta cultura em várias e escalas e em vários contextos.

51 No modelo neo-liberal vigente, destaque-se o peso de entidades que privatizam a experiência pública, desde organizações de vocação securitária ao imobiliário, passando pela espectacularização publicitária. 
a expressão de uma importante alteração histórica: ${ }^{52}$ a passagem de um sujeito orientado para o mundo para um sujeito orientado para si próprio (Schultze)..$^{53}$ Outros eventos são os festivais de luz, bienais de arte urbana ou acontecimentos especiais: The event culture of the postmodern 'Erlebnis' society attempts to organize this radical bareness and immediacy of the decentering experience ('Erlebnis') of modernity into an easily consumable commodity. ${ }^{54}$ Esta perspectiva évenementielle da cidade realiza na esfera do efémero decisões relacionadas com o marketing urbano (city marketing ${ }^{55}$ ), com reflexos em processos de gentrificação ou de disneyficação. Regra geral, é uma subserviência da criação à agenda da imagem urbana ${ }^{56}$ que caracteriza estes acontecimentos, anunciados como aqueles em que temos de lá ir (Cauquelin).

Ora importante alteração nas dinâmicas de apropriação da arte pelo público relaciona-se com uma atitude crítica que coloca as pessoas que o constituem no centro da reflexão da arte face à cidade-acontecimento. ${ }^{57}$ Isto é, a publicidade da arte determina-se a partir de factores como as condições do encontro com um 'público', ${ }^{58}$ ora 'espectador transeunte ${ }^{59}$ ora cidadão convocado. ${ }^{60}$ Nas visões mais críticas (nalgumas Artes de Rua), a ambição é a dada altura a de s'addresser à toute la population perçue comme pouvant devenir, à un moment où un autre, un «public», c'est à-dire un groupe de personnes rassemblés pour assister à une manifestation artistique. ${ }^{61}$ Esse grupo é constituído em função do encontro, no cerne de uma alquimia (Watelet) que é precisamente a atitude que alguma Arte de Rua entrega ao campo da arte contemporânea:

Ces arts redefinissent l'appartenance à une ville qui provoque l'inoubliable de la fête, de ce moment à part, vécu, presque volé par chacun pour la mémoire de tous. La mémoire collective est enrichie, devient source de fierté, de références, s'inscrit en tous pour se réapproprier de territoire, mais aussi une part de lui-même. La fête devient alors un rite social, un espace où la societé se rencontre, un lieu où la ville s'invente et se réinvinte. ${ }^{62}$

52 "Suppliers and demanders" of experience create "incessantly new forms of the desirable" which are interrelated through "rating, market shares, media penetration, and sales figures" on the one hand, and "advertising, program magazines, trend communication in media, and the visually highlighting of the new in everyday life" on the other.

53 Holert, Tom; «Culture as Event», in Sculpture Projects Münster, 2007, p. 349; Schultze, Gerhard, «Was wird aus der Erlebnisgesellshaft?», in Aus Politik und Zeitgeschichte, vol. 12, 2000 (Themenheft Erlebnisgesellshaft), pp. 3-6.

54 Idem, p. 350. Controlled in this way, experience ('Erlebnis') becomes the universal modus for programming purchasable experience. Entire cities, regions, and nation-states have entered into a global competition, seeking to generate 'quality experiences' and so attract the attention of subjects. $\neg$

55 Note-se que, na perspectiva do marketing urbano, as cidades aspiram a desenvolver poderosas operações de identificação da grande maioria da população com determinados conceitos; a rede dessas acções de marketing é ela própria um recurso. Cf. «City Marketing», in Sculpture Projects Münster, 2007, p. 340.

56 Cf. «Imagecity», in Sculpture Projects Münster, 2007, pp. 382-383.

57 Exemplo, a posição que tem vinda emergir nas 'artes da rua'. Na contracapa de La Relation au Public dans les arts de la rue (Éditions Entretemps, Vic la Gardiole, 2006), os editores assumem: Cet ouvrage raconte le public plutôt qu'il le compte!

58 Gonon, Anne; «Faut-il avoir peur du public?», in La Relation au Public dans les Arts de la Rue, Éditions Entretemps, Vic la Gardiole, 2006, p. 36.

59 Por exemplo, diante de um espectáculo gratuito, je suis partagé entre deux états contradictoires. D'un côté, du fait de l'air du temps, j'éprouve le sentiment que c'est sabs importance. Et cela induit de la distraction, une faible appropriation de l'ouvre. De l'autre, je bénéficie d'une mise en situation qui m'ouvre à la liberté d'aimer et de juger, qui contribue à la désintimidation du rapport à l'art. Sagot-Duvaroux, Jean-Louis; in idem, p. 52.

60 L'air du temps. La perte de conscience des enjeux du public face au privé. Sagot-Duvaroux, idem.

61 Idem, p. 37.

62 Delorme, in idem, p. 44. 
Claro que a emergência provisória, experimental de novos públicos tem de encaixar na indústria cultural e seu habitus: Les musées, les scènes nationales, les théâtres publics et privés, les centres d'art sont une force pour un territoire: chacun a un public qui parfois se croise, la complémentarité devient un jour source de transversalité et les arts de la rue, pluridisciplinaires, fournissent un décloisonnement supplémentaire..$^{63} \mathrm{O}$ que passa pelo gesto da gratuitidade La gratuité est alors présentée comme un moyen de sortir des codes et des castes de la salle. Elle engage un point de vue sur ce que doit être l'espace public. ${ }^{64}$ - que por sua vez, pode argumentar-se, se encontra inscrito no ethos mais profundo e radical do acto artístico. ${ }^{65} \dot{E}$ em todo o caso o convite à experiência afectada da cidade como um 'lá fora' - Dehors, il fait moins froid 6 - onde tudo pode acontecer: C'est souvent grâce au public qu l'on réalise des choses insensées dans la rue. ${ }^{67}$ Este encontro com a arte inscreve na experiência da cidade pequenas lições de economia aplicada ${ }^{68}$ Em consequência:

Pour les artistes de rue, la place du public ne devrait jamais aller de soi. Chaque nouvelle proposition redistribue les cartes et impose une conception du contexte de jeu. La rue impose ses caractéristiques singulièrs [...] Intégrer la place et l'addresse au public dans la création artistique, c'est dépasser l'ambition de «monter un spectacle» pour plutôt se demander quelle relation d'échange on va proposer. ${ }^{69}$

O público não fica 'fora de jogo'70: J'ai beaucoup aimé ton dernier public», voilà donc le plus beau compliment à faire à un artiste. ${ }^{71}$ Mas, assim como não se pode falar de públicos sem falar de territórios ${ }^{72}$, há obras mais e menos eloquentes na sua apropriação das múltiplas possibilidades da forma da arte face à forma urbana como totalidade. E portanto:

La question de la connaissance du public est interessante mais [...] Je n'ai demandé les papiers d'identité de mon public! Je tente de maddresser à la ville. Si tu as l'ambition, la prétention, de t'addresser à la ville, tu écris à la largueur de la ville, tu écris avec des pages et del lettres qui sont à la hauteur de la ville. Je m'addresse à un public de nombreux lecteurs en fait. C'est la foule. . $^{3}$

É uma multidão transeunte que redescobre permanentemente a emoção da arte: Ces foules qui nous suivent sont des foules populaires qui recherchent du sens, des émotions, qui sont prétres à les partager. ${ }^{74}$ Esta verdadeira comunicação social ${ }^{75}$, será talvez uma quimera ${ }^{76}$ ou uma ficção retórica, mas em todo o caso uma cerimónia ${ }^{77}$ à escala de um bairro. ${ }^{78}$ Neste ponto, é particu-

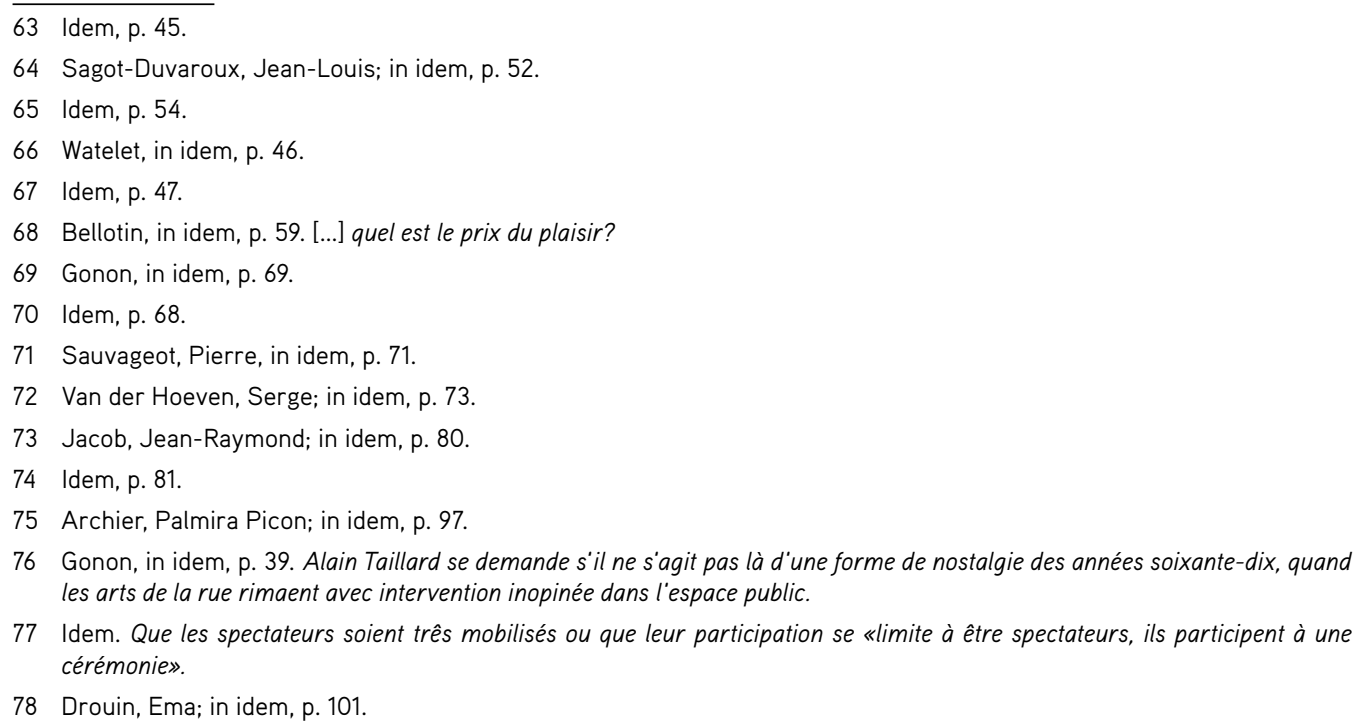


larmente pública a arte anónima que na órbita de street art lagora no mundo anglo-saxónico na esfera do graffitti) busca o seu logos de comunicação (e acção) directos no anonimato, na ilegibilidade, assumindo a sua vocação de transgressão (desde logo de propriedade), como condição sine qua non para a sua publicidade.

\subsubsection{Obras eloquentes: uma gramática}

A arte em espaços públicos é o fenómeno que melhor caracteriza as manifestações artísticas do útimo terço do século XX. ${ }^{79}$ Alguns dos seus momentos icónicos colocam os problemas mais candentes da arte pública crítica, constituindo uma gramática de base de que revisito uma tipologia possível (Javier Maderuelo).

\subsubsection{Do monumental ao social, uma síntese tipológica}

Monumentalidades. Nos anos 50, as apropriações do espaço público pelos artistas assentavam num regresso à monumentalidade, dando pertinência à adequação das peças lobjectos) aos lugares ${ }^{80}$. 0 interesse pelo volume ou a presença formal em função do sítio passou durante um certo período pela abstracção referencial, ou seja, sem pretender dotar a obra ou o lugar de um significado explícito e programático. ${ }^{81}$ Foi no quadro destas experiências que brotaria o conceito site-specificity, reacção que pressupõe um passo de gigante ao situar a obra no extremo oposto à habitual escultura "itinerante"82. Outros artistas não se conformam com a proposta de formas abstractas e pretendem recuperar também o significado das obras. ${ }^{83}$ Claes Oldenburg será exemplo dessa recuperação - irónica - do monumental a partir das categorias do quotidano e seu imaginário, tirando uma ilação crítica da pop $\operatorname{art}^{84}$. Os 'embrulhos' de Christo também parodiam o monumento e o monumental, ainda que a megalomania implícita neles acabe por os converter em novos monumentos do pós-modernismo. ${ }^{85}$ Postura mais radical na questão da desmaterialização (visual) do objecto são o caso de Walter de Maria na sua obra para a Documenta de Kassel, uma vara de um quilómetro de

79 Maderuelo, Javier; in «O Fenómeno da Arte nos Espaços Públicos», in Vv. Aa,; Espaço Público e Interdisciplinariedade, Centro Português de Design, Lisboa, 2000, p. 240.

80 Cf. Entrada «Drop Sculpture»; in Sculpture Projects Münster, 2007, p. 355-356. Malcolm Miles complementa que é a figura da sublimação que caracteriza a relação da escultura monumental com os valores de uma determinada sociedade. Cf. Miles, Malcolm, «The Monument», in Art, Space and the City - Public art and urban futures, Routledge, London, 1997, pp. 58-83.

81 Maderuelo, p. 243. Numa tendência contrária à da tradição da ampliação de maquetas de pequenas dimensões.

82 Idem.

83 Idem.

84 Cf. comentários de Félix Duque sobre a peça Spoonbridge and Cherry (1985-1988). Duque, Félix; Arte Público y Espacio Politico, Akal, Barcelona, 2004., pp. 153-158. jTécnica y arte quedan asi en entredicho en sus funciones ¿Dónde está la finalidad, entonces? Aquí, en lugar ele pender todo - directamente, como quería Arp, el artista productor, o mediatamente, como las cosas "físicas", en Aristóteles - ele un único Principio que domina sin ser dominado, que sólo tiene derechos y no deberes, que es, en fin, Aquél para quien todo es sin que Él sea para nadie, Oldenburg nos propone con su obra un sistema ele mediaciones entre Ciudad (Minneapolis, al fondo), Naturaleza (la laguna, la hierba), la Técnica (la cuchara) y el Arte (la cereza). Un sistema perfectamente armonioso, porque ni cuchara ni cereza cumpliendo perfectamente una función son útiles (a pesar ele su apariencia) para el hombre.

85 Maderuelo, p. 244. Ver também o filme The Gates (2005), de António Ferrera e Albert Maysles, sobre esta emblemática ocupação efemera de Central Park, em Nova lorque. 
comprimento enterrada verticalmente no solo, que à superfície se oferece à percepção como um círculo de metal de alguns centímetros de diâmetro. ${ }^{86}$

Comemorações. Outra categoria é constituída por obras que assumem uma revisão formal do monumento [...] sem cair na ostentação simbólica nem na arrogância dos monumentos do passado ${ }^{87}$. Um monumento histórico nesta categoria é o desenhado por Maya Lin em 1981, dedicado aos veteranos e desaparecidos na Guerra do Vietnam. A peça assume o carácter de uma narrativa emocionalmente discreta em que cada um possa extrair as suas próprias conclusões sem elas estarem filtradas pela grande eloquência de frases, imagens ou alegorias. ${ }^{88}$ Esta categoria conduziu aos contramonumentos de Jochen Gerz; ${ }^{89}$ mas também à apropriação da categoria do monumental, por exempo em Krzysztof Wodicsko, que utiliza espaços, edifícios e monumentos públicos para neles inscrever, por vezes ilegalmente ou no limite da legalidade, efémeras projecções de imagens. ${ }^{90}$

Urbanidades. Um quarto grupo reunirá obras que renunciam à forma e significado do monumento tradicional e que buscam a definição de um novo género artístico puramente urbano ${ }^{91}$. São obras que assumem o flirt com o design urbano e os seus valores de funcionalidade e utilidade; os autores são artistas urbanos que vivem e amam a cidade ${ }^{92}$ que assumem como parte integrante do seu ethos de artistas a sua condição de cidadãos activos. Em criadores como Dan Graham, a arte é no âmbito desta categoria menos uma marca autoral (o estilo), mas o resultado de um tráfico de competências - da pop à instalação, da land art à arquitectura ou ao urbanismo - orquestrada pelo artista em que um desejo pelo povo conduz os processos de formalização. ${ }^{93}$

Ambientalidades. Uma outra categoria aglutina obras com qualidade ambiental que ajuda a recriar ou a potenciar as características físicas e significativas do lugar no qual se implantam ${ }^{94}$. Quais cenografias barrocas, estas obras tratam de forma integral o espaço urbano atendendo à configu-

86 Ainda relativamente a estas primeiras categorias, ocorrem-me como casos mais recentes os bonecos gigantes de Jeff Koons ou a escultura Cloud Gate de Anish Kappor em Chicago ('the bean'), mas também o statement minimal de Bruce Naumann em Münster (Square Depression, 2007). Em Portugal temos um Oldenburg («Pá)) nos Jardins de Serralves e, em Lisboa, uma série de marcos urbanos vermelhos, realizados em betão, pelo arquitecto-escultor Charters de Almeida.

87 Maderuelo, p. 244.

88 Idem. Dois anos depois, seria construída uma escultura 'hiper-realista' de Frederick Hart representando três soldados, junto ao Muro. Some veterans and their political supporters felt that The Wall was "a black gash of shame" or a "giant tombstone." It was too abstract a design for others who wanted a more heroic, life-like depiction of a soldier. To meet these concerns, it was decided that a traditional statue would be added as an integral part of the Vietnam Veterans Memorial. Cf. http://www. vvmf.org/ThreeServicemen, consulatado em Novembro de 2011.

89 Como o de Esther e Jochem contra o fascismo em Hamburgo. Para Malcolm Miles, esta é uma arte que negates past unfreedom by articulating personal memories. In «Public Spheres».

90 Em Portugal, esta categoria poderia eventualmente ser representada pelo contestado Monumento ao 25 de Abril por José Cutileiro. Ou ainda, com resultados espectacularmente imprevistos (ver documentário Fora de Água de Catarina Mourão), a Garrafa de Água de Pedro Portugal num rotunda em Beja.

91 Maderuelo, p. 245.

92 Idem.

93 Em Portugal, casos nesta linha (raros) seriam o Jardim das Ondas (1998) de Fernanda Fragateiro, na Parque Expo ou uma peça recente de Sérgio Vicente no topo do Parque Eduardo VII, subtilmente dissimulada como mobiliário urbano, e assim não impondo o tema do seu pretexto.

94 Idem, p. 246. 
ração física do lugar, à sua carga simbólica e emotiva, ao peso da história, a problemas funcionais, seguindo a máxima dos paisagistas ingleses de escutar o genius loci..5 São 'peças' que estão na esfera do desenho urbano mais integrado (Brandão) - querem ser lugar antes de ocupar lugar -, e podem tanto ser projectos de pavimentos (Burle Marx, passeio de Copacabana em 1960) como de configuração de estruturas naturais lo eloquente Storm King Wall [1997-98] de Andy Goldsworthy, no Storm King Art Center em Nova lorque). ${ }^{96}$

Participatividades. Inclui obras que exigem a participação dos cidadãos [...] surgem de complexos processos criativos e administrativos nos quais intervém, para além dos artistas, políticos, técnicos, funcionários, empresários, engenheiros ${ }^{97}$. Nesta categoria temos duas situações politicas opostas. Numa, as intervenções são isoladas dos cidadãos por aparelhos decisórios que os ultrapassam; noutra, a cidade revela toda sua dinâmica social, actualizando ancestrais tradições de espaço público como os festas populares, as procissões, os enfeites nas ruas, tradições de envolvimento e participação que os artistas contemporâneos, com base numa acepção sempre personalizada da escultura social de Beuys, transformam na contínua renovação do conceito de happening total. Momentos icónicos nesta modalidade são os primeiros programas coordenados por Mary Jane Jacobs em Chicago; já na peça The Battle of Orgreave ${ }^{98}$, rigorosa reconstituição histórica por Jeremy Deller de acontecimentos violentos ocorridos na sequência de uma greve ocorrida em 1984, teríamos um exemplo teatral desta categoria. ${ }^{99}$

Esta categorização de Maderuelo é instrumental para a crítica da arte pública na forma urbana; ajuda a definir a imagem urbana criticamente e favorece a leitura do carácter vivencial dos espaços que habitamos (uma ampla diversidade de contextos e de linguagens). Ela revê a sublimação monumental (tradicional) em baixa, substitutindo-a por uma presentificação cognitiva da vida urbana que é crítica da irrupção meramente decorativa lacrítica, trivial, kitsch) ${ }^{100} \mathrm{~A}$ arte pode então aparecer sob o signo da provocação, quando os artistas invertem a funcionalidade habitual de objectos ou formas e nos surpreendem pelo inesperado, pelo absurdo, pelo choque que algum graffitti tem aportado à paisagem urbana. Convoca-nos para uma participação efémera mas particularmente activa, transformando a paisagem

95 Idem.

96 Em Portugal, de novo O Jardim das Ondas poderia ser uma referência nesta categoria, mas talvez mais propriamente o projecto de pavimento de Bruno Soares para o Terreiro do Paço em Lisboa, se tivermos em conta a forma subtil como articula os fluxos pedonais.

97 Idem, p. 247.

98 O cordão humano organizado por Pepe Espaliú, doente de SIDA, que ligou o Círculo de Belas Artes ao Museu Reina Sofia - cordão ao longo do qual o artista, em estado terminal seria levado em braços; 0 evento teve a participação de mais 800 pessoas, incluindo 280 residentes, alguns originalmente envolvidos nos confrontos. Organizada pela Artangel, a iniciativa teve a colaboração de uma empresa de reconstituições históricas, que utilizou fatos e técnicas autênticos dos anos 80 .

99 Em Portugal destaco a provocatória intervenção de Xana numa praia do Algarve, «Muro de Lisboa / Areia para os Olhos», de 2008, que interrompia o areal com um 'muro de Berlim' tão risível quanto perturbante; várias intervenções de Lisboa Capital do Nada - Marvila 2001, com destaque para as obras de José Maçãs de Carvalho, Mariana Viegas, Paula Figueiredo, que ostentam níveis de participação cidadã claramente mais evidentes do que as peças de Catarina Campino, Vasco Araújo ou André Guedes, que caberiam na quarta categoria. Ainda na LXCN, o momento emblemático que epitemizou o evento, um cordão humano em que 4000 pessoas 'deram as mãos por nada', seria difícil de dizer se integraria a primeira ou a segunda vertentes.

100 Em Portugal, quase todas as esculturas em rotundas viárias são uma expressão do 'belo' na paisagem; a colocação de objectos escultóricos, de que o arranjo dos espaços exteriores é a moldura (que curiosamente, finge não se aperceber da violência formal da sinalética ou da publicidade outdoor). 
da cidade num palco concreto para a performatividade de indivíduos e grupos. Neste tipo de obras, a utopia da interacção criativa é uma forma de resistir à ideologia neo-liberal que nos coloniza o corpo, o espírito e as relações sociais, transformando-nos em meros consumidores - e não produtores - de espaço.

\subsubsection{Os outros ali ao longe e aqui ao pé}

Entre o inframince duchampiano e o momento lefèbvreano, a questão da instersticialidade é aspecto determinante da performática do corpo democrático. Duas obras recentes - uma de grande escala, suportada por operações de marketing social mainstream e outra de pequena escala, ancorada no meio académico, ambas remetendo-nos para outras operações ${ }^{101}$ - são exemplo de estratégias radicalmente contrastantes na apropriação do meio-arte para convocar a identidade cidadã na cidade contemporânea. One \& The Other (Anthony Gormley, Londres, 2010) decorreu no plinto vazio de Trafalgar Square, ocupado durante cem dias por 2400 pessoas, cada uma durante uma hora. As pessoas foram escolhidas entre 34 500 propostas, sendo que a ninguém era solicitada qualquer informação prévia sobre as suas intenções uma vez sobre o plinto. O projecto ofereceu 2400 performances em ordem alietória, transmitadas com apoio do patrocinador principal (SKY NEWS) na internet e na televisão $0^{102}$. But was this a monument by other means, when the conventions of a national culture have no currency? Or was it an extension of participatory art? Can One \& Other be understood via the new framework of relational aesthetics, or was it the last gasp of a dead genre? ${ }^{103}$ Para o artista, a obra was intended to represent the nation in its diversity, in a city in which more than a hundred languages are routinely spoken. Mas impõem-se várias perguntas: Does participation make the work a more authentic representation (or is that an oxymoron)? Or does One \& Other present a picture of individualism in place of the social body? A questão é candente quando o modelo de 'participação' favorece a reificação de várias modalidades de civilidade - nas figuras mediatizáveis do filantropo ou do excêntrico - , mais do que questionar o sentido das mesmas numa economia de valores comunitários. Ironicamente,

If public monuments are designed to produce social ordering, was One \& Other a reinvention of the monument to promote a picture of a nation whose troubles are no more than personal idiosyncrasies? [...] And perhaps it was appropriate, then, to use a plinth to present this picture of the nation to itself, much as statues present a nation's citizens with images of the values and hierarchies they are required to observe..$^{104}$

Nestes termos, One \& the Other parece um mecanismo de defesa - keeping anarchy at bay ${ }^{105}$.

101 Freee, The Social Function of Public Art is to Subject Us to Civic Behaviour, realizado no mesmo plinto que Gormley, em Trafalgar Square, local frequentemente utilizado por vários artistas interessados em arte pública.

102 Miles: For Jonathan Jones [...] One \& Other was reality television: not 'a celebration of the creativity of ordinary people [... ] a diminishing, isolating image of the individual' when 'people will try anything to get their voices heard.'

103 Miles, Malcolm, « One, Other and the Rest: a composite picture of participation?», 2010.

104 Prossegue Miles: The site of One \& Other - Trafalgar Square - is, further, a monumental zone designed in the 1820s as an inscription of order, following the clearance of dense habitations on the site seen by the authorities as housing crime. The square denotes urban cleansing, a purging of the social body of its dirt. This may be overlooked by the tourists who flock to the National Gallery, but perhaps the plinth retains a function here as the sign of a hierarchic genre. Yet, again, the status of the work as art constructs a tension, as if its representation of the nation denotes no power-relations, only a game, dressing up and having fun, doing as one likes. Or was it not art but entertainment?

105 Idem. Pelo menos na perspectiva do do New Labour, força hegemónica em Inglaterra. 
A relacionalidade do dispositivo desvela-se dimensão de uma engrenagem:

If the plinthers could decide what to do on the plinth, they were still like out-sourced producers of the work under the management of a system which included the artist but also the sponsor, the authorities who gave permission to use the square, and a network of dealers, curators and critics who invisibly decide what constitutes contemporary art.

E então, somos outros apenas quando há um projecto, pelo menos implícito? Do these parodies of a world governed by exchange really open a critique, or do they reaffirm an antisocial tyranny? The difference between the work on which Bourriaud writes and that of, say, WochenKlausur (cited by Kester) is that WochenKlausur retain an avant-garde idea of a better life. ${ }^{106}$ Isto é, a dignidade ao cidadão (Senett) implica consciência crítica do possível da festa (um horizonte que não se confunde com o espectáculo do caos):

The epitome of this is festival; but Lefèbvre's point is that moments of liberation occur within the dull routines of everyday life under capitalism. I am not persuaded that this happens in the cases of art cited as articulating a relational aesthetic. They seem too often to relapse into an aesthetic distancing, or a knowing familiarity with market mechanisms which leaves those mechanisms more or less intact, transposed to art-space as an extension of the market. If there is paradox - displacement and complicity at once - it lacks a vital third element: critique.

Da crítica se pode então dizer que é a superação de um medo específico:

As Jacques Rancière says of the nineteenth century, it was haunted 'by the Platonic paradigm of the democratic dissolution of the social body" - the conflict of individualism and the social bond. I read One \& Other as, underneath, articulating a similar fear. And perhaps that fear informs relational aesthetics, too: a fear that the artist would have no place in a truly democratic society, in which, everyone was an artist. It seems gloomy. But perhaps it is not.

Entrementes, em Weimar, terra natal de Schiller, temos outra abordagem do espaço urbano intersticial. Koka Inn (Weimar, 2010), iniciativa de um grupo de investigação sedeado em Weimar e Salvador da Bahia, apresentou-se como um quiosque de arte contemporânea, uma experiência de ocupação de um espaço urbano ${ }^{107}$, que durante duas semanas se tornou ponto de encontro para encontros inesperados ${ }^{108}$, sob o mote da gentileza: The prophet Gentileza was right, Gentileza gera Gentileza ${ }^{109}$ : kindness generates kindness. The recipe was easy: a smile, a coffee, a waffle, a hammock, a game, a beer, a table with chairs and a couple of sofás. A simplicidade de desafio empático - Activities unfolded themselves in affects, as the people engaged with the place - não dissimula a complexidade projectual que o encontro (Deleuze, Grout) exige, patente na abertura programática:

One visitor interpreted it as a contemporary approach to the 18th century museum culture of collecting and exposing the exotic. Quite a few people understood it as an experiment of social practices, on participation, on utopia. There were many who, neither questioning nor judging, stopped to trade an object, to sleep in a hammock, to share a meal, or to drink a coffee. For me, it was an artistic initiative ${ }^{170}$ that brought to this Weimar cormer and the Art Kiosk a 24/2weeks informal usage of the public space.

Todos estes entendimentos constituem em si um argumentário, em torno de temas concretos, perfeitamente perceptíveis para o transeunte, convidado a envolver-se produtivamente

\footnotetext{
106 Idem.
}

107 Quanto ao quiosque aí previamente existente: It is only since the 1990's that the kiosks have been disappearing increasingly from our cities, making it all the more essential to hold onto the few remaining representatives by attaching cultural value to them. In Hirte, Ronald; Hohmann, Katharina; «The Kisok on Sophienstiftsplatz. From 1968 to 2010, p. 32.

108 Koka Inn, p. 3.

109 Figura controversa do Rio de Janeiro, que nos anos 80 pichou os pilares de uma importante autoestrada com aforismos como este, naturalmente com implicações no entendimento da ordem urbana.

110 Desenvolvida no quadro de um interesse performático pela relação entre o corpo e a cidade, no quadro da bodigrafia, a form of microresistance to the spectacularization of cities, cultures and bodies [...] leading us to an embodied form of urbanism (Paola Berenstein Jacques, in Koka Inn, «Tension Zones», p. 260). 
com a situação. Quanto à sua estrutura temporal, Koka Inn was not finished before it started, nor after it ended. It was a living organism giving and getting impulses of vitality to and from Weimar's public life. Note-se as diferenças entre os dois eventos efémeros, ao nível da burocracia envolvida, ou melhor, da forma como esta é superada para que o projecto aconteça. Onde Gormley lida com o espaço mediático altamente abstracto, Brasil lida com infraestruturas sociais de base, elementos na totalidade da vida urbana ${ }^{111}$. É o desenho vernacular do quotidiano que vai permitir realizar os objectivos projectuais:

The installation should host encounters, at the same time be flexible and deregulate its surroundings. To achieve that, we started by not organizing the group in a methodic way and therefore leaving space for subjective interpretations and situational decisions to be made. [...] this non-strategy in the way the spatiality was designed: by a variety of wishes expressed in constant negotiations and an almost total absence of plans.

Mais uma vez, é possível extrapolar o sentido contingentemente táctico do projecto para um logos de liberdade: 14 days of freedom ${ }^{112}$, um objecto relacional que questiona hegemonic routes and brands in the culture of consumption by collaborating with informal economies and investigating how the trade value of their objects shifted when placing them in other contexts. ${ }^{113}$ Ao contrario de One \& The Other, o sistema permite breves mas intensas experiências de re-conhecimento: [...] certain objects became catalysts for encounters [...] mixed participants shared various amounts of their time with us. ${ }^{114}$

Não diabolizo o cinismo mediático de One \& The Other face à singeleza de intenções de Koka Inn. Mas sublinho que, se qualquer obra de arte, ao ser iluminada (pela teoria, pelos conceitos), gera sombras específicas, apenas o entendimento retórico da sua mecanicidade permite que estas duas obras, na sua radical diversidade sejam ambas arte pública excepcional, embora pressupondo valores de projecto muito diferentes, senão opostos. Isto é, se são ambas dispositivos urbanos ${ }^{115}$, apenas a segunda cria um espaço de afectos (sentimentos), até na promoção de pequenos - e maiores - conflitos potenciais. Por isso Brasil há na segunda uma vitalidade micropolítica e campo semântico activista a condizer: It was a kind of subliminal street-forum [...] A molecular revolution that takes place not only in discourse, but is something one can feel in such encounters, that is in people's gestures and attitudes. ${ }^{116}$ Este é o espaço público de the liberated in the midst of ordinary life ${ }^{117}$, a situation or an experience beyond the merely empirical routine of some activity ${ }^{118}$, cuja intensidade e significado, no limite, se furtam à filosofia, à dialéctica, à ciência, gerando uma experiência da cidade que projecta a cidadana, mesmo que sem a realizar formalmente: Perhaps, in present conditions, an incipient public sphere is as much as can be anticipated ${ }^{119}$. Ao mesmo tempo, estamos ple-

111 Brasil; «Introduction», p. 10: The platform forn this open process of occupation and usage was the Art Kiosk plus the scaffolding towers, two chemical toilets and the surrounding urban space. [...] we ended up living our full everyday life in and with the public.

112 Idem, p 12.

113 A acção reage ao novo contexto urbano provocado pela aberturta de uma nova loja IKEA na proximidade.

114 Brasil; «Introduction», p. 18.

115 Idem, p. 20.

116 Idem. Brasil referencia Guattari e Rolnik, 2004. E de facto, em dispositivo-situação, It is clear that each object - each issue, generates a different pattern of emotions and disruptions, of disagreements and agreements.

117 Public Spheres», p. 146.

118 Shields, Rob; Lefèbvre, Love and Struggle, Routledge, London, 1999, p. 58.

119 «Public Spheres», pp. 142-143. Até porque, como assume Brasil, What is difficult is to map is the intensity of those lived experiences. 
namente na retórica da totalidade da acção artística na forma urbana; no seu seio, podem então medrar os futuros urbanos na cidade pós-industrial, com valor de uso para o urbanismo contemporâneo ${ }^{120}$, pelo menos sempre que o sentido deste tipo de peças seja (tornado) público. E assim: O facto de se ser cauteloso perante as soluções não é negar a necessidade de intervenção, é antes perguntar como, por quem e para quem, e considerar a intervenção como um processo contínuo que irá sempre gerar mudança, mas nunca encerrará a discussão. ${ }^{121}$ Para se compreender o alcance destas palavras em casos concretos, é fundamental partir do constructo da esfera pública em Tim Collins e Reiko Goto ${ }^{122}$ para o entendimento da arte pública - intervenção crítica entre/de arte e cultura urbana - em toda a sua intensidade retórica, quer como participação, quer como provocação ${ }^{123}$.

\subsubsection{Problematização radical da cultura urbana}

Seen through the lens of function, spatial order appears instead to be controlled by natural, mechanical, or organic laws. It is recognized as social only in the sense that it meets the purportedly unified needs of aggregated individuals. Represented as an independent, it appears to exercise control over the very people who produce and use it. The impression of objectivity is real to the extent that the city is alienated from the social life of its inhabitants.

Malcolm Miles

Perante uma sociedade em evolução no sentido da negação tecnológica da vida humana, identifico a cultura burguesa com um mecanismo de deslocamento, que contém os desejos de um mundo melhor numa dimensão estética separada da vida quotidiana e da intervenção política. Both cultural criticism and some areas of cultural production and reception exhibit a retreat from material and social realities to an aesthetic realm which may yet offer critical possibilities, or be realm of ideology concealing rather than exposing contradiction in the prevailing value structure and social system. ${ }^{124}$ Marcuse identifica este problema crónico da arte

120 À pergunta Could such an experiment [Koka Inn] actually be applied as a method in urban planning?, o investigador em ciências políticas e planeamento urbano Max Welch Guerra responde: Yes. Yes, of course. An experiment, but not in the sense that we say now let's mass-produce it. In Koka Inn, p. 256.

121 Vv. Aa,; Espaço Público e Interdisciplinariedade, Centro Português de Design, Lisboa, 2000, p. 104.

122 Idem, pp. 40-41. Os autores mencionam um modelo movido pelo mercado e pelo Estado (que implica alguma tensão entre a irracional demanda dos mercados e uma lógica de controlo por meio de prémios, compensações, multas...); um modelo de cidadania activa (inspirado em Arendt e Habermas e pressupondo um campo discursivo e de acção que emerge quando as pessoas actuam deliberada e concertadamente); um modelo espacio-social (o do planeamento, que conhecemos de Jane Jacobs, 1961), que assenta num trabalho de comunicação e convenções, articulando dinamicamente a distância e a proximidade sociais, na órbita da civilidade); e finalmente o modelo feminista, que releva acima de todas a questão espaço público/espaço privado.

123 Miles, Malcolm, «Participation and provocation», in Urban Avant-Gardes. Art, Architecture and Change, Routledge, 2004 Looking selectively at visual practices from the 1970's to the present, I draw two overlapping tendencies: work that involves the participation of others in its making; and work that, while not involving co-production, seeks to provoke active reception in exposure of social, cultural and economic conditions. Malcolm Miles introduz assim um texto que menciona como caso de estudo a acção da Extra]muros[ em Marvila.

124 Miles, p. 57. 
no termo cultura afirmativa: $:^{125}$ aestheticizing hope rather than translating it into practice ${ }^{126}$. Mas Maio de 68 e as neovanguardas que o enquadram são uma tentativa de a arte multiplicar (retoricamente) as esferas da sua acção cultural, precisamente para tornar operativa a ideia de esperança (por exemplo, nos projectos de colaboração e participativos). Ainda segundo Marcuse, pouco resta porém à arte senão manter-se atentamente autónoma estética -, sob pena de - como diria Adorno, ou hoje Groys - perder a sua autoridade la autoridade que a afirma face ao trivial alienante). Eis-nos de novo na questão crucial da (re) distribuição do sensível: ${ }^{127}$ a arte crítica - eminentemente cultural mais do que meramente artística - procura rever o sentido e a validade dos conceitos de utilidade ou beleza que a cultura impõe; ela responde à problemática da evolução dos valores precisamente pela sua inscrição retórica como instância crítica do status quo. Ou seja, muita arte, quando cede à tentação do ideal - à pureza da galeria e do museu -, deixa-se seduzir por uma realidade transcendente, nomeadamente para o seu público potencial: When the reproduction of material life takes place under the rule of the commodity form and continually renews the poverty of class society, then the good, beautiful, and true are transcendent to this life. ${ }^{128}$ Cabe de qualquer forma ao intelectual (Gramsci) encontrar vias para lidar com essa ansiedade especificamente burguesa: Anxiety stands at the source of all idealistic doctrines that look for the highest felicity in ideational practice: anxiety about the uncertainty of all the conditions of life, about the contingency of loss, of dependence, and of poverty, but anxiety also about satiation, ennui, and envy of men and the gods. ${ }^{129}$ Numa constelação de problemáticas e temas - a cultura, o design, e na sua articulação, a posição única, nasce uma fusão radical (de raíz) da arte pública como Tecne e Skhema de vida na cidade.

\subsubsection{Cultura, o lugar público da arte no capitalismo}

«Cultura» é uma palavra particularmente complexa (Eagleton). Tendo Natureza por antónimo histórico ${ }^{130}$, - a palavra codifica várias questões filosóficas fundamentais:

Num único termo, os contornos de questões como liberdade e determinismo, actividade e resistência, mudança e identidade, o que é dado e o que é criado, surgem difusamente. Se cultura significa a procura activa de crescimento natural, a palavra surge, então, numa dialéctica entre o artificial e o natural, aquilo que fazemos ao mundo e aquilo que o mundo nos faz. Trata-se de uma noção epistemologicamente «realista», na medida em que pressupõe a existência

125 There is a concept of culture that can serve as an important instrument of social research because it expresses the implications of the mind in the historical process of society. It signifies the totality of social life in a given situation, insofar as both the areas of ideational reproduction (culture in the narrower sense, the "spiritual world") and of material reproduction ("civilization") form a historically distinguishable and comprehensible unity. [...] By affirmative culture is meant that culture of the bourgeois epoch which led in the course of its own development to the segregation from civilization of the mental and spiritual world as an independent realm of value that is also considerd superior to civilization. Its decisive characteristic is the assertion of a universally obligatory, eternally better and more valuable world that must be unconditionally affirmed: a world essentially different from the factual world of he daily struggle for existence, yet realizable but every individual for himself 'from within', without any transformation of the state of fact. Idem, p. 69.

126 Miles, p. 66

127 L'autonomie réelle de l'artiste, qui n'a rien à voir avec l'illusion d'une prétendue liberté créatice, reside uniquement dans la liberte de choisir, de surmonter cet ensemble de contraintes dans l'espoir d'une rencontre, toujours incertaine, avec autrui. Ce choix pourrait bien viser se que le philosophe Jacques Rancière nomme pertinemment le «partage du sensible». Jimenez, p. 259.

128 Marcuse, pp. 67-69.

129 Idem, p. 70.

130 Ainda que do ponto de vista etimológico 'cultura' seja um conceito que deriva da Natureza. 
de uma natureza ou matéria-prima para alem de nós próprios; mas também uma dimensão «construtivista», uma vez que esta matéria-prima tem de ser trabalhada até ser-lhe conferida uma forma humana com significado. ${ }^{131}$

Para Eagleton, a natação é uma hábil imagem da referida interaç̧ão, na medida em que o nadador cria activamente a corrente que o sustém ${ }^{132}$. Depois, há algo de estranhamente necessário na superabundância gratuita a que chamamos cultura. Se a natureza é sempre, de alguma forma, cultural, então as culturas são construídas a partir do tráfico incessante com a natureza a que chamamos trabalho. ${ }^{133}$ Ao focar-se na actividade laboral - com o 'laboratório' -, a reflexão de Eagleton sobre a cultura encaixa nas visões marxistas de crítica que aspira a mudar o entendimento do próprio conceito de cultura no sentido da sua apropriação transformativa do socius (Jameson Roberts). Ora está aí a ponte para a cultura enquanto logos arbitrário (Lefèbvre, Bourdieu):

Mas cultura é também o crescimento de regras, o que envolve igualmente uma interacção entre regulado e não-regulado. Cumprir uma regra não é obedecer a uma lei da física, dado que tal cumprimento implica uma aplicação criativa da regra em causa. [...] Acresce que não podem existir regras sobre o cumprimento de regras, sob pena de infinito retorno. Sem esta abertura, as regras não seriam regras, tal como as palavras não seriam palavras; o que não significa, porém, que todo e qualquer movimento possa ser considerado como o cumprimento de uma regra. [...] As regras, tal como as culturas, não são nem totalmente fortuitas nem rigidamente estabelecidas - o que significa que ambas têm ínsita a ideia de liberdade. . $^{134}$

No domínio de uma percepção profunda da criticidade da própria condição humana,

\begin{abstract}
A ideia de cultura significa, então, uma dupla recusa: do determinismo orgânico, por um lado, e da autonomia do espírito, pelo outro. Trata-se de uma recusa simultânea do naturalismo e do idealismo, insistindo contra aquele que existe algo na natureza que a ultrapassa e destrói, e afirmando contra o idealismo que até a actividade mental humana mais elevada tem as suas humildes raízes na nossa biologia e no ambiente natural. O facto de a palavra «cultura» (tal como «natureza», aliásl poder ser simultaneamente descritiva e apreciativa, significando quer o que na realidade evoluiu como o que deveria ter evoluído, é relevante para esta recusa simultânea do naturalismo e do idealismo. Se o conceito se afirma contra o determinismo, está igualmente atento ao voluntarismo. ${ }^{135}$
\end{abstract}

Mais, explicita a dimensão da cultura como atenção ao ethos da própria atenção ao mundo como lugar de vontade $e$ por essa razão, à medida que a palavra «cultura» nos desvia do natural para o espiritual, convoca também uma afinidade entre ambos. ${ }^{136}$ Aqui Eagleton foca a construção de uma realidade espiritual através da cultura ${ }^{137}$. Esta questão será determinante na reflexão sobre o pathos da arte que convoca as ideias de comunidade, de civilização, de colectivo, de partilha e participação entre 'semelhantes' (de Nancy a Zizek) conduzindo-nos à eventualidade de uma graça secular. Nestes termos, a própria experiência da fé, como da conviç̧ão política, como da construção 'laica' da identidade ética e no limire, a festa (Gadamer), são formas culturais por excelência, que no âmbito do aqui e agora terreno, salvam, regeneram, inventam quotidianamente a nossa própria situação política. Daí que ${ }^{138}$ a) se no momento

131 Eagleton, Terry; A Ideia de Cultura, Temas e Debates, Lisboa, 2003, p.12-13.

132 Idem: [...] é precisamente esta resistência que lhe permite agir sobre ele. A natureza produz os meios da sua própria transcendência tal como o «suplemento» a que se refere Derrida está já contido naquilo que amplifica.

133 Idem, p. 14.

134 Idem.

135 Idem, p. 15

136 Idem.

137 Enquanto autocultivadores, somos barro nas nossas próprias mãos, simultaneamente redentor e não regenerado, padre e pecador num mesmo corpo. Abandonada aos seus próprios recursos, a nossa natureza condenável não se erguerá espontaneamente até à graça da cultura; mas essa graça também não pode ser-lhe rudemente imposta. Em vez disso, tem de cooperar com as tendências inatas da própria natureza, de forma induzi-la a transcender-se.

138 Idem, p. 19. Em suma, considerar a cultura superior à política - sermos primeiro homens e depois cidadãos - significa que a política tem de movimentar-se no âmbito de uma dimensão ética mais profunda, extraindo recursos da Bildung e formando indivíduos 
idealista-romântico (Schiller) foi possivvel a cultura ser crítica ideal e uma verdadeira força social; b) hoje a cultura está ciente de que tem de agir como uma espécie de crítica imanente ou desconstrução, ocupando por dentro uma sociedade por regenerar para quebrar a sua resistência às pulsões do espírito. ${ }^{139}$ Por isso, a Kulturkritik está em conflito, não em sintonia, com a civilização. Aliás, quanto mais agressiva e degradada parece a civilização, mais se reafirma o carácter crítico desta ideia de cultura. Neste contexto as tendência críticas tenderão a reunir-se, por um lado, em torno dos princípios do Kulturpessimismus (Spengler), por outro, em torno de possibilidades da via prática, estética e artística.

O termo 'consumer culture' dá ênfase ao facto de que o mundo das mercadorias e dos bens e seus principios de estruturação são fundamentais para o entendimento da sociedade contemporânea, nomeadamente da sua dimensão cultural (Jameson). Se Today there is no fashion: there are only fashions. No rules, only choices ${ }^{140}$, desenha-se um vasto campo de influências, saturações, gostos e regras de acesso à cultura e à arte que as obras interpretam, criando elas próprias subpúblicos, enquanto dispositivos de diferenciação superficial (não necessariamente de radical subjectivação). A arte é aí meramente elemento de subjectivação consumista. Esta situação está relacionada com a emergência do gosto ${ }^{141}$ (muito em especial no campo elitista da arte contemporânea), mas ao nível da ética artística na era do consumo, o termo ganha outras nuances, a caminho de um consumo conspíquo, ${ }^{142}$ o oposto da arte pública. No extremo:

These more recent meanings both involve collectivities: the collective name for forms of cultural production, dissemination, and reception; and the collective values of a social groups as expressed in the habits and expressions of everyday lives. The two senses overlap, directly when immersion in cultural activity is a way of life for an artist; and indirectly when cultural objects denote values produced in specific cultural conditions. Cultural consumption in museums, or museum shops and cafés, for instance, may be part of the way a privileged social group displays its capacity to spend time non-productively and to buy objects which are in effect markers of social status. ${ }^{143}$

Na tradição dos Estudos Culturais, e em consequência, elitism is not their [the arts] defining condition any more than the substitution of culture for the sacred which conventional museum architecture implies. ${ }^{144} \mathrm{E}$ logo, ganha corpo a ideia da crítica da cultura como a base para

para serem cidadãos adequadamente harmoniosos e responsáveis. Esta é a retórica das aulas de educação cívica, sendo um pouco mais ambiciosas. Mas uma vez que «humanidade» significa, neste contexto, uma comunidade livre de conflito, o que está em jogo não é apenas a prioridade da cultura sobre a política, mas sobre um determinado género de política. A cultura, ou o Estado, são uma espécie de utopia prematura que abole a luta a um nível imaginário para que ao nível político não seja necessário fazê-lo. [...] Assim, o que a cultura faz é destilar a nossa humanidade comum dos nossos sectários eus políticos, redimindo os espírito das sensações, arrancando o imutável ao temporal extraindo unidade de diversidade. A cultura significa um tipo de autodivisão bem como de autocura através do qual os nossos eus fragmentados e sublunares não são abolidos mas aperfeiçoados a partir de dentro por uma mais ideal espécie de humanidade. A fenda entre o Estado e a sociedade civil - entre o modo como o cidadão burguês gostaria de representar-se e no que ele na realidade é - é preservada mas também desgastada. A cultura é uma forma de objectividade universal em laboração dentro de cada um de nós, tal como o Estado é a presença do universal no domínio individual da sociedade civil. Tal como Friedrich Schiller os descreve nas suas Cartas sobre a Educação Estética do Ser Humano (1795) [...]

139 Idem, p. 20.

140 Ewen, Stuart; Ewen, Elizabeth; Channels of Desire - Mass Images and the Shaping of American Consciousness, University of Minnesota Press, 1982, pp. 249-251.

141 Hall, Tim; Miles, Malcolm, Miles, p. 51. To arrive at a contemporary meaning [of culture], or two contrasting meanings, we need to extend the eighteenth-century idea of taste in the high arts to include a diversity of cultural production in the arts and media - the kinds of activities a Ministry of Culture makes policies - and to take into account the anthropological meaning, initially from German thought in the nineteenth century, of culture as a way of life.

142 Veblen, Thortsne; The Theory of the Leisure, New York, new America Library, 1899.

143 Hall, Miles, idem.

144 Idem. 
uma retórica integrada - total - da arte face à cultura urbana. A noção de 'público' vai inclusive ganhar a potência de uma crítica situada do gosto, aliando-se ao desejo de transformação das condições de acesso das pessoas à produção artística. É nesta articulação que o conceito de arte urbana, intermutável com o de arte pública, ganha particular interesse, enquanto atenção prática aos desfavorecidos da sociedade industrial capitalista.

The introduction of an idea of solidarity as culture renders culture an active force. It bears an imprint of the conditions of its production, but creates a sense of common cause. This may enhance opposition, and make intervention more likely; and brings culture directly into a social formation. [...] This implies that alongside intervention at the barricade, then, there is a possibility for intervention in the ways in which society is perceived, and from that for new perceptions of how it might be organized. ${ }^{145}$

Recordo o romantismo alemão problematizou o cerne da relação entre arte (pulsão criativa) e esfera social (sociedade). Foi nesse sentido uma crítica da exigência da cultura em tempo útil, cultura da civilização:

In german thought this idea of cultre is seen in opposition to the idea of civilization, the latter taken as industrial society's development through mechanical invention. The meaning of culture as an enduring expression of spirit is informed by German Idealism, and rejects the Materialism associated with industrial societies. [...] Kultur at first meant the process of civilization which was a society-wide equivalent of the cultivation of the human mind - a national refinement, as it were - but goes to say that, following Johann Herder's argument that culture is not universal but specific to the groups who produce it, it comes to mean the distinctive qualities of different civilizations or societies, or of different groups or classes within a society. ${ }^{146}$

Porém,

Se a primeira variante da palavra «cultura» é a crítica anticapitalista, e a segunda uma redução, a par de uma pluralização, da noção e uma forma de vida integral, a terceira é a sua redução gradual ao domínio das artes. ${ }^{147}$

E portanto, se hoje podemos encontrar a criatividade na arte, isso dever-se-á ao facto de não podermos encontrá-la em qualquer outro lugar? Parte importante do modernismo (resiliência à cultura industrial) revolveu-se em torno deste problema, que entronca no do lugar do artista na polis:

A história das consequências disto para as próprias artes, ao verem ser-lhes atribuído um enorme significado social que a sua própria fragilidade e delicadeza as impedem de assumir, desmoronando-se por dentro à medida que vão sendo obrigadas a substituir Deus, a felicidade ou a justiça política, faz parte da narrativa do modernismo. Depois a pós-modernidade [...] que irá tentar libertar as artes desta opressiva carga de ansiedade, instando-as a esquecer todos esses sonhos de profundidade, libertando-as, assim, para uma espécie de liberdade bastante frívola. Muito tempo antes porém, o Romantismo tentara a quadratura do círculo, encontrando na cultura estética uma alternativa à politica e, naquela, o próprio paradigma de uma ordem politica transformada. Não foi tão difícil quanto parece, uma vez que, se a finalidade última da arte era a sua ausência de finalidade, então o mais exuberante dos estetas também podia ser. num certo sentido, o mais dedicado revolucionário, tributário de uma ideia de valor como autoavalidação, verdadeiro reverso da utilidade capitalista. A arte podia agora modelar a boa vida não através da sua representação mas pelo simples facto de existir, não pelo que dizia, mas pelo que mostrava, oferecendo o escândalo da sua própria existência inútil e autocomplacente como crítica silenciosa do valor de troca e da racionalidade instrumental. ${ }^{148}$

\section{Em suma,}

[...] there could hardly be a greater cultural constrast than that between the technologies and institutions of what is still mainly called 'modern art' - writing, painting, sculpture, drama, in minority presses and magazines, small galleries and exhibitions, city-centre theatres - and the effective output of the late-twentieth-century metropolis, in film, television, radio, and recorded music. ${ }^{149}$

\footnotetext{
145 Idem, p. 54.
}

146 Idem, p. 55.

147 Eagleton, p. 29. [...] Esta acepção da palavra assinala, também, um dramático desenvolvimento histórico. Por um lado, sugere que a ciência, a filosofia, a política e a economia não podem continuar a ser consideradas criativas ou imaginativas. E sugere igualmente para levar a tese até às suas mais sombrias consequências - que os valores «civilizados» já só podem encontrar-se no reino da fantasia.

148 Idem.

149 Hall, Miles, p. 59. 
Consequentemente, o urbanismo cultural integra a produção de uma esfera pública decididamente cultural e já não apenas artística. Os temas da intervenção nos interstícios dos espaços sociais e públicos (para além da esfera pública museológica), do momento lefèbvreano (tal como certa produção situacionista e contextual aborda) e finalmente da articulação entre activismo social e político e participação cidadã (mais ou menos susceptíveis de actualizar a problematização da utopia) são o contínuo reavivar de hipóteses de comun(al) idade, enquanto isso parecer viável. ${ }^{150}$ Para tal, a arte, enquanto lugar público, tem de problematizar a cultura de que é imanência. Isto implica regarding a public sphere as ephemeral, a process rather than a civic identity aligned with certain kinds of urban space, and as spanning received divides of public and private realms (or public and domestic spaces).151 $\mathrm{A}$ questão da forma urbana é assim potencialmente a da totalidade dinâmica da materialidade da cidade, na actualidade, na contingência e no efémero da acção, numa altura e que o modelo arcaico da democracia ateniense é manifestamente insuficiente. E se The metropolis housed the great traditional academies and museums and their orthodoxies; their very proximity and powers of control were both a standard and a challenge, ${ }^{152}$ temos de entender as neovanguardas dos anos 60 como anunciando mudanças radicais que uma larga maioria tem dificuldade em integrar na sua cosmovisão. É ainda uma questão comunicacional que está em causa: ou a arte se torna cultural, ou as suas obras tenderão a fechar-se em sentidos reificados (estilos, normas, códigos) em vez de abrir-se poética e poieticamente à vida crítica. No espaço urbano isto passaria por conceber a street art como antídoto de invasão publicitária.

Há portanto que permanentemente questionar a validade das esferas públicas disponíveis e integrar a sua inventividade na agenda colectiva, também retrospectiva e anamnesicamente ${ }^{153}$. Miles propõe então uma esfera pública incremental, em que movements for change gradually gain ground and minor advances contribute to what may become a shift of attitude and practice, hence of power ${ }^{154}$ Algum activismo ambiental, social e artístico segue este plano de resistência e criatividade da multitude (Negri), criticamente consciente de três categorias a distrinçar: o espaço público como domínio material; um espaço público monumental e vocacionado para o controle; e finalmente um espaço público de auto-determinação social. ${ }^{155}$ É nesta constelação do pensamento crítico face à forma urbana uma arte pública depois-da-crítica, que há que laborar e fazer das fraquezas e das dificuldades la indefinição contemporânea entre espaços privados/espaços públicos / espaços intersticiais) a força de uma convicção - estratégica (e táctica) para a arte contornar formas de poder institucionais de facto que têm um forte impacto na forma urbana, numa escala outra digamos. Tal exige, em todo o caso, uma articulação com o desenho urbano e o urbanismo.

150 Sigo o modelo de pensamento de Malcolm Miles, nos textos: «Critical Spaces - Monuments and Changes», «Public Spheres» (2009), «Aesthetics in a Time of Emergency» (2010) e One, Other and the Rest: a composite picture of participation? (texto inédito, cedido pelo autor após a conferência «Político.Criação.Valor» apresentada no Museu do Neo-Realismo, Portugal, em Novembro de 2010).

151 In «Public Spheres», 2009.

152 Hall, Miles, p. 63.

153 Idem. A revolução de Outubro em 1917, o Verão do Amor em São Francisco (1967) ou Maio de 68 são a emergência súbita de uma esfera pública em que direct action re-defines public space as a site of militant occupation manifestamente a contraciclo do que serão zones of monuments and public parks, or spaces for the leisure of middle class male society in which the values society as a whole is required to respect are represented in bland statues.

154 Idem.

155 Idem, p. 136. 
But is there a possibility for a non-oppositional public sphere that does not carry in its attitudes and tactics a counter-image of the oppression it seeks to overthrow, which it later replicates? What, metaphorically, would be its site? ${ }^{156}$ Penso que a retórica como sistema de intensidades na forma urbana é instrumental para esta problemática tendo em conta que The actors have no script, but a vocabulary of possible ways of seeing, doing and speaking ${ }^{157}$. Para Catherine Belsey, a cultura é assim um vocabulário no seio do qual fazemos o que fazemos; it specifies the meanings we set out to inhabit or repudiate, the values we make efforts to live by or protest against... ${ }^{158}$ Relativamente à articulação genérica entre forma urbana, e retoricidade do espaço público, há que assumir uma dinâmica propriamente urbanística da esfera cultural, em direcção a uma nova e indefinida ordem de conhecimento ${ }^{159}$, uma ética projectual que exige que a dúvida se sobreponha sempre à certeza. A private apartment or domestic space such as the kitchen may in some conditions be where a politicized social life occurs. In contrast, the public spaces of a city, or its work spaces, might be more under surveillance (or the gaze of a monumental realm). ${ }^{160}$ Alguma arte pública crítica abordará esta questão a partir de uma rejeição do seu próprio consumo cultural. Se cultura é dominação (Miles), a arte pública crítica é a retórica auto-crítica de todos os processos envolvidos na produção de consciência acerca dessa inevitável dominação cultural.

Ontem, como hoje, a globalização enquanto processo $0^{161}$ que define o quotidiano no mundo afluente é um aspecto determinante da arte contemporânea que desde os anos 90 responde com cinismo e cultura aos desafios da contemporaneidade. Certa arte contemporânea funciona como plataforma de um exercício retórico de apropriação do problema de uma forma genericamente positiva: A globalized culture refers here specifically to the way in which people, integrating the general signs of an increasing interdependence that characterizes the globalization process with other critical positions and assumptions, have constructed a pessimistic 'master scenario' (Hannerz 1991) of cultural domination. This is the speculative discourse that I want to criticize. ${ }^{162}$ Isto é, We surely need to find new critical models to engage with the emerging 'power geometry' of globalization [...].163

\subsubsection{Subjectividade, emancipação: cidadania}

Articulo as questões da emancipação ${ }^{164}$ na perspectiva da complexidade da cidadania con-

156 Idem, p. 135.

157 Idem, p. 144. Por exemplo, em 1989, alguém pichou no plinto de uma estátua de Marx e Engels 'Wir sind unschulding' (somos inocentes). Miles conclui que allegories [...] use standard typologies as if almost anything can be represented.

158 Belsey, Catherine; Shakespeare and the Loss of Éden, Basingstoke, palgrave, p. 7.

159 Fischer-Lichte, Erika; Performance e cultura performativa - O teatro como modelo cultural, 1997; p. 168.

160 «Public Spheres», p. 146. The latter is a product of a Cartesian system, using its coordinated to conjure a seamless, universal space (or quality of space) in which all is ordered and predictable.

161 Miessen, Basar, in Miesse, Basar (eds.), p. 22. Today, the need to identify and instrumentalise "spatial practices" becomes relevant due to the unprecedent visibility of what one might call "globalization at work".

162 Tomlinson, p. 89.

163 Idem. Isto para além, quer da moda (paradoxalmente reveladora de estruturas profundas) quer da valorização dos aspectos étnicos ou folclóricos (arte 'global').

164 Santos, Boaventura Sousa, Revista Crítica de Ciências Sociais, 32, p. 204.0 pilar da emancipação é constituído pela articulação entre três dimensões da racionalização e da secularização da vida colectiva: a racionalidade moral-prática do direito moderno; a cognitivo-experimental da ciência e da técnica modernas; e a racionalidade estético-expressiva das artes e da 
temporânea: Sabemos como o dispositivo capitalista fez com que o pilar da regulação se tenha sobreposto ao da emancipação, instrumentalizando a cidadania nesse projecto 'liberal' - o desenvolvimento hipertrofiado do princípio do Mercado em detrimento do princípio do Estado e de ambos em detrimento do princípio da comunidade. ${ }^{165}$ Noutros termos, a representação democrática assenta na distância, diferenciação e mesmo na opacidade entre representante e representado. ${ }^{166}$ Marginalizada a comunidade (...), a sociedade civil é ao mesmo tempo entendida como necessariamente monolítica, em que a empresa - fora do político (....) - adquire um peso extraordinário na Lebenswelt. Não havendo sociedade sem regulação - a sociedade capitalista baseia-se no conflito entre princípios de cidadania e a subjectividade monumental do Estado -, torna-se particularmente complexa a relação entre cidadania e subjectividade:

Ao consistir em direitos e deveres, a cidadania enriquece a subjectividade e abre-lhe novos horizontes de auto-realização, mas, por outro lado, ao fazê-lo por via de direitos e deveres gerais e abstractos que reduzem a individualidade ao que nela há de universal, transforma os sujeitos em unidades iguais e intercambiáveis no interior de administarções burocráticas públicas e privadas, receptáculos passivos de estratégias de produção, enquanto força de trabalho, de estratégias de consumo, enquanto consumidores, e de estratégias de dominação, enquanto cidadãos de democracia de massas. ${ }^{167}$

Esta consciência não impediu, e até gerou, irrupções emancipatórias; mas já depois de surgir a classe operária como movimento monumental (Badiou), capaz de contrapor o seu logos ao do Estado capitalista, sabemos que o capitalismo não proletarizou as populações nos termos previstos por Marx e que, em vez de homogeneizar globalmente os trabalhadores, se alimentou das suas diferenças existentes ou, quando as destruiu, criou outras em seu lugar. ${ }^{168}$ Hoje, emerge no entanto uma cidadania social, fruto de narrativas diferentes, que não encara a cidadania como corolário da sociedade do consumo. ${ }^{169}$ Uma grande questão torna-se assim a de pensar em novas formas de cidadania (colectivas e não individuais); menos assentes em direitos e deveres do que em formas e critérios de participação. ${ }^{170}$ Os movimentos socio-artísticos dos anos 60, neste contexto, apenas raramente, e com dificuldade, conseguiram integrar-se na única forma de cidadania historicamente constituída; ao mesmo tempo, conduziram a experimentações - muitas contraditórias - que estão em sintonia com a potencialidade da deriva cínica (Sloterdijk) da produção contemporânea da subjectividade.

Importante é reter: Para além da fragmentação e gobalização da produção e da despolitização e da naturalização dos imperativos económicos, a difusão social da produção tem ainda um terceiro aspecto, mais complexo mas talvez de maior importância no futuro próximo: a crescente confusão ou indiferenciação entre produção e reprodução. ${ }^{171}$ A posição crítica de incrementação cidadã caracteriza-se portanto, por um esforço de conexão (Debord): As lutas pela cidadania social no segundo período (capitalismo organizado) tiveram por objectivo explícito vincar que entre produção e

literatura modernas. O equilíbrio pretendido entre a regulação e a emancipação obtém-se pelo desenvolvimento harmonioso de cada um dos pilares e das relações dinâmicas entre eles.

165 Idem.

166 Idem, p. 205.

167 Idem. Para além das ideias de autonomia e de liberdade, a subjectividade envolve as ideias de auto-reflexividade e de auto-responsabilidade, a materialidade de um corpo (real ou fictício, no caso da subjectividade jurídica das «pessoas colectivas») e as particularidades potencialmente infinitas que conferem o cunho próprio e único à personalidade.

168 Idem, p. 209.

169 Idem, p. 201. No período do capitalismo liberal a cidadania civil e política, enquanto parte integrante do princípio do Estado, não só não colidiu com o princípio do Mercado como possibilitou o desenvolvimento hipertrofiado deste.

170 Idem, p. 213. Face à organização taylorista do social, o compromisso social-democrático, já de si assente numa concepção restrita (liberal) do político, acabou, apesar das aprências em sentido contrario, por reduzir ainda mais o campo politico

171 Idem, p. 217. 
reprodução havia uma conexão económica íntima mas que, para além dela, a desconexão era total.172 Isto passa naturalmente por pensar a arte como actividade para além de mera ocupação de um segundo turno do trabalho produtivo ${ }^{173}$; mas, na constelação ideológica em que se misturam o renascimento do mercado e da subjectividade como articuladores nucleares da prática social ${ }^{174}$, a cidadania é desvalorizada em relação à (re)valorização da subjectividade. A aspiração de autonomia, criatividade e reflexividade é transmutada em privatismo, dessocialização e narcisismo, os quais, acoplados à vertigem produtivista, servem para integrar, como nunca, os indivíduos na compulsão consumista. [...] O novo subjectivismo é objectístico e o culto dos objectos é o ersatz da intersubjectividade. Em suma: a hipertrofia do princípio do Mercado leva a que seja socialmente possível viver sem duplicidade e com igual intensidade a hegemonia do Mercado e a luta contra ela. ${ }^{175}$ Diversas práticas artísticas - mais ou menos relacionais (multiplicando-se) mas confinadas à cultura::

Ao nivel da emancipação, ocorre também um fenómeno correspondente de globalização-localização. Uma vez libertada do encaixe estrutural que Ihe conferiam as relações sociais de produção - o Estado capitalista e o movimento operário - a tarefa de desocultação das opressões e da luta contra elas é potencialmente uma tarefa sem sim, sem um sujeito social especificamente titular dela e sem lógica de cumulatividade que permitia distinguir entre táctica e estratégia. Os valores, a cultura e a qualidade de vida em nome dos quais se luta são, por si mesmo, maximalistas e globalizantes, insusceptíveis de finalização, e pouco inclinados para a negociação e o pragmatismo. ${ }^{176}$

Em suma, nos novos movimentos sociais e em paralelas derivas artísticas, a novidade [...] não reside na recusa da política mas, ao contrário, no alargamento da política para além do marco liberal da distinção entre Estado e sociedade civil; ora precisamente como acontece no activismo neste quadro,

[...] o princípio da comunidade rousseauniana é o que tem mais virtualidades para fundar as novas energias emancipatórias [...] em última instância, uma nova qualidade de vida pessoal e colectiva assentes na autonomia e no autogoverno, na descentralização e na democracia participativa, no cooperativismo e na produção socialmente útil.177

Será este então o motor de arranque da arte pública crítica, enquanto factor de diferenciação cultural pós-moderna:

A nova teoria de democracia - que também poderíamos designar por teoria democrática pós-moderna para significar a sua ruptura com a teoria democrática liberal - tem pois, por objectivo, alargar e aprofundar o campo politico em todos os espaços estruturais da interacção social. No processo, o próprio espaço político liberal, o espaço da cidadania, sofre uma transformação profunda. ${ }^{178}$

Através de nova equação entre subjectividade, cidadania e emancipação ${ }^{179}$ interdependente da criação de um novo senso comum político, ${ }^{180}$ o pensamento político do ponto de vista das

172 Idem, p. 218. Aliás, muito mais especificamente, a ideia era que só a conexão económica tornava possível a desconexão a todos os outros níveis.

173 Idem, p. 218. Sendo que, a par do jogging, da ginástica, da musculação, a arte seria mais uma 'ocupação dos tempos livres', note-se que esta promiscuidade entre produção ereprodução social tira razão ao argumento de Habermas (1982) e de Offe (1987) segundo o qual as sociedades capitalistas passaram de um paradima de trabalho para um paradigma de interacçèo.

174 Idem, p. 220.

175 Idem, p. 221.

176 Idem, p. 224.

177 Idem, p. 227. A politização do social, do cultural e, mesmo, do pessoal abre um campo imenso para o exercício da cidadania e revela, no mesmo passo, as limitações da cidadania de extracção liberal.

178 Idem, p. 237.

179 Idem. Mas, enquanto futuro o socialismo não será nunca mais do que uma qualidade ausente. Isto é, será um princípio que regula a transformação emancipatória do que existe sem, contudo nunca se transformar em algo existente. [...] 0 socialismo e a democracia sem fim [...]

180 Idem. O cultivo desse campo imenso que tem vindo a ser tentado com êxito diferenciado pelos NMSs, será o produto produtor de uma nova cultura. Não «cultura política» porque toda a cultura política. Cabe recordar aqui, a terminar, o maior teórico africano des- 
artes, (Chantal Mouffe) tem vindo a propor uma lógica de pluralismo agonista ${ }^{181}$ e recorda então, também ela questionando a instrumentalidade da biopolítica de Foucault nos novos contextos: Liberalism does away with political concepts and attempts to replace them with non-political ones like "humanity" or "population". For that reason, the logic of liberalism is always in tension with the democratic one, which requires the possibility of drawing a frontier between who belongs and who does not belong. ${ }^{182}$ Tal liminalidade é pedra de toque da extramuralidade de qualquer projecto face às comunidades ou grupos que deseja envolver.

\subsubsection{Outra política cultural para a indústria - o desígnio do design}

O diagnóstico do dispositivo social em Bernard Stiegler é marcante pela leitura da industrialização global' ${ }^{183}$ a partir de uma crítica cultural do design. É um design que repensa o seu ethos moderno, subjugado a uma divisão do trabalho específica, assim emergindo com novo desígnio:184

Il faut redesigner le design, et faire en sorte que les designers, cette fois-ci, ne soient plus ceux qui pensent à la place des autres, mais ceux qui pensent des processus d'individuation collective, c'est à dire qui donnent les moyens aux autres de penser ensemble. Cela suppose évidemment du social engineering, c'est à dire de l'ingénierie sociale qui permette industriellement de produire de nouveaux processus d'individuation.

Recorda Stiegler que c'est bien la liaison entre l'intention de transformation, le dessein, et sa représentation, qui se trouve au cœur de cette discipline. La question du style est absolument secondaire - bien qu'elle ait une importance symbolique. Isto é,

Tout acte de design est la somme de l'intention de transformation, de l'anticipation des conséquences du projet - le dessein - et de l'imagination d'un mode existant - le dessin. Une fois que «dessein», «dessin» et «volonté de transformation» sont acquis, débute la longue et difficile aventure de la réalisation, qui relève déjà de la culture participative, puisquiau moment de la réalisation c'est à chacun de s'y mettre, à chacun d'essayer de poursuivre le concept premier.

Neste quadro, serão verdadeiras as transformações comunais, ou motivadas pela comunidade e já não exclusivamemente pela vibração do mercado (Jimenez) e os assomos estéticos de uma classe privilegiada, os dois principais agentes de miséria simbólica (Stiegler) em que se transformou o quotidiano urbano, dominado pelas transformações superficiais que mantém intacta uma situação crónica de que padecemos. ${ }^{185}$

te século, Amílcar Cabral, para quem a cultura e o ranascimento cultural constituem, por excelência a pedagogia de emancipação.

181 Papastergiadis, Nikos; «The Global Need for Collaboartion», in Collaboartive Arts, www. Collabarts.org. Consultado em Setembro 2011.

182 Mouffe, p. 104. Mas ainda aqui questiono-me se a lógica de pluralismo agonista de Mouffe entretanto recuperada ela própria no cinismo liberalizante que reina nas margens do 'político', não é ela própria menos radical do que um cinismo espiritual-humanista que finalmente desiste de mudar para kunicamente desvelar esse sentido útimo da emancipação, a transformão da vida em 'boa vida'.

183 Constatando na sua actual expressão uma hegemonia tecno-cultural norteamericana, e a propósito da necessidade de uma política europeia que faça face à americana.

184 Le problème, c'est qu'ils ont pensé cela dans la séquence industrielle «recherche fondamentale - recherche appliquée - recherche développement - production - marketing - design ou stylisme - distribution - consommation». C'est une séquence linéaire qui a été conçue au début du XXième siècle dans ce quion pourrait appeler la nouvelle division du travail intégrant la question de la conception et du design.

185 [...] Tout cela sans parler de la honte (qu'il ne faut pas sous-estimer, parce qu'elle aussi relève du symbolique) d'être parmi ces hyperconsommateurs égoistes des pays riches, alors que nous savons qu'une partie de la planète continue à mourir de faim, que nos égaux se voient rejetés de façon complètement inhumaine à nos frontières, que nous consommons abusivement les réserves d'énergie des autres, celles des générations à venir, que notre consommation abusive déséquilibre la balance climatique naturelle, que nos politiques économiques détruisent des cultures millénaires, etc. Honte d'autant plus grande que nous savons 
Face à (e apesar da) sobredeterminação da tecnociência, Stiegler fala de investimento durável: Aujourd'hui les investisseurs n'investissent pas, ils spéculent. Investir, c'est investir dans un projet de transformation sociale; cela suppose que toute la société s'y investisse, ce riest pas simplement un investissement financier. ${ }^{186}$ Isso implica uma noção expandida de participação no sistema. A arte contemporânea tem redefinido estas questões sob a forma de propostas modestas ${ }^{187}$, no quadro do cinismo ambiental. Isto é, se na linguagem corrente da arte o cinismo qualificaria as posições de obras e artistas tanto num sentido 'negativo' la arte contemporânea é cínica porque regida por falsos valores), como 'positivo' (dando à ironia e à paródia o papel de ridicularizar os valores decadentes), o que importa é que D'un côté, le cynisme peut être une puissance de refus qui s'inscrit dans le sillage de la philosophie antique; de l'autre, il peut épouser la ligne d'un accompagnement. ${ }^{188} \mathrm{O}$ ponto de vista do cinismo é preponderante num esquema de aproximação instrumental ao dispositivo artístico.

\subsubsection{Cinismo e progresso. Para um ambiente propício à democracia}

O cinismo ajuda a denunciar a 'loucura de Sócrates ${ }^{189}$, que sob a pulsão legítima mas abstracta do amor pela verdade, esquece as condições e fins elementares da vida na polis. A par do estoicismo e do cepticismo, o cinismo reforça a questão da vida individual (ética), face às convenções sociais, os poderes e quaisquer idealizações - por exemplo as que dão origem às instituições. Estas são revistas em baixa, como num sobressalto necessário que tanto pode tomar as coisas è letra como inverter ironicamente o sentido de uma qualquer máscara. O cinismo adquire neste quadro o carácter de uma técnica fundamental da vida social, que desestabiliza os dados adquiridos (quotidiano reificado) em nome da vitalidade do discurso contextualizado e situado ${ }^{190}$, tornando sua matéria o contexto-poder. A ideia de contemporâneo designaria um trabalho que temos de fazer e que está relacionado com uma capacidade de nos subtrairmos àquilo que seriam as tendências entrópicas de uma determinada época. ${ }^{191}$

A este propósito, retenha-se o facto de que o espaço actual tem sido vítima do fenómeno da consumição, em que as disciplinas, saberes e consciências projectuais acabam por

que des solutions existent.

186 Bouchardeau, Hélène; «Bernard Stiegler et Ruedi Baur. Changer de modèle industriel». Bernard Stiegler a ajouté que dans ce climat de violence, la volonté de puissance devient en effet une volonté de domination. C'est une absurdité : pourquoi accumuler de l'argent si il n'y a pas de projet?

187 Esche, Charles; «Modest proposals...» in: Bos, S. \& Fletcher. A. (eds.) Berlin Biennale. Berlin, 2001.

188 D'une «raison cynique» telle que le philosophe Peter Sloterdijk l'a definie let qui fut souvent retenue comme une caractéristique première du postmodenismel.

189 Cometti, Jean-Pierre" «Socrate devenu fou» Le Cynisme par les deux bouts, in Artpress. Passo a parafrasear este artigo.

190 Idem. Lorsque Diogéne, répondant à une question de Philippe II de Macédonie, declare à celui-ci: "Je suis l'éspion de ton avidité», il exprime insolemment la nature même d'une inspiration qui, comme pourrait en témoigner l'image de la déraison à la Renaissance, traque sans concession les mirages de la foi que dispense sans compter la sainte alliance du savoir et des pouvoirs. Nietzsche (face a Wagner), Zanoviev (na agonia do Império Soviètico) ou Musil (acerca da Estupidez) são exemplos maiores de um cinismo notoriamente produtivo ao nível cultural - que diz a verdade escandalosamente (parrhesia) —, com a função de resistência e de antídoto a quaisquer status quo (social, politico, cultural, etc.). Essa resistência acontece como capacidade para déjouer, détourner, certes, mais aussi par les formes que revêt generalement la fausse conscience éclairée et par celles qui, dans l'art meme, mènent à bien des égards le jeu des institutions et des pouvoirs.

191 Silva, Rodrigo; «HERDAR. Heranças Culturais. Aproximar e reestruturar », in Matos, Sara Antónia (Coord. e Ed.); ESPAÇO, Oficinas do Convento, Montemor-o-Novo, 2009, p. 103. 
surgir como actividades efectiva ou potencialmente redentoras, mais ou menos engajadas em possibilidades de regeneração da urbe. O carácter 'gasoso' (Jimenez) da arte contemporânea proporciona aqui premissas atmosféricas para uma comunidade democrática. ${ }^{192}$ De acordo com Latour, Weibel ou Flusser, que propõem uma política quotidiana de coisas las quais criam elas próprias o seu público), há que dar atenção à continua expansão dos dispositivos que tornam as coisas públicas (e que criam públicos para as coisas). Ora o que importa, na arte pública crítica, é que essas coisas determinem já não apenas uma política possível mas uma possibilidade da política, para além das premissas representativas e institucionais tradicionais, há muito exangues (face à vida urbana das coisas integradas num monumental dispositivo mercantil, comunicacional e sobretudo experiencial).

Em The Age of Access (2001), Rifkin avança a ideia de que a criatividade, a espiritualidade ou a própria convivialidade são valores culturais tanto quanto produtos disponíveis sob a forma de mercadorias e serviços. La transformation en bien de consommation de l'expérience constituerait ainsi le stade ultime de la reification marchande. [...] Dans ce contexte, a question qui valait comme la métaphore fondatrice du pop-art - What is that makes today's homes so different, so appealing? - a ainsi été transformée en celle-ci: Are you experienced? ${ }^{193}$ No negócio da experiência de uma aldeia global, uma 'mass costumization' ocupa o lugar da produção de massa clássica, num quadro de normalização dos produtos avesso ao jogo radical le ambiental) das possibilidades. Quanto à arte ${ }^{194}$ aspira, quando crítica, a criar uma cultura de apetência pela politização através das coisas, tanto quanto os seus dispositivos experienciais souberem problematizar a paz da argumentação trivial face à guerra das coisas - the question must surely be whether there are other ways of persuading citizens to lay down their swords and under what conditions such a procedure can be carried on. ${ }^{195}$ Ora, para Sloterdijk, algumas das coisas por onde deve começar-se a anamnese crítica do dispositivo moderno (do consumo) é a questão da poética do espaço, ${ }^{196}$ perspectivada como uma questão tensional, entre exteriores e interiores:

Modernity renders the issue of residence explicit: Benjamin in the arcades project starts from the anthropological assumprion that people in all epochs dedicate themselves to creating interiors. The capitalist man in the $19^{\text {th }}$ century expresses this need using the most cutting-edge technology in order to immunize existence by constructing protective islands. [...] this [a arcada] sparks a trend that is perfected in the $20^{\text {th }}$ century apartment design as well as in shoping mall and sport-stadium design. ${ }^{197}$

Certo é, tudo isto tem a ver com uma certa construção, ou tectónica, uma vontade de incluir tudo no interior da construção. Porém, quando se inclui tudo dentro da construção, a mesma pode desabar para qualquer lado. ${ }^{198}$ Movida por uma cultura da impaciência ${ }^{199}$ - in the city things

192 Sloterdijk, Peter; «Atmospheric Politics», in Latour, Weibel, eds.; Making Things Public, MIT Press, Massachussets, 2005, p. 944.

193 Cf. Pécoil, p. 49.

194 Idem, p. 51. Là encore, il est fait appel à l'art dans la resolution de cette contradiction entre massification et unicité - un modèle «naturel», puisque l'art est lui-même confronté à ce dilemme depuis plus d'un siècle.

195 Idem.

196 Sloterdijk, Peter; «Spheres Theory: Talking to myself about the poetics of space».

197 Idem.

198 Miranda, José Bragança de; «LIGAR. Modernidade. Telescopiar o passado. Renunciar ou religar», in Matos, Sara Antónia (Coord. e Ed.); ESPAÇO, Oficinas do Convento, Montemor-o-Novo, 2009, p. 140.

199 Cito Kafka de cor: Talvez haja apenas um pecado capital: a impaciência. Devido à impaciência, fomos expulsos do Paraíso; devido à impaciência, não podemos voltar. 
do not mature, things are produced ${ }^{200}$ - e da 'comunicação social' - Modernity's dictatorial traits all stem from an excessively communicative anthropology for all to long the dogmatic notion of an excessively communicative image of man was naively adopted 201 - Sloterdijk aprofunda a ideia de uma sociedade de comunicação (Cauquelin, Flusser) que possa abrir-se à conectividade e à criação de uma ambiente para essa conectividade. Isto sabendo-se que Buildings are thus systems to compensate for ecstasy... ${ }^{202}$

Ora se Urban spaces are a humanized environment where nature is completely replaced by a man-made reality e se o mundo social se torna a form of 'connected isolation', lidamos quotidianamente com a necessidade de uma metafísica prática - uma imunologia (Novalis) - que dê resposta à situação em variadas esferas de acção: from a biological level, to the juridical and the social levels, to the symbolic and ritual levels, we are always trying to create and find a protective environment. ${ }^{203} \mathrm{Nas}$ arcadas do consumo (Benjamin) - the whole world of trading and exploring - is neutralized and re-presented in the presence of the commodity. ${ }^{204}$ E assim, Modernism in architecture has always also implied the transition of the climatic into the age of its explicit presentation and production. ${ }^{205} \mathrm{Na}$ busca de outras economias ecológicas para um dispositivo social omnipresente (globalização), Sloterdijk recorda o 'estar-no-mundo' (Heidegger) como uma descoberta bio-lógica, para depois avançar para um quadro metafórico que enquadra as práticas sócio-artísticas mais radicalmente ecológicas-ambientais: The vegetative counterpart to Geworfenheit would then be "enracination". [...] what we have is a situation in which the human or plant is surrounded or embraced by a circle of incompatibility. ${ }^{206}$ Claro que diferentes modalidades de dispositivo e suas consequências comunicacionais (persuasivas) têm diferentes impactos no demos; de qualquer forma, as intervenções de arte pública crítica constituem o cerne de uma politização experimental da arte, isto é, das coisas da arte entre as coisas do mundo, o quotidiano. Assim se reconstitui a ideia de natureza como construção maquínica cultural (de Novalis e Kleist a Capra), abrindo a questão de uma salvação quotidiana pelas coisas simples. Coloca-se assim a hipótese de um discurso-vida e de uma vida-discurso que saia do trivial: Modern societies are "weather-chat" communities. ${ }^{207}$

200 Miranda, idem.

201 Idem.

202 Idem. People are ecstatic beings. They are, to use Heidegger's terms forever held outside in the open... in the ontological sense, they are "outside" in the world, but they can only be outside to the degree that they are stabilized from within from something that gives them full support. This aspect needs to be emphasized today in contrast to the current romanticism that enable us to give being-outside a tolerable form. [...] Como em Flusser, esta questão é da ordem da matéria arquitectónica: For this reason from my viewpoint the architect is someone who philosophizes in and through material. Someone who builds a dwelling or erects a building for an institution makes a statement on the relationship between the ecstatic and the enstatic, or, if you will, between the world as apartment and the world as agora.

203 Idem.

204 Idem. Between the modern shopping mall and the primitive árcade of the early 19th century, there was a step that is very symbolic. This is the London Crystla Palace, which is for me the major symbol of the Postmodern construction of reality.

205 Sloterdijk, Peter; «Atmospheric Politics», p. 945.

206 Idem.

207 Sloterdijk, Peter; «Spheres Theory: Talking to myself about the poetics of space». By describing the weather as nature's performance to the community, metereologists muster individual sinto an audience of connoisseurs under a common sky; of each individual, they make a climate-critic who evaluates nature's latest performance according to his own personal tastes. 
Ao nível ético, há aqui uma descoberta da condição existencial urbana: Whereas for the organism the meaning of the "en" in environment or the "sur" in surrounding consists of the perfectly calibrated dependence on the original stimuli, in the case of existence in the world they signify an abyss above which one hangs, or a transcendence into which one is suspended. ${ }^{208}$ Quanto às consequências deste facto para a teoria política, retira-as dos filósofos pós-socráticos, ipso facto environmental theorists ${ }^{209}$ :

What the early philosophers termed polis is in essence nothing other than an artificial construct ruled by nomos and amounts to the practical answer to the challenge posed by the improbability of bringing numerours strangers together to coexist behind shared walls. [...] The Greek city was a greenhouse for people who agreed to be uprooted from the modus vivendi of living in separation and instead be planted in the disarming modus vivendi of living together. [...] the city as a form of life always stood as out like a social wonder of the world against the background of preurban conditions. ${ }^{210}$

Temos aqui a potencial articulação entre democracia grega (e comunismo wagneriano) e maravilhamento (a minha graça social), associada à ideia da natureza como nossa 'casa. ${ }^{211}$ Nesta altura do seu argumento, Sloterdijk vira-se para Aristóteles, ficcionando-o ${ }^{212}$ para dizer da sua actualidade bio-política na nossa contemporaneidade: According to Aristotle, it was not the social drive of survivors of the great natural disaster that gave rise to the polis but the insight on the part of the prospective citizens that a cooperative constitution could be advantageous for them compared with the prior modus vivendi. ${ }^{213}$ Isto é, a cidade é inventada menos por necessidade que por interesse, menos por medo dos elementos que por uma racionalidade afectada realizada nas coisas. Logos e dispositivo socio-urbano são da mesma ordem maquinal, e suas coisas determinam, nas relações entre si e que estabelecem connosco, a base - projectual - de um pragmatismo vivencial cujos afectos nos educam (bilden).

[...] Aristotle's expressing of a view otherwise seldom encountered in classical antiquity, namely that polis-like coexistence is fundamentally a very artificial way for people to live together. This does not, incidentally, contradict his renowned hypothesis that man is a zoon politicon, as in this context the epithet politikos specially does not imply a reference to urban culture but quite simply pinpoints the biological fact that we live in groups or packs. Instead, what is striking is that Aristotle judges that the synousia ${ }^{214}$ of people in the city is the result of their special psycho-political treatment. Humans are, he suggests, by no means urbanites by nature but have to be turned into such; they cannot simply be posited as city-dwellers, because a simple decision by individual will does not suffice to stabilize such an improbable state of affairs as the coexistence of the many in the polis. So there must logically be a third term that comes between nature and such an assumed act of wil, one that would be strong enough to neutralize the powers people have to repel one another and to overcome their aversion to involuntary neighborhood. ${ }^{215}$

Nesta comunidade expandida (Latour, ${ }^{216}$ ou muito antes o Novalis de Cristandade ou Europa), há que dar-se a metamorphosis that can be compared with the moral alchemy of Christendom, with the difference being that what we have here is love to your neighbor not your next of kin.217

\section{Idem.}

209 Idem, p. 946.

210 Idem.

211 O Mundo é a nossa Casa... José Gomes Ferreira: Quem foi o arquitecto, que fez este café? / Tão longe da natureza / e tantos homens de pé / Cuidado! Põe esta gente na rua / E abre um buraco no tecto / que eu quero ver a lua!...

212 Imaginando a descoberta de uma diálogo entitulado Daedalus - or the art of Building Cities.

213 Idem.

214 Ideia de contacto social, já em Xenofonte e Platão.

215 Idem.

216 Latour, Weibel, eds.; Making Things Public, MIT Press, Massachussets, 2005, p. 946

217 Sloterdijk, Peter; «Atmospheric Politics», in Latour, Weibel, eds.; Making Things Public, MIT Press, Massachussets, 2005, p. 947. Nos anos 60, CSN\&Y cantavam sem abdicar da ironia romântica, If you can't be with the one you love, love the one you're with. 
$\mathrm{E}$, instead of nature or tyranny, the democratic psycho-politics is based on rituals that we must invariantly consider the skilful application of anti-misanthropic procedure. ${ }^{218}$

\section{Cinismo(s) produtivos para públicos saudáveis}

Face a este cinismo construtivo e ambiental, outro cinismo é o que decorre de uma mais básica simbiose com o dispositivo social que enquadra a actividade artísitica. ${ }^{219}$ Nesta perspectiva, o cinismo aparece como expressão de uma pós-história, substituindo a temporalidade em aberto da modernidade (o futuro), em nome dos prazeres retóricos da ironia, da provocação, o sarcasmo, o absurdo ou o non-sense, precisamente no mundo da arte que, enquadrado pelas suas instituições, os seus actores sociais e culturais, tend à se coaguler dans un mélange ambigu de conformisme et d'émancipation qui le constitue comme «milieu», avec ses rites, ses formes de reconnaissance partagée, ses rivalités et ses interest specifiques. ${ }^{220}$ Mas se na ideia de cinismo temos sempre a ideia de jogo (uma modalidade do dispositivo que explode com a pós-modernidade, claramente actualizando Schiller em novas condições de produção), o cinismo é uma espécie de metáfora operativa central no campo da arte contemporânea, mormente (e aqui não há paradoxo) a mais engajada em processos de ligação arte-social:

Sa variante artistique s'illustre dans le travail de personnages connus et reconnus, don't la caractéristique majeure consiste à intégrer à leur travail una variable mondaine ou sociale, voire politique, en faisant appel, de façon fine ou grossière, aux evidences de l'heure, generalement genereuses et bien pensantes, qu'elles concernent la misère sociale, les préjugés raciaux ou la justice dans le monde. On peut y avoir affaire à des images, à des performances ou à des installations: l'artiste y est intervenant, médiateur, voire inventeur de formes ou d'expériences nouvelles. Sa qualité d'artiste, socialement identifiée comme telle, légitime ce qu'il entreprend, en meme temps qu'elle s'en nourrit. Ce cynisme «artiste» ne serait pas pensable sans celui du «monde de l'art».221

Finalmente, há um cinismo antigo. Le cynisme ancien, celui qui s'est maintenu dans quelques figures singulières et sans âge, était étranger à l'art, et lorsqu'il s'y est conjugué, ce fut essentiellement pour en dire la contingence, la vanité ou la nécessité de passer a autre chose. Ce cynisme-là c'est toujours refuse à dissocier la pensée et la vie. ${ }^{222}$ Agentes desta resiliência do contexto e do processo face ao objecto e à instituição, des figures individuelles detachées des pouvoirs, quells quils fuissent ${ }^{223}$, que muitas vezes chegam para apregoar a criticidade da arte na esfera pública e concomitantemente da trivialidade do próprio sistema da arte lou

218 Idem. [...] il ne depend pas seulement de l'esprit des acteurs ou des agents, quelles que soient les motifs qui individuellement les animent: il entre en rapport avec un état général du monde et avec une situation artistique qui, grosso modo, est celle da la «fin de l'art» et des avant-gardes.

219 Idem.

220 Le cynisme y est idiot - Cometti ecoa os termos de Perniola (idiotia) acerca de um sistema artísitico que celebra a arte estercorária (Jean Clair).

221 Idem, p. 13. Pas seulement parce qu'il n'y a d'art que dans et par rapport à un monde de l'art qui en constitue la condition d'interprétation, mais en ce que les dispositifs insttitutionels ou médiateurs qui lui assurent ses conditions de circulation, de visibilité et de légitimité, en sont intrinsèquement partie prenante; ils y puisent leur propre condition de légitimité, ou en tout cas une image qui n'est pas seulemnt celle d'aministrateurs ou d'agents de l'État, de promoteurs et d'agents du marche, mais d'esthètes éclairés, dévoués à l'art ou du moins à la fonction qu'il doit remplir à nos yeux dans une societé liberale et démocratique, qui participent à l avie de l'art et enrichissent ainsi l'esprit commun. Não concordando completamente com Cometti, este comentário ajuda a contextualizar-se o cerne desta investigação, a questão da produção curatorial do autor face ao mundo da arte, como exercício ou jogo cínico com aexpectativas da arte, em nome de valores críticos.

222 Idem, p. 13.

223 Idem. 
da cidade). É um cinismo performativo - como nas acções de Diógenes - reactivo a um cinismo de corte:

Le cynisme de cour, qui n'a rien a voir avec une forme de vie individuelle revendiquée comme telle, ne croit en vérité à rien, sinon aux faux semblants qui lui permettent de se soustraire à cette evidence. Pour lui, en réalité, tour est égal, bien qu'il puise avec une apparente ferveur dans l'intelligence - don't il s'arroge le privilege - d'un objet don't il se recommande avec la fausse modestie des serviteurs que le Prince honore. C'est le jeu banal des institutions et des hommes de cour dot l'art a toujours été un pole priviligié. II s'étend sur ce qu'il glorifie, atant que sur ce qu'il rejette. [...] Le langage des managers lui-même a désormais adopté celui de la «critique artistique», tandis que le monde de l'art s'ouvrait symétriquement à des desseins lui assurant une fonction et une justification que les avant-gardes, par exemple, ne lui eussent pas offertes. Cet état de confusion dans lequel les roles s'inversent et se mélangent est l'inévitable contrepartie d'un cynisme qui n'a plus rien à defender, là ou la fonction se nourrit du cadaver de l'art, en béneficiant de toutes sortes de complicités. 224

Mas Comment dénoncer les conventions, les normes et les instituitions sans finir par secrétement aimer ce que l'on dénonce?225 Este é paradoxo lógico (Laurent Jeanpierre) da posição cínica, que se prende com o desafio de conseguir-se criar um outro jogo depois do apartarmo-nos violentamente. De Dada ao situacionismo, passando por Duchamp, plus d'un trait commun avec les cyniques grecs: le rejet des conventions, le recours à une certaine naturalité pour les détruire, la pratique du scandale public 226 - mas depois, perguntam os críticos: quiavez-vous bâti sur les ruines que vous avez produites? Quelle reconstruction avez-vous commencée, après vos deconstructions explosives?227 Sloterdijk sugere que Aristóteles (modelo inaugural do peripatetismo ${ }^{228}$ ) era neste quadro já uma protosituacionista, ou um agitador Fluxus avant-la-lettre: By contrast, the references to psychic urban planning are striking: instructions on the rituals that need to be established in order to generate or strengthen the citizens' sense of commonality. ${ }^{229}$ Vejo aqui a noção do quotidano como consciência (cínica e ao mesmo tempo embebida na existência), de carácter reflexivo-projectual, na base do que Sloterdijk denomina democratic technique ${ }^{230}$. Ressoando aqui a noção lefèbvreana de uma arte do/como quotidiano. This vat of dye impregnates the citizens with a shared pride in the freedom of their own polis as well as with respect for the beautiful acts of megalopsychia, or, to couch it in modern terms, the generosity thanks to which some citizens stand out from others. This pride and respect must precede all other statements of a political nature in the city. ${ }^{231}$ Mais uma vez, uma arte pública gasosa (Jimenez), e depois vernacular (Knight), entregando-se a uma técnica social geral (Roberts), vai de encontro a um permanente deskilling emocional cínico e num trabalho público sobre as emoções (articula uma política emocional (Gross). Esse trabalho sobre o cinismo de cada acção (Sena da Silva) é necessariamente (paradoxalmente?) total, apontando inclusive para a pre-logical or pre-discursive premises of the art of urban coexistence. ${ }^{232}$ Eis como Sloterdijk imagina um Aristóteles leitor de Bakhtin - To again resort to modern terms, we could say that here the philosopher for the first time gives voice to the

224 Idem, p. 15.

225 Jeanpierre, Laurent; «Faire de sa mort une ouvre d'art», in Artpress 2, p. 15.

226 Idem.

227 Idem.

228 "Peripatético" é a palavra grega para 'ambulante' ou 'itinerante'. Peripatéticos (ou 'os que passeiam') eram discípulos de Aristóteles, em razão do hábito do filósofo de ensinar ao ar livre, caminhando enquanto lia e dava preleções, sob os portais cobertos do Liceu, conhecidos como perípatoi, ou sob as árvores que o cercavam. No termo denuncia-se uma orientação empírica da escola, em oposição à Academia platónica, muito mais especulativa.

229 Sloterdijk, Peter; «Atmospheric Politics», in Latour, Weibel, eds.; Making Things Public, MIT Press, Massachussets, 2005, p. 947

230 Idem.

231 Idem.

232 Idem. 
climatic or psycho-political conditions for social synthesis ${ }^{233}$-, tanto quanto a cidade se desvela espaço da polis em que se multiplicam não apenas novos possíveis, mas enhanced improbabilities $^{234}$. Numa conclusão radical, que sustenta toda a arte da intersticialidade social, Sloterdijk conclui: In order for politics to consolidate as the art of the improbable, procedures have to be developed from which citizens arise as agents of coexistence in the improbable. ${ }^{235} \mathrm{E}$ portanto, e sabendo-se que nenhuma comunidade pode ser construída com base num único afecto ${ }^{236}$ :

The agora is the manifest urban form, therefore, but we can only gain an adequate notion of its function if we construe the coming together of persons in this space as an installation. Installations such as those which we are familiar from contemporary art have the task of developing compromises between observation and participation. Their meaning is to transform the position of juxtaposed observation into an immersive relationship to the mileu that surrounds the erstwhile beholder. By means of installation, modern artists endeavour to strengthen the position of the work, vis-à-vis the observer: If, in regard to the conventional art objects, isolated sculptors or pictures hung on a wall, the beholder essentially holds a position of strength (to the extent what we can be satisfied with casting a fleeting glance in passing), the installation forces him to take a far less dominating role and compels him to enter the work. Thus, the opportunity to experience art shifts from the pole of the beholder to that of the participant. ${ }^{237}$

Conclui Sloterdijk acerca da relação entre cidadão e cidadania como uma questão de discurso:

The citizen as a highly improbable artificial figure of political anthropology would thus first become possible by a combination of actor and spectator in a single person, and that said, the entire public domain would have to consist of this type of agent. In this synthesis the more difficult half - and here we part company with the idea of the installation - without doubt involves the creation of the viewing or observing half, for if humans are beings that by nature have instincts, passions and interests, then only by more or less elaborate cultural techniques can they be persuaded to activate their possible analytical or theoretical behavior. It is no coincidence that Athenien democracy appears to be the first literate collective on the stage of cultural history. ${ }^{238}$

Sloterdijk refere estas bodas da cidade com o discurso como um encontro triplo do demos com o teatro, a retórica e a própria filosofia, técnica discursiva: The essence of the written and representational media is that they allow users to manipulate the temporal axis thanks to which diachronic sequences can be transformed into a synchronic image. ${ }^{239} \mathrm{Na}$ prática,

The res publica arises from this act of capturing objects. If you do not possess suitable techniques for arresting them, then you cannot stabilize fleeting events and cannot give voice to them in the political domain. To this extent, democracy is preceded by a pre-political dimension in which the means to slow down the flow of speech/es is made available. ${ }^{240}$

Esta performatividade social é retórica, mecanismo comunicacional incluindo todo um conjunto de aspectos poéticos e expressivos num tempo-espaço antropológico.

A psycho-political foundation for the city must be added to the media-based foundation of the polis by the urban media (writing, theater, agora, rhetoric, philosophy) that serve to prevent spoken utterances draining away into nothingness (or into the formlessness of memories). The psycho-political underpinning function to spare the citizen's pride and to render the aristocratic impatience of the former landed gentry compatible with the slowness of democratic procedures. ${ }^{241}$

Perante o desafio pós-modernista de 'abrandar' a modernidade capitalista (desde o Crystal Palace para cá), Sloterdijk recorda-nos a ligação entre mecanismos de representação do discurso e de visibilidade das dinâmicas sociais. Mencionado a criação de listas de

233 Idem.

234 Idem.

235 Idem.

236 Idem, p. 948.

237 Idem.

238 Idem.

239 Idem, p. 949.

240 Idem.

241 Idem. 
oradores $^{242}$ na agora grega como dispositivo fundacional da democraticidade, Sloterdijk conclui, apontando para uma tectónica e uma habitalidade do socius baseada na discrição das formas na cidade. Isto é, Democracy depends on the ability to lend a spatial dimension to things said one after the other; ${ }^{243}$ Mais, esta noção - editorial-linguística-discursiva-textual - é indissociável de uma noção de prudência e sensibilidade para o imponderável político, que o termo grego sophrosyne define:

What the Greeks meant by the expression sophrosyne, a term usually poorly translated as "self-control", or "prudence", can in broader sense be interpreted to the impact of a written culture; in the practice of the polis this not only includes the ability to exercise the faculty of judgement, but, and more important, the ability to listen, the ability to wait and let others wait, indeed the resolve to compel others to wait to the extent that is needed in order to disarm any overly heady sentiments among the citizens.

Greek psychology, which hinged on the basic concept of thymos, taked note of the fact that real persons always constitute complexes of pride - rancor (more generally: of agitation) and of arguments. Now if you wish to establish democratic forms of living, you must ensure that if the thymos is agitated does not directly result in action(s). [...] This can only be achieved by establishing the virtues of observation. ${ }^{244}$

[...] An intelligentsia of observers is fostered in a city only if this is preceded by the theatralization of agitated feelings, or, but differently, it requires that a stage be erected from mutual observation by people who know that their respective opinions are in part the defined by their thymos. Anyone wanting democracy had to strenghten the observer, albeit not with the means of meditatation such as were characteristic of eastern spirituality but with the means of the urban agon and its specific performances. This includes the principle of the equal power of agents/arguments or isosthenia. ${ }^{245}$

Há então na 'origem' da democracia um sentido de discurso embebido nas coisas (vide Flusser), que a cultura retórica (Gross) ajuda a cerzir:

We could paraphrase it in light of the above to read as pride-infused inter-patience between powerful individuals. [...] One of the pre-political premises of life in the polis was to put in place a matrix for a broader distribution of powers in which repeatedly new isosthenic situations could be practiced. [...] It is not communication or the freedom of speech as such that make democracy possible, but the ability of the agents to prevent themselves mutually from acting out unilateral pretensions. This is the core of the anti-despotic affect in the citizen of a polis. Despotes is the man who wishes to comport himself in the city as if with in his home four walls: he confuses public and private space and the surge to act on the agora as does an owner on his own grounds (Daedalus would say: the despote did not take part and bathe in the polis fountain. Tyranny is the success phase of a lack of opponents; [...] the atmospheric premises of liberty include the athletic love of effort, ponophilia [...].246

Concluo este excurso às potencialidades da filosofia de Sloterdijk para a crítica artística da cidade com um exemplo da sua aplicação imediata. O filósofo, em colaboração com arquitectos, inspirou a criação de um objecto arquitectónico portátil que pode ser montado em qualquer parte do mundo em 24h (mais horas de voo de transporte). Entre idealismo, absurdo e activismo politico em prol da democracia, The Pneumatic Parliament ${ }^{247}$ é uma obra emblemática do gesto retórico como proposta de acção, rápida, no imediato, porém filtrada por uma paciência fundamental, que é afinal a espera (cínica) pelas oportunidades (retóricas) da sua inscrição.

242 Idem. The simple device of the list of speakers itself is based on a far less simple psycho-semiotic premise: the audience's ability to, as it were, lend the temporal sequence of speakers a spatial dimension, in the sense that we have just indicated as regards the relationship between the spoken and written word, meaning that here, too, the temporal sequence is transformed into synchrony.

243 Idem, p. 950. [...] it therefore implies constant training in patience. Kafka identificou esta questão da impaciência no âmago do psiquismo do progresso...

244 Idem.

245 Idem. And it was the early Nietzsche who pointed to the significance of this for the way the Greeks saw life. [...]

246 Idem, pp. 950-951.

247 Cf. Sloterdijk, Peter; Haegen, Gesa Müller von der; «Instant Democracy: The Pneumatic Parliament@», in Latour, Weibel, eds.; Making Things Public, MIT Press, Massachussets, 2005, p. 944. Questiono-me entretanto, acerca da necessidade ou interesse do $®$ de Marca Registada. 


\subsubsection{Cinética mobilizadora, dar lugar à materialização da cultura}

Ora em Mobilization of the Planet from the Spirit of Self-Intensification, encontro uma posição ética de síntese que vem ao encontro do problema específico do quotiano (Lefèbvre). Sloterdijk parte da ideia da cinética. ${ }^{248} \mathrm{~A}$ cinética seria a ética da modernidade ${ }^{249} \mathrm{e}$ base da sua crítica pós-moderna do progresso. É uma posição renovadamente crítica dos traços cinéticos do dispositivo socio-cultural hegemónico (pelo menos no Ocidente) e ela própria movimento - acção.

Progress is the expression of movement in which the ethical-kinectic self-awareness of modern times expresses itself most powerfully and at the same time is heavily disguised. [...] At the beginning of progress there was the presumption whether right or wrong, of a "moral" initiative that cannot rest until the better has become the real. ${ }^{250}$

In the political, technological, and historical-psychological doctrines of progress, the ongoing epoch declared its kinetic self-evidence. However, what it did not admit loudly was its secret inclination to take a the moral motives seriously only to the extent that they serve as engines of outer movements. It is part of the essence of a progressive process to begin with ethical initiatives in order to continue its kinetic self-movements. ${ }^{251}$

Em Kafka já surgem imagens poderosas desta consciência, como depois em Musil ou Beckett, todos vindo desestabilizar a subjectividade num quadro de formas culturais em acelerada mutação.

If something like progress does exist as a matter of fact it is because movement originating from subjectivity do undeniably take place. Kinetically, they are the material that modernity is made of. [...] Therefore, the term "progress" does not mean a simple change of position where an agent advances from A to B. In this essence, the only "step" that is progressive is the one that leads to an increase in the "ability to step." Thus, the formula of modernizing processes is as follows: progress is movement toward movement, movement toward increased movement, movement toward an increased mobility. [...] Only because of the validity of this formula are ethics an immediate result of kinetics in modernity. To the same degree as we modern subjects understand freedom a priories freedom of movement, progress is only thinkable for us as the king of movement that leads to a higher degree of mobility. [...] Modern "dynamism" has made a contribution toward preserving the mindless rigouer among super-mobile forms. ${ }^{252}$

Se o romântico Novalis havia proposto a ideia de uma máquina social autopoiética, dela continua a ser possível tirar ilações, desde logo a crítica da sujeição do socius a coisas que the destruam a vitalidade, mesmo que sob o signo de uma fascinante aceleração. ${ }^{253}$

Revelando o poder de uma filosofia embebida no real quotidiano da metrópole, refém do desenho urbano (em função da lógica automobilística, por exemplo), Sloterdijk diz, sem ponta de ironia:

248 Sloterdijk, Peter; «Mobilization of the Planet from the Spirit of Self-Intensification», in TDR: The Drama Rewiew 50:4 (T192) Winter 2006, p. 36. As an expression of movement, the ethical-political adventures of the human mind become a branch of physics. [...] a philosophical kinetics originating from three axioms. First, that we are moving in a world that is moving itself; second that the self-movements of the world include our own self-movements and affect them; and third, that in modernity, the self-movements of the world originate from our self-movements which are cumulatively added to world-movement.

249 Idem.

250 Idem. What is worrisome or even obscene about these can only be diminished by referring to the old doctrines of progress that we are very familiar with. There, the relationship of morals and kinetics seem still to be controlled morally as a matter of fact, modernity has also defined itself from the beginning in kinetic terms because it determined its mode of realization and existence as advancing and progressive.

251 Idem.

252 Idem, p. 39. Novalis was the first to bring up a concept of the kinetic utopia of modernity by think the subject and the machine together in the image of the "mill itself". [...] The diagnostic power of Novalis" formulations was not understandable to us in this full extent before today.

253 Idem. [...] In the meantime, we know without a breath of romantic irony what the self is able to achieve in its machine even if it is not quite a self-grinding mill. [...] Therefore, the automobile is the sanctum of modernity, it is a cultural center of a kinetic world religion. It is the rolling sacrament that makes us participate in something faster than ourselves. 
On these glowing hot afternoons Europe's longest parking lot, in a 30-mile-long caravan of immobile and hot steaming steel dark thoughts rise into the air just like black exhaust fumes: drivers gain historical-psychological insight; critical words for civilization pronounced endlessly scape their lips; the obituaries of modernity blow out of the sidewindows: whatever school degree the drivers have, they come to the conclusion that it cannot go on like this for much longer. [...] Can we gain a serious theory of the present from these flickering observations? They do their job well enough if they help to create suggestions for our next step, which consists in applying the term mobilization to describe and explain the basic process of modernity. [...] Mobilization is a category of a world of wars. It includes the critical processes by which combat potentials at rest reach the point of operation. [...] The aesthetic shudder from the world could easily seduce us to turn away from the only concept that gave the name to the dynamic pattern of modernization. ${ }^{254}$

E assim, num assomo nietzscheano (na sua crítica de Sócrates ecoa a crítica da mentalidade burguesa em Lefèbvre), the category of mobilization can liberate intuitions that are not compatible with the Sleep of the Just in the project of modernity. ${ }^{255}$ No modelo cínico, modernidade e crítica são fundamentalmente compatíveis, mas apenas sob condições retoricamente viáveis imobilizando sensibilidades. Nesse modelo, a abertura de espaços dialógicos de abrandamento da velocidade cega que caracteriza o dispositivo capitalista le dos seus 'movimentos' prematura ou erroneamente reificados como 'evolutivos') é determinante:

Thus any criticism of society becomes criticism of a false mobility. If, after the debacle of Marxism and after the ambiguous fading away of the Frankfurt School, there is the possibility of a third version of an ambitious critical theory, it will probably only be in the form of a critical theory of movement. Its therapeutic criteron would be the differentiation, if it is possible to make it precisely, between real mobility and false mobilization. ${ }^{256}$

Mais uma vez focando o papel do quotidano nesta via alternativa do progresso,

Through a critical theory of mobilization, the gap between the thinking process and what really happens with basic principles would be bridged - thinking "outside" would not longer exist, a theorist would have to be asked with every sentence if what he is doing is a sacrifice to the false god ${ }^{257}$ of mobilization or if what he is doing is cleary different from this. Because a theory can only be critical, no matter what critical semantics it transports, if it annules in the worst of all possible directions its kinetic complicity with the movement of the world processes. [...] Only as a tranquil theory of movement, only as quiet theory of loud mobilization can a critique of modernity be different from that which is criticized - everything else is the rational make-up of complicity, giving the train that is already running a push, consciously or unconsciously mimesis of the basic process in the process of reflection. ${ }^{258}$

$\mathrm{Na}$ arte, a diferença do pensamento que a possa instaurar - um encontro lento com a sua contemporaneidade -, passa por artistas e público partilharem a descoberta de outra vulnerabilidade na sua subjectividade separada e desconectada; o que passa por dar espaço ao sofrer (Gross) das emoções contraditórias que o rescaldo da modernidade nos lega: It is now understood what the memory of movement brings to us: the approach to the epistemologically inscrutable point where a theory without wisdom is not even useful as a theory. ${ }^{259}$ De Gruen a Gross, a Aristóteles, é a velha questão, em parte estóica, da 'boa-vida', indissociável do ethos retórico. Este torna-se o sustentáculo de uma consciência do dispositivo social, a partir de observações tão pertinentes como: Terror explicates the environment from the aspects of its vulnerability, iconoclasm

254 Idem, p. 40.

255 Idem, p. 41.

256 Idem, p. 42.

257 Falsos Deuses é o título de ensaio marcante de Arno Gruen, relacionado coma experiência contemporânea da negação através do poder político ou do consumo.

258 Idem. All that can be said is that we had experiences with the so-called post-modern passive and that it does not take much more to admit that we, specially in the prospective view, have come to the suffering side of modernity. In this case, the following formula is valid: the more modern, the more postmodern.

259 Idem. 
explicates culture from the experience of its parodiability; Science explicates first nature from the perspective of its substitutability via prosthetic devices and its ability to be integrated into technical procedure. ${ }^{260}$ Em suma, há uma arte que abranda, senão suspende, a ideia de futuro, em nome de um possível-agora que é já esse futuro sob a forma de urbanismo experimental, artístico, cínico.

Radicalmente, podemos concluir, com Flusser ${ }^{261}$ numa actualização tecno-lógica do quotidiano de Lefèbvre), que todo projecto é ao mesmo tempo solução e obstáculo, a única certeza é de um aumento da complexidade, em escalada geométrica. [...] Sabe-se apenas que a nova fronteira, daqui para a frente, é aquela de nossa própria consciência do sistema construído, o qual nos comanda mais completamente no momento em que temos a impressão de usufruí-lo. ${ }^{262}$ Num argumento importante para o artistic turn que vai definindo a contemporaneidade com o contributo crucial da cognição proporcionada pela arte pública, Flusser propõe:

A questão "abrasadora" é, portanto, a seguinte: antigamente (desde Platão, ou mesmo antes dele) o que importava era configurar a matéria existente para torná-la visivel, mas agora o que está em jogo é preencher com matéria uma torrente de formas que brotam a partir de uma perspectiva teórica e de nossos equipamentos técnicos, com a finalidade de "materializar" essas formas. [...] Antes, o objectivo era formalizar o mundo existente; hoje o objectivo é realizar as formas projetadas para criar mundos alternativos. Isso é o que se entende por "cultura imaterial", mas deveria na verdade se chamar "cultura materializadora". ${ }^{263}$

Flusser propõe que pensemos menos se as formas são verdadeiras ou falsas, mas e mais se nos servem enquanto modelos - o que naturalmente leva a que deixe de fazer sentido - regressamos sempre a Fiedler e Wagner, mas também a Schiller, Novalis, Bergson ou Beuys - diferençar a ciência da arte. ${ }^{264}$ Esta é outra ciência, que veio com a desafectação do cientismo. ${ }^{265} \mathrm{Em}$ termos especificamente críticos, que integram as questões da emancipação do Homem face à tecnociência através de uma plástica do desenho de tudo, Flusser remata: O critério para a crítica da informação hoje está mais para a seguinte pergunta: até que ponto as formas aqui impostas podem ser preenchidas com matéria? Até que ponto as informações são operacionais ou produtivas? ${ }^{266}$ E então, uma obra, uma plataforma projectual, como um novo entendimento da antropo-pedagogia do projecto, partem do entendimento de um desafio potencialmente anacrónico, entrevisto em Feurbach ou Marx a Lefèbvre, hoje objecto de estudo em Agamben, Sloterdijk ou Stiegler, relativo às consequências da fabricação social, integrando a noção de fábrica ${ }^{267}$ num novo contexto de abstracção pós-industrial.

Portanto, as fábricas são lugares onde aquilo que é dado (Gegebenes) é convertido em algo feito (Gemachtes), e com isso as informações herdadas tornam-se cada vez menos significativas, ao contrário das informações adquiridas, aprendidas, que são cada vez mais relevantes. As fábricas são lugares em que os homens se tornam cada vez menos

260 Sloterdijk, Peter; «Spheres Theory».

261 Precisamente, Flusser parece integrar-se numa genealogia aristotélica, schilleriana, lefèbvreana, do logos da vida social como dispositivo imersivo vivido em complexas tensões antagónicas. Cardoso: Flusser não recuou diante da imensidão do desafio de conciliar a tradição iluminista com as forças aparentemente caóticas e destrutivas que regem a desagregação em escala planetária das antigas certezas civilizacionais. Talvez tenha sido ele a última voz da razão, no melhor e mais elevado sentido dessa palavra. Idem, p. 18.

262 Idem, p. 17.

263 Flusser, pp. 31-32.

264 Idem.

265 Lins, p. 10: O Deus da ciência é um homem sem limites, alheio à ética e moldado segundo uma retórica bem próxima de uma economia libidinal que faz do desejo o carrasco do amor.

266 Flusser, p. 32.

267 Idem, p. 36: As fábricas são lugares em que os homens se tornam 
Ora/mas pode-se, portanto, esperar que a louca alienação do homem com relação à natureza e à cultura, que atingiu o grau máximo na revolução das máquinas, possa ser superada. $E$ assim a fábrica do futuro não mais será um manicómio, mas um lugar onde as potencialidades criativas do Homo faber poderão se realizar. ${ }^{269}$ Flusser dá a ver esse logos (desejavelmente pós-industrial, já não exactamente como ética (Sloterdijk) mas enquanto meta-dispositivo potencialmente transformável de uma rede de máquinas (logos): Por serem ambivalentes, os fios dessa rede podem ser organizados de modo centrípeto ou centrífugo. Ao longo dos fios centrípetos, as coisas relacionadas à natureza e aos homens são absorvidas pelas máquinas para que que lá possam ser convertidas e utilizadas. Ao longo dos fios centrífugos, as coisas e os homens transformados saem para fora das máquinas. ${ }^{270}$ Regressamos à vigorosa metaforização da retórica extramuros - 0 'sair' da maquinaria social tal como materializada na cidade contemporânea e concomitantemente suas expressões artísticas. Desenha-se assim uma hipótese cognitiva e emancipatória realista:

A natureza inteira é atraída, de forma concêntrica, por essa sucção das máquinas. Essa é a estrutura da arquitectura industrial dos séculos XIX e XX. Essa estrutura mudará radicalmente em função dos aparelhos electrónicos [...] por não serem mais uma constante em relação ao homem. Fica cada dia mais evdiente que a relação homem-aparelho electrónico é reversivel, e que ambos só podem funcionar conjuntamente: o homem em função do aparelho, mas da mesma maneira, o aparelho em função do homem. ${ }^{271}$

Historicamente, da problematização da cultura urbana como a recebemos da modernidade à antevisão crítica de um futuro pós-industrial trata-se de resolver definitivamente um erro de princípio: Agora começa a desvelar-se o erro fundamental dos platónicos e dos românticos. Enquanto escola e fábrica estão separadas e se depreciam mutuamente, governa a maluquice industrial. ${ }^{272}$ Ou seja, o lugar do design desvela-se subitamente, em Flusser como em Stiegler, o de sacralizar a sabedoria e esta - essa é a minha intuição - é sempre relacional, efémera, contextual e situada. Ecoando agora Aristóteles (e Wagner, na terminologia), Flusser assevera, no sentido do domínio artístico do dispositivo: $O$ que importa é que a fábrica do futuro deverá ser o lugar em que o Homo faber se converterá em Homo sapiens sapiens, porque reconhecerá que fabricar significa o mesmo que aprender, isto é, adquirir informações, produzi-las e divulgá-las. ${ }^{273} \mathrm{E}$ numa nota menos optimista, mas que coloca o design - e naturalmente o desenho público da arte - no coração da resiliência intelectual e produtiva à designificação do quotidano que levou à tecnociência hoje (ainda) hegemónica:

Esse é um problema de design: como devem ser as máquinas, para que seu contragolpe não nos cause dor? Ou meIhor: como devem ser essas máquinas para que o contragolpe nos faça bem? Como deverão ser os chacais de pedra para que não nos esfarrapem e para que nós mesmos não nos comportemos como chacais? Naturalmente podemos projetá-los de modo a que nos lambam, em vez de mordernos. Mas queremos realmente ser lambidos? São questões difíceis, porque ninguém sabe de fato como quer ser.

268 Idem, p. 39.

269 Idem.

270 Idem, p. 40.

271 Idem. Esta visada telemática, pós-industrial e pós-histórica sobre o futuro do Homo faber apresenta, no entanto, um pequeno problema: quanto mais complexas se tornam as ferramentas, mais abstractas são as suas funções. In idem, p. 41. Todo o trabalho de Christian Nold, como veremos na Parte II, procura 'resolver' este diferendo.

272 Idem, p. 43.

273 Flusser afirmava à porta dos anos 90: [...] semelhantes escolas-fábricas e fábricas-escolas já estão surgindo em toda a parte. Idem, p. 44. Exemplo nacional desta abordagem, o lançamento do livro de exercícios de desenho Design pelo Desenho, de Philip Cabau, em que o autor explicita a importância da aprendizagem por oposição ao ensino. Cf. Cabau, Philip; Design pelo Desenho, FCA Design, Lisboa, 2011. 


\subsubsection{Futuros urbanos na cidade pós-industrial}

The true issue is not to make beautiful cities or well-managed cities, it is to make a work of life. The rest is by-product. ${ }^{274}$ The functionalization of the city, which presents space as politically neutral, merely utilitarian, is then filled with politics. For the notion that the city speaks for itself conceals the identity of those who speak through the city. ${ }^{275}$

Rosalyn Deutsche

\subsubsection{Cidade e urbanismo, cultura e arte: a atenção à cidade}

Na prática, o modernismo resultou numa abstracção da vida pública, isto é, incapacidade de produzir um público. ${ }^{276}$ Tempo de planos e manifestos, o modernismo revelou-se um rotundo falhanço ao nível pragmático 277 - com Le Corbusier, por exemplo, sendo capaz de, quanto muito, representar only a tiny speck in the great mountain of unsolved problems in the contemporary human environment ${ }^{278}$; esta incapacidade de lidar com a evolução do tecido social face ao tecido edificado fez esquecer a ideia da cidade participada, que porém nunca deixou de assomar à psique do projecto modernista mais crítico. Quando se levanta a voz de Canon Barnett já 1893-4, em defesa de uma cidade de interacções humanas, é disso que se trata, de uma carência (Wagner) de vida urbana ${ }^{279}$. Anos 90 adentro, Elizabeth Wilson explicita: [...] we will never solve the problems of cities unless we like the urban-ness of urban life. Cities [...] are spaces for face to face contact of amazing variety and richness. They are spectacle - and what's wrong with that? ${ }^{280}$ Estrutura e vivência de overlapping forms of spatial organization, ${ }^{281}$ a cidade pode por isso ser vista como palimpsesto e a arte uma das principais instâncias da urbanidade (que o valor da 'qualidade' da vida urbana apenas lacunarmente formula). Em suma, a cidade é um organismo de que nunca se conhece a totalidade (Graça Dias ${ }^{282}$ ), mas no seio do qual podemos reflectir sobre os problemas ambientais que resultam da espacialização das hegemonias política e cultural. Esta visão da cidade a partir de um ethos ecológico (Burgess, nos anos 20) defende uma ideia central: a cidade como organismo dinâmico em

274 Deutsche, p. 420. Deutsche é uma autora fundamental na deriva, durante os anos 90, de uma crítica de arte do campo estético para o da posição socialmente crítica; daí a sua importância para a esfera mais pragmática e imediatamente sensível da teoria e do planeamento urbanos. Na abordagem da questão dos sem-abrigo em Nova lorque, Deutsche nota que precisamente o tratar-se deste assunto como uma conjugação de problemas individuais, nos impede de compreender algo de mais profundo e complexo: as formas espaciais são estruturas espaciais.

275 Deutsche, p. 422. Propondo a sua versão de um ethos de complexidade sistémica, Deutsche prossegue: The city is not an object produced by a group in order to be bought or even used by others. [...] The city is an environment formed by the interaction and the integration of different practices.

276 Carlo, p. 6: [...] the Modern Movement represented an important chance for cultural renewal in architecture. But we need to question architecture's 'credibility', i. e. It's capacity to have a 'public'.

277 Miles; Malcolm (Ed.), The City Cultures Reader, Routledge, London, 2000, p. 7. Conduzindo ao de-humanising environment of the social housing project, which has nothing in common with another key idea about the city, that it is a place for engagement.

278 Carlo, p. 7.

279 Miles; Malcolm (Ed.), The City Cultures Reader, Routledge, London, 2000, p. 7.: [...] the city with its streets and its markets, its manifold interests, and its hum of life...

280 Wilson, Elizabeth; The Sphinx and the city, 1993, p. 158.

281 Miles; Malcolm (Ed.), The City Cultures Reader, Routledge, London, 2000, p. 8.

282 Cf. Documentário Lisboa Capital de Nada, 2002, de Luís Alves de Matos. 
que processos sociais e formas físicas são correlativas), levando à premência da ideia de cultura urbana, termo com enorme potencialidade metafórica dado que expressão de uma cultura urbana complexa mas projectável. ${ }^{283}$

Com os primeiros modelos de crítica da cidade a partir do design, afirma-se o design da totalidade urbana também como investigar da relação entre cidade, cultura urbana e personalidade humana. Mumford ${ }^{284}$ representa essa perspectiva humanista em que a cidade não passa sem uma dimensão de teatralidade, ${ }^{285}$ relacionada com um desenho e um planeamento simpatéticos, tal como virão a defender Jane Jacobs ou Don Appleyard e, décadas mais tarde, os defensores do Projecto Urbano. Antes em Simmel, 'pai' da sociologia urbana e figura-chave numa emergente antropologia do espaço ${ }^{286}$ - senão de uma filosofia cultu$\mathrm{ral}^{287}$-, a investigação sobre a cidade prende-se com uma atenção inédita a elementos urbanos que jamais haviam sido objecto de uma abordagem tão específica e ao mesmo tempo tão multidimensional. Nesta proto-teoria crítica da metrópole, Simmel articula os elementos da cidade com os valores da liberdade e do social: Freedom would at once permit the noble substance common to all to come to the fore, a substance which nature had deposited in every man and which society and history had only deformed ${ }^{288}$. É uma liberdade já não exactamente individual, mas uma soma dinâmica de frágeis emancipações políticas. ${ }^{289}$

Vejo aqui a intuição de uma realidade mutante que apenas um sentido de colectivo torna retoricamente operacional. Sabemos que Wagner assistiu com entusiasmo às conferências de Simmel em Berlin ${ }^{290}$ e creio que a ideia de Povo no segundo é necessariamente uma solução possível para a cidade de reecontrar com a sua graça social (entretanto 'perdida'). Num reencontro material e simbólico com uma solução para o anonimato (alienação) e o consumo (egoísmo) galopantes, se tivermos em conta que assistimos a uma inédita expan-

283 Para a questão da cultura como conhecimento e associada aos desafios da mudança ver Koch, Gertraut; «Intercultural Communication and Competence Research through the Lens of an Anthropology of Knowledge», in Fórum: Qualitative Social Research, Vol. 10, n. 1, Art. 15, Jan. 2008.

284 Mumford é dos primeiros a chamar a atenção para a questão das funções sociais da cidade, escamoteadas por políticos e planeadores; sublinha de resto que as visões mais remotas de Aristóteles ou até Platão são mais efectivas que as dos técnicos seus contemporâneos, sugerindo a pertinência de um humanismo informado e a persistência de uma linha ou genealogia de reflexões sobre a condição urbana. E conclui, numa lógica reflexiva que abrange um sentido social para a arte: The city, in its complete sense, then, is a geographic plexus, an economic organization, an institutional process, a theater of social action, and an aesthetical symbol of collective unity. The city fosters art and is art; the city creates the theater and is the theater. It is in the city, the city as theater, that man's more purposive activities are focused, and work out, through conflicting and cooperating personalities, events, groups, into more significant culminations. Mumford, Lewis; "What is a city?' - Architectural Record [1937]», The City Cultures Reader, pp. 28-29.

285 Veja-se a perenidade deste tropo literário de Balzac a Baudelaire e sua articulação óbvia com a natalidade de Arendt.

286 Cf. Silvano, Filomena; Antropologia do Espaço, Assírio e Alvim, Lisboa, 2011.

287 [...] one of the finest and most critical understandings of modernity and its totality is still found in the writings of Georg Simmel. Aram, A. Yengoyan, «Simmel, Modernity and Germanisms, A Review Essay», p. 620.

288 Cf. «The Metropolis and Mental Life», The City Cultures Reader, p. 19.

289 Idem. Besides this eighteenth-century ideal of liberalism, In the nineteenth-century, through Goethe and Romanticism, on the one hand, and through the economic division of labour, on the other hand, another ideal arose: individuals liberated from historical bonds now wished to distinguish themselves from one another. The carrier of man's values is no longer the 'general human being' in every individual, but rather man's qualitative uniqueness and irreplaceability. The external and internal history of our time takes its course within the struggle and in the changing entanglement of these two ways of defining the individual's role in the whole of society. It is the function of the metropolis to provide the arena for this struggle and its reconciliation. For the metropolis presents the peculiar conditions which are revealed to us as the opportunities and the stimuli for the development of both these ways of allocating roles to men.

290 D. Frisby, Cityscapes of Modernity: Critical Explorations, Polity, 2001. 
são da criatividade quotidiana, precisamente instigada pelas práticas criativas intersticiais e não encomendadas, podemos dizer que é nesses lugares 'entre' que a arte cria ligações sociais no sentido avançado por Simmel ou Mumford.

The physical organization of the city may deflate this drama or make it frustate; or it may, through the deliberate efforts of art, politics, and education, make the drama more richly significant, as a stage-set, well-designed, intensifies and underlines the gestures of the actors and the action of the play. [...] One may describe the city, it's social aspect, as a special framework directed toward the creation of differentiated opportunities for a common life and a significant collective drama. ${ }^{291}$

Na dinamização da conectividade do urbano, a cidade como forma-texto depende das instâncias comunicacionais que cada um consegue ou não dominar; e portanto [...] when the physical environment itself becomes disordered and incoherent, the social functions that it harbors become more difficult to express. ${ }^{292}$ Mais tarde, os situacionistas vão recorrer à deriva para exprimir este problema: ${ }^{293}$

Where were these dériveurs? They hid themselves in the sinuous folds of large cities. What they experienced is incommunicable, unrepresentable. It happened and it will never return other than as allusions and suggestions, maps and drawings, photos of cities in which to wander. It will also return, but as if in relief, in the form of social criticism, [...] devoted to city and regional planning. [...] The Theory of 'Unitary Urbanism', which the Situationists contrasted with the urbanism of power, was developed by drifting, by walking, by evaluating the ambience of the oldest parts of Paris and other European capitals, Debord found theory through the soles of his feet.

No séc. XXI, muitos artistas influenciariam os planeadores nesta atenção ao peripatetismo (Aristóteles, ainda), assim como a ética do planeador certamente teve impacto no trabalho dos criadores engajados na urbe.

\subsubsection{O planeamento progressista: modelos}

In all cases, planning is about knowledge that informs decisions and enables action. We all want to make the best decisions in life; planners help us to see the total picture [...]. ${ }^{294}$ Para aprofundarmos esta questão - a da consciência crítica do/no planeamento urbano -, é necessário percorrer brevemente a história das principais visões do planeamento progressistas ${ }^{295}$. A genealogia crítica da arte urbana relaciona-se com a evolução dos modelos de planeamento radicais que colocaram em cheque the modernist paradigm on which planning practices have been constructed ${ }^{296}$. O essencial é o entendimento da comunidade: As new and more complex

291 Mumford, p. 29. A nivel individual: As indirect forms of association, with the aid of signs and symbols and specialized organizations, supplement direct face-to-face intercourse, the personalities of citizens themselves become many-faceted: they reflect their specialized interests, their more intensively trained aptitudes, their finer discriminations and selections: the personality no longer presents a more or less unbroken traditional face to reality as whole. Here lies the possibility of personal disintegration; and here lies the need for reintegration through wider participation in a concrete and visible collective whole.

292 Idem.

293 Sheringham, p. 144: He introduced activism to the field of urbanism, something that was nowhere to be found among the surrealist dreamers, who were too passive, too ready to let themselves go, carried away by chance on the unconscious. To avoid this it was necessary to move beyond the past and passivity, drifting had to be more controlled, more systematic, and new cities and spaces had to be invented that would provide greater scope for the derive.

294 Hefele, Noel; «Green Visions / Grey Infrastructure: interventions in the post-industrial society», in Miles, Malcolm (ed); New Practices, New Pedagogies, Routledge, Oxon, 2005, p. 234.

295 Sandercock, Leonie; «The Death of Radical Planning: Radical Praxis for a Postmodern Age», in Cities for Citizens - Planning and the Rise of Civil Society in a Global Age, eds. Mike Douglas e John Fridmann, John Wiley, London, 1998.

296 Sandercock, p. 424. Em 1969, Giancarlo De Carlo é dos primeiros arquitectos a manifestar both the optimistic and egalitarian spirit of 1968 and the anger of a younger modernist generation discovering that the social ideals of the Modern Movement had been lost or betrayed. Carlo, Giancarlo De; «Architecture's public», in Gloso Marion von Osten, no título «Politics 
kinds of of ethnic diversity come to dominate cities, the very notion of shared community, of "the public interest,", becomes increasingly exhausted. These struggles over belonging take the form of struggles over citizenship, in its broader sense, of rights to and in the polis. ${ }^{297} \mathrm{~A}$ questão da visibilidade (Arendt) da diferença torna-se crucial ${ }^{298}$, desde logo na emergência de perspectivas críticas como a feminista: Beginning in the 1970's a new wave of feminist writing and activism began to dismantle/deconstruct the city as it had come to be understood in modernist thought. ${ }^{299}$ Progressivamente, desde os anos 90, mais vozes das margens (voices from the borderlands, Sandercock) foram obrigando planeadores, programadores, políticos e gestores a integrar nas suas visões projectuais vários 'outros' até aí diminuídos na sua expressão pública projectada. $\mathrm{E}$ in all of their spatially inscribed everydayness, ${ }^{300}$ tendo em conta o colectivo não apenas genérico (visões de classe, por exemplo) mas específico (questões de identidade e performatividade individual) e sistémico (as relações entre os seus membros). Os modelos teóricos de boas práticas de planeamento pelo menos desde os anos 40 , têm definido parte importante da teorização do projecto de paisagem urbana. Entre eles, o modelo de planeamento radical revelar-se-á talvez o mais afim das práticas artísticas críticas.

\section{Seis modelos de boas práticas}

Com epicentro na Universidade local, o chamado modelo de Chicago Irational comprehensive model), assentou na epistemologia do lluminismo para sublinhar a autoridade incontestada do planeador como dotado de um conhecimento professional cuja objectividade científica se considerava, à partida, benigna e neutra. Nos anos 60 , chegou o primeiro desafio a este modelo, sob a forma do advocacy planning model, em que o interesse público é não tanto uma questão técnica, mas depende de uma perspectivação do contexto político. ${ }^{301}$ Este segundo modelo conduziu a classe dos planeadores a percursos diferentes - uns procurando aperfeiçoar o modelo genericamente, outros a dimensão processual, outros a capacidade de empowerment por parte das comunidades envolvidas. O que nos leva ao terceiro modelo, o radical political economy model, avançado pelos hoje influentes David Harvey (Social Justice and the City, de 1973) ou Manuel Castells (The Urban Question, de 1976). Neste modelo de génese marxista, planning was no longer the hero but more like the divine fool, naive in its faith in its own emancipatory potential, ignorant of the real relations of power which it was serving and in which it was deeply and inextricably implicated. ${ }^{302}$ Porém, the lasting value of this model is at

beyond the white cube», in Jones, Peter Blundell; Petrescu, Doina; Till, Jeremy (Eds.), Architecture and participation, Taylor\&Francis, London and New York, 2005.

297 Idem, p. 425.

298 Idem, p. 426: Negotiating these spaces, claiming them, making them safe, imprinting new identities on them, is a central socio-cultural and political dynamic of cities and regions, in which planners have a pivotal role. Entraria aqui a questão das ethnoscapes (Appadurai, 1990), e toda a complexidade de encontros e cruzamentos entre comunidades emergentes e nostálgicos de ordens imaginadas do passado, e portanto também entre advogados de diferentes visões para a arte na cidade.

299 Idem, p. 425.

300 Idem, p. 428.

301 Idem, p. 429. The idea of advocacy planning was that those who had previously been unrepresented would now be represented by advocacy planners, who would go to poor neighborhoods, find out what those folks wanted, and bring that back to the table in the planning office and city hall. Em Portugal, esta posição esteve patente nas Operações SAAL.

302 Idem, p. 430. 
the level of critique rather than of action ${ }^{303}$; por outro lado, o enfoque nas questões económicas e de classe ignorou, pelo menos inicialmente, outras formas de exclusão e opressão, baseadas no género, na raça ou na preferência sexual; seja como for, o planeador, nesta posição, torna-se um cartógrafo e um diagnosticador de contradições.

Um quarto modelo de planeamento progressista, o equity planning model, recupera a posição dos advocacy planners e concentra-se num esforço de ética aplicada: os equity planners são those who consciously seek to redistribute power, resources or participation away from local elites and toward poor and working-class residents. ${ }^{304}$ Escolhendo os políticos com quem querem trabalhar, estes profissionais têm um posicionamento projectual que se concretiza na capacidade dialógica (reuniões e diálogo com diversos poderes); neste modelo, o profissional do desenho urbano é um comunicador, figura-charneira num esquema inclusivo (mas ainda top-down). Já nos modelos social learning e communicative action, o técnico da cidade sente necessidade de articular o conhecimento especialista e saber experiencial (nomeadamente dos protagonistas-objecto do seu estudo), num processo de aprendizagem mútua, o transactive style of planning (John Friedmann):

This involved acceptance of the authenticity of the other person; a fusion of thinking, moral judgement, feeling and empathy; a recognition of the importance of the non-verbal as well as the verbal; and an aceptance of and willingness to work with and through conflict. What is radical about this approach is its epistemological shift away from the monopoly on expertise and insight by professionals in an acknowledgement of the value of local, or experiential, knowledge. It is also shift away from a static conception of knowledge las a "body" of knowledgel to a more dynamic concept and metaphor of learning. ${ }^{305}$

Aqui a praxis projectual introduz um elemento retórico fundamental: basing it [critical planning] in the Habermasian concept of communicative action, the work of this group [John Forrester com outros] has moved from the instrumental rationality of the earlier model to an emphasis on communicative rationality. ${ }^{306} \mathrm{E}$ a lógica pedagógica (Freire) do ouvir:

For Forrester, planning is primarily a form of critical listening to the words of others, and observing their non-verbal behaviour. [...] It equity planners can be said to be trying to perfect planning as an Enlightement project by representing the interests of the poor and the marginalized in city halls, the communicative action theorists might be said to be trying to perfect the Enlightenment's democratic project by removing the barriers to communication, by creating a model of open discourse. ${ }^{307}$

Neste modelo eminentemente dialógico aproximamo-nos finalmente do radical planning model: Radical practices emerge from experience with an a critique of existing unequal relations and distributions of power, opportunity and resources ${ }^{308}$. A posição radical é a de um desconforto com o status quo, fruto da atenção à necessidade de considerar uma structural transformation of these systemic inequalities and, in the process, to empower those who have been systematically disempowered. ${ }^{309} \mathrm{E}$ aqui, nesta abertura crítica ao imponderável dos processos de saber e intervenção, o radical planner requires nothing less than a new professional identity [...] in opposition to either state or corporate economy, or both. This implies an epistemological break with [...]

\author{
303 Idem, p. 431. \\ 304 Idem. \\ 305 Idem, p. 432. \\ 306 Idem. \\ 307 Idem. \\ 308 Idem, p. 432. \\ 309 Idem, p. 433. Obviously the focus of radical practice will depend on the focus of the critique
}


what it means to be a planner, and what it is that planners do $0^{310}$. Vejo aqui uma 'colectivização' ou transpessoalidade de competências, partilhadas entre profissionais e não-profissionais, como na arte pública mais crítica; a partilha de um ethos diluído, a praxis aberta e um sentido de pathos colectivo que é o culminar (provisório) da evolução dos cinco anteriores modelos de planeamento urbano). Nos termos de Friedmann, recordo de qualquer forma, que o engajamento nos processos implica a noção de distância (cínica): a radical planner has to maintain a notion of critical distance. ${ }^{311}$ Depois, relativamente à tradução dos dilemas que se desenham entre espaço e esfera públicos, the appropriate image may be that of crossing back and forth, of blurring boundaries, of deconstructing ("community", "the state") and reconstructing new possibilities. ${ }^{312} \mathrm{Na}$ arte, de Beuys a Kaprow, de Fluxus a Platform, Wochenklausur ou Stalker, as semelhanças com esta posição são muitas. Trata-se, de uma epistemologia de aprendizagem social, que o planeamento urbano tradicional tem dificuldades em considerar, na medida em que não é capaz de verbalizar ou formalizar as premissas modernas mais inovadoras de que vinha incumbido de realizar: So it is that planning, which but a few years ago enjoyed enormous prestige, no longer elicits a consensus, still less enthousiasm. Planning by institutions is criticized, and not without reason, for impoverishing the social. ${ }^{313}$ Ao mesmo tempo, e complexificando a questão, o planeamento ficou fora de moda para a ideologia neo-liberal vigente la mesma que favorece um certo sistema da arte em detrimento da sua abertura à transformação emancipatória do social).

\subsubsection{O urbanismo geral de Argan}

Em The Politics of Modernism (1989), Raymond Williams afirma que a cidade moderna é mais uma ideia cultural que um conjunto de dados objectiváveis. ${ }^{314}$ É neste enquadramento que me parece produtivo entender a actual reflexão sobre a cultura urbana ${ }^{315}$ na confluência com o urbanismo geral de Giulio Carlo Argan. Em História da Arte como História da Cidade (1983), este autor explicita como a cidade é o resultado da acção plástica traduzida na forma urbana: Da distinção de um espaço, de uma forma urbana descende, gera-se a arte, que, por sua vez, permite distinguir, separar; intimamente relacionada, portanto, com a cidade, da qual nada mais é que a complexa epifania, a fenomenização. ${ }^{316}$

É em torno da crise do objecto (o belo, na cidade) que Argan vai procurar os sinais de esgotamento de modelos urbanísticos que deverão então ser ultrapassados, sob pena de a cidade morrer. Para Argan, no espírito de Wagner, a cidade é lida como Gesammtkunstwerk,

310 Idem, p. 434. There is a "crossing over" implied here [...] a dramatic shift from the other five models of planning, in which the planner is still the key actor.

311 Idem., p. 434.

312 Idem.

313 Idem, p. 100.

314 Williams, p. 58. The metropolis is itself a cultural construct, more a matter of certain kinds of experiences rationalized as patterns of sociation than data.

315 Cf. o conjunto da obra de Malcolm Miles, desde logo a partir dos títulos dos seus livros.

316 Contardi, in Argan, p. 1. Argan: De fato, no interior da cidade, tudo se realiza segundo uma techné cujo modelo é o processo que realiza a obra de arte; e entre o objecto e a obra de arte existe uma diferença hierárquica lou seja, uma diferença qualitativa, de valor) mas, ainda assim, sempre no interior de uma mesma categoria, de uma mesma série. 
e a arte encarada com uma "atividade tipicamente urbana, não apenas inerente, mas constitutiva da cidade". ${ }^{117}$ A validade do modelo de Argan (que foi presidente da Câmara Municipal de Roma), que vem articular-se com a dos planeadores, reside na capacidade de pensar diacronicamente a relação entre arte e cidade, rejeitando uma história do urbanismo sujeita aos ditames de uma história da arquitectura (ideologia urbana). Esta crítica do monumental (Maderuelo) apela a uma inovadora ética profissional (Brandão) para a superação das crises de qualidade vivencial que abalam as cidades. Tal superação apenas é possível a partir de uma atenção moldada pelo conceito de cuidado - o besorgen das coisas. ${ }^{318}$ Por outro lado, Argan promove a consciência de que há arte porque há uma forma urbana que confere à actividade artística um lugar, uma função, limites. E só há cidade porque há história, intriga (no sentido de Ricouer), coisas para contar e para inscrever no tecido narrativo das relações sociais, da história social (para parafrasear a 'escultura social' de Beuys). Historicamente, habituámo-nos a reconhecer nos marcos urbanos, nas esculturas, no adornos dos edifícios, a epifania artística do urbano; hoje, compreendemos que, graças aos avanços na antropologia do espaço, das sociologias, da geografia, que a arte enquanto manifestação do urbano está longe de se restringir às formas tradicionais do edificado pública e/ou crítica; mais, que é na arte monumental crítica, aquela que problematiza a sua própria discursividade face ao tecido social, que a cidade se diz em construção, em emergência.

Actualizando Benjamin e Adorno, mas sem sinais de nostalgia ou luto, Argan estabelece uma relação entre a crise da cidade (enquanto agregação histórica), a crise da arte e a crise do objecto. O tema que conduz a reflexão de Argan, é o da crise da história da cidade: Os objectos, as obras de arte - numa sociedade cuja estrutura cultural não seja mais a história, como que corre o risco de acontecer com a sociedade atual - são fragmentos de um passado não mais relacionável ao presente, são quase ilhas, resíduos de um continente submerso. ${ }^{319}$ Não é difícil extrapolar esta análise para a situação da arte contemporânea, cujos objectos são tanto mais irrelevantes, para a dinâmica evolutiva social, quanto formos incapazes de os introduzir na engrenagem da construção social colectiva, por via, senão da história, pelo menos de uma terapêutica anamnese. Esta passa por problematizar a dimensão do ego na experiência artística; numa sociedade em que o ethos artístico seja estático, formalista, pobre nas suas ligações constitutivas (nomeadamente no confronto institucional com os outros), a arte tenderá a ser desligada dos grandes temas emergentes, confina-se a uma dimensão, de cariz meramente expressivo (e não produtivo-intencional), tornando-se incapaz de situar o indivíduo na torrente dos factos sociais. Trivial nos casos de menor capacidade expressiva, patética (nos casos retoricamente mais desequilibrados), a arte surge separada do comum wagneriano. Assim, Argan identifica a dissolução pós-moderna com uma fragmentação do tecido urbano que é fundamentalmente incompatível com qualquer projecto de real emancipação cidadã: eliminando-se o valor do indivíduo, do ego, foi sendo reduzido, até ser eliminado [...]. Eliminando-se o valor do ego, elimina-se o valor da história de que o ego é protagonista; eliminando-se o ego como sujeito, elimina-se o objecto correspondente, a natureza... ${ }^{320} \mathrm{Ou}$ seja, a ética deixa de ser

317 Idem, p. 2.

318 Idem. Besorgen significa 'cuidar'. Extrapolo o cuidado pela cidade como curadoria do urbano.

319 Idem, p. 7.

320 Idem. 
uma instância discriminante e equilibradora do saber na cidade. A realidade não mais é dada pela escala humana - ou seja, na medida em que pode ser concebida, pensada, compreendida pelo homem - e sim na medida em que não pode e não deve ser pensada, mas apenas dominada ou suportada; 321 a cidade oscila penosa e angustiadamente entre o sublime, o absurdo e a idiotia. Então, algumas formas de arte pós-modernas, explicitamente interessadas no sublime, ou resignadas a um ínfimo sismografar do mundo emocional (um 'belo de câmara), são extremos de um arco de expressões artísticas caracterizadas pela ausência de argumentação. Valorizo por isso a posição de Argan como desafio para uma renovação ética da arte e do design urbanos, informada pela recuperação de uma dimensão social da própria vanguarda:

[...] um design que, excepcionalmente, parta da livre atribuição de um sentido - ou de um valor - a um objecto pelo contexto, ou seja, que leve em consideração o valor do objecto e a relação objecto-sujeito, tal como a definiu a corrente dadaísta, de Duchamp a Man Ray, a Schwittters. Portanto, um design que se volte para a produção (se ainda é possível defini-la assim) de objectos que sejam, "em sentido etimológico, 'simpáticos', isto é, adequados a uma fácil coexistência... efémeros instrumentos de informação e comunicação... objectos em valor que satisfaçam necessidades, ligados mais à fruição do que à produção". Enfim, um design caracterizado pela atitude a que Lévi-Strauss chama do "bricoleur": quase um "jogo de contas de vidro" (Tafuri), que parta (mas seriamente) da derrota da vanguarda histórica. ${ }^{322}$

\subsubsection{Ambientes responsivos - da totalidade operativa (do design transdisciplinar) no Espaço Público}

Se Argan e Sloterdijk exigem à arte pública que a fenomenação da cidade seja determinada por uma crítica lúdica (Schiller) dos ambientes, em Responsive Environments, de 1985, ${ }^{323}$ encontro sistematizados alguns dos principais valores de um desenho simpático da cidade. São valores que o cerne do Projecto Urbano partilha com a arte pública como discurso na/ da forma urbana:

La tragédia del diseño moderno consiste [...] en que los proyectistas nunca han realizado un esfuerzo unificado para encontrar las implicaciones formales de sus ideales políticos y sociales. Es más, la auténtica fortaleza de una actitud comprometida con esos ideales parece haberles llevado a la conclusión de que la preocupación por la forma en sí misma era de alguna manera superficia ${ }^{324}$.

Ou seja, muitos projectistas esquecem que o ambiente edificado pelo homem constitui um sistema político - à micro-escala de uma barreira arquitectónica ou de um conjunto de constrangimentos, regras ou leis que balizam o desenvolvimento de uma cidade, de uma região ou de uma comunidade. ${ }^{325} \mathrm{Na}$ sua aparente generalidade, várias premissas do desenho urbano responsivo partilham com a arte pública crítica discursos, estratégias e tácticas, numa interdependência fundamental vocacionada para o desenvolvimento urbanístico. E se toda a história da arte contemporânea é, em termos de desenho da cidade, uma pro-

321 Idem, p. 8.

322 Idem, pp. 8-9.

323 Vv. Aa.; Entornos Vitales - Hacia un Diseño Urbano y Arquitectónico más humano - Manuel Practico, Gustavo Gilli, Barcelona, 1999. Note-se a tradução: responsive environments (ambientes responsivos) por Entornos Vitales.

324 Idem, p. 9.

$325 \mathrm{Na}$ esfera do desenho urbano, alguns valores de projecto tornam-se particularmente instrumentais: permeabilidade da circulação das pessoas, variedade na medida das actividades possíveis, legibilidade dos seus elementos e do seu todo integrado, versatilidade das diferentes apropriações, imagem visual adequada às expectativas de uso, riqueza das experiências proporcionadas, personalizado da fruição ao nível individual. 
gressiva apropriação mútua de linguagens disciplinares na forma urbana; o conhecimento crítico do design urbano pode fazer a diferença.

Muitos decisores, programadores, activistas, artistas, conscientes desta possibilidade do desenho da forma urbana, conferem à arte pública o papel ingrato de tecer cidade, colmatando défices de poder variados. Face a díspares oportunidades, políticas públicas deficientes e/ ou decorrentes de engenharias sociais 'incompetentes' ou estrategicamente injustas, o problema essencial de muitos artistas e curadores torna-se o de desenvolver dispositivos específicos capazes de criar cidade sem reificar a arte como função neo-liberal (por exemplo, de gentrificação). Isto levou certas obras e intervenções a desenvolverem um ethos cirúrgico e táctico - o design de uma cidade é, assim, uma arte intemporal, mas raramente pode usar as sequências controladas e limitadas de outras artes temporais como, por exemplo, a música. Em ocasiões diferentes e para pessoas diferentes, as sequências são invertidas, interrompidas, abandonadas, anuladas. ${ }^{326} \mathrm{E}$ é isso que determina uma função cultural do design, na cidade-naturalizada; isto é, enquanto actividade consciente - imagens mentais (Capra) —, o design é não apenas um modelo de apropriação do real, mas também de produção orientada desse real: Designed structures are always created for a purpose and embody some meaning. ${ }^{327}$ É esta busca crítica de sentido, que tanto determina o design urbano como racionalidade fundamental da cidade contemporânea. Na era da globalização, transbordante de significados (Jeudy) mas degradada ao nível da vida e das suas possibilidades de sustentação/sustentabilidade ${ }^{328}$ (Capra), o design da arte faz com que o insuportável possa ser/fazer sentido.

Quanto à forma como a arte integra na sua agenda a experiência das consequências mais agressivas da globalização ${ }^{329}$; identifico a criação de espaços estratégicos de liberdade; o aparecimento de novas geografias híbridas (; a produção de novas consciências. A implicação deste programa heterotópico (Foucault) na forma urbana é evidente, num período de complexidade extrema, em que emerge não apenas uma nova semântica, mas uma nova sintaxe ${ }^{330}$ dos espaços urbanos, transcultural (Berger) e transdisciplinarmente (Basarescu). Ler o texto da cidade (e dizê-lo), através da arte pública é compreender, o quão estratégicos se tornam estes espaços intersticiais e a sua leitura/legibilidade táctica. 0 caso dos italianos Stalker é aliás exemplar de um saber acumulado por via de dispositivos específicos, que vale a pena relacionar com as ideias quer de um urbanismo geral (Argan), quer mais claramente do urbanismo intersticial (Sola-Morales): Les dispositifs plastiques du laboratoire d'art urbain Stalker (cartes, vídeos, photos, atlas performatif) sont des morphologies vagues de territoires actuels qui différent des plans portraits de la ville, lesquels en représentent la morphologie exacte. ${ }^{331}$ Estas protogeometrias dos territórios actuais (Davila) são a modalidade crítica

326 Lynch, Kevin; A Imagem da Cidade, Edições 70, Lisboa.

327 Capra, p. 105.

328 Idem.

329 Podemos partir de três conceitos-chave - representação, narração e retoricização (Sassen) e quatro constatações: a emergência de novas subjectividades políticas protagonizadas pelos actores sociais - os sujeitos como actores Besnier, Yannick, in La Relation au Public dans les Arts de la Rue, Éditions Entretemps, Vic la Gardiole, 2006, p. 106. Le développement d'un territoire ne peut passer que par ses habitants qui doivent en être les acteurs.

330 Argan, p. 17.

331 Davila, Thierry; Marcher, Créer - Déplacements, flâneries, derives dans l'art da la fin du XXe siècle, Regard, Paris, 2002, p. 152. 
de um urbanismo intersticial empenhado no tecido social, afectado por uma esperança no design do agora comunicacional da situação: Croire au monde, c'est aussi bien susciter des événements même petits qui échappent au controle, ou font naître de nouveaux espaces-temps, même de surface ou de volume réduit. ${ }^{332}$ Há uma arte de entrega aos interstícios vitais da cidade que é redenção pelo projecto transdisciplinar, a sensibilidade que dá sentido à descrição operativa das várias componentes discretamente interligadas por uma atenção à totalidade sistémica (Capra). Nos seus termos espiritualistas, Nancy complementa.

Lugares divinos, sem deuses, sem nenhum deus, estão dispostos por todo o lado em nosso redor, abertos e oferecidos à nossa vinda, à nossa partida e à nossa presença, abandonados ou prometidos à nossa visita [...] não são já templos, mas antes a abertura ou o espaçamento dos próprios templos, uma dis-locação sem reserva nem circunscrição sagrada -outros traçados, outras vias, outras habitações para todos os que estão lá. ${ }^{333}$

Ora, se, como vimos até aqui, há toda uma gramática de experimentações artísticas que podem ser revistas à luz das suas qualidades responsivas, é certamente com o concurso indispensável da perspectiva transdisciplinar, que de alguma forma está para a separação das ciências como o design está para a estratificação histórica das modalidades artísticas. Há muitas questões da cidade que não podem caber no campo restrito e autosuficiente de uma única disciplina. ${ }^{334}$ Para Pedro Brandão, a interdisciplinariedade é absolutamente necessária para uma cultura de interacção, não apenas entre diferentes disciplinas técnicas, científicas e artísticas mas delas com outros actores não profissionais, numa cultura aberta às visões do outro. ${ }^{335}$ Está em causa a capacidade de os agentes envolvidos num processo de arte pública e/ou desenho urbano (e que em Brandão são essencialmente uma e a mesma coisa) de colaborarem produtivamente, ${ }^{336}$ o que passa pelos processos colaborativos e participativos que as metáforas da 'negociação' ou da 'auscultação' - ou até da 'especulação' - explicitam. [...] só uma perspectiva inter e mesmo transdisciplinar permite reunir, desde ínício, a cumplicidade de todas as disciplinas do desenho, para poder não apenas responder mas também criar expectativas, 0 que é uma capacidade histórica das artes do desenho, tão ou mais importante que a de responder a necessidades. ${ }^{337}$ Isto pressupõe um desenho - um design - complexo, não mero estilo: ${ }^{338}$

No século $X X$, de entre as disciplinas do desenho, chamamos design àquela que mais se aproximou do sonho das vanguardas, de colocar a arte no quotidiano. Historicamente, é coisa do século XX: implicado na revolução industrial, capitalista, moderna e ocidental. [...] Para o bem e para o mal, não é uma parte marginal ou circunstancial na nossa cultura: ele acabou por se tornar uma componente estrutural do modelo de sociedade industrial. E é ainda por seu intermédio que se desenha a sociedade pós-industrial, do consumo, do lazer e da informação. [...] Se hoje já não é fácil apresentar-se fora do sistema, é porque ganhou o seu lugar na discussão da cidade e da comunicação. ${ }^{339}$

Bernard Stiegler tem aprofundado esta questão, convocando um ethos de força histórica para o design, racionalidade projectual capaz de criar formas mais livres, mais habitáveis [...]

332 Deleuze, Gilles; Pourparlers, Paris, Minuit, p. 239.

333 Nancy, J. L.; Des Lieux divins - Suivant de calculs du poète, Mauvezin, TER, 1997, p. 50.

334 Vv. Aa,; Espaço Público e Interdisciplinariedade, Centro Português de Design, Lisboa, $2000 ;$ p. 7.

335 Idem, p. 7.

336 A ideia de uma co-produção, which retains the expertise of the Professional but equates it with the cognition or expertise of non-professionals. Miles, Malcolm; «Participation and provocation», in Urban Avant-Gardes. Art, Architecture and Change, Routledge, 2004.

337 Idem.

338 Idem, p. 9.

339 Idem, p. 54. 
economias e novas políticas, contextos de pensamento para as razões do viver em conjunto. ${ }^{340} \mathrm{Na}$ sociedade 'designificada', o design tem portanto uma missão essencial: a produção de antídotos para a alienação consumista, produzindo uma partilha da inteligência - acção decisiva da invenção social: repensar a escala da cidade, a caminho de uma prosperidade pós-consumo ${ }^{341}$. Portanto o design urbano, mais do que a arte enquanto divisão histórica - está porventura mais vocacionado para assumir-se sofisticado pharmakon do mundo urbanizado, em iniciativas indistrinçáveis de uma ars publica como um desafio forme educativo e pedagógico.

\section{A profunda participação das pessoas}

Na ética transdisciplinar, o tema da participação cidadã é determinante nos debates do desenho de espaço público, sob o desígnio de uma participação profunda:

Programar a participação deste modo supõe estar-se disposto a transferir parte da "tomada de decisões" para a população e requer métodos que permitam uma operacionalidade politica. Apesar de, em todos os programas europeus, nas formulações do New Urbanism americano, o tema da participação ser central, não se avançou muito no tema. [...] Negociar a "forma do espaço" com os cidadãos supõe correr-se o risco de se perder a capacidade na decisão edificadora, ou perder, em definitivo, metros quadrados de rentabilidade económica.

Uma [...] razão contra a participação tem os seus fundamentos nos territórios disciplinares que exercem a sua acção sobre o território. Arquitectura, urbanismo, paisagismo, arte, arte pública, têm-se desenvolvido como territórios autónomos desde meados do século XIX. Estes territórios configuram um "campo" que possui uma determinada lógica operativa e que como condição cria "barreiras de entrada" para poder actuar como campo. A formação e a prática supõem a superação destas barreiras de entrada e permitem o desenvolvimento da actividade. Como se entende, pois, o programa em que o cidadão "descalço" possa operar no interior do campo, sem ter a formação e os recursos de linguagem necessários? $?^{342}$

Este ponto da transferibilidade (Gabriela Vaz-Pinheiro), que vem das artes para enriquecer o léxico do planeamento do projecto e do desenho urbano, é aspecto crucial nos modos de participação no desenho do espaço público: um primeiro, baseado no "pensamento", em imaginar como queremos que seja o futuro [...]; em geral, dá lugar a projectos publicados, livros, revistas, folhetos; um segundo baseado na "imagibilidade", a capacidade de concretizar uma ideia em resultados formais de tipo gráfico, visual, territorial, etc. ${ }^{343}$ Porém, 0 cidadão não pode participar somente no início e no final do projecto, deve participar no processo e desenhar-se as metodologias pertinentes. ${ }^{344}$ Afinal, nenhum campo, do urbanismo à arte, passando pelo quotidiano, pode ou deve reivindicar exclusividade de legitimidade de acção; nem o projecto de arte pública que não pressuponha ou subentenda estas questões - numa tradição genuinamente intermedia - pode ser considerado deliberadamente - projectualmente - crítico. É este conjunto de questões que leva então Brandão a uma definição e

340 Rodrigo Silva, conferência «Fazer Acontecer», Caldas da Rainha, Junho, 2010.

341 Idem.

342 Idem, p. 67

343 Idem, p. 65. Brandão: Este tipo de processo é o necessário para permitir a participação em processos de desenvolvimento territorial, projectos urbanos ou de arte pública. Estes tipos de processos praticamente não se dão

344 Idem, p. 66. [...] a participação supõe fazer ouvir o cidadão [...] supõe partir-de so pressuposto de que existem diversos "agentes sociais" que devem intervir no processo de tomada de decisões e que este processo não é da competência exclusiva de nenhum "sector ou campo" profissional. Em segundo lugar, deve-se assumir a complexidade real que este processo supõe, incluindo o caso tão simples da colocação de uma escultura no espaço público. Uma complexidade que é determinada por aspectos legais, políticos, económicos, sociais, etc. Em terceiro lugar assumir que até o processo de desenhar é um processo complexo com fases muito diferenciadas nas quais é possivel definir e delimitar a participação dos diversos "agentes sociais". $\mathrm{Se}$, como indicam os analistas, os processos de regeneração urbana tendem a "orientar-se por processo" e não "por projecto" tal como tem sucedido até muito recentemente, dar uma solução a este tema é crucial. 
síntese de Arte Pública, agora na perspectiva do desenho urbano como processo participado conscientemente interdisciplinar:

[...] quando falo de Arte Pública utilizo o conceito de uma forma muito geral, entendendo-o como o conjunto de "artefactos" de características eminentemente estéticas que mobilam o espaço público. A Arte Pública viria a ser um interface desenhado, estetizado, entre o domínio do privado e a mesma territorialidade do espaço colectivo, a película que outorga sentido e significado ao território colectivo. Esta acepção do conceito supõe conceber a Arte Pública como um "agente de co-produção" do sentido do lugar, a Arte Pública seria um dos elementos chave para a colocação em marcha dos processos sociais de apropriação do espaço, através da sua capacidade simbolizadora e geradora de "identidade". Assim, quando falo de Arte Pública refiro-me a coisas tão díspares como o desenho do espaço público, o paisagismo, a escultura, as performances, etc. [...] De certo modo a minha acepção de Arte Pública coincide com a de Design Urbano. ${ }^{345}$

A partir dessa hipótese - o espaço público é a nova cultura de cidade ${ }^{346}$ - Brandão propõe o entrelaçamento táctico de «Três elementos de uma estratégia para o espaço público», e cito: 1. Considerar as diferentes actividades que se exercem no espaço exterior las necessárias, as fortuitas e as induzidas) [...] 2. Considerar o espaço público como forma construída, e que por isso tem de ser desenhada [...] 3. Aplicar um conceito mais vasto de espaço público integrando nele os valores. ${ }^{347} \mathrm{Com}$ a figura do cidadão pensada a partir do conceito de user, concreto e político, mais do que abstracto ou idealizado, impõem-se algumas notas menos efusivas:

Há três problemas principais no facto de privilegiar o espaço público como um objecto de planeamento urbano e de design, na prática ou na formação: primeiramente o modelo da cidade convivial no qual é baseado é contraditório; segundo, se o espaço público é um domínio público, isto, na modernidade, é diferenciado por "género" e resulta na marginalização do domínio do doméstico; terceiro, a categorização binária do espaço urbano como público ou privado, ignora os espaços transitórios que podem ser influentes na formação de padrões de socialização. ${ }^{348}$

Ou seja, no actual contexto de globalização, é necessário abordar a questão das decisões de projecto no quadro do capitalismo cognitivo/ cultural e portanto os projectos como um todo, sempre crítica - e autocriticamente. A representação instrumental do espaç ${ }^{349}$ é uma questão que, como já vimos, alguma arte relacional de génese ambiental, promovida e teorizada por mulheres, inscreveu no ethos do projecto urbano mais completa e directamente engajado na apropriação dos espaços por toda a comunidade ${ }^{350}$. Miles evoca por isso Lefèbvre ${ }^{351}$, na sua chamada de atenção para a vivência dos espaços intersticiais da cidade los mesmos que o desenho e o planeamento urbanos mais burocráticos, funcionalizados e negados sistematicamente destroem). Em suma, a articulação desenho urbano / espaço público / arte pública é a contínua emergência de um inefável campo inter- e

\footnotetext{
345 Idem, p. 67.

346 Idem, p. 55

347 Idem, p. 57.

348 Vv. Aa,; Espaço Público e Interdisciplinariedade, Centro Português de Design, Lisboa, 2000, p.. 101. Doren Massey refere a este respeito uma questão crucial, que implica com toda a hegemonia da imagem na contemporaneidade e especificamente a questão do fetiche da imagem urbana das cidades em competição umas com as outras: o sentido visual, que suporta o planeamento e design da cidade, está mais ligado à masculinidade, como um meio para objectivar e distanciar aquilo que é observado.

349 Idem.

350 Malcolm Miles nota: O espaço público tem, portanto, uma relação problemática com a democracia, e historicamente é um lugar para assuntos de homens. Uma definição de um domínio público localizado em espaços públicos e institucionais implica, também, um domínio mais doméstico em casa, um outro domínio não-público e coloquialmente mais privado. Contudo, esta divisão é idealizada, quando os mass media trazem para dentro da sala de estar os blocos de notícias, quando o design de espaço público inclui mobiliário urbano domestico [...] Para os sem-abrigo, também as ruas são um espaço doméstico. Ao mesmo tempo, a privacidade proprocionada pelas portas fechadas de um lar encerra actos de violência doméstica e abuso. In Idem, p. 102.

351 Idem. Nestes lugares, as pessoas, segundo os termos de Lefèbvre (1991), criam o seu próprio espaço. Lefèbvre é cuidadoso ao evitar a oposição binária, delineando um modelo tripartido: a prática espacial, o espaço concebido (como nos planos e no design) e o espaço vivido (como na ocupação e na fantasia).
} 
transdisciplinar da contemporaneidade urbana em que se joga o destino de um importante legado cultural, o iluminismo, pelo menos no que este tem em comum com o romantismo e o modernismo, um sentido de Estado e de colectivo problematizável - cinicamente - a partir das figuras da democracia e da utopia. Precisamente perante uma crescente desmaterialização da artisticidade do urbano de acordo com a apropriação táctica do intersticial, - os loose spaces ${ }^{352}$ - Miles pergunta-se lindo ao encontro das questões interligadas da autonomia da arte e dos espaços do político):

[...] se os actos de ocupação tornam todos os espaços transitórios, os seus significados mudando à medida que as pessoas entram e saem, e o domínio público é tão mistificado como a liberdade universal, poderá sustentar-se o que subsiste deste ícone da modernidade? A pergunta é importante, na medida em que questiona até que ponto é possível reformular criticamente e desde o seu interior o projecto do iluminismo. ${ }^{353}$

352 Franck, Kaven (Ed.); Stevens, Quentin (Ed.); Loose Space - Possibility and Diversity in Urban Life, Routledge, Oxon, 207. 353 Idem, p. 103. 


\subsection{Espaço Público vs. esfera pública: uma dynamis na esfera do urbanismo}

The degree of criticism society can bear is the benchmark for the creation of a public. Marius Babias

\section{Dar visibilidade da liberdade}

Hannah Arendt, influenciada por Aristóteles, pensa o cerne de uma emancipação quotidiana do sujeito a partir do conceito de natalidade. Com traços iluministas, ${ }^{354}$ é a base filosófica de uma racionalidade crítica do espaço público. A arte pública como espaço público terá então a ver com a habilidade (ou incapacidadel de criar uma arena pública em que o que proclamamos acerca de nós próprios esteja em consonância com o que realmente somos. ${ }^{355}$ Esta questão da visibilidade social, no espaço da cidade, transforma-se num aspecto essencial do filosofar da atenção. A natalidade é momento de 'segundo nascimento' a que é submetido o eu maturo na sequência da percepção atentiva do(s) outro(s). ${ }^{356} \mathrm{Na}$ ética arendtiana, desenrola-se depois uma constelação fundamental: espaço público, excitação e acção:

Excluded from the place where we appear to others and they to us, the play of arousal, the provocation between those who see and those who are seen, remains largely dormant. That aesthetic-existential urge to make our presence felt - the urge Arendt theorized as an active response to being perceived - is thwarted, the passion to excel unawakened. And with this comes suffering that is crippling. ${ }^{357}$

Face a um atrofiamento da vitalidade da experiência urbana, Arendt reaprofunda a ideia de cultivação romântica ${ }^{358}$.

It is tempting to interpret this crippling largely within the frame adopted by modern theorists of individual liberty who were influenced by the Romantic expressive tradition. Here, however, the focus is on self-development, and although Arendt is not uninterested in this type of individual flourishing, her primary concern is with existencial crippling. Those relegated to oblivion suffer a loss of feeling for their own existence, their own reality, as well as for the larger world and their relationship to it. 359 Arendt relaciona ainda as formas da arte com modalidades subtis de negação do social: ${ }^{360}$ num dos primeiros diagnósticos da negação da arte moderna (cultivação da distinção individual - separada, dirá Debord - do Povo - havia dito Wagner). Arendt é um contributo decisivo para o nascimento de um idioma do espaço público, lugar apenas possível desde

354 Curtis, Kimberley, 'World Alienation and the Modern Age: The Deprivations of Obscurity', in Our Sense of the Real: Aesthetic Experience and Arendtian Politics, 1999, p. 324.

355 Metcalff, Eugene; in Lippard, p. 262.

356 Curtis, p. 325. The deepest sign of the modern age is loss of the condition of the world understood as both the subjective-in-between that intangibly forms between people who share a common life and the thing-quality or objective-in-between. 0 conceito de natalidade tem portanto uma essência dialógica, que a modernidade (logo em Balzac, Baudelaire, Benjamin) começa por experimentar e racionalizar como perda. Arendt aborda esta questão em Men in Dark Times (1955), e comenta, entre outros, a obra de Walter Benjamin e Bertolt Brecht.

357 Curtis, p. 325.

358 Curtis, p. 326. Neste pathos arendtiano, o paradigma do ser invisivel é o mendigo. Sem atenção ao outro invisível de que o mendigo é símbolo, não há consciência socialmente transformativa; não há condições para uma resistência à injustiça social. É um tema recorrente na arte pública crítica, de Wodisczko a Kurvitz, passando por Gasco. Um exemplo remoto desta atenção ao mendigo é o filme Boudou sauvé des eaux (1932), de Jean Renoir.

359 Idem.

360 Idem, p. 326. In the modern age, the allure of riches as the road to engaging the 'passion for distinction' easily displaced the deeper path this passion can tread. 
que seja coextensível com a provocação estética mútua (Rancière). Em Arendt, a liberdade é o cimento da esfera pública e o valor supremo de um espaço público de encontros. Não há liberdade sem visibilidade (e discurso): a liberdade é the freedom to call something into being which did not exist before (Between Past and Future; liberdade e plasticidade (potencialidade, possibilidade) tendem a coincidir. Politically relevant freedom, by contrast, is manifest only amid the sensuous aesthetic provocation of speaking and acting beings. ${ }^{361}$ É neste quadro que uma análise da forma urbana exige o conceber de lugares específicos para a visibilidade-natalidade social, pois Yet some phenomena require a more specialized theater for their appearance, some require a "publicly organized space" if they are to have much reality for us. ${ }^{362}$ Curtis conclui que o espaço urbano é o locus de inúmeras visões da liberdade ${ }^{363}$ não necessariamente consensuais (o antagonismo, em Mouffe), e por isso a retórica é 0 idioma comum de um crítica (e de uma praxis) multi-, inter- e e transdisciplinar das formas urbanas. E a arte pública o seu modelo de intervenção mais (im)pertinente. Indeed, one of the most important purposes of the public sphere is to give this capacity some tangible reality. ${ }^{364}$

Se a arte tornar tangível a liberdade no seio do socius, o Espaço Público pode bem ser a categoria instrumental que concretiza o conjunto de intuições radicais (cultivação, natalidade, visibilidade, dialogismo). O trabalho dos artistas e programadores críticos não é o de simplificar este Projecto (trivializá-lo, instrumentalizá-lo), mas de lhe acrescentar infindamente dimensões e problemas, numa esfera pública crítica incremental, ela própria meta-teorização da liberdade do político. É aliás com a convicção deste valor supremo - e contingente - da liberdade, que Kafka conclui as Investigações de um Cão. Mas que liberdade é esta? Não se trata já da liberdade inaugurada pelos Estóicos, um domínio interior de encontro com a soberania (sob a forma de revêrie, solidão, retiro), mas uma liberdade da necessidade performativa, no palco social, um virtuosismo das identidades e das relações emancipatórias. ${ }^{365}$

Arendt often referred to "the deeper significance" of the public-political realm. It was, she argued, also a "spiritual realm" in which can be seen not what you are - an inspired teacher, fat, from the middle class, a gifted mechanic, and so on) but who you are (MDT, 73) Implicit in all our relations but barely known to ourselves, who we are can appear fully only to others when we enter the public sphere (MDT, 73-74). ${ }^{366}$

É neste plano que podemos ver a arte como a form of media or media operation that produces a public sphere rather than simply being an object or gesture that enters the public sphere from somewhere outside it. ${ }^{367}$ Tal implica a actualidade do encontro.

361 Curtis, pp. 326-327.

362 Arendt, Hannah; Between Past and Future, Viking, New York, 1961/1968, p. 154.

363 A articulação arte e liberdade, esfera pública e cidade é constitutiva não apenas da natalidade, eminentemente dialógica, mas da ideia de uma arte crítica capaz de integrar as dimensões mística-vitalista e científica-marxista em efémeras propostas de provocação dos sentidos. Desde Arendt que, aliás na sequência dos românticos, que revolução e sensualidade não têm de ser mundos separados e que a liberdade é o seu tropo mais irredutível.

364 Idem, p. 326

365 Curtis, p. 328. The "original field" of freedom, Arendt argues, is "the realm of politics and human affairs in general" (BPF, 145). Phenomonologically, freedom is first and foremost a worldly engagement, and from such original engagements "derive" our experiences of freedom in other domains of human experience. [...] Thus to summarize "the crippling consequences" of obscurity we find the following. Denied that movement in relation to others in a public sphere, denied the dense and pressing presence of speaking and acting beings, our own urge to appear remains unprovoked. [...] And if this were not sufficient cause for despair, the denial of this political freedom over time may well undermine our capacity for inner freedom as well.

366 Idem, p. 329.

367 Kwon, Miwon; «Public Sphere»», in Sculpture Projects Münster, 2007, p. 433. 


\subsubsection{Actualizar a amizade no espaço da arquitectura}

O facto de Sócrates não ter sido capaz de persuadir os seus juízes da sua inocência e dos seus méritos, apesar de estes serem mais do que óbvios aos olhos dos melhores e mais jovens cidadãos atenienses levou Platão a duvidar da validade da persuasão. [...] Era em persuadir, peithein, que consistia a forma especificamente política do discurso, e uma vez que os atenienses se orgulhavam de, ao contrário dos bárbaros, conduzirem os seus assuntos políticos sob a forma do discurso e não da compulsão, consideravam a retórica a arte de persuasão, a mais elevada e verdadeira forma de arte política. ${ }^{368}$

No episódio da morte de Sócrates, a cidade não via qualquer utilidade num filósofo, e os amigos não viam qualquer utilidade numa argumentação política. ${ }^{369}$ Dramaticamente, A oposição entre a verdade e a opinião foi decerto a conclusão anti-socrática por excelência que Platão tirou do processo de Sócrates. Sócrates, ao falhar na tentativa de convencer a cidade, mostrara que a cidade não é um lugar seguro para o filósofo. ${ }^{370}$ Note-se que Para compreendermos a dimensão exorbitante da exigência platónica de que o filósofo se torne o governante da cidade, teremos de ter presente estes «preconceitos» comuns que a polis alimentava em relação aos filósofos. ${ }^{371}$ Aliás

A filosofia, o amor da sabedoria, de modo nenhum era considerada como sendo a mesma coisa que este discernimento, phronêsis. Só o sábio se preocupa com questões exteriores à polis, e Aristóteles concorda inteiramente com a opinião pública a este respeito, quando afirma: «Anaxágoras e Tales eram homens sábios, mas não avisados. Não estavam interessados no que é bom para os homens [anthrôpina agatha]. ${ }^{372}$

Daí que a retórica prevaleça sobre a dialéctica em termos de instrumentalidade de um bem comum da cidade, o que ao nível da interrelação filosófica tem a ver com a maêutica, a arte da parteira: [Sócrates] queria ajudar os outros a fazerem nascer aquilo que eles próprios de certo modo pensavam, a descobrirem a verdade na sua doxa. ${ }^{373}$ É uma arte do diálogo situado, devendo

[...] certificar-se da posição que o outro ocupa no mundo comum [...] dialegesthai, o falar com alguém sobre alguma coisa - mas esta dialéctica traz mais verdade, não destruindo a doxa ou a opinião, mas revelando, pelo contrário, na opinião da sua própria verdade. O papel do filósofo, portanto não é governar a cidade, mas ser um «moscardo» - não dizer verdades filosóficas, mas tornar os cidadãos mais verdadeiros. ${ }^{374}$

Donde que dos diálogos empreendidos na cidade não há que necessariamente esperar conclusões, sabendo-se que isso é possível apenas entre amigos ${ }^{375}$ - é por isso que Sócrates tentou estabelecer a amizade na cidadania. ${ }^{376}$ Parece-me evidente que afectar a consciência da polis através da atenção às diferentes visões e percepções do seu quotidiano está em sintonia com tal desígnio. Donde que Arendt conclui: A igualização que tem lugar na amizade não significa evidentemente que os amigos se tornem uns os mesmos que os outros, ou iguais uns aos outros, mas antes que se tornam participantes iguais num mundo comum - que, no seu conjunto, constituem

\footnotetext{
368 Arendt, p. 12.

369 Idem.

370 Idem, pp. 13-14.

371 Idem, p. 14. Mas não em relação aos artistas e poetas.

372 Idem. A entronização platónica da ideia do bem no lugar mais alto do reino das ideias, como a ideia das ideias, encontra-se na alegoria da caverna e deve ser entendida neste contexto político. [...] A principal distinção entre persuasão e dialéctica é que a primeira se dirige sempre aos muitos (peithein ta plêthê), enquanto a dialéctica só é possível como um diálogo entre dois. O erro de Sócrates foi dirigir-se aos juízes sob a forma de dialéctica, sendo por isso que não poderia persuadi-los. [...] Mas a persuasão não decorre da verdade, decorre das opiniões, e só a persuasão leva em conta e sabe como lidar com os muitos.

373 Idem.

374 Idem, p. 19.

375 Idem, p. 19.

376 Idem.
} 
uma comunidade. ${ }^{377}$ E esta é dialógica (Buber): O elemento político da amizade consiste no facto de no diálogo verdadeiro cada um dos amigos é capaz de compreender a verdade contida na opinião do outro. ${ }^{378}$ Também aqui me parece evidente que a compreensão que Arendt sugere é a compreensão do dispositivo que permite a conversação: Sócrates parece ter acreditado que a função política do filósofo era contribuir para a instauração destas espécie de mundo comum, construído a partir do entendimento entre amigos, que torna a dominação desnecessária. ${ }^{379}$ Esta é uma noção até pré-socrática, de uma profunda fé no logos, que Arendt actualiza através de Aristóteles:

Aqui devemos voltar-nos de novo para Aristóteles se quisermos encontrar um eco já enfraquecido de Sócrates. [...] 0 critério é aquilo que os próprios homens são quando agem, e não qualquer coisa de exterior como as leis, ou acima do humano como as ideias. Ninguém duvidará de que estes ensinamentos estavam, e estarão sempre, de certo modo em conflito com a pólis, que tem de exigir o respeito das suas leis independentes da consciência pessoal. ${ }^{380}$

Note-se como Aristóteles é mais perspicaz do que Platão, de cuja alegoria da caverna, é Arendt que o nota, estão ausentes os termos fala e aç̧ão. ${ }^{381}$ Isto é, ao espírito filosófico de Platão opõem Aristóteles e Arendt a inteligência situada da política. Por outro lado, a utopia, sem deixar de ter a sua instrumentalidade própria (e limitada), integra agora a complexa emergência da vida urbana: Se o homem perdesse a sua faculdade de fazer perguntas últimas, perderia no mesmo lance a faculdade de fazer perguntas com resposta (Arendt). Nos meus termos, se o homem perdesse a capacidade de imaginar perderia a capacidade de criar, produzir, realizar. ${ }^{382}$ Numa cidade política, portanto, A política ocupa-se da coexistência e da associação de homens diferentes. Os homens organizam-se politicamente de acordo com certos aspectos comuns essenciais que descobrem num absoluto caos de diferenças ou dele abstraem. ${ }^{383} \mathrm{~A}$ política vai então depender dos direitos que garantirmos uns aos outros (Arendt), e a liberdade só existe na necessidade da evidência da política, realizada no afecto pelo demos. Ora há este povo, sem um espaço que o represente?

\title{
Espaço e arquitectura
}

Espaço e arquitectura são categorias correlativas, o que abre à arquitectura como saber uma dimensão senão necessariamente redentora (Gadanho), pelo menos micropoliticamente operativa.

\begin{abstract}
Não foi nem há meio século que, em pleno advento modernista, o discurso arquitectónico inventou para si a importância do espaço. Depois foram rescritas todas as histórias possiveis para que o espaço se revelasse, para a criação arquitectónica, o protagonista incontornável que sempre estivera lá. Daí à espacialização da teoria e à época do espaço como descrita por Foucault. Daí à geografia pós-moderna e à à evidência psicossociológica do especial, foi um pequenos alto para que as mais variadas disciplinas exercessem os seus direitos de propriedade sobre uma dimensão que se propõe substituir o tempo e a história. Informe, desprovido de uma definição concreta, o espaço passou a ser a condição propícia à osmose de diversos saberes, o lugar do contágio. ${ }^{384}$
\end{abstract}

377 Idem, p. 20.

378 Idem, p. 21.

379 Idem.

380 Idem, p. 26.

381 Idem, p. 31.

382 É uma noção instrumental em qualquer contexto: Deus dá-me serenidade para aceitar o que não posso mudar, coragem para mudar o que posso e sabedoria para saber a diferença.

383 Idem, p. 85.

384 Gadanho, Pedro; «Contributos para uma breve história do espaço. Do horror ao vazio à sublimação do lugar», in Matos, Sara Antónia (Coord. e Ed.); ESPAÇO, Oficinas do Convento, Montemor-o-Novo, 2009, p. 165. 
Concretizando, Everyone is secretly, profoundly cultured about their built world. They just don't know it, yet. And this is because architecture is worldly glue; it gathers phenomena ltime, events, people, memories) and makes life possible. ${ }^{385} \mathrm{~A}$ arquitectura é

[...] a pliable system for the application of physical constraints and the effectuation of political and social ends. As high-
-end.conceptual architecture is reduced to the latest Money-printer for the developer, or a simple mechanism to counter
the powerful city planners, architecture at its most basic represents the cutting edge of the inhumane. The greatest
asset of architecture is its inability to exist without performing both organisational and psychological functions. [...] But
it is the inescapable symbiosis of space and psychological state that is critical to a future where architecture assumes
an important role in a drive to increase empathy levels between humans. ${ }^{386}$

Já não estamos tão seguros do valor da arquitectura como Adorno ${ }^{387}$, mas tendem a ser arquitectónicas muitas práticas artísticas mais radicalmente contemporâneas. Na resiliência artística de KVA Architects, Lacaton e Vassal, West 8, Ezyzt, Saprophytes ou He-He há uma recusa, pela arquitectura, da condição reificada do fetiche ${ }^{388}$, em nome de um encontro imponderável com a cidade complexa e contraditória (Venturi). Estes são exemplos de uma arquitectura que se integra na ars pública que é a cidade como um todo: Como referirá Henri Lefèbvre [...] os arquitectos passam a oferecer uma «ideologia em acção», algo que, afinal, se traduz apenas na ideia de um «espaço vazio» ou de «um contentor preparado para receber conteúdos fragmentados, um meio neutral no qual coisas desconexas, pessoas e habitats podem ser introduzidos». ${ }^{389} \mathrm{~A}$ crítica do modernismo por via do contexto vai ser informada pelas ciências sociais; talvez se possa mesmo dizer que a deriva contextual da arquitectura mais experimental é a condição da sua contemporaneidade - Da mera percepção geométrica do espaço à sua apropriação social dá-se um salto conceptual considerável. ${ }^{390}$ Desde que consciência do espaço social (Simmel) e depois da morfologia social (Lefèbvre), a arquitectura torna-se factor crucial no entendimento das formas do socius. No dealbar da teoria crítica, é um labor muito associado à leitura e interpretação dos signos desse espaço; entretanto, complexificou-se a possibilidade de activar esse espaço social, alargando-se a praxis arquitectura-ambiental à produção de vivência, memória, contexto. Ou seja, hoje uma hipótese de arquitectura ambiental do espaço passa por assumir-se a artificialidade do dispositivo construtivo para

[...] criar uma experiência perceptiva e fenomenológica que está muito para além da afirmação tradicional das permanências arquitectónicas. [...] A ambição de desmaterialização presente na arquitectura de excepção do nosso tempo revela não só uma aproximação propositada às sublimações do campo artístico, mas também uma resposta inconsciente à economia da experiência e aos atractivos de uma virtualidade em voga. ${ }^{391}$

Ora estamos perante o problema de situar (e não apenas reconhecer) a retórica como racionalidade política - total e global, expressiva e cognitiva - na forma urbana:

\footnotetext{
If the authorities and places in which issues of social life are negotiated become out of reach, and are neither accessible nor can be found eithers in the abstract sphere of politics or in concrete aspects of life in the city, then it makes sense for those with something to negotiate to work with political and urban topics (topoi). As opposed to topics that merely Express prevailing conditions and lend them consistency, such self-made topics work with assertions, images, and changes that give expression to a specific situation. They 'transform' it, thereby putting it up for grabs again. Topoi

385 Basar, Shumon, in Miessen, Basar (eds.), p. 32.

386 Murphy, Matthew; «Glimpses of a furure architecture», in Basar, in Miessen, Basar (eds.), p. 68.

387 Idem, p. 169. Sardo refere-se à fusão matricial das artes (sob a égide da arquitectura) em Hegel e à conferência proferida por Adorno em 1966, «A Arte e as artes».
}

388 Gadanho, p. 160.

389 Idem.

390 Idem, p. 161.

391 Idem. 
denote places, between whcich discursive spaces emerge. In their origin and construction they are always local, not having an effect until positioned in a space that points beyond te local. 392

Perante uma crise urbana que é crise política (Harvey, Bauman, Sloterdijk), cada construção de um novo tópico - o dar nome, voz, sentido, à situação-contexto - é um concrete embedding num complexo palimpsesto (daí a importância vital da memória), abrindo um novo campo político na materialidade de uma urbe ${ }^{393}$ refém de acelerados movimentos de que estão ausentes a política e o design (Kniess, Voggenreiter) transformadores.

$\mathrm{Na}$ aproximação arquitectura-arte por via da desmaterialização crítica (e pós-crítica) da intersticialidade da arte urbana (encetada por projectos híbridos como Stalker), diviso assim a deriva sistémica e ambiental das práticas arquitecturais de espaço público la vida entre os edifícios), uma linguagem transversal paralela à da community art mais radicalmente desenvolvida. Mas é ténue o fio entre seguir a moda dessa desmaterialização la arquitectura como meta-modalidade de uma praxis projectual híbrida) e procurar na arquitectura um efectivo saber da cidade capaz de integrar, desde logo, a ideia colectiva e comum de jardinagem-cuidar (Grout) nas suas ousadias materiais e formais. Gadanho é ainda claro na articulação desta arquitectura do possível com a categoria do efémero: Eis o fim da permanência da ideia de espaço e o regresso pleno do tempus fugit. ${ }^{394}$ Será na figura do espaço público 'entre' os edifícios que a arquitectura - de espaço híbridos e efémeros (Luís Santiago Baptista) ${ }^{395}$ - recupera um sentido crítico contemporâneo que a moda e o estilo modernistas impediram de afirmar?

\subsubsection{Espaço(s) Público(s)}

Quando o 'espaço público' começa a integrar o jargão da arte crítica nos anos 60, as coisas eram relativamente simples. ${ }^{396} \mathrm{O}$ modelo iluminista parecia válido para integrar a actualização do desejo de participação e crítica. Mas rapidamente se impôs o diagnóstico de um desvio do espaço público para uma esfera pública de relações, onde a sugestão e a manipulação suplantavam os processos de socialização típicos. Face a uma crescente inospitabilidade ${ }^{397}$ do meio urbano (que foi gerando movimentações críticas na esfera do urbanismo, do design urbano, da arte pública e do projecto urbano), o discurso sobre o espaço público reflecte notas habermasianas, entre o desejo de emancipação crítica (suportada por uma teoria do discurso que é do acto de comunicaçãol e o desejo de resgatar a cidade para os cidadãos, numa recuperação do projecto democrático original (grego) - ainda hoje modelo icónico e espaço de negociação, ${ }^{398}$ da complexidade das problemáticas de hoje. ${ }^{399}$ Note-se que

\footnotetext{
392 Kniess, Bernd \& Voggenreiter, Meyer; in Miessen, Basar (eds.), p. 187.

393 Vê-lo-emos na produção do Nada em Marvila.

394 Idem.

395 Ver as séries temáticas: 'Intervenções Informais' e 'Produções Efémeras', Revista arq./a, 2008-2010, n.o 62-77.

396 Laistar, Judith; «Public Space», in Sculpture Projects Münster, 2007, p. 431.

397 Mitscherlich, Alexander; Die Unwirtslichkeit unser Städte. Anstiftung zum Unfrieden, Frankfurt am main, 1965.

398 Laistar, idem.

399 Neil Smith e Setha Low mencionam vários aspectos cruciais dessas problemáticas: o atrofio da espacialização do público na economia neo-liberal, em função de uma lógica do lucro na perspectiva do consumo lque redunda em pro-
} 
"Public Space" envelops the palpable tension between place, experienced at all scales in daily life, and the seeming spacelessness of the Internet, popular opinion, and global institutions and economy. [...] It is impossible to conceive of public space today outside the social generalization of private spaces and its full development as a product of modern capitalist society. [...] Public space, in fact, only comes into its own with the differentiation of a nominally representative state on the one side and civil society and the market on the other. ${ }^{400}$

Nesta articulação entre a sociedade civil e o estado há uma certa tonalidade elegíaca e melancólica no discurso de Habermas que não está de acordo com activismos vários na órbita de uma arte do espaço público ou de várias acções na esfera do urbanismo radical, expressões de uma 'lost geography'. ${ }^{401}$ Este trabalho colectivo, muitas vezes anónimo e transgressor (Trespass) tem sido feito no campo da prácticas espacial (Miles) como reflexão política: de um lado, o trabalho eminentemente espacial de arquitectos, geógrafos, planeadores, antropólogos, urbanistas, artistas; $^{402}$ do outro, os debates acerca da operatividade de uma esfera pública democrática (discursos mais eminentemente político-culturais). Aprofundam Smith e Low, a propósito das diferentes culturas (esfera pública vs. espaço público):

Where the weakness of the public space literature perhaps lies in the practical means of translation from theories of political and cultural economy to the materiality of public space, the public sphere literature offers an historically embedded discussion of the continual making and remaking of the public vis-à-vis the state and related institutions, and ideologies and modes of communication and power. By corollary, the weakness of the public sphere literature may lie in the distance that it maintains from the places and spaces of publicness, whereas it is precisely the insight of the public space literature that produced public spaces naturalize the very assumptions interrogated by public sphere theorists and provide an extraordinary palimpsest for detailed scrutiny. ${ }^{403}$

Em ambos os campos de trabalho porém, Abstracting from the location of real events and social relations removes an entire dimension of political relationality. ${ }^{404}$ David Harvey e Richard Sennett abordam esta questão - a da relação co-constituiva do espaço público e da esfera pública (valorizando a sua essência colectiva). Malcolm Miles ou Jane Rendell inspiram-se naqueles autores para partir para uma resposta específica, sob o mote dos espaços intersticiais ou intermediários. ${ }^{405}$ Ou seja, teorizar o espaço público é ter em conta a forma urbana na sua dinâmica complexa e integrada, em que todos os espaços têm um determinado carácter e geram uma experiência fenomenológica específica, irredutível à lógica de uma 'esfera pública' burguesa: [...] public space is trechereous terrain for the work of art, which finds itself in the other's territory and with an always ambiguous reason for being there. [...] in public space,

blemas específicos quanto à regulamentação do acesso e à natureza do controlo dos comportamentos); a cada vez mais complexa imbricação entre o espaço da vida privada e da vida pública (em função da multiplicidade de micro-esferas públicas disponíveis, com destaque para as que surgem quotidianament com o domínio dos media digitais); a extrema dificuldade em levar a colaborar os profissionais de diferentes campos, nomeadamente os profissionais do espaço las profissões do desenho de Pedro Brandão) e os profissionais das ideias (os cientistas sociais e os filósofos políticos). Smith, Neil; Low, Setha; «Introduction: The Imperative of Public Space»,

400 Laistar, p. 431.

401 Smith, Neil; Low, Setha; «Introduction: The Imperative of Public Space», p. 6.

402 Idem, p. 5. [...] seeking to comprehend the ways in which social and political, and economic and cultural processes and relations make specific public spaces and landscapes, and the ways in which, in turn, these geographies reaffirm, contradict, or alter their constituent social and political relations.

403 Idem, p. 6. [...] If the public sphere can be described as "the sphere of private people coming together as a public" (Habermas, 2001; 27), its emergence clearly has a history, as we have seen, but it has an equally clear geography. Once recognized, that spatiality of the public sphere potentially transforms our understanding of the politics of the public. An understanding of public space is an imperative for understanding the public sphere.

404 Idem, p. 7. [...] the respacialization of our sense of the public brings the opportunity of a more complete repoliticization of the public than would otherwise be available.

405 Clifford, James; Routes. Travel and Translation in the Late Twentieth Century, Harvard, 1997. 
the artist's contribution is only rarely faced with a consenting public. ${ }^{406}$ Jane Rendell menciona aqui a negociação do limite entre o público e o privado, 407 no território tudo menos inerte do espaço urbano. ${ }^{408}$ Rendell acrescenta e conclui:

I argue that in order to engage with practical problems of public and private space, we must operate at a theoretical level. We must construct what Júlia Kristeva has called "a diagonal axis" between theory and practice, "a place between" the two, where a more integrative approach to the making and interpretation of public spaces can begin. ${ }^{409} \mathrm{E}$ de facto, Art has an important role to play here. [...] Art provides gifts of time and space, creating occasions where new mediations between public and private might yet be articulated.

A questão da arte pública como economia da dádiva (Mauss) - palco da generosidade (Purves) - é determinante para a noção de sentido partilhado da cidade. ${ }^{410}$ Num território de análise obrigatoriamente inter- e pluridisciplinar que articula a geografia, os estudos urbanos e a geografia da arquitectura, urge discutir where meaning lies in public art, a reflection on the theoretical perspectives and methodological approaches employed by writers on the subject and thoughts on the partiality of much work to date. ${ }^{411} \dot{E}$ a partir desta convicção que os clusters temáticos museu/intervenção; contexto/situação; activismo/participação nos acercam da questão do significado da arte em espaço público. Perante o jargão (tecnocrata) da arte pública realizada sob o mote da regeneração urbana, são porém escassos examples of work that offer methodological clues to an alternative approach to uncovering meanings in public art and in everyday engagements with open space, that have been largely missed in critical writing to date. ${ }^{412} \mathrm{Na}$ prática,

[...] culture was being deployed in a commodified and sanitized form in cities to create the impression of affluence, vibrancy, conviviality, change and regeneration, while at the same time being used to mask the increasingly fractured and polarized social and economical realities that characterized life for the majority of urban dwellers (Harvey). ${ }^{413}$

Hall vai complementar a ideia com a questão do acesso à vivência da cidade por via da arte pública:

It has been argued that public art works have presented selective versions of history, or myths of harmony, offering another layer in the composition of elite images of the regenerated city. This is of significance, not just because the image (how cities are represented by the minority) is out of step with reality (how cities are experienced by the majority) but because there is a tangible relationship between the former and the latter. Image and appearance are important parts of the way that cities are understood and acted upon and hence they are embedded in the material reproduction of urban space. ${ }^{414}$

Noutros termos, compreender a arte pública, no limite, é já nela participar - e participar na

406 Barak, Ami; «Espace Public», in Sculpture Projects Münster, 2007, p. 349.

407 Rendell, Jane; «Public Art: Between Public and Private», in Advances in Art \& Urban Futures Volume 1. Locality, Regeneration \& Divers[c]ities, Intellect, 2000. No artigo, a autora distingue diferentes 'Espaços Públicos': como não-privados, livres ou democráticos, dimensões cada qual com as suas próprias características. No mesmo texto, o espaço privado é abordado do ponto de vista das questões da privacidade, distância e limite,

408 Michel de Certeau (na ideia das histórias espaciais, que sublinham o elemento espacial na narrativa) e mais atrás, Walter Benjamin (a imagem dialéctica como constelação de antiguidade e modernidade, sonho e vigília) são dois aspectos processuais deste encontro da arte com o espaço público urbano.

409 Idem, p. 23-26.

410 Tim Hall, 'Opening up Public Art's Spaces: Art, Regeneration and Audience, from Cultures and Settlements (2003).

411 Hall, p. 110.

412 Idem, p. 111

413 Idem. Voltaremos a esta questão na secção acerca do desenho urbano.

414 Hall, p. 112. De qualquer forma: Lefebvre's laudable project to find a bridge between experienced space, representations of space, and spaces of representation has proved too hard to put into operation empirically. The crucial link between the construction of place in representation and at the level of everyday experience has not been demonstrated. Cf. Savage, M; Ward, A.; Urban Sociology: Capitalism and Modernity, MacMillan, London, 1993, p. 132. 
cidade - , antes do mais ao nível da tensão entre discurso e vivência espacializada. Aliás, Martha Rosler, começa assim um dos seus textos fundamentais, inserido na colectânea If you lived here, de 1991: What variety of means is available in the effort to persuade and convince? ${ }^{415}$ Haveria frase mais evidentemente retórica, na afirmação crítica da própria arte pública como retórica crítica, meta-dispositivo comunicacional de elogio implícito le por vezes explícito) do Espaço Público? Podemos voltar a Flusser para concluir este ponto:

\begin{abstract}
Flusser describes communication as a peculiarly human artifice. Only through the generation, storage and distribution of information, he writes, are human beings able to make their lives meaningful and overcome their 'natural' condition of loneliness and inevitable death. In order to achieve this goal, a given person needs a fairly even balance between "dialogue" and "discourse." "Dialogue" here refers to an exchange of stored information that has the potential to create, that is, to generate genuinely new information (the kind of achievement he later refers to as art); "Discourse" refers to the distribution of this information-critical to its preservation. At one time, paintings or sculptures or speeches were the means of discourse. In our own context, it takes television, radio, and print. When there is a radical imbalance between dialogue and discourse, as there is for most of those living in post-industrial societies today, a crisis arises, somewhat ironically, a sense of being unable to communicate. The problem is certainly not that there isn't enough communication. Of the common contemporary complaint about feeling isolated. Flusser writes: What people mean is obviously not that they suffer from a lack of communication. Never before in history has communication functioned so well, so intensively and extensively as it does today. What people mean is the difficulty in establishing a genuine dialogue, that is, in exchanging information in the interest of new information. And this difficulty can be traced back to just that communication that functions so perfectly today, namely that superb, omnipresent discourse that renders every dialogue at once impossible and unnecessary... When discourse prevails, as it does today, human beings feel lonely, even though they are in almost continual contact with so-called 'information sources.' If the village dialogue prevails, as it did before the communications revolution, people feel lonely despite dialogue because they feel 'detached from history'. ${ }^{16}$
\end{abstract}

\title{
2.2.1.2 Entre o público e o privado, o espaço público como display
}

O conceito de Espaço Público, em toda a sua ambiguidade e poder sugestivo, metáfora operativa para o display ${ }^{417}$ da arte pública, articula as operações projectuais que quanto a mim definem a arte pública enquanto movimento excêntrico face ao mainstream da arte ${ }^{418}$. Enquadro as obras de arte pública que importam do ponto de vista da criação de Espaço Público, isto é, já não estritamente de uma esfera pública mais ou menos representativa-discursiva (Habermas), mas de espaços transicionais que fazem o que podem face à situação urbana.

A ideia de um espaço público com potencialidade emancipatória evoluiu desde os anos 60, quando emerge nos discursos artísticos: The concept public was a reference to the legacy of civil enlightenment, and conveyed the ideal of critical participation in the composition of societal life $e^{419}$. O espaço era concebido como pedaço de território livremente acessível, disponível para a comunicação social ${ }^{420}$ e a criação. Sem perder uma certa aura de iconicidade de-

415 Rosler, Martha; 'Fragments of a Metropolitan Viewpoint', in If You Lived Here, p.118.

416 Roth, Nancy; «Collaboration and Originality», in Collabarts; www.collabarts.com. Página consultada em Setembro de 2011.

417 Patrick, Keith; «Foreword», in in Advances in Art \& Urban Futures Volume I. Locality, Regeneration \& Divers[c]ities, Intellect, Bristol, Portland, 2000., p. 7. [...] by display, I include not only the physical environs in whcih ar tis exhibited, but the more nebulous philosophical context that determines our address to the art object.

418 Do museu à intervenção; do contexto à situação; ao activismo à participação.

419 Laister, Judith; «Public Space», in Sculpture Projects Muenster, 2007.

420 O termo foi definitivamente corrompido pela lógica mediática, que o usurpou ou uso inicial, destronando o conceito de meios de comunicação de massa. 
mocrática ${ }^{421}$, tem porém deixado de ser fundamentalmente acessível para ser consumível, On the one hand, a "structural transformation of the public sphere" can be noted: from being culture debated to being culture consuming. The public according to the discourse-influencing diagnosis by Jürgen Habermas, has been replaced by public relations, which is as an instrument of suggestion and manipulation, supplants critical processes of socialization. ${ }^{422} \mathrm{~A}$ estas 'relações públicas' vejo-as como parte de uma retórica total na cidade-cenário ${ }^{423}$ no seio da qual o poder, tomado por uma ideologia hegemónica, considera o Espaço Público supérfluo.

À crise do espaço público se associa a decadência da metrópole. O espaço público se apresenta como materialidade supérflua na aceleração do tempo e na percepção plana da paisagem urbana; espaço desnecessário quando a informação midiatizada substituizada substitui a experiência dos sentidos, ultrapassado pelo espaço acidental, heterogéneo, fracionado. ${ }^{424}$

Então,

\begin{abstract}
On the other hand, the "inhospitality of our cities in an age of increased modernization and automobilization was avowed, through which urban space was degraded to a functional element for movement. Today, public space is still being negotiated along these two paths of discourse - a call for critical-emancipatory participation in processes of societal composition, and a call for reclaiming the city as a forum for social Exchange, cultural localization, and collective-memory work. ${ }^{425}$
\end{abstract}

Algumas premissas projectuais do Espaço Público como racionalidade radical ou utópica, ou simplesmente vitalista, podem então ser articuladas a partir do questionar - em teoria e em praxis, por vezes em simultâneo- da pertinência da distinção entre espaço público, esfera pública e espaço/esfera privada (Rendell). Isso confirma, em todo o caso, que o espaço público é - ainda - um espaço de negociação de vários modelos societais, precisamente por via de acções centrífugas e extradisciplinares (Holmes), tão difíceis de compreender empiricamente quanto de controlar. ${ }^{426}$ Laister complementa, confirmando a orientação das minhas intuições: At the discoursive level, this search reveals itself in rhetorical constructions, such as "sites and non-sites", "contact zones," "splinter spaces" or "third spaces". Toda a teoria que acompanha a produção de obras de arte em espaços transicionais expande (Krauss) este 'jargão do espaço público dentro do jargão da arte pública crítica. The boundaries drawn around notions of private and public are not neutral or descriptive lines but are contours which denote specific value systems. ${ }^{427}$ São vários os pontos de vista ${ }^{428}$ para se enquadrar esta questão, todos passíveis de serem traduzidos em opções formais: o espaço público como espaço não-privado: são os lugares de um estar com os outros (interacção social) fora do círculo doméstico (Arendt); o espaço público como espaço livre: na linha de Habermas, um espaço disponível para o encontro dialógico ou colaborativo entre duas ou

421 Laister, p. 431.

422 Idem.

423 Villac, Maria Isabel; «Comunidade Politica no Espaço Público», in Arte Pública e Cidadania - Novas Leituras da cidade criativa, Caleidoscópio, Lisboa, 2010. A identificação da metrópole contemporânea se relaciona com a sua transformação em cidade cenário; a era tecnológica que permite "a concentração de uma "domiciliação" sem domicílio" e a crise das grandes narrativas que apontam para a decadência do espaço urbano e o esvaziamento do espaço público. A arquitectura estetizou-se e está ao serviço da representação. O espaço construído é confrontado pela imaterialidade dos vectores de expressão instantânea das imagens e das mensagens.

424 Idem.

425 Laister, p. 431.

426 Idem.

427 Idem.

428 Sigo a tipologia de Rendell, Idem, p. 19-20. 
mais esferas contidas ${ }^{429}$; o espaço público como democracia: definido pela acessibilidade, e ao mesmo tempo pelo que Chantal Mouffe enquadra nas ideias do conflito e da paixã $0^{430}$.

\section{Como pode a actividade artística - ontologicamente 'privada' - ser 'pública'? \\ Public art places 'private' art in 'public' space. Extrapolating this mode of thought, takes us to a far more disturbing position - where the 'art', believed to derive from the 'private' world, the personal interests of the individual artist, is placed into the 'public', where the public indicates a passive and homogenous body of people, rather than a collective group of individuals who actively identify with one another. ${ }^{431}$}

Nesta última ideia do espaço público como democrático - das acções monocelulares, de Alys a Régis Perray, passando por Wodiszco, às coreografias do colectivo (Jeremy Deller, Spencer Tunnick) - vem ao de cima uma necessária crítica - radical, cínica, irónica - do campo da arte, que dos incipientes gestos conceptuais e land às mais complexas formas relacionais contemporâneas, mais ou mais arquitectónicas, acaba sempre por ser um problema de lidar com a divisão cultural (elitismo) que a instituição-arte pressupõe. 0 espaço público da arte é por isso, hoje, o terreno de críticas populistas em nome do vernacular (Knight, citando Christo) ou do filistino (Freee, citando-se a si próprios). É aí que entra o modelo transicional de uma contínua emergência de um noema (informe) de espaço público: Thinking between is a way of moving beyond the binary of public and private. It is a liminal zone. ${ }^{432}$ Tal implica, projecto a projecto, na atitude projectual, equacionar as formas de espaço público disponíveis ou desejadas. E portanto, através da retórica específica de cada projecto ou obra, reconquistar para a arte um posição de humilde superioridade moral (Gross): To place art outside the gallery is potentially theatening, but also means that the role of the artist working in the urban real is charged. ${ }^{433} \mathrm{O}$ artista, o teórico, o público (a audiência) podem então todos (totalidade social) ser co-responsabilizados pela racionalidade imanente da urbe, multiplicando-se as oportunidades de acção: There are many locations between public and private - they can be spatial, methodological, emotional - concerned with places, processes and people. ${ }^{434}$ No jargão da arte pública, estão aqui plasmados os temas-instâncias do quotidiano, da situação, ou do dialogismo participativo na materialidade da vida urbana. Sigamos Rendell: The everyday is constituted through practices such as walking an shopping, and objects such as litter and bricks. The ordinary, the mundane, the repetitious allow a critique of 'fine art' and of 'cultural elitism', instead reinstating the importance of popular culture and the found object where the whole urban fabric can become a kind of art. ${ }^{435} \mathrm{O}$ que coloca uma questão-chave: But if the city is understood as art, when everyday urban fragments and practices already say it all, what is the role of the

429 Rendell, Jane; «Public Art: Between Public and Private», in Advances in Art \& Urban Futures Volume I. Locality, Regeneration \& Divers[c]ities, Intellect, Bristol, Portland, 2000, p. 20. In Habermas' view, it is the entry of the non-bourgeois class, the mass-media and the welfare state, that has eroded the origin of the public sphere - the secure border between the private and the public.

430 Idem: Chantal Mouffe argues instead for radical democracy, one that embraces conflict and passiom. For Mouffe, antagonism designates the relationship between a social identity and a constitutive outside that blocks its completion. A grande questão aqui é como exercer, na forma urbana, a resistência aos dispositivos de poder alienante da cidade contemporânea em toda a sua complexidade e violência. Mais: em que medida é operativa esta visão, apesar de tudo reactiva ao infinito social; isto é, em que medida a tradição antagonista é mais operativa, e/ou redemptória, que formas discretas de resistência moral ou espiritual. E em que medida existem modelos híbridos entre ambas.

431 Idem, pp. 19-26.

432 Idem, p. 22.

433 Idem, p. 23

434 Idem, p. 24

435 Idem, p. 24 


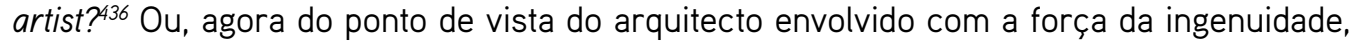
The distance between an amateur's bedroom and the world stage is improbably truncated. How might this be a "spatial practice" though? 437 Talvez seja o de aliar a produção de sentido à produção de povo, um povo urbano na multidimensionalidade da recepção-produção da cidade: This may tend toward the choreographic, where the work is manifest less as an object and more as an event, a series of relationships people make with another. ${ }^{438}$ Só tendo estas questões em mente pode a arte pública, na sua forma institucionalizada, evitar ficar-se por ser a product of a funding category [...] not a departure but an adjunct to the mainstream. ${ }^{439}$

\subsubsection{Museu, intervenção - rever o valor, a memória e a representação colectivos}

\subsubsection{Ritual da arte: o museu e o objecto}

O museu é um modelo de recepção para a arte, mais do que mera instância da sua fruição. ${ }^{440}$ Instituição moderna, o museu desenvolveu as bases de um dispositivo expositivo que tem um impacto tremendo na própria ideia de arte como percurso de valor (não apenas no seu raio de acção mais próximo, mas em territórios afastados da sua influência directa). O museu - como o salon ou a galeria - inscrevem uma lógica de poder simbólico específica, sob a forma de rituais sociais. Sucessivas vanguardas - de Dorner (do 'interior' do Museu, na posição do curador crítico) a Kaprow (do 'exterior', na posição do artista) problematizaram esse poder, do ponto de vista de um desejo de vida e de ligação arte-vida. ${ }^{441}$ Kaprow sintetiza: There is no essential difference between a Jean-Baptiste-Siméon Chardin painting hung in a museum and a Frank Stella painting hung in a museum. ${ }^{442}$ Daqui deduzo a equiparação operativa belo-museu; o belo é o que encaixa no dispositivo definido, reificado, hierarquizado, definitivo, do museu; por contraste, o sublime, é o que escapa ao controle do poder, seja nos regimes comunicativos do efémero, do acontecimento ou da participação ${ }^{443}$.

436 Idem.

437 Basar, in Miessen, Basar (eds.), p. 33.

438 Idem, p. 25. The making and receiving of art work is an economy - a series of relationships of Exchange between people. Art is not just produced by artists - $i$ tis the product of viewres, users, subjects and urban dwellers of all kinds.

439 Miles, Malcolm; Critical Spaces, p. 68.

440 Recorde-se que Duchamp não estava tão interessado no objecto de arte quanto na instituição arte. Ao levar Fountain para o museu, he was questioning the site-generality of the museum. In his action the museum becomes one specific site among others. (Lash, p. 32) Por outro lado, o crucial de $O$ Acto Criativo é a consciência da posteridade, ou seja da recepção, e uma recepção assumidamente alargada, da obra de arte, que prefigura uma retórica da atenção máxima ao outro-espectador, tropo fundamental de um social informe que brota no exterior da instituição, qualquer.

441 Kaprow, p. 57. The museum is thus a comparatively recent evelopment that we have assumed always belonged to the nature of art - though in fact most of the past did without it. And it is already obsolete. But even as art is becoming part of the world, more museums are being built to entomb it. It is tragic that painters and sculptors who have reviled the edifice as a tomb willingly consign their life's work to an early burial there. The only hope is that this process will soon stop and that modern museums will be converted into swimming pools or nightclubs.

442 Kaprow, p. 202.

443 O sublime, quando acontece no museu é por isso mais do que o belo celebrado, ele explode, suspendendo-os em consequeência da apropriação do público, os limites da instituição. Penso nas meninas de Velásquez lautonomiado-se da 
O museu é a moldura, o pedestal: Call the museums, concert halls, theaters, journals, and so forth frames of mind. ${ }^{444}$ Ora a arte que não se queira lou que sinta impelida por necessidade a fazê-lo) confinar ao museu pode agir como se o museu não existisse; mas pode também abordar o museu (o pedestal, a moldura, a modalidade, a disciplina) criticamente e chegar a uma crítica imanente (Groys), do museu em si e do museu como divisão cultural na sua relação com o socius ou o demos.

A Revolução Francesa criou o primeiro museu de arte moderna (Louvre), pensado como evidência de virtude política. Desde então, o Ocidente encara os museus públicos de arte como necessários num estado liberal desenvolvido. ${ }^{445} \mathrm{O}$ museu é um artefacto cultural que propõe uma experiência cerimonial complexa englobando a arquitectura, a disposição programada dos objectos, práticas de instalação altamente racionalizadas (Duncan). Em sociedades que separam o religioso (o espiritual) do secular, os museus (como as universidades) transportam um tipo de verdade específico, recolhendo determinados valores e memórias (teoricamente, as mais 'elevadas'), preparadas para serem experimentadas, num estado de receptividade liminal (Turner) cuja dimensão transformativa - teoricamente uma liluminação - é por princípio a aceitação de uma narrativa mais ou menos hegemónica las histórias contadas do programa político vigente). ${ }^{446}$ Para Duncan, uma via crítica é investigar de que forma um ethos de igualitarismo na invenção do museu ocidental poderá hoje ser revisitado, para além da ideia do museu como templo de apática civilidade, em que the political passivity of citizenship is idealized as active part appreciation and spiritual enchantment. ${ }^{447}$ Aliás, é por os museus serem poderosas máquinas de definição de identidades que os artistas das neovanguardas deles procuraram retirar uma cínica antagonalidade, assim como hoje ols) cinismo(s) neles encontram uma oportunidade para resistir (de Groys na teoria, a Sophie Calle na prática). Ou seja, e numa ligação ao terceiro tópico duplo deste capítulo, What we see and do not see in our most prestigious art museums - and on what terms and whose authority we do or don't see it - involves the much larger questions of who constitutes the community and who shall exercise the power to define its identity. 448

Anos 90 adentro, os museus, entretanto motores e signos de poder numa pós-modernidade que investe na reconstrução das cidades por via de operações urbanísticas - o Guggenheim, em Bilbau -, integram na sua programação toda uma geração de projectos institucionais que não deixam de cortejar o quotidano e a vida social no que transportam para o interior. Sophie Calle é eloquente exemplo desta vertente indoor do conceptual crítico ${ }^{449}$.

restante colecção do Prado) ou Guernica de Picasso (autonomizando-se do contexto da sua integração numa Exposição Universal).

444 Idem, p. 203

445 Duncan, Carol; «Art Museums and the Ritual of Citizenship», pp. 88-103.

446 Idem, p. 92. Of course, what the museum presents as the community's history, beliefs and identity may represent only the interests and self-image of certain powers within the community.

447 Idem, p. 94.

448 Idem, p. 102.

449 Cf. Godfrey, p. 404. Em 1994, a artista francesa realiza no Museu Boymans-van Beuningen Museum uma peça que funciona como dispositivo de visita guiada; nessa obra de som que envolve o espectador numa reminiscência extremamente pessoal, a voz de Calle é uma nova camada de significado na tecitura narrativa da própria colecção do Museu, uma posição de comentário artístico do mundo que, nomeadamente em Calle, tende a ser de atenção aos pontos de 
Algumas propostas de Calle (intervenção no Freud Museum, participação na Bienal de Veneza de 2007) são expressão de uma nova fase na relação entre os artistas e o espaço afirmativamente institucional do museu; se a primeira geração conceptual (Flynt, Smithson, Haacke) via no museu um factor inimigo da arte, os artistas neo-conceptuais utilizam o museu, encaram-no como um espaço - público em mais do que um sentido (Rendell) - onde negoceiam novos significados para o seu trabalho; e onde, no limite, há condições - um contexto -, para problematizar a própria noção de museu. E é neste quadro que muitos artistas se decidem eles próprios pela curadoria, levando o rigor da posição museológica para o espaço urbano; e outros encetam projectos de requalificação urbana que museologizam a cidade, como - para citar dois exemplos em que escala e simplicidade comunicacional andam a par - Deux Plateaux, de Daniel Buren ${ }^{450}$ ou L'Axe Majeure, de Dani Karavan.

Ora a haver um acto fundador da arte pública contemporânea, pode ter sido um afastamento crítico, estratégico, refundador, da categoria burguesa do Museu. O espaço social, público, urbano, político, são outros tantos lugares de uma vida a ser vivida que a obra de arte, em sede de momento, situação, instalação, poderá então integrar, muitas vezes actualizando as figuras do monumento e do memorial, através de uma ideia de intervenção excêntrica face às regras e ao habitus museológicos. No meu argumentário, isso decorre do facto de que 0 museu, também fora das suas 'quatro paredes', determina uma forma específica de atenção:

"Liminality", a term associated with ritual, can also be applied to the kind of attention we bring to art museums [...] a mode of consciousness outside of or "betwixt-and-between" the normal, day-to-day cultural and social states and processes of getting and spending. [...] Likewise, the Swedish writer Goran Schildt has noted that museums are settings in which we seek a state of "detached, timeless and exalted" contemplation that "grants us a kind of release from life's struggle and... captivity in our own ego." 451

A experiência de visitar um museu (ou qualquer centro de cidade 'museologizado') é portanto idealizada; desde logo como alargamento de perspectiva, mas num regime pessoal e controlado, pelo menos acríticamente identitário, ao contrário da intervenção artística urbana que se desenrola em processo dialogicamente contingente e transparência argumentativa, na construção periclitante do seu público específico. Outra coisa é certa: o museu trabalha a partir de um foco preciso, o do valor e necessidade do objecto - e do seu cuidar ${ }^{452}$ - na história cultural humana ${ }^{453}$ : The existence of such objects - things that are most properly used when contemplated as art - is taken as given that is both prior to and the cause of art museums. ${ }^{454}$ Ora Goethe, uma das primeiras testemunhas do desenvolvimento

contacto entre um mundo exterior e o mundo interior de que o discurso procura apropriar-se produtivamente. Neste tipo de intervenções (como as de Kosuth em 1990, no Brooklyn Museum, em que frases comentam as peças expostas; ou de Fred Wilson, que reorganiza secções inteiras do Maryland Historical Society, em Baltimore, para contar 'outra história' com os mesmos objectos), o museu torna-se repositório de coisas vividas, não apenas de coisas.

450 Buren, o inovador da arte na forma urbana efémera, realiza com Deux Plateaux (Paris), um exemplo notável de desenho urbano, gerindo uma noção decorativa da sua arte conceptual, com um sentido de medida e de integração que museologizam a cidade sem que isso signifique a mera afirmação da arte como distinção. Karavan...

451 Duncan, p. 74.

452 A profissão de curadoria tem a origem na instituição museológica.

453 O Centro Cultural expande essa filosofia para uma educação ou introdução à estética, num sentido mais amplo.

454 Duncan, p. 76. Importante notar que Carol Duncan o afirma em 1995, quando eu próprio procurava, fora do museu, um lugar para realizar a Dor. 
museo-lógico ${ }^{455}$, questiona cedo a ingenuidade e a bondade desta ideia iluminista. ${ }^{456}$ No fundo, tendo servido a emergência da cultivação (Eagleton) - o museu vê problematizada a sua validade crítica, numa esfera pública mais complexa que a de Oitocentos e sobretudo que aspira a mais democracia e mais cognição social generalizada. Talvez o museu esteja então para a vida lá fora como o centro urbano requalificado para o espaço público. Importante nuance porém: talvez uma museologização radical do espaço público traga uma noção de valor colectivo que torna a arte um acontecimento por excelência do mesmo, enquanto campo do estético (como em Deux Plateaux). Um estético que passa a integrar o funcional na sua 'racionalidade' plástica, isto é, na complexa materialização da obra - o que na cidade passa por outras formas hibridamente funcionais. A explosão da arte urbana (em particular a decorativa, de remota filiação Arts\&Crafts ${ }^{457}$ ) foi de resto a continuação da secularização - ritualizada, é certo - do estético:

$[.$.$] the invention of aesthetics can be understood as a transference of spiritual values from the sacred realm into se-$ cular time and space. Put in other terms, aestheticians gave philosophical formulations to the condition of of liminality, recognizing it as a state of withdrawal from the day-to-day world, a passage into a time or space in which the normal business of life is suspended. ${ }^{458}$

Por outras palavras, a disposição museológica - visando instruir e iluminar um público ao nível moral, social e até político, nunca desaparecendo totalmente, é substituída, na arte que critica o museu (Duchamp), por um desejo de partilhar, com o público, aspectos dialógicos do seu próprio valor. E se é recorrente a utilização da palavra 'graça' para descrever a sensação de iluminação que certos objectos de arte oferecem no ritual museológico ${ }^{459}$, é evidente que não é da mesma graça (beleza) que se trata nas obras de arte pública que inscrevem formas conviviais do sublime. No 'museu' o que se pode esperar é uma experiência de comunhão sublime com os espíritos brilhantes do passado, mas nunca o contacto com a efervescente imponderabilidade do presente social; a não ser em formas híbridas parcialmente 'desmuseologizadas' de celebração do tempo comum, lá fora, ao ar livre, em contacto com a imponderabilidade do clima. Termino esta secção com notas sobre o que seria um 'museu do futuro', que Peter Weibel coloca numa tensão axiomática entre a imagem-pintura e o espaço do mundo-rea ${ }^{460}$. Weibel defende que o problema da legitimidade da arte é secundário em relação à questão da competência ${ }^{461}$ - questão na qual uma ideia emergente de museu tem futuro:

If anyone and everyone can be an artist, and anything and everything can be art, then no one needs to be competent and no competence is required [...] In exemplary fashion, ar tis sinking to the bottom of an ocean of incompetence and becomes the iceabreaker of incompetence. ${ }^{462}$

\section{Idem.}

456 Idem, p. 77. Goethe, for example [...] realized that the very capacity of the museum to frame objects as art and claim them for a new kind of ritual attention could entail the negation or obscuring of other, older meanings.

457 Ou ainda a que transporta para a cidade a autonomia modernista (escultura abstracta).

458 Duncan, p. 76.

459 Duncan, p. 78.

460 Weibel, Peter; The Museum of the Future, in Miessen, Basar (eds.), p. 173. At happening and ambience, or object culture and installations, depart from the Picture as their arena of action and, in its stead, have taken reality by storm: the real world becomes their stage or showcase of action.

461 O termo tem sempre sentido linguístico e propriamente retórico.

462 Weibel, p. 174. Of course this apparent legitimising of incompetence is nothing more than incompetence in legitimisation. And of course there are underlying motives for such incompetence and illegimacy, which are, as always, of an ideological nature. 
É desta constatação que os mais viáveis projectos de intervenção urbana partem, em busca da activação da competência artística como Plastik social.

\subsubsection{Resgatar, activar, propor a memória}

O ser humano lida mal com o esquecimento. ${ }^{463} \mathrm{~A}$ anamnese (terapêutica da memória ${ }^{464}$ ) é um modelo que a arte tem para renovar o seu compromisso com um social para além da reificação museológica. Obrist sintetiza: There is only a now and there is only a here. If we lose memory, there is no time, there is only now. If we cannot move, there is no space: it becomes virtual..$^{465} \mathrm{Na}$ sua busca dos caminhos para o sentido urbano, a city embodies and enacts a history: ${ }^{466}$ It would be reductive to insist that no levels of mediation can exist between those who experience a situation and those who view it. ${ }^{467}$ Ou seja, a dupla consciência da arte como dispositivo mediador e representação dessa possibilidade dá seguimento à convicção de que it is not possible to change social reality without challenging its simplifying overlaid images. ${ }^{468}$ Tal passa, inevitavelmente, por blur "inside" and "outside", to abolish the distiction between the gallery space as a large, squarish room and as a world apart, a zone of aestheticis, ${ }^{469}$ mas sobretudo pela criação de momentos de memória na cidade: registos emocionais - não um marco, mas uma observação, uma forma de invocar pessoas e locais [...] na eterna busca da cidade por progresso empírico, 470 criando memórias alternativas, efémeras ou ficcionais, todas elas desfazendo e refazendo o tecer da memória colectiva. ${ }^{41}$ Noutra escala de investimento e perenidade recordo o memorial realizado por Peter Eisenmann para homenagear os Judeus assassinados na Europa - uma imponente peça de escultura-arquitectura-paisagem em cimento, tornada ícone cultural da nova imagem de Berlim.

Mas comparemos duas essenciais formas de a arte se entregar ao tempo de forma significante:

Oddly, when the sun sets after a summer's day, the field gives off the heat stored in the cement and creates a warm microclimate. But on the whole it's complicated, expensive, heavyhanded and pompous. Some of the overly fine details work against the harsch effect the ensemble seeks It's worth thinking abut whether monuments by artists such as the sometimes facile Jochen Ger $Z^{42}$ aren't more powerful and effective than this architect's 20000 tons of concrete. It's also hard not to compare Eisenman's design to the project of Renata Stih \& Friedler Schnock who wanted, instead of building a mment, to put up a bus shelter in the middle of the field and organize transportation to the various locations

463 Hobsbawn: [...] humans don't want to forget. It's built into them. In Obrist, p. 18. Aprender a esquecer seria não menos importante, na renovação do nosso compromisso com o agora da emergência.

464 Cf. Morgan, Sally J; «Memory and Identity in the Urban Landscape: a tale of two Barons», in Advances in Art \& Urban Futures Volume 1. Locality, Regeneration \& Divers[c]ities, Intellect, 2000.

465 Obrist, p. 19.

466 Uma conclusão que a levaria a aproximar-se da lógica do documentário, e naturalmente a integrar a própria noção de investigação-participação autocriticamente.

467 Rosler, p. 120.

468 Idem.

469 Idem.

470 Seno (Ed.); McCormick; Schiller; Wooster Collective; p. 83

471 Penso em projectos como Ghost Bikes (2003 -), em que surgem bicicletas e motos brancas nos locais onde se deram acidentes mortais com este tipo de veículo; ou The Pansy Project - Fuck off and Die Faggots!, de Paul Hartfleet (2007), que planta amores perfeitos perto dos locais onde foi ofendido por concidadãos homofóbicos. São uma espécie de arte folclórica urbana [cuja] temporalidade fora de portas [é um] meio para evidenciar a ausência. Idem, p. 82

472 O autor refere-se a 2.146 Stones - Monument Against Racism em Saarbrücken, de 1993, ou o Memorial Anfifascista de Saarbrücken, de 1986-93. 
of the Shoah. A less politically correct project than Eisenman's, but quieter too. His monument remains abstract and moderate, and and can never replace a visit to the extermination sites. ${ }^{473}$

Na forma urbana, tudo isto é naturalmente uma função da apropriação, capacidade de distinção estética e museo-lógica, e estas, como o monumento, evoluem e desenvolvem-se no tempo, como o mostram as fotografias de visitantes do memorial de Eisenman, passeando por entre as monumentais 'campas e, cinzento verde', de acordo com formas de atenção díspares e multidimensional. É precisamente da consciência desta deriva no sentido de intervenção múltipla que 0 artista parte para dar atenção a outras realidades (sociais/ relacionais) e concomitantemente de repensar o dispositivo estético de representação do seu trabalho de envolvimento. Quando Martha Rosler realiza, com If You Lived Here (1981), uma exposição que não responde aos cânones usuais do white cube precisamente para não abdicar de uma pedagogia de memória do público, esta pedagogia artística no exterior do museu torna-se pragmática: Despite twenty years of rethinking the art system, a spotty amnesia has broken out in this regard, and some have forgotten that the art-world audience isn't born but constantly constructed and reconstructed, laboriously, just like any constituency. ${ }^{474}$ Kirsten Hastrup fala numa textura imaginativa dos espaços sociais. ${ }^{475}$ Nestes termos, todas as nuances do memorial podem caber numa arte pública da memória colectiva, muitas vezes redemptória, das formas mais anónimas (graffitti, stickers) às mais institucionais, de que o monumento-memorial de Maya Lin às vítimas norteamericanas na guerra do Vietname é historicamente um modelo particularmente bem conseguido. ${ }^{476}$ Surge aqui a ideia de um tempo público, sendo que ora virado para o passado, destinado à vivência emotiva lo memorial em Lin, Gerz), ora para o futuro (visões experimentais de comunidades efémeras, como na dialogical art), ora ainda na pura materialidade do presente em festa (no festival) ou de urgentes cartografias (Acconci em Following Piece), todos estas situações tempos outros que o do museu. Haverá por assim dizer um tempo da rua, como aliás as 'artes de rua' em França se encarregarão de teorizar.

O afastamento do museu e/ou do white cube é ainda um espaço-tempo, outro teatro de operações, através de uma contínua reinvenção da liminalidade: I suggest that although theatre certainly is a particular place [como o museu], it is also one among other theaters of action in which people become caught up in their acts, so to speak. Social spaces emerge through a practicing of places. ${ }^{477} \mathrm{~A}$ intervenção urbana crítica que começa com um contestar da lógica museológica é uma reflexão que articula arte e memória - e a memória viva da arte - no espaço público como possível e potencial. A esfera pública torna-se assim plataforma de aparição, problematizando as exclusões implícitas nos modos de representação que dominam o quotidiano. Há um 'lá fora' como motor da intervenção - if art is to resist the totalizing effect of the spectacle the politicizing of art must be premised on an ethical commitment to exteriority; to that which

473 Ruyter, Thibaut de; «Peter Eisenman's Memorial to the Murdered Jews of Europe», in Art Press, Novembro, 2005, p. 41.

474 Idem, p. 124.

475 Hastrup, Kirsten; «All the world's a stage - The Imaginative Texture of Social Spaces», in Space \& Culture, vol. 7, n. 2, May 2004. "The social" itself is a performed space space, where notions of place, performance time, and coactors play a crucial role in tha shaping of individual actions. [...] meaningful action is always partly based on a sense of the plot in which one participates, and thus in anticipation of what will happen next.

476 A ponto de surgir no livro infantil de Barack Obama, como exemplo de arte.

477 De Certeau, Michel; 1984, The Practice of Everyday Life, Berkely, University of Califórnia Press, p. 117. 
resists (interrupts and disturbs) the completion of a political identity and its spectacular commemoration. ${ }^{478}$ Curtis, no fundo, aprofunda (na senda de Lyotard ${ }^{479}$ ) a visibilidade e a natalidade arendtiana nas expressão spaces of presencing and beginnings, ${ }^{480}$ ou seja, espaços onde não são necessariamente a comemoração, o consenso e deliberação (Habermas) dominantes, mas possam irromper como pluralidade escandalosa (Rancière), como política (que a própria Arendt, em A Condição Humana, contrapõe ao perigoso consenso). Tal é todo um programa de atenção à alteridade como em inúmeras expressões do micro-activismo. Em suma, a sociedade pós-industrial e hipermoderna exige múltiplas e renovadas formas de memória e de anamnese, e a arte crítica que se orienta para a intervenção urbana tanto antecipou esta ansiedade como muitas vezes a sustentou pragmaticamente redimindo-a. Untitled Monument, de Rachel Whiteread ${ }^{481}$ é uma peça que situa este conceito da aparição da anamnese; sempre de base discursiva, apesar do seu poder contravisualmente desestabilizador:

\footnotetext{
[...] while still working in the spirit of Lyotard's writings, which constantly turn us toward an exteriority that disturbs our realm of intelligibility and representation, I think it is helpful to borrow something akin to Bakhtin's (1981) conception of language with its copresent centripetal and centrifugar forces to see that one need not abandon communication while bearing witness to the incommunicable. [...] One might add that it is also dependent on the genre of discourse, to use Lyotard's idiom, in which the utterance or action takes place. In this manner, we can see a range of communicative practices at work in the space of anamnesis signalled by Whiteread's sculpture. It is possible to separate Untitled Monument into at least four generic moments which I will distinguish as the historical, the formal, the technical and the ethical, with only the ethical being the moment of anamnesis. ${ }^{482}$
}

Pode-se então perguntar: a partir de que momento e em que termos é a intervenção no tempo e na memória da cidade inteligível e instrumental? Quando uma arte popular (Knight) conquista o espaço público com o seu eloquente domínio do estético? Ou quando, numa sociedade apática, o choque despoleta a comunicação? Ou quando no anonimato da noite, a poesia irrompe nos muros decadentes de um bairro social? Mas então e as intervenções permanentes, que contribuem para a progressiva identificação dos cidadãos com a sua cidade ${ }^{483}$ ? Ou as intervenções inscrevem a temporalidade do efémero de uma forma rigorosamente cognitiva - penso no modelo latente em The Battle of Orgreave, de Jeremy Deller? Memoriais, comemorações, festas, festivais, artes da rua, street art podem então adquirir valor anamésico - até face ao corpus da arte historicamente consagrada, dentro e fora do museu - , uma vez haja essa co-constituição pública (a posteridade em Duchamp), e isso de acordo com a forma como os seus interventores conquistaram quer os cheios (património, identidade), quer os vazios (não-lugares) da cidade. $A$ verdade é que se espaços como praças monumentais com estátuas equestres ao centro ${ }^{484}$

478 Curtis; Spaces of Anamnesis - Art and the Immemorial, 2004, p. 1.

479 Lyotard, Postmodern Fables, Minneapolis, University of Minnesota Press, 1997, p. 216.

480 Curtis, p. 2.

481 Também House mereceria destaque neste ponto. Dou destaque a esta artista pelo factode ser amplamente reconhecida no campo da arte e estas peças terem sido polémicas.

482 Curtis: Her response to the request to fill the empty plinth and temporarirly "complete" the Square was to re-present the void; to restate the absence or lack that she was asked to negate. The transparent cast is in many respects and antimonument, and yet such an oppositional reading fails to address what is at stake here. Untitled Monument is not a snub of traditional architecture and monumental sculpture; rather it traces its own contradiction, namely that such memorial politics can only function through forgetting.

483 Obras reconhecidas sobretudo pela capacidade de gerar a apropriação quotidiana, muitas a vezes a longo prazo, como a famosa sereia de Copenhaga, ou em Lisboa, a efígie de bronze do poeta Fernando Pessoa sentado junto à Brasileira, acompanhado por milhares de turistas que ali tiram a sua fotografia.

484 Recordo que na Praça da Figueira em Lisboa, o projecto camarário de deslocar a posição da estátua equestre, para se ganhar uma vista coerente, é um exemplo raro de subtil adaptação do pré-existente a uma visão contemporânea, com um cuidado que se torna potencialmente crítico, pelo menos em termos de desenho urbano. 
(ou, festivais efémeros sem implicações críticas) claramente demonstram a relação intrínseca entre política hegemónica e arte 'oficial' - aliás como a utilização de espaços nobres da cidade para celebrações cujo motto é essencialmente comercial485 -, isto é, a utilização da arte como veículo para uma narrativa histórica (heróica, valorativa, forte), é neles que a estetização da politica de que fala Benjamin não apenas está mais presente como mais dissimulada.

\section{Resistir lá fora, intervenções soltas}

E é esta 'política' que tem de ser objecto de resistência na arte pública crítica. This resistance, however, is misguided if it makes art necessarily complicit, that is, if art is seen to be in some fundamental way dangerous when thought in relation to politics; that art somehow infects politics with an unreality, or automatically assists politics in the construction of an illusion. ${ }^{486} \mathrm{Em}$ resposta a esta questão, a politicização da arte implica o desafio ao senso comum nos lugares comuns da afirmação da comunidade, virando essa comunidade programaticamente para o seu próprio exterior: In a world threatened by the certainty and beligerence of political actors, such an intervention must not be desmissed. 487 Lá fora, a obra de arte pública compõe com o real (metáfora musicall: Every utterance for Bakhtin, and this can be extended, I believe, to every action, is a play of assonance and dissonance, of unity and disunity, with the balance between centripetal and centrifugal forces operating to a different degree in each case. ${ }^{488}$ No caso da arte pública, vários autores (Maderuelo, Abreu) colocam por isso a questão da intervenção do memorial como resultante da falência quer do museu, quer da função credível do monumento, desde o momento-charneira que dá origem ao movimento da arte pública conceptual e portanto à sua vertente contextual e participativa. Maderuelo refere explicitamente que a morte simbólica do monumento decorre de um problema de comunicação, retórico, e que é dessa situação que surgiu uma nova e multíplice monumentalidade quotidiana. A propósito da tradição estatuária que nunca deixou de ir sendo produzida mas sempre com um impacto mais residual e motivando cada vez maior distância por parte do público:

[...] esta falta de credibilidade deve-se fundamentalmente ao facto de se terem perdido algumas das qualidades que definiam e caracterizavam os monumentos da era clássica, tais como a capacidade de dar significado, ao criarem-se esculturas sem tema que, devido à sua generalidade, carecem da capacidade retórica de mover o espectador [...] Por poucas palavras, durante o século XX perdeu-se a lógica e a coerência da arte monumental urbana. ${ }^{489}$

Esta falência, paralela à do modelo do museu como espaço de reconhecimento social do valor da criatividade, enquadra a deriva contextual, cujas formas híbridas de comunicação, conjugando vários media, como na instalação, vai entender o contexto - para Lucy Lippard, o lugar em toda a sua complexidade constitutiva - no seio das suas preocupações ${ }^{490}$. E ao fazê-lo buscou o sentido vivido da cidade, especialmente no tempo alernativo da arte, como

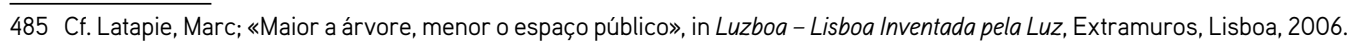

486 Curtis.

487 Curtis. De qualquer forma, a ideia de intervenção vai ser tanto mais operativa quanto integrar uma questão que Curtis não aborda explicitamente no seu artigo, a questão dos lugares de memória (Pierre Nora) e da sua relação com a arte pública. Mas também a questão do lugar como totalidade (Norberg-Schulz, 1980), aspectos que José Guilherme Abreu aborda em «Um modelo fenomenológico para escultura pública», in Revista da Faculdade de Letras, Porto, 2003, I Série vol. 2, pp. 385-418.

488 Idem.

489 Maderuelo, Javier; in «O Fenómeno da Arte nos Espaços Públicos», in Vv. Aa,; Espaço Público e Interdisciplinariedade, Centro Português de Design, Lisboa, 2000, P. 242

490 Lippard, p. 284. 
nas reinterpretações de Jeremy Deller, nas plataformas mediáticas de Stalker, nos processos colaborativos de Santiago Sierra. Agarrar o espaço, a oportunidade ${ }^{491}$, na sua 'soltura', talvez seja a metáfora apropriada para esta ideia de intervenção da arte na cidade, fora do confronto da sua instituição monumental ou museológica.

For a site to be loose, people themselves must recognize the possibilities inherent in it and make use of those possibilities for their own ends, facing the potential use of doing so.

The possibility to become loose will occur varies with place (or building) type, types being the categories cultures have developed to organize the world, their beliefs and activities (Scneekloth and Franck 1994). Some types are purely imaginary (heaven, hell, utopia); others refer to kinds of places found on the earth (beach, river, forest, desert); and others result from humanmanipulations and constructions (field, house, park, street, sidewalk, plaza, playground, library, prison). Types order activities and the manner of carrying them out. 492

$\mathrm{E}$, naturalmente, one way to think of a type is an interconnected set of features of form, use and meaning, often particular to a specific culture and historic period (Franck 1994). ${ }^{493}$ É o que fazem os criadores intervencionistas, seja por conquista do espaço, dissidência e contra-consumismo, ou recuperações ambientais: ${ }^{494}$ We try to take familiar sites and open them up to new readings and possibilities 495 - o que exige a abertura para o entendimento da própria escultura antisocial ou anti-pública:

Squattant l'espace public, s'appropriant les tropes de la sculpture in situ ou confisquant les missions de la monumentalité, ils développent une relation ambiguë à leur proper statut de merchandise, et semblent oeuvrer contre les balises idéologiques de la sculpture publique, non sans flirter avec un certain cynisme. [...] La sculpture anti-publique briserait le lien la rattachant à l'espace social, voire renverserait complètement son «utilité» supposee. Une sculpture antisociale, dénigrant la société, ses mécanismes d'intégration, ses autorités d'agrégation et la bienséance de ses usages collectives. 496

Aliás, Cette sculpture squatterait l'espace public ou détournerait les tropes de la sculpture in situ à des fins radicalement opposes à celles que pursuit cette dernière, et par cette confiscation indigne, démontrerait la vanité des ambitions de réforme sociale de l'art contemporain. 497 Há uma arte que provoca as próprias expectativas da sua função de ligação arte-vida, e é nisso inversão dos laços sociais - Tilted Arc de Richard Serra é por isso discutido há décadas, porque a sua posteridade é crítica, e o seu cinismo pertinente, para não dizer persuasivo. Paralelamente, noutros casos, temos aquilo a que Dewar chama o grau zero do monumento, ${ }^{498}$ como se me afigura neste quadro Public Sculpture Tackle, autodenominada The Bruce High Quality Foundation placa uma escultura pop de Robert Indiana las mesmas que estiveram em Lisboa, aparentemente, perante a apatia geral).

491 Parafraseio Franck, A. Karen; Stevens, Quentin, Loose Space, Routledge, London. «Tying Down Loose Space».

492 Idem. É na concatenação com esta ideia de um espaço solto que a ideia de espaço público pode ser imaginada, entreos traços de acessibilidade, liberdade de escolha, densidade e variedade de população (aspectos 'positivos') e os de privatização, mercantilização, sendo que estes últimos, although they are privately owned and accessibility and freedom of action are curtailed, they still offer opportunities for unexpected actions.

493 Idem. Dois exemplos: o cultivo de jardins em frente ao palácio imperial de Viena, num memorial temporário às faltas de mantimentos no final da II Guerra Mundial; em Lisboa, a recente ocupação da Av. da Liberdade com uma monumental 'quiinta' (porém visivelmente patrocinada por um hipermercado).

494 Parafraseando títulos de capítulos de Trespass, ed. Ethel Seno (2011).

495 Thompson, Nato; «Trespassing Relevance», in The Interventionists - Users Manual for the Creative Disruption of Everyday Life, MASS MOCA, 2006, Los Angeles, p. 18.

496 Idem, p. 56.

497 Idem.

498 Idem, p. 67. 
Seja como for - e mesmo na arte que contribui para a cidade com momentos de urgente sustentabilidade (Adam Purple, The Garden of Eden, 1982-1986; arrasado pela Câmara Municipal de Nova lorque, contra a vontade dos moradores - There is no political consensus among interventionists. Interventionism is not a political movement disguised as art. ${ }^{499}$ Instado acerca do que para ele significa a ideia de intervenção, Wodiczko responde, englobando várias das temáticas do meu argumentário no seu statement:

I try to contribute to the process of transformation of the fearful silence of the invisible and unheard city residnets (the participants) and of the deaf ear of those who are visible and heard (the public) into agonistic public discourse of 'fearless' speaking and listening. My artistic method has consisted of creating a socio-aesthetic situation that allows, inspires, and protects a process where others may become (if only in brief) artists themselves. In this way my art may be used as a transition in the development of their lives and the lives of others. An articulation of the city silences and transmissions of the regained inhabitant voices - a newly developed 'response-ability,' practiced with a sense of responsibility is, in my opinion, an intervention. ${ }^{500}$

Ícones desta posição são precisamente as projecções não autorizadas de Krzyszlof Wodiczko sobre monumentos. Em 1983, numa altura em que o Partido Democrata Cristão da Alemanha Ocidental pretendia distribuir mísseis Pershing 2 pela principais cidades, projectar a imagem de um destes mísseis sobre a coluna de um monumento militar do século XIX, respondia tacticamente a uma questão crítica. ${ }^{501}$

Quanto à questão da tensão entre o museu (e a instituição) e a intervenção (no espaço público), concluo:

Fashionable or not, however, political art has continued, albeit off the art world radar screen, thoroughout the 1990's, The most telling point of departure for this "off the radar" art practice is its increasing emphasis on the tactics of intervention. Instead of representing politics [...] they place their work into the heart of the political situation itself. "Tactics is the key term for discussing interventionist practices [...] the term "tactic" as a manouvre within the game which, for the interventionists, is almost always the real world. Their projects are made to operate within and upon systems of power and trade using the techniques of art. ${ }^{502}$

Mais: If it's true that artists operate as both a social litmus of politics today and a harbinger of politics tomorrow, then this is a good time to survey the field. ${ }^{503}$ É um território que implica a consciência dos contextos possíveis e o desejo de criar situações. Estas, para Weibel, correspondem a uma possibilidade de enfrentar um crise de competência ${ }^{504}$, no sentido de encontrar soluções para um dos problemas mais prementes do séc. XXI - a relação da arte com as massas. ${ }^{505}$ Do infotainment (Weibel) dos museus interactivos, com impressivos gráficos que deleitam o espectador (mas não lhe oferecem a experiência da esfera pública, nem sequer a burguesa) à experiência cognitiva da auctoritas museológica vai uma distância que muito poucos projectos percorrem, porque não têm a consciência de que The museum

\section{Idem, p. 21.}

500 Wodiczko, in Thompson, p. 28.

501 Note-se, de Wodiczko, quase sempre, procura autorizações prévias para as suas intervenções.

502 Thompson, pp. 13-14.Tactics can be thought of as a set of tools. Like a hammer, a glue gun, or a screwdriver, they are means for building and deconstructing a given situation.

503 Idem.

504 Perante o facto de que nos museus expõem as mais das vezes imagens e representações e não as acções concretas na esfera do social (dá o exemplo do activismo Greenpeace), ao mesmo tempo que 'douram a pílula' da complexidade social em nome de pedagogias do estético 'paternalistas', What remains, the, is to assuage the guilty consciences of potential museum visitors and to rob these persons of heir ability to differentiate critically so that they can really take pleasure in what they see; [...] To put it concisely, the legitimacy crisis serves a purpose, namely, to justify the pressure puto n museums to chieve quotas. And the crisis of competence, in turn, serves the purpose of legitimising incompetence. Weibel, p. 176.

505 Weibel, p. 176. 
is and remains a collective memory, just as its works are land remain) parts of a collective biography. ${ }^{506}$ Permanecendo instrumentos de comunicação, e experimentação de protocolos artísticos diversos ${ }^{507}$ - uma ecologia do dispositivo -, os museus do futuro lassim como os eventos que traduzem o 'museu' para a 'rua', como algumas das mais marcantes iniciativas de arte pública ${ }^{508}$ ) podem contribuir para libertar os visitantes de um papel passivo enquanto consumidores. É isto que tem dado posteridade à posteridade de Duchamp, hoje numa conscientização da interacção cidadã e da interculturalidade, informadas pela teoria dos sistemas (Luhmann): An artist is only one actor out of many other actors of equal worth in the social field of culture. ${ }^{509}$ Isto justifica que muitas 'partidas' do mainstream museológico pareçam resumir-se a isso mesmo (mesmo sendo mais que isso): The production of art must be seen from the standpoint of a multiplicity of social componentsand institutions, whereby the work itself or the artists are only one component out of many. ${ }^{510}$ Pelo menos, é neste sentido que encaro o intervencionismo artístico como uma partida de sentido cognitivo, começando por rejeitar o mito da neutralidade espacial do white cube. Talvez sejam até estas partidas que têm ajudado o museu a redescobrir o seu poder (Groys) e um significado heterotópico (Weibel) no quadro das indústrias culturais, por vezes abraçando a imponderabilidade da evolução social - The museum of the future can thus be understood to be an unpredictable, incalculable, high-risk but risk-loving institution. ${ }^{511}$

\subsubsection{Contexto/situação - equacionar o lugar, a temporalidade e os limites do objecto}

Para Lippard, contexto e lugar ${ }^{512}$ são indistrinçáveis, numa perspectiva da arte como possibilidade de ostentar laços mais fortes entre acção, espaço e acesso público. Uma place-specific public art $t^{513}$ exige ao acto artístico que se torne parte do contexto em que decorre, tanto quanto possível levando o lugar a significar mais para quem nele vive ou onde passa tempo. ${ }^{514} \mathrm{Na}$ forma urbana (das cidades norte-americanas e algumas europeias), é uma atitude que veio questionar um quadro típico do pós-guerra: pedaços de cidade definidos por uma conjugação entre esculturas modernistas banais, desenho urbano funcional pobre e uma entediante atmosfera suburbana. ${ }^{515}$

\footnotetext{
506 Idem, p. 177.

507 Weibel destaca as interactividades intuitiva (Fluxus) e exacta (computer art), nos extremos de muitas outras gradações de entendimento partilhado. Weibel, p. 179. A operatividade de muitas neovanguardas relacionais baseia-se neste tipo de protocolo com o espectador, concretizado em 'instruções de uso' para o dispositivo-arte.

508 Penso no paradigma que é Over the Edges (2000), com curadoria de Jan Hoet, na sequência de Chambres d'Amis, de 1986, ambos na cidade de Ghent.

509 Weibel, p. 180.

510 Idem, p. 182.

511 Idem, p. 186.

512 Abordo a questão do contexto por via de Lucy Lippard (autora do seminal The Lure of the Local, 1997) e depois por via de Un Art Contextual de Paul Ardenne (2004).

513 Lippard, p. 263.

514 No limite, como quando ocorre a passagem de uma especificidade de instalação para a transferibilidade de uma praxis do lugar. Cf. Vaz-Pinheiro, Gabriela; From Specificity to Transferibility: Debating Place-Specific Art Practices, in Artinsite, Torres Vedras, 2004.

515 Idem.
} 


\subsubsection{Da arte contextual à arte da rua, a situação como encontro urbano}

Em continuidade com Lippard, Ardenne propõe hoje a designação 'arte contextual'516 para práticas que, no fundo, são as abordadas pela americana.

Sous le terme d'art "contextuel", on entendra l'ensemble des formes d'expression artistique qui différent de l'ouvre d'art au sens traditionel: art d'intervention et art engagé de caractère activiste lhappening en espace public, "manouvres", l'art investissant l'espace urbain ou le paysage (performances de rue, art paysager en situation...), l'ésthétiques dites participatives ou actives dans le champ de l'économie, des médias ou du spectacle. ${ }^{517}$

Esta arte contextual aparece-me como possibilidade da actualização do termo-chave dos situacionistas, situação. ${ }^{518} \mathrm{Um}$ conjunto de títulos numa revista recente ${ }^{519}$ (concanetadas a versão francesa e a tradução para inglês, permitem compreender certas operações conceptuais) sugere todo um campo semântico e de acção plástica na cidade.

L'ESPACE PUBLIC EST DEVENU UNE FICTION / Public spaces have become a myth / ELOGE DE LA PARTICIPA(C)TION / In praise of participation / NÉCESSAIRES MISES EN SITUATIONS / Highly valuable test runs / A QUI L'ESPACE PUBLIC? / Who do our public spaces really belong to? / RUE LIBRE / Freedom of the streets / TRAFICS INTIMES / Intimate goings-on / PRODUIRE LA RENCONTRE / Producing encounters / ILOTOPIES, LES UTOPIES AU TRAVAIL DE L'ART / llotopia* - art as a catalyst for utopian vision ${ }^{520} /$ CONSTRUIRE DES INSTANTS DE JUBILATION COMMUNE / Building moments of communal jubilation / NE DITES PLUS «ARTS DE LA RUE» / Don't call it "street art". 521

A perspectiva contextual é um modelo de comunicação, proposta retórica a de transmutação dos contextos em acções específicas das quais é possível inferir um complexo saber urbano (dimensões social, arquitectónica, jurídica, etc) ${ }^{522}$ o que é exponenciado pelo facto de que Enfrentar o contexto é tornar inevitável a "resposta" a esse contexto (Ardenne). Resultado da presença e contínua reconstituição de um ou vários públicos, ao contrário do que acontece com uma arte da interpretação (o teatro tradicional), ou da exposição (as artes plásticas tradicionais), ou ainda nas red carpet arts, na arte contextual os significantes não são integralmente elaborados a montante, mas antes se deixam modificar contextualmente. Na sequência da expansão do campo da arte (Krauss) e das experimentações in situ do happening, mas também de um desenvolvimento fulminante das artes do espectáculo (a cultura dos eventos) e do seu mercado, a arte contextual é um novo termo para uma 'velha' valorização plástica, a do processo da arte na vida, no espaço e na esfera públicas. Ardenne vai buscar outras genealogias que o campo estrito da arte contemporânea tende a menosprezar; e assim, pouco depois de Bourriaud cunhar a expressão 'relational aesthetics' (1998), sugere a importância de uma remota filiação das artes de rua quer nos mistérios cristãos da Idade Média, quer do Globe Theatre de Shakespeare, quer ainda o teatro de vanguarda russo logo após a revolução de Outubro. Nas várias genealogias em campo, uma fundamental para quem se

516 A origem do termo poderá recuar até ao sociólogo Guy Sioui Durand, que é quem primeiro terá avançado o termo art en context réel.

517 Ardenne, Paul; Un Art Contextuel, 2002.

518 Ardenne, Paul, in «Lieux Publics», Centre National de Création, 2008.

519 Idem.

520 Nota do tradutor: ilot, em Francês tem o significado de 'pequena ilha ou comunidade'.

521 Cf. «Lieux Publics», Centre national de création, 2008

522 Algo no termo contextual é mais abstracto, analítico, axiomático, que o termo mais complexo, senão 'sujo' de 'lugar', o que me leva a priviligiar, não sem todas as reservas, o primeiro. É como se contexto permiti-se uma posição mais fria e ao fim e ao cabo mais desengajada que a de lugar. Talvez se trate de uma mera questão de ressonância simbólica do termo (mais intelectual o primeiro, mais existencial o segundo). 
posiciona face ao mundo da arte, é a que nos chega por uma via da vanguarda, retirando da crítica da autonomia - e, concomitantemente, da anomia - um ethos projectual que procura sedimentar a autonomia do campo artístico face a outras dinâmicas do socius, mais que a mera imersão total da obra e do trabalho artísticos no tecido urbano. A esta luz, cette autonomisation lque leva à criação dos primeiros museus de arte moderna, precisamente por artistas) réussie a sa contrepartie: elle isole l'art nouveau du public, elle le spécialise 'l'exès, elle tend à le rendre étranger à la culture collective. ${ }^{523}$ É uma situação que apenas nos anos 60 terá uma significativa (e global, Scholette) reacção no sentido da apropriação do espaço público pela arte - critica e não-crítica - , uma reacção que Ardenne não deixa de relacionar com as experiências de Piscator e de Wagner ${ }^{524}$.

Ardenne pensa numa arte que intervém por via da interpelação: Si l'on cherche l'efficacité, on interpelle son prochain partout où il se trouve, quel que soit l'endroit où il se trouve. ${ }^{525}$ Esta é uma deriva urbana e comunicacional de uma arte que teatraliza a rua transfigurada em gigantesca sala de espectáculos, num tempo de experimentação «grandeur nature». Orquestrando a acção, o artista que, desde o ready made e agora perante a sociedade da comunicação, procura transpor para a actividade estética e plástica uma problematização dos consensos, considerados, como em Lippard, perigosos: Dans les sociétés três normalisées [...] relèveront de l'"art" le plus intéressant a priori les créations qui ne se satisfont pas de surproduire de la conformité mais celles qui instillent dans la mécanique du controle une figure d'indiscipline, d'irréducibilité à la normalisation. ${ }^{526}$ Nestes termos, os 'instantes' comunais de certas peças são momentos-argumentos numa re(apropriação) individual-colectiva do espaço público, que muitas vezes se torna objecto de profundos mal-entendidos, dada a hibridez sócio-cultural das práticas em questão: L'animation pour destin - et les artistes, dans ce nouvel espace du Spectacle triomphant, comme les alliés de la lobotomisation générale ${ }^{527}$. Em resumo, a haver uma arte crítica característica da condição urbana contemporânea, nas democracias ocidentais, ela é contextual, porquanto pensa a vida do socius caso a caso, contexto a contexto. No limite, a posição de Ardenne não exclui a demagogia participativa ${ }^{528}$ ou um benévolo populismo (Knight); mas muitas organizações estão dispostas a correr esse risco, quando o que pode ser ganho é uma experiência de instantes de júbilo comunal. Basta qui evocar a experiência que os artistas retiram da contextualização vernacular da sua praxis: Quand tu t'addresses directement aux gents, il y a la vie en face!, explique Léa Dant. L'alchimie se fait à deux, c'est três palpable. Ce type de spectacle ne done jamais lieu exactement à la même rencontre. [...] Mais pour dire quoi? ${ }^{529}$ Conclui Georges Matichard, do colectivo Restins Vivants: «Se mettre un peu en travers du sens des choses, c'est déjà le premier déraillement, c'est là que

523 Ardenne, Paul; «Art International de Proximité», 2008, p. 5

524 Idem, p. 5

525 Idem.

526 Idem.

527 Idem, p. 9. N'exagérons pas. [...] La chance de l'Occident, et de l'union européenne en celui-ci, c'est la continuité active, in útero, de la démocratie politique et son souci aigu, cette dernière serait-elle en butte aux tentatives forcenées de régulation du capital (faire du profit) et des pouvoirs institués (maintenir la culture dans le périmètre des productions soumises et non séditieuses. A arte contextual implica uma politica (cultural) alternativa.

528 Bordenave, Julie; Idem, p. 11.

529 Idem, p. 11. 
commence l'imagination. [...] Ce qui m'intéresse, c'est de dire a tout le monde "attention, le jeu n'est pas seulement dans ce qui est produit, mais aussi dans votre façon de regarder"».530

\section{A situação, hoje: o acontecer da cidade}

No reino da acção (Aristóteles) - o lugar da esfera pública como espaço público - contexto e situação são dois termos-chave numa abordagem sensível da cidade ${ }^{531}$ e na consciência plena de que a situação é a modalidade formal da interpelação do urbano que, definitivamente, permite que petites formes possam gerar grands effets. ${ }^{532} \mathrm{Na}$ eloquência de cada projecto, a situação é um entrelaçar (entremêlement), da temporalidade projectual: c'est trouver le moyen de stopper le flux, marquer une pause: nous rappeler avec qui nous vivons et dans quel espace [...] d'inventer un mode de rencontre entre tous [...] faire un numero de séduction [...] le temps d'une expérience commune ${ }^{533}$... Assim, é o sentido (Lippard) que revitaliza os lugares intervencionados. É na situação - mais táctica que estratégia - instância geradora de momentos (no público, ao nível da experiência individual mas também grupal, comunitária ou colectiva), que a arte pública se transforma em retórica crítica da forma urbana, tanto quanto as suas premissas, valores ou mecanismos de funcionamento forem sendo capazes de ser partilhados pelos intervenientes. ${ }^{534}$ Mas atenção: é preciso devolver ao termo situação uma pureza intencional:

At any rate, with "we have a situation here" we have moved far away from the days of the situationists, and from their zealous celebration of the situation, which was seen as a sensual liberation from metanarratives and from the Great political and moral lies of that era. Today we can no longer understand this aspect of sensual truthfulness, because we have lost precisely this sensuality from our image of the situation as a vehicle. [...] today it seems to be not something that one should experience, but that one should always have under control, should always dominate. ${ }^{535}$

Na contemporaneidade, a 'situação' perdeu por assim dizer em momentum filosófico e místico o que ganhou em proficiência projectual (Claire Doherty). Por via de uma evolução dos conceitos de contexto e instalação, esta redução da situação acompanha o desvanecer de termos que se vão tornando apenas remotamente operativos (pelo menos para o grande público, como o trágico aristotélico ou o infra-mince duchampiano; a situação revela-se elemento básico da gramática da arte urbana. [...] it is precisely this putative lack of context or this vehicular character of the situation as opposed to its condition or position, which makes it so fit to be a basic element that prevailing understanding of history. ${ }^{536}$

\footnotetext{
530 Idem, p. 12.

531 Idem, p. 23. É nesta perspectiva que na Terceira Parte abordo situações urbanas que pensadas para responder eloquentemente à questão do contexto e do lugar, de acordo com diferentes modalidades, registos e intensidades de atenção, empatia, envolvimento.

532 Kahn, Fred; in «Art International de Proximité», 2008, p. 26.

533 Adolphe, Jean-Marc; in «Art International de Proximité», 2008, p. 20.

534 A questão do dispositivo face à infinita imponderabilidade do quotidiano social urbano A arte genuína, programática e radicalmente participativa inscreverá estas questões; mas em casos menos conseguidos apenas reproduz a própria ideia reificada de uma participação encerrada na mentalidade burguesa, supondo que o papel do cidadão se encontra definido e 'fechado' à inovação; ou que o papel do espectador e inerente distribuição do sensível está definitivamente decidida nos parâmetros actuais disponíveis.
}

535 Röggla, Kathrin; «Situation», in Sculpture Projects Münster, 2007, p. 451.

536 Idem. 


\section{Encontros urbanos}

Em Urban Encounters, Helen Liggett ${ }^{537}$, entregue ao fascínio da vida urbana, propõe, o conceito (activista) de situation awareness. ${ }^{538}$ These encounters are based in urban experience without pretending to tell the truth or even to construct a narrative about the city. Rather than assessing the city as a site of economic production or as an object of governance, this work seeks out cities as places of life. ${ }^{539}$ Vejo aqui aqui uma espécie de redenção do olhar e da consciência, através de um encontro com a gramática básica do social urbano, o essencial da vida na cidade. É um encontro sempremergente (Thrift) em que the joys of looking around are combined with the deep pleasures of making connections. ${ }^{540}$

Para que o encontro com o urbano aconteça, há que desenvolver o conceito de situação como revelação/desvelação de ideias feitas e preconceitos que, embebidos nos códigos culturais, impedem a experiência da relação com a cidade que é espaço vivido lo grande tema de Lefèbvre ou Certeau). Para tal, Liggett propõe quatro grandes tópicos, o urbano, o espaço, a cidade e a rua, que aborda fundamentalmente através da recuperação comparada de autores como Benjamin, Lefèbvre e Foucault. Se o seu objectivo na secção Urban é desmontar ideias feitas (mormente do marxismo clássico) acerca do tecido social (priviligiando o sentir sobre o cognitivo na abordagem do problema fundamental das classes sociais); e na secção Space é chamar a atenção para a coexistência complexa entre espaços heterotópicos e a ordem espacial geral, normalizadora; é em City e Street que procuro uma posição de síntese sobre a situação (intervenção plástica) e uma ponte para uma redenção especificamente urbana para o tópico do efémero. $\mathrm{O}$ seu entendimento do espaço da cidade é fundamental para compreendermos o que é determinante na condição da nossa luta quotidiana com a cidade pós-moderna:
In early modernist theory the city and the culture of industrialization were often conflated. To read the city was to write about modernity. At the same time the city was accepted unproblematically as bounded physical and social space. Today, in contrast, the city is better understood as subset of contemporary urban practices. Compared with the bounded chal- lenges understood as traditional issues of modernity, we wander through an age without borders or boundaries. Rather than moving between clearly defined urban life and a nostalgically rendered rural existence, we are part of a global urban culture. Rather than relying on the need to explain continued growth and development, we experience alternative proces- ses of assembly and disassembly. Rather than growing roots we are rewarded for developing the capacity to navigate.

Nesta autora reencontro a cidade como texto de uma totalidade complexa que edito e/ou ensaio - e assim redefino o meu entendimento do binónio contexto-situação a partir da ideia de práticas urbanas, quadro em que os valores da intersticialidade e do efémero se tornam altamente operativos - de forma tanto mais radical e metaoperativa quanto mais assumida for a questão da especificidade concreta e material do conceito de arte pública crítica - enquanto arte de viver e/ou de dar vida à cidade. É neste sentidoque determinadas metáforas projectuais (por exemplo extramuros) se enquandram no vital em Lefèbvre. ${ }^{541}$ Tudo isto impli-

537 Liggett, Helen; Urban Encounters, University of Minnesota Press, Minneapolis, London, 2003. Ligett é uma autora que realiza um trabalho de ensaio visual (fotográfico) de apoio às suas reflexões sobre a consistência social da cidade.

538 Idem.

539 Idem, p. ix.

540 Idem.

541 Idem, p. xiii: Henri Lefèbvre also saw the potential of the city as the space of life. Contemporary urban processes have made the city heterotopic space. It remains available for "urban encounters," moments that sidestep the dominance of the abstract spaces of late capitalism. 
ca continuar a redefinir retoricamente a cidade, e o regime da sua visibilidade. ${ }^{542}$ Noutros termos, a situação - o momento que dá corpo crítico a um contexto - torna a cidade visível ao nível da suas formas em emergência, sendo que a arte pública é nestes precisos termos que pode ser entendida como espécie de epifania do urbano (Debord, Argan). No território contingente da articulação entre o material e a experiência, é algo como uma terapêutica da própria atenção à cidade, se quisermos recuar a Benjamin através de Liggett:

What is relevant to both Benjamin's time and ours is the extent to which conventional expectations and the need to escape them are tied to the politics of presentation. Benjamin uses participatory thought as a grounding in the material world (as it exists) as as a mode of enlarging the capacity of the reader. Whether or not we think of ourselved as visually literate, we operate all the time in environments dominated by images. ${ }^{543}$

É esta ideia do espaço como indissociável do vivido das situações mais díspares - da cidade como contingência também projectada- que abre uma via crucial do entendimento - apenas possível se situado. Nesta dialéctica experiencial-cognitiva - a political economy of inteligibility, ${ }^{544}$ é a posição literalmente espacial (Liggett) que torna Lefèbvre mais operativo na abordagem do dispositivo urbano que Foucault, Bourdieu ou Heidegger. O dispositivo-cidade é por isso apropriável a partir da ideia de situação urbana los 'momentos' da arte urbana), naturalmente para além do trabalho e do consumo los frutos da abstracção que a modernidade trouxe para a definição contemporânea de espaço citadino ${ }^{545}$ ). Contexto e situação tornam-se, nestes termos, os pontos de partida para a emancipação da forma urbana na vida-forma urbana: For him [Lefèbvre] the possibilities for an aesthetics of existence are tied to the gestures that would produce spaces and selves that develop our capacities to engage life fully. ${ }^{546}$ Talvez a referida ocupação do espaço - cujo entendimento é necessariamente processual $^{547}$ - apenas faça sentido, na economia retórica, a partir da categoria do efémero.

\subsubsection{O efémero de outra modernidade}

A arte crítica urbana é um dos motores de uma transformação que implica resolvermos alguns paradoxos que herdámos da Modernidade; a imaginação do agora não se compadece com uma visão de futuro subjugada a agendas sócio-políticas da democracia representativa. Recuperar a ideia de vanguarda, neste sentido, é (re)imaginar o que nessas vanguardas correspondia a uma energia centrípeta de mudança. A questão ética dá aqui lugar à questão moral, e de situar na materialidade projectual da obra, porque não há projecto sem decisões propriamente projectuais; ao nível do projecto urbano, palco privilegiado para esta actualização social da arte. ${ }^{548}$ Em termos

542 Liggett, p. xii. If it appears necessary to make a case for the city, this partly because of the disjunctures between representations of urban space and spatial practices within cities. Within conventional systems of valuation certain aspects of daily life are reduced and/or become visible, sometimes even to those who enact them. My purpose here is to present another approach: to use the city as a site where the daily patterns that involve ongoing negotiation with existence within it can be made to surface.

543 Idem.

544 Liggett, p. 76. He [Lefèbvre] connects the formation of subjects to space by gestures of occupation that are constitutive of both self and space. He also goes beyond critique to articulate uses of space that could fully engage life within the context of contemporary urban processes.

545 Idem.

546 Idem.

547 Processes that produce space as an ongoing practice are what space is for Lefèbvre. Idem, p. 80.

$548 \mathrm{Em}$ última análise, trata-se de cultivar o conhecimento dos movimentos artísticos e sua relação com os seus tempos coevos, mas ao mesmo tempo reconstruir provisoriamente universais culturais - Christine Buci-Glucksmann empreendeu tal empresa no campo da recuperação do ornamental, do primitivo, do feminino - e de fazê-lo com mecanismos 
filosóficos, joga-se aqui um traço moderno no entendimento da comunidade na pós-modernidade:

[...] Lefebvre argues that "urban encounters" can overcome the separations and spatial distances that characterize our age. They can be means of wrestling back autonomy - the taking of time for one's own use. This is in contrast with the more familiar exchange of time and control of time for compensation. Encounters in the city between memory and experience are profoundly noninstrumental. They are examples of life as an angaged art. ${ }^{549}$

O que importa, nestes tempos - a arte urbana como intervenção temporal, mas fora do tempo mercantil ou do consumo - , é desenvolver um campo transcultural (Berger) em que diferentes saberes se confrontam e procuram soluções sob os auspícios de plataformas efémeras (necessariamente discursivas). Ora uma forma - em certo sentido, a única de abordar a totalidade do espaço de forma directa é a apropriação da questão do agora, que evidentemente nos posiciona necessariamente como artífices do futuro (i)mediato; um mecanismo de aprensão do tempo na sua essência, tal como o trabalho de Opalka ou de On Kawara já em 65 ou Néle Azevedo, com Minimum Monument Project (2003), uma escultura antropormófica em gelo diante do congresso Nacional, em Brasília, fazem entrever, à micro-escala do criador compulsivo que tem de inventar o seu próprio tempo: L'objectif n'est pas, de façon illusoire, de suspendre le temps, mais de rendre sensible cette faculte qu' a l'homme de l'étirer. ${ }^{550}$ Não há espaço sem gesto (Liggett), e estes são antes do mais intenções (Miles), orientações ${ }^{51}$, encontros potenciais; gestos que definem uma atitude le a atitude é o projecto, Sena da Silva). Esta questão avança pistas para uma arte do fluxo que responde a uma vontade de intervir em aberto, de agir rapidamente mas com conviç̧ão, de estarmos atentos ao pequeno e ao grande [em contacto], ao infinito e ao ínfimo [em comunicação], como se todas estas gramáticas da existência merecessem não apenas o mesmo grau de atenção, mas idêntico respeito ontológico. ${ }^{52}$ É um paradigm-shift existencial e filosófico: bastaria considerarmos o efémero a essência do social, no já da comunidade, que não é outra coisa que o tempo do efémero do/no espaço público, na situação:

[...]. Aussi, penser l'éphémère comme une valeur positive consiste à revenir sur cette 'a priori de douleur', et a révéler una face cachée de l'art plus nietzschéenne et plus mondialisée. Un savoir du léger, celui du danseur sur l'abîme de Zarathoustra, qui peut accompagner le tragique en le métamorphosant. [...] Car l'éphémère est toujours promesse de légèreté, de transparence et de ce 'matérialisme aérien' qu'affectionnait Bachelard. Comme si le temps des formes laissait place aux formes du temps, au temps comme quatrième dimension de l'art. ${ }^{553}$

Cito-me a mim próprio e a Christine Buci-Glucksmann no catálogo da Luzboa:

[...] Na passagem histórica de uma cultura dos objectos e das permanências para uma cultura dos fluxos e das instabilidades globalizadas - e das redes - o efémero surge antes como poderoso signo do social contemporâneo, modalidade do tempo adequada à globalização: Éphémère des familles [de Family Idea, de Ron Haselden, em Luzboa 2004...] à géometrie variable, éphémère du travail de plus en plus flexible [a Misérias llimitadas, Lda, de Javier Nuñes Gasco, em Luzboa 2006...] et menacé, éphémère des vies et des identités qui perdent leurs repères fixes tout révèle une sorte d'accélération du temps qui déracine les stabilités, en occultant la limite extrême de l'éphémère, la mort. Comme si cette conscience de l'éphémère était devenue la perception d'un social précaire et sans projet, celui d'un 'temps mondial', au sens de Zaki Laidi, marqué par la fin des 'grands récits' et par une 'logique de l'instantanéité' et de l'eternel présent, et suscité par des nouvelles technologies et la perte du sens lié à la mondialisation.

É de ter em conta que este efémero por meio da arte nos conduz a um confronto com os dados antropológicos de um presente acossado pelos 'impérios do efémero' próprios da cultura de massas, onde tudo se renova no âmbito de uma 'estetização' forçada do quotidiano. Buci-Glucksmann afirma com um senso cósmico: Or,

próprios tanto do tempo como da ideia de tempo que perseguirmos.

549 Idem, p. 90.

550 Millet, p. 128

551 Liggett, p. 93.

552 Caeiro, Mário; «À Luz», in Lisboa Inventada pela Luz, Extra]muros[, Lisboa, 2007, pp. 18-22.

553 Buci-Glucksmann, p. 16 
l'acceptation du temps, de son alterité et de son altération, en est la condition. [...]. Un temps qui ne sera plus retrouvé, et ne donnera pas lieu à cette vue optique des choses extra-temporelles de l'art, même si 'la beauté des images est logée à l'arrière des choses.'554

A recuperação do Barroco por Buci-Glucksmann (La Raison Baroque) ecoa as investigações de Deleuze/Guattari sobre um maneirismo ocasional: Il est beaucoup plus proche de la quête de l'intervalle propre à la culture japonaise du Ma (espacement, intervalle, videl que de la seule jouissance hédoniste du présent qu'il implique. 555

A integração dos valores do efémero e do acontecimento nesta grelha de leitura vai apontar para a problemática do sublime. Ela permite uma apropriação deste, emancipada e finalmente mundializada - e não 'apenas' localizada ou territorializada - da sensação de fluxo ${ }^{556}$, que caracteriza a condição contemporânea deste neo-barroco (Calabrese) que se deduz da Land Art ou de projectos contextuais de longa duração, inclusive os que reivindicam novas funcionalidades políticas para o monumento ou a celebração que são antes do mais 'situações' e não tanto 'comemorações'. Smithson, Maya Lin ou Jochen Gerz destacam-se por isso, numa extraordinariamente rica diversidade de visões da monumentalidade na pós-modernidade, na medida em que o seu trabalho, L'éphémère r'est pas le temps mais sa vibration devenue sensible..$^{57}$ A categoria do efémero - particularmente instrumental no memorial ou no festival - ilumina assim uma genealogia de heterotopias ${ }^{558}$; é uma arte do kairos, acção aéria e icaria$n a^{559}$, do contexto como desvelamento de uma situação, da activação do infinito, na absoluta fragilidade e superficialidade dos novos fluxos da $\operatorname{arte}^{560}$, condenados à paixão pelo contexto, no amor pela situação. Derrida define este problema na ideia de testemunho - que vai ser a ponte para o activismo e a participação. ${ }^{561}$ Face à imponderabilidade da incerteza que Marx introduz na nossa concepção do tempo urbano, uma leitura participatória ${ }^{562}$ quer da possibilidade, quer da concreticidade da situação, a caminho de meios para efectivar o testemunho $0^{563}$ é condição sine qua non para a participação, desde já como experiência produtiva de um sublime social.

\footnotetext{
554 Idem. p. 21.

555 Idem, p. 26

556 Um fluxo que não se reduz à fluidez dos mercados: Comme si le temps, celui du voyage-flux et de ses cartographies, était devenu métaphore de tout scape, dessinant en cela l'ultramodernité d'une civilisation paysagière. Celle de flux, qui ne se réduiraient pas à ceux du marche, et poseraient la question de la «production de la localité» en ermes spatiaux temporels. Déjouant simultanément les intégrismes religieux ou nationaux du sujet, et tous les mythes de la transparence ideologique produite par l'Occident. Buci-Glucksmann, Christine, Esthétique de l'éphémère, Galilée, Paris, 2003. p. 79.

557 Buci-Glucksmann, in idem, p. 26.

558 Idem, p. 81.

559 Idem p. 84.

560 Idem, p. 85.

561 Idem. $n$ Spectres of Marx, Derrida theorizes the the relationship of intellectuals to their (Marxist) past in terms that activate this relationship at a constitutive level. His challenge is that "there is no inheritance without a call to responsibility".

562 Ligett, p. 104.

563 Idem.
} 


\subsubsection{Activismo/participação - promover a imaginação social partilhada}

Há uma arte crítica urbana que apela a uma complexa performatividade conversacional. Ela instaura situações - encontros urbanos - que são dispositivos e meta-dispositivos de mudança participada num quadro em que Participation is simply a tactic of complicit curiosity scaled to the space you're currently in. ${ }^{564}$

The notion of conversation can act as a powerful metaphor in any institution committed to change, especially when its future direction envisages a dynamic relationship with the local, national and global context. But [...] any wider, external conversation will only have legitimacy if mirrored by an institutional conversation that embodies such qualities as trust, active listening, openness, humility, integrity and empathy. ${ }^{565}$

São momentos de uma outra economia de troca ${ }^{566}$ em que as 'leis' da arte, com tudo o que nelas é insustentável para uma mentalidade modernamente refractária aos valores burgueses (Lefèbvre), são suspensas. Neles irrompe um sentido comunitário ${ }^{567}$ - de Zygmunt Bau$\operatorname{man}^{568}$ a Jean-Luc Nancy ${ }^{569}$ - que, a ser entendido como abertura do campo artístico e projectual à realidade do urbano, pode ser subsumido a um modelo activista para o desejo marxista de transformação social. Em oposição ao que Millet define como um traço narcísico da arte contemporânea, é na acção plástica colectivizante que a arte encontra um sentido para além da constatação da sua separação (Debord) da vida social. Perante tal origem da arte, as múltiplas modalidades contemporâneas e actuais da arte activista - colaborativa, participativa - são antídoto radical para uma ilusão de autonomia da arte que a mantém distanciada do político. Activar uma dimensão comunitária torna-se portanto o punctum da arte crítica.

\subsubsection{Activar a comunidade experimentalmente - do activismo lúdico às batalhas pela dignidade}

Qualquer obra pode integrar o meu corpus de arte participativa sob determinadas condições de avaliação (colectiva, comum, vernacular) do seu sentido. Começo, com Malcolm Miles, por distrinçar entre um activismo urgente; e o que Miles chama slow type of activism, ${ }^{570}$ cujo 'resultado' pode tanto ser um painel solar ou uma estufa. ${ }^{571}$ Ambos são alternativas ao mainstream, mas o activismo lento terá uma dimensão pedagógica e cognitiva que a dimensão mais reactiva das acções relativamente mais urgentes não terão. Noutros termos, o intersticial do activismo de fundo tem um valor retórico menos espectacular, mas obriga a complexos percursos negociais e de participação-inclusão radical, como sugere Paulo Freire, em Pedagogia do Oprimido. ${ }^{572}$ Para usar terminologia mais 'artística', as identidades de artista, curador e público

564 Miessen, Basar, in Miessen, Basar (eds.), p. 28.

565 Renshaw, Peter; «Connecting Conversations - The Changing Voice of the Artist».

566 Scholette, Gregory; «Interventionism and the historical uncanny. Or: can there be revolutionary art without the revolution?», in The Interventionists, p. 133.

567 Millet, p. 145.

568 Bauman, Zygmunt; Comunidade, 2001.

569 Nancy, Jean-Luc; «The Inoperative Community», in Participation, ed. Claire Bishop, Whitechappel, London.

570 Kahn, Fred; in «Art International de Proximité», 2008, p. 26-7.

571 Miles refere a título de exemplo os Ala Plástica - uma designação que alia uma noção de vanguarda 'militar' a um plasticidade do social beuysiana (Plastik), e repetidamente obras de PLATFORM e Wochenklausur.

572 Nesta é reconhecida ao educando a possibilidade de se assumir sujeito cognoscente - discovering that they are capable 
são real, efectiva, potencial ou retoricamente intercambiáveis ${ }^{573}$. Daqui infira-se que nos processos colaborativos que visam mobilizar novas formas de acção colectiva ${ }^{574}$ - o programa da arte dialógica segundo Grant $\mathrm{H}$. Kester - a conexão entre saber e poder lentre discurso e produção) é alternativa radical à hegemonia capitalista. Está em causa o activismo de uma articulação necessariamente colectiva cidade-natureza (Duque), mesmo quando começando com um encontro místico com carácter pessoal. Como no que os autores de Trespass chamam pensamento mágico, termo que ressoa tanto o encontro do conceptual com o espaço urbano, como uma anacrónica capacidade romântica de a arte de fazer mundos (do slogan poético de 68 'sous les pavés, la plage' às projecções interactivas de Paul Notzold, TXTual Healing (2007), consistindo em balões de BD cujos textos são os enviados pelos transeuntes por sms. As perspectivas destes novos 'earthworks' (Smithson) apontam para uma art of empowerment, ${ }^{575}$ mesmo quando, como no dialogismo (Bakhtin) de Kester, se trate de pouco mais do que uma suspensão da rotina e uma ténue retórica de substituição do estado social. ${ }^{576}$

Partindo da experiência de investigadores como Peter Renshaw ${ }^{577}$ ou artistas como Mathew Cornford, tal envolvimento exige uma interacção intensiva entre pessoas e organizações; as obras dependem de um intercâmbio de atitudes entre artistas, artistas e público e/ou colaboradores - e em certos casos mais sólidos a transferibilidade em Gabriela Vaz-Pinheiro - que vem enriquecer um 'político' indissociável de uma teoria do inconsciente (Butler); e volto assim a posições filosóficas de Jacques Rancière, Jean-Luc Nancy ou Grant H. Kester em busca de uma comunidade conversacional:

Conversation, then, becomes the bedrock of any cultural engagement in which the artist's voice resonates with the myriad of individual voices within the wider community. [...] Any deepening of the understanding within our present world of diversity and inequality, can only be realised through engaging in a 'conversation' that respect differences, sees commonalities and crosses boundaries ${ }^{578}$.

Numa sociedade disciplinada pela divisão formal dos saberes, a conversação só é possível num entendimento proactivo do valor do Amador Profissional no processo colaborativo:

I'd like to suggest that the perennial estrangement of "professional" to "amateur" denies the possibility of a chemichal conflation that at first sounds like a ridiculous oxymoron: "The Professional Amateur". Its ridiculousness lies in the operative nature of its semantics: it is like valorizing a minus sign so that everyone stops thinking it's a minus sign anymore under the delusion it's in fact a positive sign. The duplicity is so transparent that, well, why would you bother to try?579

of knowing... in which process they also become critical "significators". Freire, Paulo; Pedagogy of Hope, London, Continuum, 2002, p. 37. Ver também Rancière, em O Mestre Ignorante, 2004.

573 Warstat, Andrew; in Showing Expectations, p. 79.

574 Miles, Malcolm; «Aesthetics in a Time of Emergency», in Third Text, July, Vol. 23, pp. 421-434.

575 Idem.

576 Idem.

577 Renshaw, Peter; «Connecting conversations», in New Practices, New Pedagogies, European League of Institutes of the Arts, Routledge, London and New York, 2004, p. 3.

Explicação detalhada de três projectos, em Corord, Mathew; Cross, David; «Unrealised: projects 1997-2002», in New Practices, New Pedagogies, European League of Institutes of the Arts, Routledge, London and New York, Pp. 53-61, 2004.

578 Idem, p. 100.

579 Basar, in Miessen, Basar (eds.), p. 31. A questão é crucial no título Lisboa Capital do Nada - Marviila 2001, podendo questionar-se em que medida não apenas começa aí, como está aí toda a questão da recepção da LXCN como projecto exemplarmente participativo. Note-se paralelamente que a figura do amador, na economia hegemónica, está tradicionalmente ligada a alguém que não chega a ser suficientemente bom para ser profissional e portanto auferir uma remuneração em consonância. Repare-se então nas consequências do agente da transformação admitir que só sabe que nada sabe (Sócrates), ou que o que está a fazer é nada? Noutros termos, o nada que é tudo (Pessoa) é o 'dentro' que 
O paradoxo deste oxímoro particularmente produtivo - fulgurante no sentido novaliseano define uma forma do pensamento que convida ao envolvimento emotivo, colocando ideias nos sentimentos e vice-versa. ${ }^{580}$ Então, a contingência e a sorte tornam-se materiais nobres de um socius que acredita: Belief that when everything is possible, the possible is merely another part of everything. ${ }^{581} \mathrm{~A}$ emoção conjunta é a de uma redenção de graça cognitiva.

Na tradição contextual francesa, há esta ligação entre activismo e participação na linguagem:

Si la societé du spectacle, communicante, n'est plus un spectre mais une réalité, rien n'empêche donc que l'on en démantèle les rouages. [...] Ces nouvelles écritures des villes lovent l'acte artistique dans le vécu propre du spectateur. En confrontant un paysage urbain fragmentée à une vision poétique, on cherche à construire l'espace collectivement. ${ }^{582}$

Para que o modelo participativo-colectivo/comunitário da prática artística se torne mais claro, recupero um texto recente de Roberto Jacoby que nos anos 70, com Tucumán arde colocou a Argentina e a América Latina no mapa da arte pública crítica. Jacoby refere como origem do grupo um ethos inicialmente de vanguarda e reactividade, que depois se transforma em consciência de que havia que desenhar-se novas formas de vida fora dos museus, das galerias e do mercado. ${ }^{583}$ Tucumán Arde, originalmente mezcla de investigación salvaje, campaña publicitaria y activismo [...] una tarea por entero extra artística; para muchos [...] ademá, una locura o una estupide, ${ }^{584}$ foi entretanto considerado por la crítica y la historia del arte como una pieza canónica del arte conceptual político. ${ }^{585}$ Jacoby entende que um dos problemas na institucionalização deste tipo de projectos activistas e comunitários tem a ver desde logo com a sua resiliência à auto-representação - [...] las comunidades experimentales no se dejan retratar. ${ }^{586}$ Se a melhor forma de lhes surpreender a identidade é por vía do oxímoro - Negri diria, de um outro projecto de Jacoby (Venus), tratar-se uma logia pública, ${ }^{587}$ o crucial desta experimentação é a decisão de fazer:

La decision de hacer es el motor principal de las comunidades experimentales.

Si bien muchos de sus participantes pueden albergar esperanzas de un cambio sistémico completo, no temen a las imputaciones de reformismo, filantropía, utopismo, alternativisno, derrotismo, hedonismo, etcétera, porque la urgencia por producir algo ya, en esta vida, en este mundo, con los elementos realmente existents, los lleva a realizar una crítica práctica de las condiciones de vida imperantes.

La noción de experimento los inmuniza, en cierto modo, respecto de todas las acusaciones que puedan hacerse: son tentativas que se hacen en buena medida para conocer y en buena medida para disfrutar. Ellas permiten eludir la viscosiade del mundo real, su escaala colossal y aplastante, el peso agobiante de las certezas aceptadas, la dimension monstruosa de la estupidez, el sufrimeniento inutil y la fealdad. [...] En estas comunidades los procesos son mucho más

é 'fora', numa perfeita relação pragmática, mas também simbiótica, com a totalidade.

580 Godard: There are ideas in feelings. Basar, in Miessen, Basar (eds.), p. 32. Shumon Basar exemplifica este acontecer gracioso da participação a partir de um fenómeno pop - o público cantando em uníssono "Angels" de Robbie Williams, com o cantor a baixar o microfone para se tornar ele o público do seu próprio público. Nesta súbita alteração da hierarquia cultural, There are no instructions to this scenario, it can't be taught, or planned. The amateurish singing takes on a professional proportion and is formulated into a spatial contract of mutual consent. Basar, Shumon, in Miessen, Basar (eds.), p. 34.

581 Idem.

582 Beauvallet, Eve; in «Art International de Proximité», 2008, p. 36.

583 Jacoby, Roberto; «Comunidades experimentales. Archipiélagos en el oceano de lo real», in Carta, Primavera-Verano 2011, Madrid, Centro de Arte Reina Sofia, pp. 25-26.

584 Idem, p. 25.

585 Idem.

586 Idem. El arte de imagen puede ser pensado, pero no necesita ni debe, normalmente, ser narrado. Et arte de imagen substituye, precisamente, el lugar de los relatos verbales, En cambio, los proyectos de comunidades experimentales no pueden no ser narrados, aun cuando produzcan, impliquen o utilicen imagenes que funcionaen siempre como auxiliares del relato.

587 Idem, p. 26. 
relevantes que los resultados. Finalmente, si bien estas comunidade smantienen un a relación ambígua con su propria valoración en tanto arte, no dudan en estabelecerse dentro de este territorio de fronteras móviles, no vacilan en utilizar el arte como aquel espazio social , podría decirse, aquella laica desde onde se puede partir para explorar los procesos de autonomia y las economias del deseo. ${ }^{588}$

Tecnologia da amizade (Arendt), dos afectos, a arte pública é una sociedaded sin Estado, su realidad es la vida quotidiana. ${ }^{589}$ Nesta linha durante os anos 90 , o colectivo ecologista Reclaim the Streets introduziu uma dinâmica muito específica na ideia de arte urbana, the combination of pageantry and civil disobedience. ${ }^{590}$ Explicitamente ancorada no campo da arte e capaz de mobilizar milhares de pessoas em acções espectaculares, a sua versão do activismo é festiva e lúdica - as acções consistem basicamente em festas urbanas que se baseiam na supresa táctica ${ }^{591}$. Estes e outros colectivos mais orientados para a resistência no campo do digital têm uma noção de comunidade muito pragmática, relacionada com o acesso a tecnologias específicas, já no quadro de uma high-tech gift economy (Barbrook). ${ }^{992}$

Noutro registo ainda, temos um activismo que não pode aceitar o 'jogo' da política de forma festiva. A propósito do movimento União dos Comités de Mães de Soldados da Rússia ${ }^{593}$, num país em profunda rejeição do legado 'comunista', Irina Aristarkhova propõe o conceito de politica maternal, que é um desenvolvimento da amizade fraternal de Derrida. No lugar de qualquer superação da dicotomia amigo/inimigo (Derrida), o termo de Aristarkhova refere-se a um conjunto de acções concretas e de grande alcance social e político, envolvendo milhares de cidadãos russos contra a Guerra na Tchetchénia. Como que tirando lições de outros combates pacifistas, este movimento tem-se preocupado por manter a sua actividade fora do registo agonista, e revela toda uma potencialidade ética realmente produtiva, porque nela teoria e prática não se excluem. Ora a inovação neste activismo decorre da extrema oportunidade da argumentação e da precisa ancoragem do debate num real partilhado que a muitos cidadãos diz respeito e cuja abordagem acarreta a experiência uma revelação fundamental - isto num país em que o conceito de Mãe tem extraordinária importância. É um activismo comunal, que não é por não se dirigir directamente aos problemas da sociedade de consumo ou da alienação que deixa de ser profundamente radical e artístico, naturalmente que no quadro da escultura social que lhe é implícita. Aristarkhova surge como continuação nossa contemporânea de uma linhagem do cuidar feminino da cidade. No seu discurso a interrelação entre aspectos psíquicos, sociais, estéticos e comunicacionais no activismo 'pós-media' está empenhado em retirar franjas da população da apatia:

[...] "Becoming a mother" in this sense is not a gesture of radical literary or artistic experimentation, identity swapping, transgression of sexual envy. It is an open and silent invitation to join, facilitate, help, get help, partake in an on-going struggle of a group of a few women with the military and state apparatus of Rússia. ${ }^{594}$

588 Piglia, Ricardo; «Retrati del artista invisible», in Carta, Primavera-Verano 2011, Madrid, Centro de Arte Reina Sofia, pp. 25-26.

589 Idem, p. 29

590 Thompson, p. 17

591 Moore, Alan W.; «Artists' Collectives Mostly in New York, in in Collectivism after Modernism; Ed. Stimson, Blake; Scholette, Gregory; University of Minnesota Press, Minneapolis, London, 2007 p. 213.

592 Adaweb, Rhizome, Etoy, ® ${ }^{\mathrm{TM}}$ ark.

593 Aristarkhova, Irina; «Beyond Representation and Affiliation», «Artists' Collectives Mostly in New York, in in Collectivism after Modernism; Ed. Stimson, Blake; Scholette, Gregory; University of Minnesota Press, Minneapolis, London, 2007 p. 255.

594 Idem, p. 268. [...] What is important is that is has worked effectively and ethically since 1989 in a situation of political stagnation 
Se quisermos regressar às metáforas da saúde e da medicina, estas obras podem funcionar como ligaduras (Wodiczko):

Wodiczko is under no illusion that he is capable of acting as social service agency. He believes this is the Job of a proper functioning government. The artist's Job is different: "The oldest and most common reference to this kind of design is the bandage. A bandage covers and treats a wound while at teh same time exposing its presence, signifying both the experience of pain and the hope of recovery." 595

\subsubsection{Transcendência obscurecida, comunismo}

De Tucuman Arde a Reclaim the Streets e às mães da Rússia abre-se um amplo leque de modalidades de activismo social em que se pode falar de uma ideia de participação cujo campo semântico se relaciona com o transcendente que a civilização tecnológica (Lefèbvre) rejeitou integrar no seu projecto de modernidade. ${ }^{596}$ É um activismo espiritual. ${ }^{597}$. Ora a descendência sócio-comunitária desta tendência espiritual adquire por vezes a forma de obras sociais que são quase a tradução materialista de teorias sociológicas e antropológicas para o plano do projecto; em graus diferentes, aí ocorre com regularidade um informe transpessoal, de uma espiritualidade que todos partilhamos e que $o$ artista se propõe celebrar na sacralidade de um momento: Même quand leur message est politique, nous leur accordons cette dimension spirituelle perdue chez nous. ${ }^{598}$ Zizek tem aliás procurado recuperar esta espiritualidade para a actualidade do político: No seu discurso existe uma demonstração contínua da conexão entre o que poderíamos chamar o divino, o eterno, e a realidade prontamente vivida. ${ }^{599}$ Caso actual desta espiritualidade concretizada em aguda consciência do projecto é o de James Turrell, em que o projecto arquitectónico tem a função alquímica de instaurar uma atmosfera e uma situação em que a mística total da existência procura condições para se tornar um acontecimento. Os espaços de Turrell são espaços de contemplação mas, sobretudo, 'revelação'.

and the crisis of the Russian political syste, and Western party politics or left politics as well. While many activists resort to old types of representational politics or "no exit" pessimism, these acts of political innovation and the success of Soldier's Mothers allow us to widen our own horizons of political resistance, both practically and conceptually. [...] It is the interrogation of the ethics of politics itself through the position of the "mother" that complicates the "self-other" division [...] There is no other subject position that is defined and experienced in such "selfless" terms, such nonpolitical and nonsocial terms loutside of the social realm) as parental position. And though the paternal aspect, more specifically, the male aspect of the parental couple (father and son), is often cited as the foundation of religious, missionary, literary, political, and other types of social structures, the maternala spect is rarely reresented outside its subjective, psychological, presumbolic, biological, or psychoanalytic trappings.

595 Thompson, p. 18.

596 Milet, p. 168. L'une des fonctions essentielles de l'art consiste désormais à mettre au jour, et à deplacer, ce fonds de l'humanité que la religion ne prend plus en charge et que la science ne peut envisager. De Pessoa a Kandinsky, de Mondrian a Malevich, de Lorca a Yves Klein e a Beuys as experiências de articulação entre arte e a espiritualidade, a magia, o transcendente ou o religioso, em enquadramentos gnósticos, esotéricos, antroposóficos são não apenas frequentes, como fundamentais para se compreender toda uma ideia espiritual de desubjectificação num sentido de activação do transcendente.

597 Cf. De resto, a ideia do artista como 'feiticeiro' ou místico nunca deixou de ser um leitmotiv, no próprio Duchamp; na arte povera, no happening, na instalação, tirou partido da superação das diferenças entre materiais e formas, entre público e artista, numa espécie de neopanteísmo (Millet). De Merz a Pistoletto e a Beuys, a pobreza dos materiais escondia uma nobreza intelectual a que não era alheia a ideia de um arte que resgatava poesia ao real, como que numa alquimia. Bill Viola, por exemplo, tenderá para impregnar os seus trabalhos, sobretudo em vídeo, de referências místicas; ao mesmo tempo, porém, que Anish Kapoor salvaguarda que o termo spiritual é 'cheio de dificuldades' http://www.doononline.net/ pages/info_features/features_spotlights/spotlights/akapoor/abbcr.htm. Entrevista a Joan Bakewell, 5 de Janeiro 2001.

598 Millet, p. 153.

599 In Belanciano, Vítor, «Zizek. O impossível é possível», Público, 5 Agosto 2011. 
Martin Buber ${ }^{600}$ em Do Diálogo ao Dialógico ${ }^{601}$ (de inspiração hassídica), apresenta com clareza a sua filosofia da relação, do encontro e do diálogo. Bastam algumas notas acerca do autor da frase fundadora Toda vida verdadeira é encontro ${ }^{602}$ para conferirmos à questão do activismo participativo, fundado na conversação como a revelação da arte, um estatuto filosófico (e também meta-filosófico), que vai actualizar todas as gramáticas formais - do minimalismo à 'arte da luz' - num quadro de radical promoção da participação espiritual:

Para realizar plenamente o seu Eu, o homem precisa entrar em relação dialógica com o mundo - ele precisa dizer Tu ao outro, e este dizer - Tu só se faz com a totalidade do ser. É preciso perceber e aceitar o outro "na sua totalidade, na sua unidade e sua unicidade". É preciso que ele se torne presença para mim..$^{603}$

Para além das ressonâncias com o jargão do dialogismo na arte comunitária contemporânea, o campo semântico de Martin Buber relaciona-se com a comunidade inoperativa de Jean-Luc Nancy. Em Buber, temos a consciência de um silêncio comunicativo ${ }^{604}$ - a questão da Paz - inseparável do filosofar das acções de Observar, Contemplar, Tomar Conhecimento Íntimo ${ }^{605}$, conduzindo à conversação genuína ${ }^{606}$ mesmo entre múltiplas vozes ${ }^{607}$ iluminem a poderosa metáfora da comunalidade da morte em Nancy. Este propõe a concepção da comunidade não propriamente como um 'estar em comum'608, mas como um désouvrement (um 'trabalhar') desse estar em comum. A metáfora existencial da morte é uma espécie de ovo de Colombo da ideia de participação, recordando ao sujeito (como em Buber, mas de forma mais performativa ainda, na poesia) os seus traços nietzscheano, aristotélico e até comunista $^{609}$ (Wagner) como a experiência radicalmente solitária ${ }^{610}$ da contemporaneidade pós-moderna; 'bastando' entender a presença graciosa desse denominador comum que é

600 Poderiam ainda ser evocados Bakhtin ou Levinas. Cf. Deborah J. Haynes, «Bakhtin and the Visual Arts» in A Companion to Art Theory, Blackwell Publishing, Oxford, 2002.

601 Buber, Martin; Do Diálogo ao Dialógico, Editora Perspectiva, São Paulo, 1982. Outra obra a consultar, embora mais especificamente orientada para a experiência histórica da utopia é O Socialismo Utópico, 1971/1986, Editora Perspectiva, São Paulo, 1986

602 Buber, Martin; Do Diálogo ao Dialógico, Editora Perspectiva, São Paulo, 1982. p. 7.

603 Queiroz; Marta Ekstein de Souza; «Prefácio do Tradutor», in Buber, Martin; Do Diálogo ao Dialógico, Editora Perspectiva, São Paulo, 1982. p. 8. O diálogo genuíno só se dá em clima de plena reciprocidade, quando o indivíduo experiencia a relação também "do lado do outro", sem contudo abdicar à especificidade própria. [...] Numa situação dialógica, o homem que está face a mim nunca pode ser meu objeto; eu "tenho algo a ver com ele". "Talvez eu tenha que realizar algo nele; mas talvez eu apenas tenha que aprender algo e só se trata do meu 'aceitar'... O que importa agora é unicamente que eu me encarregue deste responder." [...] É o mundo através dos seus acontecimentos do dia-a-dia que se dirige a mim. Tudo o que me acontece diz algo a mim de uma forme única, numa linguagem nunca antes pronunciada. "Nós respondemos ao instante, mas respondemos ao mesmo tempo por ele, somos responsáveis por ele..."

604 Buber, Martin; Do Diálogo ao Dialógico, Editora Perspectiva, São Paulo, 1982. p. 36.

605 Idem, p. 41.

606 Idem, p. 153.

607 Idem, p. 155.

608 Nancy, Jean-Luc; «The Inoperative Community», in Participation, Ed. Claire Bishop, Whitechappel, London, p. 54.

609 Idem, p. 55. Face à traição do ideal de justiça, liberdade e igualdade no 'comunismo real', Nancy nota que these burdens are still perhaps only relative compared with the absolute weight that crushes or blocks all our 'horizons'. É nestes termos, que Badiou continua a defender a operatividade da Construção Monumental Comunista. Cf. Noys, Benjamin; «'Monmental Construction'. Baiou and the Politics of Aesthetics», in Third Text, Vol. 23, Issue 4, July, 2009, p. 383. Ou que Zizek se tem tornado numa voz de renovação radical do projecto comunista: Não se trata de repetir o modelo que fracassou, mas de preservar o momento em que foi possível ter a liberdade de pensar e agir segundo a ideia de que o capitalismo não era inevitável. In Belanciano, Vítor, «Zizek. O impossível é possível, Público, 5 Agosto 2011.

610 Idem, p. 56 But the individual is merely the residue of the experience of the dissolution of community. [...] the individual reveals that it is the abstract result of a decomposition. It is another, and symmetrical, figure of immanence: the absolutely detached for-itself, taken as origin and as certainty. 
a alteridade radical do social, horizonte mortal. Para tal There has to be an inclination or an inclining from one towards the other, of one by the the other, or from one to the other, Community is at least the clinamen of the 'individual' ${ }^{611}$ Isto é, Nancy vem afirmar não apenas que $o$ átomo é um mundo, 112 mas também que as formas burguesas de intersubjectividade, ainda fundadas no sujeito clássico (dá o exemplo de Sartre, e, no extremo oposto, Barthes), são desadequadas para assumir, hoje a (eterna) relentlessness of the word communism ${ }^{613}$. E numa operação conceptual verdadeiramente nietzscheana: This is why, even as we establish that communism is no longer our unsurpassable horizon, we must also establish, just as forcefully, that a communist exigency or demand communicates with the gesture by means of which we must go farther than all possible horizons. ${ }^{614}$

Daí que Nancy explicite que a 'perda de comunidade' moderna e contemporânea não é a perda de algo que existia previamente: No Gesellshaft has come along to help the State, Industry and capital dissolve prior Gemeinshaft. [...] So that community, far from being what society has crushed or lost, is what happens to us - question, waiting, event, imperative - in the wake of society. ${ }^{615}$ Relembro o que Kafka afirma no aforismo Nada ainda aconteceu - The communion to come does not grow distant, it is not deferred: it was never to come; it would be incapable of coming about or forming a future. ${ }^{616}$ Nancy fornece o cerne do apparatus filosófico para este nosso tempo de luto das grandes narrativas. É uma teoria do infinito, informe social: That which is not a subject opens up and opens onto a community whose conception, in turn, exceeds the resources of a metaphysics of the subject. ${ }^{617}$ Ora, a haver uma verdade contemporânea, exequível, experienciável, dessa comunidade que está a vir (parafraseio Agamben), é a da morte ${ }^{618}$, a descoberta de Nancy para dizer o indizível do social em emergência no ethos pós-moderno. Na articulação comunidade-comunicação, Nancy avança no sentido de um radical defesa de um dialógico que não se confunde com a comunicação (Habermas), muito menos no sentido mais corrente, uma vez que acontece também num estado de pré-linguagem, pré-comunicação:

Communication consists before all else in this sharing and in this compearence (com-parution) of finitude: that is, in the dislocation and in the interpellation that reveal themselves to be constitutive of being-in-common - precisely in as much as being-in-common is not a common being. [...] Under these conditions, community is not a bond. [...] compearance is of a more originary order that that of the bond. ${ }^{619}$.

Uma relação importante que Nancy estabelece então é a da impossibilidade de esta comunalidade nascer do trabalho (como em Arendt d'après Aristóteles): One does not produce it, one experiences or one is constituted by it as the experience of finitude. ${ }^{620} \mathrm{O}$ que implica uma

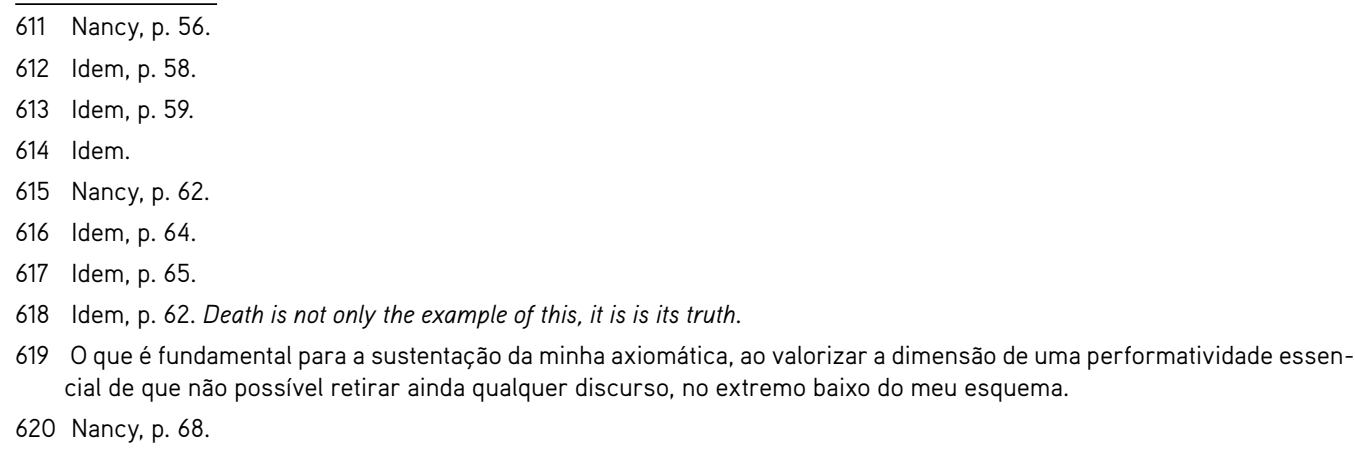
cial de que não possível retirar ainda qualquer discurso, no extremo baixo do meu esquema.

620 Nancy, p. 68. 
nova abordagem do político (e do ethos comunista) - na figura da escritura: 'Political' would mean a community ordering itself to the unworking of its communication, or destined to this unworking: a community consciously undergoing the experience of its sharing. [...] It implies being already engaged in the community, that is to say, undergoing, in whatever manner, the experience of community as communication: it implies writing. ${ }^{621}$ É toda uma renovação do utópico na produção da urbe.

\subsubsection{Transgrediência: uma ética dialógica}

Para Bakhtin, toda a actividade estética é exotópica. George Herbert Mead, com base numa psicologia social baseada na linguagem, di-lo de outra forma: There must be other selves if one's own is to exist ${ }^{622}$. Entra aqui o conceito fundamental de transgrediência, factor constitutivo do eu (no) social, definido também, por exemplo com Butler, do ponto de vista da justiça social, ou pelo menos de um realismo das desigualdades. É altura de rever o valor pós-moderno desta transgrediência e sua operatividade discursiva.

Trangredience - which may also be rendered as transgradiance, a stepping across - specifies Bakhtin's notion of the ratio of self to other, which is not that of the collapse of the self into the other ${ }^{623}$ (which would be no more than the obverse of the reduction of the Same to the One) - but a dialogical process of working through the exigencies of relationship [...] by sustaining productive difference. [...] What is pertinent here is Blanchot's location of subjectivity in language: infinite deferral along ongoing multivocal channels of formulation and Blanchot's notion of conversation, or entretien, to cite his French term with irs connotation of "keeping it up,", keeping the conversation going without definitive closure, accords with Bakhtin's notion of the dialogic chain of utterance in relation to the function of transgredience. ${ }^{624}$

Esta lógica discursiva é comunista: Dialogism has rightly been perceived by certain thinkers on the left as a useful correlative to Marxism, for it argues that sharing is not only an ethical or economic mandate, but a condition built into the structure of human perception. ${ }^{625} \mathrm{E}$ portanto, a negação (Gruen) da empatia social, é não apenas contra-ecológica, como contra-natura. A pulsão social inscrita na arte, e que a arte pública crítica representa no actual panorama da arte, vem sempre ao de cima. É por isso que o termo comunismo é (ainda) crítico: [...] dialogism differs from the pseudo-Marxism of regimes that use 'Communism' as a license for totalitarian government. For as the ultimate critique of any claim to monologue, it is intransigently pluralist. ${ }^{626}$ Estamos perto dos comunismos heterodoxos de Badiou ${ }^{627}$ ou Zizek. ${ }^{628}$ A este último, o que lhe interessa (no

621 Idem. Nancy menciona a dada altura uma série de figuras de uma genealogia do que arrisca denominar um 'comunismo literário: Bataille, Lyotard, Badiou, Ellul, Deleuze, Pasolini e Rancière. Será este comunismo (finalmente) humanista a versão possível, na actualidade, de um romantismo cognitivo? Benjamin plays on words: The reader is always prepared to become a writer... (Malcolm Miles).

622 In Holquist, p. 55.

623 Como no sublime místico cristão, em certa medida em Weil.

624 Gabriel, Barbara; Ilcan, Suzan (Eds.), Postmodernism and the Ethical Subject, McGill-Queen's University Press, Québec, 2004 , p. 84. Every strange Face is a traumatic moment of dialogic overture to a beyond of the monologic closure of identity and familiarity. It challenges with the danger and possibility of the transgredient moment. [...] I turn to another thinker of the postmodern, a percursos to Derrida, Maurice Blanchot - to his remarkable book. The infinite Conversation (1993), particularly to the first section, "Plural Speech,", where he engages in dialogue with the Levinas of Totality and Infinity.

625 Holquist, p. 34.

626 Idem, pp. 34-35.

627 Cujo conceito de construção monumental, renovadamente moderno, merecia mais demorada análise.

628 Que tem os principais detractores entre a esquerda, que diz que ele é... comunista. Belanciano, Vítor; «Zizek. O impossível é possível», in Público, 5 de Agosto, Lisboa, 2011, p. 10. 
comunismol é o momento da energia transformadora em si, o momento de emancipação e de liberdade. ${ }^{629}$

Mas se no dialogismo a vida é expressão ${ }^{630}$ - ressonâncias de Bergson - essa realidade fundamental é indissociável da sua tradução em signos. Há uma vida (dos e) nos sinais (semioticidade), tanto quanto uma coisa apenas existir se tiver significado. Sabemos com Capra, na perspectiva sistémica do social ${ }^{631}$, o quanto isso é um dado crucial na vitalidade da vida simbólica das sociedades, não apenas indissociável de uma ciências das ideologias ${ }^{632}$ - e esta não poderia existir sem a racionalidade retórica. Capra menciona mesmo a questão da metáfora no cerne da vida social ${ }^{633}$. E Zizek afirma que pode haver mais verdade numa fantasia e numa ficção do que no real. ${ }^{634}$ De certa forma, já Mumford, em 'What is a city', refere: One may describe a city, in its social aspect, as a special framework directed toward the creation of differentiated opportunities for a common life and a significant collective drama ${ }^{635}$. Mais, the individual/society opposition, like the self/other relation which contains it, must not be conceived as a dialectical either/or, but rather different degrees each possesses of the other's otherness. ${ }^{636}$ Por isso, Official discourse is autism for the masses. ${ }^{637} \mathrm{~A}$ graça das plataformas dialógicas vai assim afirmar-se algures num fugaz espaço-tempo emergente-experiencial-discursivo. A obra de arte pública crítica é então - Deus está nos detalhes - o domínio de uma percepção, consciência e produção pontual, situada, dos elementos discretos e sua articulação dialógica, uma atitude que nunca é apenas o que está à vista mas é sempre apenas e só o que está à vista na forma urbana. Estas são sempre a manifestação discursiva do impossível como possível - termos que com Miles (do ponto de vista da arte pública com participação) ou Zizek (do ponto de vista da política macro) veio destronar a utopia. Talvez o espectro redentor da democracia seja o vazio desta retórica.

\section{As posições de Claire Bishop e Grant Kester: os problemas de colaboração}

O político (a cidade) veio para destronar o white cube (a arte) ${ }^{638}$, sobretudo desde que os aspectos mais filosóficos e propriamente retóricos da community art's practice vieram para expandir o campo da arte para a dimensão da comunicação da cidade e sua produção.

[...] community arts practice is about collaboration. The driving force is the community itself, aided and abetted by the artist. It is the community, combined with the momentum, inspiration and orchestration of the artist, that develops the subject matter and means of artistic intervention. As such, community based public art is one of the only deliberate acts in the regeneration process which simply cannot take place without the active involvement of at least some of the

629 Idem. [...] e não o que veio depois.

630 Idem, p. 49.

631 Capra, Fritjof; «Social Reality», «Life and leadership in organizations», in The Hidden Connections, Flamingo, 2003, pp. 61-112.

632 Holquist, p. 50.

633 Capra, p. 89: The medium of organization and management is metaphor. Management theory and practice is shaped by a metaphorical process that influences everything we do.

634 Belanciano, p. 10.

635 Mumford, Lewis; «What is a city?», in Miles; Malcolm (Ed.), The City Cultures Reader, Routledge, London, 2000, p. 29

636 Holquist, p. 51.

637 Idem, p. 52.

638 Gloso Marion von Osten, no título «Politics beyond the white cube», in Jones, Peter Blundell; Petrescu, Doina; Till, Jeremy (Eds.), Architecture and participation, Taylor\&Francis, London and New York, 2005. 
Para Claire Bishop, na instalação e nas experimentações da arte interactiva, é the social dimension of participation rather than activation of the individual viewer in so-called 'interactive art and installation ${ }^{640}$ que lhe interessam, pelo facto de pressuporem o valor da colaboração.

Their emphasis is on collaboration, and the collective dimension of social experience. Recurrently, calls for an art of participation tend to be allied to one or all of the following agendas. The first concerns the desire to create an active subject, one who will be empowered by the experience of physical or symbolical participation. [...] The second argument concerns authorship. The gesture of ceding some or all authorial control is convencionally regarded as more egalitarian and democratic than the creation of a work by a single artist while shared production is also seen to entailthe aesthetic benefits of greate risk and unpredictability. [...] The third issue involves a perceived crisis in community and collective responsibility. This concern has become more acute since the fall of communism, although it takes its lead from a traditionof Marxist thought that indicts the alienating and isolating effects of capitalism. One of the main impetuses behind participatory art has therefore been a restoration of the social bond through a collective elaboration of meaning. ${ }^{641}$

É altura de aprofundar de forma dialéctica as posições de Lippard e Ardenne. Um bom ponto de partida para abordar a questão é a da qualidade em arte pública levantado numa polémica decorrida entre dois autores fulcrais, nas páginas da revista ARTFORUM, dá o mote. Relativamente aos critérios a ter em conta na avaliação da arte 'socialmente engajada', Claire Bishop sugere que, de uma forma genérica, e em conta a realidade da arte pública centro-europeia e norte-americana, a questão estética é de alguma maneira sacrificada no 'altar da mudança social'. Grant H. Kester contesta porém que, mais importante, e fundamental para definição da função da arte, proteger práticas em que os criadores possam comunicar fora das exigências retóricas do seu estatuto oficial. ${ }^{62}$ Logo, a estética da arte comunitária suggests a very different image of the artist, one defined in terms of openness, of listening [...] and of a willingness to accept a position of dependence and intersubjective vulnerability relative to the viewer or collaborator ${ }^{1643}$. No limite, o projecto de arte participativa pressupõe que o artista funcione como um trabalhador social (social worker), abandonando um banking style of art $^{644}$ contribuindo ao nível local, de comunidades e situações específicas, para reformas que o estrito universo da politica não quer ou não sabe enfrentar. Nesse processo, a arte acaba por abdicar de algumas das suas competências e técnicas históricas (Roberts), para integrar outras competências específicas da contemporaneidade - bureaucratic, diagnostic, aesthetic/expressive, and so forth. Neste ponto, community art cannot be analyzed with a conventional approach to art. Na internet, esta polémica chega a ser acesa - transcrevo pela energia da sua imponderabilidade:

639 Williams, Katherine Vaugh; «We need artists' ways of doing things: a critical analysis of the role of the artist in regeneration practice», in Jones, Peter Blundell; Petrescu, Doina; Till, Jeremy (Eds.), in Architecture and participation, Taylor\&Francis, London and New York, 2005, p. 221.

640 Bishop, Claire; «The Social Turn: Collaboration and its Discontents», ARTFORUM, Fev. 2006.

641 Idem.

642 Kester, Grant H.; Conversation Pieces, University of Califórnia Press, 2004. Kester destaca criadores como Stephen Willats e Artists Placement Group, ou Suzanne Lacy, ou ainda Helen e Newton Harrisson. Mais recentemente, Ne Pas Plier e Wochenklausur, estes últimos também muitas vezes referidos por Malcolm Miles.

643 Kester; Grant H.; Conversation Pieces, p. 110. Community artists 'replace the conventional, "banking" style of art lto borrow a phrase from the educational theorist Paulo Freirel 'in which the artist deposits an expressive content into a physical object, to be withdrawn later by the viewer - with a process of dialogue and collaboration'. Ora a abertura da esfera artística à colaboração não-especializada passa por uma crítica de algumas perversões aportadas pela vanguarda: [...] the modern avant-garde developed 'a series of strategies designed to anchor the meaning of the work so thoroughly in the recalcitrant individuality of the artist, and to frustrate existing norms and expectations so completely, as to render it utterly unpalatable to the appropriative powers of consumer culture. The act of semantic resistance gradually becomes an end in itself and one of the defining characteristics of avant-garde art'.

644 Termo que Kester recupera de Paulo Freire. Kester, p. 10. 


\begin{abstract}
Art's only power comes from its powerlessness, its uselessness. Art=jesterism. Putting real people and real activism into that equation leaves a bad taste in my mouth for two reasons: Trying to fight the fact that art and reality are different things by throwing a bunch of reality into art makes art less powerful. When it's fake and you can do anything because it is fake, art has the power to take the human mind anywhere. When it's about reality and what can really be done, that's an unnecessary limit on human creativity. Besides, the art context will minimize whatever you're doing anyway. Why put real people with real problems into this minimizing machine?

(DilettanteVentures) offered: Working against categories can be interesting as long as there is a reasonable amount of rigidity to those categories. The problem is that the boundaries have collapsed and in less you're advocating a hardcore return to a Greenberg or Fried like puritanical aesthetic, it just doesn't make sense to operate in that way. "This work is important - why dilute its importance by calling it art?" Funny, Bishop seems to think that calling something art, or treating it critically as such increases its importance. [...]

E outro: I know that Bishop and Kester think that art is more important than life, but I think this is a problem of context. Contemporary visual art is not particularly relevant to ordinary folks. [...] Bishop and Kester should try teaching art in the public schools, or even teaching an art appreciation class to nonmajors at their respective universities Inot lecturing, teaching a section). I see how making something art increases its visibility, but how? To whom? As someone flailing around trying to market quasi-political art myself. I find myself looking to the regular-person media as a practical matter. The art market is so highly specialized and its concerns are so narrow that I have a hard time trusting its ability to get anything across. These are gut reactions, they sit alongside my gut reaction that this total, irreversable collapse of boundaries is a last gasp of modernist reduction, that it's a red herring. I don't think a hardcore return to puritanical Greenberg/Friedism is necessary at all it's not like you have to back up the truck for 20 miles if you figure out the road you're on is eventually going to dead end. There are turnouts all up and down the thing, leading to new places. You write: "Ultimately, can't we create new conceptual/discursive networks and structures for supporting these activities?" Yes, definitely. The great thing about Oda Projesi, for example, is the way it injects creative thought and artistic models of thinking into non-art spheres. This is beautiful and right and good and should be the goal of art education everywhere. But this kind of practice is a hybrid - it's applied, first of all, and it's also fundamentally social and non-visual. It's using art strategies for non-art goals. [...] Why make "art" the miscellaneous drawer? That does seem like a dead end to me - the logical conclusion of a modernist experiment that works reductively, chipping away at the stone to get at that one essential truth hidden underneath it. Again, dilletanteventures, you've got me beat when it comes to booklearnin'. But I don't see why a hardcore return to old thinking is the only way to create a structure for understanding what art is and what it does - why it's relevant to other people. I don't think that including everything that other folks won't take seriously accomplishes that goal, and this leaves potential viewers out in the cold, trying to like art but being unable to because it makes no freaking sense. Call me a populist - the thing I don't like about Kester's theoretical position is that it does not reach out past the ever-shrinking sphere of people who already care. Worse, it assumes that art has more power than it actually has. That seems small and ungenerous to me.
\end{abstract}

\title{
2.2.4.4 Estética (relacional) num tempo de urgência: o discurso da provocação à produção, o colectivismo depois do modernismo
}

Em «Aesthetics in a Time of Emergency», Malcolm Miles realiza uma comparação entre os discursos de Bourriaud, Kester, Bishop e Rancière. $\mathrm{O}$ artigo foca-se nas possibilidades de a arte crítica urbana representar possibilidades de provocação e de co-produção (respectivamente, o que é significativo, os meus vectores 'baixo' e 'direita'), assim cobrindo de forma clara parte importante da minha problemática. Pensando no trabalho dos PLATFORM ${ }^{645}$ : To me [...] the question as to whether an intervention is art is not interesting [...] It seems more interesting to observe, as Rancière advises, what an intervention does, how it is received by the publics it creates, and to what if any extent it states or tacitly implies a political position or programme. ${ }^{66}$ Independentemente das nuances que Rancière identifica - arte como documentação histórica; arte contravisual, de resposta à desvalorização da imagem nos media

645 Caracterizado por um blurring of art and campaigning (cf. Nota supra), ou seja, necessariamente envolvendo uma dimensão activista que assenta na informação e da comunicação propagandística, que necessariamente exige a transposição para media gráficos e textuais.

646 Miles, Malcolm; «Aesthetics in a Time of Energency», in Third Text, July, Vol. 23, pp. 421-434. 
(Pedro Costa), arte baseada na metáfora, jogando com a ambiguidade e a ambivalência - o que se exige à arte crítica de hoje é que ela explicite os mecanismos da dominação por forma a tornar o espectador num agente consciente das transformação do mundo. ${ }^{647}$ Rancière não é um especialista em arte pública, mas Miles retira dos seus comentários as conclusões necessárias também para a praxis artística na forma urbana, onde porventura os referidos mecanismos de dominação - sejam eles edifícios (Christo), monumentos (Wodiczko) ou mobiliário urbano (Ne Pas Plier) - são a matéria prima dos criadores mais inconformados. Mas Miles e Rancière estão em sintonia ainda noutro ponto, o da arte como espaço negocial:

[Critical art] must borrow the connections that provoke political inteligibility from the blurry zone between art and other spheres. And it must borrow the sense of sensible heterogeneity that feeds the political energies from isolation of the work of art. It's this negotiation [...] that permits the formation of combinations of elements capable of speaking twice: from their readbility and from their unreadability. ${ }^{648}$

Para mim, isto significa enriquecer e intensificar as consequências de uma deriva performática da arte pública desde Duchamp (conscientemente interpretada ao longo de um vector horizontal que vai do Museu e da instituição à imponderável experiência colectiva da urbana), deriva essa que é tanto mais instrumental quanto integrar uma dimensão mental-intelectual-política (quadrante superior direito) que suporta teoricamente a necessidade de a arte estabelecer contradições com os confinamentos caracterísiticos da vida política.

A chamada estética relacional, cunhada por Nicolas Bourriaud, tem obtido visibilidade na esfera destas questões:

Rétablir le contact entre le public et la production artistique contemporaine [...] créant dês situations transactionelles et interactives [...] Ces événements mimetiques de la réalité exigent sans doute qu'on les prenne au «second degré». Mais leur banalité revendiquée ne permet guêre de mesurer l'ironie salvatrice et véritablement subversive qu'ils sont censés exprimer. ${ }^{649}$

Jimenez desmonta esta arte relacional 'institucionalizada' como responsável por uma elasticidade do conceito de arte que, ao limite, não deixa de retirar a esta a operatividade crítica: Mais la question cruciale [...] n'est-elle pas surtout de se demander si cette élasticité n'est pas désormais, et avant tout, l'une des principales caractéristiques de l'instituition ${ }^{550} \mathrm{E}$ nestes termos, muita da liberdade aparente de certos percursos artísticos será ao fim e ao cabo o reforço do status quo - precisamente devido ao desvanecimento mais ou menos encenado e virtual das suas margens? Em suma, If the role of the institution and the quality of the communities is not incorporated into the considerations, the Relational Aethetics will remain, as opposed to institutional critique, only a genre and not a method. ${ }^{651} \mathrm{E}$ nestes termos que a estética relacional veio ampliar a mobilidade de certos artistas em contextos em que a desigualdade da distribuição do sensível é evidente. ${ }^{652} \mathrm{O}$ que falta a muita estética relacional parece ser então um pathos colectivo? Recupero a tendência colectivista na arte crítica contemporânea, que leva ao extremo a ideia de colaboração iniciada por Futuristas, Dadaístas ou Surrealistas e ain-

647 Rancière, Jacques; «problems and transformations in Critical Art», p. 83.

648 Idem, p. 61.

649 Jimenez, p. 172.

650 Idem, p. 221.

651 Möntmann, Nina; «Relational Aesthetics», in Sculpture Projects Münster, 2007, p. 434.

652 Maio, Fernanda; A Encenação da Arte, Textiverso, Lisboa, 2011. 
da produtivistas, muralistas e realistas sociais ${ }^{653}$, todos subalternizados numa história de arte que, não reconhecendo o valor do colectivo como vital and primary artistic solution ${ }^{654}$, preferiu destacar os ícones do expressionismo abstracto, de Fluxus, da pop, do minimalismo, da arte conceptual mais contravisualmente icónica. Mais, os criadores que pontualmente, ou até mesmo regularmente, adoptaram este princípio vital para a sua criação - Matta-Clark é exemplo - vêem-se consagrados pelo sistema, sim, mas com este tipo de experiências relegadas para uma espécie de não-historicidade ou uma historicidade. Matta-Clark, que parte da sua experiência como estudante de arquitectura para uma intervenção sintomática que é pura arquitectura de resistência silenciosa ao mundo social - e em que as assumidas influências situacionistas se revelam - é reconhecido na visualidade das suas imagens, no mito da sua persona, mas esquecido como agitador político. No fundo, o sistema cultural (e o campo da arte contemporânea especificamente) não reconsidera um aspecto essencial do ethos romântico. ${ }^{655}$ Baseado na urgência da emergência do indivíduo criador como ser autónomo e livre, este ethos nunca deverá abdicar de uma legitimação popular e de uma total imersão da criação no corpo do socius, elevado a categoria histórica e filosófica (traduzida no quotidiano lefèbvriano). Face a uma evolução solipsista, e materialista da arte, apenas recentemente, e agora com solidez argumentativa (da teoria crítica à filosofia radical) e pela primeira vez na história à escala do globo (Scholette), redescobrimos o colectivo como instância crítica da criação. There is a specter haunting capitalism's globalisation, the specter of a new collectivism. ${ }^{656}$ Menciono, como característicos desta esfera de actividade, o trabalho de Wochenklausur na Áustria, Le Groupe Amos, no Congo ou Temporary Services em Chicago. Estes colectivos desenvolvem rupturas incompletas ${ }^{657}$ que equivalem já não apenas a um collaborative turn (Lind) mas propriamente a um resiliente Cultural Turn ${ }^{658}$.

Nesta linha da produção de 'mais-valias' colectivas - o quotidiano como troca, na transparência e informalidade dos seus dispositivos - Christian Nold é um artista em que parecem reverberar com radical intensidade referências históricas como a dos Critical Art Ensemble, cujas acções inspiradas no movimento anarquista e integrados no que hoje se denominam os tactical media, funcionam como células colectivas que empreendem molecular interventions and semiotic shocks that contribute to the negation of the rising intensity of

653 Scholette, in «Preface», Collectivism after Modernism; Stimson, Blake; Scholette, Gregory; Eds. University of Minnesota Press, Minneapolis, London, 2007, p. xi.

654 Idem.

655 Idem. Individual self-understanding was indeed downplayed as it had been before the war, it might be objected, and this was the basis of this later period's legitimate claim to be "neo-avant-garde." But it was different: now the nexus of artistic activity was projected outward and away from the core of the old Romantic expressive subject toward the material infrastructure of art-making - to the paint and canvas and drips and splatters, for example, or to the street or landscape, or to the gallery, the contract, and the adverstisement - and not outward toward questions of social organization and collective identification. Looked at in retrospect such a turn of hand is not surprising, really: the old modernist collectivism was indissolubly linked with a bigger ism, a bigger ideal that had failed - communism - and it had little choice but to distance itself.

656 Frase inicial de um texto que periodiza o colectivismo, na obra supra.

657 «Introduction: Periodizing Collectivism»; in Collectivism after Modernism; Ed. Stimson, Blake; Scholette, Gregory; University of Minnesota Press, Minneapolis, London, 2007 p. 4. Os autores referem-se a experiências radicais de Malevich a Mondrian e Magritte, de Zero Dimension a Critical Art Ensemble, Group Material ou Yes Men.

658 Scholette; Gregory; Stimson, Blake: As one cold war bureaucrat put it, "the tremendous importance of the art" was that they could serve "as an antidote against collectivism." Idem, p. 7 Citação por Frances Stonor Saunders, The Cultural Cold War: The CIA and the World of Arts and Letters (New York: New Press, 1999). 
authoritarian culture. ${ }^{659}$ Se a cultura autoritária (em que não vale a pena argumentar) exclui o colectivismo imanente dos CAE ou dos FREEE, There is only room for one collective enterprise now and that is state sanctioned marketplace fetishism as imagined community. ${ }^{600}$ Todo o desafio está portanto em desenvolver uma experiência quotidiana da troca, na transparência $e$ informalidade como dispositivos. Cultural politics may have ended, but in a world all but totally subjugated by the commodity form and the spectacle it generates, the only remaining theater of action is direct engagement with the forces of production. This repoliticization of the economy brings with it the ghosts of collectivism past ${ }^{661}$. Nesta linha de pensamento, apenas um modelo retórico - que no fundo mantenha in su sitio o filosofar e o agir político - mina a hegemonia psicológica do Eu ocidental ${ }^{662}$, que se aglutina num demónio que todos os outros demónios servem (Kafka), o individualismo como fetiche: that of individual sovereignity through which all maner of social privilege is venerated and colective aspiration is redeployed as a dehumanized abstraction, as a machine of exploitation and oppression. ${ }^{63} \mathrm{O}$ facto de hoje o Estado ser, no fundo, a lógica das grandes corporações, em nada muda o essencial, uma marcha em que o colectivo é porventura a grande perda cultural numa negação hegemónica do humano. Portanto, a haver um activismo relevante, This means neither picturing social form nor doing battle in the realm of representation, but instead engaging with social life as production, engaging with social life itself as the medium of expression. ${ }^{664} \mathrm{O}$ slogan vanguardista e, mais atrás, o motto romântico, da fusão arte-vida, encontram assim o sentido de actualização de uma linhagem graciosa:

[...] the ancient dream of the glorious, all encompassing body of the collective - of Christ or God or Allah or King or Leviathan or Nation or State or Public - the dream of redemption, of experiencing the imagined community as an end to alienation and as a promise of eternal life, realise itself not as an image or as flight from images but instead as a form of social building that brings itself into being wherever and whenever it can. ${ }^{665}$

\section{Outro autor coloca a mesma questão:}

Artist's collectives do not make objects so much as they make changes. They make situations, opportunities, and understandings within the social practice of art. The collective mode of organization has become another strategy artists use to construct situations that work on particular social problems or sets of issues. [...] The new collectivism is about vision and the future. Authorship is beside the point. 666

Perante o imobilismo que significa negação do eu e redução da experiência humana na

659 «Introduction: Periodizing Collectivism»; in Collectivism after Modernism; Ed. Stimson, Blake; Scholette, Gregory; University of Minnesota Press, Minneapolis, London, 2007 p. 11.

660 Idem, p. 12.

661 El Lissitzky: The private property aspect of creativity must be destroyed; all are creators and there is no reason of any sort for this division into artists and non-artists. In «Suprematism in World Reconstruction» (1920), in El Lissitzky: Life, Letters, texts (London; Thames \& Hudson, 1967), p. 333.

662 E seu cerne, o narego (ego narcísico). Cf. Araeen, Rasheed; «Ecoasthetics. A Manifesto for the Twenty-First Century», In Third Text, Vol. 23, Issue 5, September, 2009, 679.

663 «Introduction: Periodizing Collectivism»; in Collectivism after Modernism; Ed. Stimson, Blake; Scholette, Gregory; University of Minnesota Press, Minneapolis, London, 2007 p. 7.

664 «Introduction: Periodizing Collectivism»; in Collectivism after Modernism; Ed. Stimson, Blake; Scholette, Gregory; University of Minnesota Press, Minneapolis, London, 2007 p. 13.

665 Idfem, $\mathrm{p} 13$.

666 Moore, Alan W; «Artists' Collectives Mostly in New York, in in Collectivism after Modernism; Ed. Stimson, Blake; Scholette, Gregory; University of Minnesota Press, Minneapolis, London, 2007 p. 216-217. Mas ainda aí, resta saber até que ponto se poderia falar em dumping por parte dos criadores high-tech do sistema, dos verdadeiros e múltiplos activismos que afinal garantem a 'sombra' da actual arte publica, de Cuba (como farei questão de explicitar) a Portugal (como a actividade extramuros procurou levar a cabo). 
sociedade actual (Gruen), e sem nunca perder de vista a imanência acutilante da humildade (Gross), urge interpretar activamente, performaticamente, colectiva-comunitariamente (Nancy), no quadro de um metafilosofar tendencialmente anónimo (resiliente à autonomia modernista-burguesa), os dispositivos, nomeadamente discursivos; os que temos ao dispor e os que hão-de-vir: There is a continuous conflict between artists, many of them involved with collectives and public art, who seek to enlarge the sphere of public creativity, and an art market that requires a scarcity of artistic products. This is basically a conflict between inventive creativity and the embodied power of capital. ${ }^{667}$ Esta nota é válida, naturalmente para a relação entre poder público e arte pública - em que os termos público nas duas expressões não são de todo equivalentes - e portanto para o papel que a arte pública crítica pode ou deve desempenhar no dar corpo público à cidade (Freee). Perante isto, existirão tantos tipos e modalidades de activismo quanto contextos (multiplicados por indivíduos e grupos, sensibilidades pessoais e personalidades dos agentes). O que importa aqui sublinhar é o processo discursivo e sobretudo participativo, ${ }^{668}$ fazendo sentido começar por uma questão básica - ainda que porventura insustentável, ${ }^{669}$ a da igualdade. Para Rancière, a igualdade é uma posição a partir das quais as pessoas pensam e agem, não uma ideologia que possa ou deva ser atingida. No projecto participativo acontecem formas muito subtis de exclusão estética que mostram como é difícil realizar a premissa de igualdade entre os participantes.

But we did not worry about what people might submit. This was not neglectful behaviour on our part, we had made a critical and ethical decision to accept that participants would contribute whatever it might be that they thyemselves chose to contribute to the exhibition. Our role was not to judge, edit or apparaise but to be supportive of people's choices, and to focus on trying to make possible a welcoming, positive and critically active environment in which people would be unconditionally trusted, respected and valued. ${ }^{670}$

Tudo depende do que os grupos envolvidos possam pensar da própria instrumentalidade do conceito arte (ou 'arte pública'), isto é, a actualidade crítica da sua função colaborativa. Concluo então com uma nota que relaciona a participação e o quotidiano lenquanto valores de projecto):

What needs 'factoringin' if one is to apprehend the everyday street is not something extra-aesthetic, subjective or intellectual - added from the outside, but our lived experience of it, our participation and immersion in its fields, the way in which we make it part of our world and recognize it as as such. [...] Certeau rebuts this view of pratique. For him people know more than we imagine; doing is a kind of thinking. In his logic of practice, what makes pratiques operative and efficacious is the level and context of their application. It is not a matter of knowledge or power but of local, pragmatic flair. In Certeau pratique does not possess its own content or space: it is a secondary production that exists only through the way it uses what is already in place, but it does thereby have a projective, dynamic aspect: it produces by reusing rather than reproducing. ${ }^{671}$

667 Moore, Alan W; «Artists' Collectives Mostly in New York, in in Collectivism after Modernism; Ed. Stimson, Blake; Scholette, Gregory; University of Minnesota Press, Minneapolis, London, 2007, p. 214.

668 Cf. Höller, Christian; «Participation», in Sculpture Projects Münster, 2007, p. 364.

669 José Gil, sugere-o, ao interpelar Rancière na conferência «A Era da emancipação já passou?», Fundação Calouste Gulbenkian, Lisboa, Novembro 2011.

670 Offering someone the opportunity to act autonomously can undoubtefully be risky and some artists, academics and arts professionals (encumbered by their own expectations and attachments to aesthetic conventions) were dismissive of the invitation we had extended to the community groups which they seemed to think was naive. Wilks, Su; «Putting (Political) Policy into (Art) Practice, in Showing Expectations, http://www.showingexpectations.co.uk/.

671 Sheringham, pp. 142-143. 


\subsubsection{O estranho, o hóspede e a máquina - da mediação à externalidade}

Papastergiadis define algumas características da prática colaborativa na contemporaneidade, da autoria colectiva sob a forma de plataformas efémeras lao contrário da ideia de grupo no rescaldo dos primeiros modernismos) ao cosmopolitanismo vernacular e mobilidade global (eventos culturais transnacionais). Um seu comentário sobre Rancière conduz-nos à ideia de mediação embebedida no projecto curatorial.

Rancière and Marcus share a belief that ordinary people possess the inherent capacities to create meaning from the context of their everyday life. By entering into this partnership the artist is no longer in an observational position of exteriority that is somehow detached from the event, but is inserted as a co-partner whose presence will be one of the forces that shapes the process. Rancière's analysis of art as an emancipatory practice is based on the recognition that both the artist and the public assume an active role in constructing the creative meaning. He stresses that the act of perception is always an active engagement with the conditions of spectatorship. Seeing is not a disembodied intellectual exercise that alienates the body. Seeing is on a continuum with acting. This conjunction of the sensorial process with the manifestation of action suggests that the reception of art is always pregnant with political responses. The work of art becomes an intermediary object in the ongoing production of meaning. Just as the artist is not only transmitting an idea, but is also creating a field for the transmission of ideas, the spectator no longer 'looks at' or 'for' the meaning that is in the work. Rather than art being seen as a destination point for meaning, it is seen as a station that activates the spectator's self-awareness. Rancière'ss confidence in the equality of intelligences has nothing to do with the elevation of prior learning or the delivery of a miraculous formula for instant enlightenment. It is drawn from his belief in the inherent capacity that everyone has for learning by means of association. Metaphorical thinking - seeing similarities amongst dissimilarities - is the process by which he claims that everyone learns their mother tongue: 'by looking at and listening to the world around him, by figuring out the meaning of what he has seen and heard, by repeating what he has heard' (Rancière, 2007b: 275). It is the activation of this capacity for perceiving, recognising, relating and discovering connections that provide for Rancière the crucial link between aesthetic experience and political engagement. By showing a non-hierarchical relationship to knowledge, Rancière moves the understanding of collaboration from a one-sided exercise in instruction, to a mutual process of problem solving.

\section{Clarificando o 'salto' da colaboração até à participação,}

Collaboration, of the order that Marcus and Rancière were referring to in the process of collective knowledge making, can finally step out of the shadowy zone in which proprietorial claims were seemingly suspended but then redistributed to an individual. In art criticism the sceptical and derogatory approaches towards collaboration follow from a deeply ingrained mistrust of collective production.

\section{A posição céptica de Foster (na linha de Bishop), pode porém argumentar al contrario.}

A more sceptical view of collaboration would stress that all collective actions carry the flaw of inauthenticity as they seek to conceal individualistic motivations and bypass prevailing social divisions. In this paradigm the humanist ideals of sharing and empathy are forever doomed by the fatal drive that delivers the benefits of collectivism to a cunning individual. Hence, Hal Foster doubts the value of collective collaboration because in his view the artists have never undone their privileged authorial status and more importantly have failed to acquire the capacity to have a genuine dialogue with the other.

Em todo o caso a igualdade fundamental das inteligências será cerne do paradigma da mediação:

As Marcus would argue, this is not the way to do fieldwork in a global world, and as Rancière might say, such a low regard for others is not helpful in art. If the potential encounters and possible exchange between the insider and outsider are now bound as 'epistemic partners', or to put it in Rancière's terms, if participants proceed on the assumption that there is an 'equality of intelligences' (Rancière, 2007a: 271), then the status of collaboration is no longer poised on the purity of their idealist motivations, but rather succeeds or fails in relation to the mediation, rather than the description, of a better sense of 'who we are' and 'how we can live together' (Gillick, 2007).

Contestando o 'optimismo' bottom-up de Brian Holmes, e agora na linha de Lucy Lippard, que olha para o ciberactivismo menos como como transformativo e mais como reflexo directo de mudanças socio-políticas mais amplas, Papastergiados conclui:

It is my contention that this level of critical attention has a tendency to miss the point of collaborative art practice. Here, the effects of art tend to be registered only to the extent that they appear outside of its own, apparently autonomous, field. Is art only of value when it transforms or reflects the social? This question presumes that art is external to the existing forms 
Isto entronca na ideia (Flusser, mas também Sloterdijk) da arte como form mediation, ${ }^{673}$ na dimensão formal da cidadania artística (ou não, para ver a questão secundária ou técnica). Indistrinçável de uma retórica totalizante, a more robust and rigorous understanding of the affirmative role that occurs in mediation, ${ }^{674}$ o encontro torna-se quotidiano:

Following on from Deleuze, we can conclude that the work of artistic mediation occurs in the indeterminate space through which people pass and construct their own narratives. By highlighting the role of mediators in the field of cultural production, I have also sought to relocate the «idealised» position of the artist at the forefront of the engine of social change, and move it inside the processes of social production, so that artists see themselves as mediators in the global and local networks of communication. This shift in position also corresponds with a switch in the ambition that many contemporary artists express: a desire to be in the contemporary, rather than producers of belated or elevated responses. ${ }^{675}$

Na história do pensamento organizacional sempre houve a necessidade de enquadrar a co-existência de estranhos, hóspedes e máquinas. ${ }^{676} \mathrm{~A}$ vida política é basicamente uma questão de incorporar e distribuir socialmente poderes vitais externos (Corsín Jiménez). ${ }^{677}$ Tomando estes conceitos numa óptica de crítica tanto da familiaridade do lar como da publicidade da esfera pública, nesta articulação do liminal vejo uma noção de dispositivo participativo (meta)crítico que nos faz sentir em casa no processo de conhecimento. No seio de uma teoria da pura relacionalidade entre estranhos (Michael Warner) o importante de un mensage es que se escuche y no que se entienda, el denominador común mínimo de la comunicación es la estrañeza. Un mensage estraño nos coje a todos por igual. ${ }^{678}$ Talvez então a máquina social liberal, que desde o romantismo de Novalis até ao cinismo de Sloterdijk, com o estruturalismo pelo meio, se tornou fundamentalmente mais discreta e ao mesmo tempo mais pervasiva, deve ser objecto de um escrutínio especificamente dedicado ao seu modo de encarar a vitalidade do sistema do ponto de vista da definição de externalidade:

[...] la esfera pública liberal funciona, por tanto, qual Máquina de la Diferencia: linde ontologica donde al adentro y el afuera se espejan como metáforas y enemigos el uno el otro. Se trata, pues, de una máquina anticipatoria, generadora de sus proprias externalidades. De hecho, asi lo entiende la economía contemporánea, para la cual el concepto del bien público funciona como una externalidad: aquelo que desborda (spillover) las lindes del mercado; por tanto, que le es externo o extraño al mercado. ${ }^{679}$

672 Papastergiadis. Mediation requires more than just familiarization with and representation of known and knowable differences. The crucial link between the process of mediation and evaluation of difference in contemporary culture is that it seeks to go beyond the mere inventory and display of differences and seeks to develop new strategies for co-existence that are based on mutual understandings. In contemporary culture there is already a surplus of differences that are in competition with each other. The task of mediation is not to develop a criterion through which cultural differences can be ranked by some universal code, or discover a mode of address that can redeem historical damages. Rather, it seeks to create an understanding of new social possibilities by allowing each partner to go beyond their own certitudes and participate in collaborative knowledge making that is not just the sum of their previous experiences.

673 Idem.

674 Idem.

675 Idem.

676 Jiménez, Alberto Corsín; «El extraño, el huésped y la máquina», in Carta, Primavera-Verano 2011, Madrid, Centro de Arte Reina Sofia.

677 Idem, p. 16. La hospitalidad es la técnica de gestión de la estrañeza: el dispensario de protocolos, rituals y buenas maneras que invitan al extraño a sentirse como en casa. La hospitalidad es, por tanto, la tecnología por excelencia del umbral: alli donde el interior e el exterior, donde el anfitrión y su huéped, el amigo y el enemigo, solventan sus diferencias.

678 Idem. Como dice Raymond Geuss, la condición de estrañeza - las relaciones que se entablan entre estraños - exige l ala observación máxima del princípio de desatención: cuanto menos caso se hace a alguén, mayor su condicón de estraño. Geuss cita a modo de ejemplo la famosamasturbación pública de Diógenes de Sínope. El episodio demuestra has ta qué punto el espacio público de la civilidad se sostiene sobre un imaginário de la hospitalidad: donde el umbral del cuerpo interior, corrupto e poluto de Diógenes nos coje desprevenidos como público. En el curepo de Diógenes colapsa así el edifício de la liberalidad pública occidental. Nuestra vulnerabilidad como exraños nos pervierte como público.

679 Idem, p. 17. 
Mais do que cenários alternativos, a Teoria Crítica tentou contrapor à emergência deste quadro linhas de fuga imanentes (Corsín Jiménez), deslocando as derivas utópicas e escatológicas para uma operatividade aqui e agora do entendimento do lugar-economia, entendido cada vez mais como uma morada común. ${ }^{680}$ Isto vai conduzir a fenómenos de open source no domínio da ciência ou da tecnologia, nomeadamente no campo em expansão das tecnologias de informação e comunicação enquanto novas formas de vida pública. ${ }^{681}$ No lugar de uma esfera pública representativa (Habermas), temos então uma vida pública global, o que já pressupõe la imposibilidad de separar la politica de la estética, el afecto de la cognición. ${ }^{62}$ Confirmando a minha intuição da questão da informação como fulcro do processo de transparência significante no processo participativo, e ainda na mesma esfera de analogias que Wagner (agora enrobustecida pela tecnologia informática) Jiménez sublinha, apontando decidamente à arte como techne vital do dispositivo social: Es más, el énfasis en el térmico vida apunta también la possibilidad de concebir la información como fuente viva, como sistema autopoético, incluso como multiplicidad compleja que, más allá de comportarse como erramienta dócil, resulta por el contrario generativa, inventiva y creadora de mundos (wordling). ${ }^{683}$ É esta hipótese que leva Thrift, ${ }^{684}$ superando de certa forma o impasse deleuziano (apenas diagnóstico, ainda não terapêutica) à ideia de um capitalismo vitalista, afectivo e post-fenomenológico, alerta a las modulaciones básicas del espíritu, sus impulsos, carencias, excitaciones y temblors. Un capitalismo que se concibe a sí mismo como economia de las cualidades. La economia como cuerpo nervioso, como Máquina Vibratoria. ${ }^{685}$ Corsín Jiménez dá outras metáforas críticas para entender, nesta era do acesso (Rifkin), a liminalidade crítica do dispositivo: Ya no hay anfitriones ni huéspedes. Ya no hay extraños, no enemigos, ni amigos. Solo pura vibración. Nesta economia tal como pensada por Gabriel Tarde e hoje Latour, la economia es el colectivo, el enjambre, el entrecruzamiento de todas esas vibraciones, nazcan o no de nuestros intereses e nuestras pasiones. También las cosas - los materials, las herramientas, la cacharrería - vibran, también tienen pasiones. ${ }^{686}$ Donde que mais uma vez apenas a retórica - porque efectada e alimentada pela paixão, consegue dar ao filosofar uma noção de sentido tanto mais urgente quanto biologicamente necessária. Perante a vida (a rede) como inteligencia pura e común, ${ }^{687}$ a retórica é pura discursividade do entendimento proactivo no seio de uma participação total na máquina social.

\section{Communitas, horizonte}

Entre 1968-69 e 1983, ${ }^{688}$ Blanchot escreve vários textos determinantes para a ideia operativa de comunidade. A Comunidade Inconfessável (1983) culmina uma concepção da vida

\section{Idem.}

681 Idem. O trabalho de Christian Nold está no enfiamento desta posição.

682 Idem.

683 Idem.

684 Idem. Cf. Thrift, 2008.

685 Idem. Jimenez refere-se ao conceito proposto por Lepinay em «Economy of the germ: capital, acumulation and vibration», em Economy and Society 36, de 2007.

686 Idem.

687 Idem.

688 Blanchot, Maurice; The Unavowable Community, Station Hill Press, 2006. 
pública que se abre a uma indeterminação fundamental, um vazio metafísico no coração da cidade, contrastando resilientemente com a sua estruturação em funções, posições, identidades (raças, género, classe). Para Blanchot,

an empathic idea of public space as empty and open space appears in moments of rebellion and revolution [...] for the sake of the common appearance of human beings in the public space. Space has been appropriated in order to empty it out, to present it as empty, open for everybody. ${ }^{689}$

Tornando-se visível com Maio de 68, esta é uma apropriação polémica (Hirsch), romântica (Lefèbvre) da espacialidade, cujo valor positivo - como em muitos projectos de arte pública - acaba por reverter sempre para uma potencialidade negativa: a arte é o que (se limita a) interrompe(sr) a ordem corrente das coisas (o trabalho, o comércio, os transportes, a especialização). Mas existirá a hipótese de esta negatividade tornar-se positiva? The question is: How can this new symbolic power be described properly? And how can it be distinguished from, or related to the political question of a new collective organization of society? ${ }^{690}$ Noutros termos, como podemos relacionar a resiliência quotidiana, a performance do antagonismo, a multitude (Negri), com o desenho (design) de uma nova monumentalidade (Badiou), materializando-a, isto é, informando-a (Flusser) no tecido urbano? Maio de 68, ou 25 de Abril em Portugal ${ }^{691}$ adquirem assim o significado de uma questão por resolver, o que é mais instrumental que considerá-los projectos inacabados. Isto obvia um certo esteticismo de esquerda, muito presente nos discursos da arte contemporânea e do urbanismo (Hirsch), em favor de uma retórica que supere a dicotomia liberdade/consenso. Isto não pressupõe abandonar-se o fascínio estético evidente que quer a utopia consensual, quer a estética do antagonismo oferecem à memória colectiva. ${ }^{692}$ Mas sim situá-lo num construtivismo comunitário, de que Blanchot ${ }^{693}$ é arauto, ajudando-nos a compreender o sentido da manifestação: ${ }^{694}$ enquanto estar-junto, comunista: it is more a matter of presentation than of representation. ${ }^{695}$

Ora The historical political movements of anarchism and communism we know both suffer from the immediate projection of their empathic, radical ends onto political forms or means. ${ }^{696}$ Entretanto, as imagens contemporâneas do comunismo - de Nancy a Agamben ou Badiou - sugerem ethical and aesthetical modes of free communal exchange [to] have their aim in themselves. [...] They are related to an ethics and aesthetics of the occupation or appropriation

689 Hirsch; Michael; «The space of comunity: between culture and politics», in Miessen, Basar (eds.), p. 291.

690 Hirsch, p. 293.

691 Ambas as revoluções, alegadamente 'culturais' e não 'políticas', deixando a estrutura política e social intacta, transformando-se, mesmo assim mais em França que Portugal, num anti-estilo burguês que em última análise se compatibiliza com a imperturbável manutenção das formas sócio-políticas hegemónicas (Hirsch).

692 Where conservative, right-wing and totaitarian aesthetics believes in forms and images of unity and consensus, and tend to monumental representations, organic Gestaltungen of this unity, the new left wong aesthetics seems to believe in the beauty of unresolved conflicts and their expression. It is an aestheticim of antagonism. Hirsch, p. 296. Retomarei esta perspectiva sob a forma de um axiomática que estrutura as tensões entre a arte do Belo, confinada ao objecto no museu, e uma arte contingentemente paisagística, no 'lá fora' da comunidade por vir. Por outro lado, ela coloca a questão nunca resolvida, de como, numa política afectada, as questões esquerda/direita são, de tão historicamente determinadas, simplesmente absurdas.

693 Note-se, apaixonado e determinante leitor de Kafka.

694 Hirsch, p. 296.

695 Idem, p. 297.

696 Idem, p. 297. 
of public space as such.697 Donde a importância, agora com Sloterdijk, de uma terapêutica total da cidade-terra que sob o signo do cinismo face ao(s) dispositivo(s) permite vislumbrar um sentido colectivo para além da própria communitas. Em suma, Is it possible to give a both critical and positive account of this non-political being? Talvez, numa

implicit deconstruction of Blanchot's evident logic of distinction between the ethical exposition of community and the formulation of a political project. [...] intrinsic refraining from the formulation of a political project or end of the common presence of singular beings as the new political projet itself. ${ }^{698}$

Donde que:

Our task is to give a productive form to this seemingly pessimistic account of the situation. Appearing together in an open, indetermined space - in order to understand what this is about. We have to liberate ourselves not only from the "positive" idea of the conquest of power, but also from the "negative" idea of the constestation or provocation of autority 699

Isso ultrapassa uma estética de meros gestos simbólicos de resistência (Agamben), fazendo com que a intervenção (a criação de situações) não caia da hubris de tomar a heteronomia política por garantida - como acontece nalguma street art e actvismos participativos ingenuamente proselitistas, ou pelo menos nas visões que deles temos nos circuitos mainstream. Por outro lado, supera-se a tentação de petrificarmos a constelação antiautoritária (e implicitamente autoritária, diz Hirsch de Agamben) de Maio de 68, por forma a que eventuais suspensões da normalidade ${ }^{700}$ possam ser enquadradas pelo projecto politico da criação legal de algo como uma nova forma de ordem (Hirsch). Forma (emergente) e horizonte (sentido) tornam-se elementos de uma mesma constelação ineditamente emancipatória, no sentido lefèbvreano, e porventura gramsciano ${ }^{701}$, de constituirem um metafilosofar, material e situado, da pulsão artística pelo social. Só assim uma retórica da totalidade da boa vida evita que politics becomes [...] an end in itself, instead of a means to change the real conditions of life. ${ }^{702}$ É com este horizonte na distância que o tropo e a experiência da graça se torna, no contexto da produção extramuros, uma metametaforização $0^{703}$ dos ethoi atenção, envolvimento, engajamento artísticos e dos logoi dispositivo social, dispositivo tecnológico e dispositivo expositivo. A graça do social é fulguração de uma modalidade do comunismo wagneriano especificamente citadina.

697 Idem, p. 298. They are about a change in our ethical attitudes. They are "means withiut ends", to use Giorgio Agamben's words.

698 Idem, p. 298.

699 Idem, p. 304.

700 Hisrch precisa the dangers of empathically an-archic manifestations in the public space: the risk that the state of exception from the left or from below almost inevitably provokes a state of exception from the right or from above. Idem, p. 300.

701 Retenha-se a ideia de uma democracia bottom up,: Gramsci's novelty and merit consisted in changing the perspective of the politics of emancipation, and instead of focusing on the traditional and direct strategies of political inclusion, he opened up a broad inquiry over the social and cultural conditions of subordination and exclusion. He looked at modernity from the bottom of its peripheries. Urbinati, Nádia; From the periphery of modernity: Antonio Gramsci's theory of subordination and hegemony», in Political Theory, Vol. 26, n. 3, Junho 1998, 270-391.

702 Idem, p. 301.

703 Quando o metafórico se explicita filosoficamente (Cossuta). 


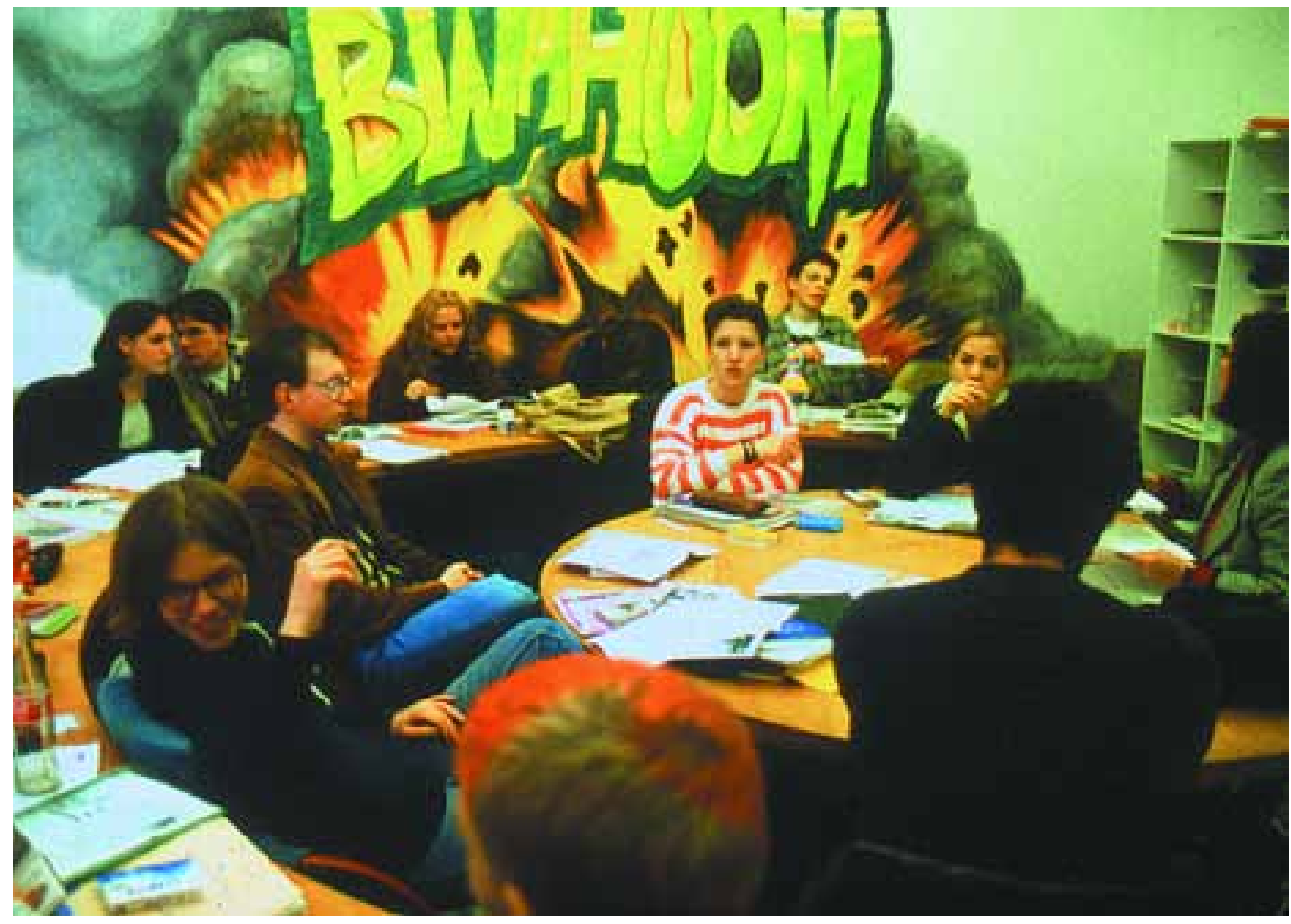

Intervenção numa escola, Wochenklausur 1996.

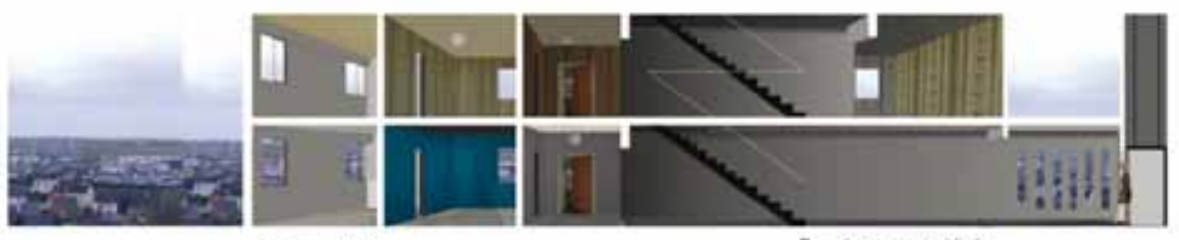

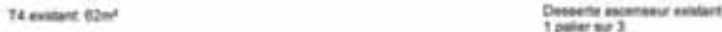

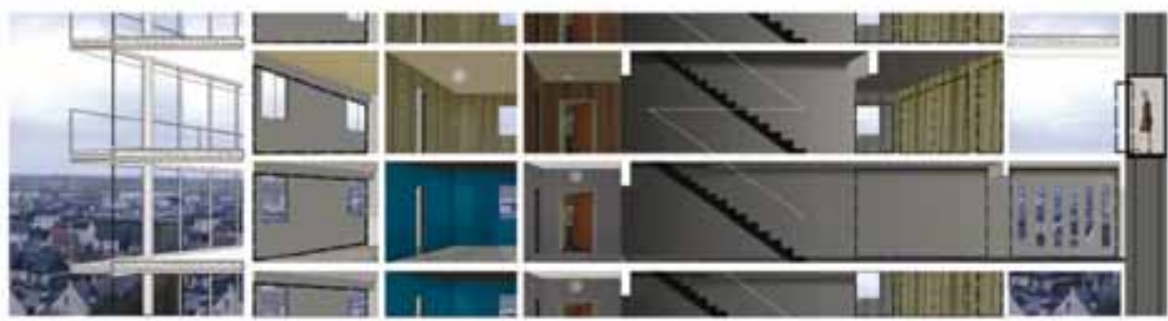

nos in tiven

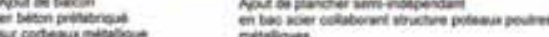

netoringer

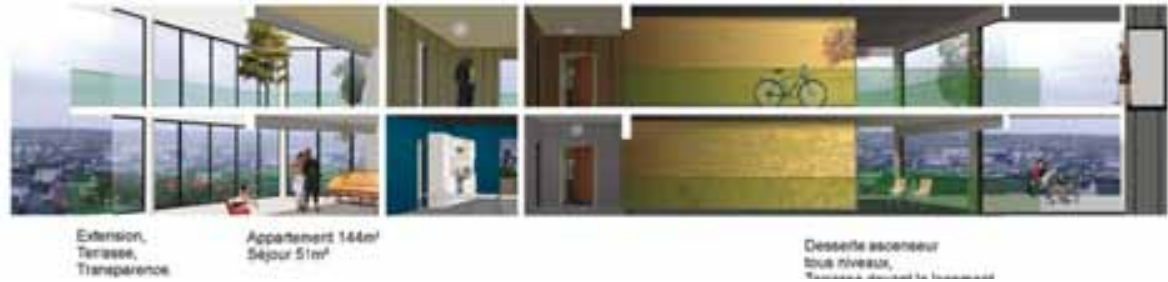

PLUS - Les grands ensembles de logements - Territoires d'exception, Lacaton\&Vassal (c/Druot), 2004 


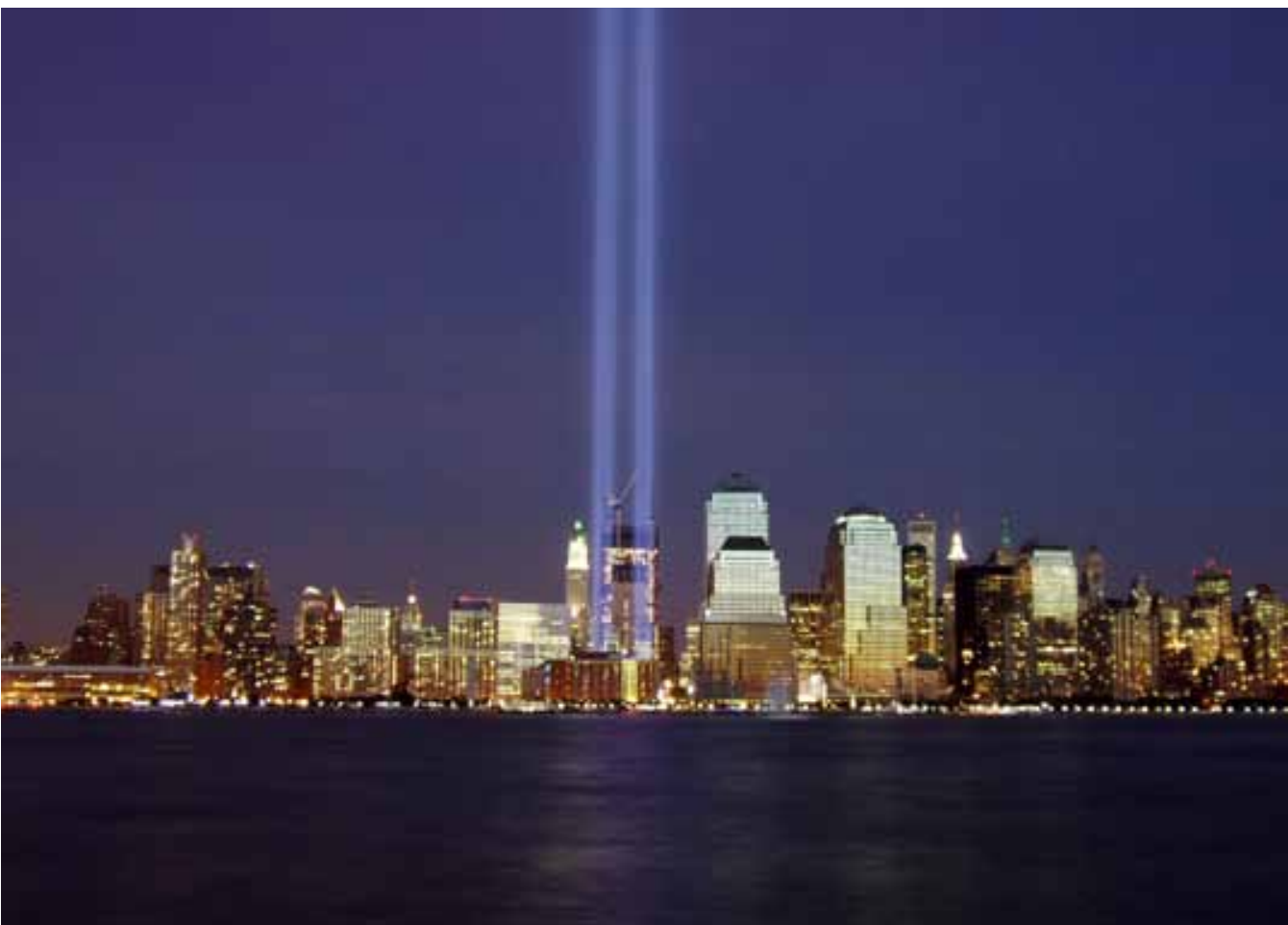

Memorial 11 de Setembro "Tribute in light", 2002-2011

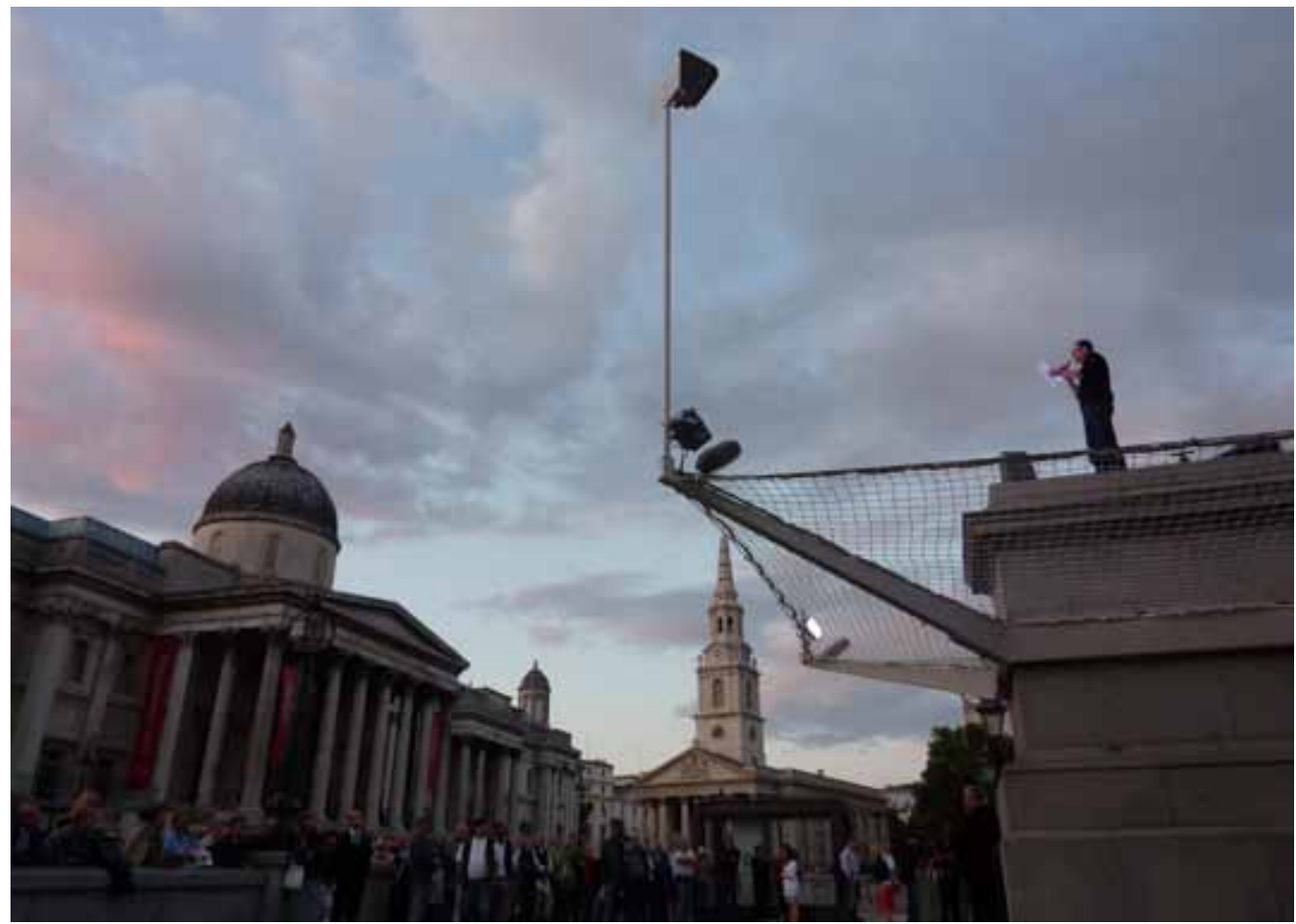

One \& The Other, Anthony Gormley, Londres, 2010 


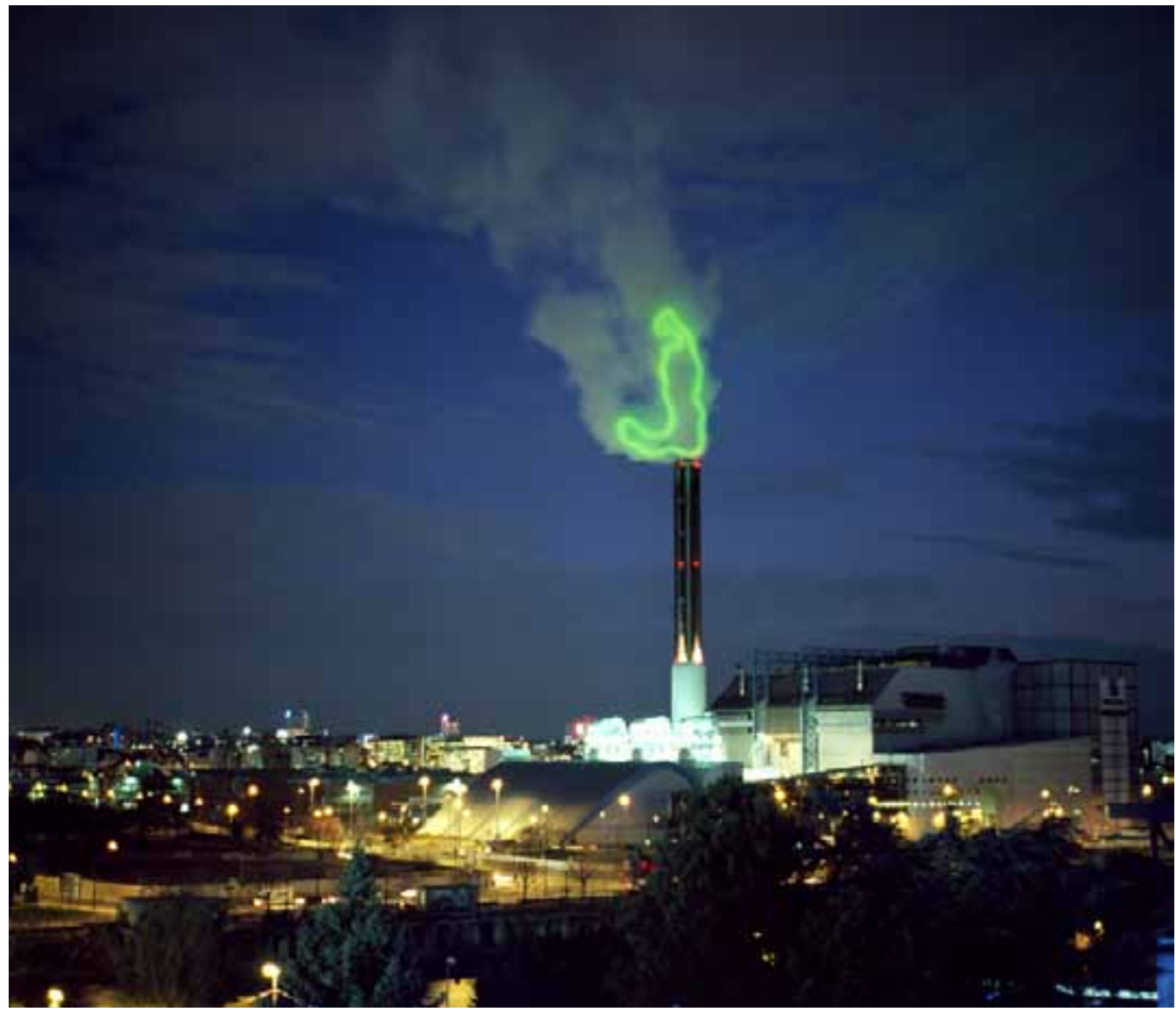

Nuage Vert, He-He, 2009

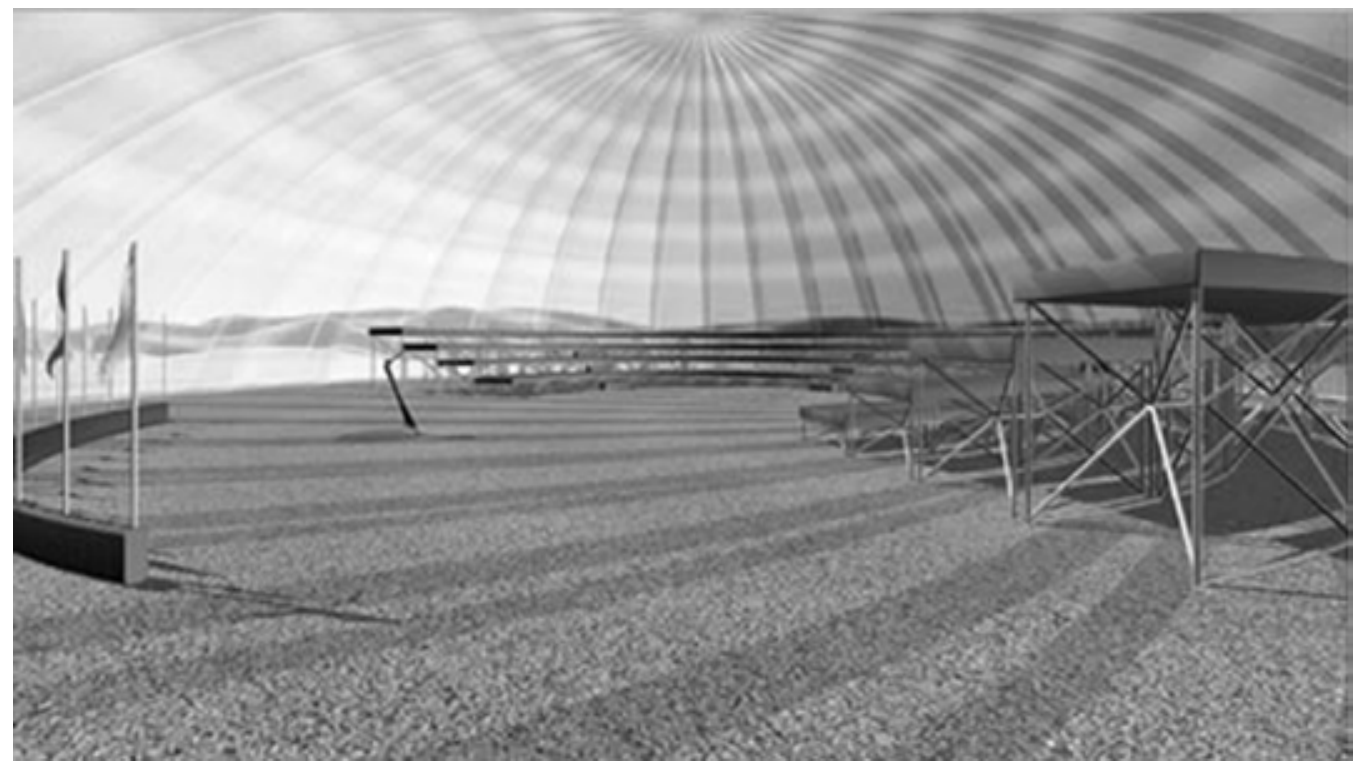

The Pneumatic Parliament, Peter Sloterdijk, Gesa Müller von der Haegen, 2006. Global Instant Objects. 



\title{
II. DO NADA À LUZ: UMA PRAXIS CURATORIAL
}

\section{LISBOA, ATITUDE EXTRAMUROS: METÁFORA OPERATIVA E PRINCÍPIOS PROJECTUAIS}

\begin{abstract}
Extra muros. O Museu inundando as suas próprias margens. Tornando permeáveis as fronteiras entre cidade e instituição, entre interior e exterior, entre público e privado. Os projectos temporários site-specific que o Museu lançou ou co-organizou nas últimas décadas podem ser caracterizados de inúmeras maneiras, mas quaisquer descrições definem-se sempre a partir desse ponto de partida.
\end{abstract}

Jan Hoet

A Associação Extra]muros[ nasce em 2000, sendo a forma para um conjunto de investigadores-criadores desenvolverem a sua actividade independentemente e o projecto Lisboa Capital do Nada em concreto. ${ }^{1} \mathrm{O}$ investimento necessário para realizar o evento ${ }^{2}$ exigiu forte enquadramento institucional. ${ }^{3}$ A Associação apresentava-se em 2000 como estrutura cultural pluridisciplinar, movida pelo ethos do Espaço Público e vocacionada para a intervenção na cidade. ${ }^{4}$ Pode dizer-se que foi consequência, também em Portugal, apesar da décalage, de uma dinâmica específica do regresso do politico, evidente desde meados dos anos 80 e global desde os anos $90^{5}$. Isto ao mesmo tempo que havia de operar hibridamente na operatividade da ingenuidade (Ernesto de Sousa) e da atitude (Sena da Silva): By working this way [...] voices act instrumentally and dynamically, ensuring that the editorial and conceptual direction of a project is uneven, awkward and impure. ${ }^{6}$

1 Concebido por Mário Caeiro com a participação inicial de Catarina Campino, e sobretudo Luís Seixas e Daniela Brasil (ambos arquitectos, ela arquitecta-urbanista formada no Brasil), com colaboração muito próxima da geógrafa Teresa Alves e depois de vários colaboradores.

2 Por forma superar os anteriores Retratos da Alma (1995) e Um Cálice de Dor (1989), culminando a trilogia.

3 Que viria fundamentalmente do Ministério da Cultura (Programa Operacional da Cultura) e outras entidades como a Fundação Calouste Gulbenkian e o Centro Português de Design.

4 A Extra]muros[ associação cultural para a cidade é uma associação cultural sem fins lucrativos sediada no Concelho de Almada, essencialmente constituída por profissionais da área projectual - designers, arquitectos, urbanistas, arquitectos paisagistas, geógrafos e cientistas sociais - que procuram através da Associação ter uma intervenção eticamente fundamentada em questões relativas ao meio urbano. Através da promoção da criação, do debate e da intervenção no Espaço Público, enquanto lugar da cidadania e da experiência convivial, acreditamos poder ser uma mais-valia cultural na vida dos habitantes, em nome da sua autovalorização e da sua urbanidade, considerada como factor de bem-estar social e humano. Será este facto que faz com que cada um dos nossos principais eventos tenha sido objecto do Alto Patrocínio da Presidência da República Portuguesa. As práticas da Extra]muros[ serão assim sempre transdisciplinares, praticando a transversalidade de teorias, técnicas, saberes e práticas como forma de aproximação dos cidadãos entre si, entre os cidadãos e as instituições intervenientes no Espaço Público, $e$ finalmente entre personalidades interessadas em abrir a sua actividade profissional/pessoal às questões acima apontadas. Em suma, os interesses e especialidade da Extra]muros[ são o Desenho do Espaço Público, a Ecologia Social, Políticas Urbanas, a Arquitectura, a Arte Contemporânea, enquanto corolário de um desejável enriquecimento estético da experiência urbana. Neste quadro, a Extra]muros[ é o parceiro adequado para quem aspira a intervir de forma ética, criativa e fundamentada na Cidade e na Cultura contemporâneas.

5 Basar, in Miessen, Basar (eds.), pp. 31-32. The political, as project, came back from the dusty bedsit of revolutionary 1970's prop declamations, except, this time, it had gone to university, done a Doctorate, and now, had publishing deals with Verso or Routledge. Nos termos de Shumon Basar, tratou-se de tentar criar condições para to make getting lost a way of living.

6 Basar, in Miessen, Basar (eds.), p. 33. Referindo-se à sua própria praxis em ateliê colectivo: We exploit our own Professional naivety as strength. We choose to remain amateurish. [...] By industry standards, this is perverse. Se calhar não 
Extra muros, termo com que Jan Hoet abre o catálogo Over the Edges ${ }^{7}$ (2000), foi referência escolhida para orientar a futura Associação, agora com os parêntesis rectos Extra]muros[ denunciando $o$ acto de abertura conceptual e rejeição de fechamentos de qualquer tipo. Estava encontrado o princípio projectual (metáfora) de todas as acções, pressupondo-se que o Museu é portador de um poder (Groys) com potencial de actualização, desenhando-se oportunidades de renovação das suas próprias relações com um público alargado e em crescendo, entendido não apenas como fruidor do valor da excepção (de que múltiplas formas de visão e segregação cultural são expressão e/ou causa), mas co-constituindo-se obra comum e colectiva, no domínio do Espaço Público como ideia. É este conceito que dá implicitamente sequência a derivas críticas da neovanguarda portuguesa, na articulação inevitável com novos contextos. Resiliente ao logos burguês da sociedade de consumo-comunicação (indústria cultural que nos anos 90 se afirma ${ }^{8}$ ), procurávamos factos culturais para além do seu carácter de produtos, visando situações de contacto que contribuiriam para uma arte do espaço público. Excêntricas face aos sistemas da arte (campo da arte contemporânea e da cultura erudita) e da cidade (campo da política representativa e das disciplinas projectuais), as iniciativas da Extra]muros[ a (E]m[) concentrar-se-iam na dimensão espacial-territorial da experimentação plástica. Esta abertura transdisciplinar e o seu ethos inclusivo seriam um fardo e um estímulo, numa época em que o objecto artístico se desmaterializa enquanto dispositivo consumado no mainstream. ${ }^{10}$

A experiência organizacional da E]m[ conduziu-nos ao valor da auscultação - um soundbite repetido era first ask people what they want, Malcolm Miles), - uma auscultação-negociação que incluiu sempre o potencial negociar do nosso estatuto no campo cultural estabelecido, a sua validade junto das diferentes comunidades-alvo das acções e finalmente a sua capacidade de introduzir novas formas de entendimenteo da arte e da cidade no discurso do poder hegemónico. Num registo transparentemente cínico-humanista, E]m[ nunca se posicionou fora do tecido cultural existente mas nos seus interstícios (Miles), optando pela desideologização do seu discurso para empreender uma programa em que as tensões entre várias tradições - humanista, liberal, libertária, activista ou outras (da pedagogia ao urbanismo radical) -, na sua irresolução, motivaram focos de conhecimento crítico intensamente vividos. De acordo com filosofia do ensaio (Barrento) mais heterodoxo, uma criação extramuros ${ }^{11}$ surge como

tanto no sentido da ingenuidade em si (impossível), mas de uma abertura ingénua para o autoquestionamento, a partir dos dados recolidos colaborativamente.

7 Over the Edges, S.M.A.K - Stedelijk Museum voor Actuele Kunst Gent Gent, 2000. Este evento de arte pública sucedia a experiência, Chambres d'Amis, na mesma cidade.

8 A Extra]muros[ não propõs qualquer confronto directo (antagonismo operacional) com a indústria cultural, tirando partido de alguns dos seus mecanismos de gestão, financiamento, produção ou comunicação (a ideia de evento).

9 Alguns episódios caricatos revelam o ostracismo que sofreria uma organização com sede na Margem Sul. No primeiro telefonema para o Ministério da Cultura, para indagar das condições de acesso ao Programa Operacional da Cultura, visando a candidatura da Lisboa Capital do Nada, recebo a seguinte resposta: Mas o que é que uma associação cultural da Margem Sul quer fazer em Lisboa? Este episódio revela como o poder cultural hegemónico encara um novo movimento de que não consiga deduzir a previsibilidade do seu centro.

10 A organização lidou frequentemente com a visão redutora do facto artístico por parte de gestores culturais e patrocinadores e organizações sócio-culturais, criando-se focos de tensão que apenas a presença continuada nos media e o reconhecimento académico atenuariam.

11 Retiro os parêntesis rectos, clarificando um ethos que já vinha de iniciativas anteriores. O Atelier Fortespolio (Mário Caeiro, Isabel Lopes, Luís Silva) havia realizado Por Timor (1993) Retratos da Alma (1995) e Um Cálice de Dor (1999). Recordo as palavras finais de Um Cálice de Dor: «Um Cálice de Dor» apareceu como tópico a trabalhar em 1995 precisamente no dia em que 
táctico jogo de apropriação da arte, mas não enquanto mero projecto de derrube do poder do status quo cultural (para os membros da associação, qualquer tentativa de antagonismo nomeadamente político esteve sempre votada ao fracasso e ao equívoco).

A conceptualização do projecto decorreu da experiência do Curso de Pós-Graduação em Desenho Urbano, no âmbito da qual estudei ${ }^{12}$ os processos de revitalização urbanística e cultural da Expo 98 e da Porto Capital da Cultura 2001, entre outros casos de estudo. A retórica do projecto adoptaria, em parte, o marketing urbanístico, afim àquelas iniciativas, mas com a metáfora do nada (contra a metáfora do tudo, a totalidade no projecto urbano) remetendo-nos para uma cultura bottom up e periférica. Contra a 'alta cultura' do espectáculo (arquitectónico), a E]m[ manifestou um desejo de cidadania que rapidamente encontrou eco nas ansiedades da população. Parte das classes criativas desejariam mesmo que esse desejo permanecesse e se espandisse decisivamente como movimento (Remesar $\left.{ }^{13}\right)$, mas uma retórica de efemeridade, baseada em sucessivas metáforas operativas (temas para a acção transformados em conceitos e slogans) parecer-nos-ia a estratégia adequada para, paradoxalmente, obter impacto duradoiro junto dos mais diversos públicos e organismos sociais. ${ }^{14}$

\section{Metáforas operativas - aproximação à edição e à curadoria, princípios projectuais e directivas}

Para Voggenreiter (e Baumann), it is the curator who focus on marginal but nonetheless necessary social discourses in their projects, thereby making them public. This is precisely what curating means: pointing up the relevance of those "weak things" and "impossible" aspects that constitute the heart of culture and community. 15

Obrist define o curador como um generalista. É alguém que, como Dorner nos anos 20 ou Szeemann nos anos 70 não deve colocar-se no caminho de um crescimento irreprimível do museu (por extensão, da arte) enquanto complexo sistema de aprendizagem ${ }^{16}$ que traz para o território expositivo os saberes de outros. Motivando, enquadrando e editando conversas $^{17}$, o curador é agente de transdisciplinariedade ${ }^{18}$ o que é indistrinçável da figura

inaugurou a exposição «Retratos da Alma», quase secretamente erguida pelo Atelier Fortespolio, algures numa ruela agitada do Bairro Alto. Cinco anos depois, o tema recuperou a sua pertinência, talvez por estarmos a escassos meses do virar da página no calendário, rumo a um novo milénio que nunca foi tão desconhecido. Entendemos por isso esta exposição como uma despedida [...] Séculos vão e vêm, e com eles dores. Mas parece evidente que esse desconhecido pedirá outras perspectivas, melhores metáforas para dizer esta nossa situação colectiva à beira do nada. In Vv. Aa; Um Cálice de Dor, Fortespolio, Lisboa, 1999.

12 Com o concurso de personalidades referenciadas em capítulos anteriores, como Pedro Brandão, Fernanda Fragateiro ou Delfim Sardo, docentes, juntamente com Filomena Silvano (Antropologia do Espaço) ou João Nunes (Arquitectura Paisagista).

13 Cf. «Algo aconteceu em Marvila, Lisboa Capital do Nada», in Vv. Aa, Lisboa Capital do Nada, Marvila, 2001, Extra]muros[, Lisboa 2002, pp. 470-481.

14 Referências bibliográficas crescentes e o reconhecimento no campo universitário nunca foram nosso objectivo prioritário, mas uma consequência natural da entrega implícita no nosso modelo organizacional.

15 Kniess, Bernd \& Voggenreiter, Meyer; in Miessen, Basar (eds.), p. 200.

16 Obrist, p. 14.

17 Idem, p. 16.

18 Idem. 
mediadora do tradutor. ${ }^{19}$ Para Obrist, como para outros curadores de referência na arte contemporânea com sensibilidade para a esfera e o espaço públicos (Hoet, Brissac), it was never about leaving the art-world. The art-world permits this enormous degree of freedom. It allows you to make these external connections. ${ }^{20}$ É dentro dos limites desta posição ${ }^{21}$ que alguns temas identificados pelo curador alemão como cerne do ethos curatorial podem ser revisitados, agora na perspectiva da experiência concreta. Assim, o curador crítico tenderá a - e passo a parafrasear vários termos em Obrist - propor modelos curatoriais colaborativos, integrar questões do urbanismo experimenta ${ }^{22}$, tornando tais arquipélagos legíveis para um público. Nesta ética, o curador não ocupa um espaço existente, antes cria um espaço livre. Obrist recorre a metáforas como a da ponte pedonal ${ }^{23}$ para cerzir o retrato do curador como proporcionador de situações efémeras, zonas de contacto numa liminalidade específica: We can only understand the global if we are at the same time looking very careful and in a focused way at local conditions. ${ }^{24}$

Até que ponto podemos então enquadrar a praxis curatorial extramuros nesta postura de atenção ao contexto e condições para a inscrição da criação? Ponto em comum, a ideia de partir do museu para encontros imprevistos com o social, redimindo a sua temporalidade; ponto eventualmente divergente, a abertura para uma autoquestionamento da posição curatorial como válida, num oximoro performativo - como na expressão Take my advice, don't listen to me (Neil Young ${ }^{25}$ ) - que explicita aforisticamente a consciência do dispositivo comunicacional (e naturalmente, também expositivo), na orgulhosa humildade (Gross) da interacção. Entre estas duas nuances, a tensão (uma partitura de possibilidades projectuais) é depois interpretada pelos projectos artísticos individualmente, sendo que, ao final, tudo se resume à capacidade de comunicar porque sim. Seria esta a 'origem' da curadoria, inventio da energia do contínuo recomeço da participação: [...] so / believe that the critical issue is to use language that people can understand, penetrate and eventually use. So the process in my opinion takes a lot longer to form. Participation is something that you should start - and this is something that you should not forget - it lasts forever. ${ }^{26}$

A posição curatorial da E]m[ inicialmente desenvolvida sem uma real consciência teórica conforme Obrist, Wedibel, Groys ou Kniess e Voggenreiter a explicitam, é indissociável de uma ligação aos Estudos Literários, campo disciplinar em que a 'metáfora'27 é um fecundo modelo

19 Idem.

20 Idem,

21 Apesar de ser necessário questioná-la radicalmente, de acordo com a evolução do socius na nossa actualidade, não sendo este o lugar para o fazer.

22 Para Obrist, o não-plano de Cedric Price, a auto-organização de Yona Friedman ou a forma aberta de Oskar Hanson. Cf. Obrist, p. 16.

23 Coincidência inteerssante com a denominação do projecto SKYWAY, na Polónia, em que a ideia da ponde pedonal avançada por Félix Fénéon, na imagem do curador como ponte pedestre -, ampliada pelas ressonâncias cósmicas, explicita uma noção da cidade como espaço de atravessamento capaz de gerar o prazer da experiência.

24 Obrist, p. 17.

25 («Hippie Dream», Landing on Water, 1986)

26 De Carlos, Giancarlo; In Obrist, p. 18.

27 s. m. (gram.) tropo em que a significação natural de uma palavra se transporta para outra por virtude de relação de semelhança que se subentende; imagem; figura. (Do gr. Metaphorá, «transporte», elo lat. metaphôra-, «id.»). Ibidem. 
de abordagem do real. Tendo em conta que cada operação metafórica - a ideia de situar a metáfora na cidade - funcionaria como desafio ao entendimento e ao envolvimento por parte do público, o aposto 'operativa' traduziu uma dinâmica linguística e poética na esfera do acontecimento cultural, ${ }^{28}$ sucessivas metáforas operativas dariam origem a um conjunto de factos estéticos que definem o devir de uma consciência particular, a progressiva elaboração de um discurso próprio e a finalmente a legitimação de uma determinada intenção interventiva.

Os acontecimentos fundamentais promovidos pela E]m [ - de que fui mentor, coordenador, produtor ou curador - são o contributo de um grupo fluído (uma geração) para a arte do Espaço Público cuja genealogia elaborei nos capítulos anteriores. Revisito este caso de estudo de acordo com o aparelho teórico da Problemática, embora pontualmente novos autores sejam chamados à liça. $O$ essencial que liga estes projectos entre si passa pela minha visão retórica progressivamente testada, assim como pela improvisaçãa ${ }^{29}$ que foi sendo chamada a reagir a diferentes contextos e oportunidades, qual ensaio urbano in progress. ${ }^{30}$ Outros dois modelos complementaram este programa metodológico: primeiro, a ideia de edição-programação culturais, perspectivando um determinado tema a partir de múltiplas posições (técnicas, filosóficas, politicas, existenciais), como que poliedricamente; segundo, a consciencialização progressiva da figura do curador, enquanto orquestrador das energias e investimentos envolvidos. Por outro lado, existe um tipo de edições que sob a tipologia da colectânea de ensaios ilustrados concretiza como que um mise-en-abîme interpretativo. Tais edições explicitam abordagens técnico-científicas diversas, abrem a essas áreas envolvidas uma plataforma de debate inexistente no coração das disciplinas. Um exemplo deste tipo de edição que me definiria enquanto programador foi Le Macchine celibi. ${ }^{31}$

Estava encontrado o modelo para um tipo de trabalho - acção urbana (intervenção) acompanhada de reflexão (publicação) que respondia à minha formação académica (Design de Comunicação, Estudos Literários, Desenho Urbano), expandia experimentalmente a minha própria experiência profissional (designer de comunicação editorial) e finalmente enquadradava uma ansiedade específica, organizar acontecimentos. Estes fariam tanto mais sentido quanto pudessem 'explodir' em todas as direcções, no pressuposto de que tal caótica dispersão haveria de basear-se numa emergente meta-consciência aglutinadora, validada como esfera pública não-representacional. Mais uma vez, a figura de Szeemann é tutelar:

Personalidade independente [...] o crítico foi conhecido por sua aproximação inabitual da arte e sua capacidade de suscitar curiosidade por meio de uma utopia positiva, quase ingénua, da vida. Szeemann não era um teórico. E muito menos um conservador de museu. Embora tenha estudado história da arte, arqueologia e jornalismo, era um 'crítico' na acepção verdadeira e revolucionária do termo. [...] era também radicalmente contra os guetos nacionais e estéticos. Sempre abolia os muros de separação entre as obras, mesmo entre artistas jovens e consagrados, exigindo uma confrontação global. ${ }^{32}$

28 Eventualmente reminiscente do sentido de operacionalidade estética em Ernesto de Sousa.

29 Keith Jarrett, a propósito da Improvisação (no jazz), em The Art of Improvisation DVD): By virtue of the holistic quality of it, it takes real time, it takes everything to do it, no editing possible, it takes your nervous system would be on alert for every possible thing.

30 A consciência do ensaio como modelo de acção cultural nasce com a publicação de $A$ Vida e o Monstro, em 1997. A obra foi apresentada por João Barrento na ZDB (lançamento da marca Águaforte, que na ocasião publicou igualmente $O$ Acto Criativo de Marcel Duchamp, (ideia e tradução de Rui Cascais). Cf. Caeiro, Mário; A Vida e o Monstro, Águaforte, Lisboa, 1997. É indissociável da minha reflexão académica sobre Kafka e o aforismo (Tese de Mestrado, As Investigações de um Cão.)

31 Szeemann, Harald (coord.); Biblioteca Electa, Milão, 1989. Tive contacto com esta obra numa viagem a Veneza para visitar uma exposição antológica de Marcel Duchamp.

32 Idem. 
Esta abordagem crítica do sistema da Arte está ausente do mainstream da arte pública, e este défice motivar-me-ia nos projectos que se seguiram, todos eles plataformas projectuais que reafirmam a criação como um lugar-tempo propício a encontros. Auscultar o corpo urbano resultaria assim, na criação de dispositivos de atenção às pessoas e ao social. Num artigo de 2008 destacaria 'a frio' o inventio daquela abordagem:

\begin{abstract}
Na cidade, tipologia de aglomeração em que a maioria da população mundial vive, e sobretudo nas cidades industrializadas do Ocidente, o mundo é um quotidiano de regulamentações, compromissos, direitos e deveres. Ao mesmo tempo, é o espaço da performatividade social, da performance do social. O real contingente onde acontecem a vontade, a representação, o desejo. I É o desejo de pensar o mundo quotidiano como totalidade o ponto de partida para esta breve reflexão sobre a Arte no palco público desse mundo, a cidade. Sobre a arte como expressão, representação e modalidade de actividade intelectual que se constrói, individual e colectivamente, quando queremos pensar o mundo e intervir no quotidiano. É uma reflexão sobre a arte enquanto prática crítica da forma e da condição urbanas. / Propomo-nos fazer um elogio da arte urbana crítica, uma dimensão da praxis artística na cidade que propomos seja apreendida a partir de um princípio activo que convencionaremos chamar extramuros. Por princípio activo entendamos uma energia vital, que se projecta como compromisso [na ordem da moral, com a coisa pública], objectivos programáticos [no campo do projecto, enquanto design] e estética [como regime de comunicação, sensivel]. Propomo-nos enunciar e pensar acções e eventos artísticos que colocam em prática um princípio emancipatório, e que, em simultâneo, em si mesmos, vão cartografando - enquanto propostas retóricas - possibilidades de emancipação individual e colectiva imaginadas a partir do dispositivo artístico. ${ }^{33}$
\end{abstract}

As notas históricas que se seguem explicitam o tipo de energia - de abertura, liberdade, transparência, informativa - que moveu a produção cultural e artística, no âmbito da E]m[ (até 2006) e depois; destaco as obras mais marcantes em função dos seus efeitos retóricos fundamentais; são núcleos de argumentação acerca do que é a arte pública na contemporaneidade, cujo

[...] o princípio crítico, face à cidade e ao seu desenho, face às formas de contacto com o público, face à própria ideia de arte urbana - historicamente assente numa ideia emancipatótia de espaço público -, esteve sempre, senão subjacente a todas estas obras, pelo menos enquanto motivação vital dos agentes que as promoveram. Esse princípio assumiu várias formas e intencionalidades, mais ou menos restritas ou complexas, revelando modos e graus de empenhamento social extremamente diversos, mas realizou-se sempre como manifestação de uma espécie particular de energia e de visão táctica, uma energia e uma visão que, muito tempo depois de muitos destes projectos se darem aparentemente por 'concluidos', parece permanecer e motivar sempre novas actualizações críticas. ${ }^{34}$

A posição retórica permite-me avaliar essa criticidade ${ }^{35}$ a partir do sentido destas obras, as quais, em conjunto, e de forma dinâmica, desenharam um 'estilo':

Do corpus de realizações e reflexões identificadas na encruzilhada destas quatro directivas, gera-se o contributo concreto
para um modelo de criatividade urbana que funciona, na prática, como sistema (de valoração, logo metodológico e auto-
crítico). Este sistema de coordenadas, ou regime de valores, tem servido, de forma progressivamente mais clara, para re-
flectir sobre a estrutura e as componentes das iniciativas estudadas (e realizadas), e constitui um esquema dinâmico para
articular vários interesses numa visão de conjunto, e na desejada apologia de uma maneira de ver a arte e a sua função.

Este regime de valores foi articulado a partir de quatro directivas:

- na conviç̧ão de que a transversalidade é um traço inalieniável do processo de conhecimento. Tal convicção decorre de uma visão holística dos fenómenos, pressupondo o interesse pela transdisciplinariedade como modelo de conhecimento para além das ideias instituídas, redutoras, de ciência, política ou arte. O modelo transdisciplinar afirma, entre outras coisas, que há uma linguagem e um pensamento capaz de articular todas as formas de saber, e coloca o Homem, enquanto ser racional, no cerne de uma performance do inteligível. / Porque o nosso campo de eleição é a arte, e a ideia de arte pública em particular, quaisquer obras, movimentos ou artistas que proponham formas de criatividade que superem as condições previsiveis da sua génese, da sua inserção social ou que comportem informação e saberes de várias disciplinas - ou com interesse para várias disciplinas - configuram um quadro transdisciplinar para a criatividade, são intrinsecamente extramuros.

33 Caeiro, Mário; «Da prática crítica da arte urbana. Por uma estética extramuros», in Arq./a, n. 23, Maio 2008, Lisboa.

34 Idem.

35 Definição de crítica: acto consciente, motivado pelo desejo de transformação e suportado por uma vontade de conhecimento que aceita a imponderabilidade como um valor, na exacta medida em que privilegia o momento em que o referido conhecimento se constrói. Acrescento, qualidade de transparência cognitiva num determinado dispositivo. 
- na consciência do peso da discursividade na experiência do conhecimento e da performance social do Homem.

Tal decorre de uma visão do mundo e da experiência humana enquanto facto a que é inerente o problemática do discurso, no sentido de 'fala intencional' e de competência comunicacional no tempo. Pressupõe ter-se em conta aspectos linguísticos ou semióticos na consciência dos actos artísticos, o que, em última análise, e no quadro dos valores civilizacionais vigentes, radica numa premissa operativa, a de que a retórica é um campo da acção-conhecimento, intrinsecamente humano, capaz de conduzir a uma possibilidade de esfera pública partilhada e em construção colectiva, com base no fenómeno da comunicação e da concomitante consciência crítica dos media.

- na perspectiva da espacialização/territorialização como expressão performativa do ser humano e da sociedade Esta ideia está relacionada com a ideia e a experiência da cidade, do espaço público, na órbita dos Estudos Urbanos (Geografia, Antropologia do Espaço), da Arquitectura (mais experimental, teórica elou conceptual) e em que valores como o da participação e do contexto são cruciais, nomeadamente no quadro de uma ideia de desenho efectivo [da] forma urbana.

- no valor moral subjacente ao desejo de experiência da liberdade.

Corresponde a um desígnio espiritual e emancipatório [que tenho vindo a representar, literariamente, de Wagner a Brecht ou Kafka], articulando hipóteses de activismo inconformado com o sentido usual de política, de democracia ou de revolução, de redenção ou de graça, projectando contributos para a criação de autonomia [no sentido psicológico e tal como teorizado por Arno Gruen] nos sujeitos - nomeadamente, no campo da arte, face aos constrangimentos [o das indústrias culturais é um dos evidentemente visiveis relativamente à obra de arte] mais diversos. ${ }^{36}$

Destes pontos deduzo que a arte consegue ser um campo para sonhar o sonho - não vivê-lo, mas sonhá-10. ${ }^{37}$

Estas são quatro orientações de trabalho, investigação e ética profissional, que, não sendo estanques, constituem uma grelha para uma teoria do conhecimento em que a praxis, nomeadamente discursiva, e do projecto enquanto tal, é a instância determinante. A estes quatro campos ou orientações estruturais é ainda inerente um forte sentido da importância do social como categoria essencial da existência humana - o eu em relação (Buber) -, e do filosófico como acção (Aristóteles), interpretado num âmbito específico: o da valorização da experiência como processo em aberto, com a experimentação e a subsequente reflexão a suportarem uma busca incessante de/da verdade e das formas de representá-la. Uma praxis total portanto, meta-operativa e encandeada no tempo, interessada no real e no valor emancipatório (ou redentor, conforme o ponto de vista) da criatividade e da arte perante esse real. ${ }^{38}$

Assim, o reencontro com as obras marcantes de uma estética extramuros constitui uma viagem a uma genealogia pessoal que será tão interessante quanto souber explicitar a sua exemplaridade ao nível da atitude (ethos), do dispositivo (logos) e da recepção (pathos), sempre que se torne possivel falar de projectos exemplares, aqueles em que a arte foi construção colectiva de significados e vivências. ${ }^{39}$

À altura da realização destas obras, a maior parte das posições teóricas apresentadas no Capítulo anterior eram-me desconhecidas; elas representam posições de fundo que em várias épocas são avatares de um mesmo princípio anímico, constante, inerente ao humano criativo em relação - se 'todo o homem é artista', também todo o homem é sensível à experiência crítica e sua renovação radical. Isto é, a metáfora extramuros condensa a vertente crítica destes projectos face à vida na polis. Que tal atitude crítica implique, virtual ou potencialmente, a destruição da arte como entendida na hegemonia burguesa, é apenas consequência lateral da contínua redistribuição do sensível. Que esse seja o menor dos elogios ao papel emancipatório que a arte tem advogado na história da humanidade, como parceira importante na definição do(s) destino(s) das cidade(s). Ora a metáfora extramuros de ressonância histórica-urbanística consegue trazer esse movimento de exterioridade radical para o jargão do desenho urbano e colocar a ênfase não em aspectos superficiais dos dispositivos artísti-

36 Idem.

37 Adelaide João no espectáculo O Lar da Tosca, de Martim Pedroso \& Sílvia Filipe, Teatro Nacional de S. Carlos, 2011.

38 Idem.

39 Idem. 
cos, mas num princípio filosófico activo (indissociável da sua materialidade como dispositivo) que anima tanto os criadores como os públicos que não queiram expulsar a arte da cidade.

\section{Da Informação, poiesis da arte urbana, ao assunto capital da cidade participada}

A dimensão crítica extramuros consuma-se em acontecimentos que irrompem no espaço quotidiano, em resultado de actos de desenho ${ }^{40}$. São acontecimentos em que determinadas opções do dispositivo artístico e expositivo tornam esse dispositivo mais participado pela comunidade, mais disponível para ser interpretado pelo colectivo e sobretudo mais fundamentado numa ética comunicacional do eu em relação. São acontecimentos emancipatórios na medida em que comunicam dados objectivos e subjectivos sobre a cidade e particularmente a sua experiência quotidiana, ao mesmo tempo que tendem a permitir o entendimento em transparência do próprio acto artístico e das suas condições de produção.

Aqui, a tese da arte como abrandamento (Duque) - modalidade de entrega ao fluxo relaciona-se com a ideia de que, perante uma obra de arte, há que dar ao conhecimento um tempo próprio para este se revelar (Grout). Na cidade, há que dar-se espaço ao 'quadro' para este nos 'falar'. Isto é, a arte pública, quando crítica e extramuros, equivale a uma permanente refundação do próprio Espaço Público intelectual. Entretanto, no contacto com as ferramentas específicas do Design Urbano e do Projecto, e informada por uma crítica de teor simultaneamente filosófico e técnico, as experiências encetadas pela Lisboa Capital do Nada (LXCN) ecoam uma questão de fundo: Trata-se de dar resposta a pelo menos uma pergunta: a que papel podem aspirar criadores, profissionais da área projectual e actores da vida urbana, na reivindicação de uma ocupação responsável do espaço público, enquanto lugar de cidadania? ${ }^{41}$ Isto pressupõe que as decisões tomadas pelos indivíduos lartistas, mediadores, cidadãos), quais personagens de um romance colectivo ${ }^{42}$, possam ser confrontadas com vias alternativas à sua reificação, daí se retirando a leitura de um período histórico e seus acontecimentos mais vibrantes como uma narrativa em que inúmeros actores de uma mesma família de projectos, constroem, aqui e agora, uma visão do Mundo. Nestes termos, o desenho (do) urbano torna-se activismo na esfera do urbanismo cultural, sob o chapéu de uma visão interdisciplinar do espaço público; ${ }^{43}$ isto é, o jargão profissional destes projectos passou cada vez mais a ser o de uma programação cultural atenta à totalidade da cidade, em que uma vertente retórica e filosófica permeia o discurso sobre a forma urbana. Neste permanente desejo (ou inevitabilidade) de fugir às classificações, a promoção da cultura projectual representa, nos mais variados circuitos do poder, do conhecimento ou da comu-

40 Pedro Brandão; A Cidade entre Desenhos. Profissões do Desenho, Ética e Interdisciplinaridade, Livros Horizonte, Lisboa, 2006.

41 Mário Caeiro in Lisboa Capital do Nada, Vv. Aa.; Extra]muros[, Lisboa, 2002, p. 5.

42 Penso no narrative thinking de Peter Goldie. Cf. Goldia, Peter; «Narrative Thinking, Emotion and Planning», in Vv. Aa; Estética das Emoções, Húmus, Lisboa, 2011.

43 Desde a frequência em 2000 da Pós-Graduação em Desenho Urbano (Espaço Público e Interdiscipinariedade, Centro Português de Design/Faculdade de Belas Artes de Lisboa/Universidade de Barcelona). Os colegas eram arquitectos, arquitectos-paisagistas, antropólogos, geógrafos, artistas plásticos, designers de comunicação, 'obrigados' a desenvolverem acções em equipa, nomeadamente, como trabalho final, um Projecto de Desenho Urbano englobando todas as valências conceptuais, discursivas e técnicas necessárias a uma eventual concretização física. 
nicação, uma equação 'impossível', pois perturba todos os quotidianos com a sua interrogatividade de comunicação/produção do urbano. Este desígnio poético passa sempre pelo deskilling associado à participação, no projecto, de não-profissionais:

Estamos nitidamente num momento de transição e tenho ideia que o que existe é de tal maneira impensável que não se pode prever o que se irá passar a seguir. Portanto, como é que os espaços públicos podem reflectir ou melhorar isto? Neste momento, só conhecemos uma maneira: levar os profissionais para trabalho de campo e trazer pessoas não-profissionais a integrar equipas. Isto não é utopia nenhuma, É o mais básico senso comum: conhecer mais profundamente o território e, para isso, reunir pessoas que o conheçam bem. ${ }^{44}$

Para concretizar esta disponibilidade, a interdisciplinaridade não surge como categoria ideologicamente neutra; ela altera radicalmente as relações entre técnicos e users da cidade..$^{45}$

A partir daí, todo este processo de intercâmbio entre uma comunidade intelectual, projectual, tecnologicamente evoluida e essa outra comunidade de pessoas que, no terreno, conhecem melhor, deve procurar qualquer tipo de linguagem comum para, então, passar para essa comunidade mais abrangente as decisões entretanto tomadas. Isto cria uma nova dinâmica local, e cria uma nova classe de pessoas mais atentas e mais sabedoras do que se passa. ${ }^{46}$

No quadro modernista, por definição, qualquer movimento de vanguarda é instância anunciadora de um sentido do futuro - um futuro que depois nunca chega (Miles); é uma proposta erótica (sublimando o desejo), colocando no campo dos possíveis, da utopia, a possibilidade de um prazer social com alguns traços específicos. Mas como evitar que a transdisciplinariedade surja como novo mito do design e da arte participativa?

A ideia de que um mundo melhor poderia ser engendrado através do design pertencia ao Modernismo. A sua intenção era racional e justa, mas os seus métodos fundavam-se numa separação entre o conceito e a experiência. Actualmente, as oportunidades mais interessantes para intervenção cultural encontram-se nas brechas da sociedade dominante, onde a transparência pode ser criada nos processos urbanos. ${ }^{47}$

Todo o percurso que explicitarei procura escapar àquela lógica anunciadora, isso passa por encarar a utopia (a ser necessário, o termo) como contínua renovação quotidiana e processual. Foi esse o sentido de editar uma obra, logo em 2001 denominada Para além do Espaço Público, de Malcolm Miles, ${ }^{48}$ que de forma pragmática conclui: Então, para além do desenho do espaço público como afirmação de um domínio público, há a observação dos traços da ocupação de todos os dias. Mas um processo de observação não distanciado, crítico enquanto incrustado, imaginativo e participativo. ${ }^{49}$ Define-se assim o tom como a arte do espaço público se insere na cidade: tonalidade maior no espírito mas menor no gesto, ela gere as valências do efémero, do participativo, do contextual num quadro que será tanto mais público quanto mais for de todos quanto for de cada um, daí obtendo a sua validade como plataforma para a visibilidade de indivíduos, grupos e situações.

44 Caeiro, Mário, in A Alma do Design, Centro Português de Design, Lisboa 2003, p. 73.

45 Há trinta anos, já experiências profundamente revolucionárias - que desconhecíamos por altura da LXCN - ou na órbita das acções de Dinamização Cultural levadas a cabo pelo MFA no Pós-25 de Abril, tinham empreendido processos semelhantes. Hoje, iniciativas independentes como Em Trânsito (2005), coordenada por Marta Galvão Lucas e Daniela Brasil, percorrem os mesmos caminhos.

46 Caeiro, Mário, in A Alma do Design, p. 73.

47 Miles, Malcolm; Para Além do Espaço Público, trad. Mário Caeiro, Extra]muros[, Lisboa, 2001.

48 O título português do texto (da palestra original), Beyond the Public Realm', substituindo estrategicamente a 'esfera' pública pelo mais mais material 'espaço' público.

49 Miles, Malcolm; Para Além do Espaço Público, p. 29. 


\section{A ARTE COMO PROVOCAR DO ESPAÇO PÚBLICO: LISBOA CAPITAL DO NADA - MARVILA 2001}

O artista e a cidade. Pois o artista, diferentemente do artesão concebido por Platão, não orienta o seu trabalho numa área limitada e definida, segundo o princípio inflexível da divisão do trabalho e do especialismo intransigente que inspira a cidade ideal. Antes, de modo semelhante a Proteo, muda constantemente de fazer, inclusive de ser, até ao ponto em que pode definir-se como um indívíduo que pretende ser e fazer todas as coisas.

Eugenio Trías

LXCN é momento-charneira no percurso desta investigação, quer pelo impacto que teve na carreira dos vários intervenientes, quer porque os ecos da experiência perduraram como amplo projecto de intervenção criativa e reflexão social..$^{50} \mathrm{LXCN}$ nasce da coincidência entre uma metáfora, uma ideia de projecto e um espaço, qual autopoiética da arte pública crítica. Da complexidade, durée e intensidade da experiência guardo posições implícitas e explícitas no projecto; face à matéria argumentativa da Problemática (Parte II), elas podem ser articuladas pela dynamis retórica ethos/atenção, logos/dispositivo e pathos/graça, nomeadamente a partir da sua expressão na forma urbana de Marvila, em Lisboa ${ }^{51}$.

Lisboa Capital do Nada - Marvila $2001^{52}$ decorreu, enquanto evento público, entre 1 e 30 de Outubro de 2001. Projecto transversal de dinamização cultural e reflexão pluridisciplinar sobre a cidade, envolveu dezenas de criadores, num processo documentado no livro-catálogo editado em $2002^{53}$. A iniciativa foi pioneira na forma integrada como articulou arte contemporânea, fotografia, reflexão urbanística e o elogio da cidadania, explicitando o seu próprio processo numa acção de exemplar transparência discursiva. Trinta dias de eventos diários e vários meses de preparação, sucedidos por momentos de avaliação pública, foram estruturados como um todo pragmático, cujos projectos artísticos mais emblemáticos incluíram a valorização dos 'heróis locais' através de uma campanha publicitária dispersa por toda a Cidade, o enquadramento simbólico de espaços verdes e paisagens notáveis através de intervenções escultóricas, a realização de projectos culturais em colaboração estreita com os organismos associativos locais ou o cordão humano realizado a 1 de Outubro, reunindo mais de 4000 pessoas 'dando as mãos por nada'. O evento integrou ainda uma série de debates realizados num restaurante e transmitidos via rádio ou uma noite de fados num coreto, numa programação multifacetada que convocou diversificados públicos. Com efeito, a LXCN nitidamente cruzava o domínio das artes visuais contemporâneas com a lógica social da freguesia de Marvila. ${ }^{54}$ Quanto ao seu programa,

50 David Santos, Arq.a no 13, Maio/Junho de 2002.

51 Tendo em conta que a LXCN assenta as suas bases numa abordagem territorializada da arte pública crítica, é essa formalização territorial que deu consistência - terroir - à própria metáfora extramuros.

52 Lisboa Capital do Nada - Marvila 2001. Coordenação de Mário Caeiro, Luís Seixas e Daniela Brasil.

53 Lançado em 28 de Maio de 2002, no CAM da FCG, em Lisboa.

54 David Santos, Arq.a no 13, Maio/Junho de 2002 
[...] surgiu desde logo como uma manifestação consciente das necessidades de reflexão em torno de alguns dos problemas sociais mais recorrentes da zona oriental de Lisboa: a exclusão social, a marginalidade e a degradação do nível arquitectónico e urbanístico que invariavelmente não deixa de se reflectir nas dificuldades de preservação e crescimento de uma comunidade que, com grande sacrifício, se mantém ainda fiel a um espaço cada vez mais desertificado. Por outro lado, o espaço-comunidade de que aqui se fala representa de algum modo o conjunto de bairros periférios da grande Lisboa que tendencialmente se isolam, recusando voluntariamente qualquer tipo de participação cívica e de cidadania. ${ }^{55}$

\subsection{Introdução: da recepção do evento}

A LXCN, a começar pelo título e depois pela sua lógica de implantação no terreno ${ }^{56}$, colocou questões complexas e estimulou o debate acerca do seu sentido ${ }^{57}$ e do das obras que integrou. Uma dessas questões é relativa ao papel do artista e ao lugar da arte na vida social urbana - a 'velha' questão da vanguardas, da arte face à vida. Esta dimensão de reflexividade e de posicionamento filosófico (desde o primeiro momento apregoado como valor projectual) - aportou algumas fragilidades 'ontológicas' ao projecto, precisamente porque é desvalorizada a dimensão experiencial, de vivência e durée do mesmo, para além dos seus traços deliberada e retoricamente híbridos; algumas reacções negativas ao longo dos anos assentaram em leituras au pied de la lèttre do discurso do projecto e do seu impacto no circuito académico-artístico, separando deliberada, mas acriticamente, a figura do artista da do cidadão, algo que me parece ser um ponto de partida errado para abordar um projecto que foi antes do mais um projecto de activação plástica da cidadania; outras reacções, encomiásticas, valorizaram, de novo acriticamente, o impacto da LXCN, esquecendo aspectos problemáticos - falhados - em prol do sublinhar dos seus aspectos mais inovadores. Ora, num certo sentido, o projecto jogou tão somente o jogo do real, fazendo confluir de forma rara (desde os projectos neovanguardistas dos anos 70, 80 e 90) a realidade da arte e a realidade tour court, de forma conscientemente complexa e integrada. Foi a forma possível para que os discursos se despoletassem no esplendor da sua graça e, 'desatrelados' de quaisquer amarras (ideológicas ou disciplinares, isto é, disciplinadoras), assumindo um desígnio colectivamente ensaístico, em torno de um cluster de questões: a arte/social na perspectiva do Espaço Público subjacente, um espaço público discursivo que suspendeu conclusões em nome do wit da acção. A dimensão, qualidade e consequências da participação do público espectador da LXCN (em destaque os habitantes da freguesia) foi em consequência um tema recorrente na recepção da intervenção, quer por parte de quem acha que houve pouca real participação local, quer por parte de quem entende que a participação existiu e foi determinante, mormente no seio da visão e missão do projecto). De qualquer forma tem valido a pena confrontar os acontecimentos - separadamente e como um todo - com expectativas diversas (oriundas dos foros académico ou político), para que a aura mítica do projecto continue a animar debates que são ainda hoje presentes.

\footnotetext{
55 Idem.

56 Idem. Marvila era commumente considerada uma das zonas mais esquecidas e abandonadas da cidade de Lisboa, desde pelo menos o declínio da cintura industrial fixada na margem direita do Tejo. Inclusive durante a EXPO-98, Marvila teve uma participação meramente simbólica (com algumas exposições integradas no programa Caminho do Oriente), confinada assim à sua reduzida importância eleitoral.

57 Nas palavras do próprio presidente da Junta de Freguesia em Lisboa onde tudo aconteceu, seriam necessários anos para aferir as consequências da LXCN.
} 


\subsubsection{Tema e território: o espaço público como totalidade}

É impraticável distrinçar um único tema na LXCN; se se pode falar de um cluster temático, isso acontece porque esse cluster exige uma abordagem transversal, oblíqua e multidimensional entre as suas componentes. Estas articularam, no essencial, o Nada (desafio filosófico e pretexto territorial para pensar a totalidade), o Espaço Público (sob a forma de activação de cidadania, de expansão da actividade artística, de reflexão situada no âmbito do urbanismo geral ou experimental) e a própria Arte Pública (como complexa conjugação de factores curatoriais, formais, reflexivos, na aproximação arte-vida / arte-e-social). Esta opção de fundo conduziu a um contínuo trabalho comunicacional sobre a ambiguidade (e a violência) simbólica dos próprios conceitos e das fórmulas para a sua veiculação. Estes viram-se então, até certo ponto, suspensos - 'despolitizados' -, em nome da criação in situ de um 'tempo 'outro' - o da durée da produção social da arte. Donde que, em certo sentido, o 'tema' do projecto acabou por ser a 'arte' em sentido lato. ${ }^{58}$ Enquanto 'arte da totalidade' - da acção e do lugar - imaginei essa arte como criação de pontos críticos, num convite à mais radical humildade científica, tintada de intersubjetividade. Essa era uma primeira ingenuidade deliberada do projecto: a concatenação desenho urbano / arte pública / vida urbana, numa amálgama em que uma ideia global de 'Espaço Público'59 - conceito-chave ao longo de todo o projecto, se tornaria o leit-motiv da processualidade transdisciplinar (de que apenas uma ínfima parte era possível dar conta publicamente). ${ }^{60}$

Noutros termos, o projecto advoga uma dimensão tanto experiencial (sentimental) como cognitiva (intelectual). Com as análises ao contexto ocupando parte importante da intervenção, Marvila surge como espaço da acção mas também protagonista (personagem). ${ }^{61}$ - realizar-se um 'evento cultural'. As dificuldades desta intencionalidade persuasivamente tautológica la identidade artística, entre artefacto projectual e dispositivo de comunicação cidadã), procuraram, pela poesia e absurdo, blindar eventuais debilidades críticas, como se o 'ir a jogo' da arte face ao social e ao território pudesse ser apenas concretizado na mais radical ironia - romântica, kafkiana ${ }^{62}$ - e através do projecto como retórica. ${ }^{63}$

Neste sentido, as condições proporcionadas aos artistas e ao público da LXCN foram performáticas e, longe de aspirarem aos modelos de participação e envolvimento reificados por qualquer ideologia, procuraram tão-somente abrir uma 'brecha cultural'. A LXCN passou por uma disponibilidade para articular o ensaio e a filosofia, as ciências sociais e a refle-

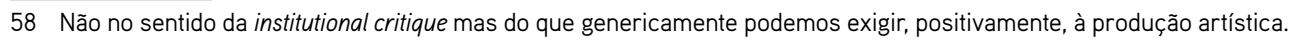

59 Recorde-se, o tema da Pós-Graduação no CPD.

60 O espaço público do contacto intersubjectivo não seria sobrecarregado por questões teóricas especializadas.

61 Independentemente das dificuldades de se atribuir a um sítio uma identidade, mesmo provisória e de aí, em condições de incoerência - um 'nada', no meio do 'nada... Assim era visto o projecto do ponto de vista dos centros decisores. Poucos ou nenhuns críticos de arte se deslocaram ao evento.

62 O catálogo teria por epígrafe um pensamento de Kafka: Quanto mais cavalos atrelares a um bloco de pedra, mais depressa conseguirás. Pode ser que não sejas capaz de movê-lo, mas é possível que as correias se partam e obtenhas um passeio alegre e vazio. In Caeiro, Mário (coord.); Lisboa Capital do Nada - Marvila 2001, Extra]muros[, Lisboa, 2002.

63 Retórica aqui como metadiscurso: primeiro, no sentido de consciência crítica e explicitação pedagógica da comunicação artística como composta por elementos sobre os quais é possível tomar decisões e concomitantemente ter opinião; segundo, enquanto modelo de uma conscientização das contingências discursivas que é propriamente moderna. 
xão sobre a cidadania, e finalmente a arte e o espaço urbano, pensando e refazendo os limites de várias racionalidades e pragmatismos, em função do valor de possibilidade e de provocação que o conceito extramuros pudesse comportar. Enquanto convite à experiência-emergência da totalidade urbana crítica e em fluxo, a escolha de um lugar concreto, com pessoas reais, numa totalidade quotidiana complexa, implicou o que alguns críticos definiriam como um turismo do outro (Maio), exploração etnográfica de uma realidade local em nome dos valores universais da arte; mas vários testemunhos individuais de vários criadores e colaboradores locais contrariam esta ideia, uma vez que desde a localização de peças às características formais e temporalidade das mesmas, houve múltiplos momentos de negociação e colaboração com vários agentes locais e foi a complexidade deste desejo de fazer e mostrar que se fazia - sem ilusões de representatividade, nem mitos democratizadores - que, tornou o processo de arte pública genuinamente participativo. Como mais tarde em outros projectos subsequentes como Sinais - a Cidade Habitada ${ }^{64}$ e algumas intervenções da Luzboa - Bienal Internacional da Luz, a deriva política de alguma arte contemporânea reencontrou-se assim com a actividade contextual, na esfera pública. Esses encontros fundaram-se a partir da categoria experiencial do momento (Lefèbvre), da táctica apropriação de oportunidades pontuaispara ver a cidade de outra maneira, enriquecida pela experiência, as perspectivas e as expectativas de pessoas que no quotidiano do mundo da arte não têm qualquer peso negocial. A dupla 'negatividade' - o Nada em Marvila - funcionou assim como metáfora da totalidade ética do politico: LXCN foi o tudo em todo o lado, independentemente de isso (também) significar a habitual mobilidade da intelligentsia $e$ uma impossibilidade teórica.

Terá sido essa a essência do mecanismo simbólico da LXCN: o seu ethos paradoxalmente emancipatório, transformacional, que viu as suas componentes participativa, contextual, colaborativa, sobrevalorizadas, precisamente porque houve um capital de esperança imediatamente evidente a partir do momento em que a atitude da organização e dos criadores foi não de imposição de uma visão, mas de auscultação. Problemas e valores locais tornaram-se aspectos de um partilha efémera de ideias e soluções, mesmo que a maior parte das vezes num âmbito restrito - o da arte privada em espaços públicos (Sardo) e em momentos relativamente breves (nos encontros preparatórios, nos eventos, na reunião de avaliação final). Ou seja, o que tornou o evento um acontecimento foi, primeiro, o grau de abertura ao imponderável do social em relação, a qual partiu dos dispositivos da arte contemporânea e do festival para os submeter a um imperativo ético e moral do qual, a dimensão estética seria uma componente central; depois, o seu valor de exemplo, que despoletou expectativas em diversas sensibilidades (do meio académico ao activista). Em suma, o debate quotidiano e intensamente vivido, sobre a construção da cidade e dos seus espaços, tornou-se pura poesia total.

64 Projecto de sinalética desenvolvido em 2003, em resposta à LXCN, com a comunidade a ser envolvida, por via de questionários e várias acções conviviais, na elaboração de designações, logotipo, imagem gráfica e mobiliário urbano. Cf. 3 Projectos Experimentais. 


\section{Do título ao tema 'Espaço Público' - que territorialização...}

A operação poética - e poiética - inerente ao título Lisboa Capital do Nada é crucial em qualquer abordagem do projecto. Quem o lia/lê pela primeira vez, criou uma forte reacção de surpresa; a ironia era evidente. ${ }^{65}$ Mas mais do que uma blague, havia nessa territorialização - sublinhada no sub-título 'Marvila 2001' - um desejo de visibilização e potencial activação exemplares de um espaço social; aí, articular Marvila como capital do Nada era ao mesmo tempo surpreender um nada na Capital que é Lisboa. ${ }^{66}$ Esta operação retórica (além de poética, especificamente literária, propagandística e publicitária) tornar-se ia um elemento crucial da comunicação do conceito ${ }^{67}$. É um título-situação, que implica uma lógica aforística, altamente performática ao nível discursivo. Esta ironia escapou a quem procurou, no evento, determinar problemas de uma eventual e abusiva territorialização inusitada do nada. Noutras palavras, quem não percebeu 'a piada' não poderia estar sensibilizado para um encontro radical com a construção colectiva e negociada dos sentidos da expressão. Mas o título do projecto despoletou, por outro lado, encontros informais de base discursiva. A expressão trazia consigo um energia própria de resiliência a qualquer (reificação) das relações de poder.

O projecto talvez tenha tentado superar - como a AZ em 77 - os constrangimentos formais da condição crítica entretanto estabelecida (ainda que não generalizada) e procurasse outros registos para a consciência radical, que passassem já não por modelos de combatividade e confronto (o cerne do político em Laclau ou Mouffe), mas por iluminações ou expressões retóricas e expressivas que, em sede de revelação da graça social pudesse mostrar como certas coisas poderiam ser diferentes (Malcolm Miles). Neste aspecto, é difícil dizer se a LXCN é propriamente uma acção ingénua ou cínica na manifestação do político da arte face à esfera da política); essa ambiguidade é no entanto o segredo do sucesso junto de vários círculos culturais. Só assim os 'territórios do nada' (Alves) puderam funcionar eles próprios como metáforas situadas da sua própria consciência. Meta-linguística-, ingénua-, cínica- e ironicamente, a realidade poliédrica e polissémica daquela cidade dentro da cidade tornou-se sensível.

O tom de enigma - que começa no nome e prossegue no sentido ambíguo das várias acções dos artistas - cativou uma meta-esfera pública, porque o que havia a apropriar era a própria hipótese de as pessoas terem um discurso sobre o que quer que fosse. No limite, esta é a questão comunicacional de fundo, 'ultrapassada' em sede de contacto humano, tal como parte importante dos artistas procuraram concretizar e a organização promoveu repetidamente. No âmbito desta questão comunicacional, a LXCN é um monumental exercício de apropriação do urbano na medida em que, na linha da definição lefèbvreana, o conceito de apropriação é inseparável de uma crítica situada e realizada da hegemonia abstratizante e

65 O Porto era na altura Capital Europeia da Cultura (em Lisboa, a Expo '98 e a Lisboa '94 eram memórias remotas), e o projecto explorava as expectativas habituais na lógica de recepção dos grandes eventos, paradoxalmente localizando-o porém em Marvila 2001.

66 Contradição entre algo ser 'capital' (importante, fundamental, hierarquicamente superior... centro) e 'nada' (vazio, irrelevância, esquecimento... periferia).

67 Cf. a introdução da jornalista Paula Moura Pinheiro, num dos primeiros programas a dar notícia do Evento, na Rádio Paris Lisboa, Outubro de 2001: E agora vamos falar desse projecto com o nome inesquecível de... Lisboa Capital do Nada. Transcrição in Lisboa Capital do Nada - Marvila 2001. 
alienante (do capitalismo cognitivo) e das suas formas de poder (estatais, privadas) que a cidade materializa; ora, apesar do projecto vir a ser objecto de financiamento ${ }^{68}$ e de haver uma Junta de Freguesia envolvida, seria no mínimo desonestidade intelectual julgar o projecto como fundamentalmente envolvido com as dinâmicas de afirmação do poder estatal sobre aquele lugar. ${ }^{69}$ De qualquer forma, e como já havia acontecido em outras aproximações vanguardistas do fenómeno da arte, a LXCN procura não apenas a ambiguidade (reduto de liberdade) a mas a própria contradição, o não-lugar do livre pensamento, aqui no projecto integrado de visibilidade de um contexto-situação de encontro com o social, sob o mote 'criar, debater e intervir no espaço público'. Em Marvila. ${ }^{70} \mathrm{O}$ sítio existia física e socialmente, mas não ao nível mediático e de reconhecimento generalizado - era 'um nada' entre o centro da capital (a Baixa) e a zona oriental (Parque Expo). Desde o início, porém, o 'formoso sítio de Marvila' não era apenas mais um sítio, mas o sítio para uma intervenção deliberadamente exemplar - os artistas teriam de trabalhar num quadro organizacional que pressupunha serem cidadãos a corpo inteiro, negociando a sua acção num quadro de activismo cultural em que cada peça era debatida de um ponto de vista do que traria para a dinâmica conceptual e territorial do evento.

Finalmente, o próprio projecto foi um espaço público de expressão, com o slogan mais tarde repetido na capa do livro-catálogo 'Criar, debater e intervir no espaço público', que deu voz a determinados protagonistas locais e à sua relação com o território; foi quer o espaço do dizer dos problemas, quer dos seus dados contingentes, quer de algo muito mais prosaico, o dizer das experiências concretas no espaço público dos afectos. Este decorreu de acordo com muito variados paradigmas de envolvimento social e de acordo com muito variadas hipóteses de continuidade (reuniões de Fernanda Fragateiro com os moradores do Bairro dos Lóios, workshops de Daniela Brasil com crianças do Espaço da Flamenga). Esta recepção interessada das obras foi estimulada - era aliás irreprimível, dada uma certa sofreguidão, por parte de moradores, por exemplo, em resolver, se possível com a ajuda da arte, questões do seu quotidiano. Ela passaria por uma lógica de sucessivos encontros em aberto, que ilustram a necessidade de reconceptualização da identidade territorial. ${ }^{71}$

Enquanto sistema informativo que desse forma a essa identidade, a LXCN criou aliás focos de legibilidade e apropriação do espaço: sinalética experimental, ${ }^{72}$ infocentros, infopontos,

68 In extremis. A decisão relativa ao financiamento do evento chegou apenas após visita pelo Secretário de Estado da Cultura, realizada no penúltimo dia da programação de Outubro. Tivesse essa visita sido adiada por alguma razão, era difícil de imaginar o consequente financiamento, sendo que nessa altura estavam contraídas dívidas pelos jovens protagonistas.

69 Os apoios essenciais chegam depois doa maior parte feito in extremis, para que o projecto não desse um prejuízo financeiro mais significativo.

70 Mas onde fica Marvila? Um contacto informal (Florbela Godinho) levar-me-ia a outra pessoa que comentou que, a haver um sítio que era o 'nada' em Lisboa, seria aquela área de Marvila. Nesse preciso momento fiz a mesma que me lançariam os interlocutores durante vários anos.

71 Massey, 1993, p. 66. Na altura, filme, Zona J, era particularmente problemático para parte da população (que não queria ser confundida com o seus 'heróis'), mas objecto do orgulho por outra parte da população). LXCN debateu esta tensão.

72 A linguagem gráfica do projecto, com suas cores e formas predominantes, ganhou três dimensões no espaço urbano (carácter plástico e escultórico). Várias setas brancas, acompanhadas de um estrutura metálica em forma de «n» demarcaram os limites da freguesia, assinalaram o 'território do nada'; a estes elementos se acrescentaram setas em tecido vermelho que foram espalhadas pela Freguesia. Em pontos-chave do sistema viário, três «portas» foram elementos-chave de todo o projecto, aliando o carácter de intervenção plástica e de apelo à notoriedade. A Porta da Bela Vista - quatro «rios» de plástico estendidos numa encosta do Parque - poderia ter tido outro impacto e escala, 
e sobretudo, ${ }^{73}$ as visitas guiadas foram formas encontradas para apelar à participação e à leitura do evento como acontecimento local. A sinalética efémera de LXCN teve carácter integrado e dinâmico; integrado porque reflecte uma posição holística perante a comunicação, dinâmico porque intencionalmente aberto às interferências registadas durante a sua concepção e produção. Estas integraram, não apenas as obras de arte leixo central da programação), mas também a realização conjunta de concertos (um memorável «Fado na Praça», num coreto raramente utilizado), sessões de teatro e pinturas murais. No global, prevaleceu a ideia de que a riqueza de um lugar advém em muito da multiplicidade de discursos que alberga. ${ }^{74}$ Mais do que um esforço de colaboração do tipo community art, e de longa duração, estava em cima da mesa a mais directa partilha de um momento de visibilidade, com a Organização a ceder espaço mediático, no seu programa, no catálogo, a iniciativas completamente independentes e autónomas ${ }^{75}$ - o festival dentro do festival. Tudo isto acumulava capital simbólico para que as obras condensassem determinadas questões e intensificassem o debate que lhes seria implícito.

\subsubsection{O projecto urbano como processo}

LXCN foi preparada durante cerca de um ano, tendo nascido fundamentalmente de duas dinâmicas: a necessidade de concluir uma Trilogia para o Séc. XX, rematando, com o Nada, os eventos anteriores sobre a Alma (1995) e a Dor (1999); a oportunidade gerada pelo convívio entre colegas da Pós-Graduação em Design Urbano, entre os quais devo destacar a personalidade de Luís Seixas, arquitecto, junto de quem encontrei a disponibilidade pessoal, a visão filosófica e o modus operandi que seriam fundamentais para uma estruturação inicial - a fase de concepção - do evento. ${ }^{76}$ Os meses de preparação da iniciativa decorrem fundamentalmente entre as instalações de um escritório pessoal (Monte de Caparica) e um equipamento no local da intervenção (Bairro da Flamenga). As sessões de trabalho eram regulares e frequentes, destacando-se a grande abertura para a equipa integrar inúmeros colaboradores pontuais, em sucessivas aproximações a diversas escalas, âmbitos e dimensões do projecto. Esses colaboradores, nomeadamente artistas, eram consultados

houvesse meios disponíveis. Ainda assim há registo de este momento de «dor inerente à transformação urbana» [ali havia há poucos anos um bairro da lata famoso] funcionar como momento visual sugestivo. A Porta Marvila assinalou o momento em que, na Estrada de Chelas, se «entra» na Freguesia, sendo das intervenções mais conseguidas, talvez pela literalidade. A Porta para o Nada teve por conceito provocar um paroxismo na relação obra/lugar, podendo ser entendida como uma «janela» para o vazio do terrain-vague onde foi instalada.

73 Estavam inicialmente previstos três centros em pontos-chave da freguesia. Neles estariam pessoas disponíveis para dar informações diversas, nomeadamente mapas próprios do evento, além de ser possível navegar pela versão electrónica do evento. Dos três Infocentros previstos, o principal, no bairro do Armador, não foi disponibilizado à organização a tempo. Outro dos centros, no «casco velho», à Biblioteca do Vale Fundão, não teve o impacto previsto. Apenas o Infocentro no Bairro da Flamenga funcionou com dinamismo. Por aqui se depreende que dificuldades as sentidas no terreno acabaram por perturbar a comunicação do evento. A uma escala mais pequena e dispersos pelo tecido urbano, uma vintena de infopontos tiveram um papel complementar, enquanto rede informal de colaboração entre a organização e os locais.

74 E]m[, in Lisboa Capital do Nada - Marvila 2001, Extra]muros[ Lisboa, 2002, pp. 280.

75 Pelo cantautor Fernando Melão, bandas de rock evangélico, Beto, jovem representante da cultura hip-hop local.

76 Nesse primeiro período, outras duas pessoas foram aportando contributos específicos, Daniela Brasil e Teresa Alves, respectivamente arquitecta-urbanista e geógrafa. Foram quem, enquanto membros da equipa de coordenação da $L X C N$, desenvolveram o projecto muito para além do seu términus oficial; Teresa Alves no âmbito de vários projectos de investigação e Daniela Brasil prosseguindo os seus estudos no campo, na Alemanha, Bauhaus, Weimar). 
em encontros abertos aos vários níveis da coordenação, com grande transversalidade da informação e transparência de processos ${ }^{77}$. Cada artista era acompanhado pessoalmente por membros da coordenação que por diversas vezes os conduziam aos locais de intervenção e apoiavam à realização das obras, de forma colaborativa e orgânica. Neste período de arranque, a teoria foi 'suspensa', mas ao mesmo tempo 'testada' - e era evidente que passávamos todos por uma fase pragmática e potencialmente activista. A premência dos assuntos abordados - uns directamente pelas obras, outros indirectamente pelo projecto como um todo - ia obrigando a sucessivas adaptações, o que sempre foi visto como uma dimensão dinâmica, fundamental e genuinamente interessante para as obras.

Depois de, internamente, ter definido o tema com colaboração de Catarina Campino ${ }^{78}$, eu tinha encontrado um sítio para se fazer o nada. ${ }^{79}$ A reacção de José Augusto Pereira, presidente da Junta ao nosso primeiro telefonema foi de grande abertura e de confiança - a provocação da proposta, telegraficamente exposta ${ }^{80}$ - foi abraçada pelo presidente como um desafio que valia a pena, sendo adequados à dinâmica programática do próprio poder local e seus circuitos de afirmação e produção simbólica. Dava-se aqui uma primeira articulação numa colaboração que se espelharia aos mais variados níveis das decisões e em grande cumplicidade. Aqui, um aspecto da preparação do evento foi determinante: uma visita realizada pelos artistas convidados ao sítio; a visita durou várias horas, com pessoas especialistas em muitas áreas, reunidas num encontro com a realidade quotidana le pessoas locais) que funcionou igualmente como brainstorm. Começava aqui outra marca do ethos e do logos da LXCN, a 'carta branca' dada aos criadores. Tal fez a diferença, na medida em que o programa genérico não era imposto, mas sugerido aos criadores.

\section{'Processo', comunicação, criticidade: aforismos urbanos}

$\mathrm{Na}$ LXCN, a programação reage à forma urbana, nomeadamente às suas descontinuidades simbólicas e físicas; o tecido urbano foi a base da implementação dos projectos estruturantes; a existência de terrains-vagues e espaços sobrantes convidou à intervenção artística; áreas consolidadas ou em fase de consolidação foram pólos de convergência, atracção e desenvolvimento; camadas de memórias motivaram visões; equipamentos com condições para proporcionar uma ampla partilha de experiências foram activados. Tendo isto em conta, o essencial do projecto - o seu logos - consistiu na sua processualidade dialógica - meses de encontros e reuniões com os mais diversos 'protagonistas' -, enquanto estrutura que afirmasse um modus operandi para além da qualidade intrínseca de cada projecto. Na prática, as diversas apropriações da forma urbana decorreram da capacidade de o projecto estabelecer premissas de envolvimento e de empatia (Gross), com as questõas mais notoria-

77 Particularmente importante por o projecto concorrer a fundos europeus, de acordo com proposta de Teresa Alves.

78 Em reunião em que esta artista, curadora e crítica propunha estar-se a atravessar um momento muito interessante na produção artística, nomeadamente por parte de uma série de jovens artistas do seu círculo de influência.

79 Havendo já uma ideia prévia - um programa prévio - à sua implantação - isso poderia ser visto como uma debilidade conceptual do projecto pelos padrões de uma filosofia radical bottom up; quanto a mim, isso é a natural consequência de uma visão curatorial que havia vindo a ser perseguida desde 95.

80 Lembro-me de avisar que não iríamos desenhar passeios ou fazer rotundas, mas sim colocar ideias nas cabeças das pessoas... 
mente 'políticas' decididamente passadas para segundo plano, numa lógica de comunicação humanista - o modelo encontrado para se falar das coisas para lá dos conflitos, mas não aquém da noção de manipulação dos poderes e jogos sociais. Neste aspecto a sua perspectiva exploratória - mais que meramente experimental - suspendeu os discursos mais tradicionalmente politizados sobre o social; depois, e apesar da tendência discursiva, uma sensação genérica de valor da acção sobrepôs-se às noções de reflexão ou estruturação, tal como no processo de enamoramento (paixão). Esta atitude relativa ao prazer (Barthes) do real, independentemente da sua problematicidade e porventura em função desta, encaixa numa visão do político que leva a celebrações como a do Cordão Humano, em que não são inocentes, mas também nada óbvias, a relação entre o vermelho das $t$-shits le de toda a imagem gráfica do projecto) e a cor política do poder local.

Decorre do ponto anterior que o projecto tinha um lugar (place-specificity) a respeitar; mas também um desígnio ético de transformação experimental (virtualidade, possibilidade); aí os processos de abrandamento da arte serviram para controlar o desejo utópico e revertê-lo para a transparência das decisões projectuais. Estas foram assim sendo objecto de escrutínio (não apenas ao nível da equipa do projecto, como de parceiros locais, que se reuniam autonomamente com regularidade), podendo dizer-se que a democraticidade do trabalho era uma tema assumido. Em última análise, o processo consistiu na sua própria comunicação (low budget e agit prop), integrando esta mecanismos de socialização (auscultação, colaboração, negociação, aos mais diversos níveis e em diversas fases). E chegou a aceitar a realização apenas parcial de um projecto enquanto confirmação da sua qualidade crítica ${ }^{81}$.

Com a LXCN inicia-se uma sucessão de momentos com carácter aforístico. ${ }^{82}$ Recordo Kafka, num aforismo que define as possibilidade que cada novo projecto ou obra artística implicitamente desafia: O momento decisivo no desenvolvimento humano é um todo contínuo. É por isso que estão certos os movimentos revolucionários, que declaram nulo ou inútil tudo o que ocorreu antes deles, pois nada aconteceu ainda. Há assim obras e acontecimentos que têm a capacidade de tornar fulgurante a narrativa da cidade na sua enunciação de uma sentença aberta mas ética ou moralmente fundada, visando a coisa pública como bem, exponenciando numa imagem concentrada - uma acção, uma vista - infinitas camadas de significação. 0 gesto aforístico, que supõe um saber decantado, ancorado na experiência total da existência, adquire nessas alturas a leveza de um contacto, aplicando as mais básicas componentes da comunicação à expressão de uma realidade tão complexa como a vida social urbana. Isto aconteceu, sem dúvida, no evento Lisboa Capital do Nada. Voltaria a acontecer, pontualmente, nalguns dos projectos mais declaradamente extramuros da Luzboa Bienal Internacional da Luz, oferecendo à opinião pública momentos de rara concisão simbólica, e assim actuando como presentificação do espírito, dos ambientes e do património comum da própria cidade. A constante procura desta energia do aforismo - e do ensaio, aforismo distendido - levaria à constante preocupação com o nome dos projectos (programas meta-

81 Caso de um parque infantil de João Pedro Vale que não passou das páginas do catálogo. Ou das Azinhagas de Marvila, projecto de Pedro Pacheco e José Adrião. Ou ainda da campanha de publicidade nos mupis de Lisboa, substituída por peça-campanha de José Maças de Carvalho.

82 O aforismo surge como ponto de contacto entre o filosófico e o literário. É um estilo de discurso ligado à percepção expressiva do mundo. 
fóricos). Tal tornou algumas das peças inesquecíveis - pois, na ressonância produtiva com o público de cada tempo, Ao fim e ao cabo, o acto criativo não é desempenhado apenas pelo artista; o espectador põe a obra em contacto com o mundo exterior ao decifrar e interpretar as suas qualidades internas e, acrescentando, assim, a sua contribuição ao acto criativo. ${ }^{83}$

O estatuto aforístico que permeou muitas das intervenções decorreu de uma consciência produtiva:

[...] é possível que com Lisboa Capital do Nada saia mais uma vez reforçado o exercício de poderes tradicionais - do artista, do comissário, do arquitecto, do designer, do planeador, dos poderes locais instituídos - que podem ter ganho novas ferramentas para praticar velhos vícios, agora transformados em virtudes, graças à caução de um conjunto de experiências que, por vezes, revelou forma subtis de irresponsabilidade, desconhecimento e arrogância ${ }^{84}$.

Neste quadro, havia que lidar, na obra colectiva que é o evento e nas obras em separado que the dão forma, com a violência simbólica inerente à actividade artística. A atenção à qualidade aforística torna-se assim um acto discursivo (performático, ao contrário por exemplo do 'ditado' ou a 'sentença', que seriam prescritivos). Radicalmente sintético, o aforismo adequa-se por outro lado a uma economia da recepção, adequada para enfrentar um tempo mediático com que quotidianamente temos de aprender a viver. O processo tentou servir esta problemática abrindo espaços de encontro informal em função de uma estética que ia sendo elaborada durante o processo. Isto é, cada decisão processual era parte do continuum do projecto estético em curso; garantido este sentido de organicidade motivada pela forma urbana como totalidade, a moral projectual permaneceu crítica e sempre disponível para o imponderável, nomeadamente o do(s) ponto(s) crítico(s) de cada obra. Se a tautologia do projecto acarreta por isso certa fragilidade instrumental, então tal materialização da consciência lida produtivamente com uma dimensão não-representacional que é radicalmente indissociável do contínuo emergir do demos na totalidade da polis.

A LXCN interpretou à sua maneira algumas das premissas da arte crítica, em função dos elementos contingentes que decidiu valorizar explicitamente. Isso explica duas linhas de força. Por um lado, a crítica institucional, um dos pilares da arte crítica, não foi considerada uma questão determinante no processo - do que não podemos falar é melhor calarmo-nos. Por outro lado, quando Hannah Arendt nos diz que o exercício da democracia na polis passa pela publicidade dos seus membros, a plena experiência do político passa pela consciência crítica dessa dimensão, e da forma como é colectivamente construída e tornada acessível. Esta sim foi uma premissa central da LXCN, no sentido comunicacional (propagandístico) e especificamente gráfico (diagramático). Isto determinou formas de presentificação dos desejos dos participantes que tornaram o evento conscientemente mediático, submetendo a visibilidade arendtiana às regras da comunicação (da arte) na forma urbana contemporânea, na radicalidade retórica da arte pública crítica. Obra a obra e como todo integrado, a LXCN explicitou a dinâmica da retórica crítica que a arte pode aportar à cidade.

83 Duchamp, Marcel; O Acto Criativo, Águaforte, Lisboa 1997, p. 10.

84 Caeiro, Mário in Lisboa Capital do Nada - Marvila 2001, Extra]muros[, Lisboa, 2002. 


\subsection{Capital do Nada - obras comentadas}

A LXCN consistiu num conjunto de encontros, aspirações e sonhos que revelou, como num espelho gigante e multifacetado, um campo de intervenção urbana. Em Lisboa rara e em Marvila inédita, tal intervenção assentou na viabilidade da sintonia entre instituições públicas (mormente estatais), organizações diversas (nomeadamente com carácter associativo), grupos informais e públicos. Suportada pelo carácter ético da operação, aquela provisória sintonia traduziu-se em opções curatoriais disponíveis para o seu próprio questionamento na esfera pública. Refractário à lógica de padronização característica da sociedade da afluência, a LXCN apresentou-se como festival de arte contemporânea, workshop colectivo ou animação urbana, mas deveria falar-se com maior propriedade de um encontro espiritual (como o defendeu uma associação mística) ou acção exemplar de cidadania participada (como movimentos de esquerda tenderam a interpretá-la). O certo é que se exercitou um campo de conhecimento na área do desenho urbano, na durée de um «auscultar» do corpo citadino através de um conjunto alargado de ferramentas, umas estritamente académicas (meta-operativas, teóricas) outras culturais e artísticas (experienciais, materiais).

A LXCN abriu um parêntesis na vida das pessoas que com ela contactaram mais demoradamente. Fê-lo trazendo essas pessoas à participação no processo de produção colectiva, da discussão dos grandes e pequenos tópicos de trabalho à apresentação dos seus valores no palco mediático. Os profissionais do desenho ou das diversas ciências envolvidas foram chamados a intervir de forma pessoal, eticamente responsável, a uma escala e numa temporalidade em que era possível haver aprendizagem, partilha e negociação. Cada Núcleo do Evento - Projectos Estruturantes, Arte, Fotografia, Edição e Debate, Intersecções e Outras Actividades - tinha um papel a desempenhar na economia geral, procurando possibilitar uma experiência em que concorresse uma importante componente de «real», vivida em situações concretas de interacção entre público e território. ${ }^{85} \mathrm{O}$ conjunto de projectos desenvolvidos, na sua diversidade, dispersão e efemeridade, funcionaram como indícios, oportunidades, gestos. Tratou-se de uma oportunidade para questionar políticas territoriais, mas sobretudo apelar à disponibilidade e envolvimento dos cidadãos, introduzindo nas equações habituais da fruição e da troca culturais aspectos de renovação, revitalização, requalificação, questionamento e transformação. O conjunto de intervenções passou por criar focos de legibilidade e apropriação do espaço, em activação e valorização do tecido urbano, em particular de alguns vazios: sinalética experimental, infocentros, infopontos, e sobretudo as visitas guiadas foram formas encontradas para apelar à participação e à leitura do evento, nomeadamente ao nível local.

A acepção do Nada promovida pela Direcção do Evento foi abrangente e de uma forma geral muito bem recebida pelos interlocutores mais activos, que de imediato valorizaram a potencialidade dialógica da situação; a colaboração com os artistas, alargou o Conceito a muitas interpretações, desde durante a pré-produção até depois do evento. Uma delas, de teor territorial, prevaleceria como o ângulo chave - aí, o Nada foi acima de tudo o de um 'vazio urbano', em que a identidade potencial Marvila/Chelas seria longa e extensivamente debatida e tornada operativa. O Nada foi então menos o do gueto lainda que por vezes os

85 Cf.Lisboa Capital do Nada (2002), o documentário de Luís Alves de Matos. 
jovens continuassem a tirar partido da acepção) e mais o da liberdade de as pessoas poderem decidir o seu próprio destino, ainda que por uns dias. Aspecto que torna a abordagem do projecto delicada é aqui o da escala e complexidade do Evento. ${ }^{86}$ As opções tomadas neste âmbito, na sua articulação com a metáfora do Nada, tornaram o Espaço Público uma categoria em aberto e que podia portanto surgir nos espaços, situações, temporalidades e formas mais diversos (como aconteceu).

\subsection{1 'Projectos Estruturantes'. Expressão mediática, contacto humano, gesto ecológico, memória urbana}

A criação de quatro projectos estruturantes visou a produção de momentos emblemáticos que, num registo próximo do de acções de comunicação, cidadania, marketing urbano, implicassem a colaboração da comunidade ou dos seus representantes no sentido de uma expressão comunitária simultaneamente espectacular (visibilidade) e localmente significativa (identidade). Estes projectos teriam de, conjuntamente, contribuir decisivamente para alargar o alcance territorial da iniciativa: ligação entre bairros, visibilidade no exterior da Freguesia, duração para além do acontecimento, impacto visual no tecido urbano.

Cordão Humano. No dia 1 de Outubro de 2001, quatro mil pessoas «deram as mãos por nada», unindo simbolicamente o «casco velho» e o «casco novo» daquele território, e assim as diferentes realidades sociais de cada bairro. Animando musicalmente a operação, estiveram, vindos dos dois extremos, os bairros do casco velho e do casco novo, respectivamente uma banda filarmónica (Bandinha da Alegria) e um colectivo de DJ (liderado por DJ Johnny), simbolizando o cruzamento de culturas (de uma forma literal, pois as duas formações cruzaram-se, a caminho do extremo oposto. Foi um projecto semiótico, com várias simbologias entrecruzadas num momento que teria de funcionar como de abertura do Evento. $O$ perímetro de cativação desta iniciativa foi o mais desafiante, pois o que propúnhamos era uma ligação entre bairros, pessoas, instituições, atravessando fisica e simbolicamente inúmeras barreiras, a começar pelas fisicamente impostas pelos vazios de Marvila. Relativamente às nuances simbólicas relacionadas com a cor do cordão - substituindo os brancos tradicionais dos cordões humanos (pela Paz, por exemplo) por um vermelho que tanto evocava uma identidade política (a Junta de maioria comunista), como uma noção de espectáculo da paisagem lé uma cor que se presta aos melhores contrastes com os brancos do tecido urbano e os verdes envolventes), como ainda uma ideia de vermelho porventura à sua reificação nos terrenos da política representativa. Apesar de existir um autor do conceito, a obra foi assinada como sendo do colectivo da Extra]muros[, nunca assumida como 'obra de arte'.

Independentemente dos troços que ficaram por «fechar», permanecerá em quem participou a memória de um dia diferente. Apesar de participarem treze estabelecimentos do ensino básico e secundário (todos locais), os media, à excepção de uma rádio, ignoraram

86 Houve momentos em que as contrariedades anularam ou atrasaram a programação prevista, o que foi sendo integrado numa dinâmica de permanente compensação, face ao que achávamos serem eventuais expectativas locais. 
olimpicamente um acontecimento que pensávamos teria todas as condições para ser notícia. O dia de chuva não ajudou, mas esta 'peça' de meta-agit-prop foi o momento mais arriscado e irresponsável de toda a iniciativa, entretanto 'validado pelas fugazes emoções dos participantes. Dois exemplos:

Foi giro e animado, mas ao mesmo tempo estranho, pois foi a primeira vez que participei com o Colégio numa coisa destas. Para mim foi uma experiência nova, mas interessante, como aluno do Colégio Valsassina, ter feito este cordão ao lado de alunos de outras escolas. Foi como sair de uma ilha [...] $]^{87}$

[...] senti um sentimento dentro de mim muito especial. Esse sentimento parecia não ser só meu, mas sim de todos. ${ }^{88}$

No catálogo, esta peça motivou uma reflexão específica acerca da relação entre sociedade e comunidade - esta uma espécie de solidariedade primitiva ${ }^{89}$ que por breves minutos é uma experiência intensa, mágica e rara ${ }^{90}$. Em termos retóricos, a efemeridade do encontro entrou em ressonância com a evidência da articulação ethos/logos; isto é, a potencialidade do carácter colectivo da consciência da cidade materializou-se num cordão humano que desenhou no território a ligação entre os diferentes realidades que caracterizam Marvila (e a cidade em geral), numa efémera celebração do comum, da comunidade, que seria logo de seguida objecto de reflexão posterior, nomeadamente nas Escolas, motivando trabalhos pedagógicos de análise do significado daquele 'absurdo'.

E-vazão. No vale de Chelas, num terrain vague onde duas palmeiras são simultaneamente marca rural e referência urbana, Cláudia Taborda e Víctor Beiramar Diniz, arquitectos paisagistas, propuseram «a construção de um lugar determinado pela vontade». Uma matriz definiu no terreno a condição e o ritmo das transfigurações: indício de uma oportunidade. A proposta transfigurou o sítio através da possibilidade de acumulação de matéria viva e abandonada: árvores negadas a existir na paisagem construída do Alqueva (barragem em construção no Sul de Portugal) poderiam contribuir para humanizar um lugar onde resistem as duas palmeiras alienadas. A 'participação' foi nula, pois ninguém exterior à organização plantou qualquer árvore, mas o dispositivo não deixou de resultar como denúncia visual dinâmica (conforme a direcção de onde nos aproximámos, a cor da peça alterava-se). Se a peça terá evocado, para a intelligentsia, as célebres Lighting Field de Walter de Maria, ou 7000 Oaks de Joseph Beuys, o comentário de um morador comprova a vernacularidade da solução:

Sobre o caso da escultura dos postes: temo dizer que pouco ouvi e que a mensagem não tenha passado; uns observam «será em memória das vítimas de Timor?», para mim era algo interessante, pois tinha várias leituras, decorrentes dos campos de visão, tanto pelo seu colorido, 4 cores, assim como pela geometria imposta, ora diagonal, ora paralela, lembrando como que a necessária ordenação a este espaço, como que aclamando a necessidade que haja ordem no nada. Apreciei esta escultura. ${ }^{91}$

Azinhagas de Marvila. Os arquitectos José Adrião e Pedro Pacheco interpelaram a economia do evento através de um projecto de teor urbanístico. A ideia era pintar os muros

87 Sobral, Eliana; in Lisboa Capital do Nada - Marvila 2001, Extra]muros[ Lisboa, 2002, p. 128.

88 Saraiva, Pedro; in Lisboa Capital do Nada - Marvila 2001, Extra]muros[ Lisboa, 2002, p. 130.

89 Cf. Caeiro, Mário; in Lisboa Capital do Nada - Marvila 2001, Extra]muros[ Lisboa, 2002, p. 131-132.

90 Note-se que um grupo de centenas de crianças mais pequanas, ao terem saído tarde demais para poderem dar as suas mãos às das outras escolas (os organizadores hesitaram em trazê-las para a chuva), acabaram por, por iniciativa da sua escola, fazer o seu próprio cordão autónomo, em volta do coreto no exterior das suas instalações.

91 Quadrado, Manuel João; in Lisboa Capital do Nada - Marvila 2001, Extra]muros[ Lisboa, 2002, p. 108. 
de um ancestral sistema de azinhagas, demonstrando-se a beleza do mesmo e advogando a necessidade de a cidade contemporânea pensar a sua evolução a partir de bases mais sólidas que as da mera arbitrariedade da construção. No processo de negociação com a Junta de Freguesia para a realização da obra (que teria por base a pintura dos muros de pelo menos uma azinhaga histórica, com tinta branca luminescente), prevaleceu porém a opção do poder político local de não realizar o projecto.92 Antoni Remesar e João Pedro Costa, numa análise crítica dos aspectos falhados desta acção, (contra)propuseram formas de continuidade; ${ }^{93}$ mas o debate nunca chegou a conseguir sair de um plano algo técnico. Ao contrário do que aconteceu nos projectos de interacção social mais informal (Cordão Humano, E-Vazão), Azinhagas de Marvila implicou-se com uma questão urbanística 'dura' (não meramente 'cultural'), e isso foi tanto o seu ponto forte (ethos urbanístico, estruturante) como fraco lincapacidade de lidar com a oportunidade do evento enquanto palco de uma espectacularidade pedagógica).

Note-se como todos estes projectos têm o carácter de intervenções de Land Art - desenham o território através do corpo encenado na paisagem, da aç̧ão regeneradora, da explicitação da cidade como sistema vivo.

\subsubsection{O caso Maçãs de Carvalho - imponderável comunicação}

Porque é que existe o ser em vez do nada? Maçãs de Carvalho desenvolveu um projecto faseado que visou dar visibilidade àquilo que o artista definiu como os «heróis» de Marvila: pessoas que são referências no seu bairro, pelo seu mérito ou valor. Sob a figura de uma campanha de comunicação (hotline ${ }^{94}$ ), o projecto passou pela selecção de um primeiro grupo, dos quais foram escolhidos cinco jovens que figuraram em mupis, cartazes, folhetos, postais e na internet, cuja fotografia era acompanhada por um telefone móvel (símbolo da sua individualidade). Aparecendo no espaço público com vários meses de antecedência em relação à inauguração do Evento, e com uma distribuição em toda a Lisboa e difusão em publicações de âmbito nacional, foram muitas as solicitações de informação sobre os jovens e a Freguesia, assim como sobre o próprio evento. Já em Outubro, quando o Mário, a Vanessa, o Beto ou o Francisco eram já de alguma forma reconhecidos, foi colocado um gigantesco retrato da Débora (dirigente da Associação Africana) numa empena do Bairro do Armador, tendo a «heroína» sido escolhida pelo condomínio do prédio.

Este projecto, solidamente estruturado na sua abordagem dos elementos da forma urbana que the pudessem servir, foi definido como sequência de acções sempre devidamente monitorizadas no seu impacto (como em qualquer campanha publicitária). Um ethos de

92 O projecto ficou refém de decisões de índole politico-partidária; ao pretender intervir na Azinhaga da Bruxa, sendo os muros desta, de um lado, camarários, do outro privados (pertencentes a figura pública da Contrarevolução e da Direita em Portugal, Galvão de Melo).

93 Em conferência realizada durante o Evento e mais tarde no catálogo. Lisboa Capital do Nada - Marvila 2001, Extra] muros[ Lisboa, 2002.

94 Modalidade de contacto característica, à época, de determinadas campanhas de comunicação que procuram auscultar o seus consumidores em directo, por via do telemóvel. 
atenção à identidade humana, social, quotidiana, integrou como poucos projectos em arte pública em Portugal uma potencialidade dialógica (imponderável, pois cada chamada era um encontro único), assumida também por via de alguma possibilidade de confrontação (comunitária). Entre o pendor conceptual e uma dimensão agit-prop, o dispositivo recorreu a soluções relacionadas com a moda (e a/na) comunicação (iconografia). 0 artista já havia realizado hot-lines anteriormente, mas aqui multiplicava as suas decisões projectuais, abrangendo a utilização expandida de vários circuitos publicitários (fax, revistas, jornais, postais, mupis, empena); uma reflexão sobre o estatuto do retrato fotográfico na paisagem mediática la busca de um registo adequado à situação dos retratados, realizado num tom de grande sobriedade); uma hibridez cínica entre obra de arte e objecto publicitário, aumentada pela realidade contingente das situações conversacionais criadas lautonomia das reacções dos heróis às chamadas ${ }^{95}$; : e ainda a decisão rigorosa dos limites do projecto e das suas regras de implantação. A campanha assentou numa série de posters ilustrados com fotografias de pessoas em planos americanos; muitas pessoas que não quiserem ou não puderam telefonar para os heróis não puderem ser indiferentes a esta dimensão visual, que concretizou uma disseminação da imagem da LXCN, e não apenas de si própria. Qual o estatuto daquelas imagens? Que diziam aqueles cartazes? Qual o seu papel na paisagem audiovisual de uma capital europeia? Podemos falar, de uma simbiose entre o espaço publicitário e uma abertura para o imaginário, paradoxalmente epitomizada no olhar inexpressivo e na banalidade das posturas dos heróis (dimensão contra-espectacular dos retratos). ${ }^{96}$ Por outras palavras, aquele espaço de diferença propôs a dignidade da banalidade daquelas presenças (com o plano americano das imagens remetendo para o desafio de uma aproximação física àquelas personagens-pessoas, vestidas de fato de treino lo polícia Casimiro) ou com uma blusa a dizer 'Nobody' (a dançarina Vanessa). ${ }^{97}$

\section{Faseamento, envolvimento, comunicação}

O envolvimento do artista no processo-dispositivo de Porque é que existe o ser em vez do nada? foi determinante na constituição de um ethos credível, não apenas da peça mas do próprio evento - a produção passou por sessões de esclarecimento e reuniões de selecção de potenciais heróis, sessões fotográficas no território da Freguesia e todo um trabalho de

95 A dimensão contrapontística do trabalho esteve na possibilidade de cada herói atender ou não as chamadas, de responder segundo os seus critérios às questões (e provocações); por outro lado, o dispositivo constituía uma gesto simples de inclusividade, em transparência, uma vez que ao distribuir os heróis por diferentes redes de comunicações (com os prefixos 91, 93 e 96) se estava ao mesmo tempo a sugerir uma diversidade contingente relacionada com o tecido social numa das suas expressões mais quotidianas e inconscientes, a das redes de comunicações móveis.

96 Quando o artista me apresentou as imagens que serviriam de fundo à sua campanha, antes de existirem quaisquer decisões quanto aos conteúdos dos cartazes, os primeiros comentários da nossa equipa foram no sentido de achar aquelas expressões apáticas, resignadas. A este reparo o artista respondeu que não era seu objectivo embelezar a realidade, recorrendo aos modelos publicitários para engrandecer a realidade, mas antes procurar o registo adequado para tornar aquela representação do quotidiano uma forma de não apenas dá-lo a ver com máxima dignidade (a da atenção ao real), mas igualmente de uma forma potencialmente critica, o interesse no lugar da mera simpatia (empatia trivial). Ou seja, não bastaria nunca as imagens serem belas ou feias segundo parâmetros sempre arbitrários; elas teriam de funcionar como gatilhos de uma interrogação e cumprir, então, com os textos, um sistema de interpelação que apenas teria impacto se o seu discurso fosse suspenso, não declarativo, ao mesmo tempo que ancorado na realidade concretamente vivida daquelas personagens.

97 Comparar com os retratos de Transurbana de Luís Campos. 
desenvolvimento da criação gráfica e tipográfica, acrescentando-se à política de difusão (selecção de heróis de acordo com cada espaço media). Ao contrário de muitas campanhas de publicidade com objectivos 'sociais', bem como de manifestações ingénuas de solidariedade (que recorrem a ideias feitas e a bancos de imagens estereotipadas - metáforas mortas), estes cartazes resultaram de uma preparação prévia extremamente estruturada e negociada ao mais ínfimo detalhe. Tal estruturação foi a base da solidez do trabalho artístico, que assim compensou, no rigor, o perigo eventual de não ser representativo da população e dos seus problemas; o artista agiu sobretudo em conformidade com uma sistemática e fundamentada leitura do terreno social em causa, sustentada na auscultação de personalidades locais.

Se ao nível do ethos estava garantida - até certo ponto - a credibilidade das escolhas, ao nível do pathos Maçãs tinha por importante que a obra de arte deve sempre desiludir ${ }^{98}$, isto é, deve haver uma dimensão de decepção ou frustação comunicacional na obra de arte, que é o que the garante um estatuto diverso do espectáculo. A propósito deste trabalho sobre a desilusão la possibilidade, como aconteceu, de vários números estarem pontualmente desligados), da parte da Organização houve a presença de espírito para que a obra de Maçãs fosse, na prática, a campanha de lançamento do próprio projecto. Acção arriscada mas que predava a obra do artista (e ela a nossa). ${ }^{99}$ Porque é que existe o ser em vez do nada? foi então particularmente estruturante ao permitir ao evento comunicar durante um período alargado de tempo a sua proximidade temporal, para além dos limites formais do mês de actividades previsto e dos habituais mecanismos de difusão cultural. Isto revela, em grande medida, como o evento comunicava, nesta peça, a sua abertura radical ao imponderável micro-social. ${ }^{100} \mathrm{Com}$ o tempo, esta dimensão pretensamente comunicativa (chamemos-lhe de primeiro nível) dava lugar a uma dimensão de percepção mais profunda. Nesse momento, a peça cumpria o seu desígnio mais consistente: tornava-se uma obra que abordava as suas temáticas não com ideias feitas, logo morais, mas por via da criação de uma plataforma de debate - simbólico, também literal - em torno dos temas do outro, da comunidade, da sociedade, do território. No ponto critico da obra, cerne da sua legitimidade crítica, esteve o facto de que a própria sociedade do espectáculo é toda ela um dispositivo que, por momentos, pode ser manipulado no seus elementos mais basilares - no caso, as estruturas de publicidade e, no âmago dos seus discurso, a relação imagem/texto/situação, assim sendo possível problematizar o lugar do humano nessa dinâmica.

\section{Débora}

Localmente, a imagem desta peça que teve maior impacto foi realizada em função de uma decisão partilhada entre o artista e coordenador do evento; quando este último propôs ao primeiro a utilização de uma empena de um prédio local para aí colocar um monumental cartaz, havia que manter precisos os parâmetros constitutivos da obra, mas encontrar as nuances

98 Conversa com o artista.

99 Ou seja, aceitávamos que o inventio da LXCN assentasse na arte de uma das suas obras, o que revela uma atitude muito diferente da instrumentalização dessas obras por exemplo a jusante de uma mera campanha de publicidade.

100 Vários heróis (Vanessa), incomodados com o número de chamadas recebido, desligavam os seus telemóveis. 
adequadas para que o mesmo conceito funcionasse, mas agora numa escala diversa (não podendo a colocação do cartaz limitar-se a ser uma ampliação dos mupis). Ao nível local, por outro lado, a obra teria de poder ser percepcionada como algo partilhado. Quanto à primeira questão, a sua solução passaria por eliminar-se a referência a qualquer número de telemóvel, signo-chave da campanha; quanto à segunda, pelo processo democrático da escolha da heroína. ${ }^{101}$ Uma nova frase foi então decidida entre curador e artista: Eu sou a Vanessa. Obviamente, estes gestos de democraticidade têm um traço micro-simbólico que, se por um lado inscreve a alteridade, não o faz impunemente; esta questão particularmente problemática da representatividade no espaço público teve ecos na reacção de uma associação local:

A Direcção deste clube tem comentado que como projecto organizado por pessoas que mal conhecem a Freguesia de Marvila talvez não se pudesse esperar melhor, embora as pessoas que Associação Extramuros contactou antes de o projecto começar ficou muito a desejar em relação a muitos factores, desde a ajuda, como de ideias, de disponibilidade, para levar em frente este evento que à partida era ambicioso. / Cartazes, fotografias, estampas nos jornais, de pessoas que nada fizeram ou tem feito pela Freguesia de Marvila [...].102

O excerto, denunciando nas imagens uma acção promocional - os heróis promovendo-se a eles próprios $^{103}$, desvela uma questão recorrente no espaço público discursivo - se o projectista age independentemente, corre o risco de laborar em solidão arrogante; se adere a uma sede de poder local, para viabilizar o projecto (foi o caso), é facilmente acusado de não integrar todas as pessoas não abrangidas por essa instituição. Não existe projecto participativo sem (este ou outro) conflito iminente, tanto mais ampliado quanto existir uma componente mediática ou de reconhecimento público; e nestes termos, esta foi uma lição muito interessante acerca das possibilidades de representatividade de um projecto lque Maçãs, na verdade, nunca quis realmente, mas cuja verve publicitária provocou); e aí o comissariado é sempre cúmplice; da invisibilidade de certas dinâmicas no projecto e da exposição do artista à violência da crítica - e se no final dizíamos que era como um 'chuto' de realidade, o que seria o maior desafio a realizar era decidir o que retirar desta experiência. Em particular do dispositivo como mediação da condição pós-moderna, conforme David Santos escreveria, seleccionando este como dos principais projectos da LXCN:

\footnotetext{
José Maçãs de Carvalho actua assim numa perspectiva do artista enquanto sociólogo. Lógica de activismo artístico que em parte se aproxima do conceito de "artista como etnógrafo" que Hal Foster desenvolveu no seu estudo The Return of the Real (1996) como novo paradigma da prática artística dos últimos anos: "Neste novo paradigma o objecto de contestação continua a ser ainda a instituição burguesa-capitalista da arte lo museu, a academia, o mercado, os media), as suas definições exclusivas de arte e de artista, identidade e comunidade. Porém, o tema de associação mudou: é o 'outro' cultural elou étnico em nome do qual o artista engagé luta a maior parte das vezes. Por subtil que pareça, esta deslocação de um tema definido em termos de relação económica para um outro definido em termos de identidade cultural é significativo". Foster situa aqui uma espécie de transição entre o "artista enquanto produtor", como na tese de Walter Benjamin dos anos 30 - onde defendia o sentido utópico e modernista de uma arte politicamente empenhada que fizesse desaparecer a arte e a cultura burguesas, no exemplo do construtivismo russo - e o "artista como etnógrafo" das últimas décadas. [...] E não se trata aqui da visão sobre o "outro" que os modernistas promoveram ou no primitivismo caro aos expressionistas e cubistas ou na unidade textual das collages dos surrealistas que tomaram do inconsciente esse desejo do "outro". No fundo toda a convocação do "outro" que o modernismo realizou tem como sustentação essencial o idealismo de uma unidade universal, não já para "educar" ou "converter" o "outro" mas para se auto-anularem precisamente no "outro", como se este personificasse um novo ideal. Ora é na anulação do valor idealista do "eu" ou do "outro" que o "artista enquanto etnógrafo" se distingue não só do "artista como produtor" como do modernista que interpreta com entusiasmo o primitivismo tornado redentor. Isto, se o "artista enquanto produtor"
}

10114 votos contra dois no condomínio determinaram que fosse a Débora a jovem escolhida.

102 In Lisboa Capital do Nada - Marvila 2001, Extra]muros[ Lisboa, 2002, p. 109.

103 Idem. 
traduzia uma vontade de intervenção social a partir de uma experiência criativa traduzida no auxílio ao "outro", entendido como explorado pela sua condição económica e social desfavorável, e utilizando sempre em favor dessas questões os mecanismos de promoção e difusão mediática próprios das artes visuais contemporâneas e de todo o seu milieu essencialmente burguês, já o "artista como etnógrafo" promove no interior do meio artístico burguês-capitalista uma possibilidade de leitura pela alteridade cultural do seu propósito. Afinal a diferença antropológica e cultural do "outro" poderá assim significar uma derradeira oportunidade de combate e alteridade transformadora contra a omnipresença imagética do tardo-capitalismo, que é ainda uma outra forma de dar continuidade a um certo sentido da tese de Walter Benjamin da substituição da arte burguesa por uma "arte produtivista".

Quanto à questão específica do espaço público, David Santos: Tomando deste modo a (in) visibilidade do espaço público, os efeitos de surpresa e comunicação foram obtidos no sentido de uma revalorização da mensagem intrínseca ao labor social destes novos heróis de Marvila. Contudo, os resultados concretos de um projecto desta natureza, com todo o seu empenho político e social manifesto, têm necessariamente de ser confrontados com a realidade mediática na nossa contemporaneidade que tudo parece diminuir, anular, ou converter em favor da grande máquina imagética e sígnica do sistema capitalista.

\section{Até certo ponto, este projecto deu o tom a toda a iniciativa, explicitando uma genealogia.}

Na verdade há uma filiação deste projecto num certo tipo de intervenções características da arte política das décadas de 60,70 e 80. O espaço público torna-se então o lugar previligiado da aç̧ão artística, e, por sua vez, esta toma como essencial uma maior consciencialização acerca dos valores políticos e ideológicos que se reflectem na estratificação social do capitalismo da segunda metade do século XX.

É assim que a 'liberdade' dada esta inciativa foi antes de tudo o mais a de experimentar o trauma ${ }^{104}$ (e a cidade de que este é produto):

Descrente, confuso e interpretando o real através de uma radical e poderosa acção mediada, o sujeito contemporâneo, recebe assim uma noção do real que só se realiza paradoxalmente pela própria ideia de crise da mediação, enquanto registo mais actual contemporâneo sobre a crise de sentido e identidade que é em última instância da ordem do ser e da existência, tal como na aproximação reflexiva instaurada pelo projecto de José Maçãs de Carvalho. [...] No fundo é esse o contexto donde parte o projecto. [...] Os Heróis de Marvila servem deste modo a uma interrogação acerca da mediação e do conhecimento de si para os outros, e destes para si próprios, isto é, um complexo processo de interacção identitária (individual e colectiva), recorrendo aos efeitos aparentemente exponenciais do espaço público, nomeadamente através da utilização de estratégias em tudo similares às da publicidade que invade o espaço visual urbano.

O círculo fecha-se. A peça cria uma zona livre de indústria cultural no espaço mais nuclear de todo o evento, precisamente o ponto em que a LXCN comunicava com o resto da cidade:

Mais do que um reconhecimento individual dos marvilenses que se aliaram ao projecto, este confirma a lógica de adulteração identitária que todo esse processo de (in)visibilidade (dos outdoors às críticas e notícias nos jornais) promove sobre o sujeito contemporâneo na sua auto-consciência ao nível existencial, remetendo assim, por mediação contemporânea, para o sentido da interrogação filosófica de Heidegger, aqui convertida em slogan de todo um projecto que envolve sedução, contacto e experiência através de uma mediação constantemente reactivada. ${ }^{105}$

104 Santos: De facto, Hal Foster defende desde os anos 90 uma tese essencial que poderá servir igualmente para enquadrar o trabalho artístico de José Maçãs de Carvalho, diz o teórico norte-americano que hoje "a realidade já não é entendida como efeito de representação, mas como acontecimento de trauma". Na verdade, o registo traumático de alguma da melhor experiência artística e reflexiva da nossa contemporaneidade releva fundamentalemente de uma crise de sentido e do sujeito acentuada desde, pelo menos, o segundo pós-guerra. A crise do sujeito é também uma crise da identidade, do corpo, da autoria e do significado, tal como na tese essencial de Roland Barthes. Por isso, o derradeiro esforço de produção de sentido em torno da experiência artística realiza-se mediante a expressão física e psicologicamente traumática, seja em imagens de infinitamente reproduzidas, como em Warhol, seja na tomada directa e cruel do corpo, como em Gina Pane, Acconci ou Chris Burden. Aparentemente, sem efeito ao nível da representação só a imagem do trauma poderá ainda remeter para o sentido. Todavia, este fenómeno identificado por Foster em algumas manifestações das neo-vanguardas dos anos 60 e 70 parece ter-se igualmente convertido em mais um estágio dessa neutralização progressiva promovida pelo universo imagético do capitalismo avançado.

105 Santos: Se por um lado estes cidadãos de alguma forma pontuam uma distinção social lpor aquilo que fizeram ou fazem aindal por outro o sistema de promoção imediata inerente ao processo de exposição pública promovido pelo 


\subsection{As componentes 'Arte' e 'Fotografia' - obras comentadas}

\section{Paisagens combinadas}

Várias peças da LXCN representam abordagens críticas da paisagem que albergou o Nada, desenvolvendo soluções precisas para habitar essa paisagem com narrativas, experiências ou prospectivas colectivas.

Paisagem Combinada, de André Guedes consistiu no movimento de pessoas na paisagem do Vale de Chelas, uma vazio suburbano aberto na geografia de Marvila. O projecto de AG articulou um amplo gesto espacial - paisagístico - com a disponibilidade de um conjunto de jovens do Clube Recreativo e Cultural MarvilaJovem, que se viram transformados em actores dos percursos que o artista coreografou. Nos dias de apresentação, uma bancada com 40 lugares era mais do que o indício de que havia ali um espectáculo, ela era o símbolo da espectacularidade própria de todo aquele momento urbano: o recorte dos prédios ao fundo, as pessoas que ao longe atravessavam baldios a caminho de casa ou do supermercado, tudo factores de um periclitante edifício estético feito de vida e arte. Era grande a expectativa perante esta peça, pois estava acordada uma colaboração intensa entre o artista e o Clube Desportivo Marvila Jovem. Guedes funcionou como um 'maestro', orquestrando os indivíduos colaboradores (membros do Clube) na paisagem, as cores dos seus equipamentos os seus percursos, terminando o happening com um músico em fato de treino, passando junto da bancada efémera, tocando violino. Mas a peça não terá tido os ajustes necessários para obviar uma certa tensão entre artista e os membros da associação colaborante, uma vez que acabaram por ser manifestamente poucos os corredores. No entanto, a forma como a bancada, durante apenas dois dias foi uma bancada para o espectáculo do vazio do Vale de Chelas tornaria a peça icónica do 'Nada'; a haver uma experiência da totalidade da arte e do social, ela foi ali veiculada, pelo menos ao nível da imagem e para o restrito grupo de 30 pessoas que ali se deslocou para um monumentalmente paradoxal espectáculo situacionista. Escusado será dizer, a mobilidade e arbitrariedade do artista foi aqui expressiva - a arbitrariedade de códigos em confronto (arte/desporto, cultura/associativismo) redundaria numa tensa problematização dos limites na distribuição do sensível. Na sua quase arrogante pujança conceptual, Paisagem Combinada deu da participação uma definição, no mínimo, desencantada, com a instrumentalização dos meios humanos e materiais longe de corresponder aos modelos mais canónicos e equitativos da community-art - mas e se no choque de culturas que a peça assume estiver a genuína criação de um outro em processo concreto, portanto de co-constituição, num terreno já não da 'arte' ou da 'cultura' e apenas e só da imediaticidade das oportunidades dialógicas? $\mathrm{E}$ se isso fosse a mensagem mais profunda da peça, consequência súbita da espectacularidade do seu vazio ideológico na abordagem do território?

projecto de Maçãs de Carvalho anula os efeitos reais sobre essa mesma distinção apesar de poder operar uma eventual e talvez passageira confirmação da singularidade dos "eleitos". É na fronteira desse jogo de opostos (reconhecimento/anulação indentitária e reflexão/ausência de reflexão acerca do ser e da singularidadel que o projecto de José Maçãs de Carvalho se desenvolve, perscrutando as inefáveis consequências da nossa contemporaneidade mediática quando confrontada com a questão heideggeriana "porque é que existe o ser e não o nada?". 
Quanto a Belcanto, de Catarina Campino, consistiu numa série de cinco concertos de ópera em outros tantos espaços-tipo do território ${ }^{106}$ - constituiu-se, à maneira de Paisagem Combinada de Guedes, como uma violenta colagem tridimensional ('alta cultura' vs. 'subúrbio'), deliberadamente impositiva mas, ao mesmo tempo foco de emoções estéticas inequívocas. Para Filomena Silvano, a intensidade do desequlíbrio retórico ofereceu porém graves problemas:

\footnotetext{
A interacção humana que esta peça pressupunha colocava-a necessariamente no interior de um terreno de reflexão complexo, em que se desenhavam múltiplas questões culturais, éticas e politicas. Entre elas, a questão das fronteiras entre a cultura erudita e a cultura popular, a questão da posse de capitais culturais, a questão da legitimidade de deslocação de uma prática artísitica para um contexto material que objectivamente a desvirtua, a questão das formas de relação coma cultura dos outros. A complexidade das implicações que um projecto destes contem implicaria a sua clara enunciação prévia, de forma a que o processo performativo fosse, no terreno, minuciosamente controlado pelos operadores artísticos. Caso contrário, abre-se espaço a um sem número de equívocos e ambiguidades. ${ }^{107}$
}

Estes dois projectos-colagens contrastam com o de Fernanda Fragateiro, cuja relação com o espaço público é sustentada por um quadro teórico segundo o qual a cidade deve ser desenhada com a participação das pessoas. Em Marvila, Fragateiro tinha uma ideia-base - «fazer um jardim» -, decorrente da sua leitura do espaço inóspito de uma praceta no Bairro dos Loios. Numa das reuniões iniciais, a Associação Tempo de Mudar, do Bairro, manifestou interesse em trabalhar com a autora do Jardim das Ondas ${ }^{108}$ (prova do poder de atracção vernacular desta obral, e o projecto passou a desenvolver-se em grande articulação, assegurando a sua legitimidade. Depois, tratou-se de ultrapassar problemas e vencer etapas, como a de integrar o projecto no projecto urbano geral da CML para a Praça Raúl Lino, assim reflectindo aspirações dos moradores e o desejo da artista de intervir na evolução urbanística. A custo da visibilidade imediata, $O$ paraíso é um lugar onde nunca nada acontece deu tempo de maturação às potencialidades da relação arte-sociedade, na qual desenho urbano participativo, arte e animação urbana se enriquecem mutuamente. A obra seria realmente concluída apenas dois anos depois ${ }^{109}$, mas dessa durée resiliente à economia do espectáculo há que reter que a artista tomou em mãos próprias e com toda a autonomia (de quem conhece e domina os mecanismos da arte urbana), aproveitou o contexto de um Evento para deixar uma marca permanente e útil. $O$ Paraíso..., enquanto qualificação do espaço urbano, realizou-se de acordo com os parâmetros da community art, ou seja, com os habitantes da cidade [...] chamados, por via da metodologia de desenho utilizada, a intervir ${ }^{110}$.

Já Vasco Araújo, que interveio igualmente num espaço público contido, instalou Palanque durante cerca de um mês no pacato Bairro da PRODAC. Numa atmosfera de aldeia, VA desenhou algo entre o palco e o coreto, espécie de «ovni» efémero - base de palco negra de planta oval, estrutura tubular de onde pendiam plásticos vermelhos como cortinas - que conseguiu o carinho dos moradores mais próximos, pelo seu carácter «oco», disponível, à espera de quem se apropriasse dela para ali se exprimir. Tratou-se de, simbolicamente, de

106 A adaptação da ideia da peça ao território foi de extrema precisão, levando a artista inclusive a adaptar não apenas as horas de actuações-surpresa como o reportório de cada concerto a cada contexto:

107 Silvano, Filomena; in Lisboa Capital do Nada - Marvila 2001, Extra]muros[ Lisboa, 2002, pp. 461-462.

108 Recordo que a artista tinha realizado Jardim das Ondas dois anos antes, encontrando na LXCN uma oportunidade para desenvolver algumas ideias daquele projecto (permanência, usufruto quotidiano), agora num quadro participativo, enquanto activação de um projecto arquitectónico (da autoria de Gonçalo Byrne) em evidente crise.

109 Cf. documentário de Luís Alves de Matos, A Praça. 52', 2004.

110 Silvano, Filomena, p. 462. 
dar voz às pessoas e à sua expressividade le ficarão como memória do evento as crianças em cima do palco entoando o «Atirei o pau do gato»). Mas diferendos internos (Fernandes Dias ${ }^{111}$ e/ou deficientes diligências junto da comunidade impediram que a obra funcionasse como previsto, um animado palco para uma programação regular de concertos. Ainda assim, mais uma vez as dificuldades fazem o sentido da obra, exigindo ser analisadas $e$ avaliadas atentamente. ${ }^{112}$ Reconheço finalmente que, nas visitas prévias feitas com o artista, a opção conjunta por aquele local, ao seguir uma lógica de enquadramento visual (estética) talvez tenha levado a perder-se uma oportunidade daquele investimento gerar real interacção com a comunidade, uma vez colocado noutros bairros mais jovens e populosos. ${ }^{113}$

Roda do Tempo. Eurico do Vale (em colaboração com o arquitecto Francisco do Vale) apresentou doze fotos a preto e branco de uma bailarina em movimento, pretendendo criar um momento de cidade caracterizado pela harmonia e sua durée num parque público. A construção foi instalada numa praceta inclinada à entrada do Parque da Bela Vista lapós dificuldade em convencer o Departamento de Espaços Verdes em ali colocar uma obra cuja estrutura de suporte era em betão), propiciando o diálogo crítico urbanidade-natureza/ homem-natureza (tema-objectivo durante a longa répérage do artista); se o interior desta espécie de pavilhão proporcionou uma experiência sinestésica de beleza e serenidade, as faces exteriores oferecem-se à cidade, num convite implícito a que os graffitters se apropriem daqueles muros nus (o que não se concretizou, talvez por respeito à 'obra de arte'). Talvez pela sua beleza comum - a vernacularidade da estrutura circular -, Roda do Tempo garantiu opiniões muito favoráveis entre os visitantes e, de forma mais consensual que Palanque, respondeu a um apelo monumental. A sua efemeridade foi porém das mais chocantes, porquanto, no final da iniciativa, a peça foi completamente demolida (não se sabe por quem), deixando da experiência daquela beleza um derradeiro travo de amargura, contrastante com a experiência de leveza e serenidade que a obra proporcionou durante o evento.

Avenida do Aeroporto. Para José Manuel Rodrigues, a fotografia encontrou na LXCN uma materialização radicalmente diversa. Avenida do Aeroporto consistiu na produção e distribuição de uma série de cinco postais de grande formato, num total de 5000 exemplares, que tocou um público específico do espaço urbano, os automobilistas. Todas as segundas-feiras pelas $8 \mathrm{h00}$ da manhã, ${ }^{114}$ elementos da equipa de produção garantiam que a experiência de percorrer aquela artéria da cidade se tornasse uma realidade mais rica, uma vez que as imagens eram retratos dos locais exactos onde eram distribuídas. A obra interpretou processualmente o espírito do fluxo urbano e sua representação crítica (desmaterializada), de forma mais directa que as obras da componente Fotografia que se ficaram essencialmente pela representação do território em espaços culturais indoor; ${ }^{115}$ ou

111 Dias, José Fernandes Dias; in Lisboa Capital do Nada - Marvila 2001, Extra]muros[ Lisboa, 2002, pp. 225.

112 Idem.

113 E nesse caso, seria a mesma peça?

114 Quando nos atrasámos houve quem telefonasse a saber porque é que não havia postais...

115 Esta obra contrastou com a de Fabrice Picard, que apresentou imagens de acumulação de signos e significados (grafismos urbanos) nas paredes do Espaço Municipal da Flamenga. O modelo expositivo de Picard não foi ao encontro das exigências urbanísticas da LXCN (o aforismo na forma urbana), a não ser através do facto de o trabalho se ter apresentado num equipamento cultural recente, que interessava valorizar. Mais exemplar pela 
que as acções que, próximas da formação, tinham por função essencial servir uma missão pedagógica e/ou dar a ver equipamentos da Freguesia através da sua ocupação produtiva. ${ }^{116}$

Concluo com as peças de Paula Figueiredo e Mariana Viegas, cujos dispositivos - faseados, integrando momentos de intensa participação - foram tão discretos quanto eficazes. Quanto a Paula Figueiredo, em Ádito, o processo teve notável simplicidade. Numa primeira fase, recolheu imagens antigas do «casco velho»: da arquitectura industrial aos trabalhadores que a habitaram. Depois, envolveu pessoas que trabalham hoje nos armazéns de outrora. Garantida a pertinência histórica e o envolvimento humano, expôs as imagens no Clube Oriental de Lisboa, com desarmante proficiência, evitando impor as regras da arte (o furar de paredes como no white cube, as legendas junto às fotografias) ao quotidiano associativo. Montou assim as suas fotografias por entre recordações da glória daquele clube, nos corredores, no bar e no átrio (em ambos os locais limitando-se a encostar as imponentes molduras às paredes, em grande interacção física com os utentes), criando condições para uma rara fusão de públicos. O facto de quase todas as imagens serem de espaços que apenas os informantes conhecem fez com que, naquela situação, fosse o público habitual da arte a sentir-se desconfortável; e os locais perfeitamente integrados no sentido último das imagens e sua origem documental. Nesta peça, o pathos do tema não é devassado pela divisão cultural da arte.

Caminhos de Mariana Viegas, foi uma exposição (e processo preparatório) que registou os percursos que os adolescentes percorrem no seu dia-a-dia. Num processo psicogeográfico que envolveu estudantes da B2+3 de Marvila e da Esc. Sec. D. Dinis, o território em acelerada mutação foi incentivo para se criarem oportunidades ${ }^{117}$ no momento de os resultados serem «devolvidos» à escola, a montagem, nos espaços de convívio, revelou perfeita sintonia com a vivência própria de cada sítio. Muito interessantes foram os aspectos da montagem e de follow-up. As fotografias foram montadas de forma tão integrada quanto possível no quotidiano da Escola (e utilizando-se as vitrinas, embora sem exclusividade); por outro lado, a intensidade da relação criada entre a artista e os seus jovens colaboradores ajudou a que houvesse grande disponibilidade para mais colaborações com a comunidade

forma como deu a ver a Freguesia e ao mesmo tempo uma estrutura viva foi a intervenção de Paulo Muge, João Mariano e Lenia dos Santos na Galeria Promontório. Grandes formatos do vazio territorial da Freguesia e memórias de um Verão ensoleirado foram suspensos nas instalações do atelier de arquitectura, numa apropriação «pública» de espaços semi-privados, no caso onde se desenha a própria cidade. A violência da intrusão e a consequente perturbação valeram soretudo pela adesão de várias centenas de crianças e jovens, que ali se deslocaram em inúmeras visitas guiadas, muitas por iniciativa das próprias escolas.

116 Ainda na Flamenga, Tiago Pereira integrou desenhos das dezenas de crianças que frequentavam o Equipamento no seu vídeo $0=2$, em que Marvila surge representada em animação de volumes e imagem real. Foi uma iniciativa de impacto junto das crianças frequentadoras do Infocentro e dos visitantes das visitas guiadas. Outras iniciativas que se podem definir como ao mesmo tempo conviviais e formativas foi a acção «Pequenos Grandes Nadas», por Dora Isabel Batalim e Carlos Céu e Silva que realizaram um inquérito junto de centenas de crianças de várias escolas e jardins de infância, chamadas a descrever e interpretar a cidade, depois publicando-se os resultados, que passaram por um estudo estatístico, numa brochura ilustrada com desenhos das crianças participantes, $A$ Cidade Inventada.

117 Um professor de Artes Visuais, sabendo da exposição, proporia aos seus alunos um trabalho de desenho de mapas... 
escolar ${ }^{118}$. Este é o tipo de peça em que a vertente informativa, de interesse para muitas áreas disciplinares interessadas na efectiva ocupação da cidade (para além do desenho), se vê valorizada e ao mesmo tempo efemeramente tornada inoperativa pelo contexto, assim conseguindo outro nível - mais honesto - de envolvimento com o território.

Quanto a Francisco Tropa aceitou o convite para participar na LXCN com uma condição fundamental, não revelar aspecto algum da sua peça senão a posteriori da sua realização. Ficámos a saber em que terá consistido a peça apenas durante o evento ${ }^{119}$ : alegadamente, com a verba que the foi disponibilizada, Tropa mandou fazer um pequeno cilindro em ouro e ofereceu-o ao presidente da Junta, a corporização do Espaço Público a nível político. Esta obra-ficção foi ao mesmo tempo mito risível, argumentação política, e complexo aforismo; se do seu carácter quase íntimo não se pode inferir uma relação explícita com a forma urbana, é inequívoco que o artista consegue abordar a substância do evento - a questão do espaço público - por uma via inesperada. A intervenção de Tropa ilustra decisivamente a liberdade de acção dada aos criadores. Foi uma peça possível porque o artista tinha status, mormente junta da Organização, mas também existia a confiança, da nossa parte, na bondade da figura do artista-cidadão. Ao nível retórico, a peça é um statement de autonomia artística; essa autonomia é porém o assumir de uma diferença fundamental e, do ponto de vista dessa divisão, a plena tradução dessa diferença num gesto à escala do próprio criador que assim encontra uma modalidade plástica, num interstício institucional, para estabelecer um diálogo entre o cidadão(-artista) e o poder-(-político) - no caso, o representante institucional do poder democrático. Relativamente à forma da peça - um tubo cilíndrico de ouro, no valor da verba atribuída pela organização - o artista coloca o minimalismo ao serviço de uma retórica de singeleza do acto conjunto organização/curador/ apoiantes; o gesto adquire por isso paradoxal relevância, num quadro de confiança mútua de que torna o troféu. 0 wit da obra - e o poder da arte - parece aqui estar no jogo mistificador que o artista empreende, precisamente para fazer passar uma verdade política por entre a chuva do jargão da arte pública. Com o tópico Espaço Público concentrado na figura humana que o simboliza (no quadro da democracia representativa) e resultando de uma processualidade enigmática (característica do trabalho de Tropa), o artista introduzi uma provocação radical numa programação que terá considerado poder tornar-se pedagógica no pior sentido. ${ }^{120}$ Concluo que o brilhantismo da solução enfrenta o obstáculo de uma esfera pública cada vez mais alargada (e no limite não-operativa); mero artist's joke ou não, esta obra corresponde, na economia geral do acontecimento, a uma posição de humildade filosófica capaz de relembrar, na subtileza de certos círculos, quão pequenas podem ser as grandes acções do entendimento.

118 O projecto Sinais trataria de o confirmar.

119 - isto porque na prática, nunca cheguei a 'vê-la' apenas durante a preparação do catálogo, para o qual o artista enviou a imagem, sem quaisquer outros comentários a não ser a confirmação de que a sua obra havia consistido na produção daquele objecto e do seu envio para a Junta de Freguesia.

120 A ambiguidade de a peça ter o formato idêntico ao de um cigarro introduz uma nota de humor literal, duchampiana, permitindo que a divisão cultural de partida tenha sido claramente relativizada por uma auto-irrisão kúnica (uma vez que o artista não voltou a aparecer em público). 


\section{Continuidades}

O Projecto LXCN, apesar de fisicamente concluído em 2002, continuou nos anos seguintes a despoletar interesse junto de várias instituições e personalidades no campo artístico. ${ }^{121}$ Uma das suas marcas mais positivas, para além de ter conseguido criar uma ligação efémera com a/entre uma comunidade, foi o facto de ter proporcionado aos artistas a oportunidade, em alguns casos pela primeira vez, de intervir num espaço urbano. No contexto português, a LXCN não apenas demonstra a importância da criação de formas alternativas de intervenção no espaço público ${ }^{122}$, como representa um arrancar o espectador ao papel de observador passivo, conseguindo que se torne no papel de produtor: Embora esta não tenha sido uma exposição no sentido tradicional, tratou-se de um evento que concretizou formatos de obra artística que, passando pelo expositivo, abordaram problemáticas da movimentação da obra e do público e, consequentemente, dos significados, de uma forma dinâmica e fluída. ${ }^{123}$ Os artistas directamente envolvidos guardam, por outro lado, recordações extraordinárias da experiência: Neste caso a arte fez-nos questionar, pensar e repensar, a sua verdadeira e primordial função. ${ }^{124}$ Realço o conceito de 'função', num quadro de abertura ao colectivo que não abdica da liberdade da necessidade da autonomia:

Queria ainda mencionar um outro projecto colectivo, menos significativo em termos da inserção canónica no circuito
de arte contemporânea mas provavelmente mais gratificante do ponto de vista do ponto de vista criativo, e mesmo
social ou ético, que foi 'Lisboa Capital do Nada'. [...] Foi um projecto ambicioso de grande risco, conjuntamente as-
sumido por mim (e pelos outros artistas) e pelo comissário, e a minha primeira experiência de «arte pública» ou no
espaço público. Este projecto trouxe para minha agenda de trabalho questões de índole social ou política não expressos
anteriormente. Digamos que marcou o meu primeiro confronto com o «mundo real», fora dos espaços museológicos
ou expositivos. [...] Posso inclusive falar de um antes e de um depois de 'Lisboa, Capital do Nada, Marvila 2001', na
minha vida e no desenvolvimento da minha sensibilidade e personalidade. Estes momentos são raros e até hoje ando
à procura de outros «convites de dois gumes» que me incitem para o abismo. ${ }^{125}$

A realização da $L X C N$ teria muitas consequências, e uma das principais a repercussão na academia; fomos chamados a debates e palestras. ${ }^{126}$ Para os envolvidos, a complexidade da experiência - conhecimentos, emoções - pode ser vista tal como Stephen Johnstone coloca a questão da aproximação da arte contemporânea ao quotidiano.

For some, this turn to the ordinary leads to a recognition of the dignity of ordinary behavior, or the act of stating simply, 'here is value'. For others, it may result in an unveiling of the 'accidentally miraculous', or the desire to make art with the unassuming ease of the amateur photographer. For others still, an art that focuses on the everyday might construct 'a vaguely ethnographic aesthetics', or be nothing more than the record of simply venturing out and happening across something interesting. ${ }^{127}$

Perante este campo de possibilidades, a $L X C N$ definiu sobretudo o estilo, que acções posteriores procurariam revisitar criticamente, evitando a sua reificação como demagogia participativa.

121 Por exemplo, entre os primeiros. Cf. Pinheiro, Gabriela Vaz; in Anamnese, Fundação Elídeo Pinho, Porto, 2006, p. 298.

122 José Pedro Regatão, Arte Pública e os Novos Desafios das Intervenções no Espaço Urbano, Lisboa, 2006, p. 147-156.

123 Anamnese, [Miguel Von Hafe Perez, Ed.], Fundação Elídeo Pinho, Porto, 2006, p. 298.

124 Idem, p. 262.

125 Idem, p. 196.

126 Destacaria aqui as afinidades electivas com outras iniciativas imediatamente anteriores - a apresentação da ópera Wozzeck, no Porto, no âmbito da Porto 2001 lenvolvendo a população do Bairro do Aldoar, dos mais estigmatizados no Porto) -, ou posteriores - o Projecto Relvinha, (teatro em espaços urbanos, em Coimbra).

127 Johnstone, p. 15. 


\section{O DESIGN COMO ACÇÃO DE CIDADANIA: SINAIS, A CIDADE HABITADA}

\subsection{Introdução: um projecto de sinalética participada para Marvila}

Sinais, a Cidade Habitada foi novo projecto interdisciplinar e experimental, desta vez de sinalética participativa, dando continuidade à Lisboa Capital do Nada ${ }^{128}$, agora com enfoque no design de equipamento e comunicação. A equipa de projecto ${ }^{129}$ desenvolveu uma série de componentes, que incluiram inquéritos à população, acções conviviais, a instalação de protótipos no espaço urbano. 0 pragmatismo do esforço desenvolvido culminou na instalação de mais de quatro dezenas de estruturas de sinalética urbana, respondendo a um Espaço Público (e a um público) mais 'objectivo' que o dos projectos artísticos anteriores.

Na sequência de um input inicial do Centro Português de Design, ${ }^{130}$ foi conseguida uma conjugação de interesses entre o $\mathrm{CPD}$, que desafiou a Extra]muros[ a dar sequência à sua acção em Marvila através de um projecto participativo «permanente, objectivo, concreto e funcional»; a Extra]muros[, responsável pelo desenvolvimento da acção; a Escola Secundária de D. Dinis, epicentro territorial da iniciativa e principal parceiro local le onde o projecto estava sedeado) que enquadrou toda a acção e assegurou real e efectiva participação e continuidade através do envolvimento de toda a comunidade escolar; a Junta de Freguesia, que contribuiu desde o início para definir as áreas prioritárias para intervenção e gerir os resultados práticos da iniciativa. À Junta cabia aproveitar o processo para prosseguir as suas políticas de requalificação urbana, com a colaboração da SECIL - Laboratório e Pré-betão. ${ }^{131}$

\subsubsection{Tema: um sistema de sinalética específico para a freguesia de Marvila}

A ideia teve a sua génese em 2001, após a LXCN, Na altura,

[...] deparámo-nos com um território claramente deficitário em termos de identidade, de imagem e muito em concreto de reconhecimento dos seus limites. No fundo, havia uma realidade urbana particularmente rica que porém era não apenas difusa - a confusão entre Chelas, Marvila ou o Poço do Bispo é um exemplo flagrante -, como de imagem problemática - tratando-se de um território bastante ostracizado.

Durante o Nada germinou a ideia de semear «sinais» positivos e identitários pelo território, através de um Núcleo de «portas» e actos de sinalização experimental. Paralelamente, a "A Cidade Habitada» estimulou formas de cidadania activa; crianças de três escolas primárias deixaram o testemunho sobre a sua visão da cidade. Os novos sinais, já sistema de sinalética, que Marvila vai albergar vêm na sequência daqueles outros sinais que um projecto efémero «recenseou».132

128 Quer pela dimensão de permanência e funcionalidade, quer pela de desenvolvimento de aspectos previamente entrevistos (o projecto de implantação da LXCN, nomeadamente de sinalética experimental).

129 Composta por Mário Caeiro, designer cordenador, Dora Batalim, técnica de animação pedagógica, João Carlos Fernandes, designer de comunicação, Samuel Roda Fernandes e Luís Pena, arquitectos, Mário Lampreia, designer industrial, Carlos Céu e Silva, psicólogo, Emanuel Brás, fotógrafo, autor do sub-projecto de fotografia de paisagem e Rita Pombo, estudante e informante local. Com a colaboração de responsáveis e docentes da ESDD e membros do executivo da JFM, para além da de outros informantes anónimos e episódicos.

130 Pedro Brandão que entendia ser possível e desejável a LXCN deixar outro tipo de marcas que não as das efémeras intervenções artísticas de 2001.

131 Da Câmara Municipal de Lisboa, chegaram gestos simbólicos e circunstanciais, mas não o interesse em desenvolver o mesmo projecto para várias freguesias lo que na altura chamávamos um arco de Marvila ao Restelo, passando por Campolide ou Lumiar).

132 Caeiro, Mário; entrevista a Jornal dos Espaços Verdes, 2003. 
Na sequência da Cidade Habitada (2001-2002), tirou-se partido do envolvimento prévio de vários agentes da vida social do lugar para intervir com impacto e efeito de exemplo numa problemática delimitada: o espaço público enquanto espaço do estar, do passear e do conviver. A escolha do campo da sinalética prende-se com a necessidade de, dentro de um budget relativamente reduzido, potenciar aspectos de comunicação e da paisagem como totalidade; nesse sentido, um sinal na paisagem é também a própria paisagem lo que decorre de uma sensibilidade compósita, entre a Land Art e o design gráfico). A equipa de intervenção teve então por prioridade os campos da sinalética, do mobiliário urbano e das micro-intervenções arquitectónicas, tendo em conta a opinião da população (estudantes, transeuntes, moradores) em várias fases de um processo participativo e marcado pela interacção convivial. Foram fases importantes do projecto um conjunto de sucessivos inquéritos feitos à população ou a produção de protótipos inovadores instalados no espaço urbano, assim como os sucessivos protocolos estabelecidos entre o CPD, a E]m[ e as organizações que forem aderindo à ideia. 0 projecto desenvolveu-se segundo um cronograma preciso, em que se intercalaram momentos de auscultação da população local - através de eventos com carácter lúdico ou de divulgação, apoiados por fazedores de opinião locais - e fases de projecto técnico, em que prevaleceu o trabalho pluridisciplinar da equipa, sempre veiculado por um discurso quotidiano de inclusão.

\subsection{Processo: áreas, componentes e fases}

Foram cinco as áreas-chave identificadas no âmbito do projecto Sinais, a Cidade Habitada ${ }^{133}$ : arquitectura, desenho urbano, design industrial, design gráfico e engenharia. Um entendimento integrado e situado das suas questões ${ }^{134}$ conduziu a princípios projectuais de mobilidade e acessibilidade, cujos termos-chave foram: Informação, Mobiliário urbano, Sinalética e Ambiente, justificados no dossier de projecto:

Informação A informação urbana é um factor essencial para o desenvolvimento do cidadão consciente e activo. É igualmente fundamental ao nível dos mecanismos de participação democrática na vida da cidade. [...]

Mobiliário urbano 0 mobiliário urbano constitui um factor extremamente importante da experiência do passeante, podendo revelar-se sob múltiplas formas. Uma listagem do que se entende por mobiliário urbano inclui todo o tipo de acessórios arquitectónicos que se podem encontrar em parques, praças ou ruas, desde luminárias até latas do lixo, passando por bancos, jardins ou sinalética. Trata-se de uma área da intervenção urbana que integra ainda a arte pública - nomeadamente esculturas -, fontes, paragens de autocarro ou finalmente os suportes publicitários. E que ainda passa pela iluminação pública e ambiental. O mobiliário urbano, quando correctamente desenhado e bem integrado no território, transforma positivamente o espaço público, usualmente desiquilibrado e disfuncional.

Sinalética Um sistema de sinalética apropriado contribui decisivamente para a identidade de um lugar, assim como para a sua legibilidade por parte dos seus habitantes ou visitantes. Enquanto sistema disponivel que não apenas auxilia a orientação, mas também convida à integração das várias comunidades e indivíduos que compõem um quadro social [através de símbolos, cores e formas atractivos], a sinalética pode constituir um factor de qualidade de vida, fundamental na renovação de toda uma imagem visual.

Ambiente Apesar de se tratar de um tema «gasto» pela opinião pública, nunca a questão do ambiente foi tão pre-

133 Cf. Vv. Aa., O Chão da Cidade, Centro Português de Design, Lisboa 2003.

134 Na preparação do projecto, e pela sua influência na percepção do Espaço Público, foram estudados os seguintes aspectos da experiência do território: Estrutura urbana (grelha de ruas e espaços); Grão urbano (padrão dos quarteirões, lotes e edifícios); Paisagem (forma, contorno, ecologia e características naturais); Densidade e diversidade (desenvolvimento e diversidade de usos); Escala (altura e volumetria); Fisionomia (detalhes e materiais); Identidade (grau de relacionamento com o espaço); Localização (relação com envolvente). Este estudo tirou naturalmente partido da experiência da produção e recepção das várias intervenções da LXCN. 
mente. Por outro lado, é uma temática a que os jovens [em idade escolar] estão particularmente sensíveis, sendo possivel envolvê-los em acções e campanhas que tirem proveito das principais estratégias ambientais para o desenho de soluções de desenho urbano eticamente fundamentadas.

Estes princípios traduziram-se num conjunto de objectivos, publicitados enquanto tal:

- Conceber um sistema de sinalética para Marvila;

- Promover Desenho Urbano participativo;

- Contribuir para a valorização da identidade local.

Ideias-chave: a participação, o processo, o desenho colectivo, no quadro de um dispositivo que opusesse ao tom filosófico e experimental do Nada e inequívoca requalificação visual dos Bairros. A sinalética, pelo preço relativamente baixo e a possibilidade de marcar a identidade dos lugares, foi a área de intervenção considerada ideal para o timing e o orçamento disponíveis, enquanto projecto integrado de renovação da imagem urbana da Freguesia de Marvila. Sinais, a Cidade Habitada tornar-se-ia um projecto pioneiro na área do Desenho Urbano participativo, ao envolver um segmento significativo da população de um bairro lisboeta na criação, produção e instalação de novos elementos no espaço público capazes de contribuir para uma melhoria evidente da vida urbana da comunidade envolvida. 0 projecto apresentou-se como um modelo. ${ }^{135}$

Em entrevista imediatamente após a implementação do projecto, tive a oportunidade de afirmar, questionado sobre as fases do projecto: No fundo, a auscultação das pessoas, a recoIha das opiniões, vai acontecendo em todas as fases e não num período determinado; isso é que enriquece o desenho e em última análise o legitima, mais do que qualquer forma estabelecida de "voto». ${ }^{136}$ De qualquer forma, o projecto foi entendido como sucessão de encontros ${ }^{137}$ e só depois como sistema grafo-visual em suportes físicos reais, integrando-se esse projecto numa intervenção global ao nível da imagem de comunicação da própria Freguesia de Marvila (símbolo, logotipo, cores, aplicações).

Quanto ao conceito e objectivos específicos do sistema projectado:

O conceito-base é tripartido e pretende ir de encontro a várias problemáticas-chave: identidade, conforto visual, sustentabilidade.

A identidade assenta, por exemplo, na criação de uma imagem global e respectiva gama de cores apropriada e baseada na realidade local, assim como na colocação criteriosa das peças em relação às vivências quotidianas, formando uma

135 Alguns exemplos de como o trabalho se desenrolou: os alunos de Design estudaram formas, cores e suportes para os sinais, os de História estudaram aspectos de toponímia, os de Sociologia e Geografia ajudaram a preencher e reunir questionários. Finalmente, os estudantes, mesmo a título individual, responderam a perguntas que lhes foram feitas durante os intervalos. Momentos particularmente conseguidos decorreram junto de um grande mapa de Marvila instalado na sala de convívio da Esc. Sec. D. Dinis, onde os jovens, coordenados pela Prof. de Geografia, eram chamados a intervir através de formas de catalogação e análise espacial, num retrato espontâneo da realidade urbana. 0 modelo da intervenção seria explicitado num publicação que apresentou todas as componentes do Projecto e o seu faseamento: 3 Projectos Experimentais, Centro Português de Design, Lisboa, 2003.

136 Na mesma entrevista: O faseamento de um projecto participativo em Espaço Público é ilusório ou até falso. O Design acontece em movimentos de avanços e recuos em que se questiona muitas vezes o próprio processo em curso. Mas é possível entender-se por fases momentos com características diversas, interligados num sequência: 1) um momento de análise e reflexão prévia [estudos, recolha de dados e reivindicações, inquéritos, envolvimento da equipa e dos corpos autárquicos; 2) uma fase de desenvolvimento de ideias, definindo prioridades, âmbito e escala do projecto, parceiros prioritários; 3) um culminar do processo que passa pelo desenho técnico, as opções finais, a instalação.

1370 mais emblemático foi um pedipaper que reuniu mais de 200 jovens e seus acompanhantes adultos. Participaram alunos de três escolas de Marvila, organizados em grupos de cinco, cada qual com um nome de «competição» e acompanhado por um monitor, oriundo das turmas de Ed. Física: Escola Básica 2+3 de Marvila (9.9 ano), Esc. Sec. D. Dinis (10.? ano), Colégio Valssassina (11. - ano). Participaram ainda estudantes do ensino especial (Casa de S. Vicente) e elementos da Direcção do Centro de Arqueologia de Almada. Note-se, nesta acção, como se adapta a novo quadro o mesmo espírito que havia animado o Cordão Humano na LXCN. 
malha lógica para os transeuntes, sobretudo pedonais; o conforto visual tenderá a contribuir para uma vivência positiva da rua, da praça, e afinal para a afirmação de um verdadeiro Espaço Público, talvez pela via mais simples, o mero facto de que o que dantes não estava assinalado passar a estar, e numa escala que «habita» o espaço urbano...; a sustentabilidade é essencialmente ao nível da gestão quotidiana do sistema, donde as opções por materiais simples, desenho minimal. No todo, a informação disponibilizada deve convidar a uma apropriação imediata, sentida como participada.

De notar que as opções finais nas 44 peças instaladas - o verde-seco com inertes à vista da estrutura, os tons e configuração do logotipo, resultaram de demorada consulta a habitantes e seus representantes, com ponto alto numa reunião mantida na Junta de Freguesia em que estiveram duas dezenas de instituições (polícia, escolas, associações de moradores). No essencial, foi produzida uma única peça-base de geometria simplificada, a partir da qual se desenvolveu uma gramática básica. ${ }^{138}$ Quanto às soluções técnicas, os principais materiais utilizados foram o betão e o metal (alumínio). Notoriamente inovadora foi a estrutura em betão, escolhido pela sua durabilidade, economia, facilidade de produção e valor estético possibilitado pelas inúmeras variantes de acabamentos disponíveis ${ }^{139}$. No final do projecto, o modelo surgia válido para outras oportunidades:

[...] é preciso complementar outros processos de investimento na qualidade de vida urbana que, apesar de válidos em muitíssimos aspectos, são expressão de uma globalização que não atende ao carácter de sítios e seus habitantes. Este tipo de projectos pode portanto gerar aquela preservação cultural e identitária que as soluções de sinalética e mobiliário «pré-fabricado», se bem que optimizadas a outros níveis, é certamente incapaz de oferecer. E há mercado para esta riqueza formal, política e processual.

\subsubsection{Emanuel Brás - Os 'Lugares-paisagem'}

Na produção dos Sinais, houve um projecto que se imiscuiu, acabando por lhe dar um interesse acrescentado: 'Do lugar à paisagem' foi uma intervenção de fotografia e arte contemporânea, utilizou várias as placas de sinalética para apresentar fotografias de grande formato de Marvila, colocadas nos sítios onde haviam sido feitas as tomadas de vista. Esta acção dentro da acção pretendeu levar as pessoas a reflectir sobre o seu espaço envolvente, e certamente a valorizá-lo como experiência consciente. Nas palavras de Emanuel Brás, o artista:

Procurar as fotografias pode ser um jogo de olhar esta zona de Lisboa, sem regras definidas. Não há percursos melhores que outros, o que importa é encontrar as fotografias; passear por Marvila como se fosse a primeira vez, olhar a realidade envolvente, estar no lugar. Nas sinaléticas, esta inovadora abordagem político-filosófica da paisagem enquanto lugar mental e de valor, encontra-se representada pelo pictograma azul «Lugar-paisagem».

Portanto, também nos Sinais se abriu espaço para activismo artístico intersticial, no caso como convite à deriva: passear por Marvila como se fosse a primeira vez, olhar a realidade envolvente, estar no lugar. Nas sinaléticas, esta abordagem político-filosófica da paisagem

138 A peça apresenta-se como estrutura em betão armado, à qual se adossam placas metálicas cobertas por películas adesivas. $O$ desenho resulta de uma síntese formal, material e metodológica, ressaltando o facto de o mesmo molde industrial poder dar origem a duas configurações com funções distintas, graças a uma solução técnica elementar: o enchimento total do molde dá origem a um pórtico; o enchimento seccionado na vertical dá origem a dois totens (ou «meiospórticos»). Estes elementos poderiam ou não vir a ser complementados por uma peça de carácter celebratório e não informativo, estrategicamente colocada no «coração» da Freguesia, com a função de marco urbano. Para além da sinalética propriamente dita, e dos estudos colectivos que a ela conduziram, o projecto incluiu ainda um estudo para ciclovia (traçado e percurso-piloto), produção de mapas da Freguesia e, aspecto fundamental que se revelaria muito importante, a produção de novo logótipo e imagem da Freguesia (que se mantém até à data deste texto, sendo muito visível no autocarro da Junta).

139 Inertes diversos à vista, lavagens e impressão de texturas, aplicação de colorações e/ou vernizes. 
enquanto lugar mental e de valor, encontra-se representada pelo pictograma azul «Lugar-paisagem», confirmando um cuidado que desejavelmente decorre da primazia da experiência sobre a representação. Até hoje, a cidade de Lisboa mantém portanto um projecto permanente de elevado rigor conceptual que persiste em fornecer uma informação urbana crítica. ${ }^{140}$ Na prática, o que determinou a viabilidade da acção foi a generosidade de Emanuel Brás, uma sua posição de controlo do dispositivo muito na linha da de Maçãs de Carvalho e a abertura curatorial para integrar aquele input inesperado.

\section{Cidadania(s)}

Sinais - como a LXCN -, funcionou portanto como processo experimental de articulação entre profissionais, população e seus representantes eleitos, e os sectores cultural/empresarial/industrial. Ao prefigurar fórmulas de enriquecimento imediato de cada um dos elementos da equação, a equipa de projecto colocou em prática processos de desenho colaborativo, tirando partido desta oportunidade para criar soluções potencialmente inovadoras para o Espaço Público; a população participou em eventos e equipas onde pode analisar, criticar e propor formas de estar no espaço público de acordo com as suas necessidades e aspirações, dando um passo decisivo - sua escala e continuidade é outra questão $0^{141}$ imaginando a melhoria da sua própria qualidade de vida; as empresas e a indústria, por outro lado, puderam desenvolver novos produtos ou materiais, pensados de forma a contribuir decisivamente para soluções viáveis numa área de negócio em expansão.

Quanto à ideia de Espaço Público, e depois dos casos de requalificação urbana da Expo 98 (Parque das Nações) ou Porto Capital da Cultura 2001 o projecto demonstrou que o 'bom desenho' do Espaço público, independentemente da escala (valor, financiamento), e em função aquilo a que presta atenção, pode valorizar o património paisagista, arquitectónico urbanístico, e até social, recuperando zonas degradadas através de projectos em larga escala. Sublinhou vivencialmente que o «bom desenho» da cidade integra a consciência da própria cultura urbana, sensibilidade de suporte para uma cidadania criativa. Ora ser-se cidadão completo é participar, ter opinião, ser ouvido. Criar, debater e intervir (o motto da LXCN) no que entendemos como o Espaço Público implica que a cidade seja construída - e habitada - por mais pessoas e mais interessadas, como os Sinais procuraram tornar claro. Baseando-se nas centenas de mapas mentais realizados em Marvila, um poema realizado por Dora Batalim e Céu Carlos Céu e Silva resume a questão:

\footnotetext{
Mais do que um espaço público, a cidade também é:

Um lugar de múltiplos ambientes;

Um lugar de diferenças e desigualdades;

Um lugar de construção e de experimentação;

Um lugar de ruídos mas não só.

[...]

Uma cidade renova-se a cada segundo.

Basta estar atento aos seus SINAIS.
}

140 E que em 2011, às portas da terceira travessia do Tejo, que cairá em Marvila, mantém a maior actualidade.

141 Como a que interpreta as possibilidades do empreendedorismo resultar em inovação. 
Ainda Carlos Céu e Silva, agora num texto com título «A urbe que é do cidadão [UM SINAL: CARTA ABERTA AOS MEUS CAROS CONCIDADÃOS]» ajuda-me a concluir:

[...]

A sinalização que se apreende nas ruas, só serve para obedecer. É muito pouco.

Ela, se quer ser valorizada e respeitada, precisa ser mais atraente e estimulante. E humana. O que é que isso quer dizer? / É preciso ver na sinalização sinais de arte de rua. Arte espontânea mas com significado. Ou sem. Ou com outro conteúdo qualquer. Que se reflicta, já. / E fico por aqui, caros concidadãos, mas ainda preciso acrescentar: - Não é através dos sinais que iremos comunicar com os outros, de forma livre e natural. Com os sinais, comunicamos, por obrigação. E enquanto comunicarmos assim, a vida de caminhante será feita de muitos desastres, desrespeito por regras e muita indiferença pelos mais fracos, quer dizer, pelos peões. [...]

Os Sinais e LXCN constituem então, como espero ter vindo a demonstrar, uma unidade possivel e um continuum deliberado (projectado), como esta reflexão despoletada pelos lugares-paisagem de Emanuel Brás explicita:

[...] Também aqui a arte se aproxima da antropologia. Mas se através deste projecto as fronteiras entre a arte e a antropologia se diluem não é, e repito, porque a arte se interesse a partir dele pelo "«outro» cultural elou étnico", cada vez mais difícil de dizer onde está e quem é, mas ao contrário, porque ao intervir no espaço público e ao fazer participar a população no debate sobre os problemas sociais e urbanos da freguesia, está a activar e a chamar a atenção para os processos de produção social da identidade e da diferença dos quais a própria arte, mas também o design, a arquitectura, a arquitectura paisagista e as ciências, não se podem excluir.

[...] Foi a alguns destes processos de construção social e política da identidade e da diferença que eu tive a oportunidade de assistir recentemente numa reunião de apresentação e discussão de propostas de sinalética da freguesia de Marvila que de alguma forma continuam Lisboa Capital do Nada. [...] A construção do sentido é na verdade essencial para a orientação no espaço e para que este possa ser habitado lo projecto de sinalética apresentado intitulava-se "Sinais, a Cidade Habitada"), e tornou-se numa das principais preocupações dos arquitectos, designers e urbanistas, visto que as aceleradas transformações a que assistimos presentemente esboroam os sentidos existentes. Se a construção de sentido é um elemento essencial para a ocupação e apropriação do espaço, então ele torna-se num dos elementos que nos vincula a um território, sendo uma das pedras de toque do sentido de pertença e de constituição da identidade. Neste processo a toponímia ocupa um papel central. [...] Decorre então o processo de negociação e fixação dos nomes dos lugares para o qual se elaboraram inquéritos. Na reunião a que assisti discutiram-se propostas de sinalética, a produção do emblema da junta de freguesia, e ainda o nome de alguns lugares latravés da resposta a um inquérito que viria a ser amplamente distribuido). Estamos pois perante um processo de negociação de toponímias, grupos de pertença e identidades.

Nesta reunião esteve também presente o fotógrafo Emanuel Brás que se associou ao projecto, e que irá expor fotografias da paisagem de Marvila nos suportes de sinalética pedonal. Se através da sinalética se procurou construir uma unidade coerente e "cosida" de sentido, as fotografias de Emanuel Brás pretendem jogar com o confronto entre a experiência e a representação, abrindo brechas na longa e consolidada tradição da fotografia de paisagem. As fotografias serão expostas, não numa galeria ou num museu, mas no próprio lugar a partir do qual foram tomadas, invertendo, como diz o fotógrafo, o processo de recepção habitual da fotografia de paisagem. Antes de se ver a fotografia é preciso visitar o lugar fotografado. [...] É por se transformar as convenções da fotografia de paisagem que se transforma a experiência do lugar. Aqui, Emanuel Brás pretende transformar em paisagem lugares raramente fotografados e renovar a imagem que deles se tem, pretendendo atribuir-lhes outra dignidade, que é indubitavelmente um dos propósitos de Lisboa Capital do Nada. ${ }^{142}$

A partir daí, e porque a Trilogia estava concluída e o projecto Sinais era na verdade a primeira encomenda (logo não um projecto artístico autónomo em sentido estrito), havia que proceder à activação de nova metáforta operativa, capaz desta vez de conjugar os aspectos mais provocatórios e niilistas da Lisboa Capital do Nada com a dimensão construtiva e funcional dos Sinais.

142 Xavier, Sandra; Do Nada aos Sinais: Arte fora de portas, in http://homelessmonalisa.darq.uc.pt/pagina2.htm, página consultada em Setembro de 2011. Emanuel Brás cita e subverte alguns dos cânones da fotografia de paisagem. Procura, por um lado, vistas panorâmicas, uma relação visual com o rio, espaços verdes, incluindo ainda o parque da Bela Vista, ele próprio organizado de acordo com representações paisagísticas. Por outro lado, faz representar uma relação com o espaço e com a natureza que subverte tais convenções. Bancos com vista sobre rio surgem-nos vazios, como se as pessoas os evitassem. Hortas surgem ao lado de parques urbanos. O espaço circunscrito pelo convencional gradeamento de um jardim público é apropriado por moradores para um jardim privado. 


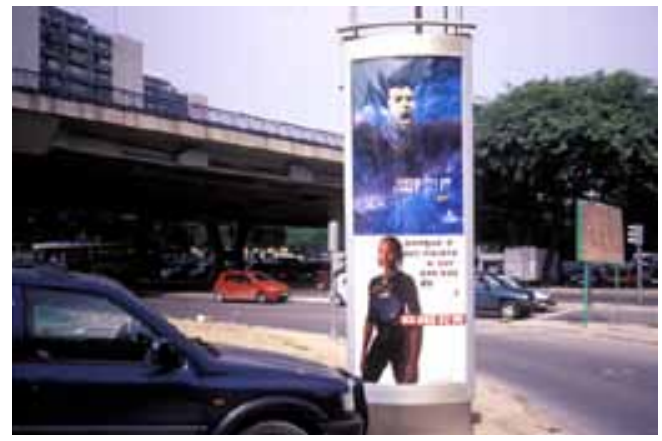

Porque é que existe o ser em vez do nada? Maçãs de Carvalho, Lisboa Capital do Nada, Marvila 2001

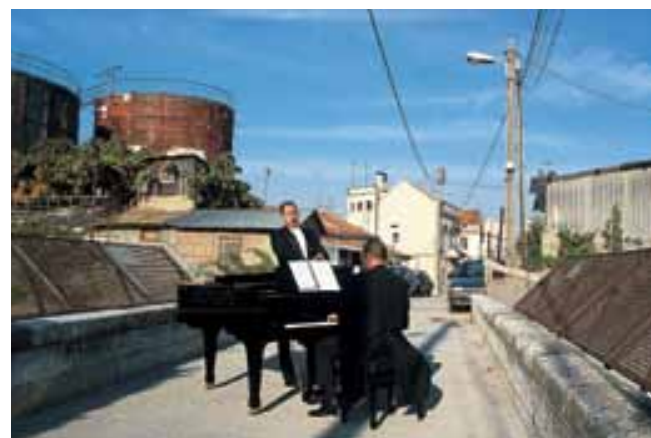

Belcanto, de Catarina Campino Lisboa Capital do Nada, Marvila 20015.

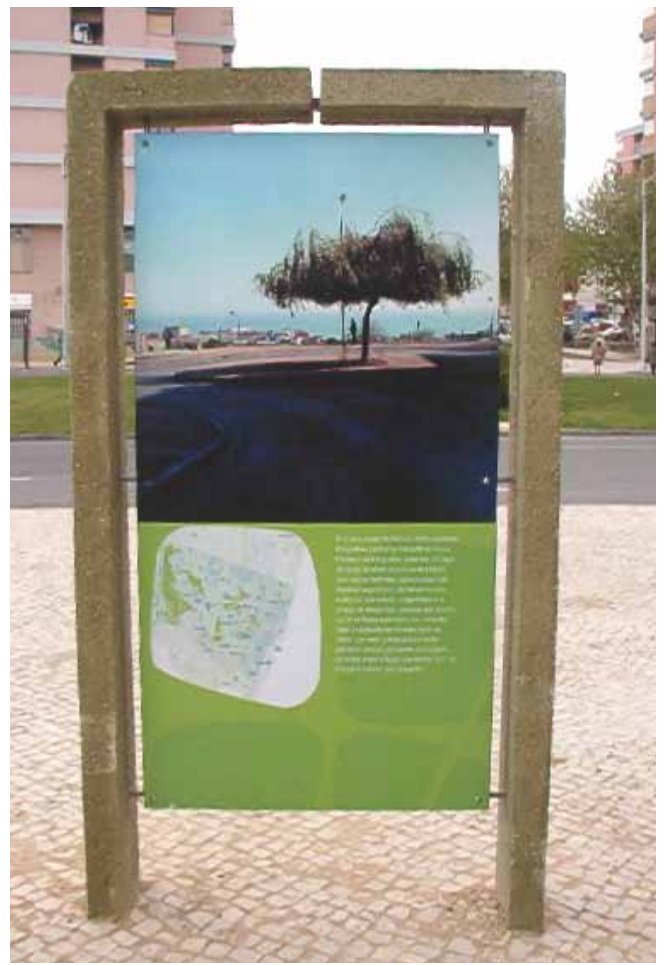

Sinais, a Cidade Habitada, 2003

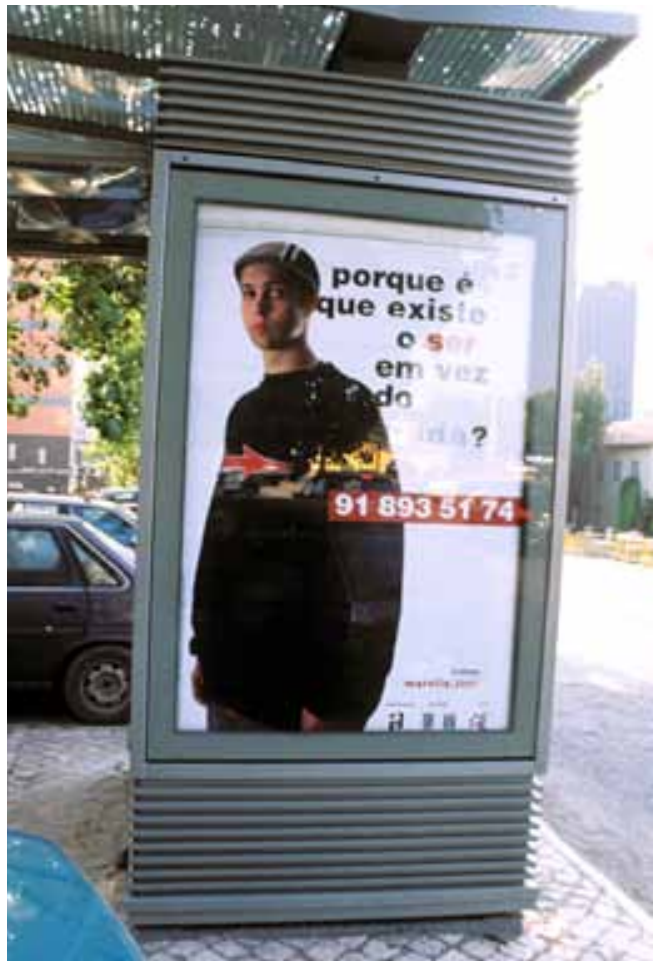

Porque é que existe o ser em vez do nada? Maçãs de Carvalho, Lisboa Capital do Nada, Marvila 2001

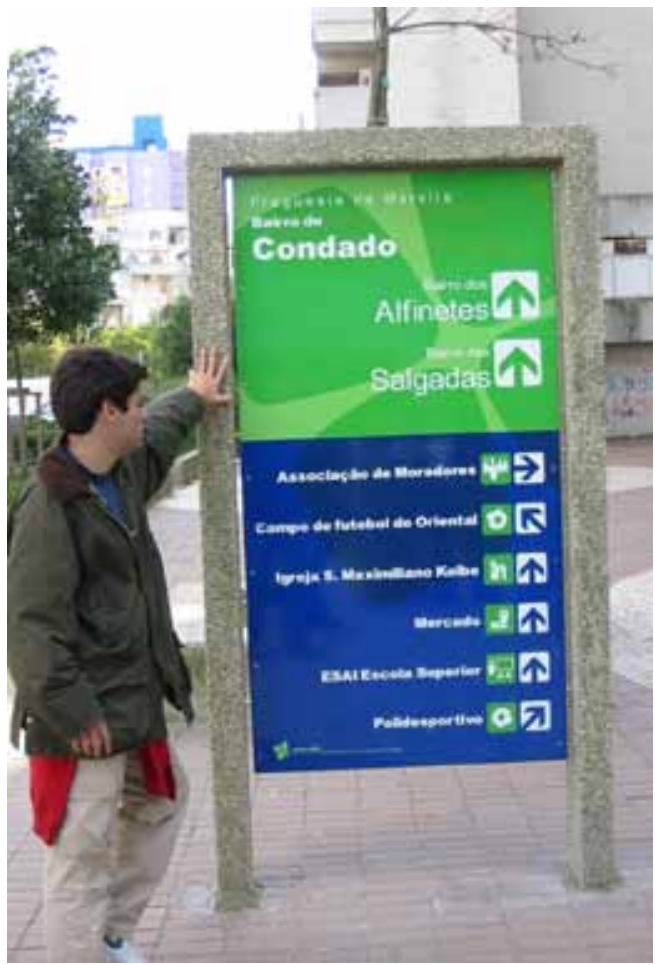

Sinais, a Cidade Habitada, 2003 


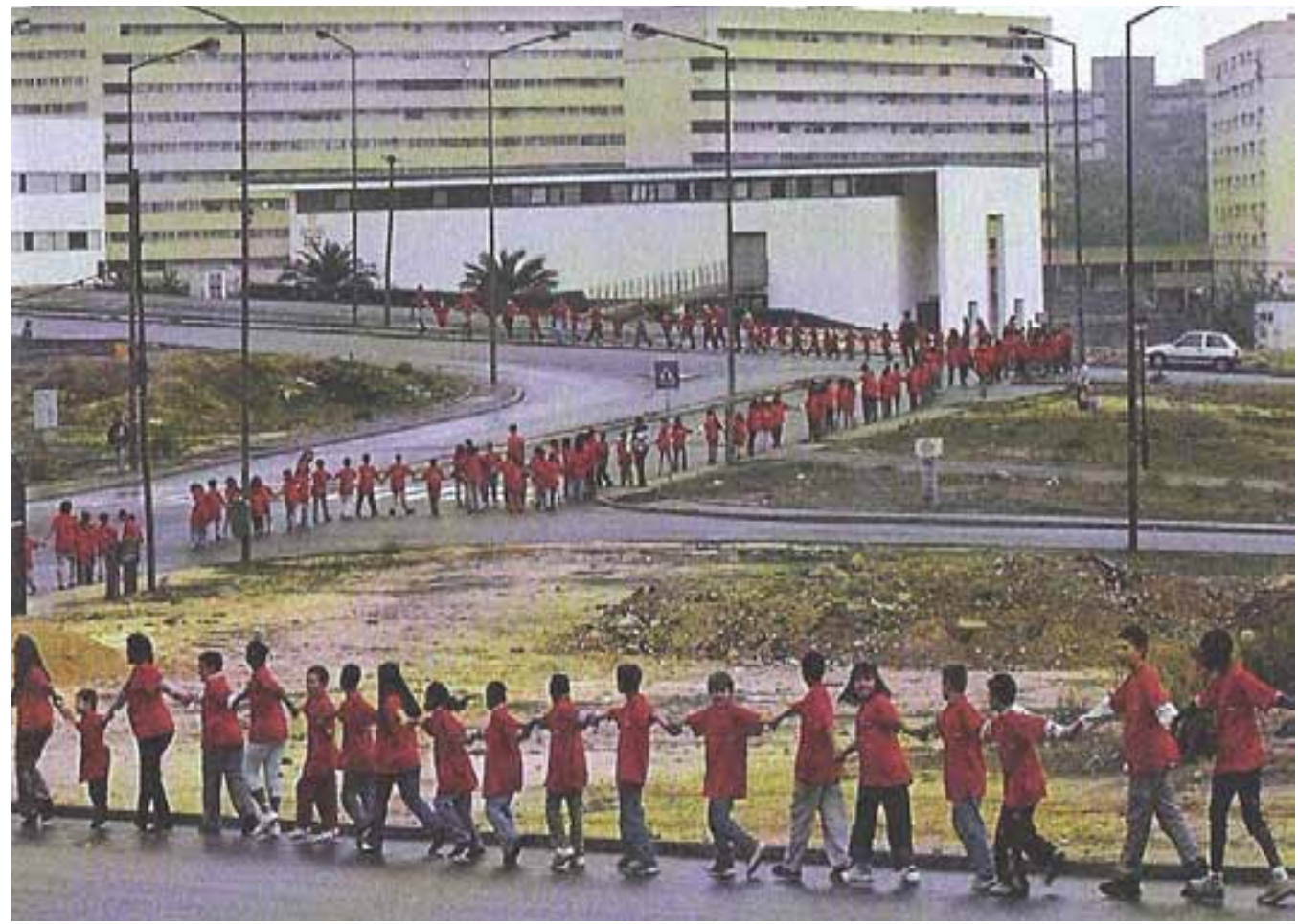

Cordão Humano, Lisboa Capital do Nada - Marvila 2001

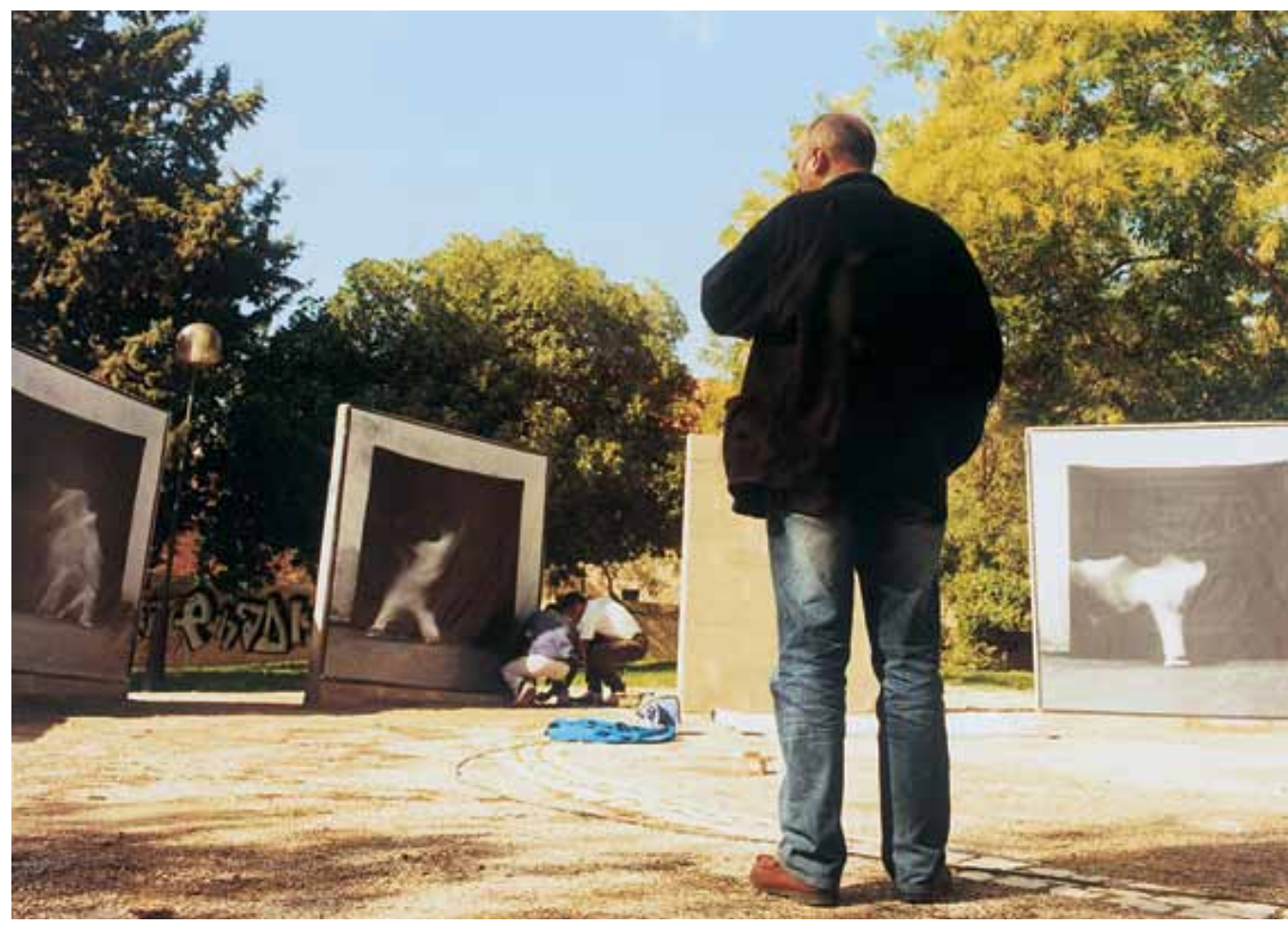

Roda do Tempo, Eurico do Vale, Lisboa Capital do Nada - Marvila 2001 


\section{A ARTE DA LUZ COMO CELEBRAÇÃO DA CIDADE: LUZBOA $2003-2006$}

A ideia para uma 'Luzboa' surgiu de contactos com docentes na área das tecnologias de iluminação e um curador internacional oriundo do campo da Arte Contemporânea. ${ }^{143}$ Projecto cíclico, pensado para perdurar no tempo e enquanto ritualização - domínios opostos à filosofia do Nada (Evento Efémero) ou dos Sinais (Intervenção Permanente) - a Luz-boa baseia-se numa nova metáfora operativa, por natureza transdisciplinar, disponibilizando-se para uma negociação do objecto artístico cada vez mais complexa. Esta 'fuga para o centro' corresponde a uma intenção kúnica de não deixar que o espírito LXCN se tornasse pretexto para a sua própria guetização. ${ }^{144} \mathrm{O}$ nada estava vazio, e assim o deixámos, não era naquele contexto que importava prosseguir o trabalho até porque havia que dar um tempo - previsivelmente anos - para digerir os factos e as consequências. Se o nada lá ficou, cumprindo um função na cidade nada negligenciável ${ }^{145}$, agora contextualizado por placas informativas desenhadas com o contributo da população local, a Luz havia de orientar novos desenvolvimentos de uma arte pública crítica.

\subsection{Introdução: Arte da Luz em Lisboa - conceito}

Os museus actuais não servem. As galerias de arte actuais não servem. As bienais e "documentas" actuais não servem... e os festivais que anunciam a nova era apenas começaram a vislumbrar a imensa tarefa que têm pela frente.

António Cerveira Pinto

Luzboa foi o terceiro evento urbano que tive oportunidade de coordenar, nascendo na sequência de um compromisso institucional entre a Extra]muros[ e a Embaixada de França. ${ }^{146}$ Germinada entre Fevereiro de $2002^{147}$ e Novembro de 2003, o inventio da iniciativa foi a luz na cidade:

Constatámos o evidente parentesco e as correspondências que ligavam a luz à reflexão levada a cabo por alguns artistas contemporâneos, sem mencionar, naturalmente, os urbanistas e os arquitectos. Decidimos então lançar um projecto que em nós já germinava, mas do qual não tínhamos ainda encontrado os contornos exactos. Habituados a eventos ligados à arte pública, tínhamos a intenção de limitar este domínio, extremamente vasto, e concentrarmo-nos num tema mais preciso. A luz surgiu assim, desde logo, como o ângulo que nos faltava. ${ }^{148}$

143 Marc Pottier, Adido Cultural Francês em Portugal entre 2003 e 2006.

144 Recordo-me de um colega designer, também organizador de eventos, me perguntar: Então agora és o designer dos pobres?

145 O terrain vague representa fuga e oportunidade de alternância, distância e contemplação, aspectos críticos em qualquer cidade. O terrain vague tem a capacidade de deslocar o habitante, o poder de desdobrá-lo em si, no outro que contempla, mantendo uma importante função cultural da cidade. Cf. Luís Pedro Sá e Melo, arquitecto, in «Terrain Vague - Notas de Investigação para uma Identidade», 2007.

146 Com Marc Pottier.

147 Nesta altura, já eu havia entregue uma proposta sucinta que passava pela instalação de quatro peças de grande escala em Lisboa, com destaque para uma obra de Charles Stone, o designer que soube traduzir o drama do 11 de Setembro numa das mais emblemáticas peças-de-luz da contemporaneidade.

148 Pottier, Marc; in Luzboa - A arte da Luz em Lisboa, Extra]muros[, Lisboa, p. 130. 
Ambos estávamos de acordo acerca da validade das ferramentas teóricas (conceptualização) e pragmáticas (produção) que o projecto LXCN poderia aportar a uma nova iniciativa, que teria por objectivo engalanar a cidade para o 'grande evento' EURO 2004, num espírito próprio: o aberto quer pelas experiências da Escola de Los Angeles (Dan Flavin, James Turrell, Nancy Holt, Robert Erwin), quer por inovadoras perspectivas recentes (Ron Haselden, Olafur Eliasson), quer por desenvolvimentos nos campos da cenografia urbana (Richi Ferrero).

A ideia da Luzboa já não é tanto a de um acontecimento, como a LXCN, mas de um Evento. A sua tipologia, Bienal da Luz foi um jogo semântico; a ideia de Bienal estimulou muitas situações de colaboração e apoios, permitindo dar uma intensidade inaudita aos primeiros esforços organizacionais. Um ambicioso seminário «Desenhar a Luz», realizado no Instituto Franco-Português em 2003, em que participaram mais de 70 convidados $^{149}$ deu o mote da dinâmica projectual, que haveria de desenvolver plataformas inter-e transdisciplinares enquanto factor de qualificação estética da cidade. Pela coincidência com o EURO 2004 e o ROCK IN RIO, houve assim uma mediatização suplementar ${ }^{150}$ de uma iniciativa que, de outro modo, teria tido menos envolvimento camarário, menos cobertura jornalística, menos parcerias por parte de empresas e certamente menos público e transeuntes ${ }^{151}$.

A Luzboa não teve princípios tão explicitamente críticos ou políticos como a LXCN ou os Sinais, mas havia da parte da equipa de coordenação a consciência de que o percurso desenvolvido pelos eventos anteriores não era necessariamente inarticulável com o de um evento popular no centro da cidade afluente. Importante seria rever a noção de extramuralidade em algumas peças, colocando essa questão tacticamente num novo quadro de valores e oportunidades. $E$ vital encontrar um registo crítico que soubesse superar habituais antagonismos da arte crítica em nome de uma posição colaborativa, sobretudo com quem define os destinos da cidade ao nível do seu quotidiano projectado, da Autarquia à empresas que fornecem os serviços e os equipamentos de iluminação pública. Luzboa, consumada em duas edições sucessivas e com impacto no quotidiano dos transeuntes, pode ser assim considerada uma acção global razoavelmente crítica, se tivermos em conta o que nos informa ou conscientiza acerca da forma urbana do ponto de vista da arte da luz. Tal dimensão concretizou-se aliás na expectativa e depois recepção que o evento criou e teve junto das pessoas, que compreenderam a sua vocação para criar momentos de poesia urbana potencialmente transformativos ${ }^{152}$. De resto,

Sem verdadeiramente se oporem às estratégias políticas em matéria de iluminação pública, alguns artistas contrapõem ao poder de atraç̧ão da luz a sua transformação num revelador visual das complexidades muitas vezes invisíveis da cidade, e até do seu tecido social. [...] A luz, neste caso, induz uma interpretação do sentido dos lugares, em vez de neles incorporar um sentido orientado, decidido por alguns. ${ }^{153}$

149 Entre eles, nomes incontornáveis da produção artística contemporânea e em particular da emergente 'cultura da luz' como Daniel Buren, Aviella Masbourgi, Magdalena Jetelová, Yann Kersalé, Nathalie Junod-Ponsard, Jean-Luc Vilmouth, Jean-Claude Deschamps, Dominique Perrault ou Jan Ejhed.

150 Caeiro, Mário; Luzboa - A Arte da Luz em Lisboa, Extra]muros[, Lisboa, p. 131.

151 Recorde-se que o EURO foi um período em que largos milhares de pessoas se reuniam em locais públicos para celebrar os jogos da selecção nacional de futebol em colectivo, e os espaços da Luzboa não foram excepção, mormente o Infocentro e seu sistema audiovisual. Neste quadro de loucura festiva, era impossível prever como o conceito poderia vir a ter continuidade, sendo a aposta a realização de uma primeira acção o maior e mais impactante possível.

152 Este 'equívoco' não deixaria mesmo de levar a comentarários de que a Luzboa era um projecto comercial, acrítico e que desbaratava um capital político e activista acumulado na LXCN.

153 Marc Latapie, in Luzboa - Lisboa Inventada pela Luz. 
A Luzboa, nestes termos, veio promover uma vertente existencial e comunicacional da arte contemporânea enquanto refundação do papel da Luz na cidade:

As premissas deste projecto partiram de uma reflexão crítica acerca da cidade enquanto entidade orgânica, agregadora de pessoas e serviços, num desejado equilíbrio entre direitos e deveres por uma convivência cívica. A cidade da luz, a cidade que temos versus a cidade que desejamos, a urbe participada. A abordagem do tema suscitou questões tão amplas coo a redifinição das especificidades da espacialidade ou a noção de política na arte contemporânea, em apologia da permanente edificação da cidadania e crítica construtiva da esfera pública. ${ }^{154}$

\subsubsection{Do Conceito ao Evento. Luzboa '04 - tema-contexto da primeira Edição}

De todos os encontros, debates, opiniões e experiências realizados no âmbito da preparação da primeira Bienal Internacional da Luz ${ }^{155}$, foi possível retirar várias conclusões importantes acerca da luz de Lisboa e das prioridades a ter em conta nos projectos de arte pública ou de iluminação pública e ambiental a desenvolver. A Luzboa nunca foi só sobre luz, ou arte, ou cidade, mas a dinâmica da sua interrelação na obra de arte urbana. No fundo, tratava-se de abordar o centro da cidade de forma temática e cíclica, a partir da questão da Luz e do Efémero (Buci-Glucksmann), no cerne do desenho (do) urbano évenenementielle. ${ }^{156}$ Os seus princípios correspondem a um ethos projectual que a visão do urbanista Costa Lobo integra num programa genérico ${ }^{157}$ :

- Luz natural, génio do lugar

- A noite por transfigurar: demais luz

- Poluição luminosa: a morte do céu

- Planeamento e economia

- Melhor noite

- À luz do Património

- Espectáculo da luz: o lazer

Nesta posição teórica emergente em Portugal, Costa Lobo sublinha:

Quanto à questão da Luz natural enquanto génio do lugar ${ }^{158}$ [...] são factores a considerar no momento de gerir a noite, seu ambiente e imagem. Todo este tópico raramente foi explorado pelos criadores de arte urbana em Lisboa e é por assim dizer um 'tema perdido' com enorme potencialidade turística (e portanto de criação de valor), de que as reflexões sistémicas raramente se aproximaram.

A noite por transfigurar: demais luz [...] Lisboa tem, em geral, um «excesso de luz artificial» [Roger Narboni, designer de Luz]. Devido à inexistência de contrastes, não se regista real valorização de espaços e imagens visuais nocturnas, não se experienciam sensações de profundidade, ritmo ou colorido. Muita luz é desperdiçada, incapaz de reforçar eixos visuais, criar momentos diversificados, surpreender. ${ }^{159}$

154 Checa, Natxo; «Cidade lluminada», in Luzboa - A Arte da Luz em Lisboa, p. 200.

155 Desenvolvidos já com o concurso de Teresa Alves, geógrafa, e Samuel Roda Fernandes, arquitecto, e de uma equipa de outros colaboradores.

156 No qual várias cidades europeias têm apostado, de Lyon a Turim, de Paris, a Genebra. Cf. LUCI - Lighting Urban Community International.

157 Costa Lobo, Manuel da; «A Cidade e a Luz», in Luzboa - A Arte da Luz em Lisboa, Extra]muros[, Lisboa, pp. 56-60.

158 Idem. Recordo que a luz natural de Lisboa é peculiar, em especial junto ao rio, onde uma grande reflexão lem grande parte exponenciada pela calçada portuguesa e as superfícies azulejadas) a torna difusa e brilhante. Devido a essa particularidade, e à proeminência de mármores e calcários nos materiais de construção de edifícios e pavimentos, «até as sombras de Lisboa são iluminadas» [Luís Pavão, fotógrafo].

159 Idem. Este problema é dramático, à microescala do desconforto individual lquantas casas são bombardeadas com a luz viária do sódio de baixa pressão, até ao terceiro andar!) e à macroescala de uma desidentificação entre a Luzboa diurna e a Lisboa 
Poluição luminosa: a morte do céu - A fobia do escuro - os «watts políticos» - faz com que seja frequente um excesso de iluminação pública, a ponto de cortar totalmente a ligação visual com o céu. A perda de conhecimentos, referências culturais e afectividade por deixar de ver-se o céu são «consequências irremediáveis para as actuais gerações» [Nuno Crato, divulgador científico]. A sua recuperação é um imperativo global ao qual os gestores da cidade não podem ficar indiferentes.

Um aspecto do Planeamento e economia da noite - A inexistência [ou não-concretização] de um Plano Geral de lluminação e de Planos Parcelares para certas zonas da cidade lou pelo menos a sua inexistência pública, tanto quanto sei), integrando a componente artística, impede a prossecução de uma política capaz de, em simultâneo, rentabilizar os recursos energéticos e gerar uma política para a luz urbana com vantagens sociais, económicas e culturais imediatas. [...] A criação de momentos urbanos através da Luz propicia descobertas, fluxos e vivências, vida social.

À luz do Património. Certo é que alguns monumentos estão excessivamente iluminados [Basílica da Estrela, Panteão Nacional, Palácio da Ajuda, entre outros], durante demasiadas horas; outros desaparecem durante a noite, perdendo o seu carácter diurno. A leitura pública do Património e dos marcos urbanos exige todo o rigor, para que o mesmo se torne motivo de orgulho e identidade para todos. A própria noção de património, devidamente actualizada e encarada à luz das tecnologias disponíveis, merece olhares renovados. A questão do Património, material e imaterial, é fulcral no entendimento do acontecer da cidade, em sede de eventos culturais. ${ }^{160}$

O desejo de ritualização da Luzboa passou pela apropriação crítica da cidade como valor patrimonial (nomeadamente arquitectónico-urbanístico), na direç̧ão de uma progressiva requalificação urbana e ambiental da capital através de projectos-luz, no quadro de um urbanismo-luz com interesse em integrar experiências luminosas oriundas da arte.

A Luz de Luzboa leva a questão da transdisciplinariedade não apenas para a totalidade dos mecanismos de realização dos artefactos da arte, ${ }^{161}$ mas, para um encontro entre a dimensão espacial (legado do minimalismo e das neovanguardas, em particular a cultura da instalação), a dimensão discursiva (poética, filosófica, metalinguística ${ }^{162}$ ) e a provocação - que arrisca outros públicos, bem mais latos que os de Marvila. Se a Luzboa atinge - e cria - um público cultural, fá-lo porém não enquanto manifestação da indústria cultural, mas como proposta crítica da mesma (em sede do pathos da Luz). Algumas notas conceptuais-teóricas, de forte pendor meta-utópico, confirmam-no, recolhidas na espuma dos debates, encontros e textos realizados.

Graças à iluminação, estamos hoje, talvez, a sonhar em levar o dia para a noite; e somos por vezes injustos para com a noite, ${ }^{163}$ [...] Graças à Luzboa e pelo nosso pensamento, podemos atingir o invisível. Eu penso que esta manifestação, de uma forma ou de outra pode atingir o invisivel. [...] É um problema universal e do mundo do amanhã. Quanto mais iluminamos o Mundo, mais o tornamos escuro. Vai ser necessário encontrar uma forma de equilíbrio entre estes dois dados: entre a obscuridade e a luz/iluminação, entre as sombras e os objectos e entre os próprios objectos, porque este snecessitam das sombras, não podendo existir apenas numa forma de iluminação absoluta. Desse modo são negados na sua existência tridimensional, corporal. [...] Experimentemos ser a luz, com as pequenas possibilidades que possuímos. A luz da memoria, a luz da transcendência do outro, a luz que projectamos sobre o Outro ${ }^{164}$.

Noutra posição, Malcolm Miles, em «Um tempo de desassossego», fala de uma ansiedade especificamente luminosa no projecto crítico (que o autor retira do trabalho de Krzystof Wodicko ${ }^{165}$ ). Ela norteia uma reflexão imbrincada que passa por questões fundamentais como

nocturna, patente no desaparecimento de marcos urbanos, monumentos, paisagens, atmosferas.

160 Idem.

161 Entendimento equívoco do 'transdisciplinar' na documentação oficial do Ministério da Cultura.

162 Neste aspecto, Cf. o debate entre a Clara Pracana, Henrique Pinto e Pedro Teixeira, com moderação de Ana Cristina Ferrão, pp. 41-49.

163 Bavcar, Evgen; «A Luz Invisível», in A Arte da Luz em Lisboa, Extra]muros[, Lisboa, p. 36.

164 Idem, p. 38.

165 Malcolm Miles («Um tempo de desassossego», pp. 41-49). Miles refere-se em particular à intervenção em Trafalgar Square, Londres, em 1985, em que o artista de origem polaca projectou a imagem de um míssil cruzeiro sobre a coluna 
a relação entre a luz e o planeamento urbano iluminista (o contexto da Baixa Pombalina), assim como entre a luz e os modelos do artista na Modernidade (de Baudelaire a Pessoa), à luz de uma actualização da teoria crítica, de Simmel a Benjamin, de Arendt a Adorno e Lefèbvre (Teoria dos Momentos). Entre a concisão aforística de Bavcar e o intrincado ensaísmo transdisciplinar de Miles, sublinho a ambiguidade operativa no cerne do projecto-luz, na abertura de um contexto cultural para o trabalho da luz na forma urbana e portanto também de uma arte pública contemporânea que parte da Luz como fundamental matéria retórica.

\title{
O 'Projecto-Luz': revelar Lisboa, a dimensão global do projecto Luzboa
}

O projecto-luz ${ }^{166}$ encara a luz como factor de projecto, tornada vector de desenvolvimento, desígnio, numa cultura de projecto própria, que transvasa domínios estabelecidos do design, da arquitectura, do urbanismo, do espectáculo, da encenação de ambientes.

\begin{abstract}
Projectos-luz serão então todos esses projectos em que factor Luz - a ideia, o conceito, a tecnologia, a estética, a expressão, as expectativas inerentes -, tudo o que na verdade se associa à palavra em si - se torna o ponto-chave da recepção por parte do público - o já referido pathos da Luz. Neles a metaforização obriga-se a passar por uma materialidade da forma urbana - é de facto um ir além da metáfora.

O Projecto-luz parte de uma reflexão sobre o fenómeno em si e enquanto tema filosófico-cultural, como acontece com a demanda de artistas-farol como James Turrell. Pode levar os fenómenos da Luz e da percepção a terem um papel estruturante e excepcional no seio de acções com polos de interesse mais diversificados - como acontece nos melhores projectos de cenografia, arquitectura ou instalação vídeo. Em muito diversas situações, nomeadamente de Arte Pública, a Luz, sendo encarada de forma relativamente autonomizada, abre-se como fenómeno de criação, investigação e estudo, implicando uma retórica e porque não também uma estética particulares.
\end{abstract}

Assim, o projecto-luz seria a ferramenta para ir ao encontro das questões de planeamento urbano que Manuel da Costa Lobo elenca:

- Admita-se a diferenciação e a hierarquia das intensidades, em termos funcionais e da importância dos símbolos a iluminar;

- Introduza-se o tema 'luz' no planeamento geral urbano e na definição da imagem das cidades;

- Procure-se ligar os custos da iluminação à contribuição dos privados, obtendo comparticipações para soluções sóbrias mas devidamente assinaladas;

- Encare-se a iluminação como elemento susceptível de recriar imagens e de valorizar as panorâmicas e os recantos da cidade, com seus valores e dinâmicas próprias;

- Procure-se o ritmo próprio para a alteração das soluções de iluminação através do tempo e para sublinhar acontecimentos;

- Tenha-se em vista a personalização e identidade dos lugares, evitando introduzir elementos publicitários insólitos que reduzam o valor cultural das panorâmicas das cidades». ${ }^{167}$

Ao mesmo tempo que sugeriram ideias-chave para a lluminação de Lisboa, uma manifestação de Lisboa, os projectos-luz da Luzboa ofereceram a moradores e turistas a noite transfigurada pela arte pública, na heterotopia das mais diversas linguagens plásticas. A liberdade foi porém enquadrada pela ética que o jogo de palavras pressupõe. Para além da relação umbilical com

de Nelson. Mas se logo aí um evento militar foi arrancado à sua normalização como marco urbano turístico (Miles), crucial é a atitude táctica, projectando de forma ilegal, durante escassos vinte minutos (até as autoridades aparecerem), uma suástica sobre a adjacente South África House. Nota Miles: Foram distribuídos postais e as pessoas que não estiveram presentes diriam mais tarde que «quando olham para o frontão, é como se estivesse lá a suástica, como se se tratasse de uma espécie de pós-imagem retiniana».

166 Pottier, Marc; Caeiro, Mário; Alves, Teresa; Fernandes, Samuel Roda; «Projectar a Luz», in Luzboa - A Arte da Luz em Lisboa, p. 52.

167 Documento fornecido ao autor. 
'Lisboa', o projecto teria de constituir-se factor positivo, valorizante e clarificador ${ }^{168}$ da cidade.

Espectacular ou ambiental, a luz pode no entanto tornar-se factor de poluição visual na cidade contemporânea. Não apenas para os artistas, mas sobretudo para urbanistas, arquitectos, designers, técnicos e políticos nunca como hoje foi tão importante dominar a sua linguagem: dos planos de iluminação ao desenho da luminária, nas vertentes simbólica e psicológica, enquanto sinal no espaço urbano ou finalmente pedra-de-toque no domínio do privado, a luz é elemento-chave numa polis de qualidade. ${ }^{169}$

\section{Objectivos, programa}

Sintetizo as linhas gerais do programa da Luzboa '04, de acordo com as suas componentes: Projectos de expressão urbana, Projectos na rede institucional ou de equipamentos culturais, Formação e Acções culturais de cidadania. ${ }^{170}$ Tal categorização mostra como o projecto era de totalidade - a dinamização de espaços públicos em horário nocturno aliando-se ao desejo de colaborar com múltiplos agentes da cultura; a criação de massa crítica para futuras iniciativas aspirava a interpretar um sentido de comunidade, no quadro da ânsia, no quadro de uma ideia de cidade mais bela e participativa. Às críticas que vislumbram neste tipo de eventos traços de megalomania, responderia com os termos do historiador José Sarmento de Matos $^{171}$, a propósito de uma vocação luminosa de Lisboa que assim se viu confirmada: Em que momentos da História é uma cidade capaz de ser cidade-luz, emitindo valores e gostos, criando um universo identificado? [...] tal criação de valores estéticos, arquitectónicos, urbanísticos é também uma criação de luz, de um corpo, de uma sensibilidade..$^{172}$

É a partir destas questões que cada obra integrou uma economia simbólica. Algumas revelaram a mais delicada percepção de contextos e oportunidades, por vezes de forma colaborativa (interdisciplinariedade) ou participativa (activismo social), sempre em busca proactiva do contacto intersubjectivo; outras inscreveram-se de forma relativamente neutra na paisagem, sendo apropriadas sobretudo como imagens estéticas - apesar de totais de cor, som atmosfera urbana. Depois, se umas procuraram deliberadamente o lugar comum (dimensão vernacular), outras procuraram o regresso e suspensão poética, no seio de uma civilização ocidental tornada demasiado materialista e consumidora ${ }^{173}$ - mas todas enquanto irrupções de efémeros sentidos no quotidiano, cuja retórica espero deixar minimamente implícita nos breves comentários individualizados que se seguem. É uma retórica, em todo o caso, que passaria sempre pela dimensão de cenografia efémera de cada lugar, conferindo-lhe, por via da Luz, um significado marcante, talvez o sensível da verdade; a sobreposição de aspectos estéticos e comunicacionais tornariam mesmo algumas peças importantes mecanismos de debate público acerca de contextos urbanos relativamente específicos, por vezes partindo de um elemento quotidianamente invisível da forma urbana.

168 Pottier, Marc; «Luz-boa. O jogo de palavras», in Luzboa - A arte da Luz em Lisboa, p. 7.

169 Texto de apresentação e contextualização do Seminário Internacional 'Exercício sobre a Luz / Desenhar a Luz', Instituto Franco-Portugais, Novembro de 2003.

170 Cf. Caeiro, Mário; «Luzboa é uma iniciativa cultural...», in Luzboa - A arte da Luz em Lisboa, p. 130-132.

171 No que seria seguido por alguém como Malek Abbou, como veremos mais à frente.

172 Matos, José Sarmento de; «Queria agradecer aos organizadores...», in Luzboa - A arte da Luz em Lisboa, p. 135.

173 Pottier, Marc; «Fête», in Luzboa - A Arte da Luz em Lisboa, p.164. 


\subsection{Luzboa 2004, uma constelação de eventos - obras comentadas ${ }^{174}$}

Entre Maio e Setembro de 2004, decorreria em Lisboa a Primeira Bienal Internacional de $\mathrm{Luz}^{175}$, com impacto relativamente transversal e popular ${ }^{176}$. Sob o tema 'Entre o céu e a terra assistimos ao espectáculo do Mundo'177 participaram duas dezenas de artistas, que realizaram vários projectos inovadores pela forma como a Luz urbana foi reconsiderada, a partir de valores como a poesia, a imaginação, a qualidade ou a excelência. 0 programa incidiu no domínio da arte contemporânea, mas a Luzboa obteve a atenção de vários públicos através de acções muito diversas, contribuindo para uma imagem integrada do meio urbano. Alguns desses projectos definiram as directrizes do Evento:

- Importância de realizar tanto projectos de grande escala como de pequena escala, de acordo com múltiplas noções e oportunidades espaciais-vivenciais;

- Necessidade de articulação com as instituições que não se resuma às estritamente artísticas [museus, galerias] mas se estenda às de carácter tecnológico e social178;

- Enfoque numa leitura não apenas do tecido cultural estabelecido, mas do próprio Espaço Urbano - esta uma das mais-valias mais francamente evidentes do Projecto.

A programação de '04 distribuiu-se equilibradamente entre instalações urbanas e instalações em espaços culturais de acesso restrito. Integrou as intervenções realizadas durante cerca de um mês em Julho, uma série de obras integradas num circuito de equipamentos culturais, propostas concebidas mas por concretizar ${ }^{179}$, acções de valoração (Prémio Luzboa), acções de comunicação («Luzes, câmara... Martini»), vários ateliês «Desenhar a Luz» (com destaque para «Fazer Céus» - Arcos de Alfama», iniciado ainda em 2003) ${ }^{180}$ e um Percurso Monumental no Aqueduto das Águas Livres (vertente de visitas guiadas), tudo objecto de um Livro-catálogo ${ }^{181}$ editado logo a seguir ao evento.

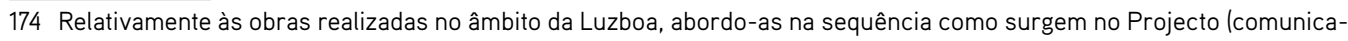
ção social e Livro). Pontualmente, obras menos importantes para a argumentação são reunidas em comentários mais breves, assim 'saindo da ordem'.

175 Iniciativa da Extra]muros[ e do Instituto Franco-Portugais / Embaixada de França, contando posteriormente com a colaboração de entidades públicas e privadas, nomeadamente a parceria estratégica com a Câmara Municipal de Lisboa.

176 Mais de 250000 visitantes e notoriedade pública consubstanciada num significativo dossier media.

177 Verso de Carlos Drummond de Andrade proposto por Teresa Alves.

178 Aspecto desenvolvido mesmo em parcerias posteriores ao encerramento do evento.

179 Cf. A Arte da Luz em Lisboa, pp. 204-209.

180 No quadro da preparação da Bienal e visando o desenvolvimento de massa crítica, esta ampla acção de formação incidiu, com resultados concretos (projectos de iluminação urbana), num aspecto específico da forma urbana de Alfama, o conjunto de arcos ribeirinhos, dos quais se partiu para a idealização de momentos de conforto e magia com um máximo de efeito e custos simbólicos. Assim, o Arco das Portas do Mar, o Arco de Jesus, o Arco e Travessa de S. João da Praça, o Arco do Rosário, o Arco de Nossa Senhora da Conceição e o Arco do Beco Escuro foram objecto de uma abordagem projectual transdisciplinar que, informada por palestras prévias (entre outros, por Laurent Fachard) por parte de vários especialistas, conduziram a uma integrada operação de requalificação urbana, informada pela 'arte e a cultura da luz'. Outros ateliês foram dedicados ao Aqueduto das Águas Livres («Um Percuso Monumental...», com tutoria de Magdalena Jetelová), ao cinema São Jorge («Encenar a Arquitectura», com coordenação de João Garcia Miguel) e à Boca do Vento em Almada (tutória de Yann Kersalé) ou a «lluminar com Emoção», com Peter Gasper, celebrizado pela iluminação da arquitectura de Óscar Niemeyer).

181 Que se sucedeu à obra A Luz e a Paisagem, de Roger Narboni, editada e lançada pela Livros Horizonte em parceria com a Luzboa em Novembro de 2003. 


\subsubsection{Luzes exteriores: os elementos iluminados}

Luzboa \#1 foi a primeira peça projectada para integrar o evento. Da autoria de Sérgio Vicente ${ }^{182}$, nasceu mais uma vez da cumplicidade com o Centro Português de Design. Interessado em realizar um escultura permanente, que o autor imaginaria como uma superfície reflectora de luz, baseada nos processos técnicos da cestaria. ${ }^{183}$ Colocada junto à entrada do CPD, cumpriu uma função ambígua de objecto independente e de comentário visual dinâmico às suas actividades (função de marco urbano). Aspectos importantes da peça foram, por um lado, a noção de uma forma que remete para uma temática partilhada entre CPD e Extra]muros[ (o design, e sua expressão quotidiana e ancestral, a cestaria); por outro, a mais-valia de um gesto tecnológico, ao se aplicar à peça uma dimensão lumínica inovadora latenta à necessidade de traduzir a luz solar para a linguagem da luz artificial. De acordo com o conceito da cestaria, o autor havia proposto a ideia de uma escultura 'a metro', a realizar em função do espaço, das verbas e dos apoios disponíveis. Esta retórica desmonta a habitual equação escala-financiamento da arte pública tradicional ('turd on the plaza'), ao mesmo tempo que celebra a singeleza e a quotidianeidade do design anónimo. Uma vez instalada, a peça, cujas dimensões mínimas foram decididas entre as partes envolvidas, integrou-se no espaço como discreto comentário à arquitectura pós-moderna do edifício-sede do CPD), mais, que como marco urbano. Sendo a peça uma notável solução conceptual, formal e técnica ${ }^{184}$, o desígnio programático de constituir-se como elemento de transfiguração urbana cumpriu-se num âmbito apenas reduzido (dada a sua confinação ao espaço semi-público da zona circundante do Centro); a peça ali permanece porém, até hoje, como discreto testemunho de uma desejável relação arte-projecto-design-cidade.

Emanuel Brás participou na Luzboa em dois momentos ${ }^{185}$. No segundo, apresentou uma monumental fotografia cobrindo a fachada do Arquivo Fotográfico Municipal. A imagem-base, aplicada sem quaisquer dizeres suplementares, foi a de uma folhagem de árvores por entre a qual a luz solar é refractada. Há um certo aspecto tautológico na forma 'fotografia' tal como ali colocada na fachada - Estando a imagem colocada na rua e sendo a fotografia em si mesma fragmento de um fluxo temporal e corte no espaço, o que esta imagem faz é protagonizar a sua própria natureza. ${ }^{186}$-; mas esta imagem é contextualizada por aspectos de montagem subtis la utilização de tela perfurada, aliada à vida habitual do edifício e às contínuas alterações atmosféricas, criou uma imagem 'realista"187. Por outras palavras, a simplicidade do tema aliada à simbiótica da solução de colocação levanta questões que noutro tipo de imagem, mais enfática, passariam para segundo plano. Isto é, trata-se ainda, basicamente, de um outdoor, mas o seu carácter de paisagem é imediatamente sentido

182 Escultor, com várias experiências de arte pública permanente e que havia sido meu colega na Pós-Graduação em Design Urbano.

183 Vicente, Sérgio; «Luzboa\#1», in Luzboa - A Arte da Luz em Lisboa, p. 138.

184 O painel reflectindo um número aparentemente infinito de combinações luminosas, que se vão repetindo ciclicamente (Vicente, Sérgio; «Luzboa\#1», in Luzboa - A Arte da Luz em Lisboa, p. 138.), foi De acordo com a OSRAM, a primeira instalação de LED dinâmicos num espaço público em Portugal.

185 Exposição Ralo, em Novembro de 2003 e depois intervenção na fachada, no Verão de 2004.

186 Dias, Luísa Costa; in Luzboa - A Arte da Luz em Lisboa, Extra]muros[, Lisboa, p. 144.

187 Idem. 
como pausa na malha urbana ${ }^{188}$. A imagem, cuja escala e relação com o edifício sugerem algum tipo de funcionalidade (tapume), acaba por rejeitar qualquer tentação de protagonismo (por exemplo autoral, ou relacionado com as mensagens com que somos bombardeados no quotidiano):

Ao contrário do visitante habitual do Arquivo, aqui o observador é um transeunte (em trânsito), duplicando na sua mobilidade o fluxo das imagens que povoam o quotidiano. A imagem, para ser vista, não implica nenhuma decisão, impõe-se ao olhar de quem passa. A fachada funciona, então como um ecrã de cinema, em que não é a película que se desloca, mas o espectador. ${ }^{189}$

O artista, tendo recorrido à imagem ${ }^{190}$ - um tema quase 'tabu' na lógica projectual da Luzboa -, esquiva-se ao repto retiniano da publicidade-espectáculo, apesar de utilizar a mesma matéria prima.

Como que tornando os lugares a experiência imersiva de uma imagem total, a intervenção Bellas Sombras, de Frédérique de Gravelaine e Virginie Nicolas consistiu na transfiguração pela luz de toda a ambiência de quatro miradouros em Lisboa ${ }^{191}$, em contacto visual uns com os outros, o que, de acordo com a proposta de localização pela equipa da Luzboa, potenciou os aspectos mais íntimos da obra com uma dimensão comunicacional (do Evento na paisagem nocturna). A dupla criativa (escritora + designer de luz) fez de cada espaço um ambiente-luz - pintando o real de luz e cor como se a cidade fosse uma tela tridimensional e animada pelo som. A experiência resultante foi em grande medida a-discursiva; o prazer físico do 'estar ali' era mais forte que quaisquer impulsos de explicação ${ }^{192}$.

Bellas Sombras: Árvores vestidas de luz criam sombras coloridas, murmuram poemas, em lugares escolhidos pela força da sua alma e sua visibilidade na cidade. Durante o dia protectoras contra o calor do sol, de noite devolvem a anergia armazenada. De dia como de noite, oferecem um momento de meditação e incitação poética. ${ }^{193}$

E assim, na Graça, «Les pins rêvent la mer» mergulhavam o público numa intensa luz azulada, apenas pontuada por laivos de rosa, que conferia à traça da Igreja uma extraordinária desmaterialização da sua imagem habitual de monumento; no Torel, «Musical», a música de Vianna da Mota habitava um mundo feito de recantos em diversas cores, todas como que criando espaços dentro do espaço, de acordo com os elementos arquitectónicos, nobres (fonte) ou menos nobres (chafariz); «Fa-do,» em São Pedro de Alcântara era gesto impressionista, criando um jogo de contrastes e sombras, de destaques (os bustos em pedra) e enquadramentos (as áreas abertas) particularmente agradável (pela fusão de tonalidades de rosa-vermelho e azul-verde, acentuadamente distintos do tecido amarelado da restante cidade); «Le Tenebreux» na Senhora do Monte era mais perturbantemente soturno, prevalecendo os vermelhos e os azuis escuros numa penumbra misteriosa. Um segundo ponto a destacar nesta obra, dando ao seu carácter sistémico e programático uma dimensão táctica de grande sensibilidade ao momento, prende-se com um detalhe da atitude artística

188 Idem.

189 Idem.

1900 mesmo acontecerá com Abílio Leitão, Jean Luc Vilmouth ou Virgínia Fróis (todos estes em situações indoor), Luís Campos, ou Gerald Petit e Het Pakt já na Luzboa 2006.

191 S. Pedro de Alcântara, Senhora do Monte, Graça e Torel.

192 Tal totalidade da fusão entre espectador e obra voltaria a estar presente com tal intensidade apenas na Bienal seguinte, com os Het Pakt.

193 Gravelaine, Frédérique; Nicolas, Virginie; «Bellas Sombras», Luzboa - A Arte da Luz em Lisboa, p.150. 
face à riqueza da cultura urbana em que se integra. Perante a notícia da morte de Sophia de Mello Breyner - que morava no Largo da Graça - , na véspera do encerramento do Evento, Gravelaine tem a iniciativa de rapidamente comprar CD com poemas ditos por Sophia e assim substituir a banda sonora original por gravações da voz da Poeta. Esta atitude de atenção ao tempo presente e ao seus significados colectivos - e potencialmente mais profundos - é uma sinal de autonomia relativa que se alimenta precisamente pelas interferências exteriores aos seus desígnios iniciais.

Fête de Ron Haselden consistiu num estrutura de tipo tenda, com as arestas da sua configuração sublinhadas por guirlandas com centenas de pequenas e coloridas lâmpadas incandescentes, pulsando, e animada por um som ambiente (valsas populares). A colocação desta peça, que exigia à partida um espaço verde (relvado) e possivelmente valores naturais como água na proximidade) relacionou-se de novo com um desejo de interferir na imagem urbana; era importante a peça dar a ver o rio (celebrar a relação de Lisboa com o Tejo), e dar fluxo de transeuntes (lazer) que seria o potencial público-alvo (para além dos automobilistas que, à distância, tinham também uma perspectiva muito clara do desenho e da sua dinâmica. Entre possível experiência de imersão, percepção da abstracção do conceito e uma dimensão estritamente visual (decorativa), a peça mantém apesar de tudo um estatuto de objecto relativamente confinado no espaço urbano e na paisagem. Na sua economia formal, o artista dissimula o que são aspectos técnicos complexos (programação electrónica da componente de luz e som) na busca do efeito de ingenuidade; a metáfora do circo - da Festa - com o que implica de valorização do efémero e do irrepetível ${ }^{194}$ vê-se assim perfeita- - e paradoxalmente - materializada naquele aranhiço de luz. ${ }^{195}$

Outra obra emblemática da Luzboa foi Eléctricos, de Yann Kersalé, uma ambiciosa peça móvel que ambicionou vestir de luz os eléctricos lisboetas. Temos aqui uma situação semeIhante à de Ron Haselden, pois Kersalé é outro autor consagrado, com obras emblemáticas em todo o mundo. ${ }^{196}$ Conhecido pela capacidade de articular imagens poéticas com a sua apropriação da forma urbana laqui o circuito de transportes públicos e sua dimensão sinestésica), Kersalé desenvolveu um projecto que alia os icónicos eléctricos a uma vivência experimental quotidiana. Aparte a desilusão de apenas um eléctrico ter sido intervencionado, ${ }^{197}$ o que permaneceu da peça foi uma intensa transfiguração em movimento, a ponto de muitas pessoas estarem convencidas de que havia muitos mais eléctricos em circulação. Dar aos eléctricos uma outra roupagem foi ao mesmo tempo a criação de um momento urbano íntimo (para os viajantes), transpondo os lugares comuns do Natal las luzes utilizadas eram as redes de luz características do período natalício) para o pico do Verão.

194 A peça seria capa do livro-catálogo, precisamente por articular questões candentes do espaço urbano (como decorá-lo efémera, mas dinâmica e identitariamente?) e cumprir a ideia de festa que a arte pública extramuros procurava promover.

195 Como um internauta anónimo chamou à peça, carinhosamente, numa crítica encomiástica.

196 Com destaque para a cobertura da Ópera de Lyon, para/com Jean Nouvel, que se transformou numa das imagens icónicas da cidade; ou a cenografia urbana do Porto de Saint Nazaire, um caso de estudo em todo o mundo, pela forma como a iluminação alterou um estado de coisas global, em zona deprimida. Reconhecido na confluência urbanismo/arquitectura, Kersalé não é um nome propriamente incontornável no quadro mais específico da arte contemporânea com sistema.

197 Por problema técnico importante, decorrente do facto de os eléctricos portugueses terem características muito próprias ao nível da sua alimentação da corrente eléctrica. 
O que me leva a Luís Hortalà, que com Tempestade trouxe a Lisboa uma obra que procurava simular o efeito visual de trovões reais. Motivado por uma experiência pessoal da Luz, enquanto alpinista, o seu interesse era o de desenvolver uma acção que, assim as condições atmosféricas o permitissem (céu nublado), teria o enorme impacto de simular uma tempestade num dos pontos mais altos da cidade, o Castelo S. Jorge. O que estava em causa era a capacidade (ou não), de o artista conseguir transpor para o espaço urbano o poder do seu conceito; ora, depois de todo um esforço organizacional e financeiro, os céus de Lisboa não estavam suficientemente carregados de nuvens para reflectir a bateria de projectores de luz branca instalados junto às muralhas los flashes de luz, vindos de baixo, pareceram mais uma iluminação intempestiva das muralhas). Com a idealização artística a não corresponder às expectativas prometidas, resta saber até que ponto esta liberdade de falhar é um direito do artista (e da organização) - questão que nunca deixou de assombrar os debates da arte pública desde que esta assume uma esfera pública amorfa com as suas irrupções motivadas por lógicas que não as da 'lógica'. Pode sempre invocar-se que a obra assumia o tema da Bienal na sua dimensão cósmica, integrando então os elementos da natureza lo trovão que recorta o firmamento) na artificialidade do discurso humano da arte, o que é o mesmo que comparar os trabalhos e os dias de Golias (a Natureza) e David (a arte). Neste quadro, a peça será cinicamente autoirónica na sua apropriação do contexto e da oportunidade: falhando lao nível da comunicação ou da experiência no quadro das indústrias culturais) ela não deixa de celebrar a ingénua humildade da tentativa do artista), logo sempre acto heróico que se esquiva, kunicamente, à co-responsabilização social característica dos projectos participativos. Estas desenham uma clivagem entre artista que vêm do campo da arte contemporânea (Hortalá), especialistas de espaço público (Kersalé) e aqueles que, no limiar entre esses dois mundos (Ron Haselden), passam de um campo para o outro sem problemas maiores de legitimidade, competência técnica ou discurso face à cidade contemporânea. Sendo que os graus de felicidade da obra são muito dependentes da graça colectiva que os projectos conseguirem promover, e nestes termos poderia dizer-se - embora não o ouse - que entre Tempestade, Eléctricos e Fête há uma gradação ascendente de um pathos produtivo das obras.

\subsubsection{Templos do social}

Em Family Idea, mais ainda que em Fête, Ron Haselden interpreta eloquentemente as componentes mais ricas do programa da Luzboa. Transformando num conjunto espectacular de 'desenhos de luz' os desenhos feitos por crianças da Cova da Moura, convidadas a desenvolver a sua 'ideia de família' e a apresentá-la no centro da cidade, o resultado expressou vivências individuais no jardim público do Parque Eduardo VII e ao mesmo tempo a efectividade de uma dimensão colectiva da obra de arte, sendo por isso muito bem recebida ${ }^{198}$. Sobre a génese da peça, há notas que desvelam um logos de abertura processual desde o primeiro momento, integrando várias dimensões do real social na abstracção formal do ante-projecto. O artista, que havia estado em Lisboa em 2003 para uma primeira apresentação

198 Tornar-se logo a seguir um must dos festivais de Luz, tendo desde 2004 sido apresentada já nas cidades de Lüdensheid, Genebra e Eindhoven. Na Luzboa, foi inaugurada antes de todas as outras, para poder constituir factor de diferenciação da Feira do Livro, que abria em Maio. 
pública do seu trabalho, regressa em 2004 para a realização do que previamente havia decidido - realizar uma peça de arte pública participativa, em colaboração com uma 'comunidade desfavorecida'.199 O envolvimento de Ron com a ideia de comunidade começa quando, à sua chegada, mostra a intenção de de imediato ser levado a um lugar onde pudéssemos encontrar uma comunidade-alvo ${ }^{200}$. Logo nos dirigimos para ao bairro da Cova da Moura, onde existia uma situação mediatizada de desfavorecimento social e uma associação de solidariedade social - o Moinho da Juventude - com provas dadas no campo da animação sócio-cultural. Em visita surpresa, conseguimos reunir com a responsável local e num ápice, em brainstorm colectivo, chegámos conjuntamente à ideia da peça ${ }^{201}$. Este episódio revela a processualidade típica da arte como serviço, ainda que a retórica seja menos a da arte comunitária e algo de mais prosaico e honesto - mas também mais cínico... - isto, a retórica efémera de um encontro imprevisto e rigorosa- e minuciosamente orquestrado pelo artista. Numa segunda fase do projecto, 0 artista trabalhou com jovens artistas recém-licenciados ${ }^{202}$ na produção executiva da ideia, num demorado processo de 'tradução' estética:

[...] Os desenhos foram passados à sua versão escultórica através de dois materiais: verguinha de ferro e guirlandas de luz flexiveis, que constituiram o suporte tridimensional dos traços feitos no papel. A escultura em si é o conjunto das várias dezenas de grupos de figuras, dispostas em cascata, segundo uma disposição geométrica específica, por forma a produzir o efeito de 'passeio descendente' ao longo do Parque Eduardo VII. ${ }^{203}$

Quanto à implantação urbana, seria confirmada como excelente suporte para a obra, dado situar-se num ponto alto, com a cidade viva a seus pés. ${ }^{204}$ Tal opção - o seu carácter de ocupação intersticial, paradoxalmente numa zona nobre da cidade - apenas foi possível porque a Luzboa tirou partido de uma 'distracção' dos poderes da cidade-comunicação $0^{205}$. Portanto, se logo nas intenções e no título esta obra icónica da Luzboa estabeleceu o valor da arte como representação do mundo mental (lugar de memória, afecto, cognição), a sua filiação conceptual (deskilling do desenho aliado à singeleza dos materiais e à noção de cena urbana típica da land art) desenhou a sua própria apropriação do espaço urbano como possível do político, integrando-se de forma simultaneamente estratégica e táctica na configuração urbana de que se tornou epifania ${ }^{206}$. Através do seu trabalho, crianças dos arredores de Lisboa tiveram assim a oportunidade de, participando, sentir orgulho no seu contributo para um evento de grande dimensão e visibilidade artística, a decorrer numa zona importante da cidade..$^{207}$

199 Logo se ficou a saber que existiam 64 crianças no Jardim Escola e que estava definida a comunidade colaborante ficando como comunidades-alvo secundárias o conjunto das famílias e a comunidade da Cova da Loura e apenas em terceiro lugar o campo cultural da cidade.

200 Maioritariamente constituída por uma minoria étnica, em que houvesse um conjunto de crianças com quem se pudesse trabalhar. $\mathrm{O}$ artista queria dar continuidade a projectos como Mille Enfants de Lyon, em que um milhar de crianças contribuíram com os seus nomes manuscritos para uma enorme projecção urbana.

201 Que Susana Pinto sugerira ter o working title de Family Idea.

202 Rita Cachão e Tânia da Fonte.

203 Haselden, Ron; «Family Idea», in Luzboa - A Arte da Luz em Lisboa, p. 158.

204 Idem.

205 Num período em que todas as principais artérias da cidade tinham a obrigatoriedade de ostentar símbolos do Euro 2004 (bandeirolas e bolas de futebol penduradas), aquela monumental alameda pedonal havia 'milagrosamente' escapado à fúria publicitária.

206 Notar apenas que, paralelamente à intevenção-chave, o artista teve apreocupaçãode apresentar uma colagem de desnehos das crianças no Museu da Marioneta, distribuir um poster e um livro às emsmas, em acções invisíveis para o grande púboico mas importantes na estabelecimento de relações de prodiução e colaboração.

207 Haselden, Ron; «Family Idea», in Luzboa - A Arte da Luz em Lisboa, p.158. 


\section{Entretanto, no coração da Baixa, ao Largo do Teatro Nacional de S. Carlos,}

Limbo foi a instalação de uma estrutura paralelipipédica de $5 \times 5 \times 10 \mathrm{~m}$, branca, com uma entrada de $1,5 \mathrm{~m}$ a toda a largura de um lado. O tecto é preenchido por uma caixa de luz, com múltiplas imagens de corpos nus sobre um fundo negro, numa organização formal radial; corpos de pessoas de iadde diversa, deitadas sobre um vidro e vistas à transparência, em anamorfose provocada pela compressão contra o vidro. Limbo não é o Ceú nem o Inferno, não é culpa nem graça, castigo ou recompensa, é uma existência intermédia, qualquer coisa que está entre. [...] Limbo é metáfora de um estado limiar, onde é possível que já estejamos, enquanto indivíduos, povo ou humanidade. ${ }^{208}$

Este intróito interliga aspectos descritivos e filosóficos deliberadamente, destacando a pertinência cultural-civilizacional da peça e as formas que essa posição ética procura la analogia entre a estrutura arquitectural-visual e a de uma capela ou igreja ${ }^{209}$ ). Na intertextualidade que a imagem no interior comporta (ideia de tecto pintado), evocando cenas do último julgamento 210 , Campos está consciente de que amplia uma dimensão sacra: é desta forma criado um lugar de contemplação no meio da cidade, um espaço iniciático, de transcendência ${ }^{211}$, locus de um encontro com outro céu e a provocatória chamada para uma experiência colectiva/do colectivo.

Se toda a cultura pressupõe uma tensão crítica com as ideias quer de natureza, quer de civilização, e comporta, como notou Bourdieu, imposição simbólica, uma obra como Limbo é tipicamente uma intervenção táctica que tira partido de um determinada conjuntura para, acima de tudo, adquirir um certo protagonismo comunicacional. É-lhe subjacente uma ideia do social e do papel social da arte, e Limbo concretiza-a como interpelação que nos interroga acerca da possibilidade de a consciência da condição humana acarretar uma ideia de comunidade. ${ }^{212}$

A peça vive então da intensidade dialéctica de um carácter duplo, a partir da ideia do paviIhão visitável (arquitectura);

[...] instaurou-se como dispositivo contra-espectacular construído - o paradoxo é aparente - pela articulação entre arquitectura, ambiente e discurso característica de uma arte pública total. Os seus componentes: um pavilhão efémero de traça ascética, uma imagem fotográfica retroiluminada [com a função de cúpula], o loop de uma composição musical como ambiente e o todo paisagístico do lugar e do contexto, dia e noite, 24/24 horas..$^{213}$

\section{Sugere finalmente uma passagem específica:}

Mantendo-se face ao visitante num registo distanciado, evitando o logro do sentimentalismo, a peça reflectiu um conjunto de decisões projectuais que contribuíram para a sua eloquência enquanto dispositivo. Todas concorreram para articular a referida dimensão aforística, quer como breve e compacta formulação de uma ideia, quer como comentário potencialmente moral [na senda de Hipócrates6]. Limbo foi uma experiência da simplicidade de processos, tendo em conta um conjunto de aspectos fundamentais: escala [pela sua dimensão e implantação central, a peça 'tomou conta' de toda a praça], permeabilidade [aos fluxos pedonais], dimensão comunicativa [o jogo exterior/interior, em que a forma 'cega' do exterior funcionava como gatilho da curiosidade e, ao mesmo tempo, recatava o interior]; todas as soluções projectuais, ponto por ponto, interpretaram um programa genérico de criar um templo urbano laico. ${ }^{214}$

A obra estabelece assim uma decidida ligação retórica, entre os tropos do Belo (seu equilíbrio formal e integração na praça, através do desenho), do Sublime (a amplitude do tema, na imagem fotográfica) e a Graça (a experiência redemptória que se desenha entre as decisões de projecto - simples e visíveis - e a verdade do encontro de cada espectador com o dispositivo).

Luís Campos conseguiu na obra um equilibrio retórico entre uma esfera ética [o ethos do artista], uma esfera emotiva [o pathos, amalgamado no momento da fruição visual da cúpula...] e uma esfera projectual [o logos da arquitectura e

208 Campos, «Limbo», in Luzboa - A Arte da Luz em Lisboa, Extra]muros[, Lisboa, p. 146.

209 Idem.

210 Idem

211 Idem.

212 Caeiro, Mário; «Limbo - Templo do Social», in Luís Campos, Obras 1982-2008, O Museu Temporário, Lisboa, p. 128.

213 Idem.

214 Idem. 
do design de exposições, como encadeado de momentos de aproximação e vivência].

O modo como as pessoas acediam à experiência foi elucidativo desta retórica. Ao colocar a abertura a uma determinada altura - metro e meio - o artista conseguiu que os visitantes tivessem de, ao franqueram a entrada, agachar-se ligeiramente, executando um subtil movimento com o corpo; à saída desse movimento, e perante a ausência de motivos visuais até à altura dos olhos, de novo os rostos se viravam à procura, primeiro em volta, depois para cima, sendo então submergidos pela poderosa imagem de uma caixa de luz com uma composição radial de corpos nus deitados, em anamorfose. ${ }^{215}$

Mais, Campos integra numa mesma experiência do foro colaborativo, no espaço público, a questão fundamental do corpo como verdade colectiva:

Limbo propôs-se, nestes termos, como recuperação de uma arte em que o corpo assume centralidade epistemológica: Il n'y a qu'un seul Temple au monde, et c'est le corps humain. Rien n'est plus sacré que cette forme supérieu- re. S'incliner devant un homme, c'est rendre hommage à cette révélation encarnée. ${ }^{216}$

Determinante é depois a leitura de uma função articulada de limiar e fluxo (desde um 'cima-baixo' de poderosas ressonâncias religiosas), que aqui são um entendimento particular da mais intensa (e luminosa) intersticialidade:

\begin{abstract}
À primeira vista "Limbo" parece ser a cristalização mais límpida da metáfora do lugar-entre. E no entanto o seu modo de funcionamento está longe de ser simples ou unívoco. A questão fundamental é que não se trata de um lugar-entre, mas sim de dois: se por um lado os corpos espalmados sobre o vidro no momento da sua captação fotográfica ocupam uma situação de suspensão entre o céu e a terra que nos deixa entrever sentidos possíveis, como o de uma humanidade de lugar nenhum ou o de uma contemplação da ambiguidade do destino individual, por outro lado o espectador encontra-se também ele num lugar retirado da circulação ritmada dos dias, um lugar que se lhe impõe como lugar ritual, um ponto de suspensão da desordem e da ordem, da velocidade e das desatenções e obstinações quotidianas. Estes dois não-lugares, na sua sugestão de uma quase simetria que não pode deixar de ser a radical assimetria das mínimas diferenças, desencadeiam múltiplas correntes de funcionamento, múltiplos fluxos internos: da comunhão dos corpos para a respectiva diferença, da individualidade desses corpos para dissolução da individualidade no plano inferior do ritual de comunhão entre os espectadores, da imponderabilidade imóvel do plano superior para o peso terreno da carne que se move, da incomunicação dos corpos sobre o fundo negro para a comunicação (im)possível entre espectadores, da comunhão potencial para a incomunicabilidade actual, e assim por diante... Estes fluxos materializam, pois, outros tantos lugares-entre, de uma segunda ordem: entre os corpos, entre o em cima e o em baixo, entre os sujeitos que observam este mecanismo estético, entre esses sujeitos e os corpos que lhes são dados a ver, etc... 217
\end{abstract}

Miranda Justo confirma o sentido de totalidade dinâmica em fluxo que a obra de Luís Campos instaura, sentido de que Limbo é uma acção urbana e com escala inédita, assim ocupando um lugar central numa ars extramuros:

Assim, a fruição da obra de Luís Campos parece exigir a introdução de um conceito multímodo de «fluxo»: temos por um lado um fluxo, a que poderíamos chamar linear, que se pode determinar nos grandes passos que conduzem gradualmente dos momentos mais recuados da obra até ao presente; temos depois os fluxos internos de cada um dos momentos da obra, plasmados numa exposição, num video ou num conjunto coerente de imagens; mas temos também aquilo que se pode designar como fluxos de constelação, ou seja, os fluxos instantâneos que se detectam no conjunto da obra quando encarada na perspectiva de uma totalidade dinâmica. ${ }^{218}$

Esta peça revelou-se das mais importantes no historial da Luzboa. Parte de um conjunto de criadores no campo da arte contemporânea que, não sendo dos mais mediáticos, ofereceria o alcance de uma produção madura, respondeu à chamada começando por 'respeitar' à letra a proposta poética de Carlos Drummond de Andrade e depois propondo uma solução plástica que estabeleceu uma continuidade dia-noite, provocou a emoção colectiva e estimulou a refexão sobre a função da arte na forma urbana - tudo em delicada noção de inserção do

\footnotetext{
215 Idem.

216 Idem.

217 Justo, José Miranda; «Prospectivamente, Luís Campos: Intensidades e Fluxos», in Luís Campos, Obras 1982-2008, 0 Museu Temporário, Lisboa, p. 19.

218 Idem, p. 18.
} 
objecto (patente nas proporções da peça ou na sua relação com quadrícula do pavimento). De notar como a tradição modernista e do minimalismo convive aqui com um apelo ao pathos visual mais mainstream - temperado porém pelo estranhamento provocado pela imagem e, ao mesmo tempo, gerido formalmente, através da criticidade das proporções e altura total da abertura para o interior la tal altura que obrigava os espectadores a um subtil gesto do corpo e da cabeça, tornando necessário o movimento de reverência que a situação impunha).

\subsubsection{Indoors: o sol, a cor, paisagem, um barco}

Dentro de portas, várias intervenções da Luzboa constituiram ocupações temporárias de espaços semi-públicos, integrando determinadas possibilidades de acessibilidade e circulação ${ }^{219}$. Esta programação intramuros procurou relacionar-se porém com a problemática extramuros da luz em contexto urbano. No Caso de Nuno Cera, Pure Light, na Sala do Risco, criou um diálogo som-luz extremamente coerente ${ }^{220}$. Abílio Leitão, também ele fotógrafo, abordou um tema importante no quotidiano da experiência da luz na cidade ${ }^{221}$. 0 projecto, que consistiu em fotografar uma série de espaços urbanos vagos, industriais, periféricos ou abandonados, à luz amarelada do entardecer, introduziu um tema caro à arte extramuros, o de atenção aos aspectos negligenciados da cidade:

\footnotetext{
Comecemos por uma lição de humildade. Em vez de procurar lugares extraordinários para olhar o sol, o que importa é estar atento ao modo como opoente pousa suavemente a sua luz sobre todos os lugares: mesmo aqueles onde nunca ninguém vai ver o pôr do Sol nem, aliás, coisa nenhuma. / Falo da humildade democrática do poente quotidiano. Para a captar, não é necessária a arrogância aventurosa do viajante, mas sim o silêncio empático de uam fotógrafo como Abílio Leitão, que conhece e sente, de dentro para fora, os meandros e discretos segredos desse lugares suburbanos, desolados e periféricos, onde nunca ninguém vai e onde ele, desde há muitos anos, vem realizando algumas das suas melhores reportagens fotográficas. 222
}

No decurso das visitas guiadas ao evento, esta foi uma incursão violenta da realidade exterior no espaço interior da galeria de arte - que, para muitos visitantes, não costuma albergar imagens tão banais. Montada como uma grande paisagem circundante, em fotografias de grandes dimensões (cerca de $2 \times 1$ metros), a exposição era ela própria um lugar/ não-lugar tocado pela luz maravilhosa do final da tarde, como pela humildade do fotógrafo que a havia 'descoberto'.

Noutro extremo da cidade, entretanto, Virgínia Mota e Carlos Nogueira apresentavam respectivamente S/ título e Construção. Com luz no Museu Nacional da Arte Antiga. Mais duas obras de interior, de novo num espaço semi-público. Na forma-museu que foram chamadas a comentar, estabeleceram novas relações efémeras, a apropriação de todo um contexto rico e complexo através de dois statements. Como sublinhou José Luís Porfírio, director da instituição, acerca da efemeridade da accrochage:

Uma Luz boa invadiu pacificamente dois espaços, quase contíguos [...] E, ambos os casos, é a luz que trabalha,

219 Sempre com visitas guiadas, um modelo relativamente inclusivo de fruição.

220 Não apenas na série de fotografias expostas, criando um painel de experiências visuais, mas em particular no vídeo, cujo som, de forma enfática, como que conseguia 'traduzir' a vibração sonora do sol.

221 Leitão, Abílio; «Entardecer / Nothing gold can stay», in Luzboa - A Arte da Luz em Lisboa, p.181: Terá a luz do entardecer o poder de sossegar os nossos corações e o poder de submeter os nossos sentimentos, de modo tão absoluto, a esse sentido do idílico?

222 Melo, Alexandre; «O sol de cada dia», in Luzboa - A Arte da Luz em Lisboa, p.183. 
desmaterializando o metal, primeiro, instituindo a obra e o seu peso depois. Assim, coincidentes quase por acaso, estas obras de luz se opuseram durante um mês no Museu Nacional de Arte Antiga, e pela, oposição, se completaram enquanto efeito e presença. ${ }^{223}$

Virgínia Mota foi particularmente estimulante na provocação; a toda a largura de uma sala térrea de fácil acesso (acompanhado de um ruído de fundo monótono) apresentou uma instalação vídeo em que a imagem era constituída por manchas que iam sugerindo, de acordo com cada espectador, e possibilidade de se tratar de uma paisagem. Na prática, o surpreendente filme era simplesmente composto por manchas em movimento lefeitos de solarização), 'começando' assim no território movediço do acontecer da percepção. $O$ que temos aqui é uma imagem que se remete voluntariamente a um ponto crítico da sua abstracção, por forma a colocar no espectador a responsabilidade - e o prazer pessoal - da (re)constituição do seu sentido como intervenção:

Doze minutos de tensão interiorlexterior - aquilo que somos e sabemos, o que esquecemos, a relação fundamental com as imagens exteriores [...] Passagens, criação de diferentes intensidades e alterações morfológicas - um princípio de textura, uma sensação de relevo [...] Fica a memória de um sentir.224

Acontece que, no MNAA, onde as artes estão ancoradas numa lógica de modalidades lo retrato, a natureza morta, a paisagem...), a abertura radical de Virgínia Mota proporcionou uma intensa participação - pelo menos para os espectadores mais familiarizados com as problemáticas modernistas da representação. Foi um micro-acontecimento quotidiano, nesse lugar secreto que é a experiência individual (da luz, e do som, no caso) de uma peça que funciona incómoda e inquietamente. ${ }^{225}$ Numa palavra final sobre esta peça, sublinho o prazer extremo no encontro entre o tema do evento e uma pedagogia da sua substância,

[...] esta luz-substância que nos coloca no interior do ver, coo quando pela força a luz do sol ou da lâmpada do scanner atravessam as pálpebras, ou como quando o som atravessa o ouvido, a percepção, e rompe o espaço do corpo para tocar fisicamente o coração [...] Estas imagens em movimento [...] são um mínimo e um máximo que podemos pensar e sentirface ao ver. ${ }^{226}$

Quanto à obra de Carlos Nogueiraa ${ }^{227}$, foi colocada no hall de entrada ${ }^{228}$. Ali no Museu da arte 'antiga', dignificou as neovanguardas mais 'frias' (conceptual, minimal) num espaço que valorizou estas linhas rectas e estas massas nuas face à ornanentação do barroco ou as convenções do classicismo. Em suma, a peça introduz, no limite, mais uma nota de silêncio e abstracção no circuito museológico, talvez de forma pedagógica - quando se percebia como um determinado efeito luminoso (lâmina de luz junto ao solo) muda a nossa noção de peso e de massa no objecto físico diante de nós. ${ }^{229}$ Também João Pedro Vale ${ }^{230}$ participou

223 Porfírio, José Luís; in Luzboa - A Arte da Luz em Lisboa, p. 186.

224 Ferreira, Célia; «S/ título», in Luzboa - A Arte da Luz em Lisboa, p. 184.

225 Porfírio, José Luís; in Luzboa - A Arte da Luz em Lisboa, p. 186.

226 Ferreira, p. 184.

227 A escolha deste artista para integrar a Bienal foi por razões semelhantes às que nos levaram a convidar Luís Campos; em Nogueira diviso um tratamento recorrente da luz como matéria particularmente integrada no objecto escultórico de matriz minimal.

228 Não, conforme inicialmente previsto, na Capela das Albertas, por razões técnicas relacionadas com o peso da obra.

229 Como que provando esta ideia, noto que, quando a peça é fotografada, e nas fotos surgiu o fio eléctrico que alimentava a obra, o autor deu instruções para apagar aquela marca de materialidade acessória. Certamente porque tal constituiria um ruído do real certamente desnecessário à fruição da obra como uma artificiosa provocação da arte arte contemporânea - também aqui como em Mota - a todas as formas de nivelamento por baixo da experiência visual.

230 A escolha do artista, que já havia participado na LXCN, foi de compromisso com o director do Museu de Arte Moderna, 
na Luzboa com uma peça indoor: um barco, ou o que resta dele, coberto ou reconstruído por fitas de tafetá branco com a inscrição «Não há fim para o caminho». ${ }^{231}$ Bonfim - Não há fim para o caminho terá pouca relevância para as questões de arte pública. Pendurada precisamente debaixo da abertura de luz zenital da sala laí podendo dizer-se que algo 'lá fora' está implícito), a sua relação com a forma urbana é nula; apesar do valor escultórico 'em absoluto'232 e da complexidade dos seus mecanismos metafóricos ${ }^{233}$ teve uma importância diminuta na afirmação da originalidade do Evento.

\subsubsection{Da ficção da política e do encontro fenomenológico}

No Príncipe Real, Jean-Claude Deschamps, ${ }^{234}$ Guantanamo Bay foi a ocupação cenográfica da totalidade dos espaços de acesso público do Reservatório da Patriarcal (Museu da Água). O que levou o artista a escolher aquele lugar para a sua intervenção foi uma noção de potencialidade do lugar: Há esta visita, ao acaso de uma passeata, no Outono de 2003, ao antigo reservatório de água do Príncipe Real. Sou o único visitante, está fresco e húmido, a iluminação é branca-amarelada, suja, banal. A arquitectura admirável, porém ilegível. ${ }^{235}$ Assim é, mas: $A$ modificação da cor da iluminação transforma totalmente o lugar. A arquitectura encontra a sua legibilidade e a pesada atmosfera do lugar, um sentido. ${ }^{236}$ Portanto, há a intenção de qualificar esteticamente aquele espaço, aportando-lhe ressonâncias das Prisões de Piranesi, e depois, num arco de actualização, as imagens mediatizadas dos prisioneiros vestidos de laranja na prisão norte-americana de Guantanamo, em Cuba. O interessante na peça começa então por ser compreender como um tema encontrava formas de se expressar através de um contexto ambiental pré-existente. A arquitectura específica é aqui uma espécie de micro-contexto, um suporte para a ficção (mais que para a argumentação política): E assim, bastaram

[...] algumas «escorregadelas». Modificar a cor da iluminação. Utilizar o verde, cor cirúrgica, fria, mas repousante para os deoentes; mas também cor dos cadáveres. Utilizar o azul do mar das Caraíbas [no pequeno lago exterior]. Projectar a sombra das placas metálicas contra uma parede. Instalar duas lanternas vermelhas. Colocar em evidência uma escada gordurenta e criar sons. ${ }^{237}$

Para ao evento, os horários de abertura foram expandidos, podendo aceder-se às salas e galerias iluminadas por uma omnipresente luz verde, pontualmente interrompida por discretos apontamentos evocando uma narrativa potencial luma silhueta vermelha ao fundo de um túnel, misteriosa e inacessível; a simulação de luz natural zenital, mostrando-nos quão fundamental é a luz do dia quando dela somos privados, como na prisão) ${ }^{238}$. 0 artista está consciente da múltipla tensão entre a experiência fenomenológica da luz, a vivência

Pedro Lapa, e tratou-se fundamentalmente de uma decisão capaz de realizar sinergias de programação e publicitação.

231 Ferreira, Nuno Alexandre; «Não há caminho para o fim», in Luzboa - A Arte da Luz em Lisboa, p. 195.

232 Já de depois de concluída a Bienal, João Pedro Vale venceu, com Bonfim, o Prémio de Escultura City Desk 2004.

233 Cf. Ferreira, Nuno Alexandre; «Não há caminho para o fim», in Luzboa - A Arte da Luz em Lisboa, pp. 194-197.

234 Artista e na altura director do Festival de Luz Christmas Tree Festival, hoje Arbres et Lumières.

235 Deschamps, Jean Claude; «Guantanamo Bay», in Luzboa - A Arte da Luz em Lisboa, p. 176.

236 Idem.

237 Idem.

238 Idem. Piranesi chega a Guantanamo, passando por Salazar. Nada muda. 
casual e a conscientização política que a peça amalgama numa totalidade teatral. Como nos Jardins-miradouros de Graveleine e Nicolas, a luz consegue aqui manter uma subtil distância entre ser apenas e só efeito cenográfico lo momento do prazer perceptivo obviamente fundamental para se gerar empatia) e constituir-se como âncora de um modo de conhecimento (que de imediato se impõe por via do carácter imersivo e impressionante da instalação), e é o domínio rigoroso desta tensão - que aqui passa por controlar com absoluta precisão todas as fontes de luz e a relação entre elas - que torna a obra memorável. Importante é ainda o facto de o artista estabelecer relações formais importantes latravés do contraste azul/verde (exterior à superfície/interior subterrâneo), assinalando, no tecido urbano, a presença de um valor arquitectónico - o reservatório - que era relativamente desconhecido para muitos transeuntes e lisboetas ${ }^{239}$.

Tal como Deschamps, também Daniel Schlaepfer ${ }^{240}$ realizou a sua obra numa cisterna. A obra consistiu basicamente na associação entre projecções de luz rasante, a colocação de colunas de som flutuando e uma instalação sonora que, a partir de gravações de gotas existentes no local, multiplicava as mesmas numa composição quadrofónica que deixava o público suspenso dos seus ritmos extremamente pausados (constrastando com a noite urbana e seus ruídos, assim como a azáfama diurna). Tudo começou por um encontro feliz: Quando entrei na cisterna, compreendi imediatamente que este local era o lugar que eu procurava desde há vários anos. O perfeito espelho tranquilo da água, com as suas paredes-écrã, a obscuridade, tudo nele estava reunido. ${ }^{241}$ Muitas das questões levantadas pela peça anterior se repetem aqui, mas é ainda mais radical esta experiência in situ da linguagem da iluminação ambiental.

Preparação / Propuseram-nos intervir na cisterna da Casa do Fado e da Guitarra Portuguesa, no sopé do bairro de Alfama. Muito depressa a magia deste lugar revelou-se. Imersos na cisterna, apercebemo-nos da vida da água que ela alberga, os seus movimentos, as suas sonoridades. Uma coincidência limpida teve lugar entre esta cisterna e as pesquisas de cada um de nós. / Realização / A fim de tornar visível e audível a vida desta água, foi desenvolvido um dispositivo para a fazer vibrar. A extrema sensibilidade do lugar surpreendeu-nos aquando da realização [...] tivemos de adoptar um ritmo muito lento e gestos delicados para acariciar a água. Os dias passados na escuridão da cisterna criavam pouco a pouco uma temporalidade estranha, um outro espaço, desconhecido, da cidade. ${ }^{242}$

A experiência da peça começava sempre com a descida dos espectadores à cisterna e implicava um período de cerca de dez minutos de habituação visual, entre uma percepção de apenas a escuridão e a progressiva emergência de desenhos dinâmicos nas paredes circundantes:

Após os primeiros instantes de obscuridade, o aparecimento de uma onda transforma a superfície da água e projecta ondulações luminosas nas paredes e nas colunas, desmultiplicando-se, pouco a pouco desaparecendo no escuro, renascendo depois de novo. O espaço sonoro é semeado de finas gotas de água que explodem e libertam ressonâncias musicais. ${ }^{243}$

Note-se que era a emissão do som através das colunas colocadas na água que fazia a água ondular, e que era depois essa vibração que a luz rasante projectava (efeito de refracção) sobre os muros-écran. As imagens eram assim variações ínfimas e simultaneamente infi-

239 Aliás, tanto assim é que, um ano depois, a Extra]muros[ seria convidada a realizar uma peça-de-luz para a associação Cais para um evento que, desenrolando-se no interior do reservatório era vital assinalar exteriormente, através de uma peça de arquitectruar efémera luminosa.

240 Artista pluridisciplinar, aqui em colaboração com Nicole Blanchoud e Stello Tzonis.

241 Schlaepfer havia já realizado outras obras em que a água e a luz interagem, como Lumières du Port (1992, Lausanne) ou Miroir Celeste (1996, Bex \& Arts).

242 Schlaepfer, Daniel; «Undae», in Luzboa - A Arte da Luz em Lisboa, p. 192.

243 Idem. 
nitas de um mesmo 'desenho', 244 cuja estrutura pressentíamos e, no fundo, compreendíamos (reconhecimento), mas que pela sua complexidade natural e pura materialidade sentíamos como experiência sublime. Num registo austero, acrescenta aos pretextos da Bienal a qualidade de um exercício de atenção máxima ao essencial, ${ }^{245}$ uma muito precisa articulação entre aquilo que nas formas do edificado sugerem a intervenção, a forma como essa intervenção se submete e ao mesmo tempo enriquece esses dados de partida e finalmente a transparência do dispositivo que assim se explicita como modelo de intervenção. ${ }^{246}$

Numa sinergia importante por representar a ligação a mais um campo o mundo da arte, o comissário Natxo Checa convidou quatro artistas/colectivos ${ }^{247}$ para ocuparem as instalações da ZDB Galeria Zé dos Bois com a exposição colectiva Cidade lluminada. Nesta exposição, as obras - filmes, instalações-vídeo e fotografias, manifestando modalidades crípticas de crítica, extremamente codificadas enquanto 'arte contemporânea - , foram portadoras de mecanismos de reflexão difíceis de enquadrar no âmbito das mais genuínas preocupações da Bienal. ${ }^{248}$ A 'dificuldade' de integrar Cidade lluminada na linha estética da Luzboa talvez tenha decorrido de dificuldades de articulação entre dois modelos expositivos que aqui chocaram, apesar de partilharem um certo sentido de vanguarda e contemporaneidade: um modelo interessado na partilha da informação na transparência do dispositivo público (a rua); e um modelo da arte contemporânea disponível para o encontro participado porém ainda no território rarefeito do espaço museológico. ${ }^{249}$ Cidade lluminada teve aliás uma peça capaz de abordar criticamente o cluster 'galeria' / 'exposição de artes plásticas' / 'cidade' / 'arte urbana'. Tirando partido do know how técnico-científico do colaborador Pedro Rogado (arquitecto), Sancho Silva elaborou uma instalação que questionasse as suas delimitações. ${ }^{250}$ Fruto de residências na Galeria, Vertizonte e Pixel ('Ponto de vista) conseguiram realmente questionar a forma como os espaços são definidos, como os seus limites e fronteiras são desenhados, demarcados e transformados. Neles se espraia mais uma actualização site specific do minimalismo, colocando no corpo do observador uma performance física do próprio acto de ver a própria cidade. São peças que se destacam, enquanto elementos de surpresa e de mistério, assim como pelos mecanismos, sempre presentes, do voyeurismo e da vigilância. ${ }^{251}$ Noutros termos, o artista soube reconhecer na forma urbana (aqui vista de dentro do edifício), a oportunidade 'janela' e dela retirar uma máxima expressividade e performática - a ponto de, em Vertizonte, a peça mais longa, todo o

244 Alguns espectadores julgaram estar perante projecções vídeo.

245 The essential is no longer visible, afirma Virilio, frase que Magdalena Jetelová, que participou como conferencista em Desenhar a Luz em 2003, aplicou aos bunkers da Normandia.

246 Contactámos a EGEAC no sentido de tornar a obra permanente, mas responderam laconicamente, por carta, que a peça não tinha qualidade artística para ser reinstalada.

247 Colectivo ZDB, Sancho Silva c/ Pedro Rogado, João Maria Gusmão + Pedro Paiva e João Tabarra.

248 Digamos que é forçado ver no vídeo de uma corda esticando-se até partir (Apparent Phenomena estudo 2) uma discussão sobre a sustentabilidade da organização espacial, física e emocional dos territórios urbanos. Cf. Checa, Natxo; «Cidade lluminada», in Luzboa - A Arte da Luz em Lisboa, p. 202.

249 Seja como for, as visitas guiadas e um serviço educativo competente fizeram desta sinergia - que se prolongou durante os vários meses que a exposição esteve patente - um exemplo de como também os grandes eventos urbanos podiam não apenas estabelecer colaborações não apenas com as entidades mais estabilizadas do campo da arte (MNAA) mas estruturas emergentes com dinamismo programático (ZDB).

250 Idem.

251 Idem. 
corpo do espectador mais afoito - ou curioso - se encontrar já totalmente 'para lá' do limiar da janela, suspenso, apenas pela obra de arte, sobre a cidade, de que, paradoxalmente apenas vislumbra um frincha (frincha a qual the permite, por outro lado, ver sem ser visto).

Noutro registo, mais diletante, Bar da Sedução, realizado no Teatro Municipal S. Luiz, consistiu na transformação luminosa dos ambientes, tanto no interior como no exterior [...] elaborada a partir desta estética que define o teatro: os desdobramentos narcísicos, os jogos de espelhos, a iluminação e a exuberância. ${ }^{252}$ No exterior, a obra de Jean-Luc Vilmouth sublinhou linhas arquitectónicas existentes, multiplicando espelhos de camarim em todas as janelas da fachada (papel autocolante espelhado aplicado aos vidros, por sua vez emoldurados por centenas de pequenas lâmpadas incandescentes) - operação porventura mais simbólica que efectiva, mas que de facto sinalizava aquele edifício e a sua função na cidade. Este aspecto exterior da peça era

[...] um chamamento para o que acontecia no interior: um sem-número de bolas de luz candeeiros de linhas sóbrias e arredondadas pendurados no tecto, suspensos a alturas variadas por um sistema de cabos eléctricos. Para modificar o aspecto das mesas foi aplicada a cada uma delas uma superfície adesiva espelhada, gerando-se um jogo de reflexos e projecções coloridas. Mais candeeiros dispostos sobre as mesas reforçaram o efeito estético produzido pelos jogos de espelhos. ${ }^{253}$

Note-se como a intervenção colocou todo um edifício ao serviço do momento relacional, quadro para brevíssimos encontros que ficariam registados, sempre de forma diferente, na memória de cada visitante; tema dos mais complexos e irredutíveis da experiência social era assim abordado, de forma extremamente ligeira, mas não menos elucidativa, tal a natural intensidade daquela versão do efémero,

[...] intensamente performativa: Na noite da inauguração da Bienal, 21 de Junho, um grupo de actores e actrizes realizou uma sessão de sedução com a sala do Jardim de Inverno repleta. Cada sessão durou entre três e quatro minutos, A brevidade potenciou a energia de cada encontro, envolto pelos sorrisos generalizados do restante público. A situação obrigou actores e actrizes a uma performance intensa, uma vez que, para convencer, era necessário realmente seduzir. Recepcionistas geriram o fluxo dos visitantes e o tempo de cada sessão de sedução. ${ }^{254}$

Durante o restante período do evento, foram instalados monitores vídeo com gravações previamente preparadas, que deslocaram a sedução para novo contexto, agora mediado pelos écrans e em que o ambiente era de cacofónica sobreposição de apelos sedutores. Pode ver-se uma modalidade de 'documentação', que decorre da abordagem camaleónica do objecto de arte face aos contextos, sempre capaz de desmultiplicar as suas decisões centrais, na experiência total do social.

No jogo com a inevitabilidade das instituições, Miguel Palma foi outro artista que tirou partido da dinâmica de diversidade e inclusiva do Evento para continuar a revelar o seu mundo de irrisão.

No interior de uma ambulância, construí uma cidade. Uma maqueta de cidade. Com ruas, prédios, avenidas e seus cruzamentos. Uma série de automóveis à escala 1/18 moviam-se, soltos, com as oscilações provocadas pelo movimento da ambulância. / Várias câmaras de vídeo, no interior destes pequenos automóveis e instaladas nestas ruas em miniatura registam acidentes que se aproximam de uma realidade qualquer. Esta ambulância (dispositivo de salvamento) constrói os seus próprios acidentes, que seriam, em última análise, a razão da sua existência. ${ }^{255}$

252 Vilmouth, Jean-Luc; «Bar da sedução», in A Arte da Luz em Lisboa, p. 198.

253 Idem.

254 Idem.

255 Palma, Miguel; «Accident Motion Pictures», in A Arte da Luz em Lisboa, p. 188. 
Aqui, o 'jogo da arte' - representando o jogo da vida - , como noutras peças de Palma, é levado ao extremo de um ready made (a ambulância) que integra aspectos de representação banais (a maqueta). Está na peça também a questão das economias da mobilidade urbana, isto é, traços de temáticas de política urbana incontornáveis que são abordadas com a leveza do aforismo paradoxal - ambulância que leva cidade dentro, cidade dentro da qual carros chocam uns com os outros fazendo vítimas, que é preciso 'salvar'... versão situacionista de um mise-en-abîme da própria forma urbana num jogo de aproximações de escala. Friso que Palma - como já havia acontecido com Festival Aéreo, na LXCN - não faz cedências a uma esfera da comunicação social que porventura faz parte, para ele, do mesmo macro-dispositivo que urge suspender através a obra de arte, instância do possível num sentido quase infantil da liberdade de problematizar o tecido urbano.

\subsection{Luzboa 2006, um percurso de Luz na cidade - obras comentadas}

Luzboa foi um conceito germinado na continuidade entre teoria e prática, conhecimento e acção, dando ao complexo tema da luz inédito protagonismo. Pela escala que atingiu, mas também pelo rigor conceptual e formal que algumas intervenções introduziram no campo da investigação-acção da arte pública em Portugal, foi dos principais acontecimentos urbanos $^{256}$ em que a relação entre arte contemporânea e cidade - a retórica extramuros agora na órbita do tropo da luz - foi metodicamente empreendida. Face a 2004, a Luzboa 2006 foi uma oportunidade para consolidar a iniciativa, sucedendo-se a várias consultas a artistas e técnicos ${ }^{257}$. Sob o mote 'Art gets you through the night' - adaptação de um verso de John Lennon - foram assumidos quatro objectivos fundamentais:

- Trazer a Arte Contemporânea para a rua, ao encontro de amplos estratos da população, convidando-a a participar e a fruir o espaço urbano.

- Celebrar o carácter e a beleza da noite de Lisboa, assegurando-lhe um enriquecimento da vivência nocturna, ao nivel das imagens e dos ambientes.

- Promover, ao nível nacional e internacional, a imagem de Lisboa, numa perspectiva contemporânea e dinâmica, capaz de atrair um significativo turismo cultural.

- Desenvolver um evento único e original, de qualidade e renome, capaz de se tornar uma referência artística de nível mundial.

Luzboa 2006 foi mais uma vez uma oportunidade:

- Luzboa é a oportunidade de transformar Lisboa no cenário das propostas artísticas de importantes artistas mundiais, enriquecendo a oferta cultural da Capital e contribuindo para a sua valorização no panorama das cidades culturais europeias;

- Luzboa é oportunidade para debater o desenho da noite, nomeadamente quanto ao papel da arte pública e da iluminação ambiental no Planeamento e Reabilitação Urbanos;

- Luzboa é oportunidade para criar sinergias entre a população, agentes culturais, a administração pública e o sector empresarial e tecnológico, com benefícios estratégicos para os domínios do Urbanismo, da lluminação Pública, do Turismo, da Economia e da Cultura.

256 Figurando entre os acontecimentos da década na Cronologia de David Santos para Arte e Artistas em Portugal, de Alexandre Melo.

257 James Turrell, Felice Varini ou Jaume Plensa foram alguns deles. Por razões muito diversas, desde a indisponibilidade física em determinadas datas à escala incomportável das verbas envolvidas em alguns dos ante-projectos discutidos, da dificuldade em obter parceiros e sponsors específicos à não-autorização para as intervenções por parte de diversas entidades, nem todas as propostas inicialmente desenvolvidas puderam 'ver a luz do dia'. 


\subsubsection{Implantação, percurso, programação: intervenção, intervenções}

Luzboa propôs em 2006 um circuito de arte urbana atravessando alguns dos bairros e zonas mais carismáticos da cidade. Revelação poética de um território, esse percurso único, subdividido em três segmentos, uniu o Príncipe Real a Alfama - passando pelo Largo Camões, as zonas do Chiado e da Baixa e a zona da Mouraria. As intervenções artísticas, que incidiram em espaços públicos e edifícios notáveis, foram complementadas por acções de valoração (Ateliês 'Desenhar a Luz') ou formação (Prémio Luzboa-Schréder) que decorreram em equipamentos (museus, universidades e espaços associativos), alguns municipais. No essencial, a Bienal foi em 2006 um grande passeio público de acesso livre, popular e nocturno. O percurso foi essencialmente pedonal e linear, com duas zonas extremas (Rato-Camões e Portas do Sol-Sél com acesso também viário. As intervenções proporcionaram uma transfiguração dos sucessivos ambientes urbanos, diversos na sua tipologia e imagem visual, sendo o público convidado a experimentar a alteração de todo o ambiente urbano, quer através das instalações, quer da transformação da iluminação urbana por meio da colocação de filtros coloridos nas luminárias públicas.

Definido um percurso genérico que realçasse as características urbanísticas e culturais de várias áreas, estava encontrada uma lógica tripartida. ${ }^{258}$

Esta lógica territorial foi evidenciada pelas próprias obras de arte e um projecto de comunicação urbana. Não incidindo numa leitura restrita procurando revelar a Luzboa como ampla plataforma interdisciplinar, de interesse para os mais variados públicos, profissionais ou não. ${ }^{259}$ Da mesma forma, o Congresso da Noite Sob o tema 'Símbolos, Representações e Vivências', promoveu uma reflexão sobre o modo como a noite tem sido sentida, representada e vivida, de modo a formular novas prospectivas para o ordenamento global da cidade, no que à iluminação pública diz respeito ${ }^{260}$. O que a Luzboa 2006 colocou em causa foi fundamentalmente como uma cidade pode ou não ser traduzida do dia para a noite.

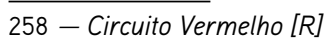

Rato, Largo de São Mamede, Jardim Botânico, Príncipe Real, Jardim de São Pedro de Alcântara, Elevador da Glória, Largo Trindade Coelho. e Largo Luís de Camões

- Circuito Verde [G]

Largo do Chiado, Largo do Teatro Nacional de S. Carlos, Rua Garrett [Pátio Garrett], Rua de Santa Justa.

- Circuito Azul [B]

Escadinhas de São Cristóvão, Mercado do Chão do Loureiro, Largo das Portas do Sol, Rua do Limoeiro, Largo do Correio-Mor, Largo de Santo António à Sé.

259 As visitas guiadas e uma exposição didáctica nos Armazéns do Chiado acentuaram esta ideia.

260 Cf. Alves, Teresa; «'Congresso da Noite'. Símbolos, representações e vivências», in Luzboa - Lisboa Inventada pela Luz, p. 266. Entre as conclusões do evento, destaco, parafraseando Teresa Alves: a importância de: sublinhar na noite, menos a carga negativa (que nunca desaparece por completo) e mais a pertinência do ganhar novas representações, mais poéticas, e que se relacionam com aspectos como a liberdade e a criatividade; recorrer a todas as formas de arte como aspecto de mediação crucial para a compreensão de um espaço-tempo com traços específicos; colocar em causa a percepção distorcida de que a menos luz urbana corresponde menos segurança; por em marcha a mudança de um paradigma em que o planeamento da cidade diurna não encontra espelho adequado no planeamento da cidade nocturna (com consequências perniciosas ao nível da mobilidade, por exemplo); no domínio da iluminação pública, promover o planeamento de que a cidade parece estar grandemente ausente; por fim, levar as pessoas a viverem a cidade nocturna. 
A Bienal assentou em duas vertentes-chave: a) um suporte expositivo, claro e preciso, motivador da curiosidade e de inegável impacto mediático (Projecto RGB); b) uma acepção artística não redutora, que englobou modalidades artísticas diversas. Se o Percurso resultou da capacidade das obras imporem a sua presença, também é verdade que 0 impacto das mesmas resultou da vontade subjacente de respeitar o Percurso, pelo que a segunda Bienal retirou dessa tensão a sua capacidade de penetração no público. Fruto de uma implantação incontornável para o transeunte comum, a identidade da Luzboa foi em 2006 maior que em 2004, funcionando como um todo evidente.

O Projecto RGB consistiu num plano de iluminação efémera - marcação e clarificação dos limites do Percurso da própria Bienal. Esta transfiguração espacial de todo o 'edifício' da Bienal, por meio de uma intervenção plástica que modificou a cor da iluminação urbana (410 luminárias), diminuindo a sua intensidade, explicitou três percursos interligados, cada um correspondendo a um ambiente urbano característico ${ }^{261}$ e foi enfatizada por dois conjuntos de intervenções (Esquiços e Art gets you through Night ${ }^{262}$ ). A coerência cromática e lumínica assegurou o enquadramento visual das obras artísticas e a própria comunicação urbana do acontecimento, através da paradoxal criação de um museu nocturno a céu aberto.

Graças a esta ideia de percurso e a um guia de passeio - mapa -, qualquer pessoa podia procurar o que mais the interessava; e se porventura se cruzava com o Evento inadvertidamente, tinha a noção de que penetrava num território convidativo, porque alterado com critério. O Projecto RGB tornou incontornável a comunicação e a própria existência do Evento, semanas antes do mesmo sequer ter início (tempo de duração da aplicação dos filtros). De autoria colectiva, terá sido a pedra de toque para o sucesso da Luzboa em 2006, levando as pessoas não apenas ao encontro das peças individualizadas, mas desde logo levando-as a redescobrir uma cidade que, do dia para noite, é banhada pela luz amarela - trivial - dos candeeiros públicos. O Projecto RGB potenciou assim as opções de implantação da Bienal no ano de 2004 (mais dispersa), exprimindo a hipótese de cada nova edição integrar como que 'por camadas' um projecto urbano ${ }^{263}$ ao longo do tempo, que pudesse acumular experiência sobre a cidade. Portanto, o 'edifício' RGB, o museu sem muros que albergou primeiramente a própria canalização dos fluxos, depois momentos de sinalização (Esquiços), momentos de pausa prolongada e de continuidade (AGTN, onde se sentia défice de obras ${ }^{264}$ ) e finalmente as próprias obras, foi também ele obra de arte, tanto quanto membrana de contacto social. Pensado para permitir uma determinada distância entre peças, de maneira a que houvesse por assim dizer uma circulação com um ritmo previamente desenhado, acumulou ainda várias funcionalidades numa mesma imagem, que

261 Uma Lisboa Aristocrática do Príncipe Real ao Camões, uma Pombalina entre o Chiado e a Baixa, uma Antiga da Mouraria a Alfama: RED - da Praça do Príncipe Real ao Largo do Camões; GREEN - do Largo do Chiado à Rua de Santa Justa; BLUE — das Escadinhas de São Cristóvão ao Largo de Santo António da Sé.

262 Homenageando os passos de Pessoa na Cidade, a proposta, com coordenação de Catherine da Silva, consistiu em criar uma marca, simultaneamente lúdica e poética, incitando à deambulação nocturna entre as peças do programa principal. Também AGTN, igualmente colectivo, procurou esta dimensão de comunicação urbana, porém numa linguagem porém menos bidimensional e mais envolvente - encenando vistas, bolsas espaciais ou pequenos elementos por forma a reter a atenção do passeante ao longo do percurso.

263 Cf. Fernandes, Samuel Roda; «Projecto Urbano Luzboa», in Luzboa - Lisboa Inventada pela Luz, p. 42.

264 Numa primeira versão idealizada do Evento, havia a intenção de ter mais 5-6 obras no circuito. 
indirecta- mas conscientemente procurou contribuir para um debate específico:

- os decisores foram alertados para a importância da concepção de planos de iluminação concebidos por especialistas;

- houve oportunidade de debater o binómio luz vs. segurança e desmistificar preconceitos e opiniões pouco esclarecidas;

- falou-se de luz na rua através de um percurso que retratou a história da cidade, oferecendo instalações artísticas que valorizaram os locais onde se instalaram;

- apelou-se acima de tudo a caminhar na noite, numa noite transfigurada.

\subsubsection{O habitar do espaço público - palavras, desenhos, tendas}

A Invenção de Lisboa, de Malek Abbou, consistiu na publicação de crónicas diárias num jornal diário, ao longo de todo o período da Bienal. Esta acção foi complementada por uma residência aberta no bar do piso térreo de um hotel, com o escritor lespecialista na relação entre arte e cidade) a receber os visitantes interessados em conhecê-lo, traço relacional da 'instalação' que alimentaria a sua escrita. Tratou-se de tirar partido, começando alguns dias antes da abertura oficial do Evento ${ }^{265}$, de um espaço público imaterial - os media para introduzir o logos poético na dinâmica comunicacional: Lisboa é um conto para crianças contado por uma ama. E esta noite, a ama contou-me que, aqui, uma Grécia secreta sobrevive à própria Grécia. Este eléctrico que desce para a Baixa, com seu único olho raiado de vermelho, não é mais do que Polifemo fugindo de Ulisses. ${ }^{266}$

Convidar um estrangeiro ${ }^{267}$ para tão delicada operação tirou partido da situação amorosa típica do confronto turístico, ampliando pela notória capacidade retórica do autor, que nos seus textos integra sempre noções de arte contemporânea e impressões existencialistas, aspectos meta-produtivos e elementos puramente informativos. Abbou foi o típico espectador-enamorado, convidado a realizar o seu 'trabalho' num escasso período ${ }^{268}$, sujeito a prazos e constrangimentos (a obrigatoriedade do envio diário dos textos), com a toda a tensão da oportunidade e da responsabilidade de ser a 'voz' do Evento num órgão de comunicação social de referência. Espécie de alter-ego - da curadoria, dos vários membros da equipa de projecto, do próprio público - esta personagem celebrou o kairos de uma forma explicitamente ensaística, plena de wit, relacional ${ }^{269}$. Nalgumas passagens, Abbou veiculou mesmo a teoria urbana por detrás da Bienal:

[...] com a noite por único tecto, e as fachadas dos prédios por únicos muros, as ruas lisboetas tornam-se na maior aventura do momento. / Esta noite, a rua vai adquirir uma dimensão experimental, em que a relação com nós mesmos e com a noite será questionada através das luzes da arte. Fazer a Luzboa é utilizar a noite como suporte de criação. O risco é o de uma teatralização espectacular da cidade que suprimisse a sua dimensão humana, mas vejo que a qualidade das intervenções é de molde a conjurá-lo totalmente. ${ }^{270}$

265 Como havia acontecido com Porque é que existe o ser em vez do Nada? de Maçãs de Carvalho para a LXCN.

266 Abbou, Malek; «A Invenção de Lisboa», in Lisboa Inventada pela Luz, p. 80.

267 Também nesta peça houve serendipidade, quando Abbou, que eu conhecera brevemente em Lyon por intermédio de Marie de Brugerolle, revela e sublinha, nos seus textos, um fascínio excepcional pela cidade de Lisboa. De resto, a ideia de inventar Lisboa, é a Abbou que devo.

268 Chamada de capa: Bienal da Luz transforma três bairros de Lisboa / Crónica de Malek Abbou / o artista francês que tem dez dias para perceber a cidade.

269 Foi publicitada a presença do escritor no seu hotel e este recebeu várias visitas do público.

270 Abbou, Malek; «A Invenção de Lisboa», in Lisboa Inventada pela Luz, p. 78. 
Explicita-se assim a consciência romântica da totalidade como mais do que um 'tema' sobre que se escreve (ou sobre a qual se elabora um projecto):

É assim que nasce a essência do meu trabalho, no acaso de um encontro. Não conheço melhor forma de ir unindo as palavras no que as mesmas designam e não vejo ouro modo de descrever o estranho sortilégio de Lisboa. Pois, talvez seja ela que me vai escrever, assim como um abalo telúrico rubrica um sismógrafo. ${ }^{271}$

Ao fim e ao cabo, a criticidade da peça estende-se ao papel da palavra nas artes editoriais (media, marketing); vários dos textos sugerem um fundo crítico que dá da comunicação de massas (erroneamente tida por 'comunicação social') o verdadeiro sentido de um encontro entre texto e mundo, e entre as vivências que entre mundo e texto se vão materializando, mais uma vez, como em Campos, com o prazer do corpo no coração da emoção. É Camões - Abbou refere-se à estátua do Vate, na Praça homónima - que me sussurra "Tens dez dias para medir a voltagem desta cidade". Sim, a sua voltagem e a sua capacidade para iluminar este corpo que é o meu e que não aspira a mais do que a ver e a mover-se. ${ }^{272}$

Jana Matejkova ${ }^{273}$ criou um labirinto de traços de luz vermelha, evocando o pulsar de um coração, numa configuração de coração rizomático ${ }^{274}$ que evocava um intrincado electrocardiograma da cidade. A peça, no projecto inicial, era um labirinto linear, a aplicar a um gradeamento de metal dos tipicamente utilizados para delimitar zonas de obras e curso, gradeamento esse a colocar ao longo do passeio público, no Jardim do Príncipe Real, que acompanha a movimentada Rua da Escola Politécnica; mas a artista, ao chegar, interessar-se-ia por um aspecto mais preciso do locus e adaptaria a peça à presença física de uma monumental gardénia, desenvolvendo-se in situ e organicamente em torno da mesma, e da vivência quotidiana do Café-restaurante anexo, em cujos vidros se veria dinamicamente reflectida ${ }^{275}$. Ao som estranho de uma banda sonora realizada a partir da gravação de sons do coração da própria artista, esta intervenção revelou-se um ponto de encontro para muitos dos participantes e visitantes. Jana convidou então uma performer ${ }^{276}$ a interagir com a escultura, sublinhando ou desvelando a potencialidade lúdica mas também meta-sagrada daquela estrutura que, na sua aparente fragilidade era abordada como um desafiante labirinto intocável (metáfora da intocabilidade da obra de arte?). Isto é, a artista interpreta o espaço urbano não apenas nos seus valores (a árvore, o café e a sua luz, os fluxos), como nas hipóteses de fruição, e tudo numa durée convivial, comprovada pela intensidade das relações sociais despoletadas pela atmosfera criada, de uma graciosa communitas provisória:

o coração amplificado de Jana Matejkova que redescubro em todas as suas dimensões. Seria errado vê-lo apenas como não sendo mais do que um trabalho de forma, como uma representação da vida, quando ele é o meio mais aventurosa de a atingir. O coração oferecido por Jana pede-nos para o ouvirmos. Ele escuta-se. [...] Na verdade, quando não representa, antes do mais, a oportunidade de nos curar da gravidade, a arte não nos traz notícias novas do mundo. ${ }^{277}$

271 Idem.

272 Idem, p. 78.

273 Com a colaboração de Carlos de Abreu.

274 Abbou, p. 80.

275 Miguel Mouta Faro; «Uma associação de ideias», in Luzboa - Lisboa Inventada pela Luz, p. 54.

276 Márcia Lança, com música de Dídio Pestana, Marek Bradác e Petr Vysohlíd. Baseando-se no butô japonês, demonstrou virtualidades da peça até aí apenas imaginadas ou em potencia, conseguindo a performer a proeza de dançar por entre o emaranhado de cordões de luz.

277 Abbou, p. 84. 
Igualmente performativo no processo de montagem e apropriação pelos visitantes, Abrigo- me de André Banha consistiu na construção de um abrigo, íntimo, mas público ${ }^{278}$, em madeira, de acesso livre, remetendo para a memória infantil da 'casa na árvore'. O jovem autor, nesta sua primeira experiência num espaço público, teve de enfrentar enormes dificuldades na execução da obra, inicialmente rejeitada pelos frequentadores habituais do Largo, alguns deles marginais. Esta viria porém a ser aceite, e as pessoas puderam ter o prazer de ver a cidade de um novo - ainda que efémero - posto de observação. Releve-se ainda o facto de que a peça era também visitável durante o dia, antes de anoitecer.

Demo_polis pelos MOOV279, num sentido semelhante, propôs um espaço de contaminação social em que a figura do alojamento improvisado e temporário explora o contraste entre um modo de vida consolidado, mas egoísta, e um modo de vida precário mas gerador de cruzamentos de indivíduos, crenças, culturas. ${ }^{280}$ No projecto desenvolvido pelo colectivo de arquitectos no Pátio Garrett, é inerente uma atitude polémica e a tentativa de construção de um espaço de contacto social, materializado por quinze tendas temáticas, cada uma com um programa específico que redundava numa panóplia de ambientes surpreendentes. $A$ instalação foi das mais visitadas, reunindo consenso quanto à sua pertinência conceptual e humor. Toda uma estética de resistência jogou cinicamente com a dimensão comunicacional (design gráfico, estética (ow cost), a instalação chamando a atenção pela manipulação extremamente depurada das emoções sociais. Da desproporcional cablagem à vista lencenação quase patética do provisório) à personificação da cada tenda, da cumplicidade estabelecida com os espectadores (que chegou à distribuição gratuita de champagne) ao debate acerca do espaço e da arquitectura que intersticialmente ia sendo promovido pela situação criada, pode dizer-se que foi outra das peças emblemáticas da Bienal ${ }^{281}$. Isto porque ao ethos convivial, de abertura para o diálogo, táctico dos criadores, se justapunha um logos de densidade e de intensidade que, rapidamente, criaram as condições para uma das experiências mais graciosas da Bienal, isto é, onde a consciência dos problemas não era dissociável do prazer inusitado do estar ali.

\subsubsection{Imagens e corpos: flores interactivas, a lua à mão, rostos cerrados, mãos estendidas}

Sur Nature, de Miguel Chevalier ${ }^{282}$, apresentou-se como um luxuriante jardim virtual, simbiose entre o desenho urbano e a arquitectura, interrogando os transeuntes de forma interactiva. Sobre a fachada exterior do edifício do Centro Comercial do Chiado - encimada pelo ex-libris da Baixa que é o logótipo dos Armazéns do Chiado, foram projectadas uma série de imagens digitais, elaboradas por meio do software Music2eye, especificamente concebido para a criação deste projecto. $O$ resultado surpreendeu pela imediaticidade com

278 Faro, Miguel Mouta; «Uma associação de ideias», in Luzboa - Lisboa Inventada pela Luz, p. 54.

279 Moov é uma plataforma multidisciplinar de arquitectura, design, artes visuais e performance. Fundada por António Louro, José Niza e João Calhau, em 2003. A sua participação foi sugerida por Miguel Faro.

280 Moov, in Luzboa - Lisboa Inventada pela Luz, Extra]muros[, Lisboa, 2007.

281 Seria seleccionada para Prémio de Arquitectura, meses depois.

282 Miguel Chevalier (México, 1959) é reconhecido como um dos pioneiros da arte virtual e digital, investigando desde 1982, os fluxos e as redes subjacentes à sociedade contemporânea. 
que as 'plantas' - desenhos de síntese em tempo real e não meras projecções vídeo reagiam aos fluxos urbanos, nomeadamente ao dobrarem-se à passagem de viaturas ou grupos mais numerosas de visitantes, à porta dos Armazéns. Esta foi uma intervenção cuja tecnologia foi apresentada em Portugal pela primeira vez.

De forma ainda mais icónica, Ubiquity Variations Module de Bruno Peinado ${ }^{283}$, no Largo de São Carlos, era

[...] grandeza e enigma condensados num objecto simultaneamente reconhecível e estranho, que adquiriu a beleza e o estatuto de uma jóia - ou pelo menos de um original mobiliário urbano -, ao reforçar a elegância e o significado de um espaço urbano particular, uma das praças mais nobres da Capital. Esta foi outra das peças mais fotografadas e referenciadas nos jornais, e também, certamente, uma das mais físicas e mais atractivas, pois foi frequente os visitantes não resistirem a 'tocar a lua'.284

A surreal instalação ofereceu/exigiu aos transeuntes uma disponibilidade para a imaginação. Lune é, ao fim e ao cabo, aquela peça fotogénica que não abdica que manter para si uma forma serena de desassossego. ${ }^{285}$ Ora até que ponto teria sido previsível o sucesso de uma obra que muitos achariam 'fácil' e outros um momento de sublime poesia? Aparentemente tão discreta quanto autocontida, a obra oferece, no espaço público, uma proximidade inusitada com a arte, convocando o irreprimível prazer do contacto, E assim, alguns pormaiores' determinam toda uma problematizam contextual, primeiro, no facto singelo de que o 'balão' tinha um lado não impresso (a face oculta da Lua?), colocando em causa o lapenas aparente) realismo da imagem; segundo a escolha do ponto exacto para a colocação da obra, que ali como que exigia ser, enquanto arte efémera e comunicacional, de temática directa, um contraponto inequívoco do distante 'mundo da arte' tal como representado pela Ópera e o seu Teatro Nacional.

Telas translúcidas animadas pelo vento, projecções de imagens realizadas a partir da técnica da 'camera obscura'; retratos revelando as personagens, cantando separadamente um mesmo fado ${ }^{286}$. Cada uma das vozes, gravada em fita, foi depois alterada para se ajustar às restantes, formando o coro. Era também possível ouvir as vozes separadamente, ecoando do interior das entradas das casas. Esta foi uma instalação dos belgas Het Pakt ${ }^{287}$ em que o canto de moradores e colaboradores da Bienal, aliado às imagens dos seus rostos de olhos fechados ${ }^{288}$, formaram um melancólico coro urbano. A densidade dos elementos e o cuidado estrutural - uma geometria de cabos que tirava as linhas invisíveis do espaço de intervenção - conduziram as emoções para uma experiência perturbante, angustiante mesmo, profunda e de certa forma, mais uma vez, a-discursiva. Tributo ao Fado e ao seu significado colectivo, a peça contou durante a produção com o envolvimento da comunidade local. Se houve peça

283 Bruno Peinado (1970), quando realiza intervenções urbanas, busca um diálogo com imagens-chave da história da arte e da sociedade contemporânea.

284 Caeiro, Mário; in Luzboa - Lisboa Inventada pela Luz, Lisboa, 2007, p. 104.

285 Iles, Anthony; «Luzboa, Lisboa, Portugal», in Luzboa - Lisboa Inventada pela Luz, Lisboa, 2007, p. 104.

286 Os célebres e populares «Fado do Cacilheiro» e «Não Venhas Tarde».

287 Colectivo formado por Jan Bossier, Jef Byttebier e Lieven Neirinck, desenvolvem engenhosas instalações multimédia, recorrendo a soluções performativas interactivas que incluem o vídeo, a fotografia, a projecção, o grafismo.

288 Plano aproxiado, captados por pin hole, projectados por vai de slides sobre panos brancos esvoaçando na brisa. 
que conseguiu recolher a unanimidade quanto à sua originalidade e qualidade, foi esta ${ }^{289}$. Abbou transmite o essencial da experiência:

Confesso que ainda tenho uma noção imprecisa das fronteiras entre estes bairros, pelo que não poderei dizer por onde
passei até ouvir esta voz por detrás de uma porta das Escadinhas de São Cristóvão, como um queixume lento a elevar-
-se até aos retratos suspensos que demarcam a passagem. Desta vez, Lisboa implora a alguém que não venha tarde.
[...] O apelo chegava-me como a rebentação das ondas, como uma maré, como um vagaroso bailado de neve nos
ouvidos... e os transeuntes que vinham pouco a pousar nos degraus prolongavam a escuta num silêncio emprestado
às banquisas. Sem dúvida que todos nós imaginávamos a emoção sentida pelo primeiro homem que ouviu estas pala-
vras. O Fado Morgana do Het Pakt faz-me uma vez mais pensar que nem todo o peso de uma biblioteca me ajudará
tanto como o degrau de escada na noite a descobrir onde estamos no tempo, com estes medos, estes desejos, estes an-
seios que batem no mais fundo de nós e nos apertam o estômago para melhor fazer subir o coração até à garganta. 290

Abbou concluirá a sua nota sobre os Het Pakt com a ideia de que a cidade é um estado de corpo: ${ }^{291} \mathrm{O}$ coro convidou à deambulação por esse espaço, onde se descobria a individualidade de cada uma das vozes. Esta dinâmica foi diferente da dinâmica comum normalmente associada às cidades. ${ }^{292} \mathrm{~A}$ peça habitou assim o espaço, criando um momento que celebraria a alma de um 'coro urbano' de vozes individuais, numa espécie de consciência-memória colectiva. Proporcionando a partilha de emoções profundas, a peça permitiu, até pelo carácter de silencioso anfiteatro do site escolhido, um raro tipo de fusão entre espectador e obra. Invariavelmente, a reacção foi de enorme emotivo respeito, senão comoção, uma vez que foi reconhecida à intervenção a capacidade de 'dizer Lisboa'.

Javier Núñez Gasco apresentou Misérias Ilimitadas, ${ }^{293}$ que consistiu na constituição e gestão de uma empresa, com o nome de Misérias llimitadas, Lda. Contratou pessoas para pedir esmola (actividade ilícita), recorrendo à electricidade pública e sem descurar todas as obrigações relativas ao pagamento dos devidos impostos. Primeiras impressões nos visitantes: pedintes equipados com placas iluminadas foram dispostos em artérias de grande fluxo pedonal. ${ }^{294} \mathrm{~A}$ sua presença provocadora - uma vez que os típicos cartões manuscritos eram dispendiosos dispositivos em néon vermelho - levantou questões relacionadas com a exclusão, ${ }^{295}$ um

289 Cf. Becker, Kai; O lado escuro da 'Cidade Branca'», in Lisboa Inventada pela Luz, p. 285.

290 Abbou, Malek; «A Invenção de Lisboa», in Lisboa Inventada pela Luz, p. 82

291 Abbou, p. 82.

292 Faro, Miguel Mouta; «Uma associação de ideias», in Luzboa - Lisboa Inventada pela Luz, Extra]muros[, Lisboa, 2007, p. 4.

293 Cf. Luzboa - Lisboa Inventada pela Luz, Extra]muros[, Lisboa, 2007

294 Chiado, Rua do Carmo, Rua do Calhariz, Rua da Misericórdia e Rua Augusta.

295 Conceito-chave: questionar de problemáticas sociais complexas, relacionadas com a Justiça Social e o Emprego, por meio de um interface em que a componente artística se dilui em mecanismos de cariz empresarial. A obra, vincadamente processual, consistiu primeiramente na constituição de uma empresa, com o nome de Misérias Ilimitadas Lda., procedendo à contratação de pessoas - mendigos - a partir de um anúncios de imprensa publicados em jornais de âmbito nacional. Os anúncios referiam tratar-se de uma multinacional de mendicidade - actividade proibida pela Lei Portuguesa. Numa segunda fase, uma colaboradora do artista recebeu os telefonemas e ajudou no processo de pré-selecção dos candidatos. Seria marcada uma entrevista, realizada no espaço público (Calhariz), altura em que foram entregues aos candidatos questionários com uma série de perguntas e os pré-requisitos necessários para que pudessem vir a ser contratados. Após uma fotografia colectiva realizada na rua, com todos os candidatos sentados no chão, de mão estendida, costas contra a parede, foram seleccionadas três pessoas, que vieram a ser contratadas pela recentemente formada empresa. Foi então realizado um workshop com a intenção de definir o comportamento dos 'actores' contratados, sendo-lhes finalmente entregues, a cada um, uma grande mala em couro negro e os respectivos dísticos apelando à caridade dos transeuntes, executados em néon vermelho. $\mathrm{O}$ trabalho dos jovens consistiu na mendicidade durante dez dias, ao longo de seis horas diárias, com intervalo para jantar. 
A uma dimensão colaborativa e táctica (negociámos o número de mendigos inicialmente previstos até chegarmos ao número mínimo de três; estudámos conjuntamente os locais dos mendigos, monitorizando os fluxos dos transeuntes). Misérias é antes do mais uma peça-estrutura com capacidade estratégica ao nivel da sua interrelação com os domínios não apenas da arte, mas dos Media ou do mero quotidiano da Baixa de uma Capital. ${ }^{297}$ Tal carácter é eminentemente o de uma arte intersticial nas estratégias de ocupação dos espaços, difusa nas consequências comunicacionais, mas absolutamente controlada nos seus limites e estruturas formais. ${ }^{298} \mathrm{O}$ impacto nos media foi aliás enorme, gerando notícias e artigos de opinião nas contracapas de vários jornais diários e destaques em algumas revistas ${ }^{299}$. A ironia e a humanidade ${ }^{300}$ da obra marcariam a Bienal pela radicalidade da abordagem do tema do Espaço Público, podendo dizer-se que foi das intervenções que melhor deu continuidade ao trabalho mais 'antagonista' da LXCN: A prática artística de Javier Nuñez Gasco investiga empiricamente, através de processos performativos, as patologias do meio social. Nuñez Gasco sente-se responsável pela consciência colectiva, cuja exploração integral, disfarçada de ironia, é o objecto da sua vida e da sua obra. Abbou di-lo-á com outro enfoque: Para além da mensagem que manifesta, o projecto de Núñes Gasco é um combate sempre activo, uma guerrilha táctica contra o peso ubíquo de uma máquina universal de triturar o humano. ${ }^{301}$ No catálogo mencionei mesmo, no que já era uma antevisão da leitura iminente de Lefèbvre, a sua táctica de sobrevivência moral num mundo absurdo e alienado ${ }^{302}$,

[...] e se em outras obras, Núñez Gasco tem colocado em jogo a sua imagem, a sua saúde, a sua identidade, o seu corpo, o seu equilíbrio, o seu ser [...] obras que interrogam limites por via de uma disponibilidade para a imolação no palco social, em Misérias a operação estética, pela expressão pública, directa, senão explosiva, apela ao pathos referido por Abbou por via de um típico mal-estar quando somos interrogados no campo da ética, com todas as suas implicações, nomeadamente comportamentais e jurídicas. ${ }^{303}$

Profundamente dependente dos media - essa hidra do 'baixo'- a peça é ao mesmo tempo um território de liberdade, consciência e autonomia. Resiliente ao tempo-écran que nos cerca.

Só que... algumas obras, como esta de Gasco, evitam o logro do chamamento - o 'vem' que Derrida outorga à Desconstrução ou que subjaz a muita arte participativa - e conseguem ultrapassar a 'pose' ou bandeira para se converterem em cerimónias, rituais geradores de experiência, pulverizando a rotina estética ${ }^{304}$, esa hibernación pavorosa en la que están localizadas muchas obras. ${ }^{305}$ Obras como esta de Núñez Gasco celebram portanto o Espaço Público, enquanto território urbano e conceito existencial. Porém, num registo que não o da mera teatralização do social,

296 Caeiro, Mário, «Gasco, ou a estátua de ferro a arder», in Luzboa - Lisboa Inventada pela Luz, p. 99

297 Idem.

298 Idem, p. 100.

299 No dia em que a Luzboa era chamada de capa nos jornais de referência, estes 'mendigos profissionais' faziam o pleno das contracapas dos jornais sensacionalistas.

300 Abbou, p. 85.

301 Idem.

302 Caeiro, Mário, «Gasco, ou a estátua de ferro a arder», in Luzboa - Lisboa Inventada pela Luz, p. 100.

303 Idem.

304 Inclusive a dos funcionários bancários, fiscais das finanças, forças de segurança ou técnicos camarários com quem o artista e a Organização da Bienal mantiveram contactos.

305 Flórez, Fernando Castro; «El toca-cojones y el teatro integral de Oklahoma», Javier Nuñes Gasco, DA2 Domus Artium 2002, Salamanca, 2007. 
mas de concentração em fluxo, em aberto e em progresso, da própria plasticidade desse social. Recusam o conforto do proscénio [da Arte], dispõem-se como reformulação contemporânea do Realismo. Neste caso, no quadro do que Javier denomina ,ready made institucional'.

Para a Luzboa, foi acima de tudo uma experiência directa do urbano e das suas consequências, um exercício de contacto com o Outro Imais que o Outro habitual da relação classe dominante / público cultural, não deixo de destacar a importância de inúmeros transeuntes terem tido contacto com o Outro da Arte que foi o próprio Núñez Gasco em acção]. Uma iluminação pois, fugaz, frágil, contestada e inquirida a partir de várias esferas do poder executivo da cidade, mas recebida com absoluto fair-play e curiosidade natural por parte de quem mais interessava atingir: o espectador comum, próximo, em relação. ${ }^{306}$

Simultaneamente hiper-realista e abstracto, ${ }^{307}$ dotado de uma gravidade genial - uma graça veloz $^{308}$ - este tipo de obra é como [...] rizoma em volta da verdade, nomeando tão somente os dados limitados do discurso e da gramática social, num murmúrio, cujo eco, porém, não cessa. ${ }^{309}$

\subsection{4 Écrans em ponto crítico}

Estreada na Luzboa em 2006, Light, Color and no Sound havia sido originalmente pensada para ser retroprojectada numa montra de uma ruela. Na peça, Pedro Cabral Santo propôe uma homenagem aos poetas americanos Adrienne Rich, Bob Kaufman, TS Elliot e Amiri Baraka, autores que têm em comum a capacidade de criar atmosferas polisensoriais e a atenção que dispensam à dimensão social, denunciando injustiças, pobreza e exclusão. As suas cores fortes, com a função de atrair a atenção de quem passa, a literalidade da solução audiovisual - o vídeo são essencialmente barras de cor com texto, poesias que passam tipo scroll - sugerem tratar-se de um dispositivo publicitário, ainda que em local inesperado. Mas não havendo som, apenas cor, luz e poesia, a tensão que a peça inscreve é dupla: entre a beleza dos laivos de cor que banham as fachadas em volta; depois a tensão entre a ideia de leitura lafinal, com paciência, era possível ir lendo excertos, senão a totalidade dos poemas) e a de imagem (evidente no registo televisivo, assim reflectindo a hipótese de uma crítica à era mediática e às suas simultaneidades informativas alienantes). Entretanto, muito próximo, Double Print, de Carlos Sousa, ${ }^{310}$ consistiu na projecção de dois pequenos filmes sucessivos sobre um muro lateral do Mercado do Chão do Loureiro (Bar das Imagens). A elaboração das imagens teve origem na desconstrução mecânica de um objecto quotidiano - uma impressora de jacto de tinta - e sua transformação em interface de efeitos de som e luz, mas a relação entre as dimensões da imagem e o écran luma parede) não conseguiram a integração arquitectural da peça de Cabral Santo. Em contraste, a obra de Gérald Petit encenava e pervertia o dispositivo mediático (publicitário), num registo kitsch-pop. Usualmente, as fotografias de Gerald Petit, ${ }^{311}$ entre as convenções do retrato e a ficção, reflectem um encontro com personagens num quadro de ambivalência: verdade

306 Caeiro, Mário, «Gasco, ou a estátua de ferro a arder», in Luzboa - Lisboa Inventada pela Luz, p. 100.

307 Delfim Sardo, in Javier Nuñes Gasco, DA2 Domus Artium 2002, Salamanca, 2007.

308 Caeiro, Mário, «Gasco, ou a estátua de ferro a arder», in Luzboa - Lisboa Inventada pela Luz, p. 100.

309 Idem. Misérias Ilimitadas, Lda., a empresa, há-de se expandir, internacionalizar-se, vender acções, cotar-se na bolsa, empregar jovens com 'boa apresentação' que busquem um futuro melhor. Numa Bienal, como na Vida perto de si.

310 Carlos Sousa é estudante finalista de Artes Plásticas da ESAD Escola Superior de Artes e Design das Caldas da Rainha.

311 Francês, Gerald Petit nasceu em 1973, de mãe portuguesa. O seu trabalho é um teste às modalidades da aparência, da geração à captação de imagens. O enigma da identidade é elemento unificador da sua obra. 
e/ou ilusão. Ora, Nightshot \#2, Instalada no ponto alto do Largo das Portas do Sol, Mar da Palha em fundo, foi muito mais do que uma caixa de luz com estrelas pulsando dinamicamente. Algo no estatuo da imagem remetia para uma homenagem à Humanidade e ao Universo; mas também a qualquer pessoa - a modelo foi escolhida após casting público - e ao céu. De facto, $O$ sistema de consumo que se apropria do espaço público, o molda e desenha, foi interrogado no gigante outdoor de Gerald Petit. O outdoor, elemento de mobiliário urbano tão característico das cidades capitalistas, aqui não apresentou um produto vendável, mas sim uma possibilidade de sonho. ${ }^{312}$ Questão central na morfologia do urbano e em particular relativa ao problema de arte e da comunicação enquanto comunicação no dispositivo 'cidade afluente', resta saber em que medida a potencialidade crítica (nível secundário, crítica do excesso de luz nos céus de Lisboa) terá sido suplantada pela evasão onírica ou a contemplação estética. Neste peça surgiu, de qualquer forma, a questão do género e sua comunicação no espaço público, aqui exponenciada por uma dimensão erótica da imagem: nas visitas guiadas, era frequente eclodirem debates acerca do enquadramento da imagem, que o artista soube colocar num ponto crítico do peito da modelo retratada ${ }^{313}$.

\subsubsection{Indoor/outdoor: intervenções de câmara, o mar ao largo}

Bruno Jamaica, ${ }^{314}$ apresentou A Gaiola do Pássaro tem Luz Artificial: longos elásticos negros, iluminados por projectores coloridos, sugerindo a forma de um sólido suspenso do tecto, afectando a área de entrada do bar-sala de concertos Santiago Alquimista. Apelativa e com algum carácter lúdico, a peça podia ser tocada. Mesmo ao lado, nas paredes de outro canto no átrio de entrada, um desenho de luz em lento movimento, por Marisa Teixeira + Filipe Frazão. ${ }^{315}$ A programação deste desenho, por meio de um projector vídeo com luz localizada, revelava, destruía e de novo reconstruía os fragmentos, lgestos lumínicos dinâmicos, desvelando a presença física do próprio desenho preparatório, por sua vez inspirado nos detalhes arquitectónicos do local). Esta intervenção, extremamente subtil, foi claramente capaz de reflectir sobre a Luz (e a sombra) de forma profunda, revelando um enorme rigor na abordagem do espaço (e do tempo) expositivo. Na economia da Luzboa estas peças (como Virgínia Mota em 2004) ajudam a estabelecer momentos de pausa convivial entre intervenções de maior escala; em si, não assumem muitas das premissas da arte pública (desde logo porque estão mais constrangidas pelo lugar que ocupam),,316 mas são oportunidades para jovens criadores testarem os limites das suas soluções.

312 Faro, Miguel Mouta; «Uma associação de ideias», in Luzboa - Lisboa Inventada pela Luz, p. 55. Note-se porém que, uns meses depois da Luzboa, Petit expunha uma fotografia da mesma rapariga, em escala pequena, em Galeria de arte, pondo-se a questão de a obra ser aí ainda a mesma (ou ter o mesmo valor), uma vez integrada no circuito artístico tradicional.

313 Para muitos homens, teria sido desejável abrir o enquadramento um pouco mais para baixo; para muitas mulheres, teria sido preferível subi-lo...

$314 \mathrm{Na}$ altura, finalista da ESAD.cr, Bruno Jamaica reinventa frequentemente a sua/nossa relação com um lugar, por meio da instalação de fitas elásticas esticadas.

315 Marisa Teixeira e Filipe Frazão, à época estudantes na ESAD.cr, trabalham frequentemente em conjunto, em projectos site-specific.

316 No entanto, a intervenção de Jamaica soube enquadrar-se com a funcionalidade de um espaço nocturno frequentado, de tal maneira que os seus proprietários solicitaram a permanência da obra. 
Metallocallmorfose, de, Adriana Sá ${ }^{+}$Hugo Barbosa, consistiu numa itha de mar sonoro-visual no meio da cidade, gerada por um dispositivo tecnológico - o 'instrumento de (vídeo) luz sonora' - que Adriana Sá tem adaptado a múltiplas situações performativas. Para a Luzboa, Sá determinou uma paisagem sonora (chuva, mar, tempestade) mediante imagens vídeo (códigos náuticos) projectadas com recurso a sensores de luz. A existência desta 'ilha' culminou com uma performance-concerto, decorrida no último dia da Bienal. Cítaras, trompete, trombone, guitarra, dobro e electrónica sobrepuram-se, desvanecendo-se e entrelaçando-se com os sugestivos fragmentos marítimos. A obra foi criteriosamente concebida e desenhada para tirar partido da forma urbana de um pequeno largo que funcionava como momento cenográfico. Perto de Metallocallmorfose, André Gonçalves ${ }^{317}$ propôs os seus Ressonant Objects. No Largo de Sto. António, iluminado de azul, um conjunto de globos brancos pulsava, reagindo ao fluxo viário. Intervenção muito discreta, cada globo funcionou como um micro-ambiente que, emitindo som, criava um espaço próprio e proporcionava luz. Não terá correspondido à potencialidade que se esperava desta peça na exacta medida em que o escasso número de objectos não permitia uma efectiva ocupação do espaço da praça ${ }^{318}$. Nesta peça como em Parada de Luzes, por Fernando César Vieira + Cynthia del Mastro ${ }^{319}$, há um desfasamento entre as expectativas que as obras criam e a sua experiência concreta. Em Vieira e del Mastro, como em Gonçalves, tratou-se de um problema de fulgor lumínico, escala da intervenção e comunicação deficiente. Estava previsto que personagens vestidas de luz interpelassem os transeuntes com a sua dança sensual, convidando-os a percorrer a Bienal. A verdade é que a função festiva se viu comprometida por um défice de garra, animação. Não muito longe destes blind spots da Luzboa, no imponente Terreiro do Paço, Rigo ${ }^{320}$, propôs a reunião num contentor, por natureza itinerante, de uma colecção de triciclos ${ }^{321}$. Em The Tricycle Museum, que, ao nível institucional, resultou de uma parceria importante (ZDB), a Bienal pareceu apontar de novo a uma vertente social e reflexiva; mas a implantação desta peça fora do percurso RGB foi uma nota dissonante ${ }^{322}$.

Na Cerimónia inaugural, um happening marcou a formalidade do momento. Anthony lles chega a apelidar o evento de pomposo, não fosse a performance humorística e totalmente irreconciliável do Ensemble JER transportar o ambiente para outra artisticidade. Nesse momento e depois em mais duas actuações (uma em cada circuito), trariam a reportório

317 André Gonçalves desenvolve desde 1998 aplicações audiovisuais, utilizando-as em projectos de artes plásticas, música, vídeo, instalação e performance.

318 Situação que resultou quer da incapacidade do artista responder aos constrangimentos que lhe foram colocados, mas também da curadoria, uma vez que a peça estava obrigada a estar onde porventura talvez não tivesse meios para 'brilhar' - num final de percurso em decrescendo, mormente depois do clímax de Gerald Petit.

319 Nascidos no Brasil, Fernando e Cynthia são set designers radicados na Alemanha.

320 Original da Madeira, Rigo (Ricardo Gouveia) tem desenvolvido um considerável trabalho a nível nacional e internacional, nomeadamente no território urbano de São Francisco.

321 Enriquecida ao longo do próprio processo de itinerância (depois de Taiwan e Lisboa, seguir-se-iam Cuba ou a Rússia), no que o artista considera um acervo de criatividade, ingenuidade e engenho.

322 Nunca tendo havido por parte do artista um real entrosamento com a Bienal, e dada a disparidade entre as agendas e mecanismos de produção de cultura entre a ZDB e a Extra]muros[, a obra, pelo menos ao nível do seu significado urbano, não ganhou nada em ser apresentada no contexto Luzboa, assim como a Luzboa não ganhou com a sua inclusão. 
contemporâneo (Steve Reich) um travo cénico e performativo. Os músicos apresentaram-se com narizes de porco, smoking vermelho e capacete de construção civil com lâmpadas, suscitando uma dimensão cómica, e tiraram partido de pontos estrategicamente conviviais do percurso - esplanadas ao Largo de São Carlos, Miradouro das Portas do Sol, Jardim do príncipe Real. Nesses momentos, a Luzboa activou 'cenas urbanas', com a música pontuando a figura sensual de Petit diante da paisagem a perder de vista ou a atmosfera sensualmente abstracta do labirinto de Jana Matejkova. Num registo de fantasia complementar, Ceci n'est pas un bus, pelos Het Pakt, realizado durante várias noites, levou um número limitado de passageiros, por marcação, a assistir a uma intervenção fora do vulgar - embora se tratasse, aparentemente, de apenas uma visita de visita guiada de autocarro. Ceci n'est pas un bus foi, precisamente, uma viagem coreografada ao detalhe, durante parte da qual os passageiros se viram conduzidos com os olhos vendados; chegados a um local pré-determinado - no Centro Cultural de Belém - eram surpreendidos, tiradas as vendas, com um espectáculo de vídeo-arte projectado em vários écrans que rodeavam integralmente o autocarro. No interior, a sensação de imersão nas cenas era potenciada pelo dinamismo das imagens. Em termos de resposta do público, outro grande sucesso o factor fundamental foi a entrega deliberada de cada espectador à emoção, o abandono a uma experiência totalmente radical do passar na cidade (neste caso com o transporte público a levar-nos através do (e para o) estranho lugar da arte).

\subsubsection{Luzboa '06 - Balanço}

A Luzboa 2006 contou com mais de 500000 visitantes e assinalável recepção por parte da comunicação social. O conceito foi um legítimo modelo de intervenção cultural urbana que, por meio da iluminação pública e intervenções artísticas, poderia contribuir para uma requalificação do Espaço Público da Capital. Por outro lado, Luzboa demonstrou que a arte e a cultura aspiram por vezes a mobilizar sectores da cidade para a importância de questões abrangentes (no caso, a iluminação artificial e a sua relação com vectores estruturantes da cidade. ${ }^{323}$ Mas esta visão de um futuro urbano não tem facilidade em acertar o passo com dinâmicas político-partidárias e de diferentes visões do desenvolvimento urbano pelo que, face à sua ambição, talvez a Luzboa tenha proposto uma ilusão (utópica) algo desligada da realidade sócio-cultural do País. ${ }^{324}$ Entendida como ideia-semente, a Luz foi porém decidida acção cultural crítica e parece ser esse, anos depois, o seu contributo para a vida social.

Na comparação entre as duas Luzboas, a tensão entre a ideia de percurso (2006) e constelação (2004) seria frequentemente equacionada. Por outro lado, deu para entender que o predomínio de instalações site-specific num festival é quase uma condição obrigatória para que haja sucesso na relação entre obra e espaço público. ${ }^{325}$ Tal como acontecera com a LXCN e os Sinais, a Luzboa afirmou-se igualmente como evento transdisciplinar. A sua afirmação

323 Urbanismo, arquitectura, arte pública, espaço público, sustentabilidade, cidadania e qualidade de vida, e transversalmente, a Identidade Contemporânea da cidade de Lisboa).

324 A própria Extra]muros[ encerra a actividade no final do Evento.

3250 que, parecendo evidente, nem sempre é opção primordial na lógica dos festivais e em particular de alguns festivais de luz que, sob a capa do site specific, acabam por repetir ad eternum soluções decorativas. 
envereda por caminhos de intervenção urbanística sustentados por contributos conceptuais, técnicos e científicos múltiplos, sendo a arte, por natureza comunicativa, uma oportunidade fundamental para aglutinar à sua volta conhecimentos e trocas de experiências úteis para o posterior desenvolvimento da própria Cidade. O contributo de urbanistas, geógrafos, historiadores, artistas, filósofos, designers de iluminação, engenheiros electrotécnicos, mais do que um todo incoerente de opiniões, revelou-se um discurso válido e colectivamente legitimado, empenhado em motivar os decisores do meio urbano relativamente à melhoria da lluminação Pública com um papel claramente reservado à 'Arte da Luz'. Coloca-se assim a questão de como repetir a magia destes encontros, quando cada nova oportunidade tem novos limites e constrangimentos. Isto é, como e com que sentido é que cada experiência vivida processualmente - contexto, conceito, intervenção, experiência - se pode transportar, dinâmica e vitalmente, para novas ocasiões?

A história de duas Lisboas é finalmente também a história de um conjunto de dilemas cada vez mais difíceis de gerir: a relação entre arte e financiamento/patrocínio tem-se complexificado exponencialmente; a relação com os media tem-se revelado determinante (eventos aferidos pela sua capacidade de penetração no mercado mediático); a crescente profissionalização das equipas aponta para uma abandono do discurso do acontecimento (ingenuidade) para se adoptar o do evento (indústria); a própria categoria de Espaço Público revela debilidades instrumentais na cidade pós-industrial. Estas são apenas algumas das questões levantadas no final da experiência Luzboa. Os eventos em que me envolvi a seguir (Skyway), não sendo capazes de lhes dar respostas definidas, procuraram uma economia de escala e um cinismo que de alguma forma calibram o investimento (a todos os níveis) nos projectos e ao menos tempo procuram criar expectativas de uma forma menos enfática e mais 'realista'. De qualquer forma, com a Luzboa, enquanto desenvolvimento do Nada e dos Sinais, senti que evoluiu a consciência do que serão 'boas práticas'326 — da iluminação criativa, do espaço urbano, da liberdade característica da arte - e portanto as possibilidades retóricas de qualquer acção futura. A ideia de Projecto Urbano consolidou-se, porém abrindo-se aos inputs mais improváveis (já não apenas arquitectónicos ou urbanísticos) lá está, de acordo com cada nova oportunidade. Isto é, a arte pode permanecer autónoma em muitas das suas premissas, mas igualmente manter um diálogo com as decisões acerca da vida social que a torna inevitável parceira de uma cidadania tota ${ }^{127}$. Isto tendo em conta que entender tal cidade fora das questões da vida na forma urbana pode ser um erro de análise a evitar. É neste sentido que as palavras de Miguel Faro apontavam: a Luzboa 2006 é mais do que uma simples apresentação de intervenções artísticas cuidadosamente implantadas no espaço público. Este evento é em si mesmo uma obra com linguagem própria, resultante de um leque de contribuições das mais diversas áreas. ${ }^{328} \mathrm{E}$ Faro 'recua' - ou 'avança' - até à questão do espaço público para estabelecer um núcleo logo-ético da acção desenvolvida: $A$

326 Entre obras com interesse para a área da Luz e da lluminação, destaco, no quadro da preparação da Luzboa, $A$ Luz e a Paisagem de Roger Narboni, recolha de projectos de iluminação ambiental, profusamente ilustrada, editada por ocasião do seminário internacional Desenhar a Luz.

327 E esta evolui, nomeadamente na esfera dos projectistas e decisores. Provam-no as iluminações recentes no Jardim de São Pedro de Alcântara ou Princípe Real (já de luz branca e não amarela), que fazem parte de um continuum do projecto urbano colectivo de Lisboa (de certa forma como Argan sugere, enquanto obra de arte anónima e total).

328 Miguel Mouta Faro; «Uma associação de ideias», in Luzboa - Lisboa Inventada pela Luz, Extra]muros[, Lisboa, p. 50 
sua riqueza não reside no seu carácter festivo, mas sim na sua implantação no espaço público, no lugar onde o seu eu se descobre, reflecte e forma ${ }^{329}$. Eu não seria capaz de exprimir com maior clareza esta questão cognitiva da pulsão artística da intervenção urbana enquanto projecto de cidade, essa temporalidade em aberto onde, necessariamente, tudo pode acontecer $^{330}$. E onde o encontro com o real - esse espaço de negociação, político, onde a neutralidade não existe 331 - é na forma urbana que se substancializa:

O percurso (da Luzboa 2006) pretendeu mostrar diversas cidades existentes em Lisboa. Cidades morfologicamente diferentes por razões topográficas, sociais, politicas e históricas. No entanto eram as vivências e práticas actuais da vida corrente, de cada uma dessas cidades, o alvo de estudo e foram estes elementos que serviram de base para cada uma das intervenções ${ }^{332}$.

Com outras palavras, o crítico inglês Anthony lles, convidado a visitar a Luzboa como observador, deixa entender o quão complexa é a negociação experimental da criação da cidade pós-industrial, evocando tanto o historial que a Extra]muros[ conduziu do Nada à Luzboa, como o principal desafio que se coloca à criação crítica.

Through previous projects, 'Luzboa's' organisers, the cultural association, Extralmurosl, have developed challenges to the cultural amnesia and solipsistic urbanism of one of Europe's most beautiful and most decadent cities. Notably, one of their projects, 'Lisboa Capital do Nada' ('Lisbon Capital of Nothing'), interrogated the 'nothingness' of the city by focussing on a much disliked and poor neighbourhood, Marvila, to champion new forms of urban design and cultural renewal 'from below'. 'Luzboa' continued the group's research into forms of experimental urbanism and convivial ambience, this time in the context of the tourist city. Having developed a reputation as the 'curator of the poor' Mario Cairo, the charismatic director of Extra]muros[, was keen to change tack and assault the mainstream, to put public art and the aesthetic theme of the biennale, light, on the city's agenda. [...] When the world is globalising to the tune of Hans Ulrich Obrist's, or another star curator's latest fanfare, it is quite refreshing to find the Portuguese politely disinterested, critical, not yet enamoured of this new 'international style' of temporary, distributed, urban events. Yet the mood of disengagement and wariness that saturates Portuguese culture is what Extra]muros[ are kicking against. With contemporary and public art's status as an anomaly in Portugal, their multi-disciplinary approach makes some headway into trends of contemporary urban and cultural projects on its own terms. But, the stronger efforts to interrogate the particularity of Lisbon and the ruins of the enlightenment project it is still couched in, may in the future elicit a more dynamic and singular cultural trajectory beyond the apparently 'inevitable' neo-liberalisation of the city currently marching forth. ${ }^{333}$

Fundamental é reter, ainda com Faro: Este modo de actuar não resultou propriamente num sistema, mas sim numa sensibilidade - outro termo para uma retórica de envolvimento e de atenção ao quotidiano. Na sensibilidade situada a que Faro se refere, vislumbro a noção fiedleriana da emergência e uma fusão novaliseana entre entidade cognoscente e real cognoscível: Da relação não estática entre o espaço público e a equipa de projecto resultou a obra única que é o Luzboa 2006. De certo modo lembra Pareyson, no sentido em que a equipa de projecto se fundia no espaço público e que ao actuar sobre ele descobria o modo como essa acção deveria ser feita. ${ }^{334}$ Miguel Mouta Faro, que se havia aproximado da associação por via do seu interesse das metodologias explícitas na LXCN, e integraria destacadamente a criação da Bienal, reafirma uma linha de continuidade na ars extramuros:

Assim, na Extra]murosl, a única premissa é a de que sendo o devir o elemento fundamental da cidade, no espaço público tudo pode acontecer. A não existência de qualquer tipo de dogma no seio dessa associação levou a uma proposta

\footnotetext{
329 Idem.

330 Idem.

331 Idem, p. 51.

332 Idem.

333 Untitled, Spring, 2007.

334 Faro, p. 51.
} 
de intenções não estáticas que se traduziriam num evento. O objectivo desse evento seria transpor para algo mais concreto e material a atitude característica da associação: o debate permanente, a ausência de verdades absolutas e a constante interrogação de todos os passos, comparando-os com os seus negativos. ${ }^{335}$

Nos melhores momentos da Luzboa, tratou-se de promover uma arte em fluxo, uma Estética do efémero ${ }^{336}$, teoria da sensibilidade em que a beleza é faculdade de recriar sentido, de maneira a construir uma 'hermenêutica do sujeito' aberta ao cuidado de si e do outro. E se L'éphémère n'est pas le temps mais sa vibration devenue sensible, ${ }^{337}$ muitas obras, e certamente o evento como uma proposta integrada, interpretaram esta hipótese. Termino com a pena sensível de Abbou:

À l'évidence, les artistes de Luzboa confrontés aux configurations urbanistiques de la ville, vont s'appuyer sur des pratiques de vie locales, sur des restitutions mnésiques, sur des correspondances analogiques de forme. Tout cela devrait nous parler éloquemment. [...] Je retrouve cette exigence-là dans le projet Luzboa, et plus largement le désir de rompre avec cette idée de l'événement culturel entendu comme seulement une promotion spectaculaire à visée touristique, ou comme instrument de gestion de la passivité. Je vois que les projets composent concrètement avec la réalité géographique et humaine de leur site d'élection.

335 Idem.

336 Christine Buci-Glucksmann, Estétique de l'ephémère, Galilée, Paris, 2003.

337 Idem. 


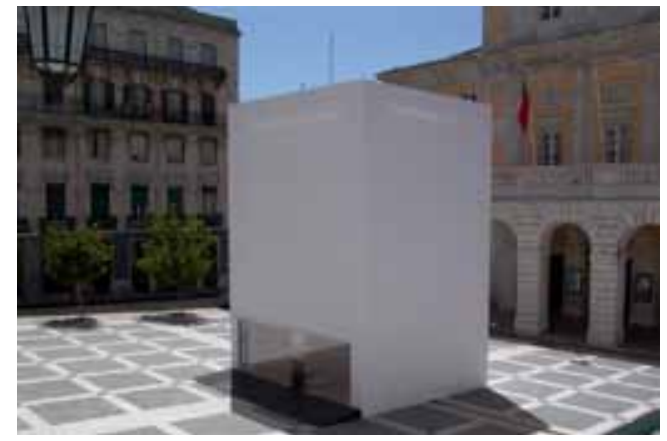

Luzboa \#1, Sérgio Vicente, Luzboa 2004

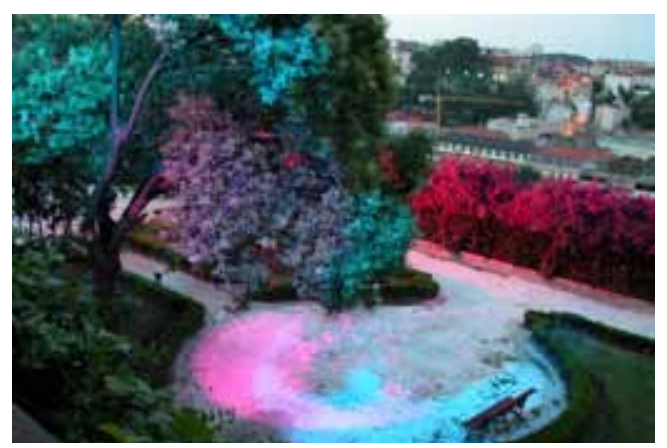

Bellas Sombras, «Fa-do», Frédérique de Gravelaine e Virginie Nicolas, Luzboa 2004

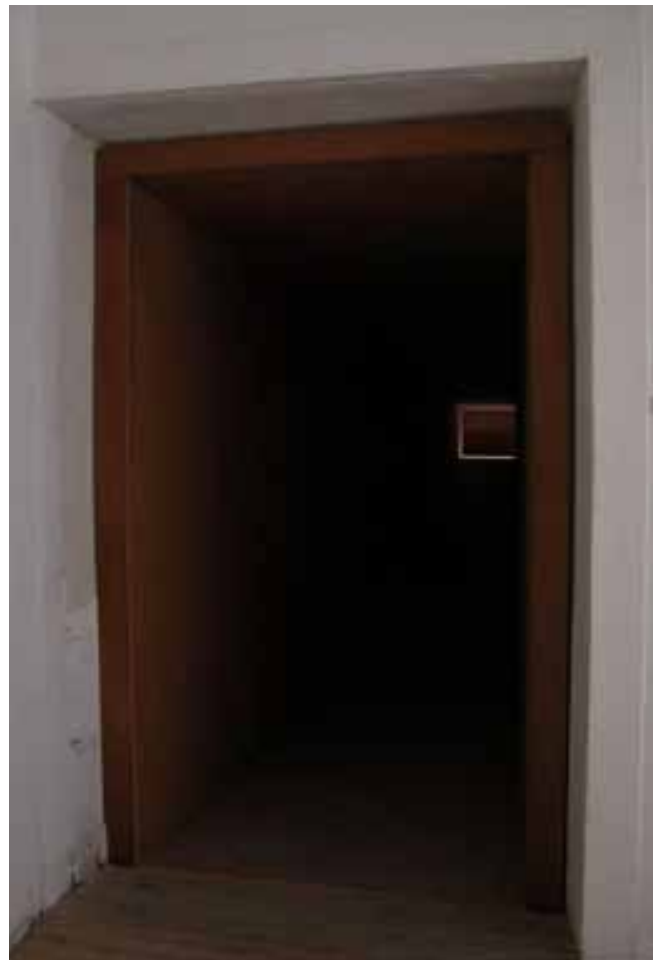

Vertizonte, «Cidade lluminada», Sancho Silva, Luzboa 2004

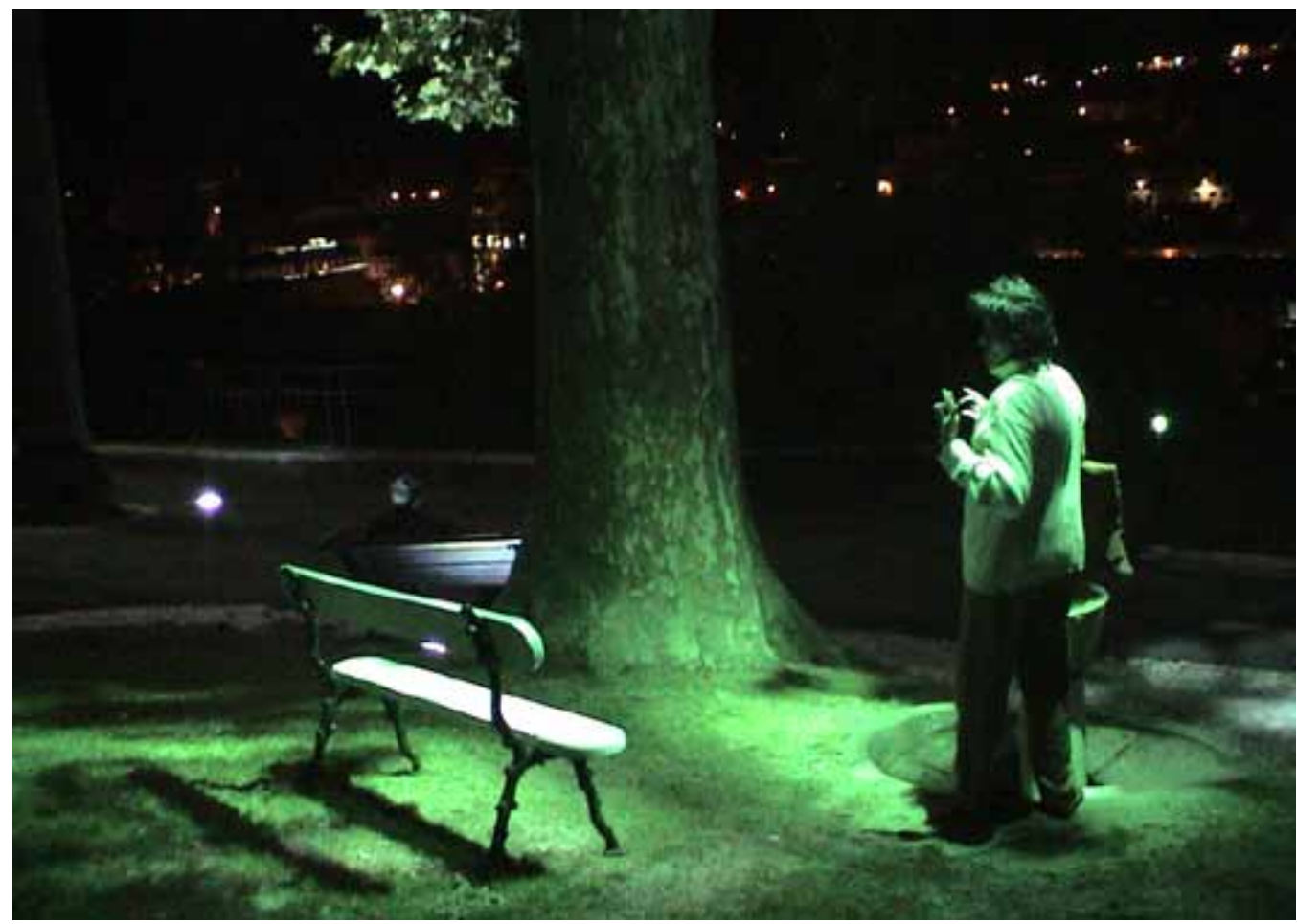

Bellas Sombras, «Musical», Frédérique de Gravelaine e Virginie Nicolas, Luzboa 2004 


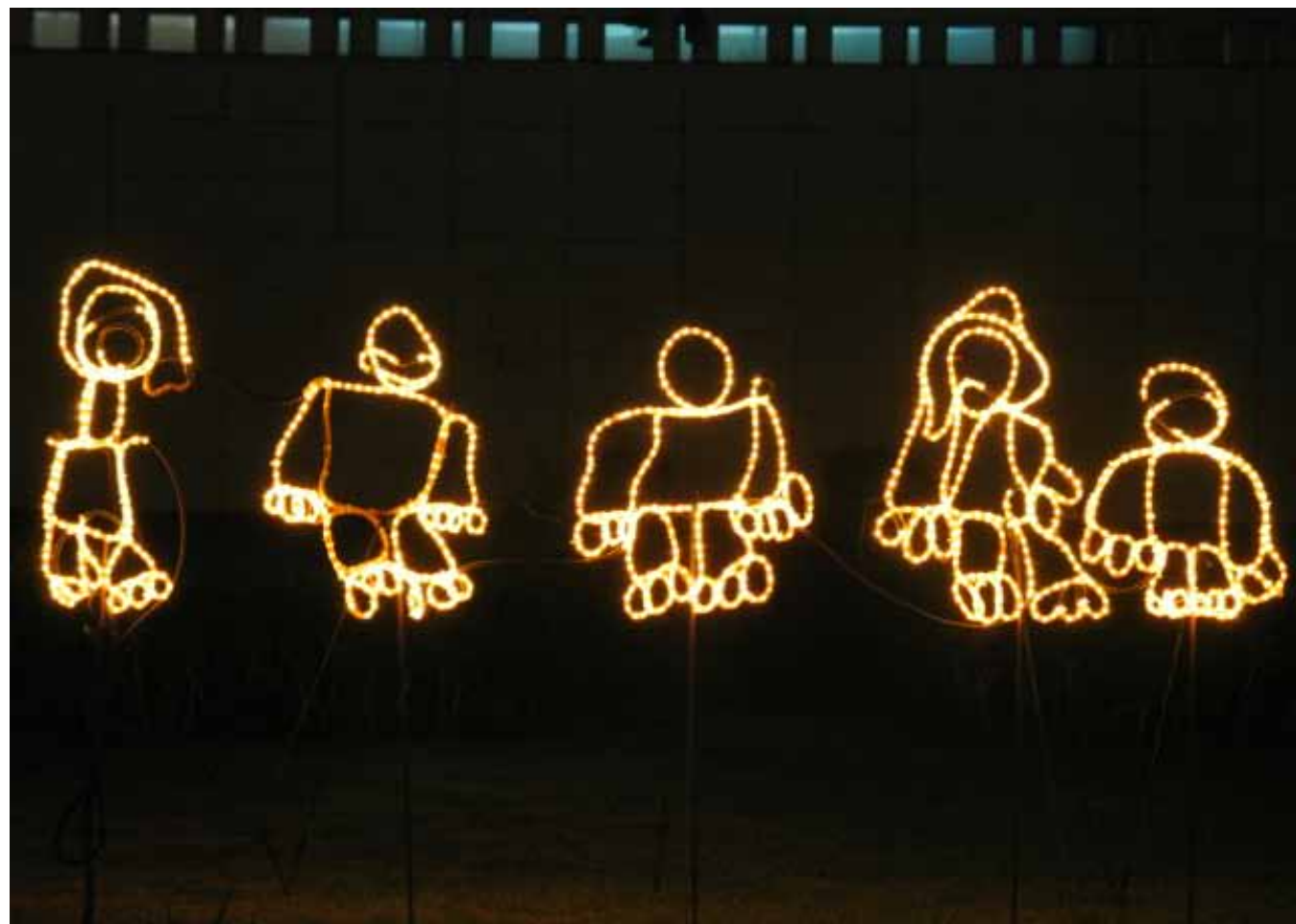

Family Idea, Ron Haselden, Luzboa 2004

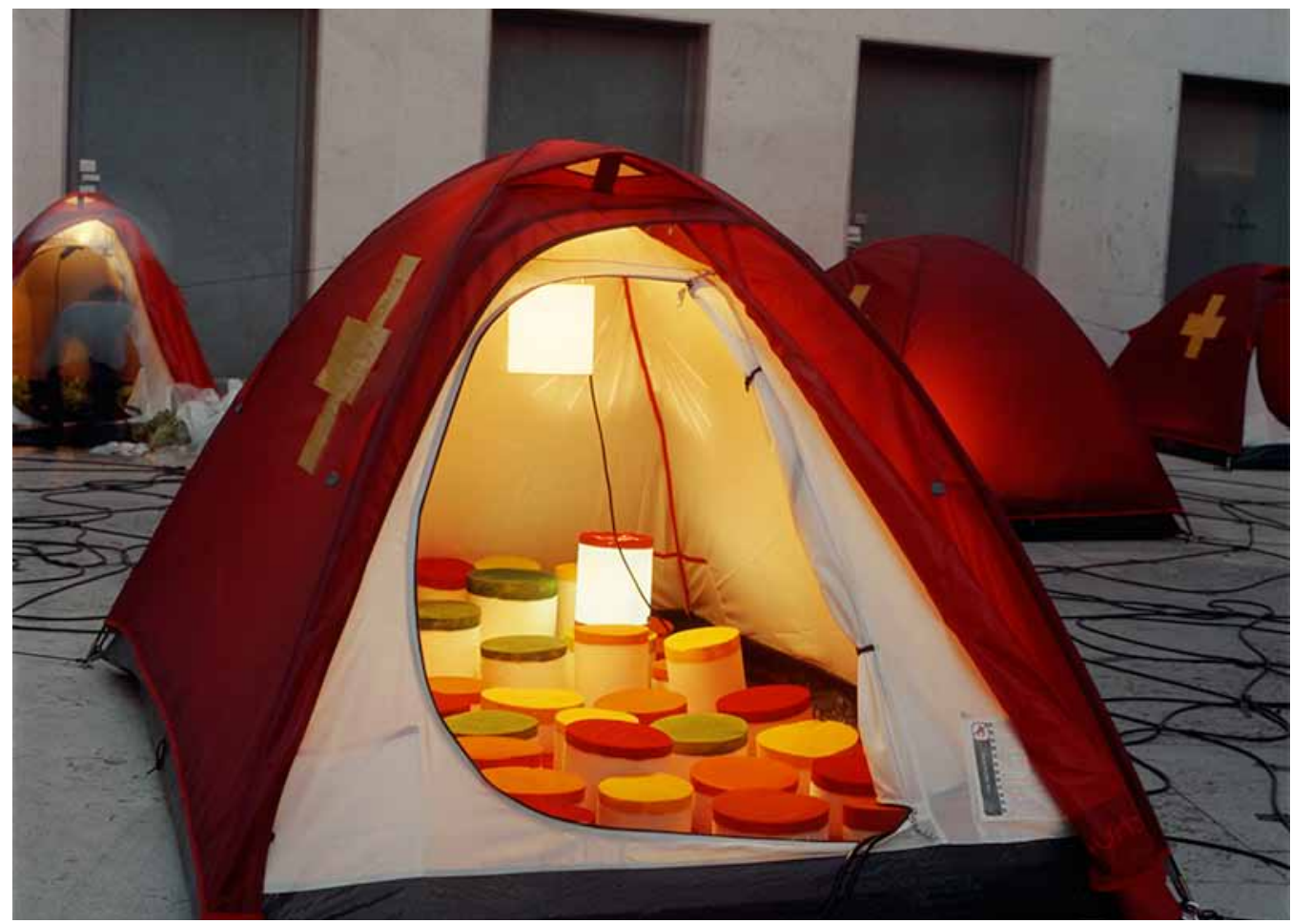




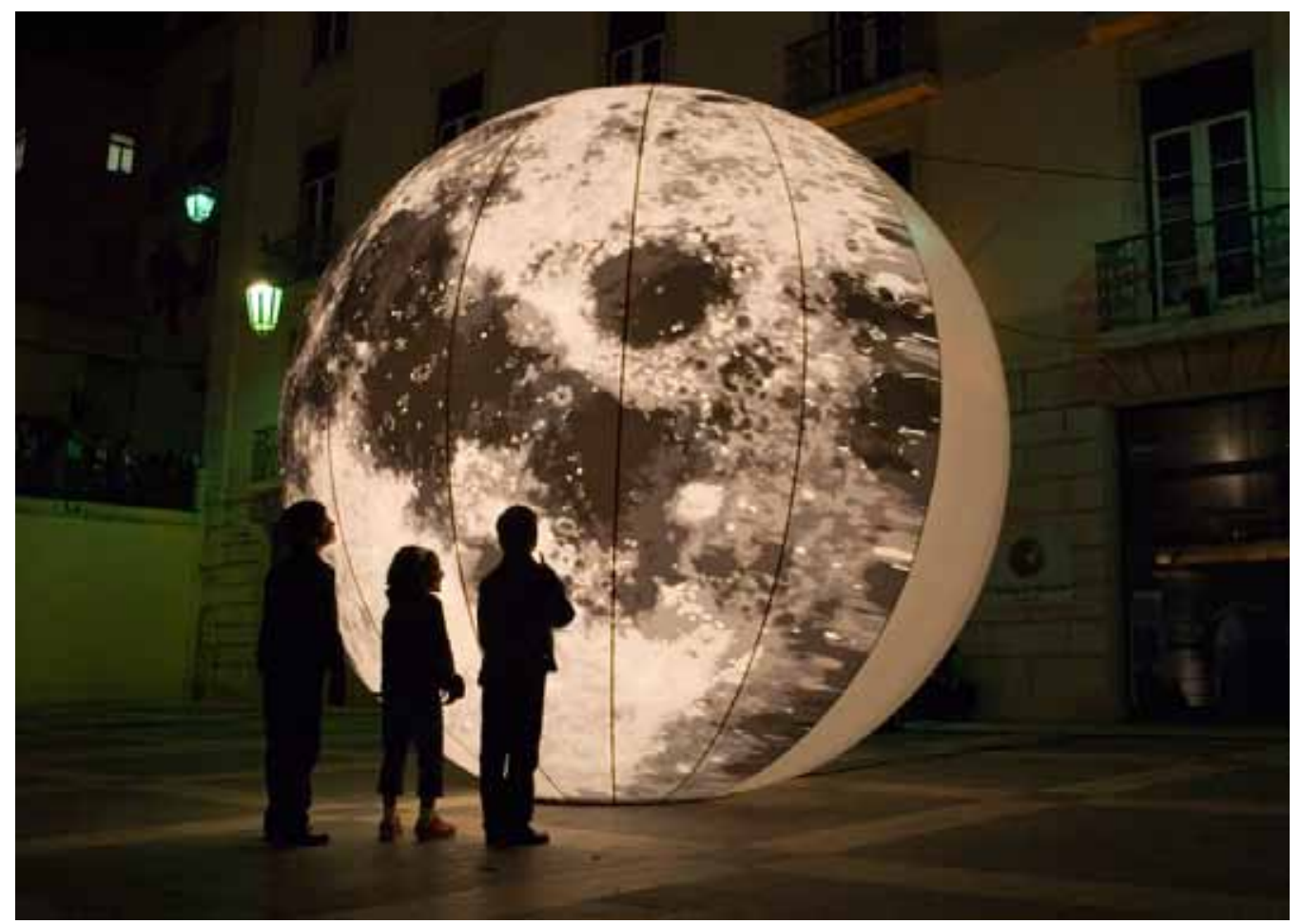

Ubiquity Variations Module, Bruno Peinado, Luzboa 2006

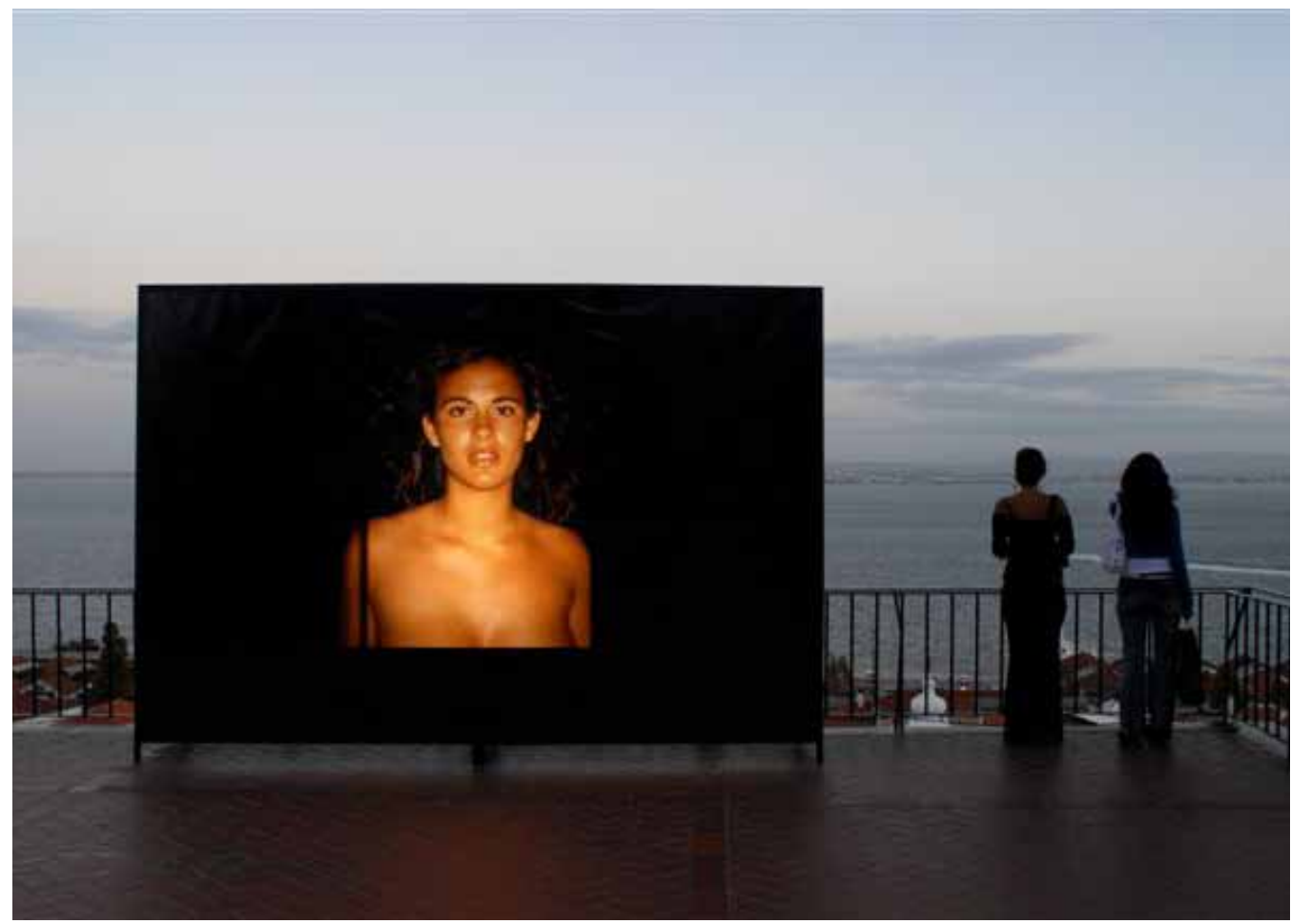

Nightshot \#2, Gerald Petit, Luzboa 2006 


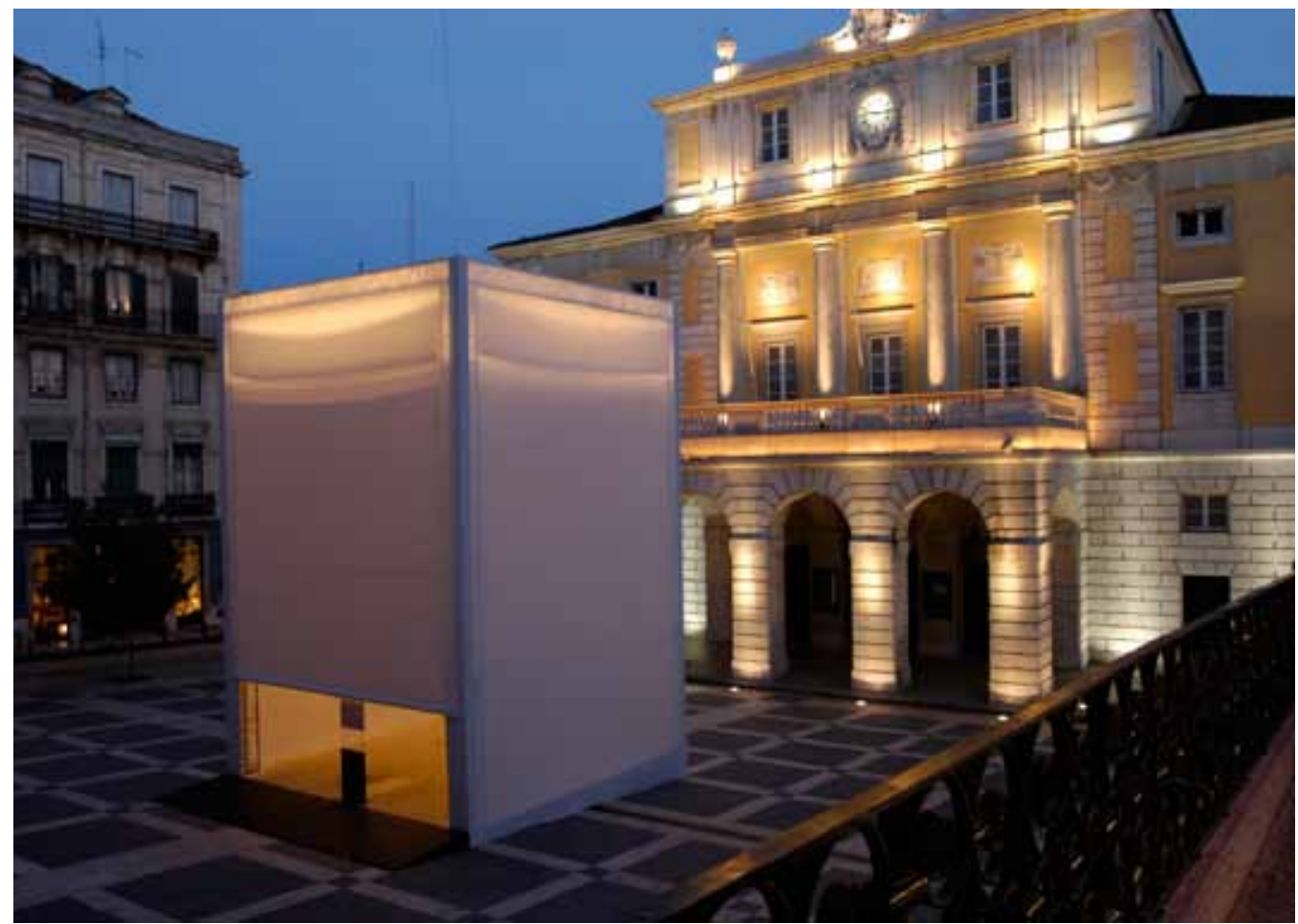

Limbo, Luís Campos, Luzboa 2004

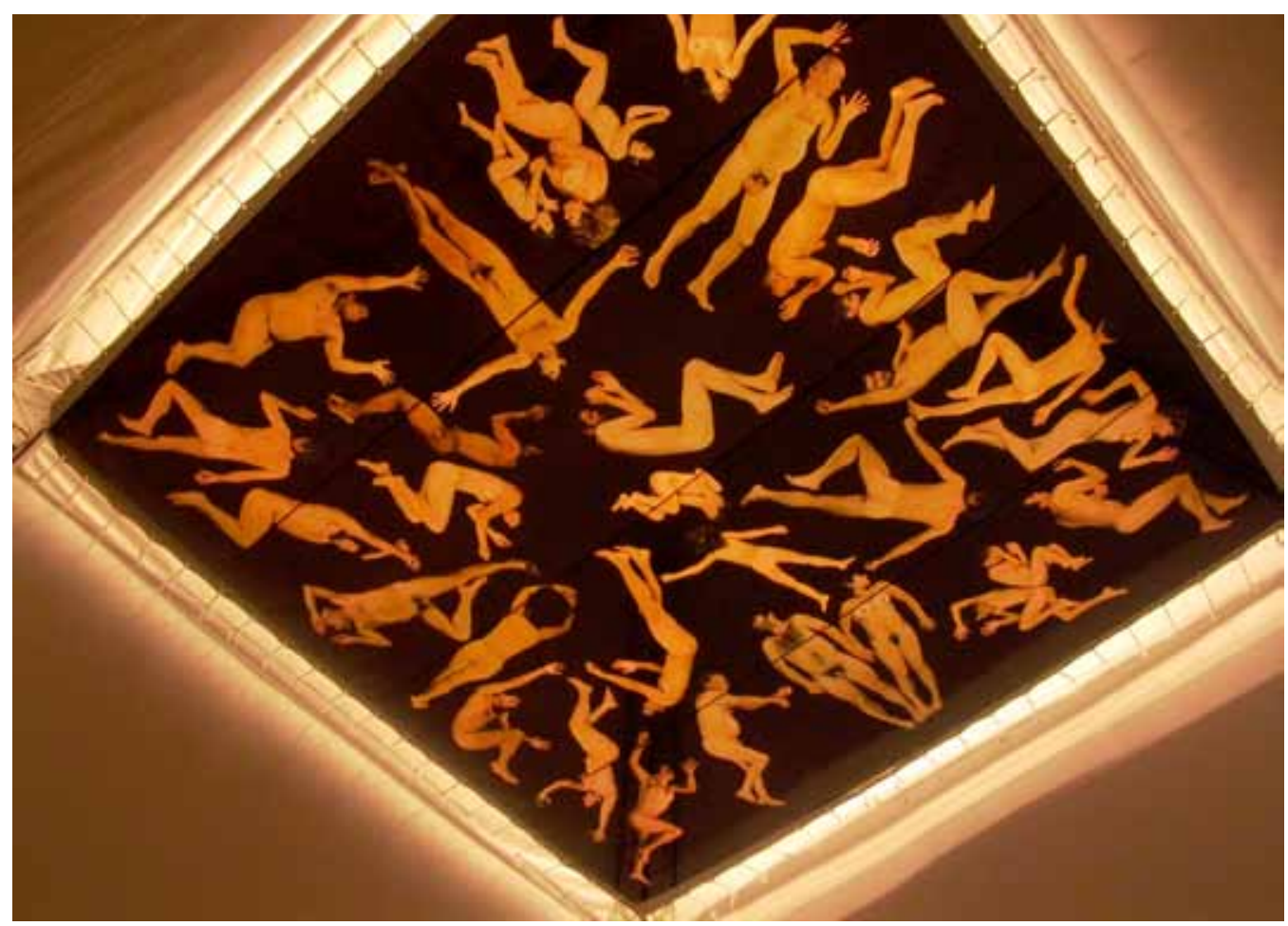




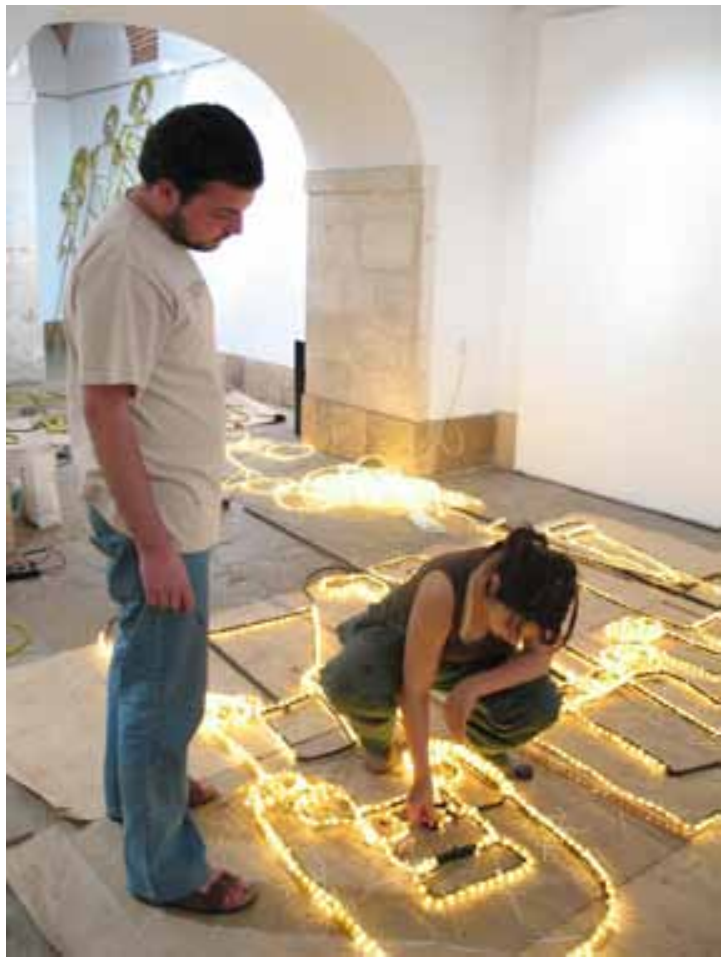

Family Idea, Ron Haselden, Luzboa 2004

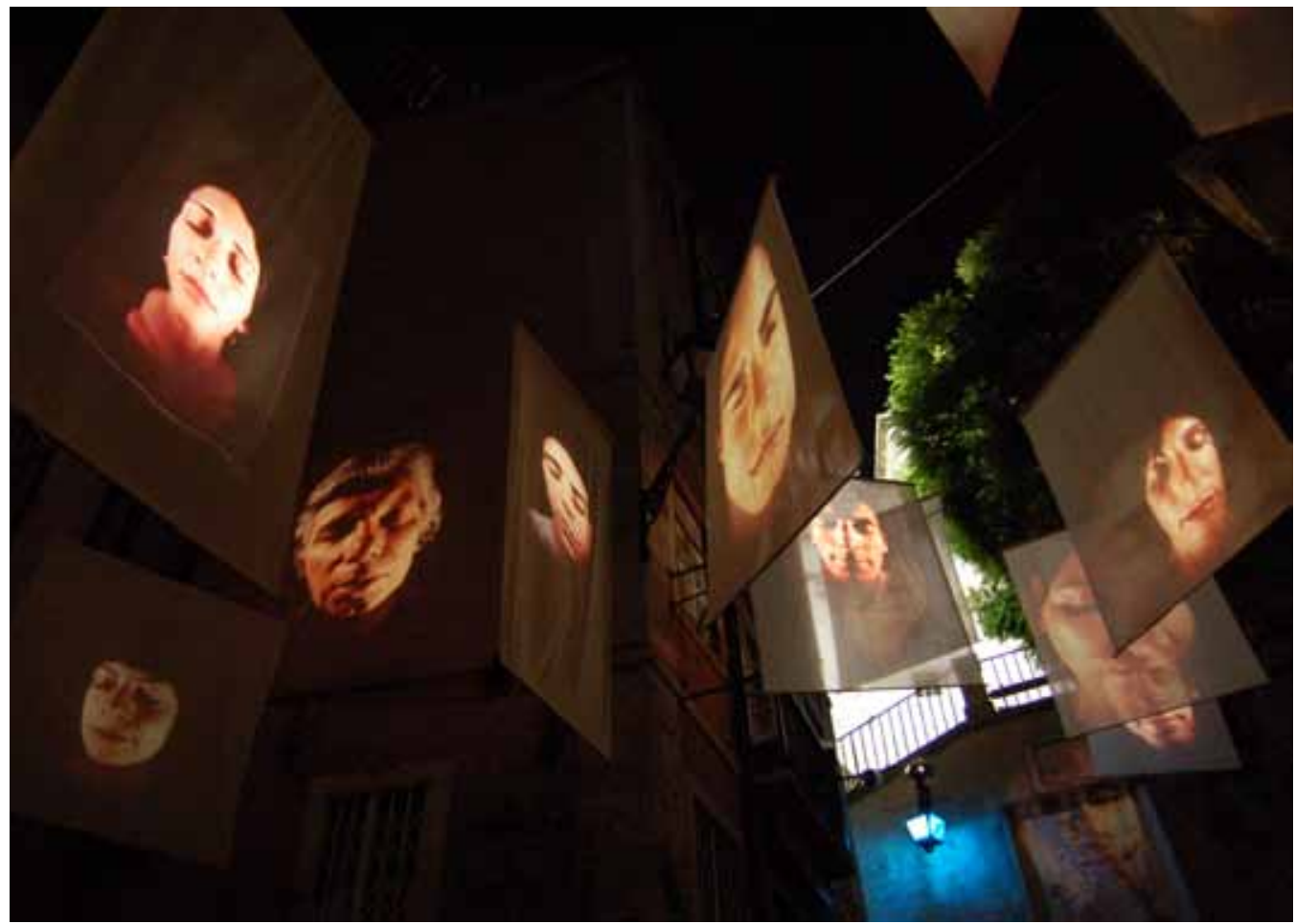

Fado Morgana, Het Pakt, Luzboa 2006 



\section{SKYWAY '09: UM EXERCÍCIO DE ESTILO}

\subsection{A aplicação do modelo Luzboa noutra cidade}

Em 2007, depois de realizadas dezenas de intervenções urbanas o meu conjunto de competências curatoriais tomou forma enquanto linguagem. Surgindo a oportunidade de realizar um evento de Luz na Polónia, ${ }^{338}$ concebi o Festival SKYWAY, o primeiro de Luz no país, com o objectivo de apoiar a candidatura da cidade de Torun a capital Europeia da Cultura e dar expressão a um anseio local por arte urbana inovadora. A inspiração para o nome veio de novo da cultura do rock (Donovan, Cosmic Wheel ${ }^{339}$ ), cujo poema corresponde ao briefing que me havia sido confiado: realizar um evento que aportasse luz, leveza e graça ao quotidiano da belíssima mas relativamente estagnada localidade gótica de Torun.

O importante era que a afirmação de Torun, cidade-berço de Copérnico e em que se destaca uma prestigiante universidade, fosse feita de passos decisivos baseados na originalidade, sem esquecer a sua dimensão pedagógica. A exemplaridade que se exigia não se coadunaria com a mera apresentação de nomes mais ou menos soantes; ela exigiria artistas envolvidos num projecto projecto cultural. Num território rico de factos históricos, complexo e problemático ao nível de certas dinâmicas sociais, a intervenção exigia a maior sensibilidade. A cidade aderiu prontamente à proposta de criação de um mundo emocional assente na Luz e nesta experiência efémera. Colocar-se-iam doravante, como tinha acontecido em Lisboa, uma série de desafios: o da programação (pertinência no quadro de uma perspectiva artística), o da sustentabilidade social do evento (adesão da população) e o da criatividade enquanto novo pólo da afirmação da região, num quadro organizacional-institucional autárquico, procurando na dimensão artística do socius um plus do projecto de cidade local.

\subsubsection{Circuito e implantação em 2009}

Poder-se-ia continuar a falar de uma atitude crítica extramuros, num evento literalmente intramuros realizado numa cidade medieval? Ora entendi o SKYWAY como um exercício de aplicação dos conhecimentos obtidos entre a LXCN, os Sinais e a Luzboa, agora numa forma urbana que desconhecia previamente. Apesar de inúmeras diferenças culturais nos detalhes do quotidano como na mundivisão subjacente - muitas das experiências lisboetas puderam ser revisitadas na Polónia, numa 'tradução' que foi muito mais a adaptação ensaística das descobertas durante o processo que qualquer imposição de uma visão pré-definida ${ }^{340}$. Quanto à implantação de SKYWAY '09, ela surge como factor aglutinador,

338 Contacto da responsável da candidatura da cidade polaca de Torun a Capital Europeia da Cultura em 2016, Olga Marcinkievicz, por sugestão dos artistas Nuno Maya e Carole Purnelle. Em breve acumularia essa função com a de consultor para a elaboração da candidatura da cidade a Capital Europeia da Cultura em 2016.

339 God is playing marbles / With his planets and his stars / Creating havoc through my life / Through his influence on Mars / That's why I'm stumbling down the highway / On my boots of steel / I should be rolling down the skyway / On my cosmic wheels.

340 Não me sendo possível extrapolar tão amplamante ilações a partir de um contexto que conheço com muito menos pro- 
na noite, de uma série de monumentos, equipamentos culturais e vistas; esses elementos tornaram-se novos graças ao contributo de intervenções sensíveis, por um lado, ao que essas peças transmitem no dia-a-dia, por outro ao que de noite pudessem aportar à identidade urbana de Torun (skyline). Com todas as escolhas a serem ampla e colaborativamente discutidas com a Organização Torun 2016, defini as componentes Instalações de Luz (Light Installations) e Acções Artísticas (Artistic Actions). ${ }^{341}$ Permanecendo fiel a opções curatoriais e de produção testadas em Lisboa, a edição de 2009 do Skyway foi um evento urbano de enorme impacto e ressonância local e regional, senão nacional. Procurei nunca sair de uma plataforma de retórica persuasão, no lugar de imposição ou da manipulação; esta posição fragilizaria a curadoria como autoria tradicional; mas, ao mesmo tempo, colocá-la-ia, enquanto mediação contínua e multidimensional, num nível negocial que abre o jogo da interacção de uma forma sempremergente.

\subsection{Obras comentadas - Os artistas interpretam o céu}

O primeiro SKYWAY decorreu por ocasião das Perseidas, um fenómeno astronómico. O público encheu as ruas do centro, ${ }^{342}$ conhecido pela arquitectura gótica que contribuiu para que o centro urbano tenha sido classificado como património cultural da Humanidade pela UNESCO. O festival lançou inéditas novas luzes sobre monumentos e espaços da cidade. Incluindo presenças escultóricas, iluminação arquitectural efémera, colaborações multidisciplinares e intersecções de dimensão social. Sob o lema Let's share the Sky!, a luz funcionou como metáfora operativa para abordar o tema do céu, quer enquanto cenário ou elemento de composição, quer enquanto tema científico ou cultural. Se a estrela do evento foi a própria cidade em festa, os holofotes da cerimónia incidiram numa arte pública audaz e delicada na abordagem dos vários temas e contextos. ${ }^{343}$ Pela primeira vez na sua história recente, a cidade aliou a sua habitual oferta turística (diurna, de curta duração) à possibilidade de uma experiência estética original (nocturna, exigindo vários dias de visita/estadia).

\subsubsection{Emoções contraditórias, objectos simpáticos}

A peça central ${ }^{344}$ do Festival, Floating Stars, foi uma monumental experiência audiovisual participativa, no coração simbólico do centro da cidade: o pátio da Câmara Municipal. Aí, Nuno Maya \& Carole Purnelle, deram o tom, com milhares de pessoas de todas as idades

fundidade que o nacional/lisboeta, a reflexão sobre o essencial do conceito SKYWAY e das peças destacadas procurará apesar de tudo ser elucidativa acerca acerca de como a LXCN e a Luzboa conduziram a projectos-luz que entretanto assumem o carácter de uma estética própria

341 Para além das relativamente secundárias Concertos/Eventos Especiais, Eventos Educacionais e Outros Eventos.

342 Desde a última visita do Papa que não havia registo de tanta gente - nomeadamente crianças - noite adentro. Os visitantes acorreram não apenas das cidades vizinhas, mas também de Varsóvia ou da Alemanha.

343 Para além do programa de arte em espaços públicos e dos vários eventos de divulgação cientítica, SKYWAY '09 apresentou ainda dois dias de conferências e conversas sobre a relação entre arte e ciência.

344 A ideia de peça(s)-âncora ganhara desde a LXCN consistência programática. 
a acenderem velas que, depois de colocadas num dispositivo vídeo - de filmagem e projecção - se transformaram todas as noites num céu de estrelas interactivas, a toda a volta da espectacular arquitectura. $O$ desejo de cada um fazer parte viu-se aliado a uma experiência colectiva em que o tema da astronomia foi realmente vivido, com solenidade e graça, interactivamente. Acerca do dispositivo da peça, ${ }^{345}$ a obra funcionou particularmente bem: o rigor da projecção (com as luzes das velas acendidas pelas pessoas no tanque imediatamente projectadas para a parede através de um circuito de quatro câmaras de vídeol foi excepcionalmente eficaz enquanto participação. O edifício mais emblemático da cidade, conhecido pela sua lógica cósmica lestrutura quadrangular, constituindo um calendário urbano) havia sido conquistado pela noite. Para além da sessão diária de Floating Stars, Maya e Purnelle apresentaram uma projecção vídeo monumental na fachada da Igreja do Espírito Santo. Os elementos gráficos, adaptados com precisão aos traços da arquitectura (mapping), evocaram o universo enquanto dispositivo dinâmico. Sky Machine foi uma intervenção son et lumière (música de Luís Cília) relativamente convencional que povoou a praça central com o seu imaginário mítico. Terá sido a obra mais apreciada pela globalidade do público (mainstream), por onde muitos iniciaram ou terminaram a sua visita.

No emblemático Planetário, a checa Jana Matejkova (Luzboa 2006) criou Wish Comet. Uma escultura de cabos de aço, fitas de papel fluorescente e iluminação ultravioleta era acompanhada de gravações de vozes de polacos vivendo no estrangeiro há décadas. Pegando na ideia de que, quando vemos uma estrela cadente, fazemos um desejo, a artista devolveu aos polacos de Torun uma amálgama de confissões e de memórias, tornada ainda mais intensa pela luz, que fez da peça um lugar de meditação. A instalação numa zona circular do pátio do Planetário, aproveitando um ponto de fixação existente no solo (para a extremidade do cometa) e vários pontos num estaleiro adjacente foi surprendente nos seus efeitos cénicos (a luz negra cintilando nas tiras de papel esvoaçando ao vento). Foi uma obra de grande intensidade retórica, mostrando como um compenetrado active listening é sinal de um sacrum - a intimidade, a memória, a emigração, a Polónia - exposto socialmente.

Os MOOV (Luzboa 2006); agora com Miguel Mouta Faro ${ }^{346}$ realizaram na rua mais característica de Torun - a Ciasna Street (Rua Estreita) - outra obra de enorme impacto cultural. A intervenção consistiu em inserir 'tijolos' de glicerina, com LED no interior, nos espaços vazios dos antiquíssimos muros de tijolo da célebre rua. No interior dos tijolos, frases retiradas da internet, relativas a confissões de pecados. Tendo em conta o contexto polaco (profundamente religioso) e o carácter da população de Torun (tida por intelectual, por influência da Universidade local), a peça teve precisão crítica e ao mesmo tempo a discrição do ornamento. $\mathrm{O}$ envolvimento afectivo do público explicar-se-á, entre outras razões, pelo facto de o tijolo ser o elemento omnipresente em Torun, e ali ser a expressão literalmente 'gasta' da 'pele' da cidade. ${ }^{347}$ Foram vários os detalhes decisivos para esta intervenção urba-

345 Os artistas não puderam dissimular a estrutura de filmagem-iluminação, pois não havia autorização para tocar nas frágeis centenárias paredes de tijolo.

346 Criador que habitualmente lida com os temas do género, da identidade e do espaço público; depois de ter colaborado na coordenação da Luzboa, é assistente de Vasco Araújo (LXCN).

347 Aliando a provocação, o confronto, a comunicação e a compaixão num equilíbrio crítico, Soap Catharsis teve tal impacto que os responsáveis pela programação e preservação arquitectural solicitaram que a peça pudesse vir a ter uma versão 
na. Primeiro, o facto de as mensagens estarem em Inglês, língua dominada por apenas parte dos visitantes, o que permitiu que um eventual escândalo (mensagens de teor sexual explícito) acabasse por não acontecer, e muitos visitantes compreendessem rapidamente que as mensagens não eram triviais. Como em Wish Comet, mas numa amplitude retórica maior, a peça consegue dar a ver um ex-libris turístico, respeitar escrupulosamente todas as regras de preservação patrimonial, introduzir uma nota de modernidade provocatória e oferecer a todo o público, ao nível da experiência lumínica contextualizada pelo tema do céu, uma experiênvia estética colectiva de raríssima qualidade - que aliás era complemantada, para que não restassem quaisquer laivos de 'seriedade', por um conjunto de acções ${ }^{348}$ lúdicas.

GUERRILLA LIGHTING, ${ }^{349}$ atacaram Torun com a sua guerra contra a má iluminação. De forma divertida e pedagógica, os GL limitam-se a convidar grupos de voluntários a passar a noite a iluminar monumentos e espaços, recorrendo a lanternas e filtros de cor. $\mathrm{O}$ que parece um acto irrisório, com a duração de escassos minutos, teve porém enorme impacto. Milhares de pessoas juntavam-se para ver os efeitos do conceito nas portas da cidade e nas muralhas - muitas deslocaram-se à outra margem do rio para ver melhor o panorama. Foram recorrentes as palmas e os gritos de exclamação que ecoavam assim que as breves iluminações mudavam por completo a imagem das muralhas e portas da cidade. Os GL adaptaram à cidade um conceito que já vêm aplicando em várias outras cidades; mas corresponderam ao desafio específico do Festival. Inspirando-se em imagens do satélite Hubble para elaborar a paleta de cores de cada intervenção! Nos GL como nos MOOV, o que é interessante é compreender a complexidade de decisões que têm de ser tomadas para as intervenções poderem ocorrer. Perante os resultados, a luz surge como poderosa ferramenta táctica para antecipar futuras opções relativas à iluminação permanente.

Untitled, Globule Ubiquity Vibrations de Bruno Peinado (Luzboa 2006) - a sua Lua - revelar-se-ia outro must de todas as visitas. Por momentos, crianças e adultos esqueciam que aquela lua era apenas um balão de hélio, e a imagem poética do astro pousado numa pequena praça, com o skyline renascentista por detrás, tornava-se um acto de leveza - precisamente a leveza mediterrânica que o evento procurou transportar para a realidade quotidiana polaca. Ao nível da sua inscrição retórica, o cuidado que houve foi que constituisse um acrescento valorizador de uma cena toruniana típica, o que passou por escolher um espaço que pudesse funcionar como o Largo de S. Carlos em Lisboa, mas com o ambiente local por detrás, tirando partido da luz da obra, retroiluminando por forma a funcionar como verdadeiro 'candeeiro' urbano. A participação das pessoas nesta peça é evidentemente por via de uma contemplação activa, apropriadora, não fosse a lua efectivamente de todos nós - era junto dela que as pessoas tiravam mais fotos de recordação. Algo de tão universal tornar-se-ia sempre metáfora do próprio Evento como acto generoso de iluminação da cidade colectiva ${ }^{350}$.

permanente.

348 Uma série de acções micro-urbanas em que os MOOV usaram LED-Throwies (uma espécie de graffiti lumínico, utilizado em superfícies ferromagnéticas com o aço) como um vírus, contaminando inúmeros lugares com a sua leitura táctica do espaço urbano, da identidade turística e das comunidades locais no seu quotidiano. A sua atitude funcionou como elemento catalizador do próprio festival, sob a forma de adições tão conviviais quanto subversivas no espaço público.

349 Grupo de arquitectos, designers e cientistas sociais, representados em Torun por Chantelle Stewart e John Harisson. 350 A peça seria escolhida para ilustrar os cartazes principais. 
No extremo oposto da rua, João Ribeiro apresentou St. Lawrence's Tears. ${ }^{351} \mathrm{~S}$. Lourenço é um mártir da Igreja Católica. João Ribeiro, em cuja arte o imaginário religioso é usualmente abordado de forma provocatória, combinou nesta peça o sentido lúdico - atraindo os transeuntes para uma curta dança com os pontos de luz em movimento - com uma evocação de poderosas narrativas mítico-científicas. Tal como em Lune, aspectos universais cruzam-se com dados informativos, mas o que prevalece é o sentido de apropriação informal e desinteressada que leva os espectadores a uma interacção quotidiana que não exige qualquer decisão crítica. Colocada na encruzilhada das artérias mais movimentadas, a obra funcionou como animação nocturna de um percurso que durante o dia é dos mais concorridos. Aliás, também de acções de animação urbana de pequena escala vive um Festival. Foi o caso das 'partidas' que o polaco Bartosz Gryczka, personagem-objecto, meio-palhaço, meio-xamã, fazia às pessoas. Quanto ao alemão Rochus Aust, habitué dos vários Festivais de Luz, inspirou-se no livro de cozinha que Marinetti escreveu para realizar um concerto-jantar-manifesto contra a 'globalização do palato', e em que a comida servida era... a sua música experimental. Quanto ao mural que a jovem Agnieszka Gajewska, pintou durante os cinco dias do evento, à vista de quem quisesse parar para conversar um pouco, constituiu também ele um momento performativo (e não apenas pictórico); aqui, era a intenção de enriquecer a cidade com arte aliada ao desejo de mostrar esse processo durante a sua produção. $O$ local proposto à artista era um muro degradado que a pintura recuperou parcialmente, como que sinalizando a sua própria utilidade. Estava aliás implícito que futuras edições do Festival substituiram aquele mural por outros.

\subsubsection{Skyway 2010, o céu afinal não era o limite}

A edição do SKYWAY em 2010 foi muito mais condicionada financeiramente que a edição inaugural, ${ }^{352}$ sendo porém imperativo que o Festival crescesse. Tomei a opção de desenvolver o tema do sistema Solar. ${ }^{353}$ Sob o mote Gravity Dance, os corpos celestes foram como que foram capturados no seu movimento orbital las linhas virtuais das suas órbitas imaginárias); de alguma maneira aterraram no espaço urbano, sob a forma de ambientes. Mais uma vez, a ideia de percurso (de Instalações, Acções, etc.).354 foi o modelo de atracção dos vários públicos, pressupondo a tradução sinestética, no caminhar, de conceitos que de outro modo implicariam menos o estar aí e mais um mero contemplar. Se Marte, Júpiter, Vénus, Saturno... no mito e na ciência, são 'mundos outros' continuamente explorados, ${ }^{355}$ aqui na terra, SKYWAY enunciou essa dança da gravidade na ideia da proximidade do maravilhamento, da familieridade encantada dos corpos celestes. O Evento desenvolveu-se a partir desta

351 A versão permanente deste chão estrelado estava prevista para 2010 e constituiria a primeira de uma série de obras com luz na cidade, mas esta hipótese não se concretizou.

352 Algo de semelhante acontecera em Lisboa, da primeira Luzboa para a segunda.

353 Agora com o concurso de um jovem astrónomo local, investigador no campo da didáctica da Astronomia (Janek Swierkowski).

354 Acrescentado de palestras de 'Arte\&Astronomia' que reuniram especialistas de várias áreas de conversa bastante informal; e, noite adentro, as visitas ao Observatório de Piwnice, organizadas conjuntamente com a Universidade.

355 A New Horizons, o satélite terrestre enviado em 2006 para explorar os confins so sistema solcar, está agora a meio caminho entre a Terra e Plutão, devendo chegar ao cinturão de Kuiper em Julho de 2015. 
metáfora-realidade-científica do sistema solar, gigante performance de harmonia e equilíbrio, como se o Cosmos estivesse a dançar para o nosso espanto. ${ }^{356}$ Com o SKYWAY, pedagogia e diversão trabalharam em conjunto para um memorável - e cósmico - happening. ${ }^{357}$

Entreguei a Wieslaw Smuzny, artista local ${ }^{358}$, a responsabilidade de criar o Astro-rei. Smuzny propôs uma peça altamente participatória, visando conectar os habitantes de Torue os visitantes do Festival numa experiência comunal. A ideia era ter o Sol a ser todos os dias empurrado ao longo das principais artérias pedonais do centro - com ironia de o acontecimento se desenrolar precisamente 'debaixo do nariz' d(a estátua d)e Copérnico! A obra do artista foi essencialmente um statement de independência artística e de criatividade interactiva. ${ }^{359}$ Mas vários problemas surgiram, a começar pela tensão patente entre aqueles que arriscavam interagir com a peça, literalmente empurrando ou mesmo atirando o sol para o $\operatorname{ar}^{360}$ e aqueles que a contemplavam, não se aproximando. A peça introduzia mesmo uma dimensão de risco, pois nos momentos em que o sol era movimentado, o seu peso, sendo possível de ser suportado por pessoas e grupos informais mais activos, era manifestamente um perigo para crianças, deficientes motores ou idosos. No final, não houve quaisquer acidentes a registar, a não ser um incidente institucional entre o artista e a Organização local. ${ }^{361}$ Apesar de se poder concordar com o facto de que o efeito visual era diminuto, a relevância simbólica era enorme; neste tipo de problemas, há aqueles que da arte exigem a pertinência concreta e definida do objecto e aqueles que da arte têm uma visão processual e comunitária, em que a dimensão de risco vale mais do que qualquer 'garantia' prévia de que o conceito funciona. ${ }^{362}$

\subsubsection{Os planetas, experiências (im)possíveis}

Depois de uma visita inicial à cidade ${ }^{363}$, Dominik Lejman interessou-se pela arquitectura do Planetário e da Prisão:

The idea which links two buildings by the one projection comes out of a very special location of two buildings in Torun - the prison and the planetarium. They both share the distance of just about 40-50m. Paradoxically enough, both round buildings were designed for observation - the stars and the prisoner, so we could say they mirror each other as panoptical machines. [...] The metaphor of watching and being watched at the same time was represented by two projections linking up the two building by images of rotating crowds taken from surveillence cameras - the one on the

356 Janek Swierkowski: It's in the idea of the Solar System as a giant performance of gravity and balance, as if the Cosmos were dancing to our amazement, where astronomers and 'regular people' come together as human beings, amazed by a mystical "something".

357 Press Release.

358 Cuja longa carreira passou pelo histórico projecto LUCIM, iniciativa na mesma linha genealógica da LXCN, em que a dimensão crítica, participativa e micro política foram determinantes. Hoje, Smuzny é docente de referência na Escola de Belas Artes da Universidade Nicolau Copérnico.

$359 \mathrm{Na}$ linha de projectos desde os anos 70, em que o corpo dos intervenientes é sempre chamado a desempenhar algum tipo de presença actuante (despindo-se para ser decalcado sobre superfícies que depois são apresentadas como ambientes arquitecturais, ou obrigando-se a esforço físico sem o qual a 'obra' não existe, como foi o caso do Sol).

360 Caso do presidente da Câmara Municipal que o fez diante das câmaras televisivas.

361 Esta considerou a peça uma grande desilusão, quer ao nível da escala, quer da solução técnica (LED inseridos no PVC, que se soltariam com as pancadas, eliminando-se o efeito previsto inicialmente).

362 Este episódio levaria a Organização, no ano seguinte (2011) a exigir dos artistas estudos prévios (visualizações), para que não surgissem falsas expectativas perante as obras.

363 Realizada a horas tardias da noite, à procura dos espaços possíveis para uma intervenção. 
planetarium as ornament walking in circles as if in the prison's pathwalk, repeating the prison's windows; the one on the prison showing free floating crowd in two circles surrounding the building.

A peça, intervenção extremamente subtil, vive de uma relação crítica da projecção vídeo com a luz envolvente - uma vez que a zona de projecção, possível porque a luz de dois candeeiros havia sido apagada, tinha de ver o seu efeito diluído, à medida que a imagem contornava os limites curvos do corpo cilíndrico do edifício, precisamente com o concurso da luz envolvente, a usual iluminação em sódio de baixa pressão. A obra exigiu dos espectadores, uma mudança de paradigma - do espectáculo que se impõe ao olhar para o comentário atento à forma urbana, seduzindo pela subtileza, isto acontecendo não apenas num mas em dois edifícios 'gémeos', cada um com imagens do mesmo tipo (pessoas a andar) mas diferentes percursos na arquitectura, rigorosamente integrados nas superfícias que por sua vez se davam a ver como nunca antes, animadas pela representação aforística e ao mesmo tempo enigmática do social.

Perto de Mercúrio, Agata Dworzak-Subocz ${ }^{364}$, apresentou uma obra que contrasta radicalmente com a de Lejman: um pequeno filme colorido, em loop, com os seus desenhos animados em Flash. A artista não respeitou as instruções da curadoria, que havia proposto uma peça com ciclos bem mais longos que os cerca de 3' do filme, e assim as suas 'imagens de câmara', conscientemente kitsch, projectadas sobre a fachada luminosa do teatro Horzyca Theatre não tiveram a relação entre ética projectual e logos de implantação que se exigia. Valeu pelo contraste de Vénus com Mercúrio, tanto mais importante quanto, para a artista, o que ali estava em causa, através do humor, da delicadeza e da luminosidade colorida, era contestar a estratégia cultural e turística do Município, assente no marketing do Gótico. Para a curadoria, foi uma forma de manter a atenção de um público em que, era evidente, muitos queriam retirar do evento a celebração da cor.

O britânico Simeon Nelson ${ }^{365}$ desenvolveu para o Collegium Maximum, sede da Universidade local, uma projecção inspirada pelo tema da descoberta de água e gelo na superfície da Lua. A peça nasceu do seu fascínio pelos processos fundamentais da natureza e da matéria, relacionando-se com estudos prévios que procuram representar estados de matéria em escalas muito pequenas. A instalação foi desenvolvida como uma projecção com banda sonora que, de cada vez que era ligada, gerava, a partir de determinados por parâmetros computacionais iniciais, diferentes situações visuais ao longo do tempo, jamais repetindo-se. Visualmente, o registo era de grande sobriedade, não havendo qualquer cedência a uma comunicação mais popular. Tal opção constituiu outro ponto relativamente deceptivo do programa - especialmente quando o público ansiava por projecções narrativas como a de Nuno Maya no primeiro ano. ${ }^{366}$

364 Artista de Torun, com um trabalho na esfera da pop e da ilustração, inspirado sobretudo pela cor rosa.

365 Conhecido pelo seu trabalho nos interstícios da Ciência, da Espiritualidade e da Arte, com vária obra escultórica, pública, de grandes dimensões. Aqui em colaboração com Rob Godmann, compositor, e Nick Rothwell, programador informático.

366 Seria no entanto apresentada no ano seguinte, já não apenas em Torun, mas também em Durham e Tallin, em nova versão que deu ao conceito outras nuances, tirando partido de um enquadramento teórico e institucional de grande interesse (Luz Scientia, apoiado pela comunidade europeia). 
Já Júpiter, ${ }^{367}$ pela jovem artista local Dorota Kraft, foi entusiasticamente recebida pelo público, em particular as crianças. Consistindo numa programação visual bem mais básica que a de Nelson, projectada $90^{\circ}$ sobre o pavimento, revelou-se momento de poesia urbana interactiva, uma celebração despretenciosa em que o écran era o solo e, assim, criava uma dinâmica de piso dinâmico (tipo discoteca). O acontecimento tanto se via de longe lo aglomerado de pessoas em volta do pulsar das manchas de luz) como de perto (a estonteante composição, em registo de jogo vídeo - Kraft inspirou-se nos grafismos pixelizados dos primeiros vídeo jogos e écrans LED, ampliando o efeito de atracção através de uma melodia 8-bit pop electrónica, quintessencialmente dançávell. Esta tensão entre a dimensão visual e a experiência total do espaço (imersão) esteve presente em mais peças. We are the children of stars, de Tomasz Cebo e Lukasz Milewski, introduziram-nos Ceres (um planeta-anão) no Pátio da mais antiga escola primária de Torun. Os artistas produziram um impressivo painel de imagens vídeo, projectadas do interior; nestas, a impressiva arquitectura era totalmente habitada não apenas pela instalação sonora quadrofónica, mas a sugestão do movimento visual repetitivo (imagens obtidas com o telemóvel, da filha de Cebo a andar de baloiço). Destaco nesta peça o domínio da forma urbana, específico de uma consciência de como o público acede à obra. De facto, a projecção podia ser vista de mais perto ou de mais longe, mas sempre de fora de um muro de protecção do pátio; ora, dada a distância ideal de visualização ser sempre para lá do referido muro, aquele limite não se tornava imposição desagradável, mas sim explicitação estóica de uma barreira arquitectónica.

Nuno Maya e Carole Purnelle realizaram uma obra mais decididamente conceptual, ou abstracta. Saturno, o planeta dos poetas, consistiu numa paisagem visionária, em que a estrutura arquitectural das ruínas emulava fisicamente o sistema de anéis de Saturno. $O$ ambiente melancólico (o carácter de Saturno no imaginário popular astrológico ${ }^{368}$ ), foi compensado pela capacidade de interacção do sistema, no qual era o peso dos espectadores laqueles que subiam até à área de interacção, devidamente delimitada, protegida e sinalizada) que provocava as alterações nas cores dos anéis projectados sobre os muros. O público como que produzia uma monumental pintura de luz dinâmica, com o suplemento de que, conforme eram pisados os sensores, disparavam as vozes de Sounds of the Earth, uma gravação enviada pelo Homem na sonda Voyager, contendo sons e imagens seleccionados para representar a diversidade d ávida e da cultura na Terra.

Já Urano, entregue o jovem artista local Joachim Slugockij69 foi uma discreta instalação de luz nos jardins do Theatre Baj Pomorski. De forma bastante eficaz - embora outro envolvimento e investimento pessoais pudessem ter levado a peça para outro patamar de escala e impacto -, o artista conseguiu relacionar a sua estética psicadélica com a apropriação sensível de uma belíssima árvore rodeada de hera. Esta foi peça que revelou - como a de Kraft - o lado festivo da comunicação urbana, na relação que as pessoas estabelecem, para lá de todas as resso-

367 Adaptação, para instalação urbana, do vídeo de animação LED's dance!.

368 Saturno, senhor do tempo, remete para a ideia de consolidação das aspirações humanas, para a ideia de perseverança. O esforço saturnino permite-nos superar a linearidade das nossas vidas e alcançar a realização das nossas aspirações.

369 Com formação de pintura e sensibilidade de pintor, costuma realizar instalações em que se destacam sobreposições geométricas, monocromáticas, iluminadas por luzes negras. 
nâncias simbólicas — com a luz negra enquanto signo de festa e excepcionalidade convivial. ${ }^{370}$

\subsubsection{Formas de vida, no interior dos edifícios}

FAVELA CHIC, com Susana Guardado e Miguel Bonneville ${ }^{371}$, ficaram responsáveis por criar Marte, um planeta muito presente no imaginário colectivo. Inspiraram-se nas favelas do Rio, fundindo uma versão decadente do chic parisince, num exercício sobretudo de dança - com os artistas não apenas criando o ambiente e os sons mas 'abrindo' a pista. Tratou-se de uma ocupação estratégica (espaço multiusos no museu de arte contemporânea local), trazendo um toque de loucura do Sul ao coração gótico da cidade.

No bairro Bydgoskie Prezedmiescie ${ }^{372}$, escolhi o edifício da antiga sede da Polícia ${ }^{373}$, para realizar Neptuno, o distante 'gigante de gás'. Miguel Soares ocupou quatro salas no piso térreo, qual delas a mais desagradável e evocadora de uma violência atroz. Naquela atmosfera, com um cheiro nauseabundo e humidade agressiva, as suas paisagens virtuais e imaginárias, relacionadas com a iconografia da aventura espacial, constituíram um conjunto de momentos de subtil evasão - nunca total, dada o evidente mal-estar civilizacional que as peças supõem. O espaços foram vividos também como ambientes pulsando de luz e cor, numa fascinante visão de uma realidade alternativa em que arte e ciência se encontram numa fantasia de vídeo-jogo. Noutra sala, António Contador ${ }^{374}$ convidou dois artistas locais e realizar uma impressiva pintura de tecto com mais de $6 \times 6 \mathrm{mts}$, com a imagem da capa do disco 'Enola Gay' pelos Orchestral Manoeuvres in the Dark rigorosamente emulada. ${ }^{375}$ 'Manoeuvres in the Dark' buscou uma estranha forma de sublime (ou de belo); numa sala contígua, Contador apresentou depois seis capas de discos de vinil $33 \mathrm{rpm}$, totalmente pintadas de preto $^{376}$, silenciosamente dispostas ao longo da parede. A atitude blasé desta intervenção terá sido a adequada para enfrentar a negatividade do site, sem demagogias ou excesos de confiança? A terceira artista que expôs no mesmo edifício, Kasia Maleijka, respondeu a qesta questão com uma instalação lumino-cinética abstracta que era por assim dizer a eficaz e sedutora 'figura de convite' - um cometa $^{377}$ - da mostra colectiva.

370 Muitos espectadores brincaram com as minúsculos pontos de luz em papel, assim transformados em partículas de luzes em movimento.

371 Susana Guardado vive e trabalha entre Lisboa e o Rio de Janeiro. DJ, reconhece na experiência sensorial da música e abilidade para construir narrativas colectivas sem o recurso às palavras. O performer Miguel Bonneville é, paa além de interpréte e criador de vídeo, também ele DJ. FAVELA CHIC nas suas próprias palavras: $A$ collective. $A$ restaurant. $A$ menagerie. A circus. A bordello. A concept. An art space. A club. A sound. A party. A bar. And none of the above...

372 Particularmente interessante ao nível social e urbanístico e por isso integrado no Evento, apesar de ser fora das muralhas.

373 E da GESTAPO, durante a II Guerra Mundial, fechado ao público há mais de uma década.

374 Ex-sociólogo que recentemente iniciara uma carreira artística (instalações, objectos, filmes, música e concertos).

375 Nas paredes, dezenas de capaz do respectivo single estavam dispostas, tendo delas sido retirada a imagem lum céu de nuvens ao entardecer) que havia sido a referência para a pintura.

376 As legendas: 'Jour de fête en Pologne, flute d'Israel, chants et danses russes, les grandes marches américaines, chants et musiques des paras, 24 fameuses marches allemandes': 6 record sleeves («Jour de fête en Pologne», «Flute d'Israel», «Chants et danses russes», «Les grandes marches américaines», «Chants et musiques des paras», «24 fameuses marches allemandes»).

377 Co-organizado pelo INSTYTUT B61, 'misteriosa' associação para a divulgação conjunta da arte e da ciência, que há anos realiza lendárias situações (por exemplo em combóios ou antigos armazéns e estruturas militares desactivadas) com o contributo de muitos artistas locais e nacionais. 
Realizada por uma ONG local em edifícios camarários ou públicos, nomeadamente o edifício da Presidência da Câmara, a acção Planetóides tirou partido das janelas latravés de papéis coloridos), dando ênfase renovada aos percursos pedonais entre peças). Já o graffiti de grandes dimensões realizado por Don Chylo (Pluto) numa empena de Rubinkowo (bairro ainda mais distante do centro) servia objectivos completamente diferentes (e dificilmente pode ser relacionado como tema da Luz). Foi essencialmente um acto de inclusão simbólico, afirmando o evento que também este sector extramuros da cidade passava a integrar a dinâmica cultural. A peça seria vista basicamente apenas pelos oradores próximos, uma vez que se encontrava a vários quilómetros do centro. ${ }^{378}$

\subsubsection{O caso Kornacki}

A haver novas ilações a tirar da experiência curatorial em terras polacas, elas estão muito bem explanadas na relação encetada com o jovem artista local Stefan Kornacki ${ }^{379}$, que realizou duas peças, em 2009 e 2010. A sua mistura de conceito prévio, tacticidade (capacidade de adaptação a várias oportunidades), quotidianeidade (utilização de materiais, objectos e modalidades de comunicação na esfera da tradição ready made), sentido cósmico (uma ideia de temporalidade para além da obra e do próprio criador) e finalmente a vontade de comunicação crítica em espaço urbano, (permeada de grande ternura e humor). Entre instalação, acção e projecto de documentação, Kosmos (SKYWAY 2009) evocou a memória do Hotel Kosmos, até há pouco um dos marcos na paisagem da cidade de Torun. O monumental logo em néon, que outrora encimou o edifício (entretanto implodido para dar lugar a um novo hotel), é afinal um antigo símbolo da propaganda comunista; mas não só: Kosmos tornou-se, no quadro do Festival de Luz, uma interpelação textual - literal - da memória colectiva e pública, o dizer-se o céu num conceito espacio-temporal que é o da duração do Festival mas também uma ligação do mesmo ao que contextualmente o precede e o sucederá. Aspecto determinante é a tensão, no trabalho deste jovem artista - traço da sua ingenuidade em princípio de carreira? - entre o que é o rigor formal das peças, que ostentam um núcleo duro, extremamente estável, de conceitos, metodologias e processos que se têm repetido; e uma dimensão performativa, convivial e directamente engajada na agenda quotidiana, que passa por um encontro corpo a corpo do artista com os seus públicos, numa retórica total da sua cidadania criativa. Escusado será dizer, foi uma peça com um impacto local extraordinário, que um olhar estrangeiro não poderia captar em pleno - a não ser que soubesse, por exemplo, que associadas àquela palavra e àquele lettring se encontram histórias locais de resistência ao totalitarismo.

Vale a pena explicitar a metodologia processual de Kornacki, aliás desde já introduzindo a peça para a edição seguinte de SKYWAY, UNIWERSAM ${ }^{380}$ - correspondendo (de forma irónica) à Terra. Em UNIWERSAM, não se pode falar estritamente de instalação. $O$ artista propõs-se retirar o gigantesco logo de um grande ediício da cadeia de supermercados

378 De resto, eventos como 'Night Bycicle Critical Mass' (uma parada de bicicletas e veículos afins) ou os espectáculos de pirotecnia de Lambelico del Mondo tinham a função de manter as pessoas em circulação pelo centro, em acontecimento essencialmente conviviais e só muito lateralmente artísticos.

379 Inicialmente em parceria com Dominik Smuzny, mais tarde individualmente.

380 Realizado com a colaboração de Dominik Smuzny e do clarinetista experimental Jerzy Mazzoll. 
oficial no regime comunista, outro edifício em vias de implosão para reconstrução de novos hipermercados. Tal como em KOSMOS, o salvamento do logotipo expande um sentido de mito urbano local a uma interrogação filosófica e política. A performance da retirada da peça de comunicação urbana, com a duração de 30', foi marcada por irónicos (porém no limite da encenação realista - o lettring é retirado em três partes por um guindaste, ao mesmo tempo que os artistas cortam os seus suportes) actos performativos (o retirar das letras foi realizado no início da noite, com direito a transmissão televisiva, e ao som da música experimental de um consagrado clarinetista, recorrendo os artistas à máquinas de fumo e equipamentos ruidosos para espectactularizar a situação criada, numa espécie de acção wagneriana ${ }^{381}$. Debaixo do som por vezes ensurdecerdor de sirenes ${ }^{382}$, e das sonoridades do sopro de Mazoll, o evento conseguiu trazer mais do que uma lágrima a vários elementos do público presentes. ${ }^{383}$ No dia seguinte, o lettring - que como KOSMOS tem, no contacto directo e próximo com os visitantes, uma escala estranhamente humana foi colocado no coração comercial da cidade, a Rua Direita (Szeroka), plena de lojas internacionais. Primeiro (um dia), deitado, como que na expectativa (criando nomeadamente algum nervosismo na organização, que procurava que quanto antes algo como uma 'peça' (o objecto de arte) pudesse ser apresentada. Depois, ao terceiro dia, sobre suportes e devidamente iluminada. Quanto à iluminação, é muito mais que uma trouvaille. Como em KOSMOS, a peça de sinalética, que para ali estar teve de ser minimamente recuperada lestava degradada), e apesar de se tratar de um reclame luminoso, não tinha iluminação própria, sendo iluminada - paradoxo - por projectores correntes de rua. De uma penada, quer a questão do objecto (o dispositivo que separa o objecto do processo revela-se violência e ao mesmo tempo sentido protector da história), quer do processo (a transparência de todas as fases do processo, através da colocação, junto à letras, de um painel explicando a história dos supermercados UNIWERSAM (de um lado) e da própria obra (do outro). Entre as implicações de acto tão simples de mutação da paisagem urbana, destaco o facto de que, assim, algo quotidiano, que estava distante, abstracto, dominando a paisagem, se torna próximo, imediato, contingente, na fragilidade radical da sua significação que assim redunda instável, contingente e de certa forma purificada. Gostaria de concluir que é um trabalho em que ecoam - à vez, quanticamente? - todos os vectores da axiomática da arte crítica na forma urbana, numa acelerada intensidade de possibilidades de objectualização, de conceptualização, da performática e da processualidade transpessoal. E é curioso notar como nesta obra se poderia divisar uma fortíssima concentração do poder utópico da concatenação texto-imagem-corpo-contexto, como que no espelho das sucessivos falhanços modernos da crítica e enquanto superação hipercrítica de um estado civilizacional ${ }^{384}$ Como se houvesse a consciência de que sem discurso não há Homem, e que sem vida digna não há espaço para o discurso - uma proposição de que as peças de Kornacki são manifestamente sinal.

381 Comentário do artista na comunicação da peça (informação para press release).

382 Algumas não foram fornecidas pelos artisrtas, uma vez que os vizinhos chamaram os bombeiros.

383 Importante aspectode comoção que recoinfirmei em conversa com Dorota...

384 Rememoro aqui Things to come, o filme de 1936, poderoso libelo contra a guerra e de dialéctico debate sobre o futuro social, em que curiosamente a 'civilização' está representada nos seus lettrings, nos seus neons, nos seus cartazes, e a sua destruição polo fim da retórica (a guerra) nas paisagens em qe edsesse letrings, neons e cartazes restam caracteres destruídos, ilegíveis. 


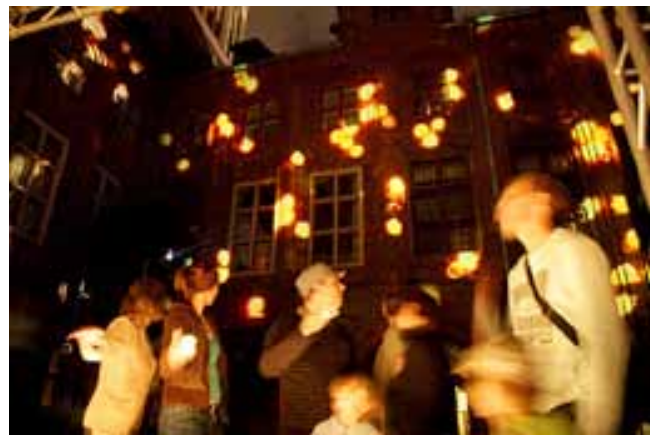

Floating Stars, Nuno Maya \& Carole Purnelle, Skyway 2009

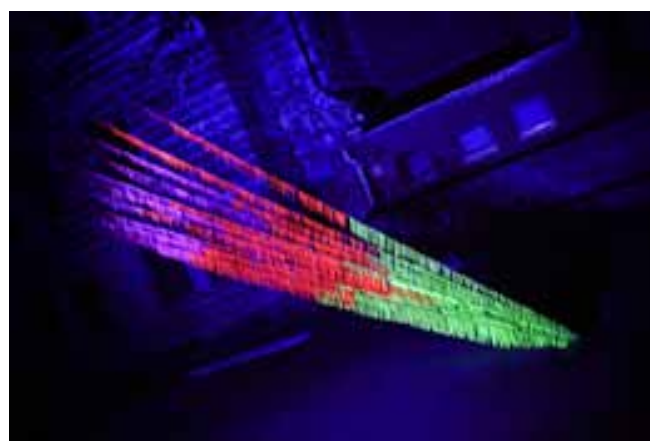

Wish Comet, Jana Matejkova, Skyway 2009

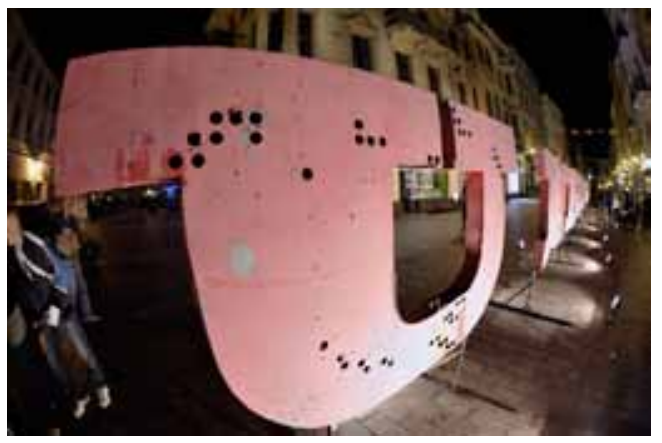

Uniwersam, Stefan Kornacki, Skyway 2010

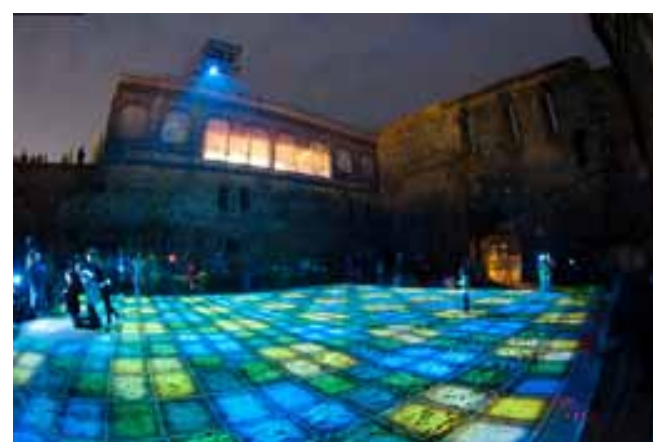

Leds Dance!, Dorota Kraft, 2010

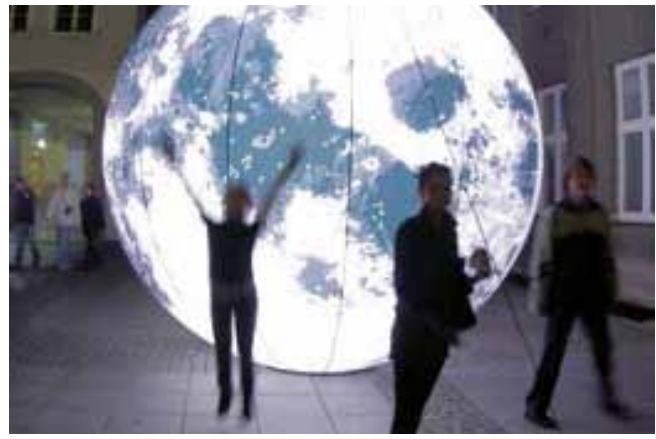

Untitled, Globule Ubiquity Vibrations, Bruno Peinado, Skyway 2009

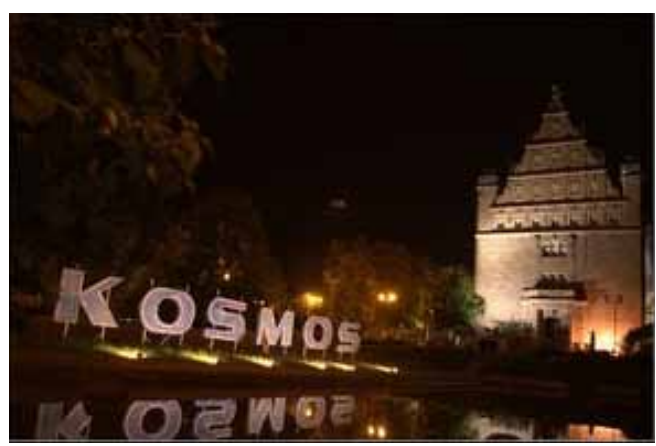

Kosmos, Stefan Kornacki e Dominik Smuzny,

Skyway 2009

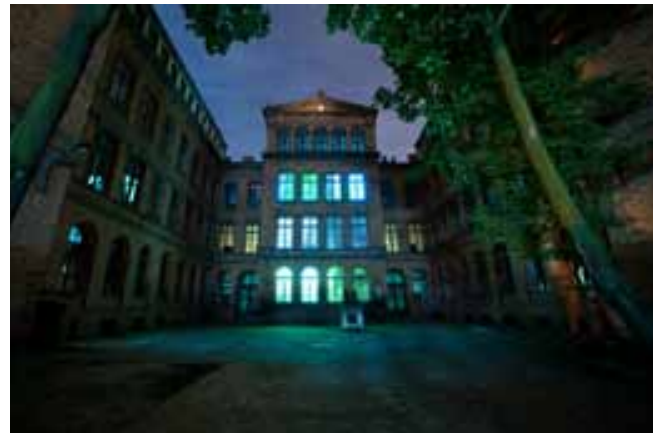

Ceres, Tomasz Cebo e Lukasz Milewski, Skyway 2010

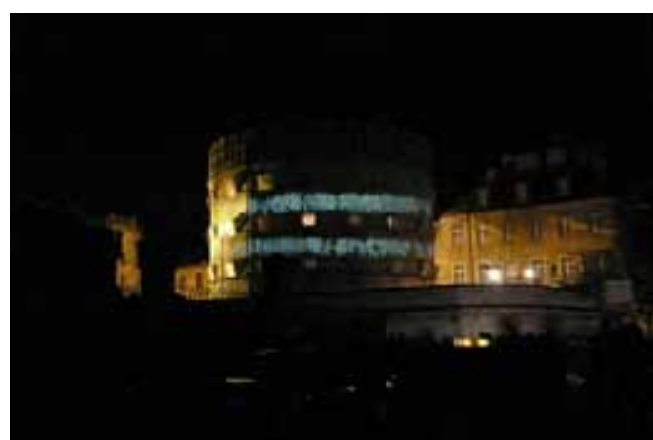

Mercury, Dominik Lejman, 2010 


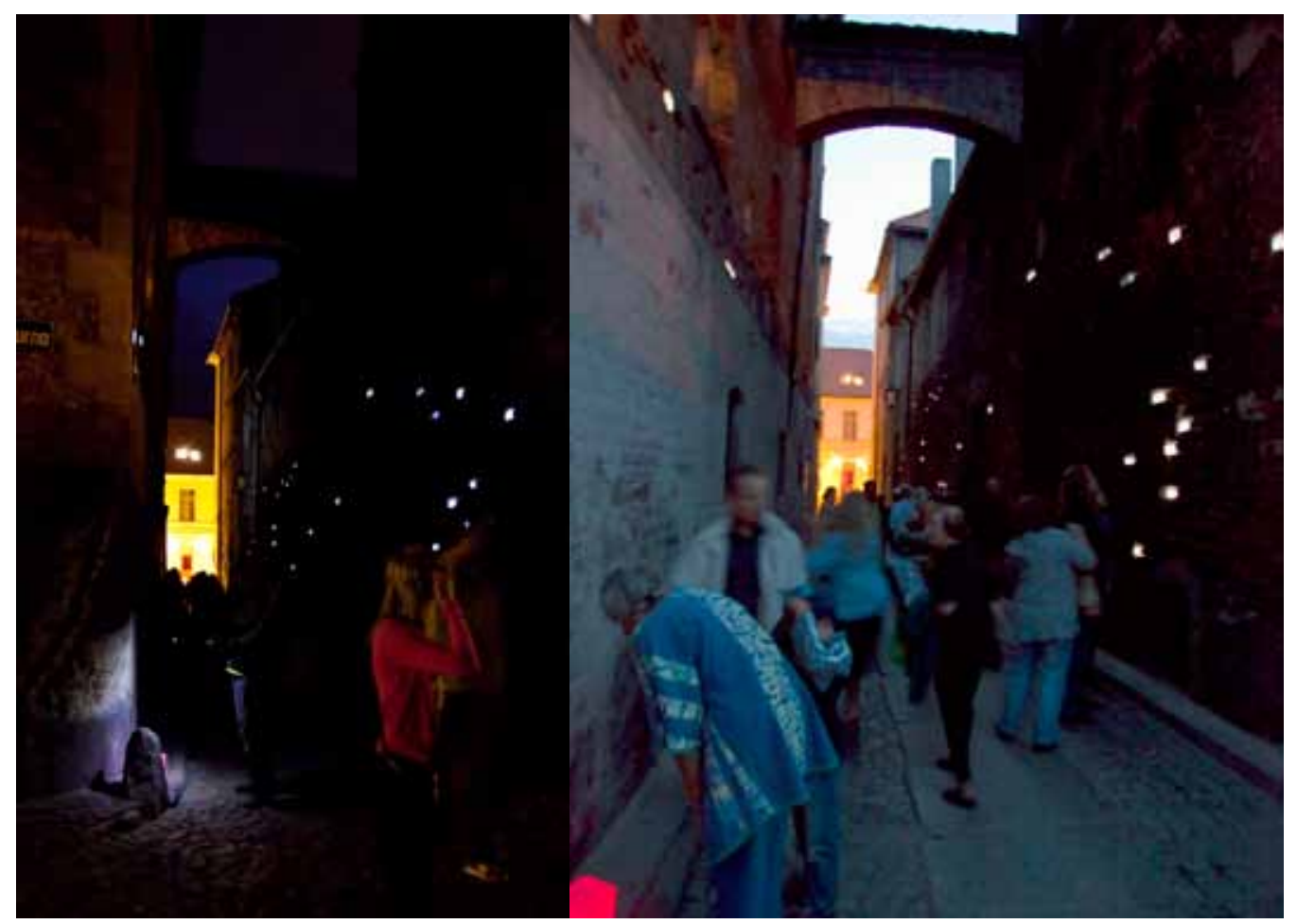

Soap Catharsis Wall, MOOV + Miguel Mouta Faro, Skyway 2009

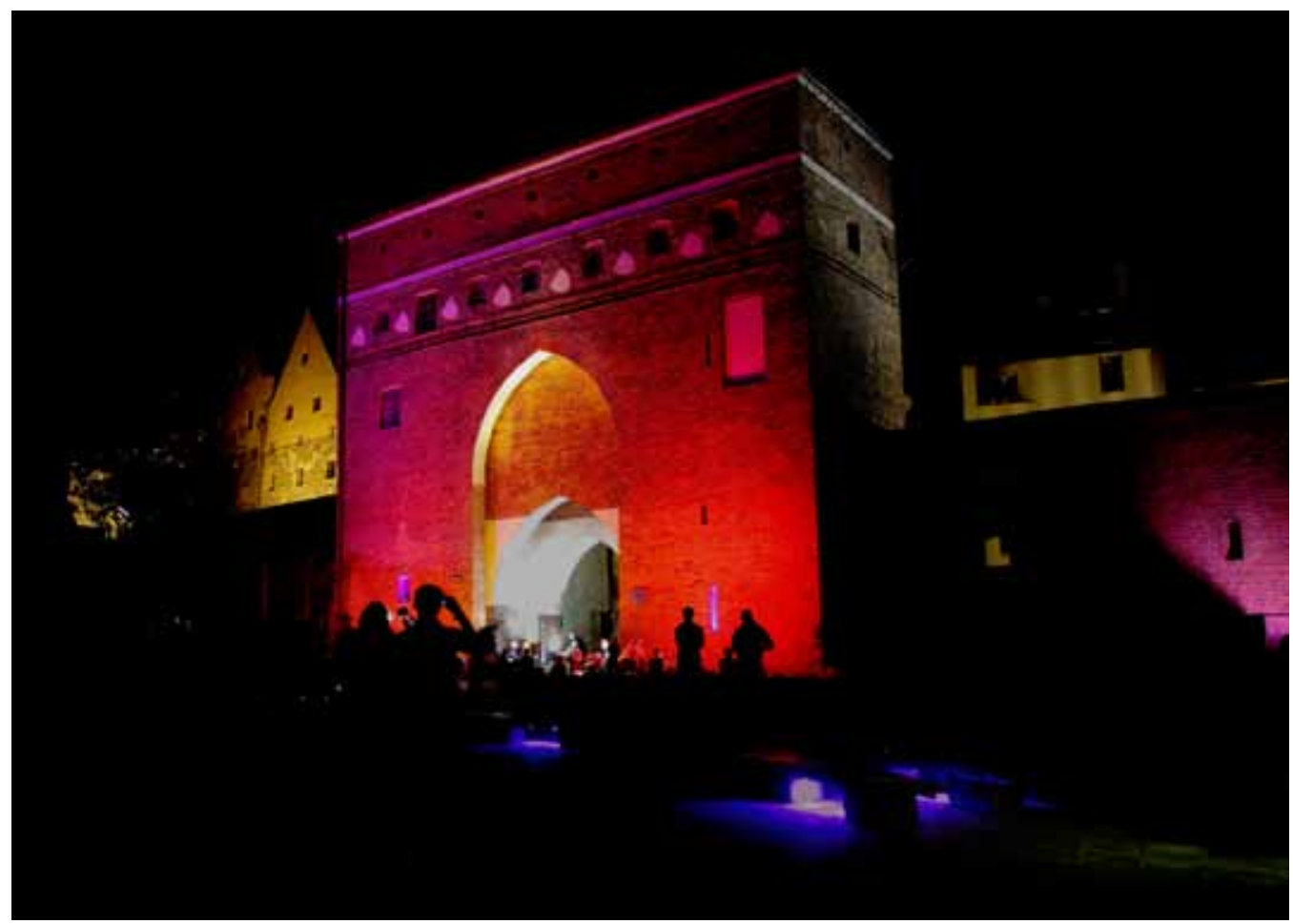




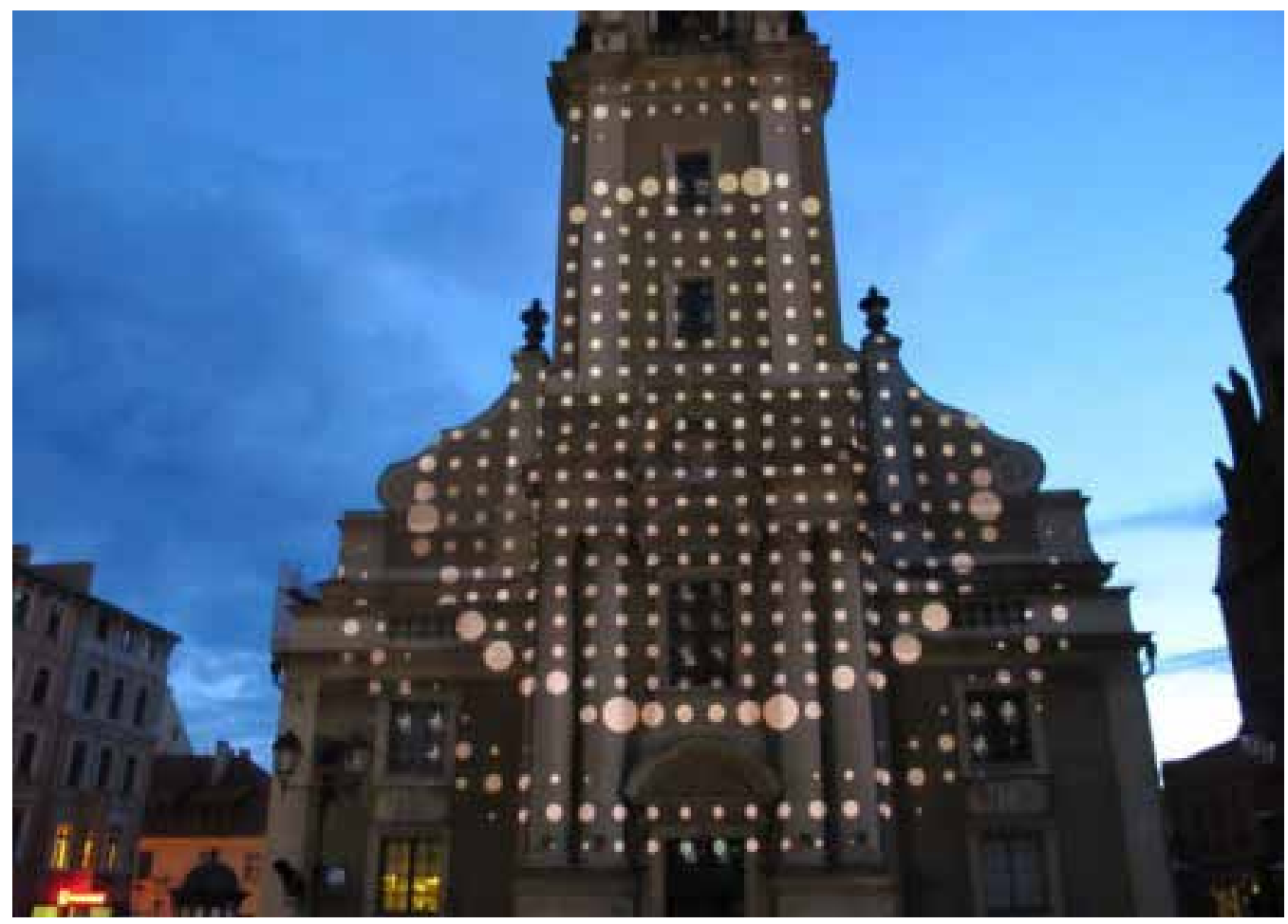

Plenum, Simeon Nelson, Lumière 2011

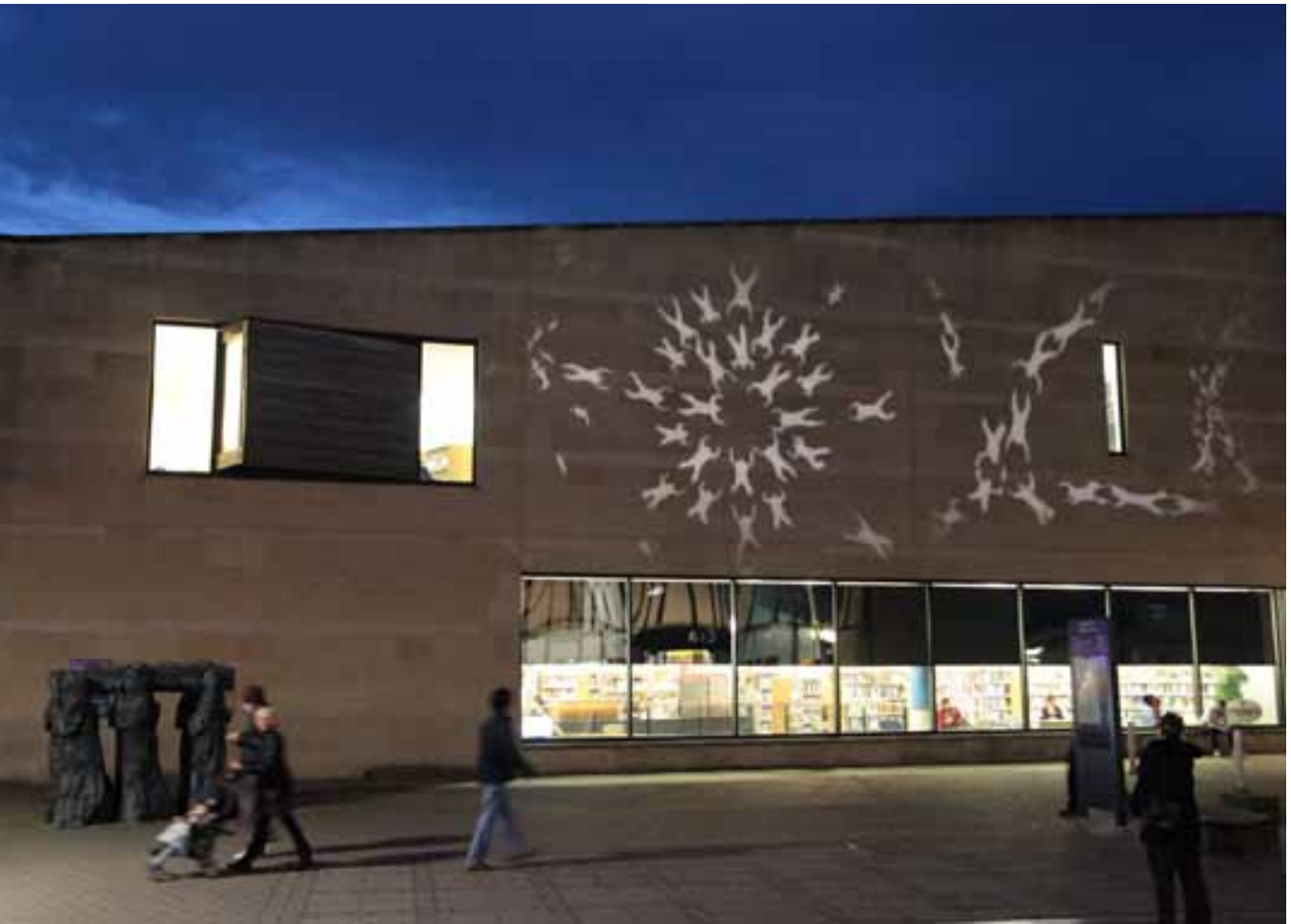




\section{O MODELO RETÓRICO APLICADO A UMA DINÂMICA CURATORIAL}

\section{AXIOMÁTICA DA INTENSIDADE RETÓRICA NA FORMA URBANA}

\section{Ethos curatorial: a questão do tempo}

A noção operativa de curadoria surgiu-me já quase todo o corpus da presente investigação estava realizado. Retrospectivamente, é porém válida para actualizar os contributos de Szeemann ou Ernesto de Sousa na percepção do meu percurso como coordenador e programador de eventos deliberadamente críticos (Judith Rugg)1', integrado num curatorial turn². Este movimento nasce como a resposta discursiva de ethoi críticos face a um conjunto de factos interligados, entre os quais the ritualizing of the experience of art through exhibitions, the rise of 'biennale culture', the expansion of the artist as a meta-curator and the large-scale curated exhibition as the new autonomous artwork. ${ }^{3}$ É perante este cluster de oportunidades e ameaças que procuro as origens remotas do seu próprio senso, confrontando-o já não apenas com as peças e eventos realizados, por si, mas com o que nesses conjuntos de obras e acontecimentos se veio a revelar, pragmaticamente, uma racionalidade retórica.

Com Rugg advogo uma estratégia curatorial relacional, em que a exposição é um espaço especializado de comunicação, apresentação e interpretação; transportando este conceito para o Espaço Público, proponho abordar a minha identidade curatorial a partir de uma posição fundamentalmente crítica - The intention is to piggyback institutions (art and non-art) temporarily, subverting conventions of thinking and introducing different rhythms and narratives that promote a continual questioning of both the nature of contemporary art and of curating practices. ${ }^{4}$

De forma muito sintética, o curatorial turn - o collaborative turn de Maria Lind ${ }^{5}$ - é expressão de uma consciência que se desenvolve nos anos 90. The ascendancy of the curatorial gesture in the 1990's also began to establish curating as a potential nexus for discussion, critique and debate, where the evacuated role of the critic in parallel cultural discourse was usurped by the neo-critical space of curating [...] extending the parameters of the exhibition form to incorporate more discursive, conversational and geo-political discussion. ${ }^{6}$ Liam Gillick afirma o campo:

The brightest, smartest people get involved in this multiple activity of being mediator, producer, interface and neo-critic. It is arguable that the most important essays about art over the last ten years have not been in art magazines but they have been in catalogues and other material produced around galleries, art centres and exhibitions.

Ou seja, o curador é figura nova que veio dinamizar o campo da arte com uma posição

1 Rugg, Judith; «Introduction», in Rugg, Judith; Sedgwick, Michèle; Issues in Curating Contemporary Art and Performance, Intellect, Bristol, 2007.

2 O'Neill, Paul; «The Curatorial Turn: From Practice to Discourse», in Idem.

3 Rugg, p. 9.

4 Idem, p. 10.

5 Lind, Maria; «The Collaborative Turn» in Billing, Johanna; Lind, Maria; Nilsson, Lars (eds); Taking the Matter into Common Hands: On Contemporary Art and Collaborative Practices, Black Dog Publishing, London, 2007.

6 O'Neill, p. 13.

7 Gillick, Liam; in Idem, p. 14. 
híbrida (que as primeiras acepções do termo não tinham): Indicative of a shift in the primary role of curator is the changing perception of the curator as career to curator who has more creative and active part to play within the production of art itself. ${ }^{8}$ Ao nível dos conceitos, esta é uma abertura terminológica, levando a que a indústria cultural possa ser substituída pela indústria da consciência9. Ora é em termos retóricos que a posição do curador aponta a novas economias de tensões:

Exhibitions are, therefore, contemporary forms of rhetoric, complex expressions of persuasion, whose strategies aim to produce a prescribed set of values and social relations for their audiences. As such exhibitions are subjective political tools, as well as being modern ritual settings, which uphold identities lartistic, national, sub-cultural, 'internationl', gender-or-race-specific, avant-garde, regional, global, etc.); they are to be understood as institutional 'utterances' within a larger culture industry. ${ }^{10}$

No início dos anos 90, já este movimento, entretanto tão global como o da arte pública crítica (Scholette) e capaz de inscrever a ansiedade emancipatória aos mais diversos níveis, deixa transparecer um desejo de encontro com a comunidade; no final de um ensaio premonitório, Bruce Ferguson, Reesa Greenberg e Sandy Naime, haviam atestado: But a more specific and sustained engagement with communities and audiences, creating meanings beyond the spectacular and mere festivalising of such occasions, may produce a new genre of exhibition ${ }^{11}$. New genre curating portanto, como a new genre public art que ao mesmo tempo se afirmava, dando forma a relações sociais, culturais, políticas ou até económicas de novo tipo, experimentalmente. Neste quadro novo, alguns curadores tornam-se estrelas da cena da arte contemporânea, à frente de um conjunto de jet-set-flanêurs (O'Neill), mais ou menos capazes de inscrever artistas e obras num emergente cânone lum misto de mito ou superstrutura da arte contemporânea. ${ }^{12}$ É nestes termos que se destacam, depois de numa primeira fase Szeemann ou Ernesto de Sousa, as posições de Jan Hoet, Nelson Brissac, Gavin Wade, Robert Storr ou Dave Beech, que representam uma curadoria activa na criação do seu próprio estatuto discursivo. É em função destes nomes que se pode falar do curador como criador..$^{13}$ O'Neill propõe hoje o termo de meta-artista ou meta-curador, que linka a curadoria experimental aos primeiros exercícios curatoriais de Duchamp..$^{14} \mathrm{O}$ termo é feliz, porque evita a reificação que seria considerar o curador como artista (como notou Storr em boa altura ${ }^{15}$ ). Como exemplo de um primeiro meta-curator numa recente genealogia de personalidades marcantes, dá aliás a figura de Jan Hoet. ${ }^{16}$

No contexto geral da pós-modernidade, os novos curadores criam contextos emergentes

8 O'Neill, p. 15.

9 Idem.

10 Idem, p. 16.

11 Idem.

12 Benjamin Buchloch, in idem.

13 Bruce Alshuler, in idem, p. 20.

14 Cf. «First Papers of Surrealism», em que Duchamp estende fio de barbante entre as obras de Ernst, Chagall ou Calder, ao dispositivo voyeur de «Étant Donnés». Phaidon Editors; Altshuler, Bruce (Eds.); Salon to Biennial - Exhibitions That Made ArtHistory - Volume I: 1863-1959.

15 O'Neill, p. 21.

16 De cujo catálogo Over the Edges, inspiração para a LXCN, retirei a designação Extramuros (que Hoet utiliza para veicular a ideia de um Museu transvazando os seus limites). 
- contribuindo para a complexidade do sistema da arte e o social com os seus discursos simbióticos; ${ }^{17}$ e tornam-se a dada altura alvos preferenciais das sensibilidades que negam a vitalidade do socius.

According to Zygmunt Bauman, it is precisely because of an absence of a single, universally accepted authority within contemporary culure that curators are becoming 'scapegoats' [...] because the curator is on the front line of a big battle for meaning under conditions of uncertainty. Bauman adds the term 'scapegoat' to a long list of ingredients for a curator's role which he lists as animator, pusher, inspirer, brother, community maker and someone who makes people work and things happen and someone who inspires artists with ideas, programmes and projects. ${ }^{18}$

Ou seja, desde que crítico e público, o curador enriquece a intersticialidade da própria arte, à custa de uma acepção de autonomia problemática para a sua própria identidade emergente. É isso que garante ao curador um lugar na revitalização da cidade, pelo menos enquanto souber integrar na sua condição valores retóricos como a esperança (Harvey), legitimando-os na ressonância de um devir e sensibilidade colectivo. Importa depois confrontar estas definições da curadoria para além da sua função estável no sistema da arte ${ }^{19}$ com a produção concreta da obra de arte na forma urbana, no quadro da axiomática que a minha praxis curatorial foi afirmando (inconscientemente) ao longo do tempo.

Entretanto, In short, good exhibitions have a definitive but not definite point of view that invites serious analysis and critique, not only of the art but of the particular weights and measures used in its evaluation by the exhibition-maker ${ }^{20}$. Por outro lado, exhibition makers must abstain from dealing with material into which they do not have a superior insight no matter how tempting the Job might otherwise be.$^{21} \mathrm{O}$ curador tem de ser um contador de histórias - contar, mais do que mostrar: Showing is telling. Space is the medium in which ideas are visually phrased. ${ }^{22} \mathrm{Na}$ arte pública, estas questões complexificam-se, desde logo sendo o infinito-informe social em emergência a matéria por excelência da intervenção urbana; sendo o público uma entidade mais ambígua e finalmente sendo a noção de prazer certamente mais complexamente formulável (do que no conforto do cubo museológico). Talvez se trate simplesmente do que o curador Ralph Rugoff aponta no seu texto para a mesma publicação: You Talking To Me? On curating Group Shows that Give You a Chance to join the Group. Isto é: a great group exhibition [...] asks its audience to make connections. Como? I think exhibitions can likewise provide us with loopholes and escape hatches from the packaging they impose on our encounters with art. ${ }^{23}$

17 A ponto de existir com frequência um receio de a visão curatorial abafar as visões artísticas em que afinal se apoia.

18 O'Neill, p. 23

19 Storr, Robert; «Show and Tell», in Marincola, Paula; What makes a great exhibition? - Questions of Practice, Philadelphia Exhibitions Initiative, Philadelphia, 2006, p. 15. The crucial issue here is not input, which is essential, but rather fending off the managerial and sometimes market-driven tendency to put together shows by committee. This leads to a bureaucratic division of labor, with sections of the overall enterprise being turned over to professionals in various fields, design (that is, form) to designers, education and communication (that is, content) to educators and press officers, and so on.

20 Realço que, para Storr, a integridade da exposição é de tal forma fundamental, que o fazedor das exposições tem de integrar na sua visão todas as cndições substantivas que definam o encontro do espectador com a obra le, para Storr, ter a última palavra nos mais ínfimos detalhes do projecto e da experiência expositiva (da iluminação à tipografia).

21 Storr, p. 16.

22 Idem, p. 23. Na "narrative thinking" (Goldie) da curadoria, os tornam-se mitos no conceitos, nomeadamente estéticos.

23 Rugoff, in idem, p. 44. 
Rugoff conclui, no que poderia ser um apelo à 'tomada da rua' pela arte da curadoria:

For this reason, I tend to conceive of the curator's role as a caretaker. We attempt to provide a meaningful environment in which the objects we work with can thrive - in which their significance can be fully explored, even amplified. We also seek to construct situations in which our audiences can thrive as well - not always an easy task given the inhospitable and intimidating nature of most museum spaces. ${ }^{24}$

\section{Tempo do tempo}

Antes de avançar impõe-se uma nota sobre a ideia de um tempo le não apenas de um espaço) urbano. Em Stephen Wright encontramos uma abordagem do actual tempo urbano ${ }^{25}$, um tanto presa à questão do espaço, cujo logos tende a excluir a possibilidade de um tempo público la reflexão sobre a publicidade, a intensidade e a própria experiência do tempo por via da memória, da anamnese, da durée, do arrebatamento emocional, etc.). $O$ autor sublinha a habitual redução dos termos esfera pública e espaço público à sua dimensão espacial, perguntando:

Might one not think of a public time as carving out breathing spots, intervals, transitory breaches in the very core of collective existence, time slots still unfetteterd by moral or political discipline? When one turns to practical examples of time-based art practices, often inscribed in the body politic or human landscapes - infiltration practices, tactical media initiatives - which unfold not only in space but in time, one is obliged to acknowledge that time is their defining but as yet entirely undefined factor. ${ }^{26}$

A irrupção de um tempo próprio - íntimo e/ou colectivo - foi teorizada por Lefèbvre (Teoria dos Momentos) e sabemos como determinadas interrupções do ritmo urbano habitual funcionam como verdadeiros oásis de experiência (abrandamentos cognitivos). Esta questão implica com a de uma conceptualização do tempo como a componente propriamente vivencial do espaço, e do espaço como a componente material - enquanto forma - do espaço social. ${ }^{27}$ Isto é, na minha axiomática, o espaço-tempo do público é total. De resto, para Rancière, a democracia é fragilmente temporal, a esfera do demos é um intervalo, o foco de conquistas provisórias (relacionadas com as identidades sociais). Wright sublinha a temporalidade desse intervalo, ajudando-nos a ler a cidade como lugar do redesenho do tempo ${ }^{28}$ :

And that sphere is essentially temporal: democracy is the process of struggle against the privatization lof the public sphere), the process of broadening the public sphere. The sort of public time that I refer to as without qualities - in other words, non-subjected to privatized usage - is the very condition of the possibility of democracy. ${ }^{29}$

É portanto a própria conceptualização do tempo como dispositivo que Wright propõe, precisamente para lidarmos com um regime de tirania do presente ${ }^{30}$ em que constantemente

24 Idem, p. 51.

25 Wright, Stephen; «Time without Qualities: Cracking the Regime of Urgency», in Public Spheres after Socialism, Ed. Ângela Harutyunyan, Kathrin Hörschelmann \& Malcolm Miles, Intellect, Bristol, Chicago, 2009

26 Idem, p.. 129

27 Esta questão é tanto mais interessante quanto, para 'captar o tempo', usamos quase sempre metáforas espaciais (Miles), sujeitando a forma urbana a uma racionalidade de base espacial.

28 Não me refiro aqui aos novos autorproclamados 'designers de tempo', que prestam serviços a quem deseja melhor organizar o seu dia-a-dia numa esquema de optimização da performance cidadã (mais ou menos normalizada).

29 Wright, p. 130.

30 Relativamente a esta questão, valeria a pena ler igualmente Luís Carmelo acerca do tema da instantaneidade, em Anjos e Meteoros - Ensaio sobre a instantaneidade. Cf. http://bocc.ubi.pt/pag/carmelo-luis-anjos-meteoros. 
nos falta tempo. O destino do tempo público está portanto na agenda de qualquer praxis crítica e/ou emancipatória. ${ }^{31}$ Em suma, a metáfora do espaço público, ou é entendida também temporalmente, ou será insuficiente para levar os criadores e enfrentar a hegemonia do capitalismo cognitivo, que é ele próprio um dispositivo imaterial de intelectualização, estetização e mesmo artificação (Wright parafraseando Montaigne) do processo produtivo (e comunicacional), sob a égide de um Trabalho Total que a todos obriga a transformar-nos em termos de um negócio. ${ }^{32}$ Concluindo, If we are to enjoy time without qualities le a lição do flâneur passou por esta resistência), time itself must be freed from commodification and an economy of scarcity. ${ }^{33} \mathrm{~A}$ arte na forma urbana é uma arte do tempo urbano.

A título de exemplo de uma posição crítica do tempo urbano actual, recordo Walking a painting (2002), de Francis Alys, em que este 'leva uma pintura a passear' nas ruas da cidade durante todo o dia, devolvendo-a ao museu para 'descansar' - o vector horizontal pintura (objecto) / cidade (processo), aqui interpretado na modalidade performativa. Noutra obra de Alys, Zócalo, é um medir do tempo de uma praça que o dispositivo de exposição luma projecção vídeo com cerca de cinco horas de duração) convida a experimentar. ${ }^{34}$

Face ao monumento como facto urbano persistente (Aldo Rossi), também os Stalker - e muita arte relacional - apresentam um modelo temporal alternativo, no que é precisamente a criação de outro tempo de vida, presentificação do social le não sua representação, como vimos em O'Sullivan):

Si, pour le laboratoire Stalker, il existe un fait urbain, celui-ci ne saurait être assimile à une construction parfaitement circonscrite dans l'espace, installé d'une façon prolongé dans la mémoire des individus et des groupes, à un ibjet dont on peut durablement faire le tour, mais à un mouvement, jamais absolument contrôlable, qui apparâit et qui meurt, à un territoire labile que l'on peut traverser sans avoir ni le désir ni le projet de l'habiter selon un plan d'occupation du sol. Ici, la ville, l'architecture, sont un processus, un devenir à l'ouvre qui se confond avec un espace abandonné, et qui révèle de que la ville formatée n'a pas forcement le temps, l'occasion ni la volonté de regarder: une autre possibilité d'existence qui sommeille dans la mégapole supposée connue, une fluctuation urbaine qui fonctionne comme le refoulé du territoire résidentiel.

Esta perspectiva é a de um abandono gracioso ao devir temporal da cidade. Para isso é preciso fundar o trabalho em noções de fluidez/fluxo, as únicas capazes de exercer uma pressão de désobjectivation du décor urbain ${ }^{35}$. As únicas capazes de integrar na obra de arte crítica a experiência vivida de participantes vários (e já não apenas 'profissionais'), e de lhes fornecer uma capacidade poiética socialmente redentora, sob a figura de uma relação poten-

html. Consultado em Setembro de 2011.

31 Uma excepção de grande relevo, em Portugal, o projecto 8!8!8!, de Pedro Penilo.

32 Que de resto não é por a arte revelar e propor intersticialidades que não deixa de ir buscar a essas mesmas experiências ideias práticas para a sua continuidade, como acontece quando marcas recuperam a linguagem visual e mesmo as formas de convivialidade urbana característicos de grupos marginais, para fins publicitários e de marketing direccionado, nem sequer directamente social).

33 Wright, Stephen; «Time without Qualities: Cracking the Regime of Urgency», in Public Spheres after Socialism, Ed. Ângela Harutyunyan, Kathrin Hörschelmann \& Malcolm Miles, Intellect, Bristol, Chicago, 2009, p. 132.

34 Davila, Thierry; Marcher, Créer - Déplacements, flâneries, derives dans l'art da la fin du XXe siècle, Regard, Paris, 2002, p. 99. Film quasiment en continu pendant une journée, ce lieu joue ler ôle d'un cadran solaire monumental, qui mesure non seulement l'ecoulement du temps, mais l'adaptation spontané du mouvement de l'homme qui marche à la durée, aux heures qui passent et à l'espace en grisaille qu'elles dessinent sur le dallage. Cf. O Efémero, em Buci-Gluchsmann.

35 Idem, p. 122. 
cial ou efectivamente lúdica (Schiller, Lefèbvre), capaz de desdramatizar, reconfigurar e porventura alterar radicalmente aspectos do quotidiano habitual - como num monumental live act. Um termo que se revela aqui importante é, já não apenas o do efémero, mas o da actualidade do território (Grout) - o projecto de cidade realizado como arquitectura-jardinagem: L'actuel n'est pas ce que nous sommes mais plutôt ce que nous devenons, ce que nous sommes en trains de devenir, à savoir l'Autre, notre devenir-autre. ${ }^{36} \dot{E}$ todo um filosofar e um metafilosofar da emergência da consciência (situada, colectiva, comunitária, sempremergente) do projecto urbano, na cidade pós-industrial, que aqui se revela. É ainda uma retórica que interpreta os valores da durée, do tempo e do movimento que procuram escapar-se à instrumentalização e à funcionalidade, modulação e controlo: l'actuel est une façon de ne pas substantialiser l'actualité, de ne pas la réifier en un état figé ou en précis situe dans une chronologie, pour la rendre fluide, pour l'envisager comme une circulation dans l'espace et dans le temps, et pour, en une totalité nietzscheènne, affirmer sa portée essentiellement inactuelle. ${ }^{37}$

O actualizar do território é naturalmente também uma conquista de memória, mormente ficcionada. ${ }^{38}$ Eis-nos num activismo do momento, em prol de futuros possiveis experimentáveis no agora, aprofundando a instrumentalidade do contravisual (Vidal, d'aprés Debord; as contraimagens em Sola-Morales) ${ }^{39}$ ou das heterotopias de Foucault. Integrando-as numa perspectiva retórica-comunicativa como na arte comunitária de média e longa duração (Kester), esta ideia crítica do tempo contribui para a originalidade formalmente política dos projectos que a seguir destacarei. Space now becomes perhaps less an optical than a performative field: as self and body are transformed into «temporal constructs». Há casos paradigmáticos desta apropriação conceptual-temporal-espacial das formas da cidade. Em 1990, Boltanski realiza um dos seus monumentos 'invisíveis', num vazio urbano em Berlim Oriental. A tradição do contra-monumento, em Boltanski, como Jochen Gerz, é uma assumpção da complexidade emocional e de uma axiomática profunda em tensão na obra de arte, que precisamente pela via da comunicação chega progressivamente a um alargado público sem que isso signifique obscurecimento quer das categorias (apesar de tudo ainda operativas) 'arte' e 'monumento', ou de noções em crise como 'democracia' ou 'política'. Em Gerz e Boltanski, a deriva comunicacional é abordada 'negativamente' (Krauss), numa performática do invisível, que é o comentário e a interpretação, por alguns agentes privilegiados do mundo da arte, a complementarem a intenção do artista. ${ }^{40}$ De qualquer forma, nestes criadores, a obra devient banal et s'inscrit dans les multiples aspects de la vie quotidienne [...] l'art semble

36 Cf. «Manifeste Stalker», in Stalker Attraverso i Territori Attuali / À travers les territoires actuels, Jean-Michel Place, Paris, 2000.

37 Davila, Thierry; Marcher, Créer - Déplacements, flâneries, derives dans l'art da la fin du XXe siècle, Regard, Paris, 2002, p. 133

38 Banes, Sally; in Johnstone, p. 117. Psychogeography set in motion a surrealist experiment with the city. Many passages in Chtechglov's Formulary For a New Urbanism' also reflect this: 'All cities are geological and you can't take three steps without encountering ghosts, armed with the prestige of their legends. We evolve in a closed landscape whose landmarks draw us incessantly towards the past. The psychogeography is fundamentally an experience of mobility, applied to space as much as to time.

39 Sola-Morales, Ignasi de, i Rubio; «Urbanité interstitielle», Inter Art Actuel n. 61, hiver 1995, p. 27.

40 É uma via críptica e enigmática, hermética, que Caros Vidal identifica aliás com o que lhe parece ser último reduto do político no regime comunicacional do espectáculo contemporâneo. 
donc de moins en moins identifiable en tant que tel. ${ }^{41}$ É portanto sob esta figura de uma dissolução vazia da obra na forma urbana que o minimalismo merece ser actualizado, agora face à complexidade sistémica do contexto e as modalidades contemporâneas da comunicação da arte na forma urbana.

\subsection{Tensões e quadrantes}

The clarification of vision is a first step towards reasonably

and humanely changing the world.

Martha Rosler

A presente secção corresponde à percepção de que quatro vectores/orientações determinam um campo de forças nos projectos e obras estudados, sendo a intensidade retórica de cada acontecimento o que define o poder dos desenvolvidos pela actividade artística, é a consciência da equivalência entre os quatro vectores que contribui para impedir a reificação de determinadas modalidades da arte na cidade. Isto é, torna-se condição de partida para garantirmos a transparência operativa do dispositivo-arte-na-cidade, a partir de um ponto básico (mas não trivial) da sua inscrição - o de como cada decisão projectual define uma atitude. É neste sentido que ressoam questões previamente levantadas - Museu/ Intervenção, Contexto/Situação, Activismo/Participação.

Esta estrutura axiomática enquadra a amplitude formal da arte pública no espaço urbano. É uma ferramenta de esfera pública, desenho urbano e contínua reconceptualização da arte. No espírito do binarismo lefèbvreano, expõe dois eixos tensionais - um vertical e outro horizontal - e a cada um deles associa valores (contrastantes, antinómicos), extrapolando um mecanismo de lassociação de ideias e contextualização das mesmas numa dinâmica de comunicação. Integrando conceitos oriundos da teoria cultural, assim como termos-chave da estética num registo ora técnico (científico, filosófico, académico), ora metafórico (poético, discursivo, pragmático), é um skhema para o ensaísmo curatorial na cidade.

A esta axiomática crítica da forma urbana confiro a responsabilidade de estruturar o que tem sido uma colonização da cidade por signos, símbolos e sentidos arbitrários de que estão ausentes processos genuinamente negociados (participativos, colaborativos, apropriativos), ou resultantes de uma progressiva consciência colectiva dos aspectos mais críticos da arquitectura, do design ou da arte. ${ }^{42}$

41 Jimenez, p. 268.

42 Grout, pp. 141-142. 


\subsubsection{Axiomática, dinâmica e realismo minimal}

Os termos que dão substância à presente axiomática são em número variável e virtualmente extensíveis até onde a elasticidade dos sinónimos e o pensamento associativo o permitem. Cinco pares de oposições operativas são o necessário e suficiente para atingir uma dinâmica 'quântica' - um aspecto de uma obra, por exemplo, ou um traço ético num artista, pode estar em dois pontos distantes do mesmo vector, sinal da sua vibração retórico-comunicacional (intensidade vibratória). O carácter crítico dessa vibração pode ser deduzido, embora não exclusivamente, da análise de como a obra se filia nalguma ou várias das três operações-chave da arte crítica la polarização museu/intervenção urbana; a articulação contexto/situação e a possibilidade de concatenação activismo-participação), actualizando-as persuasivamente num discurso pela comunidade. São assim pares fundamentais, ao nível do eixo horizontal (pólos Esquerda/Direita):

- Museu/Espaço Público (intervenção)

- Objecto/Processo

- Belo/Sublime

- Forma/Informe

- Pintura/Arquitectura-jardinagem (Paisagem)

Estas dicotomias implicam um entendimento articulado também de outras dicotomias, tais como indoor/outdoor; actividade institucional/activismo independente, expressão de uma deriva processual e fundadora da arte moderna na transição para a contemporânea. Apesar de as manter deliberadamente num limbo de significação, estas dicotomias explicitam questões fundamentais como a das modalidades de acesso do público à criação artística.

Ao nível do eixo vertical (pólos Cima/Baixo):

- Ideia/Corpo

- Texto/Imagem

- Intelecção/Provocação

- Palavra/Gesto

- Arte Conceptual/Artes Performativas

Tanto mais dinâmico for o carrossel de interpretação a partir destes termos-chave le outros associados), mais este esquema se torna o suporte de uma linguagem e não tanto, o que seria de evitar, uma gramática inerte.

Nos anos 00 some of the absurdity of the world situation is sedimented in ironic and at times aggressive art, but practices also emerge today which see a new potential for global communication and a critical visual culture, and which engage with both new agendas and those of the human condition. ${ }^{43} \mathrm{E}$ a partir desta constatação de uma arte vernacular (Knight) que, no meu esquema cruciforme, valorizo as práticas comunicativas e engajadas - isto, é o quadrante superior-direito da minha axiomática, que talvez me surja como o mais determinante ao

43 Malcolm Miles; «General Introduction», in New Practices, New Pedagogies, European League of Institutes of the Arts, Routledge, London and New York, 2004. 
nível de um entendimento (Wagner) da condição urbana. Kester, ecoando Schiller, confirma que aesthetic experience challenges systems of knowledge ${ }^{44}$ e Marcuse menciona o poder de afectação da arte lantecipando o valor político-emancipatório que hoje Gross e Thrift sugerem). Neste quadro, a minha retórica da arte pública funciona antes do mais como um complexo apparatus discursivo-cognitivo que enquadra todas estas éticas (e outras), nascendo por outro lado da experiência estética que as obras mencionadas motivaram. Este meu esforço taxonómico gera novas ideias e assim reconfigura o familiar ${ }^{45}$ num quadro de resistência a hegemonias várias. ${ }^{46}$

\section{Minimalismo: introdução à arte como linguagem axiomática}

Para muitos autores (Krauss, Maderuelo, Sardo), a origem da arte pública (crítica) é, recordo, a escultura minimalista, no punctum da minha axiomática. Os trabalhos de Morris, Andre, Heizer ou Turrell - hoje Eliasson - laboram nessa zona central ${ }^{47}$. E é assim que quando Morris ou Andre inserem no objecto escultórico uma reflexão fenomenológica que antes do mais é uma combinação de exclusões formais, temos um exercício cognitivo de enorme importância para a reflexão sobre a questão da arte na forma urbana, complexo jogo de equivalências e oposições - arquitectura-paisagem; arquitectura-não-arquitectura, etc... jogo esse sempre a redefinir pelo artista que conduz o processo de acordo com um mode of address específico e as agendas sócio-políticas do seu tempo. A reter então, no essencial, o minimalismo como reflexão estratégico-formal - como exercício lógico-axiomático; e depois a emergência de um 'campo expandido' naturalmente não apenas para a forma escultórica. É neste sentido que Krauss afirma: Labyrinths and mazes are both landscape and architecture $i^{48}$ Muitas formas de neovanguarda nos anos 70 podem então hoje ser vistas como exercícios de reencontro da escultura - e da arte - com uma sua vocação experimentalmente monumental e celebratória lagora sob outros paradigmas culturais, como os que decorrem de uma atenção pragmática à emergência do político e da memória, ao processual ou ao efémero), em afastamento tensional do objectual face ao processual (colectivo, comunitário, participativo). É nestes termos que recupero termos de Krauss, como marked sites (Spiral Jetty, de Smithson, desejo humano de inscrição cultural

44 Kester, Grant H.; Conversation Pieces, p. 3.

45 Becker, Carole; Zones of Contention: Essays on Art, Institutions, Gender and Anxiety, The University of New York Press, Albany, 1996.

46 Evitar a imprecisão de Krauss na recepção dos primeiros minimalistas - apressada- e erroneamente comparados ao construtivismo de Gabo ou Tatlin, quando o cerne da sua operatividade se decidia numa performática axiomática do objecto de arte face à articulação corpo/arquitectura.

47 Mas sublinho que não é possível recuperar as reflexões de Krauss sem as contextualizar enquanto pensamento da negatividade; a mesma negatividade que leva Balzac ou Brancusi a abdicar da lógica monumental la arte num lugar) para conferir à escultura uma autonomia específica, cujo signo é ao nomadismo assegurado pelo pedestal, que entra em crise com a irrupção conjunta do minimalismo, da land art e da pop: In being the negative condition of the monument, modernist sculpture had a kind of idealist space to explore, a domain cut off from the Project of temporal and spatial representation [...] it began by abut 1950 to be exhausted. [...] At this point modernist sculpture appeared as a kind of black hole in the space of consciousness, something whose positive content was increasingly difficult to define, something that was possible to locate only in terms of what it was not. (Krauss, p. 34)

Krauss, p. 38. 
na paisagem) ou axiomatic structures ('estádios intermédios' numa evolução lógica que vai da ideia tradicional de escultura - objecto, sujeito ao logos da 'arte' - à ideia contemporânea em que o lugar-tempo é instância de transferibilidade (Gabriela Vaz-Pinheiro).

A tónica numa pulsão de encontro com o social estabelece uma tensão entre a ideia de 'inscrição' individual (Smithson, Heizer) e o que Christo arrisca em Running Fence (1973), em que a demarcação de um território é impermanente, processual e política. Nesta abordagem do processo criativo, a arte explora as possibilidades tensionais de uma arquitectura a que se soma uma não-arquitectura - como em Robert Irwin ou Richard Serra ${ }^{49}$, a process of mapping the axiomatic features of the architectural experience - the abstract conditions of openness and closure - onto the reality of a given space. ${ }^{50}$ Essa realidade, complexa e fenomenal que chega com o minimalismo, passa por vectorializar, nas decisões projectuais, quer o corpo quer a ideia: The minimalists - and first-wave conceptualism more widely - were also involved in a move towards object exteriority. There was an emphasis on the body, language, or the site, that moved towards relations with a more heterogeneous outside. ${ }^{51} \mathrm{O}$ que vai de encontro a uma situação diagnosticada por Pasolini, em que o corpo tende a ser utilizado como algo terríve ${ }^{52}$ numa civilização apenas aparentemente 'confortável'.

Uma coisa é certa:

With regard to individual practice, it is easy to see that many of the artists in question have found themselves occupying, successively, different places within the expanded field. And though the experience of the field suggests that this continual relocation of one's energies is entirely logical, an art criticism still in the thrall of a modernist ethos has been largely suspicious of such movement, calling it eclectic. ${ }^{53}$

\section{A pequena grande arte minimal totalmente realista}

Enquanto experiências iniciais da pós-modernidade, as esculturas minimalistas supra-referidas definem-se enquanto intensas operações explicitamente lógicas - constituições de dispositivos (logos) numa retórica reactiva face à representação moderna e à sua cultura visual. São reacção a uma determinada situação cultural que retira à arte o contexto e a experiência física. A materialidade crítica do minimalismo que expandiu a escultura é portanto uma chave para compreendermos como arte e forma urbana, desde então, se encontram num diálogo que aprofunda (dando-lhe consistência) a 'abertura conceptual' da arte moderna. Mais, ao definir-se como lógica - logos, discurso linguagem, projecto, dispositivo - a arte contemporânea minimalista é um exercício tautológico e sobretudo de vazio que faz dessa sua desmaterialização face à perspectiva histórica do objecto um programa de aproximação à complexidade da vida urbana. Esse o paradoxo: na altura em que a obra de

49 Este numa linguagem objectualmente hipercompacta.

50 Krauss, p. 41.

51 Lash, Scott; «Art as concept / Art as media / Art as life», in Museus - Discursos e representações, coord. Alice Semedo e J. Teixeira Lopes, Afrontaento, Porto, 2005.

52 Nico Naldini, Pier Paolo Pasolini, Circe, Barcelona, 1992, p. 370. O corpo converteu-se na metáfora do que Marx chama a mercantilização do corpo, a alienação do corpo. O que Hitler fez brutalmente, ou seja, matando, destruindo os corpos, a civilização consumista fê-lo no plano cultural

53 Krauss, p. 42. 
arte se 'desmaterializa', ela vira-se para a totalidade dos materiais e matérias disponíveis em seu torno. Se soubermos não confundir os materiais com a matéria ${ }^{54}$, compreendemos a deriva urbana da arte pública - minimalista, ambiental, performativa, contextual, relacional, comunitária... - como uma iminente recuperação e ao mesmo tempo superação das ideias feitas pela história ${ }^{55}$ :

[...] three key shifts in conceptual and minimal art: the gradual movement away from object-based practices; the interest in making a given work of dependent on direct physical or perceptual interaction with the viewer las seen in works of Vito Acconci, James Turrell, and Robert Irwin, among others); and a related shift toward a durational, rather than instantaneous, concept of aesthetic experience las manifested in Dan Graham's early video installations, which require an extended period of viewer's participation). Taken together, these transitions set the stage for an interactive, collaborative art practice, informed by conceptual art but located in cultural contexts associated with activism and policy formation. ${ }^{56}$

É o caso de projectos de Helen e Newton Harrisson nos Estados Unidos, pioneiros numa arte urbanística; de Critical Art Ensemble, na esfera da bioética; ou Artists Placement Group em Inglaterra, que participaram em funções políticas oficiais. Chegados aos anos 90, essa é já uma linguagem que actualiza todas as instrumentalidades da instalação, da performance, mas também da arquitectura, da política, com saberes complexos também eles sempre em emergência crítica, entretanto enriquecidas (confrontados) por movimentos como o Feminismo ou os Estudos Culturais. Assim se explica a disponibilidade para alguma arte se diluir em formas contemporâneas de tecnologia ou ciência com a sua hibridez a desvelar uma radical abertura para o seu reposicionamento como 'forma' cultural. A questão é ética no sentido em que é o território de uma emergência discursiva resiliente à cegueira da matriz tecnocientífica da civilização contemporânea ${ }^{57}$. Isto se situarmos, ainda e sempre com Aristóteles, a Humanidade e o Homem no centro antropo-lógico da reflexão acerca da pulsão e da concretização artísticas em sede da vida comum. Pois que,

Déjà sous la modernité, mais plus encore à notre époque dite «postmoderne», la sphère artistique, à l'intérieur de laquelle il est possible, en théorie, de tout faire, est inséparable de la connaissance, de la science, mais aussi de l'ethique et de la politique. L'art actuel s'elabore sur la base de cês interrelation et du décloisonnement entre les disciplines. Il engendre dês pratique multiples et interfere avec la vie quotidienne. Il exprime de façon inhabituelle le monde, la société, l'environment dans lequel nous vivons. Au grand regret des tenants de la tradition, il n'est plus uniquement ce domaine de sublimation, de beauté, de perfection et d'idéalisation auquel on l'assimilait jadis. Dans ce sens, l'art actuel est devenu une fiction réaliste $[. . .]^{58}$

Testando os limites da própria communitas, esta arte minimal totalmente realista torna-se ficção híbrida de verdade (Zizek) que, ao nível da sua materialidade (necessária), tem de rejeitar - ou pelo menos problematizar - a ideia de objecto estético. Jimenez propõe, de acordo com Lyotard, a metáfora do 'gasoso' (já não apenas o 'imaterial' em Lippard):

[...] ni les arts plastiques ni la peinture en particulier ne peuvent exprimer, «présenter» la nature des bouleversements en cours. Ce que les avant-gardes avaient pressenti - a savoir l'imbrication de l'art et de l avie -, dês activité humaines, le réalise, démontrant l'impossibilité de retours en arrière, retours à l'ordre, à la prétendue clarté, aux valeurs sûres. ${ }^{59}$

54 Jimenez, p. 266.

55 Knight parte daqui para expor as limitações do campo expandido em Krauss, propondo novas tensões operativas.

56 Kester, p. 14.

57 Jimenez, p. 271: Ces pratiques dont la finalité n'est pas toujours clairement définie, révèlent l'ambiguité de l'autonomie de l'art. Elles ont un aspect exploratoire, voire expérimental. S'agit-il toutefois d'investir un territoire indéfiniment extensible de liberte toujours à conquérir? Ou bien n'est-ce-pas aussi la preuve d'un assujettissement irréfléchi aux progrès technologiques, voire une sorte de puré et simple fascination devant les pouvoirs de la science, c'est-à-dire, finalement, devant la puissance de l'industrie et dês intérêts financiers?

58 Idem, p. 272.

59 Idem, p. 273. Yves Michaud complementa, a propósito da arte que nos anos 90 a arte concluiu esta passagem ao estado 
Esse estado gasoso não é evanescência e distanciação do quotidiano; pelo contrário, é envolvimento actual nos assuntos da sociedade, onde quer que esta se materialize; quando esse envolvimento é consciente (ou mesmo inconscientemente) crítico do status quo e do seu papel no espectáculo, desvelando-se acontecer do social emergente. A arte então sai da sua negação, também ela gasosa, esquivando-se às oportunistas manobras de diversão na esfera da moda (sistemas mercantil, mediático, promocional) ou deixando-se enquadrar por estratégias disciplinadas nas esferas do turismo ou do marketing. É por via da consciência axiomática - mesmo o seu entendimento 'inconsciente', como acontece em ícones problemáticos do Espaço Público (Tilted Arc, de Richard Serra) - que o artista pode libertar-se de uma teia de relações obcurecidas pelo habitus. A trivial banalidade do quotidiano necessita de ser questionada pelo sentido cultural (e sócio-político, nos casos mais estimulantes), o que é condizente com a perspectiva de que a Grande Arte é coisa do passado (Pinçon), agora que outra arte - como um gás - permea o tecido social de forma inédita. Diluída no pluralismo, confundida com a comunicação e o espectáculo, objecto de mediações múltiplas que a tornam, no limite, uma actividade como outra qualquer, aquilo a que outrora terá podido chamar-se 'arte' é hoje um acervo de posições, experiências e objectos que apenas a actualização discursiva - hoje, a nossa - pode tornar um factor de cognição do social. Ela é uma resiliente pequena-grande arte do social.

Por outro lado, quando Jimenez afirma que l'art contemporain pense le monde, ${ }^{60}$ confirma-se a preponderância que pode ser conferida à extremidade vertical da minha axiomática gazeificada, a dimensão intelectual e mental que, juntamente com o eixo horizontal que aponta para o colectivo e o processual, definem um campo de acção para a arte que é uma política da estética (Rancière). No noema de um eixo 'mental', os temas da 'palavra', da 'ideia', do 'discurso' e do 'texto', senão da 'poesia', concorrem então, ao encontro de uma constatação: Le pouvoir des mots ne serait-il pas parfois aussi corrosif que le choc des photos, des lors qu'il s'agit de l'irreprésentable? ${ }^{61} \mathrm{E}$ de facto, no extremo oposto deste vector vertical, há que ter em conta que, graças à ruptura e à provocação, ao choque, o que as indústrias culturais vêem alargado é muitas vezes a arbitrariedade o seu campo de influência, mesmo que não excluindo formas de reivindicação performática do Eu. Numa palavra, quer o texto excrito numa fachada - Capitalism Kills Love na sede dos mineiros de Durham ${ }^{62}$-, quer o corpo humano interrogando-nos na paisagem ${ }^{63}$ - uma figura feminina emergindo da copa de uma árvore - são tanto mais operativos enquanto factores de cognição da forma urbana quanto integrados numa dinâmica axiomática do seu sentido.

Agora que a arte é culturalmente uma espécie de dispositivo radicalmente arbitrário na sua emergência gasosa, o que está na mesa é assim pensar o que se quer rejeitar na sua história e os traços utópicos que urge reconstruir. Jimenez vê aí a oportunidade de uma nova estética, mais participada:

gasoso: [...] l'art se volatiserait dans dês vagues expériences esthétiques plus ou moins éthérées. In Idem, p. 277.

60 Idem, p. 280.

61 Idem, p. 293.

62 «Capitalism Kills Love», Claire Fontaine, Lumière, Durham Miner's Hall, 2011.

63 «rau C.», Maurizio Cattelan, Frankfurt, 2007. 
Une telle esthétique accomplirait se que ria pu faire la querelle de l'art contemporain: mettre un terme au monopole élitiste du monde de l'art, en finir avec la réquisition à laquelle procèderent les instituitions officielles et, hors des sentiers battus de la Culture, ouvrir le vaste champ de l'expérience artistique à tous ceux qui souhaitent ou oseraient la tenter. ${ }^{64}$

Mais: «Êriger en conscience et en cohérence» ce qui est perçu de façon floue, indistincte, telle est bien l'une des taches du discours esthétique. ${ }^{65}$ Kester explicita alguns dos seus traços fundamentais, nomeadamente o da participação como conversação, antídoto para a apatia (Gross) que mata a arte. Na busca de imagens-chave para esta minha axiomática, recuo até Beuys para recordar a forma como o artista alemão reage ao boicote de uma acção sua em 1964. Beuys é agredido por jovens indignados, durante a sua performance Kukei, akopee - Nein!, que deliberadamente abordava o tema do nazismo e do silêncio pesado que na altura caracterizava a relação das pessoas com esse passado. Como reaje Beuys?

Depois do grupo "desestabilizador" ter abandonado o palco do auditório, Beuys, apesar de sangrar do nariz la foto circulou nos media, e não apenas na Alemanha), não foi ao tapete e a sua reacção à violência e ao caos momentâneo foi vencida por uma postura dramatizada (e ainda mais provocatória): com o sangue a jorrar do nariz, ergue na mão esquerda um crucifixo enquanto a mão direita se estende numa saudação nazi. [...] Podemos considerar este volte-face improvisado como um exemplo da prática artística baseada na intuição e da contundência com que o performer lidava com situações indefinidas e ambíguas, dando respostas, ao mesmo tempo directivas e contraditórias, agressivas e de múltiplas interpretações, às energias e às tensões criadas no desenrolar das suas "acções". 66

Avanço então ao diagnóstico de François Séguret ${ }^{67}$ que contextualiza todas as reflexões prévias numa percepção crítica do Projecto Urbano (recordo que na base teórico-prática da curadoria de arte pública como axiomática):

Bien que le thème de la transversalité ne soit à la mode et souffre d'un deficit épistemologique certain, les rapports contemporains entre l'art et la ville ne cessent d'âtre questionés comme significatifs d'un enjeu sociétal en profondeur. Aussi bien «le détour» par l'art pour expliquer la ville, son historicité et ses disjonctions temporelles, n'est-il jamais vain. ${ }^{68}$

Para tal é necessário reformular a questão da forma em arte, sobretudo quando la distance que les avant-gardes avaient revendiqués comme sens et repère de leur créativité est abolie de ce fait depuis un certain temps. ${ }^{69}$ Portanto, ao urbanista ou ao curador já não chega tratar a cidade como monumental galeria de arte ao ar livre; eles têm de superar o ressentimento da modernidade (nostalgia) e a assistematicidade e fragmentação existencial da pós-modernidade, talvez actualizando Lynch, cuja inovadora abordagem da cidade como visão, não perdendo actualidade, tem de agora passar pelo crivo de uma totalidade experienciada (Lefèbvre, Knight, Miles), portanto de quaisquer ferramentas críticas, conceptuais e propriamente artísticas que complexifiquem mas ao mesmo tempo tornem mais cognitiva a arte na forma urbana. Recorrendo à cartografia cognitiva (Lynch), à psicogeografia (situacionistas), ou hoje às formas digitais de apropriação do espaço (muitas com epicentro em laboratórios de artes digitais), o investigador, como o mediador ou o artista têm de distrinçar o 'trigo do joio' com base numa grelha retórica capaz de avaliar perspectiva- e prospectivamente as intervenções urbanas que, de alguma maneira, articulem os valores 'arte' e 'cidade'. Séguret nota - e refiro-o pela importância que adquire no extremo 'direito'

64 Idem, pp. 299-300.

65 Idem, p. 300.

66 Gomes, p. 47.

67 Séguret, François, «Três loin, la ville», in Vv. Aa., Le Projet Urbain; Éditions de la Villette, Paris, 2000, p. 136.

68 Idem, p. 138.

69 Idem, p. 139. 
da axiomática - como esta abordagem plástica da cidade é sempre a crítica das disciplinas e suas conquistas reificadas (a arquitectura mais que todas as outras). Nesta perspectiva que confere à arte a ingrata tarefa de 'substituir' o arquitectónico pelo submeter vitalismo geral da cidade (Argan) e das suas tecituras sociais (Capra), o comentário de Séguret aponta para uma 'arquitectura-jardinagem': Une part de la difficulté à problematizer le rapport ville-forme tient au fait que l'architecture continue, ou tente de continuer, de s'affirmer comme forme non-evolutive quant aux principes fondateurs. ${ }^{70}$ Questionada a validade urbanística dos principios arquitectónicos vitruvianos - utilitas, firmitas, venustas - há que arriscar-se, citando o investigador italiano Giuliano Maggiora, a substituição iminente e necessária do venustas por uma dimensão comunicacional. Significativa fatia da arquitectura mais activa ao nível urbano parece ter seguido esta linha, criando inclusive novos entendimentos do arquitectónico, enquanto integração ecosófica (Lacaton\&Vassal, Saprophytes, He-He). Untitled Monument, de Rachel Whiteread, é neste quadro uma peça de enorme ambiguidade ${ }^{71}$.

\subsubsection{Esquerda, o belo do objecto confinado}

De acordo com a minha axiomática, certas obras tendem a manter-se confinadas a um estatuto objectual e institucional mesmo quando a sua temática é decididamente a do espaço público (caso de quando red carpet arts se confundem com uma insular avant-garde ${ }^{72}$ ). Tais obras reificam a divisão artística do sistema tradicional da arte, limitando o alcance das experiências críticas (na verdade, também valorizando-as). Um caso notável, porque encara a beleza do social em toda a sua contingência é Zócalo, México, D.F., Nov 14 1998, de Alys, obra de extraordinária atenção a um detalhe pormaior na forma urbana. Trata-se de filme em contínuo rodado na cidade do México, no qual um elemento urbano (poste monumental) e a sua configuração espacial (a praça) e vivencial (os habitantes) são objecto de um olhar tão atento quanto humilde - como se a acção se limitasse ao referenciar de uma situação urbana complexa - implicando um sistema ${ }^{73}$. Ora, apesar de atenção máxima à cidade como vida urbana neste gaze, o artista apresenta o seu trabalho nas paredes da galeria ${ }^{74}$. Também as propostas ditas relacionais (Bourriaud) tendem, apesar da sua processualidade, para uma situação sociamente confinada, retendo a mesma aura autónomo-acrítica de que os primeiros neo-conceptuais tentaram abdicar:

This at first resembles a position advanced by Kaprow in 1966, that the audience of passive art-world spectators should be removed from happenings, and participants be drawns to events as meaningful activity (to which non-artists bring

70 Idem, p. 140.

71 Deveria colocá-la-ia tendencialmente na direcção esquerda do meu vector, isto é, mais próxima de uma escultura moderna site-specific? Ou o seu silêncio diz muito, e nesse caso funciona como interacção discursiva, desde logo na retórica plástica do seu processo, intensamente percepcionado pelo público? E quanto a essa ambiguidade, acaba por ser instrumental ou pelo menos operativa na apropriação da cidade por parte dos cidadãos?

72 Lippard, p. 264.

73 Davila, Thierry; Marcher, Créer - Déplacements, flâneries, derives dans l'art da la fin du XXe siècle, Regard, Paris, 2002, p. 99. Alys é Un observateur du rythme impregne par la géographie de la mégapole à la mobilité même des corps, qui constate que les déambulation des badauds construisent un ordre, un circuit, élaborent un véritable spectacle collectif, dont les badauds eux-mêmes ne savent probablement pas qu'ils sont les principaux acteurs.

74 Gabriel Orozco e Alfredo Jaar são outros exemplos de uma radical atenção ao social que aceita o dispositivo museológico como seu natural campo de visibilidade. 
freedom from the habitual responses of a Professional training, like non-professional actors on stage). But while Kaprow leaves art and its aura behind, Bourriaud retains the concept of aura. ${ }^{75}$

Podemos assim deduzir um ethos de autonomia reduzida na aura da arte como distinção cultural? Em Tiravanija há intersujectividade, mas não uma política, pois não estão em cima da mesa a visibilidade, o debate, a responsabilidade. Ao mesmo tempo, a arte mantém-se specialism $^{76}$ e não tanto criatividade quotidiana (Kaprow) mesmo quando divertida (Carsten Höller, Test Site, na Tate, em 2007). Se Rancière nela vê, ainda assim, um deslizamento interessante - the artist-colector institutes a space of reception to engage the passer-by in an unexpected way, ${ }^{77}$ - Malcolm Miles chama a atenção para algo mais efectivamente demo-crático nesses deslizamentos, no actual contexto tardo-capitalista, como assinala Kester la propósito do trabalho de Jay Koh) cria-se a discursive exchange as an antidote to the violence of economic exchange. ${ }^{78} \mathrm{O}$ que nos leva para o ponto seguinte, dedicado à arte que já elabora momentos de transferência num regime da plasticidade do social em que ponto de partida é uma convicção das equivalências morais entre aqueles e aquelas que são chamados a colaborar e a dialogar. Gabriela Vaz-Pinheiro actualiza este valor da transmissão de material cultural, num vocabulário partilhado, no termo transferibilidade. Mas não é ainda este termo que nos ajuda a destrinçar, no limite, o grau de politicidade do urbano que os projectos possam assumir, e basta lembrarmo-nos da querela Lefèbvre/Situacionistas em pleno 68: For Lefèbvre, the activities of the Situationists demonstrated art's tendency to marginalization, as if occupying a position outside the political even though the tactics used are politicized. ${ }^{79}$ Ou seja, temos mesmo de recuar a Dada para, entre a provocação pacifista ao confinamento da arte e desmaterialização conceptual, procurarmos pontos de suporte para uma progressiva publicitação transferível da arte da cidade.

O que é que isto tem a ver com a ideia de museu, templo das musas? Já em 1796, de Quincy se havia manifestado publicamente ${ }^{80}$ por ver Napoleão remover património de Roma para levá-lo para Paris, the context of "art" is no longer the context of "life"; but it is just by the making of this division that the social practice of art, in its indistintively modern sense, was brought into existence. ${ }^{81}$ Por outras palavras, se não há arte sem contexto, o que o projecto moderno acabou por impor à arte foi o contexto arbitrário do mercado e do museu ${ }^{82}$; urge

75 Miles, Malcolm; «Aesthetics in a Time of Emergency», in Third Text, July, Vol. 23, pp. 421-434.

76 Miles, Malcolm; «Aesthetics in a Time of Emergency», in Third Text, July, Vol. 23, pp. 421-434.

77 Rancière, Jacques; «Porblems and transformations in Critical Art», p. 90.

78 Miles, Malcolm; «Aesthetics in a Time of Emergency», in Third Text, July, Vol. 23, pp. 421-434

79 Idem, pp. 421-434.

80 Numa célebre defesa de Roma como um museu a céu aberto, cujos tesouros são statues, colossi, temples, obelisks, triumphal columns [...] places, sites, mountains, quarries, ancient roads, the particular placement of ruined towns, geographical relationships, the mutual relations among all these objects, memories, local traditions, still prevailimg customs, the parallells and comparisons that can be made only in this very place. (Critical Terms for Art History, The University of Chicago Press, Chicago, 1996, 2003, p. 110) Isto é, todo um teatro em que os actores são também espectadores e vice versa.

81 Jr. Mattick, Paul; «Context», in Critical Terms for Art History, The University of Chicago Press, Chicago, 1996, 2003, p. 111.

82 Digamos que a arte moderna foi 'contaminada' pela ideologia do museu; hoje, com a produção artística a considerar o museu mais um dos seus media, the autonomou arwork presents itself as definitive of its context: the relevant ritual is that of aesthetic attention. Ora isso escamoteia o invisivel do museu: Once art itself becomes a social practice, it animates physical context (typically disguised today as neutral background for display of the work), saturating places and modes of display with meaning. Jr. Mattick, p. 116 
então, reflectir diacronicamente sobre o que queremos da arte (vislumbrando o que terá sido diferente na sua recepção e produção no passado; e o que será diferente na posteridade. Trata-se de encarar a arte também como evento, e eventualmente acontecimento social:

[...] if the work is seen as itself an event, situated in a dense network of events, in history, its visual traits might no longer seem to belong to a domain of "form" as aopposed to "content." These traits, that is, might appear not as the attributes of a transhistorical substance but as themselves a mode of historical action, within the complex of contexts which structure the making and reception of art. $^{83}$

Isto é, o museu epitomiza e é o lugar (instituição) de um tipo de poder; para Debord, é o lugar de concepções erróneas, onde, a história das coisas está enclausurada, no lugar de serem conhecidas as histórias das vidas vividas.

\subsubsection{Direita: Land Art e esfera social, o contexto ecológico}

Na história da land art (earthworks) ${ }^{84}$ podemos falar de três aspectos que são outros tantos parâmetros de avaliação da sua relação com a dinâmica social - a expressão lírica, o envolvimento crítico e a acção transformativa no quadro do desenho urbano ${ }^{85}$. Tal confirma a minha intuição da centralidade da arte de Beuys no estabelecimento de um vector horizontal eco-lógico da arte na forma urbana:

Joseph Beuys' final Project [...] occurs in the intersticial space at the center of the diagram, The work was initiated by the artist, yet it required interaction (planting of trees) to reach completion. The work will ultimately transform the City of Kassel by the sheer number of elements added to this landscape. It is interesting to consider that if we were to examine the diverse body of work created by this artist, it would be distributed throughout the diagram. ${ }^{86}$

A ideia fundamental é a de que haverá um espaço público eco-lógico no coração da comunidade e da participação. Face à moda da arte, também ele exige emancipação ${ }^{87}-$ e não é indiferente que essa emancipação esteja originariamente ligada ao movimento feminista (no seio da Land Art)..$^{88}$ Independentemente do foco em temas relacionados com a bioesfera, a paisagem, o ecosistema, a vida social urbana, o que está sempre em causa é a harmoniosa articulação entre a arte da terra e um social progressivo, vital, que é sempre um cuidar. É por isso que Collins e Goto afirmam: Public space is to the commons as skin is to breath in the body. ${ }^{89}$ Esta questão do comum explicita como na forma urbana o poder vai mudando a compreensão pública não apenas do que é de todos como a própria forma dos espaços colectivos (públicos) e dos elementos a partilhar. É nestes termos que se denunciam certas manobras de privatização, ocultamento ou negação da arte pública acrítica. ${ }^{90} \mathrm{Na}$ forma ur-

83 Jr. Mattick, p. 117.

84 Nesta perspectiva de Goto e Collins, são obras essenciais dos anos 60 e 70: Running Fence (Christo e Jean-Claude), Site) Non-site (Robert Smithson); Vietnam Veterans Memorial (Maya Lin), 7000 Oaks for Kassel (Beuys).

85 Goto, Reiko; Collins, Tim; «Eco-art practices», in in New Practices, New Pedagogies, European League of Institutes of the Arts, Routledge, London and New York, 2004. p. 91.

86 Idem.

87 Idem, p. 43.

88 Idem. [...] historically nature and women have been pushed aside and constrained from the conceptualization of the public realm. [...] Women have captured their place. Nature demands advocacy and voice.

89 Idem, p. 44.

90 Idem, p. 45: There is no greater prize than wealth that is extracted from a ubiquitous once-public common good redefined as a desirable market resource. 
bana, há então formas de autonomia (autoral, por exemplo) que redundam em colonizações da atenção, assim abrindo campo para uma destruição, por parte das indústrias (também as culturais), de um património até há pouco comum como é o caso dos sistemas naturais ou da cidade como espaço patrimonial colectivo.

A arte que tem na sua agenda a crítica desta situação é participativa, comunitária, colectiva - comum. Procura (tem de?) ser ecológica, sustentável (em particular socialmente); tem de recuperar um tempo 'perdido' e um ethos tornado invisível pelo modernismo lou melhor, a sua leitura superficial, mormente 'estética', isto é, estilística). Também em radical abertura para a contínua renovação da sua identidade e mesmo da sua autonomia: From the perspective of philosophical logic, the denotation of the word art produces a larger set of things that art may be, than the set of things that art is not. ${ }^{91}$ Esta é uma questão que convoca a 'sombra' da arte para uma metaforização operativa dos próprios futuros possíveis da mesma, num quadro de engajamento com a própria transmutação institucional, visando a mudança social num contexto cultural em sentido lato ${ }^{92}$. Tal envolvimento exige um espírito transcultural (Berger):

Each person's voice has a right to be heard. Without this commitment to a conversation that is premised on the making of connections, most artists, teachers, students and managers will remain trapped in their silos, resistant to moving into unchartered territory. This can only be counter-productive for each institution and its partners, and for a profession that is becoming increasingly dysfunctional. ${ }^{93}$

Vê-se aqui como o logos participativo dos projectos é o do dialogismo: conexões, contexto e conversações: This is the heart of what is unique in art and why its effect upon society can be significant, if we choose to focus and engage, ${ }^{94}$ isto é, se assumirmos a liberdade de necessidade e ao mesmo tempo a necessidade da liberdade. Mas mais uma vez, apenas um sentido retórico do activismo na avaliação das experiências pode contribuir para ajuizarmos o seu valor (ético), o seu impacto (comunicacional) ou a sua eficácia (técnica, como acção), tanto mais fundamentais quanto existe muita arte que cumpre funções políticas na cidade sem que possa ser considerada 'política' em sentido estrito. 'TTA Logstor' é exemplo deste activismo social, em que pessoas se interessam por outras pessoas e agem em conformidade com um dispositivo de sinergias e trocas inclassificáveis:

[...] the work of Dufour and Thybo moved further in the direction of activism. They worked with squatters in Copenhagen, and experimented with alternative social structures in small, closed communities in Jutland. [...] Based in Logstor in Northern Jutland they started a ragpicker group in 1975, for the benefit of liberation movements in the third world [...]. During the 12 years the group 'TTA Logstor' (Toj Til Afrika, clothes for Africa) managed to collect the following and send it off to Africa: 112 tons of clothes and shoes 30 sewing machines 1 dental clinic 3 operating tables 15 hospital beds 17 wheelchairs 27 packages of other hospital equipment 39 packages of toys 30 packages of educational material DKK 447,911, - These means were obtained mainly by household collecting, flea markets, inquiries at hospitals etc., and clearing up of estates. TTA workers were voluntary and paid a membership fee. Thybo describes the aims of 'TTA Logstor': Interactivity within the ragpicking group: By collecting the surplus [of consumer society] and recycling it for humanitarian purposes, we solved several problems at the same time: we could make people aware of the conditions in other parts of the world and get them involved in an action, in the project.

91 Idem, p. 47.

92 Renshaw, Peter; «Connecting Conversatons: the changing voice of the artist», in New Practices, New Pedagogies, European League of Institutes of the Arts, Routledge, London and New York, P. 99, 2004.

93 Idem, p. 100.

94 Collins, Tim; Goto, Reiko; «An Ecological Context», in New Practices, New Pedagogies, European League of Institutes of the Arts, Routledge, London and New York, p. 47, 2004. 
A essência do projecto está equidistante de quaisquer catalogações como estética, política ou pura acção. Outro projecto, ainda na Suécia mas agora em novo contexto espacio-temporal, respondeu de novo uma inclassificável estrutura projectual:

In August 1995, Gothenburg was turned upside down. Sweden's second-largest city was about to host the World Championships in athletics. In an atmosphere of self-conscious activity, the urban environment was transformed through a series of 'beautification' projects, ranging from the architectural re-modelling of the inner city to the injection of a host of new commercial venues-greenery, colourful advertising and 'fresh paint' signs were sprouting up everywhere. [...] More than that, the debate over the day-to-day adjustments to all the newness made clear that, for better or worse, the Gothenburgers were losing their sense of belonging to the place they were proud to represent. The staging of the host's role turned from being as abstraction, 'the city', toward involving every single citizen. The distinction between 'guests' and 'hosts' began to dissolve. Not even a guide's uniform guaranteed discretion: everybody was new to the place they found themselves in, and to each other.

Perante este quadro, Aleksandra Mir abriu 'Life is Sweet in Sweden', um gabinete turístico alternativo na baixa de Gotemburgo:

150 square meters were made available from the public sector, and Mir renovated and decorated the premises in a half-official, half-private cosy atmosphere that should make everybody feel welcome. Equipped with comfortable sofas, plastic greenery, an aquarium, dim lights and soft muzak, electric footbaths, a television with shopping channels and even a fresh smelling lavatory, the tourist bureau was freely available for use by any and everybody. [...] With several hundred guests every day during the ten days that the World Championships took place, the tourist bureau became a social limbo, taking shape according to the constellations of people that were interacting with one another on the spot. The entire process of the situation established itself as a public coefficient where the participants, guests as well as hosts, were involved in a mutual endeavour intrinsic to sociability.

Ora,

Common to 'TTA Logstor' and Life. .. are that they initially were launched outside of the art contexts; 'TTA Logstor' as development aid, and Life. . as a contexts specific, anthropologically therapeutic project, so to speak. Both projects were later introduced, or they have an afterlife, in art discussions: Life. . was evaluated critically as art after the fact, and Dufour and Thybo presented documentation from 'TTA Logstor' for their exhibition in N55 Spaceframe, offering up the project for a new narration removed from the terminology of its time. These are the distributive similarities between Life. . and 'TTA Logstor'. But they can both be contained in the same sphere of the aims and characteristics of the 'happening' [...] Both projects, like the other examples, take place in time and depend on the other, whether it be the cultural other or the people in local surroundings waiting to become activated. Not least of all, the projects each depend on the other in order to live on as collective memories via the people who took part, and the ones the stories are told to..$^{95}$

Neste meu eixo horizontal, uma intensa vibração dos acontecimentos, entre a tradição do confinamento do objecto no museu e a criação de oportunidades inclasisficáveis de activação do socius, vai inscrever oportunidades de criação de vida urbana, em função da sua intensidade comunicacional, isto é, retórica.

\subsubsection{Baixo - Cima: performática, elevação}

Perniola afirma que duas tendências opostas se individualizaram na aventura artística do Ocidente. Uma primeira incidindo sobre as noções de indiferença, afastamento, de suspensão, para a qual a atitude estética é catarse e desrealização. Outra conferindo ênfase especial à participação, ao envolvimento, ao compromisso e à perturbação, para a qual a estética é sublimada em situações de fulgor, de choc. Não deixa de continuar a estar aqui plasmada a divisão horizontal na minha própria axiomática, entre um campo do corpo e um campo da ideia, articulação fundamental da liberdade performática. Ora

95 http://www.aleksandramir.info/texts/larsen_afterall.html 
While Performance Art (at least in its historical self-conception) is tied to individual actors and to the singular, autonomous action aimed at breaking convention, performativity refers to a non-autonomous and non-subjectively based understanding of action within and with convention. The one model operates with an ideology of externality lan externality of art from its social systems of market and museum). while there simply is no place for type of externality in the other. Using the model of performativity one can concretely determine, for example, how every artwork literally "acts" through being ingrained within convention, such as when in a museum it actively contributes - intentionally or unintentionally - to a particular model of development, progress and history, by reproducing conventions that are ingrained in that institution. Conversely, the fact that these conventions are not autonomous, but must first be created by every visitor and every artwork, opens up some manouvering space that can be artistically molded. The model of performativity emphasizes this fundamental level of meaning production in art. It is a theoretical model that allows the possibilities and boundaries of acting to be understood with and through art - and, as a consequence of this, to also understand the forms of its (societal) effectiveness ${ }^{96}$

Abordo esta questão (da performance como) performática ${ }^{97}$ como aç̧ão em ponto crítico: a propósito de John Cage no Black Mountain College, em 1952, Fischer-Lichte assevera que a peça desafiava os espectadores a agir, sem que, contudo, lhes indicasse como agir; e que encontrando-se envolvidas diferentes competências artísticas - música, pintura, cinema, dança, poesia - se dava uma espécie de acção colectiva caótica e complexa ljá diversa de acepções tradicionais do Gesamtkunstwerk wagneriano), em que cada co-autor, o público, desempenhava o seu 'papel' performativamente. ${ }^{98}$ Fischer-Lichte coloca o 'acontecimento' de Cage numa linhagem de vanguardas performativas, dando o exemplo das seratas futuristas e das soirées Dada como exemplos de um profundo mal-estar perante a cultura burguesa que encontra na performatividade dos gestos artísticos o modelo de uma comunicação compreensível à luz da teorização do acto da fala. ${ }^{99}$ Aliás, Fischer-Lichte, a propósito de como nos anos 60 a 'fuga do museu' corresponde ao movimento de 'fuga do teatro' burguês, aponta a função performativa, por parte dos artistas mais activistas, como sinal de uma oposição ao mercado de arte contemporânea, que insistia na produção de artefactos como bens ${ }^{100}$. Isso levou à procura contínua de dispositivos capazes de suspender ou superar padrões de comunicação e apresentação existentes, ${ }^{101}$ o que encontrou naturalmente na arte crítica urbana um espaço de liberdade de acção extraordinário. Tomado a cidade como materiali-

96 von Hantelmann, Dorothea; «Performativity» in Sculpture Projects Münster, 2007, p. 415. O modelo hoje clássico desta dimensão performativa pode ser encontrado em Judith Butler, que explorou a teoria anterior de Austin acerca dos actos da fala. A reter: Butler identified actions that establish reality not through the individual's intention or will, but by being rooted in (societal) conventions, repeating and updating these. Butler considers change-directed action to be conceivable only within this nexus of convention and innovation, repetition and displacement. É um poderoso argumento a favor da dimensão comunicacional da obra de arte, que muitos modernistas empedernidos hesitam em aceitar, precisamente incapazes de - ou evitando - enfrentar o real como dispositivo discursivo.

97 Cf. Fischer-Lichte, Erika; «Performance e cultura performativa - O teatro como modelo cultural», in Revista de Comunicação e Linguagens, Lisboa, 1997. Ver também diversos autores envolvidos na obra colectiva On Performatics, juntamente com as abordagens até aqui feitas no campo da história e da crítica da arte, como da teoria crítica.

98 Idem, pp. 144-145. Esta 'descoberta' deve ser compreendida à luz do pensamento de autores como Milton Singer, que nesses mesmos anos 50 cunhou o termo 'performance cultural' para contestar uma ideia de cultura baseada-manifestando-se apenas nos seus objectos materiais, ou de Victor Turner, que reflectiu sobre o ritual da arte e a liminalidade.

99 John L. Austin, mas também Barthes, em Le Degré Zero de l'écriture, de 53. Esta questão estava implícita quando coloquei a constelação de conceitos acção/activismo/acto no cerne do meu entendimento do dispositivo de arte pública (no quadro da retórica extramuros).

100 Idem, p. 148.

101 Fischer-Lichte: No início dos anos 50, o artefacto era tido, na cultura ocidental, como o factor constitutivo absoluto de qualquer arte. O teatro dramático procedia de um texto literário, a música compunha ou interpretava partituras, a poesia criava textos e as belas-artes produziam obras. Claro que, desde Duchamp e vanguardas afins, a batalha pelo dispositivo não deixaria de se relacionar, nem sempre directamente, com a batalha pela relevância política na cidade. Mas é de notar, que para Lichte, o acontecimento colectivo de Black Mountain College foi de facto um marco na cultura ocidental. 
dade, novas abordagens artísticas actualizam então antigas pulsões e programas numa nova atitude em que os artefactos desaparecem nas acções..$^{102}$

De qualquer forma não se confunda a performatividade com os termos performance, presentation ou staging. ${ }^{103}$ Pois,

\begin{abstract}
[...] to speak of a performative artwork is tautological, because there can be no non-performative artwork. Therefore , to enquire after the performative in art does not mean defining a new class of artworks. On the contrary, it means delineating a level of meaning production that exists in every artwork, but which is not always consciously and actively molded: namely, its reality-producing dimension. What kind of situation does an artwork produce? How does it situate a viewer? What values, conventions, ideologies and meanings are inscribed in this situation? This brings to the fore the contingent and conceptually difficult sphere of cause and effect that context-and viewer-related art produces. ${ }^{104}$
\end{abstract}

No realismo extremo, ${ }^{105}$ talvez o grau de abstracção do chamado 'return of the real', por via do corpo seja o sinal de que a emancipação está comprometida (precisamente porque the está vedado o discurso, o discurso como 'palco') - esse realismo [...] não faz mais que levar às extremas consequências o processo de alienação e estranheza que constitui o motor da modernidade. [...] não se trata - como aconteceu no passado - duma representação dessa realidade - o que seria da ordem do objecto sublimante - no seu sentido mais verista - no sentido identificado por Miles no primeiro Realismo -, mas duma exposição directa e pobre de meios de mediação simbólica [e de] até nojo e terror. ${ }^{106}$ O corpo, neste vector, parece conquistar relevo nas problemáticas da reresentação, e a tónica deixa de assentar na bela aparência das formas mas naquilo que ameaça a compromete a sua integridade a partir do interior da perspectiva do corpo: O lugar decisivo deste realismo máximo [Perniola] passa a ser o encontro entre o ser humano e a máquina, entre o orgânico e o inorgânico, entre o natural e o artificial, entre a pulsão e a electrónica, entre a pessoa e a mercadoria. ${ }^{107}$ Este será assim um 'realismo' artaudiano (Lacaniano) concorrente das correntes de 'realismo mágico', de que o surrealismo é a referência no campo da arte, e que sera mais 'ingénuo' enquanto política do dispositivo (Foucault, Agamben). Mas é indiscutível que a sua experiência - que não faz mais que levar às extremas consequências o processo de alienação e estranheza que constitui o motor da modernidade $^{108}$ - gerou outros sinais, de emancipação já comprometida (porque disponível para o discurso), e que são o contraponto no sentido vertical, mas também obliquo dessa 'subida', quer no sentido de um regresso ao belo do objecto (esquerda), quer do compromisso com esse 'outro' sublime ancorado na experiência total do social colectivo e contingentemente participativo (direita). ${ }^{109}$

\title{
O corpo idiota vs. o copo em movimento
}

102 Idem, p. 150.

103 von Hantelmann, Dorothea; «Performativity» in Sculpture Projects Münster, 2007, P. 415

104 Idem.

105 Perniola, p. 18.

106 Idem.

107 Idem.

108 Perniola, p. 18.

109 Ocorre-me a performance art de Marina Abramovic que, por exemplo, actualiza peças clássicas de Kaprow, Beuys, Pane, numa lógica de re-enactment lque aliás será a mesma de um artista contemporâneo, Jimmy Deller, em The Battle of Orgreave, monumental espectáculo de reconstituição de lutas operárias durante a era Thatcher). 
Ora Perniola critica a articulação exclusiva entre a dimensão do corpo-idiota com a do real imediato - essa instância da existência que, desde Shelling e hoje em Zizek, é como Pareyson descreve: o puro existente é algo de opaco, que permanence fechado e recalcitrante ao pensamento e refractário e impermeável à razão». ${ }^{110}$ Seria porém curioso investigar este real menos a partir dessa metáfora cristã da expulsão, e talvez apreciar melhor o valor da estranheza. Se recuarmos a Freud para estabelecer uma relação entre os conceitos 'unheimlich' - relacionado com o de estranheza, afim ao de distanciamento, - e 'heimlich' - sinónimo de, entre outros, de 'familiar' - , surpreendemos uma interessante hipótese: a arte na cidade, nos espaços públicos, tal como qualquer arte que se assuma crítica, é um lugar de estranheza e necessário distanciamento, necessária a uma terapêutica da vida urbana.

Ou seja, há uma hipótese (ou o desejo, sempre latente) de resgatar, através da interpretação, de narração, de ficção, o indizível da nossa experiência total (que tem por base sempre o corpo) da sua unicidade - da sua idiotia (do Grego idiotés). No conceito de performática interliga-se então essa tradição teatralmente performativa do corpo (levada ao extremo na bio-arte mais radical) e a performatividade socio-intelectual com ela articulável, precisamente no espaço social da política:

Este exercício interpretativo é levado a cabo, continuamente na vida quotidiana, para a qual a experiência do real na sua idiotia é algo de raro. [...] de resto, não existe a estupidez ocasional dos indivíduos, mas uma estupidez constitucional da colectividade; daí não se poder excluir a ideia de que o artista, enquanto intérprete da estupidez social, seja o verdadeiro artista orgânico da sociedade actual. ${ }^{111}$

Com efeito, o social estúpido é objecto do gaze artístico e depois da sua inscrição como arte, e quando do lado esquerdo do meu vector vertical, tende para um belo bizarro, espécie de sublime do social no paradoxo do seu consumo objectoficante ${ }^{112}$. Surge então a pergunta: o que acontece quando o artista é tão idiota como a realidade que olha? 0 processo retórico (vector vertical) não tem início e a sua arte perde em sombra o que ganha em aplauso la questão da relevância/irrelevância em Agamben).

Para Perniola, outra modalidade da idiotia em arte é a que se orienta acrítica e negadamente para a moda e a comunicação. É a arte das imagens de impacto emocional fácil, em intertextualidade automática com a publicidade, o cinema, a internet, o grafismo, a televisão, e que no veloz regime de comunicação que os envolve se caracteriza pelo contínuo cortejar da provocação: $A$ arte assim tende a dissolver-se na moda ${ }^{113}$, diz Perniola, ecoando decididamente termos de Wagner. E nesta arte que é a do espectáculo debordiano, está então ausente 0 carácter estruturado e mediato do simbólico, quer a rude e impenetrável traumaticidade do real.114 Nalguns casos, a resposta é um conceptual contemporâneo que faz propriamente uma pedagogia da imagem, como Jacques Rancière, Mondzain ou Virilio têm defendido. Assim se vai desenhando uma bifurcação, entre a parole vide e a parole pleine (Lacan). Na minha axiomáti-

110 Pareyson, L.: Ontologia della libertà. Einaudi, Torino, 1995, p. 404. No fundo, este modelo de produção artística é que que busca - corteja? - o real de Lacan, esse estado de que fomos 'expulsos' com a entrada na linguagem.

111 Idem, p. 24-25: Aliás, só detectamos o real na sua idiotia em condições particulares, por exemplo, quando estamos embriagados ou quanto somos vítimas de uma desilusão amorosa.

112 Jeff Koons casando com a porno-star Cicciolina e dela tendo descendência.

113 Idem, p. 26.

114 Idem. 
ca, este é o território tanto do sentido como da palavra, da luz e do discurso (como intencionalidade), o lugar da iluminação do político tal como possível-desejado também em sede do corpo: Perniola utiliza o termo palavra fundamentadora a essa discursividade que transforma profundamente quem fala e quem escuta - também ele aqui sublinhando a questão da recepção e do acontecimento discursivo colectivo no âmbito do objecto de arte, ou seja, essa radical distribuição do sensível por via de um meta-texto partilhado e participado na arte.

Na obra Marcher, Créer, Thierry Davila reflecte sobre a tendência em vários artistas contemporâneos para uma apropriação performativa do espaço urbano sustentada pelo seu deslocamento físico no espaço público. No trabalho de Francis Alys ou Gabriel Orozco, Erwin Wurm ou Stalker, preocupações antigas com o carácter do movimento la cinemática $\left.{ }^{115}\right)$ dão lugar a deambulações de micro-resistência política especificamente produtivas. $\mathrm{O}$ artista-performer torna-se ele próprio um interstício, fenomenologia do trajecto (Davila). É uma linhagem que 'encaixa' na dinâmica performativa do ready-made e da provocação Dada, inserindo na forma urbana o inframince da pulsão crítica de uma forma que leva Bishop a sublinhar que o envolvimento físico é precursor da mudança social ${ }^{116}$. De facto, nos anos 90, muitos criadores retomam os programas minimais, conceptuais e ambientais (Richard Long, Robert Smithson, Vito Acconci dão 'origem' a Mendietta ou Santiago Reyes), transformando o seu corpo num acto retórico:

Car tel est, dans le domaine de l'art, le destin de la déambulation: elle est capable de produire une attitude ou une forme, de conduire à une réalisation plastique à partir du mouvement qu'elle incarne, et cela en dehors ou en complément de la pure et simple représentation de la marche (iconographie du déplacement), ou bien elle est tout simplement elle-même l'attitude, la forme.117

Ou seja, estes criadores de alguma maneira estão libertos do aspecto retiniano da paisagem (a tradição pictórica) e transformam essa 'paisagem' no palco de um teatrum mundis - um cenário arquitectural-urbanístico - que conduzem a partir da personalização da sua fisicidade. Nesta cineplástica"18, temos a atenção ao situar do corpo-acção na cidade, em detrimento do objectual-físico da sua espacialização arquitectada-edificada (ou da sua instituição formalizada); donde que, numa ideia genérica da forma urbana como 'lugar-tempo' de abertura a essa experiência do passear-estar, está o sentido da deriva de uma personagem como Karl, em Amerika, de Kafka, representando negativamente ${ }^{119}$ uma bio-grafia da liberdade da necessidade. Assim, o artista que tende performativamente para o Baixo é um indivíduo essencialmente móvel e nómada, podendo argumentar-se que é uma atitude que é fundamentalmente a mesma que desde Rodin se associa à eliminação do pedestal (no Balzac) - on franchit les limites de la logique du monument pour entrer dans l'espace de ce quion pourrait nommer sa condition negative [...] état de déracinement absolu. ${ }^{120}$ De resto, o

115 Cf. Eadweard Muybridge, Étienne Jules Marey, que no séc- XIX lançam as bases desta investigação; e que Davila coloca num trajecto que conduzirá a Nu descendant un escalier, de Marcel Duchamp, realizado em 1912.

116 Bishop, Claire; Participation, p. 11.

117 Davila, Thierry; Marcher, Créer - Déplacements, flaneries, derives dans l'art da la fin du XXe siècle, Regard, Paris, 2002, p. 15.

118 Que prolonga, por um lado, as primeiras intuições modernas da importância da energia do movimento face aos seus traços redutíveis, e por outro a consciência peripatética que poderia ser traçada de Aristóteles lque dava aulas caminhando com os seus estudantes) a Karl Gottlob Shelle, amigo de Kant que escreve em 1802 A Arte de Passear, passando obviamente pelas experiências situacionistas.

119 E que essa utopia que é $O$ Grande Teatro de Oklahoma ironiza numa imagem tão brutal quanto sedutora.

120 Idem, p. 19. No Grande Teatro de Oklahoma, há por isso plintos para cada um dos artistas se erguerem acima do pó do 
nomadismo, teorizado operativamente pelos situacionistas, é a experiência total da cidade, e desde a deriva sócio-citadina da arte crítica dos anos 70 que esse nomadismo actualiza a flânerie da constelação Baudelaire/Benjamin em modalidades extremamente tácticas de artisticidade individual (por vezes diluída no colectivo como em Stalker ou Platform). Trata de pensar a cidade através de um corpo que é e investiga, actualizando a proposta do situacionista Ivan Chtcheglow, que recolhia da deriva uma ampliação psicoanalítica da arquitectura. ${ }^{121}$ Mais uma vez, o leitmotiv Kafka - até pela sua versão realista-fantástica do mito, da memória, da identidade, espelha deste tipo de consciência situada. ${ }^{122}$

Esta problematização do performativo-performático em contexto urbano estaria incompleta sem mencionar-se um aspecto específico do que poderá ser o ethos do homo performaticus, a questão do demos - o valor colectivo do povo face ao egoísmo do eu. Depois de Habermas, Richard Sennett, apresenta a sua argumentação em torno do declínio da esfera pública na contemporaneidade. Em The Fall of the Public Man (1974), Richard Senett aponta baterias às forças narcísicas mobilizadas pela cultura capitalista. ${ }^{123}$ Para Sennett, a vida social sofreu uma progressiva perda de teatralidade, na medida em que as pessoas estavam a deixar de representar activamente as coisas - acting things out ${ }^{124}$ - transformando-se em actores privados ${ }^{125}$. Na linha de Arendt (e de Rendell, na imagem da arte e da arquitectura públicas como coreografias), Sennett desconfia do íntimo e procura explorar a ideia de uma vida pública desenvolvida, sublinhando a expressão embodiment. E assim, para além da tirania individualista

Social expression, in a society that includes public life, is understood to be the presentation to other people of feelings that seem intrinsically significant, and not the embodiment of feelings that are only present and important to the person experiening them. In a de-theatricalized society characterized by the tyranny of the intimacy, expression is conditional on "authentic" or spontaneous feeling. [...] With the decline of the public sphere, human expression continually becomes undrstod less as presentation and increasingly as embodiment in the sense of spontaneous expression. [...] being civilized includes sparing the others from the burdens of one's own self. ${ }^{126}$

Maffesoli aborda esta questão liminarmente: Urban theatricality is now demonstrating, in various ways that the individual is an indeterminant thing. None of us have any worth unless we are an integral part of a social context. ${ }^{127}$

Uma ideia primeira no actual nomadismo - estético, social e económico ${ }^{128}$ - é a de que as situações criam sentimentos anteriormente inexistentes (Davila). Mas aqui importa em que medida tal pode ser definido a partir de uma convocação de uma dinâmica colectiva eventualmente no quadrante inferior-direito da minha axiomática. Walking Monument, de Alicias Framis é

deserto.

121 Cf. Internationale Situationiste [1958-1969], Liberie Arthème Frayard, Paris, 1997, p. 18.

122 Para esta questão, ver Para uma Literatura Menor, de Deleuze e Guattari. Evoco a experiência do urbano como 'prolongamento' do psíquico nos espaços teatralmente interiores de romances como O Processo. Como comenta Harold Bloom, se Freud abriu a mente, foi Kafka quem nos lançou nos seus labirintos, de forma tanto mais sentida quanto a dimensão física, do corpo físico, é indissociável de uma narrativa personalizada e específica da cidade moderna.

123 Sculpture Projects Münster, 2007, p. 468.

124 Idem.

125 Idem.

126 Wuggenig, Ulf; «Tyranny of Intimacy/Richard Sennett»; Sculpture Projects Münster, 2007, p. 468.

127 Maffesoli, Michel; Everyday, p. 78

128 Cf. Penders, Anne-François; En Chemin, le Land Art. 
um exemplo de efémero 'edifício humano', uma estrutura que vive e respira. A homenagem de Stalker a Robert Smithson - Stalker Rundown (omaggio a Robert Smithson) é outro exemplo. Importa-me estas relevar situações como romanescas - no sentido de uma complexificação na abordagem dos dispositivos sociais, em particular através de processos colaborativos e participativos de interesse mais ou menos permanente ou definitivo para a subjectivação de determinadas comunidades. Davila, a propósito do trabalho de Orozco, ajuda-nos a definir este desejo social complexo que o dispositivo urbano crítico possa interpretar:

Definir um cadre, un protocole, un dispositif, qui encourage le développement d'une succession, d'une addition d'événements, qui produise quelque chose comme la mise en forme d'un mouvement. Utiliser le et comme articulation du travail, comme moyen d'impulsion et perpétuation d'un geste, comme accélérateur pour une prolifération possible possible d'opérations voire comme l'outil même d'une multiplicité d'actions. ${ }^{129}$

Davila, evocando Deleuze (Dialogues), menciona o contraste entre este 'princípio de relação' e um 'princípio de exclusão' que se lhe oporia. De qualquer forma, tais acções são essencialmente gestos intersticiais numa cidade que se torna laboratório de micro-acontecimentos de generosidade, ficção, irrisão, envolvimento... Nesse acontecimentos, a cidade começa a ser menos cenário e a própria protagonista, impura e organicamente mas também como ideia.

\subsubsection{Vector vertical, Cima-direita: texto e demos - o sentido vs. o significado}

Os significados referem-se à estrutura de cada língua concreta em questão, de sinais puramente linguísticos, no contexto do código de que fazem parte. Na rede semiótica, o sentido é o valor que assume uma certa designação dentro de uma cultura específica. (Aleksandr Davìdovich Shvejcer). ${ }^{130}$ Em concreto, a questão do sentido e do significado ${ }^{131}$ é extremamente sensível para a comunicação que as obras de arte pública inscrevem nos contextos em que decorrem. Se The more open, or ambiguous, the experience offered, the more the viewer is forced to depend upon his [siclown perceptions ${ }^{132}$, é evidente que a interpretação da condição urbana no dia-a-dia é tudo menos dada. ${ }^{133}$ Recorde-se, de acordo com Jaime Soares, que Aquilo que atribui significado à linguagem não é a sua referência extra-linguística, é o uso ${ }^{134}$. Esta é uma visão pluralista, inclusiva e sobretudo pragmatista da linguagem, em que a ideia de jogo - o dispositivo discursivo a que Wittgenstein alude na sua conceptualização dos jogos de linguagem - se

129 Davila, Thierry; Marcher, Créer - Déplacements, flaneries, derives dans l'art da la fin du XXe siècle, Regard, Paris, 2002, p. 51.

130 É incontornável evocar o trabalho de Wittgenstein neste ponto, até porque as Investigações Filosóficas são uma obra de charneira tanto para os Estudos Literários como para as Artes Plásticas desde que estas abraçaram o seu Linguistic Turn, com a Arte Conceptual.

131 Jaime Soares, in «Análise do sentido e do significado do uso no domínio da linguagem nas "Investigações Filosóficas" de Wittgenstein», http://www.consciencia.org/analise-do-sentido-e-do-significado-do-uso-no-dominio-da-linguagem-nas-investigacoes-filosoficas-de-wittgenstein

132 Lippard, Lucy; «Escape Attempts», in Johnstone, p. 49.

133 Highmore, p. 82: As Blanchot writes: 'We cannot help but miss it if we seek it through knowledge, for it belongs to a region where there is still nothing to know' (Maurice Blanchot, 'Everyday Speech' [1962), 1987, 15) But this should not be taken to suggest that the everyday is completely unyielding to forms of representation /description or theory): rather it is to suggest that certain forms of discourse are not adequate to their objects and at times fail to accommodate them at all. The other side of this is that there might well be forms of representation that are more appropriate, more adequate, for attending the everyday.

134 Idem. 
encontra inscrita nas relações sociais e na dimensão comunicacional, isto é, pragmática:

Ainda que por vezes sejamos levados a pensar numa generalização da linguagem, é clara a defesa da ideia de uma pluralidade dos jogos linguísticos, que se afirmam como circunstanciais ou adaptados aos diferentes contextos implicados no âmbito da sua aplicação. A imagem da caixa de ferramentas, aplicada no $\S 11$, segundo a qual a nossa linguagem seria como uma caixa de ferramentas, em que os diversos utensílios, desempenhariam funções diferenciadas, denotam bem como Wittgenstein, defende o seu argumento relativamente à grande diversidade dos usos das palavras. ${ }^{135}$

Neste back to the basics 'mundo social da comunicação', a Lógica vê-se subalternizada pela Gramática, cuja função é ir atrás dos vários usos da linguagem com o suporte de uma demanda propriamente filosófica. ${ }^{136}$ Numa intuição da essência dialógica da linguagem (paralela ao dialogismo de Buber), Wittgenstein conclui que

[...] a defesa de uma linguagem privada é impossivel, porque é impossivel seguir regras privadamente. Seguir regras, implica directamente uma prática ou uso e é essa praxis que gera o significado. Assim. Wittgenstein rejeita o solipsismo e o cepticismo, uma vez que as expressões psicológicas em primeira pessoa não exprimem conteúdo cognitivo. ${ }^{137}$

Estas premissas de uma consciência linguística, dialógica, comunicacional, pragmática são indissociáveis da análise do sentido social da obra de arte na cidade. Com Wittgenstein le Bakhtin) abre-se à arte urbana crítica uma perspectiva muito concreta, a de constituir-se como jogo de sentidos que, na forma urbana, reflecte sobre a suas próprias condições de enunciação - pensando as suas ferramentas -, colocando-se, humildemente numa provisória plataforma de emergência de um entendimento alargado - e até suspenso - de si própria.

Recordo que «Existence as dialogue», de Bakhtin, defende o dialogismo como uma epistemologia, ${ }_{138}^{138}$ uma teoria do conhecimento orientada para a pragmática, captando o comportamento humano através do seu uso da linguagem. Mais, e agora de encontro a uma retórica crítica, isto é a biopolítica (Foucault), micropolítica (Negri), dialógica (Kester), não-representacional (Thrift), ao fim e ao cabo de resistência a todos os sistemas:

Dialogism, let it be clear from the outset, is itself not a systematic philosophy. But the specific way in which it refuses to be systematic can only be gauged against the failure of all nineteenth-century metaphysical systems to cope with new challenges raised by the natural and mathematical sciences. [...] In dialogism, the very capacity to have consciousness is otherness. More accurately, it is the differential relation between a center and all that is not the center. ${ }^{139}$

Para que esta dimensão crítica e radicalmente cultural do texto possa ser defendida, recordo que, já para os Futuristas, a forma tipográfica era menos uma extensão da capacidade de expressão das palavras que uma ferramenta para ataca a própria linguagem, assim surgindo, e na arte isto seria doravante uma bandeira da arte mais crítica, a operatividade dos pares significante/significado, texto/contexto, sistema/história e sobretudo o par retórica/ linguagem, agora expandido ao texto da sociedade:

Marinetti, disrupting the linear order of the written word was a metaphor for a larger and more radical agenda: the wholesale overthrow of accepted cultural and political norms and conversations. [...] This strategy marked a break from the rarefied contexts in which art and design ideologies had previously been expressed, contrasting radically with

135 Idem.

136 Associado a esse papel da Gramática, encontra-se a tarefa da Filosofia, que segundo Wittgenstein tem um papel terapêutico. À Filosofia cabe-lhe a função de encontrar e apontar os problemas linguísticos que se consideram a base dos problemas filosóficos. A ingerência de áreas científicas, noutras áreas ao nível do conteúdo do discurso, constitui-se segundo Wittgenstein como a principal causa dos problemas filosóficos [...]

137 Idem.

138 Holquist, Michael; Bakhtin and his world, Routledge, London, 2002, p. 14-15.

139 Idem, p. 18. 
the values of William Morris and the Art and Crafts Movement. Whereas Morris had developed a design philosophy articulated through hand production. Marinetti's medium was an industrially produced and ephemeral artefact, and the Manifesto was a political statement utilising popular media and graphic form ${ }^{140}$.

Isto é, em dado momento histórico, Futuristas e Dada 'estão do lado' da máquina da comunicação - o ser na comunicação total ${ }^{141}$ - e Morris e Arts and Crafts na barricada de uma democratização cognitiva do quotidiano - cognitive time/space is ordered very much as time and space categories are deployed in speech ${ }^{142}$. E se as colagens de Gris ou Picasso lem Portugal, Souza Cardoso) são irrupções do quotidiano no belo emoldurado da pintura ${ }^{143}$, a arte começa, ao longo do séc. XX a integrar cada vez mais signos da modernidade (Leger, Picabia, Delaunay) nos seus mecanismos de representação, culminando o processo com Duchamp e suas estratégias de transmutação dos valores estéticos ${ }^{144}$. Isto é, a irrupção do texto na história da arte é passível de ser relacionada com a emergência de práticas de cruzamento disciplinar (Will Hill), mais, se considerarmos, o movimento Dada (sobretudo o berlinense) como ponto-charneira de toda a complexidade emergente da arte como comunicação na cidade, então a questão do texto é indistrinçável de uma dinâmica geral de renovação pela arte da própria criatividade, em que a poiesis do texto é a táctica plataforma de experimentação radical. É muito em função da sua dimensão textual, do texto como base da acção, que Dada was by nature a transitory or autodestructive movement, perhaps as significant for the possibilities it proposed as for any concrete outcomes. ${ }^{145}$ Por outras palavras, a arte do possível da cidade está ligada a uma movimentação artística que atribui ao texto (que entretanto conquista inequívoca preponderância na paisagem e na experiência urbana, na sinalética, na publicidade, etc.) um papel-chave na produção cultural. Por isso, quando Theo van Doesburg desenvolve o seu envolvimento experimental na linguagem, estamos no âmago de uma conquista, pela arte e pelo logos, de um espaço discursivo, no seio de um conjunto de práticas que assim se vêem reajustadas nas suas posições relativas (donde a intercambialidade, na minha axiomática, dos vectores texto-corpo e ideia-indizível).

\section{Mediação, Conhecimento}

Hoje, a situação impõe por isso a consciência de que As communications media converge in the transition from a reading culture into a image-driven one, the dialogues become progressively more complex, the ambiguities more illuminating ${ }^{146} \mathrm{~A}$ imagem é texto e vice-versa e Warhol é dos primeiros a retirar os dividendos desta ilação, a partir da revolução textual da pop:

once you 'got' pop, you could never see a sign the same way again. And once you thought pop, you could never see

140 Hill, Will; «The Schwitters Legacy: Language and art in the early twentieth century», in Art and Text, Balckdog, London, 2009., p. 11.

141 Holquist, p. 26: 'Being' for Bakhtin then is, not just an event, but an event that is shared. Being is simultaneity; it is always co-being. [...] The other is in teh realm of completedness [...] in a world filled with the determining energies of impersonal social force, it is a potential source of freedom. The ground of other liberties from constraint of the sort Bakhtin celebrates in carnival.

142 Holquist, p. 22.

143 Hill, p. 12: The papier collé introduced contemporary subject matter, the ephemera of an industrial age, against the conventions of the still-life genre.

144 Ver em Duchamp, a constante estratégia de desenvolver nos títulos sucessivas camadas de significação para as obras.

145 Hill, p. 13.

146 Idem, p. 18. 
America the same way again. The moment you label something, you take a step - I mean, you can never go back again to seeing it unlabelled... The mystery was gone, but the amazement was just starting. ${ }^{147}$

Defendo que há uma dimensão propriamente 'textual' na deriva política da arte contemporânea, o que é aliás notória em muitas formas de arte pública corrente. Dave Beech sublinha como no sistema da arte o texto é no entanto uma posição fortemente excêntrica, precisamente enjeitada pelo 'conceptualismo de mercado:'148

Thus, an art made of language is not an art limited to language but necessarily - by virtue of language - draws us into questions about how we think, ho we live, how we judge, how we feel, how we differ and how we try to resolve our differences. [...] Language is, to use Foucault's formula, implicated at every forced and unforced conjunction of power and knowledge. And this is why, even if the term 'text-art' has gone out of fashion, the use of text $i$ art has spread like wildfire. ${ }^{149}$

Em suma, por um lado, as palavras encurtam a distância entre o espectador e a peça, como notava Szeeman am 1983..$^{150}$ Por outro lado, o cuidado com a simplicidade do discurso torna-se elemento-chave de uma transparência do acto plástico, um gesto de compreensibilidade:

Contemporary uses of text in art can be seen, therefore, as extending and complexifying the substitutional logic of the first wave of text art of the 1960's. As well as puting text where images once were, today text replaces the presence of the author, occupies the place of subjectivity, replaces experience with description, and spontaneity with mediation. ${ }^{151}$

Portanto, a arte 'textual' contemporânea, na senda das inovações conceptuais, actualiza uma preocupação com o discurso face ao quotidiano - de Wittgenstein a Judith Butler - no que é a emergência de uma filosofia da pós-consciência (um pós-humanismo); assim relativiza a tradição cartesiana - veja-se Gross e sua retórica crítica da distribuição do sensível. A arte vem enriquecer a o valor e a performatividade quer dos jogos de linguagem (Wittgenstein), quer da linguagem como jogo (Schiller). É uma arte que, não rejeitando os avanços científicos de Estruturalistas e Pós-Estruturalistas, não se contenta com a pura crítica dos limites da linguagem face ao real e vice-versa. E aqui Derrida ajuda a redefinir um campo de construção discursiva que supera os abismos analíticos, estabelecendo-se com o linguistic turn até uma ponte - e uma retórica - com o Habermas pensador da esfera pública (restritamente) discursiva e naturalmente o Rancière da escritura como performance política. ${ }^{152}$

As experiências artísticas têm tido um papel nesta desestabilização pragmática dos discursos hegemónicos - filosófico, técnico, burocrático, político..., artístico - e assim levam o jogo da construção dos afectos e das ideias para uma irredutibilidade do dizer da forma urbana como materialização do socius. É por isto que a célebre morte do autor (Barthes), que é um dos soundbites mais perenes do linguistic turn, é a metáfora que sublinha a importância de uma autoria colectiva nos discursos da cidade. Essa autoria colectiva nunca deixa de ter uma dimensão individual e íntima, na relação (criativa) de cada um - todos sermos artistas - com o texto (urbano) - todos sermos cidadãos:

$147 \mathrm{http}: / /$ www.great-quotes.com/quote/130490. Consultado em Setembro de 2011.

148 Beech, p. 6. During the 1980's and 1990's, when a new generation of younger artists were identified as 'neo-Conceptualists - Daniem Hirst, Tracey Emin and Douglas Gordon among them - were primarily interested in a postmodernist updating of the Conceptualist legacy, with the emphasis on appropriation rather than nomination, semiotics rather than ontology, double-coding rather than analytic propositions.

149 Idem.

150 Godfrey, 163. Colocam mesmo, desde Robert Barry, um enfoque no pathos da recepção discursiva.

151 Idem, p. 29.

152 Idem, p. 30. 
Les pratiques multiples du langage ne sont pas quelque chose de moins que la totalité du langage. [...] Faire usage du langage, c'est comprendre la totalité de son sens. [...] II ne s'agit plus simplement de répéter le langage ordinaire mais de le déplacer afin de composer des agencements nouveaux dans une structure ludique et inachevable. [...] ${ }^{153}$

Em Victor Burgin, um dos primeiros conceptuais interessados numa esfera pública discursiva, os 'materiais existentes' de que deve ser moldada a obra de arte são, portanto, a própria linguagem e os meios gráficos - fotográficos e tipográficos - da sua distribuição massiva. São convites à enunciação,

[...] «reflexive» sentences suggesting a certain non-linearity. They are to be «performed» [...] more «events in the life of
the user» than the transcendental vectors of Morris' and Serra's phenomenology. As stake is a «distributed intelligen-
ce», including a distribution of of intentionality, in which ther is «a shared-out labour of the artwork with the spectator
who performed Burgin's sentences».54

Vejo aqui uma importante hipótese; até que ponto a referida distribuição em Burgin e noutros artistas que colocaram a arte conceptual ao serviço da política é incompatível com o objecto da arte - a arte como objecto? Este território crítico cria um vector oblíquo, equidistante do objecto e da ideia-texto. ${ }^{155}$ Em Barbara Kruger, Anne Messager, em Guerrilla Girls, e hoje nos Freee, estas questões tornam-se óbvias enquanto mediação plástica do conhecimento: Contemporary art is not so much conceptual as mediatic. Conceptual art privileges knowledge. ${ }^{156} \mathrm{Não}$ posso fazer coincidir por completo texto e conceptualismo neste vector, mas reitero a questão dos artistas secundarizarem o que Deleuze chama «planos de imanência», tendencialmente monistas, em nome de uma dimensão dialógica que impõe ao seu vector oposto - o do corpo-sujeito - patente no problema da palavra e do discurso como fala intencional. Quando Lefèbvre, em $A$ Produção do Espaço refere a metáfora e a metonímia, veicula a ideia de uma performática da forma urbana, indescernível da vitalidade discursiva do espaço social, como recentemente nos projectos de activismo informacional de Pedro Penilo (8!8!8!, 2008). Ela recolhe da vanguarda a provocação e a intervenção, e depois ilumina-as com conceitos instrumentalizáveis e respectivas conquistas intelectuais no domínio de um contínuo cartografar das hipóteses da comunicação. Perniola refere a capacidade de a palavra assim fundadora abrir horizontes ${ }^{157}$, e isso torna o quadrante superior direito da minha axiomática virtualmente o mais premente, pois nele a abertura é princípio vital de desenvolvimento intelectual (intelecção da comunicação). ${ }^{158}$ Daqui se deve inferir a radical constatação de que a consciência da linguagem (e portanto, do texto, - incluindo o social e urbano como 'jogo' de formas ora livre ora condicionado) é, porque «grande Outro» lacaniano, o modo de contacto que temos com um transcendente fundador e não-paralizante da realidade urbana. Aliás, $A$ utilização da linguagem implica, por um lado, o reconhecimento da sua função mediadora e, por outro, colocar em jogo o outro, instituí-lo como espaço de resposta, que é, simultaneamente, constituir o

153 In Revue d'Esthétique, n. 44, 2003, pp. 104.

154 Lash, p. 33.

155 No extremo oposto desta tensão, vários trabalhos indoor dos conceptualistas - penso em Robert Barry, por exemplo, ou nos tarbalhos de Holzer, Kruger ou Guerrilla Girls quando apresentados em galeria ou museu.

156 Lash, p. 35.

157 Idem, p. 27. [...] ponto de partida para uma busca positiva que liberta o pensamento da fixidez e do mutismo. Este caminho é para Shelling o da filosofia positiva (o nosso caminho vertical, o quadrante cima-direita), ou seja, o de uma razão que se confronta com algo que está fora de si e que é, por sua vez, posta fora de si.

158 Algures no meu quadrante baixo-esquerda, se quisermos recuperar Jean Clair em De Immundo. Note-se então como no extremo igualmente oblíquo desta abertura ao processo de estranhamento crítico se encontra a confinação idiota no objecto 'mudo', 'realista' submissão do pensamento ao mercado do nojo 
espaço do sujeito. 159 Há aqui uma dimensão dialógica do valor da palavra, pois A palavra está, fundamentalmente, alienada ao outro como a imagem ao espelho, porque aquilo que procuro na palavra é a resposta do outro que me irá constituir como sujeito. ${ }^{160}$ No princípio (do social) terá sido portanto o verbo - e logo, no princípio da democracia, a persuasão ${ }^{161}$; o regresso da cultura ao verbo é o regresso a esse Outro discursivo que aí está para nos abrir os possíveis, incluindo, em operação paradoxalmente inversa, a conscientização do mergulho no corpo. ${ }^{162}$ Donde que a dinâmica desse vector cima-baixo/baixo-cima, incluindo as movimentações oblíquas, é intensa experiência dos limites mútuos do discurso e do real; é o realismo a que temos hoje direito (Perniola); é uma extimité (em oposição a intimité): uma exterioridade radical que ultrapassa a antítese entre interior e exterior. ${ }^{163}$

Para tal é preciso haver maravilhamento. 0 que muito criadores nos propõem é tanto mais crucial quanto, enquanto espectadores emancipados e portanto potenciais críticos e co-autores do acontecimento artístico, velarmos pela sua dimensão esplendorosa, que brote irresistivelmente de um ethos de atenção máxima lao real, e eventualmente ao belo extremo ${ }^{164}$ que medra nesse real ${ }^{165}$, a transpor depois para mecanismos da sua explicitação operativa. Como quando S. Francisco ou séculos mais tarde Pasolini e depois Stalker, ou a Extra]muros[ 'voltam' todos ao lugar do crime - os subúrbios -, para procurar a luz no meio do nada. Esse é o emblema de um investimento no sensível, afectado - a ideia de mergulho no prazer do texto - e da textura - do social. Na alquimia do 'nada' à 'luz', em Barthes ou em Lisboa, uma mesma experiência excessiva desvela-se profilaxia e reflexão sobre a sua própria distribuição. Quando Kafka dizia que a literatura era a religião da atenção, estava sublinhar este carácter da arte para ser mergulho («em apneia») e natação («sincronizada») em simultâneo. ${ }^{166}$

\subsubsection{Quadrante oblíquo, cima/direita: anónima totalidade inteligida}

L'ouvre d'art apparaît. Elle peut le faire soit en se distinguant de ce qui l'entoure, soit en participant à l'apparaitre du monde. Dans un cas, elle est un des éléments du monde construit par l'homme, dans l'autre, elle est du monde ou de monde avant même d'être quelque chose. ${ }^{167} \mathrm{Em}$ obras que assim se constituem como a problematização radical da sua própria separação - (o questionar da autonomia modernista nos termos da mundialidade arendtiana) -, em atenção ao movimento da cidade, trata-se uma entrada na dança, participação no movi-

159 Sá, p. 10.

160 Barthes, Roland; Marty, E; A Aventura Semiológica, Ed. 70, Lisboa, 1987, p. 47.

161 Cunha, T. Cardoso e; «Prefácio», in Da Retórica, Freidrich Nietzsche, Lisboa, Vega, 2002.

162 O que justifica plenamente o interesse de Bataille por Sade, ou a potencialidade política de Klossowski.

163 Perniola, p. 29.

164 Idem.

165 Idem. Durante o século XVIII o conceito de magnificência foi absorvido pelas ideias do sublime e do luxo. À magnificência, que em Aristóteles e S. Tomás de Aquino tinha tido um importante reconhecimento teórico, só resta empreender um caminho subterrâneao através dos paraísos e dos infernos da tóxicodependência e da psicose.

166 Mas Kafka não foi um criador da palavra pública participativa, a não ser quando lia em voz alta capítulos integrais dos seus romances nos cafés de Praga, para gáudio (e riso) do seu público.

167 Grout, p. 11. 
mento, à escala do próprio corpo. ${ }^{168}$ Nestes termos eco-sóficos, l'ouvre-processus participe à l'apparaître de la ville, tout en conservant ce qui en fait sa force. ${ }^{169}$ Recorrendo às figuras do anonimato ou da redução, o artista neste registo é um revelador do próprio suporte cidade e do contexto, revelando a situação sem se substitutir ao suporte..$^{70}$ De que ordem é este acontecimento? De que forma ele reúne o momento lefèbvreano e a sempre recomeçada projectualidade crítica da situação debordiana?

Le double sens du mot public convient à l'eventual entre-deux. Lorsque la foule apparaît à elle-même dans la presence de l'ouvre, cela a lieu en public. Le double sens du mot est pertinent quand ce n'est pas la foule constituée de personne, lorsque celles-ci de leur place se mettent à voir à un moment donné le mouvement et toutes les personnes marchant ensemble, et qu'elles réalisent qu'elles en font partie $e^{171}$

É a questão da participação total na obra de arte urbana, uma obra-processo que acompanha a sua própria inscrição da análise sócio-política, fundada na igualdade e na pluralidade de posições entre os cidadãos-público, e que Grout sintetiza no conceito de acontecimento público tendendo para o anonimato. En effet, un certain nombre d'artistes - à la suite de Duchamp, mais aussi en connivence avec la critique philosophique et sociale des dernières décenies - refusent l'auteur en tant que sujet, réclamant son effacement, allant jusquá la revendication d'anonymat. ${ }^{172}$

Em que medida pode então a arte pública ser a constação de um quadrante oblíquo entre texto e processo, entre política e graça? Na medida em que fizerem mundo ${ }^{173}$, abrindo, a partir do seu lugar restrito e protegido (a autonomia, a contravisualidade), uma disposição - visual, experiencial... - para o reencontro mágico de todos com o mundo quotidiano, superando as hierarquias e divisões (obscuridades) do culturalmente reificado para inscrever a totalidade cognoscente como programa de encontro com o colectivo ${ }^{174}$. Esta imagem permite rever obras minimais ou de Luz como as de Walter de Maria ou James Turrell, mas também Robert Erwin e ainda Gabriel Orozco, no centro lembora apontados ao horizonte infindo à sua direita) de uma axiomática que é a condição sine-qua-non para a interpretação diagramática das hipóteses de fazer mundo. Anonyme, je ne suis pas un objet, refere com precisão Grout ${ }^{175}$. Este é o 'anonimato' potencialmente colectivo que emancipa, o do artista-texto-ideia-processo:

Si Être et Paraître coincident, il se trouve que l'événement de l'apparaître actualize cette coincidence par sa rupture visa-vis des conditions habituelles de presence au monde. Il nous libère des a priori et previsions qui nous empêchent de voir et de sentir. Dès lors, la destabilization initiée par certaines ouvres d'art est tout-à-fait salutaire. Anonymes, nous sommes alors delivrés des structures, systèmes et codes quis nous disposent dans l'aliénation du monde.176

Reúnem-se numa única operação, complexa e comum, os valores do efémero e do vital, da

168 Grout, p. 33.

169 Idem, p. 35

170 Idem, p. 55. Grout reflecte em particular sobre o trabalho de Tadashi Kawamata.

171 Idem, p. 59.

172 Cauquelin, p. 98.

173 Grout, p. 62.

174 Essa totalidade é muito comparável ao estado de vazio tal como pensado por Weil (na esfera da mística) ou Merleu-Ponty (no campo da fenomenologia): Je vraiment, c'est personne, c'est l'anonyme; il faut qu'il soit ainsi, antérieur à toute objectivation, denomination, pour être l'Opérateur, ou celui à qui tout cela advient. Cf. Le visible et l'invisible, Gallimard, 1991, pp. 299-300.

175 Grout, p. 65.

176 Idem, p. 69. 
comunicação e do humano, num discurso, tanto da arte como da cidade, que se dessublima. Nesse novo jogo a participação torna-se começo $0^{177}$. O que não apenas muda totalmente a ideia de cidade e suas formas mas a própria criticalidade política do urbano: C'est sur la base de ce monde en commun que que peut se developer une sociabilité $e^{178}$. Estas reflexões de Grout são de resto motivadas pela experiência concreta e total de espaços desenhados por Erwin, Kawamata, entre outros, e sobretudo, no caso do comentário anterior, por West 8 em Roterdão, a Shouwburgplein, uma praça-luz.

Esta graça não é essencialmente da ordem do erótico: aqui o que se trata é de uma disponibilidade, a qual no entanto não é uma verdadeira presença metafísica, é sublimação dessexuada da experiência estética. Nela a diferença está provisoriamente suspensa, no demos - e no logos - sensível e permeável si próprio. Evidentemente, a obscenidade do realismo psicótico las modas Posthuman, os artistas de Sensation, do quadrante baixo-esquerda), assim como a arte estercorária de Clair não são viáveis nestes espaços abertos e luminosamente discursivos do público burguês (ou de algum outro), seria difícil programá-los nos espaços colectivos ou comunitários, a não ser sob a forma ritualística, por exemplo, da festa ou do sacrifício ${ }^{179}$. De resto, a reificação mediática da linguagem sensacional (de Hirst a Fabre) torna violentamente inútil a resplandecência do Belo confinado pelo sistema da arte; e anula a beleza de uma urbanidade imponderável - o subime social - tal como realizada nos objectos e processos urbanos da arte pública crítica. Por outras palavras, a tendência estercorária que os anos 90 inculcam no coração do sistema da arte acarreta, e isso é que é importante, uma neutralização das tensões plásticas necessárias à inscrição do artístico na esfera pública; diluída no espectáculo da morte, é um sinal de um fascismo do sensível dissimulado no cerne do que pareceria ser uma consquista palpitante da democracia la livre-expressão e a livre-circulação dos bens e das ideias), em detrimento de quaisquer formas de comunitarismo (Kester, mas aqui sobretudo Nancy, Rancière Zizek). Em arte, a participação no contexto sócio-político põe em causa esta constelação 'mundo-da-arte-democracia-neo-liberal'. A esta luz determinadas peças de Santiago Sierra ou Gonzales-Torres, ou Beuys, tornam-se apenas assomos críticos, se comparadas com a radicalidade democrática de Haacke, Wochenklausur, Platform ou um sem número de exemplos de uma arte vernacular e globalizada, de génese relacional, mas cada vez mais engajada na imponderabilidade de um entendimento do intersticial (Scholette, Miles). Este é o intersticial tanto de micro-intervenção de street-art crítica, como de sistemas abertos de consciência social (open source).

Concluo o raciocínio repetindo que a condição para a emergência socialmente transformativa da própria filosofia é a retórica. Vislumbro numa agenda humanista da arte crítica contemporânea, a redenção, pela inteligibilidade - que não é anulação da sombra, pelo

177 Idem, p. 83.

178 Idem. [...] une separation d'avec le social à la suite de Hannah Arendt, qui a montré dans Condition de l'homme moderne, comment le politique ne devait pas être confondu avec le social, d'autant que le domaine sociale est apparu ultériorement. Je reprends cette separation en proposant une anteriorité de l'urbanité sur le social, sans confondre urbanité et politique; et ce, tout en proposant un lien, ne pouvant concevoir aujourd' hui la pertinence d'un tel lieu sans savoir en esprit l'importante de la polis.

179 O ponto máximo do naturalismo (ao contrario do realismo) é o de uma chegada que Perniola não está disposto a aceitar como o fim da arte. Todo o fascínio pelos animais cortados de Hirst está nesta hipótese pseudo-catárquica de uma confusão arte-vida - que não a articulação mágica - por exemplo em Bataille ou Pasolini - desses dois destinos do homem, no discurso do corpo. 
contrário, é o afirmar da dialéctica profunda entre intelecção-luz e sublime-sombra - do regime da comunicação (Cauquelin) a que a arte e toda a sociedade se encontram subsumidos. Note-se como são particularmente determinantes noções de acção aristotélicas (recuparadas por Arendt, Habermas, Martinet, Bakhtin) - da colaboração ao activismo, passando pela auscultação do corpo urbano - e de lugares - os termos glocai, site- e context-specific em que é preciso rever a condição pós- e hipermoderna da arte la mondialité de Christine Buci-Glucksmann). São as palavras-chave para o desenho do quotidiano, um saber naturalmente abrangendo as competências electivas do urbanismo, do desenho urbano e do Projecto Urbano, que devidamente enquadradas e enriquecidas pela transdisciplinariedade adquirem uma valência estrutural inédita desde a democracia grega.

É todo um espaço utópico de resistência à psicose da arte; e é sobretudo, no espaço urbano, nas artes do espaço público, que podem ser encontradas e vislumbradas estratégias comunicativas que expõem os dispositivo da cidade contemporânea criticamente. No equilíbrio instável (ponto crítico) que algumas obras conseguem inscrever no sono da razão da cidade (parafraseio Goya), a arte aparece como acervo de obras e não o simples protocolo da agonia (Perniola), precisamente pela sua dimensão teatral, encenada, 'cinicamente fingidora' (Diógenes, Sloterdijk), em que o autêntico do dispositivo de acção artística é a ficção adequada a exprimir a sua indecisibilidade. Perniola fala n'uma zona descentrada tanto em relação à imaginação como em relação à vida vivida, ainda que relacionada com ambas. ${ }^{180}$ Daí retiro que é a arte urbana retórica - ou que se deixa valorizar pela retórica - que está agendar, como um ensaio sobre a cidade, oblíquas revoluções micropolíticas e quotidianas, enfrentando como mais nenhuma modalidade da arte o fetichismo ${ }^{181}$ do inorgânico identificado por Benjamin ${ }^{182}$ - hoje a tecnociência ou o capitalismo cognitivo, duas 'conquistas' da hipermodernidade (Lipovetski). Noutros termos, o 'mundo da arte', dedicado ao mercado do fetiche e ele próprio um fetiche de mercados maiores lo seu 'quintal' de experimentação simbólica), não estará estruturalmente preparado para dar seguimento a pelo menos uma das esperanças da modernidade, aquela que buscava novas formas de sagrado comunal e de religiosidade secular nas experiências mais políticas para essa entidade que Perniola então define como o terceiro termo do «jogo da arte contemporânea», o público. ${ }^{183}$ É nesta perspectiva que deve ser compreendida a minha atenção radical à questão da recepção, da participação, da colaboração, da identidade, da memória, da festa - e da graça -, modelos de apreensão de um desenho-desígnio profundo de a arte integrar o público na sua realidade, o mesmo é dizer, prever a sua crítica genuinamente imanente e já não metafísica, presentificação e já não apenas representação do corpo social colectivo.

Num programa de rádio recente, ouvi um DJ descrever um tema musical como... sublime... e elegante. Na música de dança, esta aparente contradição de termos decorre de uma no-

$\overline{180 \text { Perniola, p. } 70 .}$

181 In recent years the art museum has taken on many of the aspects of the church or temple: the reverential hush, the fetishism with which it preserves and guards its sacred objects. Idem, P. 6

182 De que o apagamento selectivo da memória (e dos corpos a excluir), em dialéctica relação com a função burguesa do monumento, são traços históricos.

183 Idem., p. 79. 
ção de música que é ao mesmo tempo, pulsão natural pelo ritmo, produção técnica pelo DJ ou produtor musical e finalmente experiência quase sempre anónima, colectiva e em estado de graça (a festa). Talvez esta elegância do tema seja algo como a associação entre a sofisticação que Cabral Santo gosta imaginar ser o factor determinante na acção artística e a noção de graça social que apenas pode ser conseguida numa economia retórica particular, a que liga o ethos da atenção ao quotidano e à abertura do dispositivo à publicidade subtil de uma comunidade em elevação fugaz das suas paixões num sentimento colectivo. que plasma a inteligibilidade no corpo numa utopia do instante, a entrevisão de uma possibilidade. Qualquer ideologia, e sua exaustão como hegemonia, que não o compreenda, cria condições para uma quotidiana negação da nossa humanidade. Mas há um lugar onde estas questões têm de ser tidas em conta, o projecto de arte pública crítica, e então, apenas a retórica e talvez uma retórica específica, extramuros, iilumina as decisões discretas de que se constrói, decisão após decisão, a atitude. 


\subsection{Ethos da atenção, logos do dispositivo, pathos da graça: o projecto como dispositivo, passional}

Se pudéssemos ser egoístas, seria muito agradável. Era um descanso. Mas, literalmente, não podemos sê-lo.

Simone Weil

Numa retórica total da experiência, Ronald de Sousa recorda-nos o papel das emoções numa 'edição do real'; elas são an important complement to reason because they solve the problem of how it is possible to determine which information is important and which is not ${ }^{184}$. As emoções circunscrevem as nossas opções práticas e cognitivas (de Sousa), são portanto essenciais no determinar da relevância, da pertinência ou da evidência, numa esfera pública que se queira radicalmente incremental. Elas são uma matéria viva a cidade, sucedendo-se como memória e reportório; mas apenas alguma arte crítica e pública explicita a sua importância política, contribuindo programaticamente - e não menos importante, experimentalmente para uma imunologia do próprio sistema social. Nesta concreção vida urbana/vida emocional - Simmel já o havia desvelado na sua invenção da vida mental na metrópole - Emotions, goes the strong thesis of Luhmann, are an immune system that society offers the individual. They are legitimized and legitimizing social forms of coping with the episodic or chronic contradictions we encounter within ourselves. And they do not offer a solution but only a form that allows us to continue. ${ }^{185}$ Claro que na unidimensionalidade (Marcuse), as emoções são decididamente empobrecidas (no caso de certas classes desapropriadas da emoção estética) ou manipuladas (pelo marketing, cada vez mais experiencial), amputando-se-lhes a ligação umbilical com um sentido cognitivo, obscurecido com o conluio da ignorância e da trivialidade. Ora é a arte crítica, enquanto retórica do dispositivo passional, em particular a que passa ao plano de uma política total pública, que desenvolve modelos de criação estética capazes de tornar estas questões não apenas visíveis como potencialmente instrumentais, democraticamente. Estas noções vêm englobar intuições de Arno Gruen, a propósito dos conceitos de empatia ou abstracção, ambos na base de processos sociais violentamente inumanos.

Nestes termos, uma tragédia de Eurípedes transporta mais política que um assomo estercorário dos YBA, ou um processo comunitário dos Harrissons acarreta mais ética que uma escultura decorativa no centro de uma rotunda? As coisas nunca são lineares, mas o envolvimento do público com as emoções das obras, articulado como economia retórica, ajuda-nos a ler a cidade ancorados nas emoções da arte - e daí que seja a arte pública a modalidade-chave para esta relação. Numa época em que assistimos ao dismantling of this immune system (Turk), o discurso cultural exige enorme capacidade de análise e de síntese. Começando por uma constatação: It is not that we feel less, but what has happened is that we no longer abide by certain emotional codes. ${ }^{186}$ Mais, we still occasionally judge emotions as appropriate or inappropriate in social settings, but interesting are these emotions that are inap-

184 de Sousa, p. 79.

185 Idem, p. 83.

186 Idem. 
propriate, exaggerated, misplaced, and too intense or lacking intensity. ${ }^{187}$ Eis-nos na linha tanto de Gross como de Lefèbvre, seguindo caminhos abertos na literatura (Flaubert, Kafka, Camus, Kleist, Proust...), e hoje, em novos contextos de uma redistribuição da cultura na vida urbana (de que a street art é um dos desenvolvimentos recentes mais significativos). Se nem sempre o campo da arte (seja ao nível da crítica como da produção) tem acompanhado a mecanicidade destas emergências, esta idade em que então as emoções já não têm publicamente um função social protectora (Turk), as comunidades de públicos que a arte crítica cria - sentires em comum, situares de afectações efémeras -, delimitando economias retóricas específicas face à pressão das indústrias culturais la televisão é um exemplo claro de dispositivo-máquina que gangrena a vitalidade do socius) e enquadra então a minha própria economia retórica, num equilíbrio ethos/logos/pathos que os anos sedimentaram provisoriamente num conjunto de metáforas operativas. Desenvolvo então essa retórica destacando o valor imunológico dos tropos atenção, dispositivo e graça. É o meu modelo para enquadrar as emoções à solta. Recordo que Luhmann, na sua 'estética' (conhecimento dos sentidos insiste na radical incomensurabilidade entre sistemas psíquicos (percepção) e sistemas sociais (comunicação). A arte é para ele um tipo especial de comunicação que usa percepções em vez de linguagem, operando nos limites entre o sistema social e a consciência em formas que irritam profundamente a comunicação, ao mesmo tempo que permanecem estritamente internas ao social. ${ }^{188}$ A perspectiva retórica enquadra portanto o acontecer da arte e em particular a que tenho vindo a destacar como historicamente fundadora da arte pública crítica, das partidas do museu-intervenção e contexto-situação à arte como comunidade.

Desenvolvo as ideias desta secção em analogia com uma imunologia das emoções ${ }^{189}$. É uma questão tão imponderável (na dificuldade de se integrar em qualquer teoria) quanto crucial: No aspect of our mental life is more important to the quality and meaning of our existence than emotions ${ }^{190}$. Para Turk, as emoções ensinam-nos a ver ${ }^{191}$, na sua cega sabedoria, ajudam-nos a desenvolver as bases cognitivas para os sentimentos e o mundo intelectual das ideias, aliás como as tradições da tragédia ${ }^{192}$ e da psicanálise ${ }^{193}$ deixam claro, hoje suportadas complementarmente pela teoria dos sistemas (Varela) - de que nunca é demais sublinhar

\section{Idem, p. 84}

188 Cf. Luhmann, Niklas; Art as a Social System, Stanford University Press, 2000. http://www.sup.org/book.cgi?id=1609. Consultado em Dezembro de 2011.

189 Se o sistema imunitário é um sistema de signos em que se desenvolvem dinâmicas interpretativas, uma imunologia das emoções pode ser vista como antídoto para a crise da experiências (patente integridade psíquica comprometida pela vida moderna). Turk, Johannes; «Towards an immunology of emorions», in Costa, Fernanda Gil; Furão, Igor (orgs.); Estética das Emoções, Húmus, Lisboa, 2011.

190 http://plato.stanford.edu/entries/emotion/ Consultado em Dezembro de 2011.

191 Turk, p. 73: For emotions, this means above all a shift of many assumptions we harbor about them: although they are cognitive and relate to a situation, they do not open this situation but they understand it in order to protect from its possible consequences; they occur in a subject but they mark this subject's contradictions and are a way to live with them; [...] they articulate difference and not unity.

192 Turk sublinha que a primeira tradição teórica a referir uma imunologia das emoções é a de Aristóteles, nomeadamente na questão da katharsis; complementa aliás que A more precise definition of katharsis can be found in Aristotle's Politics, where catharsis is ascribed a political and pedagogical role as educator of emotion. Idem.

193 É nesta sequência que devemos actualizar Schiller lo patético como inoculação do destino inevitável, o empático como cerne do teatro) ou Freud (o sonho como tentativa de restaurar controlo sobre os estímulos, antecipando situações) no sentido de um entendimento produtivo da complexidade social. 
a potencialidade crítica no presente tecnocientífico ${ }^{194}$. Nestes termos, estes capítulos finais estão no enfiamento de princípios estético-cognitivos que reputo à Poética aristotélica como base para uma política total ${ }^{195}$. No Renascimento, já Robortello e Maggi haviam explorado a possibilidade de as emoções serem inoculadas; Robortello interpreta a Poética a caminho de uma consciência perfeitamente moderna, em tudo harmonizada com a distribuição do sensível rancièreana, em que o mundo emocional corresponde a um processo contínuo de alteração de padrões nas emoções. Em consequência, It is not the punctal now of emotional energy but the shape of an emotional sequence that is at stake ${ }^{196}$. Isto leva-me à ideia particularmente produtiva depois das revoluções fenomenológica e estruturalista, para pensar a arte pública crítica como privilegiado palco de interacção emotivo-cognitiva, numa narrativa colectiva cujos padrões de pensamento se tornam visíveis por via dos actos na matéria urbana.

\subsubsection{A atenção: $O$ objecto de arte no coração da retórica da atenção}

A atenção é o processo cognitivo no quadro do qual nos concentramos num aspecto do ambiente enquanto ignoramos outros. Prende-se com a distribuição (focalização) de recursos de processamento da informação, combatendo a distracção (Zerstreutheit). É Walter Benjamin que introduz, na modernidade, a ideia de uma atenção 'dividida', característica da recepção em estado de distracção. Stiegler, que vem hoje dar outra nuance política ao que Husserl chamou consciência intencional ${ }^{197}$, conclui hoje, perante a negação massiva da energia libidinal colectiva pelos aparelhos psicotecnológicos:

É preciso pensar o futuro planetário a partir da questão do psicopoder que caracteriza as sociedades de controle, e cujos efeitos se tornam maciços e destruidores. No presente, o psicopoder mundializado é uma organização sistemática de captação da atenção, possibilitada pelas psicotecnologias que se desenvolveram com o rádio (1920), com a televisão (1950) e com as tecnologias numéricas (1990), disseminando-se por toda a superfície do planeta através de diversas formas de redes, e levando a uma canalização industrial e constante da atenção que, há pouco tempo, engendra um fenômeno maciço de destruição desta atenção, o qual a nosologia americana descreve principalmente como attention deficit disorder. Esta destruição da atenção é um caso particular, e especialmente grave, da destruição da energia libidinal por meio da qual a economia libidial capitalista se autodestrói. ${ }^{198}$

194 Idem, p. 81 [...] in recent years, immunology has turned into a cognitive science: "There is", Francisco Varela writes, "a strong sense in which immune systems are cognitive: they recognize molecular shapes, remember the history of encounters of an individual organism, define the boundaries of a molecular self, and make inferences about molecular species likely to be encountered" (Varela 1988, 359). In contrast to the neuronal networks of the brain to immune system is decentralized. It provides a shifting repertoire of forms for possible conflicts on the basis of a relation to the self. Its repertoire is complete, whcih means it can recognize any substance it may encounter. Chance encounters between antibodies and antigenes build a sensitivity that is the result of the system's history. Since Nils Jerne introduced the first network theory, it is generally assumed that the immune system cannot be understood on the level of its components, but only starting with the dynamics of the system, whose components react with each other and contain a relatively high level of autoimmunity. [...] It is the model that Niclas Luhmann has used to sketch in a few sentences and an immunology of emotions within the general framework of a social immune logic. According to him, emotiosn are patterns that protect individuals from certain risks that emerge from self-contardictions at the moment of events that trigger them. Their semantic is a cultural product that sets the individual free and allows it to be continue his life in spite of threats that for example have to do with the discrepancy of expectations and reality.

195 Como deixei claro ao evocar a Teoria dos Quatro Discursos no ponto 3.1.1.

196 Turk, p. 75.

197 Stiegler, Bernard; «O que faz valer a pena viver», in 2. Aparelhos psíquicos e aparelhos sociais na "economia da atenção"). Texto extraído de CE qui fait que le vie vaut le coup d'être vêcue, Ed. Flammarion, 2010, pp.5-6.

198 James, W. (1890). The Principles of Psychology. New York: Henry Holt, Vol. 1, pp. 403-404. It is the taking possession by the mind, in clear and vivid form, of one out of what seem several simultaneously possible objects or trains of thought. Focalization, concentration, of consciousness are of its essence. It implies withdrawal from some things in order to deal effectively with others, and is a condition 
A atenção é a realidade da individuação entendida no sentido de Simondon: enquanto ela é sempre psíquica e, ao mesmo tempo, coletiva. A atenção, que é a faculdade psíquica de se concentrar sobre um objeto, isto é, de se dar um objeto, é também a faculdade social de cuidar deste objeto - como de um outro, ou como de um representante de um outro, como do objeto do outro: a atenção é também o nome da civilidade, na medida em que ela se funda sobre a philia, isto é, sobre a energia libidinal socializada. Por isso, a destruição da atenção é, ao mesmo tempo, a destruição do aparelho psíquico e a destruição do aparelho social (formado pela individuação coletiva), enquanto este constitui um sistema de cuidado - se é verdade que prestar atenção (to pay attention) é também cuidar (to take care).199

E ainda, quanto à relação cognitiva e desiderativa entre atenção e emancipação:

E, por isso, a questão do terceiro limite do capitalismo não é aquela do abandono da energia fóssil, mas aquela do abandono de uma economia pulsional e da reconstituição de uma energia libinal, isto é, renovável - já que esta energia aumenta na freqüêntação dos seus objetos. O terceiro limite do capitalismo não é somente aquele da destruição dos estoques de energia fósssil: é aquele da pulsão de destruição de todos os objetos em geral pelo consumo, na medida em que eles se tornaram objetos de pulsão, e não mais de desejo e de atenção - a organização psicotécnológica do consumo provocando a destruição da atenção sob todas as suas formas, tanto no plano do psiquismo como no plano coletivo. ${ }^{200}$

Os termos de Stiegler são claros reconduzem a questão do cuidar enquanto cuidar do social, que naturalmente coloco no cerne do ethos da arte pública (e sua curadoria), enquanto motor para a geração de novas economias libidinais. Estes têm por função fazer valer a pena viver, resistindo ao marketing enquanto braço armado do capitalismo. ${ }^{201} \mathrm{~A}$ atenção é o mecanismo empático fundamental que permite tornarmos operativa a nossa consciência da passagem das psicotecnologias às sociotecnologias (Stiegler). E de facto, a atenção permite o escalar do nosso investimento na situação a que nos encontramos subjugados e que quotidianamente construímos, mais ou menos passivamente:

A perda da atenção é uma perda das capacidades de projeção a longo prazo listo é, de investimento nos objetos de desejo) que afeta sistemicamente os aparelhos psíquicos tanto dos consumidores manipulados pelo psicopoder quanto dos próprios manipuladores: o especulador é tipicamente aquele que não presta nenhuma atenção aos objetos de sua especulação - e que não cuida deles. ${ }^{202}$

A atenção ao equilíbrio ambiental no planeta, para além do cuidar egoísta da sua habitabilidade denuncia a perversidade das economias da atenção que negam o sistémico e os horizontes mais distantes em nome de uma efemeridade deslocalizada de uma instantaneidade do utópico (Carmelo). Stiegler fala numa perigosa gramatização da transindividuação, em curso através de múltiplas formas de digitalização do real (redes sociais):

Neste estado, são os mecanismos da transindividuação que são gramatizados, isto é, formalizados, reprodutíveis, então calculáveis e automatizáveis. Ora, a transindividuação é a maneira pela qual as individuações psíquicas se metaestabilizam como individuação coletiva: a transindividuação é a operação da socialização plenamente efetiva do psíquico. ${ }^{203}$

which has a real opposite in the confused, dazed, scatterbrained state which in French is called distraction, and Zerstreutheit in German.

199 Idem, p. 3.

200 Idem, pp. 14-15.

201 Idem. [...] o marketing, a partir do aparecimento das indústrias de programas, transforma as psicotécnicas de si e da individuação psíquica em psicotecnologias industriais da transindividuação, isto é, em psicotecnologias tramadas por redes, e como organização de uma reticulação industrial da transindividuação que causa um curto-circuito nas redes sociais tradicionais e institucionais.

202 Idem.

203 Idem, pp. 4-5. individuação coletiva, por meio do que se confirma espetacularmente e organologicamente a análise de Simondon, segundo a qual a individuação psíquica é também e de imediato uma individuação coletiva. Trata-se de tecnologias de indexação, de anotação, de tags e de traços modalizados (M-traces), de tecnologias wiki e de tecnologias colaborativas em geral. Aqui, a leitura de Foucault é particularmente necessária e fecunda: Foucault também mostrou na sua leitura da correspondência de Sêneca com Lucillus que as técnicas de si, enquanto técnicas de individuação psíquica, são sempre técnicas de individuação coletiva. Por outro lado, Foucault não viu a questão do psicopoder [...]. 
São termos que claramente ressoam as noções wagnerianas de uma experiência redentoramente colectiva, pela arte da totalidade enquanto resposta ao que hoje Stiegler chama as sociotecnologias, 'ponta do iceberg' mas também apparatus da experiência quotidiana dos actuais limites do capitalismo (mais do que industrial, comunicacional e cognitivo, já plenamente gramatical). São ideias que permitem situar a produção e a experiência do consumidor (da arte, da cidade, do planeta), para além dessa figura da alienação inventada pelo capitalismo. $\mathrm{O}$ consumidor (user imerso nos labirintos de um psicopoder ineditamente destrutivo dos saberes tradicionais com a questão do progresso, Benjamin, Kafka), vê-se assim desafiado por novos desejos (e não apenas novas pulsões); porque ligados a atenções e cuidados emergentes), são determinantes, desde que realizados pela consciência plena do dispositivo (logos), $\mathrm{n}^{\prime}$

[...] a condição de inventar um modo de vida constituindo uma nova forma de cuidar e de dar atenção ao mundo pela invenção de terapêuticas, de técnicas, tecnologias e aparelhos sócio-farmacológicos de formação da atenção, correspondendo às especificidades organológicas do nosso tempo: às especificidades de tecnológicas da transindividuação, formando a infraestrutura de um sistema industrial funcionando ele mesmo de maneira endógena como um sistema de cuidados: fazendo do cuidado sua "cadeia de valor", isto é, sua economia - e reencontrando assim o sentido original da palavra economia, pois economizar é cuidar.

O conceito de reinvestimento aponta à sobrevivência da dynamis do socius, como se uma ars publica pudesse ser o principal lugar onde se discute aquilo sobre que vale a pena dar a atenção - e, na prática, aquilo sobre o faz valer a pena viver. Nesta retórica, o lugar da atenção no ethos artístico, particularmente chave no ethos da arte crítica, é, d'près Kafka - que dizia que a atenção é a religião da alma - a condição para uma atenção total específica. A sua intensidade, profundidade e extensão está no cerne da minha apropriação do termo, que quero equivaler ao movimento primordial e de base que antecede um envolvimento com o real característico da arte crítica, em que as competências efectivas, emocionais, técnicas, comunicacionais, são colocadas ao serviço de uma ideia de encontro com o Outro e/ou os outros. Se o consumo é o que destrói o seu objeto, a libido é, ao contrário, o que cuida do seu objeto. ${ }^{204}$ Muitas questões críticas do consumo do objecto e das situações de arte pública laboram nesta provocação, qual pharmakon anti-consumo na polis:

Esta socialização da inovação engaja cada vez mais frequentemente formas sociais de aprendizagem que parecem se auto-organizar e escapar dos processos habituais de socialização da inovação dita "descendente" I guiada pelo complexo pesquisa/desenvolvimento/marketing): ela constitui o que se chamou de inovação "ascendente". A inovação ascendente é o que rompe estruturalmente com a organização das relações sociais no seio do mundo industrial segundo o par opositivo produção/consumo. ${ }^{205}$

No caso da atenção extramuros - e vê-la-emos na análise de uma paixão como emoção portanto, o que o olhar envolvido destaca são detalhes do real em complexas configurações esquemáticas do mesmo, de que as imagens - como os mitos urbanos - são uma espécie de obscurecimento. Nestes termos, prestar atenção é muito próximo de prestar cuidado, significa um envolvimento perceptivo, a experiência de uma edição aberta ao que de outro modo não se destacaria. No ethos extramuros é uma atenção ao que determinada hegemonia

204 Idem, p. 14. O esgotamento do Planeta que veio com o consumo é finalmente uma espécie de chance: a chance de compreender que a verdadeira questão da energia não está aí, que a energia da subsistência apenas tem interesse se ele é posta a serviço da energia da existênia - e tal que ela se constitui por sua capacidade de projetar o plano do que eu chamo de consistências. Ora, tal é também a verdadeira aposta do que se chama, em nossos dias, - com uma expressão muito questionável - inovação ascendente. Idem, p. 17.

205 Idem, p. 18. 
desvaloriza, evita ou obscurece. Esta dimensão nietzscheana não bastará porém, pois isso reduziria esta atenção a uma negatividade dialéctica. E assim talvez se possa acrescentar que se trata de uma atenção positiva radical (Espinosa, Negri) aos pormenores estéticos do real, do ponto de vista da mecanicidade dos seus dispositivos (Foucault). Isto implica actualizar continuamente a noção de participação cidadã:

\begin{abstract}
Ao invés de opor o bottom up e o top down, trata-se de constituir sistemas de produção de metadados que os agenciem e constituam assim tecnologias políticas permitindo fazer emergir processos de individuação psíquica e coletiva de um novo gênero, fundados sobre a representação das diferenças de perspectivas, polêmicas e controvérsias tanto quanto das convergências de interesse ou de pontos de vista permitindo reagrupamentos, isto é, no fim das contas, transindividuações se reconhecendo em significações, constituindo assim individuações coletivas, e instalando, no coração da vida pública numerizada, a crítica argumentada e analisável contra o rumor de baixo nível num mundo numérico suavizado e falsamente consensual na falta de instrumentos de valorização de singularidades coletivas. ${ }^{206}$
\end{abstract}

É uma participação que acontece - aliás, uma compassividade - sob as formas múltiplas de envolvimento, raciocínio, orientação intelectual, pensamento anacrónico, independentemente de antecedido ou sucedidos de outras acções. Porque sempre esquemática - aspecto retórico de diagrama instrumental, operativo, apropriável através da sua tradução em dispositivo (artístico) como o seu logos da arte crítica, é como o de uma partitura. Em tudo isto, a ideia do curador enquanto aquele que toma cuidado - taking care - ganha valor meta-dialógico, no coração de mediações do libidinal continuamente recomeçadas, às mais diversas escalas da vida cívica e urbana e suas geografias ${ }^{207}$.

\title{
A atenção em ponto crítico
}

Vários artistas (Duchamp, Warhol...) são icónicos na sua capacidade de funcionarem como economistas da atenção ${ }^{208}$ :

As economists of attention, the artists discussed all share the common understanding that, in an attention economy, "art's center of gravity [...] would lie not in objects that artists create but in the attention that the beholder brings to them". Art is reconceptualized, in other words, as "whatever the artist wishes to call to our attention. Art is an act of attention the artist wishes to invoke in the beholder".

Fountain de Duchamp é, pela sua operatividade de ready made, um primor de eficiência ${ }^{209}$ na exacta medida em que maximiza a atenção (measured in the proliferation of interpretations offered to explain or otherwise ascribe meaning to his work ${ }^{210}$ ) ao mesmo tempo que é 'mínima' a evidência material da obra. O que o próprio Duchamp denomina na equação 'coeficiente de arte' / posteridade está evidentemente ligado a esta questão, que me parece ter exposto e levado a um extremo radical, a re-redefinição do dispositivo artístico no Ocidente. ${ }^{211}$ Esta,

206 Idem.

207 É este contexto que deveria conduzir a União Européia à elaboração de um novo modelo industrial, repousando sobre uma política industrial de tecnologias do espírito - isto é, da sublimação - como a única economia libidinal durável, e em vista de produzir a energia libidinal. Idem.

208 Lanham, Richard A. "Economists of Attention." The Economics of Attention: Style and Substance in the Age of Information. Chicago: University of Chicago Press, 2007, pp. 42-77.

209 Lanham, p. 44.

210 Idem.

211 Importantly, Lanham points out that it was never part of Duchamp's agenda to operate within the paradigm of high art. The fact that Duchamp is remembered as doing everything in his power to poke fun at that paradigm (the story behind Fountain is offered as evidence of such), while at the same time purposefully placing his works in the context in which high art discourse 
é uma questão de partida para a questão da atenção na arte pública crítica, informada pela vanguarda:

[...] Lanham astutely demonstrates that contrary to those who thinly describe the difference between Futurists and Dadaists as programmatic (Futurists being those with a program, Dadaists those without), "Dada did have a program, and its program was our central trope: oscillatio. Once it got people's attention, this bi-stable poise is what it was trying to teach them. This is what the Dada brand was all about...It was about holding opposites alternately in mind".

Eis a origem do ponto crítico enquanto funcionalidade-chave no objecto de arte que procure basear as suas intuições na energia do anacronismo, aquilo a que vale a pena prestar atenção hoje e agora.

[...] Moreover, one of the highlights of the discussion of Andy Warhol as the "spiritual successor" of Marinetti is Warhol's ability to "turn the 'masterpiece psychology' of conventional art upside down" by foregrounding mass production over skilled handiwork, proletariat audiences over connoisseurs, trendiness over immutability, and repetition over rarity. This turning of the gestalt switch is a central feature of the attention economy insomuch as "style and substance have traded places".

One of the consequences of this turning of the gestalt switch is the wild success of artists who draw their rhetorical power from bottom-up processes, as opposed to top-down ones. Lanham offers "earth artist" Christo Javacheff as a quintessential example of an economist of attention cum rhetorician (his work, Running Fence, did, after all, "persuade people to reflect on the social machinery of persuasion and thus to understand its necessity" (my emphasis)l. While Running Fence is traditionally appropriated by the avant-garde art community as an exercise in art-for-art's sake, Lanham convincingly recasts the work as a lesson in bottom-up entrepreneurship and the human behavior required to persuade bodies of law to allow a 26-mile long fence adorned with thousands of yards of sail-like fabric to be constructed on dozens of people's private land and summarily dismantled after a two-week lifespan.

Donde que, se as importantes inovações da arte crítica são propostas de economias de atenção para inventar novas maneiras de ver as coisas e testar os limites (Lanham), então uma atenção extramuros está especificamente interessada em ver o social e testar-lhe os limites no apparatus da cidade.

Entre todas as palavras e termos-chave que as obras abordadas nesta investigação sugerem, é possível, com o objectivo de gerar uma economia original, selecionar três e colocâ-los no quadro de uma tripartição específica: Ethos da atenção, logos do dispositivo, pathos da graça. Mas antes, é fundamental desvelar algumas ligações menos correntes entre retórica e arte. Isto é, haverá curiosidade sem questionamento? Meyer encontra na raíz da retórica do questionamento, isto é, atenção ao problemático:

[...] Mas para obter um tal efeito de estilo, é necessário precisamente mais estilo do que raciocínio, jogando-se com as figuras e com as paixões, a fim de melhor hipnotizar o auditório, mesmo tendo em conta que este pode ser subjugado por vezes com raciocinios que afastam o que é problemático, pondo de lado as premissas que, ao serem expressas, poderiam levantar questões. ${ }^{212}$

Abordo a obra de arte na cidade deste ponto de vista, enquanto intensificação comunicacional, persuasiva, problematizando, através de fenómenos de auscultação ou participação críticos, os valores hegemónicos (e portanto triviais) característicos da platitude do consumo (Miles). Partindo do desejo de entendimento profundo, complexo e dinâmico da cidade, posso equivaler então a retórica a uma racionalidade total do socius e da política do/no espaço urbano:

Vejamos doravante a retórica como o poder que o espírito possui de desmascarar os discursos impostores que o

operates, "make[s] us oscillate back and forth between the physical world, stuff, and how we think about stuff". This "toggling back and forth" is what characterizes Duchamp and the other artists discussed [...] as economists of attention. In http://ahatter. wordpress.com/visual-rhetorics/the-rhetoric-of-attention-or-the-objet-dart/; 4 de Março de 2008.

212 Idem, p. 15. 
atacam quase quotidianamente, como para melhor anestesiar e diluir a crítica, a insolência e, sobretudo, a lucidez que tanto a retórica como o espírito pressupõem. Vejamo-la também como a capacidade que os homens possuem de se pronunciarem sobre aqui que os divide, bem como sobre aquilo que os une. ${ }^{213}$

Ora quando Aristóteles afirma que a retórica se ocupa daquilo que poderia ser diferente ${ }^{214}$, coloca aquestão do possível (Miles) no coração da moralidade política como forma de atenção à cidade; é uma premissa em que porém não temos $A$ ou não- $A$, mas $A$ e não- $A$, sem que por isso se abandone o domínio do logos. ${ }^{215}$ Isto é, se a retórica é, para Aristóteles, o desafio que consiste em integrar o problemático no logos sem ter de o pensar como tal ${ }^{216}$, talvez não exista melhor definição de arte crítica ${ }^{217}$, e naturalmente da arte enquanto ponto crítico das dinâmicas do socius. Afinal, na sua atenção e respeito pela contingência, a retórica é o homem no $\operatorname{logos}^{218}$ - a retórica é o homem no dispositivo (Foucault, Agamben). A retórica permite um reconhecimento: como o homem é múltiplo, a pluralidade das vozes traduz-se na riqueza das expressões que funcionam como atributos da realidade. ${ }^{219}$ Donde $o$ interesse de questionar as formas de articulação entre a criação e a política, pela recepção das obras em sede de emoções sociais e sua (re)distribuição, procurando, como é evidente, sintetizar a que considero essencial - a graça social colectiva em que o povo contacta com uma espécie de transcendência do seu próprio ser-dispositivo. Mas mais, importa avaliar as obras estudadas do ponto de vista da vectorialização logos-pathos, isto é, menos as intenções empáticas dos artistas e mais a recepção que as suas obras criam em função da atitude (Sena da Silva) de atenção que as definiu - o conjunto de opções projectuais discretas num devir temporal e espacial.

Hoje que há um campo expandido da retórica ${ }^{220}$ evidencia-se a arte pública crítica como esfera pública contemporânea, em ponto crítico:

Vejamos a retórica como o poder que o espírito possui de desmascarar os discursos impostores que o atacam quase quotidianamente, como para mehor anestesiar e diluir a crítica, a insolência e, sobretudo, a lucidez que tanto a retórica como o espírito pressupõem. Vejamo-la também como a capacidade que os homens possuem de se pronunciarem sobre aquilo que os divide, bem como sobre aquilo que os une. ${ }^{221}$

Ela é indissociável de uma retórica total, na dinâmica de atenção ao outro (empatia, envolvimento), generosa e ao mesmo tempo cínica - firme atenção aos aspectos lógicos da mediação.

213 P. 22

214 Meyer, p. 16.

215 Idem.

216 Idem, p. 17:

217 Meyer: Isto implica a proposicionalização do problemático, objecto último do que será a retórica para Aristóteles e os seus sucessores. [...] A é é não $A$ sem que isto seja contraditório, porque $A$ pode ser $B$ ou $C$ ou $D$, que são outros tantos atributos contingentes, flutuantes, nos quais se vem reflectir a subjectividade das diversas posições num universo intelectual que ainda não conhece a subjectividade, mas somente o humano. Idem.

218 Meyer, p. 17.

219 Idem.

220 Meyer, p. 21. O século XX pode comparar-se a estas épocas-charneira [sofismo, humanismo]: uma filosofia que se debate com um modelo de racionalidade que se esvaziou de toda a substância [Féliz Duque] depois de Marx, Nietzsche e Freud, enquanto a ciência conhece várias revoluções, com Einstein e amecãnica quântica. A retórica do século XX terá sido [...] uma das mais ricas de toda a história.

221 Meyer, p. 22. 


\section{Empatia, envolvimento}

A empatia é uma resposta afectiva - vicária (Hoffman) - a outras pessoas, ou seja, uma resposta emocional que pressupõe uma atenção especificamente orientada para o outro. 0 termo cabe hoje na reflexão sobre as competências da chamada inteligência emocional, que tanto inclui uma dimensão cognitiva (capacidade de compreender a perspectiva psicológica das outras pessoas) como uma capacidade para sentir emoções por meio da observação da experiência de outrem. Obviamente, há algo na ideia de atenção que é eminentemente empático, em diferentes contextos que são seleccionados para se tornarem os palcos da interacção. E há uma dimensão de 'como se' no entendimento empático que é em tudo articulável com o 'como se' do objecto de arte, que é e não é 'apenas' o que está à vista. Isto é, numa arte pública - pelo envolvimento do público, chamado pelo sentimento -, a questão do 'como se' torna-se cognição da empatia social, muitas vezes em sede de comunidade ${ }^{222}$. Em suma, sem empatia não temos uma condição de sujeito que a transdisciplinariedade ou a transculturalidade trouxeram, na sua crítica do positivismo enquanto valorização do humano situado e socialmente engajado ${ }^{223}$, logo radicalmente altruísta (Aglioti). Isto que passa por, note-se, um certo cinismo da emoção ${ }^{224}$, o qual necessita de passar como texto e não apenas narrativa. Certas fiç̧ões altruístas da arte pública crítica, precisamente porque retóricas, vão ao encontro desta questão. Em determinada situação de equilíbrio radical - imaginado, sentido... - a experiência do altruísmo é já não apenas a da bondade - sentimento que os mais fortes têm em relação aos mais fracos, como na caridade -, mas a de uma graça entre iguais - uma compaixão ${ }^{225}$ ou compassividade - assim se concretizando a imagem de uma igualdade radical (Nancy) em sede do sentir. Recordo que, no budismo, o altruísmo é considerado o caminho que leva à iluminação e que, agora com Buber (ou Gruen), quando reconhecemos as necessidades alheias, sentimos nossa percepção do mundo ampliar. A vida tem significados maiores quando somos úteis e nos sentimos mais activos socialmente (Dan Graham). Estas questões entroncam nas do envolvimento e agenciamento.

Ora, quanto ao conceito de envolvimento, este seja, de acordo com um dos seus significados principais, atenção total a algo. O que pressupõe cativação, concentração, fascinação, imersão, preocupação, arrebatamento. Seus antónimos são tédio e distracção, em que esquecer, ignorar ou perder (no sentido de passar ao lado), colocar de lado são acções que revelam um estado apático. Isto leva-nos ao conceito de agency (agenciamento), muito frequente na literatura de espaço público e de arte activista, o qual se torna incontornável quando o que está em causa é a capacidade de actuar no mundo, a capacidade de um agente

222 Esta tanto pode simbolizar um encontro fugaz (de vontades, de leis, de emoções), como uma tensão produtiva entre ideias, formas de vida e interesses - em ambos os casos, é inviável fora do valor da empatia (factor de saúde mental).

223 Note-se como, na senda desta associação de ideias, a questão da super-activação empática, que consiste em o agente da emoção voltar para si próprio as atenções (por exemplo deixando-se envolver a ponto do desmaio ou do choque como no sublime estercorário) está numa dinâmica oposta à da distanciação brechtiana).

224 Na doutrina comtiana, o altruísmo pode apresentar-se em três modalidades básicas: o apego, a veneração e a bondade. Do primeiro para o último, sua intensidade diminui e, por isso mesmo, sua importância e sua nobreza aumentam.

225 Compaixão (do latim compassione) - compreensão do estado emocional de outrem; não deve ser confundida com empatia. A compaixão implica o desejo de aliviar ou minorar o sofrimento de outrem, demonstrando especial gentileza com aqueles que sofrem. A compaixão, que necessita de acções para se revelar, pode levar alguém a sentir empatia pelo outro. A compaixão diferencia-se de outras formas de comportamento prestativo humano no sentido de que seu foco primário é o alívio da dor e sofrimento alheios. 
envolver-se na estrutura social - isto é, no dispositivo, em consciência e com capacidade de acção. Ora, isto tem a ver com a capacidade de fazermos escolhas e de inscrever (Gil) essas escolhas no mundo; o que já implica um domínio da retórica (consciente ou inconscientemente). $\mathrm{O}$ agenciamento é uma ficção que urge revisitar ou rever (Zizek); e á aqui que a noção de graça secular, equidistante da marxista (ou da religiosa), aponta para um modelo específico de envolvimento e de atenção que é ainda colectivo mas não colectivista. Nesta investigação, o engajamento experimental (Scholette) é um modelo ético dessa atenção-envolvimento-entendimento, debatendo-se com a estrutura do campo das artes (e da arte contemporânea em particular) para daí partir excentricamente para o contexto e a situação, a participação. É neste quadro que a atitude (Sena) de certos projectos é intervencionista (Scholette), na contingência de uma atenção ao próprio processo, assim tornando a sua emergência acontecimento gracioso do socius.

\subsubsection{Tomar atenção ao logos}

Para Górgias o logos é, diz ele, «um grande tirano que leva a cabo as acções divinas através de microscópicos materiais que são perceptíveis. Tem o poder de por termo ao medo, de apaziguar a dor, de provocar o regozijo e de incitar a piedade», o que obriga a ter em conta os seus poderes de persuasão em qualquer apuramento de responsabilidades. ${ }^{226}$ Os mais determinantes encontros com arte pública têm este carácter - o de expor a sua proficiência lógica na discrição das suas microdecisões. Explicitando a sua contingência, constituição e funcionamento formais, criam um público, intersubjectivamente. O logos torna-se modalidade de apreensão do momento da situação, n'um ponto vital: o que diz respeito à articulação entre os objectivos do orador e o tempo, o lugar e as circunstâncias do auditório ao qual se dirige, num processo que visa a produção de um discurso adequado. ${ }^{227}$ O kairos é o momento oportuno, uma forma de agarrar o fluir das coisas instáveis - eternamente em crise, desde Benjamin - aquilo a que chamamos presença de espírito ou capacidade de respostas ${ }^{228}$ É nestes termos que o efémero (Buci-Glucksmann), aponta à humildade radical da mundialidade, redenção do ethos separado burguês na totalidade que é o texto do mundo (não confundir com a experiência imersiva e inconsciente desse texto como fantasia).

Já Isócrates entendia como a linguagem, na raiz de todas as actividades humana, se havia demarcado quer dos filósofos, quer dos sofistas: dos primeiros recusando identificar o logos com a razão; dos segundos, porque rejeita a redução do logos à palavra. ${ }^{229}$ Eis-nos numa ideia de totalidade discursiva para além da palavra, englobando o corpo, a memória, as formas, e portanto uma retórica produzindo modelos de discurso ${ }^{230}$. Se Aristóteles vai depois assentar a sua retórica na pluralidade do ser ${ }^{231}$, bem com na sua contingência, Henri Lefèbvre está claramente na mesma linha de análise (muldimensionalidade e alienação). A ferramenta

226 Idem.

227 Carrilho, Meyer, Timmermans, p. 31

228 Idem, (cit. O. Reboul, Introduction a la rhetorique, Paris, 1991, p. 21.

229 Idem, p. 40.

230 Idem.

231 Idem, p. 43. 
para a percepcionar vai buscà-la-la aos Sofistas, que praticam uma arte sem objeto específico. ${ }^{232} \mathrm{O}$ paralelismo com a arte conceptual é evidente, até na forma como prefigura a invenção da posteridade (Duchamp) e da recepção (Iser, Jauss) no seio de uma teoria do texto social, a que é possível situar entre duas questões: Unidade e multiplicidade são doravate dois pontos de vista entre os quais não existe contradição; ${ }^{233}$ relativamente à acção dos homens, o domínio da acão é o da contingência, que não pode ser regido por verdades científicas, que o papel dos raciocínios dialécticos e dos discursos retóricos é indispensável para introduzir alguma racionalidade no exercício da vontade individual e colectiva. ${ }^{234}$ Tendo em conta que o que está em causa é a persuasão: Não é este o caso de nenhuma outra arte, já que cada uma das outras artes apenas é instrutiva e persuasiva no que diz respeito ao seu objecto. ${ }^{235}$ Vejo aqui a mesma dinâmica de consciência da desmaterialização conceptual (Lippard) que nos anos 60/7 elevou o estatuto da arte a um filosofar - ou melhor, a um retoricizar em grande medida da própria vida urbana, em toda a complexidade do dispositivo. Relembremos aqui a tripartição inventio, dispositio e eloquotio na estrutura de qualquer mensagem.

\section{Inventio, invenção; Dispositio, estrutura; Eloquotio, efeitos.}

A invenção consiste em circunscrever o problemático com o seu género retórico próprio diria Fiedler, de acordo com a capacidade de desenvolver-se a pesquisa em função de uma pulsão que vai de encontro ao seu contexto, alterando-o na sua materialidade constituinte. Não há arte sem esse acto inaugural, de uma imaginação circunscrita a uma certa 'imagem' que se desenha ao (co)desenhar-se. Relativamente à disposição, terá a ver com o que se isola, no âmbito do problemático, por forma a estabelecer um ritmo de leitura, de entendimento, de comunicação, de persuasão. Os artistas mais capazes definem ritmos e momentos, espaços e ângulos que tornam as suas obras não apenas legíveis como claras enquanto dispositivo expositivo. ${ }^{236}$ Finalmente, a elocução tem a ver com o estilo, a eloquência, os efeitos especiais de marca autoral, sublinhando as linhas de força de um argumento com aspectos que, não sendo estruturais, revelam uma preocupação com a ornamentação do logos.

\section{Da recepção à paixão}

No âmbito de uma teoria geral da recepção da vivência urbana, a descoberta de sucessivas vanguardas, de Baudelaire a Joyce, de Dada aos Situacionistas - é como um texto, que a figura do visitante ${ }^{237}$ ajuda a 'ler.' Ora, [...] while literary works are accessible only to the

232 Idem, p. 45.

233 Idem.

234 Perelman, Chaim; L'Empire Rhetorique, Paris, 1977.

235 Carrilho, Meyer, Timmermans, p. 47.

236 Christo embrulhando edifícios ou Spencer Tunnick fotografando gente em arquitecturas diversas laboram no seio de uma estruturação do facto artístico que, no limite, é o coeficiente de processo na obra.

237 Whereas in literature, the interaction between text and reader occurs within a framework that controls and limits the interaction, through genre, tone, structure, and the social conditions of the reader and author, in landscapes the interaction occurs through movement and viewing, framed by typology instead of genre and tone. Instead of an "implied reader," reception theory of landscapes assumes an "implied visitor," who is an abstracted concatenation of responses of many visitors at different times. http://en.wikipedia.org/wiki/Reception_theory 
imagination, physical landscapes are accessible to the senses as well as to the imagination. ${ }^{238}$ Há portanto um pathos paisagista na arte pública. Para além das decisões específicas dos criadores dos acontecimentos artísticos urbanos, ou dos modelos de produção em que ocorrem (modalidades, contextos), há significados colectivos que emergem em totalidade dessa experiência uma recepção que, sob certas condições. Nesses acontecimentos colectivos - a festa da arte (Gadamer) - não é possível ou desejável separar a celebração do entendimento (Wagner), nem a comunicação do discurso. Tal como uma obra de arte nos encontra ao nos encontramos com ela, a paixão é animada pelo logos e influencia-o, por seu turno. ${ }^{239}$ Cognição e diálogo intersubjectivos (Arendt, Buber, Bakhtin, Kester, Stiegler) levam as paixões a funcionar como elementos da acção numa perspectiva que valoriza não a revelação da subjectividade, mas antes a dinâmica intersubjectiva. ${ }^{240}$ Há então arte que vai animar um pathos de graça secular, radicalmente e comunal, porque atenta ao transcendente colectivo em sede de emoção social partilhada. É essa a luz exterior (Wagner) que ilumina as decisões de projecto, o trabalho sobre o medium (Brea), a mensagem: Aqui, o que conta são as marcas do implícito sugerido, o sentido linguístico e as condições pragmáticas da sua ocorrência, os tipos de discurso utilizados. ${ }^{241}$

Quando procuro estas nuances numa retórica logos-pathos, estou a seguir as conclusões de Perelman: o auditório, na medida em que o discurso for eficaz, muda com a evolução des$t e^{242}$. Esta a razão fundamental para a defesa da arte pública crítica como retórica, isto é, modalidade da racionalidade que desvela a cidade em sede de uma democracia discursiva. A ideia dos futuros possíveis em Malcolm Miles, actualização pós-moderna (Perniola, Vattimo, Duque) do corpo na utopia, plasma-se no dispositivo da publicidade do seu funcionamento, no elocutio crítico da sua atenção à distribuição do sensível nas redes sociais, encontrando mecanismos adequados - le mot juste (Montaigne) - para enfrentar o problema do dispositivo, o mesmo é dizer, a sociedade (Foucault e muito antes Vico). Haveria lugar à emancipação lefèbvreana ou à crítica da hegemonia (Gramsci) - isto é a sua comunicação - sem esta instância retórica? O conhecimento situado e a verdade de certas obras de arte comunicam esta evidência, quase sempre num ponto crítico da própria ideia de anamnese - que vale a pena reter do passado. ${ }^{243}$

238 Idem.

239 Idem, p. 53.

240 Idem, p. 53.

241 Isto explica aliás a visibilidade, a pertinência e a afirmação da que 'arte do texto' de Kosuth a Freee, passando por Kruger; em Portugal, de Ernesto Melo e Castro a João Louro ou Pedro Penilo.

242 Perelman, op. cit., Pp. 163.164

243 Carrilho, Meyer, Timmermans, p. 197. Note-se que Vico já suspeita da revolução tecnocientífica da modernidade (Cf. Duque), mas o verdadeiro espirito retórico, incansavelmente jovem', terá de estar disponível para sempre ir mais longe - é essa a sua energia extramuros: A idade da retórica acabou. Mas, como escreve Michel Meyer, «o grande problema colocado por este ultimo estádio, tal como pelo espírito absoluto de Hegel, é que ele simboliza o fim da retórica ao mesmo tempo que é ele próprio encarnado por uma figura de retórica, com se a superação proclamada (da armadilha retórica) se revelsse impossível. A retórica que explica a retórica deve supostamente, anulá-la de uma vez por todas e, de facto, não pára de reproduzi-la.» Questions de rhétorique, op. cit, p. 101. 


\section{Sair de si, cair no real}

A minha noção de atitude (Sena da Silva) tem a ver com a sucessão de decisões formais, que dão forma à ansiedade crítica. Podemos chamar figuras (do latim figura, formar, dar forma) aos modos particulares do discurso. ${ }^{244}$ Portanto, a arte pública é a modalidade artística que conforma a vida urbana. Falemos de figuras de sentido, de figuras de pensamento, a figura que ao contrário do tropo extravasa do seu domínio para invadir a moral, a estética, a psicologia ${ }^{245}$. etc. Isto é, é contextual, situacional, relacional, e por isso abdica de pruridos disciplinares, jargões, distinções culturais, para empreender um radical caminho para fora de si. Para se produzir essas figuras, é preciso longe da tranquilidade. ${ }^{246}$ Portanto, quando falo em pathos da arte crítica extramuros, penso na paixão pelo social mas antes também, na paixão pela paixão - espécie de princípio vital da vida social de que a pulsão artística se deixa tomar.

Recuo aos anos 70, o início do período do meu corpus, para evocar o mesmo tipo de sensibilidade que hoje continuo a surpreender sempre que a arte sai de si. Carlos Paulo, explicando como havia começado uma segunda vida com a formação da Comuna, Teatro de Pesquisa ${ }^{247}$, recorda:

Há cinco anos que fazia Teatro e estava numa fase de balanço em que, por um lado, era-me difícil optar por aquilo que sempre me atraira no teatro: a Paixão. [...] a COMUNA foi o reinício de tudo, re-começar de novo. "Quando voltas para o Teatro?" perguntavam-me, então, os mais velhos, quando perceberam que a paixão tinha espaço para ser vivida e crescer. ${ }^{248}$

Portanto, a cedência à paixão de uma saída de si é o redescobrir de uma vitalidade que a consciência descobre como desafio existencial; e que uma vez colocada no âmago da pulsão artística vai ter consequências. Ora, uma vez não seja negada esta pulsão e desde que ela se concretize na descoberta da comunidade - Paulo refere que a COMUNA era afinal a arena onde a cidade se encontrava ${ }^{249}$ - estão criadas as condições para o encontro com a graça - e Paulo refere, ousadamente ${ }^{250}$, que ali no meu espaço feito casa da cidade ${ }^{251}$ acaba por ver Deus. Aqui eu vi Deus. ${ }^{252}$ Mas esta graça decorre de uma atenção prévia, uma ética da atenção neste artista disponível para a vitalidade dos encontros com o real. É um olhar para baixo que eu nasci tendo. [...] O ser que na sociedade é chutado como uma / barata - cresce de importância para meu olho afirma Manoel de Barros em Retrato do Artista quando Coisa (1998). Daqui, desta nota sobre o envolvimento radical do artista no real - um pleonasmo -, passo à minha proposta retórica, a de especificar uma modalidade de arte na forma urbana que, a partir dos modelos de intervenção da arte pública (crítica, mas não só) - estabelece uma relação entre um ethos da paixão pelo social e um pathos da graça que esse social aporta à vida humana. Assim busco um conjunto de termos-chave que definem essa po-

244 Carrilho, Meyer, Timmermans, p. 199.

245 Idem, p.. 200.

246 Idem.

247 Grupo de Teatro de que é ainda hoje uma das principais figuras.

248 Paulo, Carlos; «A Casa do desassossego», in 25 Anos 1972-1997 Comuna - Teatro de pesquisa, p. 240.

249 Idem.

250 Para quem tem um inequívoco historial de crítica das instituições religiosas no currículo das peças representadas (Cf. 6.1.1)

251 Paulo, p. 241.

252 Idem. 
sição de atenção ou envolvimento com a esfera pública, sempre que neles divise o desejo por abrir portas à experiência do colectivo como processo em aberto ou ponto crítico. Se fui buscar a Kafka o termo 'atenção' - a literatura como religião da alma -, é para o concatenar com uma ideia de envolvimento empático - novo pleonasmo - que deveremos procurar na etimologia do engajamento e nalgumas ressonâncias históricas do termo, na origem do próprio filosofar: $:^{253}$

\begin{abstract}
A filosofia nasceu, no mundo grego, unida à problemática ético-política da cidade-estado, germe do estilo democrático de vida, que se tornou um valor para a civilização ocidental. A modernidade retomou essa proposta, que não morrera na Idade Média. Tornou-se uma proposta revolucionária, que encontrou, contudo, seus limites e seus emperramentos, de cuja gravidade dá-nos testemunho a crise atual. [...] Somente quando, no mundo grego, tornou-se realidade uma certa experiência democrática, a filosofia emergiu. [...] Desenvolveu-se menos com as técnicas que operam no mundo, que por aquelas que dão meios para domínio de outrem, e cujo instrumento comum é a linguagem: a arte do político, do reitor, do professor. [...] A filosofia é, portanto, filha da polis, não somente porque nasceu das suas entranhas, mas também porque se atribuiu a tarefa de ser a consciência crítica dela, e em função dela.. ${ }^{254}$
\end{abstract}

Note-se como estas questões são hoje recuperáveis, no rescaldo (e autocrítica) do projecto de individuação moderno: É um antropocentrismo subjetivista. Daí, poder Mattéi falar de uma reviravolta subjetivista (subjectivist turn), na modernidade, em comparação com a reviravolta lingüística (linguistic turn) dos inícios do século XX.255 Estaremos portanto na era pós-antropológica, à beira de uma ética do gracioso social, um social turn epifânico? ${ }^{256}$. Apenas quando e se o eu subjectivo - na arte com em qualquer campo se abandonar ao sentimento do social, que em muitos artistas se consubstancia numa experiência depois da crítica, especificamente informativa, do social como dispositivo ((logos) partilhado. Há aqui todo um movimento de renovação humanizada da modernidade não como a autoconsciência perfeita, acabada, esclarecida de maneira cristalina, realizada, enfim, mas como contínua criação, um perpétuo devenir, uma permanente metamorfose. E essa metamorfose tem seu arranque e sua força impulsora no processo narrativo e interpretativo da leitura e da escrita. ${ }^{257}$

Mas então é preciso refundar a heroicidade em novos termos, talvez em torno da atenção radical à reinvenção do quotidiano, re-invenção, que é sempre discursiva (no sentido de 'fala do eu') e temporal:

253 Lara, Tiago Adão; Consciência Filosófica e Compromisso Democrático, http://intranet.ufsj.edu.br/rep_sysweb/File/vertentes/Vertentes_31/tiago_lara.pdf, consultado Setembro 2011.

254 Tal situação de origem e configuração operativa ou pragmática da filosofia explica-nos a morte de Sócrates, na polis, e por decisão dela. Tornara-se ele a consciência de seus impasses. Passou a questionar os relacionamentos humanos aí em vigor

255 Lara: Em síntese, pode-se afirmar que o conceito de sujeito, nascido do confronto do ser humano com a natureza e com o transcendente (Deus), do qual a natureza é certa epifania ou manifestação, desembocou no esforço de "desassujeição" do homem em relação a esses referenciais. O homem proclamou-se autônomo. É em si mesmo que procura fundamento. Sente-se, então, na necessidade de declarar-se absoluto. [...] Sujeito, agora, define-se como auto-referência. Uma auto-referência que vai exigir, para se tornar fundamento sólido, atribuição de "absolutidade", antes atribuída ao transcendente. O sujeito é o absoluto. Recordemos os caminhos que levam de Kant a Hegel. Qualquer que seja o caminho que ela traça na história, a lógica específica do sujeito é a de recuperar por sua própria conta a determinação transcendente de que ele é originário e que decidiu abolir: 0 mundo gira doravante em volta de um eu hipostasiado e dilatado à medida do absoluto.

256 Talvez na órbita da Cristologia pós-moderna de Roger Haight.

257 Lara: [...] ler e escrever (escutar e falar) é colocar-se em movimento, é sair sempre para além de si mesmo, é manter sempre aberta a interrogação acerca do que se é. Na leitura e na escrita, o eu não deixa de se fazer, de se desfazer e de se refazer. [...] Ao final, já não existe um eu substancial a ser descoberto e ao qual ser fiel, mas apenas um conjunto de palavras para compor e decompor e recompor. No entanto, essa nova consciência impulsiona no sentido de uma nova aventura que exige também a sua própria fidelidade, o seu próprio heroísmo. Tem de se estar (sic na tradução) à altura das palavras que digo e que me dizem. E, sobretudo, tem de se fazer continuamente com que essas palavras destrocem e façam explodir as palavras preexistentes. Somente o combate das palavras ainda não ditas contra as palavras já ditas permite a ruptura do horizonte dado [...] 


\begin{abstract}
"Existência", de Exsistentia em latim, sinaliza que a vida humana implica certo desenraizamento, certo estar-fora, certa ruptura com o fundamento, com o qual se mantém, no entanto, em articulação constitutiva, pois como se pode "ex-sistir" senão pelo processo continuo desse "sair-de"? E como continuamente projetar-se, "sair-de" se não há um contínuo, também, "permanecer-em", ou seja, "insistir". Para além da etimologia, contudo, vale a experiência da vida, fluir contínuo, situações e referências retomadas e ultrapassadas continuamente.
\end{abstract}

A atenção ao efémero, circunstancial, necessário, processual e contingente, torna-se iluminação do humano em relação.

\begin{abstract}
A reviravolta consiste em reimergir a racionalidade nas peripécias da história, pelas quais aflora como compromisso de concreticidade, e não de abstrações purificadoras, assépticas. O concreto é fruto do "crescer-com": concrescere em latim, em oposição a abstrato, que significa "separação- de": trahere-ab(s). A primeira atitude, compromisso com a concreticidade, não teme as ambigüidades da vida; a segunda, fuga para o abstrato e não apenas passagem necessária e enriquecedora por ele, é um esforço para se livrar das ambigüidades, à cata de certezas e seguranças. 0 compromisso de concreticidade leva-nos à compreensão de que o ser humano que se expressa em termos de "eu", de "consciência", de "sujeito", na modernidade, revela-se como temporalidade, êxtase - novamente um ex e um stasis: exstasis, em latim - de passado, presente e futuro. Temporalidade radical.
\end{abstract}

Na totalidade existencial de que é paixão dialógico-discursiva.

[...] a linguagem não se exaure na sua dimensão de representação e comunicação. Ela passa a ser encarada como poder de intervenção produtiva; e só pode ser entendida a partir dessa dimensão pragmática: é a virada pragmática que a enreda nas situações concretas das quais e pelas quais emerge. [...]

As diferenças - o infinito social - não emergem como anomalias, mas como possibilidades pensáveis, saudáveis e, portanto, apetecíveis, valores a serem computados e acolhidos. E é a atenção que as redime, a empatia que as valoriza, o engajamento que as torna visíveis (Arendt). Concluamos com a afirmação: a filosofia é filha da cidade. Mas devemos acrescentar: a cidade só pode ser a cidade que vale a pena se gerar essa filha. Mãe e filha se co-implicam no existir. Todo existir é relação. Não existem mãe e filha absolutas.

Assim, o projecto que siga estas premissas constrói uma vectorialização inevitável entre o ethos critico (base de uma evolução exponenciada pela modernidade e em particular a teoria crítica, conforme procurei sublinhar na Problemática) e um pathos da totalidade social, eternamente adiado (a questão da superação da instrumentalidade da utopia) e eternamente reconstituído desde que a pulsão artística se virou para o social em abertura programática. $O$ destino do Povo torna-se então tanto mais persuasivo quanto se tornar emoção partilhada - informação sobre o dispositivo social capaz de revelar toda a sua potencialidade na recepção.

\title{
8.1.2.3 Logos projectual. Do dispositivo em ponto crítico.
}

A história do termo dispositivo é longa e complexa, culminando em reflexões recentes de Agamben, d'aprés Foucault. Equivalendo operativamente as noções de dispositivo, logos e projecto (Aristóteles), no carácter de investimento de/na esperança (Lefèbvre, Harven), explicitamos neste instância processual de realização progressiva de determinada actividade plástica na forma urbana (materialidade do dispositivo social). 0 projecto é assim entendido como sucessão de perguntas e respostas num continuum histórico, decisões e acontecimentos disponíveis para a autonomia (Gruen) contestar a abstracção, enquanto liberdade da necessidade. Posto isto, como definir o sentido crítico de uma ligação ethos/ 
pathos através de conceitos operativos como participação, colaboração, diálogo, efémero, improvisação? Precisamente, empreendendo o esforço metaretórico de considerar criticamente o dispositivo no centro de uma dinâmica de articulação entre um ethos de atenção, empatia, envolvimento, engajamento e um pathos da graça do social.

O que me interessa é o logos do dispositivo - uma tautologia. Ora nas obras de pendor tautológico - what you see is what you get, mas ao mesmo tempo what you get is not exactly what you see -, o que é persuasivo é a possibilidade de a arte poder ser meta-discursiva (Lefèbvre) e politicamente meta-operativa. A arte do dispositivo, no espaço público, é com efeito a arte do espaço público como conceito filosófico, na forma como parece fazer ressoar as dimensões dialógica, participativa e colaborativa no fenómeno artístico, esse lugar do dispositivo social que é explicitação - informativa, política, activista, cínica, etc. - dos mecanismos de poder, influência, institucionalização e expressão do humano-social na forma urbana. ${ }^{258} \mathrm{Na}$ minha axiomática da arte na forma urbana (secção anterior), é numa vectorialização oblíqua $\left(45^{\circ}\right)$ que podemos definir esta dinâmica de intensificação do poder retórico da arte, enquanto performática do corpo social e discurso sobre si próprio. $\mathrm{E}$ nestes termos é relativamente pacífico encarar esta retórica da arte na forma urbana, com destaque para as suas modalidades mais críticas, como uma inevitabilidade da racionalidade emancipatória do socius, no quadro de uma crítica da 'democratização' da cultura, em que o entretenimento (consumista) corresponde a uma visão empobrecida, trivial, da economia da atenção: é a própria expressão da alienação industrializada, ou mesmo daquilo que Adorno designa como uma estratégia geral de organização dos tempos livres. ${ }^{259}$

\section{Transparência, imponderabilidade, evidência}

Sublinho o meu entendimento pragmático da ideia de transparência aplicada ao dispositivo artístico. Como acontece na crítica dos modelos de democracia representativa ${ }^{260}$ transparência não significa transparência simultânea de todos os aspectos de um dispositivo; ela pressupõe uma selecção do que ostensivamente deva surgir como transparente, ou visível, assim constituindo a obra uma reflexão simultaneamente sobre si própria e sobre as condições como surge no quotidiano urbano. Associada ao conceito de informação, a transparência pode relacionar-se com níveis de governância, aspecto da acção colectiva e individual sem a qual uma democracia deixa de ser operativa. Há arte - a arte do quotidiano - que tem isto presente, precisamente em função da relação com a materialidade: This art has no particular form - in the sense that no one form or style predominates over any other [...] A break is made with art about art (interrogation of its own artistic identity) and continuity is affirmed between

258 Claro que posso sempre invocar que esta arte do dispositivo é a que nos ensina a problematizar a própria reificação da arte enquanto ferramenta de progresso ou evolução sociais, na senda de derivas radicais dos anos 60 e 70 , em conceptualistas e ambientalistas.

259 José Júlio Lopes, «A Origem dos dramas do futuro - Novas direcções para as óperas de arte do futuro», Lisboa, 1997, pp. 203-218.

260 Cf. Albert, Breton; Gianluigi Galeotti; Pierre Salmon; Ronald Wintrobe (Eds); The Economics of Transparency, Ashgate Publishing, Hampshire/Burlington, 2007 
phenomena within and beyond the art world. ${ }^{261}$

Por outro lado, é uma transparência do próprio fluxo projectual, da sua durée: Once under way, the Project highlights the conditions of the experiment, the rules of the game, the practical steps to be taken. At the core of the experimental situation are factors designed to maintain openness and avoid prejudgement. [...] The deviation into practice is designed precisely to suspend judgement and 'see what happens'. ${ }^{262}$

Neste quadro, há coisas que não podem ser explicadas ou determinadas conclusivamente. Se nos ativermos a campo da física, há um imponderável que é aquilo que não se pode 'pesar' (como o funcionamento do calor, do magnetismo...). Ora interessa-me uma dimensão da imponderabilidade moral (procurada pelos místicos). É ela que em muitos projectos determina - ou surge - , como factor de um deliberado abdicar do controlo, senão de uma cedência desse controlo a outros que não os agentes iniciais de um facto artístico. Em muitas obras, esta imponderabilidade, desde que transparente, pressupõe uma rara equivalência entre dispositivo e vida social, com amplos sectores de uma comunidade, ou diversas sensibilidades na mesma, ou ainda poderosas expressões de heterotopias antagónicas, surgirem como realidades por editar, e assim, aos olhos do espectador, como uma intensa realidade. É isso que certos projectos críticos inscrevem a emoção desse encontro - umas vezes fugaz, senão fulminante; outras no seio de um activismo de longa duração que certos projectos comunitários (Kester) inserem no tão cego quanto apressado devir tardo-capitalista da sociedade,

It is an aesthetics of experimentation that recognizes that actuality always outstrips the procedures for registering it. The work of these everyday life theories can be characterized by a hybrid mode of representation. Never simply 'theory' 'fiction', philosophy or empirical observation, 'everyday life studies' exist on on the borders and the gaps between these representational categories. It is an aesthetic that questions the suitability of 'system', rigor' and 'logic' for attending to the everyday. As such its theoretical resources emerge from a variety of sources, from writers such as Brecht and Joyce as much as from Marx, from daily observations as much as from intellectual encounters. It is an aesthetic struggling to find a place within a field (social and cultural theory) that is often oblivious to its own aesthetic protocols. ${ }^{263}$

Muitas vezes, isto implica uma atenção ao que é evidente. Na arte pública crítica há frequentemente um desejo de que a obra de arte seja auto-evidente, caminhando no sentido de uma obviedade que se imponha com valor de troca social - aspecto persuasivo apenas conquanto a sua comunicação aconteça. Nalguma arte esterocária-pós-modernista, o que é evidente pode porém não chegar a ser imponderável, pois acontece como teria de acontecer, na esfera neutralizada do museu, da galeria, ou da arte pública institucional. Isto é, tais eventos não revelam, na verdade, as evidências críticas da vida social, antes neutralizam a sua beleza (Perniola). No espírito do Romantismo Alemão, não vejo, neste ponto, grande diferença entre evidência e poesia. Sendo que, na contemporaneidade industrial, a máxima poesia está contida na ideia de máxima informação lalgo que a obra de Christian Nold exprime enorme delicadeza, e ao mesmo tempo, oportunidade). É nestes termos que

261 Watkins, Jonathan; «Every Day», in Johnstone, pp. 62-63. O autor cita as construções absolutamente quotidianas de Tadashi Kawamata, artista que tem importância no pensamento de Grout acerca da realidade pública da arte. E André, o minimalista que continuamente ressurge na minha axiomática: Carl Andre's work epitomizes the directness at the heart of this project, diametrically opposed to the theatricality. Its concrete nature, its 'this-is-this-ness', at once conveys the artist's feeling for basic materials and a tough logic which does not distract from the fact that they are simply there.

262 Sheringham, p. 145.

263 Banes, Sally; «Equality Celebrates the Ordinary», in Johnstone, p. 117. 
a evidência dos dispositivos extramuros se torna desconfortável realismo para os olhares 'estetas': I think the difficulty for many observers of contemporary art is to understand that the everyday in art is in itself an insight rather than necessarily a representation. ${ }^{264}$

Essa evidência, tornada geografia poética pelos Situacionistas, ${ }^{265}$ é um nada que é tudo (Pessoa) da vida na cidade: The evocation, through metaphor, not of the everyday experience but of a feeling, a psychic experience, of the everyday - more than its simple, literal evocation. ${ }^{266}$ Ao fim e ao cabo, também uma 'pure mobility' that presages an art with no works (Kaufmann). ${ }^{267} \mathrm{Ou}$ ainda o quotidiano tornado obra, porque explicitada a sua ausência de qualidades (Blanchot): [...] as Nietzsche pointed out, that sometimes depth can hide in the surface of things. ${ }^{268}$

Como vimos atrás, aspecto relativamente negligenciado do dispositivo crítico é a questão de quando um projecto atinge ou estabelece um ponto crítico. ${ }^{269}$ Numa analogia com o mundo das ideias e dos valores (e sua inscrição no tecido urbano), temos imponderabilidade da experiência ética, experiências com as quais não sabemos o que fazer, o que gera muitas vezes incompreensão (senão desinteresse, ou até ódio). Ora a arte atingir este ponto crítico é sinal de uma criticidade dos seus valores de projecto - às vezes nem são os que ostensivamente apregou, ou que o artista deliberadamente procurou. E então, no espírito retórico podemos estudar em que aspectos, componentes ou decisões um projecto desenhou uma situação de tensão, deduzindo daí não apenas conhecimento projectual mas propriamente um acervo de situações críticas que, em termos de ars pública, são dados profundos (Capra), ainda que por vezes inesperados, acerca do que é a cidade. Naturalmente, é muito difícil a moral retirar dessas experiências do ponto crítico o que quer que seja; a retórica sim, recolhe elementos para aprofundar a sua lógica, agora relativamente à vida urbana em toda a sua contingência, nomeadamente a que decorre de uma vida urbana que há muito anda mais rapidamente que a nossa capacidade de a controlar. Ora, talvez esta questão da informação transparente, imponderável e depois evidente da arte pública crítica não possa ser realmente comprendida - grocada $a^{270}$ - sob o signo do belo ou do sublime, mas da graça.

\section{Do Riso e da experiência da leveza à graça do social}

Há uma graciosa comicidade que torna certos projectos provocações do riso. Em muitas obras críticas, a experiência do humor brota da imponderabilidade de um acontecimento que

264 Ross, David A.; Serota, Nicholas; «The Everyday: a Conversation», in Johnstone, p. 77. The constant media cry in Britain is: 'But is this art?' or 'Why is this art?' When the art appears to be simply the representation of a slice of life. Of course whatthose questions do not acknowledge is the degree of selectivity, of distillation, of isolation that occurs when an artist like Michael Billingham or Tracey emin takes an element of life and appears to present it verbatim...

265 Kaufmann, in Johnstone, p. 95.

266 Idem, p. 76.

267 Johnstone, p. 20.

268 Maffesoli, Michel; in Johnstone, p. 78.

$269 \mathrm{Na}$ termodinâmica, o ponto crítico (estado crítico), é uma condição específica de temperatura e pressão acima da qual não se pode mais diferenciar as fases da matéria.

270 Do inglês grokking. Palavra criada por Robert A. Heinlein em Um Estranho Numa Terra Estranha. Na língua falada pelos marcianos significa ao mesmo tempo 'beber' e 'compreender algo até o ponto em que aquilo passa a fazer parte de nós'. Com o sucesso do romance, foi incorporada como gíria nos anos 70. 
encontra a forma involuntária do riso para se exprimir. Certas obras conceptuais inscrevem o humor na expressão simbólica da cidade contemporânea; independentemente do registo ora negro, ora irónico, irrisório ou absurdo, há uma base linguística neste humor que rebenta com as amarras do quotidiano, ${ }^{271}$ e que é indissociável de uma experiência com valor terapêutico: rir é expressão-experiência de felicidade ou alegria; é uma sensação agradável, que decorre de estímulos, e em que há muitas vezes o sentimento de que fazemos parte de um grupo. ${ }^{272}$ Ou seja, há algo de irredutivelmente universal e comunitário em qualquer obra de arte que despoleta, senão o riso exteriorizado, um rir interior, de reconhecimento agradável do sentido cómico da situação; no limite, um rir em conjunto, produção conjunta da piada do acontecimento. Se tivermos em conta que certos movimentos críticos são resilientes ao status quo - há mesmo uma dimensão revolucionária no riso, que por assim dizer 'acorda' uma humanidade esquecida. Infiro portanto que a arte pública crítica tende, nos momentos de graça, a surgir como expressão de uma ligeireza, uma leveza (Calvino) que é sinónima de uma capacidade artística de síntese. Mais uma vez, a arte conceptual está no centro desta dinâmica, pois a sua economia de meios é, tal como uma boa piada, concisa nos termos, absolutamente imponderável/indecisível nas consequências/ilações, económica no sentido que Stiegler advoga para a produtividade.

Para pensar esta leveza possível de certas dinâmicas do socius, regresso mais uma vez a Kafka, em cuja obra são raros mas (por isso mesmo) extraordinários os fugazes momentos de redenção ${ }^{273}$; no final de América, quando O Grande Teatro ao Ar Livre de Oklahoma recebe todos, porque todos podem ser artistas (Beuys avant-la-lettre!?). Simone Weil verbaliza esta graça sob a forma de pensamento e aforismos, que são reflexões sobre a sua própria capacidade de dizer a relação entre as $\operatorname{coisas}^{274}$ - capacidade que é para Weil, a função da linguagem que deve evitar corromper-se com a obediência à gravidade. Ora confirmando a minha intuição do dispositivo social - mecânica humana ${ }^{275}$ - como o material disponível próprio para a redenção, Weil conclui, no que é apenas aparentemente um paradoxo: A graça é a lei do movimento descendente. ${ }^{276}$ Leia-se uma provocação à exaustão

271 In modern times, the tendency is toward acceptance of incongruity as the probable cause of laughter, and incongruity-based theories are slowly gaining ground, although other schools of thought still hold some favour. A common explanation of humour (in the broader sense of 'laughter-provoking') is based on language. Premises: as we interpret a text, we automatically consider what language says, supposes, doesn't say, and implies (this is the perspective of hermeneutics); the sentences we listen to and we tell, follow the universal conversational rules, that can be reduced to only one: be relevant. This is the basis of the cognitive model of humor: the joke creates an inconsistency, the sentence appears to be not relevant, and we automatically try to understand what the sentence says, supposes, doesn't say, and implies; if we are successful in solving this 'cognitive riddle', and we find out what is hidden within the sentence, and what is the underlying thought, and we bring foreground what was in the background, and we realize that the surprise wasn't dangerous, we eventually laugh with relief. Otherwise, if the inconsistency is not resolved, there is no laugh, as Mack Sennett pointed out: "when the audience is confused, it doesn't laugh" (this is the one of the basic laws of a comedian, called "exactness"). This explanation is also confirmed by modern neurophysiology. In http:// www.crystalinks.com/laughter.html. Consultado em Setembro 2011.

272 http://en.wikipedia.org/wiki/Laughter. There are thousands of languages, hundreds of thousands of dialects, but everyone speaks laughter in pretty much the same way." Everyone can laugh.

$273 \mathrm{Em}$ As Investigações de um Cão, o momento em que a personagem principal reflecte comovida acerca da alegria de ver reconhecida a sua contribuição para a comunidade, através do aplauso de que é alvo.

274 Weil, Simone; A Gravidade e a Graça, Relógio d'Água, Lisboa, 1947/2004, p. 9.

275 Idem, p. 11. Mais à frente, em A CARTA SOCIAL: A noção de opressão é, em suma, uma estupidez: nada melhor que ler a llíada. E, por maioria de razão, a noção de classe opressiva. Só podemos falar de uma estrutura opressiva da sociedade. [...] Diferença entre escravo e eo cidadão (Montesquieu, Rousseau...): o escravo obedece ao seu senhor e o cidadão às leis. In Weil, p. 155.

276 Idem, p. 10. 
simbólica da graça católica luma metáfora morta, nas imagens do céu, como nas pinturas das igrejas), mas sobretudo a consciência de que um equilíbrio cultural é impossível: A busca de equilíbrio é nociva porque e imaginária. ${ }^{277}$ Leio aqui que a Graça enjeita quer o Belo quer o Sublime; sendo que em Weil este é um percurso místico idiosincrático, não deixa de nele transparecer uma consciência do dispositivo - o discurso, a sociedade, a religião - como um nada que a cultura desgraçadamente vai obscurecendo: $A$ imaginação trabalha continuamente para tapar todas as fissuras por onde a graça poderá passar. ${ }^{278}$ Aqui está a sombra (Perniola) de uma arte pública, de verve conceptual, da graça social; que em Weil é um possível mas em Nancy, Sloterdijk ou Zizek - ou outros pensadores críticos um imperativo político num tempo conceptual: Tentar definir as coisas que, ao produzirem-se efectivamente, em certo sentido se mantém imaginárias ${ }^{279}$.

Daqui se depreenda como, ao aproximarmo-nos de um pathos como âmago do logos social, fechando o percurso em círculo iniciado pelo ethos da atenção, percebemos como estão fundamentalmente articulados um pathos trivial de emoções partilhadas los momentos felizes da arte comunitária), um pathos do equilíbrio (o prazer da eficácia funcional no design) e a experiência do corpo na dança; mas também, depois sim e agora no meu quadrante direito e em cima - a expressão do indizível da comunidade por vir. E se o tempo é uma imagem da eternidade, mas é também um ersatz da eternidade, 280 há que DESEJAR SEM OBJECTO [...] Penetrar fundo nas origens dos desejos para extorquir energia ao seu objecto. É nesse lugar que os desejos são verdadeiros enquanto energia. O objecto em si é que é falso, mas extorsão indizível na alma com vista à separação de um desejo do seu objecto ${ }^{281}$. O contacto iluminado com esta realidade é a graça, também (ou sobretudo) no território sempremergente da vida social em toda a sua contingência e enquanto infinito de que urge reter um sentido que redima os esforços continuados na arte-como-vida (Kaprow) de 'Românticos', 'Vanguardas' ou 'Relacionais'. Será por aqui que um ethos de decriação ${ }^{282}$, em que a santidade deve ser escondida mesmo da consciência ${ }^{283}$ - humildade (Gross) radical - que uma certa imagem de Deus (palavra 'proíbida' no logos da arte pública de matriz burguesa) irrompe, agora metáfora operativa fundamental (pelo menos para a filósofa):

\begin{abstract}
A imaginação está sempre ligada a um desejo, quer dizer a um valor. Só o desejo sem objecto é vazio de imaginação. Há presença real de Deus em todas as coisas que a imaginação não dissimula. O belo captura o desejo em nós e esvazia-o de objecto ao dar-lhe um objecto presente, proibindo-o, deste modo, de se dirigir para o futuro. É este o preço do amor casto. Todo o desejo de felicidade se situa no futuro, no ilusório. Ao passo que, se só desejarmos que um ser exista, ele existe: que mais desejar nesse caso? O ser amado apresenta-se então, nu e real, não dissimulado pelo futuro imaginário. O avaro nunca olha para o seu tesouro sem o imaginar n vezes maior. É preciso estar morto para ver as coisas despidas 284 .
\end{abstract}

Extrapolando esta linguagem necessariamente poética, a graça do social - que não pode

\footnotetext{
277 Idem, p. 13.

278 Idem, p. 22.

279 Idem.

280 Idem, p. 25.

281 Idem, p. 26.

282 Idem, p. 38.

283 Idem, p. 43.

284 Idem, pp. 68-69.
} 
ser dita pela ideologia (ou a propaganda, nem sequer a filosofia, ou o amor) mas verbalmente decriada (penso em Pedro Penilo e sua arte política) - aparece-me como a visão de uma possível superação antropo-lógica do espectro utópico. Na prática, e regressando ao pragmatismo da curadoria, tudo se joga na percepção que se possa ter dos momentos em que por alguma razão projectual - uma determinada intervenção artística, fruto de determinada pulsão demo-crática, face a um determinado contexto urbano, enquanto determinada situação pública, activa uma determinada experiência comunitária. Dessa experiência que não é da ordem da representação (Deleuze/Guattari, Thrift) mas do encontro, e cuja emergência é uma marca do impulso vital (Bergson) podemos dizer que é uma graça social, deliberadamente procurada; e é retórica esta consciência. Penso, para concretizar, na comunidade por nada - como no Cordão Humano em Marvila - e que a piada social foi essa - A beleza é a harmonia entre o acaso e o bem. ${ }^{285}$

Ou seja, e agora que um movimento globalizado (Scholette) ensaia a emancipação artística nos intersticios da sociedade contemporânea, em formas de transparência, imponderabilidade e contingência que Weil (ou Kafka) não poderiam imaginar, a arte ou é pública, ou não é; e ou é crítica, ou não é arte. E ou é social ou não tem graça. Mais uma vez, é retórica - e não necessariamente mística - a racionalidade que salva. Primeiro, porque $A$ vida moderna está entregue à desmesura. A desmesura invade tudo: acção e pensamento, vida pública e privada. Daí, a decadência da arte. Já não existe equiíbrio em parte nenhuma. ${ }^{286}$ Depois - e agora numa nota que ecoa a natureza em Wagner mas também é lefèbvreana avant-la-lettre no seu entendimento da emancipação, porque

O capitalismo conseguiu a libertação da colectividade humana em relação à natureza. Mas esta colectividade assumiu, em relação ao indivíduo, a herança da função opressiva exercida anteriormente pela natureza. Isto é verdade até materialmente. O fogo, a água, etc. A colectividade apoderou-se de todas as forças da natureza. Pergunta: poderemos nós transferir para o indivíduo esta libertação conquistada pela sociedade?287

Uma obra recente do artista polaco Dominik Lejman no festival SKYWAY288, dá uma resposta incisiva. A peça consistiu na projecção de imagens vídeo, em negativo, de conjuntos de paraquedistas sobre a parede do centro de arte contemporânea local. As imagens haviam sido obtidas em filmagem dias antes, com o artista a saltar com os paraquedistas de cerca de 4 000 metros de altitude. $\mathrm{O}$ artista pediu que os cerca de quarenta paraquedistas desenhassem no espaço, durante a queda livre, um desenho colectivo - as nervuras da abóboda de uma catedral. Durante não mais de trinta segundos, estas $60^{\circ}$ cathedrals foram símbolo e evidência de uma vontade e de uma colaboração que, paradoxalmente, para se concertizar, não apenas tem de ser curta como, para não ser inviável, implica que todos os saltadores tenham aberto o páraquedas a tempo. Penso que é uma boa representação da graça social, aqui não apenas pela imponderabilidade táctica da sua projecção laparentemente uma instalação vídeo 'vulgar', porém diálogo intenso com o espaço da materialidade arquitectónica), mas pelo poder da sua singeleza formal, no registo deskilled e quase bad de imagens de baixa resolução. Em suma, a criticidade da obra de arte pública está menos no ethos apregoado las convic-

285 Idem, p. 148.

286 Idem, p. 153.

287 Idem, p. 154

288 Que tive a oportunidade de programar em Torun. 
ções de artistas, programadores, mediadores), mas antes de tudo o mais na capacidade de criar em sede de projecto - seus diferentes planos, em relação mútua - os mecanismos estéticos adequados a persuadir. Como é que os afastamentos críticos constituem uma retórica d'o possível da arte? Enquanto meta-filosofar em que o artista e o filósofo tenderão a reconhecer-se no papel «heroico-irónico» (Vattimo) que por um lado contém um elemento de desafio nos confrontos do que é socialmente dominante, ${ }^{289}$ e por outro não pode esgotar-se na transgressão. 290 O não poder esgotar-se na transgressão é o assumir de um desígnio público de comunicação meta-discursiva, legitimação dialogal, condição para a redistribuição do sensível da crítica (das divisões culturais, a sociedade como obra de arte, da utopia). É nesse meu vector 'direito/cima' que a arte reencontra uma grandeza (Pinçon) que reage aos meandros do actual regime de consumo, comunicação e negação do ethos artístico. É aí que a arte encontra sua possibilidade de grandeza (Perniola, Pinçon), eventualmente a sua graça.

\subsubsection{A redistribuição do sensível: apatia vs. empatia, outra política}

O termo 'pathos' deriva do Grego paskhein, significando uma certa experiência e uma certa condição, o sofrer; usualmente traduzido para 'emoção', este é termo chave da velha querela entre filosofia e retórica, na medida em que afere atitudes básicas acerca da natureza humana, nomeadamente face à sociedade civil em constituição quotidiana. Ao mesmo tempo In the Western canon, emotions have long been treated with caution by those who would hail the virtues of rational discourse aimed at truth. And since Plato (c. 428-c. 347 bce), such caution is the symptom of a divisive political philosophy separating experts from nonexperts. ${ }^{291}$ Em suma, a divisão do sensível (Rancière), agora na perspectiva especificamente retórica, é indescernível de uma retórica crítica das emoções - transdisciplinar e fundamentalmente não técnica, e tanto mais incontornável quanto sabemos viver um tempo de comunicação total e pervasiva (Gross). The secret History of Emotion tem por subtítulo From Aristotle's «Rhetoric» to Modern Brain Science, privilegiando uma reflexão sobre o social da arte a expensas de uma radical denúncia do reducionismo, assim compondo um programa humanista. Gross autodesigna-se aliás a humanist defending the autonomy of interpretative social studies ${ }^{292}$, confirmando a figura da interpretação, mais que a da reacção - como lugar por excelência da autonomia pública e cidadã, ou seja, a competência discursiva que temos necessariamente de dominar se quisermos compreender a subtileza

289 Platão, na República, liv. VI. - Adorar o «grande animal» é pensar e agir em conformidade com os preconceitos e reflexos da maioria, em detrimento de toda e qualquer procura individual da verdade e do bem. (Trad. Dóris Graça Dias). Weil radicaliza: $O$ vegetativo e o social são dois domínios onde o bem não penetra. In Weil, p. 159. E finalmente: Será que uam sociedade onde reine apenas a gravidade é viável, ou será que u poucod e sobrenatural é uam necesidade vital? Idem, p. 161

290 Perniola, p. 84.

291 As Socrates suggests in the Gorgias - Plato's famous diatribe against rhetorical art - the rhetorician might have luck arguing to the ignorant about something like the causes of health and sickness, but among experts, the diagnosis of a trained doctor will carry more weight. In contrast to the expert, a sophistic rhetorician working in either an expert domain or in a practical domain such as politics has no need to know the truth about things. Instead, according to Plato, the rhetorician merely hits upon techniques of persuasion that achieve the desired ends (459c). First among these techniques, as the Roman rhetoricians would later reiterate, is the appeal to popular emotion. In «Pathos and Rhetoric», http://www.communicationencyclopedia.com/ public/tocnode?id=g9781405131995_yr2011_chunk_g978140513199521_ss14-1, consultado em Setembro de 2011.

292 Gross, p. 33. 
da imbricação das emoções humanas com as instituições. A primeira ideia que se pode retirar de Gross, que reencontramos noutras reflexões acerca da política da sensibilidade, do gosto e da experiência estética (Rancière em The Politics of Aesthetics), é a de que vivemos constantemente situações de desigualdade na distribuição das emoções sociais. 0 palco público não está uniformemente iluminado (Arendt) nem as condições de visibilidade e expressão são equitativas. No espaço urbano, todo o tipo de nuances e distâncias multiplicam-se lao contrário do que apesar de tudo acontece no espaço mais normalizado da cultura institucionalizada). A abordagem retórica de Gross, baseada nos temas do orgulho e da sua expressão é um esforço para, ao nível do indivíduo, poderem então ser imaginadas subtis comunidades efémeras de sensibilidades. No senso comum - trivial, pornográfico, alienado, patético - as paixões, que decorrem numa economia desigual, apenas se constituem em função directa da publicidade e visibilidade de si próprias ${ }^{293}$. Ora da mesma forma que essa consciência discursiva do dispositivo comunicacional é indispensável a uma política e a uma economia do sentir, a sociedade apenas seria obra de arte se todos se todos sentissem artisticamente (Marcuse), o que me parece ser ainda uma outra consequência da interpenetração do pensamento de intelectos tão 'dispersos' uns dos outros como Beuys, Kaprow, Arno Gruen, Bataille, Buber, Aristóteles... Há portanto na retórica em todo o projecto urbano e de arte de acordo com uma crítica do poder, com o público que essa crítica cria.

Se a reflexão e a crítica do poder tiveram um pico de claridade em Aristóteles, desde a revolução francesa e o marxismo que a divisão/distribuição/partilha do sensível foi radicalmente revista; mas temos de concordar com Gross, no que é uma constatação do projecto moderno ao nível da gnose do social, que the democratization of emotion over the last two centuries is incomplete at best and a model of distraction at worst. ${ }^{294}$ Ora se existem inúmeras teorias económicas, políticas e até estéticas do social, contam-se pelos dedos a que colocam a problemática menos pela perspectiva filosófica e mais pela retórica (com a excepção de Lefèbvre, em quem depositei por isso a responsabilidade de desmontar o quotidiano na Primeira Parte). Para que fique clara a geneologia aristotélica de toda a Tese: we would do well to pay close attention to Aristotle and his early modern relatives if we hope to see our way beyond the current platitutes of emotion ${ }^{295}$ seria necessário para provar que, primeiro, we are first constituted as expressive agents by what the philosophers of the Scottish Enlightenment called "social passions"; segundo, que, the constitutive power of emotions depends upon their uneven distribution. A crucialidade desta questão é evidente em qualquer projecto de critica do dispositivo cultural ou artístico.

Em The Secret History of Emotion, que é em grande medida um estudo dedicado à literatura, (e o aprofundar da investigação na direcção das Humanidades) dá-se quando Gross dedica espaço ao tema da apatia enquanto categoria política produtiva le não, como é corrente no pensamento de direita, défice pessoal numa performática que se pretende positiva do ci-

293 A este nível, Fernando Pessoa, que soube introduzir aspectos cognitivos na sua poesia e afirmava que o poeta é um fingidor das emoções que deveras sente.

294 Idem, p. 5.

295 Gross refere-se consistentemente ao facto de, na sociedade contemporânea, mais depressa milhões de pessoas chorarem a morte de uma estrela como Diana, do que o anónimo assassinato de um mendigo. 
dadão). Baseando-se em Hobbes, Gross demonstra no seu livro exemplos de como e onde se dá a negação de emoções a determinados estratos da população; chamando a atenção então para esse problema maior das democracias liberais: [...] how apathy is a carefully cultivated political category, how passivity serves as a precondition for political activism, how the passion of humility constitutes a positive form of the self, and finally how, generally speaking, psyche is a matter of social difference. ${ }^{296}$ A obra explica como funciona toda uma economia das emoções que leva a que amplos estratos da população sejam politicamente passivos. ${ }^{297}$ Daqui deduzo a crucialidade no projecto democrático de todos os esforços de participação e activismo. Esta questão torna-se clara nos casos de estudo, onde precisamente irrompe um programa de humildade - uma emoção social que, ao contrário da apatia, Gross associa à possibilidade de emergência da dimensão política do social na vida mental (Butler, Guattari, Gruen).

Ora a inovação de Gross é a sua aspiração a fundar uma nova retórica de emoções que complemente a existente retórica de tropos ${ }^{298}$ - ou das modalidades, no sistema da arte até porque qualquer ramo do saber ou da praxis social é levado a cabo - e comprendido por pessoas, pessoas em economias emocionais específicas, ao sabor da pulsão artística, a quem as teorias da escolha racional (nas ciências humanas) ou da análise linguística não oferecem suficiente resposta à problematização, absolutamente necessária do que Gross denomina de protorazão 299 . Rancière está mais uma vez do mesmo lado da barricada, na denúncia da morfologia dos sistemas de divisão do sensível lque são obviamente concorrentes, para definição d'o que é a arte). ${ }^{300}$ Esta é uma crítica amalgamada, porque a retórica não admite a especialização:

[...] I want to convey how rhetoric is at once an embedded cultural practice and an inventive attitude which allows us to reflect critically upon those very same practices [...] Like classical poetics, the inventive attitude distinguishes rhetoric from philosophy, which has the basic attitude of description, and from medicine, which shares with rhetoric the basis attitude of interventioni.

296 O livro de Gross começa o seu livro com a análise desse fenómeno de histeria de massas que foi o caso Diana.

297 Gross, p. 5.

298 Idem, p. 49-50.

2990 de Gross é o de um genelogical Project of reconstituting social emotions by first showing how tehy have been obscured: in this case, by a late-modern fixation on masculine political agency asserted at the expense of political "passivism," now relegated to a dimished feminity passive, also from the Latin passio. Gross, pp. 6-7. Deixo esta nota pela importância que a questão de uma resistência 'passiva', passional e eminentemente feminina adquire no programa de intersticialidade em Malcolm Mlles. Esta problemática vai de encontro à critica da história intelectual que Gross partilha por exemplo com Judith Butler, in the directon of the humanities by considering apathy not just as the absense of emotion, but rather as the rhetorically constituted shadow economy against which a positive economy of emotion is fashioned (p. 55). E entronca na perspectiva de Carolyn Merchant, que assevera que, nos séculos XVI e XVII the image of an organic cosmos with a living female earth at its center gave way to a mechanistic world-view in which nature was reconstructed as dead and passive, to be dominated and controlled by humans. (in The Death Of Nature: Women, Ecology and the Scientific Revolution); no mesmo sentido, Marcuse refere como pré-requisito do processo revolucionário a abilidade para ver as coisas em si, numa experiência da energia erótica da natureza, precisamente proque também o natural aguarda a sua emancipação.

300 A 'economia do conhecimento' é neste aspecto uma cortina de fumo para disfarçar a falta de vontade para construir uma verdadeira sociedade de conhecimento. (Geoff Cox and Joasia Krysa, p. 34) É o equivalente, na economia das indústrias culturais, à distribuição desigual da emoção que gera a apatia cidadã (Gross). Ou noutros termos, mais prosaicos, o contrário de uma evidência: apenas a empatia permite uma verdadeira relação (Sauvageot). 


\section{Palcos de operações}

Aqui se desenha outra articulação fundamental, a de arte pública, sob a figura da intervenção cirúrgica que, como já vimos, constituiu muitas vezes, o traço definitório de um encontro com o holos, de que a ideia de sistema saudável (no espaço urbano) é símbolo. Aliás, os esforços de encontro da retórica com a uma polis total - e não apenas nos interstícios pseudo-discursivos da esfera da democracia representativa - mais do que uma técnica ou de uma persuasão pelo gosto - , são algo de muito fundamental na sociedade, e não é preciso mudar nada na lapidar definição de Aristóteles para compreender-se a dinâmica que a conceptualização retórica introduz na esfera social: For Aristotle, rhetoric's function is not to teach a particular code of behaviour, nor even to persuade; instead, it is defined as "an ability [dynamis], in each case, to see [theoresai] the available means of persuasion". ${ }^{301}$ Note-se como a aproximação à dinâmica produtiva do tecido social se dá na concreticidade, na contingência e no contexto; sugerindo portanto uma dimensão cognitiva que apenas a praxis artística consciente da situação e do momento pode aspirar ${ }^{302}$; mas também, nos casos mais precisos (face à forma urbana), revelando com inédita concisão aspectos críticos da evolução da cidade de uma forma que nenhuma outra praxis teórica ou técnica consegue interpretar. Noutros termos, para que fique ainda mais evidente, o entendimento moderno da retórica (desde Seiscentos), culmina numa revisão de possibilidades apenas latentes na antiguidade, quando a retórica se cingia grosso modo a tropos e figuras discursivas; o poder da persuasão, no âmbito do que viria a designar-se como 'situações de fala' (speech situations), é hoje um aspecto particularmente crucial do regime comunicacional da cultura (Habermas).

Fundamental é atestar que este enquadrar do possível é sensitive to more than the immediate situation in which it functioned and reflexive not just as a ruce-bound practical art. A metáfora projectada exemplarmente é a poderosa ferramenta para integrar discursos, transsubstaciar ideias e operacionalizar cruzamentos de saberes e sua implantação transformadora na cidade negociada quotidianamente. Mas atenção, é a metáfora integrada em máquinas de significação concreta - e realizadas materialmente, no caso da obra de arte na cidade isto, é capazes de superar uma situação generalizada de apatia política. É a metáfora viva e em ponto crítico, mas cuja função na forma urbana nunca pode ser confundida com mera instrumentalidade da compreensão. ${ }^{303}$ A metáfora shakespeareana do mundo como um palco, assim entendida à luz da retórica, é o emblema de uma performática (Fichte-Lichte) que labora nos sentidos (em duplo sentido) passíveis de serem retirados do drama social para que somos atirados (Gross). A grande questão que a retórica contemporânea assim

301 Gross, p. 51: Rhetorical for Aristotle is a theoretical art of human nature extracted from everyday legal and political practice. Indeed apathy - along with its relatives acedia, melancholy, indifference, boredom, ennui, and "spleen" - has been considered at least since Augustine a condition of moral depravaty, a defiant retreat from theworld of God and humankind. But much can be gained, I wager, if we consider apathy something more than the zero degree in the scale of human emotion. Esta questão 'sofre' com Kafka radical ampliação, na sua gfaleria de heróis passivos, humilhados, em inércia, com esse caso dramático da personagem a quem um abutre está a comer os pés e que o permite solicitando precisamente a outre, alguém que por ali passava, a 'necessária' ajuda... Note-se que esta apatia labora num eixo cujo termo oposto é o do entusiasmo, emoção também ela, naturalmente distribuída desigualmente, numa sociedade em que, como já o havia afirmado Hannah Arendt - precisamente na sua leitura de Aristóteles -, the actor always moves among and in relation to other acting beings, he is never merely $a$ 'doer' but always and at the same time a sufferer.

302 Idem, p. 8.

303 Idem, pp. 8-9. 
introduz é a da explicitação da possibilidade que está por detrás de todas as outras: a de sermos actores e não apenas espectadores (Freire, Rancière) de um mundo que se fica as mais das vezes por nos condicionar, quanto muito, a dizer coisas predefinidas numa esfera pública empobrecida ${ }^{304}$. Pobre porque a riqueza do contacto humano está obscurecida por uma distribuição do sensível incapaz de captar o inframince do social: Urban theatricality is now demonstrating, in various ways, that the individual is an indeterminate thing. None of us have any worth unless we are an integral part of a social context. ${ }^{305}$

Mas iria mais longe nesta actualização da retórica à luz da teoria crítica contemporânea. Diz Gross: Rhetorics is mistakenly viewed as the mere expression of real politics - never its substance - while critical strategies for parsing the political body are religiously ignored. Quando Malcolm Miles menciona a intersticialidade, Buci-Glucksmann o momento ou Kester o conversacional como temas-chave para a função da arte na cidade contemporânea, o que estão a fazer é actualizar criticamente a ideia esgotada da utopia; em rejeição das grandes narrativas, o informe do social busca formas de representação da ordem do por-vir-sendo-já. É neste modelo que a graça social surge como modo de sentir e pensar a comunidade. Esta retórica não se encontra nos discursos dos políticos profissionais, mas diluída numa esfera do político em que urge distrinçar a negação do dinamismo, algures entre os jogos de sombras da esfera pública representativa. Tal só é possível colocando entre parêntesis o próprio discurso; ou, nas artes plásticas, colocando em parêntesis o próprio dispositivo artístico. Essa é uma condição sine qua non para contornar a univocidade do discurso e ampliar o campo da argumentação: rhetorics is always in brackets (Gross). O debate pode ocorrer então no quadro de uma genuína intencionalidade do investimento afectivo, que começa na atenção cínica (Sloterdijk) ao entorno social - Materialized in brains, faces, bodies, and even in objects and architecture, such as tombstones or an amusement park, emotions clearly exceed the merely ideal - e culmina no domínio dos protocolos e dos dispositivos da comunicação artística - com destaque, naturalmente, para a forma naturalizada da arte, a exposição.

Num regime em que a criatividade é uma exigência a todos os níveis das cadeias de produção simbólica, a arte pública, como espaço potencialmente retórico, ocupa um lugar-charneira:

\begin{abstract}
Les ouvres d'art - sculpture publique, amenagement paysager, ensemble architecturé, décoration de salles de réunion - sons censées apporter una réponse aus problèmes de la ville. L'art est ce lieu de réunion symbolique unificateur des différences, qui doit faire fonction de liasion et de substituer à une cohésion difficile à trouver, en somme tenir lieu de consensus politique. [...] Cette opération de réunification ne date pas d'aujourd'hui: l'activité artistique a toujours été requise par le pouvoir pour visibiliser les concepts qui lui servent de príncipes. Arcs de triomphe, châteaux, plans d'urbanisme, avenues en perspective, jardins et parcs royaux, théâtres, cês réalisations ont touours répondu à une conception définie par le commanditaire; celui-ci choisit de faire droit à tel ou tel projet qui correspond le mieux à l'idée qu'il se fait de son image. De ce qu'il entend livrer comme image.
\end{abstract}

Fica claro que foi uma deriva retórica a definir o essencial das vanguardas e das neovanguardas, que perante diversos contextos e suas forças em jogo criaram condições, por vezes periclitantes, uma dynamis cultural que quase sempre passou por conferir ao social o carácter de tema-charneira da praxis. Essa deriva, encontra hoje novos contextos, pos-

304 Note-se que Rancière, como advoga Gross, investiga (neste aspecto como Argan) as razões históricas da experiência do sensível, perspectivando nessa diacronia a sua própria crítica da história.

305 Idem, p. 10. 
sibilidades de intervenção, experiências comunitárias efémeras e focos de graça súbita. É um social situado, ancorado numa fenomenologia (como na emergência do minimalismo): the most appropriate way to approach emotions is phenomenologically, as Martin Heidegger suggests in his fascinating commentary on Aristotle's Rhetoric, which means starting with the concrete manifestation of emotion in a meaningful world, as opposed to a world of mere matter. Ora o que me levou à criação e desenvolvimento de projectos virados para o Espaço Público foi a observação progressivamente mais consciente, primeiro da pulsão mal resolvida de a arte aspirar ao social (limitação da vanguarda); depois, da forma como o público e os artistas estabeleciam a sua relação conjunta por meio da obra de arte. No que foi fundamental em termos de consciência curatorial (crítica, tanto quanto a consciência do ethos burguês se foi desvelando), a minha descoberta da retórica dá-se, depois de um primeiro contacto efervescente com a Poética, talvez porque, como descreve Gross, rhetoric will then be the leading art, as opposed to the more abstract art of logic and mathematics or the material practices of hard science. ${ }^{306}$ A figura do curador, como a do programador ou do artista crítico - nomeadamente da/na forma urbana - são indissociáveis do modelo retórico e é isso que nos permite a todos - potencial e/ou realmente - ir formulando uma opinião sempre actual acerca do equilíbrio, nos seus trajectos, entre as incontornáveis esferas do ethos, do pathos e do logos - é essa a mensagem de Harald Szeemann, Ernesto de Sousa, mas também Jan Hoet ou Nelson Brissac, face ao (no seio do) sistema da arte contemporânea.

Nestes termos, a conação plástica da retórica com a filosofia estética de Setecentos e Oitocentos é um exercício que arrisca um outro social que possa brotar destas aproximações. Não fazendo nada mais que procurar compreender aquilo que muitas obras de arte - de Chafes (ethos, objecto) a Fragateiro (pathos, experiência) ou Gabriela Vaz Pinheiro (logos, informação) - consumam enquanto possíveis materializados/desmaterializados retoricamente nas formas da cidade, nunca abdicando de, criticamente, representar, comentar ou transformar o contingente material-temporal para lhe subverter a inumanidade. $\mathrm{O}$ seus encontros são encontros com o socius como dispositivo. A retórica da arte crítica é assim uma poderosa ferramenta de crítica do poder, mas de alguma maneira também a pré-condição para essa crítica acontecer. Só assim essa crítica pode redundar em materializações, de um desejo profundo de rever a economia da escassez emocional em que o mundo contemporâneo se especializou. Então is there not a domain of freedom inserted in the causal chains of human activity? E havendo, que lugar posso atribuir à arte como consciência crítica? Que capacidade cognitiva e propriamente discursiva posso outorgar-lhe, numa vida que [...] it is precisely the variable nature of judging that makes [...] social phenomena in the first place, as opposed to, say, phenomena that are more immediately physiological, such as thirst and hunger..$^{307}$

\footnotetext{
306 Gross, p. 10.
}

307 Gross, p. 24. Não resisto aqui a politicizar o debate acerca do contributo de Damásio para as ciências do cérebro, a propósito da 'expulsão', por parte de Descartes, da alma para a esfera do religioso, subtraindo-a à esfera do sócio-político e assim fetichizando as emoções, um factor crucial da experiência humana, precisamente por irreditivelmente social. Cito Gross: The story of amygdala-damaged "S," as told by António Damásio in the feelingof What Happens: Body and Emotion in the Making of Consciousness, deserves scrutiny at this point because it illustrates perfectly how brain science of emotion goes awry when it blunders intosocial fact (P. 29). Não me alongaria neste assunto se não revelasse, simultaneamente, como a tecnociência obscurece, pela sua realidade empobrecida, o papel da arte na sociedade, a maior parte das vezes porque em total inconsciência - que ironia - da sua constituição (como facto) psicosocial. 
Kafka aborda esta questão fundamental, que nunca deixou de estar em cima da mesa do conhecimento; em As Investigações de um Cão le o que é apenas trivialmente verdadeiro, ou seja, o objecto das ciências ditas 'exactas').

\section{Retórica e política, paixões}

Politics is about moving people. [...]

The politician, in other words, is specially skilled in the rhetorical art of seeing how vivid possibilities might be painted in the imagination. [...] Rhetoric is a sort of theoretical art that contrives human affairs, or once again in Aristotle's famous formulation, it is the "ability in each case to see the available means of persuasion?"

And since the proper domain of politics is the contingent - its substance the weakness of people, their passions, procivities, and dreams - it should be no surprise that rhetoric serves as politics first auxiliary art. ${ }^{308}$

É certo, o temor de uma estetização comunicacional da política (Benjamin) é um receio da retórica; como em Habermas uma retórica idealizada - idealização discursiva da esfera pública - é uma negação do caos dialógico. Mas é indubitável que a política como 'arte das ideias', independentemente de como é materializada na experiência da racionalização - os nichos intersticial e heterotópico são dois modelos actuais -, é o território da comunicação e da partilha produtiva de paixões exemplares, e ao mesmo tempo o espaço da instituição dessas paixões em novas economias simbólicas (Bataille) e até industriais (Stiegler). Nessas economias, uma inovação aristotélica é a consciência filosófica de um valor potencial quer da acção, quer da passividade.

The point relevant to my discussion is that for Aristotle, activity remains sheer potential if it lacks a subject. There can be no building without a buildable, no healing without a healable, no teaching without the teachable, no agency without "patience,", no action without "passion". [...] Passions, patience, and suffering are for Aristotle much more than nominal qualities of a blank state. They always express a kind of potential ${ }^{309}$.

Em suma, The passive soul is thus precondition to all sorts of change, whether religious or secular. Mas é bom de ver, a arte crítica desde os anos 60 e o seu transmutar e pós-modernidade exigem bem mais do que boas intenções morais para se tornar, ainda hoje, metaforicamente operativa:

We face on one hand the legacy of a post-1960s activism unable to articulate at what great expense political subjects are produced, on the other a postmodernism so sensitive to this expense that a new incapacity develops: postmodern sensibilities make it difficult to reconcile decentered subjectivity with political agency, passivism with activism ${ }^{310}$.

É por aqui que posso agora estabelecer a ligação entre uma arte que se torna conscientemente crítica (reactiva) durante os anos 60 e anos 80 e 90 adentro. Na reflexão sobre o pós-modernismo capaz de pensar a sombra da arte e com base no projecto de cidade que para o bem e para o mal estamos condenados a pensar e realizar (Miles), traço a retórica - especialmente a retórica no coração de qualquer praxis emancipatória e nesses termos sempre e renovadamente transmoderna. (Vattimo) - , no fundo, uma ténue a linha de divisão 
entre uma arte extramuros que por via da sua marginalidade - a energia excêntrica dos seus artefactos - cria cidade, e aquela arte que, do centro da sua própria instituição, emite um discurso a que sobra em relevância (Agamben) o que the falta em sentido (Capra). Ora a retórica histórica de Gross mostra como uma leitura atenta das posições de Adam Smith, que geralmente é considerado o teórico do mercado e portanto um ícone do liberalismo económico contemporâneo, pode ser reavaliado (por Noam Chomsky, por exemplo) como pensador revolucionário, um crítico radical do establishment do seu tempo, que se pode integrar numa genealogia que integraria Rousseau e Marx. Fico-me por uma nota de Gross sobre o man of middling rank em Smith, talvez ainda hoje um comentário que transformaria qualitativamente a emoção de ser pequeno-burguês na minha actualidade;

Whereas the man of high rank tends to provoke admiration disproportionately and the man of low rank pity, or ridicule, or nothing at all, the private man of middlink rank cultuvates those mediocre emotions such as romantic love, magnanimity, and a decidedly masculine form of compassion called "generosity" that requires not just exquisite fellow-feeling, but self-sacrifice: all of which as emotions that strenghten the social bond and ultimately make social investments more secure. ${ }^{311}$

Afinal, character must be more than the competent performance of the passions proper to our station, a performance that overlays ostensibly deeper passions more appropriate to our natu$r e^{312}$, uma natureza que não é um qualquer estado de pureza original, mas tão-somente uma negociação das posições sociais que é suposto nós representarmos (perform). Emocionarmo-nos com a arte ou partilharmos a emoção estética, ainda que num frisson pequeno-burguês, pode então ser objecto de uma reflexão política que confere a essa naturalizada cultura uma determinada energia que pode ser questionada por uma ansiedade (pelo colectivo). Nalguns momentos da nossa vida, esse programa de dinamização da economia das emoções acontece na cidade, e alguns artistas transformaram-no na sua voz retórica.

Miles recorda que há uma importante relação entre esta distribuição desigual do sensível, a economia de escarcidade e o conceito de esfera pública: Jacques Rancière describes the void [o de a política convencional face a reais possibilidades de mudança] as a denial of the right to expression of grievance in equality and openness, replaced today by the techniques of presentation, data, and the 'consensus' of the centre-right ${ }^{313}$. Isto num quadro que Miles rotula de de guerra permanente (segundo Kate Soper ${ }^{314}$ ), apenas 'disfarçada' pelo consumismo e suas ilusões de autonomia a liberdade. Pergunto-me se faz sentido falar de retórica - uma técnica da paz - nestas condições violentamente adversas; mas digo para mim mesmo que não há alternativa para quem ainda deposita na comunicação o carácter do encontro das inteligências e das sensibilidades em aberto, nesses espaços discursivo-performativos que se podem 'descobrir' entre a arte e processos de determinação social (Miles). Ou seja, independentemente das modalidades prevalecentes no seu dispositivo, há formas de arte na cidade que fazem depender o seu valor cognitivo de uma equidade das vozes em jogo (Bakhtin, Kester), o que implica, como veremos, uma interpretação do facto-arte que pode passar por o artista suspender a sua tradicional posição hierarquicamente distinta, para

311 Idem, p. 15. For rhetoricians, emotion makes language and identity matter. [...] Emotions are the contours of a dynamic social field manifest in what's imagined and forgotten, what's praised and blamed, what's sanctioned and silenced.

312 Idem.

313 Miles, Malcolm; «Aesthetics in a Time of Energency», in Third Text, July, Vol. 23, pp. 421-434.

314 Cf. Soper, Kate; «The awfuleness of the actual: Countre-consumerism in a new age of war», Radical Philosophy, 135, p. 7 Jan/Feb. 2006 
que a orquestração do trabalho seja radicalmente partilhada, participada. O que é evidente é que hors des classifications administratives [há que] introduire una brèche dans la cohérence des signes hérités. ${ }^{315} \mathrm{O}$ filósofo e dramaturgo, a propósito do trabalho pioneiro dos llotopie já nos anos 80 , sublinha que no trabalho daquele colectivo, que chega, por exemplo a ocupar uma paragem de autocarro para habitação efémera (Tashkent, 1992), há uma espécie de arte de viver em conjunto: autre monde apparaît, non seulement possible, mais concrètement vécu. ${ }^{316}$

Em suma, o projecto como dispositivo de distribuição passional é uma economia de decisões que atestam da atenção (a certos aspectos do real social), da abertura processual do dispositivo artístico (face à sua autonomia face ao quotidiano, decorrente de decisões projectuais específicas) e finalmente do tipo de emoções que gera (que defendo terem de ser transpessoais ou colectivas para que possamos entendê-las como genuinamente críticas). Existindo várias modalidades de arte crítica, aquela que está implícita na forma como desenhei a minha argumentação nesta investigação é que confere com uma retórica específica - um ethos da atenção, um logos do dispositivo e um pathos da graça. Para que essa retórica se revele, podemos agora revisitar criadores cujo trabalho epitomiza a forma como os quatro vectores da axiomática podem ser tornados operativos, ao nível de um senso curatorial. Em todos eles, gostaria de relevar as formas como o envolvimento (ethos) não se sobrepõe a uma profunda consciência crítica do logos da arte pública na invenção quotidiana. Se The clarification of vision is a first step towards reasonably and humanely changing the world (Martha Rosler ${ }^{317}$ ), é preciso manter o dispositivo arte permanentemente sob escrutínio crítico, se quisermos que a pulsão pelo quotidiano colectivo - a 'origem' da arte pública, não seja reificado.

For some as Papastergiadis, the particularity of the engagement that art may have with the everyday must be grounded in an awareness of the materiality of art and the part of the counter-intuitive knowledge that art might produce. For others, such as Ben Highmore, the relationship of art to the everyday is entirely problematic: while he may develop an argument to support the claim that art, particularly the early twentieth-century avant-garde, has played a fundamental role in identifying the everyday, he also asserts that 'high culture's propensity towards subjective expressionism relation to the everyday' must be dislodged if the aesthetic is to become an appropriate tool for registering everyday life's contradictions and inexhaustible ambiguity. 318

\section{Da paixão como terapia da democracia}

O conceito de paixão quase desapareceu do horizonte filosófico contemporâneo, podendo dizer-se que está fora de moda. ${ }^{319}$ Oriundos da psicologia e da psicanálise, os cientistas e tecnocráticos vocábulos pulsão, afecto ou tendência não têm a riqueza discursiva que me interessa destacar numa arte extramuros. É portanto adequado recolocar a questão das paixões na modernidade crítica (Gross, Turk), e mais uma vez recuar a Aristóteles, primeiro grande teorizador das paixões, para sublinhar o sentido de padecer, de sofrer, que o termo transpor-

315 Jean-Louis Sagot-Duvaroux, in «Art International de Proximité», 2008, p. 33.

316 Idem.

317 Rosler, Martha; «to argue for a vídeo of representation. To argue for a vídeo against the mythology of everyday life», in Johsntone, p. 54.

318 Johnstone, p. 17.

319 Ferreira, Maria Luísa Ribeiro; «Espinosa e a terapia das paixões», in Costa, Fernanda Gil; Furão, Igor (orgs.), Estética das Emoções, Húmus, Lisboa, 2011, p. 33. 
ta. Mas a palavra transporta igualmente algo de mais logo-lógico: num sentido restrito ela la paixão] é também a marca das coisas que suportamos. ${ }^{320}$ Nestes termos, Aristóteles antecipa o conatus em Spinosa (em Hobbes e Leibniz), ou a própria meta-filosofia de Lefèbvre na ideia de uma realidade simultaneamente sensível e racional. 0 poiein da acção, tal como o paskein da paixão não podem ser separados um do a outro a não ser numa perspectiva analítica (parcelar em relação à que aqui advogo, eminentemente ética, sistémica e pragmática).

Ora a paixão pressupõe certa passividade - sensibilidade contingente; e certa individualidade. A razão aproxima-nos uns dos outros enquanto a paixão marca as nossas idiossincrasias. ${ }^{321}$ Mas esta evidência está invertida numa sociedade abstracta e alienada, sendo certo que é o colectivizar da paixão, como a individualização da lógica, que gerem em grande medida o apparatus do socius capitalista. Por outro lado, É a paixão que permite à razão afirmar-se pois esta exerce-se sobre o passado. ${ }^{322} \mathrm{~A}$ paixão tem uma dimensão cognitiva - está no âmago da produção contemporânea dos sensíveis do consumo, do marketing e da experiência. No nosso tempo sem memória (Eduardo Lourenço, Gill), as paixões à solta têm dificuldade em integrar narrativas que as redimam como entendimento, que lhes dêem um sentido. Ora isso corresponde a uma perda fundamental que a modernidade trouxe, ao lapesar de entender a paixão como adjuvante da razão) encará-la como uma ruptura de equilíbrio e como tal censurada enquanto sinal de dependência, como exaltada enquanto motor da nossa criatividade ${ }^{323}$. Na modernidade e na contemporaneidade 'modernista', a paixão está mal arrumada - de resto como a imaginação, 'louca da casa', tolerada mas não integrada na família do socius. Já o vimos, a paixão, de Novalis a Schiller, de Nietzsche a Gadamer - veio sempre de novo bater à porta das 'boas maneiras', e de muitas formas, é essa a fundamental contribuição de uma pós-modernidade finalmente em luta com os constrangimentos modernos. Se nuns casos esse regresso da paixão é solipsista, noutros há uma paixão equilibradamente distribuída pelo dispositivo comunicacional (Luhmann) e esse paradoxo total que é a arte traduzir em decisões de projecto a dupla injunção do logos e do pathos, numa postura ética. ${ }^{324}$ Numa época resiliente a heroísmos, talvez se trate de actualizar a nota de Hegel de que nada de grande se realizou no mundo sem paixão. Ora é Espinosa que, no conceito conatus, desvela a importância da paixão como factor transitivo, implicitamente imbrincado na ideia de mudança. Na sua Ética, está a ideia do Homem como editor das suas paixões, naturalmente terapeuta (Ferreira) das mesmas numa gestão quotidiana da sua vida:

Somos responsáveis pela gestão das nossas paixões, que podemos transformar, se não totalmente, passando-as a acções, pelo menos parcialmente, diminuindo nelas o factor tristeza. De facto, o aumento de ser, que corresponde à passagem a uma maior perfeição, implica sempre alegria. ${ }^{325}$

Aparte o espírito 'obreiro' da citação, senão a nota jungiana (de que há uma melhor 'Eu'

\section{Idem.}

321 Idem, p. 34.

322 Idem.

323 Idem.

324 Creio que é a isto que os autores de Um livro para bailarinas, equilibristas, trapezistas e todas as crianças (Sílvia Barradas, Vanessa Santos ; il. Luana Geiger ; des. gráfico Daniela Brasil, Flávio Coddou ; fot. João Rocha e Castro; Centro Português de Design, Lisboa, 2004), certamente inconsciente destas ressonâncias, se referem, quando dão este título espirituoso a uma pequena brochura sobre design urbano crítico.

325 Ferreira, p. 36. A diminuição de ser, que leva a uma menor perfeição, provoca tristeza. 
em cada um, basta produzi-lo $\left.{ }^{326}\right)$, trata-se de gerir autonomia e dependência, num regime alegre. Não sendo oportuno definir esta alegria - ou a sua crítica estóica - esta deontologia potencial de qualquer projecto transporta-nos para o schilleriano plano da liberdade da necessidade, agora em pleno domínio de ume 'desapaixonada' 'retórica das paixões'. A atenção ao outro e à sua situação, nestes termos, é inevitável; o outro só é outro se soubermos compreender a sua situação e nela nos envolvermos. O grau de envolvimento vai definir muitos registos passionais, sendo que a paixão pela paixão (pela paixão) não pode ser descartada como fantasia, mas como genuíno esforço metaoperativo de cerzir a lógica projectual da arte pública crítica - a tal arte que é o que é ao mesmo tempo que mostra como funciona e cria esse público específico - aquele que quer saber como funciona e depois se apaixona pela comunicação desse encontro.

Em causa está a velha questão gnoseológica - em que a paixão se pode identificar com o conhecimento parcelar e confuso e a acção com o conhecimento verdadeiro, caro e distinto (Ferreira), mas agora num tempo complexo e urbano, em torno da grande questão que é a cidade (já nem sequer a da polis). Neste quadro, a resiliente acção do activismo focada em aspectos concretos, imediatos e por vezes urgentes da vida social - é tanto mais luminosa quanto evocar - ou levar os participantes a experimentar - a graça do conhecimento colectivo, - de certa forma, como conhecemos empiricamente na ideia de verdade. Independentemente das mais distintas variações nas artes participativas ${ }^{327}$, o que nelas é cognitivo, na minha economia de valores tendendo para um periclitante equilíbrio dinâmico, é esse conatus específico de uma publicidade da arte (Grout), uma verdade pública portanto, que por mais frágil que seja, é profundamente política.

Creio que muitas derivas ambientais activistas (Land Art) foram tentativas para concretizar em actos a suma paixão (Espinosa) pela Natureza; e de certa forma que a deriva conceptual, com Duchamp, é a prévia constituição dessa possibilidade, ao revelar-se como paixão pelo dispositivo. Ora, quer face à natureza - quer, para os mais intelectuais, face ao conhecimento (que é parte da natureza, como sabemos à medida que o pensamento sistémico, caso da Ecologia Profunda, se vai afirmando), Nem todos têm possibilidade de compreender totalmente essa relação mas todos podem gozar de uma sintonia coma natureza. ${ }^{328} \mathrm{~A}$ arte pública crítica seria então, nalguns casos, uma língua generosa e ao mesmo tempo secreta da arte pública, e da arte e geral, que porém, qual inclinação ética difusa na cidade contemporânea, só pode funcional se desligada da sua reificação ou institucionalização (seja como 'arte', como 'comunicação', seja como for).

Weil é aqui apenas um modelo de percepção da graça - como Nietzsche do pensamento crítico; as sua retóricas têm de uma intensidade e desequilíbrio estrutural porventura insuportável; e Na verdade, bem e mal não têm realidade ontológica, resultando da comparação das coisas umas com as outras. O que não quer dizer que abandonemos tais noções, úteis no

326 Espinosa defende que Tudo o que contribui para nossa realização é bom; tudo o que a impede ou dificulta é mau. Ferreira, p. 40.

327 Contextuais, comunitárias, políticas, activistas, etc.; os termos, espero tê-lo deixado claro na Parte II, valem o que valem e valem 'pouco', pois funcionam sobretudo circunstancialmente.

328 Ferreira, p. 38. 
que respeita a um modo de viver. 329 Lá está, na terapêutica contextual, situada da arte na cidade, a retórica da arte pública crítica é a técnica comunicacional por excelência, uma racionalidade complexa e afectada, simultaneamente sistémica e pragmática, que permite ler - e produzir, ou co-produzir - as obras e os acontecimentos naquilo que são realmente determinantes para o nosso modo de viver, efémera e circunstancialmente como tudo e sempre. ${ }^{330}$

\section{A dialéctica paixão/razão na sua vertente política}

Razão e cidade estão imbrincadas numa tradição crítica, a da via perardua (Espinosa) que, por um lado, nos remete para o imperativo (romântico) da união com o cosmos, por outro implica a questão da multitude, retomada hoje por Negri. ${ }^{331}$ Estudioso das paixões humanas e sobretudo consciente do seu peso na dinâmica política, Espinosa, num registo já 'iluminista', acredita possível algum equilíbrio entre o poder soberando na razão e as razões da multitude, isto é, tem uma ideia politicamente operativa de povo (Wagner). De alguma maneira, Espinosa ajuda-nos a comprender que a política 'não chega' - mesmo se Negri advoga, aliás como Hobbes, que o cerne da política espinosiana reside na sua metafísica (Ferreira). Mas a politica é, sim, mediação por excelência - o logos do social, como se torna evidente quando [O] homem dirigido pela razão é mais livre na cidade onde vive segundo o decreto comum, do que na solidão onde só a si próprio obedece ${ }^{332}$. Esta é no fundo uma noção cultural (Eagleton) da democracia e do povo, e tanto mais fundamental quanto se baseia numa gestão retórica das paixões. Numa expressão que antecipa Schiller, a sociedade é extremamente útil e também absolutamente necessária. ${ }^{333}$ Regressando a Aristóteles, a vida boa é necessariamente colectiva, noção que é a base de um realismo (Ferreira) da política espinosiana, um realismo da totalidade cultural - afinal, e isto muito antes de Arendt, os homens não nascem livres. ${ }^{334}$ Assim como há uma aprendizagem - uma cognição - especificamente urbana, do próprio Estado democrático, de que urge continuamente reformular as leis. De

\section{Idem, p. 39.}

330 Para Espinosa (no Tratado Breve) há uma gradação entre opinião, crença e saber. Neste último género de conhecimento, há uma dimensão participativa, quase mística (Ferreira, p. 41). Ora Pelo conhecimento das noções comuns fazemos ciência e vemos o real de um determinado ponto de vista, que nos dá acesso a um mundo organizado onde a causalidade domina. Só o conhecimento do terceiro género nos dá a dimensão fruitiva e amorosa que nos coloca no registo da eternidade (sub specie aeternitatis). Para a alcançar, perspectivamos o conhecimento das coisas singulares em deus, há que proceder a uma exegese simultaneamente ética e gnosiológica. Idem, p. 42.

331 O termo havia sido empregue por Maquiavel (Discorsi) e recuperado por Spinosa em vários momentos (Tractatus Theologico-Politicus), que coloca o medo do poder da multitude (as massas) na origem do poder soberano (potestas). Em Empire (2000), Negri (com Michel Hardt) coloca a questão do ponto de vista de uma metafísica revolucionária. Em The Savage Anomaly (1999). Negri apresenta mesmo uma ideia revolucionária da multitude como sujeito colectivo não mediado, revolucionário, imanente e positivo, capaz de fundar uma nova forma - não mistificada - de democracia. Dando continuidade à produção de subjectividade lefêbvreana, poder-se-á argumentar em que medida é ao mesmo tempo antagonista (face ao sistema politico hegemónico) e/ou criativa. E poderá aspirar-se com mais ou menos fervor pel'o acontecimento (e em certa medida a utopia adiada) da modernidade: o momento em que a cooperativa cooperação entre sujeitos e a gestão proletária da produção convergissem.

332 Et. IV, LXXIII, in Ferreira, p. 43.

333 T.T.P., cap V), in idem.

334 Ferreira, p. 44. 
Kafka - que coloca a questão da ética individual na parábola Diante da Lei à arte pública crítica que inventa (a) cidade através dos seus dispositivo meta-urbanos - trata-se sempre de ter a sensibilidade específica para articular a potência individual (consciência individual) com a hipótese - e para os que sabem, a constatação - de uma consciência transpessoal, a energia da graça. Ora no regresso, ao necessário realismo quotidiano, Espinosa ajuda-nos a compreender como uma noção renovada de Espaço Público é o coração palpitante da estética social como mediação do sensível em todas as dimensões: Há que gerir a dimensão passional de modo a construir um Estado em que as diferentes paixões consigam habitar ${ }^{335}$. Nesta frase estão vários conceitos-chave (Estado, paixões, construir, habitar) de um campo semântico e de tropos potenciais que a arte pública crítica, paulatinamente, edita e re-edita, num jogo de 'vazios' (ideias, conceitos) e de 'cheios' (experiências, verdades) que redimem - pelo menos provisoriamente - a vida urbana na sua totalidade. A retórica é, quanto a mim, a sua 'língua franca' - no duplo sentido do termo. Ela torna todo o trabalho contínuo sobre os mecanismos desiderativos, essa terapia das paixões (Ferreira), objecto de uma estimulante estimulação dos nossos sentidos obscurecidos pela vida moderna.

335 Idem, p. 46. 



\section{QUATRO POSIÇÕES ARTÍSTICAS}

Argument shapes - and, eventually, is - a self, and is the self's way offulfilling its role as citizen of the universe.

Martha Nussbaum

Para que muitas das problemáticas desta investigação sejam revistas à luz de casos concretos, proponho a reflexão sobre o trabalho de quatro criadores cuja abordagem do fenómeno artístico concorre para uma leitura sistemática da deriva extramuros em alguma arte contemporânea. Estes quatro autores, apontando aos quatro vectores do meu esquema axiomático, atraem clusters de questões essenciais na curadoria da arte crítica na forma urbana'. Um aspecto que os liga é a economia de meios e processos, na sua relação intrínseca com a cidade, o que torna as suas 'origens' e 'atitudes' retoricamente eficazes.

\subsection{Miguel Chevalier - a beleza efémera no fluxo da imagem urbana}

A creator is not in advance of his generation but he is the first of his contemporaries to be conscious of what is happening to his generation.

Gertrude Stein

\section{Inovações da 'arte da luz' - naturezas digitais interactivas}

Chevalier culmina toda uma cultura do dinamismo, do cinetismo, do fluxo e da imponderabilidade. Seus primeiros arautos foram Tatlin (na modalidade do monumento político, 1919), Naum Gabo ou Lászlo Moholy-Nagy (modulador espaço-luz em 1931). É uma cultura retomada por Lucio Fontana (Spatial Light para a 9th Milan Triennial at the Palazzo dell'Arte, 1951), que o artista italiano identifica como conceptualismo espacial, um espacialismo em que o objecto de arte vai ao encontro ao homem da rua e sua cultura vernacular ${ }^{2}$ iminentemente decorativa. Esta nova cultura de luz será desenvolvida por Nicolas Schöffer e Júlio le Parc que inventam a 'arte lumino-cinética', ao mesmo tempo que Gyula Kosice, na América Latina, se entrega ao neon. É porém com Dan Flavin ${ }^{3}$ e James Turrell ${ }^{4}$ que a Luz se torna percurso artístico (Pottier).

1 Convoco pontualmente outros artistas (Santiago Reyes na órbita de Gasco, Pedro Penilo na de Freee, Simeon Nelson e Dominik Lejman na de Chevalier), por terem entretanto adquridido o seu espaço exemplar na minha visão.

2 [...] what he saw as overcoming the divisions in architecture, painting and sculpture to reach a synthesis in which colour movement and space converged. Critics at the time described it variously as a lasso, an arabesque and a piece of spaghetti, but Fontana disliked this simplistic interpretation: "[It] is not a lasso, an arabesque, nor a piece of spaghetti... it is the beginning of a new expression; in collaboration with the architects Baldessari and Grisotti we have substituted for the decorated ceiling a new element which has entered into the aesthetic of the man on the street, neon, with this means we have created a fantastical new decoration". In Pasini, Francesca; trad. Shaun Whiteside. http://www.tate.org.uk/tateetc/issue14/lasso.htm.

3 Personalité essentielle du minimalisme, Flavin propose ainsi aux spectateurs une expérience existentielle concrète - relativement a une éxperience purement visuelle - qui sort l'ouvre finale de son socle ou de son cadre traditionnels. In Kvaran, B. Gunnar; «Nature\&Artifice», in Miguel Chevalier, Monografik Éditions, Paris, 2008, p. 29.

4 Turrell va plus loin encore, en construisant d'étonnants univers qui plongent le spectateur dans la lumière à la manière d'un corps tangible et volatile. Se déplacer au travers des espaces lumineux de Turrell constitue donc une expérience essentiellement 
Em Ésthétique de l'Éphémère, Christine Buci-Glucksmann empreende uma genealogia crítica implícita nesse percurso; a sua ideia é a de que estamos a sair de um 'Tempo do Cristal' - do Modernismo -, para entramos num 'tempo do fluxo', equivalente de uma contemporaneidade em rede, de acontecimentos assumidamente, dinâmicos e imprevisíveis. Esta perspectiva confirma a metáfora da Luz como apropriada para resolver alguns impasses históricos na construção do Espaço Público; significativamente, Glucksmann menciona a série de peças-instalações Sur-Nature, de Miguel Chevalier, como exemplo-chave desta arte-do-fluxo, que de Martin Creed (The Lights Going On and Off, 2001 - Prémio Turner ${ }^{5}$ ), a He-He (Pollstream Nuage Vert, 20086) tem multiplicado a sua eloquência.

Sur-Natures consiste numa obra interactiva montada em sucessivos e diversos contextos urbanos; dispositivo de geração automática de imagens de síntese digitais, reagindo em tempo real aos fluxos urbanos na rua, atingindo um ponto alto quando projectores de grande potência varrem as fachada dos edifícios, com as suas gigantes flores inclinando-se à passagem dos transeuntes. ${ }^{7}$ No interface desta obra, uma câmara colocada junto à lente do projector, munida com sensores de movimento, é sensível ao movimento das pessoas em tempo real. No campo da publicidade (Japão), existem já publicidades interactivas que reagem à passagem do público, mas Chevalier foge à lógica da comunicação funcional, sendo notória a satisfação de quem se apercebe de como o seu movimento, necessariamente ali, tem implicações na imagem. Esta imersão do espectador na totalidade do meio urbano, espécie de tradução das premissas de Turrell no território prosaico da cidade da comunicação (e já não o espaço idealizado do deserto), depende de uma dimensão de camuflagem: Vues du trottoir opposé et la nuit. Cês fleurs virtuelles se mêlaient harmonieusement à la silhouette des arbres qui bordaient les Champs-Élysées. ${ }^{8}$ Apesar do investimento nas imagens 'universais' das flores implicar uma certa mobilidade da arte (nomadismo de uma tradição pictórica), o espírito in situ está presente no cuidado como que cada nova projecção se integra no contexto, perfeitamente consciente do facto de que é apenas mais uma camada, num tecido urbano colectivo (nisto sendo perfeitamente semelhante ao entendimento da projecção em Krysztof Wodiszcko, Nuno Maya, Skyway, ou Teresa Mar, Lumina).

Chevalier é um pioneiro da arte digital'. Demorou a ver o seu trabalho reconhecido num meio hostil à inovação tecnológica. Já nos anos 80 , é dos primeiros a nível mundial a conseguir efectuar uma ponte entre as 'novas tecnologias' e uma cultura visual artística rica e profunda. Desenvolverá entretanto uma linguagem, comprovada na organicidade da evolução do seu trabalho, ${ }^{10}$ que soube integrar as principais lições do minimalismo e depois uma qualidade

physique et mentale qui fait partie integrante de l'ouvre elle-même.In idem.

5 Na cerimónia, Turner agradeceu, 'minimalisticamente', a "lot of people-nearly everyone".

6 A peça - a city-scale light installation - foi vencedora da Ars Electronica, Golden Nica (Hybrid Art Category) e 01SJ Green Prix for Environmental Art.

7 A peça integrou a programação da Luzboa 2006, projectada na fachada dos Armazéns do Chiado. Cf. http://www.luzboa.com/2006/2006.html

8 Couchot, p. 20.

9 Couchot, Edmond; «Une fête des yeux à la croisèe des arts, des sciences et des techniques», in Miguel Chevalier, Monografik Éditions, Paris, 2008, p. 17.

10 Idem, p. 18. Em mais de vinte anos de consecutiva produção artística, Les ouvres se sont enchainées les unes aux autres à la manière d'une arbre qui croît. 
empresarial que ecoa a lógica dos grandes estúdios de artistas (de Giotto a Courbet e a Warhol). Chevalier honra o seu compromisso decorativo com a cidade contemporânea através de uma lógica industrial (empresarial e tecnológica) que o torna não apenas artista mas, um mediador entre os planos quotidiano e estético da imagem urbana. Apelando ao pathos do embelezamento ornamental, quando vemos as suas peças mais emblemáticas decorarem com flores os edifícios da cidade - longe de veicular quaisquer mensagens políticas (palavras de ordem, imagens-choque, por exemplo), irrompe a produção de um belo que tem a natureza no seu horizonte mas não apela à sua reificação mitómana.

\subsubsection{Percurso naturalmente digital}

Miguel Chevalier nasce no México e assume cedo a influência da cultura visual e intelectual latino-americana la pintura, de Siqueiros a Rivera; a cultura popular das coloridas festas do Dia dos Mortos). Dessa matriz retirará um desejo de integrar os espectadores em celebrações em que qualquer um pode participar livremente, indo ao mesmo tempo ao encontro das suas origens. ${ }^{11}$ Mais tarde, Chevalier será marcado por uma visita à Casa Velázquez, onde descobre Goya e, sobretudo, um artista contemporâneo, Cruz-Diez ${ }^{12}$, que trata a luz enquanto acontecimento cromático-experiencial, na senda de Turrell e da Escola de Los Angeles. Já em França, outros artistas pertencentes ao mesmo movimento de Cruz-Diez se tornam notória influência: Agam, Vasarely, Nicolas Schöffer, Jesus Rafael Soto. Deste último, Chevalier é directamente impressionado por Pénétrable, um amplo espaço escultórico no interior do qual o espectador tem a possibilidade de se movimentar e, através do seu próprio movimento, ir alterando os dados da percepção visual e táctil. Chevalier reconhece os seus entre estes artistas que cherchaient à provoquer des sensations optiques ou kinesthésiques déstabilisantes en mettant le spectateur en obligation de déplacer son regard ou de se mouvoir devant, autour ou à l'intérieur des dispositifs artistiques. ${ }^{13} \mathrm{E}$ assim, é determinante na arte-em-fluxo de Chevalier [...] ce type d'identité changeante, cette capacite des ouvres à s'actualiser sous des aspects différents, ao cours de leur relation visuelle et corporelle, physique plus que conceptuelle, avec le regardeur. ${ }^{14}$ Trata-se da actualização, com meios computacionais desenvolvidos, das primeiras experiências do cinetismo; ao mesmo tempo, de dar corpo a uma irresistível convergência histórica da arte com outras áreas da actividade. Chevalier surge como um artista que partilha com os planos industrial, económico ou comunicacional o destino tecnológico; mas não necessariamente uma fé nas possibilidades da criatividade digital. É nesta nova realidade crítica do mundo pixelizado - da linha ao pixe ${ }^{15}$ - que Chevalier vai ser dos artistas mais precisos na transição de uma tradição ornamental-objectual da arte para uma arte relacional baseada na deriva tecnológico-participativa iniciada nos anos 60 (Myron Krueger).

\footnotetext{
11 Idem.

12 Les élements chromatiques qui entraient dans la composition de ses Psysiochromies (de fines lamelles colorées disposées parallèlement) étaient en outre préparés mécaniquement à l'avance et répertoriés avec précision: une première approche de la décomposition-recomposition de la couleur à partir d'éléments «discrets» qui seront numererisés plus tard par traitement informatique. Couchot, Edmond; «Une fête des yeux à la croisèe des arts, des sciences et des techniques», in Idem, p. 18.

13 Idem.

14 Couchot, p. 18

15 Idem, p. 19.
} 
Consciente do papel que pode desempenhar na paisagem urbana, Chevalier vai dando aos seus espectadores interfaces novos ${ }^{16}$; quando começa a explorar definitivamente a questão da locação das suas imagens em fluxo, o interesse do seu trabalho para um entendimento da retórica da arte na forma urbanas torna-se determinante. Não é dispiciendo o facto de que quase sempre essa deriva foi passando por uma assumpção de uma monumentalidade que torna cada nova obra - de certa forma como em Christo e Jean-Claude - um acontecimento inevitável da cidade, enquanto tal apropriado pela vox populi. Obra particularmente espectacular neste âmbito é La Croisée des réseaux (2003), realizada para a Nuit Blanche em Paris, no antigo edifício da Bolsa do Comércio. Os espectadores eram mergulhados num universo virtual dinâmico circular com cerca de $40 \mathrm{~m}$ de diâmetro em que se encontravam projectados, no solo, imagens simbolizando as trocas de informações entre as grandes bolsas do planeta. Actualização dos 'panoramas' novecentistas, a obra, não sendo directamente interactiva (face aos visitantes), fornece uma informação crucial sobre o modelo de sociedade que o Homem construiu, de forma palpável - paradoxo resolvido pela dinâmica lumínica e gráfica que emula a imaterialidade das sensações invisíveis. Apesar de realizada no espaço indoor, está aqui o espírito da arte pública crítica já não apenas como interface mas propriamente dispositivo de enunciação da potencialidade da arte como comunicação, sendo que essa experiência se realiza em grupo (e não ao nível solitário da televisão ou do computador pessoal). Por outro lado, Ce rapport intuitif ne signifie pas non plus que l'interacteur n'ait pas un efort à fournir pur comprendre son geste, ne tente pas des expériences limites, ne fasse pas preuve d'intelligence, de sensibilité, bref d'une certain talent. ${ }^{17} \mathrm{O}$ dispositivo revela-se então um novo jogo, e de même que l'amateur de peinture apprend à mieux aimer la penture en depassant ses impressions premières, l'interacteur doit s'initier à cês pratiques nouvelles qui commencent à constituer une authentique culture..$^{18}$ No limite, estas obras são portanto uma pedagogia da imagem digital - aí na mesma direcção, ainda que com outras premissas estéticas, que Nold. Mais do que meras experiências festivas ou alienantes da tecnologia ao serviço do estupor (os jogos on-line), nelas o espectador partilha algo de essencial com o autor - marchera après Miguel sur les même stapis fleuris, il refera les mêmes gestes devant l'image, il revrivra les mêmes instants joyeux, interrogatifs, troublés, exaltants, il éprouvera des sensations identiques ou voisines. ${ }^{19}$ Dá-se por assim dizer uma transparência graciosa do ethos artístico enquanto fluxo criativo da experiência urbana. A graça decorre desta interactividade colectiva:

Chaque passant voyait éclore cês fleurs sous les pas, tandis que d'autres pasants, à côté ou plus loin, produisaient les mêmes effets. Tout se passait alors comme si une communication secrète, une tacite complicité, s'établissait entre les passants. Le tapis fleuri les emportait dans le même monde imaginaire et insolite en les arrachant un court instant aux banalités du quotidien. ${ }^{20}$

Nestes termos, torna-se extramuros a opção do artista por laborar no tema de um universo artificialmente natural inspirado na natureza e na botânica; qual alternativa digital à

16 Numa homenagem a Duchamp - Le Grand Verre/Nature liquide (1996) - o espectador-interactor agia sobre a imagem ocultando na mão uma célula fotoeléctrica e assim provocando a sua liquefação.

17 Couchot, p. 21. A obra de Nuno Maya e Carole Purnelle para diversos Festivais de Luz está neste mesmo campo de actividade.

18 Idem.

19 Couchot, p. 22. Derrière la machinerie puissante des technologies numeriques, au-delà des calculs automatiques, des interfaces et du temps réel, c'est la présence singuière de Miguel Chevalier qui se manifeste et s'impose.

20 Idem. A descrição refer-se a Ultra-Nature, versão de Sur-Nature projectada no solo. 
land art convencional, este digital fractal acaba por reflectir uma periclitante relação das cidades com o seu equlíbrio ecológico; donde que o tema do jardim nele se apresenta com ressonâncias utópicas evidentes, aumentadas pelas cores vivas que falam a língua do espectáculo capitalista, mas neste inscrevem a poesia. Se fosse preciso certificarmo-nos desta hipótese, basta ver como Chevalier mantém as suas imagens praticamente inalteradas ano após ano, como se o seu desejo fosse o de repetir este 'evangelho' tantas vezes quanto necessários, à até a cidade o ouvir, lhe ouvir o ritmo cósmico que os seus modelos autogenerativos implicitamente - explicitamente - acabam por servir. Outra coisa é certa: apesar de a tecnologia evoluir, as suas obras mantém, ano a pós ano, a frescura de um primeiro encontro, e deveria ser motivo de reflexão este que é, no fundo, um equilíbrio da intensidade retórica no momento urbano, que torna a obra - qualquer obra de Chevalier sempre um exemplo de humildade ética aplicada ao logos tecnológico. ${ }^{21}$

Quanto ao seu lugar num urbanismo experimental, a originalidade de Chevalier22 vai ser a integração da informática e do digital nesta cultura da luz específica, que integra o espectador, aportando noções contemporâneas de urbanismo-luz (Ariella Masboungi). Inscrevendo a tautologia da arte contemporânea no cerne da escala arquitectónico-urbanística dos edifícios, as projecções de Chevalier elucidam-nos quer da artificialidade do edificado, quer da sua contingente (e histórica) beleza; o seu tecno-naturalismo ${ }^{23}$, poesia digital (ainda Kvaran), não é, note-se, um eixo inequivocamente valorizado na arte contemporânena relacional24. Isso acontecerá precisamente por sublinhar ludicamente, no coração das indústrias culturais urbanas (cidade como objecto de marketing), a artificialidade do ambiente em que vivemos: Dans son ouvre, et particulèrement dans les installations, le spectateur est guidé vers des «réalités sociales» singulières à l'intérieur desquelles la pièce est actualisée, tandis que les spectateurs prenent conscience de leur existence dans un contexte spécifique. ${ }^{25}$ É algo que o próprio título Sur-Nature activa, quanto valoriza uma identidade da obra precisamente como elemento que permanentemente se recontextualiza a cada nova apresentação em lugares diferentes, ampliando como num harmónio quer a sua elástica identidade quer a identidade mutante desses lugares. De Chevalier se pode dizer, que actualiza o humanismo tecnológico ${ }^{26}$; em pleno fluxo estético neo-tecnológico ${ }^{27}$ :

Depuis trente ans, je persiste à affirmer le rapport entre l'espace-temps et les techniques que l'espèce humaine a petit a petit forgé, et le caractère technologique et néo-technologique de notre espace-temps: «Nous ne sommes pas dans le temps, le "temps pur", mais uniquement à l'intérieur du temps que la technique, chaque fois d'une manière discontinue, laisse émerger et transparâitre. ${ }^{28}$

21 Idem, p. 25. Quanto à tensão produtiva entre abstracção (conceptual) e figuração (decorativa) no fluxo da plasticidade cette démarche renouvelle celle de Paul Klee qui ne cherchait plus à répresenter la forme - la Gestalt -, mais la formation de la forme - la Gestaltung -, ajoutant ainsi du temps à l'espace, du devenir à l'immobilité.

22 Kvaran, B. Gunnar; «Nature\&Artifice», in Miguel Chevalier, Monografik Éditions, Paris, 2008, p. 30

23 Idem, p. 31.

24 Idem.

25 Idem, p. 31.

26 Idem.

27 Costa, Mario; «Flux esthétique néo-technologique», in Miguel Chevalier, Monografik Éditions, Paris, 2008, p. 143.

28 Costa, p. 143. Prossegue o texto: Ni l'art ni la philosophie ne peuvet aller au-delà de ce temps technologiquement établi». 


\subsubsection{O belo na paisagem e na cidade genéricas}

Uma inovação da arte contemporânea é a superação do problema do belo como valor metafísico intrínseco à arte. Mesmo que o tema do belo esteja ainda extremamente presente na esmagadora maioria do público, nunca é completamente descartado da equação crítica ethos-logos-pathos, sob pena de ser desenhar uma clivagem de referências estéticas que tornariam as obras virtualmente inacessíveis. E é por isso altura de justapor a Chevalier uma certa noção do Belo com instrumento de empatia com um público que é primeiro atraído (pelo Belo das flores) e só depois pelas nuances das obras enquanto dispositivos interactivos. É por isso que se pode falar em Chevalier de um belo laicizado ${ }^{29}$, o que tem a ver com o carácter 'aglomerado' desses mesmos dispositivos - dos quais já não pode dizer-se que têm um 'primeiro plano' (produto físico) e um 'segundo plano' (produto artístico'). Digamos que em Chevalier «l'arrière-plan» disparait au bénéfice du «premier plan». ${ }^{30}$ É por isso o "espiritual" da arte cede ao sensível e ao sensorial, numa experiência a-línguística de si própria:

La production et la consommation - s'il est encore possible de distinguer cês deux moments - délaissent l'esprit pour se tourner vers les sens [...] l'intériorité du phénomène se déplace dans une manifeste extériorité [...] Les ouvres en appellent purement et simplement à l'expérience sensorielle; cette dernière est questionnée, activée, étudiée dans toutes ses possibles contaminations et hybridations avec le système de la technologie. [...] Apres des siècles de boniments spiritualistes, l'«esthétique» revient à ses origines «sensibles»; [...] Lui [Chevalier] comme d'autres «chercheurs esthétiques», semble ici produire mais aussi prospecter des états et des equilibres sensoriels. Le corps, tut ou partie, est mis, via la technologie, en situation d'expérience inédite et perturbante. [...] Ceci signifie enfim qu'au règne du «signifié» a succédé celui des «signifiants», de ces nouveaux «signifiants» technologiques» déclarés en tant que tels [...] ${ }^{31}$

Digamos que há em Chevalier, face ao ethos do artista modernista, formalmente assertivo (os turds on the plaza), desde logo uma paixão pelo sublime do próprio dispositivo urbano (paisagem, arquitectura), mas que é abordado por via e singela evidência da sua própria evolução enquanto artefacto (comunicacional-experiencial): L'expérience esthétique se déplace de l'intérieur vers l'éxterieur, et l'intériorité transfere son essence à l'extérieur, non pas dans le sens d'une objectivisation de l'esprit [...] mais dans celui de l'esprit comme un état des «choses» objectif et matérie ${ }^{32}$ - e portanto, a haver uma graça, é a de uma feliz resolução da questão da relação entre forma e fluxo: Le transitoire, l'incontrôlable, c'est-à-dire l'émergence du flux et l'événement. ${ }^{33}$

Na lógica extramuros, este tipo de trabalho corresponde ao grau zero do objecto de arte na cidade (e na paisagem). Em Sur Natures as fachadas são transfiguradas, mantendo porém a sua autonomia de 'pedaço' de imagem urbana. E se o trabalho sugere uma certa interacção, o resultado dessa interacção é essencialmente no quadro da cidade como cenário. Se Chevalier, por outro lado, levanta uma questão essencial para o dispositivo artístico contemporâno - o problema da relação entre arte, ciência e tecnologia, coloca-a de forma especular. No meu esquema, Chevalier representa portanto uma forma básica, primordial do belo em arte pública. Ainda relativamente contido, apesar das implicações filosóficas

\footnotetext{
29 Idem, p. 145.

30 Idem.

31 Idem.

32 Costa, p. 147.

33 Idem.
} 
(Buci-Glucksmann) que Nold, de forma activista, vai problematizar, em sede em processos sociais concretos que vão privilegiar a informação à imagem. ${ }^{34}$

Para Ariella Masboungi grande parte das encomendas a artistas para embelezar a cidade têm por agenda mais ou menos imediata a reconfiguração da imagem urbana; mas alguns, como Chevalier - Masboungi refere o projecto Nuage Fractal, nunca realizado, para a cidade de Marselha, no âmbito da expansão da sua linha de tramway - , contribuem para mais do que esse mero embelezamento. Masboungi emprega o termo maravilhamento nocturno e isso revela como certos criadores - Chevalier, Nelson, Maya e Punelle, Dominik Lejman - perante encomendas deste tipo e para além de contribuírem para o prazer de viver a cidade (Masboungi), oferecem

[...] pistes de travail plus ambitieuses pour renouveler le regard sur la ville et sur l'architecture, révéler des réalités secrètes, proposer des pistes nouvelles et des glissements de frontières, enfim agir à part intière pour guider le devenir des villes. À une ère où la perte des certitudes règne et où la créativité la plus large est de mise pour réinventer la ville de demain. Par la simple lecture des lieux, l'artiste peut - à l'instar du paysagiste mais sur un tout autre registre - révéler l'invisible offrant ainsi des appuis à un nouvel imaginaire du projet pour la ville et le territoire. ${ }^{35}$

O trabalho de Chevalier - como a maioria das peças de uma Luzboa - são uma bolsa de resistência experiencial, inclusão pelo imaginário; como expressão do incomensurável de uma natureza total que a cidade genérica (Masboungi, citando Kolhaas), ou o urbano generalizado (Françoise Chouay ${ }^{36}$ ), têm soterrado. Pensando em obras como Metacités, Masboungi conclui:

\begin{abstract}
Ici encore l'artiste touche l'urbaniste au plus profond de ses aspirations car la ville n'existe que par un espace public partagé, mis à mal aujourd'hui par l'extrême individualisation des modes de vie, l'etalement urbain et le règne d'un urbanisme de secteur ségrégé et monofonctionnel qui fait peu de place au vivre ensemble qu'il s'agit de prôner dans un Monde toujours plus mouvant. Aimer et rêver la ville nous dit constament cette ouvre qui s'étoffe dans la durée et qui devrait enfin trouver place un jour prochain dans des actions concrètes pour changer le monde, le virtuel venant à la rescousse du réel pour l'aider à fabriquer un récit et des mythes urbains sans lesquels l'urbain ne peut atteindre le statut de ville 37
\end{abstract}

\title{
9.2 Javier Nuñez Gasco - o ready made social
}

Introduzo Javier Núnez Gasco através de um episódio ocorrido numa residência artística. Convidado a colaborar com a coreógrafa Annabelle Bonnéry, o artista transforma-se em obstáculo, num estorvo ao movimento expectável da bailarina, uma vez que 'ata' o seu corpo luma das pernas) a uma das pernas dela, deixando-se ficar como um peso inerte. Pergunta Delfim Sardo ao artista: Es una constante de tu trabajo adoptar esa postura de situarte al "outro lado", mostrando el reverso de la moneda o de la medalla, como se dice en portugués? ${ }^{38}$ Responde Javier:

34 Donde que o que em Chevalier é 'mera' decoração com sentido de inscrição, depois em Gasco, pura materialidade do corpo social; depois nos Freee intelecção discursiva do estado das coisas, acaba por ser em Nold a inevitável acção micro-utópica.

35 Masboungi, Arielle; «Inventer l'avenir», in Miguel Chevalier, Monografik Éditions, Paris, 2008, p. 223.

36 Chouay, Françoise; Pour une anthropologie de l'espace, Editions du Seuil, 2006.

37 Masboungi, p. 226.

38 Sardo, Delfim; «Un lugar sin nombre», in Javier Núnez Gasco, Fundacion Salamanca Ciudad de Cultura / Artedardo S.L., 
Lo que se esperaba del grupo de artistas participantes era que viviesen, discutiesen e reflexionasen con vistas a producir obras conjuntas. [...] tuve que buscar rapidamente una forma de adaptarme sin renunciar totalmente a mi línea de trabajo. Viendo algunas experiencias de los otros participantes me di cuenta de que la colaboración entre artistas implica, de cierto modo, una disolución o suspensión temporal de la idea de autoria. [...] La idea de atarme a la pierna de Annabelle Bonnéry me pareció adequada para representar un proceso de colaboración forzada y en lugar de colaborar armoniosamente, opte por hacerlo de una forma parasitaria. [...] agarrado a la "máquina" interpretativa que es el cuerpo de la bailarina. Cada uno ténia una misión: ella bailar y yo estorbar su baile. Alguien describió mi acción como "convertirse en un chicle en el zapato de la bailarina". ${ }^{39}$

Gasco revela consciência do funcionamento da sua posição artística enquanto máquina que engrena noutras máquinas qual dispositivo de abrandamento total:

[...] la pregunta "¿Quién es el autor de la pieza?" es decisiva para la comprensión del território conceptual que abarcan [Prótesis para una bailarina e Cinco minutos de crítica de arte, a que me referirei mais à frente]. En quanto a lo de ofrecer el revero de la medalla... Digamos que la "medalla" se solto del cuello del "campéon", cayó al suelo e no para de rodar. 0 sea, no se define.40

Este recurso à anti-colaboração $0^{41}$ é identificável como negatividade com cariz retórico: $a$ argumentação ad contrarium, que consiste em alguém demonstrar uma coisa através do argumento inverso. Gasco fá-lo continuamente, numa acção sacrificial da sua identidade previsível de artista (em Cinco minutos de arte, 2004), de cidadão (em Autoretrato 2005 e Misérias llimitadas, Lda., 2006); ou de ser humano (Cartuchera, 2004). Quanto à materialização intersticial deste ethos negativo e de provocação, Gasco busca no meio envolvente, que define como construção do que o rodeia ${ }^{42}$ as frechas de onde extrai as ideias e obras ${ }^{43}$. E então corrige: Pero no argumento por oposición, sino más bien por alternativa o, preferiblemente, por alternativas. Es un exercício teórico y práctico al que dedico mucho tiempo, pero que me situa en la posición donde exactamente quiero estar: en constante búsqueda o proceso. ${ }^{44}$ Isto é, Gasco empreende continuamente um processo de argumentação consigo próprio e com o mundo, e de alguma maneira é a condição de fluxo que se adapta ao seu ethos de contínua confrontação sacrificial com as construções sociais. Tal supõe preterir as perguntas às respostas ${ }^{45}$ la duda mejor que la certeza y la hipotesis mejor que la conclusión. ${ }^{46}$ Este estado es más interesante cuanto más largo sea: me interesa la búsqueda que no busca nada, y principalmente la que no encuentra nada. En ese camino voy dejando atrás restos, resíduos, basura, desperdícios: mis obras ${ }^{47}$ Aqui, ecos do conceptualismo (a questão do resíduo do processo) encaixam numa lógica de busca absurda que tanto pode ser vista como dizendo algo ou nada. De uma penada, a institutional critique conceptual, vocacionada para a escalpelização do dispositivo social, encontra-se com a explicitação performática de como funciona esse mesmo dispositivo lo mesmo que Costa diz de Chevalier, agora num corpo a corpo com o fluxo urbano social).

\footnotetext{
Salamanca, 2007, p. 7.

39 Idem.

40 Idem.

41 Idem.

42 Javier Núnez; «Un lugar sin nombre», in Javier Núnez Gasco, Fundacion Salamanca Ciudad de Cultura / Artedardo S.L., Salamanca, 2007.

43 Idem.

44 Idem.

45 Idem.

46 Idem.

47 Idem.
} 
Tal corpo a corpo começa na atenção ao invisível da cidade - algo que no está visible, es algo que no se ve, bien porque no se quiere, porque no se hace el esfuerzo de intentar verlo, o bien por que nos e puede, por condicinamentos de orden social, ético, motal, intelectual, emocional o incluso físicos. ${ }^{48} \mathrm{Na}$ forma social como na forma urbana, Gasco vai procurar espaços-nada que possam ser palco da sua gnose, como se estivéssemos convidados a ser iniciados nas realidades imprescrutáveis da cidade, que a alienação quotidiana esconde, seja por uma razão (de submissão à hegemonia, por exemplo) ou outra (de negação interna do Eu). Um convite que é tanto mais imprevisto e irrecusável, quanto oferece ao espectador a decisão do veredicto final - que está tanto no debate que as obras promovem (mediatizado pela sua convidativa ressonância na esfera da comunicação social), como na experiência cognitiva que inscrevem (como em Chevalier, mas agora numa escala e num registo de contacto directo do corpo humano com todas as nuances existenciais do socius. Sardo fala de uma obra que é un sistema de relaciones que, a priori, sabes que va a ser un sistema de imperfecciones, ${ }^{49}$ aspecto performativo que paradoxalmente é comunicado não apenas para/com quem possa participar nas acções, mas - por via do discurso - em entrevistas, textos teóricos, a interpretação, que exigem uma performática do próprio sentido performativo (sob pena de este ser apropriado como devaneio do artista clown). Nota-se aqui que Gasco tem essa preocupação de contador de histórias. ${ }^{50}$ Aliás, neste aspecto, Misérias é oxímoro máximo, pela sobreposição de níveis de absurdo e contradição - a começar pelo título! E é dessa ambiguidade (kafkiana) que a arte crítica retira o essencial: Si se puede hablar de algún tipo de función del arte, siempre será la de provocar al espectador y hacerle pensar, o sentir ${ }^{51}$; sendo que, na arte propriamente urbana, essa provocação necessita de problematizar todos os constructos quotidianos para obter um estatuto de negação do visível falso. Podemos desde logo falar de uma paixão pela graça do social na formulação que Gasco faz do seu logos, que é núcleo de statement de cidadania artística: Renuncio voluntaria y conscientenete al papel de juez privilegiado. [...] Me seria imposible hablar de lo que no conozco, de lo que no he vivido. Por lo tanto, y a pesar de sentirme envuelto en esas realidades, intento volar sobre ellas en una espécie de esquizofrenia más o menos controlada. ${ }^{52}$ Mas isso implica uma noção do dispositivo artístico comparável a um interruptor - como em Martin Creed, mas com consequências sociais mais imediatas - que vai obrigar o espectador a abdicar da sua indiferença talvez denunciando que algo vai mal na organização ou na vida sociais. Nas várias peças de intervenção televisiva, que não destacarei aqui, isso é mais do que evidente.

\subsubsection{Biografia, missão, sacrifício mediático}

Mediogramadefelicidad, diz Gasco, referenciando o que distingue esse trabalho dos exercícios - algo autoindulgentes - de Hélio Oiticica.53

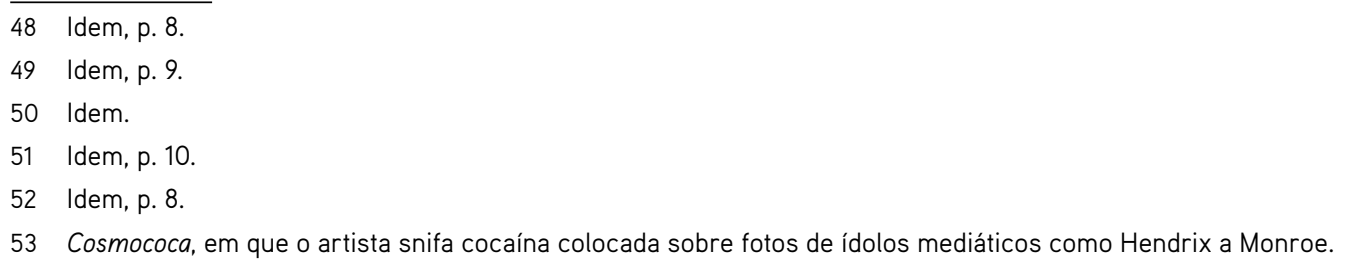


La única relación immediata que veo es el uso de la cocaína como matéria prima... O sea hay una relación formal pero sin correspondência directa de contenido o de intenciones. De hecho, en mi vídeo yo no la snifo. En realidad, la suelto por la nariz escribiendo la palabra 'felicidad'. Claro que para grabar el vídeo primero tuve de snifarla, pero luego en la edición inverti el sentido narrativo. ${ }^{54}$

Gasco utiliza as mais quotidianas materializações, os mais disponíveis dos materiais, para depois complexificar a sua estruturação social, temporal, institucional, sempre com essa marca essencial que é uma explicitação de mecanismos de produção de 'coisas' a partir do ponto de vista do núcleo duro que é o seu corpo, a sua presença física, o seu ser mental, a contingência do seu ponto de vista num lugar e num tempo concretos plasmada - como na arte conceptual, é certo - nas decisões do dispositivo e na relação (cínica, com o que chama os resíduos das acções). Há uma notável elegância na abordagem de temas complexos, elegância tanto mais surpreendente quanto os temas, em si, são muitas vezes duplamente complexos - problemas sociais candentes, muitas vezes correntes nos media e que são ao mesmo tempo cenários de perturbantes problemas da cidadania contemporânea. Para que tudo isto funcione, o 'segredo' do acto comunicacional está na ironia. Assim como a imagem de Felicidade proposta é ambígua, ${ }^{55}$ ambígua teria de ser, para funcionar, qualquer destas ludopatias, interpretadas pelo artista cujo papel é estranhamente sacrificial, exemplar e tornado sagrado pela liminalidade que propõe (por vezes no limite da legalidade, essa liminalidade essencial do socius contemporâneo). ${ }^{56}$ É no fundo o jogo do social, no esplendor dos seus absurdos - e um dos quais é, sem dúvida, a sua vertigem mediática: [...] la obra en principio fue pensada como un possible anuncio de televisión contra la droga [...] en resposta a esa hipocresia social ${ }^{57}$ que conhecemos da publicidade a produtos legais ou naturais excitantes que são 'vendidos' para que as pessoas estejam constantemente 'activas'. A obra é assim sobre a vulnerabilidade do socius à publicidade. ${ }^{58}$ Uma leitura deste trabalho é a inversão dos dispositivos sociais - comunicacionais, institucionais, e muito particularmente mediático-publicitários - contra eles próprios, por forma a que o absurdo, a arbitrariedade,a tautologia, tenham graça; que os próprios espectadores sejam interpelados por um caso real - ou pelo menos cujo realismo é incontestável -, o do próprio artista que assume a sua experiência no caso, com as drogas..$^{59}$

Em Immolación, Gasco assume a ideia do sacrifício explicitamente: Sí, por supuesto. Tengo una misión que cumprir, aun a costa de mí mesmo ${ }^{60} \mathrm{~A}$ peça consiste na ocupação pelo artista de um armazém de um bar (onde um dia havia começado a beber), sendo filmado em directo por um circuito de vídeo, filmagens durante as quais, munido de um colete porta-garrafas - evocativo dos coletes explosivos dos terroristas islâmicos - vai bebendo álcool até sossobrar. Em obras como esta Gasco dá um passo extramuros, em relação a uma linhagem de

\footnotetext{
54 Gasco, p. 13.

55 Idem, p. 13

56 Idem.

57 Idem.

58 Rosler, in Johnstone, p. 53. The eradication of craft skills, of economically productive family activity, has lessened people's chances to gain a sense of accomplishment and worth and has increased our vulnerability to the blandishments of advertising, the most potent educational institution in our culture

59 Aliás, Postfiesta é ainda mais evidente a este nível.

60 Gasco, p. 13
} 
criadores, de Abramovic a Vito Acconci, ou Gina Pane. ${ }^{61}$ Pois, a actualização do sentido de esfera pública é de outra ordem: Ellos [os artistas dos anos 60 e 70] queran hablar de limites utilizando sus cuerpos, y yo quiero hablar - o incitar a que se hable - de muchas outras cosas $y$, para hacerlo, utilizo los limites. Digamos que lo que constitui un fin para ellos, para mí es un proceso, una forma. ${ }^{62}$ Esta afirmação confirma o profundo sentido desta arte como retórica quer no sentido de que estabelece plataformas de debate público, extremamente horizontal e transversal; quer no sentido de que o artista está consciente de que labora num discurso que domina e que pode tornar persuasivo em sede de projecto de comunicação (que coincide com o projecto de obra ou de intervenção). Mas isso implica uma voz própria para além da genealogia da arte, um recomeçar: Por eso pienso que que mi obra no ganaria nada asumiendo una filiación con esa generación. [...] Digamos que podemos ser amigos pero no les considero de mi famila [Risas]. ${ }^{63} \mathrm{Na}$ linha desta suspensão do próprio estatuto artístico (no sentido de divisão cultural) - que, existindo, de todo ocupa qualquer lugar de relevo no fenómeno da comunicação, o que perturbaria o seu carácter simbiótico, camaleónico e profundamente colaborativo (O'Doherty) - vão obras como Resting Pieces (R.I.P) ou Tu Creador no te Olvida. São mecanismos de variação tautológica da arte, mas permeados por uma necessidade de interacção com os públicos que torna cada peça, em vários momentos da sua realização, completamente imprevisível.

Vale a pena recordar como se articula em Gasco a síntese contemporânea do legado provocatoriamente meta-artístico de Duchamp:

\begin{abstract}
Justo antes de la edición de ARCO-05, mi galerista me pedió alguna obra para llevar, y yo tenía muchas ideas pero carecia ben de los recursos económicos o de otro tipo para concretarlas. Entonces decidi tallar en la pared un homenage a las ideas de mi cuadreno, como si fuese una lápida commemorativa con la fecha de la idea, su descripción y el epitáfio D:E:P ("Descanse en paz"). [...] Resting Pieces [R:I:P] es una evolución de este proyecto em la que ofrezco una oportunidad de vida a las ideas de mi cuadreno, construyendo una lápida para cada una de ellas. En realidad, son una mezcla de lápida y de placa conmemorativa como las que se colocan en los teatros on en los espacios públicos. La estructura es la misma que en Tu Creador no te Olvida, pero existe una possibilidad de concreción de la idea. Si un coleccoinista adquiere labra, puede hacerlo de três formas: compra solamente el objecto, la láida, de tal modo que "mata" la idea e yo me comprometo a no realizarla; o compra la lápida y financia el proyecto, otorgándole existência. En este caso, you grabo una franja roja con el texto: "Esta idea se ha realizado gracias al generoso patrocínio de X". Por ultimo está la posibilidad de que el coleccionista compre la lápida y la obra resultante lo en su caso, el número 1 de la edición), completando de este modo el ciclo que yo propongo. [...] Las lápidas ya de por sí son irónicas porque normalmente son homenajes a algo o a alguei que ha desaparecido pero, en este caso, tienen más que ver com la vida que con la muerte, más con el proceso que con el homenaje, ya que la idea puede llegar a concretarse. En última instancia, en realidad no es una crítica al mercado, del qual dependo, sino que implico al circuito del mercado en la própria obra. ${ }^{64}$
\end{abstract}

Apesar de Gasco referir que não considera esta abordagem cínica, mas crítica e irónica, um entendimento mais rico do cinismo (Sloterdijk) vai ao encontro destes modelos de apropriação potencialmente colectiva da arte como um campo de tensões expressivas com extraordinária emotividade performática, e na prática como um nenhures das coisas, do social, das pessoas, e da relação entre tudo isto: pura possibilidad [...] donde no hay nada ${ }^{65}$,

61 Influências que não assume.

62 Gasco, p. 15.

63 Idem

64 Gasco, p. 16.

65 Idem. Na base da minha axiomática portanto, no mesmo eixo de semelhante acção pelos Freee, mas esses com um interesse pela comunicação formal próxima do ensaio ou da politica, e não, como Gasco, da autobiografia ou da confissão, para utilizar metáforas relativas aos géneros literários. 
Sardo define-o como um espaço intersticial, entre corpos e pessoas, realidade e ficção. ${ }^{66}$ À escala da sua humanidade quotidiana, terreno social do confronto, em sede de corpo, Gasco é um ponto determinante num vector performativo - esplendor [e miséria?...] da indeterminação e da utopia em construção - na figura sacrificial do artista que faz arte por nós (Francis Alys, Gabriel Orozco ou Santiago Reyes. Toda a sua abordagem da vida como durée, da morte como mento do percurso biográfico, e consciência social implícita, são no conjunto um modelo microcósmico para a arte urbana, em que o contacto do público com o artista é uma relacional constatação da mútua interdependência.

\subsubsection{O teatro de Oklahoma}

Em El Toca-cojones y el Teatro Untegral de Oklahoma, Fernando Castro Flórez contextualiza o artista espanhol num panorama complexo, que é grosso modo o da arte crítica contemporânea: Es manifesta la ambigüedad de las actitudes artísticas contemporâneas, resultando difícil saber si son formas de la resistência semiótica, poses de franca decadência revolucionária o gestos de cinismo en los que la teatralización ha substutuido a caulquer estratégia crítica ${ }^{67} \mathrm{E}$ se sem dúvida que o trabalho de Gasco é radical, é no valor da paródia que, para Flórez, devemos procurar o seu sentido; Vale que a lo mejor tenemos que asumir, en medio del ridículo, un punto de vista delirante. ${ }^{68}$ Ou seja, esta arte fala a mesmíssima língua que o real (político, mediático) que a envolve, podendo porém argumentar-se que lhe falta um passo decisivo, em termos de logos colaborativo ou participativo, para que as profundas questões que levanta redundem em acções colectivas integradas pelo ethos artístico. ${ }^{69}$

Seja como for, é a partir do ethos autoparódico que podemos começar a entrever o sentido da própria paródia na contemporaneidade, ao nível da identidade do artista que se leve a sério:

Conviene tener presente que es imposible representar una parodia convincente de una posición intelectual sin haber experimentado una afiliación previa con lo que se parodia. [...] La parodia requiere cierta capacidad para identificarse, aproximar-se, y acercarse: implica una intimidade con la posición que en el acto mismo de reapropriación altera la voz, el posicionamento, la performatividad del sujeto, de manera que la audiência o el lector no saben exactamente donde está una, si se ha pasado al otro bando, si permanece en el suyo, si puede ensayar otra posición sin caer presa de la misma durante la representation" ${ }^{70}$

Por outras palavras, há na paródia um envolvimento específico inevitável - ambivalência que é de outra ordem existencial que a arte estercorária (Clair).

Perhaps these contradictions and qualifications that characterize the everyday make it seductive territory for those artists who intuitively value the qualities of ambiguity and indeterminacy as ends in their own right (Annette Messager, Susan Hiller, Fischl and Weiss, for example). Most of the art presented or discussed here $e^{71}$ may aspire to directness or immersion but it does not approach the everyday in any straightforward documentary way. Much of it uses ruses and subterfuge to find ways of representing or engaging with the quotidian. ${ }^{72}$

66 Sardo, in Javier Núnez Gasco, p. 16.

67 Flórez, Fernando Castro; «El Toca-cohones y el Teatro Integral de Oklahoma», in Javier Núnez Gasco, Fundacion Salamanca Ciudad de Cultura / Artedardo S.L., Salamanca, 2007, p. 16.

68 Idem, p. 16; O autor cita Baudrilard de El Intercambio imposible.

69 Vários autores a que Flórez recorre para fazer valer o seu ponto de vista passam por Kafka e K. Dick, como veremos. Precisamente o que, argumentarei, será Nold a procurar fazer

70 Flórez cita Judith Butler, de "El marxismo y lo mermente cultural", in New Left Review, n.2, Ed. Akal, Madrid, 2000.

71 Johnstone, Everyday.

72 Johnstone, p. 15. 
Neste ponto há em Gasco afinidade com Freee (cujas paródias decorrem já no palco da meta-teoria marxista do espaço público). Entre estes autores desenha-se uma tonalidade - paródica - que não vejo facilmente rebatível noutro autor do texto-corpo como arte, Penilo, nomeadamente na sua totalidade poético-crítica do projecto $8 ! 8 ! 8 !^{73}$, que deliberadamente desconvoca o humor. Voltando a Gasco, há uma pedagogia lúdica dos dispositivos que, mesmo quando as suas acções parecem ser qualquer coisa (Jimenez), torna as obras - e sobretudo o seu humor - monumentos ao socius em formação, um socius ameaçado como nunca pela estupidez mediática (Perniola). É o estatuto de artista que permite a este homem como outros, criar uma história, desenvolver a sua crítica do social e finalmente inscrever a sua própria retórica - paródica, irónica, sacrificial - no altar da criatividade colectiva quais workshops de cidadania depois-da-crítica. Já vimos a aparente facilidade com que Gasco conquista espaço mediático, como o seu corpo é um dispositivo humano uma máquina de articulação entre dados universais e a especificidade dos processos que encena. Em Esto es lo que hay, Gasco, completamente nu e de cabelo rapado, com o corpo coberto de frases e slogans escritos a marcador, irrompe a meio da noite adentro de um dos bares mais populares da noite de Salamanca. A pele-tela ostenta dizeres como Soy un cabrón, si mi madre me viera ou no me gusta el fútbol pero lo respeto, etc.; o artista pega assim num modelo de comunicação urbana - os streakers - e cruza essa figura com a do homem-cartaz ambulante, num registo que desafia os critérios da moralidade de uma forma inclusiva - tendo em conta que o espaço da noite é lúdico e que o título da obra é afinal uma expressão popular e típica castelhana. Este tipo de detalhes tornam a obra de Gasco muito diversa da dos Freee, onde o humor ácido não tem a mesma ternura melodramática (Flórez) - Gasco consegue realmente competir com o patetismo do reality show. ${ }^{74}$

Relativamente às implicações desta retórica patética na forma urbana, atentemos ao denso raciocínio de Flórez, que chama a atenção para uma dimensão psico-lógica desta arte, dimensão que vai sustentar o modelo hagiográfico de uma graça perdida do social - e que assim parodicamente, 0 artista consegue levar-nos a experimentar.

\footnotetext{
Sabemos que la consciência de la alteración del espacio, causada por la introducción de lo aberrante en el seno de lo real, es compartida por la experiencia del arte y por la práctica lúcida, ajena al cinismo "urbanizante", de la arquitectura que constata que la ciudad está perdida (de la misma forma que en las artes plástica surgen, antes que nada, fragmentos, basuras, materiales de bricolage, etc.). y que lo que nos queda es un território de escombros (sorprendente escenario de la emergência de la "intimidad") en el que aparecen toda clase de accidentes. Foucault ha señalado que el espacio en el que vivimos, en el que tiene lugar la erosión de nuestra vida, de nuetro tiempo y de nuestro historia es, en sí mismo, un espacio heterogéneo. No vivimos en el interior de un vacio, sino que estamos enmarcados en un conjunto de relacciones, las quales definem unso emplazamientos que son irreducibles entre sí y no se pueden superponer. La heterotopia artística contemporânea está caracerizada por un afán contextualizador que, al fijarse obsesivamente en el território del museo, acaba por ser tautologia. Podría hablarse de la instalación, presente en la contemporaneidade de forma avasaladora, como un rococó subvertido, pues su relevância,, como ocurría con el estilo citado, no parte ya de la técnica ni del lenguaje arquitectónico, sino de la acelerada determinación de una volontad y una manera aplicadas a los espacios (generalmente interiores). Se nos emplaza frente a un tereno derivado (muchas veces por perversión o ironia o por una memoria falsamente nolstálgical de la decoración doméstica concentrada en un minucioso tratamiento de los objectos y de los detalles. "Como el rococó, la instalación es genuinamente un arte de
}

73 http://oitooitooito.blogspot.com/.

74 Cf. Esta es mi gente (Telemadrid), de 2002; e, mais uma vez, também com Misérias llimitadas, Lda., aí já na crónica de Ferreira Fernandes, no Correio da Manhã. Também em Fútbol - 9a Copa de Europa, de 2002, é patética (Flórez) a mimetização do hooligan de futebol em que o artista se imiscuiu no anónimo movimento das pessoas celebrando uma vitória histórica do Real Madrid, subindo a um monumento e sendo filmado para a posteridade, depois classificando a acção como obra de arte. 
salón, pero también, en general, un arte descontructor que modifica la estructura interior de los lugares, reduciendo o ampliando el tamaño de las estancias y sus componentes, otorgando una importância máxima a los elementos contextuales Imobiliario, enseres, ornamentos, lugares transicionales, limites, aperturas, proposiones pryectivas, huecos y otras inscriptiones) "75. Recordemos la idea de Perniola de la instalación como aquel espacio que siente el visitante, lo acoge, lo toca, lo palpa, "se extiende hacia él, le hace entrar en ella misma, lo penetra, lo posee, lo inunda. Ya no se va a las muestras para ver y gozar del arte, sino para ser vistos e gozados por el arte"76. Un espacio o, en otros términos, un escenario, recurriendo a una denominación própria de lo teatral, en el que la ideologia de la interactividad virtual queda desmontada por la interpasividad de aquello que es presencia incontestable. "La instalación [...] constituye la operación última mediante la que el arte escapa a las evdiencias desprovistas de realidad de lo cotidiano levidencia de las palabras), evdiencia de la arquitectura, evidencia de las imágenes...) para convertirlas en su matéria prima. ${ }^{77}$

\section{Flórez vê nessa instalação contemporânea -}

[...] um lugar opuesto no solo a cualquier operación de ficción, sino también a cualquier operación de descifeamiento, de elucidación del misterio es más bien una espécie de regreso a lo real [Foster, por supuesto] penoso e difícil regreso si nos fijamos en los artifícios y en las complejidades de nuestro entorno actual, esta mezcla de ciberespacio, de estereótipos, de palabras obligadas y de fórmulas convenidas)"

Neste território, momentos de intimidade, reformulações activistas, documentais ou relacionais do realismo ${ }^{79}$ podem tornar-se eloquentes iluminações do político. $O$ que Gasco propõe à esfera e ao espaço público é já não apenas tal simulacro do doméstico fascinante, mas propriamente uma realidade quotidiana alterada. ${ }^{80}$ Gasco é, mesmo quando capaz de proficiência objectual (o rigor construtivo de certas peças é quase maníaco) e artista de instalação (o domínio da criação de circuitos expositivos), já uma outra coisa social - pública -, com uma ligação intensa aos processos de socialização aos mais variados níveis da experiência urbana do espaço público le de que o espaço mediático é dimensão hoje exponencialmente multiplicada), para a qual contribui com uma partilha do sensivel peculiarmente actuante. $E$ de facto essa graça é entrevista em fugazes contactos com o sublime, é de nada mais nada menos de um contacto com o sublime social:

Toda religión empieza como crisis de culto, como "baile fantasmal de una sociedad traumatizada"81 y, acaso, nos encontramos en el umbral en el que la disolución de las experiencias que fundam comunidad ha llevado a una ritualización museográfica de aquello que servia como "escape" (precisamente el baile reducido por algunos artistas a algo digo de ser aceptado o introducido en la institución canonizadora e higienizante del colecionar o, como, la turbulência del deseo, los abismos del sexo convertidos en estandartes o consignas; la cotidianiedad abierta a una sorprendente obscenidad), asumiendo el silencio de la contemplación estética (correspondiente al "se ruega tocar") el rango de oración; comungamos con la más estricta estupefacción. ${ }^{82}$

Para Flórez, obras como Postfiesta - note-se a ironia face à festa como redenção social são mesmo essa conscientização do que já aconteceu - mais do que o nada ainda aconteceu de Kafka; são a irónica proposta de que tudo o que tinha de acontecer já aconteceu e não deu em nada de espacial - a ironia que diz o contrário do que sente. Este Gasco 'gnóstico' não se deixa arrumar no pathos da melancolia burguesa,

La nostalgia de la provocación vanguardista, transformada en lógica de lo obsceno, aquel ânsia de novedad derivada en

75 Samaniegom Alberti Ruiz; "Espécies de espacios" in ABC Cultural Madrid, 5 de Agosto de 2000, p. 20.

76 Perniola, Mário; El sex appeal de lo inorgânico, Ed. Trama, Madrid, 1998, p. 138.

77 Flórez, p. 33.

78 Auge, Marc; "Del espacio a la mirada: ¿que es un objeto de arte?, in Ficciones de fin de siglo, Ed. Gedisa, Barcelona, 2001, p. 121.

79 Flórez, p. 34.

80 Idem.

81 La Barre, W.; The Ghost Dance, dell Publishing Co., Nova lorque, 1978, pp. 239-245.

82 Flórez, p. 34. 
el gusto por la perversión que, en aparienvia, se antecipa a la estratégia neutralizadora y la carnavalización en médio del pânico, resuelta actualmente como subjectividad narcolépsica luna vivencia espasmódica en la que la palabra intensidad puede coincidir con el camuflaje autista frente a los conflictos circundantes), guardan relación con las patologías festivas ${ }^{83}$

Qual sacerdote sem templo no espaço colectivo do sacrum, Gasco surge mesmo com a eloquência de uma oráculo, numa altura em que no regime da arte contemporânea se dá la actual pérdida general de las condiciones de comunicación. ${ }^{84} \mathrm{O}$ seu ethos de transparência ${ }^{85}$ é a resposta a um 'mundo da arte' especado como um coelho no meio da estrada, ofuscado pelos faróis de um carro. ${ }^{86}$ Mas o que é que distingue o apropriacionismo do público em Gasco, das anedóticas incursões de Pipilotti Rist, Tiravanija, ou Cattelan? Precisamente, a dimensão cinicamente ritualística, pois Gasco - como Stalker ou Reyes, ou antes Knizak ou Albuquerque Mendes - realiza propostas que consiguen sobrepasar la "pose" para convertirse en ceremonias, "rituales" en los que se genera experiencia y, sobre todo, se escapa da la rutina estética, de esa hibernación pavorosa en la que están localizadas muchas obras. ${ }^{87}$ Como que Gasco dá corpo a um tanathos ${ }^{88}$ colectivo, que o sacrifício do artista introduz no quotidano, até na rejeição visceral que por vezes provoca. Mais do que alegoria, estamos perante uma fisicidade ${ }^{89}$, que vem dar outro sentido à performance-art dos anos 60-70. E acrescento, uma materialidade total do corpo-mente-pensamento do artista na forma-cidade, no quotidiano que entretanto de transformou numa visualidade superficial:

Hay situaciones y lugares que escaparon a la exhortación de la profundidad, que se conformaron co estar en la superfície y, así, ser los reservorios del carácter global, de lo cualitativo. Lo cotidiano y su "presentismo" son un buen exemplo.

El ambiente afectivo que lo caracteriza se basa en la aparência, e numa vida para ver. ${ }^{90}$

83 Idem.

84 Flórez, pp. 34-35. En última instancia, el problema de las maquinaciones contemporâneas no es la amnésia, dado que tampoco hay casi nada que propriamente sea digno de memoria, sino la desconexión. La sociedade del espectáculo ha empujado al arte $e$ incluso a la crítica al terreno del bricolage, siendo el material con el que producir la "obra" una amalgama de souvenirs que señalan un patético final.

85 Curiosamente, o contraponto de apoio a esta arte da transparência está, estrategicamente, na transparência da própria teoria - na mediação, no ensino, no acontecimento retórico - fundamentais para que os mecanismos pedagógicos da arte funcionem.

86 Flórez, p. 35. Asistimos, en muchas experiencias artísticas, tanto a una sobrecodificación cuanto a una espécie de apoteosis del secreto subversivo [...] la rebeldia está colapsada tanto por la impotência colectiva e personal cuanto por la tendencia al hermetismo, ese camuflaje que da cienta, antes de más nada, del miedo.

87 Idem.

88 Freud (Para Alem do Princípio do Prazer, 1920) veio acrescentar aos princípios do Eros e da Libido o instinto de morte (Thanatos - Building on his 1914 article "Recollecting, Repeating and Working Through", Freud highlights how the "patient cannot remember the whole of what is repressed in him, and is obliged to repeat the repressed material as a contemporary experience instead of remembering it as something belonging to the past [...] Freud, em verve ensaística, amalgama conhecimentos clínicos e especulação: se Eros é criatividade, harmonia, conexão, reprodução e autopreservação, e Tanatos destruição, repetição, agressão, compulsão, auto-destruição, temos de desenhar uma no-mans-land existencial que entre abdicação oriental e compaixão crística desenha um terreno de fruição artística extremamente retórico na sua relação com utopia modernista, e que assim, entre Nietzsche e Weil, entre Kafka e Celan ou Pasolini, define uma radical via discursiva para a comunicação do destino colectivo (precisamente para alem do espaço público 'marxista'). Seja como for, a morte é uma 'descoberta' do século XX (contrastando com a morte na Tragédia Grega (a catarse, Aristóteles); e este é um mal que doravante tem de ser integrado na dinâmica criativa (Artaud, Pasolini). Mas terá de haver uma dimensão outra para a experiência desta morte 'científica' e sublime, precisamente para além da arte estercorária (Clair) ou outras formas de sublime. Em A Carne e o Diabo estas questões são relançadas, ecoando a biologia em Freud, e nesse sentido Fritjof Capra oferece uma solução de harmonização destas forças bio-moleculares no seu Hidden Dimensions (que já integra processos sociais como os assinalados pela Teoria Crítica e em particular Foucault). Em suma, será a descoberta do instinto de morte - ou a sua invenção ensaística, em Freud, culminando em Lacan - uma reacção à condição tecnocientífica moderna?

89 Idem.

90 Maffesoli, Michel; El instante eterno. El retorno de lo trágico en las sociedades posmodernas, Ed. Paidos, Buenos Aires, 2001, p. 127. 
Tudo isto - esta capacidade de a arte pública fazer acontecer a emoção no tempo das imagens - passa paradoxalmente pela noção de imagem imediata, o domínio do logos da imagem retiniana. Neste contexto, Gasco é perpretador de um terrorismo poético, criação na forma urbana de fugazes autonomias.

[...] zonas temporariamnete autonomas: Evita las categorias artísticas reconocibles, evita la politica, no te quedes a disvutor, no seas sentimental; se implacable, arriésgate, práctca el vandalismo solo en lo que ha de ser desfigurado, haz algo que los niños puedan recidar toda la vida - pero no seas espontâneo e menos que la musa del terrorimo Poético te posea-Vistete. Deja un nombre falso. Se legendario [.... $]^{91}$

Neste 'manifesto', Gasco enjeita os dois mandamentos que colocariam em risco o sentido absolutamente banal do seu sacrifício - Deja un nombre falso. Se legendário... E no entanto, que dizer dessa acção com que gostaria de terminar esta análise? Falo de Cinco Minutos de Crítica de Arte, em que o artista se algema a um crítico intenacional, em plena ARCO '04, até este aceitar o desafio e encontrar forma de ser ver livre do lastre, escrevendo a solicitada crítica.

Hay una enorme lucidez en la forma en la que Javier Núñez Gasco se meteen los media, de la misma forma que sus juegos con la verdad documental tienen. Dentro de si, el vírus de las ficciones más perversas. Me comentaba, en torno a sus reciente colaboración con un grupo de teatro português, que su papel era el de "terrorista": tenía que introducir trozos de realidade en la obra. Acaso esas representación teatral interrumpida sirva para evitar la característica claudicación del arte en tiempo real ante la instituición Artística, ese museu unico que parece que quisiera, en un raro retorno de lo reprimido, volver a ser Wunderkammer, lugar de lo enciclopédico mezclado con el souvenir anecdótico. Son muy sagaces los comentários de Victor Zamudio-Taylor, un curator internacional al que Javier Núñez Gasco se esposó [...] "En la pieza es fundamental el elemento de sorpresa [...] no había ninguna complicidad [...] Estas en el cine y alguien grita "fuego", sin duda, el 99\% de ese público en eses cine va a entar en pânico en segundos. Escuchar el "clic" de unas esposas produce la misma reacción, es decir, es un sonido con tal carga de construcción cultural y tanto significado social que, aun que yo haya sabido que era una complicidad y que era una "performance", hubo un instante en el cual yo ni recordé o mi olvidé de que era una "performance" en el momento en que las esposas hacen 'clic".

Assim defiiu o crítico um momento milagroso da obra, em que esta se realiza como fugaz acontecimento. Até que ponto é que aqui se trata de um momento com potencialidade utópica? No romance Amerika, de Franz Kafka, o herói Karl Roßmann depara-se com um espaço de hipotética redenção humana diante de um cartaz que diz: Quem quiser ser artista, dirija-se-nos! Somos o teatro que pode dar emprego a toda a gente, a cada qual o seu lugar! O Grande Teatro ao Ar Livre de Oklahoma é assim uma espécie de não-lugar ao mesmo tempo utópico e disfuncional, mas onde «Todos são bem-vindos!»:

Todo el mundo esta contratado,la propaganda así lo indica, e ese extraño e inmenso teatro [...] Lo malo es que parece que las actividades que alli de desarrollan son ridículas, por ejemplo, subir-se a enormes pedestales y tocar, da igual que se haga fatal, una trompera reluciente disfrazado de ángel o diablo. Y, ademas, no se sabe cuanto pagan por ser artista. Javier Núñez Gasco no es solamente ese "cualquiera" que puede encontrar trabajo en el gran Teatro Integral de Oklahoma, también es, como dije hace tiempo, un tocacojones llo que implica tanto el placer masturbatorio cuanto la intempestividad de algo que otro recibe, de nuevo, por sorpresa?2.

91 Bey, Hakim; T.A.Z. Zona Temoralmente Autónoma, Ed. Talasa, Madrid, 1996.

92 Flórez, p. 45. 


\subsection{Freee - libertar as palavras}

Na minha axiomática, o trabalho de Mel Jordan, Andy Hewitt, ${ }^{93}$ em dupla ou com Dave Beech (Freee), corresponde a uma modalidade de inscrição eminentemente crítica e discursiva (vector vertical) na forma urbana e na esfera pública contemporâneas. Nos campos do slogan e do manifesto (Free Collective Manifesto for a Counterhegemonic Art, 2007) comunica a/ com a sociedade radicando-se na meta-instrumentalidade política da arte conceptual para estabelecer momentos de comunicação crítica em/do contexto urbano. Se muitas vozes na arte de vanguarda dos anos 60, 70 e 80 - Art\&Language, Lawrence Weiner, Barbara Kruger - quiseram dizer algo em sede de discurso e linguagem, hoje, esse campo tão estreito mas ao mesmo tempo tão intensamente retórico da arte pública actual confirma-se como toda uma estética da palavra, desenvolvida com o concurso do design gráfico. Os ingleses Freee são um expoente actual desta linha; apresentando-se como incansáveis 'pregadores filistinos:

Freee are writing the agenda for a new kind of dissident art within the post-industrial, post-political society. Fusing a parody of early modernist manifestos with elements of Marxism and a critique of current conditions for cultural production, they challenge contemporary art's supposedly progressive institutional structures. With wit as well as teeth, they subvert he art-world they adopt as their constituency, leaving the imprint of thie rbite on the hands that feed them. ${ }^{94}$

0 'sabor' deste trabalho, que a ser reduzido à esfera da arte perderia o seu estatuto excepcional, é a sua capacidade de ser simultaneamente pensamento teórico, manifestação a activismo, irónica expressão de cultura la sua relação de pastiche com a linguagem das vanguardas e finalmente a capacidade de introduzir a sua reflexão meta-instrumentalmente na forma urbana. Tudo isto, na particularidade de um humor contundente, coloca-os numa via conceptual-pública, que, sedeada no mundo da arte, estabelece princípios e metodologias de superação da alienação do artista contemporâneo face à agenda de uma graça colectiva; isso acontece com um trabalho que é todo ele meta-arte de encontro com o social, de uma ambiguidade política radical, ainda que de génese marxista.

Em Dezembro de 2005, os Freee apresentam-se em Lisboa ${ }^{95}$ para uma palestra que deixa claro ao que vêm:

Our practice is concerned with the discourse around arts social potential and its relationship to public space and public sphere. Recent works discuss the 'functions' of public art and the notion of public good in relationship to social and economic regeneration policy. We are also preoccupied with the question of social change and its relationship to how we regard and understand notions of utopia. Our most recent works are text works. They have been produced as billboards, beer-mats, badges and posters. Our works usually come about after a period of time considering and working within a specific context, or are made specifically for a context that we identify. ${ }^{96}$

Muito envolvidos com o que chamam a indústria da arte pública97. Mel e Hewitt concretizaram esta posição numa série de três projectos de slogan (The Functions): Why functions of public art? To talk about public art as having functions is to point out how it is connected to,

93 O contacto com estes artistas teve lugar antes de Mel Jordan e Andy Hewitt estabeleceram a actual parceria com Dave Beech. Num retreat symposium organizado por Malcolm Miles/Plymouth University em 2005, destacaram-se, aliás como Christian Nold, nos debates acerca da crítica do conceito tradicional de 'arte pública'.

94 Miles, Malcolm (contracapa) in Beech, Dave; Hewitt, Andy; Jordan, Mel; The Freee Art Collective Manifesto for a Counter-Hegemonic Art, 2007.

95 Casa dos Dias d'A Água

96 Jordan; Mel; Hewitt, Andy; «Arte, Cultura, Mudança», in Luzboa - Lisboa Inventada pela Luz, p. 272

97 Idem, p. 274. 
complicit with and instrumental for wider social forces. Studying the function of a social practice or institution, according to Anthony Giddens, is to analyze the contribution which that practice or institution makes to the continuation of society as whole. ${ }^{98}$ Isto é, Hewitt e Jordan posicionam-se na arte, mas também, na crítica da sua constituição social e histórica: Functions are historically and socially specific. There was public art before there was a bourgeoisie and public art has had other functions. ${ }^{99}$ Se decorrem do ponto de vista inevitável da arte, estes projectos de slogans, são, também, acções marxistas, que procuram a mudança, no terreno ambíguo do texto, da teoria e da inscrição propagandística (conscientes de como funciona a sedução publicitária); evocando Art\&Language, Hewitt reforça esta ideia, de combate à reificação alienada do dispositivo cultural:

If everything is functional for society as a whole, then individuals are condemned to complicity. But instead of saying that functionalism does not explain resistance and insubordinancy, we need to see that the recognition of functions is a motivation for resistance. Functions change our perspective of things. For this reason, functionalism, especially in the elevated fields of religion and art, secularizes and politicizes by drawing the metaphysics of sacred practices back into social relations and networks of power..$^{100}$

O dispositivo publicitário e propagandístico (em toda a sua quotidianidade) torna-se então pura arte-da-cidade ou pura arte-da-cidade-como-espaço-público. Para tal desvaloriza as formas da festa ou do objecto, ou do processo, para preferir a concisão linguajeira; afirma-se, sob a forma de ensaios grafo-visuais que superficialmente parecem mera publicidade.

\subsubsection{As Functions: a arte pública como valor económico, estético e social}

Em The economic function of public art, a obra-frase é: The economic function of public art is to increase the value of private property. Ela lança a questão do papel da arte pública na regeneração económica das cidades pós-industriais, sujeita a modelos de desenvolvimento territorial hegemónicos..$^{101}$ Já The social function of public art - The social function of public art is to subject us to civic behaviour - foi primordialmente instalado no célebre Fourth Plynth, em Trafalgar Square, Londres, em 2005.102 A sequência desdobra-se em logos provocatório com The neo-imperialist function of public art is to clear a path for aggressive economic expansion. ${ }^{103}$

Muitas das questões que estas frases inscritas na cidade levantam ${ }^{104}$ foram as estabilizadas pelo urbanismo crítico. Elas laboram no núcleo argumentativo acerca do sentido da arte na cidade, mas pela singeleza, que desarma pela redução de efeitos (tanto tipográficos como linguísticos, como em Kruger ou Holzer, ou Penilo), funcionam como 'arte povera' do discurso, com uma capacidade de síntese específica do aforismo filosófico ou da política agit prop.

98 Idem.

99 Idem.

100 Idem.

101 Como acontece de forma mais ou menos deliberada e evidente na arte pública autárquica.

102 Projecto de posters It's the only life we know.

103 Na Segunda Trienal de Guangzhou, na China, numa eloquente paginação nos revolucionários vermelho (fundo) e amarelo (lettring caracteres chineses) da estética comunista. Peça realizada em colaboração com Dave Beech Public Structures, para o curador Gavin Wade.

104 Cf. Parte II. 
Neste situacionismo institucional, a festa é a das associações de ideias, espelhando a capacidade do ser humano social estabelecer novos acontecimentos discursivos, ${ }^{105}$ que salvem a sua consciência num conjunto de operações razoavelmente poéticas, se tivermos em conta a forma como estas frases são recebidas - nunca como statements apenas e só em si, mas sempre face aos discursos correntes da economia, da estética, do social, que desmascaram com panache; face à forma urbana, a várias escalas, que comenta visualmente (intertextualidade): uma esquina anónima em Sheffield; uma ponte turística em Veneza, durante a Bienal... Freee situam o texto na cidade.

Quando o projecto das Functions arranca, Dave Beech comenta, situando-nos na questão acerca da pertinência do termo arte pública: Public art is vexed. Three strands to public art's strained predicament stand out: one, the complexities, contradictions and rivalries within the public; (publics) two, contestation over what art is (Ideologies), and three, the exarcebation of the first two predicaments, that arises when you put them together in Public Art. ${ }^{106}$ Neste pensamento, a própria conjugação arte-pública continua assim a expandir a sua monstruosa ${ }^{107}$ função na cidade, precisamente enquanto exarcebação do 'público' (social) e da arte (pulsão e processo). Ora mesmo quando Andy manifesta a maior singeleza na enunciação dos seus objectivos - Through the placement and dissemination of these texts we are attempting to point to the fact that public art has no primary public audience, just passers'by ${ }^{108}$ - como não ver aqui uma manifestação de um pulsão pelo colectivo quotidiano, tão antiga como a atenção ao outro, e que aqui se metamorfoseia, enquanto está a ser germinada, em reflexão circunstancial sobre as suas próprias condições de existência e naturalmente enquanto poder (de inscrição)? Ainda Andy Hewitt:

We are also thinking of Jürgen Habermas' articulation of the public realm, he says the Word public sphere is too broad and clumsy to use in meaningful conversation. He says they have a multiplicity of concurrent meaning. Not just ordinary language (especially if it bears the imprint of bureaucratic and mass media jargon) but also sciences - particularly political science and sociology - do not seem capable of replacing traditional categories like 'public' and 'private', 'public sphere' and 'public opinion' with more precise terms. ${ }^{109}$

E nestes termos, enquanto superação dos limites quotidianos da linguagem da arte urbana, não serão os outdoors de Freee, a poesia situada de Rui Gabriel Silva (92), José Maçãs de Carvalho na LXCN (2001) ou Pedro Penilo no seu projecto 8!8!8! (2009) sempre a pura poesia do espaço público possível de ser pensado e exercido no domínio tendencialmente vertical da abstracção discursiva.

Os trabalhos de Freee são assumidamente produzidos no contexto do sistema da arte tal como ele existe ${ }^{110}$, e de facto o trabalho surge como um oximoro,

[...] may look like public art, made for a conventional understanding of a public audience of art - the 'primary audience'

105 A questão do diabólico no discurso humano, ou ,s e quisermos, do diabolicamente porque discursivo. Cf...

106 Idem, p. 275.

107 Cf. Caeiro, Mário; A Vida e o Monstro, 1997, Lisboa, Águaforte: a ideia da descoberta de uma voz através da performatividade discursiva.

108 Jordan; Hewitt, p. 275.

109 Idem, p. 275.

110 Jordan; Hewitt, p. 275. Mas separe-se We should state that we are not intersted in making something unique, we do not consider the photograph a documentation of an event in relation to say Conceptual Art. 
- who we have described previously as the passerby. And it might be that the passerby does engage with the work. However the works are made with a 'secondary audience' in mind: an audience who might not pass by or see the work in its first context. This audience is those who decide what public art is, the commissioners, the policy makers, and it is through dissemination via posters, postcards, web mail, and essays and talks that this audience 'sees' the work. We like to think there may be some discomfort for those engineers of 'publicness' and social cohesion in seeing questios of pubic arts function raised so publicly in the public sphere.111

O que me interessa aqui é a consciência crítica dos dispositivos.112 Essa crítica é acompanhada de cinismo anacrónico low profile: By describing this stuff we are not suggesting that we can step outside of it, we are just attempting to think about it and bring it up for discussion. ${ }^{173}$ De certa maneira, a forma compósita como estas afirmações dos Freee se inscrevem na cidade expõem uma das mais importantes descobertas que o meu percurso curatorial e de produção de arte contemporânea me trouxe: a dimensão de aforismo urbano que aqui irrompe literalmente da articulação entre o slogan - Protest is beautiful - e as opções plásticas da sua produção discursiva na cidade - a escolha de locais, cores, tipografia, para mais no quadro de um minimalismo formal, tornam-se veículos de significação le portanto também resistência intelectual em tempos sombrios). A disseminação cultural destas propostas inquisitivas é o seu poder de despoletar debate e informação na consciência colectiva, são iluminações acerca das perguntas, bem no âmago dos nós produtivos do seu funcionamento, apenas superficialmente (formalmente) restringidos ao espaço público urbano e à palavra de ordem.

Perante as definições de cultura por Catherine Belsey, Miles recorda uma dimensão imponderável do colectivo sonhado, e que o temo utopia, atabalhoadamente, foi conjugando, tanto quanto é possível pensar o caminho ao mesmo tempo que o fazemos, sobretudo na arte, a partir da arte, que é porventura o pouco que temos, se quisermos, relacionar a capacidade de renovação da sociedade e a ideia desta como obra de arte:

The fantasy of a unified world persists. The concept of a public sphere is fabled and does not come into being. This does not mean a sphere cannot exist in which a society shapes itself. It means that I am unable to conceptualise that sphere because its from is changed in the moment of its perception, emerging beyond representation. Perhaps it makes no dfference whether the square is with or without the statues, But we ask for more than broken bronzes; we ask for a location in which a society is continuously renegotiated as an always-unfinished determinantion of itself.114

Da Foz do Arelho"15 a Veneza, as frases dos Freee funcionam então como obras de arte portáteis, imponderáveis no seu percurso até cada um de nós. Esta diluição radical do objecto anda a par da problematização do contexto socio-político em que arte pública se desenvolve.

I do not read public spaces as sites of democracy. I appreciate Zymunt Bauman's argument that the task of critical theory is to defend the vanishing public realm, or rather to refurnish and repopulate the public space fast emptying to the exit of the 'interested citizen', and the escape of real power into the territory which... can only be described as 'outer space'. (Bauman, 2000: 39). Interest in public urban space is a reaction to its growing encroachment by private-sector space [...] but the public sphere is elsewhere. It always was. ${ }^{116}$

111 Idem.

112 Que depende obviamente da criticidade do contexto, situação criada, âmbito institucional. Os Freee apresentaram-se no Porto, na Culturgest, em 2010, não havendo aqui espaço para uma reflexão sobre se a sua verve de institutional critique funcionou melhor ou pior que enquanto discurso crítico em conferência.

113 Jordan; Hewitt, p. 275.

114 Idem. De novo ecos de debates intensos acerca do que diz uma obra de arte na cidade - poderíamos voltar a evocar o episódio da cobertura da estátua de Salazar, em 28 de Maio de 74.

115 Hewitt e Jordan participaram em 2006 num simpósio-retiro na Foz do Arelho, organizado em parceria com a ESAD.CR; no dia seguinte, apresentaram uma conferência na Casa d'Os Dias da Água, juntamente com Malcolm Miles.

116 Miles, Malcolm; «Displaced Monuments and Public Spheres» in Luzboa - Lisboa Inventada pela Luz, p. 277 


\subsubsection{Espaço Público algures: um manifesto utópico}

Na obra The Freee Collective Manifesto for a Counter-Hegemonic Art ${ }^{17}$, os FREEE (Jordan, Hewitt + Dave Beech) propõem uma radical pulverização do sistema das artes e das ideias culturais que the estão subjacentes (a divisão cultural). Nessa obra, o noema Espaço Público é a pedra de toque de uma programa político para a habitabilidade do espaço urbano e da sociedade tomados pela revolução filistina: Counter-hegemonic art turns its attention chiefly to the bourgeois public sphere because it is deeply debased and bound to be carried off under more developed and confident philistine, and because the counter-public sphere will be but the prelude to an immediatly following social revolution. ${ }^{118} \mathrm{~A}$ relação que quisermos manter com este statement anti burguês, ou pelo menos anti-a-apropriação que a Civilização Burguesa fez da instância criadora e do estatuto social do criador, relegado para uma dimensão decorativa, quando ele próprio deveria poder ser plataforma reflexiva e sociall19, é múltipla. Podemos preferir admirar o registo de ironia ou convencer-nos do envolvimento activista, podemos acentuar o carácter catárquico ou de sublimação artística, ou ainda a expressividade do exercício retórico, ou finalmente as seríssimas virtualidades efectivamente políticas desta arte contra-hegemónica, mas a verdade é que a responsabilidade da decisão de estar lá là altura do nosso Tempo) é passada pelos artistas-autores para nós, leitores. A construção do noema arte pública vai assim construindo-se, com contributos diversos.

De uma penada, o próprio problema central do Poder (e do Gosto) é exorcizado:

In short, counter-hegemonic art everywhere supports every revolutionary movement against the existing social, political and cultural order of things. I In all these movements, it brings to the front, as the leading question in each, the hegemony question, no matter what its degree of development at the time. / Finally, it labours everywhere for the union and agreement of the radical art of all countries. [...] Let the cultural hegemon tremble at a philistine revolution. The philistines have nothing to lose but their shame. They have a world to win. Philistines of the world, arise! 120

Parece-nos esta ser uma forma muito contemporânea de exercitar o músculo das ciências sociais, a arte retórica e o sentido de cidadania, com graça, alcance e pertinência cívica; e estes são factores característicos importantes para repensar permanentemente a arte como espaço público. Andy Hewitt e Mel Jordan, antes e depois de serem Freee com Dave Beech, marcam a agenda de uma arte dissidente, consciente da sua situação no seio da sociedade pós-industrial e pós-cultural.

Quanto à leitura do Manifesto, é um exercício periclitante de interpretação. Limitar-me-ei a alguns tópicos que se cruzam com os temas da atenção, do dispositivo e da graça. Num aprofundar de Eagleton, os Freee começam assim o seu manifesto:

High and Low culture, folk art and courtly love, avantgarde and kitsch, mass culture and autonomous art, popular and elite culture, connoisseur and philistine, in a word, oppressor and opressed, stood in constant opposition to one another, carried on an uninterrupted, now hidden, now open fight, a fight each time ended, either in a revolutionary reconstitution of culture at large, or in the common ruin of the contending rivals within cultural division. ${ }^{121}$

117 Beech, Dave; Hewitt, Andy; Jordan, Mel; The Freee Art Collective Manifesto for a Counter-Hegemonic Art, 2007.

118 Beech, David; Hewitt, Andy; Jordan, Mel, The Freee Art Collective Manifesto for a Counter-Hegemonic Art, Freee Publishing, Sheffield, 2007. [p. 32]

119 Lançamento informal em Veneza, como actividade paralela à Bienal de Veneza, 2007.

120 Freee, p. 33.

121 Freee; The Freee Art Collective Manifesto for a Counter-Hegemonic Art, 2007, p. 6. 
No complicated arrangement [e] manifold gradation of cultural rank ${ }^{122}$ que é a cultura e sua indústria, os Freee avançam a síntese política de uma arte que, apesar de encenar, teatralizando-a, a provocação antagonista marxista (dialéctica) supera os antagonismos numa operação comunicacional que, na prática, suspende as divisões culturais para se afirmar como graça discursiva. São porém densas as imbricações dos tópicos 'sociedade burguesa', 'autonomia da arte', 'indústria cultural', 'antagonismo'; algures entre Marx e Lefèbvre:

\begin{abstract}
The debased public sphere cannot exist without novelty, constantly revolutionizing the products for sale, and thereby constantly shifting cultural relations, and with them the whole relations of society. [...] Constant revolutionizing of form and style, uninterrupted disturbance of all cultural conditions, everlasting uncertainty and agitation distinguish the culture of the debased bourgeois public sphere from all earlier ones. All fixed, fast frozen relations, with their train of ancient and venerable prejudices and opinions, are swept away, all new-formed ones become antiquated before they can ossify. All that is solid melts into air, all that is holy is profaned, and the consmer of art is at last compelled to face with sober senses the economic conditions of art and the relations between quality and hegemony. ${ }^{123}$
\end{abstract}

Neste quadro, a revolução filistina vai ser um conceito forte na argumentação dos Freee - é um conceito estrutural para a arte pública que queira integrar o vernacular, numa resposta à globalização:

Culture suddenly finds itself put back into a state of momentary barbarism; it appears as if a famine, a universal war of devastation, had had cut off the supply of every means of consensus; culture and morality seem to be destroyed. And why? Because there is too much culture, too much information, too many truths, too much controversy.

Os Freee devolvem à arte o seu carácter de meta-linguagem retórica que salva a consciência da actualidade, no tempo transbordante da cultura. Não para procurar um qualquer consenso salvífico, mas para constituir-se posto avançado (neovanguarda) de uma mudança que reputam de inevitável, mais do que iminente. 0 'nada ainda aconteceu' de Kafka fica agora 'resolvido' no 'está a acontecer' do acontecimento, pois as forças culturais em jogo

[...] bring disorder into the whole of the bourgeois public sphere, endanger the existence of the existing society. The conditions of the society are too narrow to comprise the wealth of culture created by them. And how does the cultural hegemony get over these crises? On the one hand, by spectacularizing consensus in the consumption of mass culture; on the other, by the aestheticization of the art market, and by the nostalgic and more destructive crises, and by diminishing the means whereby crises are prevented. ${ }^{124}$

E assim, When people speak of a culture that revolutionizes society, they do but express the fact that within the old society the elements of a new one have been created, and that the dissolution of the old cultural hegemony keeps even pace with the dissolution of old social forces..$^{125} \dot{E}$ evidente, este lado profético é em si uma inscrição retórica sustentada por reflexivdade dialéctica. ${ }^{126}$ Acredito que a arte extramuros é também esta inscrição de proposições mais ou menos 'avançadas num continuum histórico, e no limite, a inscrição do próprio acto de se poder reflectir livre e colectivamente, necessariamente (e não arbitrariamente) sobre os factos da vida e da vida da arte. Neste âmbito, a metáfora filistina introduz uma nota de racionalidade revolucionária na história da arte e, num certo sentido (na sua crítica da arte urbana) radicaliza todas as aberturas anteriores, de Duchamp a Klein, de Beuys, Morris, Smithson a Kaprow:

\title{
122 Idem.
}

123 Idem, p. 7.

124 Idem, p. 10.

125 Idem, p. 18.

126 Idem: No wonder, then, that the cultural distinctions of past ages, desoite all the multiplicity and variety it displays, moves within certain common forms, os structures, whih cannot completely vanish except with the total disappearence of the social antagonisms that produce them. 
There are, besides, eternal values such as aesthetic qualiy, beauty, discrimination, etc., that are known to the adequately sensitive and adequately informed spectator of art and are common to all states of society. But philistinism abolishes eternal truths, it abolishes all religion, and all morality, instead of constituting them on a new basis; it terefore acts in contradiction to all past historical experience. ${ }^{127}$

Esta questão enquadra a arte num agora que urge recomeçar sempre: one fact is common to all past cultures, viz., the hegemonic domination of one part of culture by the other. ${ }^{128}$ Foi esta a consciência crítica que aliás moveu as sensibilidades e a atenção tanto de Lefèbvre como de Situacionistas e outros neovanguardistas do campo relacional. A 'novidade' que procuro introduzir é assim, nestes termos e no campo da arte pública, a da importância do conhecimento retórico para esta deriva sempre recomeçada - que é uma cultura que parte da inevitabilidade do humano social e lhe prefigura espaços de abertura cognitiva - e serve - pelo menos para já - o programa que a visão filistina entretanto já impôs como a linguagem do que não aspira à hegemonia. Isto é, se há uma arte que desvela - e não re-vela - o seu sentido enquanto retórica do social tal como formalizado na cidade - ela é a arte extramuros. Nos momentos mais delirantes da sua proposta, o seu poder de evocação da imaginação do leitor, estamos perante a encenação em texto de uma revolução anunciada:

The philistine will use its cultural supremacy to wrest, by degree, all cultural capital from the aesthete and the bureaucrat, to decentralize all instruments of cultural power and prestige from the hands of the state and market; and to increase the total cultural and aesthetic range of pleasures and positions as free as possible. ${ }^{129}$

A questão é muito mais que uma 'piada', por uma razão: em tempos de barbárie, a comunicação da arte que os Freee empreendem é uma profilaxia da estupidez que sob várias formas nega a vitalidade da arte na abordagem realista da cultura contemporânea. $E$ basta resgatar da monumental blague que esta passagem propõe um sentido de desesperada, mesmo quando absurda, proposta de resgate da própria arte, aliás aprofundando exercícios críticos da teoria crítica e das neovanguardas:

Of course, in the beginning, this cannot be effected except by means of despotic inroads on the priviliges of aesthetic taste and established cultural distinctions, and on the conditions of the debased bourgeois public sphere; by means of measures, therefore, which appear culturally insufficient and untenable, but which, in the course of the movement, outstrip themselves, necessitate further inroads in the old cultural order, and are unavoidable as a means of entirely revolutionizing the cultural hegemony, its social functions and the social relations and hierarchies that underpin it. / These measures will, of course be different in different countries, different cultures and different subcultures. Nevertheless, in most instances, the following will be pretty generally applicable.

1. Abolition of cultural distinction and subjection of all cultural privileges to the scrutiny of counter-public spheres.

2. A corrective inversion of all existing cultural values.

3. Abolition of the institutionalized forgetting of the acquisition of cultural capital.

4. Secularization and demystification of the privileges of all aesthetes and elitists.

5. Abolition of the centralization of cultural authority and cultural capital in the universities, galleries, and other insttitutions of legitimation, by means of a national network of seld-organized institutions with state capital. The state must fund art and culture against the state.

6. Decentralization of the means of cultural transmission, intellectual communication and self education out of the hands of the state and market.

7. Extension of universities and galleries run by ordinary people; the recognition of cultural and intellectual hegemony of the bourgois public sphere, and the improvement of the culture generally in acordance with the abolition of cultural division. 
8. Equal obligation of all to establish, maintain and participate in the counter-public sphere. Establishment of cultural forums, especially for self-education.

9. Combination of bodily with intellectual pleasures; gradual abolition of all the distinction between body and mind by a more equable distribution of the pleasures over teh culture.

10. Free seld-education for all children and citizens in counter-public schools, galleries and critical forums. Abolition of the education industry and the culture industry in their present form. Combination of self-education with counter- public cultural production, etc.

O mais interessante e que Freee não deixam de, no capítulo seguinte, elencarem um série de 'desvios' - emprego a linguagem operacional - na arte crítica, que um a um escalpelizam ${ }^{130}$. Em «Radical and Oppositional Art and Culture», 'arrasam' muitas das modalidades contemporâneas da arte (pública).

\section{Com as letras todas}

Em «New Aestheticism»: Nothing is easier than to give Adornian asceticism a radical tinge [...] New Aestheticism is but the holy water with which the priest consecrates the heart-burnings of the culturally privileged. ${ }^{131} \mathrm{Em}$ «Art's Debunkers» os Freee 'cascam' nos radical precursors, and cultural overse, of the new aestheticism ${ }^{132}$ : In cultural thinking where the Marxist sociological analysis of art's elitism has become fully debeloped, a cultural position of debunking art has developed, fluctuating between philistne and aesthete, and ever renewing itself a supplementary part of the artworld. ${ }^{133} \mathrm{Em}$ «Art Activism», a o foco são os activistas:

Militants, politicos, and subversives struggle against power within and without art by direct means, thrugh political activism as art, or art as political activism, or actvism under art as a flag of convenience. Radicals, would-be radicals, and embers of revolutionary partie, eagerly seize on activism as a form or source of art, only forgetting that when these tactics immigrated from politics into art, social conditions for action had not immigrated along with them. In contact with the social conditions of art, this political activism loses a significant element of its immediate practical significance and becomes mixed with purely aesthetic aspect. This is why activists are frustraded by the formal, stylistic and aesthetic reception of their activism when it enter art's institutions ${ }^{134}$

Mais,

The work of art activists consists largely in bringing political ideas and processes into art, or rather, in annexing art without deserting their own political point of view. / This annexation takes place in the same way in which a foreign language is appropriated, namely, by translation. / It is well known how the monks wrote silly lives of Catholic saints over the manuscripts on which the classical works of ancient heathendom had been written. The art activists reverse this process with the philistinism of politics. They insert their political activities into the gap left by the critique of Inon-activist) art. For instance, the familiar format of the political poster is used to propagate ecological politics, and the conventions of the olitical campaign are used to build consciousness about torture, and so forth. The introduction of these plitical porjects on the back of art is utterly conventional despite its subversive content. ${ }^{135}$

Pior: Thus, both politics and art are completely neutralized in art activism. ${ }^{136} \mathrm{E}$ em consequência, nenhuma real consciência do dispositivo social é colocada em causa:

Their political Project, and especialy the attempt to engage politicaly in the public sphere, which is precisely what art

130 Idem, pp. 22-30.

131 Idem, p 23.

132 Idem.

133 Idem.

134 Idem, p. 24.

135 Idem, pp. 24-25.

136 Idem, p. 25. Recordo-me aliás que a noção de 'activista cultural', com que Mile sme brindou numa palestra em 2001, na $\mathrm{LXCN}$, acana por ser mais neutra e operativa... 
activism is, a bourgeois past-time, is literally cut off from the social conditions that it needs but no longer exist except in degraded form. [...] To the neo-liberal governments, with their following of aesthetes, professors, entrepreneurs, and bureaucrats, art activism serve as a welcome scarecrow against real cultural and social change. ${ }^{137}$

E portanto, to preserve this art activism is to preserve the existing state of things in cultural hegemony and social relations..$^{138}$ No final,

art activism is populist without being popular. [...] It proclaims political organization to be the model social structure, and the radical art loving philistine to be the typical citizen. With very few exceptions ${ }^{139}$, all the so-called radical and subversive art that now circulate in the artworld belong in some measure to the domain of this foul and enervating outlook. ${ }^{140}$

Estes três primeiros pontos estão reunidos, significativamente sob o ponto «1. Reactionary Radicalism». E portanto, o que estas breves notas revelam é uma muito acutilante denúncia de várias ingenuidades (Perniola) da/na arte-pública. E no final, temos que a forma textual é particularmente feliz para apreender uma tão urgente quanto inevitável desmontagem da matriz da arte em nome da potencialidade critica do pensamento e do discurso. Em Art's Debunkers, por todo o seu desmantelar da 'arte crítica' Freee resumem boa parte das 'boas intenções' em arte pública crítica, apontando a uma arte-depois-da-crítica, com saída para as 'partidas' críticas dos agentes mais resistentes do sistema.

This school of critical thinking has dissected with great acuteness the contradictions in the conditions of contemporary art. [...] It proved, incontrovertibly, the disastrous effect of cultural distinction and cultural division; the concentration of cultural capital in a few dedicated hands; it pointed out the inevitable ruin of art's elevation and separation from ordinary life, the misery of asceticism, the anarchy in the art market, the crying inequalities in the distribution of cultural capital, the cultural war of prestige between nations the dissolution of old craft skils, of the old school tie snobism, of the old elitism. I In its positive aims, however, this form of Marxist cultural criticism confined our cultural choice to restoring the old categories and values, and of the self-image of art's professioanl defenders, and with them the old cultural relations, and the old society, or to abolish art altogether. [...] The problem with the debunking of art is not that it demands the complete annihilation of serious culture but that it is not negative enough. Art can't be negated o the basis of a false dilemma that preserves art in aspic as a precondition for abolishing it. In either case, it is both reactionary and Utopian. ${ }^{141} \mathrm{E}$ 'arrumando a questão' definitivamente: Ultimately, the possibility - and actuality - of the transformation of art and reconfiguration of cultural consigns this form of Marxist cultural commentary to the footnotes of counter-hegemony. ${ }^{142}$

Este excerto de um marxismo cognitivo - será aí que Nold labora? - poderá contrapor uma vitalidade contra-hegemónica face ao capitalismo cognitivo. ${ }^{143}$ Mas a forma escolhida para o dizer é eminentemente enigmática.

\section{Noutro ponto do seu manifesto, os Freee 'atiram-se' à «Culture-Led Renovation»:}

To this section belong New labour politicians, economists, townplanners, educationalists, quangocrats, philantropists, humanitarians, improvers of the condition of the inner city, organizers of charity, nosey neighbours, hole-and-corner reformers of every imaginable kind. [...] We may cite Charles Landry's 'The Creative City' as an example of this. ${ }^{144}$

\section{Idem.}

138 Idem.

139 A julgar pelo percurso expositivo e outros dados penso poder dizer que tanto Bill Viola como Krysztof Wodisczko estraiam entre essas excepções.

140 Idem, p. 26.

141 Idem, p. 24.

142 Idem.

143 Cf. Brea, José Luís; El Tercer Umbral - Estatuto de las prácticas artísticas en la era del capitalismo cultural. Numa obra incontornável enquanto diagnóstico das prácticas culturais contemporâneas, o autor refere, como estádios anteriores do capitalismo, o capitalismo industrial e o capitalismo de consumo. Brea define, nesse quadro, o estatuto da arte contemporânea mais crítica: basándola no tanto en la localización de cortes estilísticos o formales cuanto en su relación a las transformaciones de le esfera del trabajo y la producción, y como ellas determinam alguns demarcaciones significativas en la del campo de las prácticas culturales, por un lado, y en su relación con los modos y figuras del imaginario social, con las expectativas emancipatorias de la ciudadania y la construcción colectiva de las formas del 'espíritu objectivo', por otro.

144 Idem, p. 26. 
E exemplo máximo desta atitude, como de forma 'neutra' procurei exlicitar na Parte II, é o que dá à arte pública uma função reformista: $A$ version of middle-class social reform, practical and systematic, is culture-led regeneration. [...] É a arte ao serviço de uma redução dos horizontes e das possilibilidades de mudança, senão de 'evolução':

Culture-led regeneration, therefore, ultimately seeks to depreciate every revolutionary movement in the eyes of the working class by showing that no mere political reform, but only a change in the material conditions of individual existence, i.e., their standard of living and their vocational aspirations, could be of any advantage to them. By changes in the material conditions of exietence, this type of reformism, however, by no means understands abolition of the existing relations of production. ${ }^{145}$

Conhecemos os 'apaniguados' desta posição na cultura middle-of-the road do chamado 'bloco central' (a ideologia dos partidos do centro na democracia representativa) que nunca criou um projecto colectivo, mas estimulou o consumo individual de um sonho burguês alimentado quer pelos mindscapes europeu e americano, quer por laivos de passadismo folclorista, na tradição salazarista. Isto ao nível do povo, porque ao nível da intelligentsia, muitas vezes as questões fundamentais não deixaram de serem pensadas. Em suma,

Culture-led regeneration attains adequate expression when, and only when, it neutralizes the threat of working class youth by inculcating the aspirations of the good worker. Thus, culture-led regeneration puts art's cultural hegemony into the service of social hegemony pure and simple. ${ }^{146}$ Culminando magnífica constação da ilusão tautológica da identidade burguesa: It is summed up in the phrase: the middle-class is middle-class for the benefit of the working class. ${ }^{147}$

Finalmente, que dizem os Freee dos «Cultural Studies and Critical Postmodernism», que desde logo reputam de primeiras tentativas expressas de a classe trabalhadora legitimar a sua própria cultura academicamente? ${ }^{148}$ Primeiramente,

They inculcated an uncritical celebration of popular culture and sponsored relativism in its crudets form. [...] But the philistine critique of cultural hegemony, as yet in its infancy, offers to them the spectacle of a counter-hegemony without any historical force or any independent cultural instituions. / Since the development of cultural anatagonism keeps even pace with the development of hegemony, the social situation, as they find it, does not yet offer to them the material conditions for the emancipation of the philistine. They therefore search after a new social science, after new social laws, that prefigure these conditions. ${ }^{149}$

Nesta posição há um 'aproveitamento' das ricas realidades do povo para se construírem carreiras na academia, uma incapacidade para ir além do tratamento dos objectos de estudo - as pessoas nas suas relações sociais - para além da categoria do 'consumo de massas: Only from the point of view of being the 'mass' audience does the proletariat exist for them ${ }^{150}$ - e porque não distinguem questões de classe, acabam por reject all political, and especially all counter-hegemonic art; they wish to attain their ends by means of consumption, necessarily doomed to failure, and by the force of example, to pave the way for the new social gospel. ${ }^{151}$ Já o pós-modernismo crítico,

[...] depicts an already levelled society, painted at a time when the counter-public sphere was still in a very undeveloped state and has but a speculative conception of its own universalization. The best thing that can be said of postmodernism

\footnotetext{
145 Idem, p. 27.

146 Idem, p. 27.

147 Idem, p. 28.

148 Idem, p. 28

149 Idem, p. 28.

150 Idem.

151 Idem, p. 29
} 
is that it corresponds with the first instinctive yearnings of counter-hegemony for a general reconstruction of culture.

/ This is why postmodenism contains also a critical element. 152

Porém, na sua constante e efervescente e contínua reavaliação do popular e do erudito, na sua promoção da inclusividade cultural, e sobretudo na conversion of the function of the criticism into a mere superintendence of products, são para os Freee utopia grave:

[...] although the originators of Cultural Studies and Critical Postmodernism were, in many aspects, revolutionary, their disciples have, in every case, formed mere reactionary sects. They hold fast by the original views of their predecessors, in opposition to the progressive historical development of the philistine. They, therefore, endeavour, and that consistently, to deaden the cultural prospect of a counter-hegemonic art and to reconcile cultural division. ${ }^{153}$

E então, They. Therefore, violently oppose all political action on the part of the working class; such action, according to them, can only resut from blind unbelief in the meta. ${ }^{154}$

Mas Freee sentem a responsabilidade de rematar este diagnóstico com notas prospectivas: Counter-hegemonic art supports cultural radicals in all fields, without losing sight of the fact that they invariably consist of antaginistic elements, partly of reformist, partly of radical tendencies. ${ }^{155}$ É o assumir de uma linha de orientação: Counter-hegemonic art fights with cultural hegemony whenever it acts in a revolutionary way, against the absolutes of aesthetics, the feudal hierarchy of cuture, and the bourgeois public sphere. ${ }^{156}$ Ora daqui já pode depreender-se que um arte crítica extramuros será de certa forma a que assume a agenda contra-hemónica, mas na maior transparência, democraticidade e graça dos dispositivos a que recorre; levando cada acção discursiva para um patamar de cognição do urbano que é pura poesia do devir social. O que só pode acontecer porque, como o termo extramuros indica, há uma ansiedade particular, talvez paralela à de sair de um estado de coisas: counter-hegemonic art everywhere supports every revolutionary movement against the existing social, political and cultural order of things. ${ }^{157}$

Evidentemente, é possível ler estes 'arrazoados' ressalvando a sua dimensão de análise científica, a sua dimensão poética, o seu labor utópico, a pura ironia ou finalmente a instrumentalidade metaoperativa; como num romance de Kafka, é a sua dimensão de aforismo distendido que permite suspendermos o próprio prazer da leitura num momentum de elevada intensidade retórica. Vimos atrás o objecto que na forma urbana, apesar de tudo, reflecte um aspecto temporal-cósmico-universal da sua inscrição (Chevalier), vimos a resistência propriamente humana do corpo e da sua capacidade se desligar do discurso para significar (Gasco), e vemos agora como a consciência politica e retórica do discurso (Freee) como que ponta para formas de produção colectiva capazes de entrever utopia-já da participação total cidadã (Nold). Nesta atenção inicial - parte fulcral do inventio do manifesto - eu diria que se constitui uma atenção primordial à divisão cultural vigente e ao facto de esta se traduzir em tensões políticas de fundo no seio da obra de arte, e de que a arte é refém. A posição extramuros será sempre a de contestar a estabilidade destas

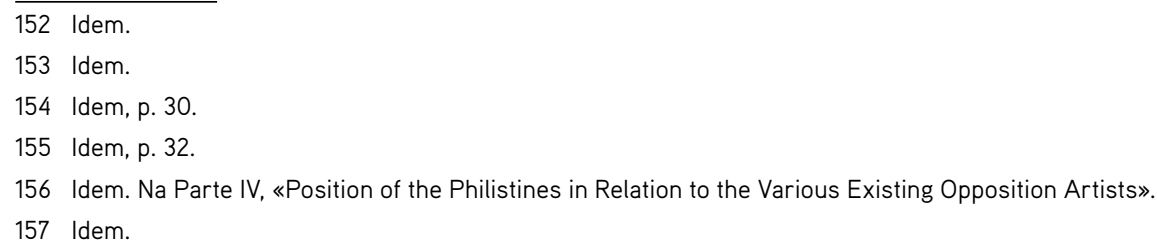


divisões e naturalmente provocar limites - ultrapassar limites disciplinares, territoriais, discursivos. Sobretudo em sede de projecto, necessariamente -, que sabemos tratar-se de um dispositivo que encerra/abre todos os outros. Em suma, e seguindo a lógica dos Freee, é necessário manter acesa a chama de uma atenção genérica ao fenómeno da arte como divisão cultural e termos permanentemente a consciência da sua inevitabilidade não com aspecto negativo ou definitivo, mas precisamente como elemento projectual (como em Gasco). Em suma, o que está em causa é a forma-arte enquanto forma-comunicação face ao qual o trabalho dos Freee é iminente superação histórica.

\subsection{Christian Nold - mediar o saber colectivo}

Um dos factos sócio-culturais fundamentais a reter quando se reflecte sobre a contemporaneidade relaciona-se com a existência de inúmeros focos de conhecimento e experimentação, tanto ao nível tecnológico como artístico, em que o próprio tema da complexidade do social motiva estudos originais e intervenções culturais pertinentes pela parte de protagonistas das mais variadas origens geográficas e territórios disciplinares. Frequentemente, os papéis do 'artista', do 'pensador', do 'cientista' ou do 'técnico' são revistos e reinterpretados à luz de uma posição de intervenção cívica caracterizada por uma transdisciplinaridade militante, como se a única maneira de intervir na organização das sociedades fosse a de problematizar as suas próprias matrizes tecnológicas, sócio-políticas e culturais das quais emanam os vícios da impotência ou do consumo. Christian Nold é representativo desta sensibilidade. $\mathrm{Na}$ sua intervenção, o princípio de extraterritorialização cultural já não corresponde apenas ou necessariamente a oportunidades de sair do museu para activar um lugar público, 'colocando arte' num determinado espaço, mas antes resultado da consideração do sítio e do mundo (Cauquelin) na sua totalidade. Isto levou-o a projectos de arte-investigação ${ }^{158}$ que são exemplares de uma suspensão da categoria 'arte' em prol de uma acção directa e imediata baseada na intersubjectividade. O resultado 'final' dos seus workshops são um mapear alternativo da cidade.

\subsubsection{Informação como consciência dos dispositivos}

Christian Nold é artista, designer, formador e investigador ${ }^{159}$. Interessa-se particularmente pela importância que os mapas participativos podem ter enquanto ferramentas de mobilidade urbana. O seu primeiro livro, Mobile Vulgus (2001), é dedicado à história das movimentações de massas com carácter político, dando o mote para uma investigação continuada ${ }^{160}$. Em Portugal, registe-se a realização de um workshop Biomapping nas Caldas da Rainha, em 2005, na sequência do qual apresentaria, na Galeria Zé dos Bois, a conferência "How

158 Ver http://www.softhook.com ou www.biomapping.net, apresentado em Portugal em 2006.

159 Mestre em Interaction Design pelo Royal College of Art em 2004, e actualmente docente na Bartlett University College London, Nold tem coordenado inúmeros projectos realizados por equipas interdisciplinares, não apenas ao nível académico.

160 Cf. Nold, Christian; «Legible Mob», in Latour, Bruno; Weibel, Peter (Eds.), Making Things Public: Atmospheres of Democracy, MIT Press, 2005. 
did we loose sight of each other?" (Como é que nos perdemos uns dos outros?), uma palestra que apresentou uma série de modelos mentais e ferramentas práticas que lidam com o problema da representação política no nosso mundo saturado pelos media. Traçando uma ligação entre os protestos de rua no Séc. XIX até ao activismo tecnológico do Séc. XXI, Christian Nold sugeriu nessa conferência o tema implícito no seu plano de trabalho: um futuro radical de ferramentas biopolíticas que reestruturam a nossa relação com o meioambiente e uns com os outros.

Christian Nold thinks we should pay more attention to how our environment shapes our emotional and physiological states. His work with Bio Mapping-which measures people's responses to their environment and connects those feelings to their physical location-suggests that a map of emotional landscapes represents a powerful tool for analyzing the relationship between place and broader social issues. ${ }^{161}$

Na visão de Nold, estamos numa fase em que as tecnologias de informação estão a transformar radicalmente as relações humanas, ao nível económico, político, cultural e interpessoal. Com a afirmação do computador como meio universal the shift of all culture to computer-mediated forms of production, distribution and communication ${ }^{162}$ é acompanhado por uma virtualidade vernacular de que urge não apenas retirar condições para encontros emancipatórios (O'Sullivan) mas, mais atrás, perceber a própria 'origem' (Fiedler, Flusser): Virtuality is the cultural perception that material objects are interpenetrated by information patterns..$^{163}$ Nold trabalha então num aumentar da realidade através de mecanismos meta-informativos. Com Nold, o regresso à realidade (Foster, Skrebowski) passa pela prática do espaço; contribui portanto, tal como as formas mais críticas de realidade aumentada ${ }^{164}$, para o spatial turn do pós.modernismo (Jameson). É praxis de uma emergente Arquitectura Informacional (Skrebowski), admittedly a young design discipline. [...] It might almost be considered a digital craft. ${ }^{165}$ É, note-se uma 'arte' (craft) do interface, e em particular de uma Interface Politics (Skrebowski), dispositivo arquitectónico mediador no habitar da cidade contemporânea em todas as suas dimensões, e naturalmente partindo da totalidade computável. Nold interpreta aquilo que Latour ${ }^{166}$ define como a ética do interface (ou dispositivo): Entre deux réseaux, il y a, une interface. Cela permet de les rendre 'compatible'.167 Só assim

We can legitimately speak of an interface politics. The design of pervasive, spatialized interfaces constitutes a political act. The act becomes increasingly political the more the interface mediates. [...] The stakes are high, nothing less than the quality of our collective life. 168

$161 \mathrm{http} / / /$ vodpod.com/biovidatv/tag/biomapping

162 Manovich, Lev; Ths Language of New Media, Mit Press, 2001, p. 19.

163 Vimo-lo em Flusser: Note that the definition plays off a duality - materiality on te one hand, information on the other. The bifurcation between them is a historically specific construction that emerged in the wake of World War II... The perception facilitates the development of the Technologies, and the Technologies reinforce the perception. Skrebowski, Luke; «Augmenting reality: pervasive computing, spatial practice, interface politics», in Basar, in Miessen, Basar (eds.), p. 42.

164 Cf. Laboratório de Luz da Universidade Técnica de Valência.

165 Skrebowski, p. 48. As such it is still seeking the visibility and legitimization of Professional status. É aliás isso que explica a relativa 'invisibilidade' de Nold enquanto 'artista-investigador', apesar de fugazes presenças em exposições de referência.

166 Curador que, juntamente com Peter Weibel, programa Nold para a célebre exposição Making Things Public - Athmospheres of Democracy, ZKM, Março, 2005.

167 Latour, Bruno; 'Interface' in Jean-François Lyotard (ed.), in Les Immatériaux, Paris, Centre Georges Pompidou, 1985, p. 105.

168 Skrebowski, p. 51. 
Para Bruno Latour, radicalizando o cinismo de Sloterdijk na materialidade das coisas, e num quadro de experiência redentora da totalidade, trabalhos como o Nold rejeitam a $R e-$ alpolitik peloa que Dingpolitik - politica das coisas. ${ }^{169}$

Desenrolam-se acesas batalhas não apenas pela representaçã $0^{170}$ mas propriamente pelo acesso, a segurança e a autonomia dos fluxos, com o público a ser chamado a sê-lo participada- e informadamente. Mas o (desenho d)espaço urbano não reage em tempo útil a estas mudanças, e toda uma nova geração de indivíduos e comunidades empreendem experiências cívicas, educativas, políticas ou ecológicas que criam os seus próprios contextos. Inspirando-se em experiências de arte pública crítica, emerge uma esfera pública pós-industrial, com os governos e as empresas a serem objecto de escrutínio produtivo, de acordo com novos parâmetros de activismo e colaboração. Nold é chamado com frequência a desenvolver o seu trabalho em contextos que não são de todo artísticos; é um actor e agente de transformação da consciência cívica, propondo ferramentas tecnológicas para criar comunidades responsivas, quase sempre através de palestras e encontros lem que o peso da palavra pública é determinante) e workshops ou experiências práticas de índole formativa (para grupos relativamente restritos, por forma a garantir uma máxima interiorização, e não a espectacularização, dos dados transferidos, entre o artista e essas comunidades provisórias. Surge assim o conceito operativo de participatory mapping, campo em que Nold se tornou referência, aprofundando inovadores mecanismos de representação numa deriva territorial quer da geografia, quer da arte (Lacy, Mapping the Terrain). Nold já trabalhou em cerca de vinte países e com mais de 1500 particpantes, incluindo grupos de pressão, instituições científicas, organizações de media, jovens, agências de desenvolvimento e autarquias. Os projectos passam por desenvolver tecnologias de computação capazes de reunir dados e ciar visualizações colaborativas juntamente com os participantes e podem assumir a forma de consultadoria, investigação etnográfica, transferência de competências, workshops ou exposições de arte contemporânea. O modelo consensual do trabalho tem o mérito de reduzir a distância entre experiências e consciência qualitativas e o quantitativas, permitindo às pessoas articularem as suas preocupações, ideias ou hipóteses colectiva- e criativamente. Para criarem eles próprios uma comunidade responsiva, estes projectos ancoram-se, por um lado, na experiência graciosa de uma efémera communitas tecnológica; por outro, numa conscientização de como podem funcionar os contra-dispositivos capazes de posicionar o humano no macro-dispositivo da tecnociência actual. ${ }^{171}$ Ora Nold assume que perante esta deriva tecnológica há uma posição de fundo a empreender, a de uma resistência pelo saber e pela sua expressão, é indissociável de uma familierização com os dispositivos tecnológicos que nos enformam o quotidiano (susveillance) e

169 Things. Rivers, for example. Why not? And now the new questions that are very interesting and critical to the show are the ones such as 'how to make a river speak? Latour, Bruno; Sánchez-Criado, Tomás; « Making the 'Res Public'», in http://www. ephemeraweb.org/journal/7-2/7-2latour-sanchez-criado.pdf. Consultado em Dezembro de 2011.

170 Gloso David Santos no título da exposição e o catálogo de abertura do Museu do Neo-Realismo, Batalha pelo Conteúdo, Vila Franca de Xira, 2007.

171 Costa, p. 147. Costa, ainda a propósito de Chevalier: Les nouvelles Technologies et les signifiants technologiques qu'elles génèrent se présentent [...] comme «aséités», c'est-à-dire comme des réalités de nature non linguistique, parfaitement autonécessaires et autosuffisantes; elles se laissent difficilement manipuler et un regard avise constaterait qu'elles se pleient bien peu à la volonté et aux intentions de qui croit pouvoir s'en servir. Ceci, d'une part, rompt définitivement avec toute conception de l'art comme «langage», et d'autre part met irrémédiablement fin à l'époque de «l'expression». 
depois - ainda que secundariamente, porque a agenda de Nold é mais básica e urgente- a sua utilização criativa. E se há uma estética da comunicação ${ }^{172}$, o dispositivo dos dispositivos, Nold surge claramente no extremo oposto de Chevalier num mesmo nível de percepção daquela; mas onde Chevalier se confina a uma beleza (flores, paisagem) entregue ao sublime da imagem urbana (a cidade, o logos autogenerativo da sua programação), Nold, na sua antropo-lógica, parte do sublime social da cidade para exercícios de graça informativa. Nold converte em informação a condição urbana contemporânea, actualizando simultaneamente Lefèbvre e Debord. Ao nível retórico, Nold, precisamente porque desenvolve um dispositivo (logos) de forte pendor informativo lanulando a sua dimensão de autor com gosto ou opinião em prol da figura de um facilitador de discursos de outros e sua interacção) leva a sua radical atenção à emergência do social para um nível emocional - empático - como o demonstram enfaticamente a sua Cartografia Emocional ${ }^{173}$. Ao propor a consciência da importância de desenvolvermos tecnologias do Eu, Nold reinscreve metaoperativamente a noção de personalidade artística que Costa sugere quase ausente em Chevalier $^{174}$, pelo menos se por arte total (Wagner) da cidade entendermos as suas incursões numa biopolítica da experiência urbana.

\section{Em entrevista que se encontra no prelo, a Rob van Kranenburg, ${ }^{175}$ Nold informa-nos acerca do seu último foco de interesse, a Internet das Pessoas: \\ This pamphlet ${ }^{776}$ is intended as a gut instinct census of how techno-social change is driving us to a future in the Internet of Things. We feel that unless we redirect our societal energies we will be driving ourselves into a concrete wall of ecological, economic and social crisis. We believe the answer lies in a dual process of horizontally scaling grass-roots workshops in conjunction with a social standard for governments and companies to allow cooperation.}

Alguns excertos desta conversa são elucidativo de uma agenda extremamente circunstanciada:

$C N$ : I hope the IOT will become something different. For me it's an ultra-localized articulation of what used to be called pervasive computing. This is not just passive technology, but also gives people new ways to interact with the world. When technologists, critics, or pundits talk about the loT, they talk about barcode replacement chips and at other times they conjure up science fiction scenarios that radically rethink the world. Can we gauge the scope and limits of the Internet of Things?

RK: The limit is a situation in which there are only sets of qualities, no more "people," "places," "things," or "situations." Humans and machines are the same. In every scenario of $10 T$ at the moment, machine-to-machine operations are very important, from basic logistics to anti-theft to e-health and energy efficient cities. This is a situation where human agency is no longer "in full control." Of course we know that hurricanes and volcanoes are not controllable but still we have this idea of our primacy of agency as givers of meaning in this world.

CN: The current military metaphor is that the human is "in-the-loop," meaning that a human operator is watching the machine going through its autonomous loop. I don't think class tensions or other power relations will disappear. Power will be felt in very concrete terms in the future Internet of Things. In one vision, it will be about high-tech fences and in another about artisan survival tools. For me, we are not talking about distant science fiction scenarios but the technology of the next twenty years. I don't think we will experience a singularity or a trans-humanist merger of everything. We will have to fight in order to embed the qualities and values that we want to be present in the technologies that surround us.

172 Idem: En 1983, je debutais L'Esthétique de la communication par ces mots: «L'esthétique de la communication n'a absolument rien à communiquer; ele ne communique rien, ni sur le plan des intentions ni sur celui des sollicitationsissues de l'inconscient».

173 Emotional Cartography - Technologies of the Self, PDF, 2009. Cf. http://emotionalcartography.net/

174 Costa, p. 147.

175 Autor de The Internet of Things, which is a critique of ambient technology and the all-seeing RFID network. For the past ten years he has been involved in the human and social aspects of pervasive computing, ubicomp, and smart cities. Co-founding bricolabs.net to investigate open source hardware and alternative scenarios and founding Council, a think tank for the Internet of Things (www.theinternetofthings.eu), has led him to believe that we have a huge agency at the moment for taking matters into our own hands. (Nold)

176 The Internet of People for a Post-Oil World by Christian Nold and Rob van Kranenburg. 
[...]

Media hegemony is so tight that grass-roots responses to climate change and peak oil don't become media issues. However, the sort of resilience networks we are talking about can be built by a large variety of groups without a media focus on decentralization. At some point, people will just notice that there is all this useful and resilient public infrastructure and great culture in their local area. Suddenly, it will just start to make sense for people to live, work, eat and produce more locally.

Explicitada esta agenda demo-crática, especifica três modalidades de uma performance do dispositivo social:

CN: The notions of "social" envisaged by social media tend to be very reductive. Social relations are envisaged as a currency that you can trade in for money. Other definitions see it simply as a kind of affirmative connectivity. The combination of this positivity combined with getting-ahead benefits is how social media is sold to people. Michael Woolcock suggests a three-part taxonomy for social capital. He distinguishes between bridging, bonding and linking. Bridging represents the weak ties between individuals which social media enables. Bonding is strong ties, often between family members, while linking is connections with dissimilar people or powerful figures.

\section{O dispositivo que conecta é em Nold um dispositivo crítico de proximidade:}

$C N$ : We don't appreciate how important proximity is right now and its role will increase rather then decrease. In the future Internet of People, we will have to rely much more on our immediate environment for support. We are already linked to our neighbors with power and water but in the future we may have to rely on them for growing food and making things. What we are really talking about is a kind of mutual responsibility that we might call solidarity. In our taxonomy of social relationships, in addition to the intensity of relationships we need to add the axis of time. Solidarity relies on strong ties, which can be just temporary to achieve particular objectives. These ties are not like your family that you have to deal with for life. Rather these are strategic and powerful alliances that are needed to get things done in a consensus way. Most activism works this way; groups who disagree on many points still have enough of a shared common goal to work together. You don't necessarily have to like people to be able to work with them.

A criticidade desse dispositivo é em certos projectos eloquente, no espírito de uma Luz-boa:

There is an artistic intervention by Jakob Jakobsen, which illustrates this well. He disconnected a road of forty houses from the street lighting network and installed a large manual switch. This meant, that in the evening when it got dark someone had to manually turn on the street lighting and someone else had to turn it off in the morning. It also raised the additional prospect of teenagers messing around with the switch. He basically used the switch to turn a utility, which we take for granted, into something that made people responsible for the functioning of their street and required social organization to manage. You could see this small intervention as training for future solidarity and local awareness. ${ }^{177}$

Nold representa um arte engajada com a complexidade sistémica - multiple intelligences form new kinds of awareness (Kranenburg). O seu logos é multidimensionalmente integrativo - aqui se explicitando como qualquer projecto afinal pode ser acedido pelo público, aprofundando-se o ethos relacional e dialógico da arte contemporânea no sentido da cognição arquitectónica: Dialogism is a form of architectonics, the general science of ordering parts into a whole. In other words, architectonics is the science of relations. A relation is something that always entails ratio and proportion. ${ }^{178}$

Perante esta realidade dialógica que dá à visibilidade arendtiana outro alcance, The world addresses us and we are alive and human to the degree that we are answerable, i. e. To the

177 Jakobsen: When I switched the lights off first it became very dark...The space had changed and it was, in a concrete way, making me realize how the street lights influence our perception of space in the city. They light up, yes, but reduce the perspective and the scale of the surrounding space. And the switching off of the lights gave rise to some poetic qualities I hadn't expected: the hills, the sky, the stars.

178 Holquist, p. 29. In addition, Bakhtin emphasizes that a relation is never static, but always in the process of being made or unmade. 


\section{degree that we can respond to adressivity ${ }^{179}$ - Nold explica a base do seu método.}

When designing project and systems I adapt an educational model called the SOLO taxonomy (Biggs \& Collis)?, as a way to embed multiple layers of interaction for different people. The model suggest that people learn in different ways:

1. Pre-structural: here students are simply acquiring bits of unconnected information, which have no organization and make no sense.

2. Uni-structural: simple and obvious connections are made, but their significance is not grasped.

3. Multi-structural: a number of connections may be made, but the meta-connections between them are missed, as is their significance for the whole.

4. Relational level: the student is now able to appreciate the significance of the parts in relation to the whole.

5. At the Extended Abstract level, the student is making connections not only within the given subject area, but also beyond it, able to generalize and transfer the principles and ideas underlying the specific instance. ${ }^{2}$

While this model is hierarchical with the implication of progression, it is useful for recognizing differences in perception while offering methods for teaching people to see themselves in a relational framework.

Há quase um século, Kafka pensava sobre um futuro de decisões irreversíveis lo progresso) e depois reflectia, através da parábola de um cão que investigava ou de uma toupeira percorrendo cega e solitariamente os seus domínios (os seus dois últimos textos), acerca da condição do criador na vida social. A conversa entre Kraneburg e Nold mostra como essa mesmíssima consciência crítica se actualiza, na consciência da importância de uma dimensão eco-lógica da emergência do habitar que é obrigatoriamente afectada - emotiva - para funcionar. Mesmo que na mais espectacular efemeridade, em Londres em 2010 lou em Madrid nas ocupações da via pública de 2011).

RK: Learning to see oneself in a network is being able to feel at home in all the layers, not necessarily in the order that is given. The key is not that Extended Abstract is a higher skill but that you are able to see all of them. It reminds me of your reference to Kropotkin who stated that people are most happy when they have different kind of jobs requiring both manual and intellectual skills.

$[\ldots]$

CN: Let me tell you the story of "Democracy Village" an event / place that occurred in 2010, right in front of the UK Parliament. While there had been a small continuous demonstration in front of the parliament for many years, they were suddenly joined by a large number of activists, homeless people and drug users. A split emerged between the people who had been there for many years "legitimately" protesting and these new comers. People had placed hand written, personal slogans such as: "I am hurting" or "after so many years why do we still cry tears?" around the Democracy Village. The mainstream media saw this as inarticulate and a break down of politics. The media and politicians labeled it a "shanty town" full of "loons" and could not comprehended the mix between political issues and social issues such as homelessness and drug use and forced the clearance of the square. In contrast I recently heard Siraj Izhar describe the situation as a "human lab for a new human subject." "It was the sharing of these people's suffering that created a new form of solidarity. As the New Statesman says, "the discourse had no invisible boundaries."4 This demonstrates the power of affect to break through artificial boundaries.

Este enquadramento sistémico, afectivo e tecnológico de que Nold é porta-voz dá à ideia de alianças temporárias (Kranenburg), base da táctica no activismo, o peso de um desafio:

$C N$ : It is not surprising that most political banners do not create broad solidarity with their language of abstraction and distance. The empathy associated with pain is the universal basis of politics. "Feeling cuts through and against signification"(Ultra-red). [...] The key question is how to reclaim affect as a progressive political force. My suggestion would be to combine affect with the systemic network thinking that is so clearly delivered by the Internet and mapping. We require an educational model for the future Internet of People which positions the personal emotion as the connection point to a wider systemic network of relationships with the environment and others.

179 Idem, p. 20. 
E depois radicaliza, ao nível do seu pathos:

RK: I'd like to pick up on two things that are very important. The first is your point of the power of affect to break through artificial boundaries which foreshadow the new solidarities that we have to feel towards our resources, plants, animals and things in order to treat them as equal entities or processes. The second is the absolute necessity of reclaiming words like love, friendship, and like, as in "liking this." Love has been sold to washing machine powder producers that urge me to love their soap. I think this has made it more easy to frame scenarios based on affect as utopian.

CN: Affect cannot stand alone. It requires a network to make local areas work. As Putnam argues, "civic virtue is most powerful when embedded in a sense network of reciprocal social relations." [...] This is where technologically enhanced perception is crucial to hearing the sap rise. I think we will see a critical blending of sense (perception) and sensor (data) networks, which are currently very separate.

Tudo isto é, comprovando a minha intuição de que o social é eco-lógico:

CN: I think recognition of the natural environment is a subtle process. The early stages might involve just noticing differences in the environment - not all trees are the same. Then one might acquire an ambient awareness where one becomes sensitized and starts to notices the daily seagull sounds. Later one may become actively \& practically involved in growing something in the garden. I would suggest that this process of growing involvement is the same for most things that are unfamiliar to us. The vision of the Internet of People that we are proposing requires a rethink of what it means to be human.

Fascinado pelas cidades, Nold recorda-nos constantemente que não sabemos o que realmente é uma cidade, mas sabemos que são feitas de pessoas e das interaç̧ões entre elas, com destaque para as experiências - sons, aspectos visuais, cheiros. Depois, que a cidade é extremamente frágil, sujeita a vicissitudes ${ }^{180}$. Para concluir que a cidade é uma ilusão, uma ficção, uma alucinação. Portanto uma enorme percentagem da população vive nessa alucinação do urbano - que é um conceito, mais do que qualquer outra coisa. Ora perante formas estabelecidas de representação da cidade - os mapas, que no essencial representam porém apenas as vias de trânsito e os edifícios e sua sfunções, não a vida entre os edifícios ou o espaço público -, Nold está interessado nas interacções sociais, em toda a sua subtileza.

\subsubsection{Bio-mapas - arte, informação, cidadania}

Em dados momentos ${ }^{181}$ a sensibilidade fina que o dispositivo informacional transporta, permite ao artista crítico desenvolver modelos graciosos - e já não apenas belos (Maya Lin) ou sublimes (Christo) - da sua pulsão democrática. Podemos até perguntar-nos para que serve saber das sensações dos concidadãos, num dado ponto da cidade: sentir o cheio a gasolina e ter vontade de voltar. senti-me bem porque senti confiança na pessoa que me estava a guiar, mas é óbvio que estes projectos de visibilidade fina nos ajudam a ter uma percepção muito mais aguda do que acontece na cidade, mesmo antes de lhe podermos ou querermos dar um nome (emergência não-representacional): lots and lots of things hapening, right? The

180 Um ataque exterior que impeça os alimentos de chegarem a uma determinada área, como nos recentes motins em Londres.

181 Acção ASPAS - Aerial Superiority Public Announcement System, em 1999, em que nold solta um simples balão vermelho junto a uma câmard e vigilância automática, que de imediato segue o objecto 'suspeito', assim se percebendo como é fácil perverter quer os entido originald a vigilância, como a própria ideia de vigilância. 
whole range of diferent... stuff. ${ }^{182}$ Ora onde Nold parece caminhar noutro sentido do que Kaprow, apesar do mesmo fascínio pelo mundo urbanizado (capitalista), é no facto de que da sua obra é posível, e por assim dizer obrigatório, retirar ilações concretas, mensuráveis, e sócio-politicamente relevalantes (até porque informadas pela vivência), como quando, no final do workshop com dezenas de crianças, o mapa final nos revela que de todas as sensações registas mais de $50 \%$ eram negativas, quando as crianças, antes desta verbalização-valoração, não tinham disso consciência. Desvelam-se assim padrões, que obviamente vão gerar configurações gráficas passíveis de serem experimenradas esteticamente lou de gerar novas formas ou modalidades do estético).

Um workshop Bio Mapping reúne duas dezenas de participantes, convidados a dar um passeio nas proximidades, com a duração de cerca de uma hora. Antes de partirem, é entregue a cada participante um equipamento Bio Mapping e, pontualmente, uma câmara digital. As pessoas são encorajadas a dar um passeio por onde lhes aprouver, mas também levadas a pensar acerca das escolhas que fazem durante o percurso, durante o qual carregaram num determinado botão sempre que se sentiram estimuladas pelo meio ambiente. No regresso, procede-se ao download dos dados recolhidos pelo equipamento, gerando- se, com auxílio de software especial, o mapa emocional de cada pessoa. Esse mapa regista os locais e as situações em que as emoções - tanto positivas como negativas, de desconforto como de prazer - foram objecto de uma determinada consciencialização. Após cada participante terminar o debate em torno do seu passeio, todas as faixas são combinadas para criar um mapa emocional comum, relativo a toda a área em questão. Este é usualmente o quadro de fundo para uma sessão de debate de encerramento, em que é levantada a questão mais ampla acerca do que representa esse mapa comunal e de que forma poderá vir mais tarde a ser utilizado pelos participantes. Nos diferentes mapas dos diferentes eventos que organiza, os passeios são representados de diversas formas. ${ }^{183}$ Esta busca constante do artista, à procura das melhores formas de visualização, faz evidentemente parte do processo. No fundo, trata-se do desenvolvimento contínuo de modelos conceptuais e interfaces técnicos aplicados à comunicação que têm o maior interesse não apenas para os participantes enquanto indivíduos, mas também para disciplinas do saber no campo das diversas ciências ${ }^{184}$. Os projectos de Christian Nold não são assim arte em sentido convencional (pintura, escultura, instalação...), mas essencialmente processos em curso - senão um processo único em constante avaliação e adaptação, envolvendo habitualmente uma determinada articulação de tecnologias computacionais locativas ${ }^{185}$ e físicas, as quais reúnem dados e criam visualizações elaboradas colaborativamente. O resultado acumulado do trabalho de Nold tem sido o desenvolvimento continuado de uma metodologia consensual de que quaisquer comunidades podem tirar partido, à medida do seu dinamismo e proactividade.

182 Nold, POP!TECH. http://poptech.org/popcasts/christian_nold__poptech_2007.

183 Por exemplo, linhas angulares evidenciando os 'picos' emocionais, ou então manchas de cores com temperaturas diferentes, sempre para evidenciar a localização geográfica dos factos emotivos.

184 Enquanto mapas que descrevem uma enorme variedade de eventos e estímulos sensoriais em contexto urbano, são obviamente apetecíveis instrumentos também para quem procura na cidade o público-alvo para as suas mensagens ou clientes para os seus produtos. Nold foi repetidamente convidado a vender o projecto a empresas de comunicação, publicidade e imobiliário (Saatchi \& Saatchi).

185 Locative media: meios de comunicação digitais, relacionados com locais reais, capazes de despoletar interacções sociais específicas, tais como as decorrentes de tecnologias móveis como o GPS ou computadores e telefones portáteis. 
Se um dos factos sócio-culturais fundamentais a reter quando se reflecte sobre a contemporaneidade artística e tecnológica se relaciona com a existência de inúmeros focos de conhecimento e experimentação, Nold é um exemplo claro de articulação entre ética e cidadania contemporânea, sendo muito interessate que a sua metáfora operativa principal seja o mapa - instância projectual entre o território e seu entendimento. Mais, mapeia-se o que se desconhece, e depois orientamo-nos pelos mapas que desenvolvemos, o que é pode então ser visto como modalidade em si para o que identifiquei atrás como a deriva territorial museu-intervenção, acto fundador da deriva pública da arte crítica. Sabendo-se que a tecnologia não é o instrumento neutro e racional e que, pelo contrário, implica, enquanto dispositivo (Agamben), uma mistura instável de controlo autoritário e deriva anárquica, a abordagem de Nold é a de quem se insere no intervalo entre estes dois pólos e usa esse espaço como meio de combinar a liberdade oferecida pelo mundo da arte com o envolvimento que se consegue obter pela via do design e da tecnologia. $O$ seu objectivo é construir novas ferramentas que possam desenvolver possibilidades ou propor usos alternativos de recursos existentes. Normalmente, cada seu novo trabalho parte por isso de uma cuidada investigação das ferramentas tecnológicas disponíveis, para desvelar as suas camadas sociais e políticas. Segue-se a constituição de práticas sociais participativas, com carácter bottom up e que são no fundo formas híbridas de uma tekne económica e socialmente sustentáveis.

Bio Mapping é portanto o projecto mais emblemático da filosofia artística de Christian Nold. Explora novas formas de nós, enquanto indivíduos, podermos utilizar a informação que reunimos através dos nossos corpos. Em contraste com as tecnologias de segurança, desenhadas para controlar o nosso comportamento, divisa novas ferramentas que permitem às pessoas seleccionar e partilhar selectivamente os seus próprios bio-dados. $\mathrm{O}$ sistema permite ao utilizador registar a sua Galvanic Skin Response (GSR), um indicador simplificado da excitação emocional em conjugação com a localização geográfica. A adrenalina foi a metáfora operativa - em sentido não apenas metafórico! - a que 0 artista chegou para se aproximar das suas preocupações la adrenalina é o que nos leva à acção, facto tanto mais inetessante quanto pudermos, em tempo real, ou no tempo diferido de um mapa -, situar essas acções e reaç̧ões na forma urbana. E assim, os projectos de Bio Mapping dizem-nos muito acerca da intensidade da reacção emocional aos factos da cidade lo carácter afectado de uma imagem, de uma vista, de uma intereacção social, de um espaço arquitectónico). Nold estimula a consciência graciosa - porque lacumulada cognitivamente - Histórias pessoais. Estas são recolhidas em conversação (Kester) pós-passeios, e delas emerge uma consciência colectiva que integra as experiências pessoais numa paisagem emocional.

Nesta dimensão específica de uma articulação emancipatória entre arte, informação e design de comunicação, destaco três acções.

NEWHAM SENSORY DEPRAVATION Normalmente percepcionamos o nosso meio envolvente recorrendo aos cinco sentidos - visão, som, olfacto, tacto e gosto. Que acontece quando passeamos pelo nosso ambiente sem visão nem som? O Sensory Deprivation Map de Newham é o resultado de um workshop em que participaram 36 estudantes do Segundo 
Ciclo, organizados aos pares. A um dos estudantes de cada par foi colocada uma venda nos olhos e auscultadores nos ouvidos, de maneira a que não pudesse ver ou ouvir absolutamente nada. Ao outro foi entregue um sistema GPS, papel e caneta. Juntos, exploraram a área em volta da escola durante uma hora. Enquanto o estudante vendado e privado de audição contava verbalmente a sua experiência sensorial, o outro tomava notas e assegurava que a viagem decorresse em segurança. No regresso, os dados geográficos reunidos durante o passeio foram descarregados do GPS e todas as observações sensoriais realizadas durante o passeio registadas num mapa. Um mapa global, combinando as anotações de todos os participantes, constituiu um inesperado mapa sensorial e alternativo da localidade.

SAN FRANCISCO EMOTION MAP O Mapa de São Francisco culminou de uma residência de cinco semanas no quadro de um projecto artístico participativo que envolveu 98 colaboradores, levados a explorar o Bairro de Mission por meio do dispositivo Bio Mapping. Durante a residência, Nold encorajou os visitantes da galeria a entrarem no projecto, sendo para tal necessário utilizar os aparelhos quer durante a semana, quer durante o fim-de-semana laltura em que se realizavam os momentos de workshop mais intensos). O projecto convidava o público a dar um passeio, com o dispositivo a registar a sua reacção ao meio envolvente e, num segundo momento, a partilhar os seus comentários. $O$ resultado final: um projecto de arte pública - foi esse o contexto institucional em que o projecto se inseriu - que procedeu a um retrato colectivo de todo o bairro e em particular do seu espaço público (incluindo o que é usualmente invisível), em que os "visados" são parte do processo.

STOCKPORT EMOTION MAP O trabalho de Nold é muitas vezes confundido com uma mera recolha de dados; mas Nold procura por vezes entender o que pode ser feito com esta informação, assim recolhida. Em Stockport, perto de Manchester, e no quadro de um preconconsultation Project, solicitado pela Autarquia, em colaboração com local developpers, cerca de 200 pessoas participaram no Verãode 2007 em vários eventos parcelares, de que se destaca aqui a acção "Drawing Provocations". Enquanto os mapas convencionais mostram uma arquitectura estética e excluem os humanos, este projecto artístico apresenta uma visão de Stockport que representa as emoções, opiniões e desejos dos habitantes locais; ele funciona como um modelo de esfera pública. Nesse evento, foi pedido às pessoas que fizessem um esboço das suas respostas a uma variedade de provocações - entre sérias e cómicas - relacionadas com a sua vida quotidiana diária: por exemplo, 'O que o/a incomoda mais em Stockport?', 'Onde encontra os seus amigos?', 'Quais são as pessoas mais importantes na cidade?', 'Quais as pessoas mais perigosas?' Outras provocações focaram a cidade e a sua história, o rio e os marcos urbanos. As pessoas reagiram entusiasticamente e criaram uma enorme pilha de desenhos - um elemento gráfico subjectivo que Nold ainda não tinha solicitado aos seus colaborantes - que foram depois digitalizados e usados para criar o mapa. No documento de síntese, tanto quanto possível, todos os desenhos foram colocados na sua posição geográfica correcta ou onde as pessoas os mencionavam. O resultado, na sua versão em papel, é um delicioso programa alternativo para um passeio turístico mas também um espaço público de possíveis concretos. Sugere um modelo de registo de conversações aparentemente triviais e eventos quotidianos, permitindo-nos vê-los em simultâneo, sem nos sentirmos restringidos a um tó- pico definido. Ora na graciosa imagem global, estas 
conversações aparentemente desconexas mostram o seu verdadeiro valor e formam um aglomerado de assuntos e preocupações. Particularmente interessante foi o facto de, apesar de os participantes referirem um conjunto de problemas, a palavra "simpático" surgir com muita frequência para descrever a zona; eis um mote possível - e devidamente fundamentado, comum - para estimular futuros projectos e visões para a área. ${ }^{186}$

Na prática, estes projectos são fundamentais para cada sujeito participante no dispositivo artístico saber mais sobre a forma como sente a forma da cidade e tudo o mais que nela se exprime; mas porque se dão a partilha (pathos) e o debate (logos), também cada sujeito fica a saber mais sobre como os outros reagem à cidade, e isso não apenas fornece aos promotores informações de síntese com base em totais ou médias, mas dá a cada um, a todos, a hipótese de um engajamento (ethos) com o outro, de uma atenção dialógica que conduz inevitavelmente à mudança das coisas. Esta questão é fundamental quando a informação gerada, uma forma de resistência, não deve ser usada para fins que são os procurados por aqueles que no final de contas não estão interessados em mais e melhor informação partilhada, nem numa consciência ampla a abrangente, e muito menos activa do espaço urbano - uma mercadoria para o desenvolvimento capitalista e um campo expandido, ou mercado, para o sistema da arte contemporânea. Mais, mantendo articulados, ao nível de todos os detalhes do projecto, a dimensão humana-experiencial-existencial e uma dimensão colectiva de cognição-informação-planeamento, o criador mantém na agenda de uma arte depois da crítica não apenas aspectos críticos da teoria, mas todo um sabor a realidade e contingência que são apanágio da graça social que pudémos conhecer a a partir de Haight. Noutros termos, Nold é o artista que prenche um papel crucial numa nova economia da atenção (Lanham). Informado pelo digital pós-industrial, Nold fornece ferramentas conceptuais (inclusive analógicas) que entroncando nas das humanidades e da retórica, nos ajudam a ganhar a vida (Gasset). Noutras palavras,

We feel that unless we redirect our societal energies we will be driving ourselves into a concrete wall of ecological, economic and social crisis. We believe the answer lies in a dual process of horizontally scaling grass-roots workshops in conjunction with a social standard for governments and companies to allow cooperation. ${ }^{187}$

O último trabalho de Nold é aliás um fabuloso - Fablab é um modelo de investigação no $\mathrm{MIT}^{188}$ - de aproximação entre a arte como mediação da tecnologia e todo um macro-con-

186 Em visita preparatória a Torun, na Polónia, Nold mostrou como este tipo de conhecimento é operativo mesmo fora do âmbito estrito dos workshops, encontrando, numa visita de apenas dois dias, uma série de tópicos comuntários para o desenvolvimento socialmente sustentado da cidade, passíveis de se tornaram emblemáticos da sua regeneração. Isto num quadro não de mera opinião estética ('eu acho que...') mas de uma posição informada por dados concretos relativos à forma urbana e sua experiência.

187 Nold, Christian; van Kranenburg; Rob; The Internet of People for a Post-Oil World: This pamphlet continues this dialogue to delineate the foundations of a future manifesto for the Internet of People. The pamphlet was constructed through a real-time dialogue over a period of months using the Skype software for audio conversation whilst writing the text in real-time using the open source EtherPad application.

$188 \mathrm{CN}$ : The MIT Fablab concept is a useful model but we will need a social framework that is less exclusive, allowing a larger variety of people, groups and companies to collaborate. Setting social standards for design will move industry away from thinking of people as undifferentiated global consumers towards becoming equal partners with mutual expertise. We need to merge the wasteful production of masses of different mobile devices into one resilient communication device that enables local networks. Standards will enable new business models for co-operation between companies and hackers to create locally meaningful technologies. This is where the role of government is crucial, they need to have the vision to look beyond the immediate horizon and push companies towards collaborating on social standards. 
texto tecnocientífico e tecnológico que o criador procura tornar socialmente mais relevante e estabelecer como macro plataforma partcipatória, a uma escala imprecedente.

Na conferência para a POP!TECH, é o próprio Nold que refere que, até Stockport, estava mais envolvido em contextos artísticos, mas que o querer ver realmente como as coisas se passam parece implicar uma alteração de contexto (do confinamento institucional da arte, o ficar-se pelas pessoas que vão aos eventos de arte, de onde Nold afinal emerge como autor, para a imponderabiliadde das interacções com as comuniaddes que realmente contam no espaço público. Christian Nold é portanto um artista de novo tipo, mas também um investigador de novo tipo. Se hoje como nunca a arte procura legitimar a sua interventividade a partir de uma inserção no social, Nold leva esse desígnio - que é notoriamente retórico - ao extremo e torna a própria vida social uma forma de arte, pelo menos enquanto sinalização da verdadeira vida que acontece entre os edifícios. Vida essa que, como comprova o humor que recorrentemente irrompe nas audiências das suas palvras, é uma forma de graça também por via dessa condição necessária que, uma vez compreendida, nos ilumina.

A original abordagem de Christian Nold dos campos da Arte, da Tecnologia e da Política, na confluência de domínios de investigação como a Informática e as novas tecnologias em geral, o Desenho Urbano e a Cultura, convida-nos a actualizar ideias feitas sobre as capacidades dos indivíduos e das organizações em gerarem a sua própria autonomia no Mundo em rede. Nold é um exemplo particularmente crítico - precisamente porque realizado no Espaço Público e sobre o Espaço Público - das prácticas relacionais (Bourriaud), dialógicas (Kester) e intersticiais (Miles), em que as antigas utopias sociais e ambiciosos programas políticos dão lugar a micro-utopias quotidianas e estratégias miméticas (cínicas) de resistência e produção. Sendo o ponto de partida de Nold o conjunto das relações humanas no seu contexto social, visando colocar em contacto diferentes níveis de realidade, estabelecendo novos modos de existência num real pré-existente mas que urge reinventar, a sua visão complementa as de Chevalier (a cidade como tela total), Gasco (o ready-made social) e Freee (a esfera pública do discurso), no sentido de uma compilação de multidões ${ }^{189}$, graciosa metáfora que aponta para a extramuralidade do socius.

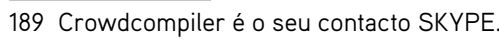




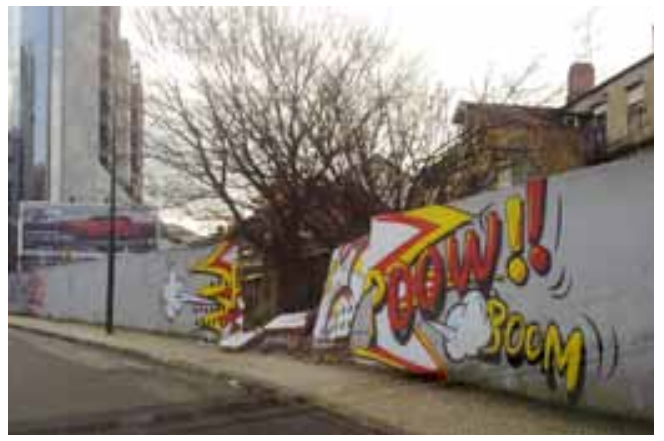

Graffitti, 2011

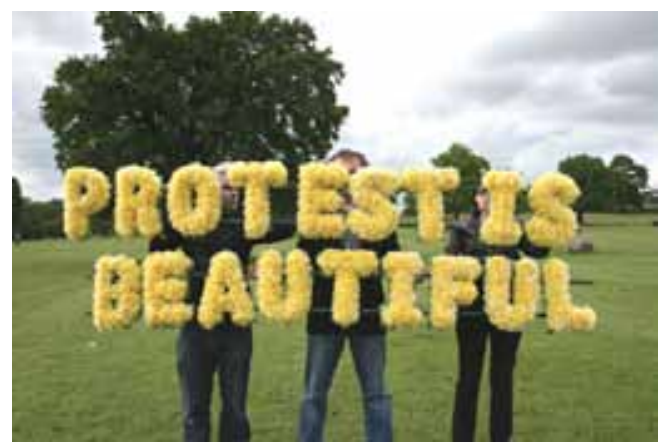

Protest is beautiful, Freee, 2007

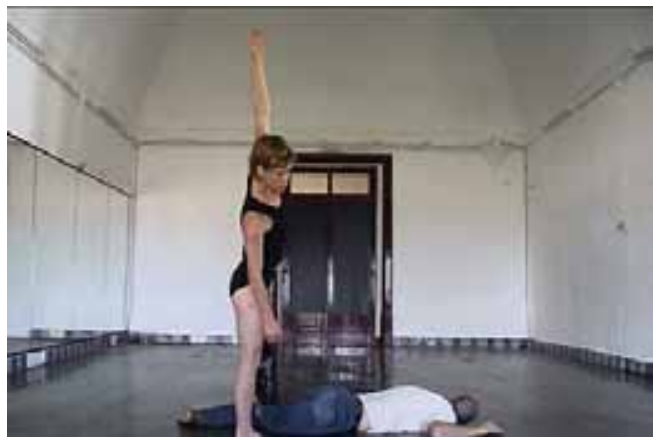

Prótesis para una bailarina, Javier Núñes Gasco, 2004

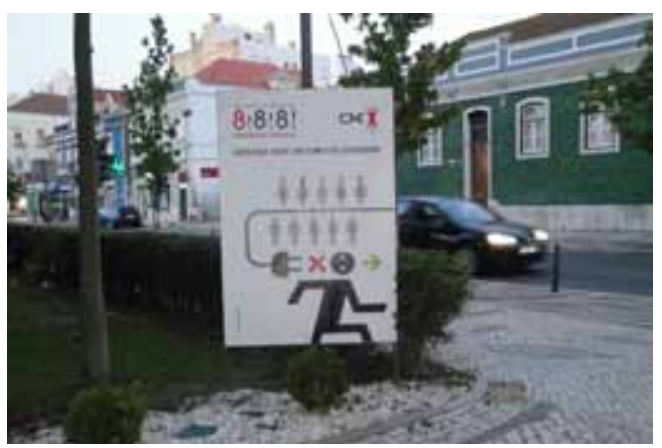

8!8!8!, Proposta para Luzboa 2008, Pedro Penilo, 2007

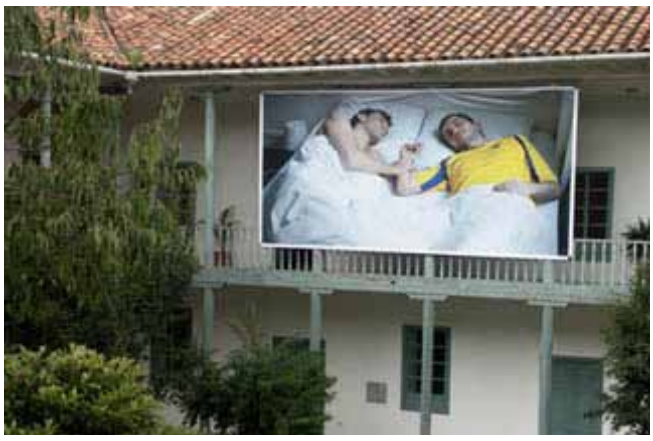

Eric et moi dormant, Santiago Reyes, 2007

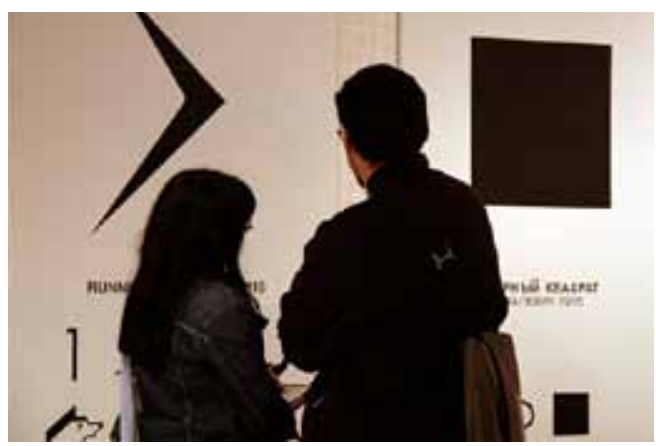

Autoestrada (1996), Pedro Penilo, 2009

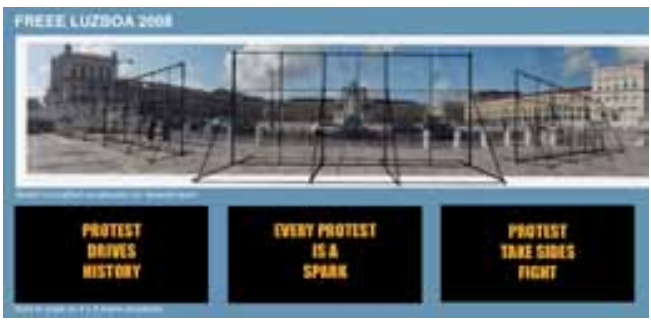

Proposta para Luzboa 2008, Freee, 2007

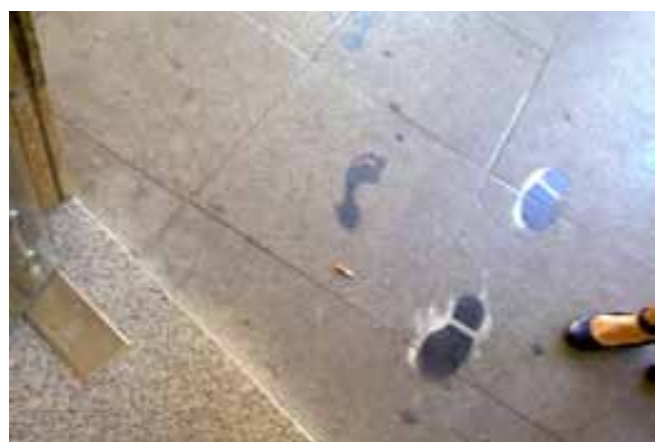

Intervenção anónima, Almada

(entrada Caixa Geral de Depósitos), 2011 


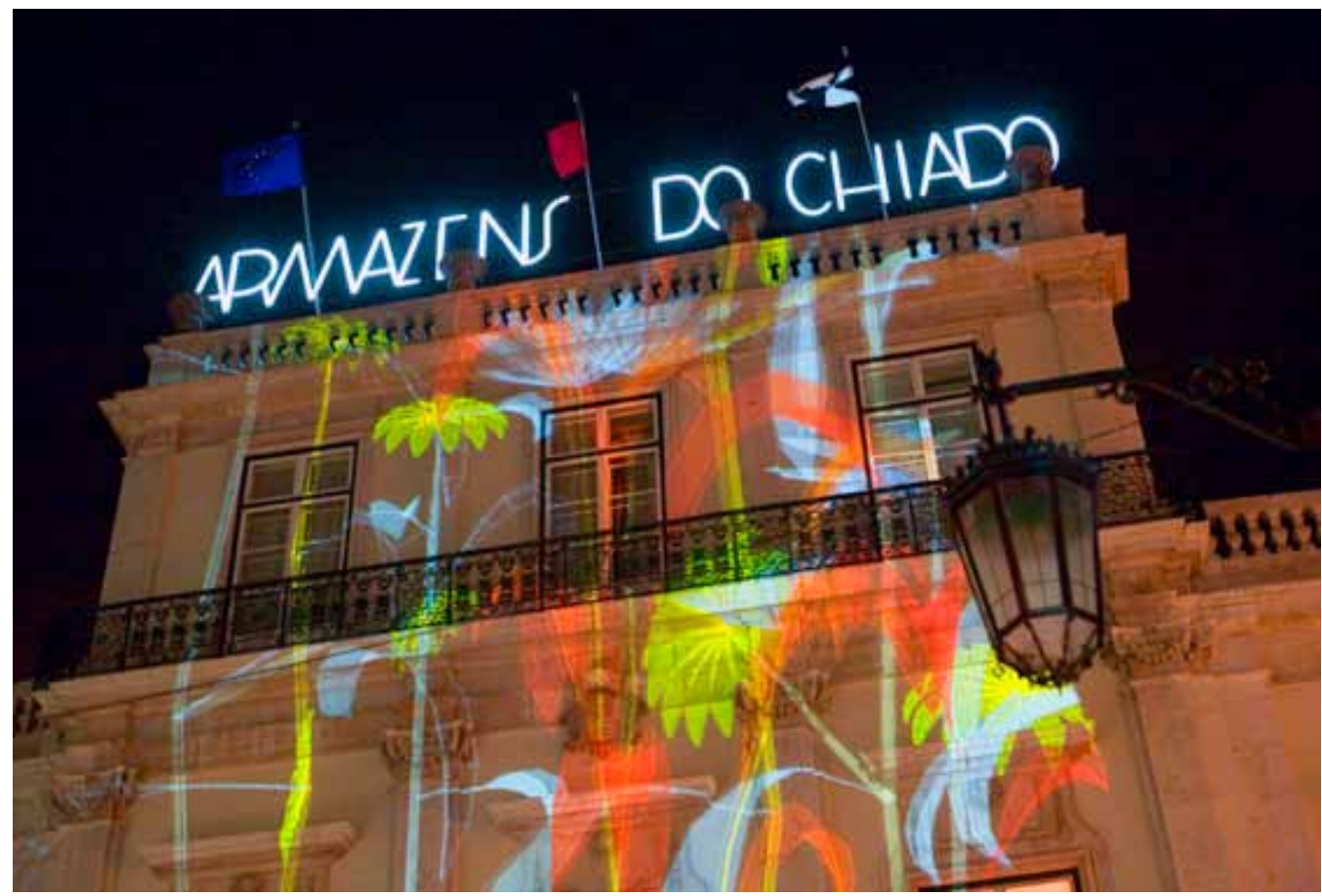

Sur Nature, Miguel Chevalier, Luzboa 2006 


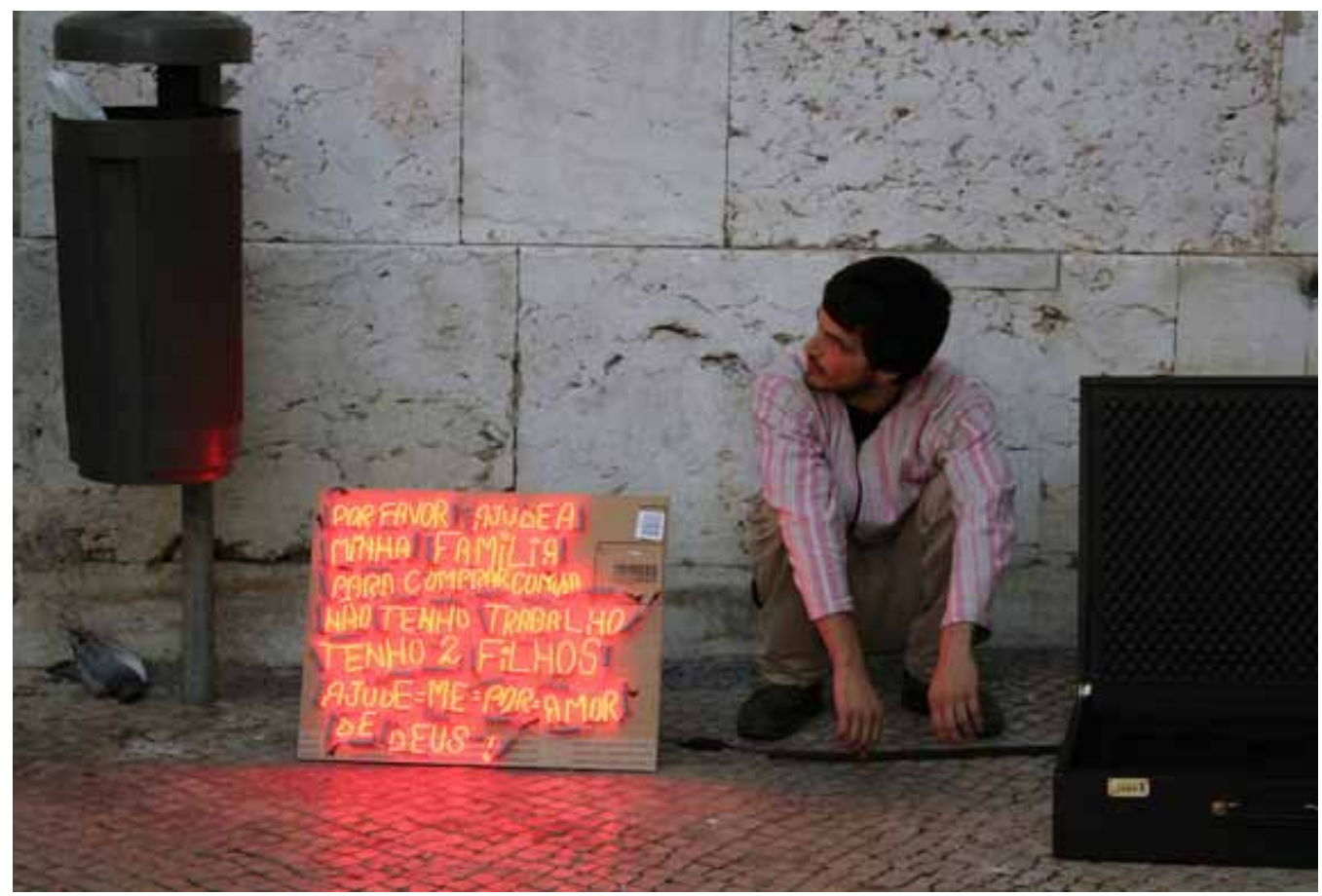

Misérias Ilimitadas, Lda, Javier Núñes Gasco, Luzboa 2006 


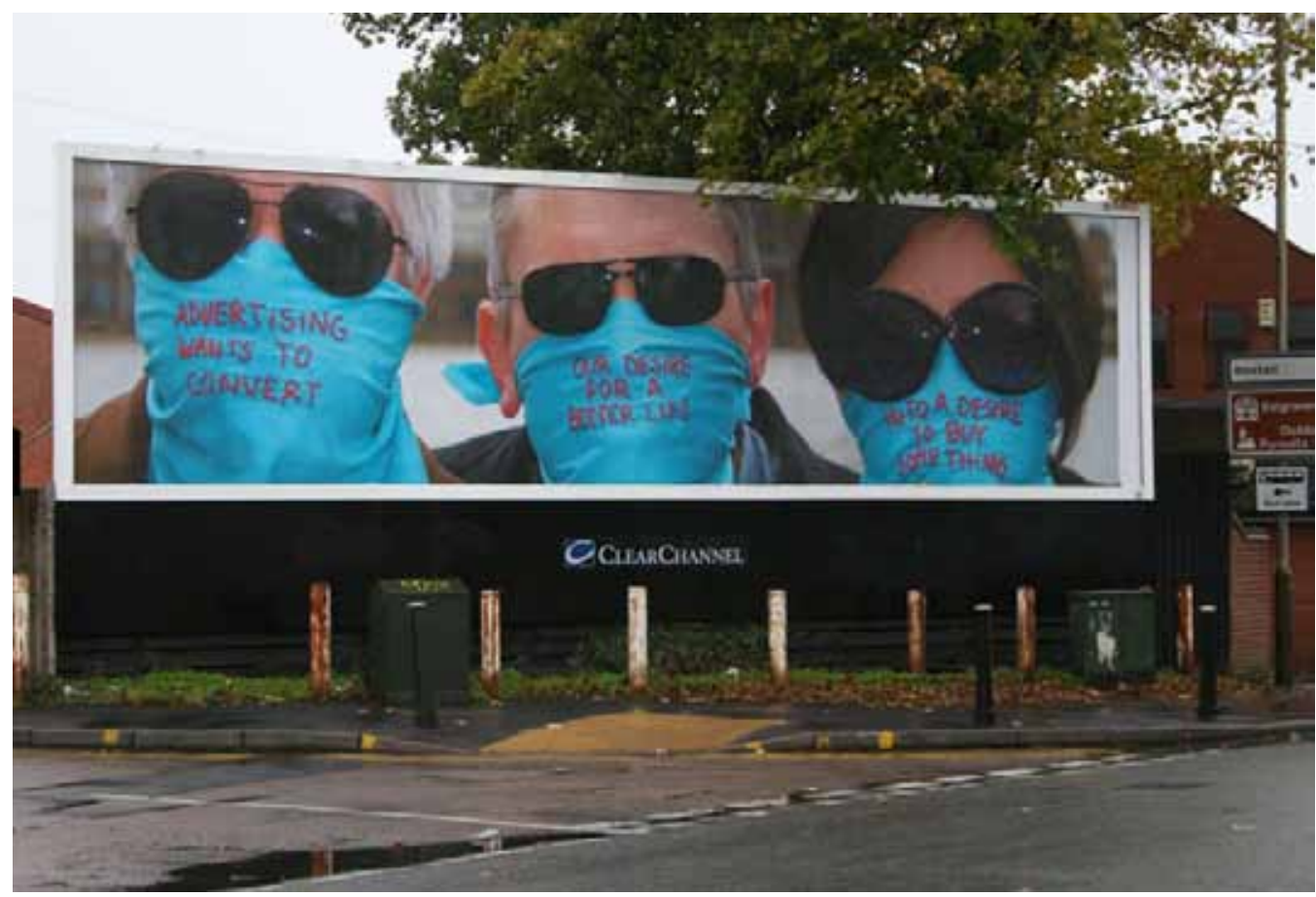

The Freee Art Collective Manifesto For A Counter-Hegemonic Art, Freee, 2007 


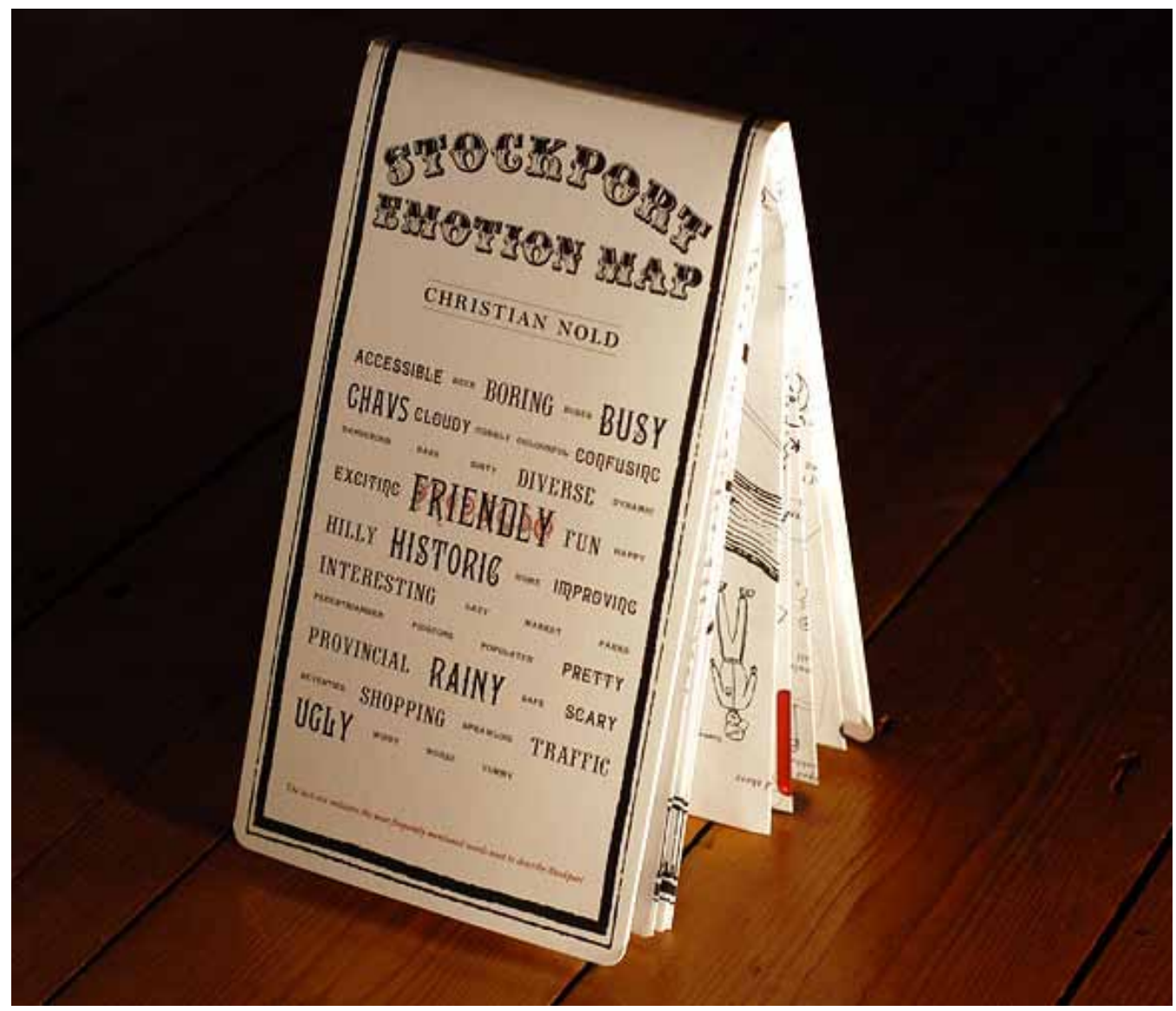

Stockport Emotion Map, Christian Nold, 2006 
More and more, the Job of art seems to me to isolate the few elements of reality contained in the mixture of fictions, not a metaphorical "reality", but simply the basic elements of knowledge and opinion that form the abc of consciousness.

J. G. Ballard

The Arrival of the Unconcious

\section{O apelo de um percurso, pensamento e acção}

$\mathrm{Na}$ qualidade de presidente de uma instituição sem fins lucrativos, denominada significativamente Extra]muros[ - associação cultural para a cidade, tive, desde 2000, a oportunidade de desenvolver uma série de iniciativas culturais integradas fundamentalmente em três eventos-charneira: Lisboa Capital do Nada - Marvila 2001, Sinais - a Cidade Habitada (2002-2003) e Luzboa - Bienal Internacional da Luz (2004-2006). Entre estas iniciativas próprias (que deram seguimento a experimentações no campo da curadoria desde 1995) e o contacto com outros agentes culturais, nacionais e internacionais, lidei com um elenco de projectos suficientemente compacto e significativo para poder falar-se globalmente de uma tendência ou estilo. Este movimento, assente num conjunto de princípios, coloca inúmeros factos artísticos na órbita do que seria uma vanguarda do pensamento sobre a arte e a cidade, não fosse a própria ideia de vanguarda - como muitas outras do jargão da arte pública - avessa aos mesmos, mais interessados num 'aqui e agora' que em elaborações programáticas, que transformam o pensar em pensamento (Lacan).

Com a linguagem que me foi estando disponível, interpretei continuamente as situações que apareceram, sempre a partir de um mesmo princípio não imutável, mas sempre capaz de voltar a transfigurar-se, ao ponto de eventualmente vir a tornar-se irreconhecível, tal a progressiva gasosidade (Jimenez) das práticas interventivas, comunitárias ou activistas, nas margens do campo da arte (o meu corpus). Estamos sempre perante a necessidade de resolver a dificuldade de articulação entre o pensamento e acção; da exercitação radical do músculo utópico que sabemos, todos, possuir, da articulação desse princípio com o conceito bergsoniano de vitalidade. É que certos projectos, acções e intervenções são capazes de proporcionar oportunidades de autonomia a pessoas concretas, explicitando uma dialéctica criativa inerente à relação indivíduo-corpo social. Convidam o espectador a sê-lo criticamente - co-produtor, co-enunciante, elemento consciente dos processos de troca e fruição de imagens, de modelos mentais, de visões do passado, do presente, do futuro, no espaço urbano enquanto quotidiano expandido. Na sua radicalidade relacional - e tão somente na que o seu enquadramento institucional e organizacional proporcionou - estes projectos têm o condão de explicitar aspectos da vida social, bem como da responsabilidade que se exige ao cidadão. Estão a mapear a vida social com resultados práticos repensando-nos enquanto agentes e protagonistas do habitar colectivo (Luís Santiago Baptista). Tudo isto redunda numa 
forma de activismo intelectual, expandindo-se por via da produção teórica que as obras de arte geram, paralelo tanto ao activismo lento (Miles) como à atitude da arte não autorizada, resilientes ao aparelho retórico da política tradicional.

\section{Aproximação a um modelo crítico}

Uma dezena de anos a ensaiar um modus operandi que se tornou progressivamente consciente dos seus parâmetros de auto-avaliação, levou a que eu procurasse a dada altura reflectir de forma mais sistemática sobre a implantação das iniciativas - da concepção à gestão, da comunicação à avaliação. Para entender a minha própria deriva curatorial enquanto linguagem, procurei reconhecer padrões de comportamento e matrizes e estruturas na minha acção e na dos artistas; o que viria a redundar numa axiomática da arte pública na forma urbana. Dá-se então uma imbricação entre aspectos morfológicos e a criação de consciência projectual. Numa fase crítica da minha experiência na organização de eventos, deduzi que se impunha, enriquecer a reflexão com referências conceptuais, teóricas e políticas, mas também míticas que, consciente ou inconscientemente, poderão ter estado na origem das acções empreendidas; mais, que essa legitimação, por via da investigação sobre a genealogia de um certo tipo de arte (ou artisticidade) seria o meu contributo para reforçar uma linha de trabalho, investigação e activismo que claramente tem sido ostracizada e menosprezada por amplas camadas do poder artístico e do status quo político, educativo e cultural.

Em suma, proponho - sem aspirações à afirmação de qualquer nomenclatura - designar operativamente um território da criação que vários artistas, curadores e activistas atravessam ou promovem com regularidade. Sabendo-se que é um território onde as condicionantes para a produção cultural são francamente mais problemáticas que em instâncias da socialização da arte tais como são o museu ou a galeria (ou outras formas institucionais), mas onde invariavelmente os protagonistas recolhem experiências particularmente gratificantes, só faria sentido abordá-lo:

- a partir de uma perspectiva e de uma experiência pessoal e profissional (com a memória e suas empatias a desempenharem um papel fundamental;

- com base num corpo teórico transdisciplinar; a posição transdisciplinar é resto, sublinhe-se, a de um pragmático humanismo (Morin);

- tendo em conta testemunhos e opiniões de um conjunto de personalidades com interesses e/ou carreiras relacionadas com as temáticas abordadas; neste sentido, relevo menos as ideias feitas que inusitadas conexões, como é corrente no espírito do ensaio, sempre fulguração a caminho de uma síntese (Barrento).

\section{Da curadoria pela retórica}

Proponho os princípios fundamentais e dinâmicos de uma praxis cujos traços identificatórios são reconhecíveis para além de uma certa superficialidade das análises estéticas cor- 
rentes no campo da arte ou da política. Se há uma Arte do Espaço Público, que não apenas no Espaço Público -; ela é deriva da arte no sentido da sua própria problematização, em nome de uma pulsão social a que sempre regressamos. Existirão assim gradações entre assumirmos um papel social restrito, no seio de um habitus cultural pré-determinado e que se aceita passivamente, como é acontece nos servidores do mundo da arte - e estarmos abertos à arte como conjugação de interesses explicitados num projecto-processo aberto e com carácter público, muitas vezes transdisciplinar. Aqui, a mim não interessou propriamente o debate filosófico no quadro de uma ontologia do projecto - definir uma arte pública crítica - mas, de forma mais prosaica, explicitar uma gramática dos projectos que ultrapassam o entendimento trivial da arte na cidade, naturalmente relevando aqueles que contém a fibra de modelos, gerando massa crítica (no quadro do pensamento curatorial em particular). Em paralelo, acredito na revisão de vários conceitos usualmente empregues na história da arte ou do urbanismo, com o objectivo da actualização de um glossário da arte do espaço público na forma urbana, agora do ponto de vista da retórica. Procuro por isso rever o contextual (Ardenne, em alta) ou o relacional (Bourriaud, em baixa) num panorama que não estabiliza qualquer definição, antes procura captar a energia da emergência caracterísica da complexidade projectual da curadoria (penso nas atitudes a ganhar forma em Szeemann). É neste sentido que procurei os contextos sociais e os processos urbanos; essa foi a evolução natural de uma posição que se foi tornando consciente de como funcionaram as metáforas tópicas (Kniess \& Voggenreiter), ao encontro de uma arte contemporânea dissidente (Kniess \& Voggenreiter), sempre disponível para perturbar a apatia do público, sem deixar de manter-se maximamente vigilante no evitar da tentação dos populismos da significação (ainda Kniess \& Voggenreiter) ou das falácias participativas.

\section{Quadro teórico e princípio valorativo de uma experiência}

Nesta investigação defini um quadro teórico-prático de referência para a curadoria e a produção em arte pública. Partindo da constatação de um jargão específico que hoje é moeda corrente (em Bourriaud, Rancière, Negri, Badiou, Nancy, Miles ou Bishop), moderei debates potenciais entre obras e acontecimentos que me pareceram destacar-se numa anamnese da arte pública (movimento reconhecivel desde os anos 60); seleccionando, ao longo do tempo, uma espécie de genealogia mítica (ao nível internacional e nacional), expus nessas obras os princípios mais consentâneos com os da minha própria metodologia curatorial. Cheguei assim ao esquema de um método, na consciência de que nos projectos mais interessantes o que acontece é um relevar de sempre um mesmo princípio projectual (transepocal, transgeracional), actualizado em diferentes contextos e de acordo com várias oportunidades. Ao perspectivá-lo como extramuros - metáfora operativa-chave - procuro pensar como, no limite, a arte pública que constantemente sai de si, cuja dimensão comunicacional é função da percepção e afectação de um público que ela própria cria, é uma praxis artístico-projectual que constitui um factor de vida na cidade e na sociedade contemporânea. Essa dimensão de vitalidade decorre de uma atitude (Sena da Silva) de excentricidade do processo face ao modus operandi tradicional de qualquer disciplina, divisão cultural ou ideologia hegemónicas. Na arte pública como a entendo - depois das constatações da 
sua vernacularidade, populismo e dos múltiplos modos da sua apropriação da categoria do quotidiano (Lefèbvre) - a inevitável pulsão da arte (Fiedler) é uma pulsão de atenção a aspectos considerados urgentes, fundamentais ou simplesmente apaixonantes do socius. Assim, estabeleço paralelismos e analogias entre conceitos e experiências de ponta da arte moderna e contemporânea (ideias-chave, obras-charneira, episódios emblemáticos, agentes de mudança, conceitos teóricos) e a minha disponibilidade para, identificando uma dinâmica retórica ethos/pathos/logos na arte pública, definir uma economia de valores projectuais específica quando se dá o desejo de levar a arte a inscrever a sua pragmática, que acontece pública e criticamente nas formas da cidade.

\section{Constatação: a linha de um movimento artístico antigo e global}

As obras e autores a que presto mais atenção encaixaram numa ideia que nutri durante muito tempo, a da continuidade helicoidal (Justo) de um ethos e de logos, senão de uma pathos ao longo dos tempos, apesar de evidentes diferenças entre as obras estudadas. Continuamente, faço apelo às coincidências de terminologia, atitude ou aspectos formais entre autores de épocas diferentes - por exemplo quando sugiro que a deriva situacionista é a actualização do peripatetismo aristotélico, ou que inversamente este é uma protomanifestação da crítica da sociedade separada de Debord. A continuidade de uma atenção à energia retórica dos projectos - do olhar retórico sobre a própria arte - surge como potenciador de consciência inusitada sobre o fenómeno artístico, o contexto social e, sobretudo, a ligação entre ambos os campos. Isto é, em todas as obras de que quero relevar o logos retórico, o que temos são felizes, ou melhor, persuasivas, formulações de hipóteses críticas para a arte. Nas obras destacadas, identifico uma paixão de fundo - entre arte e social. Vislumbrei-a nos ethoi clássico (de Aristóteles a Diógenes), romântico (Novalis, Schiller, Wagner) e moderno/pós-moderno (Lefèbvre, Rancière, Sloterdijk), confrontando-o permanentemente com uma ideia consecutivamente actualizada: a da tripartição retórica, aplicada ao tecer complexo da cidade e das suas formas, que desde as neo-vanguardas tem visto expandir-se uma panóplia de aparelhos teórico-práticos inter-, multi- e transdisciplinares. Ora entre múltiplas práticas e acções a nível global, há afinidades electivas evidentes, mostrando como é generalizada - globalizada - uma resiliência da criação contemporânea ao dispositivo social contemporâneo (capitalista) em sede de produção de subjectividade artística. Este é um quadro que tem traços da emancipação crítica (de raiz marxista) mas também nuances de formas emergentes de experimentação interventiva (Sholette). O que caracteriza esta multiplicidade, o nível do meu corpus, é a consciência de que o sistema da arte (Cauquelin, Millet), como qualquer outro sistema no mega-dispositivo que é a sociedade, é mais um aspecto fundamental, contingente, face ao qual se desenha a ética da produção artística, interdependente de uma conceptualização crítica do seu poder (Groys) e da sua auctoritas. 


\section{Viradas históricas e suas consequências cognitivas}

Na história da arte contemporânea, denoto uma renovação importante do seu sentido social a partir do momento dos linguistic, conceptual, spatial e curatorial turn, que se vão juntar às provocatórias autodeterminações da installation art, da pop art, da land art e do minimalismo para enriquecer as hipóteses comunicacionais da praxis artística face à eventual relevância - ou irrelevância - da arte pública. Ao mesmo tempo que releio sucessivas visões da vanguarda como aproximações críticas à hipótese de permanecermos sempre modernos, levo a retórica de Aristóteles e Arendt a legitimar um Espaço Público contemporâneo com carácter complexa e multidimensionalmente discursivo (Lefèbvre); desde Duchamp que há uma dinâmica corpo-ideia que, na esfera de uma arte que procura problematizar o sentido de si mesma face à sociedade, estabelecendo com o público inovadoras formas de entendimento do real. Isto é, concluo que um conjunto de gestos projectuais ao longo do século XX e depois XXI, uns mais radicais que outros, labora numa economia de valores e deles retira as necessárias consequências enquanto expressões retóricas de possibilidades (Groys, O'Sullivan, Miles). Elas tornam-se cognição vivida da cidade - o encontro (Deleuze/Guattari) com o seu devir colectivo, por exemplo quando, sob a forma múltiplice do memorial, da intervenção efémera ou da festa, um certo público - ele próprio uma comunidade efémera convocada e produzida pela arte - é levado a entender (Wagner) o logos da sua própria condição urbana. Isto é, leio as inovações da arte menos como exercícios estéticos em si, mas como le isso não invalida aquele primeiro nível), aproximações à modernidade (Lefèbvre) sempremergente da inteligência crítica em acção. Mais uma vez: na arte pública, essa acção é de encontro com o outro (Buber) da/na cidade, nas condições possíveis da mesma, numa coreografia do colectivo.

Há aqui espaço para uma anamnese de Maio de 68 (como do 25 de Abril), assim como das incontáveis efervescências críticas da arte pública, enquanto poéticas fulgurações dos possíveis do político, nomeadamente numa concreção operativa lugar/espaço/rua (Liggett) tipicamente moderna (Hirsch). Esta decorre quase sempre como figura negativa-emancipatória, triplamente determinada (Hirsch): dando ênfase aos elementos de constestação e resistência; aos de comunidade, no estar-juntos; e aos de espaço público. Sob o signo da revolução, da festa ou do quotidiano (uma descoberta lefèbvreana), o socius abriu-se entretanto ao imponderável, de que uma ideia empática do espaço urbano (Hirsch) é a metafísica fundamental. É uma metafísica do dispositivo cidade como vazio retórico, na 'origem' de um poder não-representacional (Thrift), sem imagem (Hirsch), que não serve a criação de líderes políticos, saberes reificados ou a representação de si próprio. Sob o signo da visibilidade e do aparecer (Arendt), este é o vazio que, ora sob o signo do Nada, ora da Luz, expõe a lógica da aparição comunal (Hirsch).

Mas esta questão implica a de como lidar com o carácter difuso desta resistência criativa. Os diagnósticos de Negri e Hardt, Laclau, Mouffe, Agamben, Rancière ou Badiou', e mais atrás Arendt (razoavelmente conservadora), são unânimes no considerar a democracia um estado de excepção, valorizando a premência da expressão efémera. Se, em sintonia com estas

1 Cito os que Hirsch cita, englobando-os numa linhagem politicamente avançada e, ao mesmo tempo, no quadro de uma mitologia do conflito. Cf. Hirsch, pp. 294-295. 
ideias, há uma indesmentível vitalidade e sofisticação no campo da arte pública crítica, só uma arte-depois-crítica, que reputo uma retórica total da criação na cidade - pode isolar operativamente os elementos plásticos do socius, contribuindo para que os mais variados arquipélagos (Hirsch) façam sentir a sua presença na esfera pública - por mais em crise que esta esteja (Habermas). A graça da arte pública é esta. As suas formas transmitem uma hipótese (colaborativa), um horizonte (participado), um paisagem que aparece como realidade pública (Grout).

\section{Uma comunidade projectual}

Na cultura contemporânea, há a emergência significativa de um território específico, o de uma praxis artística que acontece sempre que criadores se engajam em projectos artísticos e culturais de vocação activista-social, que aspiram, no seu discurso e na sua pragmática, a simultaneamente reflectir, comunicar e intervir de forma intencional, activa e participada no tecido social. Falo de um interesse pelo mundo que não consegue eliminar da equação artística ou do projecto cultural nenhum destes três aspectos, considerados como fundamentais e necessariamente em articulação: um aspecto intelectual e meta-operativo, no sentido de uma reflexão sobre os próprios modelos estéticos e premissas políticas das intervenções; um segundo aspecto que poderíamos chamar eminentemente plástico e estético, relacionado com uma evidência pública das decisões acerca da materialidade dessas mesmas intervenções e que por vezes é reflexão partilhada sobre uma fenomenologia das formas da arte pública; um aspecto político, no sentido de intervenção activa na polis enquanto configuração do real e o mundo social, com o meio urbano a funcionar como palco privilegiado para a responsabilidade ética e o agenciamento perante a comunidade. Na prática e nas condições actuais, esta arte é de uma forma geral desenvolvida como crítica (potencialmente) produtiva e construtiva do Espaço Público. Ela contribui para acumular conhecimento sobre a evolução não apenas do conceito de esfera pública ou de espaço público (como todos os conceitos, historicamente limitado), ou ainda da substância humana e social dos factos na esfera destes conceitos teóricos - antes da sua existência e depois da sua exaustão -, mas sobretudo para, proactiva, pragmática e poieticamente se divisarem experimentalmente hipóteses de, numa contemporaneidade hipermoderna (Lipovetski), sob o domínio do capitalismo cognitivo-comunicacional, a criação ser capaz de fazer sentido na cidade. Esse sentido só pode ocorrer, de resto, em condições específicas de empatia; condições capazes de inscrever a imaginação na experiência apática (Gross) que caracteriza as democracias actuais. Uma coisa é certa, os protagonistas e agentes desta arte, muitas vezes anónimos - até enquanto público dos seus pares le os seus pares são toda a gente) reconhecem facilmente as economias e afins à sua ética projectual. Neste logos da arte pública e crítica Dieu reconnaitra les siens poderia ser um motto recorrente.

\section{Estilos e escalas de acção}

Não se trata de uma maneira nova de encarar e produzir arte: experiências históricas anteriores, de resposta a derivas capitalistas no social, definiram os territórios do situacionismo 
à arte contextual, entretanto relativamente estabilizados com linguagens plásticas dado o impacto cultural de uma série acções de referência, icónicas junto da intelligentsia, e que depois se vêm inseridas numa lógica de sistema (o mundo da arte) amplamente empenhado em manter-se autónomo face o mundo lá fora. Do Dada ao surrealismo, e depois com particular evidência nos anos 60 e depois nos anos 90 , têm-se sucedido operações estéticas empenhadas num repensar da relação entre a arte e o real social em toda a contingência e imponderabilidade, assumindo uma miríade de formas públicas que oscilam entre, num pólo, acções fundamentalmente individuais, mais ou menos generosas, espectaculares ou exemplares; e projectos culturais colectivos de média ou longa duração, cujas componentes se aglutinam em torno de programas resultantes de redes organizacionais mais complexas, cujos discursos respondem a funções urbanas e sociais específicas, de carácter relativamente institucionalizado. Grosso modo, por um lado, entre uma posição artística que nos remete para a imagem sacrificial do indivíduo criador - auto-definido por exemplo como messias, terrorista, flâneur, clown ou franco-atirador; e uma posição em que o artista se dilui numa dinâmica colectiva organizada, por exemplo na qualidade de sacerdote, parceiro, mediador, sacerdote ou líder. Por outro, entre o criador que aposta no indizível dos seus actos e outro que cede ao desejo de comunicar e partilhar os conceitos operativos no seu discurso. Pode então falar-se de práticas intervencionistas (Scholette) de curta vs. longa duração, ou de activismo micropolítico vs. arte comunitária, etc. mas o binarismo funciona aqui sobretudo como modelo de apropriação projectual dos elementos discretos (decisões de projecto identificáveis ao nível do seu logos), nunca da complexa realidade vivencial destas experiências no território urbano, claramente de ordem não-representacional (Thrift). À escala da urbe, importa sobretudo manter constantemente a capacidade de apreensão da multidimensionalidade da prática artística, para que esta possa ser percepcionada do ponto de vista da sua emancipação, nomeadamente em momentos de acções colectivas.

\section{Em Portugal}

Perante a multiplicidade de campos e estratégias que constituem hoje o terreno de acção da arte (pública, urbana) ao nível internacional, em Portugal o sentido de social nas obras e eventos que valorizo respondem à sua maneira à realidade portuguesa. Na minha experiência, os momentos extramuros no seio dos percursos de artistas de méritos reconhecidos no sistema das artes - tanto quanto é possível rever a sua excentricidade crítica na história oficial -, das políticas culturais vigentes, da praxis das instituições, levou-me a deduzir que, nem sempre, mas com regularidade, os artistas não resistem ao apelo do socius, aceitando ou propondo para a sua criatividade modelos de desenvolvimento com carácter colaborativo, interdisciplinar, comunitário ou de intervenção social. Os casos mais extraordinários são aqueles em que, na contemporaneidade, se conjugam, em equilíbrio dinâmico, no quadro de uma postura transversal e transdisciplinar, e com expressão assumidamente pública, as funções reflexiva, estética e política da intervenção artística face à realidade específica do espaço e do território em que estas obras inscrevem os seus dispositivos. Umas, mais do que outras, conseguem porventura transmitir a liberdade da necessidade (Schiller) específica das condições em que foram realizados. Na sua evidência prática, vejo uma leitura 
crítica do panorama artístico português: há lugar na contemporaneidade para uma arte do Espaço Público, do social contingente e em construção, capaz de gerar comunicação, motivação e sentido crítico, num patamar de interactividade social mais complexo e transformador que aquele que define os circuitos e contextos artísticos tradicionais. Essa arte é hoje pontualmente posta em movimento por agentes culturais cujos objectivos, motivações e enquadramento teórico (Ernesto de Sousa, Vidal, Brandão) importa relevar, por oposição a posições perante o campo da arte imobilistas. Muitas vezes, estas acções decorrem assim, também em Portugal, abaixo do radar (Millet), mesmo quando os seus improváveis agentes são players importantes do sistema. Seja como for, a arte que é alternativa - enquanto pública, transdisciplinar, urbana, crítica - é hoje um motor de criatividade crítica, um país constantemente adiado.

\section{Arte(s) extramuros, Artes do Espaço Público}

Vários domínios da produção cultural, quer em termos da programação de eventos, quer em termos de áreas de investigação, concorreram para delimitar - ainda que de forma vaga não apenas as tipologias de projectos abordados, como sobretudo uma espécie de campo semântico-chave em torno do conceito de Arte do/como/para o Espaço Público. Sem qualquer ordem especial: Projecto Cultural, Acção Cultural, Dinamização Cultural, Intervenção Cultural, Animação Sócio-cultural, Animação Cultural, Activismo Cultural, Estudos Culturais, Indústrias Culturais, Urbanismo [cultural], Geografia Humana, Projecto Urbano, Espaço Público [e interdisciplinaridade], Sócio-urbanismo, Psicologia Social, Arte Participada, Arte Urbana, Arquitectura informal, Design Participativo, Design Inclusivo, Acção Política, Cidadania, Cidade Criativa, Educação Cultural, Educação Social... Radiquei porém as minhas conclusões acerca do que entendo por uma genuína arte pública - a Arte do Espaço Público que fui definindo como meu campo de intervenção - em torno do conceito extramuros precisamente para afirmar que existe um princípio de intervenção artística no mundo - na cidade e no território - que é

intrinsecamente 'fora': excêntrico, fora dos centros, em sentido tanto literal como simbólico. É um território e um momento historicamente caracterizados pela valorização explícita e pedagógica - senão terapêutica - da realidade quotidiana, do imprevisto, das intersubjectividade, da liberdade, da paixão. Em suma: do potencial de transformação da arte face à cidade, vivido a partir de uma movimento moral (ethos), cujas implicações éticas, modalidades estéticas (logos) e produção de afeições (pathos) merece ser entendida na sua imponderável dinâmica de inscrição. Esta é aqui entendida enquanto momento decisório no logos projectual.

\section{Questões em aberto}

No final da investigação, algumas questões-chave permaneceram como espectros, assombrando o que antes parecera límpido.

Primeira questão. A haver uma continuidade de uma criticidade da arte, que se actualiza na forma da ars extramuros como avatar actual da arte crítica, o que se segue? Que é que 
na minha investigação pode ajudar-nos a reconhecer como padrões estéticos emergentes? No limite, há uma arte depois da arte? Ela será reconhecida, com as ferramentas teóricas, conceptuais e afectivas de que dispomos? Que dispositivos artísticos o dirão? Ou já estão a dizer? Que dimensões de ars extramuros merecerão o aprofundar de análises e sínteses pragmáticas? E isso vale a pena?

Segunda questão. Há uma validade instrumental em vectorializar as opções de projecto como faço na minha axiomática - e concatenar esse saber com uma consciência da intensidade retórica? Se tudo indica que sim, até certo nível de consciência acerca do objecto de arte, qual é a acção teórica realmente determinante que, como a metáfora da vitalidade pública, nos arranca para novo período da história - ao nível individual e colectivo? Isto é, como reconhecer o acontecimento ou a festa que nos redimem no fluxo do presente? A retórica mais evoluída chega? Ou há uma outra polis, como ainda e sempre Duchamp parece sugerir, na sua muito própria visão do infra-mince como resposta à ansiedade? Fazer em vez de pensar é solução para este dilema?

Terceira questão. Partindo do princípio de que algo nestes projectos mais extramuros é da ordem da revelação, como sair do estado de iluminação e de graça (Weil) que as obras inscrevem? Ou melhor, como chegar - se é que isso faz sentido - à operatividade da revelação de uma graça social através da arte? Ela é historicamente irrelevante ao ponto de ser absolutamente necessário empreender a destruição kúnica dos feitos artísticos, sejam eles quais forem? A história já foi, e novas tensões exigem outros paradigmas de abordagem do indestrutível humano (Kafka)? E já agora, a arte é um factor diferenciador ou redentor nestas economias emergentes?

\section{Limitações do corpus}

Esta investigação deu conta, de obras de arte reconhecidas no campo da arte contemporânea e das virtualidades crítico-retóricas da sua inscrição extramuros no tecido urbano; não me foi possível alargar a reflexão a formas de arte pública informal e anónima, ou simplesmente realizada por agentes não reconhecidos pelo campo da arte (Seno), o que certamente debilita uma posição de fundo - a de que há muitas obras não-artísticas que são retóricas e críticas na sua artisticidade (Duchamp), com uma intensidade e proficiência na abordagem da forma-cidade que muitas obras de arte (do sistema) não têm. Penso em certas acções de activismo político. Ao mesmo tempo, é o campo da arte que estabelece paradigmas de excelência e de rigor conceptual (Groys), e de sofisticação (Cabral Santo) que, precisamente quando postos em causa pelas vanguardas - enfim pela vanguarda - pois se me afigura de certa forma credível a posição que quando falamos de vanguarda estamos sempre a falar de uma sempre a mesma pulsão moderna-construtivista-produtivista de vitalidade e inovação - obrigam o xadrez da artisticidade a continuamente se renovar. Portanto, apesar da limitação, a ideia foi - muito restritamente - questionar as franjas e os limites do mundo da arte quando confrontado com os desafio do povo e da democracia, do espaço público e do destino colectivo - ele próprio (como) quotidiano - , e nestes termos muitas obras de arte aqui referidas revelam como a 
partir de dentro do campo da arte o ethos artístico se confronta regularmente com a emergência inevitável de um socius que se pressente como modalidade da saudade de futuro. A outra razão para não ter avançado para mais amplas análises fora do mundo da arte - e em especial da realizada pela Extra]muros [ - prende-se ainda com um certo pudor perante o que de resto se faz quase sempre no anonimato de uma graça social que necessita desse anonimato para ter valor cultural. E assim, leia-se nas análises das obras que refiro também a valoração - por extensão - de muitas e muitas obras, intervenções ou acções 'artísticas' cuja gramática formal e cujas principais operações retóricas, com afinidades com a minha retórica extramuros, são outra arte - tal com a arte extramuros é outra arte face à ideia genérica de arte pública e a arte pública já era outra arte face à arte moderna e contemporânea.

\section{Economia conceptual de uma retórica}

De acordo com o 'postulado da Navalha de Ockham', os conceitos, para se chegar à verdade, não devem ser numerosos: a economia de pressupostos é vantajosa. Regressando a Aristóteles, esta investigação mantém este princípio: uma enorme economia de conceitos e das relações entre eles e a eles regresso para reposicionar o que, acerca dessas relações, posso afirmar como uma retórica extramuros, condição provisória de um fluxo racional de que a minha actividade curatorial e de programador cultural se alimenta. Assim, avanço a primeira ideia fundamental, a de que pulsão artística, não apenas um dado inevitável da expressão humana como, em certas ocasiões do fluxo da biografia humana lindividual ou colectiva), é indissociável de um traço de encontro deliberado com esse social. E que ela busca, uma ancoragem na efectividade de uma dimensão radicalmente dialógica (Buber) da existência humana. Proponho depois que se justaponha ao social como materialidade necessária o conceito de quotidiano (Lefèbvre), a última das categorias clássicas na filosofia. Pensar o social fora da categoria do quotidiano, na sociedade contemporânea, seria esquecer a determinante influência que sobre nós exerce o entorno urbano - a cidade -, em toda a complexidade constitutiva. Desenvolver uma reflexão acerca da pulsão artística face ao quotidiano, enquanto categoria fundadora do social, passou assim, por desenvolver aspectos críticos da cultura urbana, que toda a tradição da arte urbana (como) crítica - nas esferas da política, do activismo, da regeneração urbana - nunca deixou de interpretar, aliás na senda de experiências que se iam dando em diferentes esferas de acção lassim criando clusters terminológicos e um jargão reconhecível). Na prática, revisitei o jargão da arte pública num espírito anacrónico e contemporâneo (Agamben), em busca de um sentido possível na actualidade, apenas possível de vislumbrar em skhemas retóricos acessíveis (simples, evidentes). Os três assuntos-chave são na prática as questões da intervenção, da situação e da comunidade, 'resolvendo' os tópicos (de valor) do museu, do contexto e da participação.

\section{Experiências transpessoais da graça}

Nalguns casos de extremo envolvimento da arte pública crítica com o destino colectivo, e simultaneamente, um desejo de transparência de processos, dá-se a experiência suprapes- 
soal de uma graça secular, não longe de uma ideia de redenção. Certos acontecimentos, obras e criadores da contemporaneidade trouxeram para o campo expandido da arte dos anos 60 esta dinâmica comunicacional específica, que liga a liberdade da experiência de uma luminosa revolução à consciência fugaz de uma intersubjectividade colectiva lque começa no outro dialogal, em Buber), como acontece quando vislumbramos a retoricidade da imagem do comum como festa (Gadamer), no que isso implica de assumpção da liminaridade (Turner) ou da intersticialidade (Miles) aquando da produção do encontro da arte. É aqui que o contacto com a racionalidade retórica se torna determinante - a montante lo autor e a sua autonomia, no caso em nome do poder da arte, em Groys; o espectador e a sua emancipação, no caso em nome da sua participação, em Rancière e mais atrás, em Freire). Os mais recentes desenvolvimentos metafilosóficos de uma retórica contemporânea ajudaram-me a, a partir do campo semântico (e no fundo, também semiótico) da arte pública, a desenvolver a minha própria retórica, aqui não apenas no sentido de uma crítica, retrospectiva, de momentos da história da arte e da cidade, mas no sentido positivo e prospectivo de uma retórica extramuros para os tempos actuais, o momento possível. Noutros termos, consegui fazer coincidir aspectos decisivos de um ressurgimento da retórica - de Perelman a Gross, passando por Carrilho, Meyers, Tinnermans) - com a necessidade profunda de renovação espiritual (Sloterdijk, Nancy, Zizek) que alguma arte pública sugere, e assim, em sede de projecto urbano, deduzir premissas curatoriais operativas, com o mérito, acredito, de concatenar - sem as anular - as mais estimulantes perspectivas da actualidade. Nestas destaco, porque me cruzei com eles em momentos decisivos da minha conscientização os filistinismos respectivamente palavroso e biopolítico dos Freee e de Christian Nold, a par da singeleza ornamental de Chevalier e da provocação prosaica de Javier Núñes Gasco. Assim, uma retórica extramuros - que releva tropos em torno dos valores da atenção, do dispositivo e da graça - faz justiça, enquanto dynamis entre vectores-tipo da acção urbana, às iniciais noções de arte (como pulsão) e social (como destino), a partir da superação de alguns impasses da arte crítica.

\section{Simplicidade face ao 'mal da trivalidade'}

Interessante é notar que, na forma urbana (subjugada à ditadura da imagem rápida e da experiência directa), o logos dos projectos é tanto mais total e significante - e cósmico quanto simples e eficaz na convocação dos seus parceiros de olhar. O sentido terapêutico desta arte pública - tão presente no ethos grego (a catarse na tragédia) como no romantismo (Novalis, Schiller, ambos médicos, empenhados numa nova humanidade) vai de encontro ao aforismo como acção cínica e cirúrgica (Cirujeda) na cidade, algo que procurei exponenciar com as ressonâncias propriamente discursivas (linguísticas, genéricas) desta percepção. Em suma, tudo indica que nas condições actuais da fruição da arte e do espaço-tempo urbano, é sábio, económico, encarar a enorme transparência, redução e até evidência de certas obras (o what you see is what you get) como manifestações, de que face à complexidade do socius contemporâneo e suas alienação em mise-en-abîme, apenas a singeleza da empatia com o logos-conhecimento (Aristóteles, Wagner) - que funciona por degraus de complexidade no entendimento - pode gerar um espaço público transformativo. 
Tudo isto leva a que a arte extramuros pareça directa, pobre ou simplista, e que até as suas operações mais críticas surjam superficialmente como meras provocações, irresponsabilidades e megalómanas incursões da estética na política (um divisão afinal impossível, como sabemos desde Rancière): ora no entendimento pragmático-poiético das condições de que emerge a arte, que é campo da curadoria, isto demonstra, por um lado, que nem todo o público é público desta arte pública (Chafes fala numa aristocracia do gaze artístico, e haveria assim um povo paradoxalmente aristocrático no reconhecimento da arte que Ihe interessa); por outro que a luta contínua, sempre, no espaço de mútuo consentimento argumentativo que arte pública inventou para o ser humano que escolheu a cidade para viver. Ou seja, o que toma a arte pública extramuros um parceiro fundamental da política contemporânea é a sua disponibilidade e abertura para desenvolver um território comum entre linguagem corrente e o próprio entendimento quotidiano e situado do que é a polis - e se é esse o 'pecado original' que as obras trazem a um mundo da arte e uma democracia representativa exangues. Isto permite-me concluir do valor efectivamente metafórico de certas obras e eventos, e então, depois de ter renovado os votos com as perspectivas complementares da crítica em Lefèbvre e da energia poética em Novalis, propor, d'après Wagner (mas também Zizek), uma arte comunista, a arte-do-futuro-por-vir-como-possibilidade (Agamben amalgamado em Malcolm Miles); em temos cínicos (Sloterdijk), e tão apaixonantemente acessível por isso mesmo, podemos então começar por afastar-nos do terror da trivialidade da arte, da sua idiotia (Perniola), da sua subjugação à ditadura da moda (Wagner), para, excentricamente, manifestarmos as hipóteses quotidianas (Lefèbvre) de uma singeleza que não é outra coisa que a cidade a dizer o que tem para dizer. 
Abrahamson, Roy E.; « Art Criticism: The Potential of Conrad Fiedler's Ideas for Art Education», (Paper), Annual Meeting of the National Art Education Association, Atlanta, GA, Março 20-24, 1991.

Adorno, Theodor; Horkheimer, Max; Dialetica do Esclarecimento, Jorge Zahar, Rio de Janeiro, 1985

Agamben, Giorgio; A comunidade que vem, Presença, Lisboa, 1990

Almeida, Bernardo Pinto de, Costa Pinheiro, Editorial Caminho, Lisboa, 2005

Almeida, Bernardo Pinto de, Pintura Portuguesa no Século XX. Porto, Ed. Lello, 1993, 1996 e 2000

Almeida, Sónia Vespeira de; Camponenes, Cultura e Revolução. Campanhas de Dinamização Cultural e Aç̧ão Cívica do M.F.A., Edições Colibri / IELT, Lisboa, 2009

Alves, Fernando M. Brandão, Avaliação da Qualidade do Espaço Público Urbano. Proposta Metodológica, Fundação Calosute Gulbenkian/Fundação para Ciência e a Tecnologia, Lisboa, 2003

Armajani, Siah; Espacios de lectura, MACBA, Madrid, 1995

Ardenne, Paul; Un Art Contextuel, Flammarion, Paris, 2004

Ardenne, Paul, in «Lieux Publics», Centre National de Création, 2008.

Arendt, Hannah, A Condição Humana, Relógio d'Água, Lisboa, 2001

Arendt, Hannah, Sobre a Revolução, Relógio dÁgua, Lisboa, 2001

Argan, Giulio Carlo; História da Arte como História da Cidade, Martins Fontes, São Paulo, 2005

Aristarkhova, Irina; «Beyond Representation and Affiliation», «Artists' Collectives Mostly in New York, in in Collectivism after Modernism; Ed. Stimson, Blake; Scholette, Gregory; University of Minnesota Press, Minneapolis, London, 2007

Aristóteles, Obras Completas, Imprensa Nacional Casa da Moeda, Lisboa, 1998

Aristóteles, Poética, FCG, Lisboa, 2004

Bachelard, Gaston; A Poética do Espaço, Martins Fontes, 2008.

Barrento, João; Ler o que não foi escrito - Conversa inacabada entre Walter Benjamin e Paul Celan, Cotovia, Lisboa, 2005

Barthes, Roland; Le Système de la Mode, Editions du Seuil, Paris, 1964.

Barthes, Roland, Mitologias, Edições 70, Lisboa, 1989

Bauman, Zygmunt; Comunidade,Zahar, Riod e Janeiro, 2001.

Becker, Kai; «The Dark Side of the White City», in Professional Lighting Design, N.52, Nov./Dec. 2006, 2006

Beech, Dave; «The Politics of Beauty», in Art Monthly, May 2007, n. 306, 2007

Belamich, André; Lorca, Arcádia, Maia, S/D

Belsey, Catherine; Shakespeare and the Loss of Éden, Basingstoke, Palgrave

Benjamin, Walter, Sobre Arte, Técnica, Linguagem e Política, Relógio d'Água, Lisboa, 1992

Bennett, Sarah; Butler, John [Eds.]; Locality, Regeneration \& Divers[cities] - Advances in Art \& Urban Futures Volume 1, Intellect Books, Bristol/Portland, 2000

Berger, Peter L.; Luckmann, Thomas; A Construção Social da Realidade - Um Livro sobre a Sociologia do Conhecimento; Dinalivro, Lisboa 1999/2004

Bergson, Henri; A Evolução Criadora, Lisboa, Ed. 70, 2001

Beuys, Joseph; Cada Homem Um Artista, 7 nós, Lisboa, 2010

Bey, Hakim; T.A.Z. Zona Temoralmente Autónoma, Ed. Talasa, Madrid, 1996

Beech, Dave; Art and Text, Blackdog, London, 2009

Bishop, Claire [Ed.], Participation, Whitechapel/MIT Press, Londres, 2006

Bishop, Claire, «The Social Turn: Collaboration and its Discontents», Artforum, 2006

Bishop, Claire; Installation Art, Routledge, London, 2005

Blais; Joline; At the Edge of Art, Thames \& Hudson, London, 2006

Blanchot, Maurice; The Unavowable Community, Station Hill Press, 2006.

Bloom, Harold [Ed.]; Franz Kafka, Chelsea House Publishers, New Haven/New York/Edgemont, 1986

Bouchardeau, Hélène; Bernard Stiegler et Ruedi Baur «Changer de modèle industriel» un entretien européen, Maison de l'Europe de Paris, 2007.

Bourriaud, Nicolas; Relational Aesthetics, Presses du Réel, Paros, 2002

Boutang, Yann Moulier; Le Capitalisme Cognitif: La Nouvelle Grande Transformation, Multitude, Paris, 2007 
Brandão, Pedro; A Cidade entre Desenhos - profissões do Desenho, Ética e Interdisciplinaridade, Livros Horizonte, Lisboa, 2006 Brea, J.L., «Ornamento y utopía. Evoluciones de la escultura en los años 80 y 90 », in ARTE, PROYECTOS E IDEAS. №4.mayo 1996 Ed. UPV, Valencia.

Brea, José Luis; La Era Postmedia [PDF]

Brea, José Luis; El Tercer Umbral [PDF]

Buber, Martin, O Socialismo Utópico, Editorial Perspectiva, São Paulo, 1971/1986

Buber, Martin, Do Diálogo e do Dialógico, Editorial Perspectiva, São Paulo, 2009

Buci-Glucksmann, Christine; Estétique de l'Ephémère, Galilée, Paris, 2003

Cabau, Philip; Design pelo Desenho, FCA Design, Lisboa, 2011

Cadete, Teresa Rodrigues; «A Tensão Elegíaca ou o Sujeito com Paisagem», in Schiller, Friedrich; Sobre Poesia Ingénua e Sentimental, INCM, 2003, Lisboa

Caeiro, Mário; A Vida e o Monstro, Águaforte, Lisboa, 1997

Caeiro, Mário; «Da prática crítica da arte urbana. Por uma estética extramuros», in Arq./a, n. 23, Maio 2008, Lisboa.

Caeiro, Mário; «Forma/informe: notas soltas. Sobre a tangibilidade formal da actividade artística e o informe produtivo», in Arq./a, N. 62, Out. 2008, Lisboa

Caeiro, Olívio; Oito Séculos de Poesia Alemã, Fundação Calouste Gulbenkian, Lisboa, 1983

Capra, Fritjof; Hidden Connections ${ }^{\circ}$-Integrating The Biological, Cognitive, and Social Dimensions Of Life Into A Science Of Sustainability, Doubleday, 2002

Carvalho, de Olavo; Aristóteles em nova Perspectiva - Introdução à teoria dos Quatro Discursos, Realizações Editora, Nova Edição Revista, São Paulo, 2006.

Cauquelin, Anne; L'art Contemporain, Puf, Paris 1992/2005

Cerisuelo, Marc; «En quête d'un absolut relatif. Le moment romantique de la pensée française», in Critique - Revue générale des publications françaises et étrangères, Juin-Juillet 2009, Tome LXV - N.0 745-746, Editions de Minuit

Chibli, Faoze; entrevista a Daniel Lins, in Filosofia, 2004, Editora Escala, São Paulo

Chokr, Nader N.; «On a Genealogy of the Emotions from a Rhetorical Perspective», in Ephemera, vol 7(2), pp. 381-394, 2007

Chouay, Françoise; Pour une anthropologie de l'espace, Editions du Seuil, 2006

Clair, Jean; De Immundo. Apophatisme et apocatástase dans l'art d'aujourd'hui, Galilée, Paris, 2004.

Clifford, James; Routes. Travel and Translation in the Late Twentieth Century, Harvard, 1997

Cossuta, Frédéric; Elementos para a leitura de textos filosóficos, Martins Fontes, São Paulo, 2001.

Costa, Palmira Fontes da; «Da Natureza e Aspirações da Bioarte», in Ciência e Bioarte: Encruzilhadas e Desafios Éticos, Caleidoscópio, Lisboa, 2007

Coutinho, Bárbara, «Para tirar as aspas ao design», in Sena da Silva, Fundação Calouste Gulbenkian, Lisboa, 2010

Cox, Geoff; Krysa, Joasia; Engineering Culture - On the author as (digital) producer, Autonomedia,

Cullen, Gordon, Paisagem Urbana, Edições 70, Lisboa, 1983

Cunha, T. Cardoso e; «Prefácio», in Da Retórica, Friedrich Nietzsche, Lisboa, Vega

Curtis, Kimberley, 'World Alienation and the Modern Age: The Deprivations of Obscurity', in Our Sense of the Real: Aesthetic Experience and Arendtian Politics, 1999

Davila, Thierry; Marcher, Créer - Déplacements, flâneries, derives dans l'art da la fin du XXe siècle, Regard, Paris, 2002

De Certau, Michel; The Practice of Everyday Life, University of California Press, 2002

de la Durantaye, Leland; Giorgio Agamben: A Critical Introduction, Stanford University Press, Stanford, 2009

Deleuze, Gilles; Différence et Répetition, PUF, Paris, 1993

Deleuze, Gilles; Guattari, Félix; O Anti-Édipo - Capitalismo e Esquizofrenia, Assírio \& Alvim, Lisboa, 1995

Deleuze, Gilles; Kafka: pour une littérature mineure, Minuit, Paris, 1972

Deutsche, Rosalyn; Evictions, Art and Spatial Politics, The MIT Press, Massachussets, 1996

Dixsaut, Monique; «lsocrate contre les sophistes sans sophistique», in B. Cassin (org.), Le Plaisir de parler, Paris, 1986

D'Orey; Carmo; O que é a arte?, Dinalivro, Lisboa, 2007.

Doherty, Claire; Situation, The Mit Press, 2009.

Duchamp, Marcel; O Acto Criativo, Águaforte, Lisboa, 1997

Duncan, Carol; Civilizing Rituals: Inside Public Art Museums, London: Routledge, 1995.

Duncan, Carol; «Art Museums and the Ritual of Citizenship», in Exhibiting cultures : the poetics and politics of museum display, Smithsonian Institution Press, Washington, 1991

Duque, Félix; Arte Público e Espacio Politico, Akal, Barcelona, 2001 
During, Elie; «A propôs de Konrad Fiedler, Sur l'origine de l'activité artistique, D. Cohn (éd.), Editions "Rue d'Ulm", Paris, 2003.

Elden, Stuart; Understanding Henri Lefebvre: Theory and the Possible, London, Continuum, 2004

Elder, R. Bruce; «Harmony and Dissent: Film and Avant-garde Art Movements in the Early Twentieth Century», Wilfrid Laurier University Press, October 2, 2008.

Esche, Charles; «Modest proposals...» in: Bos, S. \& Fletcher. A. (eds.) Berlin Biennale. Berlin, 2001

Ewen, Stuart; Ewen, Elizabeth; Channels of Desire - Mass Images and the Shaping of American Consciousness, University of Minnesota Press, 1982

Franzen, Brigitte; König, Kasper; Plath, Carina; Sculpture Projects Muenster, Münster, 2007

Ferreira, Vítor Matias; Indovina, Francesco, [Org.]; A Cidade da Expo'98, Bizâncio, Lisboa, 1999

Fischer-Lichte, Erika; Performance e cultura performativa - 0 teatro como modelo cultural, Revista de Comunicação e Linguagens, v. 24, p. 143-169, 1998

Fiedler, Konrad; Sur l'origine de l'activité artistique, D. Cohn (éd.), Editions "Rue d'Ulm", Paris, 2003.

Finkelpearl, Tom; Dialogues in Public Art, The MIT Press, 2001

Foster, Hal; The Return of the Real: The Avante-Garde at the End of the Century, The MIT Press, Massachussets, 2006.

Flusser, Vilém; O Mundo Codificado, COSAC NAIFY, São Paulo, 2007

Franck, A. Karen; Stevens, Quentin, Loose Space, Routledge, London, 2007

Freee Art Collective, The Freee Art Collective Manifesto for a Counter- Hegemonic Art, Freee Publications, Sheffield, 2007.

Freire, Paulo; Pedagogy of Hope, London, Continuum, 2002

Friedman, S. Maurice; Martin Buber: the Life of Dialogue, Routledge, 2002.

Frisby, D; Cityscapes of Modernity: Critical Explorations, Polity, 2001

Fróis, Virgínia (org.), Projecto RIO - Arte, Ciência e Património, Oficinas do Convento, Montemor-o-Novo, 2007.

Gadamer, Hans-Georg, La actualidad de lo bello, Paidós, Barcelona-Buenos Aires-México, 1991

Gasco, Javier Nuñez; Javier Nuñes Gasco, DA2 Domus Artium 2002, Salamanca, 2007

Gelan, Cristina; «J. C. Friedrich von Schiller. Aesthetics and Politics»,

Gibson, Ann; «Avant-Garde» in Critical Terms for Art History, The University of Chicago Press, Chicago, 1996, 2003

Godfrey, Tony; Conceptual Art, Phaidon, New York, 1998

Gonçalves, Jorge Manuel; Os Espaços Públicos na Reconfiguração Física e Social da Cidade, Universidade Lusíada Editora, Lisboa, 2006

Gonçalves, Raquel; Ciência, Pós-Ciência, Metaciência - tradição, inovação e renovação, Terramar, Lisboa, 1991

Gonçalves, Rui Mário; «Baudelaire e a pintura, depois de 1867» in Jorge Fazenda; Hanenberg, Peter (Eds.), Baudelaire $e$ as posteridades do moderno, Universidade Católica Editora, Lisboa, 2008

Gonçalves, Rui Mário; Pintura e Escultura em Portugal - 1940-1980, Instituto de Cultura e Língua Portuguesa, Lisboa, 1980/1983

Goonewardena, Kanishka; Kipfer, Stefan; Milgrom, Richard; Schmid, Christian (Eds.), Space, Difference, Everyday Life - Reading Lefèbvre, Routledge, New York and London, 2008

Gramsci, Antonio, Los Intelectuales y la Organización de la Cultura, Editorial Lautaro, Buenos Aires, 1960

Gross; Daniel E., The Secret History of Emotion - From Aritotle's Rhetoric to Modern Brain Science, The University of Chicago Press, Chicago and London, 2006.

Grout, Catherine; Pour une réalité publique de l'art, Harmattan, Paris, 2000

Groys, Boris; «A Genealogy of Participatory Art», in The Art of Participation, San Francisco Museum of Modern Art, 2008

Groys, Boris; Art Power, The MIT Press, Cambridge, 2008

Gruen, Arno; A Traição do Eu, Assírio e Alvim, Lisboa, 1996

Guattari, Félix; Chaosmosis: An Ethico-Aesthetic Paradigm, Indiana University Press, 1995

Guattari, Félix; The Three Ecologies, Continuum, 2008

Guerreiro, António; «As alegorias da modernidade: o Baudelaire de Benjamin» in Jorge Fazenda; Hanenberg, Peter

(Eds.), Baudelaire e as posteridades do moderno, Universidade Católica Editora, Lisboa, 2008

Guerreschi, Jean; Lieux de l'Écrit, Marval, Paris, 1990

Habermas, Jürgen; Mudança Estrutural da Esfera Pública, Tempo Brasileiro, São Paulo, 1984

Harrisson, Charles; «Modernism», in Critical Terms for Art History, The University of Chicago Press, Chicago, 1996, 2003

Harten, Doreet LeVitte; «Creating Heaven» (1999), in The Sublime, MIT Press, 2010.

Harvey, David, Espacios de esperanza, AKAL Ediciones, Madrid, 2003 
Hastrup, Kirsten; «All the world's a stage - The Imaginative Texture of Social Spaces», in Space \& Culture, vol. 7, $n$. 2, May 2004.

Haynes, Deborah J.; «Bakhtin and the Visual Arts» in A Companion to Art Theory, Blackwell Publishing, Oxford, 2002 Herwitz, Daniel; Making Theory / Constructing Art: On the Authority of the Avant-Garde, University of Chicago Press, Chicago, 1993

Hewitt, Andy; Jordan, Mel; I fail to agree, Site Gallery, 2004

Hirte, Ronald; Hohmann, Katharina; «The Kiosk on Sophienstiftsplatz. From 1968 to 2010, in KoCA-Inn: An urban experiment at the Kiosk of Contemporary Art in Weimar, Weimar, 2009

Holquist, Michael; Bakhtin and his world, Routledge, London, 2002

Hunter, Lynette, in «Performatics: Making a noun out of an adjective», in Va. Aa; On Performatics, Performance Research, Vol. 13, N.2, June 2008, Routledge.

Iser; Wolfgang; L'acte de lecture, Mardaga, Wavre, 1995

James, William; The Principles of Psychology, Henry Holt, Vol. 1, New York, 1890

Jameson, Fredric; Postmodernism, or, The Cultural Logic of Late Capitalism (Post-Contemporary Interventions), Duke University Press, 1991

Jeudy, Henri-Pierre, A Sociedade Transbordante, Século XXI, Lisboa, 1995

Jiménez, Alberto Corsín; «El extraño, el huésped y la máquina», in Carta, Primavera-Verano 2011, Madrid, Centro de Arte Reina Sofia.

Jimenez, Marc; La Querelle de L'Art Contemporain, Gallimard, 2005

Johnstone, Stephen [Ed.]; Everyday, Whitechapel/MIT Press, Londres, 2008

Jones, Peter Blundell; Petrescu, Doina; Till, Jeremy (Eds.), Architecture and participation, Taylor\&Francis, London and New York, 2005

Justo, José M., «O sexo entre os Anjos. A propósito da inteligência metafórica da História em Novalis» in Novalis, A Cristandade ou a Europa, Hiena, Lisboa, 1991

Justo, José Miranda; «As articulações do pensamento e a questão da história», in Novalis, A Cristandade ou a Europa, Antígona, Lisboa, 2006

Justo, José Miranda; «Prospectivamente, Luís Campos: Intensidades e fluxos», in Campos, Luís; Obras 1982-2008, 0 Museu Temporário, Lisboa, 2008

José Miranda Justo, «O Tempo e o Anel (Wagner, Feurbach e o Futuro)», in Wagner, Richard; A Obra de Arte do Futuro, Antígona, Lisboa, 2003

Kafka, Franz, Os Melhores Contos de Kafka, Livros do Brasil, 1968

Kaprow, Allan; Essays on the Blurring of Art and Life, University of California Press, 2003

Kastner, Jeffrey; Brian Wallis; Land and Environmental Art, Phaidon, London, 1998

Kester, Grant H.; Conversation Pieces, Community + Communication in Modern Art, University of California Angeles, 2004

Kleist, Heinrich von, Sobre o Teatro de Marionetas e Outros Escritos, Antígona, 2009

Knight, Cher Krause; Public Art: Theory, Practice and Populism, Wiley Blackwell, 2007.

Koch, Gertraut; «Intercultural Communication and Competence Research through the Lensof an Anthropology of Knowledge», in Fórum: Qualitative Social Research, Vol. 10, n. 1, Art. 15, Jan. 2008

Kosuth, Joseph; «The Artist as Anthropologist», Art After Philosophy and After - Collected Writings, 1966-1990, MIT Press, 1991

Krauss, Rosalyn., «La escultura en el campo expandido» en La originalidad de la vanguardia y otros mitos modernos. Ed. Alianza, 1996

Laclau, Ernesto; Emancipation(s), Verso, London, 1996

Lacy, Suzanne (ed.), Mapping the Terrain, New Genre Public Art, Bay, 1994

Lacy, Suzanne; «Time in Place. New Henre Public Art a Decade Later», in The Practice of Public Art, Routledge, New York, 2008

Lambert, M. Fátima; in Acerca das Tendências da Escultura Portuguesa, Câmara Municipal / Museu Municipal, Santa Maria da Feira, 1996. 
Landry, Charles, The Creative City - A Toolkit for Urban Innovators, Earthscan Publications, 2000.

Lanham, Richard A; The Economics of Attention: Style and Substance in the Age of Information, University of Chicago Press, Chicago, 2007

Lash, Scott; «Art as concept / Art as media / Art as life», in Museus - Discursos e representações, Coord. Alice Semedo e J. Teixeira Lopes, Afrontamento, Porto, 2005

Latour, Weibel, eds.; Making Things Public, MIT Press, Massachussets, 2005

Leach, Neil; A Anestética da Arquitectura, Antígona, Lisboa, 2005

Lefèbvre, Henri; A Linguagem e a Sociedade, Ulisseia, Lisboa, 1966

Lefebvre, Henri; Critique of Everyday Life, London, Verso, 1991

Lefebvre, Henri; Le Matérialisme Dialectique, Presses Uniersitaires de France, Paris, 1957

Leslie, Esther; Walter Benjamin - Overpowering Conformism, Pluto, 2000

Letaillieur, Francçois; «Letrismos Situacionistas» 1946-1968, in Carta, Primavera-Verano 2011, Madrid, Centro de Arte Reina Sofia

Liggett, Helen; Urban Encounters, University of Minnesota Press, Minneapolis, London, 2003

Lind, Maria; «The Collaborative Turn» in Billing, Johanna; Lind, Maria; Nilsson, Lars (eds); Taking the Matter into Common Hands: On Contemporary Art and Collaborative Practices, Black Dog Publishing, London, 2007

Lippard, Lucy; The Lure of the Local, New York, London, The New Press, 1997

Lipovetski, Gilles; Charles, Sebastien; Les Temps Hypermodernes, Grasset et Fasquelle, Paris, 2004.

Loock, Ulrich [Ed.]; A Obra de Arte sob Fogo - Inovações Artísticas 1965-1975, Fundação de Serralves, Porto, 2004

Lungu, Arina; «Marx, Postmodernism, and Spatial Configurations in Jameson and Lefèbvre», CLC Web: Comparative Literature and Culture, 10.1, 2008.

Lynch, Kevin, A imagem da Cidade, Edições 70, Lisboa, 1982

Lyotard, Jean-François; A Condição Pós-Modena, Gradiva, Lisboa 1989.

Lyotard, Postmodern Fables, Minneapolis, University of Minnesota Press, 1997

Maderuelo, Javier [Ed.], Arte publico: naturaleza y ciudad, Fundación César Manrique, Lanzarote, 2001

Maderuelo, Javier; «Cuatro modelos de recuperación de la obra de arte publico» in Arte y espacio público. Ed. UIMP, Santa Cruz de Tenerife, 1995

Maffesoli, Michel; El instante eterno. El retorno de lo trágico en las sociedades posmodernas, Ed. Paidos, Buenos Aires, 2001 Maio, Fernanda; A Encenação da Arte, Textiverso, Lisboa, 2011

Martin, Randy; «Artistic Citizenship», in Artistic Citizenship - A Public Voice for the Arts Routledge, New York, London, 2006. p. 12.

Matos, Sara Antónia (Coord. e Ed.); ESPAÇO, Oficinas do Convento, Montemor-o-Novo, 2009

Meleiro, Maria Lucília F.; A Mitologia dos Povos Germânicos, Presença, Lisboa, 1994

Melo, Alexandre; Pinto, Ana Teixeira; Santos, David; Arte e Artistas em Portugal, Bertrand, Lisboa, 2007

Merleau-Ponty; Le visible et l'invisible, Gallimard, Paris, 1991

Merchant, Carolyn; The Death Of Nature: Women, Ecology and the Scientific Revolution, HarperOne, 1990

Mey, Jacob L.. Pragmatics - In Introduction, Blackwell Publishers, Oxford, 1993

Meyer, Michel; Carrilho, Manuel Maria; Timmermans, Benoit, História da Retórica, Temas e Debates, Lisboa, 2002

Miessen, Markus; Basar, Shumon (eds); Did someone say participate? - An Atlas of Spatial Practice, The MIT Press, 2006

Miles, Malcolm; «Aesthetics in a Time of Emergency», in Third Text, July, Vol. 23, pp. 421-434.

Miles, Malcolm, Art, Space and the City: Public Art and Urban Futures, Routledge, Routledge, Oxon, 1997

Miles, Malcolm; Degen, Mónica (Eds.); Cultural Agency, University of Plymouth Press, Plymouth, 2010

Miles, Malcolm; Azatyan, Vardan (Eds.); Cultural Memory, University of Plymouth Press, Plymouth, 2010

Miles, Malcolm; Kirkham, Nicola (Eds.); Cultures and Settlements: Advances in Art and Urban Futures, Vol. 3, Intellect, Bristol, 2003

Miles, Malcolm; New Practices - New Pedagogies: A Reader (Innovations in Art and Design), Routledge, 2005

Miles, Malcolm, Para Além do Espaço Público, Águaforte, Lisboa, 2001

Miles, Malcolm; The Uses of Decoration: Essays in the Architectural Everyday, John Wiley \& Sons, 2000

Miles, Malcolm; Hal, Tim; Borden, lain; The City Cultures Reader, Routledge, London, 2003

Miles, Malcolm, «Participation and provocation», in Urban Avant-Gardes. Art, Architecture and Change, Routledge, 2004 Miles, Malcolm; Urban Utopias: The Built and Social Architectures of Alternative Settlement, Routledge; 2007.

Miller, Abbott; Lupton, Ellen; «A Natural History of Typography», in Looking Closer: Critical Writings on Graphic Design, 
Allworth Press, New York, 1994

Millet, Catherine, L'art Contemporain, histoire et géographie, Flammarion, Paris, 2006

Mitchell, W. J. T.; «Word and Image», in Critical terms for Art History, The University of Chicago Press, Chicago, 1996

Moore, Alan W.; «Artists' Collectives Mostly in New York, in Collectivism after Modernism; Ed. Stimson, Blake; Scholette, Gregory; University of Minnesota Press, Minneapolis, London, 2007

Moran, Michael; «How Hegel was influenced by Schiller, Goethe, and Hermeticism», http://us.docsity.com/en-docs/ Hermeticism_-_Lecture_Notes_-_United_Kingdom_Philosophy_-_Michael_Moran. Consultado Dezembro de 2011. Morgan, Sally J; «Memory and Identity in the Urban Landscape: a tale of two Barons», in Advances in Art \& Urban Futures Volume 1. Locality, Regeneration \& Divers[c]ities, Intellect, 2000.

Mouffe, Chantal; Dimensions of radical Democracy: Pluralism, Citizenship, Community, London Verso, 1992

Mouffe, Chantal; «Every Form of Art Has a Political Dimension», Chantal Mouffe interviewed by Rosalyn Deutsche,

Branden W. Josep, and Thomas Keenan, in Grey Room 02, MIT. Winter 2001

Moulène, Claire; Art Contemporain et Lien Social, Éditions Cercle d'Art, Paris, 2006

Murdoch, Iris, Acasto - Dois Diálogos Platónicos, Edições Cotovia, Lisboa, 1990

Nabais, Nuno, Metafísica do Trágico - Estudos sobre Nietzsche, Relógio d'Água, Lisboa, 1997

Nancy, Jean-Luc; La communauté désouvrée, Paris, Christian Bourgois, 1983

Naldini, Nico; Pier Paolo Pasolini, Circe, Barcelona, 1992

Narboni, Roger; A Luz e a Paisagem, Livros Horizonte, Lisboa, 2003

Nelson, Robert S; Shiff, Richard [Eds.]; Critical terms for Art History, The University of Chicago Press, Chicago, 2003 Nelson, S. Robert; «Appropriation», in Critical Terms for Art History, The University of Chicago Press, Chicago, 1996, 2003 Nold, Christian; Emotional Cartography - Technologies of the Self, PDF, 2009

Nold, Christian; «Legible Mob», in Latour, Bruno; Weibel, Peter (Eds.), Making Things Public: Atmospheres of Democracy, MIT Press, 2005.

Novalis [Schefer, Olivier [Ed.]], Art et Utopie, Editions Rue d'Ulm, Paris, 2005

Novalis, A Cristandade ou Europa, Antígona, Lisboa, 2006

Novalis, Fragmente und Studien, 1798-1798, in Novalis; Schriften, Luckhohn, P.; Samuel, R.; 5 vol. Stuttgart, 1960 sq. Vol.2, section 4, n. 105.

Novalis, Fragmentos, Assírio e Alvim, Lisboa, 1992 (trad. Rui Chafes).

Nussbaum, Martha; The Therapy of Desire: Theory and Practice in Hellenistic Ethics, Princeton University Press, 1994).

O'Neill, Paul; «The Curatorial Turn: From Practice to Discourse», Intellect, Bristol, 2007

O'Sullivan, Simon; Art Encounters Deleuze and Guattari - Thought beyond representation, Palgrave Macmillan, Hampshire, New York, 2006

Orsenna, Érik; O Jardineiro do Rei-Sol, Livros Horizonte, Lisboa, 2003

Pareyson, Luigi: Ontologia della liberta, Einaudi, Torino, 1995

Patrick, Keith; «Foreword», in in Advances in Art \& Urban Futures Volume I. Locality, Regeneration \& Divers[c]ities, Intellect, Bristol, Portland, 2000

Peat, David F.; «The Dancing Strands», in Artful Ecologies, University College Falmouth, 2006

Pereira, Maria Helena de Rocha, Estudos de História da Cultura Clássica, Vol. I e II, Fundação Calouste Gulbenkian, Lisboa, 1989

Pereira, Paulo (Dir.); História da Arte Portuguesa, Círculo de Leitores, Lisboa, 1995

Pereira, Rui (Coord.); Obras de Arte - Construção - Demolição, Campo das Letras, Porto, 2002

Perelman, Chaim; L'Empire Rhetorique, Vrin, Paris, 1977

Perez, Miguel Von-Hafe (Ed.); Anamnese, Fundação llídio Pinho, Porto, 2005

Perniola, Mario, A Arte e a sua Sombra, Assírio \& Alvim, Lisboa, 2005

Pinson, Jean-Claude; L'art après de grand art, Éditions céciledefaut, Paris, 2005

Platão; A República, Fundação Calouste Gulbenkian, Lisboa, 2001

Purves, Ted [Ed.]; What we want is free - generosity and exchange in recent art, State University of New York Press, Nova lorque, 2005

Rancière, Jacques; The Politics of Aesthetics, London, Continuum, 2004

Rancière, Jacques; «The Sublime Offering» (1988), in The Sublime, The MIT Press, 2010

Reboul, O.; Introduction à la rhétorique, P.U.F., Paris, 1991

Regatão, José Pedro; Arte Pública e os Novos Desafios das Intervenções no Espaço Urbano», BonD, Lisboa, 2010 
Remesar, Antoni; Brandão, Pedro; Design de Espaço Público: Deslocação e Proximidade, Centro Português de Design, Lisboa, 2003

Remesar, Antoni; Brandão, Pedro [Eds.]; Espaço Público e Interdisciplinariedade, Centro Português de Design, Lisboa, 2000

Rendell, Jane; «Public Art: Between Public and Private», in Advances in Art \& Urban Futures Volume I. Locality, Regeneration \& Divers[c] ities, Intellect, Bristol, Portland, 2000

Roberts, John; The Intangibilities of Form, Verso, Londres/Nova lorque, 2007

Rosler, Martha; Wallis, Brian (Eds.) If You Lived Here: The City in Art, Theory, and Social Activism : A Project by Martha Rosler (Discussions in Contemporary Culture , No 6), The New Press, 1998

Ross, Sir David, Aristóteles, Publicações Dom Quixote, Lisboa, 1987

Ruyter, Thibaut de; «Peter Eisenman's Memorial to the Murdered Jews of Europe», in Art Press, Novembro, 2005

Santos, Maria de Lourdes Lima dos [Coord.] As Políticas Culturais em Portugal: Relatório Nacional, ObservaTório das Actividades Culturais, Lisboa, 1998

Sandercock, Leonie; «The Death of Radical Planning: Radical Praxis for a Postmodern Age», in Cities for Citizens Planning and the Rise of Civil Society in a Global Age, eds. Mike Douglas e John Fridmann, John Wiley, London, 1998.

Santos, David; Marcel Duchamp e o readymade - une sorte de rendez-vous, Assírio \& Alvim, Lisboa, 2007.

Santos, Boaventura Sousa, Crítica da razão indolente. Contra o desperdício da experiência, Afrontamento, Porto, 2000

Santos, Boaventura Sousa, Revista Crítica de Ciências Sociais, 32

Santos; Mariana Pinto dos; Vanguarda \& Outras Loas - Percurso Teórico de Ernesto de Sousa, Assírio \& Alvim, Lisboa, 2007

Semedo, Alice; Lopes, J. Teixeira [Coord.]; Museus, Discursos e Representações, Edições Afrontamento, Porto, 2006

Seno, Ethel (ed.); McCormick, Carlo; Schiller, Sara; Schiller, Marc; Wooster Collective; Trespass - História da Ate Urbana Não Encomendada, Taschen, 2011.

Schefer, Olivier; «Propostas para a revisitação de um Romantismo frio» in Nada, n. 14, 2010

Schiller, Friedrich; Sobre Poesia Ingénua e Sentimental, INCM, 2003, Lisboa

Schmidt, Mary (Ed.), Martin, Randy (Ed.); Artistic Citizenship: A Public Voice for the Arts, Routledge, 2006

Scholes, Paul, Protocolos de Leitura, Edições 70, Lisboa, 1991

Shaw, Philip; «Lacan: Sublimity and Sublimation (2007), in The Sublime, The MIT Press, 2010

Shields, Rob; Lefèbvre, Love and Struggle, Routledge, London, 1999.

Sholette, Gregory (Editor); Thompson, Nato (Editor); The Interventionists: Users' Manual for the Creative Disruption of Everyday Life, The MIT Press, 2006

Sholette, Gregory (Ed.); Stimson, Blake (ed.); Collectivism after Modernism: The Art of Social Imagination after 1945, Univ Of Minnesota Press, 2007

Silva, Rodrigo; «A Condição do Contemporâneo», in Matos, Sara Antónia (Coord. e Ed.); ESPAÇO, Oficinas do Convento, Montemor-o-Novo, 2009

Silva, Rodrigo; "A ética é a promessa da estética? (sobre a expectativa do espectador)", in «Cadernos Par, Pensar a Representação», n. 3, Instituto Politécnico de Leiria - ESAD.cr, Caldas da Rainha, 2008

Silvano, Filomena; Antropologia do Espaço, Assírio e Alvim, Lisboa, 2011

Smith, Neil; Low, Setha (Eds.); The Politics of Public Space, Rotledge, 2006.

Sommer, Doris; «Schiller and Company, or How Habermas Incites Us to Play.» New Literary History Vol. 40., N.o 1, Johns Hopkins University Press, 2009

Sousa; Ernesto de; Ser Moderno... em Portugal, Assírio \& Alvim, Lisboa, 1998.

Stiegler, Bernard; Ce qui fait que le vie vaut le coup d'être vécue, Flammarion, Paris, 2010

Stimson, Blake; «l am the social: Blake Stimson on the line of Edward Krasinski - Critical Essay», ArtForum 2003

Rui Silva, Gabriel; Big-Bang, Poesia, Edição de autor, 1993.

Silva, António Sena da, Projecto, Métodos e Atitude, Instituto Nacional de Investigação Industrial - Ministério da Indústria e Tecnologia, Lisboa, 1977

Simmel, Georg. "The Metropolis and Mental Life." In The Sociology of Georg Simmel, New York, Free Press, 1964.

Sloterdijk, Peter; «Atmospheric Politics», in Latour, Weibel, eds.; Making Things Public, MIT Press, Massachussets, 2005

Sloterdijk, Peter; Critique of Cynical Reason, Univ Of Minnesota Press, 1988

Smith, Mathew Wilson; The total work of art. From Bayreuth to Cyberspace, Routledge, New York, 2007

Smithson, Robert; ROBERT SMITHSON: THE COLLECTED WRITINGS, (Jack Flam, ed.), The University of California Press, Berkeley and Los Angeles, California; University of California Press, LTD. London, 1996

Stephenson, Niamh; Radke, H. Lorraine; Jorna, René J.; Stam, J. Henderikus (Eds.), Theoretical Psychology, Captus 
Press, Ontario, 2003.

Storr, Robert; «Show and Tell», in Marincola, Paula; What makes a great exhibition? - Questions of Practice, Philadelphia Exhibitions Initiative, Philadelphia, 2006

Soto, Luís G.; «Trás Aristóteles», in Revista Filosófica de Coimbra, Vol. 19, n. 37, 2010, Coimbra

Talon-Hugon, Carole; L'Esthétique, Puf, Paris, 2004/2005

Thompson, Nato; «Trespassing Relevance», in The Interventionists - Users Manual for the Creative Disruption of Everyday Life, MASS MOCA, 2006, Los Angeles

Tchougounnikov, Serguei; «Les pérégrinations européennes du mot romantique», in Critique - Revue générale des publications françaises et étrangères, Juin-Juillet 2009, Tome LXV - N.o 745-746, Editions de Minuit.

Tirner, Bryan S.; The Body and Society, Second Edition, Sage Publications, London, New York, 1984/2004

Thrift, Nigel; Non-Representational Theory - Space, politics, affect, Routledge, Abingdon, Oxon, 2008.

Thomas, Douglas; Brown, John Seely; A new culture of learning. Cultivating the Imagination for a World of Constant change, CreateSpace, 2011.

Turner, Victor; From Ritual to Theatre: The Human Seriousness of Play, New York : Performing Arts Journal Publ., cop. 1982

Urbinati, Nádia; «From the periphery of modernity: Antonio Gramsci's theory of subordination and hegemony», in Political Theory, Vol. 26, n. 3, Junho 1998.

Veblen, Thortsne; The Theory of the Leisure, New York, new America Library, 1899

Venturi, Robert; Complejidad y contradicción en la arquitectura, Editorial Gustavo Gilli, Barcelona, 1977

Vidal, Carlos; «Arte e Política, "Arte Política": Um tema ou um pleonasmo? (Para uma efectiva democracia cultural)» in Caderno Vermelho, 19, Setembro 2011, Editorial Avante, Lisboa

Vidal, Carlos; Definição da Arte Política, Fenda, Lisboa, 1997

Vidal, Carlos, Democracia e Livre Iniciativa - Política, Arte e Estética, Fenda, Lisboa, 1996

Vincent, Jean-Didier; A Carne e o Diabo, Publicações Europa-América, Lisboa, 1997

Vv. Aa.; 3 Projectos Experimentais, Centro Português de Design, Lisboa, 2003.

Vv. Aa.; 25 Anos 1972-1997 Comuna - Teatro de pesquisa, Pere, Lisboa, 1998

Vv. Aa., A Alma do design, Centro Português de Design, Lisboa 2003

Vv. Aa.; Alternativa Zero - Tendências Polémicas na Arte Portuguesa Contemporânea, Lisboa, 1977

Vv. Aa.; Andrade, Pedro (Org.) Arte Pública e Cidadania - Novas Leituras da cidade criativa, Caleidoscópio, Lisboa, 2010.

Vv. Aa.; Arte público: memoria y cidadania, Universitat de Barcelona, Barcelona, 2004

Vv. Aa,; Arte Y Revolucion, Brumaria. Madrid, 2007

Vv. Aa.; «Cidades - Comunidades, Teritórios», Dezembro 2002, Centro de Estudos Territoriais, Lisboa, 2002

Vv. Aa; Todoli, Vicente (Proj. Ed.); Circa 68, Fundação de Serralves, Porto, 1999

Vv., Creative Spaces - A Toolkit for participatory urban design, The Architecture Foundation, Londres, 2000.

Vv. Aa. [Barro, David, Ed.]; Del Zero al 2005 - Perspectivas del Arte en Portugal, Fundación Marcelino Botín, Santander, 2005 Vv. Aa.; Dialogue with the Other, Kunsthallen Brandts Klædefabrik, Odense, 1984

Vv. Aa.; Efémeros Sentidos, Tango - Edição e Design, Lda, Lisboa, 1996

Vv. Aa.; Entornos Vitales - Hacia un Diseño Urbano y Arquitectónico más humano - Manuel Practico, Gustavo Gilli, Barcelona, 1999

Vv. Aa.; Institutional Critique and After (Soccas Symposia vol. 2), JRP/Ringier, 2006

Vv. Aa.; Gonon, Anne; «Faut-il avoir peur du public?», in La Relation au Public dans les Arts de la Rue, Éditions Entretemps, Vic la Gardiole, 2006

Vv. Aa.; Brasil, Daniela (Ed.), KoCA-Inn: An urban experiment at the Kiosk of Contemporary Art in Weimar, Weimar, 2009

Vv. Aa., Le Projet Urbain; Éditions de la Villette, Paris, 2000

Vv. Aa.; Les idées de Mai 68, Le Magazine Littéraire, Hors-série N. 13, Avril-Mai 2008, SAS Magazine Expansion, Paris, 2008.

Vv. Aa.; Liberdade e Cidadania - 100 anos portugueses, Comemorações Oficiais do Vigésimo Quinto Aniversário do 25 de Abril de 1974, Lisboa, 1999

Vv. Aa., Lisboa Capital do Nada - Marvila 2001

Extra]muros[, Lisboa, 2002

Vv. Aa.; Luzboa - A Arte da Luz em Lisboa, Extra]muros[, Lisboa, 2004

Vv. Aa.; Luzboa - Lisboa Inventada pela Luz, Extra]muros[, Lisboa, 2006

Vv. Aa; Manifesto 2010, Ars Industrialis, 2010, http://arsindustrialis.org/manifesto-2010-pt

Vv. Aa.; Miguel Chevalier, Flammarion, Paris, 2001 
Vv. Aa.; Modos de Hacer: Arte crítico, esfera pública y acción directa, Ed. Universidad de Salamanca, 2001

Vv. Aa.; Portugal na Transição do Milénio, Fim de Século, Lisboa, 1998

Vv. Aa., Public Work - 1995-2000 Five Years Parktijkbureau Beeldende Kunstopdrachten, SKOR, Amesterdão, 2000 Sculpture Projects Muenster, Münster, 2007

Vv. Aa. [Szeemann, Harald [Ed.]]; Le machine celibi, Electa, Milano, 1989

Vv. Aa.; O Chão da Cidade - Guia de Avaliação do Design de Espaço Público, Centro Português de Design, 2002

Vv. Aa.; O 'Novo' na Arte de Hoje, FBAUL, Lisboa, 2004

Va. Aa; «On Performatics», Performance Research, Vol. 13, N.2, June 2008, Routledge.

Vv. Aa. [Hoet, Jan, Ed.]; Over the Edges, S.M.A.K. - Stedelijk Museum voor Actuele Kunst Gent, Gent, 2000

Vv. Aa.; The Eagleton Reader, Wiley Blackwell, 1997

Vv. Aa.; The Public Garden - The Enclosure and Disclosure of the Public Garden, NAi Publishers, Rotterdam, 2002

Vv. Aa.; Sena da Silva, Fundação Calouste Gulbenkian, Lisboa, 2010

Vv. Aa.; Um Cálice de Dor, Lisboa, 1999

Vv. Aa.; Wackelkontact / Loose Contact - Illuminating the Public Sphere, Bauhaus-Universität Weimar, Weimar, 2007

Vv. Aa., Revue d'esthétique, n. 45 , Maio 2004 «Les artistes contemporains et la philosophie», Editions Jean-Michel Place, paris, 2004

Wagner, Richard; A Obra de Arte do Futuro, Antígona, Lisboa, 2003

Weil, Simone; A Gravidade e a Graça, Relógio d'Água, Lisboa, 1947/2004

Welchman, John [Txt.], Vasco Araújo, ADIAC, Lisboa, 2007

Williams, Robert; Art Theory - An Historical Introduction, Wiley-Blackwell, Malden/Oxford/Victoria, 2004

Wilson, Elizabeth; The Sphinx and the city, Virago, LOndon,1993

Wright, Stephen; «Time without Qualities: Cracking the Regime of Urgency», in Public Spheres after Socialism, Ed. Ângela Harutyunyan, Kathrin Hörschelmann \& Malcolm Miles, Intellect, Bristol, Chicago, 2009

Zizek, Slavoj; «The Sublime Object of Ideology», (1989), in Sublime, The MIT Press, 2010

Zweite, Armin; Joseph Beuys - Natur, Materie, Form, Shirmer/Mosel, München/Paris/London, 1992

\section{Filmes/Documentários}

Lisboa Capital do Nada, de Luís Alves de Matos

Extramuros, Lisboa, 2002

Sinais a Cidade Habitada, de João Garcia Miguel

Centro Português de Design, Lisboa, 2004

Paz, Pão, Habitação... As Operações SAAL, de João Dias

Extramuros, Lisboa, 2005

Outro País, de Sérgio Treffaut, Atalanta, Lisboa, 1998

Uccellacci e Uccellini, de Pier Paolo Pasolini, 1966 



\title{
ANEXO
}

\author{
MÁRIO CAEIRO
}

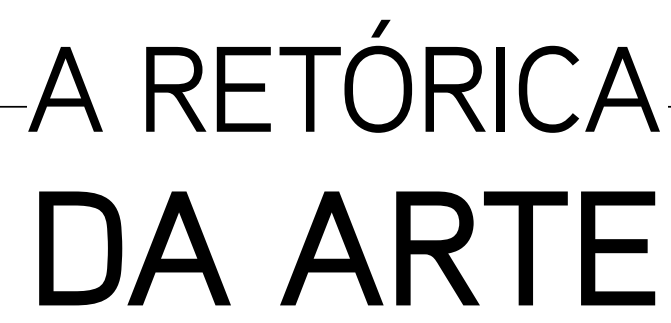

NA

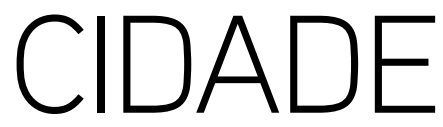

DISPOSITIVO, ENVOLVIMENTO E GRAÇA

O PROJECTO EXTRAMUROS

COMO PROPOSTA

DE INTERVENÇÃO URBANA 

Biografia e motivação pessoal 5

\section{FUNDAMENTOS}

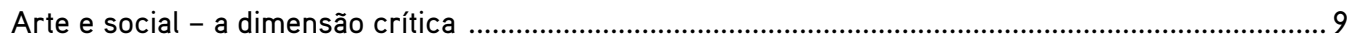

I.1. Enquadrar a actividade artística: pulsão e produção............................................................................ 9

I.1.1 Origem e futuro da arte: plasticidade vs. moda, a carência de povo ......................................... 9

I.1.1.1. Teorizar a arte para além da estética ........................................................................... 9

I.1.1.1.1 Arte e estética em Friedrich Schiller: ingenuidade vs. sentimentalismo, uma

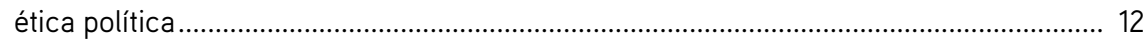

I.1.1.1.2 Da Liberdade da necessidade à quotidianeidade do humanismo diletante.......... 15

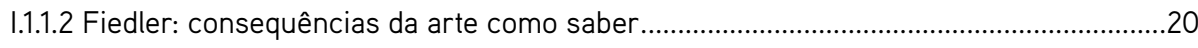

I.1.1.2.1 O saber do artista contra o gosto da sociedade .................................................... 22

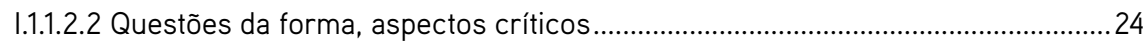

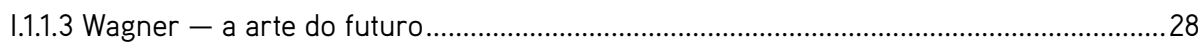

I.1.1.3.1 Natureza, criação, socius - a moda ……................................................................30

I.1.1.3.2 Teorizar o futuro. Pedagogia, populismo, performatividade....................................36

I.1.1.3.3 O Gesamtkunstwerk vs. obra de arte do futuro - máquina e transparência ....39

I.1.1.4 Excurso: de Novalis a Nietzsche: romantismo e palavra mística, poesia e polaridade. 44

I.1.1.4.1 Instrumentalidade do romantismo: poesia e tensões ..............................................45

I.1.1.4.2 Wagner/ Nietzsche. Apolo/Dionísios, da utopia à crítica ...................................... 50

I.2. Quotidiano e vida urbana: ilações da Teoria Crítica ......................................................................55

I.2.1 Aproximação ao pensamento crítico: conceitos-chave de Henri Lefèbvre...............................55

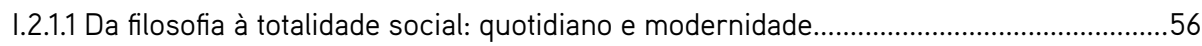

I.2.1.2 A metafísica de Lefèbvre em antecipação da retórica .....................................................60

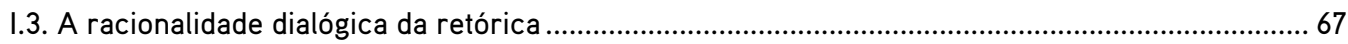

I.3.1 A arte interpelada pela retórica: dar palco (público) às paixões (sociais) ................................67 67

I.3.1.1 Retórica - do senso comum à teoria dos quatro discursos ..........................................69

I.3.1.2 Ethos, Logos, Pathos: a actualidade do império retórico ............................................... 74

I.3.1.2.1 Comunicação e Paixão: o sensível distribuído ........................................................ 76

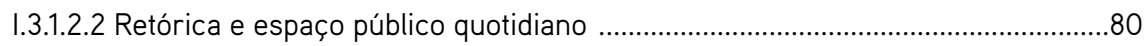

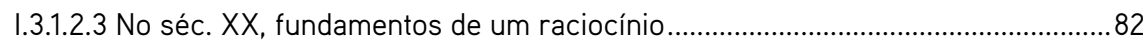

\section{ENQUADRAMENTO HISTÓRICO: ARTE PÚBLICA CRÍTICA EM PORTUGAL}

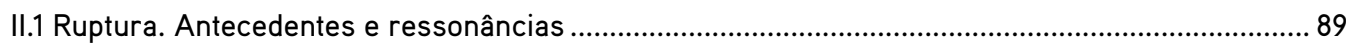

II.1.1 Acções públicas na emergência de uma cultura de cidade:

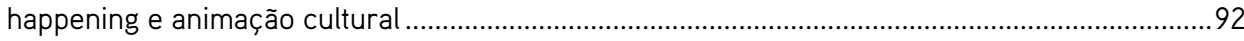

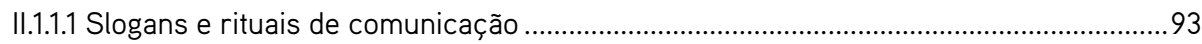




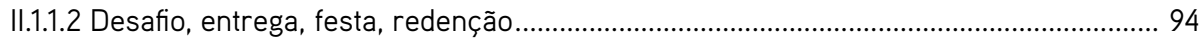

II.1.2 Protagonistas da evolução interdisciplinar: a afirmação da curadoria e do design................96

II.1.2.1 Ernesto de Sousa - ingenuidade e realismo neo ...........................................................97

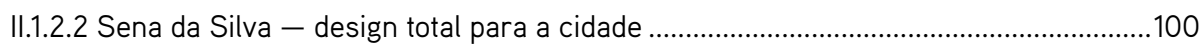

II.2 Dizer cidade. Momentos-chave na arte pública crítica contemporânea..........................................103

II.2.1 Portugal, dos anos 60 ao dealbar dos anos 70, fugazes efervescências da arte................. 103

II.2.1.1 Projectos colectivos: a arte à rua! - KWY, Acre, Puzzle e a Ogiva .................................. 106

II.2.1.2 Costa Pinheiro - «Citymobil», inscrição da arte no dispositivo ..................................... 109

II.2.2 Alternativa (Zero) vs. mainstream (da arte pública) ................................................................111

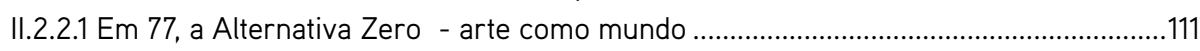

II.2.2.2 A 'arte pública' autárquica - O 'caso' José Aurélio - objectos-marco .......................... 113

II.2.3 Anos 80, 90 e 00: a possibilidade (da) crítica da cidade actual.............................................114

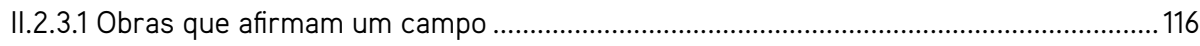

II.2.3.2 O caso Gabriel Rui Silva - a performance poética da grande cidade ........................ 126 


\section{BIOGRAFIA E MOTIVAÇÃO PESSOAL}

Meu pai e minha mãe foram influências afectivas e intelectuais na progressiva afirmação da minha personalidade como investigador, programador e professor. Minha mãe, enfermeira e docente de Enfermagem, foi entusiasta das Letras e da Cultura; humanista de esquerda com máxima sensibilidade para o humano em toda a sua riqueza e complexidade, sempre buscando equilibrar a luta pela justiça com a generosidade radical e a morabeza de Cabo Verde; meu pai foi médico (Clínica Geral), com carácter mais conservador, mas sempre em total entrega ao serviço público'. Em ambos impressionava-me a energia quotidiana e perseverança com que enfrentavam os seus objectivos e a noção de que temos de estar à altura das circunstâncias que nos definem o destino. Ao mesmo tempo, a obra de Kafka na estante da sala ${ }^{2}$ desde 'sempre' me desafiou para a mais perturbante representação do mundo e da mente. Ao lado de A Cabana do Pai Tomás (descoberta da alteridade) e de A llha do Tesouro (contacto com a complexidade do político), mais tarde de Philip K. Dick (experiência estética da distopia moderna), a leitura de Kafka foi o meu primeiro encontro (Deleuze, Grout) com o desassossego da arte.

Quanto às primeiras vezes que as artes plásticas me fascinaram, recordo-me como a minha professora de História de Arte, já de idade, vinha para as aulas carregando pesados livros, para que pudéssemos, com os nossos próprios olhos, experienciar a pintura de Géricault, Delacroix, Goya, Picasso, Gauguin... Aquela entrega significou que não estamos apenas aos ombros de gigantes (Hawking), às vezes temos de os acartar connosco. Mas qual a relação a estabelecer entre a ideação e a produção artística? Na Faculdade, a emergente disciplina do design, confirmou-se como uma meta-disciplina adequada para superar o dilema - é uma disciplina que serve todas as outras. O Design de Comunicação ensinou-me a pensar o visual integradamente, na convivência com as Artes Plásticas e Arquitectura ${ }^{3}$. Passei a estar mais consciente dos elementos em jogo na comunicação artística, linguagem (e gramática) na qual me entusiasmou o convívio com as experiências dos colegas de Belas-Artes: entre as ilustrações pop de José Eduardo Rocha e as imponentes esculturas efémeras de Rui Chafes, havia um mundo de criação, apelo paralelo às minhas experiências profissionais, primeiro no campo do design para propaganda sindical e partidária, depois numa editora de referência.

No final do Curso, recomecei os estudos (Literários Comparados). O contacto com personalidades como João Barrento, Yvette Centeno, Helena Barbas, Luís Oliveira e Silva; as aulas de Ensaio, de História das Ideias, Literatura Comparada; levar-me-iam aos primeiros exercícios de aproximação entre artes plásticas e literatura lo encontro de Giotto com São Francisco de Assis, por via de Pasolini). Já no Mestrado em Estudos Alemães, desbravei finalmente o fascínio pelo universo kafkiano, com destaque para a dimensão meta-discursiva dos aforismos e dos últimos escritos. O carácter cognitivo-epistemológico da obra kafkiana, a capacidade de tornar universal a amálgama da vivência pessoal, a originalidade

1 Chegou a ter altas responsabilidades na esfera da Saúde Pública.

2 A minha mãe realizou a dissertação final do Curso de Letras sobre A Metamorfose de Kafka.

$3 \mathrm{Na}$ ESBAL, cursos leccionados no mesmo edifício que Belas-Artes. 
do dispositivo de transfiguração literária e o alcance retórico das imagens conduziram a uma Dissertação de Mestrado: Forschungen eines Hundes, As Investigações de um Cão.

Depois, seduzido pela abertura de um Curso sobre Desenho Urbano - Espaço Público e Interdisciplinaridade, parti de novo para uma disciplina emergente - o Design Urbano - racionalidade projectual adequada à abordagrm do conceito de Espaço Público. $\mathrm{O}$ desenho da cidade - o projectar na/da cidade - abriu perspectivas para uma abordagem do mundo da cultura e da arte num quadro transdisciplinar e especificamente urbano. 0 que eram a princípio experiências pontuais (organização de exposições), tornou-se uma metodologia própria de activismo cultural no espaço público. Propus então à minha cidade diferentes temas - as 'metáforas operativas' Alma, Dor, Nada, Sinais, Luz ${ }^{4}$ - plataformas transversais atravessadas por um fascínio romântico pelo Conhecimento. Assim, tenho vindo a propor um território retórico (de experiências) e um campo semântico-operativo (conceptual, metafórico). É o território de uma praxis curatorial que urgia captar a partir de uma reflexão sobre a sua energia exemplar.

Com Arno Gruen, em A Traição do Eu (1984) e A Loucura da Normalidade (1992), aprendi que a vida é um desafio constante, em que temos de, decisão a decisão, lidar com cada sentimento, de negociar a nossa própria voz e tomar consciência das situações como oportunidades de crescimento, evitando as formas de negação do eu ${ }^{5}$. Dando sentido aos impulsos de empatia sentidos na juventude, o activismo cultural ensinou-me que o pensamento sem acção no mundo é violência sobre a nossa subjectividade. Até 1980, alguma arte surtiu em mim o efeito de um 'eco' distante de um desejo que ainda não saberia formular; seria um desejo de comunicação entre ser e mundo, em que a estética se desdobrava nos mundos possíveis dos criadores (recordo-me do Haiti de Gauguin, utopia à distância de uma viagem). Num segundo momento, de maior aproximação à maturidade, fui tendo a consciência de que a arte é um domínio por excelência para a prática crítica sobre o real, e que é preciso compreender o que no dispositivo artístico é 'natural/pré-existente' ou 'arbitrário/construído', para que possamos colocá-lo ao serviço do nosso próprio programa existencial. Esse programa depende directamente de uma capacidade intelectual e discursiva, de articulação intencional entre conceitos e praxis.

Entender o projecto como atitude (Sena da Silva) foi o ponto crucial na evolução da consciência do próprio projectar. Reflectir sobre a praxis própria, fazem-no e fizeram-no publicamente muitos artistas e intelectuais, propondo alternativas ao status quo. Mas quando desenvolvemos a sua capacidade crítica de uma forma transparente, pedagógica, na própria obra, e faz disso a força vital do seu trabalho plástico, desenvolvemos um domínio do conhecimento inconformado, resiliente ao social empobrecido do pequeno-burguês lé Lefèbvre quem sistematiza multidimensionalmente esta posição). Assim, o presente trabalho de pesquisa (misto de história, genealogia, ficção, numa lógica ensaística), bem como a

4 Em 2011, Vicente, encomenda do Projecto da Ermida.

5 Em obras que aprofundam as ideias de Erich Fromm a partir da psicanálise, Arno Gruen chama a atenção para doenças de massas como o conformismo, a adulação do sucesso material e a sobrevalorização do intelecto. Amor ou poder são apresentados como pólos de uma escolha que todos, desde o ventre da mãe, somos convidados/tentados a fazer. Relativamente à normalidade, Gruen é claro: na sociedade, as pessoas que se conformam, que não são elas próprias, são 'normais'; aquelas pessoas que desenvolvem a sua criatividade própria, a sua originalidade, os seus próprios sentimentos, enquanto núcleo do seu ser, não são 'normais'. Ao nível da vida cultural, âmbito desta investigação, a conformidade é, para Gruen, sinónimo de normalidade. Para mim, é como dizer-se que a trivialidade - que não o quotidiano - é o mal na arte. 
articulação proposicional dos factos e das conclusões - a acção - reflecte a 'lente' através da qual percepcionei a realidade plástica na forma urbana e que no léxico artístico contemporâneo se denomina 'curadoria'. A selecção de exemplos, de recolha de informação e de articulação em proposições e argumentos é, nestes termos, ele próprio um trabalho curatorial, assumpção de que é possível partilhar um modelo cognitivo e assim a transparência do esforço de investigação e a sua legitimidade. Abordo esta questão da curadoria no quadro genérico da mediação cultural possível no capitalismo cognitivo. Alguma arte pública surge como um campo-chave desta pesquisa artística e sabemos, pelo menos desde Harald Szeeman, que a curadoria crítica é uma forma de, dando forma à atitude, não nos conformamos com os conformes. 



\section{ARTE E SOCIAL - A DIMENSÃO CRÍTICA}

\section{1. ENQUADRAR A ACTIVIDADE ARTÍSTICA: PULSÃO E PRODUÇÃO, IDEIAS-CHAVE DE SETECENTOS E OITOCENTOS}

Is it enough to launch ideas and to hazard hypothesis, when some may be fruitful, and others sterile? No. If we are to advance knowledge, it is essential that we deploy a set of concepts which has inner coherence.

Henri Lefèbvre

Democracy depends on the ability to lend a spatial dimension to things said one after the other; it therefore implies constant training in patience.

Peter Sloterdijk

\section{1.1 Origem e futuro da arte: plasticidade vs. moda, a carência de povo}

\section{1.1.1. Teorizar a arte para além da estética}

Esta é uma proposta de posições e relações-chave, num debate tanto efectivo como hipotético (ou potencial) entre pensadores oitocentistas, novecentistas e contemporâneos. Parto de uma perspectiva metafilosófica da arte', para apropriar-me de um conjunto económico de ideias $^{2}$. Assumo a história da arte de forma mais helicoidal que linearmente histórica ${ }^{3}$, em que a arte pública, como construção da consciência social, é defendida na fluidez e na complexidade da sua emergência sempre provisória. Sustento esta minha ancoragem no facto feliz de o termo ser utilizado com rigor já no texto de Wagner, precisamente na definição de uma arte do futuro ${ }^{4}$. $\mathrm{O}$ facto de os pensadores que começaram por me impressionar - Konrad Fiedler (1841-1895) e Richard Wagner (1813-1883) - serem autores de teorias sobre, respectivamente a origem e o futuro da arte, é uma coincidência que assumo como gesto retórico.

Em Fiedler, é de uma aproximação à pulsão criadora que se trata - a arte como saber

1 Trata-se de laborar num quadro intuitivo (Bergson), que se cruza com a estética e a sua história, mas é sobretudo investigação-acção na esfera do discurso e de uma construção crítica que articule a possibilidade prospectiva do pensamento à contingência de uma atenção arqueológica (Foucault) ao social.

2 Entre o esboço filológico e a filosofia da arte, entre a estética e a teoria, este capítulo procura reconhecer as principais personagens de uma genealogia intelectual que construí ao longo da investigação.

3 José Miranda Justo, «O Tempo e o Anel (Wagner, Feurbach e o Futuro)», in Wagner, Richard; A Obra de Arte do Futuro, Antígona, Lisboa, 2003

4 Será a primeira de muitas analogias que procurarei desenhar a partir de A Obra de Arte do Futuro, de 1849, numa estratégia de transfuncionalidade conceptual que verei sublinhada em Henri Lefèbvre. 
produtivo, precedendo a dimensão estética. Em Wagner, o futuro é uma construção retórica (sob a forma de um manifesto arqueo-genealógico); de acordo com um programa ético sustentado num sentimento de urgência cívica, com a materialidade do dispositivo artístico ao serviço do acontecimento colectivo, perspectivado na figura (e na experiência) da redenção. Ambas as reflexões balizam a minha aproximação à arte pública como construção do social no quotidiano expandido da sociedade contemporânea, campo sobre o qual vale a pena haver debate, a partir dos problemas morfológico-discursivos da arte na cidade. No essencial, $A$ Origem da Actividade Artística (1887) de Fiedler e A Obra de Arte do Futuro de Richard Wagner (1849) abordam a criação artística com o homem-entendimento (Wagner) no centro das suas preocupações; são posições que estabelecem premissas essenciais para pensar a retórica da arte face ao social. Refiro-me, a partir de Fiedler, à ideia da arte como um processo cognitivo (o ser-se/conhecer-se no fazer artístico), a que importa ater um movimento vital, uma pulsão criadora ${ }^{5}$. Em segundo lugar, à obra de arte como resultado formal/material de um pensamento crítico que, no registo activista de Wagner, informado pela energia do povo e uma ideia produtiva de natureza, é avesso a sujeitar-se ao empobrecimento (Stiegler) trivializante da moda (ainda Wagner). São ideias a que é subjacente um desejo de dinamização de uma consciência pública, senão dos fundamentos da esfera pública que reencontraremos em vários pensadores críticos (Benjamin, Arendt, Marcuse, Lefèbvre, Habermas).

Na sua relativa a-tecnicidade, os termos-chave de Fiedler e Wagner parecem-me sugestivos e perfeitamente articuláveis com o pensamento estético-político que entretanto defininiu a multiplicidade da cidadania criativa da contemporaneidade lassente no quotidiano de Henri Lefèbvre, na distribuição do sensível de Jacques Rancière, na comunidade inoperativa de Jean-Luc Nancy, no contemporâneo de Giorgio Agamben, no cinismo de Peter Sloterdijk, na não-representacionalidade de Nigel Thrift...): Unlike political citizenship, which asks that we state authority for granted, art compels us to seek in ourselves the authority by which we are obliged to one another in the fleeting, discretionary occasions for publics to gather together. ${ }^{6}$ Tal arte, interdependente de uma pulsão de contacto com o social, consciente ${ }^{7}$ dos seus mecanismos de emergência e inscrição ${ }^{8}$, interessar-se-á pela comunicação da sua intervenção pública enquanto consciência no/enquanto quotidiano". Finalmente, potencia a criação como processo de iluminação colectiva radicado na experiência do objecto de arte que, ao acontecer como situação, leva ao acontecer da sociedade como comunidade e todo inteligível ${ }^{10}$. Uma arte assim procura superar a fragmentação (separação, Debord) cultural típica do regime capitalista,

5 Ver as teorias da complexidade e da cognição contemporâneas, de Maturana/Varela a Félix Guattari ou Fritjof Capra, nomeadamente perspectivadas face à teoria do élan vital em Henri Bergson.

6 Martin, Randy; «Artistic Citizenship», in Artistic Citizenship - A Public Voice for the Arts Routledge, New York, London, 2006. p. 12.

7 Sobre a extrema efemeridade do emergir da consciência, ver Nigel Thrift, Non-Representational Theory, Routledge, Abingdon, Oxon, 2008.

8 Randy, p. 13: The assertion of properly shared identities jostles against cultural expressions that challenge the consensus conception. The work of artistic citizenship is both to make these fissures legible as matters available to common rumination and to provide a means by which we can navigate and negotiate the differences in our midst so that they become productive and not divisive.

9 Idem, p. 17: This is art's public project, one that can embrace all manner of spaces and interest, all the more so if the public is to be an achievement and not a passive environment that artists and audiences take up.

10 Idem, p. 15: In this respect, artistic citizenship is the refusal of the divide - but not the distinction - between creating work and creating a public, between art-making and assembly of a civically engaged capacity to evaluate represented ideas about the world around us. 
através de uma aproximação a um discurso de articulação entre realidades alienadas - o indivíduo face à cultura, o colectivo face à natureza. Estas questões são, em Wagner, não apenas programaticamente enunciadas, mas explícitadas numa posição engajada.

É neste sentido que extrapolo a ideia de natureza para o campo das relações sociais como sistema $^{11}$ e me aproprio da categoria absolutamente fundamental do quotidiano ${ }^{12}$ - um quotidiano constantemente obscurecido que a arte pública, desde que forma superior de consciência colectiva, problematiza para lhe introduzir uma vitalidade própria dos desafios que se colocam à sociedade de consumo e comunicação (ver os diagnósticos precoces de Marx, Baudelaire, Balzac ou Simmel, numa altura em que começava a acelerar o impacto da sua hegemonia). Daí o sentido de pensar-se a graça social que atrás referi a partir de uma ideia de resiliência do comunismo ${ }^{13}$, independentemente de, com Lefèbvre, submetermos esse sonho ao escrutínio da dialéctica negativa ${ }^{14}$. De resto, no cruzamento de Wagner e Fiedler com a reflexão filosófica - por vezes retoricamente integrada na produção artística (poética, trágica, dramatúrgica) - chamo outros pensadores à liça - Schiller, Novalis, Schopenhauer, Feuerbach, Nietzsche ou pontualmente Kafka - , numa lógica de associações a-técnicas (Lefèbvre) que os dois autores implícita ou explicitamente convocam. Esta ligação entre arte e filosofia, pensamento e política, adquire nos anos 60 e 70 do século XX uma expressão importante, o poder da sintaxe $e^{15}$, que vai atravessar a explosão de práticas, de teorias e de modelos de intervenção artística e cultural. Um artista contemporâneo, Félix Gonzalex-Torres, coloca assim a questão: C'est au sein de ce travail concret, dans ses hésitations et dans ses avancées, que le travail proprement théoretique s'insère. [...] Un outil théoretique permettant la fabrication d'un nouvel objet, d'un nouveau geste $e^{16}$. É neste espírito que convoco as ideias-protótipo do período romântico acerca da cognição através da arte e de sua validação social (como terapêutica), com Novalis representando o expoente da perspectiva poiética do primeiro romantismo alemão; e Nietzsche já arauto de uma condição pós-moderna, negativa e crítica. Resgato aqui algumas limitações da reflexão de Fiedler ${ }^{17} \mathrm{e}$

11 Antecipando o fine-tuning desta questão por Lefèbvre em Critique of Everyday Life e teorias posteriores como as de Francisco Varela e Humberto Maturana (Autopoiesis and Cognition: The realization of the Living, 1980), Félix Guattari (Three Ecologies 2000) ou Frijof Capra (Hidden Connections, 2002).

12 Proposta, pela primeira vez, por Georg Lukács, em Metaphysik der Tragödie, em 1911, no conceito de Alltäglichkeit que designates the 'trivial life' of the human being, indistinguishable from the world of objects - the dreary, mechanical and repetitive unfolding of the everyday, which Lukácz contrasts with an 'authentic life' thanks to which this being accedes to himself through the work of art, or, even better, turns himself into a work of art. (Michel Trebitsch, In «Preface», Lefèbvre, Henri; Critique of Everyday Life, Vol. I, p. XVII, 2008). Lefèbvre retoma-a como motivo fundamental da sua Critique, publicada em três volumes entre 1947 e 1981.

13 Termo repetidas vezes empregue em A Obra de Arte do Futuro.

14 De Nietzsche a Benjamin, Marcuse ou Adorno, referências recorrentes na Critique.

15 Referindo-se à relação entre a investigação de Yvonne Rainier e o pensamento de Ludwig Witgentein, Barbara Formis afirma: En montrant cet air de famille nous avons établi l'existence d'une relation non dialectique et non instrumentale entre art et philosophie. Non dialectique, parce qu'elle ne se situe pas dans un rapport de domination réciproque inachevable entre les deux termes, mais lie les deux disciplines en tant que pratiques linguistiques égales, dont l'une n'établit aucun «savoir» sur l'autre, qui ne serait pais consciente. Formis, Barbara; «Le pouvoir de la syntaxe: Yvonne Rainier choregraphe et Ludwig Wittgenstein philosophe», in Revue d'Esthétique, n. 44, 2003, p. 106.

16 Watier, Éric; «Un art de la reproductibilité technique. Gonzalez-Torres, Félix», in Revue d'Esthétique, n. 44, 2003, p. 107.

17 Reste a demander si Fiedler, dans son souci même d'épouser d'aussi prés que possible le processus de création, ne s'interdit pas de même coup de penser le produit de cette activité. Sa poétique radicale bute peut-être sur "un défaut d'objectualité" [...] révèle en ce sens une conception encore trop opératoire de l'opération. During, Elie; «A propôs de Konrad Fiedler, Sur l'origine de l'activité artistique, D. Cohn (éd.), Editions "Rue d'Ulm", Paris, 2003. A ressalva de During ecoa a de Cassirer, 
retraço uma genealogia crítica que é na verdade o reinscrever de uma tradição romântica-política (patente na filiação assumida por Joseph Beuys face a Wagner) que nunca deixou de percorrer (subterraneamente) as ligações mais críticas, produtivas e construtivistas (três termos profundamente fiedlerianos) entre a estética e a utopia. Teço assim uma hipótese de trabalho que pode ser resumida da seguinte forma: face ao contingente social, o real do demos, a actividade artística - pulsão humana - é uma empresa que projecta/ formaliza possibilidades e futuros possíveis (Miles) num mundo em que se integra material e sensivelmente. Insistindo na realidade pública da arte (Grout), relacionamos a sua dynamis política e estética enquanto arte pública - um conceito que Wagner emprega com total clareza de propósitos.

\section{1.1.1.1 Arte e estética em Friedrich Schiller: ingenuidade vs. sentimentalismo, uma ética política}

O pensamento alemão de Setecentos/Oitocentos está em constante diálogo com as artes (sobretudo a literatura), a teologia, a política. São figuras-charneira Kant ${ }^{18}$. Hegel ${ }^{19}$, e depois

que considera que Fiedler, rejeitando radicalmente a estética, acaba por não integrar no seu sistema a experiência estética propriamente dita.

18 Na viragem do século XVI para XVII, dá-se uma importante rearticulação entre as categorias do sensível e do inteligível. Aquele deixa de ser um mero reflexo das Ideias e constitui um mundo fenomenal autónomo (Kant, na Crítica da Razão Pural. Os aisthête, factos da sensibilidade, passam a ser objecto de reflexão independente e, ao mesmo tempo, o sensível assume-se subjectivo. Os objectos deixam de ter propriedades necessariamente ligados à sua beleza sensível, o que acarreta consequências para a compreensão da forma como o belo, agora qualidade relacional, funciona: La beauté n'est pas une proprieté des objets, mais un qualificatif accordé aux objets qui procurent un plaisir spécifique: elle ne renvoie donc qu'à la relation du sujet et de l'objet. (Talon-Hugon; L'Esthétique, Puf, Paris, 2004, p. 54). De alguma maneira, o belo é a categoria por excelência que passa a mediar a nossa apropriação mais profunda no mundo, o que, com a afirmação das Belas-Artes, impõe o que Talon-Hugon denomina uma deriva estética na arte, a ideia de que a arte e o belo coincidem (Baumgarten). Mas com Kant, que não vê lugar para a estética na filosofia, a arte é objecto de uma reflexão crítica, enquanto problemática de savoir comment le jugement esthétique qui est subjectif peut néanmoins avoir une validité universelle (Talon-Hugon, p. 53). Davam-se os primeiros passos numa autonomia analítica do pensamento crítico face ao fenómeno da arte. E alguns conceitos servem esse desígnio: os de gosto e de sublime viriam a ser dois dos mais importantes. Em particular, o conceito de desinteresse motivará porém aceso debate. Afinal, estabelecer a existência de um prazer desinteressado, é em grande medida estabelecer a automomia do valor estético le, no limite, atribuir à arte o lugar central num projecto inconsciente da sua própria reflexividade constituinte (Talon-Hugon, p. 56). Precisamente, quando a questão que Wagner coloca é a de aferir a articulação entre a validade dessa dimensão estética no trabalho e no projecto artísticos, face a uma ideia de Povo, numa processualidade que introduz uma matriz social e interventiva, a teoria crítica não pode aceitar a noção de desinteresse kantiano senão com reservas.

19 Já a arte monopolizava a atenção da reflexão estética, Hegel vai rejeitar o interesse do conceito de estética em prol do de filosofia da arte, o que é desde logo um afastamento do belo natural (kantiano) e uma aproximação histórica ao fenómeno artístico (na esfera de uma teoria da hierarquização das artes). Para Hegel, a arte é a presentificação sensível do absoluto, categoria reminiscente da intuição platónica dos universais. O idealismo de Hegel é ao mesmo tempo a intuição de uma espiritualidade que seria sempre mais que qualquer forma natural ou artificial: L'art constitue donc la première étape de l'odyssée de l'esprit au acours de laquelle celui-ci triomphe de la separation entre exteriorité et intériorité, entre nature finie et liberté infinie de la pensée. L'art realize cette conciliation en spiritualisant le sensible et en rendant sensible l'intelligible. L'ouvre est unité du sensible et du spirituel (Talon-Hugon, p. 65). Por outro lado, ao estruturar a história de arte de acordo com períodos históricos, em que certas formas sensíveis correspondem a relações particulares com o mundo das ideias, Hegel abre a porta a uma crítica dialéctica, assente na observação do sensível. Nestes termos, constitui com Marx um antecedente directo de uma visão da arte como expressão material do social. Mas a posição de Hegel, ao mesmo tempo que explicita uma dimensão antropomórfica da manifestação do espírito, enuncia uma vida da subjectividade interior que já integra um programa de apoio à especulação assente na arte. Hegel reconhece assim uma progressiva espiritualização - e abstracção - do medium, que faz por exemplo que a poesia possa ser considerada, pelo grau de abstracção dos seus signos, a mais filosófica das artes. E assim o filósofo introduz a ideia de uma Auflösung da arte. O conceito é relativo a um período da arte em que esta já não corresponderia a uma forma superior de manifestação do espírito, sendo ultrapassada primeiro pela Religião e depois pela própria filosofia, capazes de carregar a chama vital que o romantismo havia reacendido. Esta intuição de Hegel, enunciando a sua especulação, e considerando o 
Feuerbach e Schopenhauer. Mas é com Schiller (1759 - 1805), poeta, dramaturgo e pedagogo, que estamos perante um homem que cria e que ao mesmo tempo reflecte, por vezes ocupando ambas a racionalidades o mesmo palco em simultâneo, tomadas estas por uma carência de justiça $e$ de beleza. Schiller é dos pensadores mas enfáticos a sublinhar a liberdade, a autonomia, a espontaneidade necessárias à produção artística face ao quotidano. $\mathrm{A}$ arte surge-lhe assim como palco dessa auto-expressividade, em que se desenrola o drama do nosso adiado encontro com o natural. ${ }^{20}$

Evoco aqui Schiller primeiramente, a partir de Don Carlos (1787), uma obra de juventude cuja representação da política é particularmente expressiva ${ }^{21}$. Em Don Carlos, um documento da Aufklärung que nos fala de uma nova humanidade, surge um dispositivo que promove o debate sobre a responsabilidade pública, e em que o autor, na carência por uma arte capaz de inventar almas (Cintra), desenhou personagens que nunca existiram, são ideias, são formas de pensamento ${ }^{22}$ :

[...] o que este teatro pede é a invenção de uma generosidade que desejamos ainda mas que não conhecemos. Mais cínica, preguiçosa e cómoda se tornou a época em que vivemos e o seu teatro. Estamos mais preparados, na nossa maneira de representar, para imitar a realidade, para um realismo que quase nunca é uma análise da própria realidade, antes é, quase sempre, uma operação para, através dos mecanismos de reconhecimento, nos assegurar numa visão desencantada da vida. [...] E nem falamos da era "decoração". De espectáculos que são como os quadros para encher as paredes das nossas casinhas. ${ }^{23}$

Schiller dá a cada ser retratado uma atenção que resulta numa espécie de realismo ideológico, com a dignidade da tragédia antiga mas disponível para a interferência da poesia, que Schiller acreditava estar na iminência de encontrar formas novas: Por mais lúcido que seja este debate, ele faz-se pela paixão, pela entrega sem defesas que não é do nosso tempo, e por critérios poéticos, musicais ${ }^{24}$. Ao nível do logos, Don Carlos é uma obra híbrida, num género algo indeterminado a que Schiller chamou 'poema dramático'25. Mas apesar de demasiado longa para muitos palcos, mostra como a emergência do encontro entre ética e forma pode ser um imperativo plástico.

absoluto coincidente com o logos, leva-nos à arte como uma coisa do passado, uma vez que já não especula. Ora aqui Hegel ajuda-nos a determinar um dos valores fundamentais tanto dos românticos como da arte contemporânea mais radical, o facto de ela constituir um exercício de especulação pública sobre si própria, na celebração das suas potencialidades em aberto, em oposição ou reacção a um estado de coisas da arte. Isto é, em Hegel recupero tanto a convicção do papel social messiânico da arte como a imponderabilidade desse estatuto, uma vez que à arte apenas é conferida uma posição intermédia num percurso que lhe é exterior. À la différence du romantisme, Hegel ne tient pas l'art pour la forme supreme de la connaissance. Comme le romantisme, il accorde à l'art un statut ontologique et un role messianique absolument inédits, mais cette santification de l'art est justifiée par un discours qui lui est extérieur (Hugon, p. 69). Voltaremos a questão com Boris Groys (Groys, Boris; Art Power, The MIT Press, Cambridge, 2008), que dirá que Hegel não contou com a possibilidade da arte conceptual.

20 É um drama com momentos felizes quando a produção consciente da mente se alia à productividade inconsciente da natureza (Schelling), numa visão do encontro holístico que será partilhada por Wagner. Mas o fundamental é que Schiller tem por inevitável no Homem a distinção entre o dever $e o$ instinto, mas condena a hegemonia de qualquer das duas forças em presença: a do instinto, porque é cega na sua fúria, como a ditadura da plebe; a outra, porque, ao reprimir o instinto, se comporta como a monarquia absoluta, privando o indivíduo de toda a autonomia. In Caeiro, Olívio; Oito Séculos de Poesia Alemã, Fundação Calouste Gulbenkian, Lisboa, p. 187.

21 Retenho na memória uma récita recente pelo Teatro da Cornucópia, com direcção de Luís Miguel Cintra. Todo o palco era um tabuleiro de jogo, com os movimentos das personagens rigorosamente marcados por forma a reforçar essa noção.

22 Luís Miguel Cintra, programa do espectáculo Don Carlos, 2009

23 Idem.

24 Idem.

25 Frederico Lourenço, Idem. 
Ora perante a polaridade entre experiência e ideia (Goethe), Schiller realiza em 1795 um tratado poetológico com enorme interesse para quaisquer fundamentos da praxis artística enquanto axiomática ${ }^{26}$. Numa secção sintomaticamente intitulada «Da Guerra das Representações à Paz dos Mapas», leia-se a diferenciação entre ingénuo e sentimental como um passo estratégico inserido na intenção de especificar os contrários para possibilitar em seguida uma associação dos mesmos como complementos. ${ }^{27}$ Implícita nesta consciência está a noção especificamente schilleriana da complexidade da cultura, patente na dupla condição do ser humano como sujeito e como objecto da mesma cultura. ${ }^{28}$ Apesar do tom elegíaco (como em Don Carlos) estão lançadas as premissas para o entendimento do dispositivo estético como moralmente afectado (Nietzsche chegará a chamar a Schiller trompetista moral), em antevisão ao que Cadete denomina um projecto hermenêutico de leitura da especularidade paisagem/sujeito. ${ }^{29}$ Isto é, a partir de uma (re)/construção simbólico-alegórica do mundo paisagístico ${ }^{30}$. Schiller transfere o interpretar para um pensar da produção-acção. O que está em causa é sempre a espacialização de uma consciência aguda da temporalidade ${ }^{31}$, não apenas enquanto dor (de algo perdido), mas das guerras de representações (Cadete), cartografando as suas fronteiras e intersecções (isto é, histórica, antropológica e genealogicamente). Schiller dá aqui seguimento à noção humboldtiana de formação (Bildung), no quadro de uma proto teoria-crítica que distrinça três momentos na experiência (três estados de consciência em progressão):

1. O objecto está inteiro diante de nós, mas confuso e fluído.

2. Separamos características singulares e diferenciamos. O nosso conhecimento é nítido, mas isolado e obtuso.

3. Ligamos o que está separado e o todo volta a estar diante de nós, mas agora já não de forma confusa mas iluminada de todos os lados. ${ }^{32}$

Noutros termos, o mundo da cultura e da arte surge como complexo trabalho de multiperspectivismo e mediação (Cadete), que tempera as dimensões terapêutica, moralista (Schiller foi influenciado pelos moralistas escoceses) e de espanto perante o real (Platão) com uma

26 Cadete, Teresa Rodrigues; «A Tensão Elegíaca ou o Sujeito com Paisagem», in Schiller, Freidrich; Sobre Poesia Ingénua e Sentimental, INCM, 2003, Lisboa, p. 8: [...] podemos ler este tratado como uma cartografia de modos de ver, de tentar entender, de criar e recompor o mundo: da escrita e da vida, da natureza e da História. [...] Neste mapa de diversidades, os contornos os contornos das distinções funcionaram como fronteiras de tensão que ajudam a configurar a identidade própria de cada conceito, de cada representação, e a reflectir como identidades tão diversas podem conviver como alteridades, contraindo-se e expandindo-se, enclausurando-se e interpenetrando-se num movimento caleidoscópico. Cadete sublinha a importância da relação entre a formação médico-filosófica de Schiller, a sua permanente exigência de avaliação antropológica completa, e a sua consciência, por via do dispositivo estético, da íntima correlação entre natureza animal e espiritual, isso sendo o que traça ironicamente os limites de qualquer excesso de esquematismos, idealismo, alheamento.

27 Idem, p. 13.

28 Idem. Com efeito, já a concepção de natureza em Schiller surge como uma figuração ontologicamente de pressupostos e cuja relação de especularidade com os estados de alma do sujeito faz que esses mesmos pressupostos se apresentem como expressão ora de liberdade, ora de necessidade, ora de exigência ética, ora de violência incontida. [...] o que equivale a admitir a interacção entre natureza e cultura como «material e execução».

29 Idem, p. 14. Já no estudo «Sobre o patético»tínhamos visto como o antropólogo Schiller [...] ao defender um interesse puramente estético no tratamento dos temas e na fruição de cenas no mínimo eticamente indiferentes, quando não moralmente condenáveis. Semelhante limiar de insolubilidade equivale a um limite de representabilidade, à intuição (presente em Schiller antes de se tornar uma certeza para os românticos e para Goethe) de que a voragem instrumentalizadora, a economia da prosa do mundo, ameaçava já no final do século XVIII as fortalezas conceptuais do essencialismo, quer elas se fixassem no conceito de natureza, quer no de cultura.

30 Idem

31 Idem, p. 15.

32 In Cadete, pp. 15-16. No primeiro estavam os gregos. / No segundo estamos nós. / O terceiro deve portanto ser objecto de esperança e então já não se desejará o regresso dos gregos. 
'saudável' propensão para os jogos socráticos da linguagem ${ }^{33}$. Schiller, consciente de como o espirito renovador (Cadete) se define a partir de nuances psicológicas nas posições críticas ${ }^{34}$; propõe uma cartografia teórica ${ }^{35}$ do fazer e do agir, contestando os excessos de sentimentalismo em nome de uma via crítica para a arte.

\section{1.1.1.2 Da Liberdade da necessidade à quotidianeidade do humanismo diletante ${ }^{36}$}

O fazer e o agir são modos de configurar o mundo (Cadete), e convidam à reflexão operativa acerca da sua materialização no socius, desde a trivilidade sentimentalista ao experimentalismo romântico, ${ }^{37}$ Schiller passa desta constatação para pensar em criar estádios de estímulo e de participação, numa busca reflexiva sobre os modos de fazer poéticos e do seu posicionamento entre a liberdade e a necessidade. ${ }^{38}$ São investigações no limiar das disciplinas, prefigurando uma auctoritas artística informada pelo pathos do público ${ }^{39}$ - mas ressalvando: Noto aqui como nós, os modernos, temos uma propensão tão grande para misturar os géneros que nem mesmo somos capazes de os distinguir. Parece resultar do facto de os artistas, que em si deveriam produzir as obras de arte no âmbito das suas puras condições, cederem ao desejo dos espectadores e ouvintes de achar tudo inteiramente verdadeiro. ${ }^{40} \mathrm{Em}$ termos de evolução teórica, Schiller, tanto no Tratado Sobre Poesia Ingénua e Sentimental (1795) como antes nas Cartas Sobre a Educação Estética do Homem (1791), concatena vários temas do ethos crítico, numa estratégia radical para corrigir excessos antropológicos.41

O Tratado é uma reflexão sobre a recepção dos produtos do fazer poético, numa altura em que o autor reflecte com acutilância sobre as diferenças entre acção dramática e acção épica ${ }^{42}$. Como que antecendo derivas pós-modernistas na sua indiferenciação genérica tí-

33 Idem, p. 16.

34 Cadete, p. 17: Como autor e como leitor, o europeu Schiller movimenta-se entre um entusiasmo pelas potencialidades da época setecentista, que em 1789 (menos de dois meses antes da Revoluçèo) transborda de eurocentrismo na lição inaugural com que inicia a sua curta carreira académica em Jena, e um distanciamento crítico com as cores sombrias do exagero disfórico da quinta carta sobre a educação estética, que parece não entrever alternativas entre uma rudeza violeta e um requinte depravado.

35 Cadete, p. 19: A única possibilidade que resta ao autor de transformar as distâncias e clivagens civilizacionais em diferenças acaba por realizar-se numa cartografia teórica das mesmas, em que é visível o esforço de equiparação e equilíbrio entre as instâncias sensíveis e conceptuais. A polaridade das mesmas vê assim aberta uma via de intensificação [...] um equlíbrio aproximativo que corresponde a uma via transcendental de aperfeiçoamento de que nunca abdicará - mas que deve ser lida con contexto assumido da guerra de representaçèoes resultante de uma lucidez empírica que resiste a toda a formatação interpretativa [...]. Estamos algures numa actualização subtil da entelechia aristotélica, a caminho do conhecimento situado em Lefèbvre.

36 Cito um subtítulo de Cadete.

37 Idem. Cadete recorda que Schiller se aliou a Goethe para, por exemplo, atirar dísticos satíricos contra o pedantismo e a trivialização do meio literário.

38 Idem, pp. 20-21.

39 Idem, p. 20.

40 Idem, p. 21: Vê-se assim no caminho da poesia que tudo concorre para o drama, para a apresentação do que perfeitamente presente.

41 Idem, p. 22. Numa reflexão sobre a optimização dos modos de fazer e de agir, de poiesis e de praxis, numa época em que os comportamentos performativos e produtivos tinham atingido (como podemos ler na quinta e sexta cartas sobre a educação estética, graus de perversão cultural em que o sentimento dava lugar à exaltação, a revindicação (de inspiração lessinguiana) de felicidade humana à legitimação da revolta, a defesa do prazer estético a uma fruição sensual.

42 Idem, p. 22. Carta a Goethe, em 26 de Dezembro de 1797. Transcrevo, pelas ressonâncias notórias com modelos de experiências fenomenológicas nossas contemporâneas como a instalação ou o cinema experimentais: $A$ aç̧ão dra- 
pica das indústrias culturais mais recentes; evitar que essa tendência de alternância recíproca não degenere numa mistura e confusão de limites, é precisamente a verdadeira tarefa da arte, cujo ponto supremo é em geral sempre esse, o de combinar carácter com beleza, pureza com plenitude, unidade com totalidade. ${ }^{43} \mathrm{Em}$ síntese, Schiller visa qualquer manifestação individualista e arbitrária seja no reino da arte e da estética, seja no domínio da realidade política, social ou económica. Também para a arte de jardinar é válido o processo de simbolização enquanto projecção de energia simbólica para o interior de uma figuração estética delimitada enquanto tal. ${ }^{44}$ Pathos e sentimentalismo equivalem-se nesta carência de um estado de espírito específico, um Empfindungszustand produtivamente sentimental. Der Spaziergang é, nestes termos, pós-peripatético (Aristóteles) e proto-psicogeográfico (Debord): [...] Uma leitura paralela da descrição do caminho de Stuttgart a Hohenheim e da elegia Der Spaziergang guia-nos por um caminho de aprendizagem experiencial, que o leitor é livre de considerar (ou não) iniciático.

Muito importante para a moderna consciência do dispositivo artístico é que toda a regra, embora contingente e reversível, não só requer uma economia interna como mergulha numa experiência de e numa reflexão sobre a desordem em que se situam as suas raízes. ${ }^{45}$ É de certa forma um dispositivo 'contra' o sublime - E tal desordem constitui para Schiller lcomo também para Goethe) uma forma de manifestação expansiva, uma ameaça invasiva frequentemente associada a formas de egocentrismo existencial e de arbitrariedade (in)estética, tendendo a esquecer o tempo e o espaço que as enquadra, as épocas de ascensão e declínio da cultura, as leis da natureza. ${ }^{46}$ Contra o diletantismo do 'vale tudo'

As razões da preocupação de Schiller (e Goethel com o diletantismo e o desempenho dos caracteres realista e idealista no mundo da vida residem assim ainda na intenção cartográfica que induz o autor a assinalar todas as formas de relevo que possibilitem uma «reactivação de potencialidades apagadas», embora ele esteja consciente da desproporção entre os sistemas de organização do mundo e as suas virtualidades de aproveitamento poético ou artístico. ${ }^{47}$

Num tom habermasiano (Cadete), Schiller está ciente de como o imediatismo consumista na recepção de certas obras é impeditivo da consciência desta liberdade da necessidade (situação que até hoje se agravou); identificando tonalidades simultaneamente wagnerianas e agambenianas, Cadete conclui: Schiller problematiza neste texto os riscos de inconsequência do reconhecimento do caminho adâmico da cultura pelo poeta moderno, tal como fizera na nona carta sobre a educação estética, em que exortava o mesmo a viver com o seu século sem ser a sua criatura e a proporcionar aos seus contemporâneos aquilo de que necessitavam, não aquilo

mática move-se diante de mim, em torno da éopica movo-me eu próprio [...] Se o acontecimento se move diante mim, então estou rigorosamente preso ao presente e sensível, a minha fantasia perde toda a liberdade, então surge e permanece em mim uma contínua intranquilidade [...] Se me movo em torno do acontecimento, que não pdoe escapar-me, então posso amnter um passo desigual, posso permanecermais ou menos tempo de acordo com a minha necessidade subjectiva, posso retroceder ou antecipar, etc. [...] O facto de o poeta épico ter de tratar o seu acontecimento como inteiramete passado e o trágico o seu como inteiramente presente, é-me bastante claro.

43 In idem, p. 23. A terceira via schilleriana entre a normatividade poética da tradição clássico-retórica e as perspectivas de uma «pan-poetização» romântica da realidade manifesta-se assim numa taxatividade que não só experimenta novas formas de taxinomia [...] mas que pretende explorar zonas limítrofes entre arte e natureza enquanto artifíco e naturalidade, disciplinamento e deleite.

44 Idem, p. 25.

45 Cadete, p. 29.

46 Idem.

47 Idem, p. 30. 
que eles louvavam. ${ }^{48}$ Vejo aqui a potencial articulação com a questão da multiplicidade das formas urbanas como resultado de carências diversas mas de remota origem pulsional comum, pois Schiller articula uma rigorosa estratégia de gestão de energia pulsional com uma liberalidade que não prescinde de formas plurais de apresentação. ${ }^{49}$ Agora num registo deleuziano, estamos no pressuposto de que a distinção entre arte e diletantismo passa, em qualquer dos domínios aflorados, pela diferença entre productividade e reproductividade ${ }^{50}$, evidenciando uma perplexidade irreversivelmente moderna face à contingência material e à arbitrariedade da ideia. ${ }^{51}$

Os traços ambivalentes com que o fenómeno é encarado mostram assim como ele é inerente a uma intensificação da comunicabilidade literária, artística e crítica, sendo os critérios de benevolência ditados pelo reconhecimento das virtualidades civilizadoras de qualquer forma de amadorismo, equivalendo, por outro lado, os traços caricaturais ao reconhecimento de que não terão sido atingidos os horizontes de exigência delineados pela educação estética, de que não terá sido alcançada a forma lúdica suprema da «figura viva». ${ }^{52}$

\section{Ora o contrário da ludicidade produtiva é o diletantismo da moda (Wagner):}

Os horrores do diletantismo, voltámos a vivê-los nestes dias e são tanto mais terríveis quanto as pessoas entretanto fazem um trabalho aldrabado com graça, assim que se admite que é suposto aldrabar. Incrivel é porém como através desta tentativa singular já toda a comunicação social, na qual nada existe para corromper, assume um contorno oco, superficial e egoísta, assim como toda a verdadeira participação na obra de arte se vê suprimida através desta reprodução leviana. ${ }^{53}$

No rescaldo da Revolução Francesa (de que Schiller foi figura querida por via de Die Räuber), Schiller, intimidado pela carnificina, partirá para um ensaio de enorme importância histórica:

O seu trabalho mais conhecido sobre a estética, Sobre a Educação Estética do ser Humano (1794), é uma tentativa para analisar onde o iluminismo tinha falhado e propor que através da arte os seres humanos encontravam uma forma de reconciliar a razão e o impulso. Longe de ser periférica a um tempo revolucionário, a arte é o meio pelo qual podemos progredir para uma sociedade civil solidária. ${ }^{54}$

Nas Cartas, Schiller havia já reflectido sobre o eu dividido e a fragmentação da sociedade trazida pela divisão do trabalho, com enorme influência em pensadores posteriores (de Jung a Sir Herbert Read, de Marcuse a Debord). 0 criador tem a noção do território determinante da sua acção, o dispositivo como segunda natureza, lugar de superação da individualidade e de cognição e expansão da consciência: Tenho para mim que cada invenção poética não passa de uma amizade entusiasta ou de um amor platónico por uma criatura da nossa mente..$^{55}$ Este diletantismo transdisciplinar, pueril e engajado, não mais deixará de ser uma tipologia de von-

48 Idem, p. 32.

49 Idem, p. 33.

50 Idem, p. 34. [...] trata-se aqui de problematizar e perspectivar formas de aproximação a opções de aprendizagfem que revelam uma relação mais ou menos reflexiva entre cultura e natureza, sendo o grau de diletantismo de certo modo inversamente proporcional à intensidade da tensão elegíaca. Esta questão inclui em Schiller já a do kitsch e da arte de massas. Cadete, p. 34: Uma análise comparativa das vantagens e desvantagens do diletantismo nos diferentes sectores [...] nota vários factores positivos que oscilam entre a sociabilidade e a convivialidade, bem como um certo disciplinamento de capacidades pos vezes próximo do que seria actualmente designadfo por terapia ocupacional; no polo oposto, manifestações de mediania e de vazio.

51 Idem.

52 Idem, pp. 35-36. O diletante teria contudo o mérito implícito de articular o mundo da vida com o da arte, e os dois padrões de actuação que Schiller/Goethe nele distinguem aproximam-se da dupla tipificação feita no final do presente ensaio do idealista e do realista: Diletantismo pode ser de espécie dupla. Ou descura o indispensável aspecto mecânico e crê ter feito o suficiente ao mostrar espírito e sentimento. Ou procura a poesia apenas no elemento mecânico, no qual ele pode adquirir uma aptidão artesanal, e não possui espírito nem conteúdo. Ambos são prejudiciais, sendo poém aquele mais prejudicial à arte e este mais ao próprio sujeito. A citação é da décima quinta carta sobre a educação estética.

53 Schiller, Friedrich, in idem, p. 36.

54 Lourenço, Frederico; in Idem.

55 Alguns excertos de Cartas, Idem (a Reinwald, 14 de Abril de 1783). 
tade de mudança do mundo através da arte, o que me leva a evocar uma reflexão do jovem Schiller sobre a Nova Tragédia que já é uma ponte para nos aproximarmos de Schopenhauer:

A nossa tragédia, se concebermos uma, deverá lutar contra a impotência, a falta de rigor, a falta de carácter do espírito da época, e contra um modo grosseiro de pensar, deve pois mostrar força e temperamento, deve tentar sacudir o pensamento, elevá-lo em vez de o assimilar. A beleza foi criada para uma geração feliz, mas devemos procurar tocar aquela que é infeliz através do sublime ${ }^{56}$

\section{Schopenhauer: do individualismo pessimista ao humanismo controverso}

Schopenhauer desenvolve uma das mais influentes teorias da atitude estética. Inspirado pela filosofia oriental, afirma que nesta se dá uma suspensão da vontade, levando o sujeito a experienciar uma elevação do estado de consciência (libertação do desejo face ao objecto de contemplação e do sofrimento associado ao desejo) ${ }^{57}$. A noção de que obra de arte adquire especial valor quando o génio suspende a vontade individual e atinge uma percepção objectiva da realidade, de certa maneira contra as ilusões de um mundo burguês e filistino ${ }^{58}$ leva Schopenhauer a uma teoria dos géneros em que a percepção da superioridade da música ${ }^{59}$ tem consequências ${ }^{60}$.

Em O Mundo como vontade e representação (1819), a reflexão sobre a arte rompe com as tradições espiritualista e racionalista, entendendo a vontade não como uma faculdade humana, mas como um real em si, liberto de aparência fenomenal. Por outro lado, noutra inovação em Schopenhauer, o caminho da arte passa pelo seu carácter de plataforma conceptual; ela dá a ver Ideias, que o filósofo descreve como actos da vontade, isolados e simples em $\mathrm{si}^{61}$, espécie de caracteres em que se encontra escrita a vida do mundo ${ }^{62}$. Ou seja, num importante avanço

56 Alguns excertos de Cartas, Idem (A Johannes Wilhelm Süvern, 26 de Julho de 1800).

57 Mas também valor cognitivo supremo, uma vez que, libertando-nos da vontade, libertamo-nos das formas subjectivas e atingimos um conhecimento mais puro (à maneira platónica). Para Schopenhauer, a experiência estética é um alívio temporário da miséria da existência Ora na evolução da consciência, a arte ocupa um degrau nobre lum lugar porém, como em Kant, relativamente delimitado, pois é no essencial, como aliás em Hegel, apenas oportunidade de evolução no seio do continuum histórico.

58 O Homem vulgar, esse produto industrial que a natureza fabrica à razão de vários milhares por dia, é, como dissemos, incapaz, pelo menos duma maneira contínua, desta percepção completamente desinteressada, sob todos os pontos de vista, que constituiu a contemplação [...] ele não prende muito tempo o seu olhar sobre um objecto: mas, desde que uma coisa se Ihe oferece, ele procura bem depressa o conceito sob o qual a poderá colocar (como o preguiçoso procura uma cadeira), depois já não se interessa mais por ela. [...] Para os homens vulgares, a faculdade de conhecer é a lanterna que ilumina o caminho; para o homem de génio, é o sol que revela o mundo. In Schopenhauer, §36, p. 245

59 A música dispensa a representação (das ideias platónicas) e reproduz directamente os movimentos da vontade.

60 No espírito de Hegel, também Schopenhauer reflecte acerca das formas concretas que as artes assumem no quadro de múltiplos níveis de contemplação, e é aí que a arquitectura, na forma directa como dá a ver a sua funcionalidade (estrutural, por exemplo) passa a ser considerada inferior. A posição de Schopenhauer é inerente à ideia de que uma arte transparente nos seus propósitos tende a ser uma arte 'menor', a não ser que se proponha ser a presentificação de aspectos da natureza humana mais complexos e subjectíveis (como o autor releva na obra de Proust ou Balzac, em que certas personagens funcionam como personificações de emoções situadas em torno do ciúme ou da inveja.) Note-se que, nesta grelha de análise, a tragédia vai de novo adquirir uma importância particular, uma vez que representa o Homem subjugado à vontade inevitável no palco do mundo e das múltiplas forças que nele se degladiam. E que é a música, como já vimos, que representa uma dimensão da vontade em si - pois não se lhe reconhece uma dimensão de representação directa da vontade em situação.

61 Hugon, p. 72.

62 Vejam-se as ressonâncias do pensamento de Galileu que a partir na matemática via a forma como o mundo estava escrito, e projecte-se esta imagem até Deleuze e a sua chamada de atenção para o facto de o mundo estar escrito na linguagem dos signos. 
no sentido da contemporaneidade discursiva, a arte é uma plataforma de articulação entre a generalidade indiferenciada da vontade e a absoluta particularidade dos fenómenos; Em suma. Schopenhauer retoma de Platão um mundo idealizado, mas ao contrário do filósofo grego, confere à arte e à experiência estética uma função de entendimento (Wagner), em que a capacidade contemplativa conduz à redenção estóica ${ }^{63}$ que a individuação toma como seu objectivo. E assim, no ensaio «On the Comparative Place of Interest and Beauty in Works of Art», vislumbro uma ponte conceptual entre a perspectiva individualista e aspectos dialógicos e relacionais na construção quer do eu quer do corpo social - no limite, toda uma dialéctica do encontro (Arendt, Buber, Rancière) com a complexidade do social que as vanguardas modernas se encarregarão de formular. The beauty of a work of art consists in the fact that it holds up a clear mirror to certain ideas inherent in the world in general. ${ }^{64}$

Schopenhauer fala na invenção de circunstâncias (no espírito da Poética de Aristóteles), tal como Debord falará de criação de situações (o momento em Lefèbvre). De acordo com a sua ideia de Belas-Artes, este envolvimento era específico da poesia e no drama, mas assim como Hegel não podia prever a arte conceptual (Groys), Schopenhauer não teve oportunidade de tomar contacto com a arte relacional contemporânea, que coloca o interesse do social no âmago do seu logos processual. Mas Schopenhauer adivinha que a questão do interesse, imbrincado numa teoria da vontade, vai implicar uma reavaliação da autonomia do belo, mormente quando a problemática do quotidiano fizer a sua aparição crítica (com Lefèbvre), impondo a teatralidade (Fried) da arte pública - arquitectural, processual - face aos limites da ideologia (e da estética) de que é imanência. Em The Art of Controvery, somos por isso introduzidos ao problema da arte pública como plataforma imponderável entre a trivialidade e o vernacular, o elitismo e o populismo, entre a arte que é mera exibição da beleza das ideias e a que transforma (um problema crucial nas querelas realistas); constatamos então uma sensibilidade inédita para a viabilidade - e a necessidade - da articulação entre a forma (para mim, da polis como arte) e a beleza (para mim, as ideias políticas implícitas na arte pública): Or we may say that interest is the body of a poetic work, and beauty the soul. In the epic and the drama, interest, as a necessary quality of the action, is the matter; and beauty, the form that requires the matter in order to be visible. ${ }^{65}$

Neste quadro, percebemos que a inovação de Schiller havia sido a de to ascribe humanity's mechanical condition to historical forces rather than universal laws, and to see in this mechanical condition something infernal. ${ }^{66}$ Metáforas aparte - a separação necessária (mecânica) das coisas como signo de uma separação moderna da unidade original das coisas - esta posição crítica do/face ao dispositivo leva a que se torne explicita uma deriva da arte para a idealização - que tanto pode passar pela questão do belo como pela do conceito lou ambas em simultâneo). Seja como for, estão lançadas as premissas historicamente possíveis de

63 The Stoic was suspicious of external authority for authority's sake and revered only reasoning itself in its commitment to the fostering of rationality in the self and in the world as a whole. The motivation behind the whole Stoic philosophy was to show respect for what is most worthy in oneself and for what is most truly oneself. This cannot be achieved by anything but good argument. Nussbaum, Martha; The Therapy of Desire: Theory and Practice in Hellenistic Ethics, Princeton University Press, 1994).

$64 \mathrm{http} / / /$ ebooks.adelaide.edu.au/s/schopenhauer/arthur/controversy/chapter4.html consultado em Novembro 2011.

65 Idem.

66 Smith, p. 13. 
um estado estético - um modelo de entendimento do político. O estado estético será aquele em que o dispositivo é ele próprio uma esfera total da publicidade dos cidadãos criativos - aliás sempre a utopia da perseguição de um possível do visível que se vai actualizando com os múltiplos conhecimentos que vamos acumulando sobre o socius. Numa frase, while all other forms of communication divide society," the "aesthetic mode of communication unites society, because it relates to what is common to all". ${ }^{67}$ Vislumbro aqui uma comunidade de consciências (Schelling), donde a importância da formação e da pedagogia (primeiro humanistas, no quadro da Aufklärung, mais tarde informadas pela subjectividade processual do Romantismo) e hoje das teorias dos sistemas (Capra, Guattari).

\section{1.1.2 Fiedler: consequências da arte como saber}

Konrad Fiedler ${ }^{68}$, em Sobre a origem da actividade artística ${ }^{69}$, define uma linha de orientação crítica face à estética tradicional, promovendo a refundação de toda a reflexão possível acerca das $\operatorname{artes}^{70}$, que passa pelo que commumente se considera um ataque à beleza ${ }^{71}$. Vislumbro uma reflexão antropológica acerca de como nasce a arte rejeitando a categoria do Belo enquanto categoria-chave para a compreensão do fenómeno artístico. Ao contrário do que acontece nas estéticas filosóficas de Kant (Crítica da Faculdade de Julgar, 1790) e Hegel (Curso de Estética ${ }^{72}$, 1835), passamos a encarar a arte como um processo cognitivo em si, um modelo de construção e conhecimento intuitivos da realidade, fundado numa necessidade urgente e essencial. ${ }^{73}$ Fiedler

strongly disagreed with the Kantian idea that art was only an undeveloped, rudimentary step in the acquiring of cognition. He saw art as a mental process involving another kind of cognition rather than the abstract, conceptual cognition. [...] identified an entire domain of the human mind, an intuitive domain consisting of artistic thinking, artistic cognition, and artistic configuration. These are holistic in their nature, being inherent endowments of gestalt, unifying lawfulness of the human mind. ${ }^{74}$

67 Schiller, in Smith, p. 14.

68 Crítico e filósofo da arte, Fiedler introduz a ideia de um domínio intuitivo na mente humana, consistindo na reflexão, cognição e configuração artísticas, holísticas e subjectivistas na sua natureza, e na ignorância das quais a reflexão estética não faz sentido.

69 Fiedler, Konrad; Sur l'origine de l'activité artistique, D. Cohn (éd.), Editions "Rue d'Ulm", Paris, 2003. Outras fontes foram "On Judging Works of Visual Art" (1876) e aforismos dispersos.

70 Cf. Afirma Fiedler, numa nota preliminar, que é no domínio particular de uma determinada arte que convém interrogarmo-nos acerca da origem do seu poder artístico. O autor adverte que a sua reflexão se limita às artes plásticas - foi contemporâneo de Cézanne, tendo privado com o artista francês, e seria futura referência do movimento Blaue Reiter ou da Bauhaus, assim como da pintura americana do pós-guerra; tal advertência deve manter-nos atentos às eventuais lacunas do pensamento fiedleriano para os campos da arquitectura ou das artes performativas.

71 Cohn, p. 9. Para o autor, a beleza tient du kantisme sa tonalité critique et participe de l'edification d'un nouvel a priori qui enregistre les acquis scientifiques d'une psychophysiologie de la perception pour élaborer une anthropologie de la vision.

72 Publicado postumamente.

73 Bergson contrastava as actividades da inteligência com as do instinto, o cerne vital da realidade. Instint is sympathy. If this sympathy could extend its object and also reflect upon itself, it would give us the key to vital operations - just as the intelligence, developed and disciplined, guides u sinto matter. For - we cannot too often repeat it - intelligence and instinct are turned in opposite directions, the former towards inert matter, theatter towards life. [...] But it is to the very inwardness of life that intuition leads us - by intuition I mean instinct that has become disinterested, self-conscious, capable of reflecting its object and of enlarging it indefinitely. In Elder, R. Bruce; «Harmony and Dissent: Film and Avant-garde Art Movements in the Early Twentieth Century», Wilfrid Laurier University Press, October 2, 2008.

74 Abrahamson, Roy E.; « Art Criticism: The Potential of Conrad Fiedler's Ideas for Art Education», (Paper), Annual Meeting of the National Art Education Association, Atlanta, GA, Março 20-24, 1991. 
Danièle Cohn verá aqui a operação racional que, ao secundarizar a dimensão estritamente estética, prefigura as revoluções cognitivas da arte moderna, do ready made (Duchamp) ao minimalismo na pintura. Por outras palavras, L'erreur premier de l'esthétique et la source de toutes les autres est d'associer art et beauté comme si le besoin d'art des hommes visait la constituition d'un monde du beau ${ }^{75}$-, ou pelo menos a sua crítica $^{76}$, será uma figura essencial da retórica das vanguardas, enquanto argumento para a sua autonomia e função crítica. Evitando aplicar à arte critérios científicos, Fiedler reforça o seu sentido de projecto humano motivado; son secret quel que soit son mode de dévoilement reside dans la signification des raisons pour lesquelles l'homme le produit. ${ }^{77}$ Isto permitirá abordar a arte não apenas do ponto de vista do seu impacto comunicacional, simbólico, cultural ${ }^{78}$, mas já como resultado de um ethos produtivo específico, no âmbito de uma processualidade.

Outra ideia de partida para abordar o legado de Fiedler é a de um desacordo fundamental com Kant (para quem a arte era passo rudimentar no conhecimento); a arte - S'il s'addresse en première ligne à la connaissance, sa dimension cognitive est singulière ${ }^{79}$ - não é redutível à cognição dita abstracta e conceptual. É portanto com Fiedler que o campo da arte se autonomiza também como um recurso de apreensão e transformação plástica do mundo. Esta sua vitalidade intelectual, discurssiva, aliada à sua democratização - questão que entronca na da sua pedagogia - tem consequências importantes, na possível equivalência entre artista e sábio, arte e saber. ${ }^{80}$ Por outras palavras, o artista ganha consciência de que a percepção sensível não se oferece como verdade imediata, mas enquanto construção do real, diversa da da metodologia científica. Em suma, é na crítica de Fiedler do projecto realista - que lhe parece sofrer da ingenuidade do útil e do instrutivo - que pretendo radicar a minha própria concepção de arte política, ainda realista mas agora no plano específico de uma produção social (e sua pedagógica emancipatória). É neste plano do possível que Fiedler substitui a interrogação clássica e substancialista - 'O que é o real? - por uma questão crítica $^{81}$ - $O$ que podemos possuir da realidade? Eis-nos na esfera de uma retórica poiética:

S'il est raisonnable de penser que nos acquis ne gagnent de consistance que par une mise en forme qui nous fait sortir de l'unicité dans laquelle nous nous mouvons tant que la prise de forme ne s'est pas opérée [...] Tant que des formes ne sont pas produites, la richesse de nos répresentations se révèle en effet illusoire, nous ne détenons rien que des fantômes. ${ }^{82}$

A importância de Fiedler para a caracterização do fenómeno artístico é assim incontornável para caracterizar a produção plástica dos dispositivos contemporâneos para os quais a ci-

75 Fiedler, aforismo 2.

76 Isto não significa que a posição fiedleriana deva ser aceite sem uma crítica da sua potencialidade de actualização. Novas recuperações e acepções do tema do Belo têm contribuído para requalificar a própria noção de Beleza precisamente para além da questão da estética tradicional; essa é uma evolução que teve o contributo de sucessivas vanguardas de arte pública - seguindo movimentos na teoria da cognição e nalguma neurociência -, que foram inscrevendo novas noções de beleza, precisamente ancoradas no problema da recepção, na experiência do outro, do colectivo e do social. Este é um ponto a desenvolver no quadro da minha axiomática da arte pública face à morfologia urbana.

77 Fiedler; «Zu neueren Kunsttheorie», in Schriften zur Kunst II, p. 281.

78 Fiedler chega a empregar o termo «decorativo».

79 Cohn, p. 9.

80 Aspecto crucial em posteriores abordagens da pedagogia e ensino artísticos.

81 Cohn, p. 21.

82 Idem. 
dade é a matéria da arte. ${ }^{83}$ De acordo com Sir Herbert Read, dos primeiros historiadores da arte a sublinhar a importância de Fiedler, o mundo - e portanto a cidade - é um puzzle visível que a reflexividade artística desmonta-remonta-monta infinitamente, em sucessivos encontros com a formação da existência ${ }^{84}$. Mas valorizar a racionalidade artística exige o apreciar dos processos da sua emergência ${ }^{85}$ enquanto componente de uma esfera pública participada e comum. Naturalmente, a obra de arte pública crítica contém si, por isso, mecanismos de subjectivação que são tacticamente vernaculares (Knight), e é por isso que na arte como realidade pública que nos apercebemos que only a peripheral aspect of art relates to aesthetics. ${ }^{86}$

Quanto à relação entre filosofia e arte, Fiedler é peremptório, colocando limites à hubris conceptual: If a philosophical insight into the relationship between art and the whole concept of the world and art is added to the correct understanding of art, there results a progress in philosophical knowledge, but not in artistic knowledge." ${ }^{87}$ Esta posição, poderá argumentar-se, conduziu à perversão da autonomia modernista, mas no seu seio há um sentido de subjectividade plástica resiliente à barbárie cientista: a real understanding of a work of art is only possible if it is grounded upon an artistic understanding of the world". ${ }^{88}$ Ou seja, a arte é ela própria também uma espécie de elemento meta-instrumental que medeia as suas próprias formações como arte. Por outro lado, Fiedler reconhece que as emoções das pessoas perante os objectos de arte não dependem de uma mensurabilidade das experiências conceptuais; e que, até, if we watch ourselves closely we shall find [that] our sensation does not stimulate and further, but rather hinders, the growth of our visual conceptions. Ora aqui o problema da arte como cognição é indissociável de uma educação estética avançada, que é, hoje, se actualizarmos Schiller por via de Rancière, Agamben ou Sloterdijk, a educação para o dispositivo. Tal educação - ou formação - é crucial como competência de base intelectual, "[...] the artist becomes an artist by virtue of his ability to rise above his sensations". ${ }^{89}$

Se um certo grau de abstracção é fundamental na experiência cognitiva, seja uma abstracção que baste (Carrilho)",90 isto é, não mera imitação nem sentimento arbitrário, mas uma construção simbólica livre, em que a intuição desempenha um papel importante.

\section{1.1.2.1 O saber do artista contra o gosto da sociedade}

A humildade e precisão do projecto de Fiedler obrigou a estética a inflectir o seu pro-

83 Argan, Giulio Carlo; História da Arte como História da Cidade, Martins Fontes, São Paulo, 2005.

84 Cf. Bild und Werk (1965, p. 126) in Abrahamson p. 9.

85 Fiedler (1949, p. 2-3) in Abrahamson p. 9. Fiedler began by stating that people usually criticize a work of art subjectively, and the more widespread the audience of viewers, the less understanding occurs. He wrote "Commonly, one regards a work of art subjectively, instead of trying to understand it in accordance with the prupose of its originator, [and] one usually thinks he has done it complete justice by judging it after his own opinion"

86 Abrahamson p. 12

87 Fiedler (1949, pp. 24-25), in idem, p. 15

88 Idem, in idem. The more they [scientific observers] advance in transforming perception into abstract concepts, the more incapable they become of remaining, even for a short while, at the stage of perception (idem, in idem, p. 33).

89 Idem, p. 30 in idem, p. 16.

90 Idem, in idem, p. 37. 
jecto de hegemonia do belo e a regressar a uma reflexão sobre a experiência artística. Ao contrário do estético, o juízo artístico apenas tem sentido se for determinante ${ }^{91}$. Nestes termos, compreendemos como não é possível separar o 'regresso ao real' social da arte contemporânea ${ }^{92}$ de uma crítica cultural concreta, na denúncia de um gosto burguês que desde então (e já explicitamente em Wagner) já ameaçava o sentido social da arte, o seu fazer-se social como fazer-se de sentido: [...] l'esthétique du gout impose en fait des critères historiques, élevés au rang de dogmes culturels dans un certain type de societé. ${ }^{93}$ Fiedler encontra-se assim num momento-chave de um critical turn da estética que aponta o dedo a uma abstracção cultural que aliena a vida em nome do gosto burguês. $E$ de facto, os juízos estéticos, então como hoje em muitos círculos da esfera cultural - críticos, curadores, coleccionadores, público cultural - se contentent d'élaborer une rationalisation élégante et bien socialisée de sentiments éprouvés face à une ouvre d'art achevée ${ }^{94}$. Fora dos conceitos de artisticidade que a teoria cognitiva de Fiedler inaugura, não poderia haver institutional critique. Ora, na contemporaneidade, o problema prende-se com a forma como é possível afirmar ao mesmo tempo a identidade do artista (a sua contingência, subjectividade) e ao mesmo tempo assegurar que esse estatuto inefável seja socialmente integrado e activo, e não apenas uma ilusão destinada a manter determinadas divisões culturais. Mais, que constitua - como vai acontecer no projecto construtivista-produtivista - um dado cognitivo e aglutinador de vontades numa evolução criadora (Bergson) e autopoiética (Matura e Varela, Capra). Esse é um problema que Wagner havia antecipado na análise do génio de Beethoven e que pode ser superado talvez apenas quando o artista introduz no seu processo de criação as figuras do povo, do outro, do real social, outorgando contingência transpessoal à sua pesquisa - um desafio que Beuys promoverá de forma particularmente interventiva já no Séc. XX.

De qualquer forma, também a dimensão histórico-historicista da arte é revista por Fiedler, para quem le grand art ne saurait mourir car sa grandeur n'a rien d'historique. Il est toujours encore à venir dans la mesure où y aura encore de grands artistes ${ }^{95}$. A arte, neste sentido, é uma actividade sempre em recomeço e, independentemente dos seus momentos de 'menos força' ${ }^{96}$, oferece ao artista a possibilidade de um papel social determinante, o de radical proponente de alternativas para a produção criativa, senão para a produção do próprio social (o social turn ${ }^{97}$ da arte da segunda metade do Séc. XX e do Séc. XXI). Esta actividade de problematização radical tem consequências imprevisíveis - também para a estética - quando se constituindo a partir da noção de autonomia radical do criador e da

91 Cohn, p. 10.

92 Foster, Hal; The Return of the Real, 1996.

93 Cohn, p. 10. La soumission du génie au goût chez Kant est typique de ce travers et ouvre la porte à un emploi «bourgeois», cuistre à tout prendre, de l'expérience esthétique

94 Idem.

95 Cohn, p. 11.

96 E já não se coloca o problema de subserviência aos Antigos (Winckelman), cujo resultado inconsciente seria o da assumpção do dogma hegeliano do fim da arte

97 Bishop, Claire, «The Social Turn: Colaboration and its Discontents», Artforum, 2006, pp. 179-185. 
obra ${ }^{98}$. L'art est une cause qui n'admet aucune finalité externe ${ }^{99}$; esta afirmação tanto assegura um estatuto intocável à arte (modernismo) como liberta os artistas para a arbitrariedade (pós-modernismo), abrindo sempre o social quotidiano a uma dimensão outra que tem a capacidade de lhe conferir (o) sentido. Dan Graham arruma a questão: All artists are alike. They dream of doing something that's more social, more collaborative, and more real than art. ${ }^{100}$

\section{1.1.2.2 Questões da forma, aspectos críticos}

A questão do informe entronca aqui. Art does not start from abstract thought in order to arrive at forms; rather, it climbs up from the formless to the formed, and in this process is found its entire mental meaning. ${ }^{101}$ Fiedler afirma então, desconcertantemente: Art, if it deserves the name, cannot be either realistic or idealistic. Art is always realistic, because it tries to create for men [human beings] that which is foremost their reality. ${ }^{102}$

Portanto, com Fiedler, a arte abdica de sofrer um processo de ontologização ou teologização (Cohn), para ser encarada do ponto de vista da sua poiesis, no seio da qual o conceito de origem - Ursprung - releva do desejo de filosofar a arte em processo. Com este foco no processo - consciência determinante em todas as vanguardas da arte contemporânea - o programa de atenção crítica à cognição artística integra (ainda não tão explicitamente quanto em Feuerbach) uma 'antropologia geral', no plano de uma crítica ideológica da própria posição da arte enquanto saber historicamente determinado. Em resultado, a arte acompanha outros encontros com a construção colectiva do social: Les artistes de doivent pas exprimer le contenu de l'époque, leur tâche est bien plutôt de donner d'abord un contenu à l'epoque $e^{103}$. E é nestes termos que dois outros motivos correlatos - visibilidade e revelação - justificam a hipótese - tão fiedleriana quanto wagneriana - da arte como iluminação de um inconsciente transpessoal. Aliás, Paul Klee afirma em 1920: o artista não restitui o visível, ele torna visível. ${ }^{104}$

Este é um princípio essencial para uma teorização da arte como produção do espaço urbano (Lefèbvre) - em tensão mística (Bergson) com as questões representacionais do ideal ou da imitação da natureza. Em suma, cognição e discurso co-extendem-se na análise da emergência da obra de arte, enquanto encontro (Deleuze) com a sociedade. ${ }^{105}$ Isto representa

98 Cf. Beech, Dave; «Autonomy and Barbarism», Art Monthly, 2007.

99 Cohn, p. 11

100 In Bishop, Claire, «The Social Turn: Collaboration and its Discontents», Artforum, 2006, pp. 179-185.

101 Fiedler, Conrad; On Judging works of visual art, trans. Schaefer-Simmern, H. Mood, F. Berkeley, CA: The University of California Press, 1949, p. 49. A arte aqui surge no cerne da evolução cognitiva do ser humano, como é evidente na apropriação por parte da criança de um mundo circundante (como jogo): Only through artistic meaning does man comprehend the visible world. Idem, p. 54.

102 Abrahamson, p. 25.

103 Aforismo 198.

104 Confession Créatice (1920).

105 Fiedler dedicou muitas páginas à questão do realismo e do naturalismo em pintura. O seu interesse explica-se pela abordagem teórico-prática de criadores como Courbet, mas também Balzac, Flaubert ou Zola, cujas obras ostentam uma investigação-acção que as torna muitas vezes posições de tese. A falência do realismo foi inclusive um dos motores fundamentais do pensamento de Fiedler (Cohn), que a partir daí se interroga mais convictamente acerca da ontologia da obra de arte, no rescaldo das tendências ou movimentos naturalista, verista ou impressionista, conforme os designa, na plena consciência da dimensão programática neles presente. 
rever dialecticamente oposições estabelecidas na história de arte, nomeadamente entre idealismo romântico e realismo. Num período de emergência da Kulturkritik, Fiedler évalue très finement l'espoir d'émancipation que représente dans ses débuts le réalisme, sa force et sa capacité à remonter en deça de la culture. ${ }^{106}$ Acerca desta questão, Danièle Cohn confirma: [Fiedler] enregistre à son profit la rupture avec l'enjolivement et la falsification romantiques. En ce sens le réalisme pourrait bien renouer avec l'Aufklärung. Couplé avec la science, l'art se déprend d'une religiosité magique dans lequel il s'est trop longtemps abîmét. À força de querer ser educativa, útil ou politicamente instrumental, o desejo de real pode porém passar ao lado do território essencial (o simbólico, em Schiller como em Gadamer) onde se joga a realidade da arte, a dimensão do fazer-se como conhecimento partilhável, e nesse aspecto cristalizar-se num dogma que as inevitabilidades históricas se apressam a tornar obsoleto, incapazes de lidar com um território de tensões que não se esgotam porque a sua matéria é o infindo sublime social ${ }^{107}$. Esta questão projecta a retórica como ferramenta antropológica para equacionar o problema da realidade da arte face ao real social, uma vez que, ao nível do discurso, criadores e mediadores podem assumir determinadas carências não apenas programaticamente mas também a nível da reflexão teórica incorporada na performatividade dos seus dispositivos (e sendo a arte ela própria um dispositivo, como sabemos desde o conceptual). Nesta potencialidade meta-operatória, estamos condenados à imanência de acto que nos inscreve formalmente, estamos condenados à forma e ao agir: Ainsi le sensible échappe à la constrainte du schématisme, l'intuition au primat du concept et l'activité devient le régime de la dignité de l'homme ${ }^{108}$. O espectro de Lefèbvre paira já nesta terminologia, num proto-conceptual turn retórico que aproxima pulsão artística e cognição social (como nos movimentos relacionais, colaborativos e comunitários na arte nossa contemporânea).

Ora se para Fiedler o artista é um homem mais acabado que os homens vulgares, a acção é necessariamente o domínio (a conquista) das formas, ou seja, do dispositivo: Tant que des formes ne sont pas produites, la richesse de nos representations se révèle en effet illusoire, nous ne dérenons rien que des fantômes ${ }^{109}$. Por outras palavras, a arte é movimento expressivo, emergência gestaltiana ${ }^{110}$, e processo despoletado por uma força que se determina por si mesma em si própria (Schopenhauer), legitimando-se numa descoberta produtiva dos seus sucessivos resultados plásticos. Pergunto então como na ideia de vitalidade fiedleriana se não se poderá propor retoricamente a figura de uma força colectiva, que seria a origem da arte pública? No fundo, Fiedler abre o caminho a um sublime específico da criatividade artística, uma graça pública secular, que Jean-Luc Nancy nos ajuda a definir como hardly an emotion at all but rather the mere motion of presentation ${ }^{111}$. Antes, Schiller já havia sugerido ser assombrado por um daimon da pulsão criadora, crítica (e emancipatória) ${ }^{112}$ que leva à acção. Isto é, a criação, na perspectiva aberta por Fiedler, passa a poder ser entendida como facto antro-

\footnotetext{
106 Moderner Naturalismus und künstlerische Wahrheit, cf. Cohn, p. 19.

107 Hoje tecnológico (Mário Costa), cultural (Fredric Jameson) ou feminino (Barbara Claire Freeman). Vão assim esgotando-se dicotomias meramente nomenclatórias como a que opõe a 'arte pela arte' a uma 'arte política'.

108 Cohn, p. 21

109 Idem.

110 Idem, p. 22.

111 Cf. Rancière, Jacques; «The Sublime Offering» (1988), in The Sublime, The MIT Press, 2010, p. 47.

112 Cf. On the Sublime (1801).
} 
pológico absoluto ${ }^{113}$, dando a ver um nada que se torna mundo sem deixar de ser nada. É uma ideia que extrapolo de Zizek, quando atenta que the relation of Beauty to Sublimity coincides with the relation of imediacy to mediation ${ }^{114}$. Fiedler, ao fazer a arte aproximar-se da mediação meta-teórica, abre espaço ao fazer artístico enquanto produção (Benjamin) no quadro de uma teoria tanto da forma (Gestalt), como da formação (Bildung), como da transformação (Umbildung). Temos agora uma chave para entender e manipular a vida das formas, existentes e possíveis. Criticamente, como veremos com particular ênfase retórico em Duchamp e depois no movimento conceptual nos quadro das neo-vanguardas. As implicações de tudo isto para uma ideia de arte pública infinitamente multidimensional são evidentes.

As descobertas fiedlerianas passam pelo teorizar da relação entre o visual e o discursivo. Fiedler avança mesmo um linguistic turn avant-la-lettre ${ }^{115}$, permitindo uma linguagem específica à crítica e à teoria da arte. Desta retiro a coincidência com a instrumentalidade da análise linguístico-discursiva da morfologia da cidade (Benjamin, Lefèbvre, Lynch, Argan, Harvey, Miles). É neste sentido que a libertação fiedleriana do historicismo contribui para a exponenciação de múltiplas singularidades - e especificidades (Perniola) - que vejo inscritas no tecido urbano em função da intensidade do seu ethos (intenção), do seu logos (dispositivo) e do seu pathos (recepção).

Recordo uma nota de Nietzsche (cuja carreira passa inicialmente pelo ensino da retórica): On n'est artiste qu'à ce prix: à savoir que ce que tous les non-artistes nomment forme, on l'eprouve en tant que contenu, en tant que la chose meme. De ce fait sans doute, on appartient à un monde à l'envers: car désormais tout contenu apparâit comme purement formel, y compris notre vie. ${ }^{116}$ Esta posição é premissa de uma acepção da arte como modo de fazer que é simultaneamente construto de um processo cognitivo infinitamente plástico que somos progressivamente levados a conceber como nosso, mas ao mesmo tempo como potencialmente de todos (já no quadro da escultura social). Quando Fiedler assume esta grande necessidade vital à própria arte - a de um relacionar-se com o mundo, formal e (i)mediatamente -, vejo um traço do paradigma crítico (teoria crítica), sobretudo porque não é possível pensar a arte face ao quotidiano, ao contingente e ao político, sem entender a forma como a arte é criada, sua projectualidade e processos, sua recepção, no contacto íntimo com a dimensão de produção (o autor como produtor em Benjamin) e depois técnica social geral (John Roberts). Na arte pública divisada a partir de Fiedler, a emergência da forma revela-se então um resto do acto místico de ligação entre imaginação e tecido social. No dispositivo devemos procurar os sinais de uma comunicação com o mundo em que a consciência da obra corresponde a um excepcional e específico alargamento da consciência desse mundo. Eis-nos assim num tropo central da modernidade crítica-política, na medida em que o artis-

113 Para Kant, a coisa-em-si existe positivamente, para lá do campo de representação; para Hegel, que radicaliza Kant, isso é impensável, e adere antes a uma negativiadde radical, em que a ideia em si é pura negatividade (Zizek, pp. 59-60). Mas para para Fiedler, aprofundando a antropologia de Schiller, é como se houvesse uma coisa-em-si-da-arte, da produção. Voltarei a esta questão por via de uma análise do sublime na contemporaneidade, na Parte II.

114 Zizek, Slavoj; «The Sublime Object of Ideology», (1989), in Sublime, The MIT Press, 2010, p. 57.

115 Cohn, p. 29.

116 Nietzsche, Friedrich; La volonté de Puissance, n. 818. 
ta com carácter está condenado a pregar um nóvel evangelho ${ }^{177}$, revelando aspectos novos (utopias?) do mundo, precisamente por ir dando corpo à actividade vital do entendimento do informe urbano. ${ }^{118}$ Ora, na génese da vanguarda - e necessariamente das artes públicas relacionais que tematizam hoje a emergência emancipatória do social - , esteve sempre, já o dissémos, uma recusa do belo (vigente) e uma apologia do novo (radical); a partir de uma tensão criativa entre uma rejeição da ideia de objecto belo na cidade e uma tendência renovada para desmaterializar o processo artístico em processos colaborativos, participativos, anónimos, o artista surge como uma espécie de cidadão exemplar empenhado em formas de revitalização do urbano. Fiedler conduz-nos a reflexão sobre a arte para uma reflexão sobre a acção artística, enquanto formalização - consagração, termo de que sublinho a conotação religiosa - de mundos que de outro modo se ficariam pela imaginação e não passariam de fantasias; transpor esta problemática para a arte pública acarreta uma expansão do conceito de obra (Krauss); a arte surge como dispositivo que problematiza e reconfigura publicamente a morfologia social de onde emana. E este é um programa em que, no sentido de emergência luminosa de um discurso vital, a metáfora da(s) Luz(es) faz e cria sentido: La métaphore traditionelle des Lumières s'en voit refraîchie, trouvant un nouvel éclat dans l'idée que seul le mouvement expressif des arts nous accorde la visibilité. La transformation réussie par l'artiste débouche sur la clarté, la luminosité d'un monde qui emerge. ${ }^{119}$

Depois há a humildade da matéria: Dans la pensée se développe una forme d'être, son pouvoir ne va plus loin. ${ }^{120}$ Ou seja, a arte é acção e isso 'chega': Si l'artiste est un homme plus achevé que les hommes ordinaires, ce n'est pas à cause du génie de son imagination, c'st parce qu'il accomplit davantage, parce qu'il agit. ${ }^{121}$ Temos que vir a retirar daqui um alcance para o conceito de todos podermos decidir sermos artistas (Beuys), ou se quisermos uma dimensão criativa e conceptual no seio do político; ou seja, somos artistas tanto quanto soubermos tornar produtiva - por via da imaginação - a nossa relação com o social, como a metáfora da escultura social afinal sintetiza. A arte surge então como a emergência sempre repetida de formas que dão sentido ao próprio fazer artístico. $\mathrm{O}$ eu apenas é livre na medida em que não deixa de agir - eis a liberdade da necessidade schilleriana. Elemento-chave do dispositivo imanentista ${ }^{122}$, este movimento expressivo, que mantém à distância o abismo instaurado entre sujeito e objecto, serve-nos para compreender a questão do dispositivo e ainda de pano de fundo de uma reflexão especificamente na órbita das teorias da interpretação e do discurso (Bourdieu, mas também Rancière). Aliás, o próprio Fiedler, responsável como já disse por um linguistic turn estava convicto de que a essência e a origem da linguagem podem esclarecer a essência e a origem da arte. Tal como o discurso contrói o mundo, a arte plástica edifica o visível, e vice-versa. E portanto, a arte pública constrói a cidade? ${ }^{123}$ Procuro articular este sentido de

117 Cohn, p. 15

118 Fiedle, aforismo 70: L'importance des artistes éminents tient à la nouveauté qu'ils apportent par les moyens de leur art à conscience connaissante de l'homme.

119 Cohn, p. 22

120 Aforismo 93

121 Fiedler, p. 23.

122 Cohn, p. 28.

123 Ainda a propósito da questão da morfologia: Pour Goethe la morphologie a l'immense avantage de ne pas être une science mais une théorie (Cohn, p. 26) Donde que não é descabido recordar que, na origem (Pitágoras), a palavra teoria era indis- 
mundo - criação de situações (Arendt, Debord, Doherty ${ }^{124}$ ) - a partir do valor da atenção, pois há que ter em conta que a actividade trivial do sujeito não chega para fazer mundo. Mas como chegar às coisas através das formas? ${ }^{125}$

\section{1.1.3 Wagner - a arte do futuro}

No ensaio-panfleto ${ }^{126}$ A Obra de Arte do Futuro, de Richard Wagner, há aspectos que estabelecem com as intuições de Fiedler (que limitou a sua análise à pintura) um território e um aparelho retóricos específicos da arte pública, enquanto projectualidade político-utópica. Dele extrapolo tropos que legitimam a arte pública como uma meta-categoria sempre-emergente da actividade artística, cuja dynamis autopoiética assenta na relação arte-social. Os conceitos-chave wagnerianos são pontos de ancoragem para um pensamento crítico e radical, em que a noção de Gesamtkunstwerk - demasiadas vezes reduzida pelo senso comum a um elogio da modalidade da ópera - se revela das mais instrumentais para nos aproximarmos de um entendimento e praxis da totalidade em fluxo ${ }^{127}$. Este recuo até Wagner serve para tornar mais abrangente a empresa crítica de Fiedler, ampliando-a com a perspectiva de uma crítica explicitamente ideológica da função social da arte. Ora, não apenas o texto de Wagner demonstra raro rigor na análise das formas da cultura ${ }^{128}$, intuindo um ethos artístico - e uma nobre função para a arte - fundados na consciência do dispositivo, como várias frases funcionam como aforismos que cabem na lógica analítico-produtiva da Teoria Crítica. O seu registo enfático (pathos) é tanto mais expressivo quando mais o entendermos enquanto acto retórico.

Saliento um ponto de contacto entre Fiedler e Wagner a partir das palavras do próprio Fiedler: C'est dans le domaine particulaire d'un art déterminé qu'il convient de s'interroger sur l'origine d'un pouvoir artistique ${ }^{129}$. O comentário incentiva-me a abordar o corpus da arte pública como uma complexidade sempre-emergente de novas modalidades (um leitmotiv de A Obra de Arte do Futuro); e contribuir para identificar pontos críticos da evolução histórica, de uma forma mais complexa e integrada que o que a mera ideia das partidas ${ }^{130}$ artísticas permitiria captar. Será então a arte do/no/para o espaço público uma modalidade artística per si - um 'género' cuja origem está na ideia de obra de arte total avançada por Wagner, Situacionistas, Fluxus,

sociável de uma paixão pelo objecto de estudo.

124 Cf. Situation, Ed. Claire Doherty, The Mit Press, 2009.

125 Cohn, p. 31.

126 Wagner escreve A Obra de Arte do Futuro em 1849 no exílio, num curto período de dois meses; após entusiástico envolvimento com a revolução alemã que é derrotada em 1849, a fuga para Zurique dá-se em condições de grande perigo. 0 tom do livro é empenhado, facto que podemos relacionar com a sua afirmação de que seria a sua última obra literária (o que não se confirmaria).

127 'Totalidade' é um termo recorrente no livro de Wagner. Entendo-o em proximidade com a noção de totalidade tal como proposta pelo físico teórico David Bohm (1917-1992), que é essencialmente um libelo contra o reducionismo.

128 Em consequência da leitura de Schopenhauer e, sobretudo Feuerbach (Cf. Justo, «O Tempo e o Anel. Wagner, Feurbach e o Futuro», in Wagner, Richard; A Obra de Arte do Futuro, Antígona, Lisboa, 2003, p. 237- 252).

129 Fiedler, in Cohn, p. 34.

130 Malcolm Miles refere-se à experiência histórica das vanguardas como partidas (departures) face ao mainstream, sublinhando a inoperatividade desta noção - as ditas 'partidas' são sempre recuperadas pelo sistema - quando o que está em causa é a reflexão radical mais profunda. 
Beuys ou a arte relacional contemporânea retomarão esta hipótese, suportados por uma teoria crítica ${ }^{131}$ envolvida em projectos de esperança (de Lefèbvre a Guattari, Castells ou Harvey ${ }^{132}$ ) na cidade em crise (Benjamin ${ }^{133}$ ). Está em causa saber como/quando uma obra de arte é um acto político; e em que medida a crítica do contexto ideológico em que ela acontece lhe chega para definir-se produtiva num sentido socialmente vital. O que importa sublinhar em Wagner é que a carência de uma arte viva se fundamenta numa crítica radical da separação das artes, conduzindo à nossa contemporânea crítica da sociedade separada (Debord). Leio aqui uma abertura inter- e sobretudo transdiscipinar avant-la-lettre. ${ }^{134}$

Em A Obra de Arte do Futuro prefiguram-se assim, enquanto modelos de inscrição da arte na totalidade do seu tempo, não apenas correntes estéticas contestatárias (Dadaísmo), mas o que mais tarde será a arte relacional pós-média (Brea, Groys). A imagem de um sincretismo ${ }^{135}$ plástico da criação face ao social talvez me permita situar a arte como espaço-tempo (durée, Bergson) de um daimon (Schiller) específico - a ansiedade por lidar com o social em toda a sua imponderabilidade e infinitude. Mas se em Fiedler o enfoque da análise da arte se encontra na instância da produção-formalização da obra de arte, ao nível individual, em Wagner o enfoque é num pathos emancipatório, produtivista e revolucionário, que deve ser entendido a partir da complementaridade entre revolução estética e revolução social. ${ }^{136}$ É uma complementaridade schilleriana que Wagner propõe seja concretizada numa arte por vir (Agamben ${ }^{137}$ ), a obra de arte do futuro, conquista romântica da criatividade contra a alienação capitalista, burguesa, industrial. Wagner acrescenta ainda uma dimensão espiritual na problemática da emancipação social através da arte, e que é no limite a proposta de uma graça e uma luz seculares, imanente à própria produção artística e/ou estética, quando eivada por uma projectualidade colectiva, o logos do povo como potência vital ${ }^{138}$. Este é um interesse pela arte que se oponha à decadência burguesa através de uma superação de divisões artificiais (causadas pelo utilitarismo da moda, na base do capitalismo), como se fosse possível regressar ao futuro através de uma arte natural precisamente na forma de dar a ver o social, com uma acutilância que não existia na diletância de Schiller, mas que reaparecerá em Brecht ou Artaud e acaba depois por ser uma reavaliação crítica do legado Grego ${ }^{139}$, com o drama a

131 Liderando, com uma radicalidade ausente de outras epistemologias, um corpo de investigação que vai naturalmente dos Estudos Culturais à Sociologia e à Antropologia da Arte, passando pela Filosofia.

132 Harvey, David; Spaces of Hope, University of Califórnia Press, 2000.

133 Walter Benjamin, em Teses sobre a Filosofia da História (1940) desenvolve um programa de acção ensaístico e fragmentário que recolhe do romantismo alemão, do messianismo judaico e do marxismo notas diversas, articulando-as numa concepção original do devir social e civilizacional que passa por reconhecer, de forma no limite redentora, que o estado de emergência em que vivemos não é um tempo de excepção, mas a regra.

134 A totalidade é para Rancière the union of the unlimited and the unlimitedness of union, in «The Sublime Offering», in Rancière, p. 50.

135 Basta situar a produção ensaística de Wagner face ao seu interesse pelas ideias revolucionárias de Bakunine, a espiritualidade do pensamento búdico e a leitura de Schopenhauer.

136 Justo.

137 Agamben, Giorgio; A comunidade que vem, Presença. Lisboa, 1990.

138 Wagner, Richard; A Obra de Arte do Futuro, Antígona, Lisboa, 2003, p. 17. Idem, p. 17.

139 Justo, p. 240: Ora o que faz com que a arte trágica dos gregos possa representar aqui o papel de um ideal, sem dúvida derivado, mas ainda assim quase-originário, é o facto de ela parecer estar ainda entrelaçada com o viver social, com o mito e com a religião gregos. 
Wagner aproxima-se da ideia de Povo a partir de Fichte, que propõe o Povo Absoluto, o Povo Eleito, o Povo do Futuro; que conservou através dos tempos o contacto com as fontes originais da humanidade, e por conseguinte encarna as energias criadoras espirituais mais elevadas. ${ }^{141}$ Não é uma ideia imperialista, mas de purificação regeneradora (Meleiro), que passa por desenvolver a relação entre a formação cultural do indivíduo e a felicidade do Estado (Humboldt).142 Este é um humanismo pela cultura, em que a dimensão colectiva do povo merece total devoção e atenção. ${ }^{143}$ Goethe, em Weimar - cidade propícia - é dos seus primeiros arautos; mas a deriva nacionalista de inícios de 1800 vai gerar mais modalidades de resistência cultural (Novalis, em A Cristandade ou Europa); chegados a 1848, Wagner é seu representante, um activista político-cultural - tendo-se tornado músico em função do fascínio que nele exerceu a Nona, hino à futura humanidade. ${ }^{144}$ Arte e social, isto é, dadas as circunstâncias, arte e revolução, estão em Wagner unidos por uma litania espiritual. ${ }^{145}$ Por isso, 0 drama musical wagneriano será representado no novo teatro, que será como um templo, um santuário, onde os crentes se reúnem para o ritual solene [...] a via musical realiza, deste modo, uma arte integral [...]. ${ }^{146}$ Mas mais, desenha-se uma hipótese de redenção colectiva pelo aprofundar do projecto artístico: Enquanto as directrizes de Goethe apontavam para um escol de eruditos, em profunda comunhão interior intelectual, longe da multidão [...] Wagner apela para as massas frequentadoras de teatros às quais oferece a possibilidade de uma catarse dos males da civilização. ${ }^{147}$ Aqui é importante perceber como é revolucionária a emergência do povo na arte. 0 povo é a metáfora para uma continuidade passado-presente-futuro, assegurando à arte a pertinência do seu devir:

\section{1.1.3.1 Natureza, criação, socius - a moda}

Em ressonância com princípios do primeiro romantismo alemão, A Obra de Arte do Futuro começa com um eloquente $A$ arte está para o homem como o homem está para a natureza ${ }^{148}$. É um programa de conhecimento e criação - entendimento - que leva Wagner a procurar, como acontece com as vanguardas de cada modernidade, uma nova função para a arte face ao colectivo e sobretudo - o que é específico de Wagner e não de Fiedler - uma ini-

140 Baudelaire será, é de notar, dos primeiros a defender esta arte que revoluciona e seus princípios críticos, modernos. E sabemos que é nessa linha que se desenvolverá toda uma genealogia de atenção (crítica e propriamente literária) à cidade, de Baudelaire a Benjamin, passando por Simmel, Kafka, Pessoa.

141 Meleiro, Maria Lucília F.; A Mitologia dos Povos Germânicos, Presença, Lisboa, 1994, p. 146.

142 Idem, p. 147. Se o Estado, esse mal necessário, assegurava a ordem e a segurança indispensável ao perfeito funcionamento de uma sociedade, inclinava-se, por outro lado, a submeter o indivíduo a uma uniformização com vista a um fim político ou útil. É então que a cultura entra em jogo, dando expressão à criação espontânea e à iniciativa individual.

143 Idem.

144 Idem, p. 149.

145 Wagner, in idem: «Creio em Deus Pai, em Mozart e em Beethoven, assim como em seus discípulos e apóstolos. Creio no Espírito Santo e verdade da Arte, una e indivisível. Creio que esta arte tem origem em deus e vive no coração de todos os homens iluminados pelo céu.

146 Meleiro, p. 150. [...] que servirá de base a genuínas iniciações filosóficas artísticas, fundamentadas nos Mistérios Antigos [...].

147 Idem, p. 159.

148 Wagner, p. 9. 
ciação revolucionária no mistério da natureza. A reter nesta ideia de natureza, uma reflexão sobre a vida, em que a necessidade dos fenómenos da existência humana é um desafio ao entendimento do que deve ser a ciência ${ }^{149}$. Em tal teorização, a questão do sentido (Capra) revela um campo particularmente vital da ontogenética humana:

[...] então a vida humana atinge a sua própria intelecção através da ciência que por seu turno faz dela objecto do seu conhecimento; porém, o exercício prático da consciência alcançada através da ciência, a representação da vida conhecida por intermédio dela, a imagem da necessidade e da verdade da vida é... a arte ${ }^{150}$

É à luz desta revelação que a filogenética wagneriana - a sua teoria das modalidades rumo a uma arte do futuro - tem sentido para os desafios políticos actuais,

[...] imagem proclamadora da consciência, imagem fiel do homem real e da verdadeira vida dos homens, da vida humana na respectiva necessidade natural, ou seja, enquanto precisar de ir buscar as condições da sua existência aos erros, aos absurdos e às mutilações anti-naturais da nossa vida moderna ${ }^{157}$.

Não é de mais reforçar, precisamente quando Wagner começa a expor a sua crítica humanista, a partir de uma denúncia da subjugação da actividade artística à moda:

Daí que não possa haver homem real enquanto não for a verdadeira natureza humana, em vez de arbitrárias leis estatais, a configurar e ordenar a vida do homem; a arte real, porém, não nascerá para a vida enquanto as suas realizações não puderem submeter-se apenas às leias da natureza, em vez de terem de se submeter ao despótico capricho da moda. ${ }^{152}$

Os termos 'real' e 'verdadeiro' - por oposição à ilusão social da moda - surgem associados, em enorme proximidade argumentativa, transformando o texto de Wagner num libelo pelo activismo realista da totalidade: Ora o homem só ultrapassa a sua dependência face à natureza na jubilosa consciência da sua conexão com ela; e a arte só ultrapassa a sua dependência face à vida na conexão com vida de homens verdadeiros e livres ${ }^{153}$. Esta é a verdadeira vida social, uma plástica (Plastik, Beyus):

Daí que só a obra de arte real, i. e. o que se representa sensível e imediatamente no momento do seu aparecer fenoménico maximamente corpóreo, seja também a redenção do artista, a supressão dos últimos vestígios da arbitrariedade criativa, a determinação indubitável daquilo que até esse momento era apenas a representação mental, a libertação do pensamento na sensibilidade, a satisfação da carência da vida na própria vida. ${ }^{154}$

Neste conceito de arte (pública, colectiva) como redenção global da sociedade, o povo não vive no Estado centralizado ou na nossa arte moderna, que Wagner considera estéreis ${ }^{155}$. A energia vital do povo - síntese de todos os singulares que compõem uma comunidade ${ }^{156}$ pode a arte empregar ou diminuir, optimizar (no design) ou negar (na ditadura), donde que

149 Em termos que serão os da biologia da complexidade tal como proposta pelas teorias da complexidade contemporâneas, nomeadamente a Teoria da Cognição de Maturana e Varela, interessada na potencialidade do conceito de cognição para uma adequada apropriação da extraordinária coesão de tudo. Wagner: Na natureza como na vida, nada há de isolado; tudo tem fundamento numa infinita coesão com tudo o resto, e assim acontece também com o arbitrário, o supérfluo, o nocivo. Wagner, p. 22

150 Wagner, p. 11

151 Wagner, p. 12. Nota-se aqui um vocabulário que virá a ser o de vozes tão diversas como Herbert Marcuse, Wilhelm Reich, Guy Debord, Félix Guattari, Arno Gruen.

152 Wagner, p. 12.

153 Wagner. p. 12

154 Wagner, p. 15

155 Wagner, p. 16

156 Wagner, p. 17 
Wagner afirma que povo que somos todos, desde o pedinte até ao príncipe ${ }^{157}$. Em termos não dissemelhantes dos de Jean-Luc Nancy ${ }^{158}$, Wagner fala então de uma falta, uma privação universal e colectiva ${ }^{159}$, a motivação psicológica para uma abertura à experiência da comunidade, uma graça secular que, por uma fracção de tempo partilhado (consciência), resolve (representa, evoca, presentifica...) as carências do povo numa imagem - materialização metafórica -, revelando (e tornando presente) uma dimensão colectiva da consciência, num beijo fraterno que selará essa aliança [a da sagrada necessidade e que] será a obra de arte colectiva do futuro ${ }^{160}$. A metáfora do beijo fraterno, crística, implica uma noção de encontro como acontecimento, uma entrega radical; quanto à imagem do futuro (utopia), é ao mesmo tempo evidência de impossibilidade e prova da necessidade do possível.

Há nestes termos um sacrum da ordem do pré-estético e do pré-político; um misticismo judaico de esquerda, que perspassa, de alguma forma, em Kafka (críptica e negativamente, em literatura $\left.{ }^{161}\right)$ e se afirma em Walter Benjamim (nostálgica e messianicamente, no ensaio) ou Martin Buber ${ }^{162}$ (dialogicamente, na filosofia); estes são autores que, como Wagner, prezam a ideia de que que uma arte do colectivo é expressão de uma generosidade vital: 0 que é exclusivo, singular, egoísta, apenas consegue receber, não consegue dar: apenas é capaz de deixar-se gerar; para que se gere alguma coisa é preciso haver um eu e um tu, é preciso que haja diluição do egoísmo no comunismo. ${ }^{163}$ Wagner propõe a ideia de participação radical do povo na construção do seu destino, em termos de que Rancière ${ }^{164}$ não desdenharia apropriar-se:

É por isso que laboram em grande erro os nossos educadores do povo que imaginam que este precisaria de começar por saber o que quer - ou seja, aquilo que na opinião deles o povo devia querer - antes de ter direito e capacidade para querer seja o que for. Deste erro decorrem todas as miseráveis indecisões, todas as incapacidades, toda a vergonhosa tibieza dos mais recentes movimentos que pelo mundo ocorrem. ${ }^{165}$

Daqui deve deduzir-se em Wagner uma concepção precisa da participação do público na obra de arte, apontando já para modernas teorias da recepção (Jauss).

Mais à frente, Wagner problematiza formas de alienação artística que entretanto esqueceram a necessidade de a criação constituir-se como regresso ao não-consciente - uma ideia kleistiana ${ }^{166}$. No seu projecto de cultura como cultivação (Buber), o trajecto do desen-

157 Wagner, p. 18

158 La communauté désouvrée, Paris, Christian Bourgois, 1983

159 Wagner, p. 18

160 Wagner, p. 21

161 Bastaria evocar a cena final de América (1910), no Grande Teatro Ao Ar Livre de Oklahoma.

162 Cf. Buber, Martin; The Knowledge of Man, Nessa obra, a arte surge como modelo e praxis de cultivação de uma qualidade inerente e universal do humano, a criatividade. O conceito de imagem-trabalho (/mage-work) é particularmente rico num esforço intelectual inédito que pensa a relação dialógica no cerne da identidade individual mas também colectiva. A intersubjectividade dialógica de Buber é a base filosófica para a praxis colaborativa da arte.

Idem; I and Thou (1923). A teoria da intersubjectividade em Buber pode e deve ser articulada com uma tradção hassídica da totalidade. As histórias de Kafka são exemplos de produção literária no espírito hassídico de um encontro revelador com a totalidade (com o traço específico de incluírem uma crítica modernista da própria materialidade da escrita).

163 Wagner, p. 23

164 Rancière, Jacques; The Ignorant Schoolmaster. Five Lessons in Intelectual Emancipation, Stanford University Press, 1991.

165 Wagner, p. 24

166 Cf. os textos seminais «On the Gradual Production of Thoughts While Speaking» e «On the Marionette Theater», em que Kleist leva a bom porto a crítica da razão instrumental iluminista, ao mesmo tempo que explicita, intertextualmente, um 
volvimento humano é o percurso racional e natural que leva da não-consciência à consciência, do não-saber ao saber, das carências à respectiva satisfação, e da não satisfação às carências... pelo menos não àquelas carências cujo fim era essa satisfação. ${ }^{167}$ Nestes termos, a arte pública é a produção de novas carências para uma carência de fundo - bio- e sociológica, biopolítica. ${ }^{168} \mathrm{O}$ informe que a invenção inventa passa então por enunciar a criatividade como produto colectivo:

Daí que vós, os inteligentes, não sejais de facto inventores de coisa nenhuma; inventor é o povo, porque e a falta, a provação, que o impulsiona para a invenção: todas as grandes invenções são realizações do povo, ao passo que as invenções da inteligência mais não são do que expropriações, derivações, quando não desmembramentos e mutilações do povo. ${ }^{169}$

Este programa é o de uma redenção do artista face ao seu papel social:

Superadas as condições de dominação exercida pela moda. Então passarão a estar automaticamente presentes as condições da verdadeira arte; como se fosse um gesto mágico a consegui-lo, ela, a testemunha da mais nobre humanidade, a arte no esplendor da sua suprema sacralidade, passará a florescer com a mesma profusão e perfeição da natureza, logo que das dores de parto dos elementos tenham surgido as condições da sua configuração harmónica que agora se nos abre.170

O de Wagner é portanto um projecto de racionalidade plástica que busca alterar as próprias condições de produção, legitimação e avaliação da arte, subjugadas ao obscurecimento do modus vivendi capitalista; antecipando os esforços mais radicais ou críticos da arte nossa contemporânea, Brecht a Haacke, Beuys e Wodiszko. E assim, com a devida precaução analógica, pode ser lida a divisa

a arte perdurará e conservar-se-á sempre geradora, como a mais pura, a mais perfeita satisfação das necessidades mais nobres e mais verdadeiras do homem perfeito, ou seja, do homem que é aquilo que, de acordo com a sua essência, pode ser $e$, consequentemente, deve ser e chegará a ser. ${ }^{171}$

Até hoje, serão muito diferentes os termos da batalha pela autonomia da arte face à barbárie, de Adorno a Dave Beech? O título do segundo capítulo de $A$ Obra de Arte do Futuro é já uma formulação do que virá a ser um objecto-chave da Teoria Crítica: o estudo d'A CONFIGURAÇÃO ANTI-ARTÍSTICA DA VIDA DO PRESENTE SOB A DOMINAÇÃO DA ABSTRACÇÃO E DA MODA ${ }^{172}$. Numa terminologia que já entecipa as de $S i m m e^{173}$ ou Barthes ${ }^{174}$, Groys $^{175}$ ou Thrift ${ }^{176}$, Wagner é claro: A essência da moda é a mais absoluta uniformidade [...] O hábito é o comunismo do egoísmo, o laço que agrega e que sustenta o egoísmo social

modelo de appropriação produtiva do dispositivo.

167 Wagner, p. 25

168 Cf. Problema central na obra de Foucault, Deleuze/Guattari, Hardt, Negri, entre outros.

169 Wagner, p. 26

170 Wagner, p. 27-28.

171 Wagner, p. 28.

172 Wagner, p. 31. Mais à frente: Se tomarmos o fim pelo princípio, a satisfação pela carência, a saciedade pela fome, então o movimento, o progresso, passa a ser também pensável somente no âmbito de carências artificiais, no âmbito de uma fome gerada por estimulação; este é, na verdade, o estímulo vital de toda a nossa cultura de hoje, e a respectiva expressão é a moda.

173 Die Grosstädte und das Geistesleben (1903) [The Metropolis and Mental Life].

174 Le Système de la Mode (1967).

175 Art Power (2008).

176 Non Representational Theory - Space, politics, affect (2007). 
inconsequente; o estimulante artificial do hábito é precisamente a moda. ${ }^{177}$ Ora porque só sabe derivar, não inventar, a moda é uma forma da criatividade social mecânica, perante a qual a arte que procure recriar a emancipação do humano tem de encontrar uma forma de afirmação, resistência ou apropriação. Não será outra a revolta das vanguardas, a crer na forma como Wagner define um dos troncos do projecto moderno: [...] o que é artístico põe de lado meio após meio, elimina derivação após derivação, para chegar por fim à fonte de todas as derivações e de todos os meios, a natureza, e aí encontrar para aquilo de que carece uma satisfação plena de sentido ${ }^{178}$. Neste quadro, é interessante como o espírito crítico de Wagner presta atenção à instância da recepção alienada - Face ao presente, porém, o espírito prescinde do aparecimento da obra de arte na superfície desse mesmo presente, ou seja, ao público, e portanto prescinde também do próprio público, tanto quanto este se encontra sob o domínio da moda. ${ }^{179}$-; ora, com a emergência do DADA e da arte conceptual, a recepção torna-se (o) lugar central da arte. Marcel Duchamp di-lo-á em O Acto Criativo; o seu linguistic turn coloca a questão do sentido (comunicacional) da obra. Ora, no tempo de Wagner, o conceito de indústria cultural era uma ideia ainda em formação, mas a vida urbana começava a revelar os primeiros sinais de uma industrialização da criatividade (Baudelaire, Benjamin, Adorno) sob o signo da moda. A este quadro a arte total wagneriana contrapõe outra comunidade, em que a ideia de uma redenção espiritual colectiva - o pathos social - é exposta com a luminosidade de uma visão da religião do futuro. ${ }^{180} \mathrm{~A}$ arte pública afirmada desde os anos 60 teve sempre esta agenda na mesa, seguindo-a ora literal, crítica ou cinicamente le até kunicamente). E se é a verdade da dimensão meta-operativa desse encontro que a arte cria o seu sentido de logos, vejo esta questão como uma chamada de atenção metafísica - transcendentalmente impura, parafraseando Cohn acerca de Fiedler - para o domínio do discurso, a techne de que o homem-entendimento dispõe para construir sentido: [...] e este é o homem-entendimento reunido pelo amor mais íntimo e mais intenso com o homem-corpo e o homem-coração..., mas nunca um deles só por si. ${ }^{181}$ Este homem-entendimento ${ }^{182}$ é chamado a apropriar-se do dispositivo social (Roberts) ${ }^{183}$, caso contrário está condenado ${ }^{184}$. É obrigatoriamente retórica esta consciência situada da dinâmica antropológica lecos de Feuerbach). Nestes termos, a haver em Wagner uma metafísica, é a do dispositivo, o garante de uma verdade do símbolo (Schiller, Lacan). Aqui já se desenha uma axiomática tipológica das vontades criativas, nesta tensão corpo-espírito de que o homem-entendimento é protagonista. Traduzindo esta intuição para uma reflexão ensaística sobre a arte na forma urbana, deduzo que a dimensão conceptual/textual, da palavra na cidade, é possivelmente

177 Idem, p. 32.

178 Idem, p. 33: Por essa via, [a moda] naquilo que produz, o que consegue não é representar a natureza, antes somente desfigurá-la. [...] porque inventar, na verdade, não é outra coisa senão desvelar, designadamente desvelar a natureza, conhecer a natureza.

179 Wagner, p. 37.

180 Wagner, p. 41

181 Wagner, p. 43.

182 Wagner, p. 49: O progresso que vai do homem-corpo, na sua exterioridade, ao homem-entendimento, passando pelo homem-sentimento, é um trajecto de mediação sempre crescente: o homem-entendimento, tal como o seu órgão de expressão, a linguagem, é o que trata de fazer a mediação de todas as coisas, mas é também o mais dependente; porque todas as propriedades que se encontram abaixo dele têm de estar desenvolvidas para poderem surgir as condições daquela que é a sua propriedade normal.

183 Em Wagner, poder-se-á falar então, relativamente ao ethos artístico, de um construtivismo avant-la-lettre? De uma liberdade de assemblagem que conduzirá ao surrealismo, ao dada, ao ready-made? Ao cruzamento disciplinar transmediático?

184 Como tantos heróis de Kafka... 
a tradução (abstracta) de uma consciência política da totalidade como carência, uma ansiedade sempre emergente, que a arte crítica provoca, como intensificação da materialidade da cidade. De facto, alguns termos de Wagner antecipam as linguagens mais enfáticas da revolução cultural dos anos 60, através da qual podemos identificar uma arte do amor que é um exercício de comunicação colectivo.

Quando Fiedler chama a atenção para o processo artístico e Wagner realiza a sua geneo-antropologia das modalidades artísticas, sinto-me convocado para recomeçar continuamente um trabalho de analogias morfo-, onto- e filogenéticas. Neste sentido, Wagner propõe um quadro de valorização da liberdade, do amor e da necessidade em simultâneo. Temos aqui uma consciência da mesma generosidade radical que, de São Francisco ${ }^{185}$ a Joseph Beuys, é uma espécie de realidade fundamental que resiste a múltiplas formas e dimensões da abstracção. O dar-se em totalidade, por outro lado, é precisamente, em determinada altura, o exigir-se tudo. Em Maio de 1968, a reivindicação da totalidade - como reivindicação do mundo ${ }^{186}$ - será expressão retórica desta carência de tudo que é ao mesmo ansiedade pelo domínio consciente do nada da matéria discursiva - the void at the heart of symbolization ${ }^{187}$. É por isso que Wagner adivinha que a liberdade das capacidades humanas é... capacidade total ${ }^{188}$. Se este amplexo retórico terá hoje as suas limitações persuasivas, até pelo desajustamento de terminologia, sublinho a associação entre arte total e o derrube de limites, antecipando uma articulação da possibilidade que vai levar-nos a deduzir que a arte pública urbana é a contínua emergência do espírito wagneriano lo que se torna evidente quando é a Brecht que Lefèbvre recorre para explicitar o mesmo princípio estético emancipatório). O que Wagner propõe em A Obra de Arte do Futuro é uma liberdade estética produtiva, que é sempre uma hipótese de superação - inter-, trans-, hiper-, metadisciplinar - das modalidades artísticas - a construção propedêutica de um futuro disponível para integrar o sublime social na responsabilidade do seu ethos.

Eis um ponto onde prefiguro as formas da instalação ou do happening nos anos 60 e as instalações imersivas que são casos extremos de colaboração (Santiago Sierra) ou participação (Carsten Höller), como na arte relacional new e post-media ${ }^{189}$. Mas o que Wagner procura ainda dizer é que, se as modalidades respondem a carências relativas e parcelares, apenas uma arte da totalidade do social emergente - noção utópica -, coloca o seu foco de interesse sobre um futuro sustentado na participação cidadã. Entendo assim que algumas formas de arte pública interpretam este programa e chegam, no caso de Christian Nold por exemplo, a vias de facto de uma simbiose entre arte e social, naturalmente que à custa de um sacrifício do que no mundo da arte muitas vezes se considera fundamental (uma ideia de autonomia assente nos limites institucionais do objecto ou da identidade autoral do artista, senão das próprias modalidades reificadas ideologicamente). Tratar-se-á de termos em conta, na produção artística, o genuíno interesse público. Condenada à experiên-

185 O primeiro santo 'urbano' e extramuros...

186 The Doors live: We want the world and we want it, now!

187 Shaw, Philip; «Lacan: Sublimity and Sublimation (2007), in The Sublime, The MIT Press, 2010, p. 52.

188 Wagner, p. 55.

189 Cf. La Era Postmedia (2001, 2002) ou El Tercer Umbral (2003. 2004) de José Luís Brea. 
cia dos limites, a arte pública está condenada, como Cassandra, a anunciar futuros possíveis (Miles) de acordo com a sua percepção das condições de produção disponíveis; quando o trabalho sobre o horizonte de expectativa das obras se transforma numa experiência retórica de máxima amplitude, aí a arte e o social, a cidade e o indivíduo, encontram-se por momentos num patamar de fluidez (outro termo que utilizo em sentido wagneriano, e que hoje Christine Buci-Glucksmann transporta para a condição contemporânea) que faz da arte um acontecer de si própria, exteriorização imanente da sua mais profunda carência original. Uma exterioridade - uma visibilidade - que é autonomia mas não no sentido da distinção social:

Só quando o impulso artístico do escultor se houver transposto para a alma do bailarino, do actor mímico que ao mes-
mo tempo canta e fala, poderá então esse impulso ser pensado como estando realmente apaziguado. Só quando a es-
cultura já não existir ou quando - segundo um direccionamento que já não será o do corpo humano - for absorvida na
arquitectura, quando a solidão hirta deste homem isolado, cinzelado em pedra, se houver dissolvido na multiplicidade
infinitamente desbordante do homem realmente vivo, quando formos capazes de nos presentificar a recordação do mor-
to, que outrora amámos, já não no mármore ou no bronze igualmente mortos, mas sim em carne e sangue e alma eter-
namente vivos, quando erguermos da pedra as edificações que a obra de arte viva se levantará, sem que tenhamos que
nos representar o homem vivo nessa mesma pedra, nesse momento então surgirá finalmente a verdadeira escultura. ${ }^{190}$

Como não ver nos termos de Wagner a emergência da totalidade na obra 7000 carvalhos, de Beuys, ou nos espaços de Smithson? Sabemos que são os anos 60 a assumir este desígnio de encontro entre o objecto de arte 'desmaterializado' e a natureza em toda a sua complexidade, e em concreto do objecto de arte face à forma urbana considerada como sistema vivo.

O egoísmo humano, que na arquitectura despida se limitava a submeter a si a natureza, rompeu-se até certo ponto na pintura paisagística, que veio fazer justiça à natureza na sua essência específica e que transportou o homem artista à possibilidade de nela se incorporar com total amor para assim poder reencontrar-se nela infinitamente ampliado. ${ }^{191}$

\section{1.1.3.2 Teorizar o futuro. Pedagogia, populismo, performatividade.}

Foi de forma deliberadamente intertextual que denominei 'Fundamentos' a esta Parte da investigação ${ }^{192}$, convicto da perenidade de um diagnóstico:

Se observarmos a posição da arte moderna - tanto quanto ela consiga ser verdadeiramente arte - em relação à vida pública, reconhecemos antes de mais a incapacidade total de a primeira influenciar a segunda, no sentido das aspirações mais nobres da arte. A razão é que a arte, enquanto mero produto de cultura, não brotou realmente da vida, e agora, transformada em planta de estudo, não consegue lançar raízes no chão natural do presente. ${ }^{193}$

Entre luxo, desperdício, passatempo ${ }^{194}$. Wagner contesta a importância dada a uma arte que não chega a ser ampliação da formação humana. ${ }^{195}$ Numa lógica radical, a expansão da esfera da produtividade do humano é necessariamente bottom up como mais tarde a procurarão definir os urbanistas progressistas: [...] a arte para poder ter qualquer eficácia sobre a vida

190 Wagner, p. 161.

191 Wagner, p. 166.

192 Tal como Wagner o faz relativamente ao capítulo IV da sua A Obra de Arte do Futuro.

193 Wagner, p. 175.

194 Idem, p. 176.

195 Idem. 
tem que ser ela mesma a flor visível de um processo de formação natural, crescendo a partir de baixo, e, pelo contrário, nunca está em condições de verter a formação cultural a partir de cima. ${ }^{196}$

Ora a resposta a este estado de coisas é uma arte do entendimento - uma arte conceptual, que teorize com paixão (um pleonasmo, se pensarmos na etimologia); e que neste contexto possa progredir teórica e cognitivamente até à redenção que a libertasse da posição solitária da sua essência não compreendida, caminhando em direç̧ão a entendimento mais universal por parte da vida pública: tornar-se-á então facilmente compreensivel que essa redenção só pode ser possibilitada pela mediação prática da vida pública ${ }^{197}$. O que aqui perspassa é uma teoria de uma arte na esfera pública - e em certa medida uma arte como mediação, como esfera pública -, enunciada como reflexão open source acerca da função da arte na cidade. Ora esse dispositivo pedagógico da arte na cidade é sempre um mecanismo de gestão de carências - Gross dirá de distribuição das paixões ${ }^{198}$-; no quadro de um edifício teatral perfeito ${ }^{199}$, dar e receber ${ }^{200}$ são duas ordens de carecimento ${ }^{201}$ que de interpenetram e condicionam, numa cena ${ }^{202}$ expandida que se obriga inclusivamente a organizar o espaço dos espectadores para que estes vivam o acontecimento como artistas. Em suma, uma mega-dispositivo intermediático. ${ }^{203} \mathrm{E}$ assim, a obra de arte total wagneriana é, na minha filogenética mítica, antepassada da actual arte pública crítica no seu campo expandido: transmedial aglutinação de saberes oriundos da arquitectura, da escultura, do paisagismo, das ciências sociais e da literatura (com relevo para o género híbrido do ensaio), a publicidade e o marketing... enfim, a arte pública é hoje uma plataforma intermodal de saberes que, quando exercitados nos limites de uma cognição de si própria irrompe com o mesmo poder oracular de Wagner no real reduzido da sociedade hipercomunicacional (Lipovetski ${ }^{204}$ ) como um oásis de atenção, empatia e envolvimento. ${ }^{205}$

Wagner reforça várias vezes a questão de esta arte ser universalmente compreensível206, antecipando uma noção de populismo (Knight $\left.{ }^{207}\right)$. Esta arte pública que esculpe o social liberta-se para encontros muito diversos - com a ciência, com a política, com a educação - mas não deixa de ser, na sua aparente fragilidade ontogenética e ontológica, na sua posição fraca (Vattimo), o coração palpitante da imaginação produtiva. Ora, no derradeiro capítulo «O Artista do Futuro» - Wagner vai, no fundo, estabelecer uma ponte genealógica entre o

\section{Idem.}

197 Idem.

198 Gross; Daniel E. Gross, The Secret History of Emotion - From Aritotle's Rhetoric to Modern Brain Science, The University of Chicago Press, Chicago and London, 2006.

199 Wagner, p. 178.

200 Idem, p. 179.

201 Idem.

202 Idem.

203 Que, de acordo com os modelos gregos de que apropria Wagner, viria a redundar numa acção pessoal da modalidade da ópera, rapidamente colonizada pela ideologia burguesa como apenas mais uma nova modalidade da fruição musical-teatral.

204 Lipovetski, Gilles; Charles, Sebastien; Les Temps Hypermodernes, Grasset et Fasquelle, Paris, 2004.

205 Atenção à atenção, envolvimento no envolvimento, graça da graça...

206 Wagner, p. 192.

207 Knight, Cher Krause; Public Art: Theory, Practice and Populism, Wiley Blackwell, 2007. 
Schiller das Cartas da Educação Estética do Homem (1795) e o Marcuse de Homem Unidimensional (1964). Na prática, trata-se de perceber os limites da arte moderna sua contemporânea e aferir da possibilidade de das suas cinzas renascer algum tipo de correspondência com a

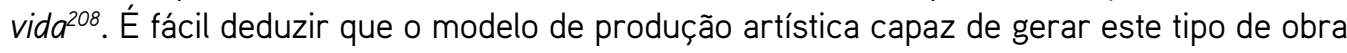
de arte do futuro parte de um foco da actividade na obra de arte como dispositivo de presentificação do social vivo. ${ }^{209}$ Ora aqui é não é possível entender este programa sem o criador assumir a missão de teorizar publicamente. Wagner, como hoje FREEE ou Pedro Penilo, leva-nos a deduzir que a verdadeira arte política não passa apenas pela necessidade vital de teorizar o seu sentido na imediato da sua produção - esse pensar estende-se à morfologia social que envolve a própria criação, a qual só é percepcionada num quadro de atenção, empatia e paixão e numa dinâmica de intensidades que a consciência artística integra de forma mais ou menos evidente no dispositivo. $\mathrm{O}$ que aqui se advoga é uma arte radicalmente performativa ${ }^{210}$ - um entrelaçamento performativo das várias modalidades artísticas ${ }^{211}-$, com o poder da transmutação dos limites - o que explica o interesse de Wagner pelo jovem retórico Friedrich Nietzsche ${ }^{212}$.

Em que medida será o programa de Duchamp, de chamada de atenção para o recentramento da consciência do dispositivo - e de atenção à participação do espectador -, a pedra fundamental do novo edifício da arte? Em que medida a vanguarda neo-wagneriana é uma agenda anti-logos ${ }^{213}$, performaticamente retórica, como a história da arte dos anos 60 parece sugerir? Não será essa viragem performativa, centrada no corpo e na palavra - um accionismo - uma crítica de facto do sistema das artes baseado apenas e só no sensível - a base de uma reactivação quotidiana, com pretensão antropológica ${ }^{214}$, do que virá a ser denominado uma performática total da comunidade humana? E como apropriamo-nos desta contínua produção material da utopia, recomeçando sempre e sabendo que esse recomeço é sempre ilusório? Numa frase que é de um carácter sintético raro, e que nos confirma a intuição genealógica da investigação, Wagner afirma: Beethoven ou Shakespeare são prenúncio do «futuro» precisamente porque neles o grau de afastamento em relação à unidade performativa das artes é mais reduzido. ${ }^{215} \mathrm{~A}$ questão performativa é um valor crucial para assegurar à actividade artística como pulsão um sentido que não se reduz ao logocentrismo separativo ${ }^{216}$. Assim evita a armadilha do «arbítrio» (termo de Feuerbach), e assim concretiza a articulação poética entre carência e produção (entre psique e linguagem, em Lacan?), uma carência símile (na minha visão analógica) da que supera a separação entre arte e social e uma produção para se realizar como

208 Wagner, p. 195.

209 Wagner, p. 207

210 Idem.

211 Idem, p. 240

212 Nesta contínua aproximação entre arte e ensaio (heterodoxo), Nietzsche - profundamente interessado pelo fenómeno da separação entre a filosofia e a arte trágica dos gregos, vocacionado para um estilo novo do pensar filosófico, ao mesmo tempo inspirado numa compreensão radicalmente crítica do carácter «dissimulatório» da linguagem e numa visão redentora da eficácia da música (Justo, pp. 239-240) - é personagem-charneira, ajudando-nos a compreender alguns dos limites do próprio projecto wagneriano.

213 Justo, p. 248.

214 Justo, p. 250.

215 Wagner, p. 252.

216 Justo, p. 251. 
poesia e redimir o homem social na plenitude das suas possibilidades - as quais, para o bem e para o mal, necessitam do fulcro negativo ${ }^{217}$ da linguagem para desenhar, em dispositivos participados, nessa metáfora entre todas as metáforas retóricas, a «filosofia do futuro». ${ }^{218}$

Este é em grande medida o retomar do programa romântico da arte como ciência-poesia da mistura (Novalis), que me interessa reter no que possa conduzir, precisamente através do conceito de Gesamtkunstwerk, à questão de a arte pública constituir, enquanto instância cognoscente do social, uma actividade poética complexa, que gera um saber dificilmente apropriável pela ciência ou pela política ${ }^{219}$, ou pela educação tradicionais. Penso poder agora afirmar que a figura heróica de Wagner e sua arte do futuro, no lugar que lhe outorgo na presente investigação, representa a consciência dupla de que a arte vive nas formas e que essas formas atingem o seu objectivo último apenas quando representam/apresentam/ dispõem uma humanidade por vir. Dessa comunidade que vem (Agamben) não é provavelmente possível elaborar representações, mas quanto muito presentificar carências, pólos tensionais, ideias, definindo-se uma leitura retórica da história ${ }^{220}$ e do futuro. Todas as leituras contemporâneas, de Duchamp a Beuys, de Haacke a Christo, de Wodisczko a Orozco, independentemente da escala, das preocupações éticas concretas, das modalidades prevalecentes, são obras de arte totais dedicadas a esse projecto - escolhendo caminhos diferentes mas movidas por questões fundamentais partilhadas. Elas são sínteses - umas atingem a precisão de aforismo, outras alongam-se na expectativa do ensaio - da pulsão social de humanidade. $E$ todas integram uma crítica da moda em nome do povo.

\section{1.1.3.3 O Gesamtkunstwerk vs. obra de arte do futuro - máquina e transparência}

A história do Gesamtkunstwerk é a de uma série de batalhas dialécticas, um ideal estético ${ }^{221}$ que a arte pública não se excusará a repensar ou integrar. Podemos perspectivá-la no fulcro de um entendimento específico da obra de arte total, como consciência comunitária sob a forma da arte, em cujo constante devir as Cartas de Educação Estética de Schiller foram

217 Justo, p. 252. Wagner antecipa aqui um interesse hegeliano pela profundidade metafórica fundamental para o funcionamento do sublime. Cf. Harten, Doreet LeVitte; «Creating Heaven» (1999), in The Sublime, MIT Press, 2010.

218 Idem.

219 Thrift.

220 Justo, p. 264: Textos como Arte e Revolução e A Obra de Arte do Futuro colocam o leitor perante o problema da «filosofia da história» [...]. Há dois tópicos fundamentais para apreciação desta tradição [de Herder a Rousseau]: por um lado, a questão da «conjecturalidade» (ou ficcionalidade) e da necessária metaforicidade (ou retoricidade) da leitura da história, e, por outro lado, a questão da alternativa entre linearidade (mais ou menos ascencional, «progressiva») e circularidade (ou curvatura, porventura helicoidal) da concepção da história. [...] Registe-se apenas, no que toca ao segundo problema, que Wagner se afasta das concepções de natureza linear, que encontram a sua melhor expressão nas Lições sobre a filosofia da História de Hegel, e se situa numa perspectiva circular que tem marcadas analogias com a de Herder, Novalis (A Cristandade ou Europa, 1799) $e$ sobretudo com a do Manifesto do Partido Comunista de Marx e Engels (1848) em que o futuro é concebido por analogia com 0 «comunismo primitivo».

221 Smith, Mathew Wilson; The total work of art. From Bayreuth to Cyberspace, Routledge, New York, 2007, p. 8: On the one hand: the Gesamtkunstwerk is impossible. It is a lantern image, a ghost in glass. Utopia, thus nowhere. On the other: the Gesamtkunstwerk is sensuous and concrete. [...] the Gesamtkunstwerk is modernity's polestar. It is an uncompromising wish for a joyful community to be realized in this life, in this world. It is a longinf for unity amidst fragmentation, for collectivity amidst alienation. It is inherently restless and potentially revolutionary, and while it is inescapably ideological its longings can never be entirely contained within the bounds of ideology. It is the shape of radical hope. 
momento-charneira ${ }^{222}$. Tal coloca Wagner no epicentro de uma constelação. ${ }^{223}$ The most frequent translation of the word is "total work of art," but even this is by no means straightforward: other possibilities include "communal work of art," "collective work of art," "combined work of art," and "unified work of art." Indeed, the concept contains all of these ideas, for it is an artform as much about collectivity as about unity, about community as about totality. 224

Para tal é preciso ultrapassar a abordagem formalista (Smith) - a questão da ópera como pseudo-síntese das três artes primárias - para, integrando a visão política em Wagner, partir do pressuposto de um génio comunal no coração da arte obra de arte do futuro, um génio do/no qual participamos (Wagner). Isto é, a arte surge como proposta de superação, mais do que sublimação, de uma época em que o comércio, a indústria, a produção em massa e a mecânica se tornam factores perturbantemente visíveis na marcha da cultura. ${ }^{225}$ Ora se o lluminismo e Primeiro Romantismo Alemão haviam sido movimentos de resistência à emergente indústria cultural movidos por carência pela síntese orgânica das artes, logo em Schiller, Wagner lê Schiller com toda a consciência de que se trata de um progenitor. Ambos pensam a liberdade da necessidade da arte face a projectos de transformação política falhados (Revolução Francesa; Revolução de 1848), num quadro de maquinaria estatal bárbara e inimigo da arte (Wagner). Wagner vai então proceder a uma 'estranha concatenação', da indústria cultural com a estética romântica (Smith). Fá-lo no seio da emergência cultura de massas, struggling with the problem of being an "artist of the people" in a mass-mediated society. $226 \mathrm{E}$ com uma intuição irónica: The "masterpiece of mechanism," by contrast, is precisely the artwork that shows the traces of its creation; as such, it is not really an artwork at all. ${ }^{227} \mathrm{Em}$ que é que isto prefigura um críticada transparência do dispositivo que não abdique ao mesmo tempo de uma dimensão bio-teleológica? Wagner entrevê o impacto da transparência do dispositivo na moderna cultura do espectáculo, sugerindo a necessidade de uma medição (retórica fundamental que filtra o funcionamento da autopoiesis): By leading forth his artwork in continuous organic growth, and making our selves organic helpers in that growth, the poet frees his creation from all traces of his handiwork; whereas, should he leave those traces unexpunged, he would set us in that chill of feelingless amazement which takes us when we look upon a masterpiece of mechanism. ${ }^{228}$ Há aqui todo um campo de articulação potencial entre edição/ensaio, experimentação e conceito, autonomia e entrega ao social, que a figura do pensar sistémico (Zusammenhang), com a relacionalidade no lugar da unicidade (Einheit), poderá ajudar a ler os acontecimentos da vanguarda (Dada, Bauhaus)

\section{Idem, p. 3.}

223 Idem. [...] terms and a historical narrative that elucidate the relationship between the total work of art, technology, and mass culture, a relationship that has generally been downplayed or overlooked in favor of the "high art" lineage of the opera house, bourgeois theatre, and concert hall.

224 Idem, pp. 8-9.

225 Idem, p. 10. Smith dá o exemplo da função de repetição do leitmotiv na economia da composição. Poderá dizer-se que Wagner reage a quente: Adorno defende que os ataques de Wagner ao mercado escondem uma afinidade profunda com o sistema. Adorno's point is not simply that Wagner could not escape the world of commodities and kitsch; his point is that Wagner's theory and practice of the Gesamtkunstwerk were fundamentally linked to the culture industry

226 Idem, p. 21. How to go on believing in "the people" when the people is rapidly becoming the mass? How to claim access to the spirit of the Volk when propagandists and marketers prove more appealing?

227 Idem, p. 17.

228 Wagner, in Smith, p. 17. 
criticamente, que é o que fará a racionalidade projectual situacionista, precisamente porque crítica da sociedade (separada) do espectáculo.

Em suma, a questão da totalidade, pensada como indistrinçável do dispositivo maquínico, obriga-nos a pensar que relações poderão existir entre todas e quaisquer máquinas de guerra (Deleuze, definindo a prosa de Kleist). Em muito poucas palavras, há uma equação a pensar quotidianamente entre o dispositivo (expositivo) artístico, a realidade quotidiana e o entendimento especificamente proporcionado pela obra de arte total. Ou seja, há que, perante várias expressões experimentais da totalidade projectada - do teatro da Bauhaus (o Totaltheater de Gropius ${ }^{229}$, aos 'teatro de marionetas humanas' de Schlemmer ${ }^{230}$ ), hoje às esculturas imersivas-comportamentais de Carsten Höller - uma multiplicidade de hipóteses de a sociedade d(a magia d)o espectáculo se tornar mais ou menos apropriável. A obra de arte do futuro, em Wagner, no seu carácter de projecção, equivale a uma arte pública que precisamente torna cristalina (são muitas as metáforas para sugerir modos de participação) uma progressivamente complexa consciência do mundo social no aqui e agora da existência. Ora o grande problema da pertinência da arte, da obra de arte do futuro, é a sua relação de sentido mais ou menos contemporâneo (Agamben) face às condições de que emerge/é imanência; a questão da obra de arte como totalidade (mais ou menos maquínica) é então a da vitalidade transformativa que a obra de arte possa aportar ao quotidano de um tempo. Naturalmente, a questão é a de saber que emoções são vitais (natureza) e que emoções destroiem a vitalidade do socius, ou seja, que emoções são humanas (mesmo que demasiado, Nietzsche) e que emoções são fruto de uma lógica maquínica arbitrária.

A questão da transparência dos disposititivos, regressando à questão 'térrea' da arte pública crítica, é então a de mostrar como funciona a máquina da sociedade, e então estabelecer tropos, figuras, modalidades, géneros, ou simplesmente formas de lidar produtivamente com o socius actual, entretanto todo ele fabulosa máquina vibratória (Corsín Jiménez) de relações de poder. ${ }^{231}$ Estão aqui as sementes para uma projectualidade total como resiliência da durée artística face a formas de alienação globalizantes. Em contextos mais próximos e com terminologia socio-políitica mais recente, ficam assim abertas as vias performáticas do acontecimento, do contexto e da situação, da comunidade, enquanto expressões actuais da sociedade como obra de arte do futuro. Independentemente da escala, dos temas, dos mecanismos de acção e participação, na arte pública, mormente crítica, a ideia de totalidade em Wagner é a ideia-chave de um tendência holística de integração de múltiplas dimensões

229 Smith, p. 49: What Gropius advocated was an artwork that sought to expose the mechanical rather than burying it beneath the veneer of organicism, and thus sought also to expose artists, too, as workers. [...] unbashededly industrialized members of a working colective. [...] The Bauhaus would be a place where the organic and the mechanical could be rejoined, or, more precisely, where mechanics could be made organic and rendered a crystalline gesamtkunstwerk. By so doing, the artist woud not oppose the machine but "overcome its demon" (Viability" 52) and thereby put mechanics in the service of building the "cathedral of the future." "Art and technology, a new unity!" he declares in 1924." "Technology does not need art, but art very much needs technolgy" ("Breviary" 76).

230 Idem, p. 55. The stages, argues Schlemmer, "should practice 'enchanting pedagogy' and become a Schillerian tribunal... [...] The theatre, for Schlemmer, thus has the "purely" aesthetic function of reviving the play instinct and the pedagogical function of serving as a tribunal anda $n$ extension of the classroom. Like Schiller and Wagner, Schlemmer wants the theatre to be simultaneosuly purposeless and purposeful, an end in itself and a means to that end.

231 Idem, p. 53. De resto, Bayreuth é uma enfática reacção projectual - mais do que estritamente musical ou dramática - de Wagner aos mecanismos alienantes do seu tempo, revelando-se o Festspielhaus sacred, because of its claim to replace the diachrony of the modern world with the spatial synchrony of the unified work. 
da alienação (Lefèbvre) numa única acção totalizante - basicamente, a ligação arte-vida - . frágil expressão finita (o estético) do infinito (social). Crucial é assim a dupla consciência simultânea de uma noção de dispositivo projectual ${ }^{232}$ e da sociedade como um todo, o que é necessariamente uma consciência da complexidade das possibilidades formais de ambas as esferas se interpenetrarem.

Termino com uma nota kafkiana, cujo máquina de literatura ${ }^{233}$ tem em Amerika $^{234}$ um dos seus movimentos finais mais concertantes, relativamente ao social como estética. $O$ texto de Kafka ajuda-nos a pensar a conciliação do espectáculo com a violência do obscurecimento 235 .

The event represents the nadir of Karl's luckless American adventures. Made to sleep ona heap of velvet curtains in a corner of her crumbling apartment, Karl must listen to Brunelde make love upon a couch she rarely leaves, and he is soon kicked out on to the terrace like a dog. [...] We never know how Karl makes his way out of his particular Wagnerian nightmare - all we know is that the next time we see him on a street corner, viewing an advertisement for "The Nature Theatre of Oklahoma"." Swept by its promise that "everyone is welcome," Karl is off to find a place in the new Theatre. He soon discovers that it is "on a much larger scale than he could have conceived possible", as all around him stands hundreds of actors, perched on separate pedestals, dressed as angels in white robes with great wings on their shoulders, blowing through gold-glittered trumpets. The placard did not lie: the Nature Theatre does indeed offer employment for all. Though he considers himseld unsuited to be an actor, Karl eagerly takes a job behind the scenes as a technical worker. A new job, a new community, a new place in the "limitless" spectacle of the New World: for the first time in the novel, Karl seems to have found a home. Nor does he need to worry about the furure: "it's an old theatre," an angel tells him, "but it's always being enlarged". 236

Conclui Smith, numa espécie de pequena-grande história do dispositivo artístico, das red carpet arts até à arte pública vernacular:

The concluding chapters of Kafka's novel come cose to an illustration of the mass-cultural development of the total work of art, from the velvet draperies of Brunelde to the Nature Theatre of Oklahoma, "the biggest theatre in the world". Our analysis suggest something of the character of this theatre as well as its enlargement. Whatever their differences, the theatres of Wagner and Disney both have the reunification of nature and humanity as one of their central aims. The form of total work of art that they share attempts to forge this reunification by its performance in the exterior as well as the interior landscape. Its performance in the exterior landscape is primarily one of retrocartography by means of pilgrimage, while its performance of the exterior landscape is primarily one of absorbing the audience into a spectacle of the desired natural state, a theatricalized form of nature more natural than the non-theatricalized world. To affect this absorption in nature, both Bayreuth and Disneyland must turn to the machine, a reliance that must be concelead from the spectacle. ${ }^{237}$

Em suma, a obra de arte pública ou é pelo menos a explicitação cínica da sua constituição, ou não é. Neste aspecto, podemos regressar sempre a Wagner, mas não para aceitar cri-

232 Em Schlemmer, este é informado pelo ensaio de Kleist Über das Marionetentreather (1810), que é das mais acabadas expressões da consciência de como um projecto se constitui enquanto relação da sua própria materialidade e componentes face ao mundo e a natureza. Note-se que as coreografias e guarda-roupa experimentais de Schlemmer, logo à época, revelavam uma tensão entre a 'desumanidade' do desenho geométrico e a 'humanidade' dos corpos em movimento. Até hoje têm sido repostas com novos materiais que supostamete tornariam os efeitos desejados mais abstractos, mas o que se nota é que há (sempre?) um reduto do gesto humano que se subtrai ao desenho. Esta questão é deteminante numa nova expressão da sociedade do espectáculo, o cinema digital, em que paradoxalmente ainda podemos encontrar os traços humanos na tecnologia performance capture.

233 Parafraseio Deleuze referindo-se a Kleist, que era leitura regular de Kafka.

234 Editado postumamente em 1927, mas cujo primeiro capítulo é uma adaptação de um texto de 1913. Kafka morre em 1924, deixando a obra inacabada, mas tendo trabalhado na mesma até pouco antes.

$235 \mathrm{Tal}$ como desde cedo os bastidores do Disney World, rigorosamente vigiados para impedir contaminações de universos de referências 'puras', são de alguma manaira a actualização comercial do fosso de orquestra escondido em Bayreuth.

236 Smith, p. 132.

237 Idem. 
ticamente a sua obra de arte do futuro, mas sim para reconstruir anamnesicamente, face a experiências historicamente consagradas ou obscurecidas pelo devir da sociedade de comunicação de massas, as múltiplas modalidades disponíveis de aproximação à nossa arte do futuro - uma aproximação que no pós-guerra passou pela ideia de renovação de cidade, informada pela de polis.

\section{Nota sobre Feuerbach - a máquina para o sentir juntos}

Quando Wagner abraça a mística antropológica de Feuerbach, verdadeiro e único filósofo da Modernidade, ${ }^{238}$ elogia-lhe o carácter trágico e a tendência social-radical. ${ }^{239}$ Para Wagner, são importantes em Feurbach a crítica da abstracção que separa o logos do pathos; o questão do corpo como lugar do encontro com a totalidade; a aproximação entre sensação e sentimento; a noção de que o ser abstracto se constitui como imagem a partir de um fazer concreto; ou finalmente a integralidade do humano que apenas uma via necessariamente anti-intelectualista pode cerzir. Na prática, Feuerbach limita o alcance da filosofia especulativa (Hegel) em nome de uma racionalidade (mecanicidade) do sensível, valorizando a via da percepção e, em particular, também a da recepção do simbólico ${ }^{240}$. É uma racionalidade no sentido do sentimento, concretizando filosoficamente uma intuição profunda, a de que há que radicar o Eu na afecção do amor, acção passiva, que sofre esse acontecimento total da sensibilidade como atenção ao outro. ${ }^{241}$ Esta percepção sensível da interioridade do outro ${ }^{242}$, que Martin Buber ${ }^{243}$, desenvolve já no Séc. XX, é não apenas o sublinhar do carácter comunitário do homem, mas, enquanto rejeição antropológica do idealismo mónada, a proposta política de um filosofar com carácter profundamente inclusivo ${ }^{244}$. $\mathrm{O}$ aforismo «Homo sun, humani nihil a me alienum puto» («Homem sou, nada de humano alheio a mim») de Terêncio é todo um programa da atenção e do engajamento potencial para o homem-entendimento wagneriano. Ora é desta percepção do papel da arte neste entendimento da totalidade afectada, que parto para a poiética de Novalis como modelo utópico de apropriação artística da vida em total plenitude discursiva. Mesmo que Feuerbach não entregue à arte - como Wagner e Novalis fazem - um papel absolutamente determinante ${ }^{245}$, capaz de significar a sintetizar a pulsão

238 Justo, p. 255. Wagner, depois da leitura de Pensamentos sobre a Morte e a Imortalidade, extraídos dos papéis de um pensador, 1830.

239 Wagner, p. 256.

240 Hegel acreditava que os símbolos eram demasiado ambíguos para servirem de meios de comunicação filosófica; os seus seguidores, empenhados na luta contra a religião, redicalizaram essa posição crítica face ao simbolismo romântico em nome de um impulso emancipatório de clareza e pleno controlo da comunicação. Enquanto Bauer insiste em denegrir a alteridade da representação simbólica, Feuerbach, que note-se é influência directa no pensamento de Marx, reintroduz o simbólico como dimensão crucial na sua teoria humanista da religião e da subjectividade. Cf. Breckman, Warren; The European Legacy: Toward New Paradigms, «Emancipation and the Bounds of Meaning: Reading, Representation and Politics in Young Hegelianism», Volume 8, Issue 4, 2003 Pp. 425-439.

241 Neste programa neo-iluminista, essa consciência é atingida por aqueles que, como os artistas maiores (Beethoven), intuiem sob o signo do «génio» um saber imediato que não deixando de pressupor uma dimensão abstracta e lógica inscreve uma essência humana, colectiva e transpessoal no correr da vida social.

242 Justo, p. 259.

243 Ao contrário de Kant, afirma Buber, Feuerbach postula o homem inteiro e não a cognição como o princípio do filosofar; por Homem, entenda-se, não o indivíduo, mas o homem com o homem, a conexão Eu-Tu. Cf. Friedman, S. Maurice; Martin Buber: the Life of Dialogue, Routledge, 2002.

244 Justo, p. 260.

245 Para Wagner, contudo, o trabalho da mediação artística é, por assim dizer, aquilo que está a mais, aquilo que significa sem- 
da humanidade (Justo), a sua teo-antropologia humanista (e materialista) conduzir-nos-á à complexidade marxista, desde logo na questão da crítica da substancialidade da religião lo que não é o mesmo que uma rejeição do sacro), ou na atenção ao humano (social) em toda a sua contingência. Feuerbach declara mesmo que é seu objectivo transformar os amigos de Deus em amigos do Homem, crentes em pensadores, devotos da prece em devotos do trabalho, candidatos ao além em estudiosos do mundo. ${ }^{246}$

\title{
I. 1.1.4 Excurso: de Novalis a Nietzsche romantismo e palavra mística, poesia e polaridade
}

\author{
Please judge me according to the main thing, practical life... I treat my writing \\ activity as an educational tool.
}

Novalis

Se Schiller me interessa na confluência idealismo/romantismo, Novalis é um expoente da racionalidade romântica. ${ }^{247}$ Se Le romantique est donc une lunette (Brentano), ${ }^{248}$ isto visa antes de tudo o mais a reabilitação do valor da imaginação no cerne da atenção ao mundo:

Si romantic/romantisch implique d'abord une focalisation sur le sujet percevant, il suppose en outre un rapport spéci-

fique de l'art à la nature: dans l'expérience romantique, la nature est perçue à travers le prisme de l'art loriginellement, le roman). Autrement dit, pour le regard romantique, ce n'est plus l'art qui imite la nature, mais la nature qui - dans une sorte de renversement du principe traditional de mimesis - imite l'art. ${ }^{249}$

Posto isto, inscrevo um ethos romântico nos mecanismos da atenção ao real através da lente da arte, tanto quanto esta seja conscientização do dispositivo-mundo que, em certas alturas, encontra modelos para ampliar o campo estético - da invenção da Estética propriamente dita, em Baumgarten à provocação pacifista do Dada Berlinense, do teatro de intervenção brechtiano ao sentido ambiental da land art ou ao cinismo ecosófico de Guattari. Mas sublinho outra origem do termo, especificamente relacionada com a axiomática no meu pensamento: De cel lien avec l'art, l'adjectif a tiré un rapport priviligié avec la peinture. 250

pre a presença indesejável do abstracto, do logos, e o fulcro do agir é o «impulso vital» [...] Assim, a «arte» é «imediatamente» e fundamentalmente expressão pulsional do «desejo», ou seja, não do «sentir» propriamente dito [...] E porque é expressão «imediata» dessa privação, a «arte» é em Wagner indubitavelmente superior às outras actividades nas quais a privação possa também ter expressão, designadamente expressão verbal, na ciência ou na filosofia; ele é o fim último ao qual a filosofia, autoaniquilando-se, terá que chegar (Justo, p. 261). Ora, para Feuerbach, carência e desejo são dispositivos de mediação, e $a$ «arte» apenas um meio - entre outros - para o «imediato» (Justo, p. 261).

246 Cf. Feuerbach, Ludwig; Lectures on the Essence of Religion (1842).

247 Proponho o termo na sua acepção filosófica, gnoseológica e crítica, designando um modo específico de apreensão do mundo, desenvolvido na Alemanha desde cerca de 1800. Já antes, Henry More, filósofo platónico, havia proposto uma ideia de romantick inventions, para designar os produtos de uma imaginação liberta de qualquer entrave (como no romance). Tal acepção confirma um sentido suspeito no termo, indiciando um potencialmente perigoso gosto pela quimera na alma humana. Passo a seguir reflexões de Serguei Tchougounnikov, em «Les pérégrinations européennes du mot romantique», in Critique - Revue générale des publications françaises et étrangères, Juin-Juillet 2009, Tome LXV - N.o 745-746, Editions de Minuit.

248 Tchougounnikov, Idem, p. 459.

249 Idem.

250 Idem. Autant, voire plus encore qu'à des referents littéraires, c'est à l'art pictural que renvoie la notion de romantique au milieu du séc. VIII. Autrement dit, romantique signifie non seulement comme dans un roman, mais aussi - et meme plus souvent encre 
Há uma filiação romântica da tradição artística da paisagem e do paisagístico; o pitoresco (mahlerisch) é a qualidade das paisagens que parecem um quadro, expressão desta sensibilidade ${ }^{251}$ pela paisagem como pintura. ${ }^{252}$ Estas acepções autorizam uma (cínica?) ambiguidade do termo - que em Wagner não de dissociará de uma manipulação consciente e precisa do dispositivo-espectáculo. Mas mais do que este aspecto materialmente sublime da acção artística, o que aqui pretendo sublinhar no termo é uma dimensão especulativa, programática e emocional do romantismo - un ensemble d'opérations philosophiques, poétiques et critiques $^{253}$ - de que Novalis é exemplo fundamental no dealbar de 800 .

\section{1.1.4.1 Instrumentalidade do romantismo: poesia e tensões}

Novalis ${ }^{254}$ forja uma série de palavras que conferem à sua raíz - romantisch - um sentido operativo específico. Primeiro, a operação retórica subjacente ao verbo romantisieren: Le monde doit être romantisé. [...] Cette operation est encore totalement inconue. En confèrant aus choses secrètes uma haute signification, au quotidian un mystérieux prestige, au connu la dignité de l'inconnu, au fini l'apparence de l'infini, je les romantise. ${ }^{255}$ Segundo, romântico designa um processo lógico de reconciliação dos contrários: le romantique est ce dans quoi fini et infini, individual et général se rencontrent et s'abolissent. ${ }^{256}$ Chegando então a ser nem mais nem menos que a actividade poética que propõe misturas heterogéneas (Novalis): poésie et prose, génialité et critique, poésie d'art (Kunstpoesie) et poésie naturelle (Naturpoesie), rendre la poésie vivante et sociale, la société et la vie poétiques, poétiser de Witz [...] ${ }^{257}$. Em suma, o romantismo, enquanto princípio plástico, é um modelo de superação de distâncias e inversão de expectativas ${ }^{258}$ actualizável enquanto eterno recomeço: Le romantisme finit mal, c'est vrai, mais c'est qu'il est essentiellement ce qui commence [...] Et certes il est souvent sans ouvre, mais c'est qu'il est l'absence

\footnotetext{
à partir de 170 - comme dans un tableau.
}

251 Na actual cultura visual, dá-se exactamente a mesma situação, no everyday dos media: paisagens que parecem um filme.

252 Tchougounnikov, p. 461. Ligado à moda da arte dos jardins, este romantismo tende para a hubris criativa, mais do que para uma humilde mimesis: il s'agit d'organiser la nature comme un tableau, pictural ou littéraire, tout en cachant le lus possible les traces de cette intervention.

253 Idem, p. 462.

254 Pseudónimo literário de Georg Philipp Friedrich von Hardenberg.

255 Novalis, Fragmente und Studien, 1798-1798, in Novalis; Schriften, Luckhohn, P.; Samuel, R.; 5 vol. Stuttgart, 1960 sq. Vol.2, section 4, n. 105.

256 Idem, p. 463: Friedrich Schlegel, ami et lecteur de Novalis en même temps qu'admirateur de Herder, apporte à cette définition un prolongement spécifique. [...] il oppose [...] la poésie antique, belle, objective, naturelle, cyclique et finie, à la poésie romantique, infinie, subjective, artificielle, progressive et parfois melée de laideur. Schlegel é a início 'conservador', valorisando a primeira face à segunda (Cersuelo). Em escritos posteriores, inverte a opinião e la poésie romantique est désormais présentée comme un privilège de la Modernité.

257 F. Schlegel, in Idem, p. 464. Para este autor, seriam plásticas a arte e a poesia e pitorescas a arte e a poesia modernas.

258 Cerisuelo, Marc; «En quête d'un absolut relatif. Le moment romantique de la pensée française», in Critique - Revue générale des publications françaises et étrangères, Juin-Juillet 2009, Tome LXV - N.0 745-746, Editions de Minuit, p. 502-503. [...] de Maurice Blanchot («le romantisme ouvre une époque») à Tzvetan Todorv («une expansion dont nous-mêmes représentons peut-être le dernier avatar»), de Philippe Lacoue-Labarthe et Jean-Luc Nancy («le romantisme ouvre l'âge critique auquel nous appartenons encore») à Jean-Marie Schaffer («c'est un fait que la plupart de nos évidences poétologiques "quotidiennes" ne constituent qu'une variante plus ou moins abâtardie de la doxa romantique»l, pour chacun l'évidence de l'importance du romantisme est à la fois ce qu'il faut démontrer et ce que l'on ne peut manquer de reconnaître. Pour reprendre le stermes de Stanley Cavell, autre penseur du romantisme, l'entreprise relève tout autant de la knowledge que de l'aknowledgement. 
d'ouvre. ${ }^{259}$ Temos aqui razões para entrever uma ligação fundamental à arte conceptual, à land art e à arte contextual como campos privilegiados de uma política total, tanto quanto a consciência romântica - desde logo na ironia - é a consciência de si da poesia (Bailly ${ }^{260}$ ); isto é indissociável de uma operação de subjectividade político-estética, gémea de Blanchot:

L'époque ouverte, est bien désormais cele de la découverte du sujet par lui-même en une double figure, celle du citoyen et de l'homme entier: "Le premier, libre dans la scène politique, le second, excédant cette sphere et cherchant à retrouver audelà d'elle ce qu'elle a efface en surgissent. Le premier, fruit du cheminement de la raison et le second fruit de l'imagination e de son débordement». Quelques pages plus loin, la reference à l'absence d'ouvre blanchotienne est orientée vers l'acte critique, le recours au fragment et, de façon plus originale, vers la dilection particulière des Romantiques pour «les ouvres brèves, écrites à la vitesse de l'instant, surgies d'un detour de la pensée, où la poésie n'est rien que le mouvement de surgir». ${ }^{261}$

Interessa-me aqui a hipótese da obra da arte pública como aforismo urbano cuja brevidade indicia desejo de comunicar; a sua dinâmica retórica assenta na transparência e na intensidade do momento, e em gesto rápido 'resolve' dilemas filosóficos na dialéctica do político:

Tout d'abord la literature (Poésie, Dichtung, critique) se donne désormais pour tâche de supplanter ou d'achever la philosophie: la literature se destine à la pensée et vise ce que l'idealisme allemand appelait de «savoir absolu». Dans le même mouvement, la littérature entreprend de s'auto-réfléchir et de produire en même temps que son ouvre les secrets de son operation: la literature devient sa théorie. ${ }^{262}$

\section{Eis a poesia como discursiva mecânica (Kleist):}

En fait, contrairement à la vulgate et aux idées reçues, le romantisme ne s'apparente en rien à un quelquonque «subjectivisme» e sa volonté de science debouche au XX siècle sur la constitution des sciences du langage. La densité d'une telle synthèse rend d'une certaine manière imparable une argumentation à laquelle il n'y a rien à redire, si ce n'est à la forme circulaire de l'argument. 263

O romantismo é portanto retórico por princípio (logos), aceitando a paixão romântica como restritamente absoluta (Cerisuelo) - desde logo na revelação artística no quotidiano. Regressando à relação entre arte e natureza, esta passa assim a ser hipótese ${ }^{264}$ (Raoul Dufy), passando ser necessário criar um romantismo terapêutico e pedagógico, engajado nos valores revolucionários do povo e sua emancipação, a descobrir por via de graciosa experiência da comunidade possível. Em A Cristandade ou Europa (1799), estas questões conduzem a duas ideias filosóficas fundamentais:

Em primeiro lugar, a história é aqui pensada não como uma construção meramente racionalradicadanuma qualquer espécie de transparência dos factos, porventura obedecendo a regrasde causalidade «natural», «económica» ou «moral», mas sim como uma sequencialização de «imagens» cuja constituição, articulação e eficácia assentam antes de mais [...] no valor da verdade da unidade dialéctica entre «sensação» e «sentimento» (Empfindung e Gefühl). Em segundo lugar, o «futuro» desta história não é pensado nem como uma utopia em que passado e presente devessem desembocar para ai encontrarem simplesmente a promessa da sua redenção, nem tão-pouco como horizonte teleológico a partir do qual as antinomias do presente e do passado se tornassem meramente transparentes ao entendimento; na linguagem de Novalis, o «futuro» é uma profecia» que por um lado radica no passado, mas por outro lado ganha completa consistência no sentimento desejante da «totalidade» indivisa do mundo, podendo assim voltar a recair retrospectivamente sobre o

259 Blanchot, Maurice; in Idem, p. 503.

260 Jean-Christophe Bailly, in Idem, p. 504.

261 Cerisuelo, p. 504.

262 Idem, p. 507. Le mouvement est d'une grande amplitude (jusqu'á Baudelaire, Proust, Valery): tout grand écrivain est critique authentique. De Lacou-Labarthe Cersuelo refere «la littérature face au discours philosophique», in Quinsard, G. (dir.), Le Grand Atlas des Littératures, Encyclopaedia Universalis, 1990, Universalis, 2003, pp. 64-66.

263 Idem, p. 507.

264 José Luís Garcia: Esta asserção categórica ilustra de forma exemplar a ideia de que a antiga condição vicária, quanto à natureza, da aptidão humana de gerar obras e estilizar o real foi suplantada pela liberdade criadora do homem moderno, que passou a opor a construção à natureza. 
Tudo isto aponta para o situar e viver do entendimento: esta objectivação da subjectividade, este ponto de vista em que o sujeito condicionado encontra a certeza incondicionada de si, já não é nem «sentimento», nem «entendimento», nem «imaginação», mas sim «espírito»(Geist). ${ }^{266}$ Como vemos, o estatuto filosófico da arte atinge com o Romantismo Alemão o paroxismo, com a arte entendida como produção de vida a partir da intuição (e da serendipidade) artísticas, antecipando o que mais tarde, no quadro transdisciplinar das modernas teorias da complexidade (Maturana e Varela, Capra), serão prementes desafios de co-produção (colaboração) à filosofiaa ${ }^{267}$, à ciência e à política. Não cabendo aqui desenvolver as idiossincrasias dos românticos de Jena (Schleiermacher, Schelling, Tieck), os aforismos e fragmentos $^{268}$ de Novalis, âmago do seu modelo operativo, constroem afinidades claras com a obra de arte contemporânea com intencionalidade crítica. Penso na concisão, precisão, economia simbólica e domínio dos efeitos de estranhamento produtivos, que tornam muitas obras de arte verdadeiros aforismos, ou fragmentos, em forma de situações.

Modelo da tensão entre romantismo e criticismo, ${ }^{269}$ Novalis interessa-se pelo ser - em ser - e não tanto em investigar os fundamentos e condições do saber: «Ce qui ne saurait être résumé dans un concept, se laisse peut-être presenter par une image; et ainsi, la nécessité de la connaissance mène à la presentation. Amène la philosophie a la poésie.» ${ }^{270} \mathrm{~A}$ utopia é encetada no poder radical da palavra, espécie de micro-arte total.

On retrouve cette ambivalence du concept de réalité sur le plan artistique. La correspondance romantique de sens et des arts (quion appellera au siècle suivant «synesthésie» et ouvre d'art totale), n'est pas seulement pour objectif la creation d'un art unique, qui serait la somme de tous les arts particuliers, mais aussi d'une ouvre polymorphe et polysémique, qui constituerait le reservoir d'autres et d'autres formes possibles. [...] Cet art combinatoire n'aurait d'ailleurs pas seulement dû se developer à l'aide d'éléments littéraires ramenés à leur plus simple expression, mais aussi au moyen de fragments de vie et de pensées, de materiaux tries de la vie ordinaire, don't on peut finalement se demander s'ils ne constituent pas la veritable raison d'être de la dissemination fragmentaire romantique, tout au moins novalisienne. ${ }^{271}$

Em Novalis, há portanto um trabalho de reconstrução imaginária ${ }^{272}$ de intensificação poéti$\mathrm{ca}^{273}$ da presença do mundo. O romantismo adquire, nesta perspectiva, a dimensão de uma tentativa - totalmente realista - de construção do real - Un réel qui implique autant le moi

265 Justo, José Miranda; «As articulações do pensamento e a questão da história», in Novalis, A Cristandade ou a Europa, Antígona, Lisboa, 2006, pp. 9-10.

266 Idem, p. 10.

267 Talon-Hugon, p. 61: Le romantisme signifie aussi une nouvelle manière de penser la philosophie, entendons cette philosophie qui doit sourdre de l'art: ce n'est plus une méthode d'investigation rationelle, une pensée discursive et conceptuelle, mais une sorte de savoir intuitif et absolu. A l'opposé de Platon chassant Homère de la cite idéale au nom des exigences de la verité et de la raison, le romantisme tient pour modèles les poètes philosophes présocratiques tells Héraclite ou Parménide.

268 Cf. Novalis, Fragmentos, Assírio e Alvim, Lisboa, 1992 (trad. Rui Chafes).

269 Talon-Hugon, p. 61.

270 Schlegel, in Talon-Hugon, p. 63. De notar que, no quadro da retórica, a articulação poesia-filosofia não é um problema de compatibilidade genérica mas de energia comunicacional - por isso, até que ponto o gesto retórico extramuros, na cidade, não é um acto poético por excelência, o resultado material de uma autopoiesis do urbano social?

271 Shefer, p. 9

272 Shefer, p. 9

273 Zumdick, Wolfgang; Translation: Rachael Barham in http://www.social-sculpture.org/influences-and-underpinnings/ novalis.htm: Novalis conceived of the world as a poetic universe. That which we encounter externally in nature is profoundly related to us internally. For this reason, there is nothing in nature that is truly foreign to us. We must, though, approach nature lovingly - that is to say, poetically. 
que le monde, l'expérience phénoménale qu'une anthropologie globale. ${ }^{274}$ Neste quadro, no par «poesia vs. «filosofia» não só não há anulação integral de um dos seus termos em favor do outro termo oposto, como acontece haver uma eficácia produtiva decorrente da oposição e do predomínio temporário de um termo sobre o outro. ${ }^{275}$

Segundo Shefer, trata-se precisamente de uma dimensão de atenção ao terreno da praxis e da produção, à realidade do fazer como base do conhecer (Flusser retomará esta ideia na de fabricação). Novalis permite-nos conceber a questão da passagem do idealismo ao realismo 276 enquanto conexão entre a ordem da transcendência e a da imanência. É do realismo do Espírito que se trata ${ }^{277}$, neste intérprete da 'alma do mundo'278. É uma posição que implica um corte com a ideia de fechamento, ou de limite, com implicações na concepção dos constructos científicos, políticos ou literários, agora tensões entre pólos: Je realize l'âge d'or en produisant le sphère polaire. ${ }^{279}$ Isto passa por

manter em equilíbrio perpétuo o incondicionado e o condicionado, o absoluto e o empírico, num processo de comunicação bidireccional e de algum modo horizontal (por oposição à verticalidade do «fundamento» fichteano), processo no qual a «acção» não empírica se repetiria indefinidamente em alternância com as «determinações empíricas» [...]. ${ }^{280}$

Digamos que esta 'poesia' ensina a elaborar o conhecimento do mundo num estado de paixão ensaística: Le genie de Novalis consiste à connecter des points de vue divergents, à penser en suivant les exigences spécifiques de la transcendance et de l'immanence, sans nécessairement les supprimer immédiatement sur un mode extatique ni les résoudre suivant une option dialectique. ${ }^{281}$ Nos aforismos, esta posição propõe um ponto crítico no dispositivo da comunicação - assumindo plenamente as contradições. Vejo neste facto uma aproximação a uma beleza efémera do entendimento e da sua formação (Fiedler) na imponderabilidade das relações intersubjectivas (e entre artista e público). Concluindo, a postura estética de Novalis é ao mesmo tempo de uma anti-mimesis radical e de uma mimesis natura ${ }^{282}$, reunindo duas posições que já conhecemos de Aristóteles, a mimesis face à poiesis.

Ce chiasme de l'artificiel et du naturel, du vouloir humain et de l'instinct naturel sera remarquablement fecund au sein de plusieurs esthétiques contemporaines. On peut ici penser au Land Art et aux travaux d'artistes tells Robert Smithson ou Walter de Maria, qui redécouvrent la complexité de liens entre l'art et la nature tout en reformulant, un peu à la manière de Novalis, l'acte mimétique en une forme réflexive d'auto-mimésis. ${ }^{283}$

Esta é questão de fundo da arte in situ, da arte que dialoga na sua génese e na sua produção com o sítio e o contexto nos quais, no limite, se dilui. Ora pode ler-se esse voluntarismo como a expressão de uma recentemente descoberta modernidade do querer. No seu idealismo mágico - priorité idéaliste du possible sur le réel ${ }^{284}$ - o Homem é colocado no centro

274 Shefer, p. 11.

275 Justo, José Miranda; «As articulações do pensamento e a questão da história», p. 11.

276 Shefer, p. 12.

277 Idem.

278 Idem.

279 Novalis, p. 14.

280 Justo, p. 13.

281 Shefer, 16.

282 Idem.

283 Shefer, p. 18.

284 Shefer, p. 22. Novalis: La vie est quelque chose comme des couleurs, des sons et de la force. Le romantique étudie la vie comme 
da sua performatividade criadora e política, algo que irá de encontro à visão nietzscheana do Poeta:

La charactéristique majeure de l'idéalisme magique est sa dimension volontaire et créatrice, qui la rattache à cette métaphysique du vouloir que nous évoquions précédemment. Cette conception subjective de la magie diffère donc fortement de l'inspiration aveugle ou du don de la grace qui saisit et dépossède le sujet [...]. ${ }^{285}$

Ao limite, e agora na esfera da retórica como a entendo. A oratória, por sua vez, não é estrita poesia, tal como não é filosofia, mas situa-se entre elas num terreno de relativa indeterminação que lhe permite usar instruentos ora de uma, ora de outra. E portanto, a religião e a politica são complementares no preciso sentido em que ambas fazem mediação entre o absoluto e o empírico, a primeira fundamentalmente do lado do «sentimento» e a segunda do lado do «conceito». ${ }^{286}$

Donde que a arte - poética, em Novalis; dramática em Schiller, musical-dramática em Wagner - é um metafilosofar conjugado das duas dimensões da magia, natural e subjectiva, estando ora fora do mundo, ora nesse mundo, sintetizando, como dirá André Breton na sua Art Magique, os planos esotérico e exotérico. A arte integra portanto uma dimensão teórica que a afasta do mero sonho utópico, é uma implicação no todo do mundo sensível, um envolvimento (como na arte dita política se pode falar de engajamento). A arte é mágica precisamente enquanto projecto de manipulação - artefacção - do mundo. Este romantismo social interessa como teoria da arte e da vida, que une arte e vida de forma necessária, numa dinâmica de vontade e maravilhamento. Nestes termos, se o objectivo do romantismo é o de unir a arte à vida - potencialização qualitativa $a^{287}$ - toda a arte subsequente à viragem conceptual e ao pensamento crítico encontra nesta ideia um poder de transformação do quotidiano, tão total quanto específico ${ }^{288}$. De resto, as Vermischte Bemerkungen (1797/98), são a antevisão de um Estado Poético:

Along with Schiller, Novalis was one of the first to see that an artistic mode is perhaps the only possibility for halting humanity's ever-increasing homelessness within the world, its growing alienation from nature and culture, from work and human fellowship, its alienation from God [...] "Be as good and as poetic as possible."289

Novalis pode finalmente ser objecto de atenção a partir da sua medicina da totalidade humana, em oposição à racionalidade técnica da ciência moderna saída das Luzes. Palavra-chave no seu projecto é pharmakon, o veneno que cura ${ }^{290}$. Desta questão da individuação a partir de uma ideia de particularidade enferma (que se relaciona com o programa kafkiano) posso extrapolar que toda a arte pública problematiza a questão da saúde da dinâmica social. Não haverá espaço para desenvolver a metáfora, mas não deixa de ser estimulante pensar a ima-

le peintre, le musicien et le mécanicien étudient la couleur, le son et la force.

285 Schefer, pp. 22-23.

286 Justo, p. 15.

287 The Romantics believed that the world had lost much of its original significance. Thus in order to regain it, one must rethink or "re-present" its content and form in altogether new and unusual ways. In this regard Novalis land the philosopher Schelling to a certain degree) especially appropriated the mathematical process of potentization, and insisted that it could be extended beyond its narrow quantitative domain. [...] Potentization broadened and rendered qualitative becomes in Novalis's terminology "romanticizing." Wood, David W; in «Introduction», Notes for a Romantic Encyclopaedia. Das Allgemeine Brouillon. Novalis, State University of New York Press, 2007, pp. xv-xvi

288 Inscrição de um pensamento que a torna não propriamente rival em qualquer visão mística, mas factor artificial-natural da evolução (Bergson). É um idealismo mágico (Schefer, p. 22).

289 Zumdick, in http://www.social-sculpture.org/influences-and-underpinnings/novalis.htm. Consultado em Setembro de 2011.

290 Rui Chafes, em conferência «Político.Criação.Valor», Museu do Neo-Realismo, 2011. 
gem do curador como aquele que 'cura' através de uma adequada disposição e inscrição do facto artístico num determinado contexto... como aquele que dá venenos a provar ao tecido social. Esta questão não se resume à evidência de muitos criadores, com destaque para arquitectos e urbanistas, utilizarem metáforas médicas e de saúde para expor os conceitos subjacentes às suas intervenções la questão da intervenção cirúrgica, nas Recetas Urbanas de Santiago Cirujeda). Para rematar este excurso confirmo a validade do romantismo novaliseano no pensamento de um filósofo contemporâneo activo na reconstrução do pensar colectivo, Peter Sloterdijk:

Um époque «autrement métaphysique «veut dire en effet, pour moi, une époque qui integre dans sa réflexion métaphysique un horizon immunologique. Au fond, plus que le bonheur, la véritable idée neuve en Europe, c'est l'impératif immunitaire, qui doit d'ailleurs être réalisé collectivement, en tant que co-immunité des uns et des autres, entre les collectifs set les peuples humains [...] c'est la seule façon d'en finir avec cet universalisme abstrait et fanfaron qui fut le nôtre. La totalité n'est plus aujourd'hui une question abstraite, mais pratique, opérationelle, devant 'I'urgence du fait que nous devons, tous ensemble, cogérer la planète. ${ }^{291}$

\subsubsection{Wagner/Nietzsche. Apolo/Dionísios, da utopia à crítica.}

Nietzsche é uma figura de transição entre utopia e crítica (entre Wagner e Lefèbvre). No final do Séc. XIX, e mais do que qualquer outro pensador - e talvez juntamente com Kafka enquanto romancista - Nietzsche vai condensar uma multiplicidade de sintomas de crise dos modelos de racionalidade.

[...] fenómenos como o romantismo estético, o sucesso do paradigma mecanicista nas ciências da vida, o pessimismo filosófico ou a emergência dos movimentos socialistas na Europa não seriam normais reformulações internas dos modelos de legitimação estética, epistemológica, moral ou política do Ocidente, mas momentos de uma exaustão absoluta da própria possibilidade de legitimação em geral. Essa desvalorização de todos os valores, essa perda radical de fundamento é, segundo Nietzsche, um processo não apenas necessário como irreversível, na medida em que surge como a consequência extrema dos próprios modelos em falência. ${ }^{292}$

O pensamento de Nietzsche, fundamentalmente retórico, é tão ou mais fundamental para a minha axiomática como o de Novalis. Da mesma forma que este me relembra uma totalidade realizada positivamente na palavra poética (o símbolo), e em particular no aforismo, em nome da consciência do desejo de uma totalidade social participada, naquele temos uma palavra negativa, do ponto de vista da posição que a produção intelectual ocupa perante as narrativas hegemónicas. Isto é, Nietzsche labora antes do mais no momento em que as palavras - e mais uma vez com o aforismo em destaque -, permitem desenhar um campo estético para a política, tornada, ainda mais que em Novalis - porque num contexto socio-político mais complexo e próximo de nós -, uma po(i)ética. É neste quadro de uma pedagógica da imaginação ${ }^{293}$ que o símbolo (instrumento romântico, num logos harmonioso de totalidade orgânica) se verá acossado pela alegoria (instrumento moderno para, e cito António Guerreiro, contrariar o optimismo ingénuo dos idealistas e positivistas e desmantelar a face harmoniosa do mundo),

\footnotetext{
291 Magazine Littèraire, Avril 2010, N. 496.

292 Nabais, p. 237. Nabais, que destaca no tropo da metafísica trágica o fio condutor de vários ensaios em que o teorizar de Nietzsche (mesmo o que não explicitamente sobre a tragédia) é colocado em diálogo com o de Wagner, Shopenhauer, Kant e Schiller; e aborda as questões do sublime e do irrepresentável, centrais para a inauguração da pós-modernidade.

293 Cf. Tomas, Douglas; Brown, John Seely; A new culture of learning. Cultivating the Imagination for a World of Constant change, CreateSpace, 2011.
} 
estratégia plástica que permite que a arte fuja à categoria da totalidade..$^{294}$

No início da sua carreira, Nietzsche é influenciado por Schopenhauer ${ }^{295}$, mas também por Hegel, cuja teoria histórica do desenvolvimento das artes lhe abre perspectivas sobre o Mundo Antigo e ao mesmo tempo a hipótese de Wagner - um encontro que o marca indelevelmente - poder ser o modelo de uma nova arte trágica. Em O Nascimento da Tragédia (1872), Nietzsche avança um conjunto de oposições dialécticas condensadas no par simbólico Apolo/Dionísios. O primeiro é associado à individuação, serenidade, ordem, proporção, forma, escultura; o segundo remete para a o informe, mas também excesso, irracional, música ${ }^{296}$, essência. Ambos simbolizam forças naturais - carências, desejos, vontade - que Nietzsche elabora respectivamente sob o signo do sonho e da intoxicação. Nestes termos tensionais, para Nietzsche, Apolo é o lugar do belo e do aparente (das belas formas); Dionísios o lugar de um transe que nos transporta para a consciência das forças fundamentais da existência (o informe sublime). Nietzsche parte daqui para a ousadia de reconhecer, na evolução da cultura, movimentos de fundo que redundam na instrumentalidade dessas daquelas duas figuras-signo mitológicas. Para a minha genealogia da motivação artística (ethos), o livro de Nietzsche inscreve a permanência desde os Gregos de um elemento expressivo irracional que contrasta axiomaticamente com um elemento optimista, construtivo da natureza humana - não esgotando, note-se, o facto de ao belo podermos associar o estatismo (e a decadência) e ao sublime a vitalidade da evolução (um informe produtivo). Nietzsche conclui aliás que a génese da decadência do Ocidente (antecipando a crítica ao Modernismo que dominaria o campo da arte) está precisamente na negação quotidiana do irracional (corpo) em nome de uma racionalidade abstracta (ideia) que, iludida pelos seus feitos civilizacionais, conduziu o mundo para uma situação desesperante.

É a partir da sua nova teorização da tragédia (sua actualização para a modernidade) que toda a crítica pós-modernista aborda não apenas alternativas à filosofia hegemónica do Ocidente (manchada pelo caso da morte de Sócrates), como, em particular, o problema da arte moderna e contemporânea como produção crítica da subjectividade. Nietzsche contribui assim com um aparelho meta-filosófico crucial na dialéctica cada vez mais complexa que se desenha entre niilistas e construtivistas; através de um método pessoal poético e polémico, desenvolve ficções (Zaratrusta) que afirmam a vida para além da verdade ${ }^{297}$, empreendendo a afirmação dos valores como uma dinâmica em aberto, isto é, inscrevendo a questão da transmutação do(s) valor(es) na retórica conservadora do seu tempo. Mas se a arte dionisíaca entrega ainda à beleza (mesmo que outra beleza) a função de superar o horror, o pensamento de Nietzsche é ainda uma metafísica ${ }^{298}$; por via do aforismo, um pensamento grávido de acontecimentos e que é puro devir (Lins),

294 Guerreiro, António; «As alegorias da modernidade: o Baudelaire de Benjamin» in Jorge Fazenda; Hanenberg, Peter (Eds.), Baudelaire e as posteridades do moderno, Universidade Católica Editora, Lisboa, 2008, p. 103.

295 Schopenhauer, que contribuira para a emergência do conceito da arte pela arte, influenciou profundamente Nietzsche, cujo par Apolo/Dionísios traduz o schopenhaueriano intelecto/vontade. Quando a crítica marxista do capitalismo integra a estética, a visão estética de Schopenhauer vai ajudar a teorizar a oposição kitsch/vanguarda (até Greenberg), precisamente a partir da ideia, repetida por Wagner, de que aos artistas cabe criar formas radicalmente novas de expressão. Em Nietzsche isso vai levar à crítica da 'manada' em Usos e Abusos da História.

296 Numa crítica nítida à estética da bela forma convencionada o dionisíaco de Nietzsche contém, no centro, o tema da autonomia mágica da música de Beethoven. Cf. Campioni, 1993, pp. 203-4.

297 E aqui respondendo por exemplo a Cristandade ou Europa (1799) de Novalis.

298 Chibli, Faoze; entrevista a Daniel Lins, in Filosofia, 2004, Editora Escala, São Paulo, p. 7. 
Nietzsche chega a uma modalidade situada e táctica da reflexão cultural - como se o Super-Homem fosse um surfista - o trabalho cotidiano de um e de outro na recepção da vida, inclusive quando há sofrimento, perigo, dúvida e curiosidade estética, vitalista, encontro com a diferença. ${ }^{299} \mathrm{E}$ uma posição crucial quando queremos passar a pós-modernidade pelo crivo do efémero e o heterónimo, como vai acontecer com muitos dos principais filósofos do nosso tempo, de Deleuze a Agamben ou Sloterdijk, todos declaradamente 'nietzscheanos'. Muito importante ao nível retórico é aqui outra noção, a de que, sendo radicalmente humildes (uma noção retórica, Gross), melhor podemos aspirar à dominação (poder, autonomia) e assim combater a normopatia do dispositivo burguês ${ }^{300}$. Nietzsche é um 'herói' no combate a essa apatia (Gruen, Gross) que o consumo cultural, consequência da mundivisão capitalista) impõe ao socius, propondo, com enorme impacto em movimentos posteriores (Maio de 68), uma nova forma de potência pública capaz de efetuar um aumento do desejo. ${ }^{301}$ Em Humano, Demasiado Humano (1878), ao mesmo tempo que se afasta de Wagner ${ }^{302}$ (que Nietzsche considera agora um romântico decadente cuja arte não passa de um narcótico ${ }^{303}$ ), Nietzsche radicaliza então a crucialidade da ideia de jogo (Schiller) na arte, abrindo o caminho para uma definitiva inscrição da produção face à reprodução (mimesis), que pode ter ressonâncias políticas: L'art n'a plus de dimension ontologique; il est jeu, arrangement agréeable de qualités sensibles permettant la promotion de la vie en démultipliant les forces vitales. ${ }^{304}$

Nestes termos, os próprios artistas podem aprender a ser os 'poetas das nossas vidas' (Gaia Ciência, §299) e regenerar a sociedade. Nietzsche propõe a sua própria teoria romântica (complementando a de Novalis): l'art tend vers le savoir et la philosophie tend vers l'art comme vers le lieu de ce savoir supreme. ${ }^{305}$ Ora poderemos concluir, com o Nietzsche de $A$ Gaia Ciência, que é do idealismo, pela sua tendência para quimera, que resulta o niilismo, uma forma patológica de convicção? Certo é que Nietzsche critica no idealismo romântico a tendência anémica, 'empobrecedora da vida', e então a vitalidade da arte surge-lhe como um remédio para o sofrimento de sofredores de dois tipos: os que sofrem de superabundância de vida, que aspiram a uma arte dionisíaca, cuja visão de base da vida é trágica, e os que sofrem de um empobrecimento da vida, que exigem à arte a calma, o silêncio, o equilíbrio, ou em alternativa a loucura, o abandono, a embriaguez e as convulsões.

299 Lins, in idem, p. 10.

300 Lins, in idem: Os dados ecológicos, sobremodo, à ecologia do corpo e do desejo, da ética e dos afetos, da capacidade de promessa são, com efeito, a consequência de uma miséria real de formas de vida e de práticas criativas. Quem sabe? Poder-se-á, mediante uma ecologia do espírito, inverter as forças devastadoras de um industrial libidinal, próxima de um revisionismo anacrônico travestido em progresso e, não raro, em bem social, em necessidades atenuantes para uma "inclusão social". A idiotice pode também criar um sentimento de pertença: aderimos todos ao bordel divino, à indústria libidinal. Ora, diante da normopatia contemporânea, isto é, da doença que impede o ser humano de explorar novas idéias, tapa-miséria de uma depressão inconfessável, diante de um narcisismo gregário socialmente gratificado, no qual cada um se reconhece no olhar admirativo que um outro semelhante lança sobre ele, como inventar as formas vivas (plásticas, plurais) de uma resistência à imagem?

301 Lins, p. 11-12.

302 Mins, p. 12: Os principais pontos de divergência - "[...] a denúncia pessimista da existência, o amor intenso como compaixão [...], o convite ao remorso e à renúncia, a adesão ao ascetismo cristão: todas essas noções que, com efeito, se encontram mais em Schopenhauer que em Wagner" - são, portanto, ecos de uma impressão multifacetada de seus dois antecessores. [...] Pensando apenas em Wagner, podemos vê-lo, ao lado de Nietzsche, confrontado com uma Grécia mitificada, buscando na música perdida do povo heleno uma sombra de seus desejos de revolução cultural no seio da Alemanha.

303 Está aqui uma crítica explícita à estética da totalidade wagneriana, que apesar de tendendo para o colectivo e o público, ia estabilizando-se como estética (belo confinado), reificando as suas conquistas na sua condição de arte institucionalizada.

304 Talon-Hugon, p. 76.

305 Talon-Hugon, p. 81. 
Retenho aqui a clarividência oracular, radicalmente performativa. A Genealogia da Moral introduz a figura do não, da alteridade radical, que devidamente relacionada com $A$ Origem da Tragédia, revê o valor do nilismo no coração da grande revolução estética da modernidade ${ }^{306}$ :

O niilismo encerraria a consciência europeia num paradoxo incontornável: o de viver num momento ulterior à dissolução dos modelos de legitimação dos valores sobre os quais ela própria se construíra sem, todavia, poder considerar tal posição epocal como expressão de um privilégio, pois isso significaria ainda a pressuposição daquele que era precisamente o fundamento último de tais modelos: as noções de consciência, progresso e superação. ${ }^{307}$

Quando chegarmos a Baudelaire, a sua performática é a de uma modernidade nietzscheana; por um lado, Como pessoa, tanto era burguês, como antiburguês; defendia o direito de se autocontradizer; ${ }^{308}$ por outro, descobre uma vocação demoníaca: Há em todo o criador dois movimentos: o de separação da ordem e o da livre reintegração nela, pessoalmente redescoberta ou por ele reconstituída. ${ }^{309}$ Assim se, qualquer sistema tende a enquistar e a degenerar em preconceitos ofuscantes, que impedem a apreensão da novidade, ${ }^{310}$ a visão de Nietzsche transmite a consciência produtiva, temperamental (como dirá Cézanne ${ }^{311}$ - e afinal 'positiva'! - de a humanidade ter adoptado valores contrários à sua auto-afirmação, o mesmo é dizer, valores tipologicamente «decadentes». Assim, a situação de crise em que a humanidade foi colocada pela falência desses mesmos valores aparece, paradoxalmente, como expressão de um novo vigor, de um crescimento vita ${ }^{12}$. Quando vemos o jargão da arte pública tradicional celebrar o empreendedorismo das cidades criativas - no modelo estético da moda, mercantilizando o imaginário -, o que lhe falta é esta dimensão niilista que traz consigo a permanente transvaloração das legitimidades em causa na cidade.

Neste ponto, a questão ética-estética surge simples e necessária, desde que pensada como emergente cognoscência/consciência em processo, aos mais variados níveis: pessoal, transpessoal, colectivo, sistémico: Fim do sublime como experiência ética, início da estética como experiência do sublime. ${ }^{313} \mathrm{~A}$ filosofia e a política encontram portanto na arte uma rival poderosa na construção do sentido e da verdade - uma arte pensada e vivida como o lugar da plasticidade das motivações e das pulsões, dos sonhos e dos pesadelos, da utopia e da praxis na transparência da retórica. Rancière identifica este problema, já face à questão da vanguarda: Whether the quest is for art alone or for emancipation through art, the stage is the same. On this stage, art must tear itself away from the territory of aesthetizized life and draw a new borderline, which cannot be crossed. This is a position that we cannot simply assign to avant-garde insistence on the autonomy of art. ${ }^{314}$

\footnotetext{
306 Nabais, p. 12.

307 Idem, p. 237.

308 Gonçalves, Rui Mário; «Baudelaire e a pintura, depois de 1867» in Jorge Fazenda; Hanenberg, Peter (Eds.), Baudelaire e as posteridades do moderno, Universidade Católica Editora, Lisboa, 2008, p. 158.

309 Idem, p. 163. Assim, entre os exemplos extremos, há o desregramento dos sentidos vicenciado por Rimbaud e seu re-regramento conseguido por Matisse.

310 Idem.

311 In idem, p. 163.

312 Nabais, p. 239.

313 Idem.

314 Rancière, p. 67.
} 
Rancière afirma que se trata de uma oposição que é uma dialéctica antiga e profunda no espírito das formas:

The aesthetic identification of consciousness and unconsciousness, logos and pathos, can be interpreted in two ways. Either the spirit of forms is the logos that weaves its way through its own opacity and the resistance of the materials, in order to become the smile of the statue or the light of the canvas - this is the Apollinian plot - or it is identified with a pathos that disrupts the forms of doxa, and makes art the inscription of a power that is chaos, radical alterity. Art inscribes on the surface of the work the immanence of pathos in the logos, of the unthinkable in thought. This is the Dionysian plot. Both are plots of heteronomy. ${ }^{315}$

315 Rancière, p. 67. 


\section{2. QUOTIDIANO E VIDA URBANA: ILAÇÕES DA TEORIA CRÍTICA}

\section{2.1 Aproximação ao pensamento crítico: conceitos-chave de Henri Lefèbvre}

A originalidade de Lefèbvre na história do pensamento reside na sua capacidade para elaborar uma teoria crítica que supera a filosofia tradicional'. O seu pensamento não se confina a uma posição formal e a uma consciência teórica, evitando separar forma e conteúdo, uma vez que interessado no conteúdo concreto e situado. Referindo explicitamente a questão central da totalidade, Lefèbvre introduz uma leitura filosófica e cultural da realidade urbana e burguesa, a partir do conceito marxista de alienaçãó2 esta é uma inability in all areas of life to grasp and to think the other. It renders bourgeois thinking 'incapable of grasping the world as a totality, and distances it from the real'. [...] Bourgeois life is thus alienated because it is not only fragmented, but artificial, and it is this artificiality which makes mystification possible. Iniciado em 1947, Critique of Everyday Life é o opus magnum de Lefèbvre, cujo terceiro e último volume, editado em 1981, culmina uma abordagem dialéctica ${ }^{4}$ particularmente aguda das realidades espaciais, arquitectónicas e urbanísticas do seu tempo ${ }^{5}$ : It was in terms of spatial and urban issues that Lefèvre formulated the problem of 68 [...] Because it was there - in the 'urban revolution' - that all the contradictions of modernity were operative. ${ }^{6}$

Em Lefèbvre, a articulação entre carência e povo redunda num spatial turn ${ }^{7}$ que localiza o diagnóstico das transformações da modernidade no espaço da cidade contemporânea; um urban turn que atenta ao quotidiano como o espaço social onde a arte procura fazer (o) sentido (possível). ${ }^{8}$ Portanto, desde Lefèbvre (também com The Production of Space, 1974), o espaço (social) é um produto social', não existindo em si mas enquanto produção. Este é um

1 Trebitsch, Michel; «Presentation: Twenty Years After», in Critique of Everyday Life, Verso, London/New York, 2005, p. xv.

2 In Marxism, alienation is no longer the absolute foundation of contradiction. On the contrary, alienation is defined as an aspect of contradiction as becoming in man. Lefèbvre, Henri; Critique of Everyday Life, Vol. I, pp. 69-70.

3 Trebitsch, p. xx.

4 Por oposição à metafísica, que é o resultado de um procedimento de especialista ou de partidário (J. Francisco Saraiva de Sousa), e até reacção de defesa do indivíduo, ou do seu grupo, a dialéctica impõe-se como pensamento do movimento (real, na pulsão do ser), desalienando o homem total.

5 Com o subtítulo From Modernity to Modernism, o primeiro volume aborda uma análise da relação entre arte e social que é relevante desde logo pelo impacto nos movimentos COBRA e Situacionista; o segundo volume (1961), de (ainda) maior densidade teórica, foi fundamental para o movimento de Maio de 68.

6 Trebitsch, p. $x x$.

7 Lungu, Arina; «Marx, Postmodernism, and Spatial Configurations in Jameson and Lefèbvre», CLC Web: Comparative Literature and Culture, 10.1, 2008.

8 Kaufman, Vincent; «The Poetics of the Dérive», in Johnstone, p. 100: The city entered modern artistic consciousness because of its transformation and disfigurements, the mirror of a vanished fullness or unitiy that had to be reconstructed. [...] Rarely have cities been transformed as they were during the 1950's and the 1960's.

9 Schmid, Christian; «Henri Lefèbvre's Teory of The Production of Space - Towards a Three-dimensional dialectic», in Goonewardena, Kanishka; Kipfer, Stefan; Milgrom, Richard; Schmid, Christian (Eds.), Space, Difference, Everyday Life Reading Lefèbvre, Routledge, New York and London, p. 28. 
entendimento performativon - relacional (Schmid) - do espaço e do tempo. Space stands for simultaneity, the synchronic order of social reality; time, on the other hand, denotes the diachronic order and thus the historic process of social production. [...] They are social products; consequently, they are both result and precondition of the production of society. ${ }^{10}$

Determinante é então a forma tripartida como o espaço é produzido:

Key to Lefebvre's theory is the view that the production of space can be divided into three dialectically interconnected dimensions or processes. Lefebvre also calls them formants or moments of the production of space. They are doubly determined and correspondingly doubly designated. On the one hand, they refer to the triad of "spatial practice," "representations of space," and "spaces of representation." On the other, they refer to "perceived," "conceived," and "lived" space. This parallel series points to a twofold approach to space: one phenomenological and the other linguistic or semiotic."

Esta é uma conscientização - também no projecto de apropriação do quotidiano, que um termo alemão permite cerzir: At the core of the dialectic lies a concept whose deeper meaning emerges only in German: das Aufheben des Widerspruchs (sublation of the contradiction). Aufheben signifies, on the one hand, negation and overcoming; on the other hand, preservation and placing on a higher level. What do we find at the origin of this essential concept? A word play, an untranslatable pun, nothing formal and perhaps also nothing that could be formalized in a perfectly coherent discourse." Ao quotidiano, enquanto base do social, podemos aceder operativamente (talvez apenas) no artifício de uma metaforologia ${ }^{12}$ a inovadora produção de espaços experimentais. E estes provocam ambiguidades terminológicas, na base da criticidade do pensamento e da acção: [...] every proposition with a real content is both true and false, true if it is transcended, false if it is asserted as absolute ${ }^{13}$. E então, Against the deadly power of the sign Lefebvre, following Nietzsche, posits the metamorphosis of the sign: poesy. In Lefebvre's view, the work of art alone is the unity of the finite and the infinite, endlessly determined and living. ${ }^{14}$ A arte vem dar sequência a uma intuição de Walter Benjamin que, nas suas Teses sobre a Filosofia da História lescritas 40 anos depois das primeiras abordagens da questão em «Sobre o programa de uma filosofia do futuro»), redefines the responsibility of thought and the spaces in which thinking develops - together, as the same project. Further, experience is redefined in conversation with historial materialism, not in conversation with philosophical tradition..$^{15}$ Todo este programa actualiza o humanismo do jovem Marx (Manuscritos de 1844) no sentido de uma crítica do fetichismo da modernidade.

\section{2.1.1 Da filosofia à totalidade social: quotidiano e modernidade}

É carência de totalidade que conduz o sociólogo Lefèbvre ao interesse quer pelo marxismo, abraço ao concreto, instância pragmática (aristotélica), quer pelas vanguardas artísticas, enquanto irrupções de vitalidade no tecido cultural, em ambos desvelando-se um aspecto

10 Idem, p. 29.

11 Idem, p. 29. Sendo que: The meaning of the three dimensions becomes clear only in the overall context of the theory, and can be reconstructed only out of Lefebvre's entire work.

12 Kafka enriquece-a com metamorfose (Deleuze e Guattari, em Para uma Liertaura Menor)

13 Lefèbvre, Henri; in Schmid, p. 30.

14 Idem, p. 32.

15 Liggett, p. 98. 
místico $^{16}$ (uma genealogia do espiritual social que, como vimos, liga Novalis a Wagner, mas também Bergson ${ }^{17}$ a Buber $\left.{ }^{18}\right)$ :

[...] when Lefèbvre defined consciousness as an 'act' and as a 'relation' the other qua other, he was in effect saying that consciousness was consciousness of the other. By recognizing the other as a mixture of presence and absence, the relation between 'the same and the other' as identity in difference and difference in identity, consciousness becomes the means of acceding to totality, i.e. to Spirit, which 'reunites and concentrates the diversity spread out through space'. 19

É nestes termos que relaciono o encontro romântico com o mundo (Schiller, Novalis, Wagner) com a grande ideia que é a modernidade. ${ }^{20}$ Abordo a problemática da modernidade a partir de uma das suas categorias-instrumentos essenciais, a ideia de dispositivo (Foucault, Agamben), valorizando consequentemente a ideia do dispositivo artístico lo jogo em Schiller, a alegoria em Nietzsche, a máquina de guerra em Kleist), em particular esses dispositivos que permitem uma crítica imanente da condição urbana contemporânea, projecto meta-filosófico (termo cunhado por Lefèbvre), transdisciplinar, refractário da sua própria institucionalização epistemológica, mormente como 'sociologia'. De resto, no desejo de relacionar o conceptual com o experiencial ${ }^{21}$, tendo em conta um conjunto de categorias de contornos dinâmicos e que estabelecem entre si relações dialécticas linfluência de Nietzsche), num modelo que permite ao leitor compreender processos dramáticos ao nível da distribuição do sensível (Rancière), Lefèbvre parte do texto social na sua complexidade - corpos, paisagens, cidades, ruas, a forma urbana - para, em termos wagnerianos, emprender uma sociologia da totalidade: This highlights an aspect of democracy. Without the effective and well-founded (genuine) participation of citizens in totality, there can be no political democracy. ${ }^{22}$ Ao resgatar a categoria do quotidiano do esquecimento a que foi votada por toda a história da filosofia, Lefèbvre inaugura a radical crítica do edifício do saber a partir de uma forma de atenção especial, à forma como o próprio espaço das ideias emerge, no concreto da experiência da polis e do socius. Afinal, o real é também ele, um produto e o resultado de um trabalho, desde logo sobre o lugar no corpo na cidadania. ${ }^{23}$ Habermas, que virá a ser

16 Trebitsch, p. xxii.

17 Cf. Fraser, Benjamin; «Toward a philosophy of the urban: Henri Lefebvre's uncomfortable application of Bergsonism», Environment and Planning D: Society and Space 26 (2) pp. 338 - 358. Throughout The Urban Revolution, The Production of Space, The Critique of Everyday Life, Volumes $1-3$, and the writings posthumously collected in Rhythmanalysis, Lefebvre's urban philosophical project appropriated the ideas Bergson advanced in his three major works, Time and Free Will, Matter and Memory, and Creative Evolution, through their application to the problems of social life-a de facto collaboration that Bergson never lived to appreciate and that Lefebvre would never recognize. This connection is important not only as a corrective to the scant attention paid to Lefebvre's work by philosophers, but also because it reinforces both thinkers' own emphases on interdisciplinarity and on reconciling theories of knowledge with theories of life. The combined work of the two philosophers suggests a philosophical basis for the current emphasis of theory in both cultural studies and human geography in that it stresses the importance of acknowledging movement, process, and mobilities in approaches to the problems of urban life. The composite of Bergson - Lefebvre provides the basis for articulating a philosophy of the urban.

18 Rogers, Tim; «Applying the Spatial Critique to Theory in Psychology: toward a useful Third Space», in Stephenson, Niamh; Radke, H. Lorraine; Jorna, René J.; Stam, J. Henderikus (Eds.), Theoretical Psychology, Captus Press, Ontario, 2003, pp- 105-114.

19 Idem.

20 Idem, p. xxvi.

21 Recordemo-nos do célebre encontro entre Goethe e Schiller, 1791.

22 Lefèbvre, p. 181

23 Miranda, José Bragança de; «LIGAR. Modernidade. Telescopiar o passado. Renunciar ou religar », in Matos, Sara Antónia (Coord. e Ed.); ESPAÇO, Oficinas do Convento, Montemor-o-Novo, 2009, p. 63. No meio do sujeito abstracto amergia a brutalidade da carne. [...] A ideia burguesa de que nós somos proprietários do corpo, de que podemos fazer dele o que queremos, falhou. Havia qualquer coisa de problemático aí, porque mal a modernidade anuncia a ideia de sujeito moderno como cidadão 
dos primeiros a relacionar a emergência dos mass media com o declínio da esfera pública burguesa, levar-nos-á a compreender como a expansão do corpo público para lá da esfera burguesa andou a par de medidas contrarevolucionárias, aceleradas pelo desenvolvimento dos media, visando a estabilização da classe média na figura do consumo. ${ }^{24}$

\section{Revolução e Teoria das Situações, da apropriação à transfuncionalidade}

Para Lefèbvre, a filosofia nova tem desígnios de efectuar as mediações (ligações implícitas) na consciência humana, eliminando o que retém o movimento, o que separa e dissocia, o que impede a ultrapassagem (Sousa).

Questão fundamental é a instrumentalidade interligada da criação e da subjectivação numa ideia expandida e ao mesmo tempo atomizada de revolução. ${ }^{25}$ No diálogo com os Situacionistas, a identificação entre festa/festival e revolução é um exemplo da possibilidade de o quotidiano ser renovado. A criação de situações através da arte é, nesta linha de pensamento, a criação de momentos de interesse pela cidade, revolucionariamente. Philosophers and philosophy no longer be isolated, disguised, hidden. And this is precisely because everyday life is the supreme court where wisdom, knowledge and power are brought to judgement. ${ }^{26}$ Esta teoria das situações - que abre uma via relacional-negocial para a arte - , vai conduzir Lefèbvre a uma percepção da arte como instância de inscrição da acção. Lefèbvre aponta opções projectuais em Pirandello e Brecht para clarificar a atitude a que se refere. A obra de arte, assim, em vez de expor um ponto de vista, condensa um processo de percepção da complexidade do real que é um practical becoming: the exploration of potentialities, the transition from possibilities to actions and decisions. ${ }^{27}$ Neste teorizar da natureza humana na sua concritude ${ }^{28}$, as carências (Wagner) e as pulsões (Fiedler) podem ser hierarquizadas (editadas) no fluxo experiencial da vida de todos os dias. Regressando a Marx, ou Wagner, é preciso recordar como a prática social se apropria da natureza, da mesma forma que leva o Homem a apropriar-se da sua própria natureza. É uma competência intelectual, e por isso diz Lefèbvre do intelectual 'moderno' que he has not yet 'adapted' to the conditions of his life, to the speed of its sequences and rhythms, to the (momentarily) excessive abstraction of the frequently erroneous concepts he has so

- cidadão é qualquer coisa que no espaço público passa uma imagem e no espaço privado tem as suas paixões -, verificamos que existiam tensões implicadas nessa concepção.

24 Smith, p. 20.

25 Para Lefèbvre, como antes para Nietzsche e Baudelaire (na ideia de férocité), a revolução tem antes de mais um sentido metafórico (Bohrer), de excesso emocional e físico para lá das regras. Cf. Bohrer, p. 14.

26 Lefèbvre, p. 6.

27 Idem, p. 22.

28 Lefèbvre está mais próximo de Marx e Engels de A Ideologia Alemã (1974), do que de Marcuse. A propósito da questão do prazer, MaclnTyre nota que o hedonismo de Marcuse reifica e unifica uma essência do homem, quando: If the emotional life of people is fundamentally bound up with the particular social relations in which they are embedded, there can be no unified concept of pleasure. We can only speak of 'pleasures which are specific to particular persons in particular contexts. Bryan S. Turner deixa claro que não há no epicurismo de Marcuse um plano retórico (um nível intelectual de debate público), e que por isso Marcusean pleasures are strangely dissociated from the body. Ora já Marx, nas suas Teses sobre Feuerbach, havia observado que o mundo sensual é uma actividade prática, actividade humana-sensual. Cf. Tirner, Bryan S.; The Body and Society, Second Edition, Sage Publications, London, New York, 1984/2004, pp. 71-73 
recently acquired. ${ }^{29}$ Isto é, o intelectual é chamado a desenvolver caminho para o conhecimento (dialéctica), e não apenas laborar acriticamente no seio das tipologias instituídas da transmissão e reificação do saber (lógica, ciência). É nestes termos que Lefèbvre antecipa uma carência colectiva como base de uma pós-modernidade radicalmente construtivista, no que é um exercício de crítica sistemática do projecto humanista, entregando-a na dialéctica total o papel de dar corpo à diferença (Adorno).

Entrementes, a arte pública, sob a forma de um belo cognitivo ou um sublime instrumental $^{30}$, é, neste mesmo quadro epistemológico, uma forma de conhecer a cidade (Situacionismo). Em aproximação entre modernidade e retórica, a arte na cidade, - quando arte da cidade - é vivida como escolha e acto - o que leva à importância de um pensamento eminentemente linguístico ${ }^{31}$ (e matemático), na base do logos discursivo-projectual: This is why an option involves a strategy and a series of options which amount to a series of bifurcations and disjunctions ${ }^{32}$. Esta é a racionalidade do jogo (Schiller, Gadamer) na 'origem' da pulsão de plasticidade (Fiedler, Beuys): Play recalls forgotten depths and summons them up to the light of day. ${ }^{33}$ Mas mais, é o jogo que abre a experiência do social à graça: We are protesting against the loss of grace and gracefulness. Play is a lavish provider of presence and presences. [...] Like that of (free) critical thought or of art (when it is truly free), which can and must appropriate matters which do not concern them from the point of view of social integration and the functional. ${ }^{34}$ Ora nesta outra modalidade artística, a arte do social, inefável (Thrift), desenrola-se um monumental espectáculo-jogo-alegoria que é a sociedade em toda a sua 'vida': palavras e gestos extend reality, and are equally as real; acting explores what is possible; in the abstract, play-acting does not exclude sincerity; on the contrary, it implies it, while at the same time adding something extra - something real: the knowledge of a situation, an action, a result to be obtained. ${ }^{35}$ Lefèbvre conclui: It is precisely in this way that everyday life resembles theatre - and that theatre is able to resume, condense and 'represent' life for real spectators. ${ }^{36}$ Eis-nos na esfera de que o mundo é um palco (Shakespeare) e que nele representamos não apenas papéis, mas a própria possibilidade de compreendermos como funciona o espectáculo que é a sociedade; sociedade do espectáculo, cujo princípio emancipatório Lefèbvre designa transfuncionalidade - a transmutação dos valores (Nietzsche) em sede de projecto.

Lefèbvre prossegue, numa aguda análise da forma urbana que contesta o funcionalismo, e que transcrevo pela intrincada reverberação de quase todas as questões que tenho vindo a levantar:

What would life be like for an organism which exercised the functions of each of its organs simultaneously and in isolation? What would our lifes be like if - and the idea is horrendous - we had to use our consciousness and our hands to control, the functions of our stomachs, our hearts, our livers or our kidneys. Functionalism leads to a dead end, the kind of false world nightmares are made of. The multifunctional exists, and so does the transfunctional. By the latter we mean whate-

29 Vol. I, p. 120. . His nerves and senses have not yet been adequately trained by the urban and technical life he leads.

30 Lefèbvre: Under cover of the sublime and the superhuman, all manner of dehumanization is being smuggled in. Under cover of purity and 'pure' beauty, we are invaded by impurity and ugliness. Vol. I, p. 123.

31 Lefèbvre, Vol. II, p. 257: Language is a work, the work of society.

32 Idem, p. 195.

33 Idem, p. 203.

34 Idem, pp. 203-204.

35 Lefèbvre, Vol. I, p. 136.

36 Idem. 
ver we cannot reply to by 'yes' or by 'no' when asked the question: 'Is it useful?'Play, for example, is transfunctional, and so is art, or the work of art, because they contain a play-generating 'yeast' (which does not exhaust them and which they do not exhaust). [...] Play is a momentary transfuncionality which consists of its own unfolding: the ephemeral work of an individual or several individuals, successfull or not, perfect or not, marvellous or not. A town is durable transfunctionality. [...] Towns were no more than the vaguely conscious or even 'misconscious' work of everyday life. They must become a fully conscious work, with the purpose not of 'integrating' an everyday which has been cast aside at the lowest of levels, but of metamorphosing the everyday into work, on the highest level the level of art and freedom. ${ }^{37}$

Esta a articulação realista romântica da 'verdade' do urbano.

\section{2.1.2 A metafísica de Lefèbvre em antecipação da retórica}

Na meta-filosofia retórica de Lefèbvre, está subjacente uma visão que substitui o escatológico ou o messiânico por uma activação produtiva, no aqui e agora da necessidade (colectiva, imanente), e do contingente (hegemonia, ideologia), projectando- $a$ em/como estratégia de esperança. Propositions concerning what is possible must be scrutinized, confronted and argued. When projects are confronted with 'real life' (with practice) it is imperative that the interested parties participate. ${ }^{38}$ Lefèbvre fala em hipóteses estratégicas:

Taking the most distant possibilities as its starting point, it returns to the present in an attempt to extend the force lines and the tendencies of the real towards this extreme point of what is possible. Its aim is to be more precise than the other hypothesis in the way it mediates between facts and concepts, and between givens and solutions to problems. It connects all the fragmented empirical facts with the concepts it is elaborating and constantly calling into question. ${ }^{39}$

No fundo, Lefèbvre identifica lugares discretos do social:

The discreteness of the elements of the everyday (work-family and 'private life' - leisure activities) implies an alienation; and perhaps at the same time a differentiation - certain fruitful contradictions. In any event, like all ensembles lor totalities), it must be studied in terms of the interrelation of its elements. ${ }^{40}$

O pensamento crítico passa por esta consciência - estruturalista-marxista - da própria história, que Lefèbvre se propõe levar ao extremo da sua potencialidade radical (precisamente com recurso à anamnese, como quando avalia os modelos artísticos de Chaplin ou Brecht). Ou seja, a carência de totalidade em Lefévre não se consuma na mistificação de qualquer categoria no imediato do nosso tempo, mas num trabalho dialéctico sobre as categorias que o pensar vai determinando e problematizando. Este traço cognitivo leva-me a um entendimento lato da arte pública como fundamentalmente desestabilizadora de quaisquer assumpções no território da plasticidade social, nomeadamente as advogadas hegemonicamente. Pois a própria noção de alienação, que não desaparecerá enquanto a racionalidade for racionalidade, may be grasped on the level of understanding ${ }^{41}$ (entendimento, Wagner) e é depois desse acontecimento intelectual - o encontro em Deleuze ${ }^{42}$ : a ideia de que algo no

37 Lefèbvre, Vol. II, p. 206.

38 Idem, p. 116.

39 Lefèbvre, Vol. II, p. 116.

40 Idem, p. 32.

41 Idem, p. 76.

42 Cf. Deleuze, Gilles; Différence et Répetition, PUF, Paris, 1993, p. 1. O encontro deleuziano é um modelo para colocar a arte e a filosofia em relação produtiva. Simon O'Sullivan, com base nos exemplos dos earthworks de Robert Smithson e dos Abstracts de Gerhard Richter, afirma que, ao contrário da representação, que reforça hábitos de pensamento e confirma os nossos sistemas de crença, o encontro, pela via do poder afectivo, e não sem alguma violência, estimula em nós a nossa carência de compreensão da confusão que se segue à disrupção do hábito. O'Sullivan recusa a melancolia adorniana e busca uma alternativa afirmativa para a filosofia; é um apelo, a partir de Deleuze, de um pensamento menos 
mundo nos força a pensar - que nasce a contínua renovação do conceptualizar; ora alguma arte pública, aquela que se deixa surpreender pelo logos retórico nalgum momento da sua inscrição no tempo e no espaço - inscreve na prática social, em experiências de compreensão profundamente meta-instrumentais, que outras formas de comunicação simbólica a religião, a política, a ciência, que são hábitos - não conseguem criar. Arte (contemporânea, crítica, pública) e retórica (total, emancipatória, urbana) tornam-se então, em certa medida, a mesma coisa. É uma atenção genérica ao social que está por detrás de todas as outras: Uneven development remains the prime law of the modern world, and there is much to learn and to be said about it. ${ }^{43}$ É por outro lado uma atenção que é interdependente de um princípio de atenção à emergência da própria carência: The god-like amazement of seeing the world for the first time and the marvel of first smiles is not enough. If he is to work and create, man must experience want. Without the experience of need and want, without actual or potential privation and destitution, there can be no being - consciousness and freedom will never spring forth. ${ }^{44} \mathrm{E}$ daqui que Lefèbvre parte para o cerne do seu próprio logos, a teoria das situações, em que o social não apenas acontece como é deliberada e concretamente provocado (no projecto).

Portanto o homem está sempre por definir, nos actos, no discurso e na consciência. Ao nível da produção artística, é preciso continuamente - sob pena de ficarmos presos a uma mundovisão burguesa-capitalista que nega a vida (Gruen) - submeter a arte a um escrutínio retórico que é uma dialéctica antropológica:

Dialectical anthropology does not exclude culture but neither does it parenthesize nature in the name of culture (which would be a 'culturalism'): By concentrating on this humble territory, which forms and structures both inhabit, it hopes to avoid unilateralities and neofetishisms lof signification, of non-signification or of the thing without signification - of structure and of the spontaneous - of culture and anticulture, of totality and non-totality, for example)..$^{45}$

De resto: To speak actions, events and objects - to put them in words - is the only means for conceiving of them (for developing concepts). [mas ao mesmo tempo:] dialectical thought implies a permanent critique and autocritique of discursiveness, of logic, and of their categories. ${ }^{46}$ Esta elevação é discursiva; irmã da potenciação qualitativa novaliseana, Lefèbvre sublinha que todas as contradições lógicas são bem vindas na quotidiana construção colectiva de uma racionalidade urbana total. É uma construção onde a obra de arte assume o estatuto de um momento em equilíbrio estrutural (de tensões ou polaridades), encontros e desestabilizações (desassossegos): In this sense, any cultural, philosophic or aesthetic work is a highly complex social product, and quite distinct from material products. ${ }^{47}$

Juntamente com a Teoria dos Momentos, a Teoria do Campo semântico interessa-me por nela a dimensão retórica ser não menos determinante. Mantendo que a linguagem é apenas um nível da experiência total do conhecimento, nela Lefébvre critica o fetichismo da

\footnotetext{
reactivo e mais criativo, concebendo a função da arte contemporânea na sociedade como mais construtiva que crítica. Cf. O'Sullivan, Simon; Art Encounters Deleuze and Guattari - Thought beyond representation, Palgrave Macmillan, Hampshire, New York, 2006

43 Lefèbvre, Vol. II, p. 3.

44 Idem, p. 5

45 Idem, p. 97.

46 Idem, p. 258.

47 Idem, p. 260
} 
própria significação, dominante não apenas nas ciências sociais da época como nos discursos fragmentados ('política', 'arte', etc.). ${ }^{48}$ Mas elabora mais ideias fundamentais: Individual consciousness and even social consciousness can speak only of the parts of the semantic field on which they have set up home. They cannot bring total knowledge of it, but they do offer material for that knowledge. ${ }^{49} \mathrm{Ou}$ seja, a arte pública é retórica da sua própria retoricidade - na transparência material do seu discurso. [...] so we must think of the total semantic field using dialectical reason, rather than thinking of dialectical reason as something within that field.50 Está justificada a minha intuição de uma axiomática (de polaridade ou vectores) sempre em emergência (já em Schiller), em permanente autocrítica dos seus próprios termos mas segura das provisórias conclusões que encontra sempre que confirma, no terreno do social, as suas experimentações cognitivas. Historicamente, é na Grécia Antiga que esta consciência apareceu pela primeira vez:

What transpired when signs became more and more in evidence, and when men became aware of the use of signs as implements in their society? This took place not only with the invention and use of writing, but also with the advent of urban life, aesthetic and political life, and with the conscious use of discourse..$^{1}$

Posso então inscrever a sensibilidade ética de Lefèbvre na antecipação da complexidade do Espaço Público de hoje:

As categorias social, absoluto, abstracto, contraditório e diferencial, foram multiplicadas na teoria por oblícuo, perverso, paranóico, pós-moderno e cyber espaços; para não mencionar os qualificativos deleuzianos dobrado, pregado e estriado. Mais recentemente formularam-se noções como: espaço «entre», intersticiais, liminares ou limiares, intervalares, suspensos, informes. Esta dobragem teórica sobre a categoria [espaço] demonstra que a contemporaneidade encara o espaço como uma matéria sujeita à modelação e à reinvenção social. ${ }^{52}$

Aliás, The broader the semantic field, the more acute its inner tensions /the manifestations of dialectical movements). ${ }^{53}$ Por outro lado, Every revolution destroys a set of symbols. Or else, in attempting to destroy them, it destroys itself. It cannot but try to destroy them, because, as we now know, such symbols play a structural or 'structuring' role which is all the more effective for being hidden. ${ }^{54}$ Talvez aqui se compreenda como a arte pode ser revolucionária e que, ao mesmo tempo, isso é uma impossibilidade! Para a abordagem do meu corpus, o importante, a este nível axiomático, é recordar que a vida quotidiana burguesa, ainda que pareça almejar um estado de tranquilidade, é feita de contradições fundamentais que precisamente a arte moderna veio desvelar/revelar/provocar. Nesses momentos de iluminação artística, dá-se the reorganization of one level by another, and phenomena of rupture. ${ }^{55}$ Nos 7000 carvalhos de Joseph Beuys ou nos Homeless Vehicles de Wodiszcko, encontramos esta performática

48 Idem, p. 276.

49 Idem.

50 Idem, p. 299.

51 Idem, p. 302.

Exemplo extraordinário deste momento, na sua formulação artística, é a obra Acasto, de Iris Murdoch, que representa um debate filosófico entre homens que chegam do teatro, entre os quais Sóctares e Platão. É um texto que ecoa, porventura inconscientemente, a nota de Lefèbvre sobre a riqueza conceptual-ética do percurso epistemológico grego, de um diversidade ainda hoje actuante. Cf. Lefèbvre, Henri; Critique of Everyday Life, Vol. II p. 302.

52 Matos, Sara Antónia; «Becoming, ou Espaço do Devir. Relendo Anthony Vidler», in Matos, Sara Antónia (Coord. e Ed.); ESPAÇO, Oficinas do Convento, Montemor-o-Novo, 2009, p. 153.

53 Idem, p. 304.

54 Idem.

55 Lefèbvre, Vol. II, p. 306. 
total da arte urbana; mais recentemente Christian Nold ou FREEE são criadores em arte e retórica são concidentes numa ética da ruptura, em reacção produtiva à cidade da comunicação e do consumo: The 'world of objects' as they appear in the street is like a large, front-age news item, and yet it constitutes one of the most subtle and least defined systems of signs. ${ }^{56}$ Ora In the street, commodities are on offer, but their commercial essence is concealed. They want to be nothing but loveliness, enchantment, pleasure and serenity. ${ }^{57}$ Esta vívida análise por Lefèbvre da rua subjugada pela publicidade e o marketing é estruturante:

Infinitely near, because they correspond to a desire which is both genuine and phoney, and yet frighteningly inaccessible, like superbly presented women up for sale, objects lead their sovereign life behind the shop Windows. The street is an intermediary between human lives, and its commodities are exchange values elevated to sovererign heights. [...] Certain streets have the same beauty as museums, weary and lifeless. It is a closed circuit in which products - commodities - are changed into desirable and desired goods. Here, in this involuntary work, the street, the specific beauty of our society is accomplished. Through the interplay of objects offered and refused, the street becomes a place of dreams and imagination, but also a reality at its most implacable..$^{58}$

A rua é com Lefèbvre esse lugar complexo e contraditório onde a obra de arte pública inscreve a sua condição formativa-pedagógica, emancipatória, que apenas ocasional e por vezes involuntariamente se torna verdadeira celebração de humanidade vital. Essa festa dos sentidos é por definição uma superação da trivialidade, em que predominam os estereótipos e mistificação das decisões políticas negadas que definem um quotidiano politicamente reduzido de que a arte aspira a ser uma redenção súbita, (n)a forma urbana. Por outro lado, tal festa coresponde a um desejo profundo, e, numa importante passagem, Lefèbvre associa a questão da carência a uma pulsão vital (mística, Bergson; espiritual, Sloterdijk, no tecer da cidade:

There are many mediations between need and desire. In fact, there is everything: society in its entirety lproductive activities and the modes of consumption), culture, the past and history, language, norms, commands and prohibitions, the hierarchy of values and preferences. Desire only becomes desire when it is assumed by the individual via his conflicts in a conscious and accepted way, and when it is confronted with 'goods' (the object) and the enjoyment afforded by them. It only truly becomes desire when it becomes a vital and spiritual power, accepted and used by the individual, and when his life is metamorphosed into a creative consciousness. ${ }^{59}$

\section{Quotidiano (trivial) e projecto em arte (contemporânea)}

Nos anos 30, o quotidiano correspondia basicamente a uma categoria negativa, mas Lefèbvre contribuirá decisivamente para mudar essa percepção:

Earlier thinkers like Lukács and Heidegger (and Lefebvre himself in the 1930s) had, to very different philosophical purposes, presented the everyday as simply a negative category: dull, ordinary, rote existence, the dreary unfolding of trivial repetition. [...] 'Everyday life' - properly speaking, came into being only with the rise of the masses, when European cities began to swell with the arrival of large numbers of newcomers, when the lived experience of those new urban dwellers became organized, channeled and codified into a set of repetitive and hence visible patterns, when markets became common between the provinces and the capital, when everything - money, work hours, miles, calories, minutes - became calculated, and calculable, and when objects, people and the relations between them changed under the onslaught off such quantification. Only then, midway through the last century, and only there, in the last

56 Lefèbvre, Vol. II, p. 311.

57 Idem.

58 Idem, p. 312.

59 Lefèbvre; CEL Vol. II, p. 8 
western metropolises, did the world, in Lefevbre's words, 'turn to prose'.60

Gloso a metáfora e proponho que a arte pública - tanto mais quanto crítica - é então um género revolucionário que veio para dizer o quotidiano como conceito, inscrevendo a sua transformação; a arte pública veio sublinhar a necessidade colectiva de nos emanciparmos - sermos discursivamente produtivos - na forma urbana:

Lefebvre made it clear that to formulate the quotidian as a concept, to wrench it from the continuum in which it is embedded (or better yet, the continuum that it is), to expose it, examine it, give it a history, is already to form a critique of it. And to do so is to wish for and work towards change, transformation, a revolution in the very nature of advanced capitalist society in the second half of the twentieth century. ${ }^{61}$

Noutros termos, há valores - justiça, democracia, conhecimento - que a sociedade tem dificuldade em traduzir em actos. A sociedade vive esses valores de forma mistificada (Lefèbvre), no mundo do cinema ou na televisão (Barthes), nas formas de recusa do mundo de certos misticismos, incluindo posições artísticas de reclusão; mas a condição urbana ou promove espaços de debate (expressão, produção, mediação) sobre os valores como um todo sistémico, ou as classes sociais entram no jogo viciado da mediatização globalizada do capitalismo comunicacional. E assim, é a noção de quotidiano que vem dar outro possível ao trivial:

Here Blanchot closely follows Lefebvre, who argues that the everyday is the place 'where repetition and creativity confront each other': it is both humble and sordid' and 'simultaneously the time and place where the human either fulfils itself or fails'. ${ }^{2}$

Foucault complementará: We must cease once and for all to describe the effects of power in negative terms: it 'excludes', it 'represses', it 'censors', it 'abstracts', it 'masks', it 'conceals'. In fact, it produces reality; it produces domains of objects and rituals of truth. ${ }^{63} \mathrm{De}$ On Kawara a Sophie Calle, de Daniel Buren ou Dan Graham a Lucy Lippard ou Gabriel Orozco, todos redimem o quotidiano, ampliando, independentemente da sua consciência da categoria, o conceito de cidadania artística, contribuindo decisivamente para a ideia da arte como produção do/no quotidiano:

All of which alerts us to another important point about the relation between art and theories of the everyday: most artists don't read Henri Lefebvre or Michel de Certeau in order to discover the ordinary. When the artists above perform these actions they are not doing so in order to illustrate the central theses of the Practice of Everyday Life in the Modern World. What becomes evident in the interplay between the theoretical writings of such theorists and the examples of individual artworks presented here is a dialogue in which all of those interested in the everyday search to find a language or form that can adequately convey its complexity, ambiguity and elusiveness. ${ }^{64}$

Trata-se de uma pulsão de inventividade realizada no dia-a-dia da cidade:

The agency of practices in the constitution of the everyday - the projective dimension through which practices 'invent' the quotidian, not as an objective statistical reality but as lived experience that has its own bearings - finds its counterpart in the project. What the project figures is the active, performative dimension of the everyday, the way it inheres in 'arts de faire'. Thus I would like to probe further how the everyday finds its articulation in ad hoc grass-roots projects, involving both a marked practical dimension and an ample pinch of salt. ${ }^{65}$

60 Ross, Kristin, «French Quotidian», in Johnstone, p. 42.

61 Idem,, p. 43

62 Johnstone, p. 15. Maurice Blanchot goes so far as to suggest that the everyday exhibits an absence of qualities', that it cannot be approached cognitively, and 'displays an energizing capacity to subvert intellectual and institutional authority'. In Discipline and Punishment

63 Foucault, , 1975.

64 Johnstone, Stephen; «Introduction / Recent Art and the Everyday», Everyday, Whitechappel London, MIT Press, Cambridge, 2008.2008, p. 16.

65 Sheringham, Michael; «Configuring the Evereyday», in Johstone, p. 144. 
Tal articulação, que vem ampliar as emergentes questões do estilo (Balzac), é a kind of 'playgenerating yeast' in the everyday; an action that suggests both the splitting down into simpler substances and the process of fermentation, agitation and disruption. ${ }^{66} \mathrm{E}$ é uma arte que exists below the threshold of the noticed and is everywhere and nowhere at the same time.

Secondly, there is a desire to confront things in the world at large rather than in the art world li.e. the critique of other art or of art institutions). Thirdly, when artists and curators allude to the everyday it is almost always to suggest that what is at stake in such a gesture is the extent to which an artist is able to get close to things, to be immersed in the world, as opposed to observing and judging from afar. And finally, running through many of these examples is the sometimes unstated but always implicit notion that a turn to the everyday will bring art and life closer together. ${ }^{67}$

E então,

The everyday cannot be reduced to its content. Its is not just repetition that makes daily activities part of everydayness, but the endless variation and sedimentation which, according to Jacques Rancière or Certeau, turn the quotidian into a sphere of invention. Driving to work, getting the groceries talking to friends are all objective phenomena - instances of which can be analysed in a wide variety of ways - but the everyday invokes something that holds these things together, their continuity and rhythm, or lack of it, something that is adverbial, modal, and ultimately therefore ethical, because it has to do with individual and collective art de vivre [...]. ${ }^{68}$

A categoria do quotidano veio para redimir o trivial burguês, e cabe à arte tornar espacialmente operativa esta injunção, qual inventio da consciência, para além do texto da cidade:

[...] if the sensory and the everyday are seen as already fully colonized by discourse and representation, as if nothing could possibly be outside the forms of representation that are currently in use, then everyday life is neither problematic nor capable of generating counterdiscourses. It becomes merely a term used to designate an area already fully represented. An everyday aesthetics would have to negotiate to avoid either one of these endgames. ${ }^{69}$

A posição de Lefèbvre abre caminho a uma consciência do social na arte que é uma consciência que é produção de si própria, pragmática experiência do conhecimento situado e vivido:

What needs 'factoringin' if one is to apprehend the everyday street is not something extra - aesthetic, subjective or intellectual - added from the outside, but our lived experience of it, our participation and immersion in its fields, the way in which we make it part of our world and recognize it as as such. For Certeau this is the dimension of pratique. [...] Certeau rebuts this view of pratique. For him people know more than we imagine; doing is a kind of thinking. In his logic of practice, what makes pratiques operative and efficacious is the level and context of their application. It is not a matter of knowledge or power but of local, pragmatic flair. In Certeau pratique does not possess its own content or space: it is a secondary production that exists only through the way it uses what is already in place, but it does thereby have a projective, dynamic aspect: it produces by reusing rather than reproducing. ${ }^{70}$

Isto traduz-se numa atenção radical aos lugares da arte (contexto, situação) e aos outros da arte (participação, activismo), na sequência de um afastamento histórico (intervenção) dos artistas face ao museu (instituição): It is as though philosophy suddenly wakes up to find that there is a dense swarming territory beyond its own mental enclave. ${ }^{71}$ Depois de abertas as comportas desta atenção à cidade, todas as posições, desde que conscientes da sua dinâmica retórica, são válidas.

Perhaps this is where Lefebvre's notion of art as play-generating yeast is useful. Artworks that attend to the everyday are not arguments; they do not offer resolutions or indeed even rational observations. As Messager herself suggests in 1976, an art of the everyday might be nothing more than a modest and highly ambiguous form of paying attention and tinkering. ${ }^{72}$

\footnotetext{
66 Johnstone, p. 14.

67 Idem, p. 13.

68 Sheringham, p. 142.

69 Idem, p. 82.

70 Sheringham, p. 142-143.

71 Highmore, p. 81.

72 Jonhstone, p. 21.
} 
É nesta perspectiva que me interessa destacar em Barthes, a sua consciência retórica, a sua noção de prazer do texto e finamente a noção operativa de mitologia:

In his book Mythologies, the French thinker Roland Barthes wrote that "we are condemned for some time yet to speak excessively about reality". This means that as an analyst of myths, you could no longer be one with the myth-consumers; the analyst has an uneasy cerebral relation to the goings on of the world, being in society but not inside it, producing analyses of social space which are often anything but social:

"...we constantly drift between the object and its demystification, powerless to render its wholeness. For if we penetrate the object, we liberate but destroy it; and if we acknowledge its full weight, we respect it, but restore it to a state which is still mystified".

Isto é, o quotidiano, em si, não salva, mas desprezar a sua ideação no projecto é votar a arte a uma mitificação alienada e desnecessária. Em suma, life should be lived as a Project. ${ }^{73}$

73 Harvey, David; «Afterword», in Lefèbvre, Henri; The Production of Space, p. 431. 


\section{3. A RACIONALIDADE DIALÓGICA DA RETÓRICA}

\section{3.1 A arte interpelada pela retórica: dar palco (público) às paixões (sociais)}

The thesis of the colonization of the lifeworld posits that the economic and political systems, having been decoupled from the lifeworld, are now expanding back into it in a manner which is corrosive of it.

\section{John Michael Roberts and Nick Crossley}

The 'democratization of emotion' over the past two centuries or so is still incomplete at best and a model of distraction at worst.

\section{Daniel M. Gross}

Rhetoric always represents the possibility that things might be otherwise.

\section{Daniel M. Gross}

Na Grécia Antiga, os Sofistas (Górgias) apontam o kairos como categoria fundamental para articular os objectivos do orador com o tempo, lugar e circunstâncias do auditório a que se dirige. É toda uma ciência do efémero da comunicação e do acontecimento que assim se inscreve na história humana, e em particular niaquilo a que chamamos presença de espírito ou capacidade de resposta, e que é a alma de toda a retórica viva. ${ }^{1}$ Ora, ao contrário de Platão, ${ }^{2}$ cuja filosofia julgava inapta para a formação ética e política do homem grego, Isócrates vem tentar conciliar a filosofia e a retórica num mesmo projecto comum. Noutros termos, se entre os filósofos que colocam a tónica nos fins últimos e os oradores que pensam a realidade na imanência e no momento presente, há um antagonismo fundamental, Isócrates responde com o esbater do dualismo platónico, identificando a retórica, entendida como síntese entre a persuasão e o viver em comunidade, com a filosofia, numa assimilação que tem por base a procura de um objectivo comum, a sabedoria (phronesis), guiando-se preferencialmente por um "espírito de subtileza», enquanto Platão procedia sobretudo segundo um "espírito geométrico». ${ }^{3}$

Aristóteles (384 a.C. - 322 a.C.) vai surgir como uma proposta de síntese que supera esta dualidade, realizada na humildade do ofício da comunicação (logos): uma retórica fragmentada, dividida entre a argumentação e a estilística, com um logos propício simultaneamente ao raciocicio lógico e à mobilização das paixões, sem que se saiba, aliás, muito bem como uma tal

1 Reboul, O.; Introduction à la rhétorique, Paris, 1991, p. 21.

2 Platão vê retórica como instância do pensamento mágico, uma empireia de natureza quase exclusivamente prática; na sua posição está contida uma diabolização da palavra, ferramenta base dos sofistas, que jogam com as convenções discursivas para atingir objectivos pragmáticos.

3 Meyer, Michel; Carrilho, Manuel Maria; Benôit Timmermans; História da Retórica, Temas e Debates, Lisboa, 1999, p. 39. 
amplitude se torna possível. ${ }^{4}$ Por outro lado, essa questão deve por-se a partir de uma noção de filosofia moral que continua a ter pertinência para a modernidade. ${ }^{5}$ Consiguientemente, no se trataria, por ejemplo, en ética, de rechazar el ideal (ilustrado) de autonomia, sino de conseguir que esta, la autonomía, fuese, además de ideal, asimismo real... ni tampoco, por ejemplo, en politica, de rechazar la idea (ilustrada) de cuidadano, sino de lograr que este (el ciudadano) fuese, no solo súbdito, sino también soberano. ${ }^{6}$ Esta questão fundamental e sempremoderna da cidadania tem percorrido a crítica das linguagens e sujeitos que se vão realizando num quadro hegemónico - a 'fala' de economistas, juristas, do mercado e do estado ${ }^{7}$. Nesse quadro, é reconhecida a questão da passividade: o sujeito entendido, fundamentalmente, como sujeito passivo, nas figuras do trabalhador-consumidor e do eleitor-subscritor - la autoridad toma la forma y es una función del sistema (Luhman) ${ }^{8}$ - confrontado al sistema y conformado por el sistema. ${ }^{9}$ Este sujeito resulta "prácticamente" vacio ${ }^{10}$, porque esvaziado da possibilidade de agir ou de entrar na acção. Ora, o aristotelismo, e neste a retórica constitui o logos, impregna as linguagens existentes con lenguajes conocidos y experimentados por los sujetos $^{11}$, expondo posições antitéticas (Soto) no seio dos referidos campos da felicidade e da democracia $^{12}$, cabendo a esta, enquanto actividade integrada, materializar as virtualidades dos valores colectivos e individuais.

A presente investigação, apesar de se concentrar na questão da arte na forma urbana, procura afirma o carácter cognitivo da retórica na forma urbana a partir do inventio da arte pública crítica, pretendendo contribuir para a consciência sempremergente de um espaço público total-discursivo, de que Aristóteles, responsável por uma refundação da retórica ${ }^{13}$ no seu tempo, me parece ser um dos pensadores fundamentais (Arendt). Comento o legado aristotélico, por um lado, com notas sobre a história da retórica; por outro, com abordagens relativas às problemáticas da argumentação, do diálogo/dialogismo e da distribuição social da emoção. A primeira ideia de fundo a reter é a de que a retórica é uma área do saber pragmático, técnica formalizada ${ }^{14}$ na qual se joga quotidianamente o destino do homem e dos seus discursos. O objectivo da minha investigação não é, por isso, justapor dois campos da produção/saber humanos - a arte e a retórica -, mas abordar uma via transdisciplinar, político-epistemológica, que vejo subjacente em Chaim Perelman (O Império Retórico, 1999), na

\footnotetext{
4 Idem. 15.

5 Soto, Luís G.; «Trás Aristóteles», in Revista Filosófica de Coimbra, Vol. 19, n. 37, 2010, Coimbra, p. 85. El interés contemporâneo por la filosofia moral de Aristóteles solo en parte cabe atribuirlo a su desencanto y/o una reacción frente a la modernidad. Muy al contrario, no poças veces, la vuelta al pensamiento del estagirita obedece a la necesidad de encontrar claves para, precisamente, avanzar en la modernization.

6 Idem, p. 86.

7 Idem. Soto menciona menciona o papel de Roland Barthes nessa denúncia.

8 Idem, p. 88.

9 Idem.

10 Idem, p. 89.

11 Idem. Não cabe aqui desenvolver o tema do bem da cidade para os Gregos, apenas notar que era menos abstracto que vivido no contexto do bens de cada um. Soto: Así, el mejor régimen asume, explicitamente, esta tarea: contextualizar y preservar el bien del indivíduo.

12 Para a noção integrada de democracia em Aristóteles, ver Soto, pp. 100-102.

13 Sá, José Carlos Vasconcelos e; «Espaço Público, Argumentação e Retórica», in Interacções, n. 11, p. 18.

14 Sá, p. 18.
} 
sua Teoria da Argumentação; na História da Retórica (Timmermans, Carrilho, Meyer, 2002); e em Daniel E. Gross, (em The Secret History of Emotion, 2006).

\section{3.1.1 Retórica - do senso comum à teoria dos quatro discursos}

Considerando-se a lógica uma ciência auxiliar, transversal às restantes, três são os ramos das ciências fundamentais segundo Aristóteles: as teoréticas, as práticas e as poiéticas lou produtivas). Nas primeiras procurar-se-á o saber em si mesmo, não se vislumbrando outra motivação na sua aquisição (como a instrumentalização em relação a qualquer fim prático). Tais seriam as ciências mais elevadas a que poderia o homem dedicar-se, destacando-se entre elas aquela que veio, na tradição ocidental, a ser conhecida como metafísica ${ }^{15}$. Quanto às ciências práticas, não buscariam o saber por si mesmo, mas alcançar a perfeição moral e a felicidade, de molde a predispor o Homem a alcançar a sua finalidade intrínseca: o bem. Compõe o quadro destas ciências a «filosofia das coisas humanas»: a ética e a política. Enquanto ciência da actividade moral dos homens, quer como indivíduos quer como cidadãos, a política é a filosofia das coisas humanas ${ }^{16}$. É ao terceiro e último grande ramo das ciências, o grupo das ciências poiéticas ou produtivas ${ }^{17}$, que pertence a retórica. Daí ser também denominado este grupo das ciências de produtivas, já que buscam o saber em vista de um fazer. Aqui estariam todas as ciências - e técnicas - que pretendessem desenvolver uma metodologia técnica para a confecção de algum objecto. Noutros termos, o objecto da retórica é a produção do acto de persuadir, a sua mecânica e seu funcionamento prático, não sendo ciência do conteúdo desse acto, mas da forma de sua efectivação. É assim possível afirmar que a retórica, nos moldes aristotélicos, além de visar a melhor forma de dirigir eficientemente o discurso para alcançar um fim preciso, é uma 'outra' ciência poiética, produtiva, da persuasão, e, ao mesmo tempo, sempre, um ofício de conceitos e sua efectivação em acções (discursivas) efectivadas na polis. Em que medida é a retórica a chave para articular arte e social de forma produtiva? Se nem sempre um artista ou a sua obra aspiram deliberadamante à persuasão, qualquer obra tem uma estrutura (logos), uma autoria (ethos) e consequências emocionais (pathos) numa dinâmica retórica na sua constituição. Toda a obra é acontecimento retórico na polis - na cidade - , enquanto intensificação e afectação de determinados valores.

A retórica surge na Grécia como técnica formal e cultura performativa, no quadro de uma noção de uso da linguagem para uso persuasivo. Desde o início, surge como uma meta-racionalidade inerente à vida social e politica ${ }^{18}$. Mas no debate acerca do seu alcance, as

15 Por razões de ordem conceptual, comporiam o grupo destas ciências ditas teoréticas, além da metafísica e da física (que, para Aristóteles, incluía a psicologia), também a matemática.

16 Como subdivisão da política, comparecem a ética e a política em sentido estrito, no sentido moderno de teoria do Estado. Ambas, a ética e a política, possuíam fins práticos, sendo a ética submetida à política, já que também para Aristóteles, como para o pensamento grego antigo, o homem feliz é antes de tudo o cidadão, estando a cidade acima da família e do homem individual na hierarquia dos seus valores.

17 Atente-se que o vocábulo poiético aponta para o sentido de um fazer, modelar, produzir, confeccionar ou, ainda, do estabelecimento de regras para se engendrar algo.

18 The very act of defining itself has been a central part of rhetoric, appearing among Aristotle's Topics. In http://en.wikipedia.org/wiki/Rhetoric, página consultada em Setembro de 2011. 
opiniões dividiram-se sempre entre quem a procura limitar a um discurso específico (política), e quem a entende abranger todos os aspectos da cultura. ${ }^{19}$ Ora,

Because rhetoric is a public art capable of shaping opinion, some of the ancients including Plato found fault in it. They claimed that while it could be used to improve civic life, it could be used equally easily to deceive or manipulate with negative effects on the city. The masses were incapable of analyzing or deciding anything on their own and would therefore be swayed by the most persuasive speeches. Thus, civic life could be controlled by the one who could deliver the best speech. ${ }^{20}$

Na verdade, entre Aristóteles e Platão desenha-se um entendimento muito diverso do logos e da sua fundamentação democrática, e que hoje podemos reler à luz de um constructivismo social. ${ }^{21}$ Numa transbordante (Jeudy) e veloz (Virilio) era do espectáculo (Debord), estas questões complexificam-se com os contributos das ciências sociais e das teorias da complexidade, bem como dos media e seus dispositivos, desenvolvendo-se estas exponencialmente e aparentemente sem controlo; neste quotidiano saturado de imagens, a retórica torna-se uma resiliente farmacologia não apenas dos excessos (significantes) das mesmas como das relações críticas (imaginativas, Marcuse) com a palavra e o conceito:

Por outro lado, a imaginação é a derradeira dimensão para que a persuasão se concretize pragmaticamente. "Imaginar é, antes de mais, acreditar. Se isto se verifica no plano emotivo, também acontece no plano racional: os argumentos não são interiorizados de forma fria, mas a sua apreensão também implica uma representação imagética dos mesmos. As cadeias argumentativas tornam-se imagens mentais formadas em conjunto com os elementos da ordem afectiva. É este todo que levará à crença ou à performance. Neste ponto, vemos que a imaginação já não entra em confronto com a razão por só estar vinculada às paixões. Afinal, tanto o docere como o movere têm a sua carga imagética, na formulação e na recepção, e a razão e o coração não estarão assim tão longe. ${ }^{22}$

Mais, sendo o sistema linguístico ele próprio suportado por outros regimes de signos (Deleuze),

A palavra pretende dar a ver, provocar a imagem, trata-se de "um fazer ver da linguagem" (Babo, 2005:105) que nos leva a defender que a retórica da imagem está presente desde os primeiros textos retóricos na medida em que o texto oralizado precisava de despoletar um dar a ver, recorrendo à imaginação. Hoje dá-se a ver, mostrando, mas a lógica encerrada no texto continua a ser a mesma: dar a ver e neste dar a ver há sempre algo que se oculta para melhor seduzir, mas há sempre um dar a ver pela imaginação, em que a presença da imagem física, ou dos apetrechos técnicos, não é fundamental pois se o texto for metafórico será imagético. ${ }^{23}$

19 Because the ancient Greeks highly valued public political participation, rhetoric emerged as a crucial tool to influence politics. Consequently, rhetoric remains associated with its political origins. However, even the original instructors of Western speechthe Sophists-disputed this limited view of rhetoric. According to the Sophists, such as Gorgias, a successful rhetorician could speak convincingly on any topic, regardless of his experience in that field. This method suggested rhetoric could be a means of communicating any expertise, not just politics. [...] Aristotle extended the definition of rhetoric, calling it the ability to identify the appropriate means of persuasion in a given situation, thereby making rhetoric applicable to all fields, not just politics. [...] Yet, Aristotle also outlined generic constraints that focused the rhetorical art squarely within the domain of public political practice. He restricted rhetoric to the domain of the contingent or probable: those matters that admit multiple legitimate opinions or arguments. [...] The contemporary neo-Aristotelian and neo-Sophistic positions on rhetoric mirror the division between the Sophists and Aristotle. Neo-Aristotelians generally study rhetoric as political discourse, while the neo-Sophistic view contends that rhetoric cannot be so limited. Rhetorical scholar Michael Leff characterizes the conflict between these positions as viewing rhetoric as a "thing contained" versus a "container." The neo-Aristotelian view threatens the study of rhetoric by restraining it to such a limited field, ignoring many critical applications of rhetorical theory, criticism, and practice. Simultaneously, the neo-Sophists threaten to expand rhetoric beyond a point of coherent theoretical value. In idem.

20 Idem.

21 Robert L. Scott states that rhetoric is, in fact, epistemic. His argument is based on the belief that truth is not a central, objective set of facts but that truth is based on the situation at hand. Scott goes as far as stating that if a man believes in an ultimate truth and argues it, he is only fooling himself by convincing himself of one argument among many possible options. Ultimately, truth is relative to situated experiences, and rhetoric is necessary to give meaning to individual circumstances. Idem.

22 Complementarmente, e como Deleuze e Guattari defendem, o signo linguístico se mistura sempre com outros regimes de signos (2005:103), desacreditando num "logocentrismo da língua."(Idem). Cf. Babo, Maria Augusta; «A dimensão imagética da metáfora».

23 Ferreira Ivone; Prior Hélder; Bogalheiro Manuel; «Em defesa de uma Retórica da Imagem», in Revista Rhêtorikê \#0. 
Numa palavra (sic), o imagético é mais visceral que o textual, que é convencionado. ${ }^{24}$ Mas entre ambos se desenham múltiplas hipóteses po(i)éticas - a experimentação emancipatória seria a mais 'nobre' - como desde a arte conceptual ficou exemplarmente demonstrado, desde logo no seu ethos de resistência política ao modernismo.

\section{Os quatro discursos, uma noção obscurecida na contemporaneidade}

Olavo de Carvalho, na sua teoria dos Quatro Discursos ${ }^{25}$, propõe: o discurso humano é uma potência única, que se atualiza de quatro maneiras diversas: a poética, a retórica, a dialética e a analítica (lógica). ${ }^{26}$ Olavo de Carvalho deduz que dessas modalidades derivam quatro ciências fundamentais - a Poética, a Retórica, a Dialética e a Lógica - que constituem também variantes de uma ciência única. ${ }^{27}$ Resolve desta forma um dilema antigo, que está implícito em autores que abordo nestes fundamentos, relativo à tradição de encarar os discursos poético e lógico separadamente, com se tivessem conjuntos de leis incomensuráveis entre si ${ }^{28}$. Por outro lado, a retórica - sujeita à opinião generalizada de que o seu propósito é puramente prático, como, por absurdo, se tratasse de um Manual a que faltasse a teoria ${ }^{29}-$, só recentemente começa a ser implicada numa revisão da cultura em geral e de uma teoria cultural da cidade (Lefèbvre). Possibilidade, verossimilhança, probabilidade razoável e certeza apodíctica ${ }^{30}$ são por

http://www.rhetorike.ubi.pt/00/pdf/ferreira-prior-bogalheiro-em_defesa_de_uma_retorica_da_imagem.pdf, pp. 5-6. Consultado em Novembro 2011.

24 Abrantes, Carlos; «Breves Contributos para uma Ecologia da Imagem», in idem, p. 10.

25 Carvalho, de Olavo; Aristóteles em nova Perspectiva - Introdução à teoria dos Quatro Discursos, Realizações Editora, Nova Edição Revista, São Paulo, 2006.

26 Idem, p. 25. Há embutida nas obras de Aristóteles uma ideia medular, que escapou à percepção de quase todos os seus leitores e comentaristas, da Antiguidade até hoje. [...] A essa idéia denomino Teoria dos Quatro Discursos.

27 Idem.

28 Idem, p. 27. Para que conste, acerca de como os textos fundamentais de Aristóteles acabam por integrar o cânone ocidental: Aristóteles escreveu uma Poética, uma Retórica, um livro de Dialética (os Tópicos) e dois tratados de Lógica (Analíticas I e III, além de duas obras introdutórias sobre a linguagem e o pensamento em geral (Categorias e Da Interpretação). Todas essas obras andaram praticamente desaparecidas, como as demais de Aristóteles, até o século l a. C., quando um certo Andrônico de Rodes promoveu uma edição de conjunto, na qual se baseiam até hoje nossos conhecimentos de Aristóteles.

Como todo editor póstumo, Andrônico teve de colocar alguma ordem nos manuscritos. Decidiu tomar como fundamento dessa ordem o critério da divisão das ciências em introdutórias (ou lógicas), teoréticas, práticas e técnicas (ou poiêticas, como dizem alguns). Esta divisão tinha o mérito de ser do próprio Aristóteles. Mas, como observou com argúcia Octave Hamelin, não há nenhum motivo para supor que a divisão das obras de um filósofo em volumes deva corresponder taco-a-taco à sua concepção das divisões do saber. Andrônico deu essa correspondência por pressuposta, e agrupou os manuscritos, portanto, nas quatro divisões. Mas, faltando outras obras que pudessem entrar sob o rótulo técnicas, teve de meter lá a Retórica e a Poética, desligando-as das demais obras sobre a teoria do discurso, que foram compor a unidade aparentemente fechada do Organon, conjunto das obras lógicas ou introdutórias. Somada a outras circunstâncias, essa casualidade editorial foi pródiga em conseqüências, que se multiplicam até hoje. Em primeiro lugar, a Retórica - nome de uma ciência abominada pelos filósofos, que nela viam o emblema mesmo de seus principais adversários, os sofistas - não suscitou, desde sua primeira edição por Andrônico, o menor interesse filosófico. Foi lida apenas nas escolas de retórica, as quais, para piorar as coisas, entravam então numa decadência acelerada pelo fato de que a extinção da democracia, suprimindo a necessidade de oradores, tirava a razão de ser da arte retórica, encerrando-a na redoma de um formalismo narcisista.

29 Curiosamente, os Tópicos, que são um manual técnico-prático, já não são usualmente objecto da referida crítica.

30 Carvalho, pp. 35-37. As razões que alego para justificar essa mudança são as seguintes:

1. As quatro ciências do discurso tratam de quatro maneiras pelas quais o homem pode, pela palavra, influenciar a mente de outro homem lou a sua própria). As quatro modalidades de discurso caracterizam-se por seus respectivos níveis de credibilidade: (a) O discurso poético versa sobre o possível [...] (b) O discurso retórico tem por objeto o verossímil [...] (c) O discurso dialético já não se limita a sugerir ou impor uma crença, mas submete as crenças à prova, mediante ensaios e tentativas de traspassá-las por objeções. [...] O discurso dialético mede enfim, por ensaios e erros, a probabilidade maior ou menor de uma crença ou tese, não segundo sua mera concordância com as crenças comuns, mas segundo as exigências superiores da racionalidade e 
Em suma, está desenhado o quadro de uma dialéctica total - necessariamente moral e transdisciplinar -, no seio do que se me afigura, desde que convoquemos para esse quadro a obra de arte urbana como acontecimento discursivo ${ }^{32}$, uma retórica crítica do total social. Assim, temos uma ideia dinâmica da co-definição de qualquer discurso, com a poética laborando na questão da abertura ilimitada das possibilidades e a retórica num domínio mais restrito - aquilo de que vale a pena falar-se na praxis colectiva, note-se, atribuindo o papel-charneira ao logos:

Retórica e Poética uma vez retiradas do exílio "técnico" ou "poiêtico" em que as pusera Andrônico e restauradas na sua condição de ciências filosóficas, a unidade das ciências do discurso leva-nos ainda a uma verificação surpreendente: há embutida nela toda uma filosofia aristotélica da cultura como expressão integral do logos. ${ }^{33}$

No limite, chegamos então, pela teoria dos quatro discursos, ao cume da reflexão filosófica, que coroa o edifício da cultura, [...] com efeito, gnosis gnoseos, o conhecimento do conhecimen$t^{34}$. Passamos assim a poder apreciar Turrell e as suas câmaras astro-lógicas (Roden Crater), o accionismo corporal vienense, uma qualquer rábula hassídica subjacente a uma intervenção conceptual, um filme contravisual de Debord ou o ready made duchampiano no quadro de uma megadispositivo plástico da vida social de que a actividade da arte pública será, talvez, a mais complexa e meta-operativa das acções humanas.

\section{Da Poética à Retórica}

A influência da Poética de Aristóteles no mundo ocidental é contínua pelo menos desde o Renascimento. ${ }^{35}$ A Poética sugere pontos de continuidade com a Retórica, desde logo numa apropriação (refundação) política e meta-instrumental do conceito de mimesis ${ }^{36}$. Eis-nos no seio de um elemento ficcional da realidade que é elevação ${ }^{37}$ (cognitiva) da mesma, e acrescento, abstracção instrumental, dispositivo intelectual. Relativamente à tragédia, esta

da informação acurada. (d) O discurso lógico ou analítico, finalmente, partindo sempre de premissas admitidas como indiscutivelmente certas, chega, pelo encadeamento silogístico, à demonstração certa [...] da veracidade das conclusões.

31 [...] a Poética estuda os meios pelos quais o discurso poético abre à imaginação o reino do possível; a Retórica, os meios pelos quais o discurso retórico induz a vontade do ouvinte a admitir uma crença; a Dialética, aqueles pelos quais o discurso dialético averigua a razoabilidade das crenças admitidas, e, finalmente, a Lógica ou Analítica estuda os meios da demonstração apodíctica, ou certeza científica. Ora, aí os quatro conceitos básicos são relativos uns aos outros: não se concebe o verossímil fora do possível, nem este sem confronto com o razoável, e assim por diante. Idem, p. 38-40.

32 Aqui muito a questão do 'tomar da palavra', uma das fórmulas simbólicas mais eloquentes da civilização ocidental, pelo que significa de vontade individual e de capacidade política de assumir o discurso público livre e desassombrado. Sá, José Carlos Vasconcelos e; «Espaço Público, Argumentação e Retórica», in Interacções, n. 11, pp. 9-31. ๔ do Autor 2006.

33 Aliás, o que é importante para noutra ocasião se aferir da relação dialéctica entre saber e luz (iluminação): $E$ como a natureza sensível não é para Aristóteles apenas uma "exterioridade" irracional e hostil, mas a expressão materializada do Logos divino, a cultura, elevando-se do solo mitopoético até os cumes do conhecimento científico, surge aí como a tradução humanizada dessa Razão divina, espelhada em miniatura na autoconsciência do filósofo. Aristóteles compara, com efeito, a reflexão filosófica à atividade autocognoscitiva de um Deus que consiste, fundamentalmente, em autoconsciência. Idem, pp. 42-43.

34 Idem, p. 43.

35 Pereira, Maria Helena da Rocha in «Prefácio», Aristóteles, Poética. FCG, Lisboa, 2004, p. 7. Idem, p. 30-31.

36 Pereira, p. 12. Aristóteles entende-a entre dois aspectos diferentes: um, que é o seu verdadeiro âmbito (acção), e outro, o seu verdadeiro significado (retrato dos universais).

37 Cf. Cap. 2 da Poética. 
surge então como modalidade de uma purificação do reaß ${ }^{38}$. Nesta definição, a questão de a tragédia ser um acto público é fundamental, assim como a da catarse ${ }^{39}$ como 'acto médico'. Esta valorização terapêutica (e emocional) da mimesis da tragédia e da catarse purificadora são aliás a resposta de Aristóteles às objecções de Platão relativamente aos efeitos psicológicos da poesia trágica, uma posição que chega até nós renovada, nos círculos mais radicais e críticos do pensamento sobre a relação entre arte e vida ${ }^{40}$. Instância totalizante da arte de persuadir, ao serviço da(s) verdade(s) (logos), a retórica reflecte sobre os artifícios da articulação e ordenação do discurso (ideia e palavra) pelos quais os falantes estruturam e reforçam as mensagens que emitem. ${ }^{41} \mathrm{Em}$ consequência, há qualquer coisa de universal na presença da retórica tanto no quotidiano como nas esferas em que os seres humanos se elevam para trocar ideias. Mas se retórica clássica estava centrada na oralidade e na presença física, hoje, o discurso público é veiculado por órgãos de comunicação de massas. Sendo que, exactamente como preconiza a racionalidade crítico-antropológica de Lefèbvre, da obra de Aristóteles Poderemos dizer que o movimento geral vai desde o estudo da realidade paralela até a um intenso interesse pelos factos concretos, tanto naturais como históricos ${ }^{42}$, e a uma convicção de que a «forma» e o significado do mundo devem ser encontrados, não para além, mas embebidos na sua «matéria» ${ }^{43}$, a retórica será assim uma espécie de materialismo mágico (Beuys, Flusser) para os tempos que corrrem? Logo, a consciência dos fundamentos da retórica é assim ferramenta conceptual incontornável para pensar a arte (e toda a cultura projectual, nomeadamente o design) na era da comunicação, tanto mais eficazmente quanto, na arte, e necessariamente no quadro da tripartição retórica, invenção e trabalho especulativo ${ }^{44}$ animam a dinâmica de produção de discurso. Por outro lado, Aristóteles é claro: consistindo a retórica no poder divisar os caminhos possíveis de persuadir as pessoas de qualquer assunto dado, ela é do possível, ou não o é.

38 Pereira, p. 12: A tragédia é a imitação de uma aç̧ão elevada e completa, dotada de extensão, numa linguagem embelezada por formas diferentes em cada uma das suas partes, que se serve da acção e não da narração e que, por meio da compaixão (eleos) e do temor (phobos), provoca a purificação (katharsis) de tais paixões. Rocha Pereira acrescenta que também uma outra paixão, pothos (anseio) é commumente objecto de abordagem no mundo grego, embora Aristóteles não lhe pareça dar grande importância. O pothos é ainda assim aspecto importante de uma ansiedade amorosa vital, que complementa a de Eros (a do impulso inicial), de Anteror (o amor compartilhado), Himero (o desejo físico) com um amor sempre diferido, que jamais se realiza. Os Gregos falavam de "anseio por aquilo que nunca está lá", saudade de um "não sei o quê" que nos falta... eu acrecsentaria, a bem portuguesa imagem das saudades do futuro.

39 Idem, p. 20. Para Pereira, Haliwell considera a extensão do campo semântico de katharsis, com realce para as aplicações médicas e religiosas, [...], para concluir que a katharsis da Poética apenas "tem um efeito comparável ao da terapêutica médica", é "uma doutrina com a natureza e efeitos psicológicos da experiência emocional da tragédia, e a sua presença na definição mostra que há uma forte dimensão afectiva na teoria aristotélica do género".

40 Caso de Rancière e sua ideia de distribuição do sensível ou de Daniel E. Gross no seu projecto de democratização das emoções. Cf. Gross, Daniel E.; The Secret History of Emotion - From Aritotle's Rhetoric to Modern Brain Science, The University of Chicago Press, Chicago and London, 2006.

41 Figuras - emprego de palavra ou frase em sentido figurado), actuantes na dispositio (escolha sintagmática macroestrutural dos signos) e na elocutio (procura dos efeitos que irão amplificar o poder do discurso), que se seguem à inventio inicial (selecção paradigmática dos signos da linguagem visual ou escrita).

42 Desde pelo menos Nicolaus Caussin, no séc. XVII, que a retórica é não apenas temporal e situacional, mas propriamente indissociável da pluralidade cultural e das contingências históricas.

43 Ross, David; Aristóteles, Publicações Dom Quixote, Lisboa, 1923/1983, p. 29.

44 Sá, p. 19: De facto, o trabalho especulativo do orador é uma capacidade que, só até certo ponto, pode ser explicada e ensinada, porque depende, em grande medida, da performance daquele que toma a palavra. Sá reforça a nota de Ricouer, que sustém que Aristóteles está plenamente consciente da performatividade retórica: Destaco esta palavra, porque o seu significado parece assumir um peso concreto na definição de retórica de Aristóteles: 'retórica é a faculdade de descobrir especulativamente o que, em cada caso seja susceptível de persuadir' (Ricoeur s/ data: 17). 
Finalmente, quanto aos meios técnicos ${ }^{45}$, Aristóteles menciona três: os que se baseiam no carácter do orador; aqueles que consistem em provocar um sentimento emocional nos auditores; e aqueles que fornecem a prova pela mera força do argumento. Não é difícil reconhecer aqui as três instâncias do edifício retórico, a sua estrutura tripartida e simultaneamente indivisível - a instância do ethos lo orador, o eu, a origem do discurso, com a sua validade, legitimidade, credibilidade, carácter); a instância do pathos (o auditório, o outro, soma de sensibilidades a tocar, o público); e finalmente a instância do logos (o discurso propriamente dito, incluindo o aparelho discursivo e sua estruturação, a argumentação e o domínio técnico das ideias e das palavras). Aristóteles, em que a dimensão filológica e genericamente cultural (proto-enciclopédica) está sempre presente, dedica muito tempo a explicitar «subespécies» deste terceiro meio de persuasão $0^{46}$. Esta é uma nota a reter, quando procurarmos ver inscrito na teoria do dispositivo artístico uma fundamentação retórica que parte da esfera do logos para abordar a obra de arte do ponto de vista do projecto (cultural, artístico, urbano) e da sua eficácia e intensidade comunicativa e emocional. Isto num quadro em que, de acordo com Barthes, as paixões constituem pura intertextualidade. De qualquer forma, é para isso que serve a retórica, para provar opostos. A retórica aristotélica não pode nem quer aspirar à condição de ciência estritamente lógica - isso seria a anulação da sua capacidade de gerar debate e portanto a própria vida. Ela é toda sobre a imponderabilidade do ponto crítico da comunicação, como a mais emblemática arte crítica.

\title{
I. 3.1.2 Ethos, Logos, Pathos: a actualidade do império retórico
}

\begin{abstract}
À dimensão do espectador, Aristóteles chama-lhe ethos, já que nada é mais convincente nem mais sedutor do que a força moral, o carácter e as virtudes de autoridade de que deve fazer prova numa certa matéria aquele que procura persuadir ou agradar. À dimensão do auditório, Aristóteles caracteriza-a como pathos, porque aquele que ouve passivamente o discurso do orador é percorrido por paixões desencadeadas pelos enunciados proferidos (daí o conceito de emoção). Quanto à dimensão abarcada pela linguagem. Aristóteles chamou-lhe logos, que é definido simultaneamente pelo estilo e pela razão [itálico meu], pelas figuras e pelos argumentos, ou, como se diz hoje em dia, pelo figurado e pelo literal. ${ }^{47}$
\end{abstract}

Tratando-se de uma tripartição, põe-se desde sempre o problema do equilíbrio entre estas três esferas: o que é que a faz oscilar quer do lado do pathos num determinado momento, quer do lado do ethos um pouco mais tarde $?^{48}$ Ora, se desde Platão se desenha a oposição fundamental entre a retórica e a filosofia ${ }^{49}$, é o carácter e funcionalidade da supra definida

45 Os meios de persuasão são de duas espécies: os extra-técnicos (do testemunho à tortura, passando pelas provas documentais) e os técnicos, relacionados com a capacidade propriamente discursiva do orador.

46 Até porque às pessoas do público, tantas vezes incapazes de seguir um raciocínio longo, reagem melhor ao silogismo, assente em módulos de raciocínio curtos; utilizando premissas tidas como certas, é uma forma de ir assentando ideias, «arrumando» argumentos e ir atingindo sucessivos patamares no processo de persuasão. Assim, se o exemplo, equivalente retórico da indução, é particularmente persuasivo; o entinema (ou silogismo) é o método retórico por excelência e o que recolhe mais adesão emocional do público.

47 Carrilho, Meyer, Timmermans, p. 14. A retórica, estuda-se, então, seguindo o recorte ethos-pathos-logos, e é nisto que reside a sua especificidade. Se se pôde perder de vista esta relação nas definições [...] isto deve-se ao facto de os grandes mestres da disciplina terem privilegeado sempre ora uma, ora outra das suas componentes.

48 Idem, p. 14.

49 Sá sublinha que onde a analítica revela um espírito anti-comunitário, mesmo anti-democrático, a recusa da comunicação (de certa forma até na dialéctica socrática), a retórica vai recuperar a troca dialógica, a interrogação, o contacto psíquico com o outro. [...] Com Platão, em qualquer caso, estamos nos antípodas do entendimento que a retórica faz da linguagem. 0 
tripartição ethos-pathos-logos que permite que a retórica, não aspirando a filosofia, não deixe de laborar fundamental e determinantemente no seio da razão. Na arte, temos então a ideia do possível como (a ficção d)o que poderia ser diferente, ou seja, de alternativas que se exprimem por questões cuja solução não é necessária, mas apenas provável. Isto perpetua uma certa problematicidade da resposta, que pode conduzir à contestação. [...] em retórica, não temos $A$ ou não- $A$, mas $A$ e não- $A$, sem que por isso se abandone o domínio do logos ${ }^{50}$. A perturbação que a arte pública crítica inscreve na cidade é claramente desta ordem, quando é $a$ faculdade de considerar, para cada questão, o que pode ser adequado para persuadir. ${ }^{51}$

Tendendo a retórica para a (hermenêutica da) acção, como algumas teorias do século XX (Ricouer) virão a defender, ela coloca, por outro lado, as questões do afecto no centro do processo comunicativo -

[...] as opposed to the philosophy that posits language as a mirror of nature, rhetoric is an inventive attitude toward language and the world, where 'emotion' names one important way in which language and the world connect. [...] Emotions are the contours of a dynamic social field manifest in what's imagined and forgotten, what's praised and blamed, what's sanctioned and silenced. ${ }^{52}$

Meta-filosofia (Lefèbvre) da acção afectada e situada, a presente investigação mostra como a arte pública, independentemente dos equilíbrios variáveis entre as três esferas, se dá como acontecimento eminentemente retórico, a partir do inventio do envolvimento com o quotidiano urbano e suas formas culturais. Neste 'regresso' da retórica ao espaço público temos uma expansão inédita dos conceitos de racionalidade ou de evolução, corolando uma ansiedade democrática pelo saber/poder como entendimento público e colectivo, poder que o espírito possui de desmascarar os discursos impostores que o atacam quase quotidianamente, como para melhor anestesiar e diluir a crítica, a insolência e, sobretudo, a lucidez que tanto a retórica como o espírito pressupõe. ${ }^{53}$ A coincidência com o programa de emancipação intelectual em Lefèbvre é total, até enquanto processo criativo, de «suspense» e de expectativas geradas pela própria construção do discurso. ${ }^{54}$ Mais, a singularidade da coisa, a particularidade do acontecimento, só podem ser ditas por um discurso capaz de actualizar toda a potencialidade renovadora. ${ }^{55}$ Vejo aqui um elogio da necessária e contínua (re)emergência da vanguarda, cerne da modernidade, sempre que um tema se arrisca a tornar-se (ir)relevante (Agamben). Esta prática retórica já não consiste em impor uma opinião ou fazer mudar de opinião, mas em criar modelos de civilização, de cultura, de homens, produzindo modelos de discurso. ${ }^{56}$ Como poderia este realismo discursivo expandido abdicar da retórica, sobretudo quando

pensamento platónico desconfia da linguagem, mas, ao mesmo tempo, tenta servir-se da linguagem, colocando-a ao serviço da epistêmê, limitando-lhe os seus devaneios, por assim dizer. Sá, p. 17.

50 Carrilho, Meyer, Timmermans, p. 15.

51 Aristóteles, I, 1355b 25-33). Não é este o caso de nenhuma outra arte, já que cada uma das outras artes apenas é instrutiva e persuasiva no que diz respeito ao seu objecto [...].

52 Gross, pp. 15-16. Que prossegue: After all, that is why the most detailed treatment of the emotions appears in Aristotle's Rhetoric rather than in his treatises on The parts of Animals or The Movement of Animals or elsewhere in his logic and natural science, though fascinating discussions of emotion appear in the later as well. Materialized in brains, faces, bodies, and even in objects and architecture, such as a tombstone or an amusement park, emotions clearly exceed the merely ideal.

53 Idem, p. 22.

54 Idem, p. 39.

55 M. Dixsaut, «lsocrate contre les sophistes sans sophistique», in B. Cassin (org.), Le Plaisir de parler, Paris, 1986, p. 66.

56 Dixsaut, lbid., p. 84. 
na forma urbana há que imaginar soluções para comunicar as possibilidades de futuro? Eis a mecanicidade antropológica da retórica a extrapolar possibilidades de encontros entre os homens, cinco centenas de séculos antes de Martin Buber ou Hannah Arendt ${ }^{57}$ e sobretudo dessa ideia de um mundo conjunto que emerge da consciência da totalidade do outro, de Lefèbvre a Gross ou Agamben, enquanto expressão da publicidade da arte (Grout).

\section{3.1.2.1 Comunicação e Paixão: o sensível distribuído}

A retórica tem sido reabilitada e renovada, particularmente desde o reconhecimento do trabalho de Chaim Perelman (1912-1984) ${ }^{58}$, autor para quem a retórica é um campo da performatividade total da própria racionalidade quotidiana: Neste sentido, existe uma dimensão prática da vida pessoal e social que lida com valores, sendo responsável pela escolha das nossas preferências e orientando as nossas decisões. ${ }^{59}$ Nestes termos, poderia a arte pública de um tempo de incultura de massas, frequentemente pouco exigente ${ }^{60}$, passar sem a retórica - sabendo nós que é aos sofistas que devemos o nascimento do pensamento mais livre e criativo ${ }^{61}$ ?

\footnotetext{
Parece ser esta a opinião de Roland Barthes (1987: 90), quando escreve que há uma espécie de acordo obstinado entre Aristóteles (de onde saiu a retórica) e a cultura dita de massa, como se o aristotelismo morto desde o início do Renascimento [...] sobrevivesse no estado degradado, difuso, inarticulado na prática cultural das sociedades ocidentais [...] Tudo indica que uma espécie de vulgata aristotélica continua a definir um tipo de Ocidente trans-histórico, uma civilização (a nossa) que é a da endoxa. ${ }^{62}$
}

É de facto muito curioso que o ressurgimento retórico se faça por via desta necessidade de síntese em que a dinâmica perdida de uma racionalidade (demasiado tempo limitada a uma teoria das figuras literárias) vai de encontro à própria crítica da vida urbana total - uma crítica tanto romântica como moderna, que sob as formas da visibilidade, do debate, do exemplo, do envolvimento, e apenas porque retórica, se torna no âmbito no qual artistas e público, criadores e cidadãos, negoceiam/edificam o seu quotidiano na vitalidade do exercício da sua capacidade argumentativa. É nestas condições que o ethos da arte radica numa pulsão/carência de encontro com o povo, que depois não pode ser desligada de um pulsão - de Shelling a Arendt - pela justiça, pela igualdade, pela fraternidade, por sua vez indissociáveis de uma trabalho sobre a visibilidade: Na opinião de Quéré, o espaço público contemporâneo poderia ser analisado como uma 'cena pública de aparecimento' onde os actores, mas também as acções, os acontecimentos ou os problemas sociais 'acedem à visibilidade pública.' ${ }^{63}$ Mais, é em toda essa complexidade estrutural que a retórica dá o seu contributo absolutamente essencial

57 Cf. Simões.

58 Cf. Traité de l'Argumentation: La Nouvelle Rhétorique, co-autorado por Lucie Olbrechts-Tyteca em 1958. Carrilho, Meyer, Timmermans, p. 15: De facto a grande originalidade de Perelman na abordagem destas questões reside numa deslocação essencial. Vimos já que se tratava de salvaguardar a racionalidade presente em todos aqueles raciocínios que, por fazerem intervir valores e pela sua aplicação situada e concreta, eram insusceptíveis de formalização; de, portanto, conciliar a sua dimensão pragmática com um estudo teórico que os permitisse tematizar.

59 Sá, p. 25.

60 Sá, p. 28.

61 Sá, p. 13.

62 Idem.

63 Sá, p. 29. 
para fazer o que Nancy Fraser define como a necessidade de repensar a esfera pública ${ }^{64}$, algo que ela vai defender que deve passar por, ao contrário do que se pressupõe em Habermas, existirem não uma esfera pública la burguesa é a que acabamos por conhecer melhor, dela nunca nos afastando suficientemente, como sabemos desde o Lefèbvre da Critique ${ }^{65}$ ), mas muitas $^{66}$. Mais, What is at stake, for her, is not just discourse-exchange but how stratified such publics should be, and how closely each is tied to the institution of decision-making. ${ }^{67}$

A arte pública será então a plataforma de uma concatenação exemplar labstracta na sua dimensão mental e ao mesmo tempo pragmática e efectiva, na sua dimensão quotidiana) de todas as retóricas? E naturalmente que dessa plataforma se espera um espaço de investimento na informação, na participação, no envolvimento que redimam o entendimento. Este é um programa de crítica integrada da mentalidade da burguesia tardo-capitalista e tecnocientífica.

O declínio da retórica, a partir dos finais do século XVI, deveu-se à ascensão do pensamento burguês, o qual generalizou o papel da evidência, trata-se da evidência pessoal do protestantismo, da evidência racional do cartesianismo ou da evidência sensível do empirismo. O menosprezo pela retórica e o esquecimento da teoria da argumentação levaram à negação da razão prática, sendo os problemas da acção ora reduzidos a problemas de conhecimento, isto é, de verdade ou de propabilidade, ora considerados como em nada relevando da razão. ${ }^{68}$

Voilá! O trabalho da comunicação exige uma atenção à situação em que essa comunicação se desenrola e que, quando se abre à participação, exige um conjunto de preocupações estruturais relativamente ao que não deve ser objecto da transparência e da visibilidade, ou ao próprio contexto do acontecimento comunicativo. Retórica e pedagogia, retórica e cognição, passam nestes termos a terem de ser entendidas conjuntamente, sob o 'chapéu' do género epidíctico: [...] o género epidíctico é central, pois o seu papel é o de intensificar a adesão a valores sem os quais os discursos que visam a acção não poderiam encontrar a alavanca para comover e mover os seus auditores. ${ }^{69}$ É por isso que quando o discurso artístico se orienta para a política - ou seja, para a argumentação sobre os possíveis -, tem de ter formas de se revelar como intenção (proposições, Miles) num esforço de adaptação do seu logos ao auditório). É que, na busca de adesão para uma tese - pensemos em Barthes quando menciona a importância do prazer do texto - não se pode, então, apresentá-la, à partida, como uma tese já aceite pelos auditores. ${ }^{70}$

\section{Fraser, p. 518.}

65 Principalmente o terceiro volume.

66 Fraser, p. 518. Fraser sublinha que the problem is not only that Habermas idealises the liberal public sphere but also that he fails to examine other, non liberal, non-bourgois, competing public spheres. Por extensão, a Habermas escapa o poder de inscrição da totalidade experiencial de que a arte, nos seus momentos é capaz, e de forma tanto mais crucial quando se revela cognição, conflito, tensão irredutível, ponto crítico. Aliás, é nestes termos que podemos encarar os desafios estilísticos de sucessivos movimentos artísticos - rupturas e não apenas estéticas - enquanto politicas da estética como dirá Rancière. $\mathrm{O}$ que é evidente quando a arte dá a ver comunidades obscurecidas pela hegemonia, ou tão somente o outro em diálogo, assim definindo novos espaços públicos de aparição e visibilidade.

67 Idem.

68 Perelman, pp. 26-27.

69 Idem. Note-se que, na arte moderna e contemporânea, muitos criadores não querem deliberadamente comunicar, ou persuadir: isso não me impede de ver no seu trabalho ainda uma comunicação, a da divisão cultural que os seus trabalhos relevam.

70 Idem, p. 42. 
Daniel E. Gross, em The Secret History of Emotion, propõe uma nova retórica das paixões ou se quisermos, uma genealogia das emoções numa perspectiva retórica. ${ }^{71} \mathrm{Na}$ senda de Espinosa, Gross sublinha que sentimentos e razão/racionalidade não são (termos) mutuamente exclusivos ${ }^{72}$ :

Rather than seeking to understand the emotions in their biological, psycho-physiological and evolutionary underpinning and significance, or in terms of their relationship to reason and rationality or cognition, we are better off focusing on their socio-historical-cultural construction. That is to say, on how the emotions are constructed differently at different times in history, differently for different individuals or groups, and in different social and cultural contexts. ${ }^{73}$

Gross, numa frase lapidar, resume o cerne do seu/meu próprio programa: Rhetoric is an inventive attitude toward language and the world, where 'emotion' names one important way in which language and the world connect. ${ }^{74} \mathrm{~A}$ categoria complexa da emoção (pathos) define assim os contornos de um campo social dinâmico, manifesto tanto no que é experienciado como no que é esquecido, respeitado, sancionado ou silenciado ${ }^{75}$. É uma posição que estabelece a ligação entre a crítica do quotidiano de Lefèbvre e a non-representational theory de Thrift Though they are obviously materialized in brains, faces, bodies, and even objects and architecture (e.g., tombstones, amusement parks), emotions clearly exceed the merely ideal' ção' total, ancorada na fenomenologia da urbanidade - the most appropriate way to approach emotions is phenomenologically - that is, by starting with the concrete manifestations of emotions in a meaningful world, as opposed to a world of mere matter. ${ }^{77}$ Numa obra que é devastadora para alguma neurobiologia contemporânea que esquece a dimensão social da emoção ${ }^{78}$, Gross confirma-me intuições muito remotas acerca da constituição psicosocial da emoção. 0 pensamento de Gross situa-se numa linha de crítica genealógica (Foucault) que recua, por via da análise de obras literárias, até Aristóteles para traçar vários momentos de uma história de obscurecimento do real para que deste subsista, ao nível das instituições, uma gramática do sentir reduzida e sobretudo escassamente distribuída. 0 autor explicita o seu projecto:

[...] to reconstitute by way of critical intellectual history a deeply nuanced, rhetorical understanding of emotion that prevailed until the triumph of psychophysiology; second, to show by way of literary and philosophical example how this rhetorical perspective helps us read anew the the emotional complex of modernity, whether early or late. In doing so, I demonstrate that early modern theories of emotion in the Aristotelian vein can inform Judith Butler's recent efforts to integrate politics and psychoanalysis. ${ }^{79}$

71 Chokr, Nader N.; «On a Genealogy of the Emotions from a Rhetorical Perspective», in Ephemera, vol 7(2), pp. 381-394, 2007. [Gross] uses the terms 'emotion' and 'passion' without invoking a strict distinction. However, the more familiar term 'emotion' signals in general a contemporary perspective, while that of 'passion' indicates a more historical and antiquated perspective, or alternatively, vehemence and excessiveness in the expression of one's emotions.

72 Pascal já o havia deixado claro, na célebre afirmação de que 'o coração tem razões que a razão desconhece'. Para Martha Nussbaum, emotions have cognitive-evaluation dimensions as they are "suffused with intelligence and discernment," and somehow "contain in themselves an awareness of value or importance." This "awareness of value" means that ethical discourse must take account of the emotions; and that morality cannot be reduced to a system of principles to be grasped somehow by a detached intellect. Subsequently, a central part of articulating and developing an adequate ethical theory must consist in articulating and developing an adequate theory of the emotions. Idem, p. 383. Nussbaum, vai por outro lado, afirmar que as dimensões cognitiva-intencional-avaliativa são particularmente claras na articulação narrativa, particularmente aptas a revelar o esquema de fins, planos e objectivos, que cada pessoa elabora relaciona na sua história de afeições face aos outros, aos valores, ao mundo dos objectos.

73 Idem, p. 383.

74 Gross, p. 15.

75 Idem.

76 Chokr, p. 385.

77 Idem.

78 O autor expõe as fragilidades éticas do discurso do neurobiólogo Manuel Damásio.

79 Gross, p. 8. 
Estas são teorias da injustiça emocional, sintonizadas com a redistribuição do sensível como proposta por Rancière e articulável com modelos de teoria crítica contemporânea, de Agamben (dispositivo) a Laclau (emancipação). É uma tradição que pensa a retórica na/ como história da divisão cultural, e não tanto como técnica de persuasão ao serviço de uma autoria. É uma retórica cuja dimensão cívica é crítica, acompanhando a ideia neo-estóica de Martha Nussbaum de que existe uma relação recíproca entre agentes e as poderosas forças da construção social ${ }^{80}$. E que é uma relação em que a imaginação (Marcuse, Mills) assume diferentes papéis em diferentes emoções, conduzindo à questão da multiplicidade de registos na participação. Em suma, é possível que o principal problema do projecto (político) moderno seja a incapacidade de integrar a retórica na sua racionalidade dividida. Se soubermos ler na arte os sinais destas questões, compreendemos que esta 'história secreta' da distribuição das emoções ${ }^{81}$ tem sido precisamente pouco desenvolvida pelos estudos artísticos porque a estes tem faltado a perspectiva retórica.

A verdade é que Historical rhetorics remind us that, however real and consequential they might be, the institutions that help shape us are ultimately of our own making and therefore are subject to change. ${ }^{82}$ Ora daqui já se infere a dimensão cognitiva da arte pública ao propor a contínua reconfiguração de categorias fundadoras da vida psicosocial como é o caso, determinante, da categoria de Espaço Público e todas as instituições que definem as formas que o desenham, ou das modalidades e modelos artísticos reificados pelo campo da indústria artística. Trata-se de, com Vico, a arte experimentar esse poder difuso de tornar performativa a vida pública, num drama que define um campo de actores sociais e seus valores. Mais, "Political rhetoric" would then run deeper that a politician's hollow pitch, and we would look for political dynamism beyond the representative public sphere. ${ }^{83}$ Portanto, se as coisas podem sempre ser de outra maneira (Miles) e assumir outras formas, isso tanto é valido para as formas artísticas como as não artísticas, como ainda para a relação entre ambas (como Lefèbvre sublinha e hoje Boris Groys, Ted Purves, Grant H. Kester, Brian Holmes ou o próprio Malcolm Miles reiteram). É um programa de atenção ao real que começa (invariavelmente?) com uma atenção romântica à pessoa humana. ${ }^{84} \mathrm{Na}$ cidade, trata-se de valorizar a situação e o contexto (DADA, Situacionistas), no enfiamento do eixo 'horizontal' de uma performatividade especificamente urbanístico-arquitectónica ${ }^{85}$ que, nos termos de Catherine Grout, é algo da ordem da arquitectura-jardinagem. Na forma urbana, a grande questão é assim a de cotejar uma ideia de retórica urbana com o que se sabe, por um lado, da pulsão artística (Fiedler), por outro, da carência específica da arte do povo (Wagner). Ao

80 Chokr, p. 392.

81 Idem, p. 5. Descartes proposed the reductive psychophysiology of emotion that informs both romantic expressivism and latter-day sciences of the mind and brain [...] one goal of this book is to simply to recall that we do not just naturally express emotions converging on our amygdala or wherever, but rather that we are first constituted as expressive agents by what the philosophers of the Scottish Enlightenment called 'social passions'. Contrary, however, to these optimistic philosophers such as Francis Hutcheson and Adam Smith, who tried to anchor social passions in a moral sense equally shared by all, I argue that the constitutive power of emotions depends upon their uneven distribution.

82 Gross, p.13.

83 Idem, p. 14.

84 Perelman, p. 47.

85 Idem, p. 48. 
fim e ao cabo, Politics is about moving people, ${ }^{86}$ e portanto, as emoções exigem condições específicas, que se concretizam num mundo de investimentos emocionais, em que algumas pessoas têm significativamente mais oportunidades de sentir que outras.

\section{3.1.2.2 Retórica e espaço público quotidiano}

Para abordarmos a questão da relação entre retórica e espaço público podemos continuar por uma nota nietzscheana, enquadrar a questão em Arendt, face a Habermas. Como se cria e concebe um espaço púbico democrático com base na linguagem (logos)? É aqui que Arendt e Habermas divergem. Habermas, para todos os efeitos mais platónico que aristotélico ${ }^{87}$, define nas suas primeiras obras o espaço público como o conjunto de pessoas privadas fazendo uso público da razão ${ }^{88}$, no quadro de um modelo de mediação entre sociedade civil e o estado, cujo cânone é a esfera pública burguesa que nasce com o iluminismo. É um espaço de debate racional, sob a figura estrutural do consenso. Mas esse é um espaço hoje virtualmente impossível, desde logo porque há a necessidade de os actores operarem fora de redes disciplinares existentes ${ }^{89}$. Na sua Teoria do Agir comunicacional (1981), o próprio Habermas vai para além desta tipificação do espaço público burguês, considerando a sua dissolução com o advento da sociedade de massas. ${ }^{90}$ Donde que há que estabelecer-se uma ligação-chave entre racionalidade (puramente) argumentativa e racionalidade (situadamente) retórica, em toda a complexidade do socius actual.

A ideia essencial é a de pragmática universal, conceito articulado com a regulação ética das condições da argumen-
tação, fundada numa moral do orador, que é obrigado a colocar-se no lugar do outro e submeter-se a um conjunto
de condições, como, por exemplo, a sinceridade, quando toma a palavra. Se, para Habermas, o espaço público é
caracterizado pela racionalidade, verdade, normatividade e pela argumentação, vigiada de muito perto pela ética, o
pensamento de Hannah Arendt distancia-se, largamente, destas noções e elege como seu modelo canónico a esfera
pública grega, domínio da confrontação política, marcado pela mediação da linguagem, cujo instrumento comunica-
cional é a retórica. É o espaço onde homens livres competiam entre si pela palavra, o território, por excelência, da
vida política, caracterizado pela praxis (acção) e a lexis (discurso). Estruturada pelos valores agonísticos da retórica
(coragem, glória, competição), a cidadania grega implicava a assumpção de um espírito de luta baseado em disputas
verbais, visando persuadir a assistência. A polis grega era, também por isso, o espaço da afirmação e reconhecimento
de uma individualidade discursiva."1

Arendt parece-me mais realista na busca de um espaço público total contemporâneo, precisamente porque à dialéctica (iluminista) habermasiana, que é uma teoria da argumentação, contrapõe as noções de opinião e persuasão e uma racionalidade propriamente retórica. Inspirada em Aristóteles, conduz-nos a uma aproximação à polis como obra de arte total le não apenas palco da política). São já duas as consequências desta visão: a arte pública - a arte do espaço público - é um exercício de outras economias (Bataille) emocionais (implican-

86 Idem, p. 61.

87 Sá, p. 17: O pensamento platónico manifesta-se, aqui, próximo do pensamento de Habermas, ambos coincidindo na insistência sobre os conceitos da razão, da verdade e, implicitamente, concordantes nas possibilidades de controlo da linguagem, reduzindo-a a um plano instrumental, neutro, inerte, assim como uma espécie de máquina tradutora do pensamento.

88 Habermas, Jürgen; Mudança Estrutural da Esfera Pública, Tempo Brasileiro, São Paulo, 1984.

89 Miessen, p. 24.

90 Sá, p. 11.

91 Idem. 
do excessos); ao deixar que a sua atenção se concentre em determinados fenómenos (e não noutros), partilha de uma certa racionalidade psicosocial - expressiva-cognitiva-comunicacional - que encontra no dispositivo, no projecto, o seu momento de afirmação. Tanto mais retórica a arte na forma urbana, mais ela contribui para uma racionalidade impura de que a polis, a cidade, ou a comunidade e a civilização necessitam para existirem enquanto tal, muito em particular no cenário de depauperamento emotivo-experiencial pós-moderno diagnosticado por Lefèbvre, Vattimo, Lipovetsky ou o próprio Perelman. Hoje, com as indústrias culturais pervasivas, deparamo-nos com uma sensação de náusea, de ausência de transcendência, em grande medida pelo facto de esses eventos sempre 'novos' não trazerem consigo experiências realmente renovadoras, mas tão só um depuramento técnico da linguagem artística e dos modelos de apresentação vigentes (hegemónicos, Gramsci).

Daí a importância de enquadrar a relação entre arte e social por via da retórica (e não apenas pela estética (filosofia) ou história (de arte) tradicionais. A importância da Critique de Lefèbvre para sustentar esta visão retórico-dialéctica da arte na cidade é por tudo isto fundamental e esse facto fará com que todo o edifício crítico por detrás das reflexões que se seguem parta das teses de Lefèbvre acerca do quotidiano, essa categoria filosófica no seio da qual a arte, o campo da arte e especificamente uma determinada abordagem da possibilidade arte têm assumido posições programáticas ${ }^{92}$. Naturalmente, perante a esfera do social e do político, enquanto discursos, as palavras-chave que a massa crítica acaba por associar a estes projectos definem um campo semântico: democracia, revolução, espaço público, participação, ecologia, comunidade... estes termos - chavões - dão resposta a aspirações concretas, imediatas, desesperadas e urgentes de muitos criadores, mediadores no campo artístico e cultural. Mais uma vez, by making alienation 'the key concept in the analysis of human situations since Marx' Lefèbvre was opening philosophy to action: taken in its Kantian sense, critique was not simply knowledge of everyday life, but knowledge of the means to transform it. ${ }^{93}$ Neste sentido os projectos críticos decorrem de uma emergente sociedade da informação (capitalismo cognitivo94) que, na continuidade entre sociedade de consumo e da sociedade da comunicação (Cauquelin, Millet), vão conferindo à experiência criativa da cidade um papel cada vez mais reduzido e paradoxalmente mais importante, papel esse cujo valor de troca reside na consciência da sua potencialidade retórica (Miles). Há que reconhecer a este nível o papel do que Lefèbvre identifica como o problema das tácticas e das estratégias. Em vários eventos encontramo-nos com esta dimensão ora táctica ora estratégica da invenção da cidade, nos seus interstícios. Porém a visão empobrecida (muito pela democratização acrítica da história de arte) dos conceitos operatórios (que o jargão da indústria cultural e do mundo da política como espectáculo amalgamam) levou a que muitos agentes culturais interpretassem cada evento como um comentário mais ou menos localizado a paradigmas concretos e não, o que seria mais importante, enquanto uma posição intelectual de fundo - fundamental - que, independentemente da diversidade de formas

92 Cf. Johnstone, Stephen, The Everyday, The MIT Press, London, 2008.

93 Michel Trebitsch, in «Preface», Critique of Everyday Life, Vol. I, Verso, London/New York, 1991. Por isso se me afigurou adequada a percepção de Anne Cauquelin, da arte moderna como aspecto do regime do consumo.

94 Boutang, Yann Moulier; Le Capitalisme Cognitif: La Nouvelle Grande Transformation, Multitude, Paris, 2007. 
que encontrou para se exprimir, é sempre a mesma. Isto é, a haver uma ciência do homem ${ }^{95}$, na senda do logos contemplativo do humanismo aristotélico, ela tem de ser procurada, exercida, vivida no quotidiano contingente, que alimenta a micro-história e os momentos de redenção que cada ser em processo de auto-consciencialização inevitavelmente realiza.

A noção de táctica torna-se aqui modo de apropriação da figura do Amador:

It is a matter of discomforting fact that amateurs often grasp situations they are not technically trained to comprehend. Michel de Certeau, in his Practice of Everyday Life, claimed that the ways in which "users" take up the world that confronts them is "tactical": canny, improvised, and aware of the abstract codes and structures that are established around them. Users - or "people", in everyday terms - have ways of inverting the supposed power dynamics in a given situation such that, to paraphrase Certeau's, the weak become strong. ${ }^{96}$

Estes conceitos motivam, quando lidos de forma trivial, abordagens menos rigorosas da linguagem projectual; mas quando são função do entendimento dos projectistas acerca das condições e contingências tácticas e estratégias que a sua arte, enquanto dispositivo - nomeadamente retórico - assume no jogo social e político, tornam-se formas genuinamente eivadas pelo ethos antropológico. Concluo regressando à noção de quotidiano, mas agora para sublinhar a sua potência instrumental pelo menos desde que, na Antiguidade, a arte do discurso e a boa vida começaram a aproximar-se mutuamente:

The genealogy of the concept of the everyday life can be traced much further back, and the net cast more widely. Mike Featherstone finds echoes of the concept all the way to Antiquity, and draws on phenomenologicalas well as Marxist traditions. The Ancient Greek philosophers paid meticulous attention and were in ongoing debate, about what made the 'good life'. 97

\section{3.1.2.3 No séc. $\mathrm{XX}$, fundamentos de um raciocínio}

No terceiro quartel do séc XX, o regresso da retórica acompanha a descoberta do discurso (estruturalismo) e uma evolução específica da arte (arte conceptual). Quando o seu corpo teórico se tornou representativo - Habermas, Perelman, Eco, Gadamer, Barthes - já se pode falar de um rhetorical turn, que a arte crítica transporta: é sempre nos momentos em que os velhos modelos intelectuais, logo culturais, se esgotam que a retórica renasce ${ }^{98}$.

A retórica da arte pública brota do impasse na arte contemporânea enquanto campo moribundo. Curioso é estabelecer paralalelismos entre a arte crítica e certa política emancipatória, de Maio de 68 - o que nos interessa sobremaneira - o 25 de Abril, revolução que contra todas as expectativas, no wit do momento, espetou cravos nas espingardas e foi cantada como pacífica redenção colectiva: A retórica, quer queiramos quer não, funciona sempre como libertadora das velhas ideologias, ainda que a sua fraqueza seja a de apenas propor a abertura que a sua existência testemunha, permitindo que se instale o pensamento novo que a combate..$^{9}$ De qualquer forma, a retórica não se dá apenas nos grandes movimentos

\footnotetext{
95 A questão de uma antropofilosofia (na linha de Steiner) caberia aqui.

96 Miessen, Basar, in Miessen, Basar (eds.), p. 28.

97 Papastergiadis, Nikos; «'Everything that surrounds: Art, Politics, Theories of teh Eeveryday», in Johsntone, p. 69.

98 Carrilho, Meyer, Timmermans, p. 231.

99 Idem. Soa ao programa de Salgueiro Maia, militar responsável no levantamento democrático português de 74.
} 
de massas e suas súbitas efervescências passionais; é ao nível quotidiano (Lefèbvre) que podemos compreendê-la como o poder da conversação (Kester) e do diálogo (Buber), desde logo na base de um urbanismo radical alheio ao mainstream instalado da gestão das cidades: ela consiste na negociação da divergência entre os individuos no que diz respeito a um determinado assunto. ${ }^{100}$ Este omnipresente - e quotidano - logos retórico é ambivalente; é o preço a pagar para o Homem aceder a uma racionalidade total da sua existência urbana, discursivamente partilhável, crítica do positivismo lógico (por exemplo da estatística): 0 objecto desta teoria é o estudo das técnicas discursivas que permitem provocar ou aumentar a adesão dos espiritos às teses que se apresentam ao seu assentimento ${ }^{101}$. É uma adesão que hoje como nunca é proporcionada pelos mais variados media, numa esfera pública - sera que o nome ainda é pertinente? - tecnologizada. Aí temos Habermas - e Heidegder superados (Duque), de resto acompanhando as provocações proposicionais das obras de arte em que o pensar acontece. É por isso que as neovanguardas da arte (pública) não apenas fugiram de uma posição não-retórica em que porventura se encontravam confinadas (representação, símbolo); elas introduziram uma ansiedade especificamente retórica no âmago da acção plástica (produção, alegoria, aforismo.

A arte contemporânea mais radical - pós-media, contextual, dialógica, relacional... - torna-se assim como que uma arte já para além da arte, se pensarmos na arte contemporânea que, nas instituições 'apropriadas', nada diz à cidade e aos seus públicos (Duque). Afinal, se o real é em si um argumento ${ }^{102}$, este novo realismo retórico cria um auditório que já não o utópico, mas o de um futuro possivel agora. Esse futuro sente-se - Aristóteles afirmou- o e hoje a retórica contemporânea apregoa-o: Não falamos aqui de paixão, mas antes de sensibilidade ou de sentimento, duas noções fortemente conotadas com o romantismo e por ele ressuscitadas..$^{103}$ Estamos de novo em Schiller - e concretamente na hermenêutica de Schleiermacher ${ }^{104}$-, num paradigma de educação/formação estética para a contínua redistribuição do sensível (Rancière), revitalizando a festa e os símbolos (Gadamer). Em Aristóteles, para quem a retórica é a maneira de nos apropriarmos não propriamente da techne, mas da dynamis do social, onde houver retórica, havia verdade lo que vai completamente contra o senso comum); o falar-verdade da retórica, hoje, encontra eco na universalidade da hermenêutica (Gadamer), donde retórica e arte, não sendo sendo equivalentes, ocupam um mesmo espaço comum problematológico ${ }^{105}$. Ora problematizar é indissociável do que afirmei no inicio desta secção como a unidade da tripartição retórica, porque laborar nesta tripartição é continuamente antever auto- e criticamente o que (e como) cada facto (ou acto) diz perante cada nova pergunta. Olavo de Carvalho diz por isso que Aristóteles entendeu genialmente o que mais ninguém depois dele percebe: o ethos, o pathos e o logos estão em pé de igualdade na relação retórica. Desintegrar pontualmente esta unidade dinâmica - como o próprio Aristóteles faz, apesar de tudo, no sentido do logos... - é já uma operação de

100 Idem, p. 233. Existe uma questão que os opõe, uns aos outros, e por outro lado, respostas que os ligam uns aos outros.

101 Idem, p. 241.

102 Idem, p. 244.

103 Idem. p. 246.

104 Hermenêutica como arte de compreender o sentido do discurso, prática com sucesso apenas quando engloba os elementos gramatical e psicológico.

105 Carrilho, p. 266. 
qualicação e valoração de aspectos da realidade, da quotidianeidade. E assim se desenha na ars publica um ethos projectual de humildade da atenção, uma moral projectual, sempre dinamicamente inscrevendo-se no tecido de novas oportunidades e situações.

Concluo, reparando como o pensamento único do consumo, da publicidade ${ }^{106}$ e da propaganda são o oposto da retórica: Mas como é possível conferir direito de cidadania às questões (perguntas), quando o modelo de pensamento e da linguagem é construído sobre a sua neutralização sob a forma de solução? ${ }^{107} \mathrm{Na}$ arte pública crítica, cidadania criativa de um logos urbano que a arte nos convida a viver como encontro, sob signo redentor da graça social. A arte crítica nunca pode ser puro exercício argumentativo ou raciocínio dialéctico ${ }^{108}$ - o carácter que adquire a política representacional na sua dimensão mais abstracta -, mas propriamente o questionar continuado da cidade, a partir de dentro do processo da vida urbana, apaixonadamente ${ }^{109}$

É o cenário do pathos, no qual os individuos se confrontam directamente e no qual o acto de por as coisas em causa é mais directo (paixões) e, por conseguinte, longe de haver referência à norma, quem é atacado são aqueles que a promulgam. Foi por esta razão que Aristóteles fez deste cenário a sede do género deliberativo ou politico.110

Sintetizo:

Tudo isto nos leva, naturalmente, a debruçarmo-nos sobre as três componentes da relação retórica. Relembro que se trata de negociar a distância entre um sujeito e o seu auditório acerca de uma determinada questão. Quanto a esta, podemos eliminá-la, resolvê-la a priori ou proceder como se, pelo simples acto de tomar a palavra, ela desaparecesse com se estivesse resolvida. ${ }^{m 1}$

Ora se nos ativermos à questão da legitimidade da arte (do belo) face ao social (o sublime), assim como da actividade artística face à pragmática quotidiana, é evidente que

While Aristotle maintained the practical character of every instance of knowledge, he made a significant distinction between forms of knowledge. He ordered them, as it were, in a hierarchy of value whose nadir is functional acquaintance with the necessities of everyday life and whose zenith is philosophical knowledge. The latter has no purpose outside itself. Rather, it ocurs only for its own sake and to afford men felicity. Within this hierarchy there is a fundamental break between the necessary and useful on one hand and the "beautiful" on the other. [...] Separating the useful and necessary from the beautiful and from enjoyement initiated a development that abandons the field to the materialism of bourgeois practice on the one hand and to the appeasement of happiness and the mind within the preserve of "culture" on the other.

106 A publicidade, dizia eu, não é retórica por apresentar as questões anuladas. Idem, p. 270. Para David Harvey, a publicidade é a arte oficial do capitalismo e introduz a arte nessas mesmas estratégias, manipulando carências e desejos na direcção do gosto e do consumo.

107 Idem, p. 269.

108 Idem, p. 274. Na lógica [...] as questões são resolvidas eliminando a priori aquelas que poderiam ser suscitadas pela «resposta» apresentada. Dizem respeito ao sujeito ou ao predicado. Em retórica não é possível excluir essas questões e, mais ainda, devese incluir o possível acto de pôr em causa o próprio orador, de pôr em causa a sua legitimidade para estabelecer esta relação sujeito-predicado, logo a sua legitimidade para formular esta relação sujeito-predicado, logo a sua legitimidade para formular um juízo acerca do sujeito em causa.

109 Idem. O pathos designa o auditório com as suas paixões e os seus problemas. Qual é a relação entre paixão e a problematicidade existencial? A questão é tanto mais difícil quanto há já dois mil anos que as paixões deixaram o campo da retórica. Aristóteles - sempre ele - consagrou-lhes todo o segundo livro da sua Retórica, mas foi praticamente o único. Depois dele, as paixões passaram a pertencer ao domínio da psicologia, da medicina, depois de, com o cristianismo, ter sido reduzidas à categoria de pecado.

110 Como é que o logos traduz a interrogatividade? Sempre que falamos, sempre que utilizamos a linguagem em geral, fazemo10 com uma pergunta em mente. Comunicamos a resposta a essa pergunta se pensamos que esta última interessa ao Outro. Mas podemos perfeitamente solicitar-lhe a resposta se acharmos que é ele que a pode fornecer. Tudo isto faz com que o par fundamental do espirito, assim como da linguagem, seja a diferença pergunta-resposta, também designada por diferença problematológica. Idem, pp. 281-282.

111 Idem, p. 277.

112 Miles, p. 67. 
A alternativa, um mundo de retórica (e não de filosofia, ciência, técnica, tecnociência), aporta Aristóteles a novas formas de consciência do logos total do mundo. ${ }^{113}$ Ou seja, se há uma genealogia de reflexão política que é de base idealista porque coloca a experiência das ideias no cerne de uma evolução social identificada com o futuro a que o Homem aspira, Marcuse explicitará, relativamente ao facto de Aristóteles, a dada altura, abdicar de colocar a reorganização da sociedade no cerne da filosofia, que:

Behind the ontological and epistemological separation of the realm of the senses and the realm of Ideas, of sensuousness and reason, of necessity and beauty, stands not only the rejection of a bad historical form of existence, bt also its exoneration. [...] the material world remains bare matter or stuff for something outside it which it alone gives it value. All and any truth, goodness, and beauty can accrue to it only "from above" by the grace of the Idea. ${ }^{114}$

A questão é importante na medida em que desvela a operatividade (ou não) uma alternância entre uma graça 'de cima' - ou acima, em sede de iluminação pelo logos - ; e uma graça bottom up, resultante da entrega experiência total, nomeamente sensual, afectiva, do 'baixo', sob a forma de atenção (ou se quisermos compaixão) não-verbalizável. Uma leitura cuidada das consequências de Aristóteles permite por isso repensar anacronicamente a principal dynamis de Duchamp, das neo-vanguardas e depois da arte crítica pública, através da verticalidade da tensão, nas obras, entre os termos palavra-corpo ou ideia-performance.

Obscurecida por séculos de dominação por um logos redutor-reduzido, eis a pertinência emancipatória, à luz de Aristóteles e da retórica, de Bataille (por uma nova economia), Gross (pela humildade), Rancière (pela redistribuição do sensível), de Thrift (pelo valor do não-representacional), de Olavo de Carvalho (pela rejeição da tecnociência em sede de totalidade aristotélica), Buber, Freire, Bakhtin, Ardenne ou Kester (o elogio do contexto, do diálogo, da conversação), Varela e Maturana, Capra (por uma consciência do sistémico), Deleuze e Guattari (pelo interesse do encontro da arte com a verdade do sentido ecológico)... Obviamente para não falar dos múltiplos dispositivos propriamente artísticos que Beuys, Smithson, Kaprow, Wodisczko, Acconci, Christo ou Alys criam e recriam no tecer da cidadania contemporânea. Na arte crítica, essa é a genealogia e a tradição que importam, aquela que, aos lugares comuns da comunidade ou da democracia contrapõe os lugares próprios (Carilho, Meyer, Timmermans) daquilo que está em questão - dando substância experiencial a conceitos que depois encontramos em Nancy, Agamben, Laclau, Rancière, Mouffe... Desde Quintiliano que isso está definido: quem, o quê, por que meios, onde, quando... ${ }^{115} \mathrm{Na}$ minha experiência de curador, descobri que a arte pública é crítica por ser transparente acerca destas questões e no concreto dos contextos que são destacados (temas), tal como as suas múltiplas derivas especificamente sociais - a arte conceptual mais activista, a land art mais mística, a community-based art mais colaborativa - comprovam. Em tudo isto a (participação na) forma (logos) exprime a articulação entre as esferas do possível, do real e do necessário. E então: Se o contexto for suficientemente informativo tanto acerca do problema como acerca do que não está em questão, a forma vai ganhar em liberdade relativamente

113 Miles, idem: In Aristotelian philosophy, ancient theory is precisely at the point where idealism retreats in the face of social contradictions and expresses them as ontological conditions. [...] And the authentic, basic demand of idealism is that this material world be transformed and improved in accordance with the truths yielded by knowledge of the ldeas. Ao que Perelman mantém: [...] os valores abstractos servem mais facilmente a crítica e estarão ligados à justificação da mudança, ao espírito revolucionário.

114 Idem.

115 Carilho, Meyer, Timmermans, p. 280. 
à necessidade de formalização da diferença problematológica. ${ }^{116}$ Noutras palavras, isso implica uma liberdade em relação às tradições de que tanto os linguistas como os lógicos raramente fazem prova. ${ }^{117}$ Isto é fundamental quando, perante duas obras 'formalmente' semelhantes - por exemplo a 'mesma' obra dentro e fora de um museu, ou obras com características originais próximas realizadas em contextos diferentes - são na verdade portadoras de sentidos radicalmente diversos, podendo isso gerar perversas noções acríticas face ao funcionamento da arte pública como plataforma de cidadania.

Esta percepção retórica da arte é uma ideia com forte tradição nos estudos literários (mesmo se estes nem sempre lhe fazem juz, cedendo às questões específicas dos tropos e figuras), resolvendo impasses das perspectivas estéticas assentes em Kant (e que as posições pós-modernas, de Lefèbvre a Vattimo ou Perniola vieram enriquecer). Ora se, seguindo Adorno (Teoria Estética), a enigmaticidade é própria da arte e se tornou mesmo o seu valor de troca na época contemporânea; e se a arte é epifania do contexto urbano (Argan), pode um ethos curatorial retórico aspirar a orquestrar as suas variações especificas e fazer sentido? ?18 $^{118}$

Daqui entrevejo uma pedagogia da arte na contingência de cada contexto e de acordo com cada situação, isto é, um infinito e um informe definidos historicamente, uma praxis artística que pela problematologia retórica confere o direito de cidadania ao entendimento. É uma dialéctica total, situada, crítica e activa, uma super estética relacional. Nela, a arte faz a ponte, a síntese entre o antigo e o novo, exprimindo o novo a partir do antigo como uma metáfora deste último, mas também como uma ruptura tanto mais acentuada e formalizada quanto a História é ela própria provocadora de rupturas (Picasso), e a identidade, mesmo figural, não é já sustentável. ${ }^{119}$ É disto que se trata em Kafka, o génio de uma literatura menor (Deleuze/Guattari) que desvelou a aceleração da história e do progresso (Benjamin) através das imagens mais perturbantes. A arte crítica - caso de Kafka na esfera da literatura - é isso mesmo, problematicidade diferencial. Em resumo, quanto mais problemático o texto (ou a obra de arte),

pela sua textualidade, mais esse texto desconstrói toda e qualquer leitura simplesmente literal; e a demarcaão entre o literal e o não-literal, o unívoco e a pluralidade de interpretações equiplausíveis, acaba, de resto, por se jogar fora do texto, o que levou algumas pessoas a dizerem que estas categorias perdiam a sua pertinência porque remetem para uma diferença na qual um dos termos escapa ao produto textual propriamente dito. ${ }^{120}$

Estamos na órbita de uma contaminação da arte pela realidade que os formalismos modernistas, - apesar de opostos à trivialidade e à platitude (Gadamer) do/pelo quotidiano, através da criação - estavam incapazes de reconhecer como produtiva. É um pensamento textual (Barthes, na senda de Lefèbvre): A textualidade é um meio do qual é levada a cabo a passagem de um problema à sua resposta, e vimos que a forma desempenha um papel menor quando o problema é explícito, já que estamos próximos da linguagem quotidiana. ${ }^{121}$ Há neste

116 Idem, p. 282.

117 Idem, p. 280.

118 Idem. Só com a hermenêutica é que surgiu a preocupação de articular produção e recepção, mesmo que isto tenha sido feito mais uma vez a partir desta última.

119 Idem, p. 291.

120 Idem.

121 Idem, p. 292. 
urdir da obra como dispositivo textual um feitiço ${ }^{122}$, uma magia de captação do social que assombra o modernismo (e a sua recepção); muitas das suas formas mais problematológicas foram percepcionadas pela platitude de um regime da arte primeiro mercantil e depois também comunicacional, incapaz de perceber o valor pedagógico (Schiller) das conquistas formais (cognitivas, no jogo) de cada artista. Isto leva-nos à relação ente metáfora e figura, ou entre alegoria e actualidade, no coração de uma teoria da acção de base linguística-literária (como Rancière, d'après Barthes, sugere na ideia de escritura):

Os símbolos são utilizados como enigmas textuais que só podem ser resolvidos ao nível do texto como um todo [a autonomia formal da obra]. Uma maior problematicidade destes símbolos [a comunicação em ponto crítico] aumenta a dificuldade em passar do figurado a uma literalidade que responda ao enigma e retraduza o que não e imediatamente inteligivel. [...] A problematicidade [criticidade] torna-se, assim, o próprio objecto da resposta textual, em particular através daquilo que ela enuncia. O leitor deve agir, respondendo à questão levantada pela enigmaticidade da resposta textual. A própria textualidade acaba por ser como que a «significação» dos enigmas incluidos na linguagem figural, que é o seu próprio objecto, uma vez que esta textualidade já só se refere à sua própria exibição. ${ }^{123}$

Eis-nos no âmago da arte que é desalienadamente participativa (por oposição a trivial) e conscientemente colectiva (porque resiliente à hegemonia), pêndulo de um equlíbrio ethos-pathos-logos que é evidentemente mais verdadeiro na arte dialógica de Kester que na estética relacional de Bourriaud (sigo a avaliação de Malcolm Miles, relativamente à sua platitude). Eis-nos perante a arte que se encena como encontro com a arte e o real do socius ao mesmo tempo - o que é sempre passível de funcionar como ficção: $E$ a autocontextualização daquilo que está em questão que torna um texto ficcional. ${ }^{124}$ Poiesis semiótica, substitui a mimesis pela produção na exacta medida em que o texto se constitui como um código (Flusser). Se esta é uma conquista moderna - de Montaigne a Duchamp, é na arte pública crítica (Wodisczco) que o seu valor transformativo e emancipatório pode ser hoje percepcionado e eventualmente instrumentalizado (em toda a sua criticidade, isto é, para lá de demagogias democráticas ou igualitárias.

122 Idem.

123 Idem, p. 292. O aforismo é a forma máxima e simultaneamente mínima desta hipótese.

124 P. 292. O uso da linguagem figurativa é apenas a consequência deste processo, uma consequência variável como forma, mas que serve para caracterizar a ficção literária. [...] Isto só pode ser levado a cabo pela via indirecta de meios retóricos cujo objectivo é autocontextualizar os problemas. Em Kafka, a menoridade radical da literatura-dispositivo foi o tom que o artista definiu para os eu encontro (combate) com o real. 



\section{ENQUADRAMENTO HISTÓRICO: ARTE PÚBLICA CRÍTICA EM PORTUGAL}

A arte fascista faz mal à vista.

Vespeira

Desde os anos 60, vários artistas, eventos e obras enunciam em Portugal as questões críticas. O(s) sentido(s) ${ }^{1}$ específicos de cada obra decorrem de aspectos contingentes implicados na sua inscrição, mas destaco, a um nível geral, as ocasiões em que o 'palco' é tendencialmente também o 'tema' das intervenções (a cidade, a vida urbana, a forma urbana). Nesta viagem, enceto uma espécie de genealogia mítica da arte pública crítica em Portugal, um registo tão difícil quanto necessário (Isabel Carlos).

\section{1. Ruptura. Antecedentes e ressonâncias de Abril de 74 na cultura portuguesa}

Faz sentido avaliar o significado da obra de arte crítica em Portugal, tendo-se em conta o principal acontecimento do século, o 25 de Abril, revolução responsável por vertiginosa mudança na sociedade portuguesa $a^{2}$. Recupero um cluster de factos complexo e difuso; com distância histórica face aos dias vividos na aventura da descoberta [...] assumo Abril como património político, artístico e retórico, qual obra de arte total do Povo.

Portugal é durante todo o século XIX um país pobre a atrasado. Existia um contraste gritante entre a imagem real do socius português e a imagem construída pelo Estado Novo. ${ }^{3}$ Castelo-Branco \& Branco salientam a extinção da retórica de agitação com a supressão de símbolos e práticas como bandeiras vermelhas, comemorações, marchas, petições, greves, convívios, o

1 Sentido por oposição a significado, isto é, valorizando a dimensão do uso na comunicação (Wittgenstein).

2 Teixeira, Maria Eliana; Cruzeiro, Maria Manuela; «25 de Abril, Um Aventura para a Democracia. Textos Jornalísticos», p. 129.

3 Cf. Castelo-Branco \& Branco, 2003, p. 11. Para a construção de um universo simbólico que "ideologicamente" facilitasse of funcionamento sem sobressaltos do sistema politico que pretendia impor" (Félix, 2003: 211), o regime dotouse, a partir dos anos 30 do século XX, de diferentes organismos que vão executar a sua política folclorista, centrada nos conceitos de nação e de tradição, que visava a construção de um consenso nacional neutralizador dos seus conflitos globais (Braço, 1999). [...] De facto, a cultura hegemónica estadonovista que procurava "explicar aos portugueses a identidade de si" debelou resistências e suscitou o aparecimento de outras. Tal como notaram Castelo-Branco \& Branco (2003) suprimiram-se as estruturas do movimento operário independente bem como as suas expressões culturais nos espaços públicos, coincidindo a ilegalização das lutas de classe com a "emergência de uma imagética ruralizante que, neste contexto de ausência de competição pelo espaço público, nele de torna hegemónica! 
debate politico, entre outros ${ }^{4}$, ao mesmo tempo que uma cultura folclórica se afirma, à custa do País urbano. Ora o 25 de Abril chega como súbita ruptura. ${ }^{5}$ Com a liberdade, a democracia permitiu conquistar o direito de escolha, o direito à diferença ${ }^{6}$; o tempo revolucionário dos 'anos quentes' é de libertação e comunicação intensa, na contradição e no debate. ${ }^{7}$ O 25 vai assim estabelecer uma hipótese de esfera pública e uma série de parâmetros culturais os ideais de Abril. Em todo o caso, chegavam com o 25 de Abril o voto livre, mas também, logo depois, uma abstenção crescente. Foi-se percebendo que da experiência fugaz da liberdade à consciência continuada da cidadania vai uma relação por cumprir em Portugal. Mas de 1999 (25 anos do 25 de Abril) até hoje deram-se ataques a várias conquistas sociais, e a cidadania vai de novo batendo no fundo, empurrada pela ideologia neoliberal, dissimulada em discursos sobre a qualidade (de vida) ou o desenvolvimento (económico). Qualquer assomo de projecto colectivo (como no associativismo) é anulado pela divisão individualista dos interesses.

Com a entrada na Europa, a democracia portuguesa 'normaliza-se'; o que vai acontecer ao mesmo tempo que privilégios e interesses, de certos sectores da sociedade, inscrevem uma nova hegemonia cultural e uma 'indústria cultural' - que emula os modelos externos apressadamente $^{8}$, ou se deixa enredar em narrativas de 'modernidade' desligadas dos principais desafios éticos que se colocam à criação. A ausência de uma consciência profunda da retórica é a pedra-de-toque desta alienação de amplos estratos sociais dos destinos da cidade. ${ }^{9}$ Para esta investigação, o que importa é o aspecto mais prosaico e quotidiano de que, em democracia, Portugal - sempre poucochinho e em diminutivo $0^{10}$ - tem vindo a assistir a mudanças na forma urbana francamente mais rápidas - e irreversíveis - que a capacidade de reacção dos intelectuais, dos técnicos e mesmo dos políticos mais conscientemente activos na sociedade civil. $\mathrm{O}$ que tem criado muitos atentados à esfera pública em todas as suas dimensões - a paisagem, por exemplo - com pouca ou nenhuma reacção das classes criativas. Há uma narrativa da nossa alienação quotidiana que alguma arte contemporânea laliás como o cinema, com grande destaque, e a música de intervenção num certo período ${ }^{11}$ ) em geral tem vindo a abordar, mas que estranhamente está bastante ausente da arte pública, ao

4 Castelo-Branco \& Branco, p. 11.

5 Quase uma 'ruptura pela ruptura', ou se quisermos uma ruptura radicalmente generosa, sem intenções de poder, tendo-se em conta que depois de tomar o poder, os militares rapidamente se apressam a delegá-lo nas instâncias politicas, num processo inédito ao nível mundial.

6 In Liberdade e Cidadania - 100 Anos Portugueses, Exposição Integrada nas Comemorações Oficiais do Vigésimo Quinto Aniversário do 25 de Abril de 1974, Lisboa, 1999, p. 41

7 Teixeira, Maria Eliana; Cruzeiro, Maria Manuela; «25 de Abril, Um Aventura para a Democracia. Textos Jornalísticos», p. 129.

8 Numa inversão estonteante da anterior posição de isolacionismo, agora tudo o que vem de fora é que é bom!

9 Um comentário mostra como pode funcionar a consciência retórica face ao dispositivo político: 025 de Abril de 1974 foi, politicamente, o derrube do corporativismo por um movimento corporativo; foi socialmente, o rompimento com o conservadorismo pelos filhos dos conservadores; e foi, economicamente, a passagem pelo socialismo dos novos candidatos a capitalistas. Fonseca, Ana; Jornal de Notícias, http://www.jnoticias.pt/seccoes/mensagens.asp?871

10 Alexandre O'Neill.

11 Estavam onde era preciso, sempre que era preciso. Uma viola, um microfone e u estrado a fazer de palco era quanto bastava para que houvesse espectáculo. A pdoeia estava na rua eas vozes dos cantores davam-lhe forma de modo claro e preciso, que o tempo não era de meias-palavras. «Cantores desarmados», Viriato Teles, In Expresso, 25 de Abril de 1997 
contrário do que por breves meses caracterizou o processo revolucionário: Foi um tempo de grande generosidade e tudo aconteceu de acordo com esse empenhamento. ${ }^{12}$

Enquanto racionalidade pragmática (Carrilho), vislumbro na retórica da arte crítica pós-25 de Abril um modelo para exercitar a capacidade de indignação (Francisco Fanhais ${ }^{13}$ ). E de integrar essa capacidade perdida num logos colectivo, respondendo ao que José Gil nota em $O$ Medo de Existir, acerca da dificuldade da inscrição do discurso, quer do povo quer do indivíduo, no real social ${ }^{14}$ : Como reinscrever o não inscrito, como recuperar a memória do que não existiu (porque não foi dito, porque não aconteceu senão como não acontecimento? Porque há que o fazer - por razões de saúde (individual, colectiva, institucional) [.....$^{15}$ Nos momentos mais efervescentes de Abril (na Dinamização Cultural, nas Operações SAAL) esta arte da polis foi imperativo evidente; a capacidade de expressão teve de acompanhar a apetência para a liberdade, ${ }^{16}$ e diversos acontecimentos de arte urbana foram capazes de nos recordar que a solidariedade é um princípio da ética política. ${ }^{17}$ Esta questão de um cuidar compassivo, em oposição ao desinteresse egótico - é fundamental para desde já me aproximar de um ethos de envolvimento e de atenção, projecto cultural que vejo consubstanciado por Boaventura Sousa Santos numa articulação estruturante com o logos do dispositivo social: $A$ solidariedade traduz-se sempre numa rede de relações sociais, económicas, politicas e culturais. A tudo isto a arte pública crítica contrapõe a responsabilização dos agentes culturais face às formas, conceitos, imagens e experiências da arte na cidade, isto é no território (mas também na polis) como possibilidade. Esta questão prende-se com a inscrição da possibilidade do desenvolvimento; questão-chave ainda pelo que implica ao nível de percepção e depois da atitude perante o território, onde a cognição quotidiana é determinante ao nível da realidade total le bem-estar geral) dos indivíduos. Para os protagonistas das acções exemplarmente comunicativas no espaço público, a retórica da visibilidade ${ }^{18}$ - num contexto de apatia generalizada -, não é por isso qualquer oposição dialéctica entre 'evolução e 'revolução' que move os agentes críticos, cada vez mais conscientes de que tais antagonismos apenas alimentam quer a máquina mediática, quer as dos aparelhos partidários; e assim, vejo as atitudes dos artistas mais inovadores ao nível social, nestas décadas, como manifestações de profunda liberdade cívica. Eles propõem uma pedagogia le uma terapêutica. E se a cultura é o copo onde se põe o vinho dos afectos (Carlos Amaral Dias ${ }^{19}$ ), esta é uma hipotética genealogia extramuros, mostrando por um lado, que o movimento crítico internacional e global teve

12 «Cantores desarmados», Viriato Teles, In Expresso, 25 de Abril de 1997.

13 O termo tem adquirido forte actualidade, com a crise de 2011, nas palavras de Stéphane Hessel.

14 Gil, José; «O silêncio da história», in Público, 8 de Maio de 1994: Falta um anel na cadeia das responsabilidades que vem da ditadura do antigo regime até nós: [...] um vazio não dito [...] Silêncio inconsciente e apaziguador, que permitiu a Salazar reinar com um mínimo de perturbações politicas; silêncio psicogéneo, causador de fortes patologias e repressões, que explodiriam no 25 de Abril. [...] A situação é [...] armadilhada, inextricável, porque inclui os críticos na situação criticada (o sujeito da enunciação no sentido do enunciado): este tipo de inadequação entre a situação concreta do sujeito e o conteúdo do discurso é geradora de silêncio, de um silêncio inexplicável, irrecuperável, porque não inscrito na memória e na linguagem.

15 Idem.

16 Idem.

17 Boaventura de Sousa Santos, Público, 23 de Maio de 1994.

18 Vespeira de Almeida, p. 385.

19 Psiquiatra, na Rádio TSF. 
também em Portugal e na cultura portuguesa algum significado lainda que com impacto sócio-cultural relativamente reduzido ${ }^{20}$ e traços elitistas); por outro, que em iniciativas artísticas dispersas, algumas apenas vagamente relacionadas com a teoria ou a praxis crítica em sentido estrito ${ }^{21}$, irrompem com regularidade um sentido de interesse envolvido pelo social, associado a uma atitude ética que prefere o risco e a paixão à moda ou à estética instituída.

\section{1.1 Acções públicas na emergência de uma cultura de cidade: happening e animação cultural}

Em Abril de 1974, garantida a liberdade de expressão, há nuances na experiência democrática que nesta revelam faces problemáticas da experiência da liberdade. No dia 28 de Maio de 74, a revolução continuara a transvasar para as ruas. Cerca de uma centena de artistas reúnem-se para uma acção exemplar (e retórica?), numa altura em que ainda eram visíveis símbolos do regime deposto. Invadem o pátio do Palácio Foz, onde que se encontrava uma estátua de Salazar. O happening democrático que eclodiu (José-Augusto França) implicou um debate acalorado - sobre se se devia destruir a obra - , mas o colectivo decidiu-se pelo acto de cobertura da escultura de Francisco Franco com panos negros ${ }^{22}$. Naquele espaço semi-público, Vespeira imortalizou ali logo o slogan A arte fascista faz mal à vista! No wit do momento, o artista torna operacional o domínio da linguagem do logo-ali; ${ }^{23}$ foi um acto colectivo verbalizado no momento que assim ultrapassava a própria agenda dos novos governantes. ${ }^{24}$

Dias mais tarde, a 10 de Junho, Dia de Portugal, foram convidados 48 artistas ${ }^{25}$ para realizar uma obra colectiva em Belém ${ }^{26}$, ao vivo e em directo para a televisão, consistindo na monu-

20 Sendo certo que a intelliigentsia portuguesa cedo se apropria das inovações dos idos de 60 e 70 , notoriamente, por exemplo, com o contacto com os ecos da Documenta de Kassel em 72 - nota Wandschneider que isso nunca correspondeu, em Portugal a um amplo movimento de 'eco' social daquelas propostas, que fosse menos um espaço de afirmação da hegemonia do sistema da arte internacional e de seus valores, e mais um território para novas autonomias, isto é, capacidade de, incorporando modos de produção artística característicos do paradigma dominante pudessem desenvolver estilos originais alternativos a esse paradigma? Isto é, e de acordo com Wandschneider a partir de Carlo Ginzburg e Enrico Castelnuovo a propósito da relação centro-periferia nos movimentos artísticos e sua afirmação-implantação-visibilidade, olhar o caso português meramente a partir da comparação com o impacto dos movimentos artísticos e tendências europeus é um erro crasso, tanto mais que não funciona deduzir a validade de certas operações estéticas - o seu valor de inovação por exemplo - a partir de comparações com acções semelhantes ou congéneres anteriores (ou posteriores).

21 E mesmo dela completamente desconhecedoras -, ou seja em iniciativas que poderíamos definir como ingénuas, ou espontâneas.

22 Da acção chegou até nós uma fotografia e um desenho fotocopiado no espólio de Sena da Silva, em que vários dos protagonistas da acção estão identificados. Cf. Sena da Silva, Fundação Calouste Gulbenkian, Lisboa, 2009, p. 19.

23 Quantos de nós, neste espírito, não participámos já no impulso de rasurar, alterar ou pura e simplesmente destruir as imagens e os textos da propaganda política que nos incomoda? Já desenhámos bigodes, já furámos olhos..

24 Gonçalves, Rio Mário; «A Arte Liberta», in Vida Mundial, n. 15, Abril 1999, Lisboa, p. 85.

25 Dispositivo de transparência institucional na selecção de participantes: eram os primeiros 48 signatários do Movimento Democrático de Artistas Plásticos, que organizou a iniciativa..

$26 \mathrm{Na}$ Galeria de Arte Moderna (junto do Mercado do Povo e do Museu de Arte Popular), em colaboração com o MFA e com o apoio da RTP. 
mental pintura de um grande painel sobre o tema da liberdade. ${ }^{27} \mathrm{O}$ grupo de teatro COMUNA desenvolveu para ocasião um espectáculo único, ${ }^{28} \mathrm{~A}$ Cegada, inspirado nas cegadas tradicionais - em que foram satirizadas figuras públicas do regime sócio-político destituído. Precisamente quando o objecto da crítica trágico-cómica era o Cardeal-Patriarca, a emissão foi repentinamente interrompida, por instruções do Governo ${ }^{29}$. Num país (oficialmente) católico e em que vastas áreas do território estavam longe de sentir os ecos libertários dos centros urbanos, este foi o primeiro acto de censura realizado depois do 25 de Abril. Neste acontecimento, antes do mais ingénuo e um pouco anedótico [apesar da] sua autenticidade emocional e conjuntural, ${ }^{30}$ estavam presentes quase tantas posições estéticas quanto os artistas presentes, o que, se fragilizou a obra como discurso coerente, não deixou de a tornar uma monumental situação criativa, a experimentação da democracia-em-directo. ${ }^{31}$ Foi um grande lugar de inscrições de palavras e figuras, num irrepetível momento de euforia, ${ }^{32}$ presenciado por um público que, de tanto comprimir os artistas, lhes retirava mesmo as mais básicas 'condições de trabalho' e, ironicamente, a distância' necessária ${ }^{33}$. A verdade é que, ao mesmo tempo que os artistas profissionais realizavam a sua acção, crianças e adultos de entre o público encetaram as suas próprias contribuições para Festa: uma torre de tijolos logo ali pintada de forma colorida, inscrições num muro... Gonçalves atribui a estes factos o poder contagiante da criatividade. ${ }^{34}[. .$.$] transformando as próprias consciências. { }^{35}$

\section{1.1.1 Slogans e rituais de comunicação}

Entretanto, as paredes da cidade transformam-se em espaços de liberdade de expressão. ${ }^{36}$ O cartaz surge como lúcida forma de comunicar a arte e a vida, a par da imaterialidade dos slogans programáticos, que produzem poderosos dichotes: A qualidade estética é progressis-

27 O evento foi organizado pelo Movimento Democrático de Artistas, que preparou para a intervenção um monumental painel de 4,5 × 24 metros, que seria pintado à vista da população que quisesse passar por Belém durante todo o dia.

28 A Cegada, 25 Anos, 1972-1997 Comuna Teatro de pesquisa, p. 242.

29 O socialista Raul Rego, que de acordo com João Mota e outras fontes, como Manuel Pires, telefonou indignado para a RTP.

30 Melo, Alexandre; Arte e Artistas em Portugal, Lisboa, 2007, p. 45

31 No Porto, entretanto, no mesmo dia, cerca de 500 artistas realizam a acção Funeral do Museu Nacional Soares dos Reis...

32 Gonçalves, Rio Mário; «A Arte Liberta», in Vida Mundial, n. 15, Abril 1999, Lisboa. P. 86

33 Este improvisado altar da arte não subsistiria a uma série de vicissitudes: apesar do interesse internacional, não é levado à Bienal de Veneza (não tinha representação portuguesa desde 1960), nem ao Salon de La Jeune Peinture em Paris; e virá a desaparecer no incêndio da Galeria de Belém em 1981.

34 Gonçalves, Rio Mário; «A Arte Liberta», in Vida Mundial, n. 15, Abril 1999, Lisboa, p. 86.

35 Idem, p. 88. Curiosamente - ou não -, estes "murais" em espaços públicos contiuaram a ser realizados durante alguns meses, anonimamente ou sob a égide de um partidoe sem grande representatividade oficial, o MRPP. Apesar do anonimato, estes "murais", executados segundo planos prévios, obedeciam a técnicas orientadas por pintores profissionais. E foram os mais persistentes.

36 França evoca: Slogans e contra-slogans aí [nos muros] se registaram, em colagens e descolagens, em siglas e contra-siglas. As iniciais dos partidos políticos foram transformadas ironicamente: PCP passava a POP, o CDS passava a CD $\$$, e UEC passava a CUECA, etc. [...] Pode falar-se numa nova maneira de utilizar o espaço urbano, em função não apenas de valores político-partidários, mas, também, de valores lúdicos. Ao mesmo tempo, Sophia de Mello Breyner Andresen e Vieira da Silva colaboravam em dois posters que proclamavam «A Poesia está na rua». 
ta; a mediocridade é reaccionária. ${ }^{37}$ Pouco depois, em Viana do Castelo, Albuquerque Mendes, realizava um dos seus rituais de confrontação, no território retórico da performance pseudo-religiosa em espaço público. São acções que tocam no imaginário e vivências culturais mais profundas do povo, sem deixar de propor momentos de encontro com a possibilidade de novos discursos. Não menos sintomáticos foram os eventos «Arte na Rua» em Coimbra, os acontecimentos em torno da realização de um mural colectivo em Viseu (com os adultos a recusarem-se a participar num primeiro momento, depois as crianças a aderir e finalmente a população a deixar-se contaminar pelo espírito de festa). Também os Encontros de Cerveira no final desse ano, um outro mural em Évora, acções em Espinho... Ora, na efervescência das lutas políticas, a actividade plástica regular quase desaparece e parece ser 'a própria vida' a tomar protagonismo:

Os acontecimentos políticos de 74 vieram interromper o ritmo das exposições de artes plásticas, assim como o consequente trabalho da crítica. Das páginas dos jornais quase desaparecem as referências às práticas artísticas, embora a inevitável euforia da movimentação politica tenha determinado, ainda que fugazmente, a renovação da participação cultural, com a aspiração a um novo tipo de relacionamento entre artistas e público em geral. . $^{38}$

É por isso altura para uma reflexão acerca de um território de encontros arte-social particularmente importante nestes anos, primeiro pela amplitude do seu ethos lacção semi-governamental e para-militarizada que abrangeu amplos territórios em todo o Pais), depois pelo rigor estratégico do seu logos (relacionado com premissas teóricas, políticas e conceptuais precisas, aplicadas com intensidade) e finalmente a excepcionalidade das emoções (pathos) em jogo (uma arte 'em tempo real', envolvendo inúmeros criadores em operações de modificação concreta e imediata das populações, através das artes). Refiro-me às campanhas de dinamização cultural e às Operações SAAL, paradigmáticas de uma atitude e experiência críticas na história colectiva, num período (com picos de intensidade retórica entre 25 de Abril e o 1 de Maio de 74) em que Portugal viveu a explosão de uma das mais intensas festas que o mundo contemporâneo já conheceu. ${ }^{39}$

\section{1.1.2 Desafio, entrega, festa, redenção}

Nas Campanhas de Dinamização Cultural e Acção Cívica de 1974-75, largas franjas da população rural foram contactadas pelos agentes de mudança política, que lhes levaram referências intelectuais após décadas de isolamento. Num cartaz de Abel Manta (1974), vê-se o povo sendo cumprimentado por dezenas de figuras aguardando a vez para serem apresentadas à família de camponeses ${ }^{40}$. A situação representada repete-se sempre que uma comunidade está no centro de um processo comunicacional e político em que é confrontada com a abertura do seu horizonte de conhecimentos a novas referências exteriores. Manta representa o agente mediador da situação - o militar de Abril. como um militar do lado do povo,

37 Cf. Isabel Nogueira. ambos de Salette Tavares. O segundo enquadra-se quanto a mim como elogio à retórica, arte da paz. Outro slogan: Contra a agressividade, criatividade.

38 Melo, Alexandre; Arte e Artistas em Portugal, Lisboa, 2007, p. 45.

39 Sanchis, Pierre; Arraial: Festa de um Povo (1983). De acordo com o investigador Pierre Sanchis, podem até ser estabelecidas relações interesantes entre as festas de romaria (objecto do seu estdo) e a festacrevolucionária.

40 E lá está Kafka, bem ao centro, alto e de negro, esperando para introduzir o termo kafkiano no jargão do debate político das décadas que se seguiriam... 
apresentando-lhe com delicadeza e serenidade sucessivas figuras incontornáveis da história da Humanidade. Esta operação decorre de uma premissa, 'povo' e 'cultura' têm de falar a mesma língu $a^{41}$, pondo em contacto tudo o que está em planos diferentes. ${ }^{42} \mathrm{E}$ portanto o oficial que estabelece o contacto com a sua acção é o mesmo que tem de ser capaz de introduzir na operação - no dispositivo - uma dimensão de transparência capaz de integrar emocionalmente todos os intervenientes no mesmo processo em curso, e de tornar esse dispositivo uma operação empática da cidadania, urgente programa colectivo, dado o desfasamento entre o o país imaginado pela propaganda e o outro país ${ }^{43}$ real. ${ }^{44}$

No período pós-revolucionário, muitos jovens dão este «mergulho redentor» nesse 'país real' que logo procura corrigir ou compensar as tendências elitistas dos estudantes. ${ }^{45}$ Não há porém, lugar a qualquer paternalismo ${ }^{46}$, mas ao pragmatismo: Não é só para eles que aqui estamos, mas também, muito para nós. [...] Não vimos dar-lhes nada, vimos talvez, trocar, quando muito. Vimos mesmo buscar certos conhecimentos, que nos fazem falta. ${ }^{47}$ Ecoam aqui os termos avançados por Paulo Freire, ${ }^{48}$ com que os agentes culturais da época estavam familiarizados. ${ }^{49}$ No fundo, esta nota sobre a Dinamização Cultural, mostra o que nestas acções era uma festiva cultura do outro. ${ }^{50} \mathrm{E}$ se se pode falar, dado o carácter desses encontros, do nascimento de um novo mundo, ${ }^{51}$ este tipo de experiências radicalmente generosas e imponderáveis, são muitas vezes impossíveis de comunicar por palavras. ${ }^{52}$ Para as populações,

41 Correia e tal, s/d-a- 76 in Almeida, Sónia Vespeira de; Camponenes, Cultura e Revolução. Campanhas de Dinamização Cultural e Acção Cívica do M.F.A., Edições Colibri / IELT, Lisboa, 2009.

42 Idem.

43 Outro Pais - Memórias, Sonhos, Ilusões... Portugal 1974-1975, documentário de Sérgio Trefaut, 1999.

44 Almeida, Sónia Vespeira de; Camponenes, Cultura e Revolução. Campanhas de Dinamização Cultural e Acção Cívica do M.F.A., Edições Colibri / IELT, Lisboa, 2009. Muitas das acções de dinamização/animação cultural desenvolvidas na sequência de Abril envolveram não apenas militares mas também estudantes, convocados para acções de mudança pragmática no campo da assistência médica ou do alfabetismo. Ora, a par de um trabalho pragmático nestas áreas, esta campanha, tal como as suas congéneres, assumia uma missão de denúncia do "fascismo", procurando ainda ser uma experiência formadora para aqueles que a protagonizaram.

45 Leal, 1995b:56

46 Idem.

47 Idem.

48 No quadro geral dos processos de alfabetização o trabalho do pedagogo brasileiro Paulo Freire assume um lugar de destaque. Cristão e marxista, a alfabetização era assumida por Paulo Freire como aspecto da 'pedagogia do oprimido, com o objectivo essencial da 'conscientização', com o resultado último da libertação pessoal e social. Toda uma lógica de transparência é crucial neste projecto de conhecimento situado: em Uma Educação para a Liberdade, precisamente editado em Portugal, Freire defende que uma educação só é verdadeiramente humanista se, ao invés de reforçar os mitos com os quais se pretende manter o homem desumanizado, esforça-se no sentido da desocultação da realidade. Desocultação na qual o homem existencialize sua real vocação: a de transformar a realidade. (Freire, 1978, p. 14)

49 Almeida, p. 63. A autora recorda que Freire manteve contactos intensos com a 5.a Divisão/EMGFA. Os seus pensamentos seriam recuperados nos textos da Extra]muros[, via Malcolm Miles, através dos quais tomei pela primeira vez contacto com o pedagogo brasileiro.

50 Conceição Lopes, in Almeida, p. 304.

51 Almeida, p. 350.

52 Conceição Lopes, in Almeida, p. 222. Teresa Ricou, palhaço, lembra-se que quando chegava a uma aldeia, procurava sentir o que estava ali em causa; integrando dados recebidos nesse contacto nos seus sketches. Conceição Lopes menciona a consciência de um conhecimento comum: A estratégia que tínhamos da intervenção, tínhamos também ao nível da equipa, consistia em duas coisas: por um lado partilhar o conhecimento, para já entre cada um e aquilo que tínhamos adquirido, ou seja, ter um conhecimento comum, não é assim tão simples como isso. E depois era passar de um conhecimento comum para um conhecimento em comum, conhecimento comum, para isso tínhamos que falar, ouvir. partilhar, explicar, partilhar dúvidas, receios, dificuldades e ajudávamo-nos mutuamente, feito ao nível do grupo [...] íamos 
era um dispositivo relativamente evidente: O que vêm fazer? Agora vêm-me dizer, afinal que eu sou importante e que eu sou capaz..$^{53}$

\section{Paz, Pão, Habitação... ${ }^{54}$}

O arranque do trabalho de brigadas de alfabetização e educação sanitária coincidiu com o lançamento das Operações SAAL, acções de apoio fundiário, técnico e financeiro às populações organizadas para participarem na transformação dos seus bairros, aproveitando os recursos dessa população - autoconstrução e autofinanciamento - sob o controlo urbanístico das câmaras municipais. ${ }^{55} \mathrm{O}$ SAAL foi uma experiência que permitiu uma aproximação ${ }^{56}$ da classe dos projectistas ao país, agora na vertente da Habitação (combate ao problema nacional das 'barracas'): O SAAL é o único sonho que um arquitecto, quando acordado, pode sonhar. ${ }^{57}$ Aspecto crucial foi a relação com os 'objectos' das intervenções assentar não na categorização abstracta, mas no considerar essas pessoas como pessoas-utentes:

Mais do que simples operações de realojamento, os bairros SAAL do Porto expressam também a satisfação, ainda que efémera, de mais um direito, conquistado em pleno ardor do quotidiano de luta dos moradores pobres, inscrito no território e na história das práticas urbanas como renúncia ao entendimento exclusivamente mercantil da concepção e da construção dos espaços: o direito à arquitectura ${ }^{58}$

\section{1.2 Protagonistas da evolução interdisciplinar: a afirmação da curadoria e do design}

Na emergência de um Portugal crítico duas figuras-chaves estabelecem com a questão do ensaio (Prado Coelho, Lourenço, Gil, Barrento) uma triangulação no meu argumentário: Ernesto de Sousa (1921-1988) ${ }^{59}$ e António Sena da Silva (1926-2001). Respectivamente curador e designer, são referências tanto nos seus terrenos de origem como na ligação entre arte e sociedade, perspectivada como pedagógico desafio colectivo.

alargando estas reuniões e, depois, íamos construindo o conhecimento comum. [...] Essa era a forma, era pela relação, pelo lado invisível da comunicação, pelas relações positivas que se criavam, se desencadeavam e se motivavam.

53 Idem.

54 Segmento de refrão de canção de Sérgio Godinho.

55 Bases para a Definição do programa SAAL, s/d, p.1 (Centro Comunicação 25 de Abril. Fundo Alexandre Alves Costa. Caixa Comunicados e Panfletos. SAAL Nacional)

56 Note-se como a figura da operação une o acto colectivo das SAAL e a instrumentalidade do conceito do operador estético em Ernesto de Sousa (ver 6.1.2.1)

57 Távora, Fernando; in Costa, 1997: 65

58 Bandeirinha, 2001: 5-6; cit. Almeida, p. 67.

59 Note-se que o legado de Ernesto de Sousa e da sua geração chegam até à minha de forma extremamente parcelar e lacunar, sob a forma de imagens descontextualizadas, como fulgurações míticas. Lembro-me de muito jovem vislumbrar uma imagem da Alternativa Zero com a escultura-instalação de Clara Menéres, e do enorme impacto do título quando o ouvi das primeiras vezes. Quando na minha carreira me fui aproximando de forma mais constante de uma praxis crítica, o desejo de inovação, levou-me a procurar ao mesmo tempo referências e experiências no passado, e foi então que progressivamente que fui 'descobrindo' ES ou Sena da Silva, bem como como os raros protagonistas da deriva urbana da arte crítica contemporânea. 


\section{1.2.1 Ernesto de Sousa - ingenuidade e realismo neo}

Na minha aproximação à questão da curadoria crítica, a figura de Ernesto de Sousa domina o panorama cultural dos anos 60 ao final dos anos $70^{60}$, introduzindo a figura do operador estético. Esforçando-se por conquistar um lugar para a arte num País longamente refractário à inovação ou à abertura intelectuais, desde cedo que ES não separa a produção artística da teórica, a 'comercial' da 'experimental'; tal enforma a sua noção de curadoria como arte (Mariana Pinto dos Santos). ES ancora a sua inovação nalgumas premissas: as preocupações sociais do neo-realismo e a relação arte-vida retomada a partir das experiências Fluxus $e$ da arte experimental das décadas de 60 e 70, entre a pesquisa da cultura popular e o axioma de Beuys segundo o qual "cada homem é um artista. ${ }^{61}$ Estas são completadas pela noção de um realismo total: [...] aquilo que Ernesto faz é encontrar uma possibilidade real lutópica mas conceptualmente equilibrada) de realizar uma impossibilidade [...] do realismo: fazer coincidir as vanguardas estética e política num mesmo fluxo. ${ }^{62}$

Leio neste equilíbrio conceptual o equilíbrio retórico, uma posição teórico-prática realista no quadro de um sempre renovado sentido crítico da arte contemporânea face à polis e às dinâmicas politicas do seu tempo. É uma posição que aglutina as dimensões comunicativa e pedagógica; na posição de mediação que ocupa, um diagnóstico da situação cultural em Portugal. Dada a sua experiência também como artista, é um diagnóstico realizado a partir de dentro do processo criativo, com a preocupação de estabelecer uma ligação pragmática entre o Neo-Realismo e a Pós-Modernidade. ${ }^{63}$ ES advoga o valor da ingenuidade para que a modernidade possa renovar-se neste sentido; a sua valorização do espectador ${ }^{64}$ passa por inscrever a possibilidade quotidiana de uma redescoberta da arte pela empatia ingénua.

Esta aproximação é o culminar de um processo de aproximação entre realismo e conceptualismo. No debate acerca do compromisso (Vidal) da arte com o seu tempo e das formas que tal compromisso pode ou deve assumir, a questão do realismo articula-se com a da necessidade de realidade. ${ }^{65}$ Ora para os novos-realistas as formas são elas próprias território

60 Para a aferir da produção teórica, curatorial e artística (elas fundem-se em Ernesto de Sousa), cf. Santos; Mariana Pinto dos; Vanguarda \& Outras Loas - Percurso Teórico de Ernesto de Sousa, Assírio \& Alvim, Lisboa, 2007 e Sousa; Ernesto de; Ser Moderno... em Portugal, Assírio \& Alvim, Lisboa, 1998.

61 Fernandes, João; «Perspectiva: Alternativa Zero vinte anos depois...», catálogo Perspectiva: Alternativa Zero, Fundação de Serralves, 1997, p. 19.

62 Leal, Miguel; Desmembramento, Desmaterialização, Reconstrução_ para uma abordagem às mutações do conceito de escultra na arte portuguesa entre 1968 e 1977, Dissertação de Mestrado em História de Arte em Portugal, Faculdade de Letras do Porto, 1999, p. 38.

63 Cf. Santos, p. 18. Um deslocamento (Miguel Wandschneider) que ocorre em finais de 60, do campo do cinema para o campo das artes plásticas e do campo do neo-realismo para o da vanguarda, em particular a arte conceptual. É uma 'incoerência' que será lida, por uns, enquanto ilusão biográfica (Wandschneider), por outros (João Fernandes) como subjacente a um intranquilo fio condutor («Perspectiva: Alternativa Zero vinte anos depois...», catálogo Perspectiva: Alternativa Zero, Fundação de Serralves, 1997, p. 19) - imagem metafórica de que destaco a harmonia com a da intranquilidade do género ensaístico (Barrento).

64 Santos, p. 22

65 Joaquim Namorado, inaugura a expressão «neo-realismo» nas páginas de O Diabo em 1938. Namorado menciona um vasto movimento neo-realista que cresce em todos os continentes e se pode julgar iniciado em Gorki e na linha de certo realismo e naturalismo francês, embora se devam afirmar diferenças profundas. De acordo com Santos, a linha 'realista' em Namorado não poderia dar espaço à subjectividade e ao individualismo de Proust, Joyce ou Mann. Cf. Santos, p. 37. 
de combate, mesmo que à custa de um défice de comunicação com o espectador e muito em particular as massas. É neste sentido que Santos se refere ao imperativo de a arte deformar ${ }^{66}$ a vida, ${ }^{67}$ numa referência eminentemente cognitiva que já estava por exemplo em Bloch e nas perspectivas críticas do possível não vivido. ${ }^{68} \mathrm{E}$ assim podemos concordar com Mário Dionísio quando afirma que não há uma estética marxista, mas sim uma atitude marxista, ${ }^{69}$ num quadro emergente, o de um novo realismo, mais amplo, mais completo do que qualquer movimento artístico anterior, o prelúdio de uma arte que sirva a todos e quaisquer homens. $^{70}$

\section{Quotidiano (nacional), (formas do) colectivo, experimentação e proficiência do dispositivo.}

Construção de um discurso artístico especificamente português. Dimensão colectiva da produção artística ${ }^{71}$. Abertura à experimentação formal. Redefinição do conceito de moderno, enquanto condição para uma correspondência entre a arte e as necessidades, mais vivas, mais progressivas do seu tempo. ${ }^{72}$ Proficiência teórico-prática em antecipação das competências específicas da curadoria. Ernesto encara estes aspectos como indissociáveis de um conhecimento total do fenómeno artístico, o que pressupõe uma articulação entre as esferas da criação, da programação, da crítica ou da divulgação - numa palavra, da arte como fenómeno complexo na sociedade de comunicação. Ernesto propõe um mergulho no quotidiano e um regresso às origens ${ }^{73}$, com base numa reavaliação do legado de Brecht. ES vê no dramaturgo uma resiliência à ortodoxia do realismo socialista e um elogio do carácter popular da arte $^{74}$ - aspecto necessário ${ }^{75}$ para que a arte permaneça técnica operativa na sociedade ${ }^{76}$. Brecht é modelo de militância cultural ${ }^{77}$, forçando o gelo da especialização ${ }^{78}$,

66 O conceito pertence a Mário Dionísio e pressupõe a valorização de um aprofundamento, por parte do artista, da exploração dos meios próprios da sua arte, numa leitura que aponta para o modernismo greenberguiano, mas hoje autoriza uma leitura flusseriana.

67 Santos, p. 40.

68 Idem, p. 43.

69 Idem.

70 Sousa, Ernesto; «Rumos da pintura», Seara Nova n. 993, 24.08.1946.

71 Idem. Exemplificada por uma nova pintura mural ou pelo cartaz.

72 Sousa, Ernesto; «Em defesa do moderno», Seara Nova, n. 1009, 30.11.1946.

73 Santos, p. 54. Aspecto de uma originalidade cultural a perseguir - um exemplo da sua consciência desta questão encontra-se na sua valorização das excursões que alguns pintores organizaram nos anos 50 los passeios do «Ciclo do Arroz» pelos arrozais do Alentejo, com a colaboração de Alves Redo). A estas imersões no real (Santos) ES chega a considerar a realização mais coerente do neo-realismo (in A Pintura Portuguesa Neo-Realista, Artis, 1065, p. 3.)

74 Nos anos 60, Ernesto de Sousa realiza um trabalho de aproximação à realidade popular e quotidiana, esbatendo fronteiras entre a arte erudita e a popular, o que passou pela realização de um filme (Dom Roberto, para o qual realiza um trabalho de recolha de dichotes populares de Lisboa), de vários documentários, e a promoção de criadores como Rosa Ramalho e Franklim.

75 Brecht, Bertolt; «O carácter popular da arte e o Realismo», Realismo, materialismo, Utopia. Nessa obra, Brecht nota que é fundamental apresentar ao povo obras ousadas e invulgares, sem preocupações pedagógicas... mas sem se perder de vista todo um contexto comunicacional.

76 Santos, p. 55.

77 Idem.

78 Sousa, Ernesto de; «Artes plásticas», Seara Nova n. 1367, Setembro 1959. 
superando fronteiras entre a arte popular e a arte erudita, aceitando o desafio da autoria e da autonomia mas não à custa da expulsão do espectador do objecto de arte - o caminho do futuro é perfeitamente previsível: o espectador fará parte do espectáculo ${ }^{79}$. Em Portugal, o interesse por este real total era, no dealbar dos anos 60, uma excentricidade.

Relativamente à minha axiomática, ES estará profundamente consciente das posições de Kosuth em 75, em que o artista norte-americano propõe, em contradição com o primeiro conceptualismo, a ideia do artista-como-antropólogo. ${ }^{80}$ ES na linha de Benjamin, diz que o artista tem de estar permanentemente pronto a trair a sua técnica ${ }^{81}$ (deskilling, Roberts), não menos do que a aprofundar as suas capacidades de domínio da(s) mesmals) ou das de que se aproxima numa sucessão de ingenuidades produtivas. Nisto, a abertura técnica que não é dissociável da abertura política em qualquer projecto de horizontalidade ${ }^{82}$ da posição artística, implica, no que diz respeito à busca da sua própria originalidade (portuguesa), uma reflexão sobre aspectos contextuais específicos ou invariantes estruturais. ES propõe uma ingenuidade voluntária ${ }^{83}$, imagem de um apaixonado (pathos) ${ }^{84}$ que o levará a procurar sempre novas formas híbridas para a sua intervenção. ${ }^{85}$ Uma referência nesta preocupação é a Aby Warburg ${ }^{86}$, em quem há todo um projecto de relação em aberto com a memória ${ }^{87}$, cuja natureza era naturalmente a de permanecer inconclusivo, infinito.

No carácter revolucionário de ES, que outras vozes o acompanham? Alberto Carneiro: $A$ arte faz-se para transformar as imagens do quotidiano. Consciência do atrofiamento que os factores urbanos e culturais exercem sobre a alegria mais profunda do ser [...] Arte ecológica, árvore na floresta do cimento (197288); Ana Hatherly propõe A ARTE DE DEIXAR AS COISAS ACONTECEREM (1972 $\left.{ }^{89}\right)$; Álvaro Lapa recorda que O corpo é um movimento sem princípio nem fim (1972). António Areal fala de um misticismo que busca mais um estatuto ético do que uma admissão estética (197990). Estas vozes são o lado menos conhecido, mais marginal,

79 Idem.

80 Kosuth, Joseph; «The Artist as Anthropologist», Art After Philosophy and After-Collected Writings, 1966-1990, MIT Press, 1991.

81 Idem, p. 102.

82 Idem.

83 Idem, p. 104.

84 Idem. ES: A ingenuidade é a ferramenta que lhe permite pensar do zero, com total abertura, numa nova linguagem artística, ou melhor, em novas linguagens artísticas.

85 Um exemplo, as fotografias-interpretação (em oposição a fotografias-documentação) que publica na Seara Nova entre 59 e 61, num eloquente retrato da escultura portuguesa, que considerava área particularmente mal estudada.

86 Santos, pp. 110-111. Aby Warburg (1866-1929) realiza um original trabalho, de teor filosófico e interdisciplinar, de Kulturwissentschaft, assente numa abordagem radicalmente nova do fenómeno da cultura universal, que absorvia uma quantidade infinita de conhecimento, com um sem-número de possibilidades combinatórias dentro de si, e, por isso, um sem número de redes e relações entre objectos aparentemente não-relacionáveis, porque vindos, por exemplo, de épocas, zonas geográficas, contextos ou civilizações completamente diferentes.

87 Santos, p. 111. Ver a este propósito o Bilderatlas iniciado em 1927.

88 Dezembro de 1968/Fevereiro de 1972), in Alberto Carneiro, catálogo de exposição antológica, Fundação de Serralves, porto, 1991, p. 62.

89 Texto escrito para catálogo de Sylvester Houéddard, Londres.

90 Flama, 8 de Dezembdro de 1967, reproduzido em "Textos de crítica e de combate na vanguarda das artes visuais", ed. do autor, Lisboa, 1970, pp. 152-154. 
indistinto, dispersivo e radical da década (Pinharanda), dando corpo às actividades de acompanhamento do pós-conceptualismo internacional. ${ }^{91}$

\section{1.2.2 Sena da Silva - design total para a cidade}

Juntamente com Sebastião Rodrigues e Daciano Costa, Sena da Silva é figura incontornável do design em Portugal, em função de uma carreira multifacetada, ao nível teórico e prático, da qual nunca esteve ausente um ethos de transformação crítica profundamente empenhado no mundo como totalidade e nas pessoas como parceiras dessa aspiração. Esta ideia encontra-se expressa no desejo, tornado aforismo, de que o mundo continue a não ser como era. Num texto de 1982, Sena da Silva assume a condição urbana como suporte necessário do seu trabalho e percurso de vida. Numa nota autobiográfica, explicita a sua crítica do dispositivo-cidade através da forma poética/metafórica: É um animal exclusivamente urbano, que não sabe mungir uma vaca nem pegar numa enxada. No entanto reconhece a vulnerabilidade do dinossauro urbano em cujas vísceras cresceu e tem vivido. ${ }^{92}$ Perante tal vulnerabilidade, a sua 'arma' é o design como logos pacifista: Tem vivido e sobrevivido a "fazer coisas". [...] De preferência utensílios para usos pacíficos. ${ }^{93} \mathrm{~A}$ articulação ethos-logos em Sena da Silva é de incondicional defesa por um design humanista e sustentáve ${ }^{14}$ que passou por tirar as aspas ao design, imperativo de levar o design ao combates - pacíficos - de uma esfera pública que é intrinsecamente o seu 'palco': Para Sena, o design compreendia "todos os processos de desenvolvimento de uma resposta a partir do reconhecimento de uma situação de carência ou insatisfação", sendo um processo colectivo onde o designer era (sól um dos vários intervenientes. ${ }^{95}$ É com naturalidade que relaciono o ethos de Sena da Silva com a emergência de uma curadoria de arte urbana empenhada na coisa pública, pois a esta é indiscutivelmente inerente um sentido de design e Sena da Silva nunca deixou de pensar a interdisciplinariedade e o social no 'cerne' na produção cultural contemporânea.

Sena, que conheceu ES e depois lhe sobreviveu vários anos, é fundamental na perspectivação, de uma condição de consumo generalizado, na altura ainda quase imperceptível, perante a qual a consciência, retórica será a 'arma-pacífica' capaz de levar o Homem ao entendimento da suas condições de vida. ${ }^{96}$ Só um olhar excepcionalmente atento ao quotidia-

91 PInharanda, João Lima; «O declínio das vanguardas: dos anos 50 ao fim do milénio», História da Arte Portuguesa, Dir. Paulo Pereira, Círculo de Leitores, Lisboa, 1995.

92 Silva, Sena da; «Design \& Circunstância», 1982, in Sena da Silva, FCG, 2010.

93 Idem.

94 Coutinho, Bárbara, «Para tirar as aspas ao design», in Sena da Silva, FCG, 2010, p. 11.

95 Idem, p. 12. O design era, assim, e em primeiro lugar, uma capacidade inata ao homem - a de transformar o mundo natural; daí Sena falar de um homo designer, inventor de artefactos e de ferramentas que o foram ajudando a produzir novos objectos e espaços, através de um método projectual que acaba por ser, em última instancia, o sinonimo primeiro de design. Este conceito abrangia desde a arquitectura ao modelo de gestão, de atitude pedagógica à intervenção cívica, do planeamento estratégico à praxis política. [e a confirmar esta dimensão cognitiva do design, Coutinho sintetiza] Numa única frase, compreendia as atitudes, gestos e realizações do homem ao longo do seu processo de desenvolvimento.

96 Evoco um dos lemas do designer, no programa televisivo de divulgação A Qualidade da Vida, em 1980: Escolha com prazer; adquira com saber; Design - para uma melhor qualidade de vida. Consciência essa que se desdobrará particularmente em torno da questão do artefacto, que aqui não procurarei aprofundar pois isso me lavaria a afastar-me de uma ideia genérica de atitude de designer, e aproximar-me de uma ética do objecto lexemplarmente realizada no projecto Módulo Escolar, 
no da cidade - enquanto organismo vivo "onde todos os dias se destrói ou se constrói alguma coisa", captando os testemunhos do homem ${ }^{97}$ - pode provocar novas leituras, como quando propõe para Vilamoura, toda a ludicidade de uma nova onomástica: rua da paz, praça do sol, travessa dos namoradas, rua do mar, passeio das meninas lindas, rua do marinheiro sem rumo, praça do céu aberto. ${ }^{98}$ Mais do que meramente o exercitar compulsivo da veia poética, é todo um programar cultural das imagens (e dos textos) da cidade, em sede de apelo à intervenção pública. Quanto ao rigor da consciência muito específica da forma urbana:

É necessário habituarmo-nos a analisar tudo o que nos rodeia: o "porquê" de cada coisa, de cada forma, de cada material: o "porquê" da argila na telha, o "porquê" do ferro na escada. O "porque de uma escada em vez de uma rampa. o "porquê", o "porquê"... que nos permita afirmar de vez em quando que "o rei vai nu"... ou então, perguntar: "Porquê é que a roda não é quadrada?"..."99

De resto, a interdisciplinariedade fundamental no percurso de Sena da Silva liga-o indelevelmente a ES. Em ambos o projecto é retórica, do ponto de vista de uma cultura de projecto aberta à totalidade do discurso e das suas formas urbanas. Vou assim rematando, na evocação de Sena da Silva, enquanto 'espelho' de Ernesto de Sousa, um núcleo crítico-projectual-curatorial que serve de 'pano de fundo' às vicissitudes das minhas próprias intervenções. Estará em causa um trabalho contínuo de mudança de mentalidades ${ }^{100}$, sempre incompleto, mas que passa pela explicitação dos meios (Sena da Silva) disponíveis para manipulação e ao mesmo tempo que nos definem as condições para tal - base de uma cidadania participativa (Coutinho). Sena gostava de recuar à verve crítica de Eça de Queiroz, de quem recordava uma passagem de Os Maias em que face à importação acrítica do que é exterior à realidade portuguesa, para o citar: A Civilização custa-nos caríssima com os direitos da Alfândega e é em segunda mão, não foi feita para nós, fica-nos CURTA NAS MANGAS. ${ }^{101}$ É uma nota que abre o sentido de uma genuína produção cultural localizada, contextual, situada. Esta é uma consciência estruturada da ligação entre os valores de design e do projecto face aos desafios, quer do consumismo, quer da degeneração da qualidade de vida urbana lataque ao urbanismo levado a cabo pela especulação imobiliária ${ }^{102}$ ), quer da exponencial dependência do automóvel (a 'língua-franca' desse imenso rebanho dos consumidores motorizados ${ }^{103}$ ). Na prática, é ainda o desejo de integrar equipas e relações de origens disciplinares diversas, personalidades de sectores diversos como médicos, artistas, arqueólogos, engenheiros, urbanistas... ${ }^{104}-$ e de assim dar corpo a um manifesto de reconfiguração do papel do próprio design em Portugal: Os designers

linha de mobiliário pioneira). De qualquer forma, estou mais próximo de uma reflexão que o próprio Sena propõe como a paisagem dos artefactos que não me parece ser outra coisa que a expressão física do mega-artefacto que é a cidade.

97 Coutinho, Bárbara: «Para tirar as aspas ao design», p. 13. As fotografias de Sena da Silva a objectos de design quotidianos e anónimos como o clip, a fita métrica, as molas são o prolongar 'estético' de uma profunda paixão pelo quotidiano como palco da consciência de projecto Note-se a fotografia de 1970, Pretubo. Uma imagem das estruturas tubulares sustentando o vazio entre dois prédios (gerado pela demolição), com detalhes de comunicação politica na base da fotografia, quase imperceptíveis, e toda a poética do contingente no próprio logótipo da empresa PRETUBO. (Lisboa. Prova gelatina e prata em papel de revelação baritado).

98 Coutinho, p. 14.

99 Sena da Silva, António; A PROPÓSITO DE... DESIGN, 1976.

100 Coutinho, p. 16.

101 Idem, p. 17.

102 Que em quase todo o território nacional é responsável por brutais alterações na paisagem e nos modus vivendi de muitas populações.

103 Coutinho, p. 16.

104 Ferro, Francisco; in Coutinho, «Design em Português», p 180. 
portugueses têm estado confinados à produção de siglas, logótipos e normas gráficas, stands e paviIhões para feiras, cartazes, decoração e intervenções menores na fase final da concepção de alguns produtos. Serão eles capazes de responder a outro tipo de desafios? ${ }^{105}$

\section{Projecto e atitude - um texto fundamental}

Um projecto começa sempre por uma pergunta. A essa pergunta outras perguntas de seguem. $O$ modo como - sucessivamente - vamos formulando perguntas define uma ATITUDE. Uma ATITUDE é - geralmente - orientada por uma intenção. Em frases simples e discurso corrente, o designer expõe um método que apresenta ligações com uma metodologia linguístico-discursiva para o design, nomeadamente na questão do trabalho sobre as perguntas e as respostas. Estas desenvolvem-se num fluxo - o da dureé do projecto - , sendo inevitáveis as noções de acção, passo a passo, processualmente:

Uma ATITUDE é - geralmente - orientada por uma intenção. Quem diz intenção diz "designio" le quem diz "desígnio" pode dizer "design"...). A ATITUDE determina o modo como as perguntas vão sendo formuladas, mas o conteúdo das respostas (e a interpretação que lhe puder ser dada) pode exigir a redefinição da ATITUDE. / O PROJECTO desenvolve-se na sucessão das perguntas e das respostas, das dúvidas, das pro- postas e de algumas opções. O PROJECTO é sempre a concretização de uma ATITUDE DE SIIN- TESE, que se define após um certo número de oscilações. Estas oscilações resultam da confrontação de atitudes divergentes assumidas pelas entidades envolvidas no processo-projecto e também das próprias componentes de cada atitude individual. Componentes de natureza objectiva (necessidades concretas, condicionamentos quantificáveis) e também numerosos aspectos subjectivos laspirações resultantes de características particulares de temperamento, de situação sócio-cultural ou de outras circunstâncias difíceis de avaliar em termos concretos). O PROCESSO-PROJECTO linear e silogístico será apenas uma fraude ou um caminho estéril. O PROCESSO-PROJECTO que pretendemos defender exige, geralmente, um trabalho de grupo vivido intensamente, bem como o recurso consciente ou intuitivo a alguns esquemas de MÉTODO.

O conceito instrumental de processo-projecto é escalpelizado ao nível da legitimidade e sentido do seu ethos, base do realismo total que se exige à profissão do 'designer':

A imagem contemporânea do "designer" insere-se nestas zonas. Entre o projectista e o destinatário-consumidor existe
uma enorme massa de interesses contraditórios, em que se impõem condicionamentos e pontos de vista quase sempre
antagónicos dos interesses efectivos do destinatário do projecto. Os "homens do management" apenas vêem a maximi-
zação dos lucros. Os "homens do marketing" tentam visualizar os meios para atingir os objectivos dos primeiros. Estes
meios incluem a determinação das correntes de gosto e das zonas de consumo mais lucrativas, a provocação de falsas
necessidades ou a imposição de formas insólitas e "chamativas" que fomentem "modas" que rapidamente se tornem
obsoletas e insuportáveis, para que se provoquem novas aquisições... e assim por diante. [...] O projectista arrisca-se
normalmente a ter que enfrentar - por parte dos homens da produção - atitudes conservadoras injustificadas, obstrução,
imobilismo, desinteresse, incredulidade ou até sabotagem... A tudo isto, é necessário responder com compreensão, argú-
cia, diplomacia, crítica objectiva, capacidade de integração, sentido de oportunidade e bastante imaginação.

Mais à frente neste texto seminal, Sena da Silva nota que

[...] a primeira intervenção do projectista-interlocutor deverá consistir na descodificação dos sinais/imagens, através de uma série de perguntas e de aferição de interpretações que permitam definir de um modo relativamente claro e coerente os objectivos ou as aspirações que levaram o cliente a solicitar a intervenção do projectista. Esta fase deverá conduzir à "tradução" da "imagem-solução" para os termos de um problema a resolver.

Fica dado o mote para um imperativo, o de que ler a cidade e suas formas está na base de qualquer posterior acção plástica, entre noções semióticas e uma contínua renovação da vitalidade retórica dos projectos.

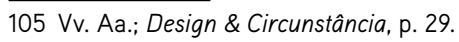




\title{
II. 2 DIZER CIDADE. MOMENTOS-CHAVE NA ARTE PÚBLICA CRÍTICA CONTEMPORÂNEA
}

\author{
Primeiro: que a única atitude ou função válida no nosso tempo é de natureza \\ estética. Segundo: que todas as vanguardas estéticas que realmente merecem esse \\ nome se confundem ou convergem para uma única a que chamarei conceptual. \\ Ernesto de Sousa
}

\section{2.1 Portugal, dos anos 60 ao dealbar dos anos 70, fugazes efervescências da arte}

Portugal vive os anos 60 sob uma ditadura duradoiramente penosa para o campo cultural, forçado a uma condição de isolamento das movimentações mais efervescentes da modernidade e a um contexto geral de muito baixo nível de formação escolar da população, a desinformação massiva da opinião pública, o conservadorismo da cultura oficial e o crescente anacronismo cultural da oposição. ${ }^{106}$ Quando a preocupação é a relação arte e social, esta questão é complexificada pelo próprio défice em formação cívica e de cidadania que o regime impôs; Esta questão leva a que não haja tradição de um espaço público moderno na realidade portuguesa, ou uma significativa esfera pública potencialmente crítica da hegemonia burguesia.

De qualquer forma, com epicentro em minúsculas elites culturais e urbanas (Melo), há a tentativa por parte de alguns criadores de se aproximarem da dinâmica internacional. Veremos que, ao longo do tempo, essa sintonização - um epifenómeno ${ }^{107}$ - ora é actualização do anacronismo do ethos crítico moderno, ora tende para a mera apropriação conjuntural de cada nova moda. Tendo sempre em mente, por outro lado, que os artistas que procuram o aggiornamento na arte contemporânea são quase sempre os que emigraram ou que tiveram experiências estrangeiradas ${ }^{108}$. Nesta lenta aprendizagem da diferença, em contacto

106 Melo, Alexandre; Arte e Artistas em Portugal, Lisboa, 2007, p. 13.

107 Idem, p. 17. Ora bem: Se todas as formas de expressão surgidas nesse período, na sociedade europeia e na dos Estados Unidos, emergiram das suas transformações socioeconómicas, em Portugal, onde há décadas nada se transformava e o alfobre era de terra sem húmus, nada de realmente novo aqui nasceu nos anos sessenta. Sem masoquismo e tentando ser realista, tenho que constatar que o facto de testemunharmos e analisarmos essas transformações, e de muitos de nós termos habitado esses espaços onde se operavam as transformações, não nos tornava sujeitos actuantes e interventivos dessas acções; estivemos "lá" como alunos estudiosos, como turistas ou, principalmente, como espectadores atentos. Se assim foi, o que fizemos nessa década, ainda que, por cá, se considere ter estado em consonância com o que surgia fora das nossas portas, não passou, a meu ver, "et malgré nous" de puro epifenómeno. Como (quase, quase) sempre na nossa História! / Portanto, a Ogiva, ou a Alternativa Zero - outra panorâmica vasta duma multiplicidade de artistas - foi honrosa vitrina daquilo que, na hora, ou com maior ou menor desfasamento no tempo, "também nós" sabíamos fazer - "fazer assim". É verdade e é pena, mas não podia ter sido de outra forma! Pinheiro, Jorge; in «OGIVA GALERIA DE ARTE, 1970-1974», Óbidos, 2009.

"O risco de sair da norma"» in http://arquivolarte.blogspot.com/2009_10_01_archive.html. Depoimento recolhido por e-mail, em 27.08.2009, consultado em Outubro de 2011.

108 Um termo de ricas ressonâncias na cultura portuguesa, dramaticamente recorrente, precisamente procurando exprimir o que normalmente, em quem é 'impregnado' pelo Estrangeiro, tem de enfrentar para o reconhecimento intramuros. 
com o Outro europeu e internacional ${ }^{109}$, os casos de Alberto Carneiro, Costa Pinheiro, João Vieira, Clara Meneres e Albuquerque Mendes são exemplos de uma dinâmica de aproximação portugalidade/universalidade. As opções que estes artistas seguem na sua projectualidade dão indicações da permanência de uma dinâmica retórica dos seus actos, por vezes ostentando o que parece ser a consciência de como a arte funciona ou faz sentido na cidade (e na forma urbana): Costa Pinheiro (n. 1932) como percurso que passa pela pop e, decisivamente (para a minha 'mitografia'), pela experiência do desenho urbano experimental, realizado na Alemanha, com ligações a Vostell e Joseph Beuys; Carneiro (n. 1937) como expoente, até hoje, de uma land art que entretanto se afirmou universalmente, também com o seu contributo, sempre afirmando uma perspectiva conceptual (desmaterialização) mas também de envolvimento ${ }^{110}$ (instalação) próximo das filosofias orientais (budismo zen, tantrismo); Clara Manères (n. 1943) enquanto criadora de alguns dos momentos mais marcantes da iconografia e da experiência da arte politica provocatória; João Vieira (n. 1951 - 2009) pela articulação performance-palavra/corpo/letra em todo o seu trabalho ${ }^{111}$, figura-charneira que introduz em Portugal os primeiros happenings, ao mesmo tempo que descobre a temática central de um trabalho em torno do alfabeto e da plasticidade da palavra (Melo), e que nunca abdica do prazer da comunicação (Barthes); Albuquerque Mendes (n. 1953) ao interpretar como nenhum outro criador português deste período um desígnio de publicidade da arte que passou frequentemente pelo ritual e uma noção performativa do encontro efémero com o público em espaços públicos. Albuquerque Mendes interessa-me sobremaneira porque o seu percurso é de autoironia e de provocação, capaz de integrar revivalismo e autoreferência, definindo uma personalidade provocadora que prolonga na esfera da sociabilidade o dadaísmo performativo anterior. ${ }^{112}$ Isabel Carlos complementa, evocando Egídio Álvaro (outra figura-chave dos anos 70): Albuquerque Mendes explorou a performance como linguagem próxima das dimensões rituais e das práticas religio-
sas (II Encontros de Arte em Portugal, Viana do Castelo, 1975), aliada a uma ausência de clímax que fazia decorrer
muitas das intervenções no meio da rua, entre pessoas, sem qualquer divisão nítida entre o artista e o espectador
I Performarte, Torres Vedras, 1985). Os seus trabalhos efectuavam uma constante desmontagem de signos, do seu
carácter simbólico, e levavam a uma instabilização desses mesmos signos (Identidade Cultural e Massificação, Socie-
dade Nacional de Belas Artes, 1977): «Porque são factor de inquietação, porque se debruçam sobre o nosso esquema
vivencial e colectivo, porque destroem velhas barreiras, tabus, interdições, receios e vergonhas e, também, porque
abrem as portas do futuro [...]» (Álvaro, 1977)

Noutro campo, nota o artista-poeta visual Fernando Aguiar, que em Portugal os primeiros happenings foram realizados por poetas experimentais. ${ }^{114}$ Terá sido o seu dinamismo que os leva a serem convocados por ES para sucessivos eventos, incluindo a Alternativa Zero.115

109 Cf. Melo, p. 18, nomeadamente referindo o papel da Fundação Calouste Gulbenkian neste período crítico da afirmação de uma arte contemporânea 'portuguesa'. E a nível nacional, a progressiva, titubeante, aparecimento de uma primeira rede de galerias de arte.

110 Melo, p. 152.

111 De Exposição pura. Ritual, galeria Judite Dacruz, 1970.

112 Pinharanda, p. 620.

113 Carlos, Isabel, p. 644.

114 António Aragão, E. M. de Melo e Castro, Salette Tavares, juntamente com os músicos Jorge Peixinho e Clotilde Rosa, e o pintor Manuel Baptista e Mário Falcão.

115 Nos anos 80, a 'comunidade' inclui Ana Hatherly, Alberto Pimenta e, pontualmente, José-Alberto Marques e Silvestre Pestana, para além de João Vieira. Decorrendo quase sempre em galerias de arte, houve momentos 
Estes curadores confirmam que, apesar de tudo, um certo clima pré-revolucionário se sentia antes de Abril (Rui Mário Gonçalves). Foi o caso de Exposição 73, na Sociedade Nacional de Belas-Artes, que reuniu centena e meia de trabalhos de 72 artistas, números surrpreendentes que denunciam um certo desejo de mudança. Fernando de Azevedo, convidado a montar a exposição, colocou à entrada, programaticamente, uma pintura de Rui Filipe mostrando uma multidão em tons castanhos e cinzentos; e junto, a escultura hiperrealista de Clara Menères, Jaze Morto e Arrefece, representando um soldado degolado. Estava dado o mote e o sentimento mais fundo e urgente de uma geração de criadores. ${ }^{116}$ Clara Menères elevava a fasquia da politização da arte, articulando em ponto crítico a inscrição expositiva.117

Entretanto, no mesmo ano, mas no espaço público, José Cutileiro inova decisivamente na estatuária monumental. Realiza com imaginação pessoal e linguagem formal revolucionária uma poderosa imagem d'O Desejado, fantasma vindo do fundo do tempo, espantalho da história, caricatura do Mito [...] Boneco dado à nossa piedade e oferecido à nossa meditação... ${ }^{118}$ Escultura pedagógica ${ }^{119}$, este jovem e frágil Sebastião propõe enfaticamente a renovação da própria estatuária pública ${ }^{120}$ - substituindo toda a ganga passadista do mito de D. Sebastião por uma figura infantil, de boneco articulado, claramente colocando questões quanto ao sentido histórico. Subtil e porventura quase inconscientemente, o objecto escultórico numa rotunda pode conter elementos críticos, com valor comunicacional. Ainda em 73 (Fevereiro), e ainda sob a figura do monumento, numa outra exposição colectiva, ${ }^{121}$ Virgílio Domingues realiza "antimonumentos", peças irónicas, que exprimiram a reacção subjectiva aos monumentos oficiais que continuavam a encher os espaços públicos. ${ }^{122} \mathrm{O}$ carácter de reacção íntima ${ }^{123}$ destas obras não impede que sejam comentário à ocupação do espaço público por arte que se limita a reflectir aspectos ridículos das cerimónias e da vida diária dos poderosos políticos e dos ricos. ${ }^{124}$

em que a poesia 'saiu literalmente a rua': como Alberto Pimenta, em 1977, se exibiu numa jaula (com o letreiro

"Homo Sapiens") no Palácio de los Chimpanzés, escandalizando os visitantes do Jardim Zoológico de Lisboa.

1160 presidente, Américo Tomás entrou casualmente no salão, ficou indignado; e Marcelo Caetano, nas suas semiimprovisadas Conversas em família, na televisão, referiu-se à SNBA como local subversivo. Essa referência foi certamente improvisada, pois o texto da "conversa" publicado no dia seguinte nos jornais, não a continha. In Gonçalves, Rio Mário; «A Arte Liberta», in Vida Mundial, n. 15, Abril 1999, Lisboa, P. 84.

117 O aspecto estético (a filiação no hiperrealismo) em tensão com a intextextualiadde (Fernando Pessoa, o título), obtendo amplificação do sentido (Gonçalves). França definirá este momento como a quebra de uma triste tradição de academismo "modernizado". Lagos pode estar orgulhosa de ter uma das melhores estátuas de Portugal. E a mais moderna de todas. Numa peça em que o momentum é tudo, a importância do hiper-realismo foi dupla. Por um lado, a escolha do tema, completamente diferente dos temas fúteis do hiper-realismo americano. Por outro lado, a consciência crítica da escultura perante o facto de a imagem "fotográfica" estar a constituir um meio que procurava substituir-se ao contacto directo com a realidade, prestando-se, por isso, a escamoteá-la.

118 França, José Augusto; «O D. Sebastião de José Cutileiro» in Revista "Colóquio Artes", n¹4, 1973, Fundação Calouste Gulbenkian, pp. 41-44.

119 Pinharanda, p. 614.

120 José Augusto França citado em João Cutileiro: D. Sebastião, 1973-1993. Maquetas de Esculturas para Espaços Públicos. [ß.ı.]: C.C.L. [etc.], 1993. Cfr. Sílvia Chico, João Cutileiro, [S.I.]: Imprensa Nacional - Casa da Moeda, 1982 (Colecção Arte e Artista), pp. 23-25.

121 Organizada pela secção portuguesa da Associação Internacional dos Críticos de Arte.

122 Gonçalves, Rio Mário; «A Arte Liberta», in Vida Mundial, n. 15, Abril 1999, Lisboa. p. 85.

123 Gonçalves, Rui Mário; Pintura e Escultura em Portugal - 1940/1980, ICALP, Lisboa, 1980.

124 Gonçalves, Rio Mário; «A Arte Liberta», in Vida Mundial, n. 15, Abril 1999, Lisboa, p. 85. Gonçalves refere ainda, nesta linha de acção indoor, a exposição realizada na SNBA logo em Maio de 74, claramente empenhada na 
Aliás, no participado salão seguinte, em 1974, Ernesto de Sousa vai sublinhar com entusiasmo a oportunidade:

[...] uma "sociedade de artistas" pode constituir-se como resposta adequada a certas características do consumo das obras de arte, tal como ele se vai cristalizando na nosssa sociedade (...) este salão demonstra (...) que os produtores de obras de arte podem tomar consciência de que eles também de lutar contra a alienação argentária, que é um primeiro passo para a total alienação da sua actividade criadora; e uma mais imediata, indiscutivel morte da arte... ${ }^{125}$

Repare-se na linguagem precisa, elencando os principais problemas da arte como produção, circulação e recepção, integrando essa consciência da morte da arte enquanto força vital, face ao diagnóstico da alienação argentária. Se vários criadores em Portugal acompanham e têm voz sintonizada com o novo paradigma da arte contemporânea, a ausência de movimento colectivo diminuiu drasticamente o impacto e os efeitos dinamizadores das novas propostas [...]. ${ }^{126}$ Isto é, chegados a 75, são poucos os colectivos com manifestos impactantes; raras as estruturas que operacionalizassem as divisões produtivas vanguarda/modernidade, mormente no tecido urbano ou numa lógica urbanística. Prefiro valorizar uma série de pequenos-grandes acontecimentos urbanos, acontecidos de norte a sul do País.

Todos eles contribuem para revermos os primeiros anos a seguir ao 25 de Abril não apenas como de festa, mas debate sobre a função da arte e sua relação com a urbanidade, num país à procura de um sentido para o seu desenvolvimento. Todas estas acções foram formas de uma classe - a dos artistas - questionar-se a nível individual e colectivo, por via de actividades que não passavam pelos mecanismos de legitimação e difusão da arte moderna. $A$ rua, o mural e a situação, o debate e o confronto, a instalação e a intervenção, por esporádicas que tenham sido, substituiram-se à galeria e ao museu, ao quadro e à escultura sobre o plinto, ao discurso académico e à crítica de arte. Por vezes com pessoas reais imiscuindo-se nos interstícios das divisões culturais que Abril jamais eliminaria por completo.

\section{2.1.1 Projectos colectivos: a arte à rua! - KWY, Acre, Puzzle e a Ogiva}

Nos inícios da década de 70, algumas dinâmicas colectivas encontram-se no teatro (COMUNA) ou na música (GAC), com destaque para os cantos livres, em que as pessoas se encontravam para ouvir canções que eram apresentadas muitas vezes em esboço, numa processualidade necessária' ${ }^{127}$. Nas artes plásticas inscrevem a actualidade da arte pública. Minha Nossa Coimbra Deles (1973) e Arte na Rua ou, mais tarde, 10000001.: Aniversário da Arte $^{128}$ (1974) foram marcantes eventos que procuraram atrair a população para a sua dinâmica plástica e criativa.

questão colonial - exposição de gravuras denunciando o conflito e repetindo com grandes letras ao longo do salão, a frase de Ronsard: «Príncipe, basta de guerrear».

125 Revista Colóquio, Lisboa, Abril 1974. De acordo com Gonçalves, o texto ecoa redifinição de uma política da arte, expressas no 3.: Congresso da Oposição, em Aveiro.

126 Idem. [...] contribuindo para a manutenção, sem grandes sobressaltos, das hierarquias estéticas e da relação de forças firmadas e ao longo da década de 60.

127 Mas aquilo de cantarmos sempre juntos, com más condições, passou a ser limitativo. No entanto era uma resposta muito necessária na altura, e acho que houve coisas magníficas. Sérgio Godinho, in Vida Mundial, n. 15, Abril 1999, Lisboa, p. 44.

128 Iniciativa dinamizada por Ernesto de Sousa (CAPC). 
João Vieira esteve juntamente com Costa Pinheiro, José Escada, Gonçalo Duarte e René Bertholo na fundação do colectivo KWY, juntamente com Christo e Voss. O KWY (programaticamente, as três letras que não existiam no alfabeto português) teve marca internacionalista e foi um dos raros movimentos de arte portuguesa que encontrou efectivo reconhecimento fora do país. ${ }^{129}$ Estabeleceu com a contemporaneidade internacional do seu tempo um continuado diálogo e terá sido o primeiro sinal de acto vanguardista ${ }^{130} \mathrm{em}$ Portugal desde Amadeo de Souza-Cardoso no início do século e dos surrealistas nos anos 40 . Um comentário de Bertholo faz justiça à sua verve: As coisas são interessantes na medida em que possam ajudar a sonhar de olhos abertos. ${ }^{131}$

Quanto ao colectivo Acre - cujo lema era Uma arte para toda a gente - são outro momento fundamental na minha genealogia. O Grupo Acre (Alfredo Queiroz Ribeiro, Clara Menères, Lima Carvalho) chegou a pintar ruas e passeios com padrões abstractos na Rua do Carmo ${ }^{132}$, agindo na calada da noite. Nessa artéria de Lisboa, cenográfica como poucas, a intervenção teve enorme amplitude retórica, desde a relação com o fluxo quotidiano (numa das artérias mais intensamente vividas da Capital) ao aspecto de 'cena' (sendo um sítio onde vemos e somos vistos. O risível da acção, ao mesmo tempo conceptual (como meta-arte) e profundamente comunicativa (decoração quotidiana), encontraria eco noutra das acções do grupo, quando distribuíram diplomas de artista (mas aí no espaço circunscrito da Galeria Opinião).

Os Puzzle ${ }^{133}$, ainda que essencialmente 'confinados' à pintura e à performance, procuraram também eles dedicar-se às questões da função social da arte e do artista. ${ }^{134} \mathrm{O}$ seu lema: Contracorrente, o conceito operativo escolhido para unir, de acordo com Albuquerque Mendes, dos mais activos membros do Grupo, para intervir no espaço urbano através de uma ação colectiva, lúdica e liberta de compromissos politicos. Nessas acções, em Lisboa, no Porto, em Viana do Castelo (1974), nas Caldas da Rainha (1977), são visíveis ligações aos rituais das procissões e das manifestações religiosas e profanas da cultura popular portuguesa e está implícita uma poderosa e inevitável dimensão colectiva no acto artístico enquanto ele decorre (ideia de participação em ponto crítico).

Que caracteriza a prática do Grupo Puzzle? [...] O desejo veemente de instaurar um diálogo aberto com os componentes da nossa cultura e com as massas arredadas da arte, e a vontade de sair dos quadros estreitos que nos foram impostos pelo isolamento geográfico e pela incapacidade dos burocratas.. ${ }^{135}$

129 Almeida, Bernardo Pinto de, Costa Pinheiro, Editorial Caminho, Lisboa, 2005

130 Almeida, Bernardo Pinto de, Pintura Portuguesa no Século XX, Porto, Ed. Lello, 1993, 1996 e 2000.

131 Ana Marques Gastão, in Diário de Notícias, 15 Junho 2005.

132 Conheço a fotografia da intevenção na Rua do Carmo, em Agosto de 1974 (cf. http://graodeareia-attac.weblog.com.pt/ arquivo/095082.html), mas não consegui encontrar imagens de uma intervenção junto à Torre dos Clérigos, no Porto.

133 Formados já em 75, compostos por João Dixo, Carlos Carreiro, Albuquerque Mendes, Dario Alves, Armando Azevedo, Graça Morais, Jaime Silva, Pedro Rocha, Pinto Coelho e Gerado Burmester e Egídio Álvaro [crítico]).

134 Questão igualmente crucial, tendo-se em conta as constantes e muito intensas divergências acerca das formas da arte num país de escassos recursos e visão política lo que passava por uma reflexão sobre os locais de exposição, os nomes a promover, etc.). Houve mesmo episódios de desentendimentos entre instâncias oficiais, com base em profundas divergências ideológicas: Gonçalves, Rio Mário; «A Arte Liberta», in Vida Mundial, n. 15, Abril 1999, Lisboa. P. 87.

135 Egídio Álvaro in Revista de Artes Plásticas n 7/8, Dezembro/Janeiro 1977 [...] Polémica é a posição destes nove artístas desde o início lo célebre jantar/intervenção na Alvarez-Dois), ao acreditarem e ao projectarem-se num trabalho colectivo para o qual nenhum (ou muito poucos) estava realmente preparados, que só lhes anunciava canseiras e preocupações, que sacudia o conforto do trabalho individual e in-discutido, que os a obrigava dialogar permanentemente, e que os lançava numa aventura, num desafio, de resultados imprevisíveis. Vanguarda porquê? Porque o conjunto de factores que constituem a proposta do Grupo é coerente 


\section{Ogiva, um espaço de liberdade}

Em Óbidos, pode falar-se de um pontual movimento de uma atitude de vanguarda descentralizado. Em 2009, a experiência da Galeria Ogiva seria assim relembrada:

À primeira vista, é paradoxal: se houve um tempo certo para a Galeria Ogiva existir, foi aquele em que as suas portas estiveram abertas, na Rua Direita de Óbidos, entre Novembro de 1970 e Janeiro de 1974. Esse foi o tempo em que o extremo cansaço face ao regime político que acanhava a vida cultural portuguesa saudou o projecto participativo e solar da Ogiva. ${ }^{136}$

José Aurélio ${ }^{137}$, artista e mentor da iniciativa, imprimiu à organização uma atitude de abertura, inclusividade e festa, adequada para a arte crítica do tempo ${ }^{138}$. A galeria respondia a Uma relevante questão de escala, portanto, e uma questão de risco, também. [...] As galerias existentes na altura, no país, não ofereciam condições tão acolhedoras. ${ }^{139} \mathrm{Como}$ diz Ana Vieira à L+arte, "ter mostrado na Ogiva um novo 'ambiente' funcionou mais como uma oportunidade de o realizar, porque não havia muitos locais para expor (...) qualquer coisa que saísse de uma determinada escala, mais comercial." O espírito de entreajuda e cumplicidade - Espiga Pinto recorda a ausência de 'honorários'... - andava a par de um sentido de documentação até aí inédito, que por sua vez se articulava com um afastamento da crítica de arte ${ }^{140}$. Hoje, os artistas que viveram por dentro o espírito da Ogiva recorrem a expressões como "lugar de encontro", "comunhão de ideias", "projecto utópico", "espaço de afectos", o que caracteriza bem a nostalgia por um tempo que se cria pleno de possibilidades. ${ }^{141}$

e se situa, na nossa cultura (e por extensão na cultura europeia) como uma alternativa necessária, justa, actuante, imbricada no presente e voltada para o futuro.

136 Rosendo, Catarina; «OGIVA GALERIA DE ARTE, 1970-1974. "O risco de sair da norma"», in http://arquivolarte.blogspot. com/2009_10_01_archive.html. Mas foi da mesma época a crua realidade económica e profissional que esmagou o seu programa a contra-corrente, pondo à vista as suas fragilidades e impondo-lhe o encerramento.

137 Juntamente com sua mulher, Alice, e o concurso de, primeiro, Rogério Ribeiro (fundamental na criação do projecto expositivo), Espiga Pinto e Eduardo Nery; depois Alberto Carneiro, Costa Pinheiro, Jorge Pinheiro e Vespeira.

138 Rosendo, Catarina; «OGIVA GALERIA DE ARTE, 1970-1974: Era um projecto de arquitectura [...] que permitia a realização de exposições, concertos e encontros e servia um programa claro: levar a modernidade a Óbidos, promover a arte portuguesa contemporânea e articulá-la com outras expressões de cariz cultural. Os três pisos da Ogiva ofereciam boas áreas expositivas, que comunicavam visualmente entre si através de mezaninos. Portas e janelas traziam o exterior para dentro da Galeria e davam acesso a pequenos terraços.

139 Ana Vieira, in Rosendo, Catarina; «OGIVA GALERIA DE ARTE, 1970-1974», depoimento recolhido por e-mail em 01.09.2009: Ana Vieira: O facto de ter mostrado na Ogiva um novo ambiente funcionou mais como uma oportunidade de o realizar porque não havia muitos locais para expor ambientes ou qualquer coisa que saísse de uma determinada escala, mais comercial. [...] De qualquer modo para mim a grande escala era essencial para que o corpo do espectador fosse, também, fisicamente envolvido. Acho que se vê com o corpo todo.

140 Que assim se via afinal enquadrada por uma 'estratégia' de comunicação muito específica: a Galeria preferiu um caminho alternativo aos circuitos habituais de divulgação: nas vésperas da primeira inauguração, a conferência de imprensa quis-se apenas local e toda a divulgação futura excluiria o envio de comunicados de imprensa. Dispensar a crítica foi um gesto de afirmação dos próprios artistas, insatisfeitos com os critérios de mediação entre a arte e o público que os críticos promoviam. Foi uma atitude corajosa e, ao mesmo tempo, ingénua, que acabaria por ser fatal, como José Aurélio reconheceria.

141 Rosendo, Catarina; «OGIVA GALERIA DE ARTE, 1970-1974. O segundo aniversário do projecto foi aliás uma verdadeira festa da comunidade artística que aí se deslocou de todo o país: Centenas de pessoas ocuparam o amplo espaço da galeria e assistiram ao "concerto simultâneo e sucessivo pelo Grupo de Música Contemporânea orientado por Jorge Peixinho e um agrupamento de jazz", e à improvisada "conferência-provocação" de Ernesto de Sousa sobre o seu encontro com Joseph Beuys na Documenta de Kassel. Com o rés-do-chão ocupado com obras dos artistas que colaboravam com a Ogiva, criou-se ainda uma zona que expunha a documentação até então produzida sobre as actividades da Galeria. 


\section{2.1.2 Costa Pinheiro - «Citymobil» ou a arte no dispositivo urbano vs. autoexílio}

A fugaz aproximação de Costa Pinheiro ao desenho urbano é um exemplo de ligação entre conceito e acção. Os objectos lúdicos de Citymobil (Munique, 1969), projecto imaginário em que a cidade é permanentemente transformada pelos seus habitantes ${ }^{142}$ - que se sucedeu a um trabalho sobre o brinquedo e seu transporte para 'cenários' de ficção científica -, são arte urbana que busca uma funcionalidade desconhecida do contexto português. ${ }^{143}$ Sublinho aqui a ironia de considerar determinante para a arte portuguesa crítica da forma urbana uma obra efémera imaginada no estrangeiro e que nunca chegou a ser realizada em Portugal. Citymobil é, aliás, para o seu criador um beco cuja saída, culminando no afastamento da coisa pública ${ }^{144}$.

Olhando para trás, quais os momentos marcantes da sua obra? O período de transição da Citymobil para o Pessoa. Dá a impressão que é uma linguagem que se contradiz na sua feitura, nas suas intenções. Uma, a arte urbana de que há agora uma inflação; a outra, esta entrada na poesia. Fui para o mosteiro. Durante o período da Citymobil fiz um diário, que publiquei num dos catálogos. ${ }^{145}$

Em Citymobil, o subtítulo Arte-Projecto indicia a posição radicalmente experimental-processual do criador, encontro com a totalidade urbana? Depois da experiência radical da arte pública, o artista 'foge' para 'o mosteiro'. Sendo possível reconfirmar esta tendência para o afastamento da coisa pública - concretizada, imaginada ou encenada - em muitas acções e percursos pessoais, corresponderá a arte pública a um 'estado de alma' (uma paixão) que não é 'sustentável' por muito tempo? ${ }^{146}$

Antes de prosseguir, há que dar-se um passo atrás para se compreender a deriva urbana, projectual e conceptual de Costa Pinheiro. Na sua obra pictórica, posterior às experiências informalistas dos anos 50 , há a exploração sistemática de um espacialismo bad ${ }^{147}$, reflectindo um estado de urgência comunicacional e de contacto imediato entre o criador e o seu

142 Costa Pinheiro. In Infopédia [Em linha]. Porto: Porto Editora, 2003-2011. [Consult. 2011-01-21]. Disponível na www: <URL: http://www.infopedia.pt/\$costa-pinheiro>.

143 À época, talvez apenas como em René Bertholo (no interior do espaço galerístico), estejamos perante tão genuínas propostas utópicas; Pinharanda, p. 614: [...] são novas discursividades (lúdicas e não-analíticas) e de situações artísticas (e comerciais) utópicas. Bertholo, que em 72 havia de realizar murais públicos em França, por iniciativa do Centre National d'Art Contemporain, na zona das Halles. Concretizam vários outros projectos de intervenção no espaço urbano, com esculturas em cerâmica e betão armado colorido, em França e, o último, em Portugal (Hospital do Barreiro, 1983).

144 Dominada, ao nível do mercado da arte, pela consolidação de nomes dos anos 60 que tiram partido do conservadorismo e imobilidade geral do sistema - apesar das dinâmicas inquestionáveis que pontuam a década, como veremos no caso Ernesto de Sousa e de artistas como o já citado Carneiro ou Helena Almeida, que já estão no que Pinharanda chama de áreas de fronteira.

145 In http://www.publico.pt/Cultura/costa-pinheiro-muitos-dos-meus-quadros-continuam-silenciosos-la-no-atelier_1327775?p=8

146 Vejamos algumas linhas da biografia: Em 1967 fez os décors e as máscaras para o teatro musical "Alter - Action Antonin Artaud", com Egisto Machi, Eberhard Schoener, F. Furtwangler, Leonid e Tatiana Massine na "Haus der Kunst " de Munique. Depois das exposições individuais em 67/68 (galeria Leonhart em Munique, Galeria Bucholz e Galeria III em Lisboa, Galeria Rothe em Wolfsburg), afastou-se da pintura e dos meios comerciais de Arte. / 96/97 Project-Art - Cosmolanguage - Aspectos de uma Retrospectiva, III parte, Galeria Kunst + Kommunikation, Munique. Repare-se a questão sempre recorrente da totalidade, quando na retrospectiva de $96 / 97$ a 'project-art' equivale à linguagem do cosmos...

147 Almeida, Bernardo Pinto de: figuras inacabadas, rasuras, hesitações assumidas, legendas inscritas, quase grafitistas, e toda uma de expressão plástica e gráfica [...] permitindo compreender a sua boa aceitação pelas mais lúcidas vanguardas alemãs dessa época, com Joseph Beuys entre os seus próximos, esboçando-se ainda, neles, os rudimentos de muito do que haveria de ser, quinze anos mais tarde, o sentido de uma Bad-Painting que na Alemanha floresceu pela mão dos chamados Novos Selvagens. 


\begin{abstract}
[...] uma longa e reflexiva pausa, em que suspendeu a actividade como pintor para se dedicar a outra sorte de projectos, de cunho quase estritamente conceptual, que em muito se aproximaram quer de um sentido de desmaterialização da obra de arte quer de um desejado clima de festa que movimentos sociais de novo tipo, como os de Maio 68 em França, encetaram. I Os textos que conceptualizaram as obras - de si mesmo pouco mais que ensaios, maquettes, fragmentos, projectos - deste longo período reflexivo, entre as quais o projecto chamado Citymobil, foram objecto de posterior publicação em livro, deixadas quase todas em projecto por impossibilidade real e material de lhes dar mais aprofundado corpo. / Serviram todavia ao artista para assumir um discurso radicalizado sobre a produção e a recepção da obra de arte e, bem assim, para o destacar então numa ordem de intensificação das correntes artísticas na Alemanha, onde vivia. Tendo-Ihe valido, assim, aliciantes convites, quer da famosa Academia de Düsseldorf, nos anos dourados do magistério de Joseph Beuys, quer de Harald Szeemann de Kassel onde justamente Beuys consagrou a sua arte entre todas experimental e subtilmente revolucionária. ${ }^{148}$
\end{abstract}

Costa Pinheiro recusaria ambos os convites - acto kúnico -, remetendo-se por mais alguns anos ao auto-exílio. Através de um processo análogo à psicanálise, o artista recua de alguma forma perante a expressão artística na esfera pública urbana, para em seu lugar decifrar os insondáveis labirintos de um imaginário escondido, íntimo e secreto. ${ }^{149}$ Diríamos que a radicalidade política se transfigura numa interioridade que não sendo necessariamente menos política, o é de forma menos transversal relativamente à vivência quotidiana da cidade. Digamos que, assim, o artista preserva a arte das suas tentações de a domesticar leventualmente em função de amanhãs colectivos). Ora até que ponto é possível encarar este processo como corrente nos artistas das décadas de 60 e 70 em Portugal? Tudo indica que a pulsão crítica e de radical intervenção social se exprime, as mais das vezes, apenas muito efémera e pontualmente, como uma irrupção; tal experiência, que é, no limite, de desindividuação, desterritorialização, despersonalização do acto artístico, redunda numa praxis que depois é rapidamente confrontada com uma certa ansiedade pelo regresso a formas porventura menos imponderáveis e dependentes do poder político-social vigente, ou seja, modelos de expressão que necessitam da circunscrição do individual para subsistirem (como uma pintura na parede). Não que esses 'regressos', após o confronto com o social sejam um recuo per si, mas parecem corresponder a um desejo de optimizar os poucos recursos existentes, de salvaguarda de um espaço pessoal que o trabalho propriamente público não favorece lum sacrifício que, de certa forma, o instinto de sobrevivência contradirial.

\title{
Regresso às obras de project art:
}

Também, pela escala vasta e ousada, e pelo modo como nelas coexistem largos fragmentos deixados em branco, violentos na sua veemência experimental de procura de uma invenção poética radical, estas obras constituem um intervalo de grande liberdade na arte portuguesa do século XX, no momento exacto do seu acerto - de que Costa Pinheiro foi um dos protagonistas evidentes - com a arte europeia e internacional. 150

A sua deambulação é a do efémero 'regresso' à cidade por via do contacto directo com o quotidiano, numa espécie de contrato entre arte e arquitectura, imaginação e cidade:

O projecto Citymobil, distribuído em policópias nos corredores do metropolitano de Munique, em 1968, referia já a necessidade de «estimular variados elementos de jogo, a possibilidade de exercícios visuais meditativos e de acção». E,

148 Idem.

149 Idem, p. 6

150 Idem, p. 8. 
mais adiante: «A cidade-móvel Citymobil não convida a que se habite nela com o corpo, mas sim com a imaginação. A monotonia brutal das cidades de hoje não convida a imaginação...» É, ao mesmo tempo, um manifesto e o desenho breve de uma utopia. Percebe-se bem isso na ideia, que percorre todo o projecto, de uma desmaterialização do objecto de arte, aqui quase só reduzido ao conceito. Não à maneira dos americanos - num conceptualismo purista que a sua cultura, de raíz profundamente europeia, não poderia autorizar -, mas de um outro modo, quiçá mais fantasioso, e sobretudo mais ligado aos conceitos então aflorados pela mão de uma série de artistas por toda a Europa. / A alegada desmaterialização do próprio corpo - que aparece substituído pela imaginação - descreve esta situação limite da experiência artística em que o artista se torna multimodo na sua acção, divergente nas formas da sua intervenção, desenhando uma linha de fuga em relação a um real dominado pela absurdidade da tecnociência. Em tudo isto, uma terna vertigem humanista que não deixa de evocar o humanismo radical dos falanstérios de Charles Fourier. ${ }^{151}$

Na sua pragmática cósmica a arte projectual de Costa Pinheiro convida a uma tal abertura aos elementos da forma urbana que essa abertura obriga os protagonistas a pisar terrenos onde o seu trabalho se torne crítico. Neste Costa Pinheiro - podemos surpreender um pensamento poético em tensão criativa com um desejo de realidade quotidiana; desejo que é superado, até certo ponto, numa ideia de projecto como instância semi-abstracta, apesar de tudo «pacífica», das ideias conceptualmente projectadas - e neste sentido não caminhamos ainda para o território mais efectivamente transformador, activista, da intervenção urbana efectivamente continuada - lenta -, levada a cabo em plena cidade.

\section{2.2 Alternativa (Zero) vs. mainstream (da arte pública)}

\section{2.2.1 Em 77, a Alternativa é Zero}

A Alternativa Xero é, no meu programa de investigação, menos 'mais uma' exposição colectiva que um statement pragmático com traços de arte pública crítica. Alguns destaques da AZ, a mais marcante das mostras concebidas por Ernesto de Sousa: Menères apresenta uma inopilante Mulher-Terra-Vida evocando anteriores 'provocações' eróticas ${ }^{152}$ e implicando um 'tratamento' quotidiano, o "aparar da relva"; a land art 'de câmara', resíduo de um ethos outdoor' $^{\prime 153}$ de Alberto Carneiro - os 'teatro-ambientes'154 -, que tão bem coloca o problema da relação entre a arte como linguagem face à vida-vida da natureza; poemad'entro de Ana Hatherly, que ao longo da carreira passaria pelo cinema e pela palavra e a escrita (como em Ana Vieira) sempre com atenção profunda ao real social; Pedro Andrade propõe uma instalação interactiva no limite da tecnociência; Sena da Silva, juntamente com Robin Fior, representa o design (e a arquitectura) como ciência do quotidiano; Julião Sarmento empreende uma análise cínica do ethos artístico na transição do período revolucionário para os anos 80. Este conjunto de autores revela como havia em Portugal a consciência dos fundamentais modelos da linguagem artística com intenções comunicacionais (por oposição ao regresso

151 Idem.

152 Lembro-me de as imagens evocarem outra peça física, como «Túmulo Ventre» de Ferdi, que havia feito furor na que é considerada a primeira exposição de arte erótica, em Lund, na Suécia, com curadoria de Phylis e Ebergad Kronhausen, em 1968.

153 Cf. As intervenções na paisagem como Operação estética em Vilar do Paraíso (1973) e Operação estética em Caldas da Rainha (....). Outra obra tem um título programático: Uma árvore é uma obra de arte quando recriada em si mesma como conceito para ser metáfora (instalação na Alfândega do Porto, 1992), in Melo, p. 152.

154 Uma linha de trabalho em que poderíamos ainda integrar Ana Vieira. 
ao pictórico, como do vale tudo (Jimenez, Claire) das décadas seguintes); ao mesmo tempo que - comprovam-nos as carreiras dos criadores no pós-Alternativa - muito pouco desta renovação plástica transita directamente para um movimento de arte pública crítica. Ainda assim, enquanto plataforma de realização cultural ao nível do dispositivo artístico, com os vários intervenientes conscientes da excepcionalidade da ocasião ${ }^{155}$, a AZ foi 'canto do cisne' de um determinado tempo, coincidindo com um período de ressaca revolucionária e normalização democrática. Para a intelligentsia da arte em Portugal, a Alternativa tanto fecha um ciclo emancipatório e politicamente empenhado, como abre um ciclo 'cínico', em que os aspectos críticos da exposição, se bem que mantendo-se em certa medida, transitam da esfera da luta política tout court, engajados - panfletários - para formas de arte sobretudo empenhadas na gestão da sua própria recepção, mormente como carreira, como no 'caso' Ogiva).

\section{Na AZ ressoa ainda o entusiasmo por uma arte programática, de consciência:}

[...] interdisciplinariedade (por oposição à autonomia das disciplinas artísticas), o trabalho colectivo (por oposição ao individualismo da autoria), a participação do público (por oposição ao espectador separado do processo de criação), a abertura do processo de produção artística, experimental, indeterminado (por oposição ao fechamento e ao fetichismo da obra acabada), e a interligação entre arte e vida, topos que presidiu ao seu pensamento e à sua prática. ${ }^{156}$

Com a AZ, algumas noções críticas são explicitamente abordadas: a desmaterialização da obra de arte, a noção de "obra aberta", o artista como "operador estético" ou o papel activo do espectador. ${ }^{157}$ Mas se enquanto marco histórico da década a AZ é já é um acontecimento, para Isabel Nogueira, ${ }^{158}$ nela poderemos entender uma continuidade contraditória e complexa entre uma época histórica pré- e outra pós-moderna; a $A Z$ representa em simultâneo a apoteose da vanguarda (o fechar de um ciclo) mas também o início de algo de novo; mas mais, a exposição estabelece, pela escala, amplitude e diversidades da propostas (à la Szeeman), muitos dos aspectos fundamentais da gramática essencial para que a referida continuidade fosse conscientemente apropriada pela criação coeva. Mas acima de tudo, interessa-me em Ernesto a dimensão do artista total que está num lugar e num tempo, disponível para inéditas interpenetrações: ${ }^{159}$ ES sabia que era a isso que se devia, fundamentalmente, o sucesso de visitantes da exposição - a festa do jogo dos possíveis. Eis Ernesto de Sousa como incontornável modelo de um artista-intelectual empenhado na desconstrução do status quo e na edificação quotidiana da festa da arte. Alguns artistas ou agentes culturais, na sua órbita, criam condições projectuais para que certos momentos da vida se encontrem carregados de um real transfigurador da própria ideia de real, em sede de abertura interpretativa, convivial, dialógica, do acontecimento artístico. Como havia acontecido na Ogiva, o conceito de Festa, na sua relação com o dispositivo expositivo, conduz à indecisibilidade produtiva acerca das próprias categorizações ou tipologias da arte criada. A obra está, então, absor-

155 Ao contrário de outros, como Noronha da Costa.

156 Idem.

157 Nogueira, CF..

158 Nogueira, Isabel; Do Pós-Modernismo à Exposição "Alternativa Zero", Vega, Lisboa, 2007.

159 Particularmente notório no catálogo. É uma peça de divulgação mas ao mesmo tempo de autoexplicação, em que a esmagadora maioria das obras se expõe como processo (Alberto Carneiro, Túlia Saldanha), como manifesto (Leonel Moura) ou até como interpelação directa (Jorge Pinheiro). Resta saber com que convicção e com que sentido em termos pragmáticos (que não os da afirmação profissional, prioridade de grande parte dos principais nomes da arte portuguesa nas décadas seguintes, precisamente lançados pela AZ). 
vida pela vida, pela densidade da própria vida, do vivido, em toda a sua durée especificamente projectual. O que implica - e implicou - um grande respeito pelo valor da contingência, do acaso, do processual, que, duma maneira ou de outra é um agente incontornável no resultado perceptivo e no próprio processo criativo. É uma estética do processo, da revolução em curso, consciente de que

a cultura é um enorme cadinho de formas recorrentes e internamente permutáveis; e capaz de interpretar o seu destino problematizador, numa percepção radical, o seu trabalho é uma permanente procura de um grau zero da acção ou da compreensão, mesclado com uma cultura histórica que lhe permitiu encontrar essa radicalidade em múltiplos momentos da(s) história(s) da arte.

Em suma, a AZ é o final da época dos primeiros artistas conceptuais, ponto-charneira de uma performática da própria arte, advogando um certo cinismo político na conscientização do seu papel no mercado da arte, das ideias e, em última análise, da cultura. Podemos dizer que o mainstream da arte pública é o espelho da $A Z$, se notarmos como suspende as primeiras questões críticas em nome de uma adequação que apenas raramente se torna (im)pertinente.

\section{2.2.2 A ‘arte pública’ autárquica - o ‘caso’ José Aurélio - objectos-marco}

O período de descentralização democrática pós-25 de Abril é caracterizado por uma autonomia camarária que traria para a vida urbana uma dinâmica de ocupação de espaços públicos por obras de arte relacionadas com uma visão e um gosto que estão nos antípodas da arte crítica moderna ou contemporânea. Responsáveis autárquicos cederam um bem comum - o espaço - a diferentes grupos de pressão e tornaram o mesmo o 'palco' de uma exposição das suas opções estéticas. Nota Alberto Carneiro, são muitos os exemplos em Portugal de obras de arte pública sem qualquer dignidade ${ }^{160}$. Vislumbro aqui a consciência de que à arte, e à arte pública em particular, se exige outra coisa que a mera decoração monumental (o lado mais pobre da experiência urbana).

Em Portugal o público associa à arte pública a estatuária - com ou sem ethos modernista numa dinâmica de simbolização do poder ou de determinada legitimidade politica (democracia representatival. Por outro lado, a proliferação de formas de escultura ou arte muitíssimo condicionadas pelos lugares comuns da arte na cidade - uma obra de arte numa rotunda é uma inutilidade ${ }^{161}$ - leva a que quaisquer visões críticas (dos sistema da arte pública, das dinâmicas politicas locais, etc.) acabe por optar por rejeitar a positividade do artefacto da comunicação em nome de outros valores éticos ou comportamentais que, ao nível das decisões projectuais se revelam depois signos de uma divisão cultural e, até, de miopia estética que, na ausência de parâmetros próprios para se avaliar, redunda em acções mais ou menos gratuitas. Em terceiro lugar, e ligado ao facto anterior, o facto de que toda a estrutura política que conduziu a esta co-existência desconfortável entre arte pública mainstream lusualmente

160 Público, 28 de Outubro, 2008. Prefiro esta ideia da falta de indignidade à falta de qualidade (Regatão), menos operativa,

161 Idem. As obras de arte são para as pessoas fruírem, para conviverem o mais proximamente possível com elas, para se encostarem nelas. 
acrítica) e arte contemporânea 'de ponta (crítica, mas num registo separado da forma urbana) se abre um vazio. 0 que estará em causa, é o problema (de certa forma corporativo) da afirmação da arte no mercado do espaço urbano, a partir dos valores de qualidade outorgados pelo sistema que representam (curador, artista, crítico). Nesta posição, a questão da divisão cultural do 'bom gosto' é problemática ao nível da democraticidade da arte, mesmo quando aquele é temperado pela mais exigente ética profissional. Em termos de arte pública autárquica, de notar que esta dinâmica deu, por', origem a interessantes casos de continuidade e comprometimento(José Aurélio em Almada, com inequívoca presença no imaginário quotidiano dos cidadãos ${ }^{162}$ ). É uma dinâmica que, ainda em Almada, conheceu outras monumentalidades mais subtis e discretas, resultantes de várias colaborações do Ar.Co com a autarquia.

As esculturas de José Aurélio, informadas por ideias de esquerda e um contexto político específico (autarquia comunista) são marcos urbanos, dotados de um discurso relativo à agenda política local. São esculturas conscientes da sua linguagem estética (pós-moderna) e que, mormente no caso do monumento aos 35 anos do 25 de Abril, conseguem dominar o 'texto da cidade' e seus fluxos (por exemplo, o jogo da silhueta e do contra-luz, face à circulação dos transeuntes automobilizados na rotunda centro-sul): Espiral do tempo, é uma peça cheia de símbolos e imagens simbólicas, e suficientemente encantatória para quem a admire, sinta o movimento subtil que ela desenha no espaço, numa simbologia que dá conta do tempo que passou após o 25 de Abril. ${ }^{163}$ Para me ficar por Almada, ${ }^{164}$ evoco a gramática de Aurélio, mesmo que não seja a altura de indagar se nela não temos um desequilíbrio notório entre os ideais apregoados e as formas plásticas da sua veiculação ou evocação; apesar de alguns traços comuns, note-se como o materialidade do aço (nomeadamente corten) tanto suporta uma linguagem mais literal-icónica (as mãos enlaçadas do Monumento ao Trabalho), como simbologias mais abstractas (o Monumento à Paz, 2000), e tanto busca novas formas numa linha modernista (...) como se enleva numa abordagem etnomuseológica (Monumento à Lisnave, realizado aproveitando peças dos estaleiros ${ }^{165}$ ). Em derivas igual ou mais abstractizantes, também os monumentais blocos de cimento (vermelho) de Charters de Almeida em Almada e Telheiras ${ }^{166}$ ou (branco) de Sérgio Vicente ${ }^{167}$, não abdicam de uma condição objectual de partida (e de fim), mas em todos há uma noção de imagem ou fluxo urbano (e mesmo de usufruto quotidiano, como no Monumento à Paz, Almadal que os torna parte integrante da identidade realmente vivida pelo transeunte, elementos vibrantes ou energéticos da paisagem.

162 Podendo dizer-se que existe um grau de intencionalidade crítica razoável, tendo-se em conta o contexto global do Pais, manifestamente distinto das opções ideológicas do PCP.

163 Aurélio; José; «Monumento "Espiral do tempo", in 25 Abril 35 Anos, Abril 2009, N.1, Câmara Municipal de Almada, Almada, p. 28.

164 Embora José Aurélio tenha peça emblemática e de grande impacto na forma urbana em Sete Rios. Instalada em 1999, da mesma afirma o artista: Nego por princípio e temperamento a escultura bibelot / A escultura precisa de muito espaço e de muita gente. In www.lisboapatrimoniocultural.pt. Consultado em Dezembro de 2011.

165 Chamo a atenção para uma coincidência: os habituais sinais de trânsito que são aplicados às obras em rotundas, normalmente destruindo a harmonia prevista pelo artista, são aqui estranhamente sintonizados com um elemento de sinalética idêntico no guindaste recuperado pelo artista!

166 Cidade Imaginária, 2001, na Praça S. Francisco de Assis ou a escultura à Ribeira das Naus.

167 Evocação do 25 de Abril, 2009, realizada por colectivo de estudantes sob sua orientação e de José Aurélio, ao topo do parque Eduardo VII. 
Noutros termos, ao mostrar como é feita, a escultura de José Aurélio surpreende pela simplicidade do resultado a que chega. Quanto mais simples [...] descubro nesta obra uma necessidade de libertar a forma, reduzindo a um signo gigantesc ${ }^{168}$, logo a um aspecto 'universal' da decoração urbana. ${ }^{169}$ As pessoas participam em todo o caso, nesta arte pública, através do modelo do consentimento (Remesar); não se envolvendo o programa (representacional) do artista para além desse convite à aceitação activa. Mas esta experiência pode tornar-se pedagógica; precisamente devido à desejável diversidade de formas da arte na cidade, daí decorre uma pedagogia da própria consciência da história da cidade através da arte (Argan), mas rica apenas quando souber integrar a arte crítica que é mais ou menos resiliente a estas formas mais institucionalizadas do monumento.

\section{2.3 Anos 80, 90 e 00: a possibilidade (da) crítica}

Com a popularização da arte e do seu sistema, novos públicos acedem a esse novo mundo da criação, que rapidamente elege os seus ícones (de Cabrita Reis a Rui Chafes), tanto mais relevantes quanto souberem laborar num quadro em que se afirma um mercado, à margem da produção crítica em contexto urbano, a arte (Perniola) não é publicamente debatida , e o desejo crítico de vernacularidade é raro. 0 quadro democrático do 25 de Abril dá lugar, por outro lado, a uma passagem simbólica do regime para outro estado de espírito em muitos sectores da intelligentsia criativa, definido quer pelo luto, quer por uma normalização da paixão ideológica-revolucionária; isto mais a quente que na Europa, porque os ideais $e$ processos de Abril estão, comparativamente com Maio de 68, mais próximos temporalmente e mais flagrantemente 'falhados' (tendo em conta problemas atávicos paulatinamente diagnosticados pela geografia, o urbanismo e o próprio desenho urbano emergente). À entrada dos anos 80 , e para além de todo um parque escultórico ao longo de todo o território le suas rotundas), subsistem pontuais exercícios de radicalidade projectual. ${ }^{170}$

Ao nível da curadoria crítica destaca-se o percurso de Cerveira Pinto ${ }^{171}$, mas há nesta década pouco a referir relativamente a uma presença inovadora da arte na forma urbana. Os anos 80 são marcados por uma hibridez táctica que decorre da continuidade, na prática, do pós-conceptualismo para o pós-modernismo assumido lenquanto 'chapéu' para englobar desde a transvanguardia à bad painting); quando Pinharanda menciona como terminus da

168 Gonçalves, Eurico; in Phoenixes, 1997.

169 Em suma, poder-se-ia dizer que onde o trabalho de Aurélio define uma posição fundamentalmente objectual, no lado esquerdo da minha axiomática; do lado oposto Costa Pinheiro representa uma fugaz afirmação de uma arte processual. Da mesma forma, João Vieira representa uma forte dinâmica vertical, entre um trabalho sobre o corpo e um traballho sobre a palavra e o conceito, acompanhando, no vector inferior, Albuquerque Mendes, e na transição para o vector superior, Ana Vieira ou Fernando Calhau.

170 Carlos, Isabel, p. 646. As últimas "performances" de José Carvalho haviam passado das marcas... Lembro-me daquela que realizou em 1979 na Sociedade Nacional de Belas Artes com José Conduto e Palolo: em certo momento, a contradição do espectáculo era levada ao paroxismo de uma hiper-realidade: José Carvalho trincava, para depois engolir, o vidro de uma garrafa de vinho esvaziada momentos antes por todos nós. Não podia ser mais impressionante e esclarecedor: a arte é para se levar a sério» (Pinto, 1982).

171 Cf. notas acerca de Miguel Palma, na secção seguinte. 
década a exposição Dez Contemporâneos (Serralves, 1992), os criadores representados ${ }^{172}$ são quase maioritariamente avessos à intervenção no espaço público. Ainda assim, algumas experiências de Cabrita, Chafes, Xana ou Pedro Portugal fazem história ajudando os anos 80 a ser mais diversificados e dinâmicos que a década anterior (com muitos artistas da neovanguarda a continuarem em actividade), mas na arte pública a produção continua a ser ínfima e marcada por pouca ou nenhuma confluência de interesses entre críticos da cidade e críticos da arte. Isto para além da situação crónica de o Estado não promover a sistemática ou significativa preservação do património artístico (Melo) - ora sem museus, não há crítica institucional; não havendo 'sistema', nem a crítica institucional nem a afirmação do valor formativo da arte chegam propriamente a conseguir 'palco' na sociedade contemporânea do País. Apesar da dinâmica curatorial, de investigação, de produção, de divulgação de instituições como a FCG (privada), não há uma consciência evidente do que é a arte face à esfera pública. ${ }^{173}$ Numa situação generalizada de desleixo face ao território, esta época é objecto primeiro da predação pelos lobbies da construção civil, depois pelos mecanismos da publicidade e da comunicação de massas.

No meio de tudo isto, algumas obras e carreiras definem o nosso sistema artístico, pelo menos o que mais directamente considero legítimo e entre elas, a exposição Homeoestéticas: 6=0 merece breve destaque, até pelo apoio decisivo de Ernesto de Sousa e João Vieira. Empreendida pelo Grupo Homeostético $0^{174}$ - uma espécie de pseudónimo colectivo para uma acção ao mesmo tempo lúdica, crítica e habilmente mediática no confronto então crescente entre notoriedades, posições e oportunidades institucionais ${ }^{175}$-, registe-se o título-programa «Continentes». ${ }^{176}$ Dentre os membros do grupo, apoiado por Ernesto de Sousa le João Vieira), Manuel João Vieira é aquele que tem intervenção mais regular na esfera pública. Performer com verve dada, cantor pop-pimba, agitador das noites, leva a ligação arte-vida ao extremo de se candidatar repetidamente à presidência da República ou liderar carismáticos grupos musicais. ${ }^{177}$ Vieira terá 'herdado' a veia de João Vieira, seu pai, temperada com uma 'arma' que desenvolve com o maior dos 'rigores' - o humor (em ponto) crítico. ${ }^{178}$

172 Sarmento, Burmester, Cabrita Reis, Pedro Calapez, Casqueiro, Chafes, Croft, Proença, Portugal e Sanches.

173 Melo, p. 74. Melo sublinha o desperdício de saberes, a falta de continuidade temporal. Eu noto a 'coincidência' AZ, LXCN (e , no meio, 6=0...?). É por causa da debilidade destes mecanismos de transmissão cultural - claramente exemplificados pela demissão do Estado ou pelo persistente anacronismo do modelo de funcionamento as instituições de ensino artístico oficial que em Portugal todas as velhas gerações se sentem ignoradas, abandonadas e desprezadas e todas as novas gerações sentem que têm de construir tudo a partir do zero, como se nada tivesse acontecido.

174 Pedro Proença, Manuel João Vieira, Pedro Portugal, Xana, Ivo e Fernando Brito. Nascidos entre 1958 e 1963, frequentaram a Escola de Belas Artes de Lisboa e realizaram cinco exposições colectivas. Alexandre Pomar: $O$ nome obscuro que usaram, sem nele diluírem as assinaturas pessoais, acompanhava breves textos onde cultivavam a incoerência ou mesmo a ilegibilidade programática e uma pose irreverente e paródica, que divergia da seriedade profissional com que nessa época se construía um novo panorama, marcado pela constante emergência de jovens artistas. In http://alexandrepomar. typepad.com/alexandre_pomar/2007/07/homeostticos-em.html

175 Quando ao livro-catálogo que seria mais tarde editado pela Fundação de Serralves: Nele se recolhem manifestos que em geral só existiram como manuscritos sem circulação exterior ao grupo e também a torrencial produção escrita lpoética ou ensaística, mas sempre delirante) de Proença, que aparece a sustentar a intervenção plástica do colectivo. Note-se que o Grupo ganha projecção, desde 1984, graças às carreiras individuais dos seus membros mais activos.

176 Em resposta a «Arquipélago», no ano anterior, no mesmo local, por Calapez, Croft, Cabrita Reis, Rui Sanches, Rosa Carvalho e Ana Léon (todos mais velhos, mas de afirmação mais lenta).

177 Os concertos de Ena Pá 2000, por exemplo, marcados por happenings, como o habitual número de Pedro Cavalheiro comer peixe cru ao vivo.

178 Melo, p. 70. Alexandre Pomar: Depois dos anos da efervescência política, chegara um tempo de euforia criativa, numa era 
Mas de todos os participantes, os que conseguirão manter a 'coisa pública' sob escrutínio (em sede de arte pública urbana), são sobretudo Portugal e Xana, com algumas obras de arte pública emblemáticas.

\section{2.3.1 Obras que afirmam um campo}

Enquanto internacionalmente se foi afirmando uma comunidade da arte pública crítica le todo um jargão), em Portugal (Lisboa) a (pouca) arte urbana é dominada por modelos de produção acríticos e pouco experimentais, que acompanham pontualmente a deriva crítico-discursiva e etnográfica dos anos 90 mas sem a radicalidade (não-objectualidade) e a consciência que era notória internacionalmente. Ao nível institucional, várias exposições de prestígio vão entretanto afirmando uma geração - Luís Campos, Miguel Palma, João Paulo Feliciano, Carlos Vidal, Paulo Mendes, João Tabarra (dos que mais focam aspectos da esfera pública).

Com Imagens para os anos 90 inaugura-se em Portugal uma polémica que a Europa já havia conhecido - entre uma atitude mais ou menos essencialista e a-histórica, e outra mais alerta em relação às questões e problemas da conjuntura cultural e social. Mais,

[...] por razões de ordem sociológica como sejam a escassez de oportunidades de carreira, a dificuldade de internacionalização e a debilidade do mercado, a década de 90 vive o paradoxo da não-correspondência entre a intenção e o acto. Assim constata-se que os artistas nunca de facto abandonam a produção objectual acrescentando-lhe mesmo uma escala institucional, a "escala museológica" que reflecte uma apurada consciência da existência e desejo de articulação com um "público consumidor" específico e constituido pelas novas instituições públicas ${ }^{179}$ [...].

Nestes termos, a arte deliberadamente 'política' acaba por limitar-se a reafirmar um sistema centralizado. José Maçãs de Carvalho vai emergir aqui com uma posição crítica propriamente metaoperativa, reflexão sobre o dispositivo em intenso contacto com o real não-artístico e quotidiano. É um exemplo de como

[...] boa parte da produção portuguesa da primeira metade da década de 90 parece enredada no paradoxo da adesão a uma postura warholiana cínica, apregoando, no entanto, uma postura brechtiana crítica e subversiva. [...] toda a produção artística dos noventa caminha, de certa forma, sobre o fio da navalha, no que diz respeito à distinção operativa entre uma postura crítica e uma actuação reiterativa. ${ }^{180}$

Esta superação (ou não) da questão de como o artista se pode ou deve apropriar dos signos e do sistema da arte capitalista é logicamente uma questão central na análise retórica, mas é progressivamente que se vai revelar estruturante, anos 00 adentro, já nos trabalhos de Vasco Araújo, Catarina Campino, André Guedes ou João Pedro Vale. São aliás exemplos de uma vaga neo-conceptual que gerou um mal-entendido ao nível da legibilidade das obras postulando uma hegemonia do assunto que obscureceu a percepção de outros níveis de significação. ${ }^{181}$

Nos anos 90, são focos de dinamismo crítioo a ZDB (desde 94) ou a escola MauMaus (desde

pós-moderna de reabilitação da pintura, diversidade estilística e livre apropriação de referências históricas. Os homeostéticos interpretavam o espírito da época com uma atitude de distância irónica que nunca os reduz a documentos de um tempo passado.

179 Melo, idem.

180 Idem.

181 Idem. 
92) - onde a perspectiva platform-art (Melo) do curador Jürgen Bock está ligada ao surgimento de uma intensa produção artístico-curatorial que rapidamente encontraria em Pedro Cabral Santo e Paulo Mendes, dois expoentes de uma estética crítica. A esta geração pertence, oriunda de outro foco, o Ar.Co, Francisco Tropa. É uma geração ${ }^{182}$ que finalmente retira alguma capacidade de manobra do facto de existir entretanto um Ministério da Cultura (desde 1995), e um Instituto de Arte Contemporânea, (dirigido por Fernando Calhau), ou ainda Serralves e o Museu de Arte Contemporânea de Sintra. Em meados de noventa, Portugal começa a poder usufruir de uma 'cena' artística relativamente ampla, com o eixo central ou 'mainstream' actualizado pelo que se fazia internacionalmente las práticas etno-relacionais, como em Ângela Ferreira ou Gabriela Vaz-Pinheiro). Este 'progresso' gera naturalmente novas franjas e margens - caso de Retratos da Alma (1995) ${ }^{183}$-, ocupando pequenos nichos de criação que vão culminar na diversidade de produção dos anos 00 (de que LXCN vai ser um dos eventos inaugurais). Nesta altura, já mostras sucessivas de Jorge Castanho (destacando-se pelo enfoque em Debord, Espectáculo, Exílio, Deriva. Disseminação: um projecto em torno de Guy Debord, 1995, ou, pela polémica, Além da Água, 1997, ambas as mostras em Beja); Paulo Mendes (destacando-se, pela explícita tematização da cidade, Urban Lab - Bienal da Maia, em 2001), mas também Delfim Sardo (Cerco, em Óbidos, 1993) ou Manuel Valente Alves (destacando-se a transdisciplinariedade da sua abordagem em sucessivos projectos expositivos e editoriais) propõem complexos produtos curatoriais que também marcam a época e introduzem o desafio da congruência e da articulação entre obras individuais e posturas colectivas, em tácticas plataformas de visibilidade efémera. Mas deve reter-se Melo quando chama a atenção para uma situação crónica de 'blindagem' da realidade portuguesa à inovação crítica na forma da arte; dando como exemplos de linguagens mais abertas precisamente artistas que, como é o caso de Ângela Ferreira - não restringem a sua acção ao País, Melo sublinha que aqueles que seguem essa via excêntrica são precisamente os que estão numa linha de continuidade com a inovação de Ernesto de Sousa ${ }^{184}$. É caso de Carlos Vidal, cuja produção plástica é acompanhada de produção teórica, contrastando com a dos seus pares contemporâneos, pela quantidade, regularidade e qualidade argumentativa. Em suma, a permanência do objectual-institucional-comercial (mesmo sob a forma festiva e espectacular da bienal, do festival ou do evento) é passível de ser lida, pelo menos em parte, como uma marca de recuo, de medo de existir (Gill), de estratégia de sobrevivência, de aceitação, no limite estóica, dos limites do socius do Pais? Ou tal 'absorção' é a expressão do adiar de sucessivas gerações críticas?

O caso de Xana merece aqui nota. A filiação pop e simultaneamente conceptual-minimalista no seu trabalho vai permitir que cada cada um dos seus objectos de grandes dimensões - não se arvorando 'arte pública' enquanto género - seja comentário atento à sua própria

182 Aparecerá com toda a verve na programação da LXCN, por proposta de Catarina Campino, que fazia crítica na imprensa especializada e que eu conhecia desde o início da sua carreira profissional, ainda não 'artista'. E seria ela que seleccionaria comigo o núcleo de artistas que, por via da sua capacidade de inscrição, colocaram a LXCN primordialmente na esfera da arte contemporânea le ao mesmo tempo trazendo para o evento uma visibilidade da produção marginal e dinâmica que outro tipo de escolha de artistas certamente não traria).

183 Retratos da Alma é parte de um panorama que passou pela dinâmica do CENTa (projectos de residência em Vila Velha de Ródão) ou, em Lisboa, pela acção Lisboa Fora de Horas (1995, coordenação de Graça Passos e Francisco Vaz Fernandes) - que aportaria a uma escala inédita a redescoberta de uma cidade informal e intersticial, em que o espaço público aconteceu pelo temporário acesso, durante toda uma noite, a casas privadas.

184 Melo, p. 93. 
integração urbana. Na Alameda da Reitoria em Lisboa (1981) o seu imaginário já assumia um programa monumental, mantendo uma dose de criticidade que decorre fundamentalmente da irredutibilidade do efémero e do humor. 0 percurso de Xana percorre os anos 80 e não deixará de inscrever nos anos 90 e até hoje o irredutível da arte abstracta na forma-cidade, porém, dada a comunicabilidade das formas e das cores, sempre implicando um aspecto lúdico ${ }^{185}$. Recentemente (2010), a intervenção no evento ALLGARVE confirmou este artista capaz de activar como um modelo eficaz de criticidade, no espaço público estival da praia. $\mathrm{O}$ artista colocou centenas de baldes vermelhos como que a construir um muro entre duas partes da praia, sendo interpretado de várias maneiras e assim gerando um intenso debate acerca da praia como coisa pública e em que a questão da acessibilidade não pode ser desprezada.

\section{Discrição, integração, imagem, provocação}

Lisboa '94 é dos eventos que nos anos 90 revelam a potencialidade comunicacional da arte urbana para um público mais alargado de transeuntes. Por ocasião da Capital Europeia da Cultura, várias obras de arte pública são parte de uma vasta operação que incluiu a remodelação de diversos espaços culturais e uma regeneração urbana procurando revitalizar o tecido sócio-cultural da cidade. Neste âmbito, o programa Sétima Colina foi fundamental para uma nova recepção da cidade como oportunidade de transformação; algumas obras, tomadas pelo desejo de comunicação e de integração, inspirariam a própria LXCN. Para além da operação crucial de pintar várias fachadas com cores 'originais', destaco a intervenção minimal de Carlos Nogueira,

[...] modulação a partir de um objecto simples, utilizado no quotidiano da cidade: o mastro, o pau de bandeira metálico, pintado de branco. A associação de muitos destes elementos em sequência linear, valorizando a sua conotação - abstracta, purificada - com ideias de percurso, de movimento ao longo da(s) ruals). I A LIGAÇÃO AO TERRITÓRIO

Um sulco, um corte em longitude, no terreno declivoso: num dorso, o assentamento dos mastros, vertical, partindo da oliveira ali deixada, quase esquecida. ${ }^{186}$

Neste contexto de aceleração da aproximação de alguns artistas a uma vocação urbana e vernacular, outros nomes da escultura 'monumental' afirmam-se, e o seu caso é crucial porque, tendo conquistado prestígio e reconhecimento no campo da arte cedo na carreira, quando são chamados a realizar obras públicas - que é Portugal é muitas vezes um sinal de consagração - revelam um domínio crítico da forma urbana. Neste quadro, Fernanda Fragateiro desenvolve projectos de arte pública emblemáticos que quase não se distinguem de uma comunicação eficaz de princípios éticos. Em 94 e no âmbito do programa de

185 Uma obra recente, como a realizada no ArtAllgarve, o artista realizou nos areais de Albufeira magníficas actualizações do percurso, numa lógica em que o ready made (baldes vermelhos) se associou ao relacional com forte impacto social las reacções das pessoas ao facto o artista ter dividido a praia em duas zonas...

186 Carlos Nogueira, permanência da água, Lisboa, Dezembro 1994, p. 35. Ao longe, lê-se como uma textura, um riscado sobre a terra castanha, inscrição depurada de uma frase longa, contínua, geométrica, urbana. E por cima de tudo, ainda a torre circular da velha construção, e o palácio de justiça de mármore - afloramentos escassos da cidade de colinas e fragmentos que Lisboa é. I DO CÉU E DOS LONGES Sobre a colina dos mastros, um avião procura a pista. Árvore, linhas verticais, terra e talude - apontando para o alto, para outra dimensão, mais ampla. E ao fundo, na neblina do trânsito e também do Vale de Alcântara - a ponte - o Aqueduto das Águas Livres, arcos em sequência, pilares igualmente verticais. Quando entramos na cidade, por este lado, ansiamos pela curva depois da qual se vêem os mastros. 
arte pública apoiado pelo Metropolitano de Lisboa ${ }^{187}$, realiza um 'tapume', na Rua Mouzinho da Silveira ${ }^{188}$, obra de grande subtileza, simbioticamente integrada no tecer da cidade - na órbita de Robert Erwin. Talvez Fragateiro tenha a capacidade muito específica de introduzir nas decisões do logos escultórico os traços formais adequados à sua apropriação. As suas criações são portadoras de uma carga poética e lúdica e conseguem contornar a ultrapassar os limites da estatuária e da escultura pública, instaurando ambientes urbanos que convidam a uma vivência por dentro da obra. ${ }^{189} \mathrm{Na}$ sua leveza formal, ao mesmo tempo proficiência minimal, o seu trabalho espelha, mais do que altera, a dinâmica da cidade precisamente porque estabelecendo uma forte relação entre arte instalada e arquitectura. ${ }^{190}$

Ora num registo que não é nem o do humor que interrompe o real com misteriosos símbolos, nem construção de espaços lúdicos, Luís Campos parte da imagem para a criação de vários momentos de consciência crítica. $\mathrm{O}$ trabalho de Luís Campos (que também e médico), na órbita da fotografia e do vídeo, é uma contínua acção de encontro com o outro. Transurbana, em 1994 - série realizada quando o centro da cidade de Lisboa se preparava para albergar a Capital da Cultura - é esse olhar delicadamente empático sobre a alteridade do urbano periférico. ${ }^{191}$ Não se podendo dizer que sejam arte pública, obras determinantes de Campos são Limiares (1993) - fotografias de grandes dimensões de rostos de pessoas no limiar da morte - ou Transurbana, investigação sobre as fronteiras dos guetos emergentes na cidade contemporânea. Estas obras representaram para mim uma linha outra - ao nível da temática, do estatuto da imagem, da clareza das propostas, da dignidade da abordagem da condição humana - perfeitamente original na sua absoluta transparência estética (nisso aproximando-se do ethos da arte pública). De todos os artistas dos anos 90 que marcaram a paisagem cultural lisboeta, Campos é, como Maçãs de Carvalho, quem directamente vai dar origem a uma genealogia crítica especificamente LXCN, precisamente ao enfrentar a ocultação da morte e a exclusão social nas sociedades actuais ${ }^{192}$. Atentemos a duas notas que atestam da criticidade deste artista, na ligação entre as pessoas e a sua dignificação através da imagem como fluxo-limiar:

Na obra de Luís Campos, a fotografia é utilizada como um registro de realidades tão conhe-cidas quanto ignoradas. Se a cultura contemporânea reconfigura o real a partir da sua imagem, explorada como possibilidade de espectacularização das suas evidências, Luís Campos contrapõe à condição da imagem como espectáculo esse inicial poder da fotografia de destruir a ignorância e de ampliar o conhecimento da condição humana através da escolha de temas, pessoas e de situações que quebram os tabus da não representabilidade pela sua óbvia exclusão das imagens dominantes do nosso tempo. [...]193

Assim, Transurbana, apesar de confinado ao espaço museológico, é sobre Gente "de todos os dias", mas não gente banal. Só é banal quem se deixa canibalizar pela banalidade que lhe impõem, como todos sabemos no nosso íntimo. Cada figura é como um pronome indefinido que

187 A operação surge integrada numa ampla operação de Arte Pública efémera que o Metropolitano de Lisboa promoveu, e através da qual o público contactou com intervenções de vários outros artistas (Xana, Pedro Proença, Fernando Calhau, Gracinda Candeias, Leonel Moura, entre outros).

188 Programa de arte nas obras de expansão do Metropolitano de Lisboa, em que destaco, entre os restantes autores, a irónica literalidade do dispositivo em Fernando Calhau, com um tapume que ostentava, em néon, as palavras work in progress.

189 Carlos, Isabel.

190 Carlos, Isabel, p.647.

191 Campos viria a ser observador na LXCN, e artista convidado na Luzboa 2004.

192 Pinharanda, p. 636. Esse traço levar-me-ia a contactá-lo para ser 'observador' da LXCN (gesto com o sentido simbólico de um contacto entre gerações).

193 Fernandes, João; «Gente», in Campos, Luís; Obras 1982-2008, O Museu Temporário, Lisboa, 2008, p. 77. 
no entanto especifica, humaniza os contextos nos quais se integra. ${ }^{194}$

Activo desde os anos 80, Leonel Moura é outro dos principais dinamizadores do debate sobre uma vocação pós-moderna para a arte ${ }^{195}$. Do seu importante trabalho em várias frentes retenho uma dimensão recorrentemente teórica e sobretudo emblemáticas intervenções públicas em Lisboa, - efémeras e permanentes -, que interrompem a imagem da cidade com a sua iconografia (popular), simplicidade (formal e material) e frontalidade (nos dispositivos, do cartaz temporário ao azulejo). A homenagem a Almada Negreiros à entrada de Lisboa (Amoreiras) ou a intervenção sobre Camões às Portas de Santo Antão são exemplos de uma arte pública relativamente discreta e 'pobre' que realiza operações de superação da função da arte na cidade, ostentando uma extraordinária capacidade de integrar toda uma história da arte portuguesa num devir colectivo (numa radical apropriação da cultura portuguesa tradicional e apropriação renovada dos seus ícones). Enquanto arte urbana, a sua linguagem é de síntese (cultura visual), compromisso (entre decoração e conceito), choque terapêutico (no contraste de uma linguagem iconológica própria com a envolvente arquitectónica).

Numa extraordinária peça efémera de 1991, Leonel Moura realiza uma espécie de campanha de aplicação de grandes cartazes nos tapumes do metropolitano de Lisboa, no Rossio. A sua evocação do quotidiano cultural traz uma temática rara, a da inscrição da obra de arte no tecido sócio-urbano, dada pela relação entre imagens icónicas da cultura portuguesa (Amália) e uma solução gráfica (colagem de cartazes) extremamente precisa, na medida em que celebra o próprio espírito do lugar (relacionando as flores dos cartazes com a estação do ano e as floristas do Rossio). Peça cósmica - pelo alcance cultural das referências visuais e textos ao longo do tempo (sucedendo-se diferentes séries de cartazes com as estações do ano), para não falar da sua capacidade de interpelar o quotidiano meses a fio - até na forma despudorada como o meio singelo do cartaz se relaciona com a efemeridade da situação, um monumental tapume que ali esteve durante apenas e só o período de obras no Metropolitano de Lisboa. Moura produziu assim uma extraordinária celebração do quotidiano daquele lugar, o Rossio, através da publicitação de um seu traço identitário quotidiano sem abdicar da possibilidade de uma identidade complexa (a portuguesa), bem no coração das possibilidades plásticas da urbe. ${ }^{196}$

Pedro Portugal é outro criador que empreende um esforço de ampliação de horizontes da sua criatividade através do contacto com a cidade, assumindo a instalação como estratégia

\section{Idem.}

195 Juntamente com o galerista Luís Serpa (e Cerveira Pinto). E depois do modernismo (um título programático), em Janeiro de 83, foi uma operação articulada de Luís Serpa, englobando artes plásticas, moda, dança e música, marcando o início de um debate acerca do que seria uma emergente pós-modernidade. Nota Pinharanda que com a maior parte dos artistas transitando da $\mathrm{AZ}$, e numa manobra de «aggiornamento» de artistas vindos da década e de atitudes anteriores, organizada como conquista do poder.

196 Noutras obras mais discretas, a estética de Moura foi igualmente precisa, na utilização do azulejo para actualizar figuras da modernidade como Almada ou ícones culturais como Camões, em espaços urbanos que não são de todo os que previsivelmente albergariam tais celebrações. No caso da homenagem a Camões (1992), no Pátio do Tronco às Portas de Santo Antão, a peça é um elemento de informação urbana sobre o quotidiano do Poeta; e no caso de Almada uma releitura da estatuária nas formas mais 'pobres' da pós-modenidade. Mais recentemente, ao artista apresenta o que chama de Jardins Portáteis, peças artísiticas de mobiliário urbano extremamente funcional (banco, estrutura verde) que se encontram ao Terreiro do Paço. 
programática ${ }^{197}$, como em Eucalipto (1992) - um eucalipto invertido, espetado no solo, com um BMW 316i ao lado, e uma forma de 'rotunda' desenhada por fitas de obras. Certamente que comentário à arte públicas dos regimes locais (muitas vezes em rotundas), e revelando uma atitude neo-dada com preocupações reflexivas ${ }^{198}$. Noutra rotunda, em Beja, realiza Água de Alqueva (1997), a sua obra mais problemática199. A sua temática, e sobretudo a celeuma, que evoca a do histórico episódio Richard Serra/Tilted Arc, expõem um carácter de espaço-laboratório que que assenta numa apropriação do conceito de arte urbana questionável (e não propriamente debatível, pois o projecto não teve origem colaborativa).

Este é finalmente um período de expansão da gramática artística que conheceu outras obras de arte urbana não conotadas em sentido estrito com a arte contemporânea. É o caso dos dois monumentais corvos que Henrique Cayatte pousou na Ponte 25 de Abril. Revelando domínio da plataforma discursiva do mito, é uma peça (de design e ilustração) ao serviço de um desígnio informacional; em todos os sentidos de enorme equilíbrio, até na sua apropriação vernacular do símbolo da Capital.

\section{A EXPO '98}

Os anos 90 são em Lisboa de particular efervescência ao nível da oferta cultural e em particular no que diz respeito à emergência de uma cultura de Projecto Urbano (Pedro Brandão). A exposição internacional Europália (1991) e pouco depois uma alternativa Lisboa Fora d'horas em 1995, juntamente com Lisboa Capital Europeia da Cultura em 94, 'prepararam' a chegada da Expo 98, num período em que afluem ao campo artístico múltiplos meios e visões de articulação entre arte e cidade (da arquitectura às ciências sociais), de forma sistemática e categórica, sob o crivo do urbanismo cultural. A EXPO '98, pela sua escala, impacto em várias áreas e importância estratégica (cultural, mas também económico-financeira) para o País, pode ser abordada tendo em conta vários aspectos, mas é fundamental a ideia de 'pedaço de cidade' exemplar (a realização, com meios inéditos de um projecto urbano) em que a arte pública é perspectivada com um sentido de integração formal no desenho urbano. Alguns dados sobre o contexto que dá origem a EXPO '98 são de recordar. Em primeiro o carácter quase de unanimidade no interesse pela iniciativa (patente em generalizado apoio pelos partidos com assento parlamentar, compreensivos em relação à escala do investimento e ao seu conceito genérico - Os Oceanos como oportunidade cultural para articular uma efémeride, os 500 anos da chegada de Vasco da Gama à Índia -; em segundo lugar, a intenção, por parte dos organizadores, de não repetir os erros de Exposições Universais anteriores lo desastre urbanístico de Sevilha 82), publicitando que a Exposição seria pretexto para monumental operação de revitalização sócio-urbanística, assente na disciplina do design urbano. ${ }^{200}$

197 Pinharanda, p. 625.

198 Pldem, p. 633.

199 Para toda a polémica, cf. documentário Fora de Água de Catarina Portas.

200 Para as consequências várias desta mega-operação urbana, nomeadamente ao nível urbanístico e habitacional, cf. Ferreira, Vítor Matias e Indovna, Francesco (org.); A cidade DA EXPO'98, Bizâncio, Lisboa, 1999. 
Quanto à evolução do programa de arte pública no terreno, e de acordo com António Mega Ferreira ${ }^{201}$,

[...] foi crescendo progressivamente com o projecto da exposição. [...] tudo se desenvolveu espontaneamente segundo as necessidades de intervenção no espaço urbano, embora tenha existido desde o princípio um tema comum, que iria servir de base de orientação para os diferentes criadores. [...] Era importante que cada obra fosse um ponto de referência na "malha urbana" e que se distanciasse "do modelo da estatuária no centro da praça pública (...) deste forma procurou-se que as [...] intervenções de arte pública desenvolvidas para a zona de intervenção do Parque EXPO'98 ultrapassassem o processo de anonimato pelo qual passa o espaço público, tornando-se acima de tudo um espaço de estada".202

No desejo de conferir autoria, identidade e excepcionalidade a cada espaço envolvente, dispondo a arte como foco de qualificação estética e vivencial, a operação teve significativo financiamento e todo o seu enquadramento - mormente a questão de uma abordagem particularmente aberta das habituais condicionantes de uma obra de arte pública permanente - tornou o modus operandi do projecto exemplar (decisões de projecto tomadas em colectivos interdisciplinares, suportadas por decisões políticas inequívocas e apoio financeiro a condizer). Aliando o profissionalismo ${ }^{203}$ ao desejo de qualificação de todas as fases dos processos de criação, conceptualização, discurso, produção, manutenção, etc, pode dizer-se que houve uma dimensão ética a enquadrar a sua relação com um Espaço Público desenhado com condições institucionais e financeiras inéditas.

De todas as obras da Expo '98, selecciono algumas cujos valores de projecto ${ }^{204}$ são mais claros. A minha axiomática entretanto vai-se confirmando: se uma peça incontornável da Paisagem da Expo é Homem-Sol de João Vieira, esta é uma obra de função notoriamente decorativa, objecto-marco convidando a uma fruição essencialmente visual; a sua verticalidade (mais de 20 metros de altura), a relação com o céu estabelecem um 'ponto cardeal' e isso torna-a um dos marcos urbanos mais notórios le desde logo, durante os grandes eventos, um incontornável 'ponto de encontro' e de memória). Já a peça de Rui Chafes, na singeleza relativa das dimensões e das proporções, na sua vocação para a experiência do corpo humano, convida a uma apropriação performática - a escultura funciona como uma modalidade de inscrição do corpo no espaço, nomeadamente por parte das crianças que cabem facilmente no interior e assim usam aquelas formas como se um estranho equipamento de parque infantil se tratasse (embora enriquecido com uma dimensão sonora: o artista tem a intenção de que ela funcione como um búzio gigante, por onde o vento cria a 'voz' do lugar). Há nesta peça, por outro lado, uma faceta paisagística-contemplativa (belo escultórico) que como em Montanha-Rio, de Rui Sanches, desenvolve toda uma 'cena', apelando enfaticamente à participação do público como observador convidado de uma paisagem. Em Sanches esse público é convocado e afinal coreografado para um dispositivo que coloca várias hipóteses de partilha desse espaço, em tempo real e de acordo com a hipótese de várias pessoas em simultâneo, em diferentes pontos do mesmo, multiplicando perspectivas e sobretudo, sem qualquer dúvida, o debate in loco acerca das mesmas como objecto da sua atenção visual. ${ }^{205}$

201 Comissário geral da Exposição. O programa de arte pública foi coordenado por António Campos Rosado, que apostou na continuidade intergeracional, o que explica a presença de José Cutileiro (Lago das Tágides) ou Alberto Carneiro (Sobre o Mar), a par de Rui Sanches com Montanha-Rio e José Pedro Croft (Sem Título).

202 Regatão, p. 138.

203 Idem.

204 Aliás objecto de reflexão no âmbito da Pós-Graduação em Design Urbano e Interdisciplinariedade, CPD, 2000.

205 Desconheço porém como este peça integra ou não os fluxos quotidianos, o que passaria por saber melor se tem seido 
No Jardim das Ondas de Fragateiro, há ainda mais afinidades entre a arte pública institucional e uma arte crítica contemporânea, absolutamente capaz de dominar a forma urbana de acordo com um programa de democratização da experiência estética lainda que não propriamente artística). Jardim das Ondas é um de dois projectos desenvolvidos por Fernanda Fragateiro para a Expo '98. ${ }^{206}$ Alegadamente inspirada pela obra literária As Ondas (Virgínia Woolf), a obra consiste na modelação de uma área relvada, um jogo de formas côncavas e convexas. No espírito da Land $A r t,{ }^{207}$ funciona como espaço de descompressão formal (face ao edificado), uma área de recreio, informalidade, amplitude de movimentos físicos possíveis e sensibilidade para integrar as reacções por parte das pessoas lo recostar-se, o saltar, o subir e descer); o limite de um exercício fenomenológico, reduz-se ao mínimo dos efeitos visuais (monocromatismo), dos efeitos físicos lé um mero desnivelar do solo, de acordo com um padrão universal, o da onda) e mesmo dos efeitos retóricos (pois se impõe como espaço apropriável muito para além de constituir qualquer statement. Em suma, a haver obra que sintetiza um espírito de anonimato com a qualidade experiencial da obra de arte na forma urbana, é Jardim das Ondas, o que é confirmado pela ampla receptividade tem tido - uma boa vontade perante a obra interdependente do facto de muitas das pessoas que a fruem serem desconhecedoras de que se trata de uma 'obra de arte'.

Resumindo, o processo desta programação de arte pública no âmbito da EXPO 98 / Parque das Nações é exemplar do que a arte pública oficial e institucional pode ser, numa dinâmica de decisões complexas que vão além da arte, e prevêem integrar as dimensões colectiva, quotidiana e anónima numa ideia de público muito articulada. A LXCN parte, em grande parte, de uma consciencialização crítica da experiência da EXPO e retomando criadores (Fernanda Fragateiro), conceitos de planeamento (a dimensão de Evento e seu recinto, formalizados em componentes como Portas ou Infocentros) e ainda de uma dimensão intertextual (ampliada por um lado pela proximidade de Marvila face ao recinto da EXPO '98, por outro lado pelo Evento que decorria simultaneamente a norte, a Porto Capital da Cultura 2001.

Para Alexandre Melo, a década de 00 começa de forma auspiciosa, em função do aumento da educação universitária, assim como pela renovação de algumas visões académicas ${ }^{208}$. É uma fase de posições curatoriais de "tese"209, sendo o ano 2000 profíquo em projectos que afirmam não só a personalidade e posição do comissário como uma séria investigação na sustentação das mesmas $^{210}$. Integro, como já havia sugerido atrás, a LXCN nesta dinâmica, que tinha nas esfe-

apropriada pelos transeuntes e se a sua localização na forma urbana o sugere ou provoca de facto.

2060 outro é Jardins de Água realizado em parceria com o arquitecto paisagista João Gomes da Silva.

207 Regatão, p. 145.

208 Delfim Sardo ou Ângela Ferreira na FBAUL, Gilberto Reis e Pedro Cabral Santo na ESAD.cr, entre muitos outros, chegam à Academia. Este facto está na génese do arranque ou consolidação de inúmeros projectos (como a Extra] muros[l, cujos promoteres são jovens criadores e récem-licenciados ou recentemente pósgraduados. Em relação à arte pública, o Centro Português foi em dada altura o viveiro desta nova mentalidade, coordenado por Pedro Brandão com uma visão da totalidade do urbano imbuída das problemáticas da ética projectual. Brandão confirmaria o projecto na sua investigação doutoral, culminada em 2008, com a Tese, em livro, A Cidade entre Desenhos. Ética e Interdisciplinariedade, Livros Horizonte, 2008. A 'geração de 00' está representada na arte crítica extramuros, no caso por Catarina Campino, Vasco Araújo, Leonor Antunes, João Pedro Vale ou José Maçãs de Carvalho.

209 Melo, p. 110

210 Idem. 
ras do sistema da arte mais inovador as figuras de Delfim Sardo, Jürgen Bock, Miguel Wandschneider (Slow Motion), Pedro Lapa (More Songs about Buildings and Food, com produção da Escola Maumaus), protagonistas para quem os outsiders ${ }^{211}$ podiam procurar referências para eles próprios se entrosarem, em posições próprias no que Melo afirma entretanto se ter constituído como a língua franca da arte contemporânea. ${ }^{212}$ Note-se que, apesar do rigor e pontualmente da excelência teórica das posições daqueles protagonistas da cena da arte, a arte pública continuava a ser absolutamente residual. Noutros termos, a questão da materialidade regressava em força, talvez sem a devida atenção aos valores não-representacionais do processo - pelo menos é esta uma preocupação nos circuitos mais irreverentes.

\section{Modalidades do sublime vs. alternativa graciosa}

Antes de avançar no sentido da leitura crítica do tempo tal como a procurei empreender, falta mencionar dois importantes criadores que com regularidade acedem ao espaço público para ai concretizarem visões pessoas que depois lidam com a questão da representação/recepção.

Rui Chafes realiza em 2004 uma discretíssima escultura pública no Hospital de Santa Maria:

Duas hastes cilíndricas e lisas elevam-se no espaço, paralelas. No topo reconhecem-se as formas esféricas de duas flores, uma fechada em botão, mas já a anunciar abrir-se, e outra aberta, com um sequência regular de lâminas ou pétalas num movimento que parece querer resistir ao fim do seu ciclo de vida. Ambas pintadas de negro, em ferro, sobem a sete metros de altura no espaço ajardinado fronteiro ao Hospital de Santa Maria, à direita, num lugar onde se bifurcam os acessos que conduzem ao Serviço de Urgências e à Maternidade. À distância da fachada imensa do edifício, as suas formas nítidas recortam-se contra a imponência autoritária e triste do hospital, impondo a sua elegância carregada de simbolismo, por entre as árvores do jardim, com um notável acerto de escala. ${ }^{213}$

À obra deu o título Despertar, associando duplamente às suas formas a ideia de nascimento e de acordar, de regresso à vida, que igualmente correspondem à escolha do sítio de intervenção, à entrada da Maternidade e das Urgências ${ }^{214}$. Escultura pública pela sua implantação num espaço aberto e acessível, pela sua escala e perfeita integração no cenário rígido da fachada principal do hospital, também, e especialmente, pela capacidade de ser portadora de um sentido colectivo, apreensível sem dificuldade, Despertar é uma obra de arte contemporânea vernacular (o tema da flor e a objectividade da sua simbologia naquele contexto) que então contraria a habitual falta de qualidade da escultura monumental que se vai instalando por cidades e rotundas. ${ }^{215}$

211 Grosso modo, uma comunidade de comissários e programadores independentes de que destacaria Graça Passos (CENTA e Lisboa Fora de Horas), Francisco Vaz Fernandes (Lisboa Fora de Horas), Dinis Guarda (Festival Número), Natxo Checa (ZDB). Mais tarde, Miguel Amado, Filipa Oliveira ou Ricardo Nicolau. O caso da EXPERIMENTADESIGN é aqui de mencionar, uma vez que empresa de sucesso ao nível de uma ligação entre as culturas do design e da arte, desde 1999.

212 Melo, p. 110.

213 Alexandre Pomar, in Expresso, Lisboa, 11.12.2004.

214 A sua experiência pessoal, reconhece o artista, motivou-o para a concepção da escultura e para o gesto da doação, que exprime a gratidão pelos cuidados médicos que o fizeram regressar à vida após um gravíssimo acidente viário de que foi vítima no Natal de 1998.

215 http://alexandrepomar.typepad.com/alexandre_pomar/2007/11/rui-chafes-2004.html. João Fernandes: Uma estátua honesta é muitas vezes mais interessante que as intervenções abstractizantes que se vêem pelas rotundas de Portugal [...] mais valia que a decoração daqueles espaços tivesse sido deixada aos cuidados dos jardineiros municipais in Público, 28 Outubro, 2008. 
Quanto a Pedro Cabrita Reis, interessa-me recuperar a sua abordagem da instalação, sempre plena de obscuridade e aforismo ${ }^{216}$. É um artista que ganha lugar na tradição da arte pública em função de alguns gestos altamente retóricos (mesmo quando executados no interior do espaço museológico ou pseudo-museológico). É o caso da sua intervenção inaugural no Museu de Serralves (impondo um diálogo crítico com a arquitectura museológica), como, mais recentemente na exposição O Poder da Arte (apresentação da Colecção de Serralves na Assembleia da República). Nos anos 90, em Óbidos ${ }^{217}$, Cabrita já integrara a sua linguagem 'neutra', mas espacialmente determinate, num território histórico de forte poder simbólico. Mas foi já durante esta investigação que, ao visitar Os Outros (2010) no Pavilhão 23 do Hospital Júlio de Matos, me deparei com uma excepcional operação auto-crítica sobre o estatuto do génio, realizada em total harmonia com a tendência da estética relacional. Nesta exposição, Cabrita deixa-se desenhar por uma série de artistas-pacientes do Hospital (a meses da sua desactivação para se transmutar num condomínio fechado), e apresenta-se depois na mostra fundamentalmente como autor de uma espécie de assemblages poveras, de madeira, betão e luzes fluorescentes (matérias de sua eleição), que funcionam com sistemas de iluminação (candeeiros) das obras dos artistas (algums amadores, outros profissionais) colaborantes. Ora o poder do gesto está, entre outros aspectos, no facto de a luz artificial das lâmpadas dialogar com a poderosa luz exterior, a qual, matizada pelos espaços verdes do Hospital, é claramente um signo de liberdade e possibilidade, num contexto semi-museológico em que o tema da cidade e da sua evolução é evidente.

\section{2.3.2 O caso Gabriel Rui Silva - a performance poética da grande cidade}

Regressemos a 1992; o poeta Gabriel Rui Silva realiza Big-Bang Poesia! - Intervenção urbana Almada, $1992^{218}$ que é, com o Citymobil de Costa Pinheiro, um daqueles eventos que aliam a enorme ausência de impacto histórico no campo da arte a um sentido de oportunidade e de domínio do dispositivo artístico notáveis. Silva aliou à sua performance uma publicação ${ }^{219}$ que começa assim: Num final de tarde do ano de 1992, os habitantes de uma das inúmeras cidades que formam a grande cidade foram surpreendidos por algo de inabitual. ${ }^{220} \mathrm{Em}$ inédita intervenção nos painéis electrónicos informativos da cidade de Almada, o poeta conseguiu transpor para um dispositivo urbano público, gerido pela Câmara Municipal, um longo poema dinâmico, cujas palavras corriam como se de uma mensagem quotidiana - relativa ao trânsito ou à vida cultural - se tratasse. A propósito deste tipo de trabalho, refere Fernando Aguiar: Este es un excelente ejemplo de la intervención del poeta en la sociedad, utilizando de una forma que se puede considerar subversiva las innovaciones tecnológicas.

\section{Idem, p. 631}

217 Num evento com curadoria de Delfim Sardo, em que participam Marina Abramovic, Giovanni Anselmo e Anish Kapoor.

218 Citamos o grafismo da publicação-catálogo. Gabriel Rui Silva, Big-Bang, Poesia, Edição de autor, 1993.

219 Descubro-a por acaso numa biblioteca, tomando contacto com ela através de uma publicação-catálogo, Big-Bang, Poesia!, cujo subtítulo, em letras garrafais, reza Intervenção Urbana. É uma obra-chave na vanguarda da articulação entre o talento poético e a reacção à chegada dos dispositivos tecnológicos - campo particular da poética contemporânea (interpretado por autores como César Figueiredo ou Almeida e Sousa).

220 Idem. O texto prossegue num registo misto de crónica poética e memória descritiva de um projecto, acompanhado de fotografias documentando com inusitado rigor informativo todos os passos essenciais da intervenção. No final, tabelas com tempos registam a duração exacta de cada fase da obra tal como vivida pelos transeuntes. 
Se o dispositivo é ele próprio ou de um subtil chamada de atenção (para a leitura), o autor revela que, claro, um transeunte que subitamente pare e se ponha a olhar para o ar leva automaticamente a que outro pare ${ }^{221}$... Então, o prazer do texto anda a par de um happening colectivo, desvelar dos fluxos humanos enquanto matéria da vida urbana:

Por entre as pessoas, juntas em torno dos vários painéis, verificaram-se comportamentos idênticos: olhares que se entrecruzavam curiosos e, aqui e além, um ou outro riso logo silenciado pelo que se seguiu. Com efeito, a pele sintética mexeu-se de novo num ondulado leve de erguer e poisar, crici-cric- de escamas verdes que produziram, a partir de então, um discurso simultaneamente astucioso e ingénuo nas questões que propunha. Pôde-se, então, ler: NÃO É VERDADE QUE / OS HOMENS FAZEM AS / CIDADES NA EXACTA / PROPORÇÃO EM QUE / SÃO FEITOS POR / ELAS?222 E como que desenhando o arco argumentativo que pretendo estabelecer entre as neovanguardas dos anos 70 e arte extramuros dos anos 00, o poeta utiliza a metáfora do cerco, do muro: ESTÃO / OS HOMENS / CERCADOS / PELAS / C I D ADES/?

A peça de Gabriel Rui Silva tem portanto, como poucas do meu corpus, traços meta-discursivos, sendo que o léxico que o seu autor priviligia - muros que caem / outros tantos / a partir faz deste projecto um emblema da arte pública 'poético-literária' e da sua comunicação urbana:

Si en la poesía literaria solo existe el contenido del poema, en la poesía visual se asiste, en muchos casos al exceso opuesto: La sobrevaloración de la forma en vez del contenido. Ambos pecan por exageración. La utilización de soportes técnicos y tecnológicos, principalmente el ordenador, podrá conjugar estos dos factores de una manera equilibrada para que forma y contenido puedan contribuir en conjunto a la consecución del poema, dentro del espíritu de la poesía visual más realizada y activa. Sólo así se puede decir que el poema visual es una obra que se aprende por la forma y se comprende por el contenido. Todavía el inverso también es verdadero. ${ }^{223}$

Concluo. No quadro de um status quo institucional na arte que não é discutido pela sociedade civil $^{224}$, os eventos mais críticos das últimas décadas vão por um lado evitar confrontos e debates que a sua filosofia dialógica e retórica entende inúteis, e vão, nos actos, revelar modalidades de diálogo arte-vida pontual mas radicalmente diferentes da esmagadora maioria da produção das décadas anteriores, sem que isso signifique nem a instauração de qualquer ideia de vanguarda, nem a anulação de genealogia crítica. Isso foi conseguido, diga-se, pela abertura, no seio do movimento, a várias visões complementares do objecto e da função da arte, entre a visão cínica de aproximação cautelosa ao sistema, a provocação anti-arte, a dimensão pedagógica, o carácter urbanístico, e ao mesmo tempo um aspecto místico; tudo vindo, na verdade, dos traços de carácter pessoal dos vários principais agentes envolvidos. Alexandre Melo perspectiva o enquadramento desta realidade artística lespecífica da era da globalização), mencionando o sociólogo Boaventura Sousa Santos.

Portugal é uma sociedade de desenvolvimento intermédio. Algumas características sociais ltaxas de crescimento populacional, leis e instituições, algumas práticas de consumo, etc.) aproximam-na das sociedades mais desenvolvidas, enquanto outras (infra-estruturas colectivas, politicas culturais, tipo de desenvolvimento industrial, etc.) a aproximam das sociedades menos desenvolvidas. [...] Se tomarmos em conta os indicadores sociais normalmente utilizados para contrastar o primeiro e o terceiro mundos [...] concluiu-se facilmente que Portugal não pertence a nenhum desses mundos. ${ }^{225}$

Depois de um longo período salazarista e isolacionista, o que nos sobra é um 'limbo' evolutivo em que pontualmente surgem acções e acontecimentos dignos de uma genealogia genuinamente crítica do status quo. Interessante seria de notar/deduzir qual o lugar do

221 Silva, p. 9.

222 Pp. 10-11. O poema prossegue: OS HOMENS / CONSTROEM / AS CIDADES / E / ESQUECEM ; TECEM / UMA REDE / DE / MALHAS / ESTREITAS ; OS HOMENS / TECEM / UM CERCO / E / ESQUECEM, numa clara aporpximação ao conceito de alienação pelo quotidiano lefèbvreano.

$223 \mathrm{http} / / /$ performancelogia.blogspot.com/2007/02/performance-poesa-sonora-y-tecnologa.html

224 Pinharanda, p. 636.

225 Melo, Alexandre; «O país adiado ou a pesada herança», in Anamnese, p. 325. 
conceito e da praxis de espaço público nesta sociedade mediamente desenvolvida - o que passa, como o trabalho de alguns artistas nesta Terceira Parte acaba por deixar transparecer por formas híbridas de publicidade do urbano. Isto é, em que medida e de que forma as sublimes irrupções de verdade social conseguiram ou não criar 'espaço público' onde ele antes era uma hipótese ou possibilidade apenas. Uma coisa é certa, a realidade multipolar (Melo ${ }^{226}$ ) actual, com diversos focos de criação, difusão e recensão artísticos, torna a própria dimensão retórica dos projectos mais importante do que nunca, constituindo hipóteses de originalidade e recepção crítica numa indústria cultural em relativa expansão. 


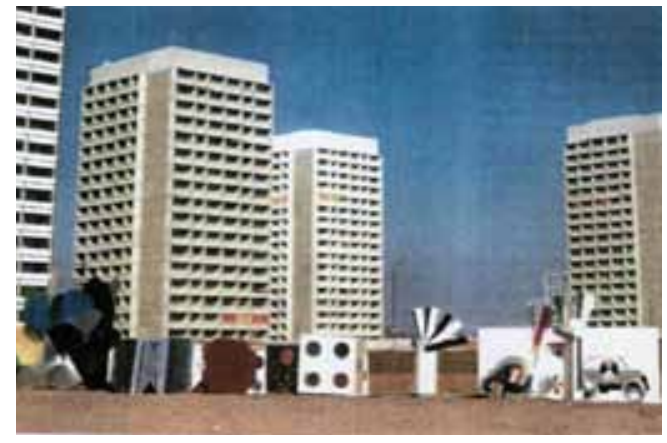

Citymobil, Costa Pinheiro, 1969

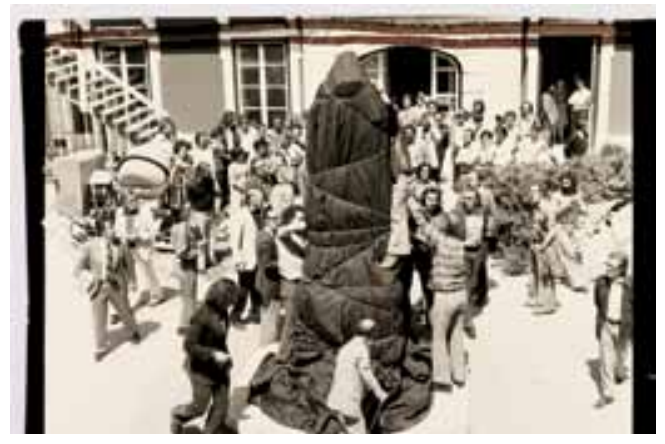

Happening, 28 de Maio de 1974

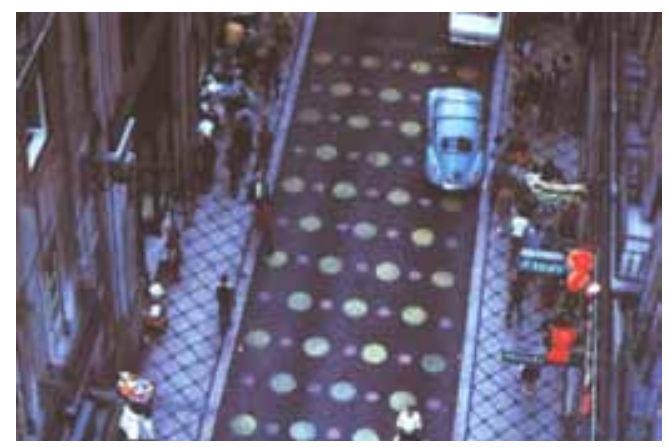

Rua do Carmo, Acre, 1974

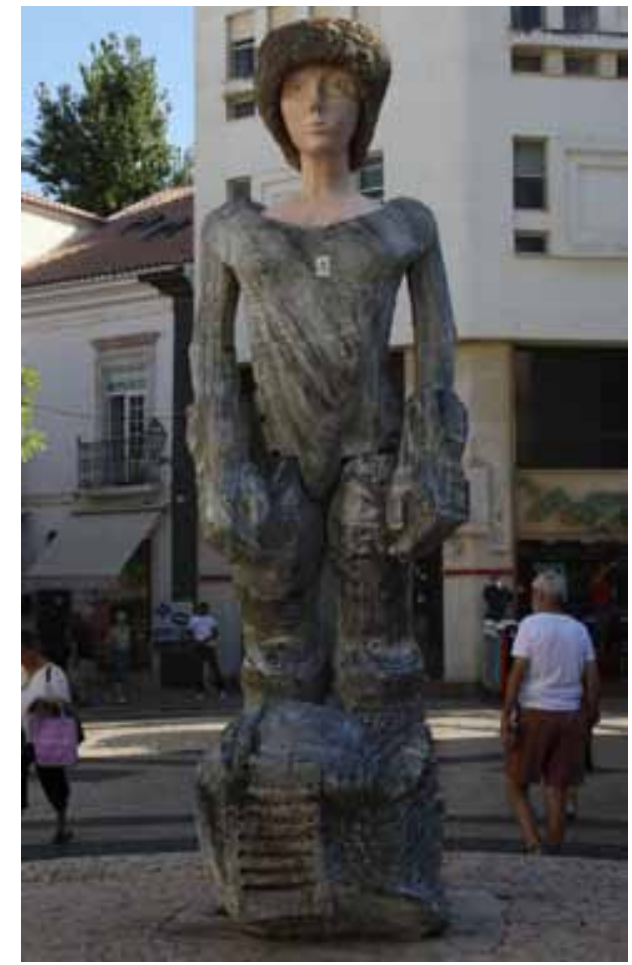

São Sebastião, José Cutileiro, 1973

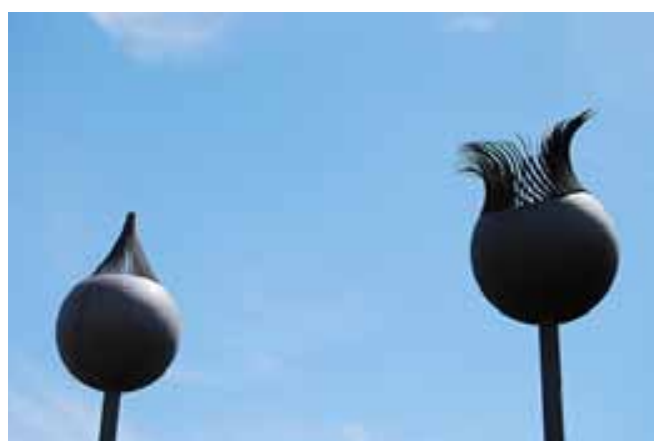

Despertar, Rui Chafes

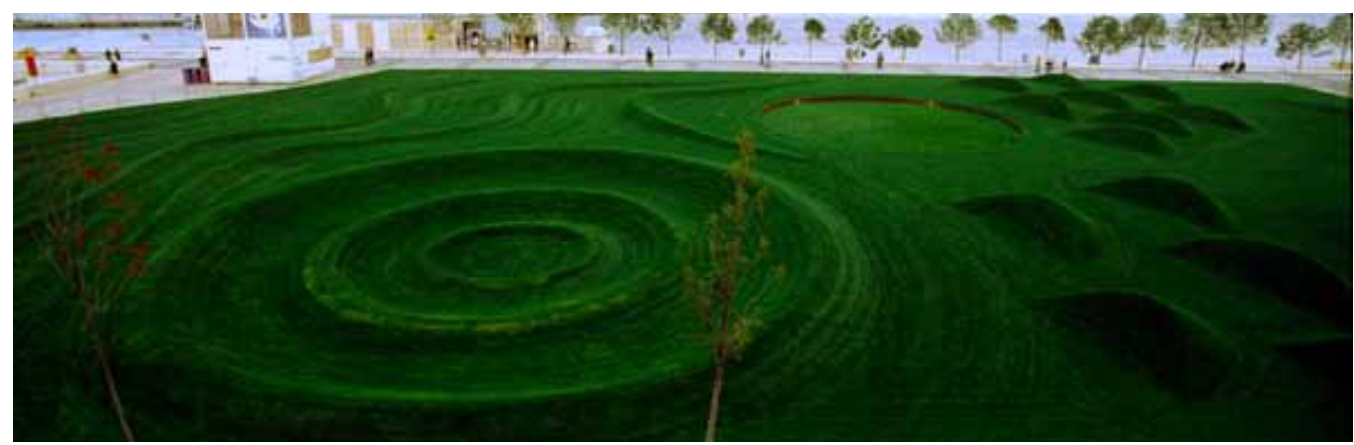

Jardim das Ondas, Fernanda Fragateiro, 1998 
